\title{
MÉTODO PARA A PROPOSIÇÃO DE DIRETRIZES PARA MELHORIA DA PRODUTIVIDADE DA MÃO-DE-OBRA NA PRODUÇÃO DE ARMADURAS
}

Tese apresentada à Escola Politécnica da

Universidade de São Paulo para obtenção do título de Doutor em Engenharia 
ESCOLA POLITÉCNICA DA UNIVERSIDADE DE SÃO PAULO DEPARTAMENTO DE ENGENHARIA DE CONSTRUÇÃO CIVIL

Área de Concentração: Engenharia de Construção Civil e Urbana

LUÍS OTÁVIO COCITO DE ARAÚJO

\title{
MÉTODO PARA A PROPOSIÇÃO DE DIRETRIZES PARA MELHORIA DA PRODUTIVIDADE DA MÃO-DE-OBRA NA PRODUÇÃO DE ARMADURAS
}

Tese apresentada à Escola Politécnica da Universidade de São Paulo para obtenção do título de Doutor em Engenharia

Orientador: Prof. Dr. Ubiraci Espinelli Lemes de Souza

\author{
São Paulo \\ Julho de 2005
}




\section{FICHA CATALOGRÁFICA}

Araújo, Luís Otávio Cocito de Método para a proposição de diretrizes para a melhoria da produtividade da mão-de-obra na produção de armaduras /

L.O.C. de Araújo. -- São Paulo, 2005. $503 \mathrm{p}$.

Tese (Doutorado) - Escola Politécnica da Universidade de São Paulo. Departamento de Engenharia de Construção Civil.

1.Estruturas de concreto armado 2.Produtividade 3.Mão-deobra 4.Organização do trabalho I.Universidade de São Paulo. Escola Politécnica. Departamento de Engenharia de Construção Civil II.t. 


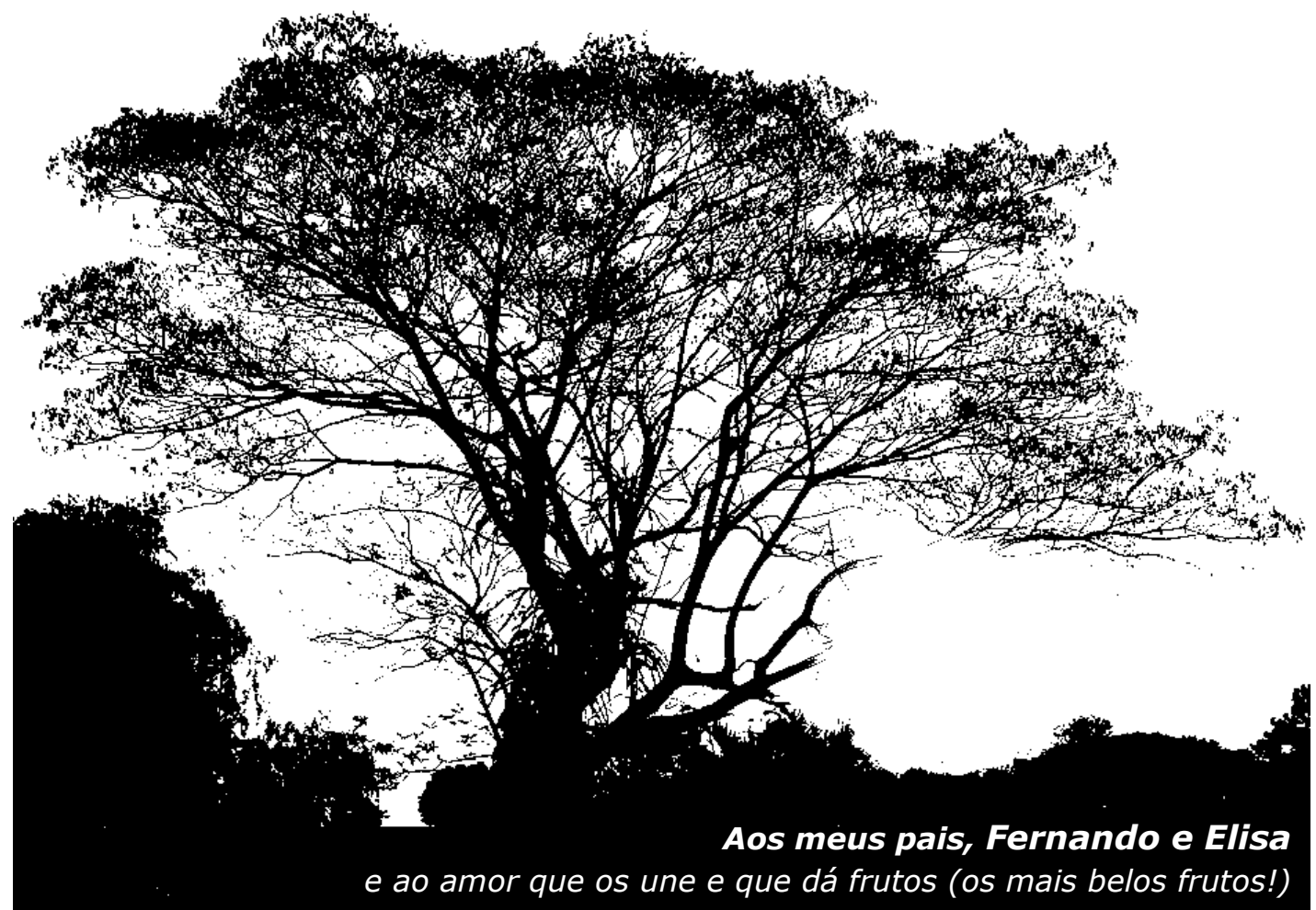




\section{AGRADECIMENTOS}

De formas distintas, essencialmente importantes, vocês se fizeram presentes nesta caminhada. Gratificado estou, agradecido serei a todos vocês, eternamente, pela maneira solícita e benevolente com que participaram do desenvolvimento dessa tese e da minha vida.

Ubiraci Espinelli Lemes de Souza, Ricardo Leopoldo e Silva França, Fernando Henrique Sabbatini, Mércia, Francisco Cardoso, Luiz Sérgio, Sílvio Melhado, Antonio Figueiredo, Silvia Selmo, Maria Alba, Wanderley John, Alex Abiko, Racine, Hermes, Henrique Lindenberg, José Carlos Paliari, Júlio Sabadine, Guilherme Parsekian, Márcio Fabrício, Celso Novaes, Sheyla, Almir, Simar, Cristovão, Barros Neto, Francisco Vela. Professores, incentivadores e amigos.

Engrácia, Reginaldo, Paulinho, Fátima, Alcione, Léo, Vilma, Fátima, Edson, Patrícia, Rogério, Luiz Alberto, Dorval, Adilson, João, Márcio. Protagonistas da minha história.

Leonardo Grilo, Sérgio Ângulo, Tomás Freire, Yoakim Petrola, Antonio Acácio, Leandro, Alexandre Maia, Artemária, Evandro, Auriciane, Fernanda Fernandes, Luciana Oliveira, Clarice, Leonardo Fagundes, Flávio Maranhão, Rogério Santovito, Claudinha. Mais que amigos da pós-graduação, irmãos de fé, de muita fé.

Fernando, Elisa, Ana Paula, Hélio, Nina, Ian, Maria Letícia, Samuel, Samuel Neto, Luís Fernando, Romilda (in memorian), José Miguel, Sueli, Fabrício, Igor, Gabi, Daniel. Razões da minha vida.

Michelle Tamburi de Souza. Durante bons anos, um bom amor.

"Araújo's" (Antonio Wilson, Elvira...), "Ulian's" (Antenisca, Érika...), "Guardia's" (José, Berenice...), Alonso's (Samuel...), "Consoni's" (Dona Zita...). Minha grande e querida família.

Alexandre Taveira, Durval Fadel, Gustavo Passareli, José Fernando, Luiz Augusto, Marcelo Mota, Márcio Zanon e Maurício Quevedo. Excelentes amigos dos bons tempos da faculdade..., amigos para a vida inteira.

Fabrício, Rhonei, Paulo Sérgio, Eliana, Toninho, Fabiana, Marcinho, Karina, Rodrigo, Juliano, Alan, Rafael, Misael, André Arantes, Janaína Boim. "Amigos Rancharienses domiciliados em São Paulo", parcerias de muito sucesso e de muitas boas histórias.

Zorzi e Paula Viana, Tomás Freire e Andréia. Queridos casais de amigos queridos, histórias de amor inspiradoras.

\section{Agradecimentos particulares:}

À Fapesp, pelo apoio financeiro ao desenvolvimento deste trabalho.

Ao Departamento de Engenharia de Construção Civil da Escola Politécnica da USP.

Às construtoras Gafisa, Cyrela, Tecnum, Tecnisa e Tarjab.

Aos escritórios de projeto Ricardo Franças \& Associados e SVS Engenharia.

Aos engenheiros (as): Zorzi, Gino Schevano, Roberto, Solano, Joelson, Jorge Batlouni, Caio, Rose, Paulo Borges, Silvio Gava, Glaico, Francisco Ozzi, Ricardo, Enio, Sílvia entre tantos outros, todos fundamentais a esta pesquisa.

Aos mestres de obras, encarregados e, principalmente aos operários da construção que tive o privilégio de conhecer, conviver e com os quais pude aprender muito nos últimos anos.

\section{Agradecimentos especiais:}


A Ubiraci Espinelli Lemes de Souza, pela orientação digna de "distinção e louvor" e, acima de tudo, pela amizade que nos une.

Aos Professores Doutores Fernando Henrique Sabbatini e Ricardo França, membros da banca do exame de qualificação, pelas importantes colocações, imprescindíveis ao fechamento desta tese.

A Leonardo Melhorato Grilo, meu grande amigo e incentivador, pelo apoio constante, marcante e fundamental a minha vida e ao meu trabalho ao longo dos últimos anos.

A Carlus Fabríco Librais, amigo do peito, grande parceiro em tantas histórias e projetos, pelo convívio diário, saudável e gratificante ao longo dos últimos onze anos.

A minha adorável "Lili", minha mãe querida, que amo com todas as minhas possibilidades, pelo apoio incondicional e gramatical.

A meu amado irmão Luís Fernando, pelo exemplo de determinação e empenho.

A Antônio Figueiredo, pela amizade e pelo exemplo de fé cristã, espiritualidade, virtuosidade e bondade.

A Luiz Sérgio Franco, pela amizade e solidariedade.

A Engrácia, amiga querida, que estimo tanto, pela dedicação, apoio e presteza.

\section{Agradecimentos fervorosos:}

A DEUS, meu pai zeloso e protetor, pela Sua presença marcante na minha vida, desde sempre.

A Nossa Senhora de Fátima, minha Mãe Celeste, sempre zelosa, pelo manto que me cobre e me afasta de todos os males!

A São JoseMaria Escrivá, pela graça alcançada.

E a você amigo, que vai esquecido nas minhas lembranças. Perdoe-me pelo deslize! 
"Que a tua vida não seja uma vida estéril. Sê útil. Deixa rasto. Ilumina com o resplendor da tua fé e do teu amor"

Caminho, Mons. Josemaria Escrivá 


\section{Sumário}

RESUMO

ABSTRACT

1 INTRODUÇÃO À TESE.

1

1.1 ContextualizaçÃo do Setor da Construção CiVil na Macroeconomia $\ldots \ldots \ldots \ldots \ldots \ldots . \ldots \ldots$

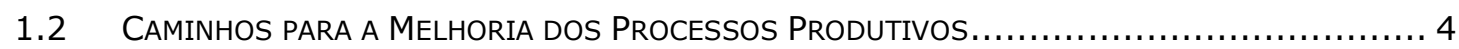

1.2.1 Panorama do setor de edificações no âmbito da gestão da produção......... 5

1.2.2 Caminhos já trilhados que corroboram na justificativa deste trabalho ....... 7

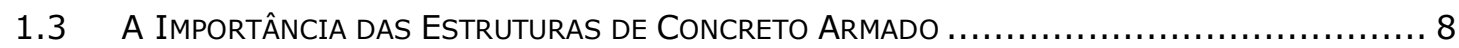

1.3.1 O Desenvolvimento das Estruturas de Concreto Armado ..................... 8

1.4 A Justificativa da Escolma do Processo de ConcepÇão e Produção de Armaduras 11

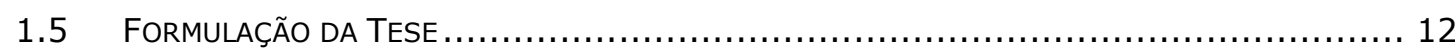

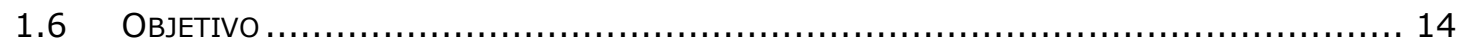

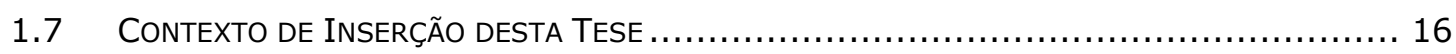

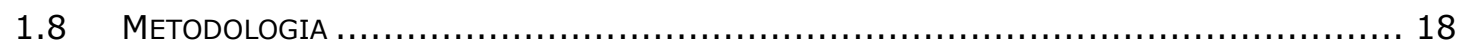

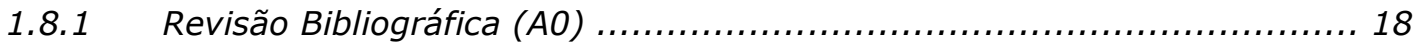

1.8.2 A1 - Estudos exploratórios ............................................... 19

1.8.3 A2 - Proposição do Método................................................ 21

1.8.4 A3 - Aplicação/Validação do Método............................................ 21

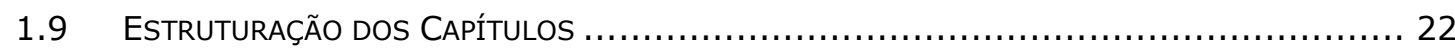

2 ARMADURAS PARA ESTRUTURAS DE CONCRETO ARMADO .......................... 23

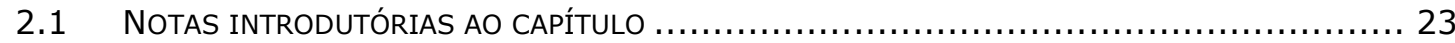

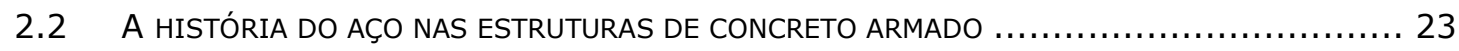

2.2.1 A Sinergia entre Aço e Concreto.......................................... 23

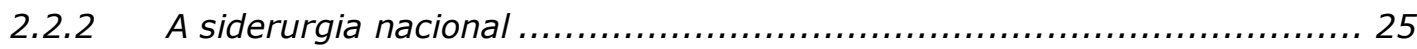

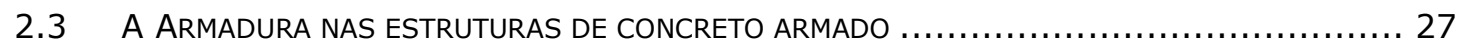

2.3.1 Caracterização do aço utilizado na confeção das armaduras................. 27

2.3.2 O Emprego de armaduras de aço ............................................ 36

2.3.3 DisposIcões construtivas gerais das armaduras............................. 39

2.3.4 Disposições Construtivas Específicas...................................... 45

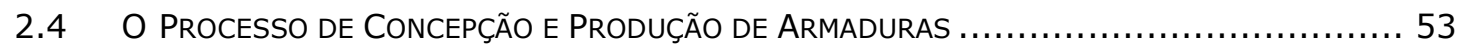

2.4.1 Definições de nomenclatura.............................................. 53

2.4.2 O Projeto no âmbito do PCPA........................................... 54

2.4.3 A Fabricação no âmbito do PCPA .......................................... 77

2.4.4 A armação no âmbito do PCPA ........................................... 89 


\section{A ORgANIZAÇÃO dO TRABALHO NO ÂMBITO DA GESTÃO DA PRODUÇÃO ......136}

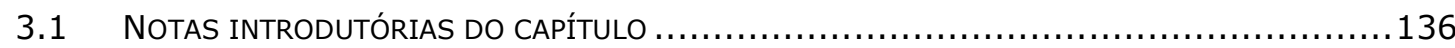

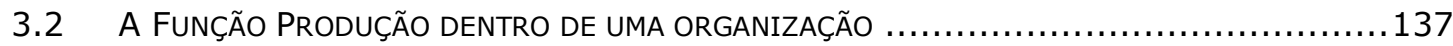

3.2.1 A Hierarquia do sistema de produção........................................138

3.2.2 O papel estratégico e os objetivos da função produção .......................139

3.2.3 A estratégia de Produção .................................................. 142

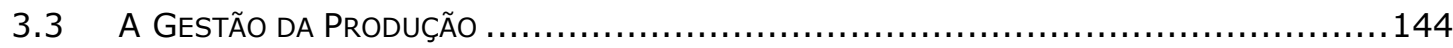

3.3.1 Ações preconizadas pela gestão da produção .............................147

3.3.2 Caminho adotado, nesta tese quanto à gestão da produção.................151

3.3.3 O Planejamento e Controle da Produção.....................................153

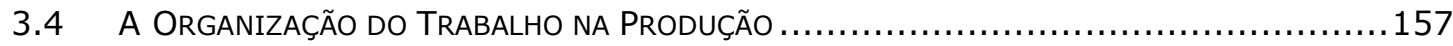

3.4.1 Considerações iniciais sobre a organização do Trabalho .....................157

3.4.2 A Evolução do Pensamento Administrativo com foco na organização do trabalho 158

3.4.3 As Pessoas no Âmbito da Organização do Trabalho.

181

3.4.4 Principais elementos considerados na organização do trabalho na produção 188

\section{A MELHORIA DA PRODUTIVIDADE COMO CAMINHO PARA A MELHORIA DO} DESEMPENHO

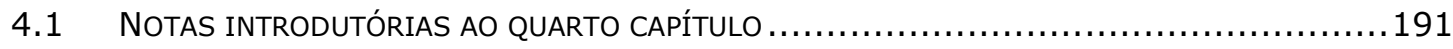

4.2 GERENCIAMENTO DE PROCESSOS DE PRODUÇÃO COM FOCO NA MELHORIA DO SEU DESEMPENHO 192

4.2.1 Diferenças entre o canteiro de obras e a manufatura ........................192

4.2.2 A variabilidade no nível da atividade..................................... 196

4.2.3 Modelos para redução da Variabilidade nos Processos de produção........200

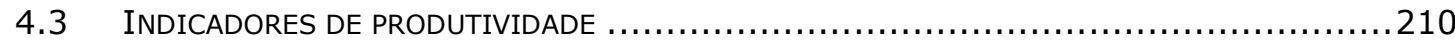

4.3.1 O papel dos indicadores na melhoria no desempenho da Indústria da Construção Civil internacional ..................................................... 210

4.3.2 A importância dos indicadores de produtividade para a construção civil.. 214

4.3.3 Patamares da produtividade da mão-de-obra que executa as estruturas de

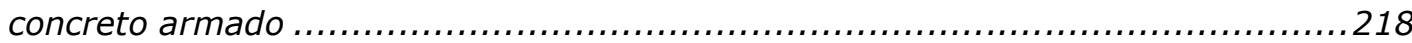

4.3.4 Caminhos que levam à melhoria da produtividade da mão-de-obra .......219

4.4 A REPRESENTATIVIDADE DOS FATORES NA PRODUTIVIDADE DA MÃO-DE-OBRA $\ldots \ldots \ldots \ldots \ldots . \ldots . \ldots . \ldots$

4.4.1 O projeto do produto e sua influÊncia na produtividade da mão-de-obra 221

4.4.2 O método de trabalho e a influência na produtividade da mão-de-obra ..236

4.4.3 A organização do trabalho e sua influência na produtividade da mão-deobra 246

5 MÉTODO PARA PROPOSIÇÃO DE DIRETRIZES PARA A MELHORIA NA

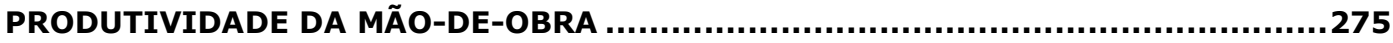

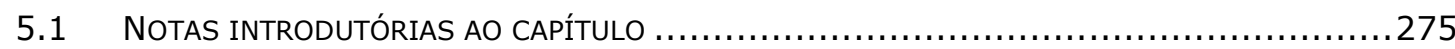

5.2 CONCEITOS INICIAIS NECESSÁRIOS AO DESENVOLVIMENTO DO MÉTODO ...................276 
5.2.1 A visão analítica do processo de produção das armaduras ..................2.276

5.2.2 Abordagem relativa ao entendimento dos fatores influenciadores da produtividade.......................................................................... 277

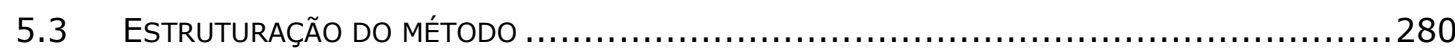

5.3.1 Definição dos Indicadores e Fatores.........................................281

5.3.2 Levantamento de dados.................................................. 298

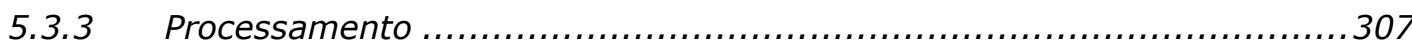

5.3.4 Proposição das diretrizes.................................................. 320

6 APLICAÇÃO DO MÉTODO PARA PROPOSIÇÃO DE DIRETRIZES PARA A MELHORIA NA

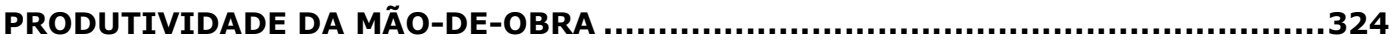

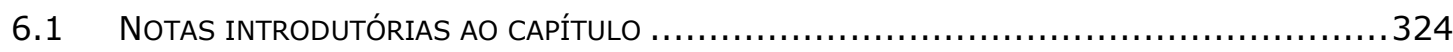

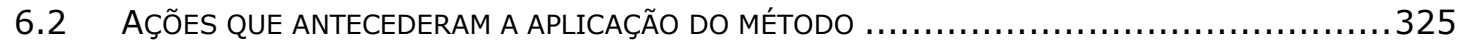

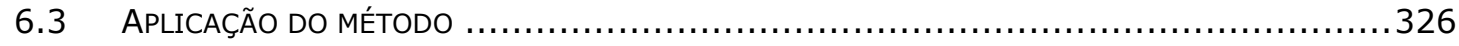

6.3.1 Caracterização da empresa construtora onde o método foi aplicado........327

6.3.2 Caracterização das obras contempladas ..................................... 327

6.3.3 Considerações iniciais sobre a condução das etapas do método..............329

6.3.4 Etapa de definição dos indicadores e fatores.................................. 331

6.3.5 Etapa de levantamento de dados ........................................ 337

6.3.6 Etapa de processamento ................................................. 384

6.3.7 Etapa de Proposição de Diretrizes........................................433

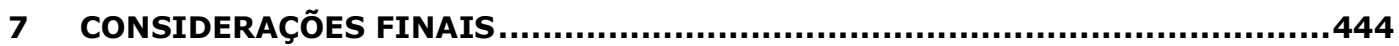

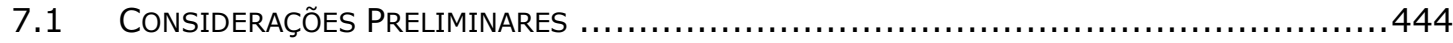

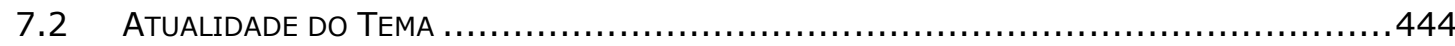

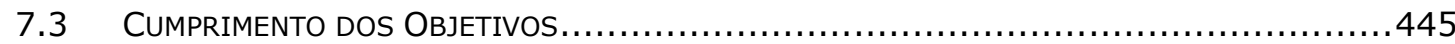

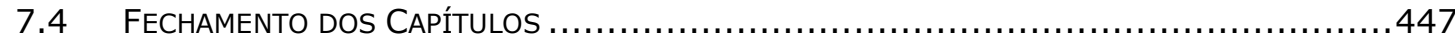

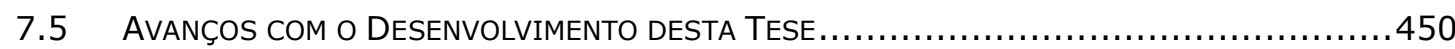

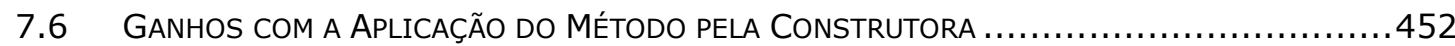

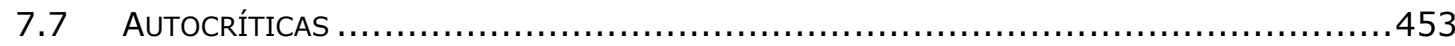

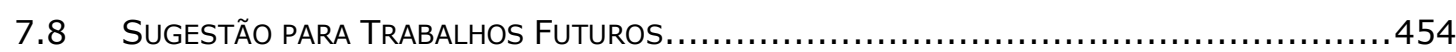

REFERÊNCIAS BIBLIOGRÁFICAS............................................................... VI 


\section{Resumo}

ARAÚJO, L. O. C. Método para a proposição de diretrizes para a melhoria da produtividade da mão-de-obra na produção de armaduras. 2005. 450 p. Tese (Doutorado) - Escola Politécnica, Universidade de São Paulo, São Paulo, 2005.

A competição acirrada no mercado da Construção Civil tem exigido das empresas construtoras a busca pela melhoria de sua eficiência produtiva. Dentro desse contexto, a melhoria da produtividade da mão-de-obra apresenta-se como caminho relevante na medida em que seus custos representam parcela significativa do ônus total relativo à produção, e existe uma variação significativa de desempenhos nas empresas atuantes no mercado.

Como qualquer outro tipo de serviço de construção, o serviço de armação carece deste mesmo tipo de abordagem, haja vista a existência, nos canteiros de obras brasileiros, de uma alta variabilidade na produtividade da mão-de-obra envolvida na fabricação e montagem das armaduras para estruturas de concreto armado (30 a 100 Homenshora/tonelada). Some-se a esse aspecto o fato de se detectar, na bibliografia, um número de trabalhos bastante mais expressivos quanto a outros serviços; por exemplo, discutem-se muito os projetos de processo para fôrmas enquanto não se dá esta mesma abordagem à armação. Portanto, o diagnóstico da produtividade e dos estudos relativos ao tema demonstram a importância do estudo de ações que possam levar à melhoria da competitividade na produção de armaduras.

Este trabalho apresenta um método para a proposição de diretrizes, relativas ao processo de produção de armaduras para estruturas de concreto armado, que visam melhorar a produtividade da mão-de-obra do serviço de armação. Para tanto, buscar-se-á, no entendimento da relação entre a produtividade e os fatores que a influenciam, o embasamento necessário para a proposição de tais diretrizes. Tais fatores podem estar relacionados ao projeto do produto (com ênfase no projeto de detalhamento das armaduras), ao método de produção e à organização do trabalho.

Para se alcançarem os objetivos propostos, o trabalho envolve um levantamento de informações prévio, realizado com base em estudos bibliográficos, entrevistas com especialistas e um intenso contato com os canteiros de obras. Para a validação do método proposto faz-se uma aplicação do mesmo através de um caso real.

As diretrizes, obtidas mediante a aplicação do método, ajudarão a tomada de decisões da construtora, que poderá auxiliar: i) os projetistas estruturais a favorecerem, no desenvolvimento dos projetos de detalhamento das armaduras, sempre que possível, a construtibilidade; ii) os contratantes na concepção de sistemas de armação, nos canteiros de obras, que possibilitem a racionalização das operações e o alcance das produtividades potenciais da mão-de-obra; iii) os responsáveis pela mão-de-obra na organização do trabalho, de maneira a favorecer a melhoria da produtividade com benefícios a todas as partes envolvidas.

Palavras-chave: produtividade, mão-de-obra, estruturas de concreto armado 


\section{Abstract}

ARAÚJO, L. O. C. Method to propose directions improving labor productivity in the steel reinforcement activities. 2005. 450 p. Tese (Doutorado) - Escola Politécnica, Universidade de São Paulo, São Paulo, 2005.

The increasing competition in Brazilian building industry has encouraged construction companies to develop efforts in order to enhance their productive efficiency. Naturally, improving labor productivity becomes a critical path to achieve the above goal, since labor represents a significant component of construction costs and its performance may vary considerably from project to project.

Likewise other construction services, concrete reinforcing planning stages reasonably lack systematic approaches to reduce the remarkable variability found in labor productivity (30 to 100 men hours/ton) throughout production and assembly processes. Moreover, and differently from other topics such as formwork, concrete reinforcing has not been covered by comprehensive studies in recent years. Therefore, the reported inefficiency in the production process, the impact on construction costs and the lack of systematic studies evidence the relevance of further investigations about this topic.

This research proposes guidelines to improve labor productivity in the concrete reinforcing. The methodology involved an international literature review and an extensive data collection, which included interviews with specialists and descriptive case studies in construction sites. Initially, factors that influence labor productivity were identified through literature review and empirical studies. Subsequently, these factors were grouped in three main categories: product design (especially reinforcement detailing), production method and work organization factors. Then a method to improve the productivity in concrete reinforcing was proposed and finally validated though application in a real case study.

The resulting guidelines may arguably support decision makers throughout the planning process of concrete reinforcing, including: i) structural engineers, who may take into account constructability issues during the conception of design solutions; ii) contractors and subcontractors, who may conceive reinforcing systems more efficiently as to rationalize production operations and achieve better performances; and iii) those responsible for workers' organization, who may bring efficiency gains to the production process and benefits for all the stakeholders.

Keywords: labor productivity, reinforcing concrete structures, guidelines. 


\section{Introdução à Tese}

\subsection{Contextualização do Setor da Construção Civil na Macroeconomia}

A economia brasileira passa, a partir do início da década de 90, por um intenso processo de reformas econômicas e institucionais. Destinadas à retomada do processo de desenvolvimento, objetivam a busca da eficiência e da competitividade na atividade econômica.

Merecem destaque avanços obtidos nos últimos anos, na condução da política econômica, por sua importância decisiva para a competitividade da indústria brasileira (e retomada do crescimento sustentado), como, por exemplo: i) o restabelecimento de alguns fundamentos macroeconômicos (inflação ${ }^{1}$ em patamares aceitáveis e estabilidade de preços, balança comercial positiva, superávit primário alcançado, austeridade fiscal; ii) as reformas destinadas à liberalização do comércio externo e dos fluxos e das aplicações do capital estrangeiro; iii) a privatização de empresas; iv) a desregulamentação dos mercados de bens e serviços; $v$ ) a eliminação de distorções nos sistemas tributário e financeiro (reforma tributária, previdenciária, nova lei de falências, lei das agências reguladoras (em andamento), leis de Parcerias Público-Privadas (PPP), algumas das quais ainda necessitando de regulamentação específica).

No entanto, o país apresenta, ainda, graves deficiências que impedem o crescimento econômico (em contraposição à grande demanda existente), tais como:

- deficiências macroeconômicas: instabilidade política e econômica, o elevado custo do capital, ausência de políticas setoriais;

- deficiências microeconômicas: altas cargas tributárias, elevado custo do capital para o mutuário, dificuldade para aprovações ambientais, regulamentação complexa ou falta de regulamentação em alguns setores, direito trabalhista, falta de independência do judiciário, etc.;

- deficiências/distorções setoriais/operacionais: equívocos que vão da operacionalização do negócio (lançamento incorreto do produto) até a produção (mão-de-obra desqualificada, perdas, desperdícios, falta de racionalização, níveis elevados de postos de trabalhos com trabalhadores sem carteira assinada (informalidade ${ }^{2}$, que está ligado a complexo direito trabalhista etc).

\footnotetext{
${ }^{1}$ Avaliação de Afonso Celso Pastore (em artigo publicado no jornal "Folha de São Paulo" no dia 15 de julho de 2004) aponta que "entre 1999 e 2004 a taxa média de inflação foi elevada, colocandose em $8,8 \%$ ao ano". Apesar de taxas reais de juros muito elevadas no mesmo período, as taxas de inflação ainda foram altas e, em geral, superaram as metas inflacionárias.

${ }^{2}$ Os pesquisadores Maurício Cortez Reis e Gabriel Ulyssea (em artigo publicado no jornal "Folha de São Paulo" no dia quatro de março de 2005) apontam que uma das características mais marcantes do mercado de trabalho brasileiro é o seu grau de informalidade extremamente elevado. "Identificar as principais características do setor informal no Brasil, como ele tem evoluído ao longo do tempo, se de fato representa um entrave ao crescimento e quais as políticas mais adequadas para lidar com esse fenômeno são questões centrais na agenda pública do país".
} 
O cenário econômico deste início de século, marcado pelas deficiências supracitadas e somado às crises que acometeram o país nos últimos anos (Figura 1.1) tem sido muito negativo para os principais setores da economia nacional, dentre eles a Indústria da Construção Civil.

Cerca de $70 \%$ de todos os investimentos feitos no País passam pela cadeia da Construção Civil (Formação Bruta de Capital Fixo), sendo que, em 1995, esse valor atingiu a cifra de US $\$ 83$ bilhões. A atividade definida como "Construbusiness" participa na formação do Produto Interno Bruto (PIB) do País com cifras significativas da ordem de $15,5 \%$, dos quais $9,1 \%$ são da construção propriamente dita (valores referentes ao PIB de 2001). "Percebe-se que a participação da Construção Civil é expressiva na formação do capital, porém o potencial indutor vem sendo limitado pelo baixo dinamismo da economia". COUTINHO (2003)

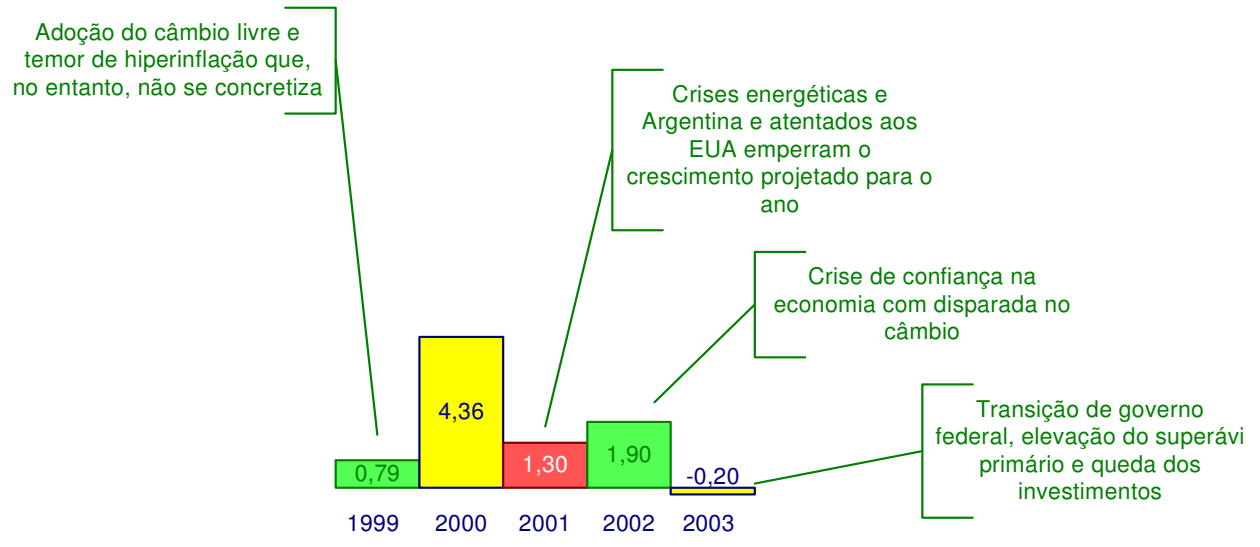

Figura 1.1 - Variação anual (\%) do Produto Interno Bruto (PIB).

Em diagnóstico sobre 0 setor da Construção Civil, apresentado durante $05^{\circ}$ "ConstruBusiness", COUTINHO (2003) lembrou que esta Indústria é amplamente influenciada, com reações instantâneas, pelas mudanças nas taxas de juros e pelo grau de confiança na economia, fatores que contribuíram para a queda do PIB real do setor nos últimos anos, conforme mostrado na Figura 1.2. Analisando o gráfico apresentado em tal figura nota-se que o produto da construção apresentou uma queda de $8,5 \%$ em 2003, em comparação ao ano de 2002. Tratou-se do maior declínio registrado por esse setor desde 1990, quando o IBGE mudou a metodologia de cálculo do produto interno bruto (PIB). Em relação a 1998, o produto da construção apresentou queda de $15 \%$.

Para BRANCO (2004), o setor da Construção Civil foi o mais penalizado em 2003. "Juros elevados, crédito escasso, renda em baixa e contingenciamento dos recursos públicos formaram uma combinação bastante perversa para a construção". A retração das atividades gerou impactos negativos ao longo de toda a cadeia produtiva (o consumo de cimento caiu $11 \%$, o consumo de vergalhão caiu $23 \%$ e a produção física de materiais de construção diminuiu $8,5 \%$ até outubro de 2003).

Segundo o Sindicato da Indústria da Construção Civil do Estado de São Paulo (SindusCon-SP), a queda na atividade da construção se refletiu em seu principal 
indicador de desempenho: o nível de emprego ${ }^{3}$ (Figura 1.3). No Brasil, foram fechados cerca de 43.500 empregos de outubro de 2002 a outubro de 2003 (queda de 3,49\%), dos quais cerca de 9.000 no Estado de São Paulo (queda de 2,47\%).

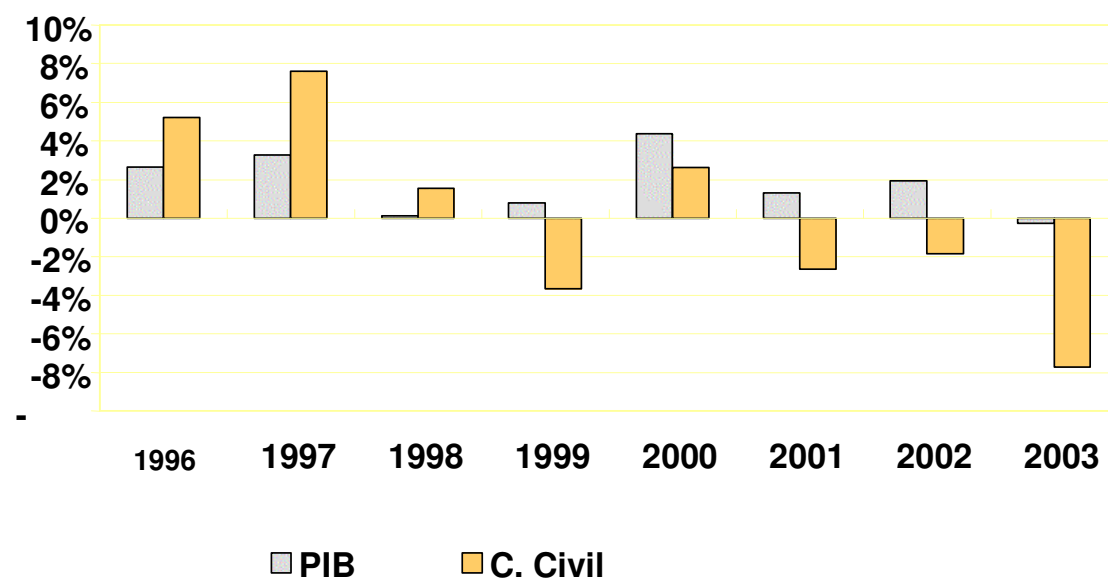

Figura 1.2 - Variação anual do PIB brasileiro comparado à participação da Construção Civil. Fonte: SINDUSCON-SP (2004)

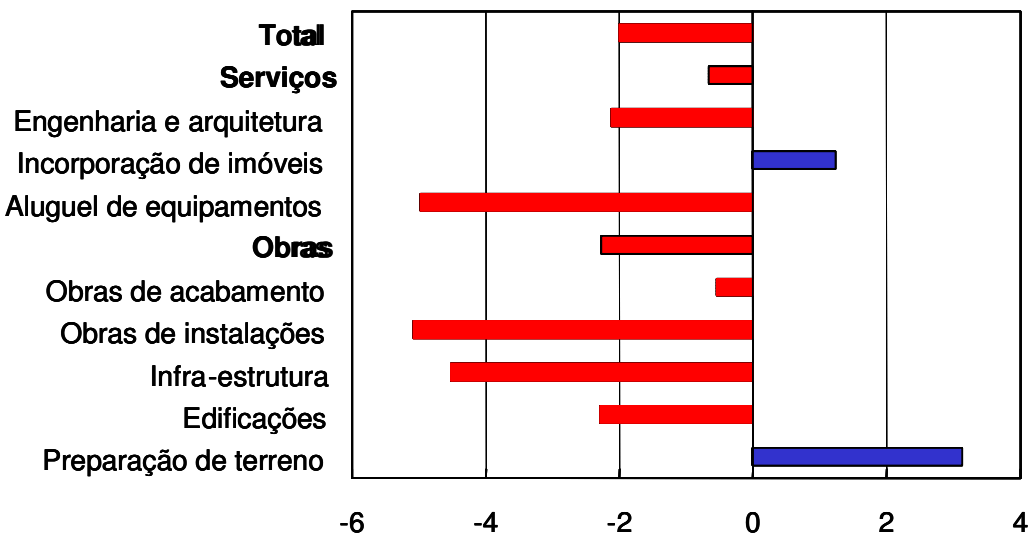

Figura 1.3 - Emprego na Construção Civil em São Paulo: variação acumulada no ano (\%), outubro 2003. Fonte: SINDUSCON-SP (2004)

O contexto desfavorável dos últimos anos levou muitas empresas de Construção a:

3 O setor é gerador de empregos, com capacidade de absorção de expressivos contingentes de mão-de-obra, especialmente de profissionais menos qualificados e socialmente mais dependentes, com grande sensibilidade às características regionais e sociais. Sua população ocupada participa na PEA (População Econômica Ativa) nacional com mais de 6\%, empregando diretamente cerca de 4,0 milhões de trabalhadores e é o setor que gera emprego a custo mais baixo. 
- operar com margens cada vez mais estreitas, enfocando o custo (contratação por menor custo) em detrimento à técnica nas contratações;

- reduzir o ritmo de lançamentos e/ou deixar/abandonar o mercado (levando a redução do nível de empregos nas obras conforme mostrado na Figura 1.3)

- reduzir o investimento em pesquisas e desenvolvimento, na adoção de sistemas de produção modernos (capital intensivo), que, por sua vez, dificultam melhoria contínua (as crises econômicas fragilizam as empresas do setor e podem comprometer os esforços rumo à melhoria ${ }^{4}$ obtidos nos últimos anos).

Neste cenário, a eficiência dos processos produtivos ganha importância ainda mais vital. Para maximizar o crescimento nos próximos anos é essencial que se acelere o ritmo de expansão da capacidade produtiva por meio de políticas que incentivem o investimento e o aumento da produtividade.

Para o Governo Federal, um dos principais desafios neste sentido passa a ser a criação de um ambiente favorável ao investimento privado. A sinalização de uma estabilidade duradoura é essencial para alcançar o objetivo, mas a ação do governo precisa ir além, com uma definição clara de prioridades que ajude a orientar as decisões privadas.

Para o setor da Construção Civil, o desafio continua a ser o de melhorar seu desempenho através do aumento da produtividade dos processos de produção. As empresas precisarão se adaptar para trabalhar com margens de lucros cada vez mais estreitas. Neste contexto, a gestão da produção passa a desempenhar um papel fundamental para a sustentabilidade do negócio num mercado restrito e de acirrada concorrência.

\subsection{Caminhos para a Melhoria dos Processos Produtivos}

FARAH (1996) aponta três tendências principais de mudança do processo de trabalho, surgidas na década de oitenta, que serviram de parâmetro para a busca do aumento da produtividade. "A primeira consiste na incorporação de novos sistemas construtivos à atividade produtiva. A segunda se caracteriza por um aprofundamento do processo de apropriação de atividades do canteiro de obras pelo setor produtor de materiais. A terceira, finalmente, incide sobre a gestão do processo produtivo, definindo uma estratégia de racionalização por parte da empresa, no sentido do aumento da eficiência".

CARDOSO (1997a) constatou, em sua pesquisa, que "a eficácia da empresa de promoção-construção imobiliária no país (ou, ainda, a vantagem concorrencial desta) depende, cada vez mais, da eficiência da condução das diferentes etapas do processo de produção, em geral, e do sistema de produção, em particular, segundo uma lógica técnico-econômica".

Ao identificar e analisar diferentes formas de racionalização da produção, o autor supracitado concluiu que as empresas de construção deveriam, ao buscar melhorias

\footnotetext{
${ }^{4}$ Os anos 90 foram marcados por forte movimento para aumento da qualidade e produtividade no setor (programas setoriais regionais (QUALIHAB, QUALIPAV etc) e nacionais (PBQP-Habitat)), caracterizando-se pela contínua implementação de sistemas de gestão da qualidade com foco em construtoras, projetistas e fabricantes de materiais e sendo marcado pela busca de à redução das perdas, melhoria da precisão dimensional, melhoria da produtividade etc.
} 
concentrar-se em: i) melhorar a organização e gestão da mão-de-obra de produção; ii) buscar o domínio tecnológico dos métodos construtivos realizados com equipes próprias; iii) melhorar as ligações/articulações entre diferentes atividades nas quais não somente atuam a empresa, como outros agentes do processo de produção.

Ressaltou que a empresa pode obter ganho de eficiência sem realizar mudanças profundas na base técnica das operações ("os métodos de construção continuam tradicionais, com baixa/média mecanização, um baixo emprego de pré-fabricação pesada, uma escala de produção reduzida, o emprego intensivo de mão-de-obra etc), estando no "âmbito das atividades e das ligações/articulações a necessidade de intervir para aumentar a eficiência da empresa e do processo de construção".

Para SALERNO (2002), "pensar a organização é pensar a eficiência do sistema de trabalho, do sistema de criação de valor". Segundo esse mesmo autor "há um consenso entre estudiosos e pessoas com experiência prática, de que a eficiência de uma empresa depende antes da qualidade da sua organização do que da última onda de equipamentos e computadores". O mesmo autor propõe que, antes de mecanizar, automatizar, informatizar, é preciso pensar o arranjo organizacional, a divisão do trabalho, sua coordenação, os procedimentos, a lógica das operações.

Cabe ressaltar que esse pesquisador compartilha das mesmas preocupações que os autores supracitados quanto à importância da busca da eficiência. Embora se acredite que investimentos em tecnologia, que busquem orientar o setor no caminho da industrialização, precisam ser feitos, defende-se que as melhorias para a Construção Civil advindas do incremento da produtividade podem e devem ser buscadas, num primeiro momento, através da gestão e organização dos processos de produção (experiências vivenciadas por este autor têm mostrado que melhorias significativas podem ser obtidas com pouco investimento).

O "salto tecnológico" é importante e o país precisa se preocupar e trilhar esse caminho. Porém, não se deve perder de vista a realidade brasileira no setor da Construção de Edificações, cuja produção em escala, necessária para suprir o déficit habitacional brasileiro é inviabilizada, quer pelo custo elevado do capital, quer pela ausência de políticas de financiamento, tornando a mecanização algo distante e fazendo com que o trabalho continue a ser fortemente baseado no uso intensivo da mão-de-obra. Não se deseja que esse "uso intensivo da força de trabalho", da forma sacrificante como é utilizada em algumas situações, perdure eternamente. Enquanto o contexto social e econômico, em que o setor se insere e que dificulta o desenvolvimento do país perdurar será preciso voltar aos processos de produção a fim de se extrair dos mesmos toda a eficiência que podem oferecer.

\subsubsection{Panorama do setor de edificações no âmbito da gestão da produção}

Uma das principais estratégias adotadas pelo setor da Construção Civil, na busca pela evolução dos processos construtivos, foi a subcontratação da mão-de-obra ((ECCLES, 1981); (BEARDSWORTH，1988); (HILLEBRANDT， 1990); (FURUSAKA, 1991); (FARAH, 1996); (VILLACRESES, 1994); (CARDOSO, 1996a); (REIS, 1998); (BRANDLI, 1998); (SERRA, 2001); (MDIC, 2002); (LORDSLEEM JR, 2002); (MILLER; PACKHAM; THOMAS, 2002); (OHNUMA, 2003)). 
Se, no início dos anos 90, essa se revelava como uma "tendência", hoje (apesar de todos os problemas e dificuldades que acometem as empresas subempreiteiras (vide autores supracitados)), trata-se de uma situação implementada que dificilmente será revertida (BARROS, 1996)

Com a subcontratação da mão-de-obra para a execução dos serviços (a mão-de-obra responsável pela execução das estruturas de concreto armado pertence, na maioria dos casos, a empresas subcontratadas (PROVERBS et al. 1999; FREIRE, 2001; ARAújO, 2003)), as empresas de construção deixaram de cuidar da gestão dos serviços no canteiro de obras, "delegando" tal tarefa às empresas subcontratadas e assumindo funções muito mais administrativas. As discussões, em obra, entre engenharia (contratante) e produção (subcontratada), passaram a tratar basicamente de valores monetários dos serviços, no momento da contratação e, durante a obra, do cumprimento de metas e medições.

Empresas especialistas, com respaldos tecnológico e gerencial, tal como se esperava com o advento da subcontratação, não surgiram no mercado brasileiro. Justifica-se essa ausência em razão de:

- falta de atratividade do setor, que acabou ficando na mão de pequenas empresas, formadas a partir da mão-de-obra proveniente das construtoras;

- relação entre contratante e contratado baseada numa lógica estritamente mercadológica;

- falta de capital para a promoção de melhorias, justificada, em parte, pelos custos significativos destinados ao cumprimento das exigências legais;

- absorção, pelas empresas contratantes, de subempreiteiras que trabalham às margens da legislação e da organização;

- busca por custos reduzidos, praticados pelas contratantes, que impedem a entrada no mercado de subempreiteiros mais capacitados.

As empresas contratantes, ao deixarem de se preocupar, de maneira devida com a produção, atentando-se apenas para os resultados, passaram a aceitar e, de certa forma, a pagar por toda a ineficiência cometida pelas empresas subcontratadas.

Para FARAH (1996) a subcontratação consistiu numa estratégia de transferência da variabilidade presente no processo produtivo para as subempreiteiras. Porém, segundo a autora, tal estratégia "aprofundou uma tendência de desqualificação dos trabalhadores de ofício e de solapamento da estrutura tradicional de saber no setor, processo que configura uma "crise de competência operária" na atividade de construção. Esse comprometimento do saber de ofício, decorrente da própria dinâmica de acumulação do setor, não teve como contrapartida, de forma plena, a clássica "expropriação" do saber operário pelo capital, definindo uma crise de competência do próprio setor".

Ajustes orçamentários praticados pelo setor, com redução dos valores pagos pelo serviço, não se justificaram por incrementos de produtividade, como haveria de ser, mas sim por pressões de redução impostas aos subempreiteiros.

LORDSLEEM JR. (2002) argumenta que as construtoras esperam obter ganhos de eficiência global do processo de produção da obra, mas na prática, a "realidade demonstra que os objetivos que justificam o emprego da subempreitada não estão sendo alcançados". As dificuldades listadas pelo autor, que sustentam o argumento, são: i) a concorrência predatória por preço (concorrência desleal com as "gatas"); ii) a ausência 
de competição por níveis técnicos, organizacionais e gerenciais; iii) o desconhecimento das exigências legais; iv) os problemas inerentes à falta de recursos na busca de melhor capacitação; dentre outros.

A necessidade de redução de custos de produção passa, necessariamente, a olhar criticamente para a produção. As empresas subcontratadas, mais especificamente aquelas que executam os serviços de obra bruta de edifícios, como as estruturas de concreto armado, não têm, em sua maioria, capacidade de lançar esse olhar crítico que possa fomentar discussões e, por conseguinte, melhorias.

Porém, como afirma LORDSLEEM JR. (2002), é preciso que as subempreiteiras enxerguem as vantagens preconizadas por processos de melhorias impostos pelas construtoras. Essas, no entanto, precisam entender que mudanças realmente efetivas envolvem a participação das subempreiteiras que devem se organizar (o autor sugere o incremento progressivo do seu nível de organização) e se capacitar, assumindo responsabilidades no resultado final da obra.

Para tanto, LORDSLEEM JR. (2002) propõe o desenvolvimento de algumas ações, como, por exemplo, a organização dos processos que constituem o sistema de produção da empresa. Quanto à responsabilidade por estimular e implementar essas e outras ações, enfatiza a importância do envolvimento do governo, órgãos públicos, sindicatos e entidades de classe, mas também, e talvez num primeiro momento, o apoio imprescindível das construtoras ("que devem realizar os investimentos necessários para o desenvolvimento das subempreiteiras que the prestem serviços e não tenham condições") e das próprias subempreiteiras.

\subsubsection{Caminhos já trilhados que corroboram na justificativa deste trabalho}

ARAÚJO (2000) indica que "a eficiência na gestão dos recursos físicos apresenta-se, neste final de século, como uma das necessidades básicas do setor da Construção Civil brasileira" e que "determinar a eficiência na transformação dos recursos físicos presentes na obra caracteriza-se como um importante aspecto para se balizar a busca da melhoria do processo de produção de obras".

Ao analisar os setores privado e público no desenvolvimento das suas pesquisas, SOUZA (1996); CARRARO (1998); PALIARI (1999); ANDRADE (1999); ARAÚJO (2000); LIBRAIS (2001); SOUZA (2001); FREIRE (2001); SILVA (2002); MAEDA (2003) traduziram em números o grau de eficiência, ou ineficiência, do setor.

Os trabalhos supracitados, fortemente baseados em diagnósticos (mensuração da eficiência na transformação dos recursos e deteç̧ão dos fatores que levam às variações dessa eficiência), têm gerado uma nova conscientização no setor de Construção de Edifícios, que começa a abrir e fomentar discussões subsidiadas por dados reais e confiáveis de produtividade (FRANÇA, 2002; ASSAHI, 2002; GRAZIANO, 2003; SOUZA, 2001; ZORZI, 2002).

A participação da comunidade científica internacional, através de convênios de pesquisas ("Beenchimarking of Labor Productivity") e grupos de trabalhos (W65 e W55 do "International Council for Research and Innovation in Building Construction" (CIB)), tem permitido discutir e comparar um conjunto de dados levantados em diferentes países, à procura das causas que influenciam a eficiência dos processos de produção.

No cenário brasileiro, os trabalhos conduzidos por SOUZA (2001) levaram à reformulação da principal tabela de composição de custos para a Construção Civil (TCPO, 2003); a nova edição $\left(12^{\mathrm{a}}\right)$, publicada em 2003, apresentou, pela primeira vez, faixas com valores detectados em 
campo, com base em método mais científico, para a produtividade da mão-de-obra nos principais serviços de construção.

Da mesma forma que trazem dados reais, os trabalhos supracitados alertam para a variabilidade significativa nas obras de Construção Civil, quanto aos níveis alcançados de eficiência na transformação dos recursos utilizados em processos de produção similares.

Tal cenário fomenta a necessidade de se criarem caminhos que ajudem as empresas de Construção Civil a operarem dentro, ou o mais perto possível, dos melhores números que, traduzidos em indicadores, expressem a melhor produtividade.

\subsection{A Importância das Estruturas de Concreto Armado}

Os aspectos que justificam a importância das estruturas de concreto armado no cenário nacional, lembrados por diversos autores (ARAUJO, 2000; FREIRE, 2001; BATLOUNI NETO, 2002), continuam válidos e assim permanecerão até que outro sistema construtivo assuma a importância e a representatividade do concreto armado na constituição das estruturas reticuladas para as edificações brasileiras de grande altura (as estruturas metálicas e a alvenaria estrutural, possíveis alternativas às estruturas de concreto armado, ainda são pouco representativas no mercado de Construção Civil no país, segundo PELIZZARI (2001)). Merecem destaque, segundo BATLOUNI NETO (2002), os custos das estruturas de concreto armado, quando comparados aos das estruturas metálicas, o domínio tecnológico nacional na execução dessas estruturas e a abundância das matérias-primas necessárias à sua produção.

Deve-se ainda ressaltar a representatividade dos custos da execução das estruturas de concreto armado em relação aos custos totais das obras de edifícios. BATLOUNI NETO (2002), ao levantar os custos das estruturas em 16 edifícios construídos na cidade de São Paulo (entre julho de 2001 e março de 2002), chegou à conclusão de que a porcentagem dos ônus relativos à estrutura, no custo total, variou de $14,08 \%$ a $22,77 \%$, tendo como valor médio $17,69 \%$ (o autor associou as variações no custo das estruturas ao padrão de acabamento das obras: "à medida que o padrão de acabamento se eleva, reduz-se a proporção do custo da estrutura em relação ao custo global da obra").

\subsubsection{O Desenvolvimento das Estruturas de Concreto Armado}

O uso das estruturas de concreto armado para edifícios multipavimentos tem ocorrido num contexto que envolve, ao mesmo tempo, elogios e críticas. Trata-se do partido estrutural mais utilizado no Brasil (BATLOUNI NETO, 2003); estudos envolvendo o "material" concreto estão na vanguarda do desenvolvimento tecnológico (HELENE; BATLOUNI (2002)), frutos de pesquisas recentes utilizam sistemas construtivos racionalizados e industrializados (FREIRE, 2001). Porém as obras e, mais especificamente, os serviços envolvidos na execução dessas estruturas, são ainda geridos de forma empírica e deficiente, causando perdas significativas de eficiência produtiva (THOMAS et al. 2002).

A evolução tecnológica dos sistemas empregados na execução das estruturas de concreto armado não tem sido acompanhada, com a mesma intensidade, por uma evolução gerencial dos processos de produção. Esse descompasso pode levar ao comprometimento do desempenho potencial dos sistemas empregados, bem como da qualidade dos serviços executados. Há ainda que se apontar que inovações vigentes não têm se 
associado uniformemente aos serviços que compõem a execução da estrutura de concreto armado.

Nota-se que houve uma evolução significativa dos sistemas de fôrmas empregados na estruturação e moldagem das estruturas de concreto armado nos últimos anos (ASSAHI, 2004; ZORZI, 2002). A preocupação com a exeqüibilidade dos projetos estruturais, durante as etapas de fabricação e montagem dos sistemas de fôrmas, têm sido tema de debates e trabalhos, tanto no meio acadêmico como profissional (ASSAHI, 2002; FRANÇA, 2002; GRAZIANO, 2002; ZORZI, 2002). O desenvolvimento das chapas de madeira compensada utilizada nos moldes tem permitido que se utilizem materiais mais duráveis. O avanço nos sistemas de cimbramento, com peças mais leves e "inteligentes" (como, por exemplo, sistemas de cabeça descendente), induzem reflexos na produtividade durante as etapas de montagem. Os efeitos desse desenvolvimento podem ser sentidos no desempenho dos sistemas, podendo-se citar as seguintes vantagens: aumento no número de vezes que os componentes são utilizados; melhoria dos índices de produtividade da mão-de-obra durante a fabricação e montagem das fôrmas; redução dos custos de material e mão-de-obra de fôrmas por $\mathrm{m}^{3}$ de estrutura executada (ZORZI, 2002).

Os sistemas de concretagem apresentaram, por sua vez, nesses últimos anos, uma evolução do "material concreto" e dos sistemas de concretagem, podendo-se citar: o desenvolvimento de concretos especiais (com maior trabalhabilidade e resistência, por exemplo); o aperfeiçoamento dos sistemas de transporte e lançamento do concreto (envolvendo o uso de bombas capazes de vencer grandes alturas); a implementação de serviços de acabamento desempenhados por empresas especialistas, com equipamentos que agilizam o processo e conferem maior qualidade; a elevação da preocupação com a cura do concreto, sentida através de controles mais rígidos e técnicas mais apuradas.

Em que se pesem todos os avanços supracitados, sabe-se que há muito o que fazer, ainda, no plano tecnológico, no que se refere aos sistemas de fôrmas e concretagens. Como exemplo, pode-se citar um tema bastante discutido ultimamente e que passa pelo desenvolvimento dos sistemas comentados (bem como pelo dimensionamento estrutural), qual seja, aquele relativo à ocorrência de "deformações lentas", que têm preocupado o meio técnico. (FRANÇA, 2002)

Em se tratando da gestão da produção das estruturas de concreto armado, há um espaço a ser trabalhado que pode proporcionar melhorias significativas no desempenho final das estruturas (menores custos em razões de melhorias na produtividade). Os trabalhos de diagnósticos citados anteriormente revelaram valores de produtividade que, ora se comparam aos melhores índices, seja no panorama nacional como internacional, ora expressam valores bem distantes daqueles potencialmente obteníveis.

Os fatores que explicam essas variações podem estar relacionados às características do projeto do produto e/ou às diferentes disposições do contexto de trabalho no canteiro de obras no qual o mesmo se desenvolve.

Assim, o conhecimento dos "fatores influenciadores" pode balizar decisões, em três pontos centrais do processo de concepção e produção das estruturas (Figura 1.4), que terão reflexos nos índices de produtividade e, por conseguinte, no custo das mesmas, quais sejam: i) projeto do produto; ii) na proposição do método de trabalho; iii) na definição da organização do trabalho no canteiro de obras. 


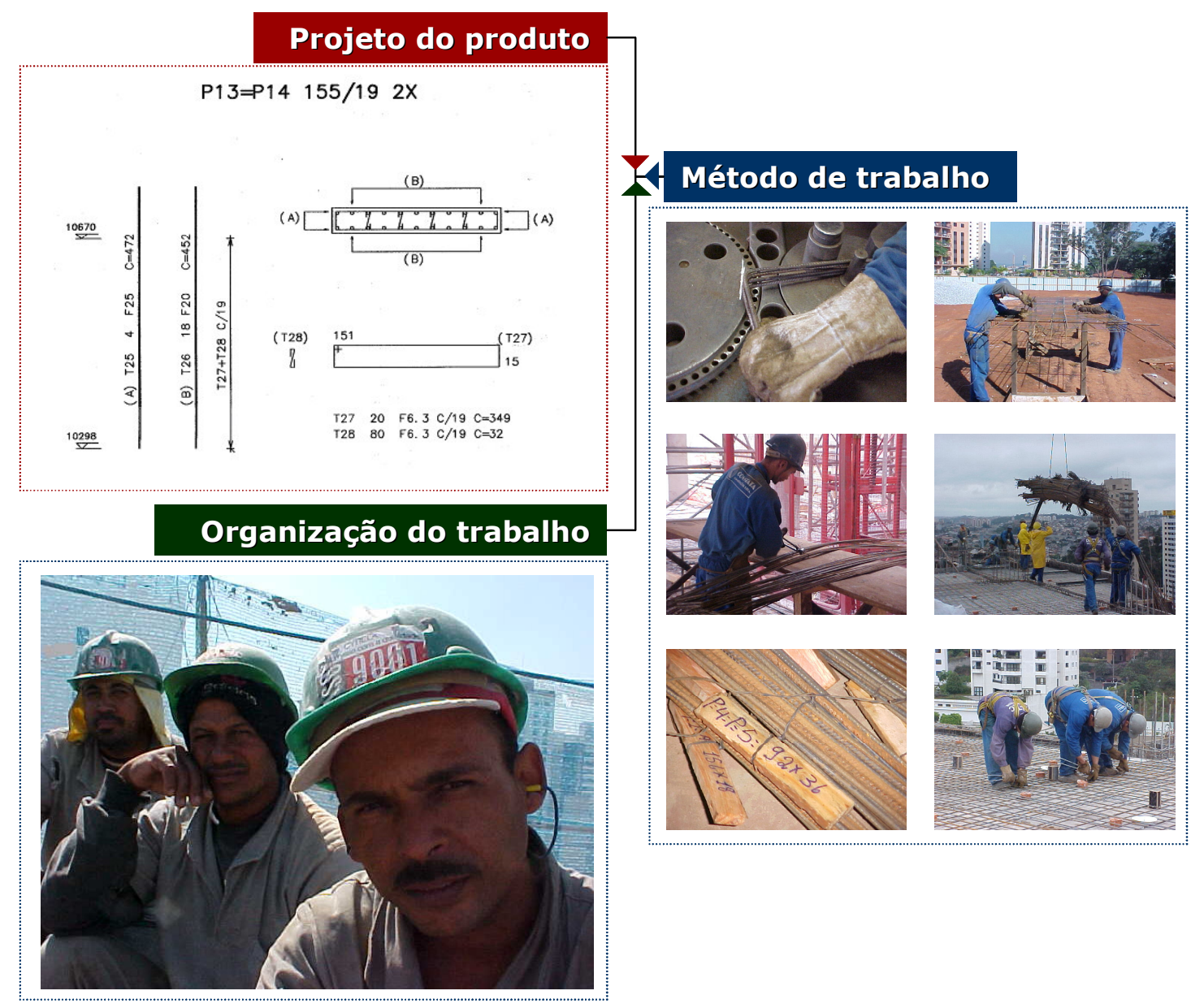

Figura 1.4 - Divisão dos fatores segundo três pontos centrais do processo de produção de estruturas de concreto armado

Os projetistas poderão, por exemplo, desenvolver os projetos estruturais à luz dos fatores associáveis a construtibilidade e, conseqüentemente, a produtividade (como no exemplo citado por FRANÇA (2002), em que propõe que se evite, sempre que possível, a presença de pilares que não sejam retangulares, favorecendo, neste caso, a montagem das fôrmas e das armaduras).

Os gestores da produção (subempreiteiros e contratantes) poderão propor métodos de trabalho que considerem: i) as características do projeto do produto; ii) as particularidades de cada operação frente ao contexto no qual estarão inseridas etc, contribuindo para elevar, dessa forma, a produtividade potencial do processo de produção.

Os mesmos gestores supracitados terão a tarefa de organizar o trabalho "otimizadamente", ao se apoiarem, para tanto, em fatores capazes de proporcionar influências positivas à produtividade da mão-de-obra. 


\subsection{A Justificativa da Escolha do Processo de Concepção e Produção de Armaduras}

Executar uma estrutura de concreto armado requer, necessariamente, a execução de três serviços principais, distintos, que se sucedem (e interagem): o serviço de fôrmas, o serviço de armação e o serviço de concretagem.

Chama-se atenção para a armação que extrapola, neste trabalho, o conceito de "serviço", sendo entendida como etapa relativa ao "processo de concepção e produção das armaduras", representado, a partir daqui, pela sigla "PCPA".

O PCPA tem uma posição de destaque nesta pesquisa, é bem verdade, já não sem tempo. Tanto as pesquisas acadêmicas, quanto a atenção despendida pelos profissionais de mercado têm mantido certa preferência pelos outros "serviços" que integram o "pacote" estrutura de concreto armado, quais sejam, as fôrmas (sistemas de fôrmas) e a concretagem (sistemas de concretagem). Trazer à tona o PCPA não se trata apenas de reavivar um tema menos abordado, mas sim, de uma necessidade real e imediata, melhor justificada, a seguir, com base na exposição de alguns aspectos relevantes:

- nos últimos quatro anos, para um IGP-M (índice geral de preços) acumulado de $69,03 \%$, o preço do vergalhão de aço subiu 194,4\% (aumento de $42,2 \%$ no ano de 2004), segundo dados apresentados pelo Sinduscon-SP ${ }^{5}$, aumentando significativamente a representatividade econômica do PCPA nos custos globais de construção de edifícios;

- os custos com mão-de-obra, na etapa de armação do PCPA, correspondem a aproximadamente $35 \%{ }^{6}$ do valor total da mão-de-obra relativa à execução da superestrutura, podendo representar até $50 \%$ dos custos totais com a mão-de-obra empregada na estrutura de pavimentos tipo (ZORZI, 2001);

- ARAÚJO (2000) constatou significativas variações na produtividade da mão-de-obra na etapa de armação do PCPA, dentro de uma mesma obra, bem como entre obras, para conteúdo e contexto de trabalhos semelhantes. Produtividades ruins foram justificadas por problemas intrínsecos à gestão, como falta de frente de trabalho gerando ociosidade de mão-de-obra, má organização dos locais de estoque etc;

- segundo FREIRE (2001), a execução da armação nas obras paulistanas é delegada a empresas subcontratadas em $80 \%$ dos casos. As subempreiteiras de armação são, na maioria dos casos, geridas por pessoas sem preparo e isentas de conhecimentos básicos de gestão de serviços;

- as subempreiteiras de armação são, em sua maioria, de pequeno porte, formadas sem nenhuma base administrativa e organizacional, muitas vezes sob indução das construtoras. Algumas construtoras colaboram para o insucesso dessas empresas ao permitirem (e podem fazer isso quando contratam pelo "menor valor") que as disputas pelo mercado se dêem não entre as mais aptas e preparadas, mas sim,

\footnotetext{
5 Os dados foram divulgados no jornal "Folha de São Paulo", caderno "Dinheiro", no dia 18 de novembro de 2004.

6 Segundo valores divulgados na Revista Construção Mercado - Índices e custos (número 35, de junho de 2004).
} 
entre as que chegam aos menores valores (muitas vezes insustentáveis ou "impraticáveis");

- a tecnologia na execução das armações nas obras ainda é baseada num modo de atuação artesanal e rudimentar, e os avanços percebidos (automação e mecanização) estão em geral situados do lado de fora do canteiro de obras, nas empresas que fornecem, para algumas obras, aço beneficiado (pré-cortado e pré-dobrado);

- as operações do processo de produção de armaduras que acontecem dentro do canteiro de obras são bastantes particulares e, nem sempre, são ordenadas para que aconteçam da maneira mais eficiente;

- não se tem conseguido explorar todo o potencial de racionalização oferecido pela utilização do aço fornecido à obra cortado e dobrado ("aço pronto") devido, principalmente, ao despreparo dos agentes (fornecedores, contratantes e subcontratados) em gerir o processo em que tal racionalização se faz presente;

- os projetos de detalhamento de armaduras não são analisados previamente pelos gestores das obras (eventuais falhas são apenas percebidas no momento em que os projetos são executados no campo);

- os projetos estruturais, em que pese aqui o detalhamento das armaduras, ainda não são realizados pensando-se, com profundidade, na sua exeqüibilidade, tanto no que se refere às operações ocorridas no canteiro de obras, quanto no que se refere àquelas desenvolvidas nas empresas que irão cortar e dobrar o aço que será enviado à obra;

- o projeto de detalhamento das armaduras trata do único canal de informação responsável por subsidiar todas as etapas do processo de produção (da quantificação, que subsidia os pedidos de material, à inspeção da montagem final) e, por assim ser, não atende, da maneira devida, a várias dessas etapas;

- as formas de representação dos projetos de detalhamento não apresentam uniformidade, dificultando a compreensão; tal variabilidade dificulta a comunicação e a troca de informações pelos executores na obra.

Se no Brasil trata-se de um tema que precisa ser melhor explorado ${ }^{7}$ em razão das justificativas supracitadas, fora do país o processo de produção de armaduras vem sendo estudado há alguns anos (BERNOLD, SALIM (1993); SALIM, BERNOLD (1994); DUNSTON (1994); DUNSTON, BERNOLD (1993); DUNSTON, BERNOLD (1994a); DUNSTON, BERNOLD, L. E. (1994b); DUNSTON ET AL. (1996); BERNOLD ET AL. (1989); CRSI (1992); MILTENBERGER, BERNOLD (1991); CHIN (2003)), o que reforça a importância da proposta de pesquisa aqui discutida.

\subsection{Formulação da Tese}

Considerando-se que:

- a eficiência do processo de produção (entradas transformadas em saídas) é condição necessária para se conseguirem bons resultados no cenário competitivo atual;

\footnotetext{
7 Destaque para os trabalhos de Tiago Marder e Carlos T. Formoso (MARDER; FORMOSO (2004a) e MARDER; FORMOSO (2004b)), desenvolvidos em Porto Alegre, e que tratam de oportunidades de melhorias na cadeia de suprimentos do aço cortado e dobrado para a construção civil.
} 
- as entradas do processo de produção são os recursos transformados (materiais, por exemplo) e os recursos de transformação (mão-de-obra e equipamentos);

- entende-se produtividade como sendo a eficiência envolvida em tal transformação;

- a produtividade da mão-de-obra é, portanto, a eficiência na transformação de esforço humano em produtos de construção;

- indicadores de produtividade, como a Razão Unitária de Produção - RUP - (SOUZA, 1996), constituem um instrumento poderoso de avaliação da eficiência;

- são três as categorias de fatores ${ }^{8}$ que influenciam a eficiência na transformação das entradas em saídas, afetando o desempenho dos processos de construção: i) conteúdo de trabalho; ii) contexto de trabalho; iii) anormalidades (interrupções);

- a RUP pode ser interpretada como a somatória de duas parcelas: uma primeira, à qual se denomina RUP potencial ( $\left.R U P_{\text {pot }}\right)$, que é determinada através da ponderação de características referentes ao conteúdo e ao contexto do trabalho; e uma segunda, determinada em função da presença de anormalidades (que levam a interrupções dos trabalhos), que podem estar associadas tanto ao contexto quanto ao conteúdo de trabalho (Figura 1.5);

- o contratante e o contratado (subempreiteiro e/ou operário) têm influências diferentes ${ }^{9}$ sobre os diferentes grupos de fatores citados; o mesmo se pode dizer quanto ao projetista estrutural responsável pela concepção do produto;

- o processo de produção de armaduras é pouco estudado, sendo discussões sobre sua eficiência e sobre os fatores que a ele se relacionam bastante pertinentes;

- o método e a organização do trabalho, responsáveis por "configurar" o contexto no qual o sistema de produção de armaduras é desenvolvido, são feitos de maneira precária nas obras de construção de edifícios;

- o processo do projeto de detalhamento de armaduras, da forma como é conduzido, não contempla, com o rigor necessário, as etapas do processo de produção de armaduras que irá servir.

Formula-se a seguinte hipótese:

O entendimento da relação "fatores $x$ produtividade" pode auxiliar as construtoras a criarem caminhos para a melhoria da produtividade. Tais caminhos devem passar, necessariamente, pela proposição de DIRETRIZES que serão destinadas: i) ao projetista

\footnotetext{
${ }^{8}$ Como já comentado em ARAUjO (2000), em situações usuais, como no processo de produção em questão, existem três grupos principais de fatores responsáveis pelas variabilidade da produtividade. $O$ primeiro deles diz respeito ao trabalho que precisa ser feito e abrange os componentes físicos do trabalho, as especificações exigidas e detalhes de projeto entre outros (por exemplo o "diâmetro médio das barras de aço"). THOMAS; SMITH (1990) se referem a eles como sendo os fatores relacionados ao conteúdo do trabalho. O segundo grupo de fatores está relacionado ao ambiente de trabalho e como ele é gerenciado; aspectos organizacionais (como, por exemplo, o dimensionamento das equipes), disponibilidade de materiais e equipamentos, seqüência de trabalho etc, caracterizam os chamados fatores de contexto do trabalho. As anormalidades configuram o terceiro grupo de fatores e são caracterizadas por situações anormais (quebra de equipamentos, por exemplo) e de difícil previsão (condições climáticas adversas, por exemplo) que afetam diretamente o serviço.

${ }^{9} \mathrm{O}$ contratante tem maior domínio sobre os fatores de conteúdo do trabalho; o executor domina os fatores de contexto do trabalho; ambos têm menos domínio sobre as anormalidades.
} 
estrutural, a fim de orientá-lo no desenvolvimento dos projetos de detalhamento das armaduras, de maneira que favoreçam, sempre que possível, a construtibilidade; ii) aos responsáveis (os próprios construtores e/ou subempreiteiros) pela definição do método de trabalho, que deverá ser orientado de maneira a permitir uma condução racional de todas as operações realizadas nos canteiros de obras no âmbito da produção de armaduras; iii) aos responsáveis (os próprios construtores e/ou subempreiteiros) pela sistematização da organização do trabalho no âmbito do processo de produção de armaduras, que deverá ser definida de maneira a favorecer a melhoria da produtividade da mão-de-obra, trazendo benefícios a todos os envolvidos no processo.

O que leva à seguinte Tese:

"É possível subsidiar o processo de concepção e produção de armaduras, com base em diretrizes para a elaboração do projeto do produto e a concepção do método e da organização do trabalho, de forma a aumentar a produtividade da mão-de-obra".

Observando-se que:

As DIRETRIZES podem estar no âmbito das decisões relativas ao conteúdo e ao contexto presentes no processo de produção de armaduras.

Assim sendo, as DIRETRIZES dizem respeito a tomadas de decisões tanto por parte do contratante como do contratado e poderão ter reflexo no desenvolvimento dos projetos do produto, do método e da organização do processo de produção das armaduras.

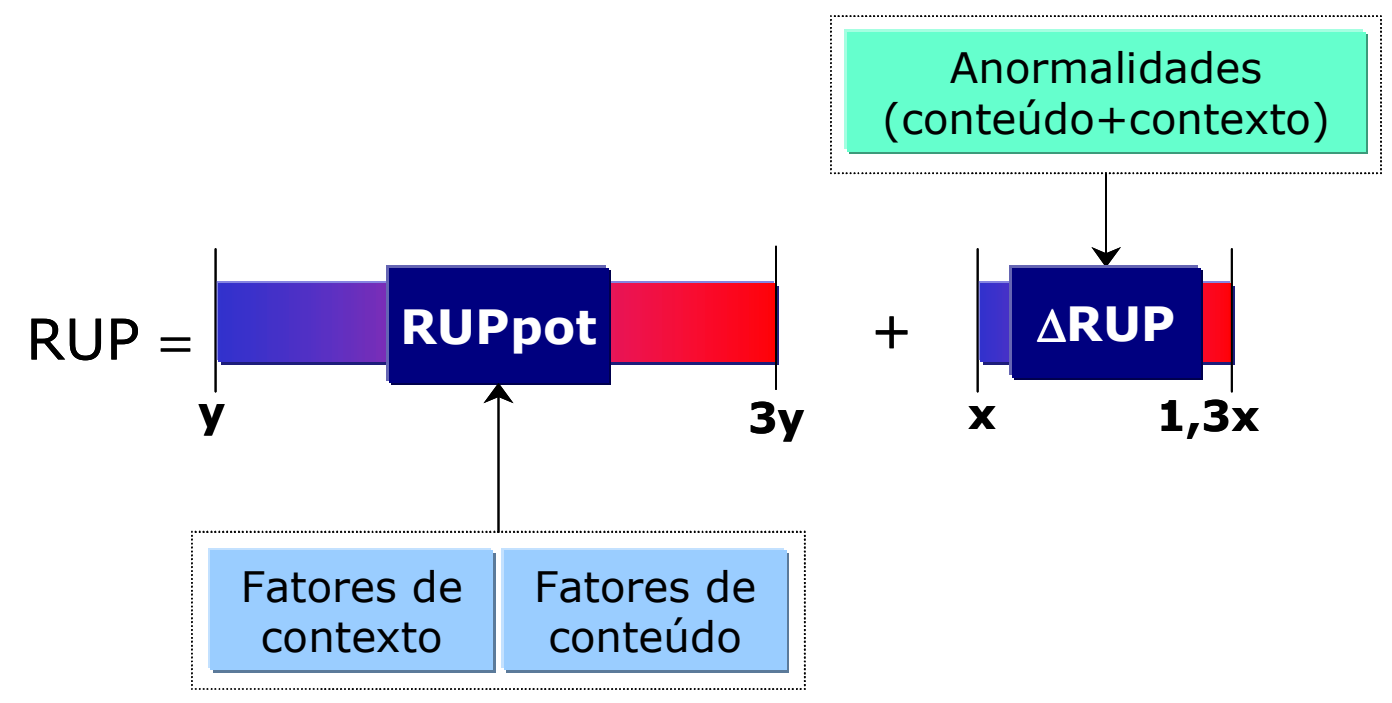

Figura 1.5 - Parcelas que compõem a RUP e fatores que influenciam tais parcelas.

\subsection{Objetivo}

Como base na formulação teórica supracitada, desejar-se-á: i) que o processo de projeto estrutural considere, sempre que possível, determinados fatores de conteúdo, no seu detalhamento, de maneira a favorecer a sua construtibilidade; ii) que o sistema de 
produção seja orientado por fatores de contexto que minimizem as influências negativas e maximizem as influências positivas ao seu desempenho. Espera-se, assim, reduzir surpresas indesejáveis durante a execução, contribuindo para a estabilidade da produtividade em níveis desejáveis e sabidamente capazes de serem obtidos.

Assim sendo, este trabalho objetiva desenvolver um método para proposição de diretrizes nos âmbitos do projeto do produto (projeto de detalhamento), do método e da organização do trabalho que, ao serem implementadas, possam contribuir para a melhoria da produtividade da mão-de-obra envolvida na produção de armaduras, em obras de construção de edifícios de construtoras.

Espera-se, assim, que a construtora, responsável pela aplicação do método, aja de forma pró-ativa, contribuindo para que o processo de produção de armaduras seja conduzido dentro de um cenário em que as variáveis de entorno (conteúdo e contexto) sejam conhecidas e que tenham sido pensadas criteriosamente, segundo as necessidades daquele momento. Estar-se-á, dessa forma, colaborando para melhorar a produtividade da mão-de-obra ao longo do processo de produção.

Como objetivos complementares, porém importantes para o cumprimento do objeto principal, estão:

- a proposição de uma sistematização de abordagem do PCPA (caracterização minuciosa, através de uma visão analítica do processo). Tal caracterização permitirá, tanto ao meio técnico quanto ao meio acadêmico, um avanço no entendimento e importância da armação, enquanto processo de produção nas estruturas de concreto armado.

- a apresentação dos principais elementos considerados na organização do trabalho nos processos de produção, presentes nos setor da Construção Civil.

- a amplificação da importância da gestão da produtividade como potente ferramenta para a melhoria do desempenho dos processos de produção presentes nos setor da Construção Civil.

- a organização de um banco de informações quanto à produtividade e fatores influenciadores em obras reais. 


\subsection{Contexto de Inserção desta Tese}

O avanço conseguido na área do conhecimento em que este trabalho se situa, ou seja, a gestão da produção, foi possível graças a um somatório de esforços despendidos na realização de trabalhos previamente realizados, imprescindíveis para o êxito do que aqui se efetiva.

Desenvolvido dentro do Departamento de Engenharia de Construção Civil da Escola Politécnica da Universidade de São Paulo, a trajetória deste trabalho esteve delineada pelos preceitos de um dos seis grupos de pesquisa (GEPEs) deste departamento, o grupo de Tecnologia e Gestão da Produção (TGP). Com forte apelo na gestão, procurou seguir as orientações preconizadas por umas das linhas de pesquisa (Planejamento, organização e gestão da produção) conduzidas pelo grupo, sob a orientação do Professor Associado Ubiraci Espinelli Lemes de Souza.

A Tabela 1.1 mostra, dentro de uma escala temporal, os principais trabalhos desenvolvidos pelo grupo supracitado que respaldaram a realização desta Tese.

Tabela 1.1 (continua) - Trabalhos que respaldaram o desenvolvimento da Tese

\begin{tabular}{|c|c|c|c|c|}
\hline Ano & Trabalho & Referência & Pontos de destaque & Objetivos alcançados \\
\hline 1996 & $\begin{array}{c}\text { Tese de } \\
\text { doutorado: } \\
\text { Metodologia para o } \\
\text { estudo da } \\
\text { produtividade da } \\
\text { mão-de-obra no } \\
\text { serviço de fôrmas } \\
\text { para estruturas de } \\
\text { concreto armado. }\end{array}$ & SOUZA, 1996 & $\begin{array}{l}\text { Parte do trabalho foi } \\
\text { desenvolvida nos } \\
\text { Estados Unidos, sob } \\
\text { co-orientação do Prof. } \\
\text { R. Thomas, que é uma } \\
\text { das maiores } \\
\text { autoridades em } \\
\text { produtividade da mão- } \\
\text { de-obra na Construção } \\
\text { Civil em todo o mundo }\end{array}$ & $\begin{array}{c}\text { Sistematização do } \\
\text { levantamento da } \\
\text { produtividade da mão- } \\
\text { de-obra }\end{array}$ \\
\hline 1998 & $\begin{array}{c}\text { Convênio de } \\
\text { pesquisa firmado } \\
\text { entre a USP e } 7 \\
\text { construtoras de SP } \\
\text { (Produtividade da } \\
\text { mão-de-obra nos } \\
\text { serviços de } \\
\text { estrutura de } \\
\text { concreto armado) }\end{array}$ & $\begin{array}{l}\text { SOUZA; } \\
\text { ARAÚJO } \\
(1999)\end{array}$ & $\begin{array}{l}\text { Interação entre os } \\
\text { agentes da cadeia } \\
\text { produtiva da } \\
\text { Construção, que } \\
\text { permitiu um } \\
\text { aprofundamento da } \\
\text { abordagem da } \\
\text { produtividade, } \\
\text { investindo-se num } \\
\text { trabalho criterioso e } \\
\text { pormenorizado. }\end{array}$ & $\begin{array}{l}\text { Conhecimento dos } \\
\text { níveis de produtividade } \\
\text { praticados pelo } \\
\text { mercado e dos motivos } \\
\text { que os determinaram. }\end{array}$ \\
\hline 2000 & $\begin{array}{l}\text { Dissertação de } \\
\text { mestrado: Método } \\
\text { para a previsão da } \\
\text { produtividade da } \\
\text { mão-de-obra }\end{array}$ & ARAÚJO, 2000 & \multicolumn{2}{|c|}{$\begin{array}{c}\text { Consolidação de um método padronizado para } \\
\text { previsão e controle da produtividade da mão-de- } \\
\text { obra envolvida na execução de fôrmas, armação } \\
\text { e concretagem passível de aplicação contínua } \\
\text { em obras de Construção Civil. }\end{array}$} \\
\hline
\end{tabular}


Tabela 1.1(conclusão) - Trabalhos que respaldaram o desenvolvimento da Tese

\begin{tabular}{|c|c|c|c|c|}
\hline Ano & Trabalho & Referência & Pontos de destaque & Objetivos alcançados \\
\hline 2001 & $\begin{array}{c}\text { Dissertação de } \\
\text { mestrado: } \\
\text { Produção de } \\
\text { estruturas de } \\
\text { concreto armado, } \\
\text { moldadas in loco, } \\
\text { para edificações: } \\
\text { caracterização das } \\
\text { principais } \\
\text { tecnologias e } \\
\text { formas de gestão } \\
\text { adotadas em São } \\
\text { Paulo }\end{array}$ & FREIRE, 2001 & $\begin{array}{c}\text { A compilação e } \\
\text { discussão das } \\
\text { informações facilitam a } \\
\text { disseminação deste } \\
\text { conhecimento e } \\
\text { subsidiam a } \\
\text { reavaliação dos } \\
\text { caminhos adotados } \\
\text { pelas empresas e pelos } \\
\text { outros agentes } \\
\text { envolvidos na } \\
\text { produção de } \\
\text { estruturas, na medida } \\
\text { em que recebam } \\
\text { informações } \\
\text { consistentes sobre } \\
\text { outras possibilidades } \\
\text { de gestão e execução } \\
\text { da mesma. }\end{array}$ & $\begin{array}{c}\text { Caracterização das } \\
\text { principais tecnologias e } \\
\text { formas de gestão da } \\
\text { produção adotadas na } \\
\text { execução de estruturas } \\
\text { de concreto armado na } \\
\text { região da Grande São } \\
\text { Paulo. }\end{array}$ \\
\hline 2001 & $\begin{array}{l}\text { Tese de livre } \\
\text { docência }\end{array}$ & SOUZA, 2001 & \multicolumn{2}{|c|}{$\begin{array}{c}\text { Muniu a Construção Civil, sub-segmento } \\
\text { Edifícios, de procedimentos para se estimar a } \\
\text { produtividade da mão-de-obra e o consumo } \\
\text { unitário de materiais, (serviços de fôrmas, } \\
\text { armação, concretagem, entre outros), e } \\
\text { fomentar uma ampla e contínua discussão do } \\
\text { assunto. }\end{array}$} \\
\hline 2002 & $\begin{array}{l}\text { Publicação da } \\
\text { TCPO } 13\end{array}$ & TCPO, 2003 & $\begin{array}{l}\text { Introdução de réguas } \\
\text { de produtividade. }\end{array}$ & $\begin{array}{l}\text { Consolidação, no } \\
\text { mercado, de } \\
\text { ferramentas } \\
\text { orçamentárias mais } \\
\text { realistas }\end{array}$ \\
\hline
\end{tabular}

Observando a Tabela 1.1 nota-se que os trabalhos preconizam o uso de indicadores de produtividade como um dos principais instrumentos para tratar a gestão da produção. Os trabalhos citados tiveram, como característica marcante, extensos levantamentos de campo (trabalhos pautados fortemente em DIAGNÓSTICOS), que consolidaram um grande banco de dados, cujas análises têm permitido: i) que o setor melhor se conheça; ii) que o setor se aperceba das variações quanto à eficiência no uso que faz dos recursos; iii) que o setor, em conjunto com a academia, busque caminhos para reduzir as variabilidades detectadas, trazendo a produtividade da mão-de-obra sempre para junto dos melhores valores possíveis de serem obtidos.

Fruto das constatações supracitadas é que surge, naturalmente, a justificativa para esta tese. A variabilidade quanto à eficiência no uso dos recursos que acomete o setor (eleva os custos) precisa ser combatida. Isso significa criar caminhos para que as empresas operem dentro, ou o mais perto possível, da faixa de desempenho relativa aos melhores números, números esses que, traduzidos em indicadores, expressem máxima eficiência, ou, melhor produtividade. Trata-se, portanto, de um trabalho que utilizará o diagnóstico (realizado em trabalhos anteriores (ARAÚjO (2000)), mas que será ampliado) para BALIZAR DECISÕES. 
As decisões estarão direcionadas ao processo de produção de armaduras. Trata-se de um processo de produção que, mesmo fortemente relacionado a outros processos produtivos que perfazem a execução das estruturas de concreto armado, como a execução das fôrmas e concretagens, possui "vida" própria, merecendo ser tratado com exclusividade (as justificativas apresentadas no item 1.4 ratificam esse posicionamento).

\subsection{Metodologia}

Para atingir os objetivos propostos no item 1.6, o trabalho foi desenvolvido seguindo quatro etapas principais, apresentadas na Figura 1.6. As etapas de revisão bibliográfica e de estudos exploratórios foram desenvolvidas concomitantemente e aconteceram ao longo de todo o período de elaboração do trabalho.

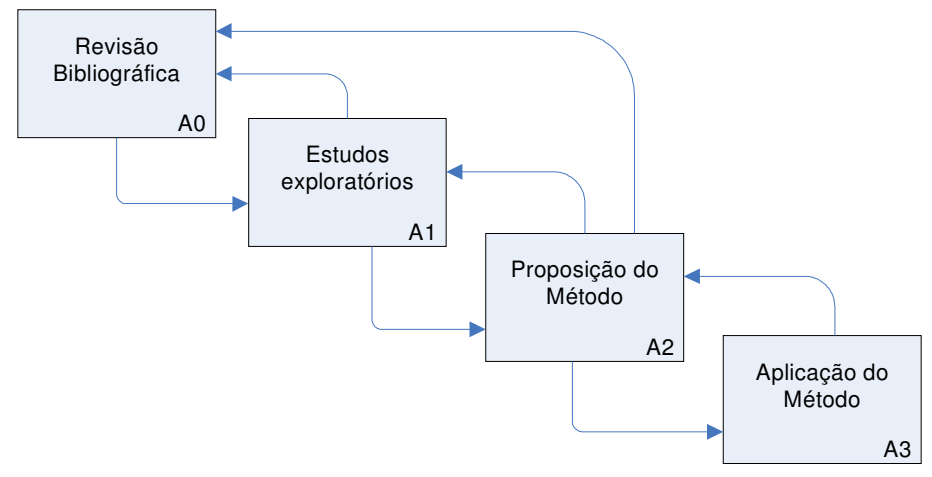

Figura 1.6 - Etapas principais para o desenvolvimento do trabalho

As quatro etapas podem ser melhor compreendidas, a seguir, com base na discriminação das partes que constituem cada uma delas:

\subsubsection{Revisão Bibliográfica (A0)}

Esta etapa pode ser dividida em duas sub-etapas (Figura 1.7), segundo os assuntos tratados e os objetivos buscados com a revisão, apresentados a seguir:

\section{A01 - Teorias de Organização do Trabalho}

As revisões aqui serviram para conferir ao autor uma visão dos aspectos relacionados à gestão da produção no âmbito da organização do trabalho. Buscou-se, num primeiro momento, conhecer as práticas e teorias advindas da manufatura (caixa A011; Figura 1.7) para, num segundo momento, investigar o comportamento da Construção Civil no campo da organização do trabalho (caixa A012; Figura 1.7).

O objetivo dessa sub-etapa do trabalho de revisão foi o de definir quais os principais elementos da organização do trabalho a serem considerados pelos gestores (construtores e/ou subempreiteiros), para melhor conduzir os processos de produção sob sua responsabilidade. 


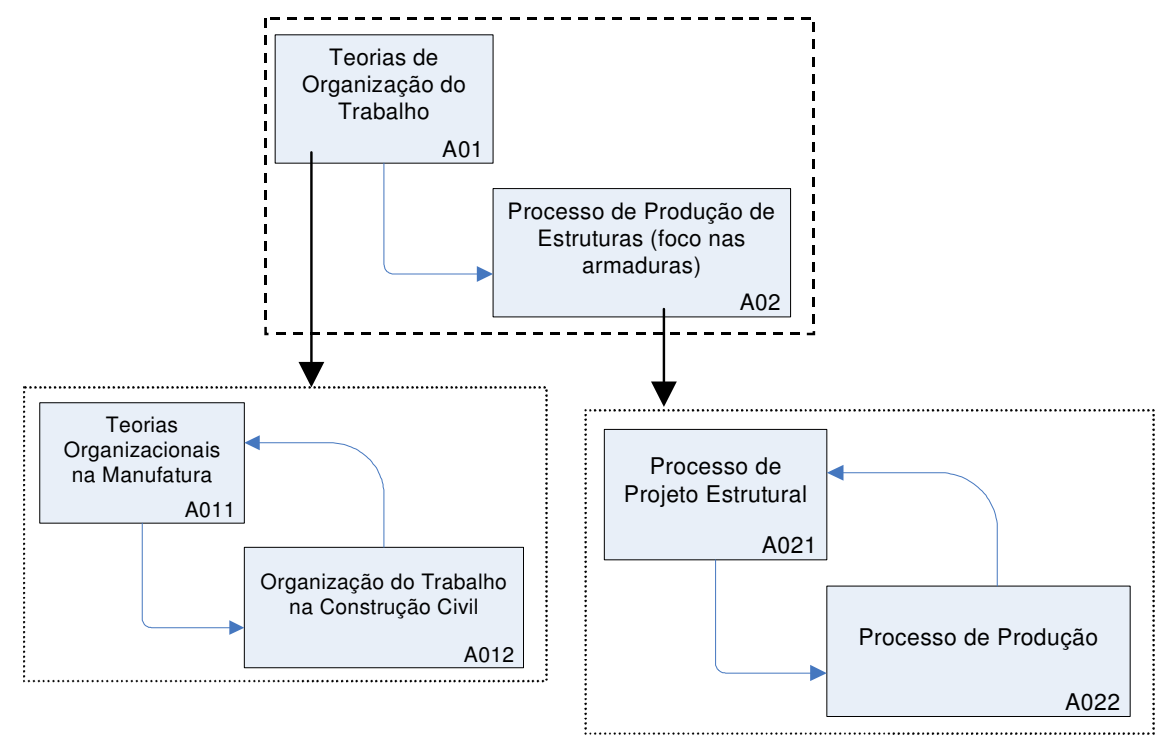

Figura 1.7 - Detalhamento da etapa de revisão bibliográfica

\section{A02 - Processo de Produção de Estruturas}

As revisões serviram para conferir ao autor uma visão analítica do serviço de armação, sem perder a visão sistêmica da produção de estruturas. Para tanto, foram considerados na revisão: i) aspectos relacionados ao processo de concepção estrutural, com preocupação especial na etapa de detalhamento das armaduras (caixa A021; Figura 1.7); ii) aspectos relacionados à produção, propriamente dita, das armaduras (caixa A022; Figura 1.7).

O objetivo dessa sub-etapa do trabalho de revisão foi o de contribuir para a proposição de uma sistematização na abordagem do processo de concepção e produção das armaduras.

\subsubsection{A1 - Estudos exploratórios}

Esta etapa engloba três passos (Figura 1.8), segundo os momentos em que se deram e os objetivos pretendidos em cada um deles, apresentados a seguir:

\section{A11 - Visitas preliminares a obras}

As visitas a obras ocorreram com grande freqüência ao longo de todo o desenvolvimento. Permitiram, ao autor, fortalecer a visão crítica com relação à produção de estruturas de concreto armado, bem como garantir conhecimentos preliminares prévios sobre o projeto do produto, o método e a organização do trabalho, orientando as etapas seguintes da metodologia.

Pode-se dizer que este passo aconteceu através do acompanhamento (caixa A111; Figura 1.8) da produção de estruturas reticuladas de concreto armado (ERCA), realizado em algumas obras (visitas esporádicas, contemplando mais de 10 canteiros de obras na cidade de São Paulo), sendo que seu cumprimento conferiu ao autor o embasamento prático necessário para as etapas que se seguiram. 


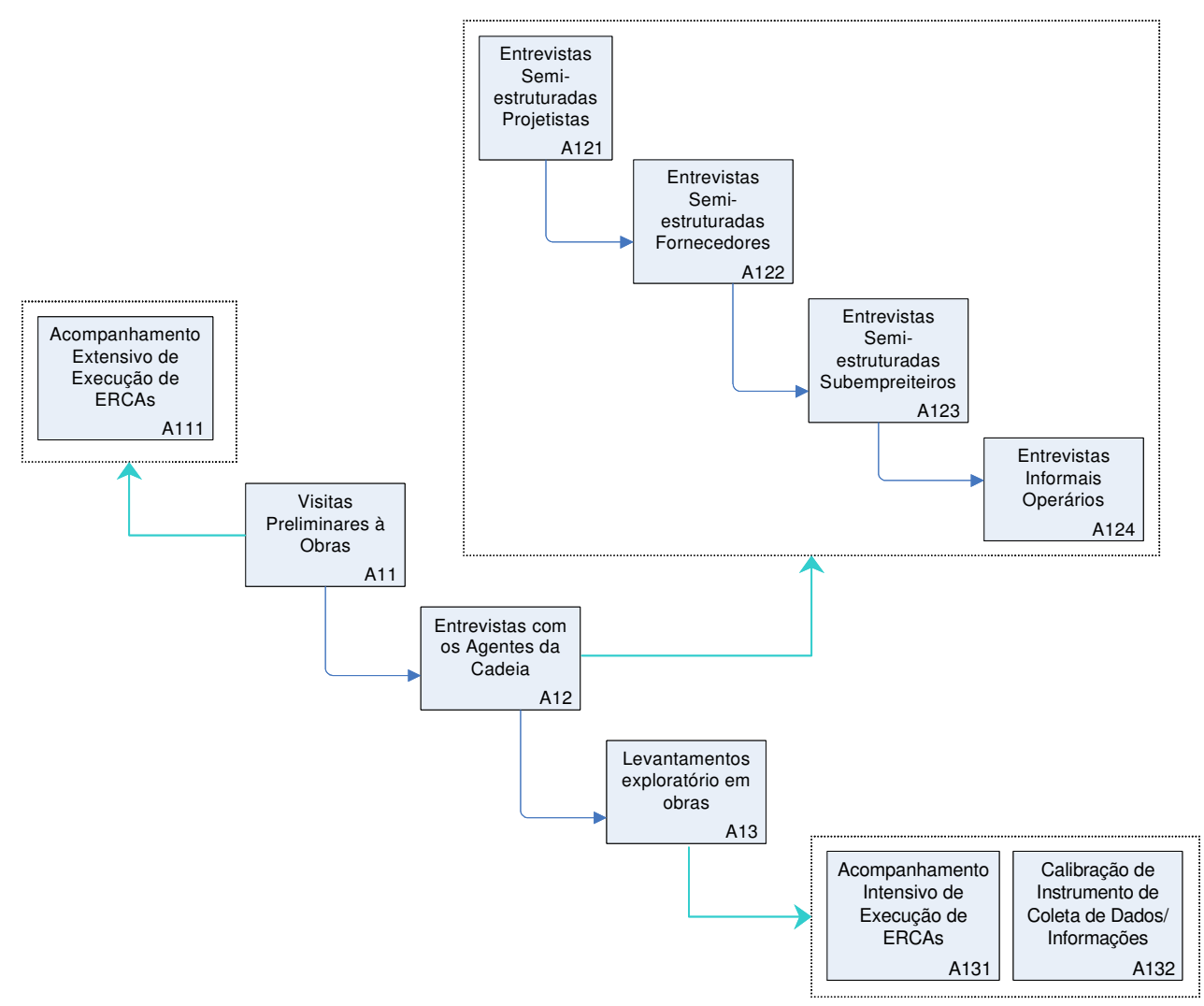

Figura 1.8 - Detalhamento da etapa de pesquisa de campo

\section{A12 - Entrevistas com Agentes da cadeia}

Foram identificados os agentes pertencentes à cadeia produtiva das armaduras. A base conceitual advinda das revisões e da visão analítica do processo de concepção e produção de armaduras, somada às práticas detectadas nas obras visitadas até este momento, subsidiaram a elaboração de questionários semi-estruturados que balizaram as entrevistas com diferentes agentes da cadeia (Figura 1.8).

Dessa forma, foram realizadas entrevistas (orientadas por questionários semiestruturados) junto a projetistas (3 escritórios de cálculo), fornecedores de insumos (dois dentre os três principais fornecedores de aço para obras de edifícios no Brasil), consultores (04 consultores em gestão e planejamento de obra), gestores de obras, consultores, subempreiteiros e operários (4 canteiros de obras, 4 subempreiteiras de estrutura/armação)

Permitiu-se, assim: i) conhecer as formas de organização do trabalho, no processo de produção de armaduras, vigentes nas obras de construção de edifício da cidade de São Paulo; ii) conhecer os métodos de trabalho adotados nos canteiros visitados; iii) conhecer a participação e o envolvimento dos agentes da cadeia situados fora do canteiro de obras (projetistas e fornecedores) na organização do trabalho. O embasamento adquirido foi imprescindível para o desenvolvimento do método, ao qual procurou-se dar uma conformação mais voltada às necessidades elencadas a partir das entrevistas. 


\section{A13 - Levantamentos exploratório em obras}

Acompanhou-se, durante um período aproximado de quatorze meses, duas obras de construção de edifícios (caixa A131; Figura 1.8). Na primeira, procurou-se focar o processo de produção; na segunda, aspectos relativos à organização do trabalho. Mais que conferir um conhecimento aprofundado sobre o processo de produção de estruturas, o caráter intensivo do acompanhamento possibilitou a que este pesquisador certificar-se de que as fontes de evidência, escolhidas para subsidiar o levantamento de informações/dados (previstos no método), seriam capazes de fazê-lo com nível de qualidade desejado. Neste período de permanência em obra, os instrumentos desenvolvidos para a coleta de dados foram calibrados e as técnicas de abordagem aferidas (caixa A132; Figura 1.8).

\subsubsection{A2 - Proposição do Método}

A terceira etapa da metodologia (caixa A2; Figura 1.6) consistiu no desenvolvimento e, conseqüente proposição, de um método que fosse capaz de orientar as empresas construtoras, de pequeno e médio porte na proposição de diretrizes que lhes permitissem, entre outros, sistematizar a organização do trabalho, aumentar a eficiência ao longo do processo de produção e orientar os projetistas na concepção de projetos de detalhamento de armaduras mais favoráveis sob o ponto de vista da construtibilidade (o intuito final, pretendido pela construtora com a implementação do método proposto, seria o de melhorar a produtividade da mão-de-obra no processo de produção das armaduras).

A última etapa do método (apresentado integralmente no capítulo 05 desta tese), prevê, por exemplo, que a determinação das diretrizes, pela construtora, se dê a partir de discussões, fomentadas por ela, com os principais agentes da cadeia da produção e concepção de armaduras, envolvendo, para tanto, os dados e informações levantados na etapa de diagnóstico.

\subsubsection{A3 - Aplicação/Validação do Método}

A última etapa da metodologia trata-se da aplicação/validação do método (caixa A3; Figura 1.6), mediante a estruturação de um estudo de caso que, segundo as necessidades da pesquisa, ficou caracterizado por contemplar, a partir de um contratante, sete canteiros de obras nos quais estiveram presentes seis empreiteiras de mão-de-obra e cinco projetistas estruturais distintos.

Evidencia-se, aqui, a excelente oportunidade aberta a este pesquisador por uma empresa de Construção Civil atuante na cidade de São Paulo (trabalho em parceria Universidade/Empresa). Garantiu-se, assim, acesso amplo e irrestrito a todas as informações necessárias para a aplicação do método, haja vista a empresa contratante ter atendido às seguintes condições: i) ter disponibilidade de obras na fase de execução de estruturas (reticuladas em concreto armado); ii) estar convencida, bem como convencer seus empreiteiros, fornecedores e todo o seu pessoal de produção, quanto à importância da aplicação do método, disponibilizando, dessa maneira, informações (principalmente projetos estruturais) e pessoal para o cumprimento de todas as etapas previstas no método.

A aplicação do método, da maneira como foi conduzida, contou com a atuação do pesquisador na sua implementação em razão do seu caráter de experimentação/validação. Porém, pelo êxito na aplicação e pelos resultados alcançados 
valida-se o método proposto nesta tese e acredita-se que as construtoras consigam implementá-lo, de forma independente, com relativa facilidade.

\subsection{Estruturação dos Capítulos}

O desenvolvimento da tese se dá ao longo de oito capítulos, com mostrado na Tabela 1.2 .

Tabela 1.2 - Apresentação da estruturação dos capítulos

\begin{tabular}{|c|c|c|}
\hline Capítulo & Conteúdo & $\begin{array}{l}\text { Etapa } \\
\text { correspondente } \\
\text { da metodologia }\end{array}$ \\
\hline $\begin{array}{l}1^{\circ} \\
\text { Capítulo }\end{array}$ & $\begin{array}{c}\text { Trata-se do presente capítulo, onde se destaca a } \\
\text { apresentação do objetivo do trabalho e a metodologia de } \\
\text { pesquisa utilizada para atingi-lo. }\end{array}$ & \\
\hline $\begin{array}{l}2^{\circ} \\
\text { Capítulo }\end{array}$ & $\begin{array}{l}\text { Intitulado "O Processo de Concepção e Produção de } \\
\text { Armaduras para Estruturas de Concreto Armado", propõe } \\
\text { uma sistematização de abordagem do referido processo, } \\
\text { percorrendo todas as suas etapas, desde a concepção } \\
\text { estrutural, focando o projeto de detalhamento das } \\
\text { armaduras, até as operações de canteiro, no âmbito do } \\
\text { método do trabalho. }\end{array}$ & $\begin{array}{c}\mathrm{A} 021 ; \mathrm{A} 022 ; \\
\mathrm{A} 111 ; \mathrm{A} 121 ; \\
\mathrm{A} 122 ; \mathrm{A} 123 ; \mathrm{A} 124\end{array}$ \\
\hline $\begin{array}{l}3^{\circ} \\
\text { Capítulo }\end{array}$ & $\begin{array}{l}\text { Trata-se de um capítulo conceitual, respaldado em uma } \\
\text { ampla revisão bibliográfica, tendo como objetivo chegar-se a } \\
\text { um entendimento sobre organização do trabalho. }\end{array}$ & A011 \\
\hline $\begin{array}{l}4^{\circ} \\
\text { Capítulo }\end{array}$ & $\begin{array}{l}\text { Apresenta modelos de gestão que buscam a melhoria de } \\
\text { desempenho através de reduções nas variabilidades de } \\
\text { processos de produção. Discute-se, também, como aspectos } \\
\text { relacionados à organização do trabalho, ao projeto do produto } \\
\text { e ao método do trabalho podem influenciar a produtividade } \\
\text { da mão-de-obra e, portanto, serem também responsáveis por } \\
\text { sua variabilidade. }\end{array}$ & $\mathrm{A} 012, \mathrm{~A} 021, \mathrm{~A} 022$ \\
\hline $\begin{array}{l}5^{\circ} \\
\text { Capítulo }\end{array}$ & $\begin{array}{l}\text { Apresenta a o método para a proposição de diretrizes, com } \\
\text { foco na sua estruturação e operacionalização. }\end{array}$ & $\mathrm{A} 2$ \\
\hline $\begin{array}{l}6^{\circ} \\
\text { Capítulo }\end{array}$ & $\begin{array}{l}\text { Apresenta a aplicação do método, ao longo de todas as suas } \\
\text { etapas, num caso real (empresa construtora de médio porte). }\end{array}$ & A3 \\
\hline $\begin{array}{l}7^{\circ} \\
\text { Capítulo }\end{array}$ & $\begin{array}{l}\text { Este capítulo traz as considerações finais, conclusões e } \\
\text { proposições de temas para continuidade da pesquisa }\end{array}$ & \\
\hline RB & $\begin{array}{l}\text { Apresenta as referencias bibliográficas citadas ao longo dos } \\
\text { capítulos anteriores. }\end{array}$ & \\
\hline
\end{tabular}




\section{Armaduras para Estruturas de Concreto Armado}

\subsection{Notas introdutórias ao capítulo}

O presente capítulo percorre as três macro-etapas do processo de produção de armaduras: a etapa de projeto estrutural, focando o projeto de detalhamento das armaduras; a etapa de fabricação das armaduras, realizada fora do canteiro de obras; e, por último, discute a etapa de armação, em que são apresentadas todas as operações realizadas no canteiro de obras no âmbito do processo de produção de armaduras.

Antes, porém, faz-se uma revisão que se inicia com a história das siderúrgicas nacionais, passando pela produção do aço, ressaltadas as características e propriedades desse material. Num momento seguinte, apresentam-se as armaduras presentes nas estruturas de concreto armado de edifícios, destacando-se suas funções e as principias características dos arranjos estruturais, respaldando-se nas definições preconizadas pela NBR 6118:2003.

Apresenta-se, ao final do capitulo, um fluxograma com as principais atividades compreendidas nas três macro-etapas do processo de produção das armaduras.

\subsection{A história do aço nas estruturas de concreto armado}

A julgar pela relevância e importância que o concreto armado atingiu no Brasil, não seria contra-senso abrir este capítulo com um breve resgate histórico desse partido estrutural, que hoje é tido como sinônimo de estrutura, tamanha a sua presença no cenário da construção civil nacional (segundo dados da Associação Brasileira do Cimento Portland $(A B C P), 80 \%$ das obras de edifício multipavimentos são em concreto armado).

A história do concreto armado no Brasil pode ser contada sob diferentes pontos de vista: do material concreto, dos primeiros projetos e projetistas, das grandes obras etc. Qualquer que seja ele, contar-se-á sempre uma história de sucesso que, somada às demais, acabou por colocar o Brasil em ponto de destaque no cenário internacional quanto à realização de estruturas de concreto armado.

Porém, como o tema central da tese gira em torno das armações, este autor tratou de recordar a história do concreto armado, focando dois aspectos, menos comentados nos debates sobre o tema, mas de grande importância e com grande contribuição para o crescimento do uso do concreto armado nas obras brasileiras: a descoberta da importância do aço como coadjuvante do concreto e a história da siderurgia brasileira.

\subsubsection{A Sinergia entre Aço e Concreto}

AMARAL (1964); FUSCO (1975); LEONHARDT (1978); SUSSEKIND (1983); em suas obras sobre os fundamentos do concreto armado, resgatam a história desse partido estrutural, citando momentos relevantes e personagens comuns (J. PARKER e a invenção do cimento romano, em 1796, na Inglaterra; o francês J. ASPIDIN que, em 1824, 
apresentou o cimento Portland; J. L. LAMBOT, que construiu um barco com argamassa de cimento reforçada com ferro, em 1855; J. MONIER, em 1861, que construiu um vaso de flores em concreto com armadura de arame; F. COIGNET que, em 1861, publicou os princípios básicos para as construções em concreto armado e apresentou, na Exposição Internacional de Paris, em 1867, vigas e tubos de concreto armado).

Os pioneiros do concreto armado, supracitados, como outros tantos, foram também mencionados com uma grande riqueza de detalhes na obra do professor Augusto Carlos de Vasconcelos (VASCONCELOS (2002)), que faz um "resgate histórico" da história do concreto armado no mundo.

"Tem-se conhecimento de que, muito tempo antes, já se havia notado o uso do ferro junto com o concreto, sob a forma de tirantes na "Loggia dei Lanzi" de Florença, na Igreja de Santa Sofia em Constantinopla e sob a forma de barras circulares e meridianas na cúpula de São Pedro em Roma. A idéia de associar barras metálicas à pedra ou argamassa, com a finalidade de aumentar a resistência às solicitações de serviço, remonta ao tempo dos romanos." (VASCONCELOS (2002)).

O professor Nilo Andrade Amaral, em sua obra "Construções de Concreto" de 1964, divagando sobre o advento do concreto armado, "imaginara" que ele "tenha surgido pelo desejo de criar-se um tipo de construção que, utilizando uma "pedra" artificial, apresentasse a durabilidade da pedra natural, tivesse a vantagem de ser fundido nas dimensões e formas desejadas e, associando o aço a essa "pedra" artificial, aproveitasse a alta resistência desse material, ao mesmo tempo que, protegendo-o, aumentasse sua durabilidade."

Assim, o professor Nilo Andrade Amaral definiu o concreto armado como sendo "a união do concreto e de um material resistente à tração (envolvido pelo concreto) de tal modo que ambos resistam solidariamente aos esforços a que forem submetidos."

FUSCO (1975); LEONHARDT (1983); SUSSEKIND (1983); VASCONCELOS (2002), assim como tantos outros mestres do concreto armado, vêem na solidariedade entre a armadura e o concreto a principal característica para a existência do concreto armado.

O professor Péricles Brasiliense Fusco, em sua obra "Fundamentos do Projeto Estrutural", de 1975, aborda o principio fundamental do "funcionamento" do concreto armado da seguinte forma:

"Para que os dois materiais trabalhem solidariamente, não deve existir escorregamento relativo entre ambos. É preciso que o conjunto, concreto mais armadura, se comporte como um todo. As barras da armadura perdem sua individualidade e passam a se constituir em fibras resistentes à tração da peça de concreto armado. A seção transversal resistente é constituída em parte pelo concreto e em parte pela armadura. Desse modo, a manutenção da seção plana, refere-se ao conjunto dos dois materiais e não a cada um deles separadamente."

Em 1995, o professor Péricles Brasiliense Fusco, em nova obra, intitulada "Técnica de Armar as Estruturas de Concreto Armado" (que se trata de uma renovação e ampliação da obra anterior, supracitada) comenta, no prefácio da edição, que:

[...] com a renovação de conhecimentos ocorrida principalmente nas duas últimas décadas, as armaduras de aço deixaram de ser consideradas como simples fibras resistentes à tração e passaram a ser tratadas como elementos de grande resistência e rigidez embutidos em massa de concreto. 
São de SUSSEKIND (1983) os comentários pertinentes, escolhidos e apresentados a seguir, para encerrar esta rápida revisão da história do concreto armado:

[...] se em termos de formulação de teorias fundamentais do concreto armado e protendido, o Brasil não apresentou contribuição maior, face ao estágio de avanço tecnológico, à época, das nações européias, podemos dizer que nas aplicações destes materiais, soube dar notáveis exemplos de arrojo e criatividade, sendo nossa Engenharia de Projeto e Construção em Concreto internacionalmente reconhecida e respeitada nos dias atuais. É preciso deixar registrada a importância do trabalho desenvolvido por Emílio Baumgart, pai da Engenharia Estrutural brasileira, que projetou o primeiro arranha-céu em concreto armado no mundo (sede de "A Noite", no Rio de Janeiro).

\subsubsection{A siderurgia nacional}

A história do ferro no Brasil data do ano de 1589, com a instalação da primeira manufatura de ferro, no lugar onde hoje está a cidade de Sorocaba, no estado de São Paulo. Apresentam-se, a seguir, trechos desta história, obtidos durante a consulta aos documentos da Siderúrgica Belgo Mineira, Grupo Arcelor, disponíveis na Internet ${ }^{10}$.

A primeira manufatura de ferro se instalou no Brasil após 1589 em Biraçoiaba (ou Araçoiaba), local próximo à atual cidade de Sorocaba, no interior de São Paulo. Apenas no início do século XIX as fábricas de ferro começaram a ganhar importância. Entre 1809 e 1814, o Intendente Câmara instalou a Real Fábrica de Ferro do Morro do Pilar, nas proximidades do Tejuco. A fábrica funcionou com dois pequenos fornos suecos e foi desativada em 1831.

Em 1810, longe dali, no sítio paulista de Araçoiaba, foi oficialmente criada a Fábrica Ipanema, da qual a Coroa participava. A administração era chefiada pelo alemão Frederico Luís Guilherme de Varnhagen. No dia $1^{\circ}$ de novembro de 1818, dia de Todos os Santos, a primeira corrida de gusa em um altoforno ocorreu em terras brasileiras. Do metal produzido naquele dia foram moldadas três grandes cruzes, sendo a maior delas fixada no morro vizinho à fábrica.

Em 1811, o engenheiro Eschwege implantou a usina Patriótica, em Congonhas do Campo (MG), em local bem próximo aos centros mineradores de ouro. Em 1812 saiu de lá a primeira partida de ferro de qualidade industrial no país. Em 1822, após a declaração da independência do Brasil, Eschwege voltou para a Europa junto com a família real. Aos poucos, a Patriótica foi se transformando apenas em ruínas, que até hoje estão em Congonhas do Campo [...].

A partir de 1950 foram criadas várias siderúrgicas de domínio estatal (CSN, USIMINAS, COSIPA) que, somadas a outras de domínio privado, constituíram o chamado complexo siderúrgico nacional.

Juntas, CSN, Cosipa e Usiminas compuseram a base siderúrgica montada pelo governo para sustentar o ritmo acelerado da industrialização brasileira naquele período. No início da década de 60, também foi criada a Cofavi Companhia Ferro e Aço de Vitória, no Espírito Santo.

Mas, naquele período, o agravamento das dificuldades econômicas e sociais gerou a "crise de 64". Após um período de crescimento vertiginoso, seguiu-se a total retração do mercado, em especial para a Construção Civil, uma das

${ }^{10}$ Siderúrgica Belgo Arcelor. Disponível em < http://belgo.com.br> Acesso em: 25 Mai. 2003 
áreas que mais consumiam produtos de ferro e aço. O Brasil possuía então 41 usinas, controladas por 36 empresas, das quais cinco eram estatais.

O governo brasileiro buscou, assim, traçar um novo planejamento siderúrgico para o Brasil, que resultou na edição, em 1967, do Plano Siderúrgico Nacional e na criação do CONSIDER - Conselho Consultivo da Indústria Siderúrgica, subordinado ao Ministério da Indústria e do Comércio, no ano seguinte. Com a missão de definir uma política siderúrgica nacional, possibilitando a retomada do desenvolvimento do setor, em parceria com o recém-criado Instituto Brasileiro de Siderurgia, o CONSIDER decidiu pela criação de uma empresa holding das empresas siderúrgicas pertencentes ao governo. Em 1973, surgia a Siderbrás - Siderúrgica Brasileira S/A, que passou a centralizar o planejamento da produção das empresas estatais.

O plano traçado pelos governos militares, durante os anos 70 , estaria completo em meados da década seguinte, com a entrada em operação da Companhia Siderúrgica de Tubarão, no Espírito Santo, e da Açominas, em Minas Gerais.

Após o grande ciclo de desenvolvimento que marcou o período entre 1968 e 1974, novamente o Brasil viveu um período de grandes dificuldades, marcado pela recessão e inflação.

Para a siderurgia, como para todos os setores econômicos, os anos 80 trouxeram a necessidade de profundas transformações, visando a sobrevivência. Racionalizar custos, otimizar a produção, investir em capacitação e em marketing, bem como aplicar novas tecnologias, eram princípios básicos de todas as empresas do setor.

No início da década seguinte, o rearranjo interno das empresas siderúrgicas foi fundamental para o novo panorama implantado a partir da desestatização e da inserção da indústria siderúrgica brasileira no mercado global.

Após os grandes leilões de privatização, as principais empresas siderúrgicas do Brasil têm buscado investir continuamente na busca da excelência, em novas rotas tecnológicas e, principalmente, têm buscado parceiros internacionais, por meio de fusões e jointventures, que têm tornado esse setor econômico brasileiro um dos mais competitivos em escala global.

\subsubsection{O Perfil da Siderurgia Nacional}

A indústria siderúrgica nacional é reconhecida, internacionalmente, como uma das mais competitivas, situando-se suas usinas entre as de maior margem operacional do mundo

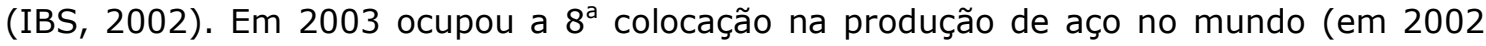
alcançou a produção de 29,6 milhões de toneladas, o que correspondeu a $52,6 \%$ da produção da América Latina e 3,3\% da produção mundial).

O parque produtor nacional é administrado por 11 grupos empresariais que operam 26 usinas, distribuídas em 9 estados brasileiros. Possui uma capacidade instalada de 33 milhões de toneladas de aço bruto por ano (atende $95 \%$ do consumo nacional de aço). Segundo dados do IBS (IBS, 2002) a siderurgia nacional gera 67.000 empregos diretos e 4 vezes esse total em empregos indiretos; obteve um faturamento de U\$10 bilhões e, entre 1994 e 2000, seu programa de investimentos foi de U\$ 12 bilhões. Recolhe, anualmente, U\$ 1,8 bilhões em impostos (segunda maior contribuição do segmento industrial). 
Cinco grande setores (construção civil, automotivo, bens de capital, utilidades domésticas e comerciais, embalagens e recipientes) representam cerca de $84 \%$ do consumo de aço no Brasil. A construção civil, conforme pode-se notar na Figura 2.1 responde por $31 \%$ do total (IBS, 2001).

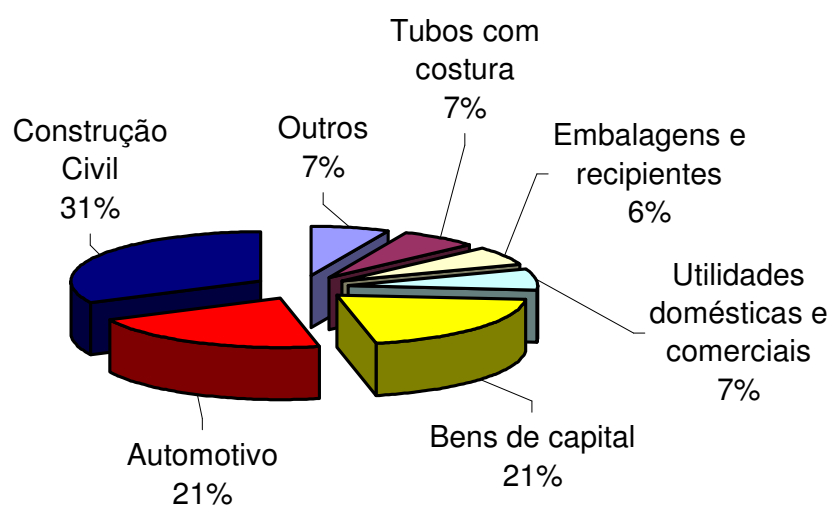

Figura 2.1 - Distribuição do consumo aparente de produtos siderúrgicos por setores consumidores finais. Fonte: IBS (2001)

Em 2002, segundo dados do Sindicato da Indústria da Construção Civil de São Paulo ${ }^{11}$, $90 \%$ dos vergalhões para a produção de estruturas de concreto armado foram provenientes de três grandes indústrias instaladas no país. Embora não seja interesse do trabalho discutir as críticas relativas ao oligopólio do aço, as construtoras têm reclamado dos preços propostos por tais fornecedores. Vale ressaltar que no de janeiro de 2002 a fevereiro de 2004 o insumo acumulou alta ${ }^{12}$ de $71 \%$.

\subsection{A Armadura nas estruturas de concreto armado}

\subsubsection{Caracterização do aço utilizado na confeção das armaduras}

\subsubsection{Matéria-prima}

Os vergalhões de aço consumidos pela Construção Civil brasileira são produtos genuinamente nacionais, assim como a matéria prima para a sua fabricação. Uma das grandes siderúrgicas nacionais, ao apresentar seu processo de fabricação ${ }^{13}$ de vergalhões CA50 e CA60, evidencia que existem vários tipos de matérias-primas disponíveis para a fabricação do aço.

Todavia, devido ao seu menor custo, maior disponibilidade e por ser reciclável, a matéria-prima básica para a produção de barras e fios de aço para armadura de concreto

\footnotetext{
${ }^{11}$ SINDUSCON/SP. Disponível em <http://sindusconsp.com.br> Acesso em: 10 Mar. 2003

${ }^{12}$ Informação disponibilizada no jornal O Estado de São Paulo, 25 Abr. 2004.

${ }^{13}$ Encontrado no site da Belgo, Grupo Arcelor, em visita no dia 27/05/2003.
} 
é a sucata ${ }^{14}$. Essa sucata, rigorosamente selecionada, é constituída por retalhos de chapas metálicas, cavacos de usinagem, latarias de carros usados, peças de aço e ferro de equipamentos em desuso e outros. BELGO (2003a)

A sucata recebida é separada por tipo (pesada, leve, cavaco de aço, cavaco de ferro, chaparia) e armazenada em locais específicos. A sucata é devidamente preparada para utilização, sendo que as de menor densidade são enviadas para prensagem, aumentando, assim, seu peso específico e melhorando o rendimento energético do forno elétrico de fusão.

Outras matérias-primas utilizadas durante o processo são:

- Ferro gusa: é um produto siderúrgico obtido através da redução do minério de ferro, e tem a função de adicionar carbono, ferro e silício ao produto. O carbono e o silício são importantes fontes de energia para o processo, através de sua oxidação gerada após o sopro de oxigênio.

- Ferroligas: (ferro manganês, ferro silício-manganês, ferro silício etc.) utilizados para ajuste da composição química do aço e para conferir as características mecânicas necessárias.

- Cal: atua como escorificante, retendo as impurezas do metal e formando a escória, e também atuando na proteção do refratário do forno contra ataques químicos.

- Oxigênio: utilizado para reduzir o teor de carbono do aço e diminuir o tempo de fusão, sendo esta uma fonte de calor para o processo."

Como se viu, os vergalhões usados na Construção Civil fazem uso acentuado de matérias primas provindas de sucatas. A transformação da sucata e demais matérias em vergalhões é um processo complexo, repleto de fases (como a aciaria, laminação e trefilação).

Em artigo publicado pela CRSI ("Concrete Reinforced Steel Institute") nos Estados Unidos, as barras de aço das armaduras usadas nas estruturas de concreto armado foram consideradas como sendo "green buiding material". "As barras de aço, assim como o concreto armado, proporcionam importantes benefícios por serem um material de construção sustentável". Mais de sete milhões de toneladas de aço são recicladas e transformadas em barras de aço para a construção todos os anos. Se fossem usadas matérias-prima no seu estado puro, para que se produzisse uma tonelada de aço seriam necessários cerca de 1100 quilos de minério de ferro, 630 quilos de carvão e 55 quilos de calcário. Há que se considerar, também, que ao não se utilizar a matéria-prima pura na produção das barras, ganha-se com a redução da energia (algo em torno de $75 \%$ ). A energia economizada a cada ano é equivalente à energia elétrica necessária para abastecer $50 \%$ das moradias norte-americanas (18 milhões de moradias). CRSI (2002)

\subsubsection{Especificações e características}

A norma que regulamenta e especifica a produção de barras e fios de aço é a ABNT NBR 7480 - Barras e Fios de Aço destinados a Armaduras para Concreto Armado: versão 1996. Antes de se comentar algumas das especificações prescritas pela referida norma, é importante que sejam feitas algumas observações:

\footnotetext{
${ }^{14}$ Segundo dados do IBS (Instituto Brasiliero de Siderurgia), de cada $100 \mathrm{~kg}$ de aço produzido, 26 $\mathrm{kg}$ provêem de material reciclado.
} 
- a diferença principal entre aço e ferro é a quantidade de carbono: na composição química do ferro, o teor de carbono é maior ou igual a 2,04\% e, no aço, este teor é menor do que 2,04\%. As denominações CA25, CA50 e CA 60 dizem respeito a materiais que possuem teor de carbono que varia de $0,08 \%$ até $0,50 \%$, dependendo do material, e, portanto, a denominação técnica correta é aço;

- as barras são produtos obtidos por laminação e os fios por trefilação. Os fios são empregados até a bitola de $10 \mathrm{~mm}$ e as barras a partir da bitola de $5 \mathrm{~mm}$. NBR 7480:1996;

- na designação desses fios e barras é usado o prefixo CA, que indica o seu emprego no concreto armado;

- a última versão da NBR 7480:1996 eliminou as classes A e B constantes na versão de 1985. Antes da revisão, segundo FUSCO (1995), pertenciam à classe A as barras produzidas por laminação a quente sem posterior deformação a frio. Já na classe $B$ estariam os fios e barras obtidos por processos que provocam o encruamento a frio, como trefilação, torção, compressão transversal, estiramento e relaminação a frio. $\mathrm{Na}$ versão de 1996 a separação em classes foi eliminada e todo o material do tipo barra, caso do CA25 e CA50, deve ser fabricado obrigatoriamente por laminação a quente, e todo fio, caso do CA60, deve ser fabricado por trefilação ou processo equivalente (estiramento ou laminação a frio);

- a escolha do tipo de aço se dá em função de condições econômicas e de mercado, sendo que, nas obras de construção de edifícios, o aço CA-50 é a principal alternativa escolhida;

- as barras de aço encontradas no mercado brasileiro têm comprimento usual de $11 \mathrm{~m}$, com tolerância de $9 \%$. Sob encomendas especiais, podem ser fornecidas barras de até $26 \mathrm{~m}$ de comprimento. As barras de comprimentos especiais podem acarretar dificuldades de transporte. Barras de até $16 \mathrm{~m}$ podem ser transportadas, na forma retilínea, por carretas rodoviárias. Barras de maior comprimento são usualmente dobradas para o transporte. FUSCO (1995).

A seguir são apresentadas as principais características das barras e fios de aço, definidas pela NBR 7480:1996 (massa linear, propriedades mecânicas, dobramento e aderência).

\subsubsection{1}

Massa Linear

A massa linear representa a massa que uma determinada barra ou fio possui em um metro de comprimento. A massa nominal está, portanto, diretamente relacionada ao diâmetro nominal ou bitola do material.

A determinação da bitola para CA25, CA50 e CA60 não pode ser feita através da medição direta, utilizando paquímetro ou micrômetro. A verificação correta da bitola é feita através da pesagem de um metro da barra ou fio e a comparação do valor obtido com os especificados na NBR 7480. A Tabela 2.1 (anexo B da NBR 7480) indica a massa linear nominal, em kg/m, para cada bitola e produto (CA25 e CA50) e as tolerâncias admissíveis. A massa nominal foi estabelecida como a massa obtida por um metro de barra ou fio sem nervuras e entalhes e diâmetro igual ao da bitola que se quer calcular. Para facilitar a verificação da bitola, a norma exige que o diâmetro nominal esteja gravado em relevo nas barras de CA50.

Como existem variações em qualquer processo de fabricação, a norma também estabelece as tolerâncias em relação a esta massa nominal. Para o CA25 e CA50 a 
tolerância é de $\pm 6 \%$, para bitolas maiores ou iguais a $10 \mathrm{~mm}$, e de $\pm 10 \%$ para bitolas menores que $10 \mathrm{~mm}$ (Tabela 2.1). Para o CA60 a tolerância é de $\pm 6 \%$ para todas as bitolas (Tabela 2.2).

É muito importante a verificação da bitola da barra ou fio, pois se essa estiver com valores da massa linear abaixo do previsto na norma, sua área de seção será diminuída, e, em conseqüência, a resistência mecânica pode ficar comprometida. Observa-se, na Tabela 2.1 e na Tabela 2.2 que os diâmetros nominais são todos padronizados pela NBR 7480:1996 em milímetros, mas, apesar disso, grande parte do mercado utiliza sua denominação em polegadas. A correlação entre o diâmetro normatizado em milímetros e a denominação usual no mercado é mostrada na Tabela 2.3.

Tabela 2.1 - Massa linear e tolerâncias. NBR 7480:1996

\begin{tabular}{|c|c|c|c|}
\hline \multirow{2}{*}{ Bitola $(\mathrm{mm})$} & \multicolumn{3}{|c|}{$\begin{array}{c}\text { CA25 e CA50 } \\
\text { Massas lineares }(\mathrm{Kg} / \mathrm{m})\end{array}$} \\
& & \multicolumn{3}{|c|}{ nominal } & máximo \\
\hline & mínimo & $0 \%$ & $+10 \%$ \\
\hline 6,3 & $-10 \%$ & 0.245 & 0.269 \\
\hline 8 & 0.220 & 0.395 & 0.434 \\
\hline 10 & 0.355 & $0 \%$ & $+6 \%$ \\
\hline 12,5 & $-6 \%$ & 0.617 & 0.654 \\
\hline 16 & 0.580 & 0.963 & 1.021 \\
\hline 20 & 0.906 & 1.578 & 1.673 \\
\hline 25 & 1.484 & 2.466 & 2.614 \\
\hline 32 & 2.318 & 3.853 & 4.084 \\
\hline
\end{tabular}

Tabela 2.2 - Massa linear e tolerâncias. NBR 7480:1996

\begin{tabular}{|c|c|c|c|}
\hline \multirow{2}{*}{ Bitola $(\mathrm{mm})$} & \multicolumn{3}{|c|}{ CA60 } \\
& \multicolumn{3}{|c|}{ Massas lineares $(\mathrm{Kg} / \mathrm{m})$} \\
\hline & mínimo & nominal & máximo \\
\hline 4,2 & $-6 \%$ & $0 \%$ & $+6 \%$ \\
\hline 5,0 & 0.102 & 0.109 & 0.115 \\
\hline 6,0 & 0.145 & 0.154 & 0.163 \\
\hline 7,0 & 0.209 & 0.222 & 0.235 \\
\hline 8,0 & 0.284 & 0.302 & 0.320 \\
\hline 9,5 & 0.371 & 0.395 & 0.418 \\
\hline
\end{tabular}


Tabela 2.3 - Correlação de diâmetros

\begin{tabular}{|c|c|c|c|c|c|c|c|c|}
\hline \multicolumn{1}{|c|}{ Unidade } & \multicolumn{8}{|c|}{ Diâmetros } \\
\hline Nominal em mm & 6,3 & 8 & 10 & 12,5 & 16 & 20 & 25 & 32 \\
\hline Polegadas & $1 / 4$ & $5 / 16$ & $3 / 8$ & $1 / 2$ & $5 / 8$ & $3 / 4$ & 1 & $1.1 / 4$ \\
\hline
\end{tabular}

\subsubsection{2}

Propriedades mecânicas

A separação dos aços nas categorias CA25, CA50 e CA60 é feita através de suas características mecânicas obtidas no ensaio de tração. Nesse ensaio são determinados: a resistência característica de escoamento, o limite de resistência e o alongamento, que devem atender aos valores padronizados na Tabela 2 do anexo B da NBR 7480:1996.

A resistência característica de escoamento é uma das propriedades mais importantes das barras e fios de aço destinados a armaduras de concreto. Do ponto de vista estrutural, limite de escoamento é a carga de trabalho que a barra ou fio deve suportar. O escoamento é a tensão a partir da qual o material passa a sofrer deformações permanentes, ou seja, até este valor de tensão, se interrompermos o tracionamento da amostra, esta voltará a seu tamanho inicial, não apresentando nenhum tipo de deformação permanente.

O engenheiro ou arquiteto utiliza o escoamento da barra para cálculo de dimensionamento da estrutura pois é até este ponto que a barra suporta cargas e sobrecargas e retorna à sua condição inicial sem deformação permanente. Ultrapassado esse ponto, a armação e a estrutura ficam comprometidas. Como pode ser observado, o valor de escoamento é que define a categoria dos aços, ou seja: $50 \mathrm{kgf} / \mathrm{mm} 2$, ou 500 MPa para o CA50; $60 \mathrm{kgf} / \mathrm{mm} 2$, ou $600 \mathrm{MPa}$ para o CA60.

O limite de resistência é a tensão máxima suportada pelo material, na qual, ele se rompe, ou seja, é o ponto máximo de resistência das barras. Convém esclarecer que carga é um valor, em kgf, por exemplo, obtido pela leitura direta no visor da máquina de tração, e tensão é o valor determinado pela relação entre a carga e a área de seção da amostra, dada em $\mathrm{kgf} / \mathrm{mm} 2$, por exemplo.

Alongamento é o percentual que o aço se alonga, isto é, se estica quando submetido a uma carga que ultrapasse o seu limite de escoamento. A determinação do alongamento (Figura 2.2) é feita pela comparação entre o valor marcado no corpo de prova antes do ensaio, denominado comprimento inicial "LO", e o comprimento do trecho marcado, obtido após a ruptura do corpo de prova, denominado de comprimento final "Lf". Para os materiais especificados pela NBR 780 o comprimento inicial utilizado é de 10 vezes o diâmetro nominal. Por exemplo, se o material ensaiado possui um diâmetro de $10 \mathrm{~mm}$ o "LO" será de $100 \mathrm{~mm}$. 

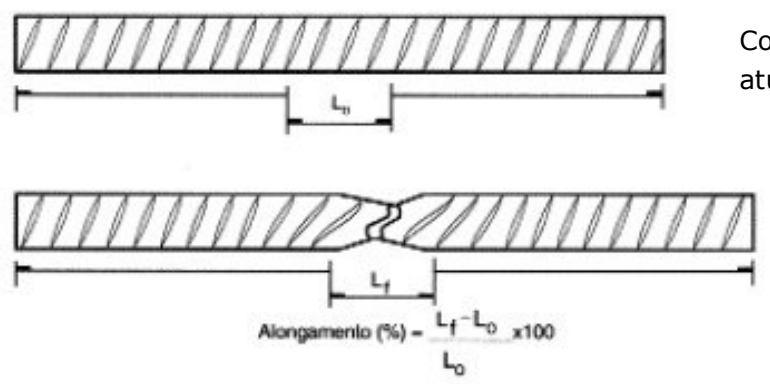

Corpo de prova antes da atuação da carga

Corpo de prova depois da atuação da carga a sua ruptura

Figura 2.2 - Ensaio de alongamento

\subsubsection{3}

Dobramento

FUSCO (1995) lembra que "a confecção de armaduras passivas exige a realização de diferentes tipos de dobramento das barras de aço". Tais dobramentos devem ser feitos com raios de curvatura que respeitem as características do aço empregado, impedindo, dessa forma, que ocorram fissurações do aço, do lado tracionado da barra.

O autor supracitado chama a atenção para o fato de que, durante o dobramento, ocorre sensível alongamento plástico da barra, fazendo com que as reais dimensões da posição dobrada ${ }^{15}$ sejam diferentes das medidas consideradas em projeto.

As normas NBR 6118:2003 (item 9.4.2.3 e 9.4.6.1) ou NBR 14931:2003 (item 8.1.5.3), ao estabelecer as condições a obedecer na execução e no controle de obras de concreto armado, indicam o diâmetro dos pinos a serem utilizados no dobramento de barras (ganchos, estribos e peças longitudinais tracionadas). De acordo com essas normas, os diâmetros dos pinos, expressos em razão do diâmetro das barras dobradas, são aqueles apresentados na Tabela 2.4 e na Tabela 2.5 (variam em função do diâmetro das barras e da classificação do aço).

Segundo FUSCO (1995), no caso do dobramento de "barras curvadas" (como os cavaletes e barras dos nós de pórticos), existe o risco de ruptura localizada (Figura 2.3) e que, por essa razão, é conveniente um aumento dos diâmetros de dobramento em função do cobrimento lateral, conforme indicado na Tabela 2.6.

Tabela 2.4 - Diâmetro dos pinos de dobramento (D) para ganchos das armaduras longitudinais de tração

\begin{tabular}{|c|c|c|c|}
\hline Bitola $(\mathrm{mm})$ & \multicolumn{3}{|c|}{ Diâmetro de dobramento } \\
\hline & CA-25 & CA-50 & CA-60 \\
\hline 20 & $4 \phi$ & $5 \phi$ & $6 \phi$ \\
\hline 20 & $5 \phi$ & $8 \phi$ & - \\
\hline
\end{tabular}

\footnotetext{
${ }^{15}$ FUSCO (1995) chama a atenção para o fato de que, nos canteiros de obras, os armadores usam regras empíricas para compensar esse alongamento. Por exemplo, costumam adotar $2,5 \phi$ (diâmetro da barras) para dobramentos a $90^{\circ}$ e $1,25 \phi$ para dobramentos a $45^{\circ}$. "No caso dos ganchos não são feitos descontos, pelo que a parte de retorno dos ganchos será algo maior que o previsto no desenho".
} 
Tabela 2.5 - Diâmetro dos pinos de dobramento para estribos

\begin{tabular}{|c|c|c|c|}
\hline \multirow{2}{*}{ Bitola $(\mathrm{mm})$} & \multicolumn{3}{|c|}{ Diâmetro de dobramento } \\
\hline$\leq 10$ & $\mathrm{CA}-25$ & CA-50 & CA-60 \\
\hline $10<\phi>20$ & $3 \phi_{\mathrm{t}}$ & $3 \phi_{\mathrm{t}}$ & - \\
\hline 20 & $4 \phi_{\mathrm{t}}$ & $5 \phi_{\mathrm{t}}$ & - \\
\hline
\end{tabular}
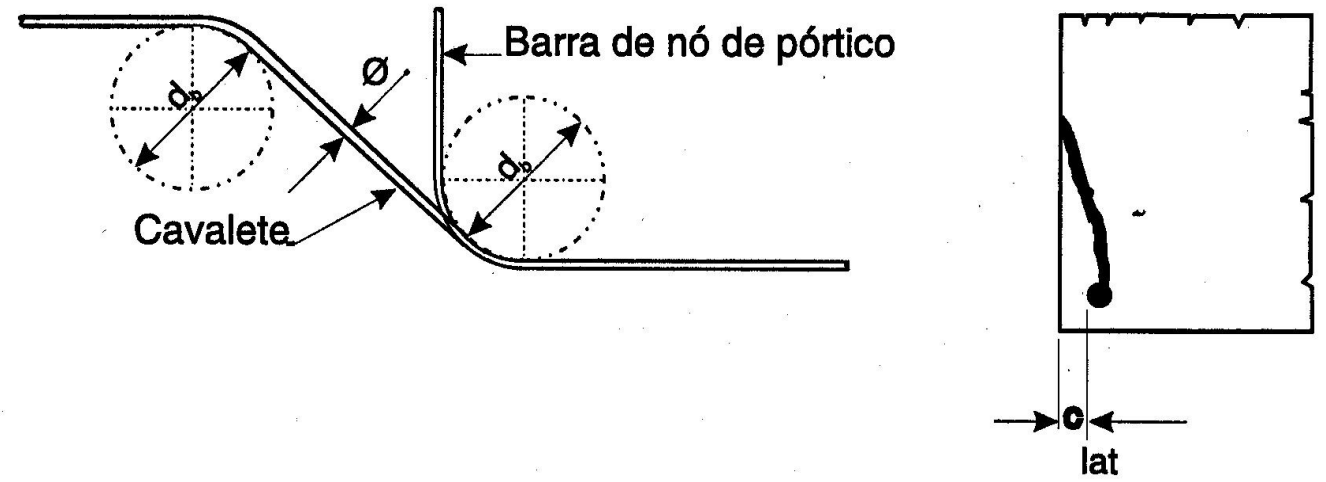

Figura 2.3 - Barras curvadas. Fonte: FUSCO, 1995

Tabela 2.6 - Diâmetro dos pinos de dobramento para cavaletes e barras em nós de pórticos. Fonte: FUSCO, 1995

\begin{tabular}{|c|c|c|c|c|}
\hline Cobrimento lateral C1 & \multicolumn{4}{|c|}{ Diâmetro de dobramento } \\
\hline C1 $1 \geq 3 \phi \quad$ C1 $125 \mathrm{~cm}$ & $10 \phi_{\mathrm{t}}$ & $12 \phi_{\mathrm{t}}$ & $12 \phi_{\mathrm{t}}$ & $20 \phi_{\mathrm{t}}$ \\
\hline $\mathrm{C} 1<3 \phi \mathrm{CA}-40$ & $15 \phi_{\mathrm{t}}$ & $20 \phi_{\mathrm{t}}$ & $20 \phi_{\mathrm{t}}$ \\
\hline
\end{tabular}

Segundo o engenheiro J.L. Andrade ${ }^{16}$, todos os grandes fabricantes de aço fazem o ensaio de dobramento em laboratórios próprios, conforme as indicações da norma NBR 7480 , e só após aprovação liberam o material aos clientes. Nesse ensaio, um corpo de prova do material é submetido a um dobramento de $180^{\circ}$ em pino de diâmetro padronizado, sendo considerado aprovado quando não apresenta quebra ou fissura na região dobrada. Esse ensaio tenta reproduzir as condições em que os materiais serão utilizados nas obras. Os diâmetros dos pinos exigidos pelo ensaio são indicados na tabela número dois do Anexo B da NBR 7480:1996. É importante observar que este é o dobramento realizado nos laboratórios das siderúrgicas para acompanhamento de

16 SIDERÚRGICA BELGO ARCELOR. Alterações da norma brasileira NBR 7480. Artigo Técnico. Disponível em: <http://belgo.com.br>. Acesso em: 30 out. 2003. 
produção de CA25, CA50 e CA60 e liberação do produto para expedição. É o mesmo ensaio utilizado pelos laboratórios externos para liberação do produto nas obras.

Pode ser observado que as condições de dobramento da NBR 7480 são mais rígidas do que na NBR 6118:2003 ou na NBR 14931:2003 dando uma maior segurança ao usuário na utilização. Alguns fatores interferem para que as condições de liberação da NBR 7480 sejam mais severas que as de aplicação. São eles: i) nos laboratórios de ensaio a temperatura ambiente é melhor controlada; ii) a aplicação da força de dobramento é constante e homogênea durante todo o processo; iii) os pinos suporte da máquina de dobramento do laboratório têm giro livre, impedindo o travamento da barra.

Segundo Andrade (BELGO (2004b)), o dobramento das barras em condições mais agressivas pode fragilizar o material em partes das regiões dobradas, seja por ter utilizado quase toda resistência do aço para dobrá-lo em pinos menores (e que exigem maior esforço), seja por provocar pequenas trincas ou fissuras nas bases das nervuras, o que diminui a área resistente da barra. O autor supracitado observa, ainda, que o fato da barra não quebrar, devido ao dobramento inadequado, acaba sendo muito pior (se ela se quebrasse, não seria aproveitada e, por conseguinte, não comprometeria o elemento estrutural, no caso de alguma sobrecarga acidental na estrutura).

\subsection{Aderência}

Segundo SUSSEKIND (1983), as primeiras barras de aço empregadas nas peças em concreto foram redondas e lisas (as mais simples de fabricar), as quais "resolveram o problema, enquanto não se pensou em aços de maior resistência, visando diminuir o consumo de armação nestas peças".

Assim, as "barras lisas" são fabricadas apenas para aços de baixa resistência. As barras de alta resistência apresentam melhores propriedades de aderência, devido à existência de nervuras perpendiculares ou inclinadas aos eixos da barra, recebendo a denominação de "aços nervurados" (LEONHARDT, 1983), ou "barras de alta aderência", segundo FUSCO (1995). Para este último autor, "essa classificação simplista decorre de que a aderência das barras nervuradas é praticamente a mesma para as diversas conformações superficiais adotadas para diferentes fabricantes."

O item 5.3.2 da NBR 7480: 1996 prevê que "as barras e fios de aço de diâmetro nominal igual a $10,0 \mathrm{~mm}$ ou superior devem apresentar as propriedades de aderência ${ }^{17}$ exigidas para a categoria correspondente, definidas pelos coeficientes de conformação superficial $(\eta)$, ou simplesmente coeficiente de aderência, igual a 1,0 para a categoria de aço CA25 e 1,5 para os aço de categoria CA50 e CA60. As barras da categoria CA50 são obrigatoriamente providas de nervuras transversais e oblíquas.

O ensaio de aderência deve ser determinado de acordo com a NBR 7477. O Item 6. 5.3 da NBR 7480 diz que "mediante acordo entre produtor e comprador e quando a utilização das barras não permitir a espera para realização do ensaio de fissuração, pode-se adotar o coeficiente de conformação superficial $\eta=1,5$, desde que sejam atendidas as exigências do Anexo A da referida norma, que são:

17 A aderência é o grau com que a barra ou fio adere ao concreto e está diretamente relacionada às dimensões das nervuras ou entalhes existentes na superfície do produto. 
- os eixos das nervuras transversais ou oblíquas devem formar, com a direção do eixo da barra, um ângulo igual ou superior a $45^{\circ}$ (Figura 2.4);

- as barras devem ter pelo menos duas nervuras longitudinais contínuas e diametralmente opostas, exceto no caso em que nervuras transversais estejam dispostas de forma a se oporem ao giro da barra dentro do concreto;

- para diâmetros nominais maiores ou iguais a $10,0 \mathrm{~mm}$, a altura média das nervuras transversais ou oblíquas deve ser igual ou superior a 0,04 do diâmetro nominal, e para diâmetros nominais inferiores a $10,0 \mathrm{~mm}$, deve ser igual ou superior a 0,02 do diâmetro nominal;

- o espaçamento médio das nervuras transversais ou oblíquas, medido ao longo de uma mesma geratriz, deve estar entre 0,5 e 0,8 do diâmetro nominal;

- as nervuras devem abranger pelo menos $85 \%$ do perímetro nominal da seção transversal da barra.

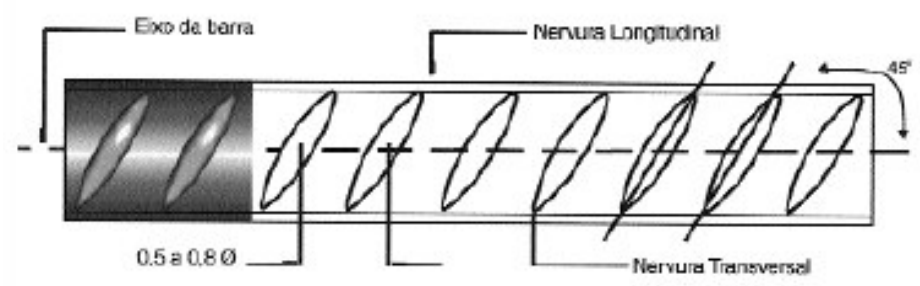

Figura 2.4 - Distância entre nervuras e ângulos em relação ao eixo da barra

\subsubsection{Aferição da qualidade do aço}

No Brasil, recentemente, foi introduzida a exigência da Marca de Conformidade Compulsória para os vergalhões utilizados na construção civil, em virtude dos aspectos de segurança relacionados com o produto. A obrigatoriedade da Marca de Conformidade foi estabelecida a partir de 09 de julho de 1999, conforme Portaria número 46 de 23/3/99 do INMETRO (Instituto Nacional de Metrologia), valendo tanto para os produtos nacionais como para os importados. (BELGO, 2003a)

Trata-se de um instrumento com endosso da ABNT (Associação Brasileira de Normas Técnicas) e principalmente do INMETRO (Instituto Nacional de Metrologia), órgão do Governo Federal, que atesta para o mercado e principalmente para o consumidor final que os vergalhões para construção civil das empresas certificadas atendem a Norma Brasileira NBR 7480 (Barras e fios de aço destinados a armadura de concreto armado). 0 termo "Marca de Conformidade" é também conhecido por "Selo de Conformidade" ou "Selo de Qualidade" e costuma estar estampado nas etiqueta que fazem a identificação do aço fornecido à obra (Figura 2.5). (BELGO, 2003a)

A obtenção e a manutenção da Marca de Conformidade é feita através de auditorias periódicas realizadas pela ABNT/INMETRO. Essas auditorias consistem na verificação de todo o Sistema da Qualidade do fabricante, incluindo a execução de testes em amostras coletadas nas usinas das empresas siderúrgicas e no mercado distribuidor. Os testes são feitos nos laboratórios das empresas produtoras, e em laboratórios de terceiros, 
credenciados pelo INMETRO. Entre as vantagens da Marca de Conformidade Compulsória pode se citar:

- segurança na utilização: os testes em vergalhões são muito caros, e somente podem ser feitos em laboratórios sofisticados que normalmente só existem em grandes centros urbanos. Em vista dessas dificuldades, é recomendada a utilização de vergalhões produzidos por empresas que detenham a Marca de Conformidade;

- economia: quando a empresa produtora de vergalhões tem a Marca de Conformidade, o número de testes feitos pelas construtoras poderá ser diminuído, gerando economia nos custos e no tempo de espera para execução dos mesmos.

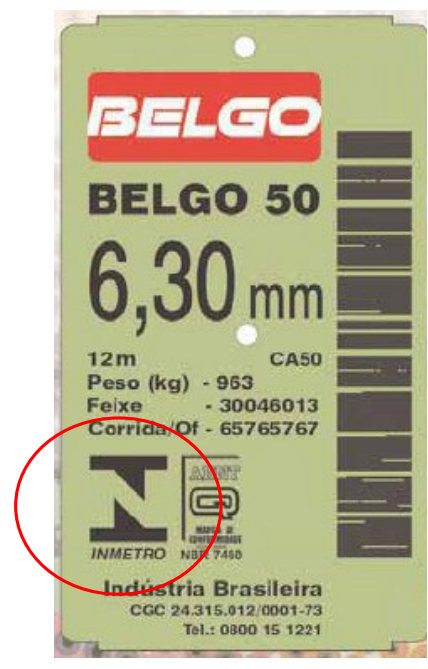

Figura 2.5 - Selo da qualidade estampado na identificação do aço fornecido à obra.

O item 4.7 ("marcação") da NBR 7480:1996 prescreve que toda barra nervurada (barras de aço CA50), em todas as bitolas, apresente marcas de laminação em relevo, identificando o produtor com o registro no INPI (Instituto Nacional de Propriedade Industrial), a categoria do material (identificação do produtor e categoria do material) e seu respectivo diâmetro nominal. No caso de CA25 e CA60, a identificação é feita na etiqueta do produto ou com marcas em relevo.

\subsubsection{O Emprego de armaduras de aço}

As barras devem ser ligadas entre si para formar "gaiolas" ou "esqueletos" rígidos, indeslocáveis. A esse conjunto de barras, ligadas entre si, dá-se o nome de armadura.

A armadura do concreto com barras, malhas ou telas de aço tem, segundo LEONHARDT; MONNIG (1978), as seguintes funções:

- absorver os esforços de tração em peças estruturais solicitadas à flexão e à tração, contribuindo para a capacidade resistente ou para a estabilidade da estrutura;

- fazer com que as fissuras no concreto, sob a ação de cargas de utilização, permaneçam na ordem de grandeza de capilares (não sejam facilmente visíveis a olho nu); 
- limitar a abertura das fissuras devido a estados de tensão produzidos por efeitos de coação, tais como o impedimento à deformação, no caso de variação de temperatura, de retração, de estruturas hiperestáticas etc.

- em peças comprimidas, aumentar a capacidade resistente do concreto à compressão (por exemplo, no caso de pilares) ou a segurança de peças comprimidas esbeltas contra a flambagem.

FUSCO (1995) atenta para o fato de que, considerando as diferentes partes das construções de concreto, torna-se necessário o estabelecimento de regras para a organização do arranjo das armaduras de cada uma das peças estruturais empregadas. E que tais regras devem estar baseadas no conhecimento da distribuição dos seus esforços internos.

O mesmo autor coloca que

[...] as armaduras de aço deixaram de ser tratadas como meras fibras resistentes à tração, que poderiam ser criadas livremente pelo projetista, procurando-se agora o conhecimento objetivo do real comportamento dessas armaduras até os possíveis estados-limite últimos das peças estruturais.

O concreto armado deixou de ser tratado quase como se fosse um material unitário e passou a ser considerado como um material composto, pelo concreto e pelo aço, devendo respeitar-se a compatibilidade de funcionamento solidário desses dois materiais.

FUSCO (1995) apresenta duas possibilidades para o arranjo das armaduras. Na primeira, as barras da armadura são distribuídas por toda a peça estrutural (ao se abrir uma fissura já existe localmente uma armadura capaz de absorver os esforços de tração que são liberados pelo concreto).

A segunda possibilidade de arranjo das armaduras decorre da constatação de que partes das barras são melhor aproveitadas quando colocadas concentradas em determinadas posições preferenciais da peça; surgem, então, os arranjos padronizados, que conferem maior simplicidade e economia.

A Tabela 2.7 apresenta uma classificação geral, proposta por FUSCO (1995), que considera as funções específicas das armaduras, tendo em vista o seu emprego em diferentes peças de concreto. A Figura 2.6 exemplifica a classificação apresentada na Tabela 2.7.

Segundo FUSCO (1995) "os arranjos das armaduras das peças de concreto armado têm a sua padronização decorrente de experiência acumulada ao longo do tempo e refletem o grau de conhecimento existente sobre o funcionamento interno das peças estruturais. A cada tipo de peça estrutural corresponde um arranjo básico de suas armaduras." 
Tabela 2.7 - Classificação e descrição das armaduras padronizadas. Fonte: FUSCO, 1995.

\begin{tabular}{|c|c|c|}
\hline $\begin{array}{l}\text { Classificação } \\
\text { das Armaduras }\end{array}$ & Subdivisão & Função \\
\hline \multirow{2}{*}{$\begin{array}{l}\text { 1. Armaduras } \\
\text { de equilíbrio } \\
\text { geral }\end{array}$} & $\begin{array}{l}\text { 1.1 Armaduras } \\
\text { longitudinais }\end{array}$ & $\begin{array}{l}\text { São dispostas ao longo da peça e freqüentemente são } \\
\text { chamadas de armadura de tração, ou de flexão. }\end{array}$ \\
\hline & $\begin{array}{l}1.2 \text { Armaduras } \\
\text { transversais }\end{array}$ & $\begin{array}{l}\text { No caso das vigas as armaduras transversais resistem às } \\
\text { forças cortantes. Nas lajes são as armaduras de flexão. } \\
\text { Nos pilares inexistem. }\end{array}$ \\
\hline \multirow{3}{*}{$\begin{array}{l}\text { 2. Armaduras } \\
\text { auxiliares }\end{array}$} & $\begin{array}{l}2.1 \text { Armaduras } \\
\text { de montagem }\end{array}$ & $\begin{array}{c}\text { Servem para facilitar a montagem geral da armadura, } \\
\text { como é o caso dos porta-estribos das vigas, ou para } \\
\text { permitir a manutenção da posição das demais armaduras } \\
\text { durante a concretagem da peça. }\end{array}$ \\
\hline & $\begin{array}{l}\text { 2.2 Armaduras de } \\
\text { pele }\end{array}$ & $\begin{array}{c}\text { Impedirem uma fissuração superficial exagerada da peça, } \\
\text { nas condições de utilização normal. São usualmente } \\
\text { empregadas em vigas altas e em peças em que o } \\
\text { cobrimento da armadura principal é excessivo. }\end{array}$ \\
\hline & $\begin{array}{l}2.3 \text { Armaduras } \\
\text { complementares }\end{array}$ & $\begin{array}{l}\text { Podem ter função de armadura de equilíbrio ou armadura } \\
\text { de pele. }\end{array}$ \\
\hline \multirow{2}{*}{$\begin{array}{l}\text { 3. Armaduras } \\
\text { de equilíbrio } \\
\text { local } \\
\text { (solidarização) }\end{array}$} & $\begin{array}{l}\text { 3.1 Armaduras de } \\
\text { costura }\end{array}$ & $\begin{array}{c}\text { São empregadas quando a solidarização depende da } \\
\text { absorção de esforços tangenciais que agem ao longo de } \\
\text { um dado plano ou de uma outra superfície qualquer } \\
\text { interna da peça. Ancoragens e emendas das barras são } \\
\text { exemplos de situações em que são necessárias armaduras } \\
\text { de costura. }\end{array}$ \\
\hline & $\begin{array}{l}\text { 3.2 Armaduras } \\
\text { contra o } \\
\text { fendilhamento }\end{array}$ & $\begin{array}{l}\text { São necessárias quando a solidarização depende de } \\
\text { absorção de esforços de tração decorrentes de uma } \\
\text { compressão localizada (por exemplo, nas ancoragens } \\
\text { feitas por meio de dobras ou de ganchos). }\end{array}$ \\
\hline \multirow{3}{*}{$\begin{array}{l}\text { 3. Armaduras } \\
\text { de equilíbrio } \\
\text { local } \\
\text { (solidarização) }\end{array}$} & $\begin{array}{l}\text { 3.3 Armaduras } \\
\text { contra a } \\
\text { flambagem das } \\
\text { barras } \\
\text { comprimidas }\end{array}$ & $\begin{array}{c}\text { Permitem levar as barras comprimidas até o escoamento. } \\
\text { Essas armaduras garantem a solidarização das armaduras } \\
\text { comprimidas ao concreto que as envolve. Os estribos dos } \\
\text { pilares são essencialmente armaduras de solidarização } \\
\text { contra a flambagem das barras longitudinais. }\end{array}$ \\
\hline & $\begin{array}{l}\text { 3.4 Armaduras de } \\
\text { equilíbrio dos } \\
\text { desvios dos } \\
\text { esforços } \\
\text { longitudinais }\end{array}$ & $\begin{array}{c}\text { Garantem a integridade da peça, seja na presença de } \\
\text { desvios do banzo comprimido das mesmas, seja na de } \\
\text { barras tracionadas curvilíneas que tendem a se destacar } \\
\text { do concreto. }\end{array}$ \\
\hline & $\begin{array}{l}\text { 3.5 Armaduras de } \\
\text { suspensão }\end{array}$ & $\begin{array}{c}\text { Necessárias nos cruzamentos de vigas, quando uma delas } \\
\text { se apóia sobre a outra, fazendo com que haja a } \\
\text { necessidade de um verdadeiro tirante interno de } \\
\text { suspensão. }\end{array}$ \\
\hline
\end{tabular}




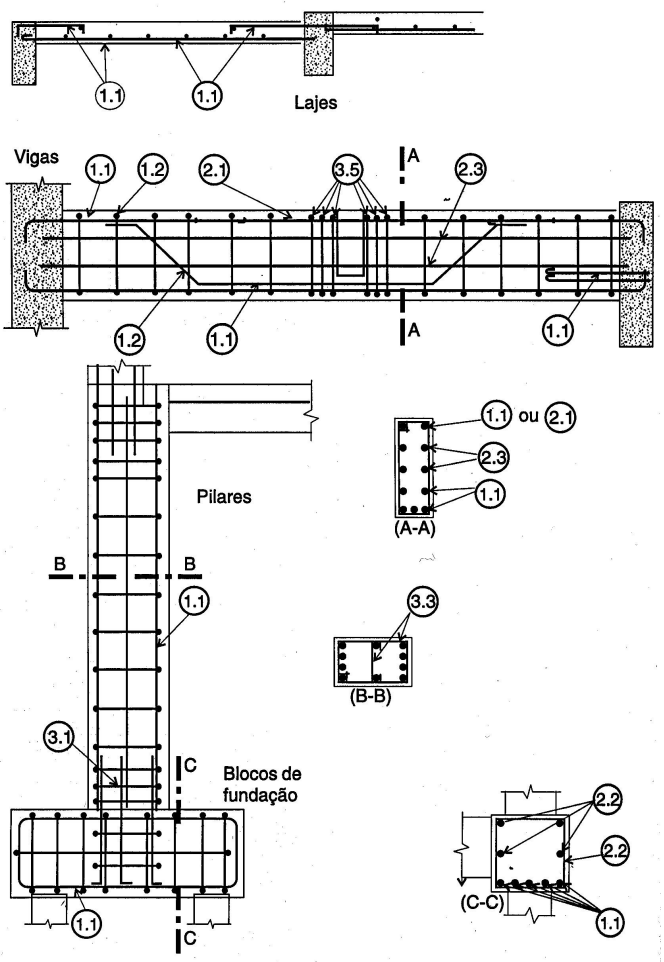

Figura 2.6 - Tipos de armaduras segundo classificação (vide Tabela 2.7) proposta por FUSCO (1995)

\subsubsection{DisposIcões construtivas gerais das armaduras}

Faz-se importante recordar algumas disposições construtivas gerais que devem, obrigatoriamente, ser respeitas no detalhamento (projeto), e na produção das armaduras. São, assim, fundamentais para que os elementos estruturais originados sejam capazes de responder, com segurança, aos esforços para os quais foram projetados. Apresentam-se, a seguir, algumas destas disposições/prescrições com alguns breves comentários (a intenção aqui é apenas a de lembrar o leitor sobre os pontos mais importantes), extraídos das obras de alguns dos mais renomados profissionais que lidam com o tema, como AMARAL (1964); FUSCO (1975); LEONHARDT (1983); SUSSEKIND (1983), bem como da NBR 6118:2003.

\subsubsection{Afastamento mínimo das barras}

O item 7.5 (detalhamento das armaduras) da NBR 6118:2003 prescreve que: i) as barras devem ser dispostas dentro do componente ou elemento estrutural, de modo a permitir e facilitar a boa qualidade das operações de lançamento e adensamento do concreto; ii) seja previsto, no detalhamento da disposição das armaduras, espaço suficiente para a entrada da agulha do vibrador.

FUSCO (1995) admite que o espaço livre entre as barras isoladas da armadura, tanto na direção vertical quanto na horizontal (Figura 2.7), deve ser de pelo menos $2 \mathrm{~cm}$ e não menor que o diâmetro das barras. No caso de barras de diâmetros diferentes vale o diâmetro da barra mais grossa. Para facilitar o lançamento do concreto, o autor supracitado diz que é conveniente e recomendável o agrupamento de barras da 
armadura, formando-se feixes (desde que utilizadas barras de alta aderência, com bitolas maior ou igual a $25 \mathrm{~mm}$ e com 2 a 3 barras por feixe).

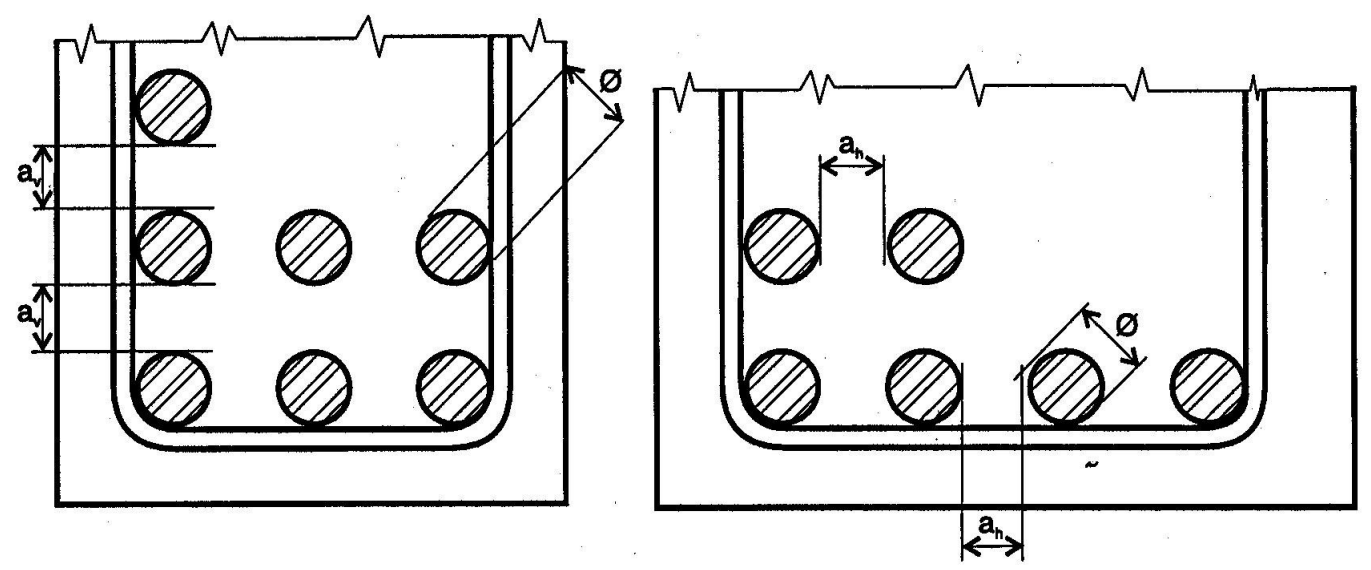

Figura 2.7 - Espaçamento mínimo de barras. Fonte: FUSCO (1995)

\subsubsection{Ancoragem das armaduras}

O item 9.4 da NBR 6118:2003 prescreve que todas as barras das armaduras devem ser ancoradas de forma que os esforços a que estão submetidas sejam integralmente transmitidos ao concreto. A ancoragem das armaduras dá-se de duas maneiras: i) por aderência; ii) por meio de dispositivos mecânicos.

A ancoragem por aderência acontece quando os esforços são transmitidos por meio de um comprimento reto ou com grande raio de curvatura, seguido ou não de gancho.

As barras tracionadas ${ }^{18}$ podem ser ancoradas ao longo de um comprimento retilíneo ou com grande raio de curvatura em sua extremidade, de acordo com as seguintes condições: i) obrigatoriamente com gancho nas extremidades, para barras lisas; ii) sem gancho nas que tenham alternância de solicitação, de tração e compressão; iii) com ou sem gancho nos demais casos, não sendo recomendado o gancho para barras de $\phi>32 \mathrm{~mm}$ ou para feixes de barras.

Os ganchos das extremidades das barras da armadura longitudinal de tração podem ser: semicirculares, com ponta reta de comprimento não inferior a $2 \phi$; em ângulo de $45^{\circ}$ (interno), com ponta reta de comprimento não inferior a $4 \phi$; em ângulo reto, com ponta reta de comprimento não inferior a $8 \phi$. (Figura 2.8)

${ }^{18}$ As barras comprimidas devem ser ancoradas sem ganchos. 

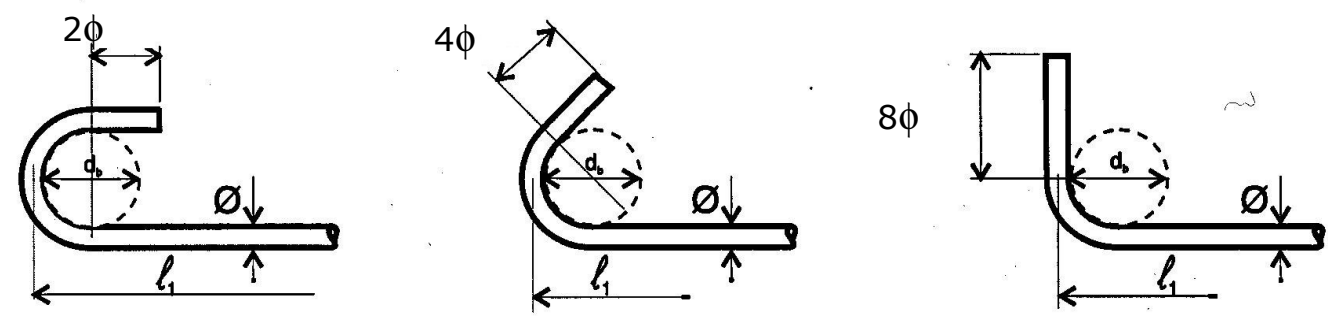

Figura 2.8 - Ganchos das barras da armadura longitudinal de tração.

Para as barras lisas, os ganchos das armaduras longitudinais de tração devem ser semicirculares, sendo que o gancho interno da curvatura deve ser maior ou igual aos anteriormente mostrados na Tabela 2.4 (tabela 9.1 da NBR 6118:2003).

Pode-se, ainda, utilizar barras transversais soldadas para a ancoragem das barras longitudinais, desde que sejam obedecidas algumas prescrições citadas no item 9.4.2.2 da NBR 6118:2003.

Em se tratando de estribos, a ancoragem por aderência pode se dar, também, através de ganchos ou barras transversais soldadas.

No caso dos ganchos dos estribos, eles podem ser: semicirculares ou em ângulo de $45^{\circ}$ (interno), com ponta reta de comprimento igual a $5 \phi_{t}$ (onde $\phi_{t}$ é o diâmetro da barra do estribo), porém não inferior a $5 \mathrm{~cm}$; em ângulo reto, com ponta reta de comprimento maior ou igual a $10 \phi_{\mathrm{t}}$, porém não inferior a $7 \mathrm{~cm}$ (este tipo de gancho não deve ser utilizado para barras e fios lisos).

O diâmetro interno da curvatura dos estribos deve ser, no mínimo, igual ao índice dado na Tabela 2.5 (tabela 9.2 da NBR 6118:2003), mostrada no item 2.3.2.2.3.

Segundo FUSCO (1995), o comprimento de ancoragem de uma armadura é função da conformação superficial das suas barras, da qualidade do concreto, da posição da armadura em relação às etapas de concretagem, dos esforços de tração das barras e do arranjo da própria ancoragem.

O item 9.4.2.4 da NBR 6118:2003 apresenta uma equação para o cálculo do comprimento de ancoragem básico, que possui um fator multiplicador " $\mathrm{K}$ " (redutor do comprimento necessário) que considera a resistência de aderência (ditada pelo uso de barras lisas ou nervuras, pelas zonas de aderência e pelas bitolas das barras).

$\mathrm{Na}$ determinação do comprimento de ancoragem necessária $\left(I_{\mathrm{bo}}\right)$, previsto no item 9.4.2.5 da NBR 6118:2003, pode-se minorar o comprimento de ancoragem básico " $\mathrm{b}_{\mathrm{b} \text {,nec }}$ " (desde que respeitados os valores mínimos) em função da presença de ganchos (o comprimento de ancoragem é reduzido em $30 \%$ quando comparado ao valor do comprimento de ancoragem de uma barra reta).

\subsection{Ancoragem por meio de dispositivos mecânicos}

O item 9.4.7 da NBR 6118:2003 prevê que quando forem utilizados dispositivos mecânicos (que podem ser elementos metálicos, de forma e tamanhos variáveis, rosqueáveis ou soldados (com ou sem o uso de luvas) às barras, conforme exemplos ilustrados na Figura 2.9) acoplados às armaduras a ancorar, a eficiência do conjunto deve ser justificada e, quando for o caso, comprovada através de ensaios. O projeto deve 
prever os efeitos localizados desses dispositivos, através de verificação da resistência do concreto e da disposição de armaduras adequadas para resistir aos esforços gerados e manter as aberturas de fissuras nos limites especificados, conforme indicado no item 21.2 da referida norma.
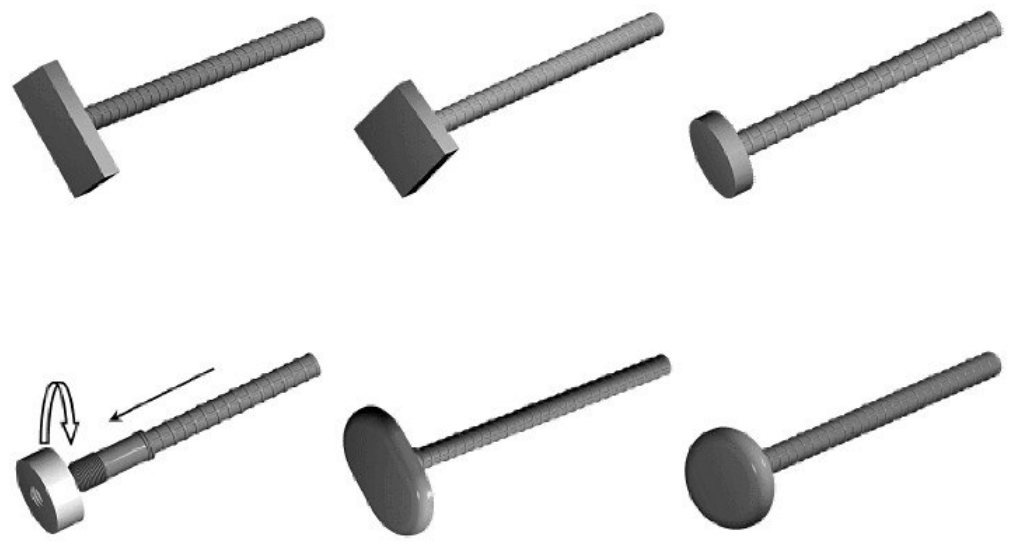

Figura 2.9 - Exemplos de dispositivos para ancoragem mecânica das barras das armaduras.

\subsubsection{Emendas das barras das armaduras}

A NBR 6118:2003 prevê que as emendas das barras de aço podem ser dos seguintes tipos: i) por traspasse; ii) por luvas com preenchimento metálico, rosqueadas ou prensadas; iii) por solda; iv) por outros dispositivos devidamente justificados.

As emendas por traspasse de barras tracionadas são feitas pela justaposição de duas barras ao longo do "comprimento de transmissão". No caso de barras de alta aderência a emenda pode ser reta, sendo facultativo o emprego de ganchos.

FUSCO (1995) recorda que as barras a serem emendadas podem ser colocadas bem próximas uma das outras. No caso de barras de alta aderência, com nervuras ou saliências, as barras podem ser postas em contato direto, pois a presença de saliências garante o envolvimento de argamassa. Neste caso as barras podem ser amarradas com arame recozido, para garantir a posição das mesmas durante a concretagem. Por outro lado, para que a transmissão de esforços possa ser feita eficientemente, a distância entre as barras a serem emendadas não deve ultrapassar o valor de $4 \phi$.

O item 9.5.2 da NBR 6118:2003 trata a questão das emendas por traspasse, apresentando valores como a proporção de barras emendadas, comprimentos de traspasse, tanto para barras isoladas, quanto para feixes de barras, considerando disposições diferenciadas para barras tracionadas e comprimidas.

O item 9.5.3 da NBR 6118:2003 prevê que, para esse tipo de emenda, as luvas rosqueadas devem ter resistência maior que as barras emendadas.

O item 9.5.3 da NBR 6118:2003 aponta que as emendas por solda exigem cuidados especiais quanto às operações de soldagem, que devem atender a especificações de controle do aquecimento e resfriamento da barra, conforme normas específicas. As emendas por solda podem ser: i) de topo, por caldeamento, para bitola não menor que $10 \mathrm{~mm}$; ii) de topo, com eletrodo, para bitola não menor que $20 \mathrm{~mm}$; por traspasse com pelo menos dois cordões de solda longitudinais. 
Chama-se a atenção para um produto desenvolvido por uma empresa Alemã (HalfenDeha ${ }^{19}$ ), conhecido como "HBT" que permite conexões entre barras de armaduras em estruturas de concreto armado de maneira simples e econômica, entre outros, por não causar prejuízos aos moldes do sistema de fôrmas quando os elementos estruturais são concretados em momentos distintos (como na situação ilustrada pela Figura 2.10).
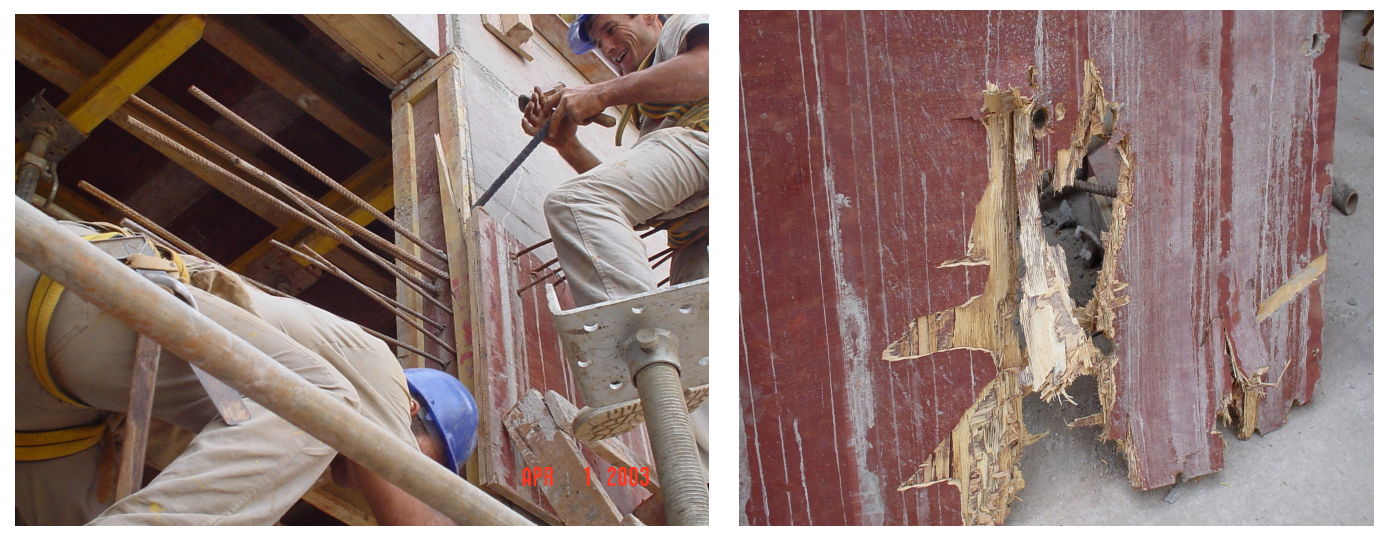

Figura 2.10 - Exemplo de prejuízo causada ao molde do sistema de fôrmas quando se têm elementos concretados em momentos distintos

O sistema consiste em armaduras pré-fabricadas que ficam alojadas em dispositivos de aço galvanizado. Esses dispositivos são posicionados internamente às fôrmas, ficando uma de suas faces ancorada na estrutura, através de ganchos disposto para este fim. A outra face, possui segmentos de barras que ficam alojados (confinados) numa espécie de "gaveta" de aço galvanizado (Figura 2.11). Após a desfoma dos moldes, remove-se tal dispositivo que enclausurava os segmentos de barras (dobrados até este momento). As barras são então trazidas, com o auxílio de chaves de dobra, a uma posição perpendicular ao elemento estrutural no qual estão ancoradas, estando aptas, a partir daí, a serem conectadas ao elemento estrutural seguinte (Figura 2.12).

19 Maiores informações sobre esta empresa e sobre os sistemas de conexão de armaduras fornecidos por ela podem ser obtidas no seguinte endereço eletrônico: www.halfen-deha.com 

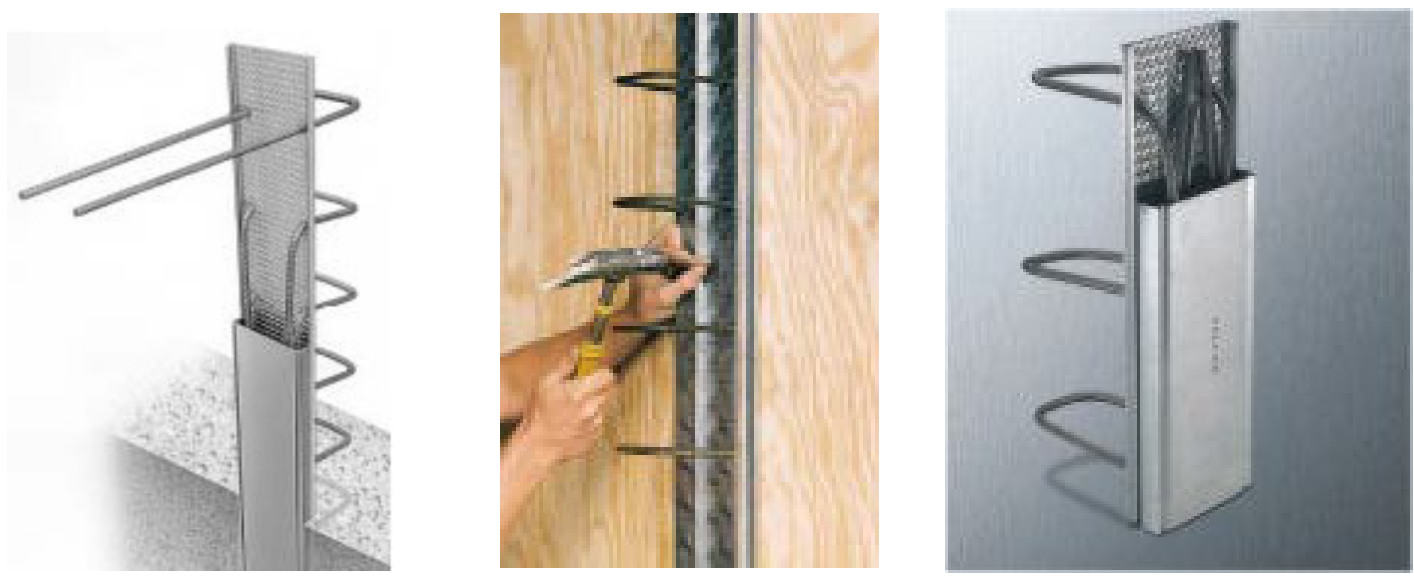

Figura 2.11 - Sistema de conexão de armaduras conhecido como "Halfen HBT"
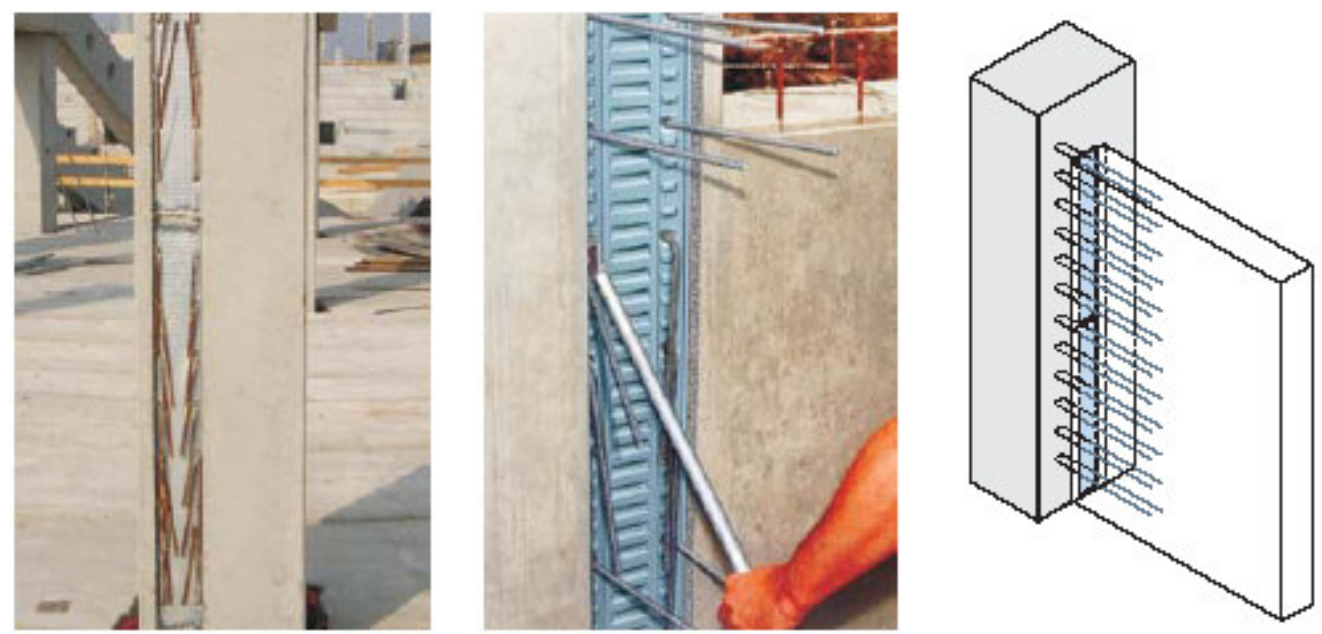

Figura 2.12 - Exemplo de aplicação do sistema de conexão de armaduras conhecido como "Halfen HBT"

\subsubsection{Cobrimento das armaduras}

As armaduras de aço dentro da massa de concreto são protegidas contra a corrosão pelo fenômeno de "passivação do aço", que ocorre em virtude da grande alcalinidade do meio ambiente (o $\mathrm{pH}$ da água existente nos poros do concreto atinge valores até superiores a 12,5). Nesse ambiente altamente alcalino, forma-se, na superfície das barras de aço, uma camada microscópica impermeável de óxido de ferro, que se constitui na camada apassivadora. Tal película impede a dissolução de íons $\mathrm{Fe}++$, tornando-se impossível a corrosão das armaduras, mesmo que haja umidade no meio ambiente. A corrosão da armadura só se dá se a película passivadora for destruída, o que pode acontecer de três formas: i) pela redução do $\mathrm{pH}$ abaixo de nove, por efeito da carbonatação do concreto da camada de cobrimento; ii) pela presença de íons cloreto ou de outros íons, como os provenientes da poluição atmosférica; iii) pela lixiviação do concreto na presença de fluxos de água que percolem através de sua massa. 
A proteção das armaduras depende tanto da qualidade do concreto (compacidade e impermeabilidade) quanto de uma camada de cobrimento de tais armaduras com espessura adequada. FUSCO (1995) chama a atenção para o fato de que "a camada de cobrimento deve proteger todas as barras da armadura, devendo, por isso, ser medida a partir das barras mais próximas à superfície da peça, considerando-se inclusive a presença de estribos ou de barras de armaduras secundárias e mesmo de armaduras construtivas" (Figura 2.13).
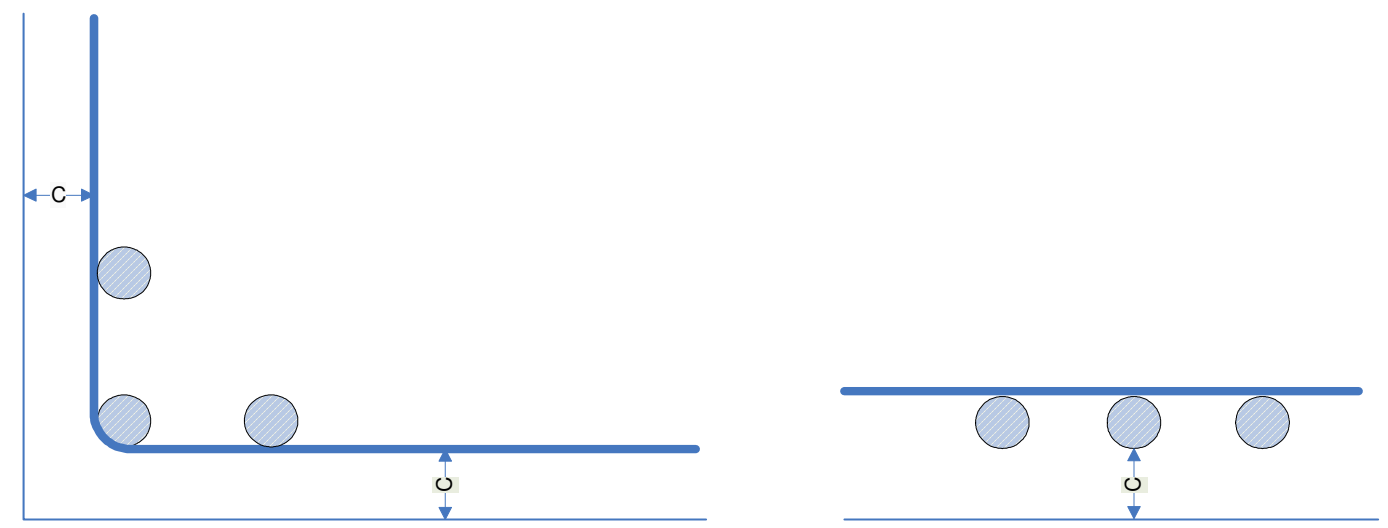

Figura 2.13 - Exemplo de camada de cobrimento (espessura "c"). Fonte: FUSCO (1995)

O item 7.4.7.2 da NBR 6118:2003 prescreve que, para garantir o cobrimento mínimo $\left(c_{\min }\right)$, o projeto e a execução devem considerar o cobrimento nominal $\left(c_{\text {nom }}\right)$, que é o cobrimento mínimo acrescido da tolerância de execução $(\Delta c)$. Assim, as dimensões das armaduras e os espaçadores devem respeitar os cobrimentos nominais, estabelecidos na tabela 7.2 da NBR 6118:2003, que considera $\Delta \mathrm{c}=10 \mathrm{~mm}$, bem como os cobrimentos nominais mínimos prescritos no item 7.4.7.5 da referida norma.

O item 7.4.7.4 da NBR 6118:2003 diz que, "quando houver um controle de qualidade e rígidos limites de tolerância da variabilidade das medidas durante a execução, pode ser adotado um valor $\Delta \mathrm{c}=5 \mathrm{~mm}$, mas a exigência de controle rigoroso deve ser explicitada nos desenhos de projeto. Permite-se, então, a redução dos cobrimentos nominais prescritos na tabela 7.2 da NBR 6118:2003 em $5 \mathrm{~mm}$.

\subsubsection{Disposições Construtivas Específicas}

A NBR 6118:2003 prevê, no item 18.2.1, que o "arranjo das armaduras deve atender não só à sua função estrutural como também às condições adequadas de execução, particularmente com relação ao lançamento e ao adensamento do concreto. Os espaços devem ser projetados para a introdução do vibrador e de modo a impedir a segregação dos agregados e a ocorrência de vazios no interior do elemento estrutural".

\subsubsection{Armadura dos Pilares}

2.3.4.1.1

Considerações gerais sobre o elemento estrutural 
A NBR 6118:2003 define pilares como "elementos lineares ${ }^{20}$ de eixo reto, usualmente dispostos na vertical, em que as forças normais de compressão são preponderantes". FUSCO (1995) diz que a seção transversal dos pilares, formada pelo concreto e pelas barras da armadura longitudinal, deve garantir a segurança em relação à resistência e à estabilidade da construção. A armadura transversal do pilares, formadas por estribos, tem como principal função impedir a flambagem das barras de aço comprimidas dentro do concreto e manter a posição das barras da armadura longitudinal durante a concretagem da peça.

A NBR 6118:2003 prescreve que a seção transversal dos pilares, independentemente da sua forma, não deve apresentar dimensão menor que $19 \mathrm{~cm}$. Porém, tal limite pode ser reduzido (até $12 \mathrm{~cm}$ ) desde que se multipliquem as ações consideradas no dimensionamento por um coeficiente adicional prescrito na referida norma. Qualquer que seja o caso, não se permitem pilares com seção transversal inferior a $360 \mathrm{~cm}^{2}$.

\subsection{Arranjos Longitudinais das Armaduras dos Pilares}

Ao NBR 6118:2003 deixa bem clara a distinção entre pilares e pilares-parede ao tratar as armaduras longitudinais. No caso dos pilares cuja maior dimensão da seção transversal exceda em cinco vezes a menor dimensão (que caracteriza os pilares-parede), além das exigências normais dos pilares, deve-se atender ao que estabelece a seção 15 da referida norma.

A Tabela 2.8 apresenta as considerações da NBR 6118:2003 sobre a disposição das barras longitudinais.

Tabela 2.8 - Prescrições quanto às disposições das barras longitudinais pela NBR 6118:2003 (item 18.4.2)

\begin{tabular}{|c|c|}
\hline Aspecto & Prescrição \\
\hline Diâmetro & $\begin{array}{l}\text { Os diâmetros das barras longitudinais não devem ser inferiores a } \\
10 \mathrm{~mm} \text { nem superiores a } 1 / 8 \text { da menor dimensão transversal. }\end{array}$ \\
\hline Taxa de armadura & $\begin{array}{l}\text { A taxa geométrica da armadura deve respeitar os valores } \\
\text { máximos e mínimos especificados no item } 17.3 .5 .3 \text {. }\end{array}$ \\
\hline Distribuição transversal & $\begin{array}{l}\text { Em seções poligonais, deve existir pelo menos uma barra em cada } \\
\text { vértice; em seções circulares, no mínimo seis barras distribuídas } \\
\text { ao longo do perímetro. O espaçamento mínimo livre entre as faces } \\
\text { das barras longitudinais, medido no plano da seção transversal, } \\
\text { fora da região das emendas, deve ser maior ou igual ao maior dos } \\
\text { seguintes valores: } 20 \mathrm{~mm} \text {; diâmetro da barra, do feixe ou da luva; } \\
1,2 \text { vezes o diâmetro máximo dos agregados. }\end{array}$ \\
\hline
\end{tabular}

FUSCO (1995) faz as seguintes observações quanto a arranjos típicos das armaduras longitudinais dos pilares:

20 A NBR 6118:2003 define elementos lineares como sendo aqueles em que o comprimento longitudinal supera em pelo menos três vezes a maior dimensão da seção transversal, sendo também denominados barras. 
- nos edifícios, por razões construtivas, as emendas da armadura longitudinal são sempre feitas acima da laje dos diferentes andares de construção;

- quando não há mudança da seção transversal do pilar de um tramo ao seguinte, somente têm o comprimento necessário à emenda por traspasse as barras que efetivamente irão ter prolongamento no tramo superior;

- quando o prolongamento da barra não é possível, empregam-se barras suplementares que funcionam como arranque para o prolongamento do pilar;

- a prática conhecida como "engarrafamento" da armadura (usual quando há redução na seção dos pilares) somente pode ser tolerada quando as dimensões do pilar são superabundantes, e sua resistência não depende da eficiência do funcionamento da armadura.

\subsubsection{3}

\section{Arranjos Transversais das Armaduras dos Pilares}

O item 18.4.3 da NBR 6118:2003, que trata da armadura transversal dos pilares, diz que ela é "constituída por estribos e, quando for o caso, por grampos suplementares, e que deve ser colocada em toda a altura do pilar, sendo obrigatória sua colocação na região de cruzamento com vigas e lajes".

A Tabela 2.9 apresenta as considerações da NBR 6118:2003 sobre a disposição das barras transversais.

Tabela 2.9 - Disposições das barras transversais prescrita na NBR 6118:2003 (item 18.4.3)

\begin{tabular}{|c|c|}
\hline Aspecto & Prescrição \\
\hline Diâmetro & $\begin{array}{l}\text { O diâmetro dos estribos em pilares não deve ser inferior a } 5 \mathrm{~mm} \text { e nem a } 1 / 4 \text { do } \\
\text { diâmetro da barra isolada ou do diâmetro equivalente do feixe que constitui a } \\
\text { armadura longitudinal. }\end{array}$ \\
\hline $\begin{array}{l}\text { Distribuição } \\
\text { longitudinal }\end{array}$ & $\begin{array}{l}\text { O espaçamento longitudinal entre estribos, medido na direção do eixo do } \\
\text { pilar, para garantir o posicionamento, impedir a flambagem das barras } \\
\text { longitudinais e garantir a costura das emendas de barras longitudinais nos } \\
\text { pilares usuais, deve ser igual ou inferior ao menor dos seguintes valores: } \\
200 \mathrm{~mm} \text {; menor dimensão da seção; } 24 \phi^{21} \text { para CA- } 25 \text { e } 12 \phi \text { para CA- } 50 \text {. } \\
\text { Quando houver necessidade de armaduras transversais para forças cortantes } \\
\text { e torção, estes valores devem ser comparados com os mínimos prescritos no } \\
\text { item } 18.3 \text { para vigas, adotando-se o menor dos limites especificados. }\end{array}$ \\
\hline
\end{tabular}

O item 18.2.4 da NBR 6118:2003 considera, especificamente, a questão da proteção contra a flambagem das barras. Diz que os "estribos poligonais" garantem contra a flambagem as barras longitudinais situadas em seus cantos e as por eles abrangidas, situadas, no máximo, à distância de $20 \phi_{\mathrm{t}}$ (onde $\phi_{\mathrm{t}}$ é o diâmetro da barra do estribo) do canto, se neste trecho, de comprimento $20 \phi_{\mathrm{t}}$, não houver mais de duas barras, não contando a de canto. "Quando houver mais de duas barras neste trecho ou barra fora dele, deve haver estribos suplementares".

\footnotetext{
${ }^{21}$ Diâmetro das barras longitudinais
} 
"Se o estribo suplementar for constituído por uma barra reta, terminada em ganchos, ele deve atravessar a seção do elemento estrutural e os seus ganchos devem envolver a barra longitudinal. Se houver mais de uma barra longitudinal a ser protegida junto à mesma extremidade do estribo suplementar, seu gancho deve envolver um estribo principal em um ponto junto a uma das barras, o que deve ser indicado no projeto de modo bem destacado". (Figura 2.14).

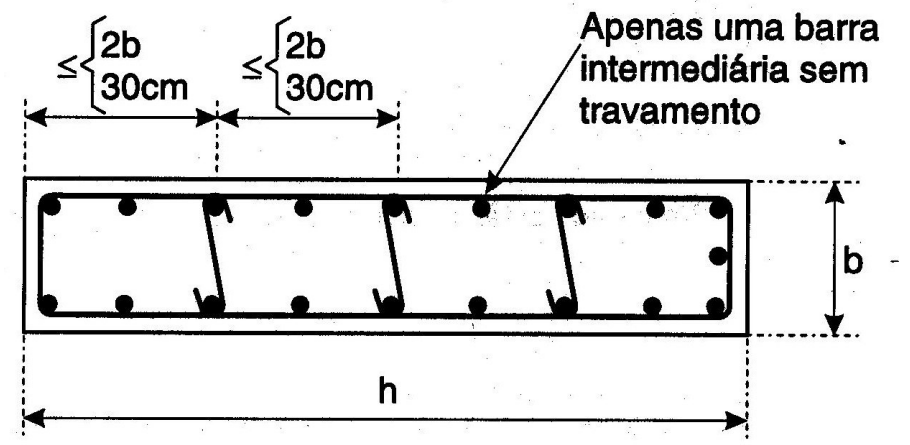

Figura 2.14 - Disposição dos estribos suplementares. Fonte: FUSCO (1995)

\subsubsection{Armadura das Vigas}

\subsubsection{1}

Considerações gerais sobre o elemento estrutural

A NBR 6118:2003 define vigas como elementos lineares em que a flexão é preponderante. FUSCO (1995)

Nas vigas, as armaduras longitudinais inferiores resistem aos esforços de tração decorrentes dos momentos fletores. Os estribos e as barras dobradas constituem-se na armadura transversal resistente aos esforços de tração decorrentes das forças cortantes. Além das barras longitudinais, existe uma armadura de montagem na face superior da viga, sendo que as barras que a constituem também podem funcionar como armadura de compressão, desde que evitada a sua flambagem dentro do concreto. Quando há cruzamento de vigas, há a necessidade de uma armadura de suspensão. Tal armadura é composta por estribos que funcionam como um pendural, colocados junto ao cruzamento e dispostos, principalmente, na viga que dá apoio à outra. Quando a viga tiver altura significativa, para que se evite a fissuração exagerada em condições de serviço, haverá a necessidade de emprego de uma armadura de pele. Para que as armaduras fiquem completas, pode haver a necessidade de outras barras de aço para absorção de esforços decorrentes de dobras, de ancoragens, de emendas ou de outras causas que ponham em risco a solidariedade existente entre concreto e o aço. Tais barras podem ser genericamente designadas por armaduras de solidarização. FUSCO (1995)

\subsection{Arranjos Longitudinais das Armaduras}

As prescrições apresentadas na NBR 6118:2003, comentadas e apresentadas a seguir, referem-se a vigas isostáticas com relação $\mathrm{l} / \mathrm{h}$ (comprimento do vão teórico da viga em relação à altura total da viga) maior ou igual a 3,0 e a vigas contínuas com relação $\mathrm{I} / \mathrm{h}$ maior ou igual a 2,0. Vigas com l/h menores devem ser tratadas como vigas-parede. 
A Tabela 2.10 apresenta as considerações da NBR 6118:2003 sobre a disposição das barras longitudinais.

Tabela 2.10 - Disposições das barras longitudinais prescrita na NBR 6118:2003 (item 18.4.2)

\begin{tabular}{|c|c|}
\hline Aspecto & Prescrição \\
\hline Taxa de armadura & $\begin{array}{l}\text { A quantidade mínima de armadura de flexão deve ser calculada de } \\
\text { acordo com o item 17.3.5 da NBR } 6118: 2003\end{array}$ \\
\hline Distribuição transversal & $\begin{array}{l}\text { O espaçamento mínimo livre entre as faces das barras } \\
\text { longitudinais, medido no plano da seção transversal, deve ser } \\
\text { maior ou igual aos seguintes valores: i) na direção horizontal: } \\
20 \mathrm{~mm} \text {; diâmetro da barra, do feixe ou da luva; } 20 \% \text { superior ao } \\
\text { diâmetro máximo do agregado; ii) na direção vertical: 20mm; } \\
\text { diâmetro da barra, do feixe ou da luva; metade do diâmetro } \\
\text { máximo do agregado. }\end{array}$ \\
\hline Distribuição longitudinal & A distribuição deve seguir prescrições do item 18.3.2.3 \\
\hline
\end{tabular}

2.3.4.2.3

Arranjos Transversais das Armaduras

As armaduras destinadas a resistir aos esforços de tração provocados por forças cortantes podem ser constituídas por estribos, combinados ou não com barras dobradas ou barras soldadas.

Na Figura 2.15 estão apresentados os arranjos básicos dos estribos das vigas propostos por FUSCO (1995). Segundo o autor, os estribos abertos são tão eficientes quanto os estribos fechados.

Observa-se, porém, que esforços secundários na estrutura tornam necessária a colocação de armadura suplementar de fechamento, mesmo do lado comprimido da peça. Quando são empregados estribos abertos, é importante observar que, por razões construtivas, o lado fechado é sempre colocado no fundo da fôrma, quer esse lado vá ser comprimido ou tracionado. Quando se empregam estribos múltiplos, os ramos horizontais se sobrepõem parcialmente, a fim de impedir que possa ocorrer a fissuração longitudinal do banzo tracionado.

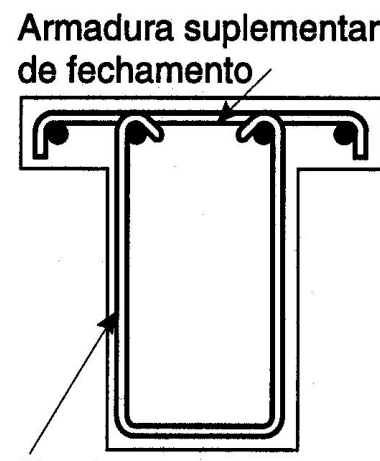

Estribo aberto

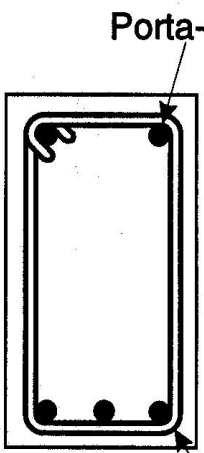

Estribo fechado

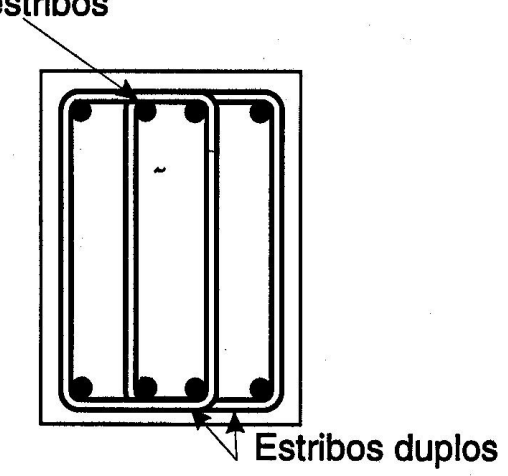

Figura 2.15 - Arranjos básicos de estribos de vigas. Fonte: FUSCO (1995) 
A Tabela 2.11 apresenta as considerações da NBR 6118:2003 sobre armadura transversal (com estribos) para força cortante.

Tabela 2.11 - Disposições das barras transversais prescritas na NBR 6118:2003 (item 18.3.3)

\begin{tabular}{l|l}
\hline Aspecto & \multicolumn{1}{c}{ Prescrição } \\
\hline \multirow{2}{*}{ Diâmetro } & $\begin{array}{l}\text { O diâmetro da barra que constitui o estribo deve ser maior ou } \\
\text { igual a } 5 \mathrm{~mm} \text {, sem exceder } 1 / 10 \text { da largura da alma da viga. } \\
\text { Quando a barra for lisa, seu diâmetro não pode ser superior a } \\
12 \mathrm{~mm} .\end{array}$ \\
& Os estribos para força cortante devem ser fechados através de um \\
ramo horizontal, envolvendo as barras da armadura longitudinal \\
de tração, e ancoradas na face oposta. O espaçamento mínimo \\
entre estribos, medido segundo o eixo longitudinal do elemento \\
estrutural, deve ser suficiente para permitir a passagem do \\
vibrador, garantindo um bom adensamento da massa. O \\
espaçamento máximo deve atender às condições prescritas no \\
item 18.3 .3 .2$.
\end{tabular}

O emprego de estribos fechados ou abertos com armadura suplementar de fechamento deve ser decidido pelo projetista, tendo em vista os problemas de montagem da armadura. Devem ser considerados problemas de colocação das barras da armadura longitudinal e do eventual dobramento do ramo de fechamento com o estribo já colocado na fôrma. FUSCO (1995)

FUSCO (1995) salienta que é importante que a largura dos estribos não seja muito grande, "pois as bielas diagonais efetivamente se apóiam nas barras da armadura longitudinal criando problemas de flexão local do ramo horizontal escolhido".

\subsubsection{Armaduras das Lajes}

\subsection{Considerações gerais sobre o elemento estrutural}

De acordo com a classificação geral das peças estruturais (FUSCO, 1995), as placas são estruturas laminares com superfície média plana, solicitadas, predominantemente, por forças perpendiculares ao seu plano médio. Nas estruturas de concreto, as placas usualmente ganham o nome de lajes. Segundo a NBR 6118:2003, as placas com espessuras maiores que $1 / 3$ do vão devem ser estudadas como placas espessas.

A Figura 2.16 apresenta os principais tipo de lajes. As lajes nervuradas são as lajes moldadas no local, ou com nervura pré-moldadas, cuja zona de tração para momentos positivos está localizada nas nervuras, entre as quais pode ser colocado material inerte.

As lajes-cogumelo são lajes apoiadas diretamente em pilares com capitéis, enquanto as lajes lisas são apoiadas nos pilares sem capitéis. 


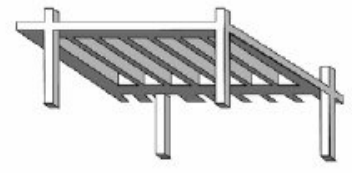

Laje nervurada

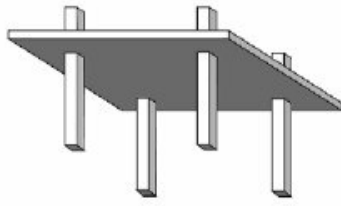

Laje plana

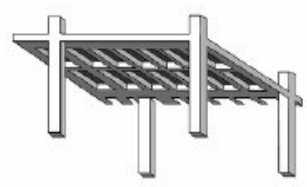

Laje nervurada

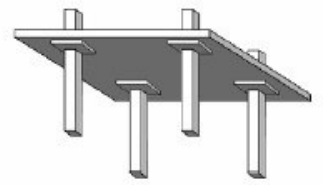

Laje cogumelo

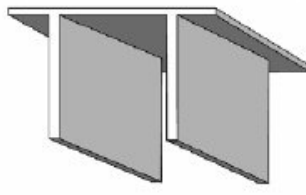

Laje plana

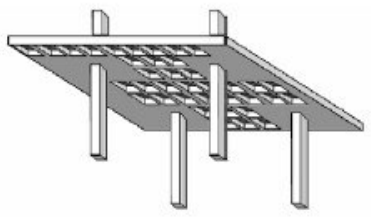

Laje nervurada

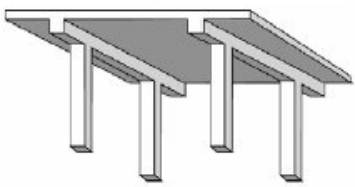

Laje com vigas

Figura 2.16 - Principais tipos de lajes

\subsubsection{2}

Critérios de Arranjo Geral

O item 20.1 da NBR 6118:2003 faz as seguintes prescrições sobre o detalhamento das lajes: i) as armaduras devem estar dispostas de forma que se possa garantir o seu posicionamento durante a concretagem; ii) qualquer barra da armadura de flexão deve ter diâmetro no máximo igual a $\mathrm{h}^{22} / 8$; iii) as barras da armadura principal de flexão devem apresentar espaçamento no máximo igual a $2 \mathrm{~h}$ ou $20 \mathrm{~cm}$, prevalecendo o menor desses dois valores na região dos maiores momentos fletores; iv) a armadura secundária de flexão deve ser maior ou igual a $20 \%$ da armadura principal, mantendo-se, ainda, um espaçamento entre as barras de, no máximo, $33 \mathrm{~cm}$. A emenda dessas barras deve respeitar os mesmos critérios de emenda das barras da armadura principal; v) os estribos em lajes nervuradas, quando necessários, não devem ter espaçamento superior a $20 \mathrm{~cm}$.

\subsubsection{3}

\section{Arranjos Longitudinais das Armaduras}

Os princípios básicos para o estabelecimento de armaduras máximas e mínimas são dados pelo item 17.3.5.1 da NBR 6118:2003. "Como as lajes armadas nas duas direções têm outros mecanismos resistentes possíveis, os valores mínimos das armaduras positivas são reduzidos em relação aos dados para elementos estruturais lineares".

O item 19.1 da NBR 6118:2003 fornece os valores mínimos de armadura passiva (necessário para melhorar o desempenho e a ductilidade à flexão e à punção, assim como controlar a fissuração), que deve ser constituída, preferencialmente por barras de alta aderência ou por telas soldadas. Os valores máximos da armadura deve respeitar o limite dado pelo item 17.3.5.2 e 17.3.5.3 da NBR 6118:2003.

\subsection{Arranjos Transversais das Armaduras}

\footnotetext{
22 espessura da laje.
} 
As lajes maciças ou nervuradas (conforme item 17.4.1.1.2-b) podem prescindir de armadura transversal, para resistir aos esforços de tração oriundos da força cortante, quando esta referida força obedecer à expressão prescrita no item 19.4.1 da NBR 6118:2003. 


\subsection{O Processo de Concepção e Produção de Armaduras}

\subsubsection{Definições de nomenclatura}

A armadura, segundo definição proposta por FUSCO (1975), "é o componente estrutural de uma estrutura de concreto armado, formado pela associação de diversas peças de aço".

As definições de armação encontradas (FREIRE, 2001; ABCP, 2002) se referem a um conjunto de operações, restritas basicamente às atividades de preparação e posicionamento do aço na estrutura.

KALIAN et al. (2000) apresentam o "processo de armação" como compreendendo três etapas: i) projeto; ii) fabricação e fornecimento; iii) construção.

Na medida em que se deseja abordar, neste trabalho, a produção de armaduras, desde o projeto até as operações desenvolvidas na etapa de construção, a utilização do termo "armação 23" ou "serviço de armação" estaria limitada, como visto na própria definição supracitada, não tendo a abrangência necessária para englobar todo o processo tal como se deseja.

Assim, respalda-se na proposta de KALIAN et al. (2000) e propõe-se que se utilize o termo, ou expressão, "Processo de Concepção e Produção de Armaduras" (PCPA) para designar o processo completo, que englobaria as etapas de: i) elaboração do projeto do produto (mais especificamente, a elaboração dos projetos de detalhamento das armaduras (PDA)); ii) fabricação de peças $^{24}$ e armaduras fora do canteiro de obras; iii) armação, que deve ser interpretada não apenas como um serviço, mas sim, como um conjunto de atividades que engloba a administração de documentos, o planejamento e a programação do serviço, as operações de produção, a inspeção das armaduras, o controle de estoques, entre outras.

A Figura 2.17 mostra o primeiro nível $(\mathrm{A} 0)$ do diagrama que representa o PCPA. Tal diagrama é expandido, num segundo nível (Figura 2.18) que representa as três principais etapas, quais sejam o projeto (A1), a fabricação (A2) e a armação (A3). O desenvolvimento do texto, apresentado a seguir, explorará cada uma delas. Nota-se que a etapa de fabricação, no PCPA brasileiro, é "opcional", isto é, pode-se optar por produzir as peças e armaduras no canteiro de obras.

\footnotetext{
${ }^{23}$ Há quem se refira ao termo "armação", enquanto atividade ou serviço, mas também como sendo a própria armadura. Essa prática é muito comum nas obras de Construção Civil e em todos os níveis hierárquicos (do operário à gerencia técnica).

${ }^{24}$ As barras de aço após terem sido cortadas e dobradas de acordo com características geométricas definidas no projeto de detalhamento das armaduras, passam a ser denominadas "peças", sendo que a união destas peças irá constituir a armadura.
} 


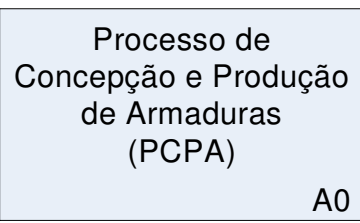

Figura 2.17 - Primeiro nível do diagrama que representa o PCPA

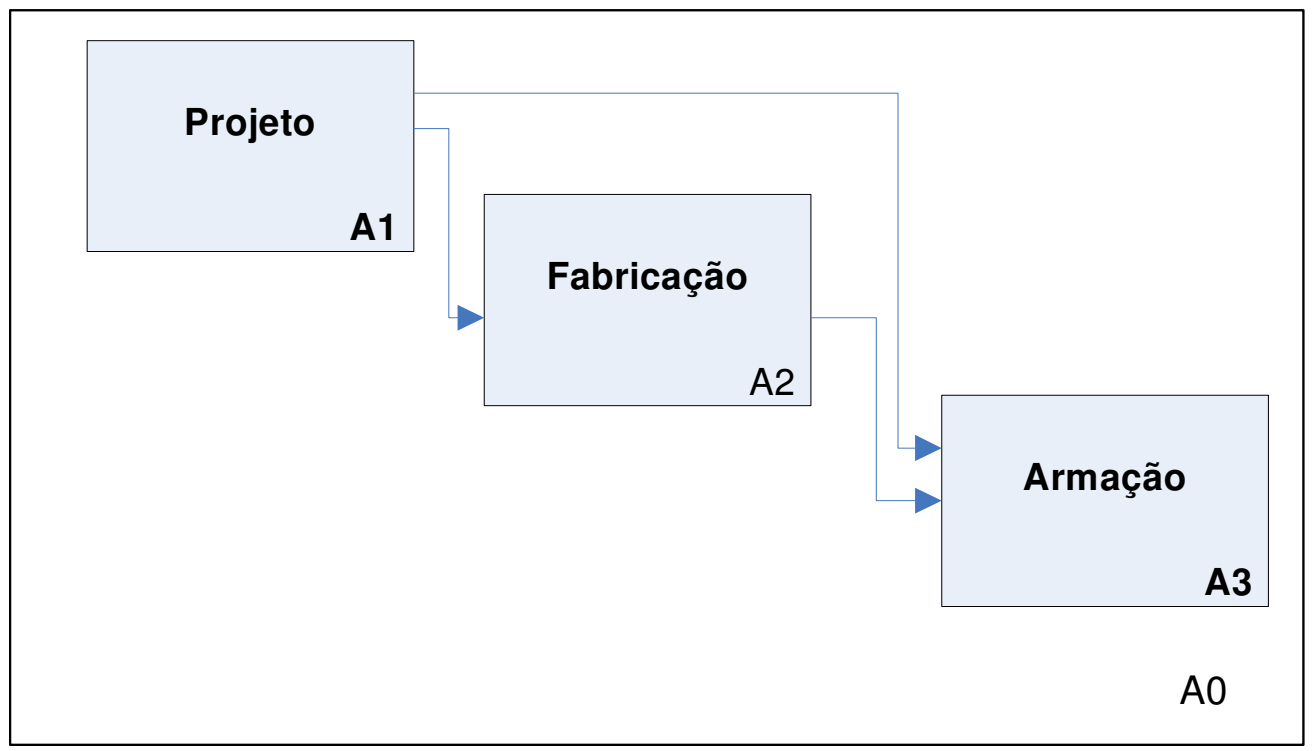

Figura 2.18 - Principais etapas do PCPA

\subsubsection{O Projeto no âmbito do PCPA}

\subsubsection{A importância do projeto estrutural no custo da estrutura}

FRANCO (2000) aponta que aproximadamente 70\% dos custos de uma estrutura de concreto armado são definidos no momento em que se tem pronto o projeto legal de uma obra, muitas vezes fortemente influenciado pelas decisões arquitetônicas. Somente os $30 \%$ restantes acabam sendo influenciados pelo projetista estrutural.

BATLOUNI NETO (2003) levantou, com base em um conjunto de dezesseis obras analisadas, que os custos referentes ao projeto estrutural representam, em média, 4,1\% do custo total da estrutura (o valor mediano representa $4,1 \%$, o valor mínimo $2,9 \%$ e o valor máximo 7,1).

Isso permite tecer-se a conjectura de que um projeto melhor remunerado (por exemplo, acrescido de $20 \%$ em relação ao valor médio de $4,1 \%$ do custo da estrutura, determinado por BATLOUNI NETO (2003)), em que o projetista poderia dedicar um maior número de horas trabalhadas, fosse capaz de reduzir em $10 \%$ a margem de $30 \%$, 
apontada por FRANCO (2000), como teoricamente influenciada pelo projetista, ter-se-ia uma estrutura 2,2\% mais econômica e um projetista $20 \%$ melhor remunerado.

Tal raciocínio, bastante simplista e, portanto, passível de falhas, serve apenas para mostrar que projetos mais elaborados (com foco na construtibilidade, por exemplo) podem proporcionar estruturas mais econômicas.

Os projetos de estrutura (fôrmas e detalhamento de armaduras), quando desenvolvidos levando-se em conta a sua "exeqüibilidade", isto é, a capacidade de tornarem sua execução mais simples e fácil, têm grandes chances de influenciarem positivamente a produtividade da mão-de-obra que os executa.

FRANÇA (2002) fez um estudo no qual comparou duas opções de lançamentos estruturais (estrutura com laje plana e estrutura com vigas), percebendo variações, em $\mathrm{R} \$ / \mathrm{m} 3$ de estrutura, de até $40 \%$ em favor da laje plana. Quando associou as opções a valores mínimos, medianos e máximos de produtividade da mão-de-obra, percebeu variações ainda maiores de custos das estruturas, ratificando a necessidade de que os projetos estruturais sejam desenvolvidos considerando as características que influenciam positivamente a produtividade.

\subsubsection{Desenvolvimento e Classificação das Etapas do Projeto Estrutural}

Os projetos das estruturas de concreto armado, desenvolvidos no Brasil, são baseados nos preceitos contidos na NBR 6118:2003 - Projetos de estruturas de concreto. Trata-se de uma norma revisada recentemente, publicada (versão corrigida) em 2004, amparada fortemente em requisitos voltados à qualidade do projeto estrutural e da estrutura gerada, haja vista a ênfase que a norma dá, entre outras, a questões como a qualidade das soluções, às descrições destas soluções fornecidas pelo projeto e à durabilidade da estrutura.

\subsubsection{1}

\section{Participantes do desenvolvimento do projeto estrutural}

LEONHARDT; MONNIG (1978) lembram que, para o projeto de estrutura, é importante a experiência dos envolvidos, que permite escolher o material mais favorável (sob os pontos de vista técnico e econômico) e um sistema estrutural adequado, bem como induzir um tipo de execução favorável.

BATLOUNI NETO (2003) salienta que cada membro da equipe multidisciplinar ("cabedal intelectual que irá transformar as idéias preliminares do arquiteto e do cliente em algo que possa ser construído") tem um papel determinado no decorrer da elaboração do projeto estrutural, conforme mostrado na Tabela 2.12 . 
Tabela 2.12 - Membros participantes do desenvolvimento do projeto estrutural. Fonte: BATLOUNI NETO (2003)

\begin{tabular}{|c|c|}
\hline Participante & Contribuição \\
\hline $\begin{array}{l}\text { Incorporador } \\
\text { da obra }\end{array}$ & $\begin{array}{l}\text { Define a vida útil (por exemplo, quantos anos deverá durar a estrutura do } \\
\text { edifício sem exigir medidas não previstas de manutenção e reparo) e o padrão } \\
\text { do edifício, que terão influências diretas na concepção do projeto. }\end{array}$ \\
\hline $\begin{array}{l}\text { Coordenador } \\
\text { de projeto }\end{array}$ & $\begin{array}{l}\text { Dará suporte a toda a equipe multidisciplinar, gerenciando o projeto de forma } \\
\text { a que sejam atendidos três aspectos principais: i) eficiência técnica; ii) } \\
\text { eficiência construtiva; iii) eficiência financeira. }\end{array}$ \\
\hline Construtor & $\begin{array}{l}\text { Fornece parâmetros e especificações ao projetista da estrutura. Auxilia o } \\
\text { coordenador no atendimento dos três aspectos mencionados anteriormente. } \\
\text { No Brasil é bastante presente a figura do "coordenador-construtor", ou seja, a } \\
\text { construtora mantém no corpo técnico este profissional. }\end{array}$ \\
\hline $\begin{array}{l}\text { Projetista da } \\
\text { estrutura }\end{array}$ & $\begin{array}{l}\text { Trata-se do maior responsável pela eficiência global do projeto estrutural, } \\
\text { influenciando de maneira decisiva o desempenho, a durabilidade e o custo final } \\
\text { da edificação. }\end{array}$ \\
\hline $\begin{array}{l}\text { Projetista de } \\
\text { Fundações }\end{array}$ & $\begin{array}{l}\text { Fornece ao projetista da estrutura os elementos da fundação que resistirão aos } \\
\text { esforços provenientes da superestrutura do edifício. Orienta o projetista de } \\
\text { estrutura no lançamento dos pilares. }\end{array}$ \\
\hline Arquiteto & $\begin{array}{c}\text { A concepção arquitetônica é o maior influenciador do custo potencial da obra } \\
\text { do edifício. O projeto arquitetônico é o maior limitador da redução do custo de } \\
\text { um edifício. Participa das definições e detalhamento construtivos, no } \\
\text { lançamento da estrutura. Define, junto com o incorporador, as características } \\
\text { da utilização do edifício, permitindo ao projetista da estrutura estabelecer } \\
\text { parâmetros de cálculo, como as cargas acidentais de utilização. }\end{array}$ \\
\hline $\begin{array}{l}\text { Projetista de } \\
\text { Instalações }\end{array}$ & $\begin{array}{c}\text { Fornece os espaços e as posições dos furos necessários para a passagem das } \\
\text { instalações, os pesos dos equipamentos e características das peças } \\
\text { estruturais. }\end{array}$ \\
\hline $\begin{array}{l}\text { Tecnologista } \\
\text { de concreto }\end{array}$ & $\begin{array}{l}\text { Define as características do concreto no estado fresco (importante para a } \\
\text { execução) e no estado endurecido (importante para o cálculo e durabilidade). }\end{array}$ \\
\hline $\begin{array}{l}\text { Auditor do } \\
\text { projeto } \\
\text { estrutural }\end{array}$ & $\begin{array}{l}\text { Em projetos de maior envergadura, verifica os cálculos e analisa a concepção } \\
\text { do projeto, atestando a qualidade do produto final. }\end{array}$ \\
\hline
\end{tabular}

2.4.2.2.2

Etapas de desenvolvimento do projeto estrutural

LEONHARDT; MONNIG (1978) apontam que o projeto estrutural é representado em desenhos de conjunto com vistas gerais. "Segue-se, após os cálculos estruturais definitivos, com o dimensionamento, quando, então, deve-se verificar as exigências de segurança quanto à capacidade resistente e à utilização. Finalmente, elaboram-se os detalhes construtivos e produzem-se os desenhos de execução. Para isso é necessário, freqüentemente, prever e levar em conta, até o detalhe, o processo de execução".

Segundo THOMAZ (1999), a elaboração de um projeto estrutural envolve basicamente quatro fases: concepção, pré-dimensionamento, análise estrutural ou numérica (dimensionamento) e detalhamento. "A participação intelectual do projetista é imprescindível em todas as fases; o trabalho mecânico do computador é muito 
importante nas fases de pré-dimensionamento e detalhamento, não podendo substituir, em nenhuma das fases, a atividade intelectual do projetista".

$\mathrm{Na}$ visão de BATLOUNI NETO (2003) houve uma alteração nos métodos de desenvolvimento de projetos com a informatização dos escritórios a partir da década de 80. "Com a implantação gradativa do uso do computador como instrumento para desenhar o projeto, perdeu-se a necessidade de desenvolvê-lo em etapas, uma vez que cada acréscimo de informação é uma evolução do mesmo desenho da versão anterior". Configuraram-se duas etapas ao longo do desenvolvimento do projeto: i) etapa 1: projeto preliminar; ii) etapa 2: projeto executivo.

BATLOUNI NETO (2003), assim, define as duas fases de projeto:

- Projeto Preliminar: é a fase predominante de concepção, na qual será estabelecido o partido estrutural e a forma do lançamento da estrutura sobre a arquitetura proposta. As pré-fôrmas dos pavimentos do edifício são o produto final nesta etapa.

- Projeto Executivo: engloba todo o desenvolvimento, desde a pré-fôrma até a fôrma definitiva, e será considerada como tal, quando já compatibilizado com os demais projetos do edifício. A partir da finalização do projeto estrutural de formas processase o detalhamento da armação.

O autor supracitado elaborou um fluxograma com as principais atividades da etapa de projeto a partir de uma reunião envolvendo alguns projetistas estruturais. O resultado pode ser observado na Figura 2.19. As caixas deste fluxograma que se apresentam sombreadas e com cantos "abaulados" indicam os documentos de saída (entregues ao cliente), apresentados pelo projetista ao cliente na seguinte ordem cronológica: i) préfôrmas do pavimento tipo; ii) pré-fôrmas dos demais pavimentos; iii) fôrmas definitivo; iv) fôrmas e detalhamento das armaduras da fundação; v) detalhamento das armaduras dos pavimentos.

Para a Associação Brasileira de Engenharia e Consultoria Estrutural (ABECE)

[...] a elaboração de um projeto é um processo complexo, envolvendo diversas interfaces e cuja contratação e coordenação racional envolve diversas dificuldades; adicionalmente, a dinâmica do mercado imobiliário tem exigido uma otimização cada vez maior do projeto. De modo a permitir essa otimização, torna-se necessário o estabelecimento de um fluxo de trabalho estável e padronizado na elaboração dos diversos projetos de um empreendimento, onde as etapas a serem cumpridas atendam adequadamente às necessidades de todos os intervenientes, e contribuam para a interação eficiente entre as diversas equipes. 


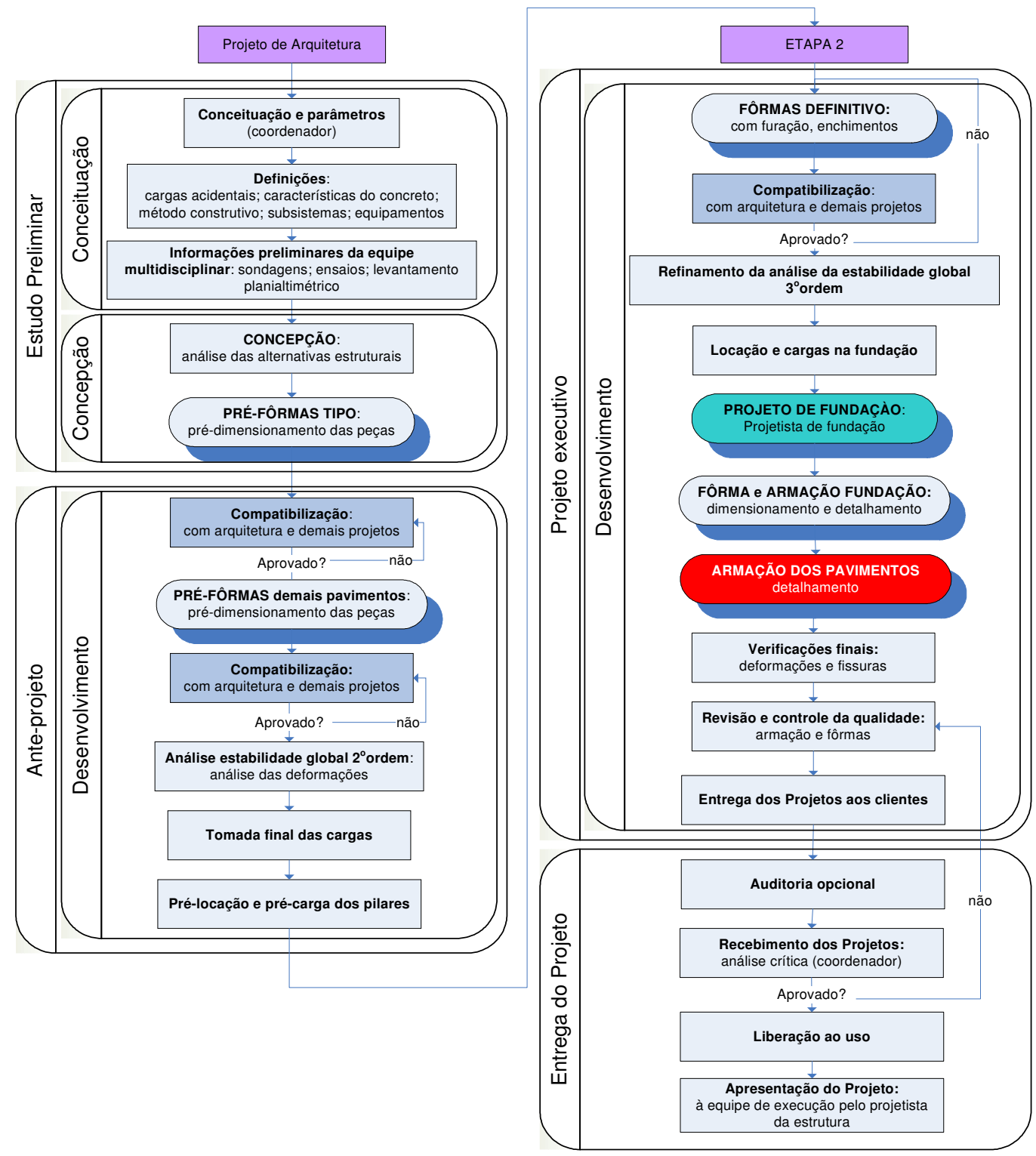

Figura 2.19 - Fluxograma de desenvolvimento do projeto estrutural. Adaptado de BATLOUNI NETO (2003)

A ABECE elaborou um documento que contém uma seqüência de atividades, organizada em fases bem definidas (são seis fases), que podem determinar com clareza cronogramas, medições e outras etapas notáveis, conforme os interesses em cada caso específico. A Tabela 2.13 apresenta estas fases e traz um breve resumo sobre o escopo de cada uma delas. 
Tabela 2.13 - Fluxo de trabalho para elaboração do projeto estrutural. Fonte: ABECE

\begin{tabular}{|c|c|}
\hline Fase & Escopo \\
\hline $\begin{array}{l}\text { Apoio à concepção do } \\
\text { produto }\end{array}$ & $\begin{array}{l}\text { Analisar a proposta arquitetônica para o terreno e indicar as } \\
\text { condições necessárias à viabilidade do ponto de vista da estrutura, } \\
\text { através de uma análise qualitativa }\end{array}$ \\
\hline $\begin{array}{l}\text { Apoio à definição do } \\
\text { produto }\end{array}$ & $\begin{array}{l}\text { Fornecer elementos para verificar a viabilidade do empreendimento, } \\
\text { suprindo as informações necessárias para o projeto legal e índices } \\
\text { para elaboração de um orçamento preliminar de viabilidade }\end{array}$ \\
\hline $\begin{array}{l}\text { Identificação e solução de } \\
\text { interfaces }\end{array}$ & $\begin{array}{l}\text { Gerar desenhos de estruturas com todas as indicações necessárias } \\
\text { para intercâmbio entre todos os projetistas envolvidos no projeto, } \\
\text { resultando, após a negociação de possíveis soluções, num projeto } \\
\text { com todas as interfaces, de outros projetistas, resolvidas (inclusive } \\
\text { furação de vigas). }\end{array}$ \\
\hline $\begin{array}{l}\text { Projeto de detalhamento } \\
\text { das especialidades }\end{array}$ & $\begin{array}{l}\text { Desenvolver o projeto de obra, ou seja: } \\
\text { Concreto e Alvenaria Estrutural: Detalhamento das armações dos } \\
\text { elementos estruturais e incorporação de detalhes de produção } \\
\text { dependendo do sistema construtivo }\end{array}$ \\
\hline Pós-entrega do projeto & Garantir o bom uso do projeto estrutural \\
\hline Pós-e & $\begin{array}{l}\text { Analisar o comportamento da estrutura em serviço ou adaptá-la a } \\
\text { novas condições de serviço }\end{array}$ \\
\hline
\end{tabular}

\subsubsection{3}

\section{Conteúdo dos projetos estruturais}

Os desenhos das armaduras que definem os componentes estruturais de uma estrutura de concreto armado não podem ser representados em apenas uma planta, seja pelo próprio espaço físico demandado para que todas as peças e detalhes sejam ilustrados, ou pelos diferentes pavimentos e trechos da obra que atendem. Logo, utiliza-se um conjunto de plantas em número suficiente para ilustrar os desenhos necessários, compondo o projeto de detalhamento das armaduras. As diretrizes específicas para elaboração destes desenhos são as citadas na NB-7191 (NB 16).

LEONHARDT; MONNIG (1978) colocam que o projeto de uma obra é representado por desenhos que contenham vistas, corte e plantas e detalhes construtivos. Os projetos de fôrmas, segundo os autores, são representados nas escalas 1:50, 1:25 e 1:20 e compreendem plantas (que representam a vista superior das superfícies das fôrmas) e cortes na estrutura concluída. Estes desenhos contêm todas as dimensões, elevações, rebaixos, aberturas, canalizações embutidas no concreto, indicações sobre os materiais, juntas, vedações etc. Já as plantas relativas ao projeto de armaduras seriam representadas nas escalas 1:50, 1:25 e 1:20, com detalhes nas escalas 1:10, 1:5 e 1:1. Destinam-se à representação das armaduras, com indicação da forma das barras, diâmetros, quantidades, espaçamento entre barras, posições de camadas, comprimentos de emendas e ancoragem, medidas exatas de cada barra individualmente ou das malhas das armaduras, diâmetro dos pinos de dobramento, marcas (posições) para a lista de barras, cobrimento do concreto, indicações sobre o tipo de aço.

BATLOUNI NETO (2003) recorda que um dos principais requisitos de qualidade de um projeto estrutural é a qualidade da descrição da solução, o que implica que os desenhos 
e especificações contenham informações claras, corretas e consistentes entre si, conforme prevê a NBR 6118. "As informações serão corretas se compatíveis com as ações, esforços e materiais adotados, ou seja, com as hipóteses e cálculos do projeto, e também com as normas técnicas. Os outros aspectos influem diretamente na produção no canteiro".

Os projetos que irão a campo, para serem executados, são basicamente os projetos de fôrmas e os projetos de detalhamento das armaduras. BATLOUNI NETO (2003) relacionou um conjunto de informações que devem estar presentes neste projetos, apresentadas na Tabela 2.14.

Tabela 2.14 (continua) - Informações que devam estar constantes no projeto estrutural. BATLOUNI NETO (2003)

\begin{tabular}{|c|c|}
\hline Projeto & Informações \\
\hline $\begin{array}{l}\text { Projeto de } \\
\text { fôrmas }\end{array}$ & 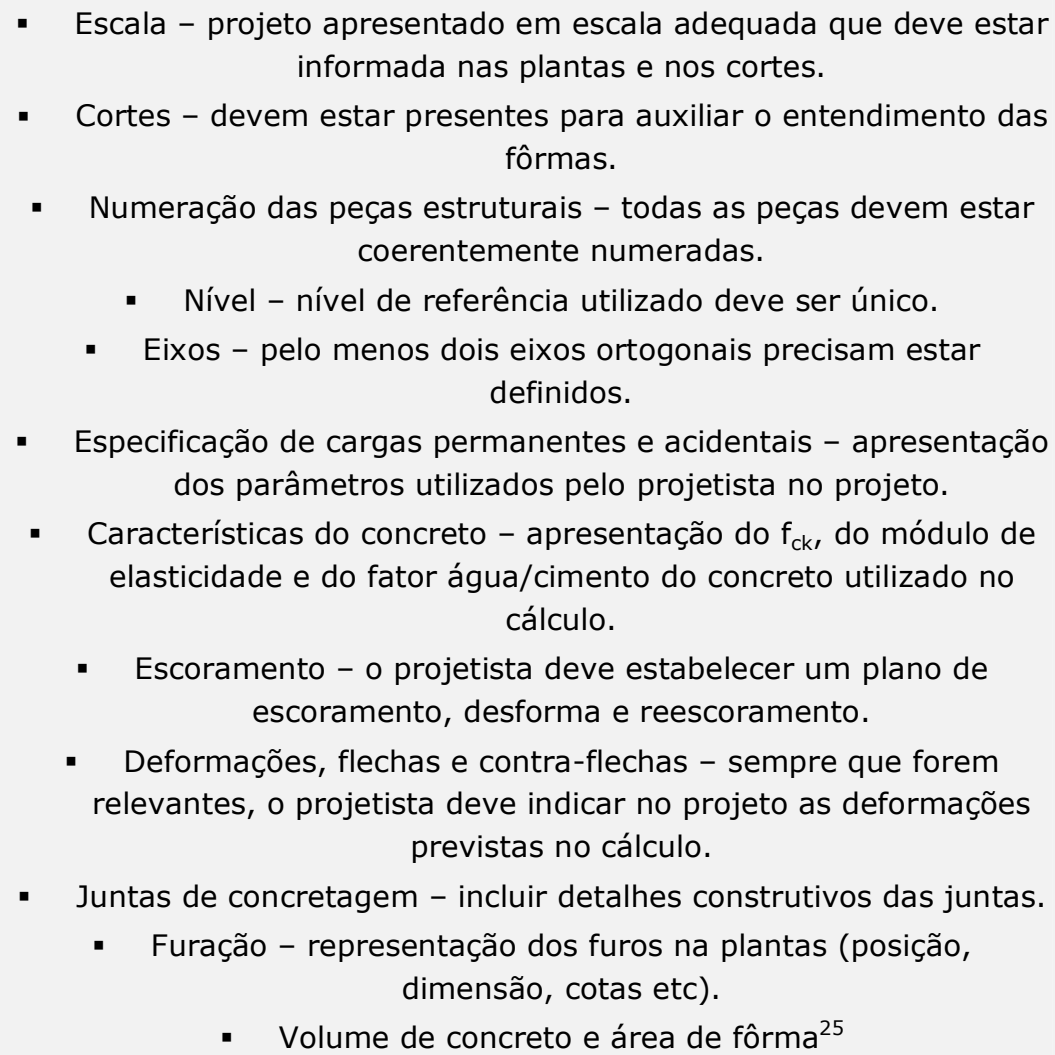 \\
\hline
\end{tabular}

25 A presença destas informações no projeto não é obrigatória, sendo usualmente contratadas à parte. 
Tabela 2.15 (conclusão) - Informações que devam estar constantes no projeto estrutural. BATLOUNI NETO (2003)

\begin{tabular}{|c|c|}
\hline Projeto & Informações \\
\hline $\begin{array}{c}\text { Projeto de } \\
\text { detalhamento } \\
\text { das armaduras }\end{array}$ & $\begin{array}{l}\text { - Especificação do aço - devem constar os aços utilizados no } \\
\text { cálculo (armadura passiva conforme NBR 7840; aço para } \\
\text { protensão: NBR 7482/91 e NBR 7483/91). } \\
\text { - } \quad \text { Plano de protensão - orientações necessárias à execução da } \\
\text { protensão. } \\
\text { - Tabelas resumo de aço - presentes em todas as folhas. } \\
\text { - Cobrimento - devem apresentar as espessuras de cobrimento. } \\
\text { - } \text { Detalhes das armaduras - devem estar presentes sempre que } \\
\text { importantes ao bom entendimento do projeto. } \\
\text { armaduras complementares - incorporar ao projeto posições } \\
\text { auxiliares e construtivas }\end{array}$ \\
\hline Ambos & $\begin{array}{c}\text { - Revisões - devem constar as revisões executas, com datas e a } \\
\text { discriminação das alterações de forma clara e precisa. } \\
\text { - Memorial de cálculo }{ }^{26} \\
\text { - Orientações de uso e manutenção - parte das estruturas } \\
\text { requerem manutenção periódica, o que deve ser informado em } \\
\text { projeto. } \\
\text { - Liberação ao uso - junto à legenda da folha deve ser previsto } \\
\text { espaço para carimbo para controle da liberação do projeto ao } \\
\text { uso. }\end{array}$ \\
\hline
\end{tabular}

\subsubsection{O Processo de Projeto com Foco no Detalhamento das Armaduras}

O projeto de detalhamento das armaduras (PDA) trata-se de uma das etapas do PCPA e, conforme se pode observar no fluxograma referente às etapas do desenvolvimento do projeto estrutural, apresentado na Figura 2.19, acontece logo após o detalhamento das armaduras da fundação do edifício. BATLOUNI NETO (2003) lembra que, por mais evoluídos que se apresentem os programas de computador para o cálculo e desenho das estruturas, alguns tipos de detalhamento não podem ser feitos pelos padrões fornecidos (muitos detalhes exclusivos ainda são feitos pelo projetista de estrutura).

Nos Estados Unidos, as armaduras para as estruturas de concreto armado são projetadas, detalhadas e fabricadas de acordo com o "Building Code Requirements for Reinforced Concrete" (ACI 318); o capítulo 7 deste código trata especificamente a questão do detalhamento das armaduras.

O ACI, através do seu comitê 315, desenvolveu um manual de detalhamento de armaduras (ACI "Detailing Manual"). Parte do conteúdo deste manual ("Details and Detailing of Concrete Reinforcement)" (ACI 315-92) está incluso no ACI Building Code (ACI 318) sendo que, a partir de 1980, assumiu a importância de norma pelo ACI.

26 Não consta obrigatoriamente do projeto, sendo usualmente contratado à parte. 
Conforme descrito no Manual de Detalhamento do American Concrete Institute (ACI 31592), a etapa de detalhamento das armaduras inclui a preparação de: i) desenhos de posicionamento das armaduras nas fôrmas; ii) desenho de detalhes das armaduras; iii) tabelas resumo de aço (as quais são usadas para a fabricação e posicionamento das armaduras na estrutura).

O conteúdo normativo supracitado ("Details and Detailing of Concrete Reinforcement") somado ao "Manual of Engineering and Placing Drawings for Reinforced Concrete Structures" (ACI 315R) compreendem o ACI "Detailing Manual".

Somam-se, às orientação dos projetos de detalhamento norte-americanos, as prescrições do "Manual of Standard Practice", publicado regularmente pelo Instituto do Concreto Armado $\left(\mathrm{CRSI}^{27}\right)$, e que contem recomendações referentes à padronização de materiais e práticas.

No Brasil, a NBR 6118:2003 fixa os objetivos básicos exigíveis para o projeto de estruturas de concreto simples, armado e protendido. Estabelece os requisitos gerais a serem atendidos pelo projeto como um todo, bem como os requisitos específicos relativos a cada uma das etapas. Os itens 18 e 20 da NBR 6118:2003 tratam da questão do detalhamento das armaduras para os elementos lineares e para as lajes, respectivamente.

\subsection{Práticas nacionais quanto aos projetos de detalhamento das armaduras}

No Brasil o detalhamento das armaduras é feito, freqüentemente, em um único momento, pelo projetista estrutural. Não há, portanto, distinção entre desenhos de engenharia e desenhos de montagem, como pode ser visto nos casos norte-americano e inglês. O projeto de detalhamento envolve um único documento que, portanto, se destina às etapas de fabricação e montagem, vem acompanhado por tabelas resumo de aço (Figura 2.20), que condensam as informações quantitativas de todas as peças presentes na prancha de desenho. O detalhe para a fabricação das posições costuma aparecer abaixo e/ou ao lado do elemento estrutural, com as indicações dos comprimentos de cada segmento da posição (Figura 2.21). A apresentação dos desenhos através de cortes orienta o armador na montagem das armaduras.

A inexistência de uma norma que proponha uma padronização quanto à representação desses projetos, permite que os escritórios apresentem simbologias, representações gráficas e disposições dos desenhos em planta de maneiras distintas. Esta falta de padronização nas formas de detalhamento dos projetos pode trazer prejuízos à produtividade da mão-de-obra responsável por executar, no canteiro de obras, tais projetos. As dificuldades de interpretação, que oneram o tempo para a realização do serviço, também podem levar a erros durante a execução desses projetos.

\footnotetext{
27 Concrete reinforcing steel institute
} 


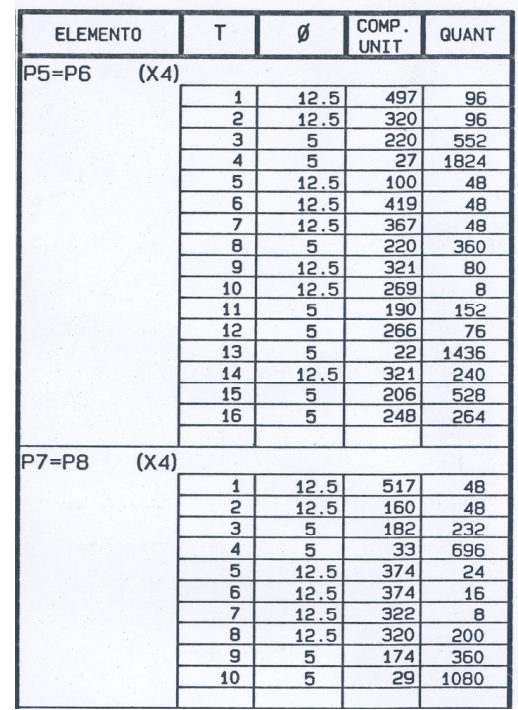

Figura 2.20 - Exemplo de tabela resumo de aço que faz parte do projeto de detalhamento

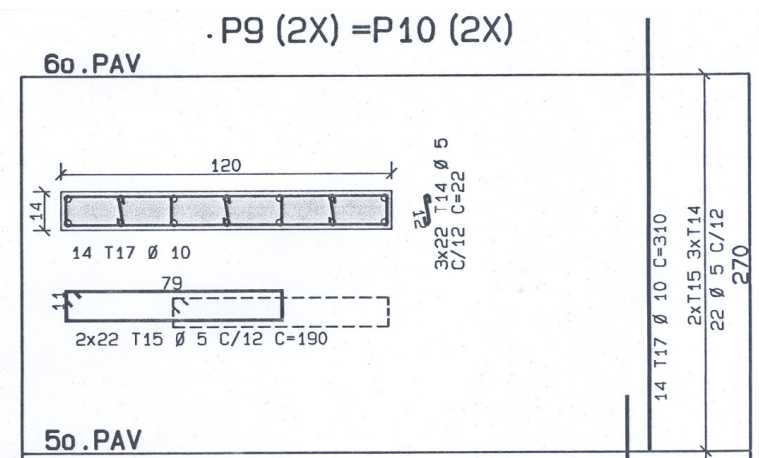

Figura 2.21 - Exemplo de detalhamento de armadura de pilar destinado à sua fabricação e montagem

A NBR 7191 (Execução de desenhos para obras de concreto simples ou armado) fixa as condições especiais que devem ser observadas na execução de desenhos técnicos para obras de concreto simples ou armado. No entanto, a referida norma não se preocupa em prescrever recomendações quanto à padronização das formas de representação dos desenhos das armaduras (disposição e organização dos detalhes nas pranchas, por exemplo), das tabelas resumo de aço, dos detalhes construtivos etc.

O item três da referida norma diz que os desenhos técnicos para obras de concreto simples ou armado podem ser dos tipos seguintes: a) desenhos de conjunto; b) desenhos para execução de fôrmas; c) desenhos para execução de escoramentos; d) desenhos de detalhe.

Os desenhos de conjunto podem aparecer em plantas, elevações, cortes, vistas e perspectivas, devendo ser feitos na escala que seja mais conveniente à sua clareza.

Os desenhos para execução de fôrmas devem conter plantas, cortes e elevações de todas as peças da estrutura, necessários ao perfeito conhecimento de sua forma e de suas dimensões. Devem ser feitos na escala 1:50 ou, quando não houver prejuízo da clareza do desenho, na escala 1:100.

No item 3.1.2.1, a NBR 7191 traz a designação das peças, que deve ser feita mediante os seguintes símbolos, seguidos do respectivo número de ordem: lajes: L; vigas: V; pilares: P; tirantes: $T$; diagonais: $D$; sapatas: $S$; blocos: B; paredes: PAR.

O item 3.1.3 trata dos desenhos para execução de armaduras, que devem conter todos os dados necessários à sua boa execução na escala 1:50, e de detalhes de seção, em escala maior. São prescritas, ainda, as seguintes recomendações:

- cada tipo diferente de barra (barras de diâmetro diferente ou diferentemente dobradas) será desenhado fora da representação da peça, com cotas necessárias a 
seu dobramento correto e indicação de seu número (item 3.1.3.2), quantidade e diâmetro $(\phi)$;

- no caso de séries de estribos de mesmo diâmetro, que mantenham a mesma forma mas cujas dimensões variem, pode-se considerá-los como de um só tipo, bastando desenhar um deles e indicar em tabela ao lado os dados diferentes dos demais (dimensão variável, comprimento desenvolvido e quantidade de cada um);

- pode-se dispensar a representação individual de cada estribo ou cinta no desenho da peça, quando o seu espaçamento for constante, bastando indicá-lo com a letra c seguida do valor do espaçamento em $\mathrm{cm}$. A mesma dispensa é permitida para as armaduras da laje, nos termos do item 3.1.3.8.

- a numeração das peças obedecerá àquela feita nos desenhos constantes no projeto estrutural de formas;

- quando forem utilizadas barras corridas (sem dobras), admite-se a respectiva representação sem cota, mas com a notação " corrido. Na lista será considerado o comprimento total, aumentado das emendas eventuais.

A representação das barras da armadura (item 3.1.3.1) faz-se (salvo em casos especiais ou detalhes onde haja necessidade de se mostrar o diâmetro da barra) pelo seu eixo, com linha cheia ou tracejada, de acordo com a conveniência do desenho.

O item 3.1.3.2, que trata da numeração, prevê que cada tipo diferente de barra da armadura será designado por um número cuja indicação far-se-á na representação das peças. Será usado o símbolo " $\phi$ " para o diâmetro das barras de armadura e, quando houver feixes de peças, será adotada a notação " $\mathrm{x}$ m", onde " $n$ " é o número de feixes e " $m$ " a quantidade de peças de cada feixe.

O item 3.1.3.3 diz que "haverá uma tabela em que se reunirão os dados referentes a cada tipo de barra, a saber: tipo, diâmetro, quantidade, comprimento de cada barra e comprimento total". As Tabela de Aço serão elaboradas obedecendo as disposições apresentadas na Figura 2.22. Tal item, traz, ainda, as seguintes observações:

- se a tabela não constar da mesma prancha do desenho da armadura, deve-se representar, em desenho esquemático, cada um dos tipos de barra;

- os estribos do mesmo tipo (item 3.1.3.b) constarão da tabela de armadura, ocupando uma só linha com todas as indicações, exceto a do comprimento parcial;

- é facultativa a indicação do peso da armadura.

\begin{tabular}{|c|c|c|c|c|c|}
\hline \multicolumn{5}{|c|}{ Tabela de Ferros - CA 50-A } \\
\hline \multirow{2nnyyn}{*}{$\mathrm{N}$} & \multirow{2}{*}{$\phi$} & Quantidade & \multicolumn{2}{c|}{ Comprimento } & \multirow{2}{*}{ Obs. } \\
\cline { 4 - 5 } & & & Unitário & Total & \\
\hline 1 & 12,5 & 12 & 485 & 5820 & \\
\hline 2 & 5,0 & 126 & 138 & 17388 & $\square$ \\
\hline & & & & & \\
\hline
\end{tabular}

onde:

$\mathrm{N}=$ simbologia para identificação das peças; $\mathrm{F}=$ diâmetro das peças em centímetros; Comprimento em centímetros.

Figura 2.22 - Modelo de "Tabela de Aço" prescrita na NBR 7191. 
Uma outra tabela, que é colocada na planta de armação, é a "Tabela Resumo do Aço" (Figura 2.23). É um resumo da tabela anterior. Essa tabela apresenta os comprimentos e pesos totais de aço correspondentes a cada diâmetro. Pode ser também denominada como a "Tabela do Comprador". É através dela que a empresa, após acrescentar uma taxa correspondente às perdas, efetuará a compra do aço. Na planta de armação deve ser colocada uma tabela de resumo do aço para cada aço utilizado (CA 50-A, CA 50-B, CA 60 etc).

\begin{tabular}{|c|c|c|c|}
\hline \multicolumn{3}{|c|}{ Resumo do Aço CA 50-A } \\
\hline$\phi$ & $\begin{array}{c}\text { Peso } \\
\mathrm{Kg} / \mathrm{m}\end{array}$ & $\begin{array}{c}\text { Comprimento Total } \\
(\mathrm{cm})\end{array}$ & Peso \\
\hline 5,0 & 0,16 & 61563 & 98,50 \\
\hline 6,3 & 0,25 & 15888 & 39,72 \\
\hline 8,0 & 0,40 & 13654 & 54,62 \\
\hline 10,0 & 0,63 & 22095 & 139,2 \\
\hline 12,5 & 1,00 & 15235 & 152,35 \\
\hline 16,0 & 1,6 & 2265 & 36,24 \\
\hline \multicolumn{3}{|r}{$\Sigma$} & 520,63 \\
\hline
\end{tabular}

Figura 2.23 - Modelo de "Tabela Resumo do Aço" prescrita na NBR 7191.

A Tabela 2.15 traz outras prescrições da NBR 7191 sobre os desenhos para execução de armaduras.

Tabela 2.15 (continua) - Prescrições da NBR 7191 sobre os desenhos para execução de armaduras

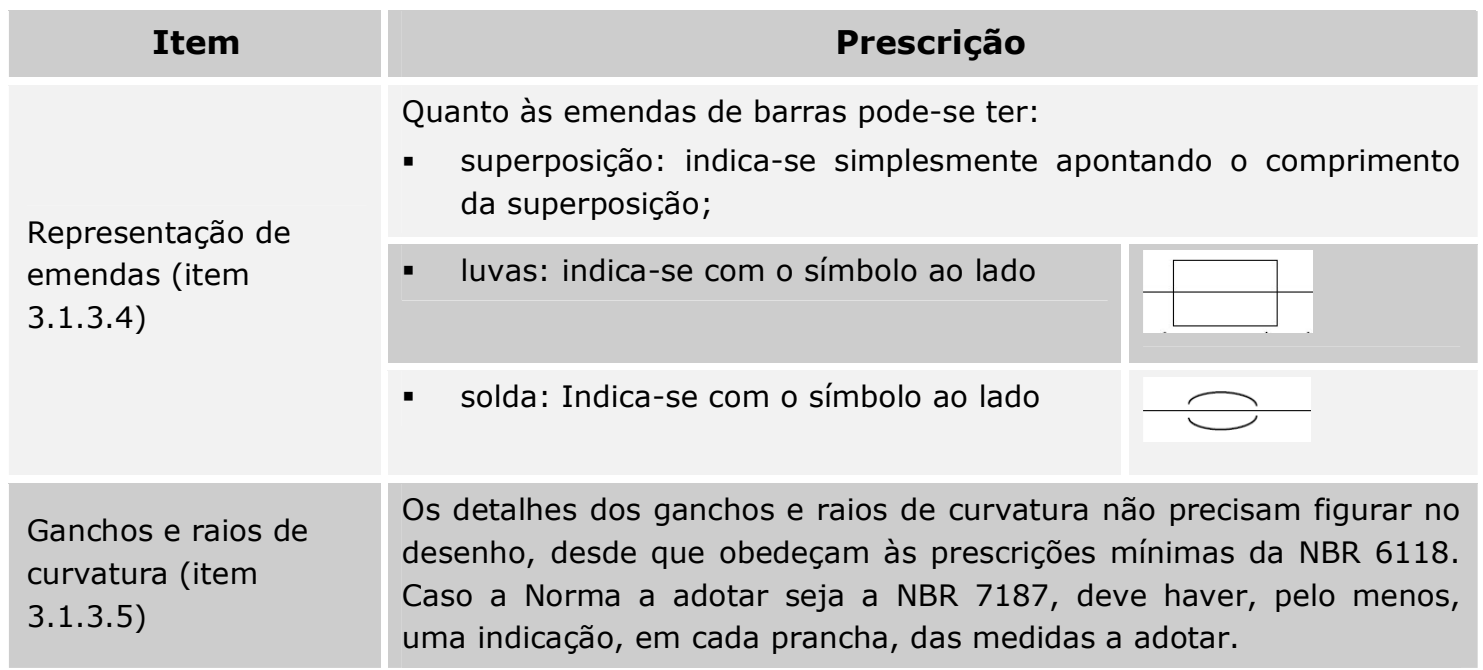


Tabela 2.16 (continuação) - Prescrições da NBR 7191 sobre os desenhos para execução de armaduras

\begin{tabular}{|c|c|}
\hline Item & Prescrição \\
\hline $\begin{array}{l}\text { Barras dobradas (item } \\
3.1 .3 .6 \text { ) }\end{array}$ & $\begin{array}{l}\text { Nas barras dobradas a } 45^{\circ} \text {, é dispensável qualquer indicação de } \\
\text { ângulo. Para ângulos diferentes, a inclinação deve ser dada na forma } \\
1: n \text { em uma ou mais barras com o mesmo dobramento. Nesse caso } \\
\text { deve-se fazer, no desenho, um pequeno esquema de marcação, } \\
\text { facilmente reprodutível pelo armador na bancada. }\end{array}$ \\
\hline $\begin{array}{l}\text { Armadura das lajes } \\
\text { (item } 3.1 .3 .7 \text { ) }\end{array}$ & $\begin{array}{l}\text { Nas lajes é facultada a representação das barras dentro ou fora do } \\
\text { desenho de cada laje, ou, ainda, a aplicação simultânea de ambos os } \\
\text { dispositivos, conforme for mais conveniente à clareza do desenho; a } \\
\text { distribuição da armadura será feita sempre em faixa normal à posição } \\
\text { ocupada pelas barras; quando a armadura superior for independente } \\
\text { da inferior, aconselha-se a execução de desenhos separados para cada } \\
\text { uma delas. }\end{array}$ \\
\hline $\begin{array}{l}\text { Armaduras de vigas } \\
\text { (item } 3.1 .3 .8 \text { ) }\end{array}$ & $\begin{array}{l}\text { A representação da armadura de vigas será feita longitudinalmente e } \\
\text { deverá conter o traçado auxiliar dos pontos mais convenientes da } \\
\text { fôrma, de sorte a se indicar a perfeita posição das barras: } \\
\text { - quando houver várias camadas, a representação longitudinal será } \\
\text { feita reproduzindo esquematicamente a posição relativa dessas } \\
\text { camadas; } \\
\text { - sempre que necessário, será feita a representação adicional de } \\
\text { seções transversais; } \\
\text { em cada prancha de armadura de vigas será anexado pequeno } \\
\text { quadro, contendo índice por ordem numérica das vigas nela } \\
\text { representadas. }\end{array}$ \\
\hline $\begin{array}{l}\text { Armadura de pilare } \\
\text { (item } 3.1 .3 .9 \text { ) }\end{array}$ & $\begin{array}{l}\text { A representação da armadura de pilares será feita por seções } \\
\text { transversais com indicação minuciosa da posição das barras e de seus } \\
\text { diâmetros: } \\
\text { - ao lado de cada seção será feita a representação do respectivo } \\
\text { estribo com as convenções do item } 3.1 .3 \text {, alíneas b) e c); } \\
\text { é obrigatória a representação esquemática dos diferentes tipos de } \\
\text { armaduras longitudinais dos pilares constantes da prancha. }\end{array}$ \\
\hline
\end{tabular}

O Item 3.1.5 da NBR 7191 que trata dos desenhos de detalhe salienta que "cabe ao projetista, nos desenhos de detalhe, a liberdade de escolha do melhor modo de representação, aplicando, em tudo que possível, as prescrições anteriores."

\subsection{Práticas internacionais quanto aos projetos de detalhamento das armaduras}

\subsection{Identificação das Práticas Atuais no Reino Unido}

KALIAN et al. (2000) comenta que o processo de projeto de detalhamento das armaduras pode sofrer alterações em função do método de contratação escolhido que, segundo ele, em se tratando das práticas usuais no Reino Unido, possuem três diferentes abordagens: 
i) abordagem "concepção-construção $28 " ;$ ii) abordagem "tradicional"; iii) abordagem "CONSTRUCT ${ }^{29 " .}$ Tais abordagens são mostradas na Figura 2.24 e comentadas a seguir.

$\mathrm{Na}$ abordagem "concepção-construção", o processo percorre cinco etapas (Figura 2.24), começando quando o cliente, ou o seu representante, assinam um contrato específico para este tipo prestação de serviço. Isto torna o contratado o único responsável pela elaboração do projeto estrutural e pela geração de documentos contratuais entre os agentes, sob sua responsabilidade, que participarão do processo de concepção e produção das armaduras. Neste caso, o contratado pode repassar o projeto estrutural (sem detalhamento) a profissionais conhecidos como "detalhadores ${ }^{30 "}$, que podem ser internos ou terceirizados (vinculados aos fornecedores, por exemplo), para que elaborem o detalhamento das armaduras e as tabelas de aço. O produto gerado pelos detalhadores é, então, submetido ao cliente (ou a seu representante) para que seja aprovado. Obtida a aprovação, o detalhamento das armaduras e a tabelas de aço são encaminhados à produção (também sob responsabilidade do contratado) para que sejam executados.

A abordagem tradicional compreende sete etapas (Figura 2.24). Nesta situação o cliente, ou seu representante contrata, separadamente, o projeto e a execução da estrutura (neste caso específico, a execução das armaduras). O processo se inicia com a contratação de um projetista estrutural que irá elaborar o projeto estrutural e os detalhamentos que se façam necessários para a sua execução. O projetista estrutural repassa o detalhamento das armaduras e a elaboração das tabelas de aço a detalhadores, que podem ser membros internos do escritório de projeto ou profissionais terceirizados. Num cenário ideal, o projetista deveria promover reuniões envolvendo os detalhadores e o executor contratado (indicado pelo cliente) para que suas recomendações e diretrizes pudessem ser incorporadas ao detalhamento. Os detalhadores produzem, então, os desenhos de detalhamento das armaduras e as tabelas de aço, submentendo-os ao projetista para aprovação. Uma vez aprovado, eles são encaminhados ao executor, que irá usá-lo nas etapas de produção. Durante os processos de produção, o executor pode retornar os desenhos para o projetista para que ele revise possíveis erros técnicos e humanos. Este processo de revisão dos desenhos tem implicações óbvias com a velocidade de construção.

28 O termo em inglês para esta abordagem é "desing\&build". Segundo GRILO (2002) o designbuild tem se tornado popular entre os clientes privados, principalmente em obras comerciais e industriais. "Os clientes, que dissolveram suas equipes internas de engenharia e passaram a focalizar o core business da organização, têm buscado preços fixos e ponto único de contato, em substituição às responsabilidades pulverizadas e à natureza adversária do sistema contratual tradicional". O autor supracitado cita algumas vantagens atribuídas ao design-build: ponto único de responsabilidade, redução do prazo, foco na construtibilidade, redução das alterações de projeto, relação mais harmoniosa entre os agentes e elevada capacidade de resposta a mudanças no escopo.

29 O nome "CONSTRUCT" se refere a um grupo formado por membros de empresas do Reino Unido que se dedica à tarefa de melhorar a eficiência na produção de estruturas de concreto armado. Disponível em: <www.construct.org.uk>

30 O "detalhador" (ou "rebar detailer", como é chamado no Reino Unido) trata-se de uma profissão regulamentada no Reino Unido. São desenhistas especializados em fazer detalhamento das peças que compõem as armaduras de elementos estruturais de concreto armado. 
$\mathrm{Na}$ abordagem "CONSTRUCT" o processo compreende cinco etapas (Figura 2.24). O cliente transfere a responsabilidade pelo detalhamento para o executor (subempreiteiro especializado na execução de estruturas de concreto armado). O cliente sinaliza sua decisão para a equipe de projeto (pode envolver o representante do cliente) de que o detalhamento será atribuído ao executor (estabelece, neste momento, um acordo com o executor a preço fechado, prevendo termos de medição (preço unitário) para eventuais armaduras adicionais, políticas relativas a mudanças tardias, e considera quaisquer ajustes para a programação das contratações). O projetista então fornece as informações necessárias ao executor para que ele seja capaz de desenvolver o detalhamento para a montagem da armadura. O executor, empregando especialistas (detalhadores) internos ou externos, produz os detalhes da armadura e as tabelas de aço, que deverão ser posteriormente aprovados pelo projetista estrutural. Uma vez aprovados, os desenhos são distribuídos para as equipes de produção.

Os detalhadores são tratados como parceiros e a informação lhes é passada conforme requerida, sem que seja necessário esperar até que se tenha finalizado um pacote completo dos cálculos, esboços e desenhos com arranjos gerais. Porém na abordagem defendida pelo CONSTRUCT, todos os desenhos passados ao executor necessitam estar completos. Nessa situação um detalhador contratado não pode prosseguir antes de receber o projeto completo do projetista estrutural.

Em qualquer empreendimento, os desenhos de detalhamento das armaduras devem ser revisados diversas vezes em razão de possíveis erros técnico ou humano ou de mudança no projeto por uma das partes envolvidas na construção. Este processo de revisar desenhos tem muitas implicações na velocidade e no custo da construção. O CONSTRUCT reivindica que sua abordagem deveria reduzir o número de vezes que os desenhos são revisados desde que a participação do executor minimize os elementos de mudança durante a execução do projeto. O tempo ganho por não se ter que retornar os desenhos para o "re-projeto" poderia compensar o tempo usado pelo projetista na preparação de grupos completos de projeto.

$\mathrm{Na}$ maioria dos métodos atuais os desenhos de detalhe retornam para a aprovação e verificação pelos projetistas. Esta é uma etapa desnecessária que, na visão do CONSTRUCT, deveria ser substituída. A abordagem proposta pelo CONSTRUCT visa ganhar tempo ao permitir ao executor tomar decisões acertadas para racionalizar as armaduras, beneficiando, por conseguinte, a montagem das fôrmas e otimizando a produtividade global da produção das estruturas. 


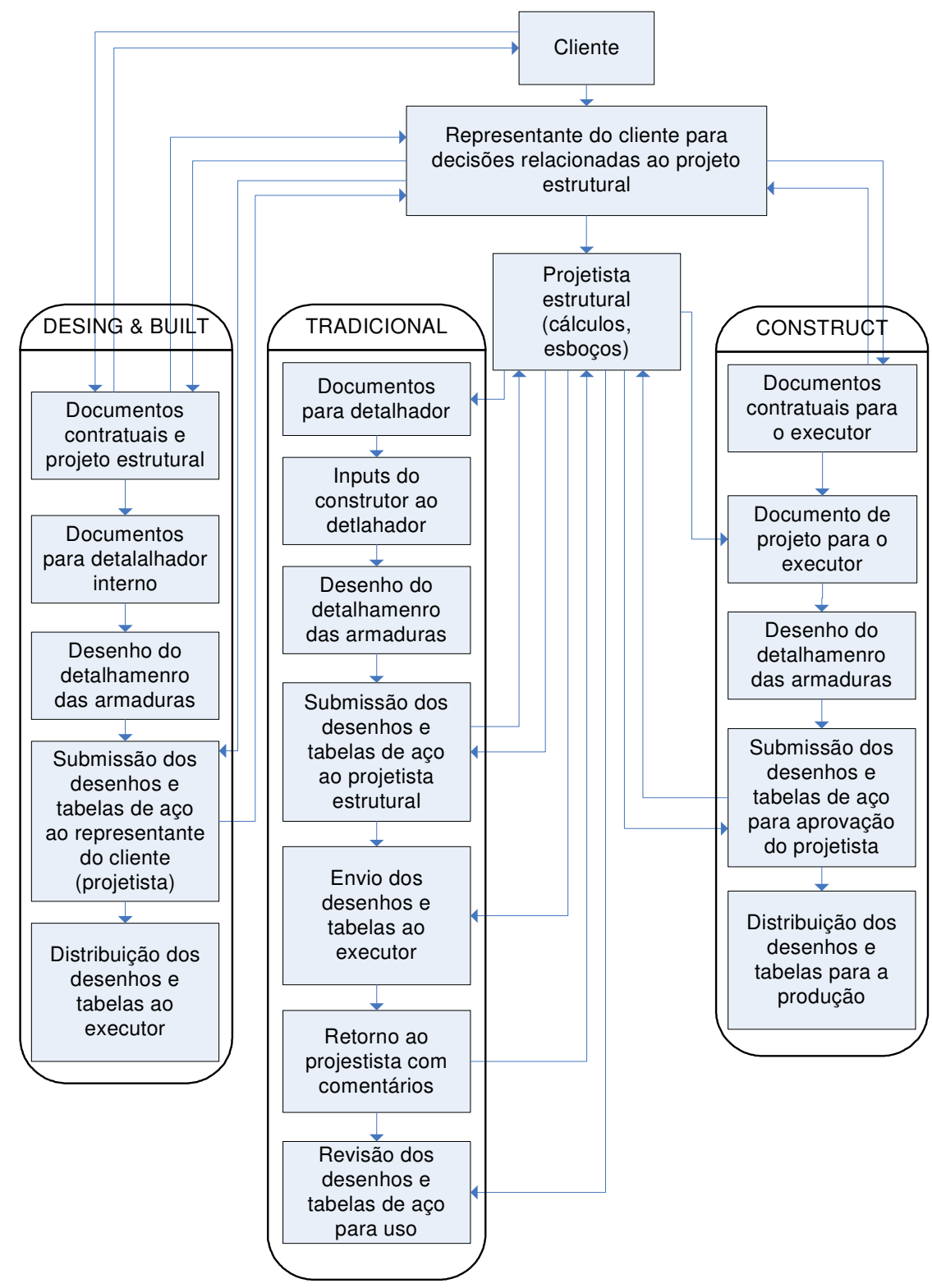

Figura 2.24 - As três principais forma de formas de contratação do detalhamento das armaduras no Reino Unido. KALIAN et al. (2000).

\subsection{Métodos e padrões de detalhamento das armaduras usados nos EUA}

Em 1936 foi organizado, nos Estados Unidos da América, o "Comitê 315" do "American Concrete Institute-ACI", com o propósito de preparar um trabalho sobre detalhamento de estruturas de concreto armado. Pouco tempo após este comitê começar a trabalhar, evidenciou-se que progressos mais rápidos poderiam ser obtidos se um esboço preliminar fosse preparado por pessoas preferencialmente familiarizadas com as 
dificuldades encontradas na interpretação dos desenhos de projeto (engineering drawings ${ }^{31}$ - "ED") contidos nos desenhos de fabricação e montagem (placing drawings "PD") das armaduras. Fez-se, então, um apelo ao "Concrete Reinforcing Steel InstituteCRSI" para que se estabelecesse um comitê representativo de pessoas ligadas à indústria das armaduras. Formou-se, então, um grupo composto por representantes de diferentes tipos de organizações fornecedoras de armadura e/ou aço para armaduras. Estas pessoas, com a ajuda de um membro da Associação do Cimento Portland, produziram o primeiro manual de detalhamento para construtores, em 1946, que foi aprovado como uma norma do ACI em 1947.

O manual, intitulado "Manual of Standard Practice for Detailing Reinforced Concrete Structures", ou simplesmente "ACI Detailing Manual", passou por inúmeras revisões desde 1947, sempre em concordância com o "Building Code Requirements for Reinforced Concrete" (ACI 318) - código norte-americano (publicado pela e sob responsabilidade da ACI), que orienta os projetos, detalhamento e a execução das edificações em concreto armado americanas. Ambos trazem práticas (desenhos ilustrativos e orientativos) de projeto que enfatizam a simplificação das formas e dos arranjos das armaduras para reduzir o trabalho no campo.

Assim, a proposta do ACI "Detailng Manual", assim como a prevista em sua primeira edição (hoje encontra-se na $4^{\circ}$ edição (ACI 315-94)), foi a de apresentar melhorias nos métodos e nos padrões para a preparação de desenhos direcionados à fabricação e à montagem das armaduras na estruturas de concreto armado.

O ACI 315-94 indica que a preparação dos " $E D$ " e dos "PD" requer um conhecimento geral de todo o processo de concepção e produção das armaduras, que foi apresentado como composto de quatro partes:

1. Elaboração do projeto estrutural: envolve o auxilio de computadores e inclui a preparação dos "ED" para mostrar os arranjos gerais da estrutura, o tamanho e as armaduras dos elementos estruturais e outras informações em forma de notas e diagramas necessários para a interpretação das idéias dos projetistas.

2. Detalhamento: consiste na preparação dos "PD", em termos de detalhes das armaduras e tabelas resumo de aço, usados na fabricação e na montagem das armaduras nas estruturas.

3. Fabricação: consiste nas atividades do processo desempenhadas na fábrica e incluem o corte, a dobra, o agrupamento em feixes e a identificação dos feixes através de etiquetas.

4. Montagem: contempla as operações de pré-montagem e montagem final das armaduras nas fôrmas.

Para o ACI 315-94, muito tempo e esforço podem ser economizados no detalhamento, fabricação e montagem das armaduras se forem elaborados desenhos simples, claros e completos. "Um desenho é mais do que uma delineação gráfica da estrutura; é, sim, uma ordem definitiva para que determinada pessoa participante do processo (o fabricante, o armador etc) possa desempenhar certas operações de uma maneira especificada".

31 Os "engineering drawings" (ou "structural drawings") são os desenhos fornecidos pelo projetista estrutural norte-americano que irão servir de subsídio para que os detalhadores (detailers) elaborem os "placing drawings" (projetos de detalhamento voltados à fabricação e montagem das armaduras). 
Para buscar os propósitos supracitados, o ACI 315-94 começa propondo uma padronização dos desenhos, com estabelecimentos de critérios conforme mostra a Tabela 2.16 .

Tabela 2.16 - Padronização dos desenhos prescrita pelo ACI 315-94

\begin{tabular}{|l|l|}
\hline \multicolumn{1}{|c|}{ Aspectos } & \multicolumn{1}{c}{\begin{tabular}{c} 
Prescrições \\
\hline Tamanho das folhas
\end{tabular}} \\
\hline $\begin{array}{r}\text { Os desenhos devem ser feitos em folhas com tamanhos padrões. } \\
\text { Todas a tabelas de um conjunto de pranchas (mesmo projeto) devem } \\
\text { ter o mesmo tamanho. }\end{array}$ \\
\hline Direção & $\begin{array}{r}\text { Uma flecha indicando a direção norte deve ser colocada em todo o } \\
\text { desenho que contenha vistas em planta. }\end{array}$ \\
\hline Escalas & $\begin{array}{r}\text { As escalas usadas devem estar identificadas em todo os " } E D^{\prime \prime}, \\
\text { preferencialmente embaixo do título de cada vista. Desenhos que } \\
\text { estejam aumentados ou diminuídos na reprodução devem mostrar } \\
\text { uma escala gráfica para auxiliar o usuário. }\end{array}$ \\
\hline Textos & $\begin{array}{r}\text { Todos os textos devem estar claros e legíveis. Se forem feitas cópias } \\
\text { reduzidas para uso no canteiro, os textos devem estar legíveis. }\end{array}$
\end{tabular}

O ACI 315-94 recomenda que, para evitar confusões, os elementos estruturais recebam as mesmas designações nos " $E D$ " e " $P D$ ". Entretanto, pode ser que elementos similares no " $E D$ " e que, portanto, recebam o mesmo nome, sejam diferentes quando detalhados nos " $P D$ ", devido a descontinuidades das peças e/ou por outras razões. Nestes casos, uma letra é acrescida após a designação original para fazer a diferenciação. Por exemplo, se uma viga que recebeu a identificação "2B3" no " $E D$ " for detalhada de maneira segmentada, O "PD" irá mostrar parte da viga como "2B3" e a outra parte como "2B3A".

Os " $E D$ ", preparados pelo projetista, devem trazer a categoria do aço, as sobrecargas, a resistência do concreto, a classe de tensão nas emendas ou comprimentos de traspasses (bem como onde eles são críticos) e todas as outras informações necessárias para que seja possível a elaboração do detalhamento das armaduras (" $\left.P D^{\prime \prime}\right)$. Freqüentemente, uma nota requerendo a elaboração dos " $P D$ ", conforme prescreve o $A C I 315$, é adicionado pelo projetista nos "ED".

A Tabela 2.17 traz as principais informações que devem estar contidas nos " $E D$ " em se tratando do detalhamento das armaduras. 
Tabela 2.17 - Informações presentes nos "ED" segundo o ACI 315-94.

\begin{tabular}{|c|c|}
\hline Elementos & Informações \\
\hline Pilares & $\begin{array}{l}\text { Pilares são quase sempre mostradas em tabelas. É importante mostrar } \\
\text { não somente o tamanho das pilares e quantidade, localização e diâmetro } \\
\text { da armadura, mas também todos os detalhes necessários, como seções } \\
\text { das pilares e mudanças das armaduras. Emendas devem estar sempre } \\
\text { claramente definidas, inclusive com definição do tipo da emenda. }\end{array}$ \\
\hline Vigas & $\begin{array}{l}\text { As tabelas de aço de vigas devem conter: nomenclatura (indentificação) } \\
\text { das vigas, diâmetros das posições, número e tamanho das barras retas e } \\
\text { dobradas, especificações para dobra, número, diâmetro e espaçamento } \\
\text { dos estribos, localização das barras superiores e informações especiais, } \\
\text { como a necessidade de duas camadas de aço. }\end{array}$ \\
\hline Lajes & $\begin{array}{l}\text { A armadura das lajes deve ser mostrada em tabelas ou em plantas, } \\
\text { elevação ou seção. }\end{array}$ \\
\hline Barras dobradas & $\begin{array}{l}\text { Quando barras dobradas são usadas, os pontos de dobra devem ser } \\
\text { definitivamente mostrados, preferencialmente através de esboços. }\end{array}$ \\
\hline
\end{tabular}

O ACI 315, no item 6.4, apresenta uma lista com um conjunto de orientações que deveriam ser seguidas pelos projetistas no desenvolvimento dos "ED". Destacam-se, a seguir, algumas delas:

1. Ter certeza de que a estrutura possa ser construída conforme projetada.

2. Assegurar-se que os materiais especificados possam ser obtidos no diâmetro, comprimento e formato requerido.

3. Assegurar-se que todos os desenhos em uma planta sejam feitos numa mesma escala.

4. Dar dimensões completas e apuradas nos "ED".

5. Evitar o congestionamento de aço nos pontos onde há intersecção de elementos estruturais. Ter a certeza de que todas as armaduras mostradas possam ser devidamente posicionadas. Desenhos em maiores escalas são desejáveis.

6. Ter a certeza que ganchos e barras dobradas possam ser posicionados e que tenham o cobrimento adequado.

7. Especificar claramente todas as barras, retas ou dobradas, que requeiram ganchos.

8. Ter a certeza de que dobras não usuais possam ser feitas com os equipamentos de dobra padrão.

Em se tratando dos " $P D$ " (comumente preparados pelo fabricante) estes devem mostrar detalhes para a fabricação e para a montagem das armaduras. Uma vez recebidos e, a partir dos " $E D$ ", o fabricante deverá: i) preparar os " $P D$ " e os detalhes de corte; ii) obter a aprovação do projetista, quando requerida; iii) preparar a listas de peças (listas de compra) e fabricá-las; iv) preparar os feixes, etiqueta e entregar as peças no canteiro de obras.

Os " $P D$ " mostram o diâmetro, o formato e a localização das peças nas armaduras; indicam como as armaduras serão colocadas nas fôrmas e servem, ainda, como base 
para preparação das tabelas resumo de aço. Para garantir a correta interpretação dos "ED", os "PD" devem ser submetidos à aprovação pelo projetista antes que se inicie a fabricação.

A Tabela 2.18 traz as principais informações que devem estar contidas nos "PD", segundo prescreve o ACI 315-94.

Tabela 2.18 - Informações presentes nos "PD" segundo o ACI 315-94.

\begin{tabular}{|l|l|}
\hline Elementos & Informações \\
\hline & $\begin{array}{c}\text { Geralmente o detalhamento das armaduras é feito em tabelas. O detalhador } \\
\text { não somente deve interpretar o " } E D^{\prime \prime} \text {, mas também deixar a informação de } \\
\text { forma clara para o armador. Ele não somente deve mostrar a quantidade, } \\
\text { diâmetro, comprimento ou posições de todas as barras, mas indicar como e } \\
\text { onde elas serão montadas. Esboços para cada pilar, a cada andar, devem ser } \\
\text { feitos. }\end{array}$ \\
\hline Vigas & $\begin{array}{c}\text { As armaduras são geralmente mostradas em tabelas. Os detalhes de corte } \\
\text { podem estar separados ou incorporados às tabelas. Devem mostrar número, } \\
\text { identificação e tamanhos dos elementos; número, diâmetro e comprimento das } \\
\text { barras retas; números, diâmetros, identificação e comprimentos das barras } \\
\text { dobradas e estribos; espaçamento dos estribos; barras de suporte; outras } \\
\text { informações necessárias à fabricação e à colocação das armaduras. }\end{array}$ \\
\hline As armaduras devem ser mostradas em planos ou tabelas. As tabelas e \\
Lajes
\end{tabular}

Como denotado na Tabela 2.19, é uma prática comum que os "PD" tragam os detalhamento das armaduras de pilares, vigas e lajes em tabelas. Um exemplo de uma tabela contendo o detalhamento de armaduras de pilares é mostrada na Figura 2.25. Não há um formato padrão para estas tabelas. Porém, é importante lembrar é que elas tomam o lugar dos desenhos e devem claramente indicar o posicionamento das armaduras na fôrma, bem como o posicionamento de cada uma das peças que irão compor tal armadura. 


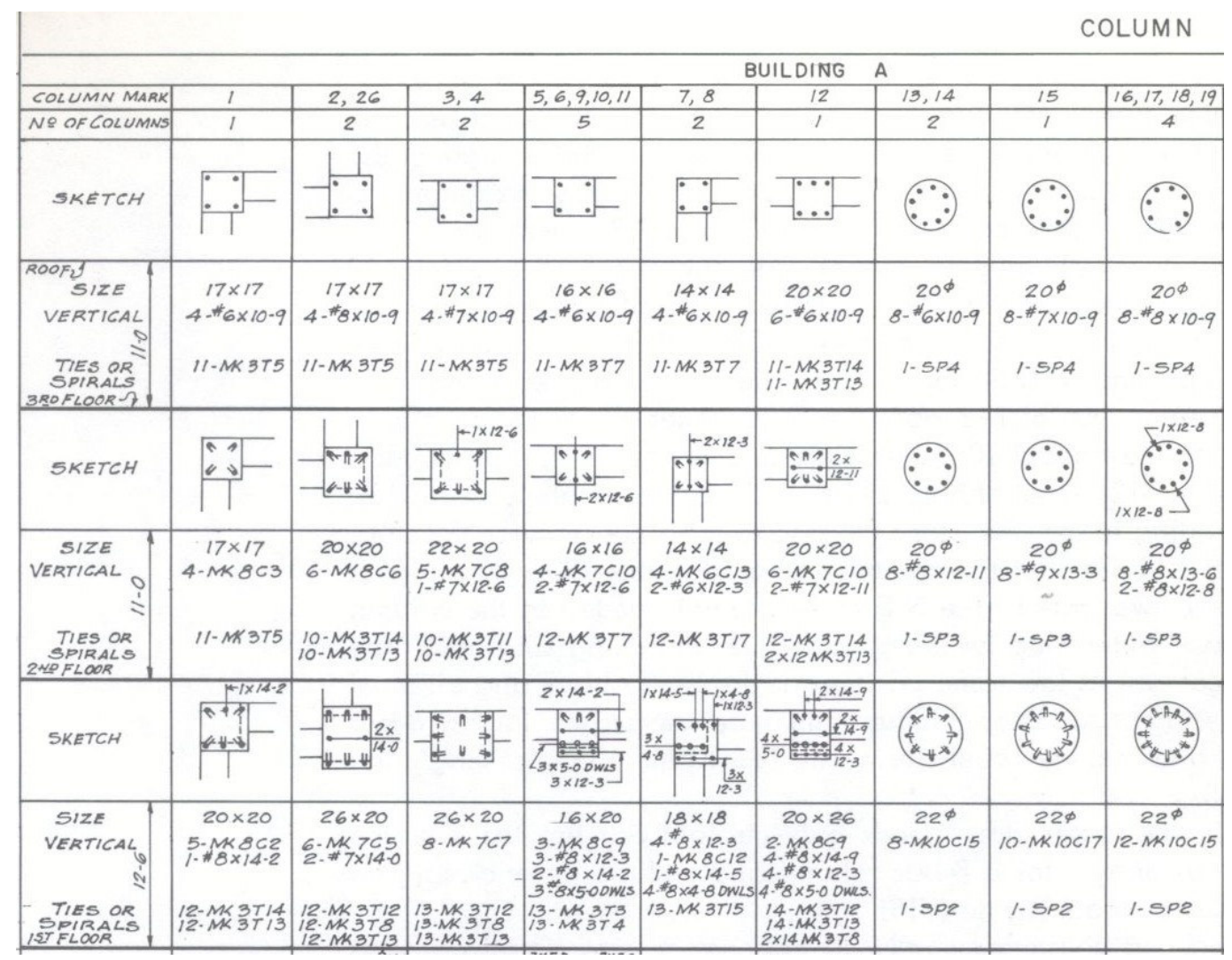

Figura 2.25 - Tabela de aço contendo detalhamento ("PD"). Fonte: ACI 315-94

Nos Estados Unidos, assim como no Reino Unido, é bastante comum a figura do "detalhador" no processo de projeto de detalhamento das armaduras. Trata-se de um técnico com boa capacidade em interpretar projetos estruturais e, a partir deles, gerar desenhos que orientam a fabricação de peças e a montagem das armaduras. A Tabela 2.19 mostra algumas características, atributos, obrigações etc desse profissional.

Tabela 2.19 (continua) - Caracterização do detalhador. Fonte: CRSI, 1993.

\section{Aspectos}

Quem é e o que faz o detalhador

\section{Características}

Trata-se, usualmente, de um empregado da empresa que irá executar a estrutura (subempreiteira) ou da empresa que fornece o aço beneficiado à obra. Usa as informações mostradas nos desenhos e nas especificações do projeto estrutural para detalhar ou listar todas as armaduras requeridas para uma porção particular da estrutura. Estas armaduras são então listadas (tabelas de aço), ou mostradas através de vistas em plantas ou em cortes, em um "desenho de detalhamento/posicionamento". 
Tabela 2.20 (continua) - Caracterização do detalhador. Fonte: CRSI, 1993.

Aspectos
Quais informações de
projeto são requeridas
pelos códigos de
construção americanos

Por que é necessário detalhar as informações do projeto estrutural?

Quais as qualificações exigidas para um detalhador?

Como os detalhadores são treinados?

O detalhador usa o computador com programas específicos?

A função de detalhador requer a formação em engenharia?

Por que os desenhos de detalhamento das armaduras são chamados de desenhos de instalação?

\section{Características}

O código de construção ACI 318 indica, no primeiro capítulo, os requisitos gerais que irão orientar o projeto. Especificamente, no que diz respeito às armaduras, o código declara que os desenhos do projeto (fornecidos pelo projetista estrutural) devem mostrar: i) o tamanho e a localização de todos os elementos estruturais e armaduras; ii) o comprimento de ancoragem e a localização e comprimento das emendas por traspasse; iii) tipo e localização das emendas soldadas e com luvas metálicas das armaduras.

As informações que constam no projeto estrutural normalmente são específicas (como as dimensões dos elementos estruturais, a quantidade e espaçamento das armaduras e tamanho das barras), mas não o suficiente para possibilitar o corte e dobra, a fabricação, a expedição e a instalação das armaduras diretamente a partir dos desenhos de projeto. Daí a necessidade que desenhos de detalhamento/posicionamento sejam fornecidos.

No mínimo, uma pessoa com o ensino médio concluído, com bons conhecimentos em matemática e capacidade visual estaria apta a se qualificar, após treinamento. Conhecimentos em informática, desenho e engenharia realçariam as qualificações.

Detalhadores são treinados: i) em escolas técnicas; ii) a partir do programa de treinamento preparado pelo CRSI, que prevê a orientação de profissionais da empresa fornecedora de armaduras (fabricantes); iii) diretamente na prática, com a supervisão de um detalhador experiente, ou através da combinação das três situações apresentadas.

Muitos fabricantes têm programas computacionais específicos que auxiliam o detalhador ou, mesmo, que produzem os desenhos de posicionamento.

Não; o detalhador é um técnico altamente treinado e capacitado em interpretar dados presentes nos desenhos de projeto estrutural. Conhecimentos de projeto estrutural não são necessários para se tornar um bom detalhador.

Como o próprio nome diz, "desenhos de instalação" são usados pelos armadores no canteiros de obras para colocar (instalar) as armaduras dentro das fôrmas. Na preparação destes desenhos, os detalhadores determinam a quantidade de barras a partir dos espaçamentos préestabelecidos, o comprimento das barras, as posições de corte e o posicionamento das barras a partir das instruções fornecidas pelos desenhos e especificações de projeto. Enquanto preparam os desenhos de instalação, os detalhadores também preparam as listas de aço. Estas listas são usadas na compra do aço beneficiado. 
Tabela 2.20 (conclusão) - Caracterização do detalhador. Fonte: CRSI, 1993.

\section{Aspectos}

Há um tipo padrão dos desenhos de instalação?
Como o detalhador deve proceder quando os dados do projeto estão incompletos, em conflito ou ambos? detalhamento devem ser submetidos ao projetista para aprovação e posterior liberação ao fabricante?

Seria vantajoso o fabricante manter um engenheiro para aprovar os desenhos de instalação?

O que implica a revisão e aprovação dos desenhos de instalação?

Quais as responsabilidades do fabricante enquanto responsável pelo detalhamento?

\section{Características}

Cada fabricante produz os desenhos de instalação que se ajustam às suas necessidades, e às dos contratados, para montagem das armaduras daquela área geográfica onde a construção está localizada; porém, existe um documento que padroniza o detalhamento das armaduras. Intitulado "Details and Detailing of Reinforcement", recebe a designação "ACI 315". O Instituto do Concreto Americano (ACI) publica o "ACI Detailing Manual", que contém o referido documento. Desenhos ilustrativos de instalação e outras informações relacionadas ao assunto constam da publicação do ACI.

O detalhador deveria, através do contratante (construtor), ou diretamente, estabelecer uma linha de comunicação com o projetista, de maneira a obter a correta informação. 0 procedimento que $o$ detalhador deve seguir é deixar em branco o desenho, solicitando que o dado seja alterado quando o projetista revisar o desenho para aprovação. Se o cronograma de construção não comportar o tempo gasto neste procedimento, o detalhador deverá requisitar a correção do dado via telefone ou fax. Nenhuma informação de projeto deve ser alterada pelo detalhador, porque ele não tem conhecimento necessário para julgar o que deve ser feito.

O CRSI acredita que os desenhos de instalação tem de ser submetidos para revisão e aprovação pelo projetista estrutural.

O detalhamento não é uma função do projeto, portanto a resposta é não. $O$ uso de um engenheiro registrado para aprovar o detalhamento implica que a pessoa seria responsável por mudanças, e não meramente um contribuinte para o trabalho. $O$ trabalho neste contexto é a análise estrutural e do projeto da estrutura para resistir aos esforços solicitados. O detalhador não é esta pessoa.

A revisão pelo projetista implica que o desenho tenha sido checado para ver se está de acordo com as especificações do projeto estrutural. Por exemplo, verificar se no caso dos pilares, os tamanhos e os números corretos das barras são os que estão sendo nos desenhos de posicionamento. Aprovar significa que este desenho reflita com exatidão o projeto estrutural.

A responsabilidade do fabricante é fornecer todos os requerimentos das armaduras mostrados nos desenhos e especificações do projeto estrutural. Isto significa que o fabricante é obrigado a fornecer o número correto de barras nos tamanhos corretos e cortar e dobrar corretamente as posições mostradas. Caso qualquer erro ocorra, como quantidade insuficiente, tamanhos incorretos, comprimentos e cortes errados, o fabricante é obrigado a retificar o erro prontamente. 


\subsubsection{A Fabricação no âmbito do PCPA}

A fabricação de peças e/ou armaduras trata-se da etapa do PCPA (Figura 2.26) que sucede o projeto de detalhamento e antecede a etapa de armação. O processo de fabricação envolve as operações de corte e dobra das barras para a produção de peças, que podem ser posteriormente unidas, através de soldas e/ou amarrações, dando origem às armaduras.

As operações de corte e dobra podem ser desenvolvidas dentro ou fora dos canteiros de obras. Quando realizadas fora dos canteiros, elas se dão ora em centrais de armação, que podem ser mantidas por construtoras, ora em ambientes fabris, pertencentes a empresas especialistas na preparação das peças/armaduras. Nestes casos - e, principalmente nas fábricas especializadas - faz-se o uso intensivo de máquinas, com alto grau de automação, capazes de minimizar significativamente intervenções manuais ao longo das operações. Os produtos dessas operações podem ser de quatro tipos principais: i) peças; ii) telas soldadas; iii) rolos (ou carpetes) de aço. Diz-se, neste caso, que as peças/armaduras são fabricadas.

Já as operações de corte e dobra do aço, quando desenvolvidas dentro do canteiro de obras, caracterizam-se pelo uso intensivo da mão-de-obra. Os produtos dessas operações são as peças. Diz-se, neste caso, que as peças são manufaturadas.

Neste trabalho, entende-se a etapa de fabricação, portanto, como sendo aquela referente à preparação de peças/armaduras, em fábricas especializadas, em que se faça uso intensivo de máquinas automatizadas para as operações de corte e dobra das barras e união das peças (para confecção de telas e rolos de aço). Ressalta-se que as operações de corte e dobra do aço, desenvolvidas no canteiro de obras, serão tratadas no âmbito da etapa de armação.

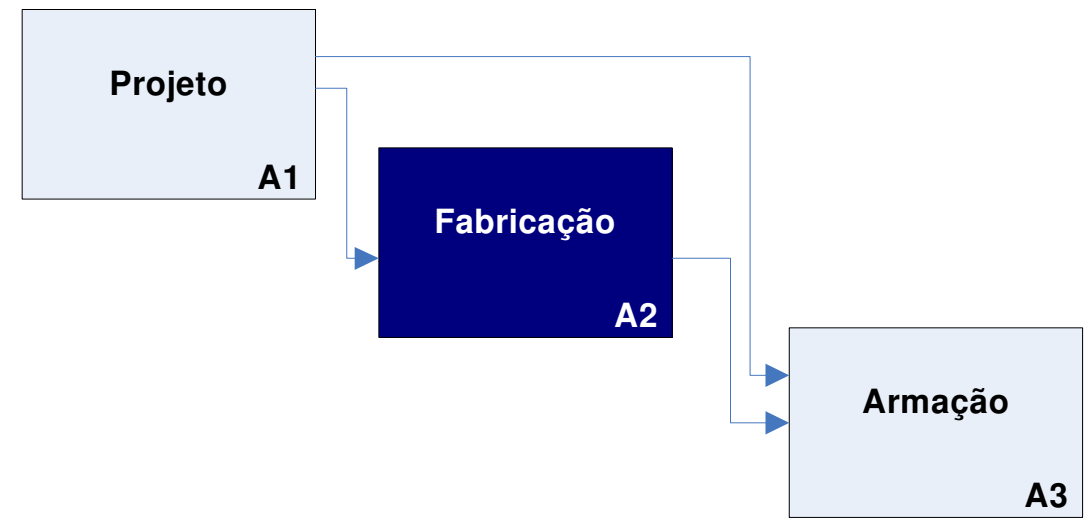

Figura 2.26 - Principais etapas do PCPA

A ABCP (2002) reconhece que, "para a execução da armação, a escolha "estratégica" está relacionada ao sistema de fornecimento do aço (Figura 2.27). Em função da análise de algumas variáveis, cada obra optará pelo sistema de armadura mais adequado à sua realidade. Cada sistema possui suas particularidades, sendo que, para cada solução 
adotada, o tempo entre o pedido do material e o seu recebimento é diferente. Além disso, as etapas inerentes, em cada processo, são distintas, sendo importante considerar todos esses fatores durante o planejamento do serviço". A ABCP (2002) lembra, ainda, que o fluxo do aço bem como a área a disponibilizar no canteiro para suas diferentes etapas podem, em alguns casos, determinar o tipo de fornecimento do aço.

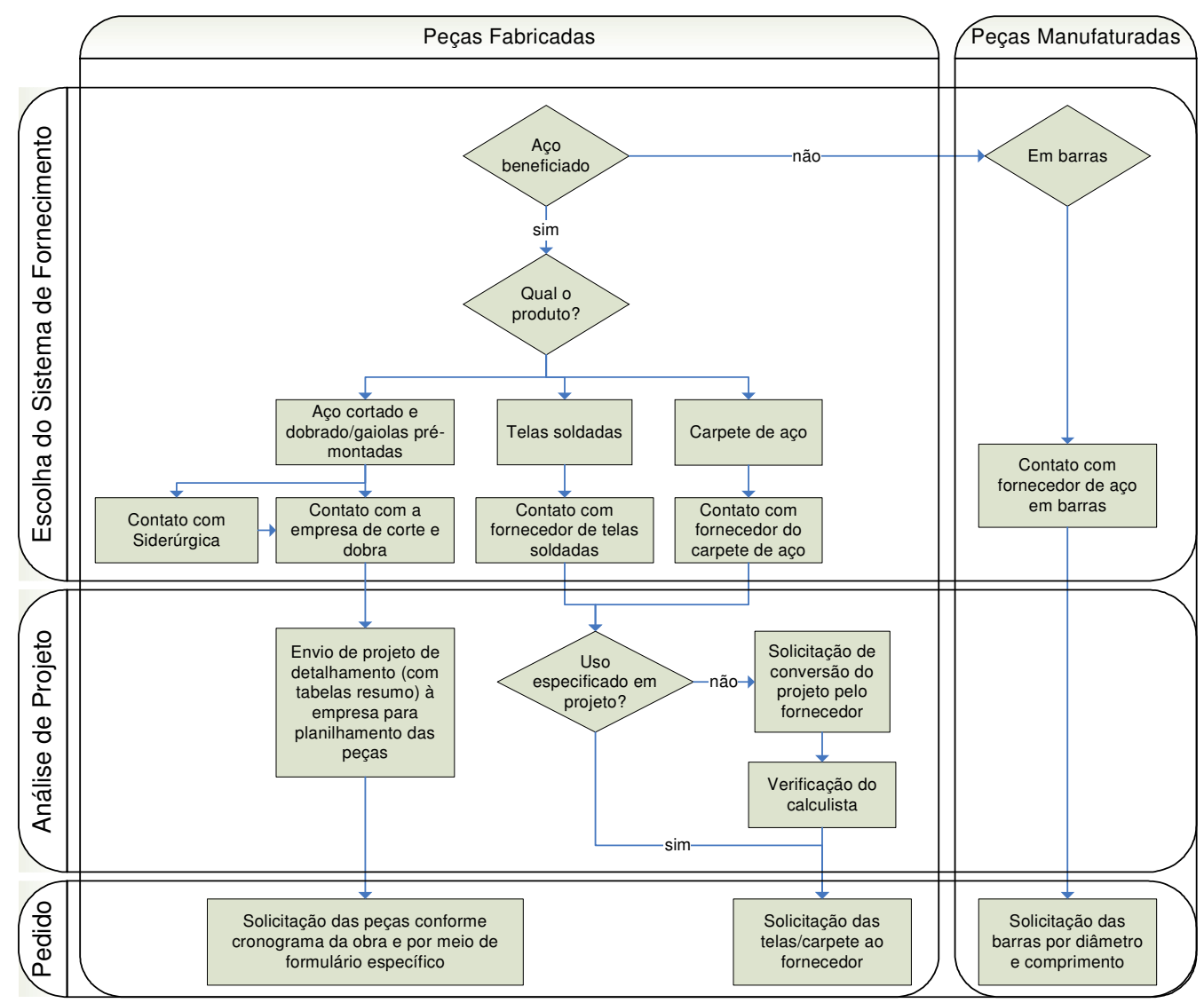

Figura 2.27 - Sistema de fornecimento de aço

O contratante, em consulta aos seus projetistas, decide o sistema de fornecimento que irá contratar, o que implicará em tomar a decisão sobre se irá transferir, ou não, parte das operações de preparação do aço para um fornecedor especializado. Se a decisão for por contratar a fabricação das peças, o contratante deverá encaminhar o projeto de detalhamento ao fornecedor, com uma antecedência necessária (algumas empresas solicitam um mínimo de sete dias) para que o pedido seja processado. KALIAN et al. (2000-b) lembram que, no Reino Unido, a prática de cortar e dobrar o aço no canteiro é raramente utilizada.

\subsubsection{Processos de fabricação de peças e armaduras}

Os processos de fabricação de armaduras industrializados são bastante diversificados. As variações dizem respeito à gama de produtos fornecidos, que vão desde uma simples 
peça, cortada e dobrada, até "carpetes de aço", bem como ao nível de automação das máquinas e equipamentos utilizados pelas empresas.

Enquanto, no Brasil, o uso das armaduras industrializadas na execução de estrutura de edifícios não é muito significativo ${ }^{32}$, quando comparado às armaduras manufaturadas no próprio canteiro de obras, em países como os Estados Unidos, as operações manuais de corte e dobra de aço, executadas nos canteiros de obras, não são recomendadas. As obras norte-americanas acabam trabalhando apenas com peças fabricadas por empresas especializadas.

No Reino Unido, a "CARES"3" e outras entidades têm defendido (KALIAN et al. 2000-b) a necessidade de se melhorar o fluxo de informações entre as partes envolvidas ao longo do processo de produção de armaduras (projetistas, detalhadores, fornecedores e construtores). Dentre os objetivos vislumbrados está a redução de perdas proporcionadas pelas máquinas de corte e dobra. Para tanto, KALIAN et al. (2000-b) acreditam que a indústria do concreto armado deveria: i) usar códigos de barras como uma técnica de identificação automática para as trocas de listas de quantitativos, notas de entrega etc; ii) usar transferência eletrônica da informação para as máquinas de corte e dobra (Figura 2.28).

A CARES encoraja a adoção de sistemas eletrônicos para a emissão de pedidos, para a produção e o fornecimento de armaduras e aços, procurando inicialmente trabalhar com um pequeno número de projetistas, contratantes e fabricantes para experimentar o seu uso.

Segundo KALIAN et al. (2000-b) os fabricantes de máquinas e equipamentos, para corte e dobra de aço, estão trabalhando conjuntamente com profissionais de tecnologia da informação no desenvolvimento de seus produtos. "Máquinas novas, que são mais automatizadas do que as de gerações precedentes, estão agora disponíveis, sendo capazes de conexão com os dados de projeto gerados nos escritórios".

A dificuldade no uso da nova tecnologia é sentida, porém, pelos fornecedores, que consideram o investimento no maquinário avançado muito caro, tanto em termos de despesa de capital quanto ao em treinamento da força de trabalho para operá-lo, observam KALIAN et al. (2000-b). A maioria dos fornecedores está usando máquinas parcialmente automatizadas. Em muitos casos, aqueles que investiram em máquinas novas não estão utilizando suas interfaces e potencialidades de automação.

Dentre as proposições sugeridas no trabalho, KALIAN et al. (2000-b) destacam que, além do seu esforço em desenvolver um maquinário mais avançado, os fabricantes de

\footnotetext{
32 Segundo FREIRE (2001), a realidade da cidade São Paulo, em se tratando de obras de edifícios multipavimentos é diferente da brasileira. $O$ autor, em levantamento realizado no ano de 2000 , constatou que $80 \%$ das construtoras paulistanas utilizavam o serviço de corte e dobre de empresas especializadas.

33 UK CARES é um órgão certificador, sem fins lucrativos, estabelecido em 1983, no Reino Unido, para proporcionar confiança aos usuários, fornecedores e especificadores de aço para armaduras. Ele atua em benefício da Indústria da Construção, oferecendo esquemas de certificação para empresas (através de um regime de regulação, testes e inspeções) que produzam materiais, componentes ou ofereçam serviços para a indústria do concreto armado. Os clientes podem especificar as empresas e produtos aprovados pelo CARES e confiar que ambos estarão em conformidade com os padrões estabelecidos, não sendo necessário que os contratantes façam novos testes e ensaios para verificação da qualidade de produtos e empresas.
} 
equipamentos de corte e dobra devem pensar em formas de promover uma atualização das máquinas mais velhas. Estas máquinas devem, então, ser adaptadas para garantir o intercâmbio dos dados eletrônicos através de redes de dispositivos para salvar os dados, como discos flexíveis etc, de maneira similar às unidades de controle das máquinas mais novas.

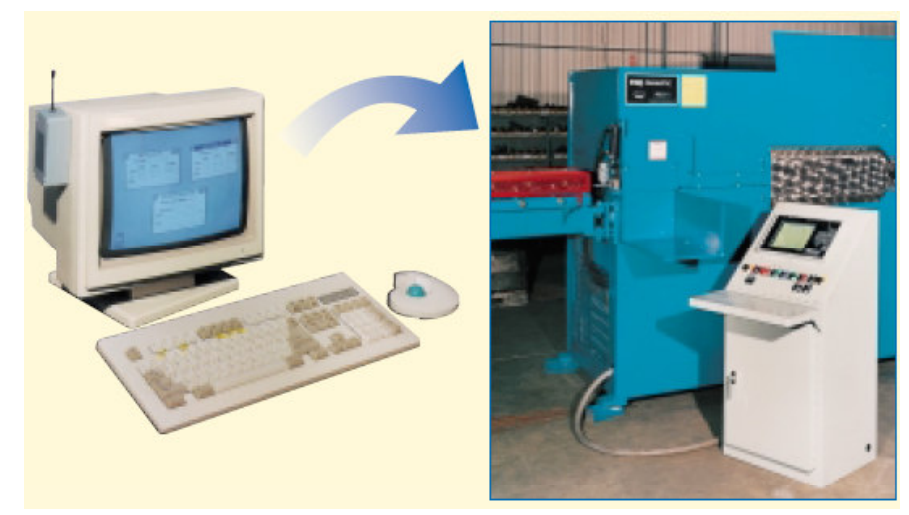

Figura 2.28 - Exemplo de sistema de transferência de informação direta da base de dados para a máquina de dobra.

Com a nova geração de equipamentos é possível transferir os dados de projeto de detalhamento, dos computadores diretamente às máquinas de corte e dobra. KALIAN et al. (2000-b) lembram que esta prática necessita ser explorada mais a fundo e requer um formato padrão da troca de dados. Esta perspectiva é mantida pelos membros da Indústria de Construção do Reino Unido, que negociam eletronicamente pela "Construction Industry Trading Electronically" (CITE). Como um primeiro passo para a automatização do processo de armação, a "American Standart Code for Information Interchange" (ASCII) propôs um formato que foi desenvolvido como parte do projeto de estandardização da troca de informação de programação de dobras. O formato foi adotado pelo CITE como padrão e os membros do CITE serão incentivados a usá-lo.

\subsection{A fabricação de peças}

As operações de corte e dobra de aço, quando transferidas do canteiro de obras para as empresas especializadas (Figura 2.29), deixaram de fazer uso intensivo da mão-de-obra, conseguindo, através das máquinas e equipamentos automatizados, atingir um patamar de racionalização único ao longo de todo o processo de produção da armaduras.

A etapa de fabricação das peças (Figura 2.30), no Brasil, começa com a quantificação dos projetos de detalhamento das armaduras, pelo contratante, para que seja efetuado o fechamento do contrato entre as partes (fornecedor e contratante). $O$ fornecedor estabelece valores para o serviço de corte e dobra, expressos em reais por tonelada de aço ( $R$ \$/ton); estes valores, regidos pelas leis de mercado, não variam, como se era de esperar, em função da complexidade dos projetos. Assim, projetos mais complexos (com, por exemplo, elevado número de peças distintas, que induzem piores produtividades das 
máquinas) custam, para o contratante, o mesmo valor, em $\mathrm{R} \$ /$ ton, que projetos mais simples (maior número de peças repetidas, com diâmetros maiores, por exemplo).

Fechado o contrato, a contratante encaminha, para o fornecedor, os projetos de detalhamento das armaduras, para que ele inicie o "planilhamento" dos projetos cujas peças serão fabricadas. Vale dizer que um cronograma deve ser passado ao fornecedor para que ele faça o planilhamento e fabrique as peças de acordo com seqüência de execução da obra. Eventualmente, esta programação pode ser passada semanalmente pela obra (através de fax, internet ou telefone).
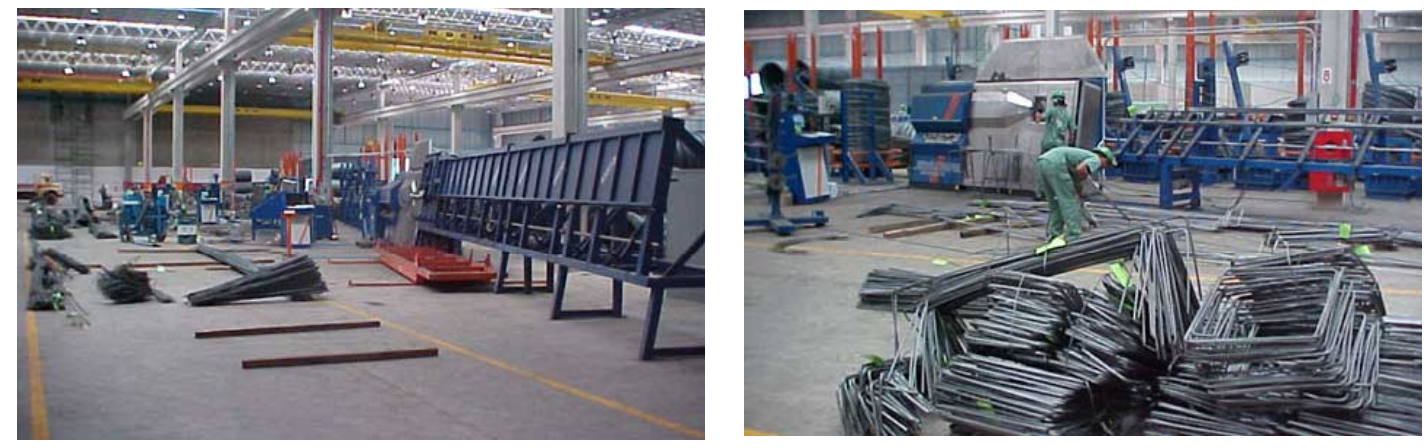

Figura 2.29 - Vistas do pátio de produção de uma empresa de beneficiamento (corte e dobra) de aço.

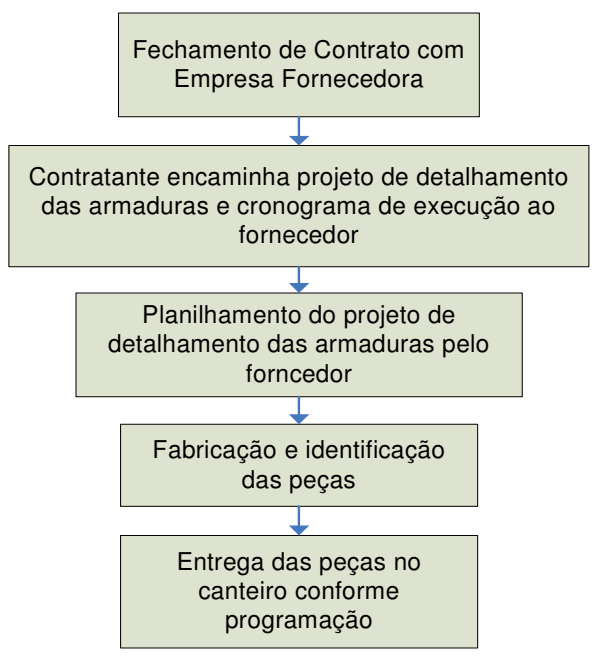

Figura 2.30 - Fluxograma da etapa de fabricação das armaduras 
A atividade de planilhamento ${ }^{34}$, executada pelos chamados "planilhadores", consiste em transformar os detalhes de cada peça em informações, que serão impressas em etiquetas, as quais servirão como ordens de produção para as máquinas de corte e dobra.

O aço processado pelas fábricas pode ser fornecido de duas formas: enrolado em carretéis (bobinas) ou em barras com comprimento de $11 \mathrm{~m}$. O aço fornecido em carretéis limita-se aos diâmetros iguais ou inferiores ao de $16 \mathrm{~mm}$.

Quando se trabalha com o aço em carretéis, esses são dispostos na máquina de "polidobra" (máquina capaz de dobrar vários formatos distintos) com a ajuda de equipamentos mecânicos (pontes rolantes e guindastes). Após o carretel ter sido conectado e ajustado na máquina, o operador digita, no terminal de operações e controle da máquina, as ordens de corte e dobra (contidas nas etiquetas produzidas durante a etapa de planilhamento). A primeira peça cortada e dobrada é checada com relação às prescrições das ordens de corte e dobra. A máquina é, então, finalmente ajustada para que produza a quantidade de peças exigida no projeto.

Quando se trabalha com o aço em barras, a máquina que corta e dobra o aço é abastecida com os feixes de barras de diâmetro apropriado ao trabalho que se deseja realizar. Após digitadas as ordens de produção nas máquinas, as operações restantes são semelhantes às contempladas no processo de fabricação que utiliza carretéis. A operação com barras tem maior probabilidade de gerar perda do material em função das pontas que eventualmente sobram após a última peça cortada. Essas pontas, no entanto, podem ser reaproveitadas na fabricação de conectores de ancoragem e outros itens especiais. Se o comprimento das pontas não permite o reaproveitamento, elas são vendidas como sucata.

A maioria das máquinas de corte e dobra podem ser consideradas como máquinas semiautomáticas, levando em consideração suas operações automáticas de corte e dobra e sua capacidade de interpretar informações a partir de uma unidade de controle computadorizada. Algumas máquinas realizam somente o corte (Figura 2.31), requerendo máquinas de dobra separadas. Outras máquinas são equipadas com elementos de corte e, também, com software de interface para o recebimento de dados diretamente do software de detalhamento.

${ }^{34} \mathrm{O}$ tempo despendido na etapa de planilhamento, quase sempre bastante significativo, depende do nível de detalhamento do projeto. O grande número de peças distintas (formatos e tamanhos) que, segundo o engenheiro Francisco Ozzi (em entrevista ao autor em julho de 2002), trata-se de uma característica dos projetos brasileiros, dificulta o trabalho de planilhamento bem como reduz a produtividade das máquinas de corte e dobra. Como exemplo, Francisco Ozzi apresenta o caso de uma obra que tinha vigas com larguras de 14 e $19 \mathrm{~cm}$ nos pavimento tipo sendo que, no subsolo, a largura das vigas mudava para $20 \mathrm{~cm}$. Dado a este fato, os estribos que poderiam ser produzidos seguindo uma única ordem, se as vigas tivessem sido padronizadas, foram fabricados separados, reduzindo, dessa forma, a produtividade das máquinas de corte e dobra. 


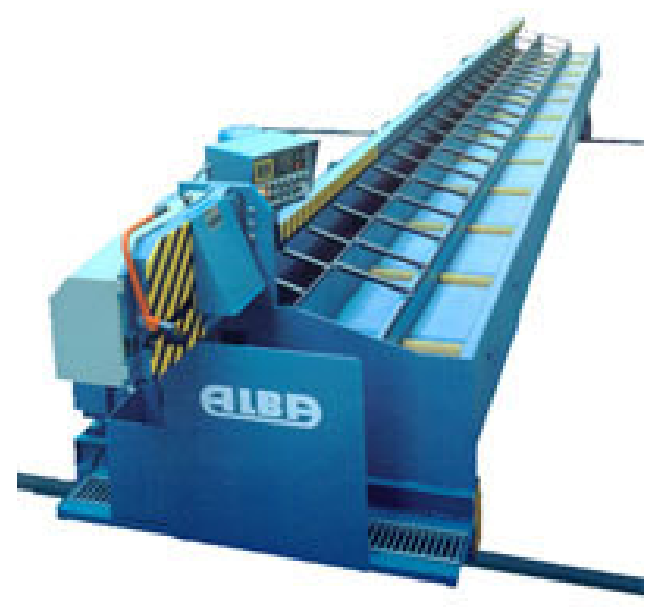

Figura 2.31 - Exemplo de máquina de corte automática

\subsubsection{2}

Telas soldadas

A NBR 7481 á a norma brasileira que especifica o uso de tela de aço soldado para as armaduras de concreto armado. Esta norma define a tela soldada como sendo "uma armadura pré-fabricada, destinada a armar concreto, em forma de rede de malhas, constituída de fios de aço longitudinais e transversais, sobrepostos e soldados em todos os pontos de contato (nós), por resistência elétrica (caldeamento)".

As telas são produzidas a partir do fio máquina, com baixo teor de carbono, submetido ao processo de trefilação (Figura 2.32), onde, na prática, ocorrerá o encruamento a frio do aço, tornando-o mais resistente. O encruamento total é feito por etapas, ou seja, reduções sucessivas no diâmetro do fio máquina. IBTS (2004)

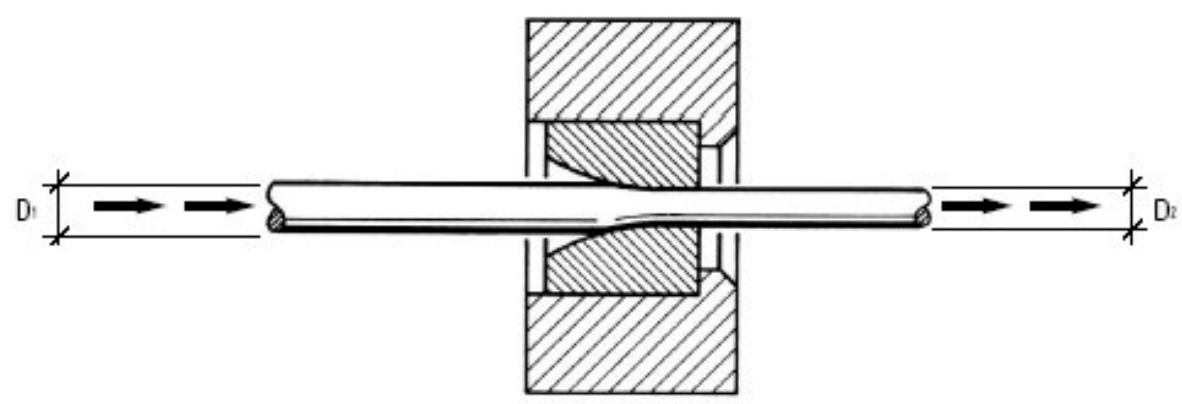

Figura 2.32 - Processo de trefilação para a fabricação de telas soldadas. Fonte: IBTS (2004)

A Figura 2.33 traz um desenho esquemático de tela soldada. A nomenclatura que aparece na Figura 2.33 deve ser interpretada conforme proposição (IBTS) mostrada a seguir:

- largura em metros $(m)$ : que corresponde à extensão total do fio transversal com relação ao sentido de fabricação; 
- comprimento em metros $(m)$ : corresponde à extensão total do fio longitudinal com relação ao sentido de fabricação;

- espaçamento longitudinal em centímetros $(\mathrm{cm})$ : distância medida entre o eixo de dois fios longitudinais consecutivos;

- espaçamento transversal em centímetros $(\mathrm{cm})$ : distância medida entre o eixo de dois fios transversais consecutivos;

- franja longitudinal em centímetros ( $\mathrm{cm})$ : extremidade que sobra, após o último fio transversal soldado, com comprimento igual à metade do espaçamento longitudinal;

- franja transversal em centímetros $(\mathrm{cm})$ : extremidade que sobra, após o último fio longitudinal soldado, com comprimento igual a $2,5 \mathrm{~cm}$;

- malha em centímetros (cm): é a figura geométrica (retângulo ou quadrado) delimitada pela interseção de pares de fios consecutivos ortogonais;

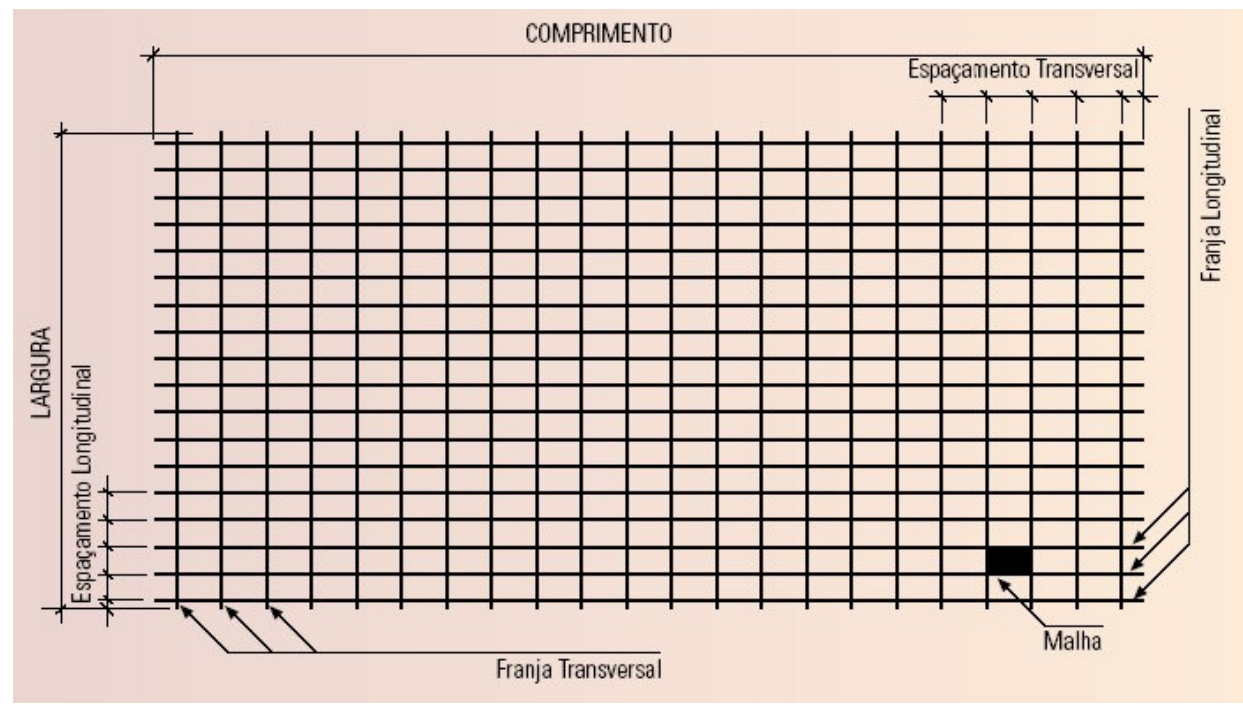

Figura 2.33 - Desenho esquemático de telas soldadas

As telas soldadas são fornecidas em rolo ou painel e se dividem em duas categorias: as telas padronizadas e as telas não padronizadas (fabricadas para atender solicitações específicas de projetos). As telas padronizadas têm largura de $2,45 \mathrm{~m}$, sendo que 0 comprimento varia em função do fornecimento (rolos de 60 e $120 \mathrm{~m}$ e painel de $6 \mathrm{~m}$ ). Os espaçamentos entre fios, para formar as malhas, podem ser de 10, 15, 20 ou $30 \mathrm{~cm}$, em cada direção. São produzidos cinco (5) tipos de telas soldadas para concreto armado, conforme comentado, a seguir:

- tipo "Q": possui área de aço longitudinal igual à área de aço da transversal; usualmente tem-se malha quadrada;

- tipo " $L ":$ possui área de aço longitudinal maior que a área de aço transversal, sem que haja uma relação definida entre as duas; usualmente tem-se malha retangular;

- tipo "M": possui área de aço longitudinal 50\% maior que a área de aço transversal, com relação fixa entre as áreas de aço; usualmente tem-se malha retangular; 
- tipo "R": possui área de aço longitudinal 75\% maior que a área de aço transversal, com relação fixa entre as áreas de aço; usualmente tem-se malha retangular;

- tipo "T": possui área de aço transversal maior que a área de aço longitudinal; usualmente tem-se malha retangular.

São dois os elementos que formam a designação dessas telas: uma letra, que define seu tipo, e um número, que informa a área de aço da armadura principal, em $\mathrm{cm} 2 / \mathrm{m}$ (por exemplo, a tela com a designação " $L$ 283" indica que a tela é do tipo " $L$ " e que possui uma área de aço da armadura principal longitudinal igual a $2,83 \mathrm{~cm}^{2} / \mathrm{m}$ ).

As telas não padronizadas, também conhecidas como "especiais", são produzidas com características específicas, levando-se em conta as necessidades do projeto com relação às suas dimensões (largura/comprimento), relação entre as áreas de aço (principal/secundária), espaçamento entre fios (longitudinal/transversal) e comprimento de franjas (longitudinal/transversal). O IBTS lembra que, no caso dessas telas não padronizadas, os fabricantes sempre devem ser consultados.

A NBR 7481 define que os painéis de telas soldadas são representados (Figura 2.34) em um projeto sob a forma de um retângulo ou quadrado em escala, com uma ou duas diagonais traçadas. Uma diagonal traçada indica ser apenas um painel (armadura simples); no caso de duas diagonais traçadas, tem-se a indicação de dois painéis (armadura composta), um sobre o outro sem espaçamento entre eles, com as mesmas dimensões e posicionados no mesmo local. A diagonal serve para identificar o painel, sendo escrito sobre ela o número do painel para identificar sua posição sobre a fôrma, o tipo da tela (designação), a largura e o comprimento em metros.
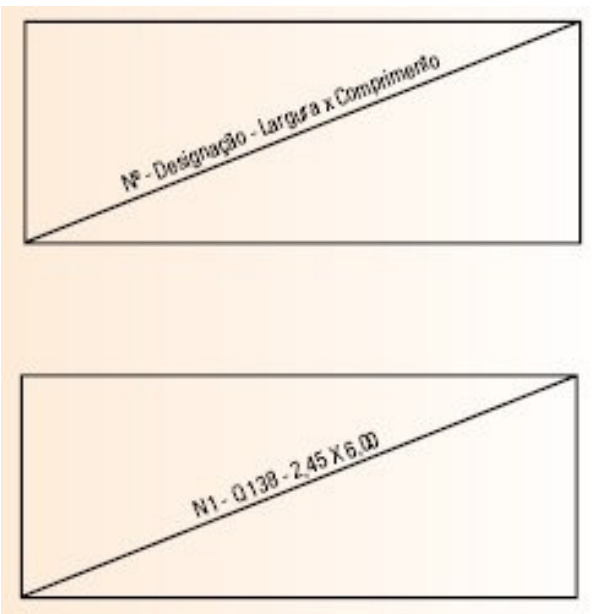

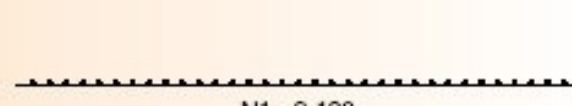

N1 - 0138

Ammadura simples
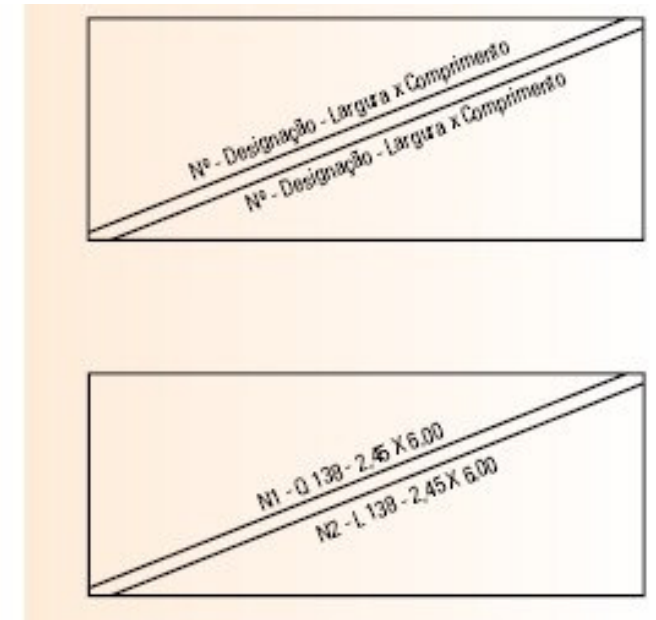

N1 -0138

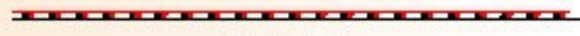

$\mathrm{N} 2-\mathrm{L} 138$

Armadura composta

Figura 2.34 - Representação gráfica de tela soldada. Fonte: IBTS (2004) 
O detalhamento do projeto da armadura da laje em telas soldadas, no Brasil, não costuma ser feito pelo projetista estrutural. O uso de telas soldadas trata-se, geralmente, de uma decisão do cliente (que pode ser aconselhado ou não pelo projetista). O cliente passa o projeto convencional (armadura das lajes com barras) ao fornecedor da tela, que refaz o projeto prevendo o uso de tela. O cliente recebe, então, o projeto re-adequado, que é repassado ao projetista para que seja verificado e aprovado. Para projetos diferenciados (panos de lajes grandes), o projetista já procura detalhar a armadura visando a troca por tela. A projetista estrutural Silvia Lopes Ferreira Crespo ${ }^{35}$ diz que, quando o cliente solicita que o projeto seja concebido com uso de telas soldadas, trata-se de prática comum a alguns projetistas repassarem o projeto ao fornecedor de telas, para que ele faça a compatibilização. Silvia alega que, para o escritório fazer a compatibilização, seria necessário manter um software especial, o que não se viabiliza em função da pouca demanda para este tipo de serviço.

\subsection{Malhas eletrosoldadas - BAMTEC ${ }^{36}$}

Segundo HAUSSLER, NIEDER (2004) o estímulo inicial para o desenvolvimento do BAMTEC foi a necessidade de se encontrar uma solução simples e econômica para a fabricação de armaduras. Os idealizadores do sistema perceberam que, freqüentemente, uma quantidade de aço, acima do necessário, era consumida quando se optava por utilizar telas soldadas para a armadura de lajes. "Por exemplo, quando apenas uma malha de tela não é suficiente, costuma-se usar duas malhas, ou malhas mais resistentes (maiores diâmetros ou menores espaçamentos), na mesma área, resultando em mais aço que o necessário. Muito projetistas acabam adotando esta prática pela falta de tempo para melhor elaborarem os projetos (valores insuficientes, pagos aos projetistas, os impossibilita dedicarem mais tempo ao projeto)".

HAUSSLER, NIEDER (2004) apontam que a solução para este problema está na otimização da disposição das armaduras regulares em cada direção, que foi possível com o desenvolvimento do Bamtec. O Bamtec diz respeito a malhas eletrosoldadas compostas por vergalhões (CA50) unidos por fitas metálicas através de solda. Baseia-se no cálculo estático e em software que projeta e pré-monta as malhas. O sistema otimiza as armaduras (Figura 2.35), pois possibilita o uso de barras com bitolas, comprimentos e espaçamentos diferentes, acompanhando os esforços da peça.

As máquinas utilizadas para a produção das malhas eletrosoldadas tipo Bamtec (Figura 2.36) são altamente automatizadas; lêem as informações diretamente dos programas de cálculo. Os dados são transferidos sem perdas de informação, de uma única vez (do projeto à produção). Os controles eletrônicos permitem que a máquina seja operada por uma única pessoa. As malhas fabricadas são fornecidas à obra em rolos, conforme mostrado na Figura 2.37. Estes rolos constituem, quando abertos, malhas com $16,5 \mathrm{~m}$ de comprimento (valor médio), com a largura variando entre 1,65 a $15 \mathrm{~m}$. Os diâmetros das barras usadas na sua composição variam de 8 a $28 \mathrm{~mm}$. Ao determinar o posicionamento

\footnotetext{
35 Em entrevista concedida ao autor em 10/06/2003.

36 BAMTEC trata-se da denominação (uma abreviação de "Bewehrungs-Abbund-MaschinenTechnologie") dada ao sistema de armadura pré-fabricada (barras unidas por fitas metálicas, fornecidas em rolos), desenvolvida e patenteada em 1994 por dois engenheiros estruturais alemães (Willhem Haussler e Norbert Nieder).
} 
das malhas, o projetista acaba escolhendo a seqüência de montagem das malhas, facilitando a organização do trabalho no canteiro de obras (Figura 2.38).

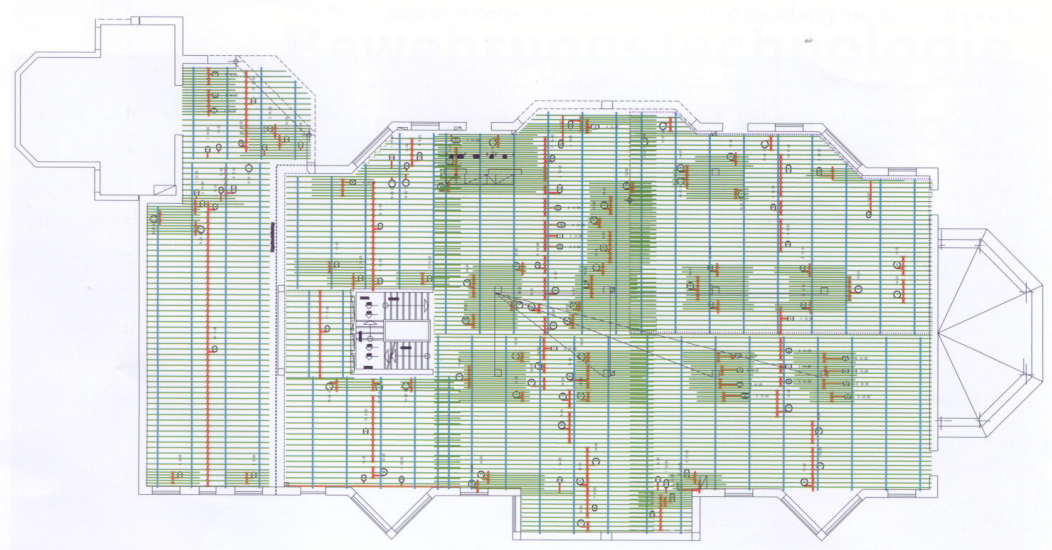

Figura 2.35 - Otimização da armadura da laje.
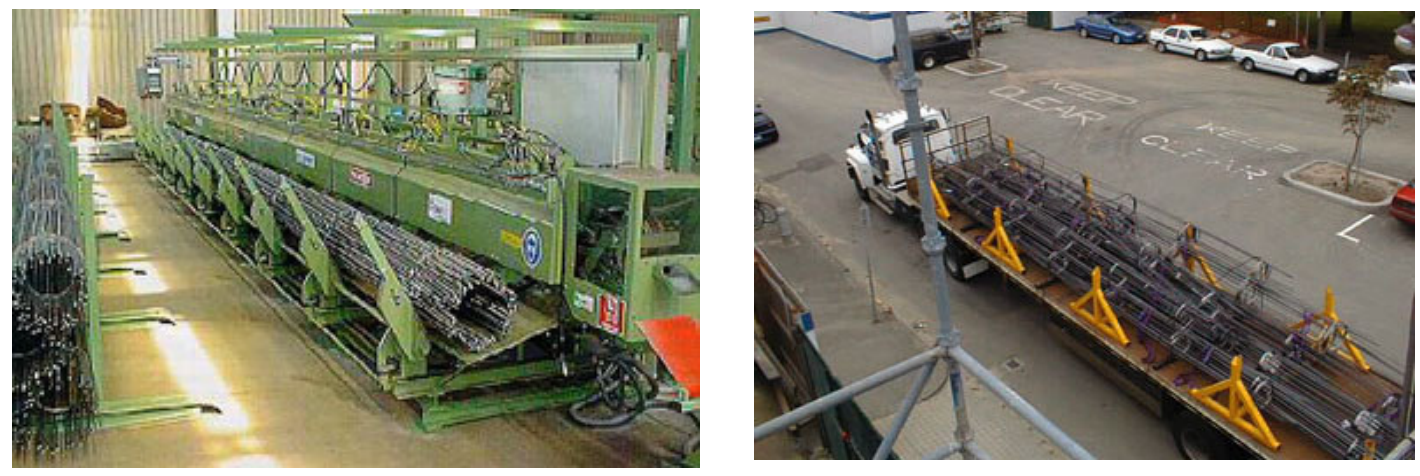

Figura 2.36 - Máquina para a produção de malhas tipo Bamtec

Figura 2.37 - Exemplo de aplicação das malhas tipo Bamtec
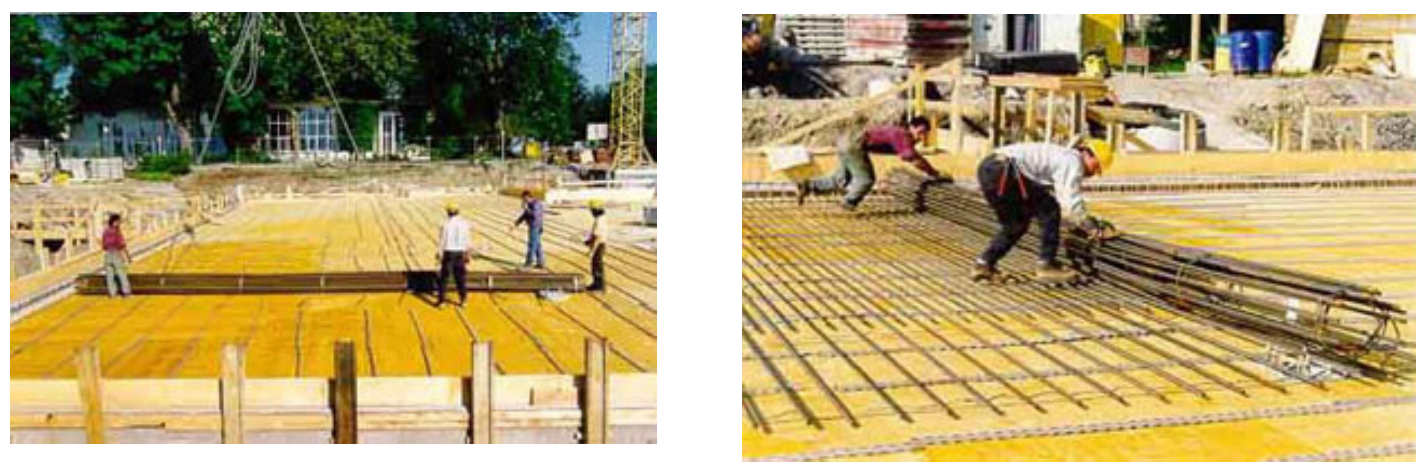

Figura 2.38 - Exemplo de posicionamento da malha na laje

\subsubsection{4}

\section{Gaiolas pré-montadas}


Para KALIAN et al. (2000-b) o uso de armaduras pré-fabricadas como telas soldadas, malhas tipo Bamtec e outros itens industrializados têm se tornado comum. No entanto, o uso de gaiolas pré-montadas fora do canteiro de obras é raro e concentrado em trabalhos específicos e em áreas especializadas. As armaduras pré-montadas não são favorecidas devido ao custo elevado do transporte e à maior responsabilidade quanto ao seu desempenho estrutural. KALIAN et al. (2000-b) dizem haver algumas vantagens a serem obtidas com o uso da pré-montagem em fábricas.

As gaiolas pré-montadas têm sido ofertadas por empresas que, até então, forneciam à obras as peças cortadas e dobradas. "Além de a obra receber estribos e barras cortados e dobrados, ela passa a receber peças pré-montadas como vigas, pilares, tubulões e blocos, de acordo com o projeto estrutural, e prontas para serem colocadas nas fôrmas" (nota encontrada no site ${ }^{37}$ de um fornecedor).

Os processos de montagem de gaiolas, nestas empresas, visando atender obras de edifício, são semelhantes aos processos de pré-montagem encontrados nos canteiros de obras, ou seja, são processos totalmente manuais.

Um certo nível de mecanização nesta atividade de pré-montagem é encontrado quando se utilizam telas soldadas para a confecção de gaiolas. Segundo o IBTS, com o auxílio de um equipamento chamado "dobradeira de telas", pode-se dar formas às telas soldadas (Figura 2.39) e usá-las para armar vigas, pilares, pré-fabricados etc. Existem dois tipos de dobradeira de telas, uma de acionamento manual (Figura 2.40) e outra de acionamento hidráulico (Figura 2.41); ambas dobram telas com ângulos que variam de 0 a 180 graus.

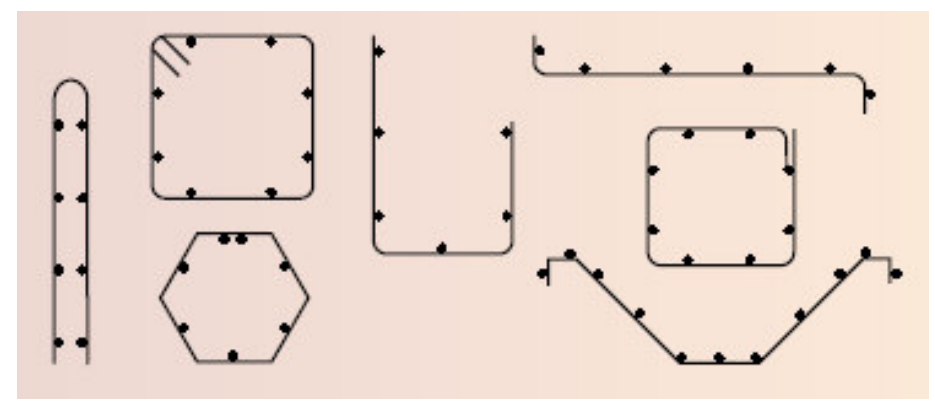

Figura 2.39 - Exemplo de dobras executadas em dobradeiras manuais

${ }^{37}$ www.bilden.com.br, acessado no dia 31/05/2004. 


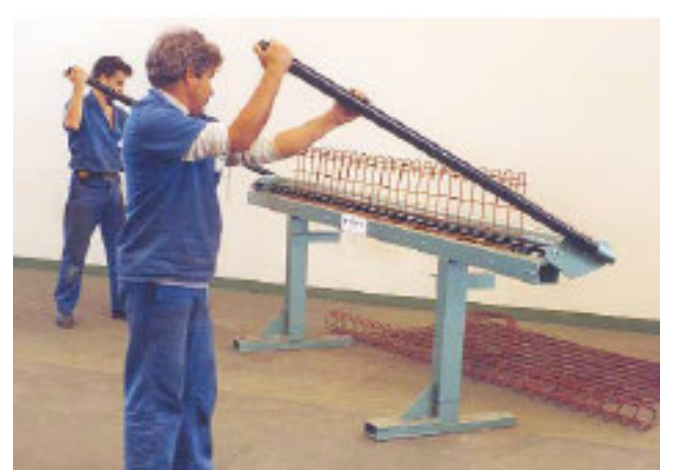

Figura 2.40 - Dobradeira de tela em máquina com acionamento manual

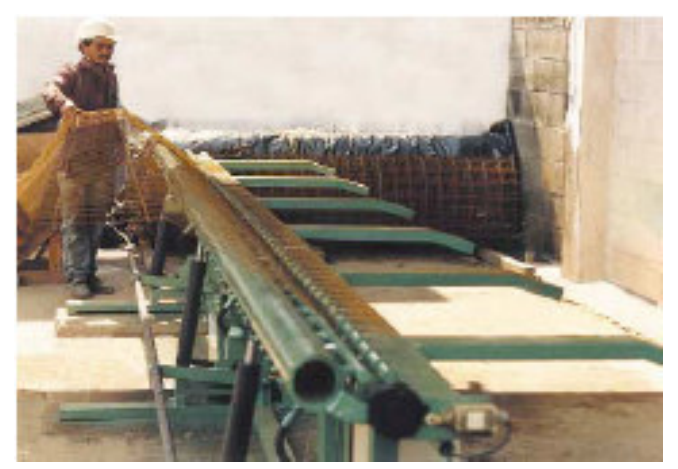

Figura 2.41 - Dobradeira de tela em máquina eletro-hidráulica

\subsubsection{A armação no âmbito do PCPA}

A etapa de armação no âmbito do processo concepção e produção de armaduras (Figura 2.42), envolve um conjunto de atividades, a começar pela administração de um conjunto documentos (projetos, certificados de ensaios do aço, formulários de pedidos, procedimentos de inspeção, execução e treinamentos etc) que irão proporcionar as condições para o desenvolvimento das etapas seguintes do processo. De posse dos documentos, como, por exemplo, o cronograma da obra, pode-se elaborar o planejamento das micro-atividades. Com a programação liberada, parte-se para o conjunto de operações de produção, seqüenciais, que têm seu início marcado pelo recebimento do material no canteiro, e o final, determinado pela liberação para a inspeção das armaduras.

Dentre as atividades supracitadas, discorrer-se-á, a partir daqui, sobre as atividades relacionadas às operações de produção, tais como o recebimento do material, a estocagem deste material, o corte e a dobra das barras, a pré-montagem das peças, o transporte das barras/peças/armaduras pré-montadas e a montagem final. O conjunto destas operações, ordenada segundo uma determinada seqüência executiva, constitui o método de trabalho. A associação de operações com características distintas ${ }^{38}$, constitui, portanto, métodos de trabalho distintos (por exemplo, diz-se que uma obra que apresenta um sistema de descarregamento manual possui um método de trabalho distinto de outra que faz o descarregamento com o auxílio de uma grua). Em razão das diferentes possibilidades de se executar cada uma das operações e das inúmeras combinações permitidas entre elas, o método de trabalho, no âmbito do PCPA, pode variar significativamente de uma obra para outra.

\footnotetext{
${ }^{38} \mathrm{Em}$ função, basicamente, da disponibilidade de equipamentos, máquinas e ferramentas.
} 


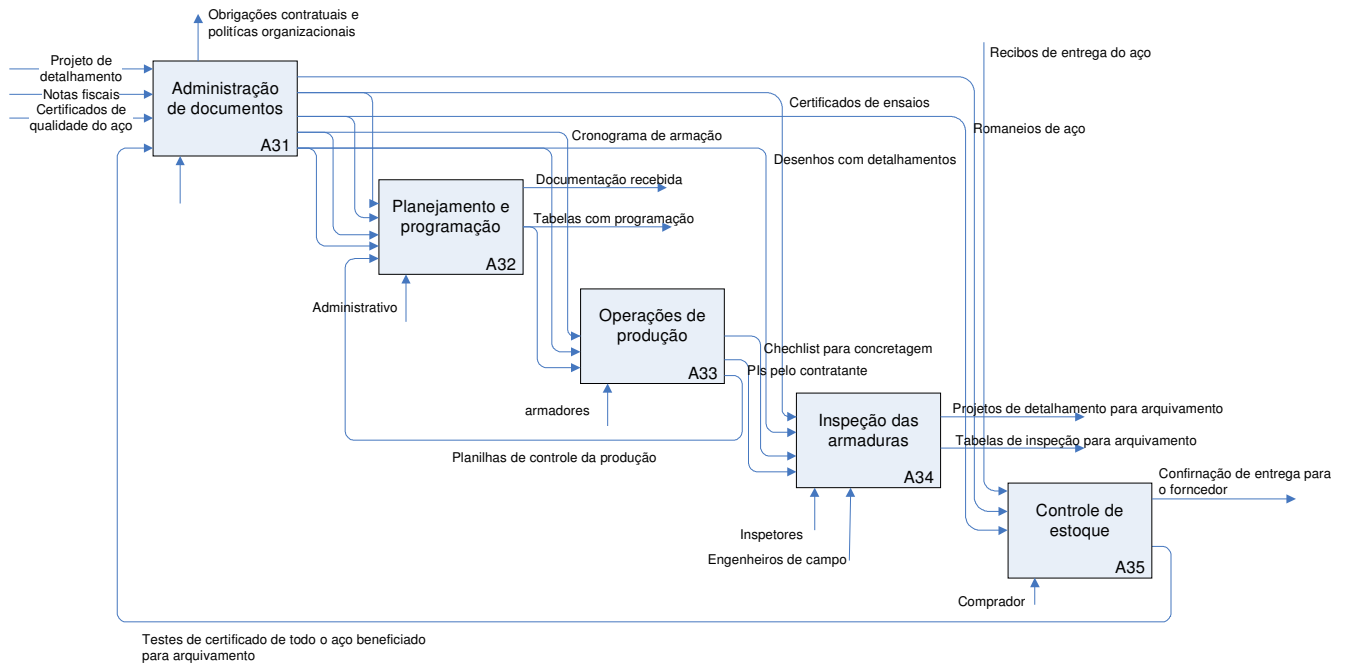

Figura 2.42 - Processo de concepção e produção de armaduras no âmbito do canteiro de obras - Etapa de armação

\subsubsection{As operações de produção}

O seqüenciamento das operações, tal como apresentado na Figura 2.43 pode ser razoavelmente complexo ao ser analisado com detalhes. O método de trabalho pode apresentar diferenças na sua concepção, a começar pelo sistema de fornecimento do aço adotado pela obra, se em barras, ou se em peças/armaduras. Cita-se, como exemplo, o fato de as operações de recebimento e estocagem do aço fornecido em barras diferirem bastante das mesmas operações referentes ao aço cortado e dobrado (fornecimento de peças fabricadas). Como será visto, estas operações são específicas para cada caso e, como tal, devem ser estruturadas de maneiras diferentes.

As demais operações, embora bem definidas, apresentam diferenças em função das particularidades dos recursos que forem alocados para o seu desenvolvimento. 0 conhecimento detalhado de cada operação trata-se, portanto, de um requisito importante, ao permitir que as pessoas envolvidas na proposição do método de trabalho tomem decisões embasadas em critérios técnicos/operacionais que mais se adaptem às condições físico/financeiras da obra, por exemplo.

Procurar-se-á, portanto, na seqüência do desenvolvimento deste capítulo, apresentar, para cada uma das operações de produção que compõem a etapa de armação do PCPA, informações técnicas e operacionais, que ajudarão a subsidiar a proposição de métodos de trabalho potencialmente mais produtivos. 


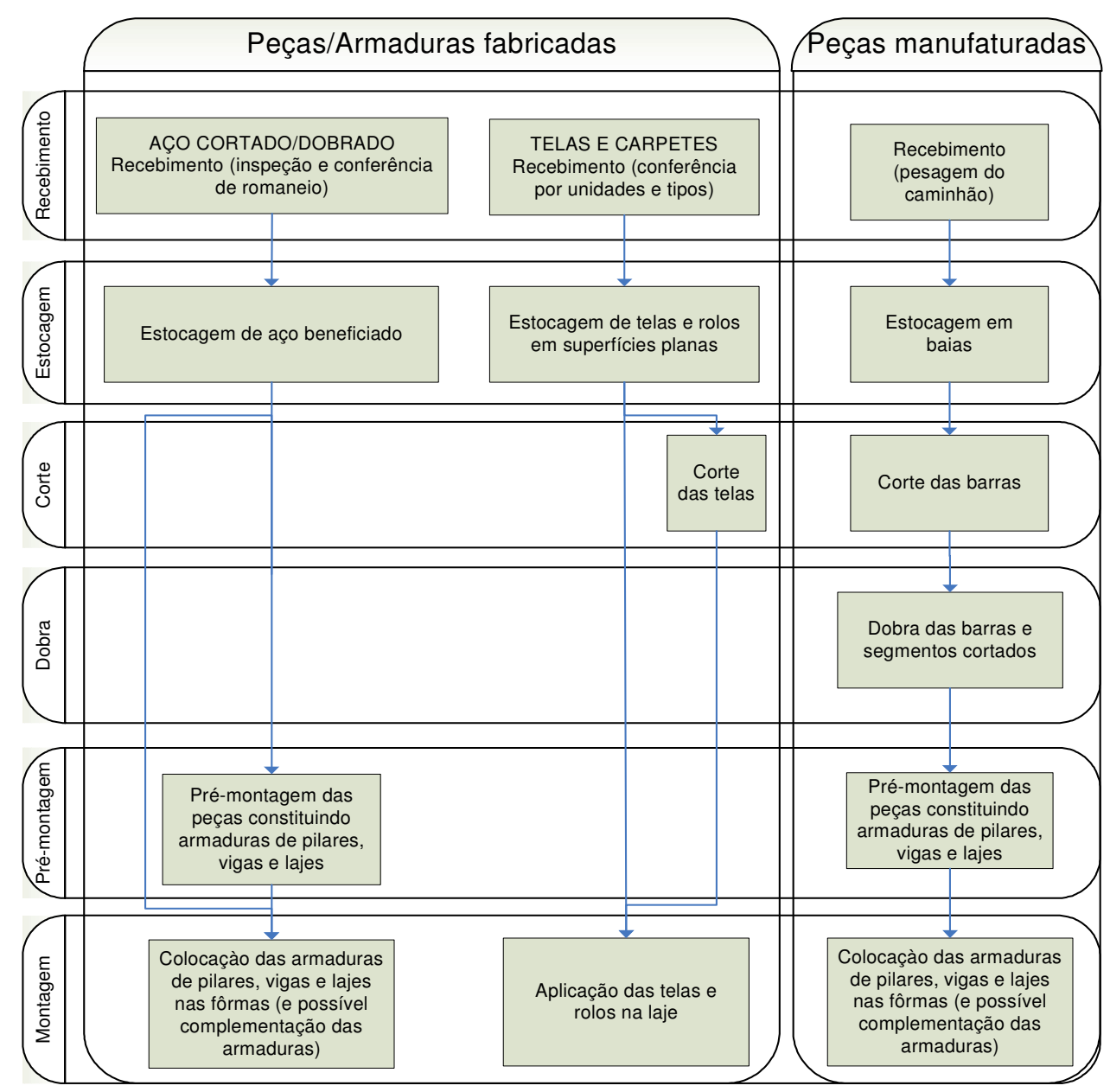

Figura 2.43 - Seqüência de operações de produção no âmbito da armação

\subsection{O Recebimento do aço no canteiro de obras}

O recebimento do aço, no canteiro de obras, contempla as atividades de conferência e descarregamento do aço.

Através da atividade de conferência, a contratante deverá checar: i) se o carregamento de aço que está sendo recebido é condizente com a discriminação apresentada na nota fiscal e/ou no romaneio ${ }^{39}$ de entrega do aço disponibilizado pelo fornecedor; ii) se o material está condizente com as características determinadas por normas específicas (NBR 7480:1996 e NBR 7841:1990), bem como pelas prescrições dos procedimentos da contratante (por exemplo, o aspecto geral das peças no que diz respeito à integridade dos formatos, a presença de esfoliações e sinais de corrosão etc).

39 Trata-se de um documento que discrimina, uma a uma, todas as peças que foram solicitadas pelo contratante (identifica a etiqueta correspondente, o formato, o diâmetro e dimensões das peças) e que, teoricamente, deveriam constar no carregamento a que ele se refere. 
Quando o aço é fornecido em barras, alguns contratantes adotam o procedimento de pesagem do veículo ${ }^{40}$ que transporta a carga (faz-se isso em dois momentos: antes e após o descarregamento, sendo a diferença entre as duas pesagens igual ao peso da carga, que deverá ser igual ao peso total apresentado na nota fiscal). A adoção deste procedimento é determinada pela contratante, que irá estipular como, quando e quantas vezes ele deverá ocorrer.

No caso do recebimento do aço beneficiado não se costuma adotar o mesmo procedimento de pesagem supracitado. A conferência, nesta situação, é bem mais trabalhosa, pois exige que todas as etiquetas ${ }^{41}$, como a mostrada na Figura 2.44 , que identificam os feixes de um conjunto de peças, sejam confrontadas, uma a uma, com o romaneio entregue pelo fornecedor. Nesta operação devem ser conferidos o diâmetro, 0 formato, as dimensões e a quantidade de peças. Esse tipo de conferência (Figura 2.45) exige a presença de, pelo menos, um funcionário com bom nível de instrução, que deverá acompanhar o descarregamento, durante todo o tempo demandando pela operação.

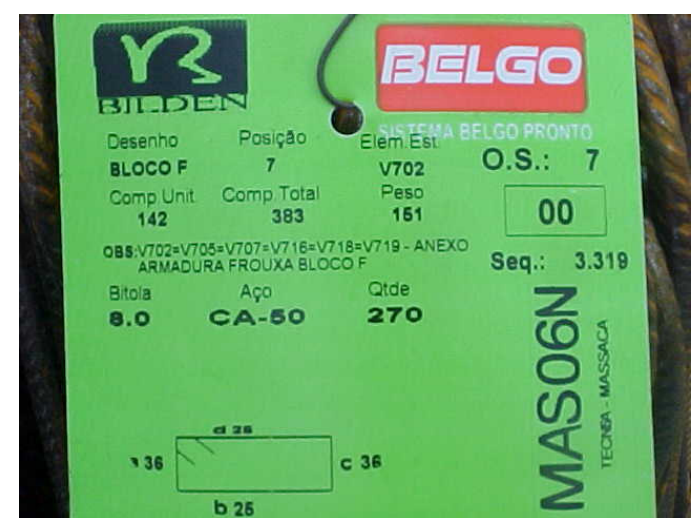

Figura 2.44 - Exemplo de etiqueta que acompanha os feixes de peças

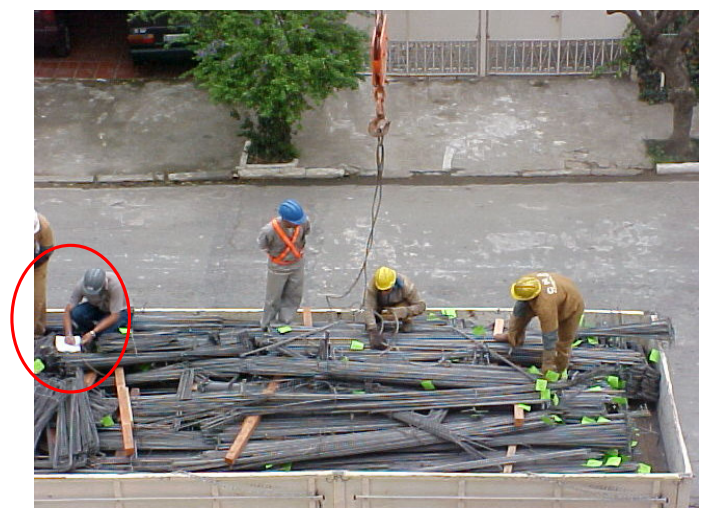

Figura 2.45 - Detalhe de funcionário encarregado de conferir o aço

Assim como em todos os tipos de recebimento, no recebimento de telas soldadas e carpetes de armadura é necessário conferir se as informações contidas nas etiquetas conferem com o material que está sendo entregue. Verificações, por amostragem, onde são aferidas as principais medidas do material comprado (dimensões das malhas, comprimento e largura) são desejáveis.

A conferência do aço pode acontecer antes, durante e/ou após o seu descarregamento. Em algumas situações é preciso que o aço seja retirado do caminhão que o transportou

\footnotetext{
40 As entregas de aço à obra, independentemente ao tipo de aço fornecido (em barras, telas, rolos etc), podem ser feitas em caminhões (com capacidade para até 12,5t) ou em carretas (com capacidades para até $25 \mathrm{t})$.

41 Num carregamento de 25t, destinado a estruturas de edifícios costumam ser recebidos dezenas de feixes, havendo, portanto, dezenas de etiquetas a serem conferidas.
} 
para que possa ser conferido. Em outras, o aço é conferido estando ainda no caminhão, como foi o caso ilustrado na Figura 2.45.

A operação de descarregamento varia significativamente (em relação à mão-de-obra envolvida, aos tempos gastos etc) em função do sistema de transporte presente na obra e da logística de canteiro, que determinará a acessibilidade ${ }^{42}$ e o posicionamento do caminhão em relação ao equipamento de transporte e ao local em que o aço será depositado. A Figura 2.46 e a Figura 2.47 mostram uma disposição, de canteiro de obras, desfavorável (caminhão em posição inclinada) e outra favorável (situação de caminhão em terreno plano, ao lado da baia de estocagem), respectivamente, ao descarregamento do aço que, neste caso, era recebido em barras e a descarga feita manualmente.

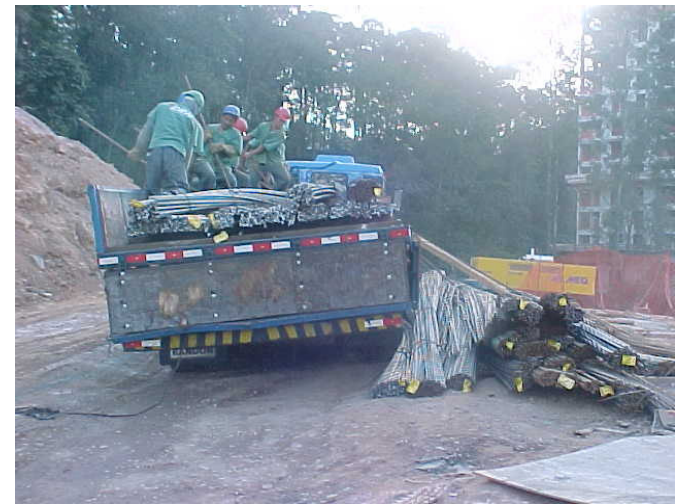

Figura 2.46 - Situação de canteiro desfavorável ao descarregamento

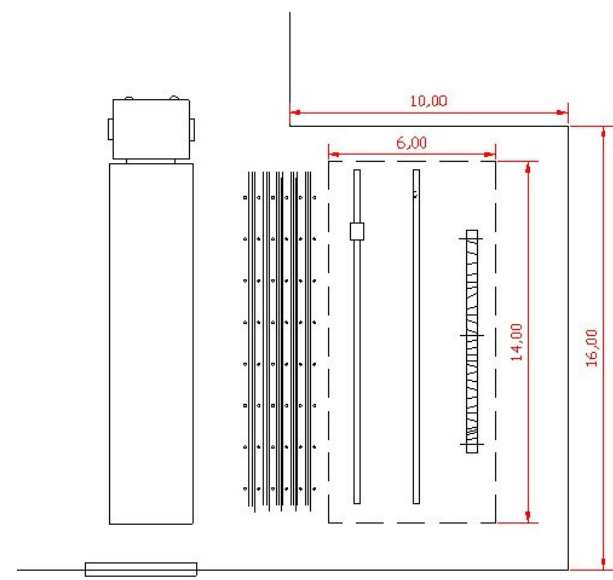

Figura 2.47 - Situação de canteiro com logística favorável ao descarregamento

Em vista do volume de aço que costuma chegar à obra nas fases de pico de execução, ao peso considerável das barras e/ou peças (sejam as barras de $11 \mathrm{~m}$, sejam os feixes com um conjunto de peças) e às suas formas que dificultam o manuseio, o descarregamento pode ser ora classificado como uma operação simples, ora como uma operação significativamente representativa em função dos tempos e esforços demandados.

Tecnicamente, a operação de descarregamento pode ser feita manualmente ou com o auxílio de equipamentos mecânicos (que podem ser uma grua ou um guindaste móvel, por exemplo). Em ambas as situações, a complexidade da operação pode ser variável, em função, principalmente, da maneira como o canteiro de obras foi organizado. Essas diferenças serão evidenciadas nos estudos de caso apresentados no capítulo cinco deste trabalho.

O descarregamento manual, conforme ilustrado na Figura 2.48 , mobiliza um significativo contingente de trabalhadores, que desempenha a atividade, na grande maioria das

42 Ao se pensar na logística de canteiro deve-se pensar na operação de descarregamento do aço, haja vista as dimensões e o peso das carretas que transportam o aço, prevendo-se, portanto, portões de acesso e áreas compatíveis para manobras e estacionamento do caminhão (reforços estruturais em algumas lajes poderão ser necessários). 
vezes, em condições ergonomicamente desfavoráveis e exposto a riscos de ferimentos. No descarregamento manual de aço em barras, conforme mostrado na Figura 2.49, os operários utilizam barras de aço, ou pedaços de madeira, que funcionam com alavanca e auxiliam na movimentação dos feixes.

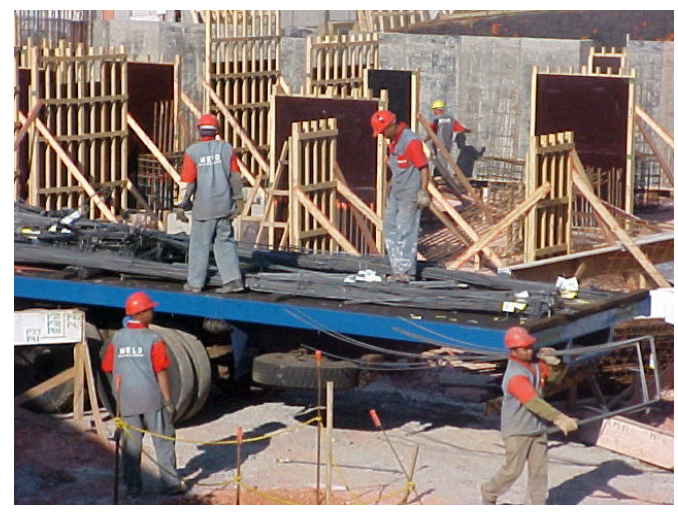

Figura 2.48 - Descarregamento manual de aço beneficiado.

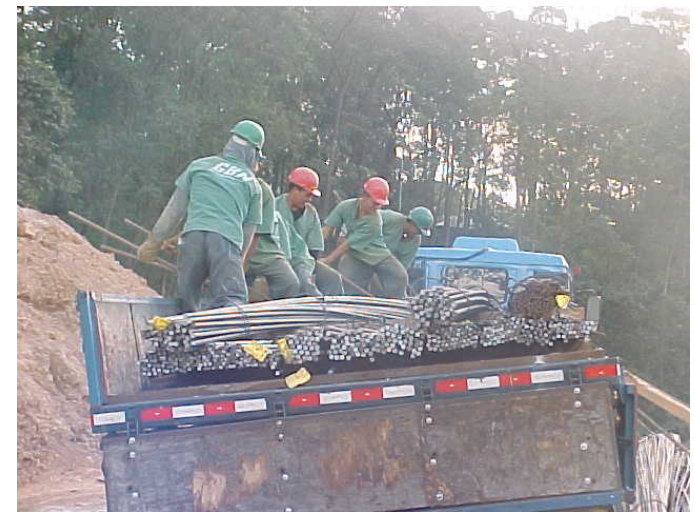

Figura 2.49 - Descarregamento manual de aço em barras.

No descarregamento com o auxilio de grua (Figura 2.50 e Figura 2.51), por exemplo, desonera-se a mão-de-obra, podendo tornar a operação bem mais rápida e eficiente. Os riscos, no entanto, continuam a existir, haja vista estar se mobilizando elementos pontiagudos, dispostos em feixes (no caso de barras e peças cortadas e dobradas) com acondicionamento deficiente (geralmente as fitas que prendem os feixes permitem que as extremidades fiquem soltas). O descarregamento das telas soldadas e carpetes de armadura também envolve riscos e requer cuidados especiais.

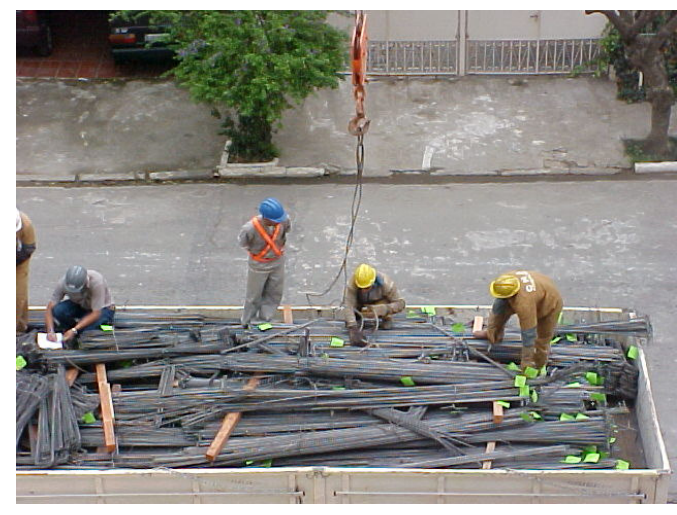

Figura 2.50 - Descarregamento de aço beneficiado com o uso de grua fixa

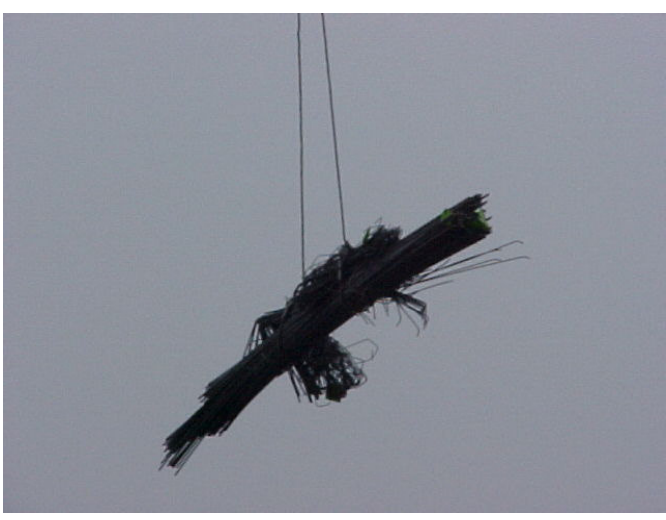

Figura 2.51 - Transporte de aço beneficiado com o uso de grua fixa 
O aço, no canteiro de obras, trata-se de um material que precisa ser deslocado várias vezes (desloca-se, dentro do canteiro, num número de vezes diretamente proporcional ao número de operações em que participa (Figura 2.52)). O aço em barras é aquele que mais vezes é deslocado e, portanto, estocado dentro do canteiro de obras. É estocado após ser descarregado e, novamente, após as operações de corte, dobra e prémontagem, conforme mostrado na Figura 2.53 e na Figura 2.54. Para cada um destes momentos, bem como para cada tipo de fornecimento (em barras, em telas, em rolos, cortado e dobrado) é necessária uma configuração específica do local de estocagem. Chama-se a atenção para o fato de o nível de dificuldade de se estocar o aço no canteiro aumentar à medida em que o aço é manufaturado. Esta dificuldade é função das áreas disponibilizadas (maiores para as peças fabricadas) bem como do próprio arranjo organizacional do aço (o aço cortado e dobrado, por exemplo, requer uma preocupação maior com a sua estocagem, haja vista tratarem-se de feixes pequenos que, se empilhados, podem dificultar o acesso).

As baias de estocagem, para o aço em barras, necessitam de uma área (deve-se atentar para o comprimento das baias que será, necessariamente, superior a doze metros, em razão de as barras de aço serem fornecidas aproximadamente com esse comprimento) reduzida quando comparada à área necessária para estocar as telas soldadas e, principalmente, o aço fornecido cortado e dobrado.

MAIA (2003) propõe recomendações quanto aos tamanhos dos elementos do canteiro de obras (baseia-se, para tanto, nas prescrições da NR 18 e da NBR12284, no código de obras do Município de São Paulo e nos boletins técnicos nos trabalhos de SOUZA et al. (1997) e SOUZA; FRANCO (1997)), definindo, entre outros aspectos, as dimensões para as baias de estocagem do aço em barras. As baias devem ser alocadas em terrenos planos; a base na qual serão depositadas as barras deve ser tal que impeça o contato do aço com o solo e, por conseguinte, com impurezas. Devem, ainda, prever dispositivos que permitam separar as barras de aço por diâmetro.

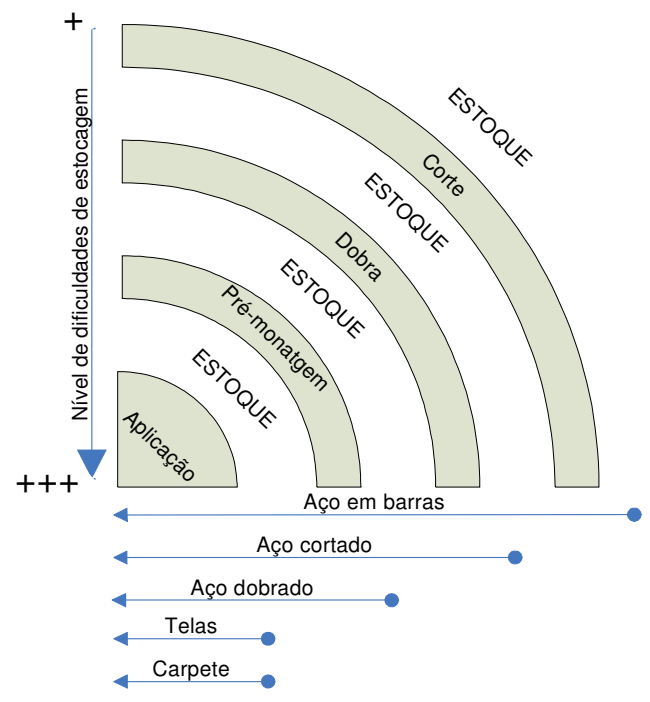

Figura 2.52 - Estágios da estocagem do aço no canteiro de obras. 


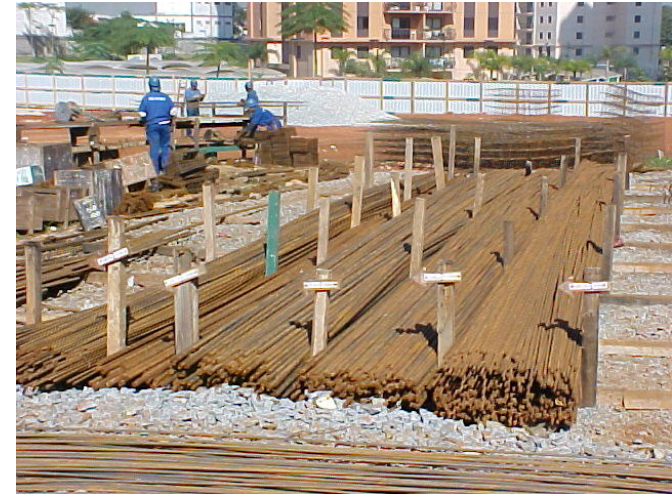

Figura 2.53 - Baia para estocagem de aço em barras

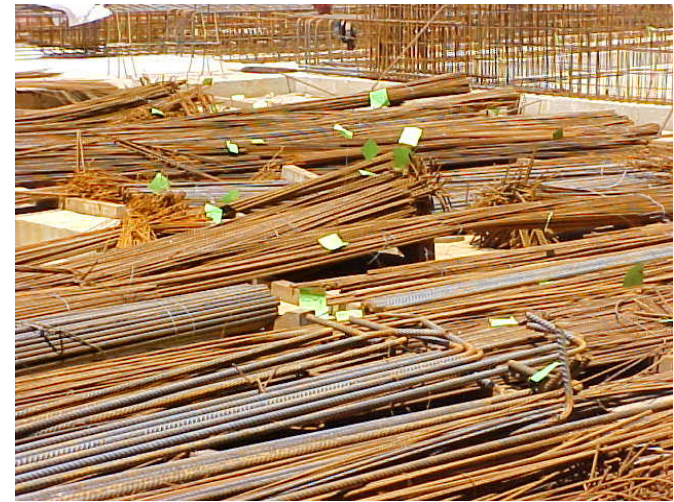

Figura 2.54 - Estocagem de aço cortado e dobrado

As definições quanto às áreas de estocagem do aço beneficiado e à configuração destes espaços não são simplistas como aquelas comentadas anteriormente para o aço em barras. A forma de estocagem das peças, se separadas em função dos elementos estruturais ou dos pavimentos aos quais se referem, por exemplo, depende muito da maneira como o aço foi comprado e, posteriormente, acondicionado no caminhão que o entregará à obra. O local de estocagem (Figura 2.55 e Figura 2.56), não mais caracterizado por baias fixas, costuma ocupar os espaços disponíveis no canteiro que, por sua vez, não costumam manter uma proximidade entre si e em relação ao local de pré-montagem das armaduras (estoques descentralizados). Isso se deve ao fato, já comentado, de as peças fabricadas precisarem ser dispostas de tal maneira que facilite a localização e retirada dos feixes que serão utilizados.

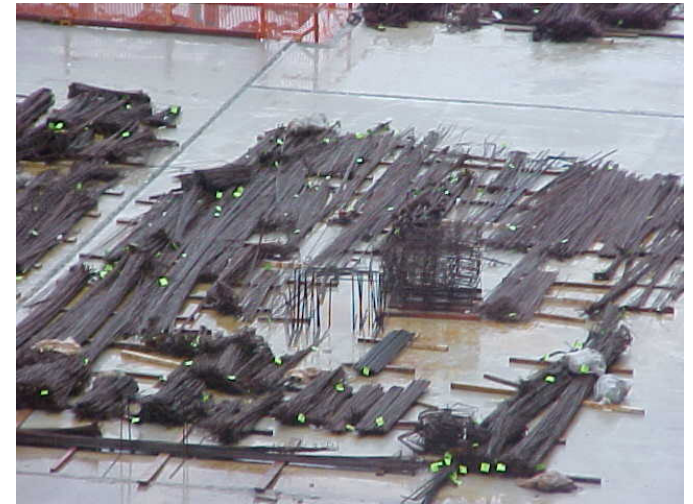

Figura 2.55 - Área para estocagem das peças

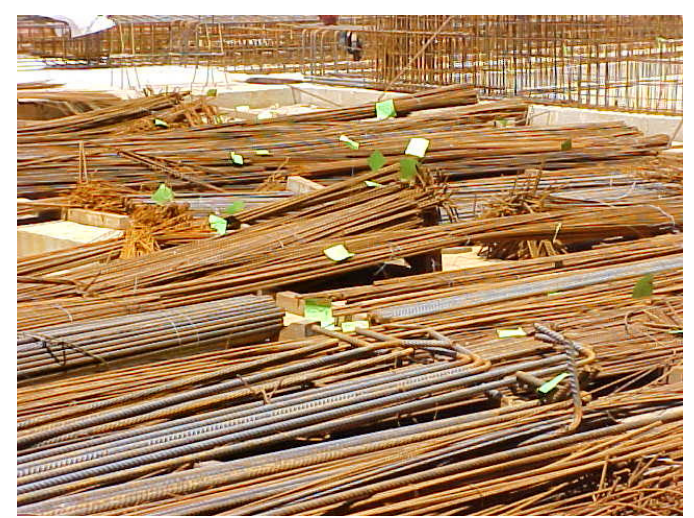

Figura 2.56 - Área para estocagem das peças

A estocagem das telas soldadas (fornecidas em painéis ou em rolos) e carpetes de armadura (Figura 2.57 e Figura 2.58, respectivamente) requer grande áreas em função 
das grandes dimensões destes elementos. Tais áreas devem ser previstas, preferencialmente, em locais a que os equipamentos que farão o transporte vertical dos elementos tenham acesso direto. Segundo a ABCP (2002), quando as telas são fornecidas em painéis, elas podem se estocadas em pé, minimizando a necessidade de áreas maiores para a sua estocagem. Assim como o aço pré-cortado e dobrado, as telas e carpetes podem ter estoques descentralizados.

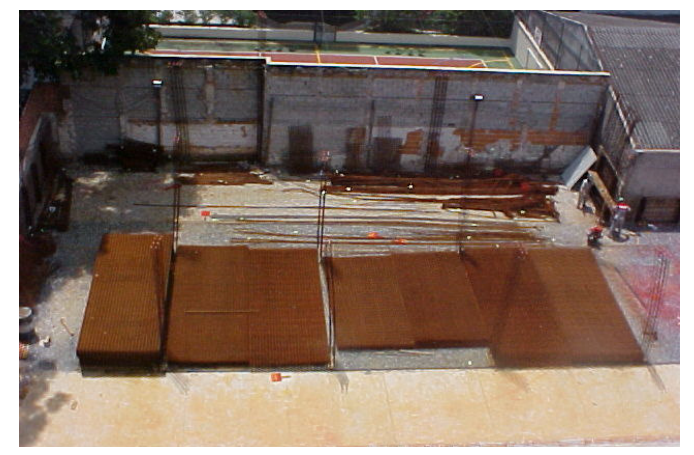

Figura 2.57 - Estocagem de telas soldadas fornecidas em painéis

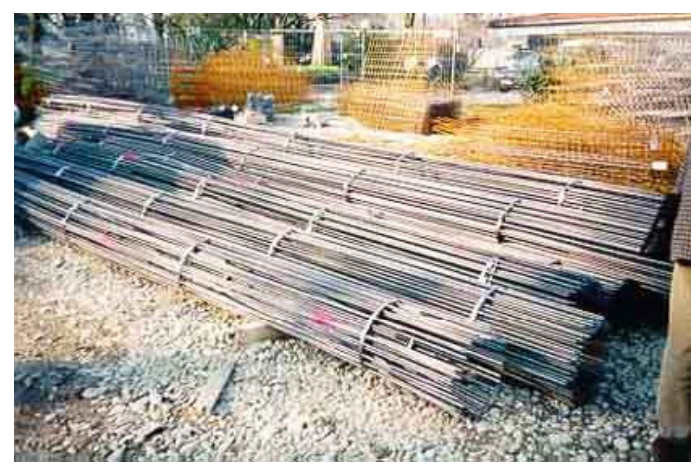

Figura 2.58 - Estocagem de carpetes de armadura

\subsection{O corte das barras de aço no canteiro de obras}

O corte se trata da primeira operação de transformação das barras de aço visando a produção das armaduras. A operação, que quando feita na fábrica é desempenhada por máquinas automatizadas, pode ser também executada nos canteiros de obras. Embora, em países como os EUA, o corte das barras seja desaconselhado quanto a ser feito no canteiro (CRSI) e, de fato, pouco ocorra (como também é o caso de países como a Inglaterra, França e Alemanha, segundo PROVERBS et al. 1999), nos canteiros de obras brasileiros trata-se de uma prática bastante comum, principalmente em cidades situadas distantes de grandes centros, e, por conseguinte, de empresas especializadas em fornecer o aço beneficiado.

Trata-se de uma operação que requer cuidados especiais, haja vista, principalmente, os riscos implícitos a que estão sujeitos os operários designados para a tarefa. Na escolha do sistema de corte das barras adotado pela obra (tipos, quantidades e disposição dos equipamentos de corte) devem-se considerar os materiais que serão trabalhados e o volume de serviço especificado, ponderando os custos associados aos equipamentos e sua disponibilidade no mercado.

A precisão do corte é uma das condições para que a peça assuma a configuração prevista no detalhamento e depende, significativamente, da habilidade e dos cuidados tomados pelo operário responsável por conduzir a operação. Numa equipe de armadores a realização do corte é geralmente desenvolvida por operários especificamente treinados para operar os equipamentos que irão efetuar o corte das barras. Normalmente estes operários só trabalham nesta operação. Junto ao equipamento de corte deve constar a identificação pessoal de armadores habilitados para a operar os equipamentos.

Os equipamentos de corte são posicionados numa bancada, denominada "bancada de corte", que deve estar, preferencialmente, posicionada num local próximo à baia de aço, 
de maneira que um armador consiga, com um mínimo esforço, trazer as barras para a bancada. A bancada de corte representa uma das partes de uma central de armação ${ }^{43}$.

As bancadas de corte utilizadas nas obras (Figura 2.59) são, costumeiramente, confeccionadas pelos próprios armadores. Normalmente, uma bancada de corte tem comprimento total de $14 \mathrm{~m}$ e largura de $0,80 \mathrm{~m}$, com altura de $1,05 \mathrm{~m}$ (NR 18). O tabuleiro é confeccionado com tábuas de madeira. Os cavaletes que sustentam o tablado podem ser executados com pontaletes de madeira. O equipamento de corte é disposto na parte central da bancada. Quando a bancada é posicionada em local desprotegido, faz-se um abrigo para que equipamento e operador fiquem protegidos das intempéries. Tal abrigo tem aproximadamente $(2 \times 2) \mathrm{m}^{2}$, sendo sua estrutura de madeira e cobertura com material resistente. MUTHER (1986) e SOUZA (1983) trazem maiores detalhes sobre o dimensionamento das bancadas de corte.
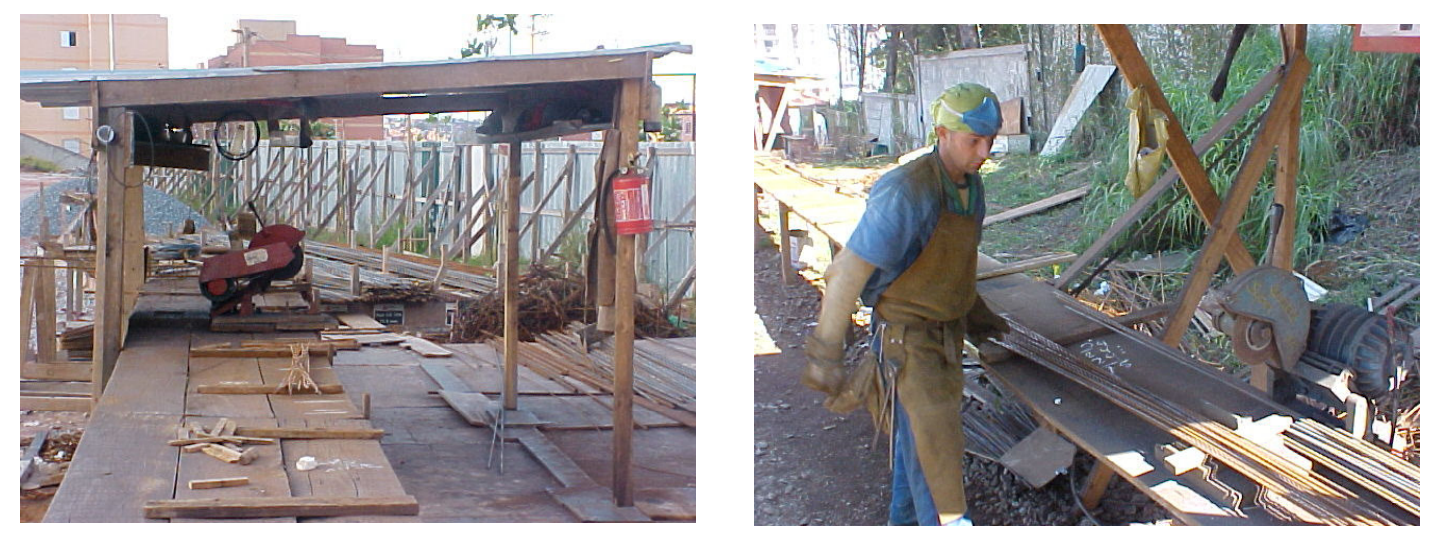

Figura 2.59 - Exemplos de bancadas de corte de barras de aço

Os equipamentos e ferramentas de corte, mais comumente utilizados, são de três tipos, classificados segundo a forma com que são acionados, conforme apresentados a seguir:

- manuais: utilizados geralmente em obras com pouco volume de serviço e/ou como apoio, principalmente durante o posicionamento das armaduras nas lajes (no corte, por exemplo, de posições variáveis), devido à sua mobilidade e facilidade relativa de manuseio. Os equipamentos e ferramentas mais comuns são mostrados na Tabela 2.20 .

${ }^{43}$ Central de armação é o nome dado ao espaço do canteiro de obras que concentra as operações destinadas à produção das armaduras, quais sejam, o corte e dobra das barras e a pré-montagem das armaduras. 
Tabela 2.20 - Principais equipamentos manuais de corte de barras de aço utilizados nos canteiros de obras.

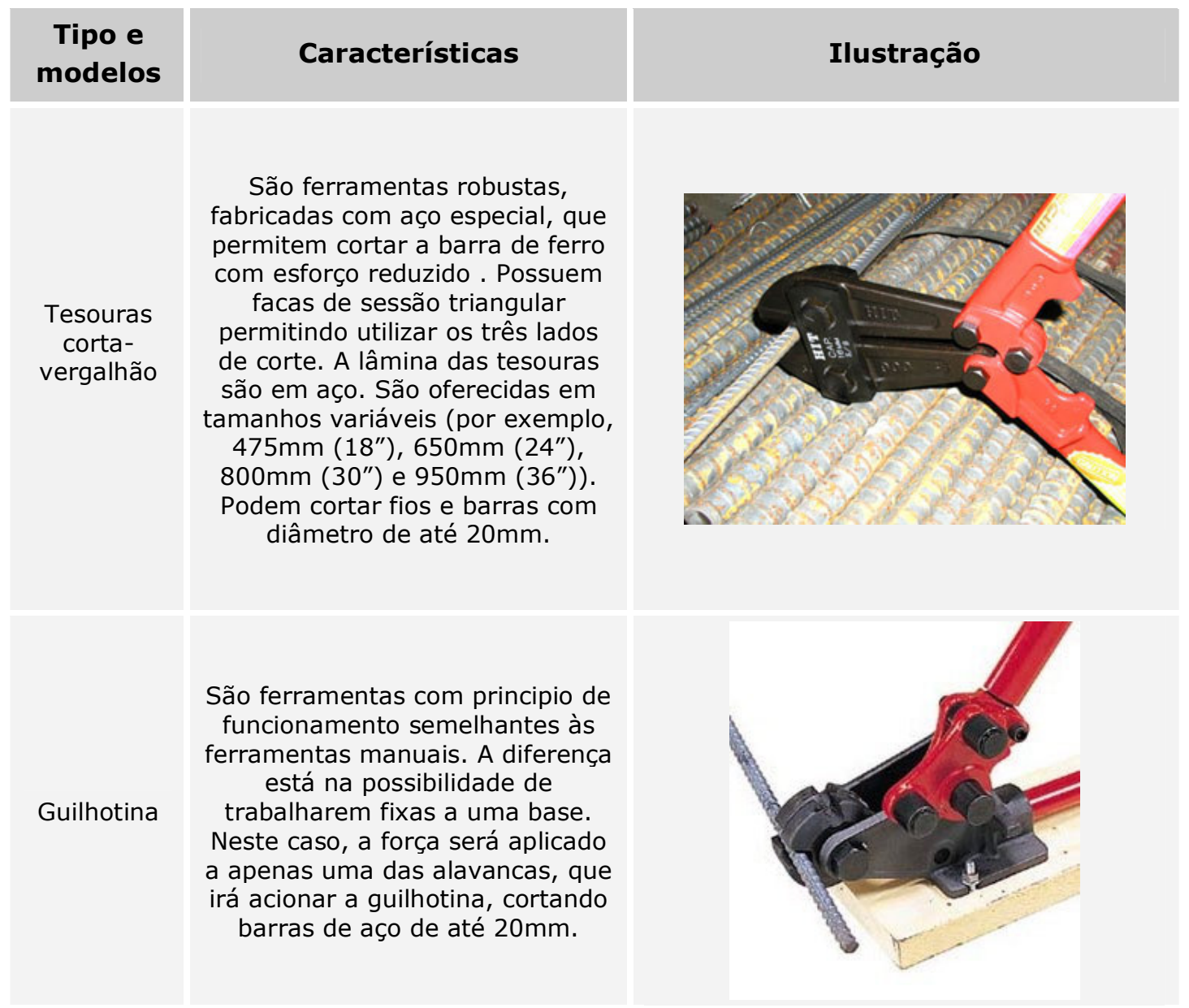

- elétricos: utilizados em obras com volume de serviço significativo, tratam-se dos equipamentos mais comumente encontrados nas obras. O principal deles é a "policorte". A Policorte, como é costumeiramente chamada nas obras, é uma serra com motor elétrico. Uma corrente, acoplada ao motor, faz girar um pino no qual é preso um disco para o corte. Através de um braço de alavanca, o operador abaixa e suspende o disco, colocando-o em contato com as barras para efetuar o corte das mesmas. A policorte permite o corte de várias barras de uma só vez, o que a torna bem mais produtiva quando comparada com os equipamentos manuais. Não tem restrições quanto ao diâmetro das barras a serem cortadas (quanto maior o diâmetro da barras, uma menor quantidade de barras será cortada de uma só vez). Vale mencionar, que o consumo de disco é alto para esta operação (um disco tem uma vida útil de duas horas, em média, trabalhando sem parar). Características deste e de outros equipamentos elétricos podem ser vistas na Tabela 2.21. 
Tabela 2.21 - Caracterização dos principais equipamentos elétricos de corte de barras de aço utilizados nos canteiros de obras.

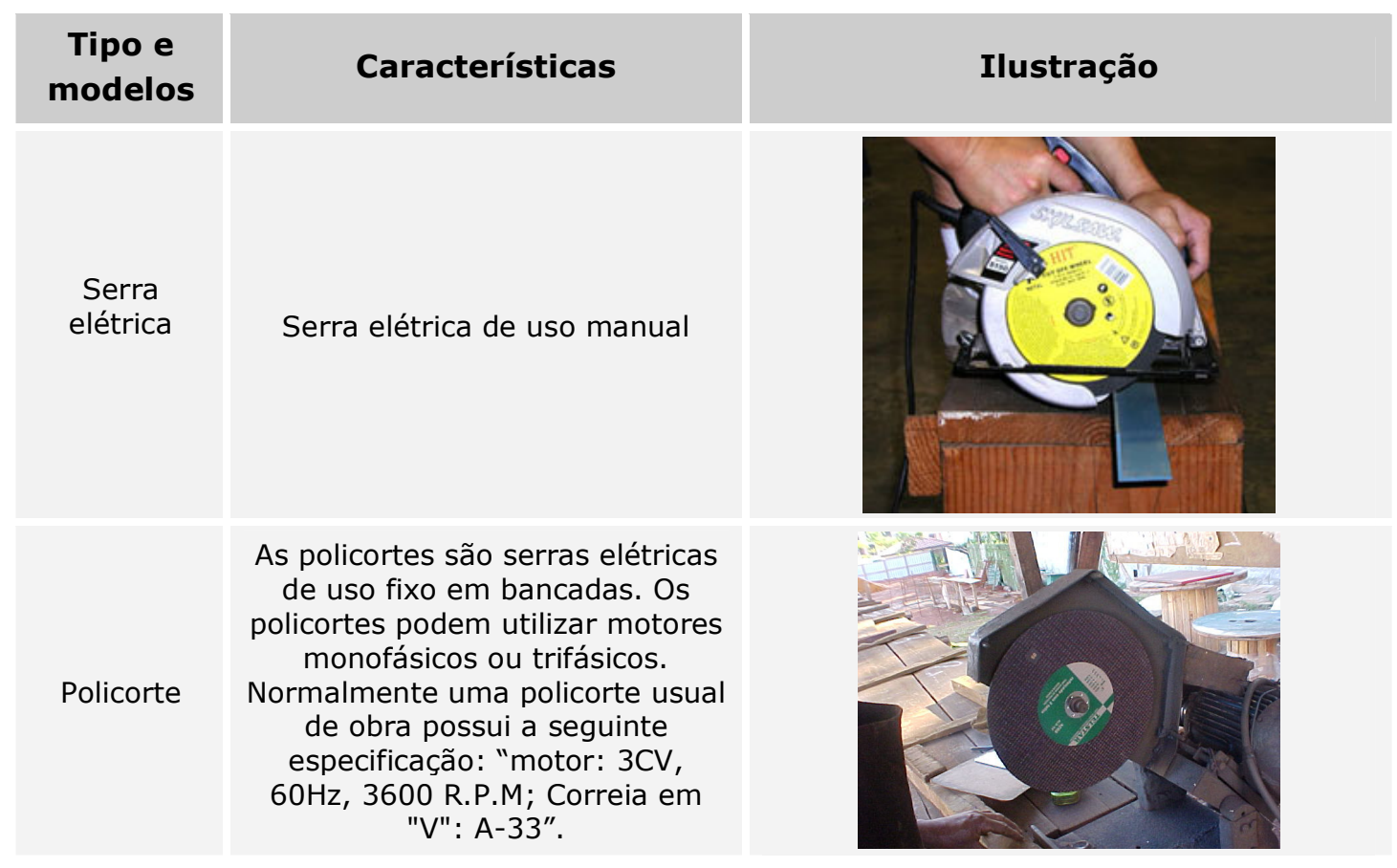

- hidráulicos: utilizados mais freqüentemente em obras com maiores volumes de serviço, tratam-se de equipamentos especificamente projetados para o corte de barras de aço. São mais eficientes e oferecem mais segurança ao operador, durante sua operação, quando comparados com os equipamentos elétricos. Seu uso é restrito devido aos custos mais elevados de compra e/ou locação do equipamento quando comparados à policorte, por exemplo. Outras características destes equipamentos podem ser vistas na Tabela 2.22. 
Tabela 2.22 - Caracterização dos principais equipamentos eletro-hidráulicos de corte de barras de aço utilizados nos canteiros de obras.

\begin{tabular}{|c|c|c|}
\hline $\begin{array}{c}\text { Tipo e } \\
\text { modelos }\end{array}$ & Características & Ilustração \\
\hline \multirow[b]{2}{*}{ Portáteis } & $\begin{array}{l}\text { Equipamentos compactos } \\
\text { Não tem restrições quanto à } \\
\text { movimentação no canteiro de obras, } \\
\text { possibilitando o corte das barras, até } \\
\text { mesmo, de armaduras já montadas e } \\
\text { posicionadas. Possibilitam corte mais } \\
\text { rápidos e seguros que os equipamentos } \\
\text { elétricos como as serras manuais, } \\
\text { cortando barras com até } 16 \mathrm{~mm} \text {. }\end{array}$ & \\
\hline & $\begin{array}{c}\text { Equipamentos compactos de bancada } \\
\text { São transportados por todo o canteiro } \\
\text { de obras, porém são operados sobre } \\
\text { bancadas. São capazes de cortar barras } \\
\text { de até } 25 \mathrm{~mm} \text {. O sistema de corte se } \\
\text { encontra na lateral do equipamento, } \\
\text { sendo o processo realizado por dentes } \\
\text { de aço que, quando acionados, } \\
\text { estriccionam a barra, cortando-a. Na } \\
\text { parte superior existe uma mesa para o } \\
\text { dobramento das barras. Ambas as } \\
\text { operações podem ser acionadas por } \\
\text { pedais. }\end{array}$ & \\
\hline $\begin{array}{l}\text { Fixos em } \\
\text { bancadas }\end{array}$ & $\begin{array}{l}\text { Equipamento de bancada } \\
\text { Possuem grande robustez, baixo custo } \\
\text { de manutenção e acionamento de corte } \\
\text { simples (através de pedais). Podem ser } \\
\text { encontrados em diferentes tamanhos, } \\
\text { possibilitando cortar barras de todos os } \\
\text { diâmetros comerciais utilizados pela } \\
\text { Construção Civil. }\end{array}$ & \\
\hline
\end{tabular}

A operação de corte das barras de aço deve seguir as informações contidas no projeto de detalhamento das armaduras. Porém, as informações necessárias para esta operação (como o comprimento unitário em que cada barra deverá ser cortada), que costumam constar nos projetos (Figura 2.60), não consideram os "alongamentos" das barras que se dão no momento em que estas são dobradas. 


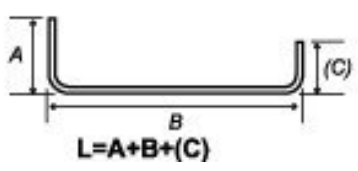

Figura 2.60 - Exemplo da composição do valor do comprimento unitário das peças que constam nos PDA

Na Figura 2.61, por exemplo, a peça "T1", possui duas dobras a serem feitas na suas extremidades. Dessa forma, a peça é representada por três segmentos, de 50, 260 e $20 \mathrm{~cm}$, respectivamente, que, somados, totalizam o comprimento total " $\mathrm{C}^{\prime}$, de $330 \mathrm{~cm}$. É este mesmo valor de comprimento que consta na tabela resumo de aço, mostrada (apenas um trecho) na Figura 2.62. Portanto, o armador que seguir as informações deste projeto, cortará uma barra (diâmetro da barra de $16 \mathrm{~mm}$ ) com $330 \mathrm{~cm}$ para a confecção da peça "T1". Nas obras, geralmente, os armadores mais capacitados sabem que é preciso que se faça um desconto ${ }^{44}$ no valor do comprimento da barra a ser cortada. Acabam eles mesmos, fazendo as contas (empiricamente) e estipulando os valores dos descontos, na maioria das vezes sem os critérios estabelecidos em norma.

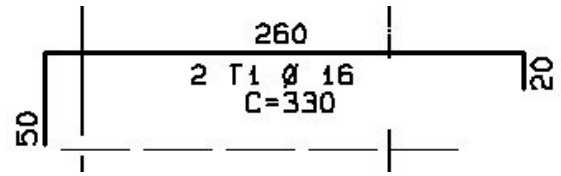

Figura 2.61 - Detalhe de peça que consta nos PDA

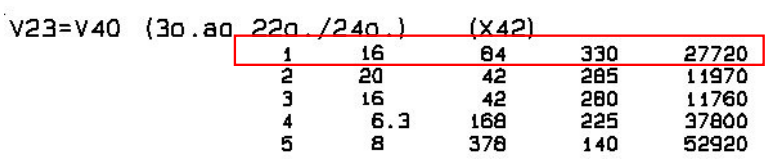

Figura 2.62 - Valores de comprimentos das peças disponibilizados nas tabelas resumo

A norma britânica (BS8666:2000) define, para cada um dos 14 formatos padrões que estabelece, os valores dos "comprimentos de corte" das barras, para que a peça dobrada atinja a conformação determinada pelo projeto de detalhamento.

No caso da peça exemplificada na Figura 2.63, seguindo-se as especificações prescritas na BS8666:200045, o comprimento com que a barra (ou segmento de barra) deve ser cortada, para garantir a conformação (formato e dimensões) prescrita na Figura 2.61, é dado pela equação mostrada na Figura 2.63, onde "r" é o raio do círculo inscrito na dobra (Figura 2.64) e "d" é o diâmetro da barra. O comprimento de corte, neste caso, seria, portanto, de $323,6 \mathrm{~cm}$.

${ }^{44}$ Os diâmetros dos pinos de dobramento, que determinam o raio do círculo "inscrito na dobra", variam em função do tipo de gancho, do diâmetro da barra, da classe do aço e do tipo da peça (por exemplo, tem-se uma dobra para estribo ou para peças longitudinais). É de posse deste conjunto de informações que se deve determinar o valor a ser descontado no comprimento de corte da barra.

${ }^{45}$ A norma britânica (BS8666:2000) estabelece um diâmetro mínimo de dobramento, para situação ilustrada na Figura 2.64 de $64 \mathrm{~mm}(r=32 \mathrm{~mm})$. Para a NBR 6118:2003 este diâmetro é de $80 \mathrm{~mm}$ (raio $=40 \mathrm{~mm})$. 


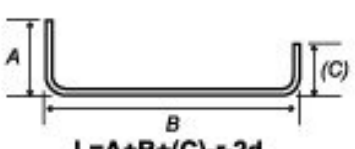

$L=A+B+(C)-r-2 d$

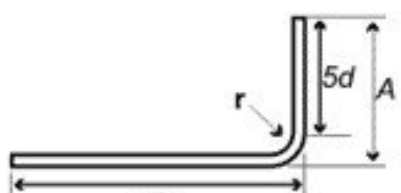

(B)

Figura 2.63 - Equação para determinação do "comprimento de corte"

Figura 2.64 - Identificação do raio " $r$ "

No Brasil, no que se refere ao PCPA, o projeto de detalhamento das armaduras é a única fonte de informação, cumprindo, ao mesmo tempo, o papel de projeto de produto (a que, de fato, se destina) e de projeto para a produção. Por ser único, acaba não sendo o mais apropriado a todas as diferentes destinações que tem. Por exemplo, ao servir como orientação aos armadores no desenvolvimento das operações do processo de produção (neste caso especificamente à operação de corte), leva os mestres/encarregados de armação a gastarem um tempo significativo na interpretação e posterior transcrição das informações em ordens de corte.

A ordem de corte trata-se de uma listagem simplificada das peças que tem a função de orientar o armador, responsável pelo corte, sobre como e quando as barras deverão ser cortadas. As ordens são feitas para cada porção da obra, separando-se, em listas distintas, as peças de pilares, vigas e lajes. A estas ordens, quando feitas pelo mestre ou encarregado de armação, no canteiro de obras, dá-se o nome de "rascunho" (Figura 2.65). Os eventuais decréscimos das barras, comentados anteriormente, podem, eventualmente, ser calculados pelo mestre/encarregado e estar contemplados nos rascunhos.

Em se tratando ainda dos PDA representados convencionalmente, as ordens de corte podem ser melhor desenvolvidas, contemplando, para tanto, aspectos ligados à racionalização da operação (corte ordenado de maneira a que todas as posições idênticas sejam cortadas de uma só vez e do material (o corte das barras é ordenado em ordem decrescente de comprimento das peças, de maneira a que as pontas que sobram possam ser melhor aproveitadas). Nestes casos, apareceria um outro profissional, que teria por incumbência elaborar a ordem de corte, usando recursos como softwares específicos (ROMMINGER, 2003) e/ou planilhas eletrônicas, por exemplo. Neste caso, esta ordem de corte pode ser denominada de "plano de corte" (Figura 2.66). 


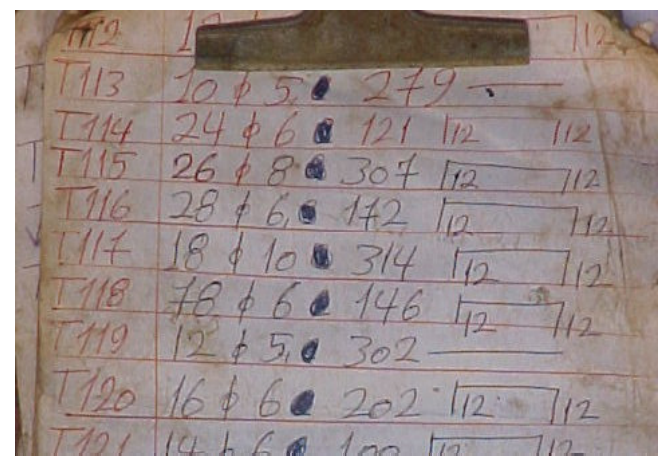

\begin{tabular}{|c|c|c|c|}
\hline posição & diametro & compr & quant \\
\hline 17 & 25 & 375 & 36 \\
\hline 18 & 25 & 278 & 4 \\
\hline 1 & 20 & 355 & 488 \\
\hline 4 & 20 & 278 & 76 \\
\hline 23 & 16 & 345 & 100 \\
\hline 9 & 12,5 & 335 & 24 \\
\hline 27 & 8 & 80 & 14 \\
\hline 28 & 6,3 & var & 8 \\
\hline 19 & 6,3 & 338 & 25 \\
\hline 20 & 6.3 & 28 & 112 \\
\hline
\end{tabular}

Figura 2.65 - Exemplo de "rascunho" para Figura 2.66 - Exemplo de plano de corte corte de barras

A padronização de formatos das peças (na Inglaterra pela norma BS8666:2000; nos Estados Unidos pelo ACI 315:96) permitiu que alguns países, propusessem formas de representação de detalhamento e tabelas de armaduras mais "esquemáticas", favorecendo significativamente as operações de produção, principalmente o corte e a dobra das peças. No Brasil, uma proposta de representação de detalhamento e tabelas de armaduras, semelhante à prescrita pelas normas dos países supracitados, foi proposta no projeto de revisão da NB-16, e chegou a ser votada no início da década de 1980, mas acabou não sendo sancionada, segundo relatou ${ }^{46}$ um dos projetistas estruturais que participou deste trabalho.

Tanto no projeto de revisão da norma NB-16, de 1980, como nas normas ACI 315:96, BS8666:2000 etc, o formato proposto para a elaboração das tabelas das armaduras contribui, dentre outros aspectos, para a racionalização das operações de corte e dobra, podendo eliminar a necessidade da elaboração das ordens de corte pela obra.

Há situações de projeto (como, por exemplo, o caso da armadura de lajes de marquises e piscinas com formatos não retangulares) que levam à necessidade de peças com comprimentos variáveis. Neste caso, o projeto de detalhamento das armaduras costuma trazer apenas as medidas das peças das extremidades (em caso de variações lineares ${ }^{47}$ ). Para se obter a medida das peças intermediárias é preciso que se calcule a variação entre elas, devendo-se proceder da seguinte forma: i) determina-se a diferença entre a peça de maior e menor tamanho; ii) determina-se o valor da "medida da variação", que é o valor da diferença encontrada dividido pelo "número de peça menos uma" do intervalo considerado. Assim, a medida da variação, somada à medida da menor peça, dá a medida com que deve ser cortada a segunda peça. A medida de cada peça seguinte é, portanto, determinada a partir da soma da medida de variação com a medida da peça anterior.

\footnotetext{
${ }^{46} \mathrm{O}$ relato foi feito ao autor pelo projetista Ricardo França durante entrevista realizada em julho de 2004.

47 Quando a variação da fôrma não é linear, o projeto de detalhamento das armaduras não traz medidas. Nestes casos, o armador deve fazer triangulações, aproximando as formas circulares de triângulos para que consiga determinar as medidas das peças.
} 


\subsubsection{4}

A dobra das barras de aço no canteiro de obras

"Dobrar ferros é uma operação que consiste em moldar ferros retos nas medidas e ângulos, conforme desenho de armação". (CNI, 1980)

A operação do dobramento das barras de aço, quando realizada no canteiro de obras, requer uma atenção especial, em função da preocupação em se respeitarem as características do aço empregado, impedindo, desta forma, que ocorram fissurações do mesmo na parte tracionada.

Daí a necessidade de se considerarem, na operação de dobramento, as prescrições da norma NBR 6118:2003, que estabelece o diâmetro correto do pino de dobramento usado nas bancadas de dobra (que variam em função do diâmetro e da classe do aço).

Tais indicações da referida norma visam a obtenção de um produto final (aço dobrado) seguro, prevenindo quebra ou fragilidade na região da dobra e não expondo a construção a riscos. BELGO ARCELOR (2004b)

O dobramento, em obra, é realizado, normalmente, em uma mesa de dobra, onde são fixados os pinos de dobramento conforme mostra a Figura 2.67. Os pinos são de dois tipos: i) pinos suporte: servem de apoio quando se faz força para dobrar a barra e impedem que ela escape da mesa; ii) pino principal (para o qual a norma NBR 6118:2003 estabelece os diâmetros): é o ponto onde se faz o dobramento da barra (o diâmetro interno da dobra será aproximadamente igual ao diâmetro do pino).

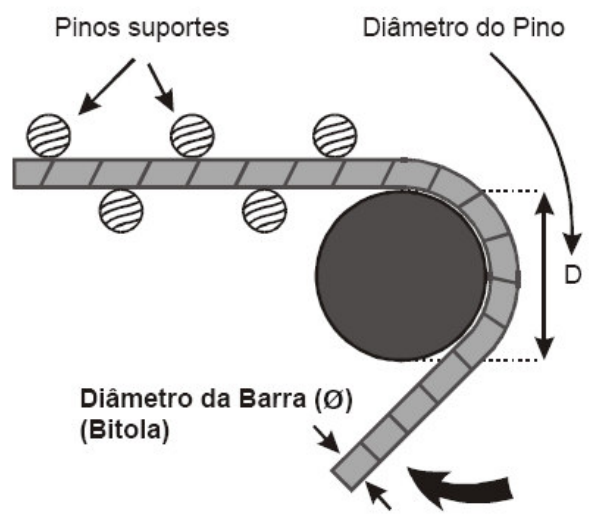

Figura 2.67 - Desenho esquemático de mesa de dobramento. Fonte: BELGO, 2003b

Segundo o engenheiro J.L. Andrade (BELGO, 2004b), é comum encontrar nos canteiros de obras brasileiros bancadas de dobras que usam pinos de $10 \mathrm{~mm}\left(3 / 8^{\prime \prime}\right)$ ou $12,5 \mathrm{~mm}$ $\left(1 / 2^{\prime \prime}\right)$ para dobrar todos os diâmetros de barras (Figura 2.68). Vale dizer que a utilização de pinos de mesmo diâmetro da barra a ser dobrada, ou ainda, de diâmetros diferentes daqueles especificados por norma (NBR 6118:2003) são, também, más práticas comumente observadas nos canteiros de obras brasileiros, e que precisam ser evitadas (Figura 2.69). 


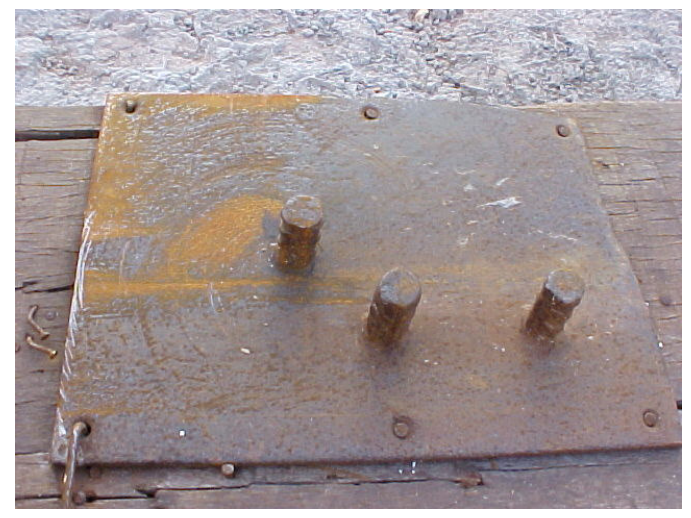

Figura 2.68 - Pinos de dobramento soldados a uma chapa metálica

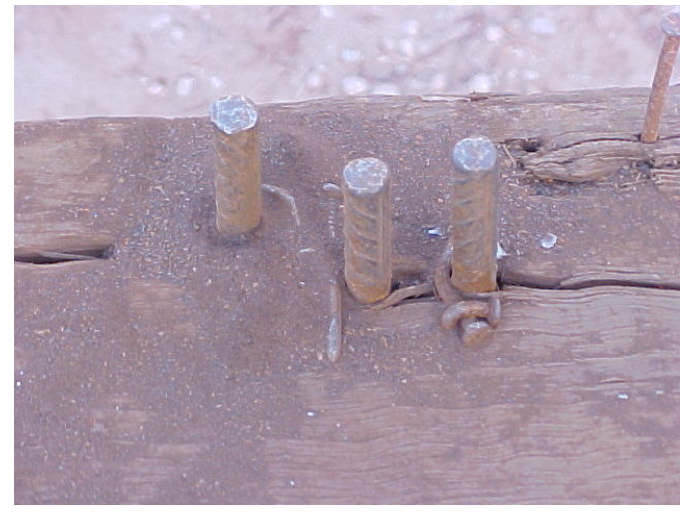

Figura 2.69 - Pinos de dobramento fixados diretamente na bancada

O autor supracitado aponta alguns outros cuidados que o armador deve ter ao executar o dobramento, listados a seguir:

- deixar uma folga entre o pino principal e os pinos suporte, evitando amassar e estrangular o vergalhão durante a execução da dobra;

- definir diâmetros dos pinos suporte (Figura 2.67) que não selam muito finos em relação ao diâmetro das barras do aço a serem dobradas. Como as nervuras do CA50 são altas, estas podem se "agarrar" nos pinos suporte, quando finos, e ocorrer um travamento ao fazer o dobramento; como a barra não desliza, pode-se provocar a quebra ou o aparecimento de trincas ou fissuras na mesma. Isto acontece mesmo quando se utiliza o pino de dobramento correto (NBR 6118:2003), pois se trata de um problema da operação de dobramento e não da barra de aço utilizada;

- evitar dobrar o aço logo pela manhã em regiões do país que apresentem temperaturas muito baixas (pode ocorrer quebra do material mesmo quando se utilizam pinos com diâmetros corretos); deve-se esperar o aumento da temperatura do ambiente, ou, então, dobrar o material mais vagarosamente, utilizando-se pinos de diâmetros maiores que aqueles exigidos pela norma.

As mesas, ou bancadas de dobra, utilizadas nas obras são, assim como as bancadas de corte, costumeiramente confeccionadas pelos próprios armadores. As dimensões destas bancadas, com exceção da altura (aproximadamente 1,05 m), costumam variar em função: i) dos tamanhos das barras que serão dobradas; ii) dos espaços disponíveis na central de armação; iii) das peças que serão produzidas (é comum encontrarem-se, nas obras, bancadas específicas para a dobra de peças como caranguejos (Figura 2.70), estribos e ganchos (Figura 2.71) etc ou podem-se utilizar, também, bancadas únicas, em que são dobrados todos os tipos de peças (desde que, é claro, sejam usados pinos com diâmetros adequados a cada caso)); iv) do sistema de dobramento utilizado: manual ou com auxilio de máquinas eletro-hidráulicas. 


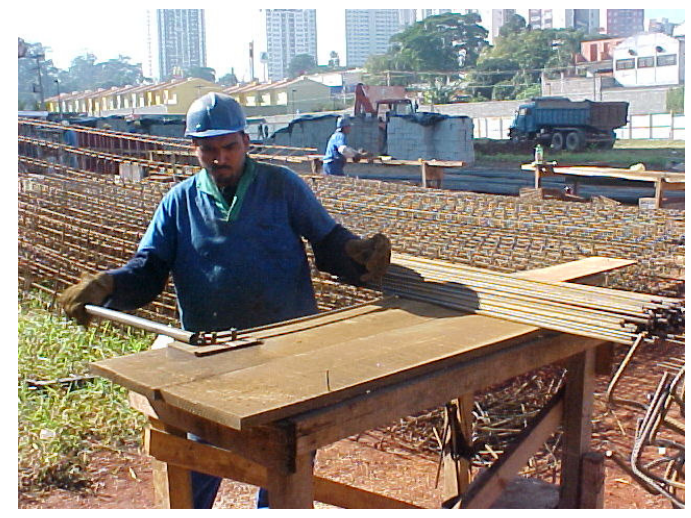

Figura 2.70 - Bancada de dobramento de caranguejos

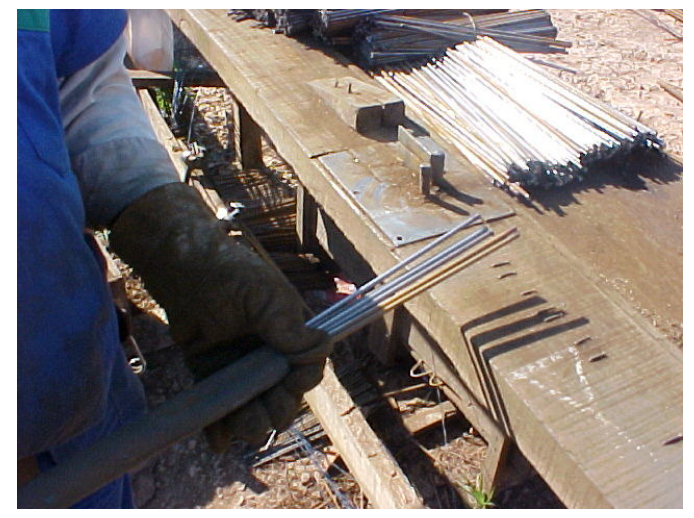

Figura 2.71 - Bancada para dobra de estribos e ganchos

O tabuleiro das bancadas de dobramento é confeccionado com tábuas de madeira. Os cavaletes que sustentam o tablado podem ser executados com pontaletes de madeira. Quando se utiliza a máquina de dobra, ela é disposta na parte central da bancada (Figura 2.72) e, neste caso, quando a bancada é posicionada em local desprotegido, faz-se um abrigo para que equipamento e operador fiquem protegidos das intempéries (Figura 2.73). Tal abrigo tem aproximadamente $(2 \times 2) \mathrm{m}^{2}$, sendo sua estrutura de madeira $\mathrm{e}$ cobertura feita com material resistente. MUTHER (1986) e SOUZA (1983) trazem maiores detalhes sobre o dimensionamento das bancadas de dobra.

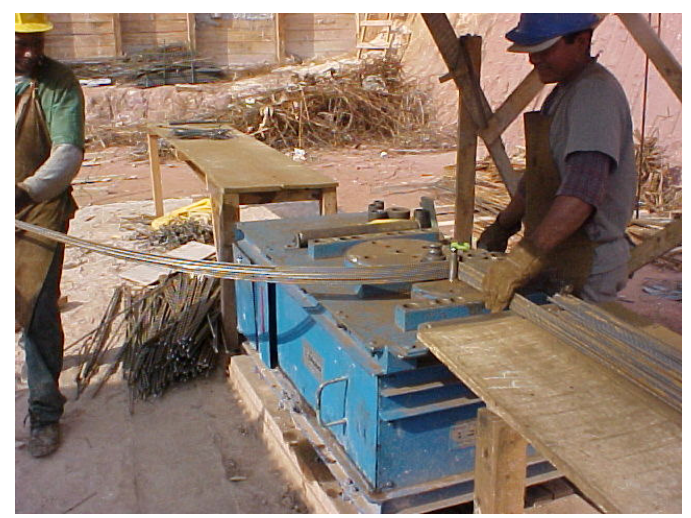

Figura 2.72 - Bancada de dobra com máquina na posição central

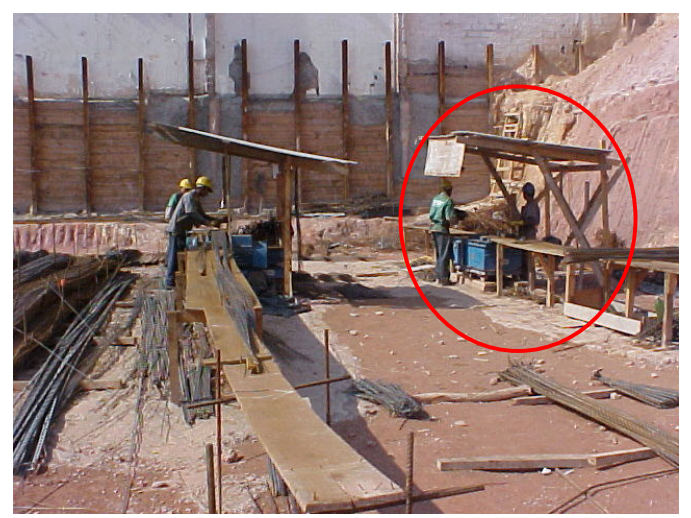

Figura 2.73 - Detalhe da proteção da máquina e operador na bancada de dobramento

Em se tratando de sistemas manuais, o dobramento das barras é feito mediante o uso de "chaves de dobra", que são ferramentas confeccionadas em aço, compostas por um cabo (alavanca de dobra), associado a uma chave, conforme ilustrado na Figura 2.74 e na Figura 2.75. Quanto maior o diâmetro das barras a serem dobradas, maiores deverão ser os braços de alavanca e chaves utilizados (Figura 2.76), reduzindo-se assim o esforço do operário (Figura 2.77). Para o dobramento dos ganchos, a chave de dobra constitui-se de um tubo de aço, com uma das extremidades "achatadas" (Figura 2.78), de forma a 
acondicionar um certo número de barras (normalmente com diâmetro de $5 \mathrm{~mm}$ ), que são dobradas de uma só vez (Figura 2.79).

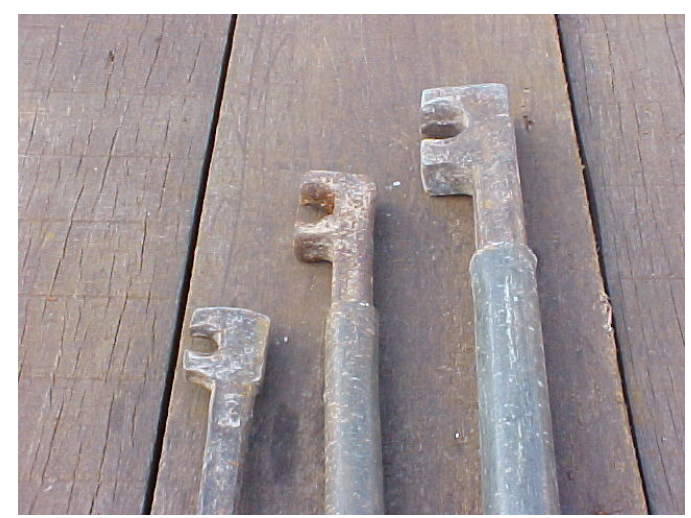

Figura 2.74 - Detalhe das chaves de dobra

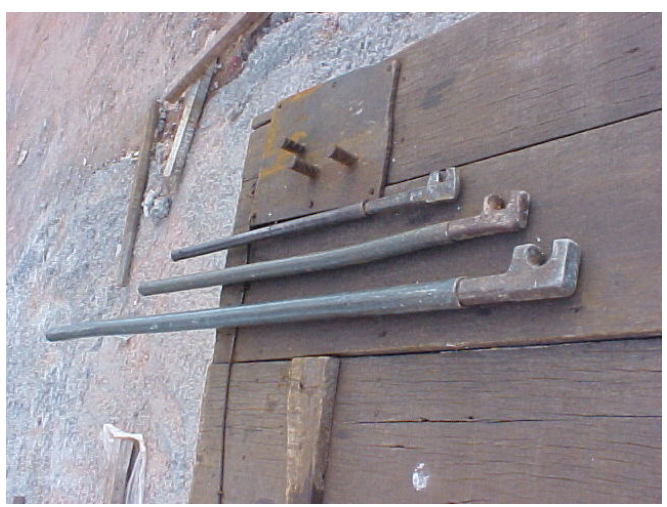

Figura 2.76 - Diferentes tamanhos de chave de dobra utilizadas pelos armadores

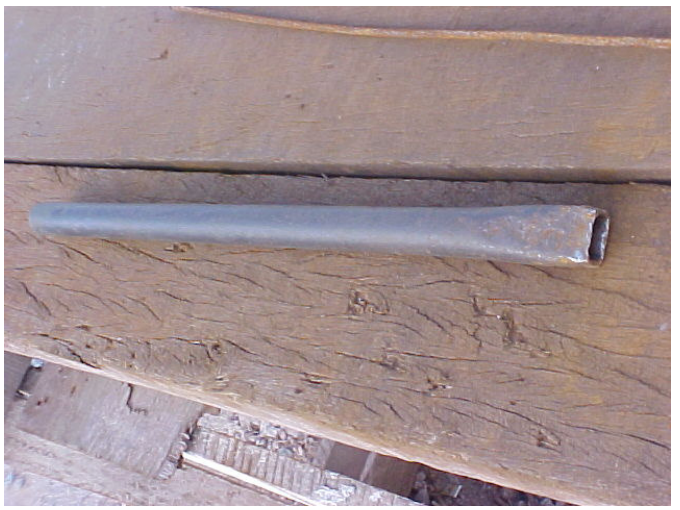

Figura 2.78 - Chave para dobra de ganchos

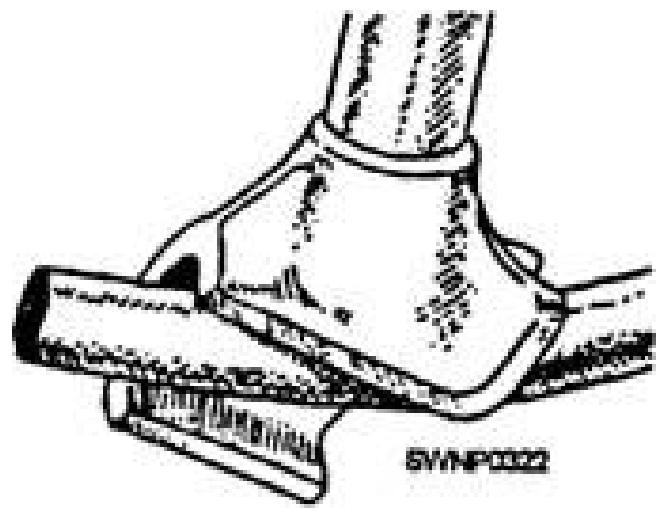

Figura 2.75 - Detalhe do dobramento fazendo o uso de chave de dobra

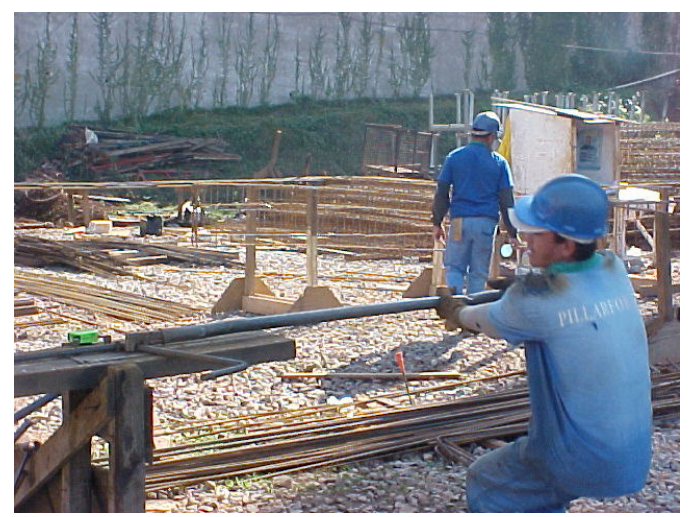

Figura 2.77 - Exemplo do uso da chave de dobra

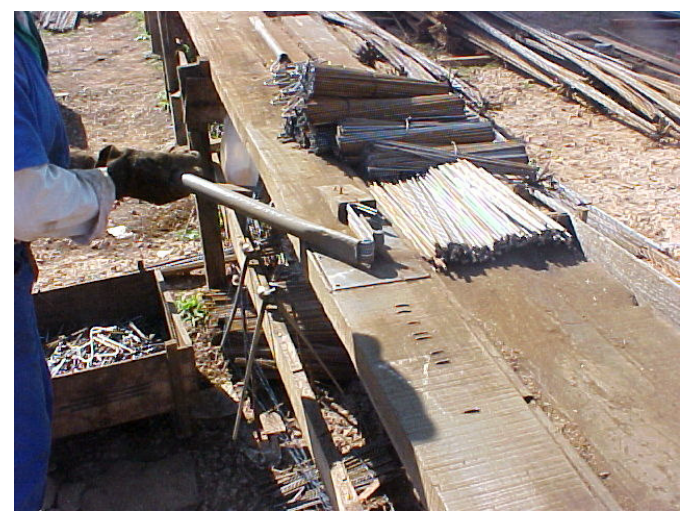

Figura 2.79 - Uso da chave para dobramento de ganchos 
A Figura 2.80 ilustra uma máquina de dobra de funcionamento manual, que traz associados, numa única peça, os pinos de dobramento, que podem ser substituídos pelo diâmetro conveniente, e o braço de alavanca. Entre as vantagens deste tipo de máquina, quando comparado às situações supracitadas (e ilustradas), está o fato de garantia de maior segurança do operário durante a operação, pelo fato da chave não "escapar" no momento da dobra, além de maior qualidade da peça a ser dobrada. Segundo dados de fornecedor ${ }^{48}$ norte-americano, a máquina de dobra ilustrada na Figura 2.80 é capaz de dobrar, de uma só vez, até 7 barras de $20 \mathrm{~mm}$ de diâmetro (preço no mercado norteamericano desta máquina é de US\$630,00).

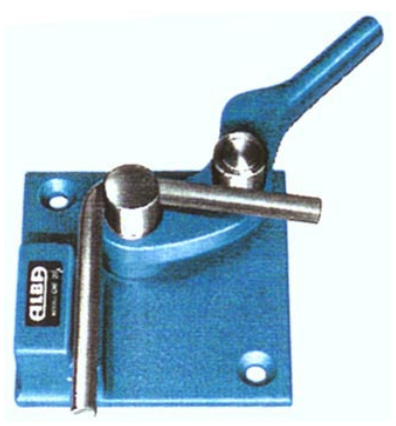

Figura 2.80 - Máquina de dobramento manual.

Em se tratando de sistemas auxiliados por máquinas eletro-hidráulicas, o esforço necessário para o dobramento não provêm mais do armador, e sim do equipamento. Não se elimina, porém, o trabalho do armador, que continua o responsável direto pela qualidade das peças produzidas, em razão de ser ele quem: i) determina os pinos que serão usados na máquina (em função dos diâmetros a serem dobrados (Figura 2.81)); ii) faz as marcações na bancada (Figura 2.82), através das quais será dada a conformação, prescrita no projeto, à peça (dimensões e formatos).

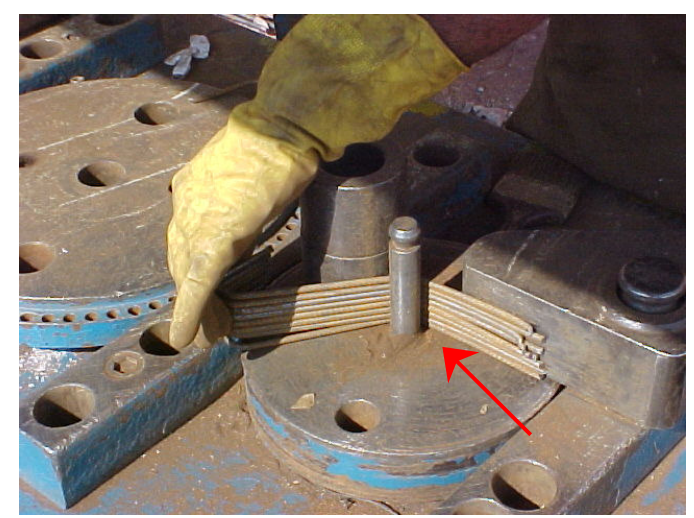

Figura 2.81 - Mesa central da máquina de obra com pino para dobramento

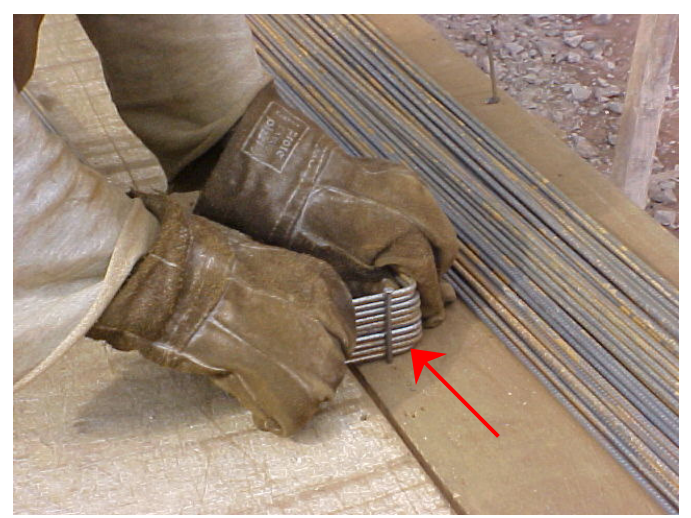

Figura 2.82 - Marcas (com prego) na bancada de dobramento

48 Maiores informações sobre o fornecedor consultado podem ser obtidas acessando o seguinte endereço eletrônico: www.constructioncomplete.com 
As máquinas hidráulicas são geralmente locadas, pelos subempreiteiros, em empresas especializadas em equipamentos para a Construção Civil. Os subempreiteiros costumam utilizar tais máquinas em obras com grande volume de aço a ser beneficiado em curtos espaços de tempo, ou, ainda, em situações em que se tenha que dobrar significativa quantidade de barras com diâmetros mais elevados (maiores que $16 \mathrm{~mm}$ ). As máquinas, desde que operadas por funcionários capacitados, são capazes de melhorar a produtividade da operação de dobramento e a qualidade das peças produzidas. Existe uma grande variabilidade de máquinas hidráulicas no mercado (desde máquinas portáteis até máquinas de grande porte), capazes de dobrar todos os diâmetros comerciais de barras de aço. Para um mesmo tipo de máquina, podem existir diferentes modelos, que variam em função: i) dos diâmetros máximos trabalhados; ii) dos ângulos máximos de dobras; iii) do número de barras dobradas por operação; iv) da velocidade de dobra por operação de dobramento.

No Brasil, a variabilidade de máquinas disponíveis para locação é pequena ${ }^{49}$. A opção pelas empresas construtoras em comprarem as peças fabricadas é uma das razões que tem desestimulado a aquisição de máquinas mais versáteis e modernas, seja pelas empresas de locação, seja pelas subempreiteiras que, quando consideram demais fatores intrínsecos à Construção Civil, como a sazonalidade das obras, dificilmente investem nestes equipamentos.

A Figura 2.83 ilustra um modelo de máquina de dobra compacta vendida no mercado americano. Trata-se de um instrumento de dimensões reduzidas no qual o mecanismo de funcionamento é elétrico. O dobramento das barras é realizado em uma canaleta, na parte superior do equipamento, que possui roldanas, ativadas pela eletricidade. Estas roldanas arrastam e conformam o aço, sendo que o trabalhador deve apenas direcionar, com suas mãos, os feixes de aço. Há ainda, na mesma máquina, um sistema de corte que se encontra na lateral do equipamento, sendo o processo realizado por dentes de aço que, quando acionados, estriccionam a barra, cortando-a. Dentre os modelos disponíveis para o equipamento ilustrado (Figura 2.83), tem-se, por exemplo, o "29RB19", que: i) dobra até 6 barras de até $20 \mathrm{~mm}$; ii) funciona em $115 \mathrm{~V}$; iii) realiza dobras com ângulos de até $115^{\circ}$; iv) possui uma velocidade de dobra de 3,5 segundos por operação de dobra.
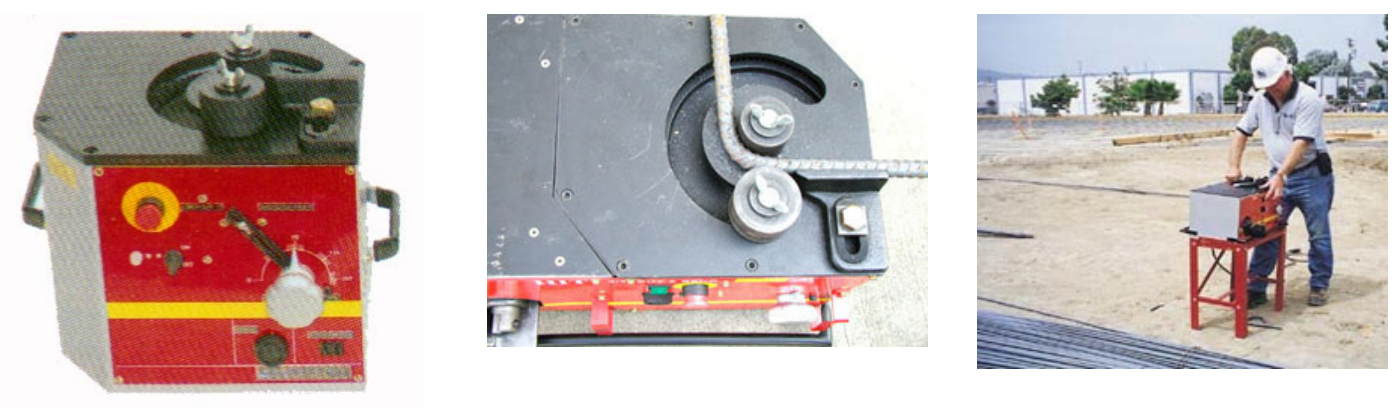

Figura 2.83 - Máquina de dobra elétrica

49 As máquinas eletro-hidráulicas que existem hoje no mercado, foram, em grande parte, importadas para atender às grandes obras existentes no país num passado recente (hidroelétricas, por exemplo). 
A operação de dobra das barras de aço deve seguir as informações contidas no projeto de detalhamento das armaduras. Os principais tipos de dobras feitos nas obras são aqueles que darão origem aos ganchos (a $45^{\circ}, 90^{\circ}$ e $180^{\circ}$, destinados à ancoragem das barras longitudinais) e às peças transversais, tais como estribos e ganchinhos. Há ainda - "caranguejo", que se trata de uma peça especial e, embora não requeira grandes precisões nas angulações das dobras, exige muito esforço do armador, em virtude do número de dobras por peças (4 dobras, em dois planos distintos) e os diâmetros das barras usadas para sua confecção (desejável que sejam superiores a $10 \mathrm{~mm}$ ).

O armador, mais que conhecer os diâmetros dos pinos para efetuar cada tipo de dobra, precisa ser orientado corretamente pelo projeto, que deve especificar claramente, por exemplo, o tipo de gancho requerido e, no caso de peças como "cavaletes", apontar os ângulos de dobramento.

Face ao grande número de peças por projeto de detalhamento, que variam não apenas em dimensões, mas também em formatos, a operação de dobramento exige que o armador dedique grande parte do tempo à realização das "marcações na bancada". Tratam-se das referências que permitem que o armador dobre as peças segundo as prescrições do projeto (e respeite as tolerâncias dimensionais estabelecidas pela norma).

As informações sobre as dobras a serem efetuadas costumam ser passadas ao armador de duas diferentes formas: i) através de plaquetas, que acompanham os feixes de barras já cortadas (Figura 2.84 e Figura 2.85); ii) através de rascunhos, semelhantes aos rascunhos elaborados para o corte das barras (costumam ser os mesmos rascunhos). Em ambas as situações, constam o desenho da peça, com as dobras a serem feitas e as respectivas dimensões. Em caso de dúvidas, os armadores recorrem ao encarregado de armação, que geralmente é o responsável pela elaboração das plaquetas e/ou rascunhos.

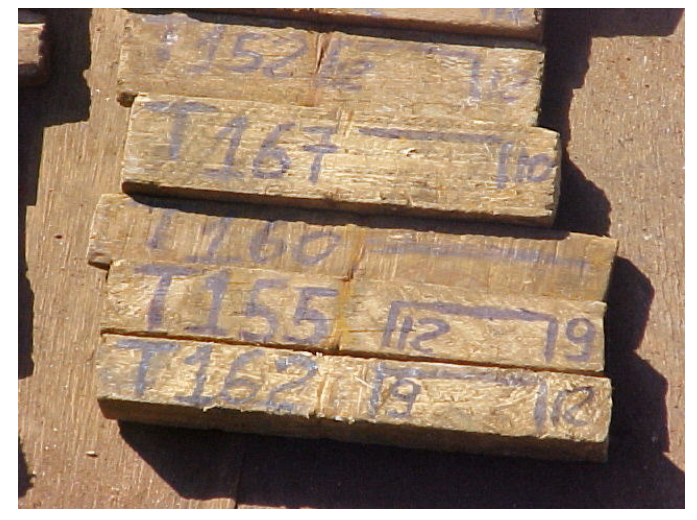

Figura 2.84 - Plaquetas com as informações para o dobramento

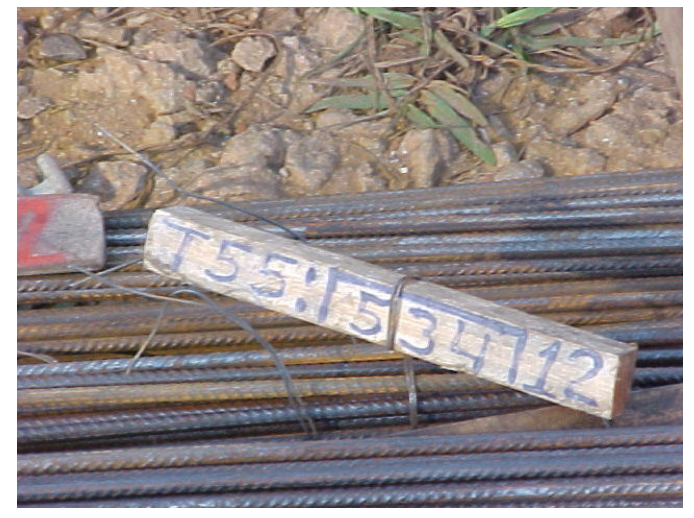

Figura 2.85 - Feixes de barras com a plaqueta identificando o dobramento

A operação de dobramento manual começa com a marcação, na bancada, das medidas das peças (no caso do estribo ilustrado na Figura 2.86, as medidas do gancho, largura e comprimento do mesmo). Para marcações à direita da bancada, como mostra a Figura 2.86, o "zero" do instrumento de medida (trena ou metro) deve ser colocado no centro do pino principal. A barra é colocada entre os pinos da bancada, sendo sua ponta posicionada, primeiramente na marca do "gancho"; faz-se, então, a primeira dobra (com 
auxilio da chave de dobra), formando o gancho. O passo seguinte é o de colocar o gancho na marca do comprimento; faz-se a segunda dobra. O procedimento é repetido, colocando a parte dobrada na marca da largura e, sem seguida, do comprimento novamente. Para concluir, faz-se, na ponta do estribo, o segundo gancho.

A operação de dobramento com auxílio de máquina hidráulica, assim como no dobramento manual, requer que um conjunto de medidas seja feito na bancada. No exemplo ilustrado na Figura 2.87 (em que se mostra a seqüência de micro-operações para o dobramento de um estribo) é feito uma série de marcações no conjunto "máquina+bancada" para servir de orientação ao dobramento. Concluídas as marcações (que demandam aproximadamente $70 \%$ do tempo gasto na operação de dobramento), dobram-se, com relativa facilidade as peças. Nota-se, no exemplo ilustrado na Figura 2.87 , que: i) são dobrados, de uma única vez, aproximadamente dez estribos; ii) são necessários dois operários para a execução do dobramento (o operador da máquina, que posiciona as barras junto às marcações e aciona a máquina, e o assistente, que ajuda no posicionamento das barras e conduz as peças durante o "giro" de dobramento).

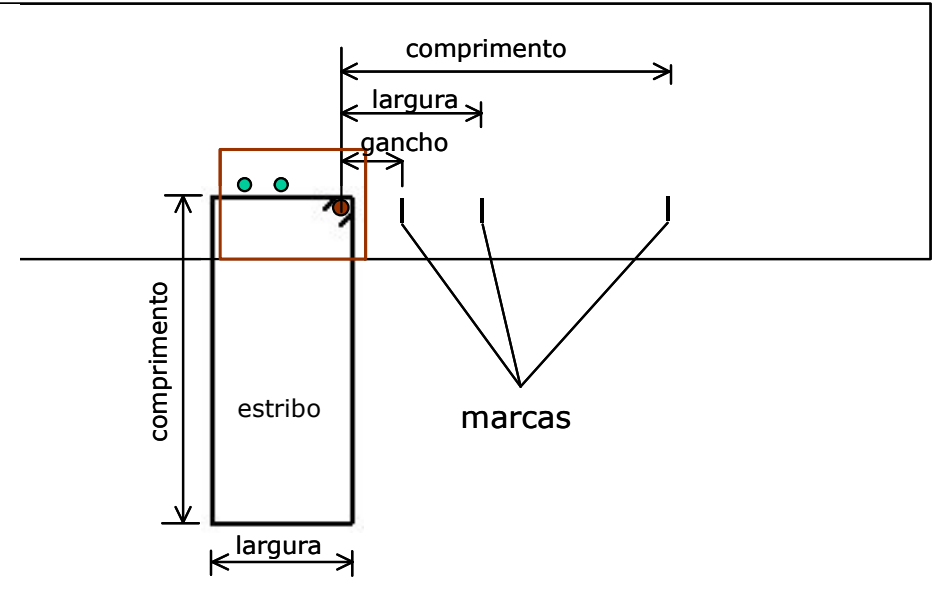

Figura 2.86 - Exemplo de marcação na bancada de dobramento 

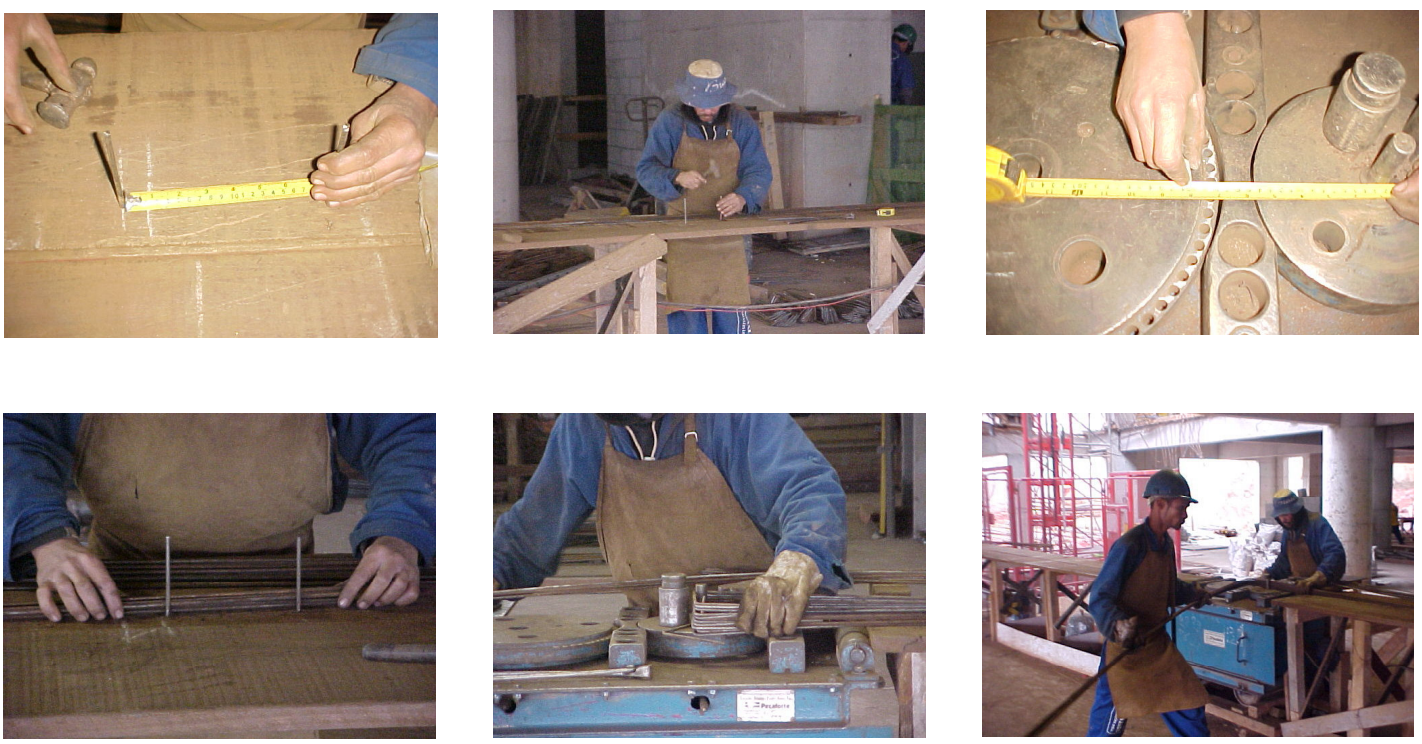

Figura 2.87 - Seqüência de dobramento de estribo com auxilio de máquina hidráulica

\subsubsection{5}

A Pré-montagem

Na pré-montagem das armaduras, as peças de um determinado elemento estrutural são unidas, seguindo-se as prescrições do projeto de detalhamento das armaduras, dando origem a gaiolas, que são posteriormente posicionadas nas fôrmas, podendo ser complementadas com demais peças ou não.

A pré-montagem das armaduras costuma ser executada em locais distintos dos canteiros de obras, porém normalmente com as seguintes particularidades, como: i) a proximidade ao local onde as peças estejam estocadas; ii) a proximidade ao equipamento de transporte vertical; iii) a proteção contra intempéries e de quedas de objetos.

No início de obra, os locais onde é feita a pré-montagem costumam ser sempre desfavoráveis, devido, por exemplo, à falta de áreas cobertas para que a operação seja desempenhada com segurança e maior comodidade (Figura 2.88). Na medida em que trechos da estrutura são liberados (retirada do escoramento "permanente" de vigas e lajes), os armadores, com a autorização da gerência da obra (que já pode ter previsto esta mudança no projeto de canteiro de obras e/ou no Programa de Condições e Meio Ambiente de Trabalho (PCMAT) transferem a operação para espaços disponíveis mais propícios, como subsolos ou trechos do térreo (preferencialmente na projeção da torre), como mostrado na Figura 2.89. 


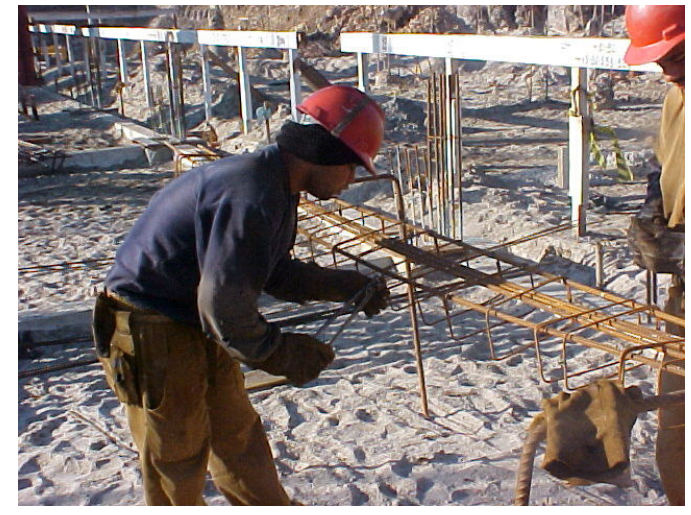

Figura 2.88 - Operação de pré-montagem em local desfavorável

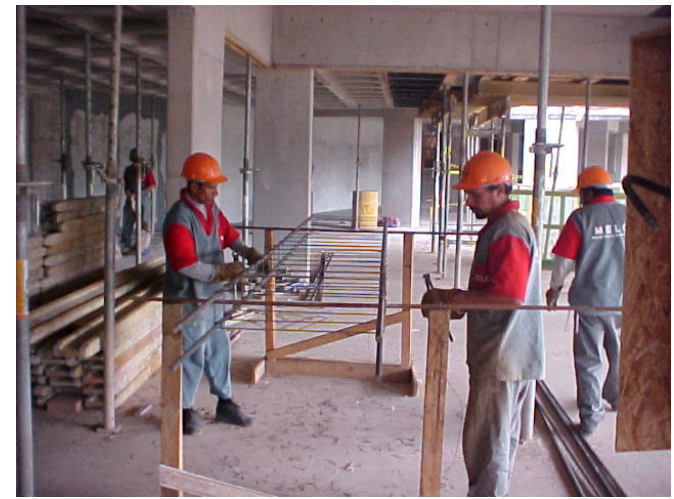

Figura 2.89 - Operação de pré-montagem em local favorável

Na pré-montagem as barras longitudinais são posicionadas (apoiadas) sobre cavaletes, espaçados na máxima distância que em que as barras não fiquem fletidas demasiadamente (Figura 2.90). Os cavaletes podem ser feitos com barras de aço, constituindo uma única peça, conforme mostrado na Figura 2.91 ou com pontaletes na estruturação e barras de aço, servindo de apoio para a gaiola, como mostrado na Figura 2.92. Esta última situação é mais favorável, pois permite uma maior mobilidade da gaiola que está sendo montada com a simples retirada das barras que a apóiam. Podem-se também compor arranjos especiais, conforme mostrado na Figura 2.93, que mostra um conjunto de cavaletes dando suporte à pré-montagem da armadura de uma escada.

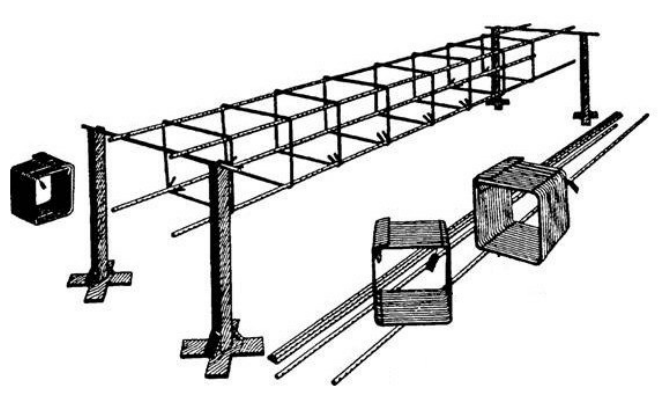

Figura 2.90 - Exemplo de estrutura para pré-montagem de armaduras

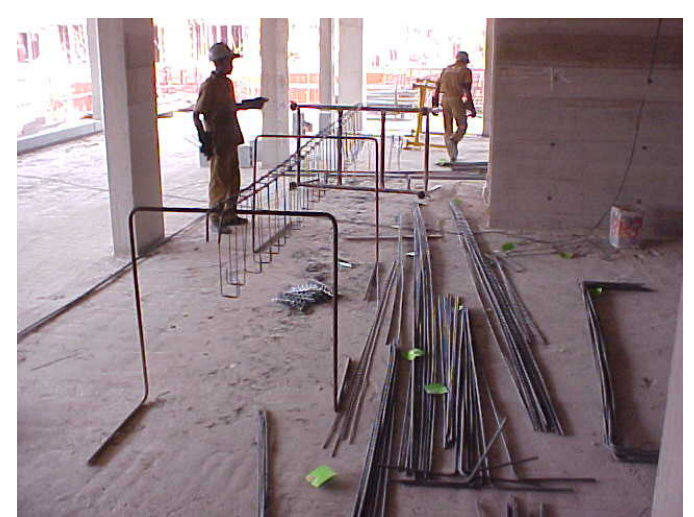

Figura 2.91- Cavaletes feitos com barras de aço 


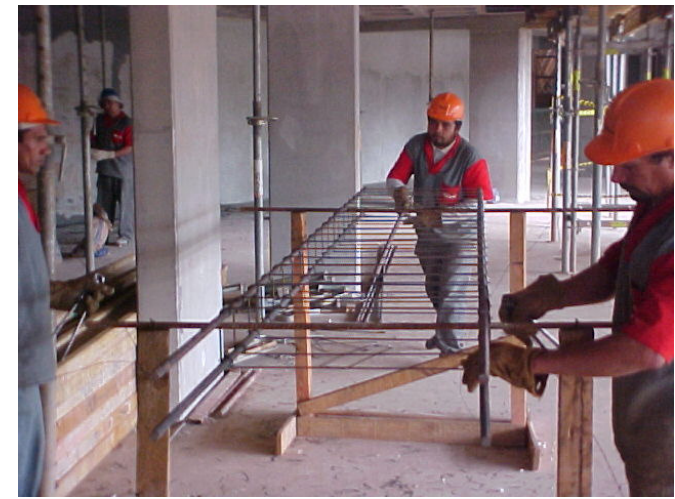

Figura 2.92 - Cavaletes feitos com estrutura de madeira e apoio com barra de aço

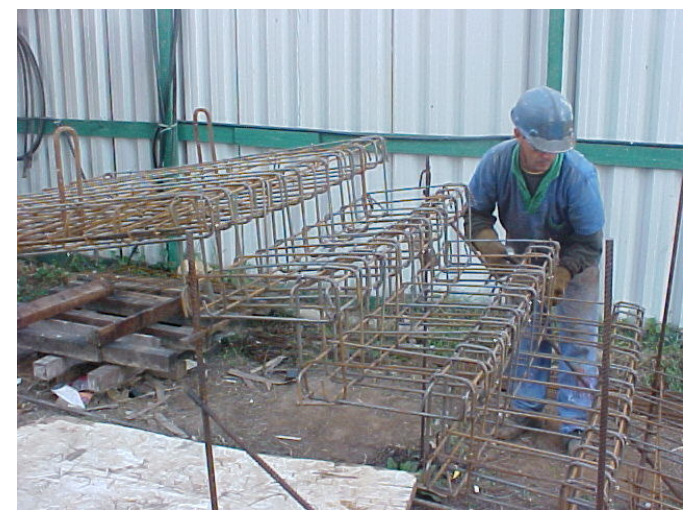

Figura 2.93 - Exemplo de cavalete para pré-montagem de armadura de escada

A união das peças para a confecção de uma gaiola é feita, nas obras, através de "amarrações", onde o armador, com o auxílio de uma ferramenta conhecida como torquês e usando pedaços de arame recozido dá um "ponto", envolvendo e, portanto, amarrando duas peças. É muito importante que a amarração seja bem feita, garantindo que as peças permaneçam em suas posições durante as demais operações da etapa de armação, bem como durante, também, a concretagem do elemento estrutural.

Em algumas situações como, por exemplo, no caso de amarrações envolvendo barras lisas $^{50}$, ou em quando as gaiolas são transportadas, é preciso que os pontos sejam mais reforçados a fim de impedir que as barras saiam da posição. Dessa forma, existem diferentes tipos de pontos para amarração das peças, como mostrado na Figura 2.94. Alguns deles são mais reforçados (como os pontos identificados pelas letras "B", "D", "E" e "F" na Figura 2.94) e, portanto, mais difíceis de serem feitos.

${ }^{50}$ Quando o ponto é dado em barras nervuradas, as próprias nervuras "contribuem" para que a posição em que as barras foram amarradas sejam mantidas. 


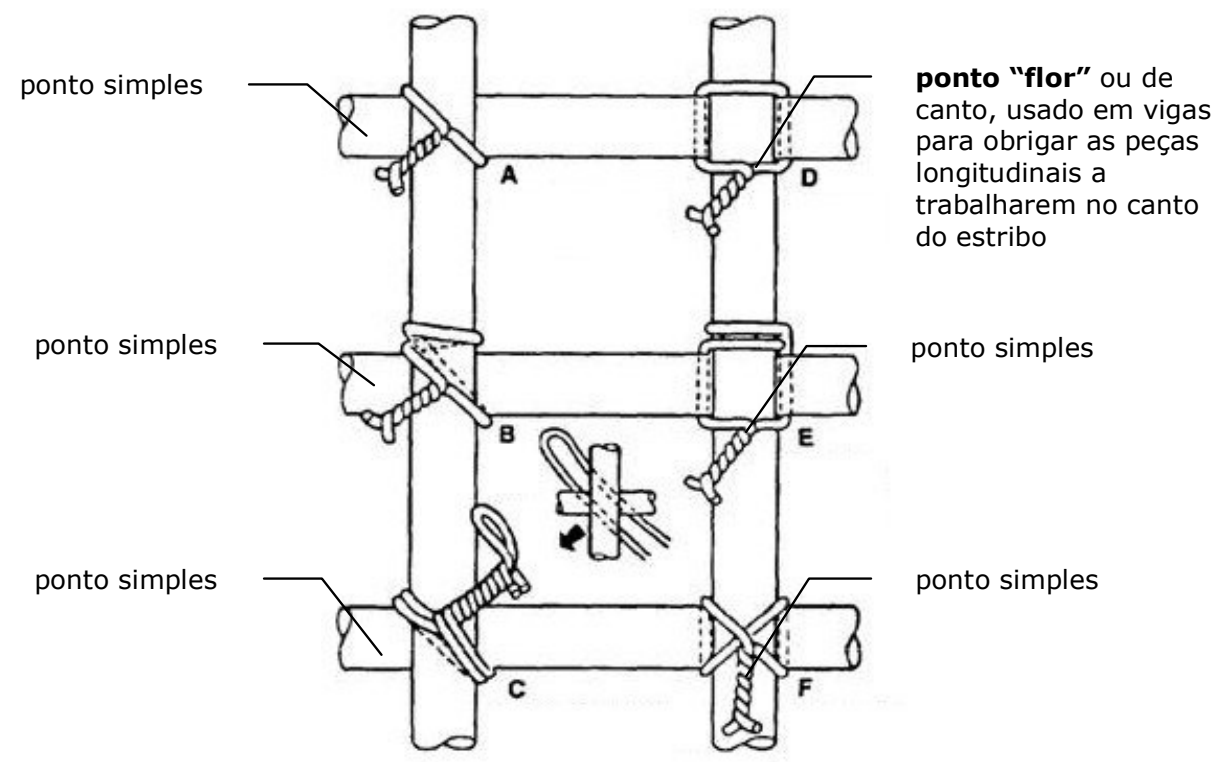

Figura 2.94 - Tipos de pontos mais comuns para amarração das peças

Não há, nas normas brasileiras (NBR 6118:2003 e NBR 14931:2003), prescrições sobre a quantidade de pontos que devem ser dados na confecção das armaduras de pilares, vigas e lajes. Em se tratando de pilares, por exemplo, não está dito em nenhum lugar se há necessidade, ou não, de amarrar todo o encontro de barra longitudinal e transversal. Há alusões quanto à importância da manutenção do posicionamento das peças, que pode ser garantido até o fechamento da fôrma. Porém, não se sabe se o número e o tipo das amarrações definidos freqüentemente (e empiricamente) pelos armadores, garantem a manutenção do posicionamento das peças durante a concretagem.

As ferramentas usadas pelo armador na operação de pré-montagem são basicamente duas: i) o metro ou trena, utilizado para assegurar o espaçamento entre as peças, prescrito no projeto (o armador costuma apontar as medidas, seja nas próprias barras ou na fôrma (em se tratando da armadura das lajes) com giz ou gesso); ii) a torquês, que se trata de uma ferramenta de corte, fabricada em aço carbono, com as arestas de corte das mandíbulas em aço temperado.

A torquês utilizada pelo armador (Figura 2.95) é semelhante à torquês do carpinteiro, porém costuma possuir cabo mais longo para permitir: i) a aplicação de uma força maior sobre as mandíbulas, necessária para cortar arames e apertar os nós dos pontos que prendem as peças (Figura 2.96); ii) o alcance às partes da gaiola onde o braço do armador não chega, ou tem o acesso restringido pela densidade de aço na armadura. Para o "ponteamento" da armadura das lajes, os armadores costumar usar torquês com braços mais curtos. 


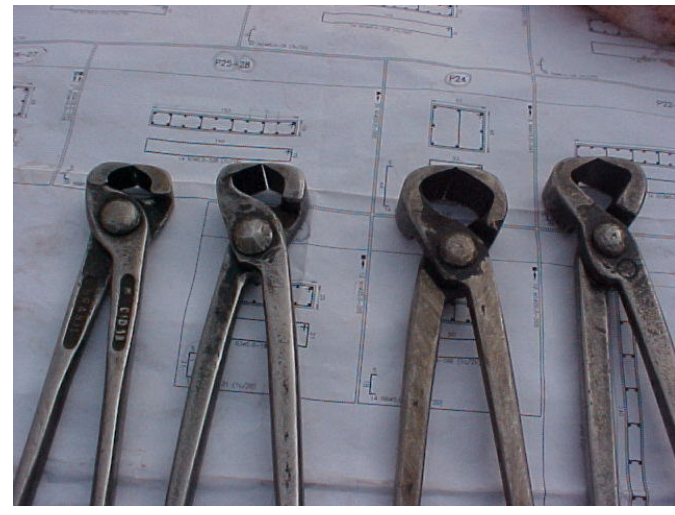

Figura 2.95 - Exemplos de torquês

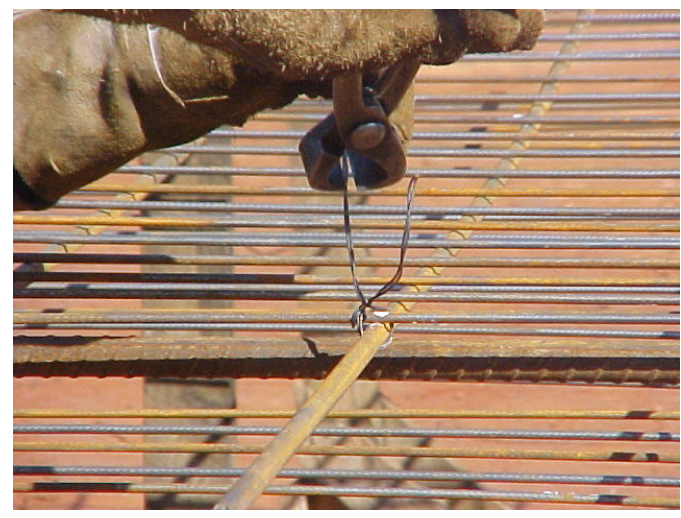

Figura 2.96 - Exemplo da utilização da torquês

Cada armador tem a sua própria torquês, que geralmente é adquirida de pequenos fabricantes, que a produzem artesanalmente, e as oferecem a preços e com qualidade, segundo os armadores, melhores que as provenientes de grandes fabricantes e encontradas em lojas especializadas. A torquês precisa, de tempo em tempos, ter as arestas de corte das mandíbulas amoladas. Existe um profissional especializado, conhecido entre os armadores por "puxador de torquês" que desempenha especificamente esta tarefa.

O arame utilizado na confecção dos pontos para a amarração das peças deve apresentar baixo teor de carbono na sua composição e, portanto, alta maleabilidade. Os fios de arames mais comumente utilizados são os de número 18 ou 20. Para aumentar a resistência dos pontos, os armadores, constituem, na obra, feixes com dois ou três fios de arame, que são então enrolados (ou trançados), garantindo assim uma coesão dos feixes. A Figura 2.97 ilustra um armador utilizando um motor para trançar os fios de arame. O arame pode ser adquirodo já trançado, disponível em pequenos rolos, como mostrado na Figura 2.98.

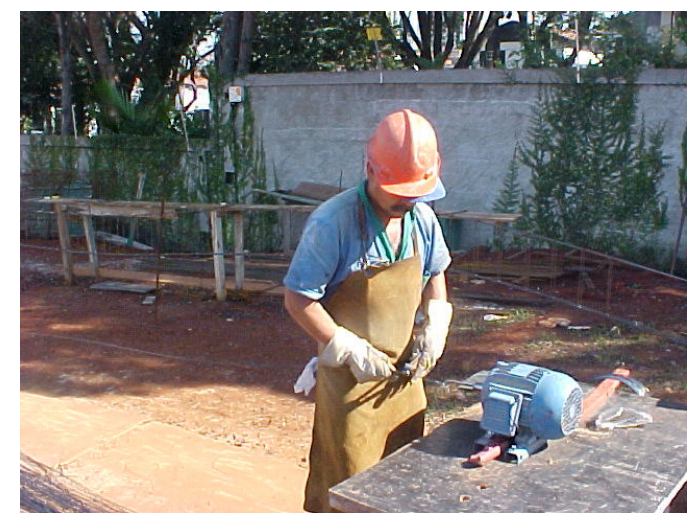

Figura 2.97 - Armador preparando arame torcido

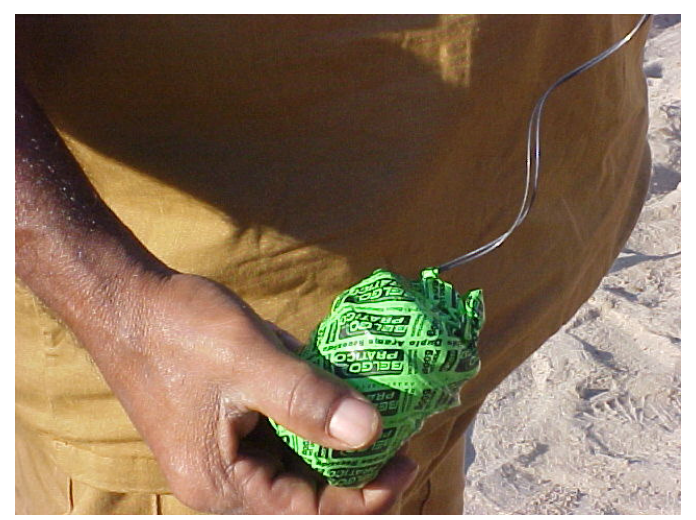

Figura 2.98 - Rolos com arame já torcido 
A pré-montagem das armaduras é sempre desejável, pois através desta operação, consegue-se: i) otimizar o ciclo de execução da estrutura ao se eliminar o tempo que seria gasto com a montagem das armaduras no pavimento em execução; ii) antecipar a confecção de gaiolas para elementos dos trechos seqüentes, diminuindo as chances de atrasar uma atividade que é caminho critico da obra; iii) garantir, ao armador, frente de serviço nos momentos em que ele não está envolvido nas operações de montagem; iv) aumentar a qualidade das armaduras produzidas; v) aumentar o tempo em que os armadores permanecem sob melhores condições (locais protegidos, posições ergonômicas) de trabalho; vi) minimizar as situações de trabalho em locais de maior risco de acidentes etc.

No entanto, a operação de pré-montagem das armaduras nem sempre é possível, estando limitada às possibilidades de mobilidade das gaiolas no canteiro de obras (do local onde foram confeccionadas até o ponto onde serão posicionadas) em função das suas dimensões (peso e formato) e do sistema de transporte presente no canteiro de obras e às possibilidades construtivas (há situações, por exemplo, onde a interferência entre armaduras não permite que as mesmas sejam pré-montadas).

A Figura 2.99 e a Figura 2.100 mostram a pré-montagem de armaduras de pilares e vigas, respectivamente. As armaduras destes elementos podem ter todas as suas peças posicionadas e amarradas na pré-montagem ou serem complementadas no local de montagem definitivo. No caso das armaduras dos pilares, a complementação pode ser feita com peças longitudinais, que não foram, eventualmente, posicionadas durante a pré-montagem para reduzir o peso da gaiola (limitado pela capacidade do equipamento de transporte), ou com peças transversais (estribos e ganchos) na região de "arranque" onde as barras longitudinais serão traspassadas (emendadas).

As armaduras pré-montadas das vigas são, freqüentemente, complementas no local, principalmente em se tratando de armaduras que tenham peças longitudinais combatendo momentos negativos.

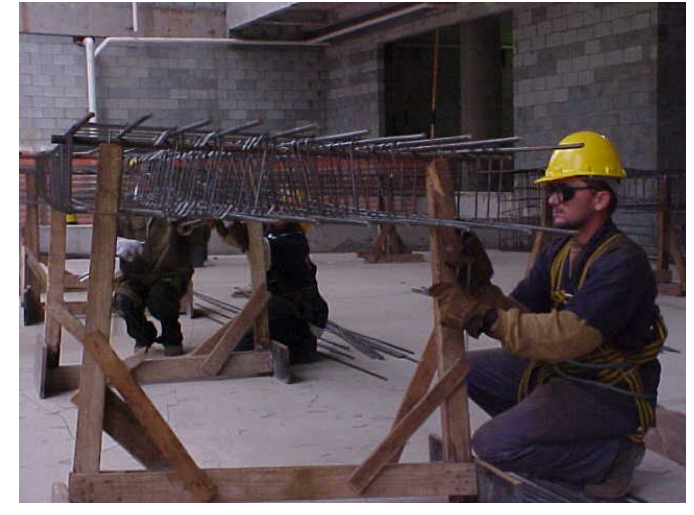

Figura 2.99 - Pré-montagem de armadura de pilar

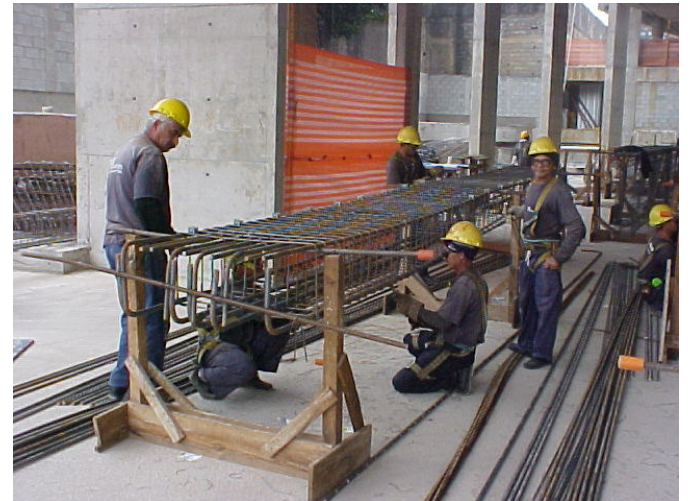

Figura 2.100 - Pré-montagem de armadura de viga

Algumas situações de projeto (e, desde que a obra apresente um sistema de transporte adequado a tais propósitos), tornam factível a pré-montagem de armaduras negativas de 
lajes. Constituem-se, assim, "malhas" de pequenas proporções, como mostram a Figura 2.101 e a Figura 2.102.

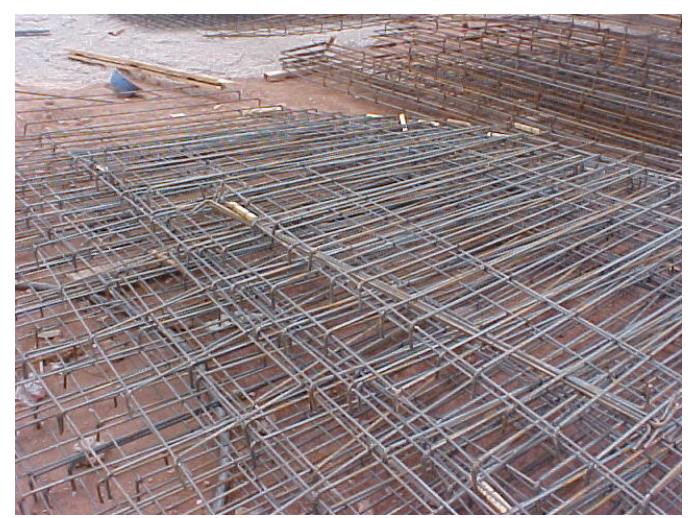

Figura 2.101 - Armadura de laje negativa pré-montada

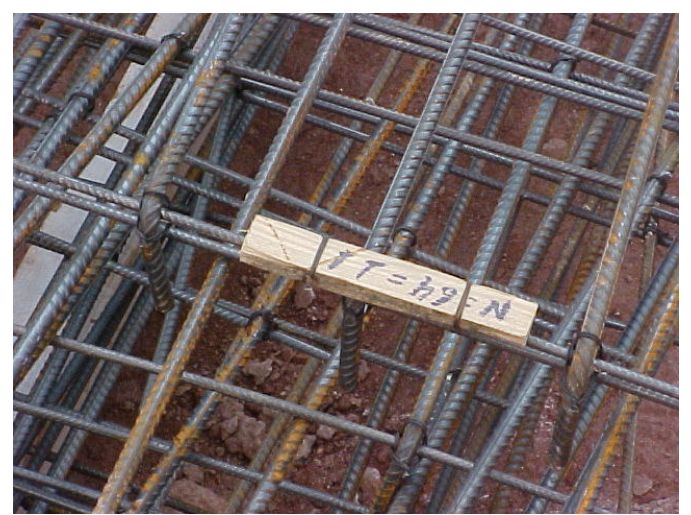

Figura 2.102 - Detalhe de armadura de laje negativa pré-montada

A pré-montagem exige alguns cuidados especiais em razão da movimentação da gaiola durante o seu transporte, como por exemplo: i) pontos reforçados que impeçam que as peças saiam de suas posições (Figura 2.103); ii) enrijecimento da gaiola durante o transporte, como mostra a Figura 2.104.

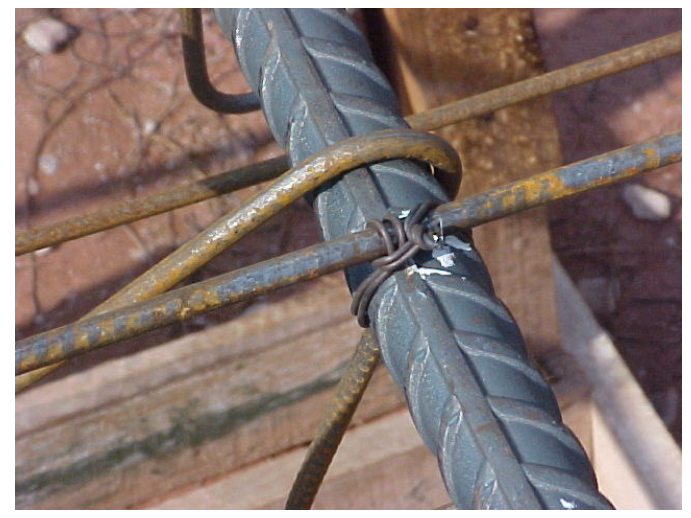

Figura 2.103 - Detalhe de ponto reforçado para amarração das peças

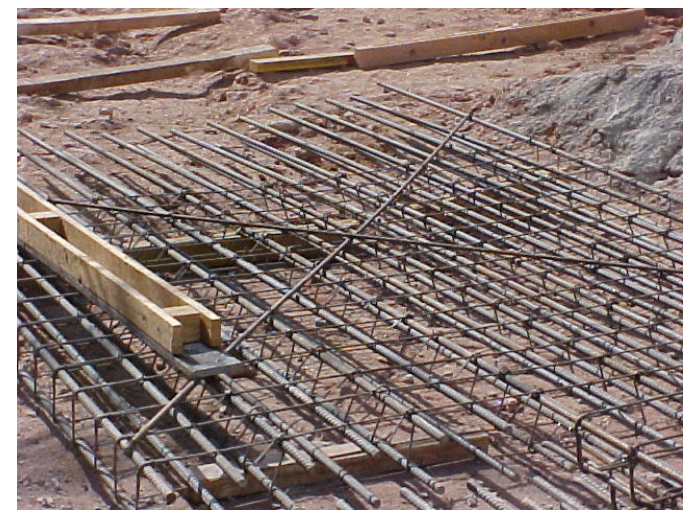

Figura 2.104 - Enrijecimento da gaiola para transporte vertical

As informações para a pré-montagem das armaduras são disponibilizadas no projeto de detalhamento das armaduras, através de desenhos como os mostrados na Figura 2.105 e na Figura 2.106, para armaduras de pilares e vigas, respectivamente. O grau de detalhamento dos desenhos (qualidade dos desenhos, número de detalhes, número de cortes, sistemas de identificação da disposição das peças etc) influi na exeqüibilidade dos projetos. Assim, projetos com maior nível de detalhes, costumam ser mais exeqüíveis, na medida em que não deixam margens para interpretações equivocadas do armador no campo, facilitam o entendimento e agilizam as operações de montagem. 


\section{$P 18=P 22132 / 552 X$}

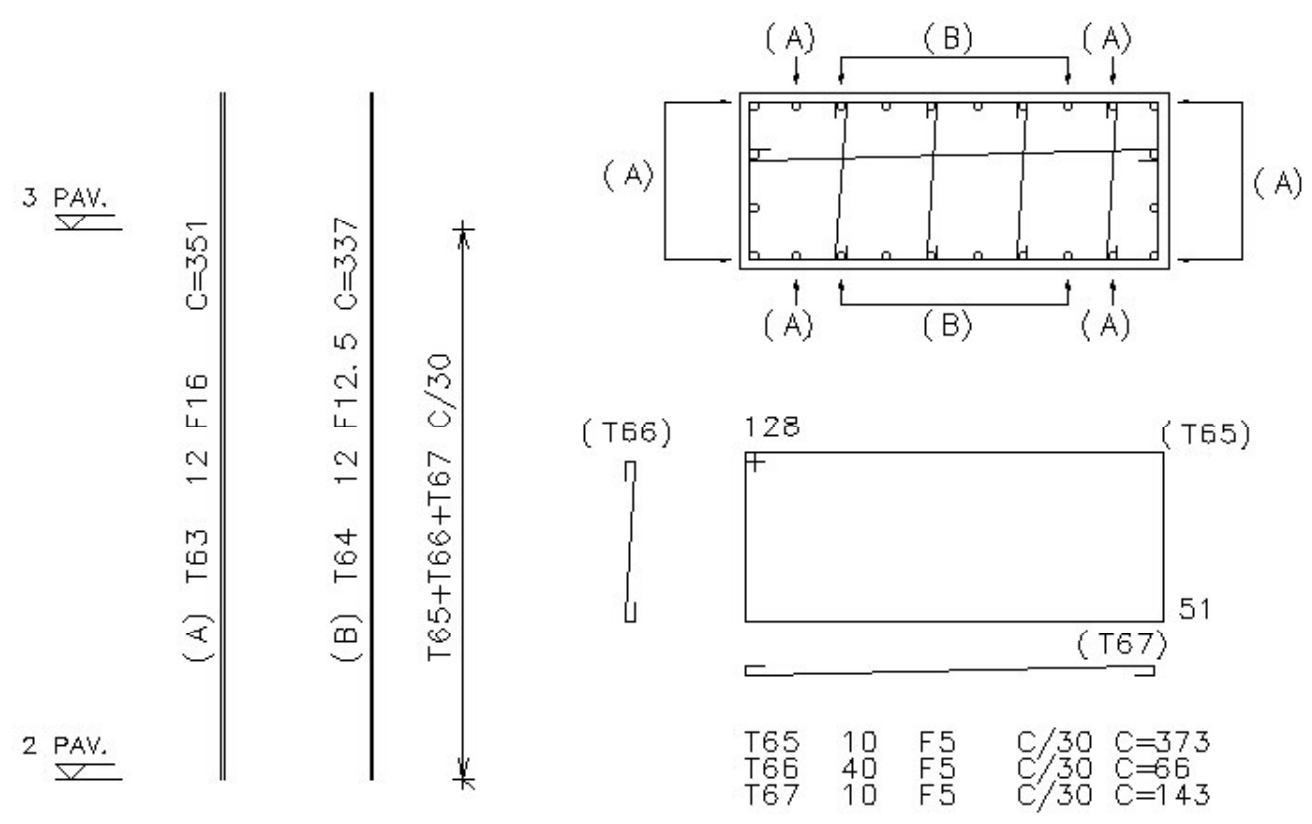

Figura 2.105 - Detalhamento da armadura de pilar

Na Figura 2.105 mostra-se um exemplo de detalhamento da armadura de um pilar, composto por três diferentes tipos de peças: peças longitudinais ("T63" e "T64", tendo-se doze peças, de $16 \mathrm{~mm}$ de diâmetro, com $351 \mathrm{~cm}$ de comprimento e 12 peças com 12,5 mm de diâmetro, com $337 \mathrm{~cm}$ de comprimento, respectivamente), estribos ("T65", sendo dez peças, com $5 \mathrm{~mm}$ de diâmetro, espaçadas, longitudinalmente, de 30 cm) e ganchos ("T66" e "T67", tendo-se 40 peças de $5 \mathrm{~mm}$ de diâmetro e 10 peças de $5 \mathrm{~mm}$ de diâmetro, respectivamente, espaçadas de $30 \mathrm{~cm}$,). O desenho orienta o armador a dispor cada uma das peças supracitadas na armadura: i) identifica as posições das peças T63 e T64 (porém, ao não apontar o espaçamento entre estas peças, deixa "subentendido" tratar-se de espaçamento uniforme); ii) traz o espaçamento dos estribos (porém, não identifica a partir de que ponto eles devem começar a serem dispostos); iii) mostra a disposição dos ganchos, nos dois sentidos (porém não especifica se os ganchos devem envolver (laçar) apenas a peça longitudinal ou a peça longitudinal mais o estribo). 


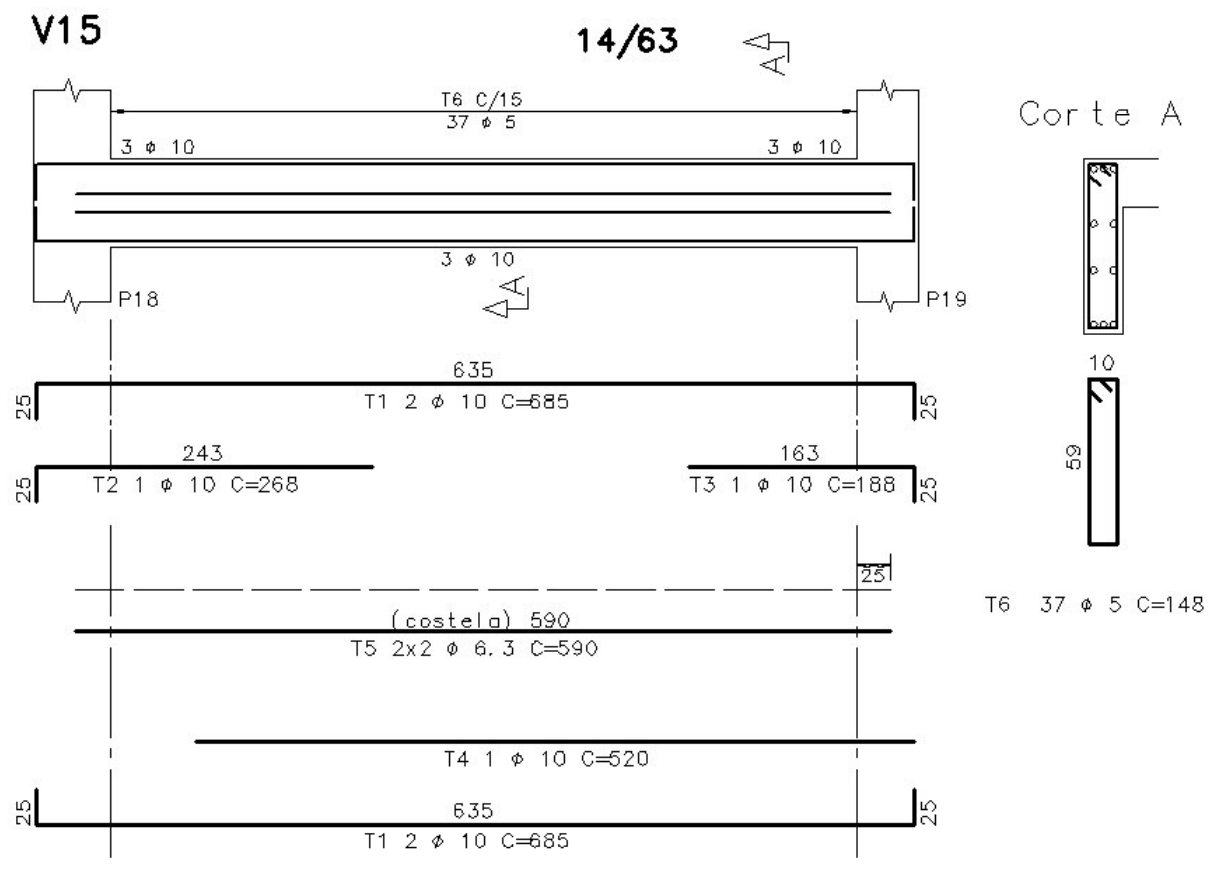

Figura 2.106 - Detalhamento da armadura de viga

Na Figura 2.106 mostra-se um exemplo de detalhamento da armadura de uma viga. A disposição das peças longitudinais requer, do armador, uma atenção especial, por estas não estarem, na maioria das vezes, simetricamente distribuídas no corpo da viga. Há peças que são dispostas em apenas um determinado trecho, como é o caso das peças "T2", "T3", "T4" e "T5" da referida Figura. Há ainda que se atentar para a colocação das peças longitudinais na posição correta (parte superior ou inferior da alma da viga; peças à esquerda ou à direita da viga). O posicionamento das peças no desenho e o detalhe do corte transversal ("A-A") devem orientar o armador nesta tarefa. A distribuição dos estribos é indicada na parte superior do desenho ("T6", tendo-se 37 peças posicionadas a cada $15 \mathrm{~cm}$ ).

O posicionamento da armadura dentro da fôrma para que, mesmo durante a concretagem e vibração do concreto, as barras permaneçam em suas posições, conservando o cobrimento de concreto especificado em projeto, é feito através do uso de distanciadores,

Ainda na operação de pré-montagem das armaduras são colocados os espaçadores (ou distanciadores), responsáveis por assegurar o cobrimento mínimo da armadura (pelo concreto), que deve estar corretamente especificado no PDA (segundo prescrição da norma NBR 6118:2003). Os espaçadores podem ser feitos na obra ou industrializados. Os espaçadores ("bolachas", "pastilhas", "cocadas" etc.) feitos na obra, consistem de uma pequena placa armassa, com a espessura que se pretende dar ao cobrimento de concreto, com traço superior ao do elemento a ser concretado, com um pedaço de arame recozido, trançado, chumbado na mesma, conforme mostra a Figura 2.107. 

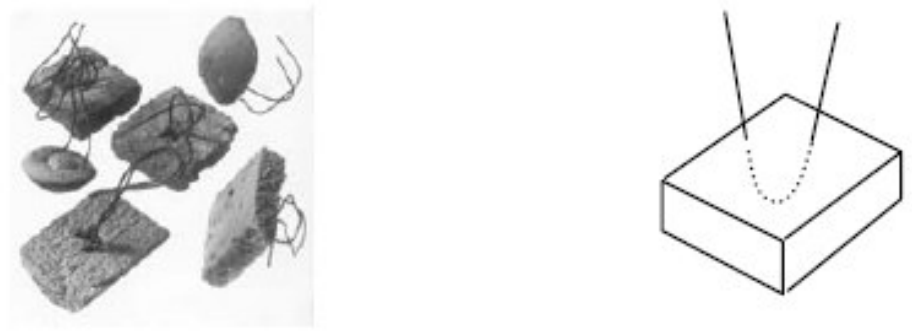

Figura 2.107 - Exemplo de espaçadores produzidos no canteiro de obras

Os distanciadores industrializados, normalmente são de plástico, de alta resistência, apresentando forma e dimensões variadas em função do fim a que se destinam (se usados em armaduras de pilares, vigas (fundo ou lateral de viga) ou lajes), dos diâmetros das peças que serão encaixados (é importante que se utilize os espaçadores adequados, garantindo-se, assim, um encaixe perfeito e reduzindo as chances de os espaçadores saírem das suas posições no momento do posicionamento da armadura na fôrma) ou, ainda, do sistema de encaixe (por exemplo, os espaçadores circulares podem ter entrada radial ou lateral (Figura 2.108))

A quantidade de espaçadores a serem colocados nas armaduras, bem como a sua distribuição são informações que não constam no projeto, cabendo aos armadores determinarem a sua disposição, de forma a garantir o cobrimento adequado a todas as peças da armadura, sem exceção (Figura 2.109).

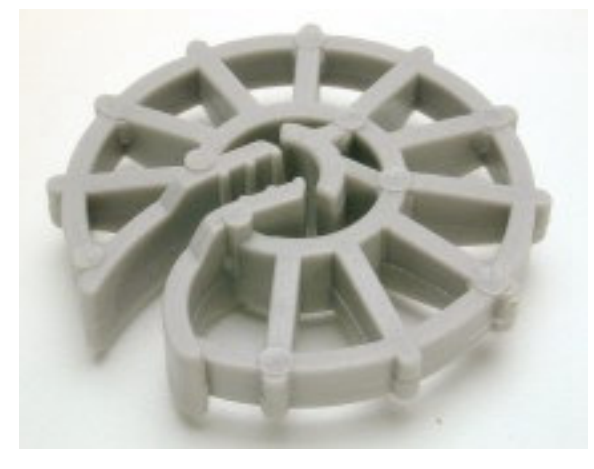

Figura 2.108 - Exemplo de espaçador plástico circular com entrada lateral

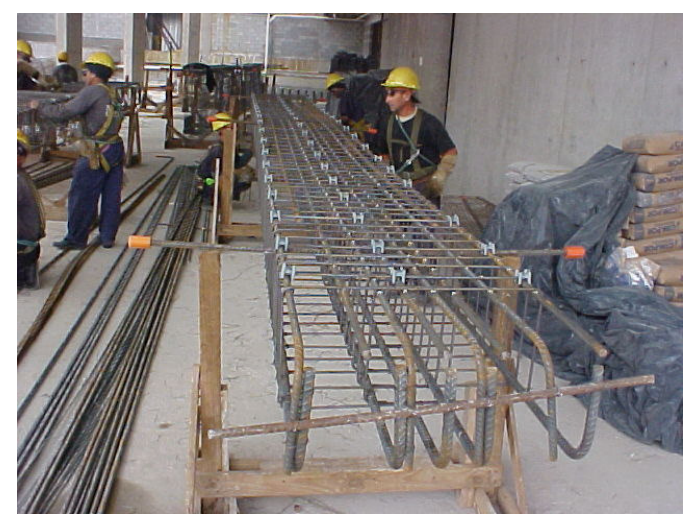

Figura 2.109 - Espaçadores posicionados na armadura pré-montada da viga

\subsubsection{6}

\section{A Montagem}

A operação de montagem das armaduras trata-se da última operação da etapa de armação. É caracterizada pela colocação da armadura na fôrma, dando-se por finalizada ao ter-se posicionado e amarrado a última peça a ela. Mais que o contato direto da 
armadura com a fôrma, a operação de montagem das armaduras proporciona a interação entre esses dois serviços, que a partir deste momento e até a concretagem, seguirão juntos

Nas situações em que houve a pré-montagem da armadura, a operação de montagem compreende, basicamente, o posicionamento da armadura na fôrma (que poderá, ainda, ser complementada com algumas peças ou não). Quando a pré-montagem da armadura não ocorreu, a operação de montagem será, naturalmente, mais complexa, caracterizando-se pelo posicionamento das peças que, depois de amarradas, constituirão a armadura.

A operação de montagem apresenta, também, distinções em função do elemento cuja armadura se deseja montar (se pilar, viga ou laje). A montagem das armaduras das vigas, por exemplo, costuma se mais complexa, principalmente em projetos em que há situações de interferências entre os elementos estruturais (como viga chegando em viga, pilares intermediários às vigas etc).

Dessa forma, tratar-se-á a operação de montagem, a seguir, separadamente, para cada elemento estrutural.

\subsection{A montagem das armaduras de pilares}

A operação de montagem da armadura dos pilares envolve: i) o transporte das peças ou armaduras pré-montadas; ii) o posicionamento das peças ou armaduras pré-montadas segundo orientação do gabarito (gastalho) ou da própria fôrma, que pode estar parcialmente montada; iii) a fixação (amarração) das peças faltantes (estribos que foram suprimidos ou amarrados fora da sua posição correta com o intuito de facilitar a montagem), peças longitudinais que são posicionadas apenas no local (redução da massa do conjunto no transporte; iv) a conferência da armadura (verifica-se se todas as peças exigidas nos projetos estão posicionadas e devidamente amarradas em suas respectivas posições).

O transporte das armaduras pré-montadas de pilares trata-se de uma das etapas que requer maior atenção e cuidados especiais (visando preservar a integridade física dos operários envolvidos) na operação de montagem. Os equipamentos e a forma em que estes são utilizados para o transporte vertical de peças e armaduras costumam apresentar variações a cada obra. Com exceção da grua (que se trata do equipamento de transporte mais propício a esta etapa, desde que utilizado corretamente), todos os demais equipamentos utilizados pelas obras (basicamente elevadores convencionais e elevadores cremalheiras) não possibilitam algumas vezes que as peças e armaduras sejam transportadas internamente ao módulo de transporte, devido às dimensões dos mesmos. Nestes casos, os feixes com as peças e as armaduras costumam ser amarrados abaixo do módulo de transporte dos elevadores. O maior perigo da operação está justamente no momento em que os feixes de peças e armaduras são puxados, pelos operários (que ficam na borda da laje, num ponto sem proteção coletiva contra quedas) para cima da laje.

Outro equipamento usado nas obras para o transporte vertical das armaduras trata-se de um guindaste, com braço móvel, fixado no topo da torre do elevador de obras (Figura 2.110), conhecido como "mini-grua". Seu uso envolve riscos, justamente por, assim, como no caso dos elevadores, levar à necessidade de os armadores se posicionarem na borda do pavimento para "puxar" as armaduras para cima da laje (Figura 2.111). É preciso, ainda, que sejam amarradas cordas às armaduras e aos feixes de peças, as 
quais permitem que os armadores os afastem do corpo do prédio e das bandejas de proteção, permitindo o seu içamento (Figura 2.112 e Figura 2.113).

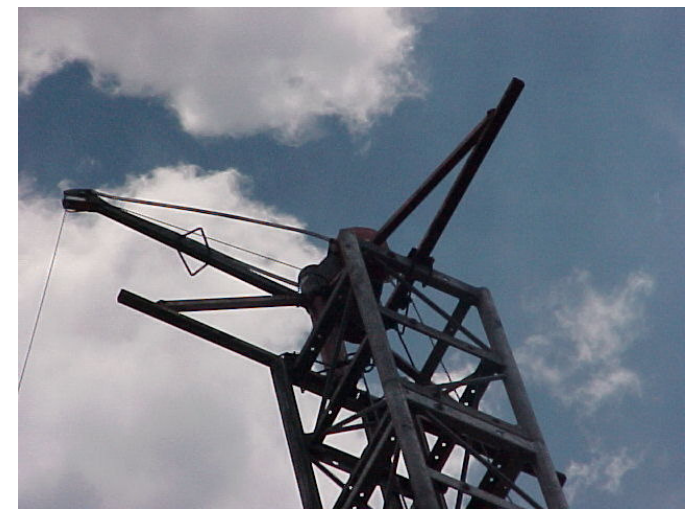

Figura 2.110 - Exemplo de "mini-grua" fixada no topo da torre do elevador

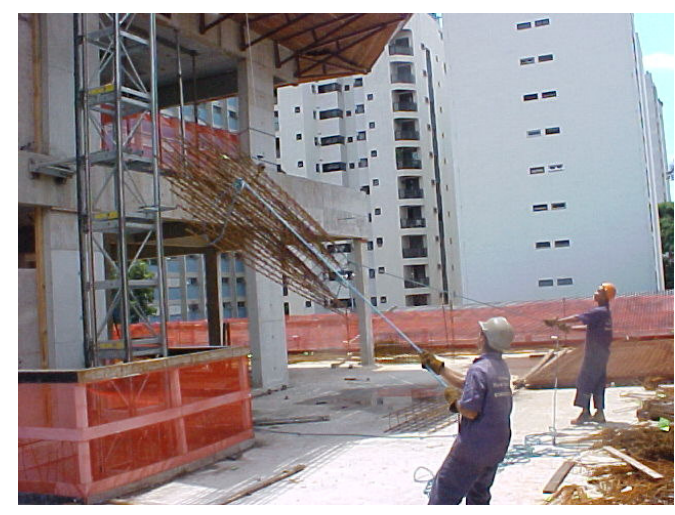

Figura 2.112 - Cordas presas a armadura para permitir o içamento

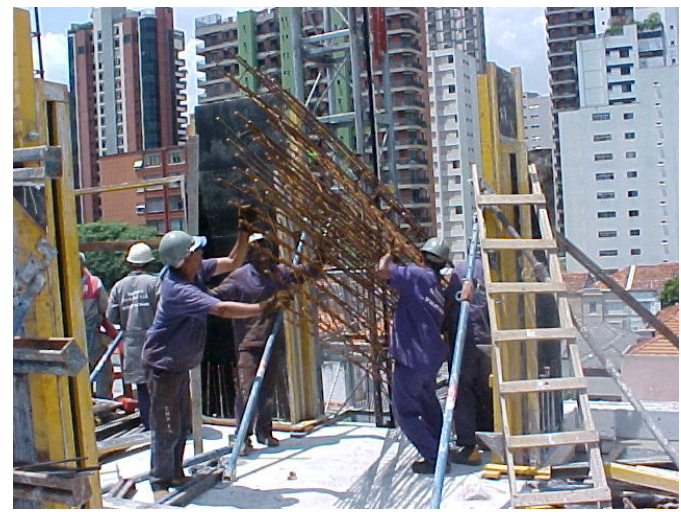

Figura 2.111 - Armadores posicionados na borda da laje para receberem a armadura

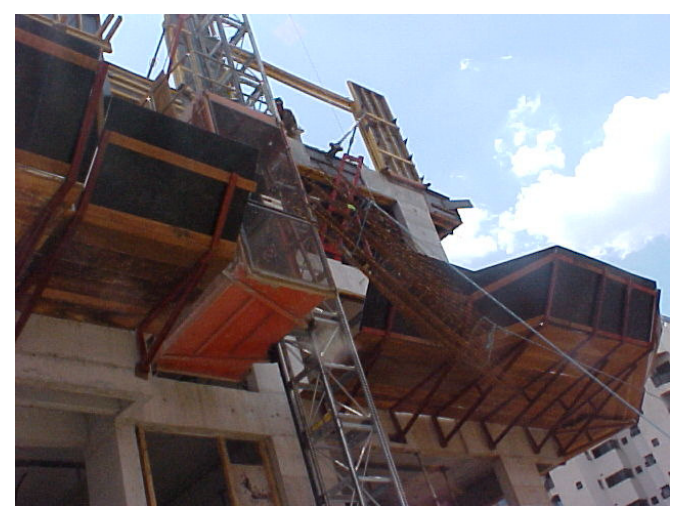

Figura 2.113 - Exemplo de içamento da armadura como a mini-grua

O posicionamento das armaduras normalmente acontece após os carpinteiros terem iniciado a montagem das fôrmas dos pilares, ou seja, terem montado três das quatro faces do pilar, conforme ilustra a Figura 2.114. A fôrma acaba servindo como apoio para a armadura, facilitando o seu posicionamento, embora haja situações em que as armaduras são posicionadas preliminarmente à montagem das três faces das fôrmas (como, por exemplo, no caso de pilares com grande densidade de armadura e/ou formatos quadrados, que necessitam que as amarrações nos arranques se dêem a partir das quatro faces). 

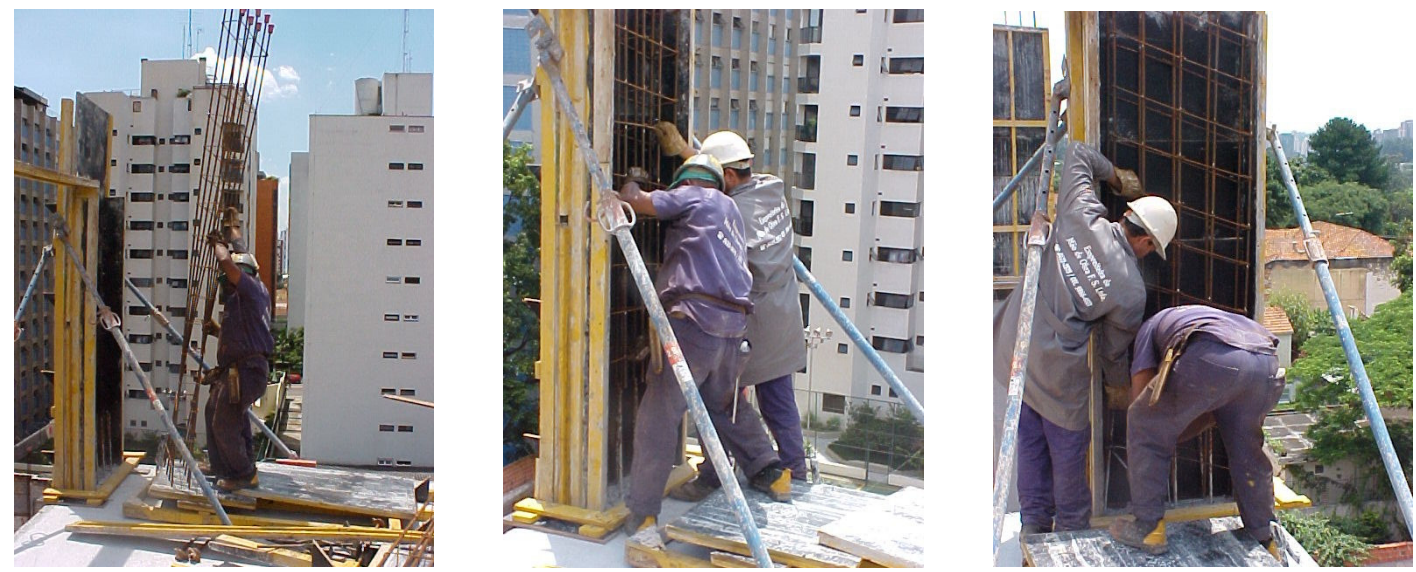

Figura 2.114 - Seqüência do posicionamento da armadura de pilar

Quando não se tem armaduras pré-montadas, algumas vezes, para facilitar o posicionamento e amarração das peças que irão compor a armadura, não se montam previamente as faces da fôrmas, como ilustrado na Figura 2.115 e na Figura 2.116.

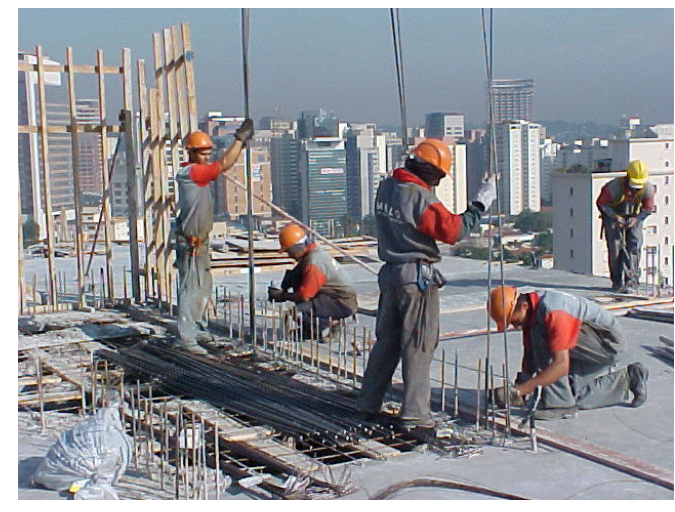

Figura 2.115 - Posicionamento das peças da armadura do pilar

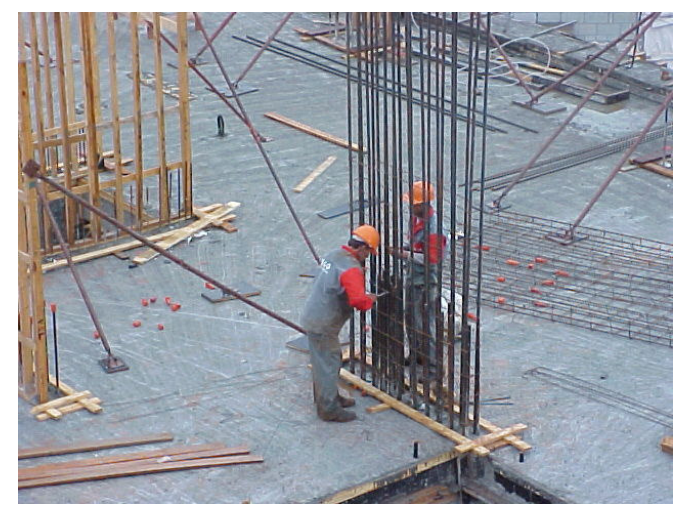

Figura 2.116 - Amarração das peças da armadura do pilar

Para facilitar o posicionamento da armadura de pilar, alguns estribos inferiores são suprimidos ou amarrados fora da posição devida. Assim, após a armadura ter sido posicionada é necessário que estas peças sejam re-posicionadas e devidamente amarradas (Figura 2.117 e Figura 2.118). É comum, também, que algumas peças que saíram de posição durante o transporte e/ou posicionamento, sejam amarradas novamente. É também, neste momento, que as peças faltantes durante a pré-montagem da armadura, são posicionadas e amarradas (a complementação da armadura com as peças faltantes pode ser feita também com a armadura fora da sua posição final, em cima de cavaletes, no andar em execução, como mostram a Figura 2.119 e a Figura 2.120). 


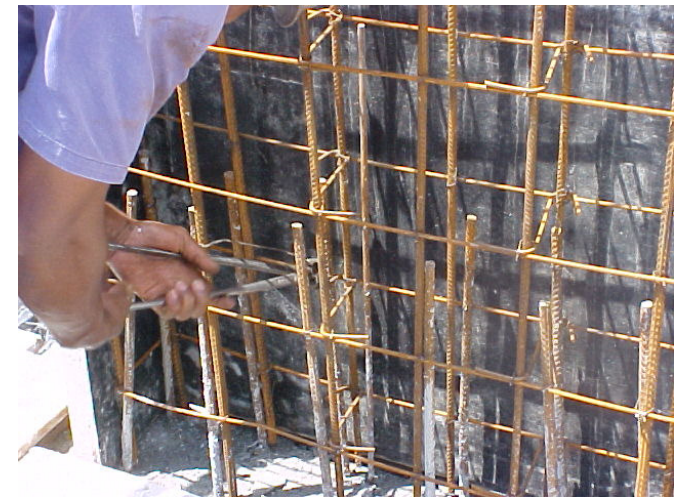

Figura 2.117 - Amarração dos estribos na região inferior da armadura

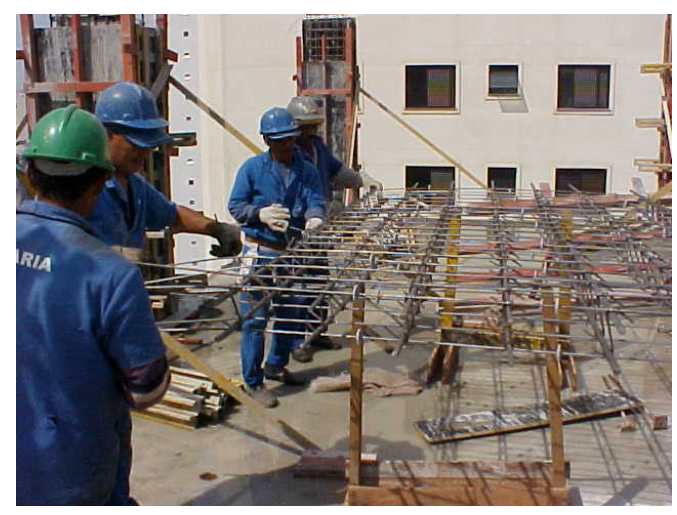

Figura 2.119 - Complementação da armadura no andar mas fora da posição final

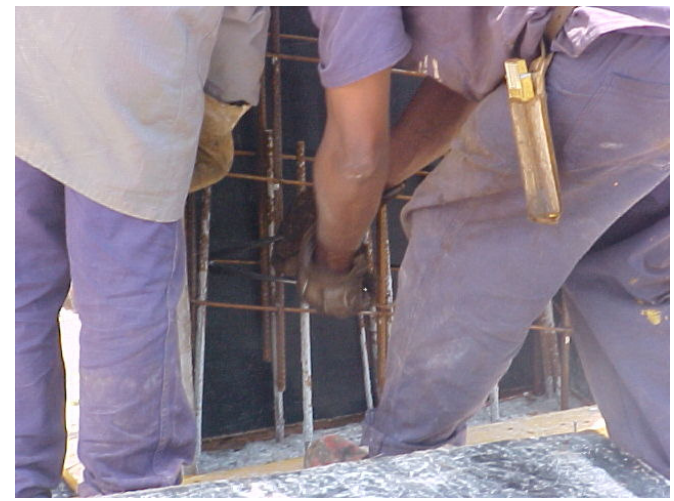

Figura 2.118 - Amarração dos estribos na região inferior da armadura

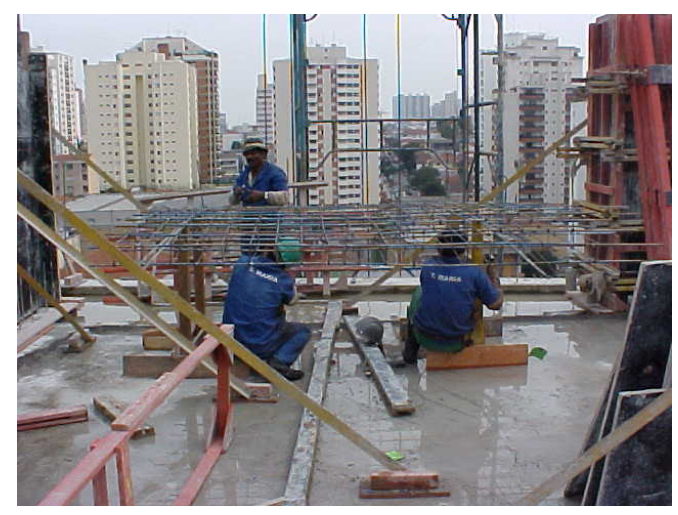

Figura 2.120 - Complementação da armadura no andar mas fora da posição final

Em se tratando de pilares paredes, que contemplam armaduras de grandes proporções, pode-se optar pelo posicionamento das peças (o que torna a operação mais lenta (Figura 2.121 e Figura 2.122)) ou pelo posicionamento de armaduras pré-montadas segmentadas, armadas em dimensões que possibilitem o transporte e manuseio das mesmas. Neste caso, a segmentação das gaiolas e a sua consolidação na montagem deve ter sido previsto e detalhado pelo projetista estrutural (Figura 2.123). 


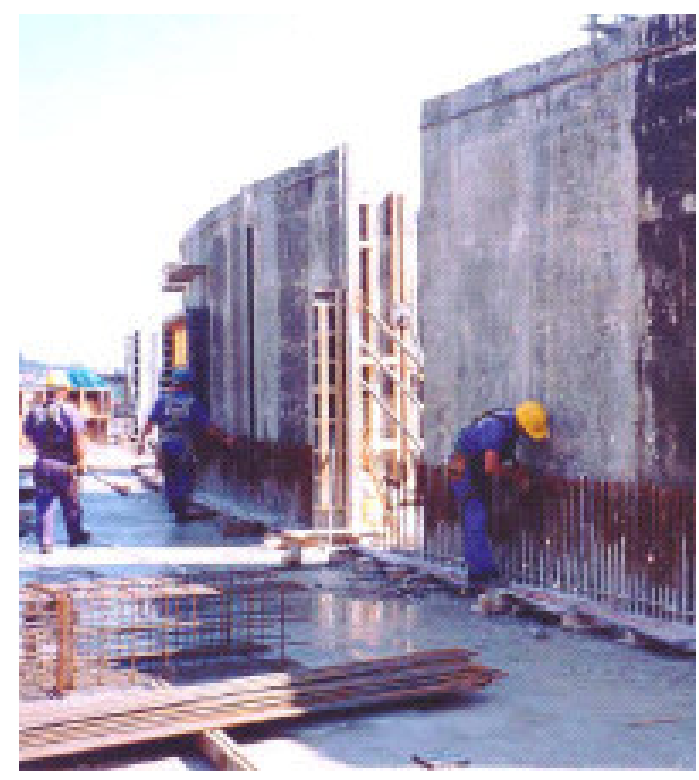

Figura 2.121 - Arranques para armadura de pilar parede.

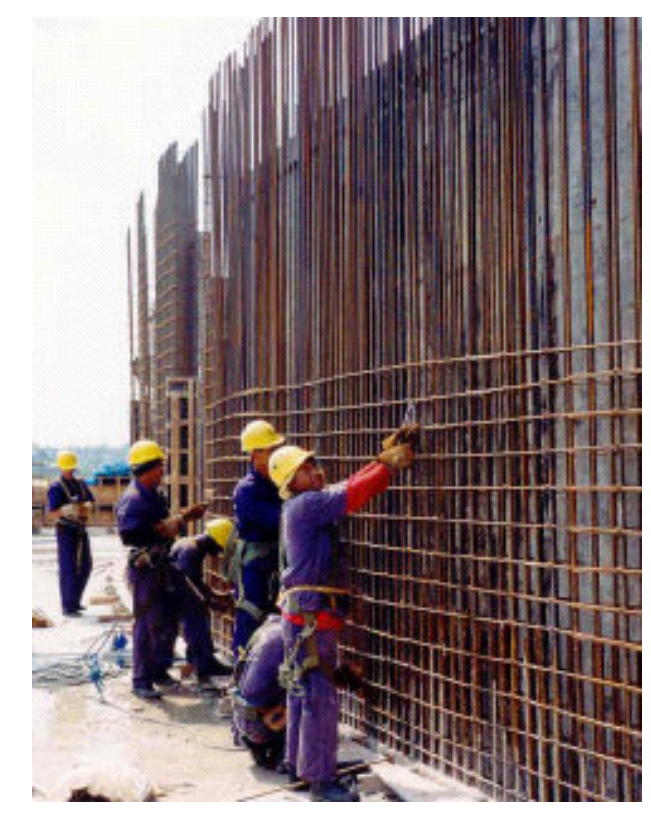

Figura 2.122 - Exemplo de posicionamento das peças nos pilares parede

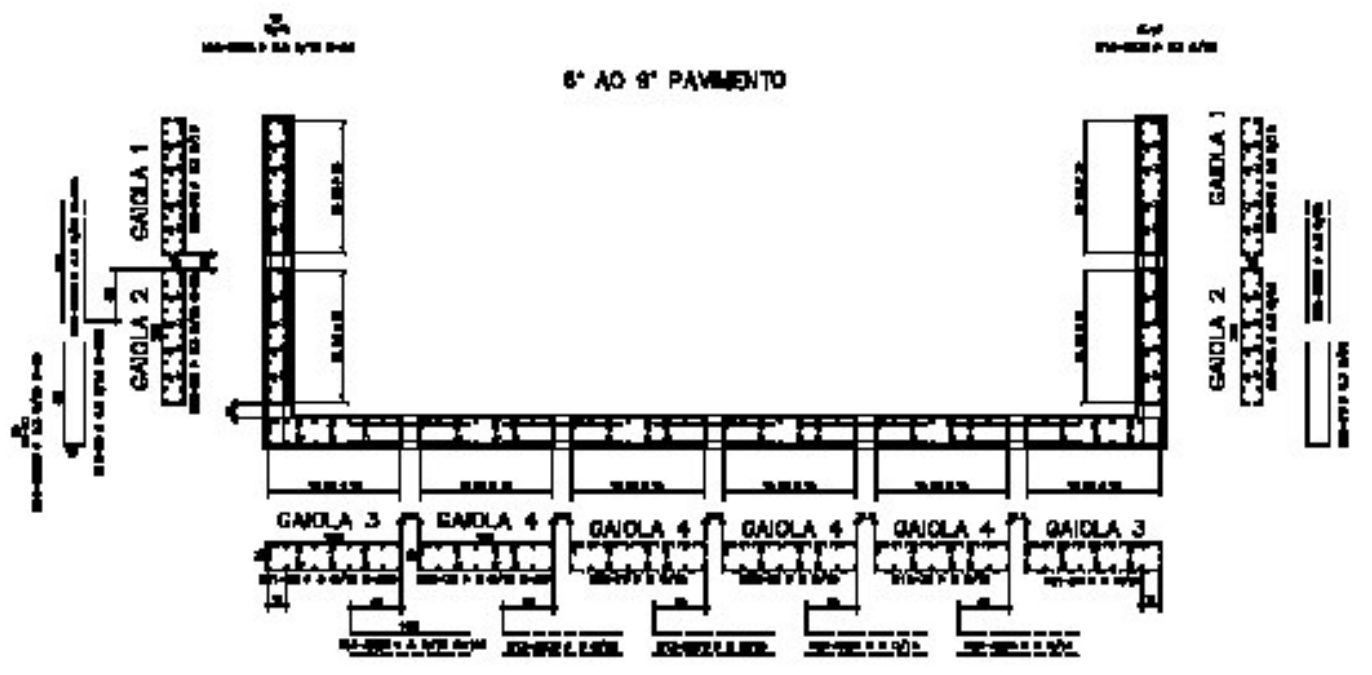

Figura 2.123 - Segmentação da armadura do pilar parede em varias gaiolas

A conferência da armadura representa a ultima etapa da montagem das armaduras. Os armadores devem checar se todas as peças foram posicionadas e amarradas devidamente e se os espaçadores estão colocados na quantidade e posição corretas. 
Feito isto, a armadura de pilares está liberada pelos armadores para que seja inspecionada pelo engenheiro de produção ou por alguém, por ele designado.

\subsection{A montagem das armaduras de vigas}

A operação de montagem da armadura das vigas envolve as seguintes etapas: i) o transporte das peças ou armaduras pré-montadas; ii) o posicionamento das peças ou armaduras pré-montadas na fôrma da viga, que pode estar parcial (apenas a fôrma de fundo da viga) ou totalmente (fundo mais laterais) montada; iii) o posicionamento e amarração das peças faltantes (a existência de pilares intermediários às vigas (com a presença de estribos no nós), faz com que as gaiolas sejam pré-montadas segmentadas, sendo necessariamente, complementadas (com peças longitudinais no banzo superior da viga) após o posicionamento das mesmas). A Figura 2.124 ilustra um trecho do projeto de detalhamento de armadura de viga, onde o projetista identifica (" $2^{\circ}$ etapa de montagem") as peças que serão complementadas após o posicionamento das gaiolas segmentadas; iv) a conferência da armadura (verifica-se se todas as peças exigidas nos projetos estão posicionadas e devidamente amarradas em suas respectivas posições).

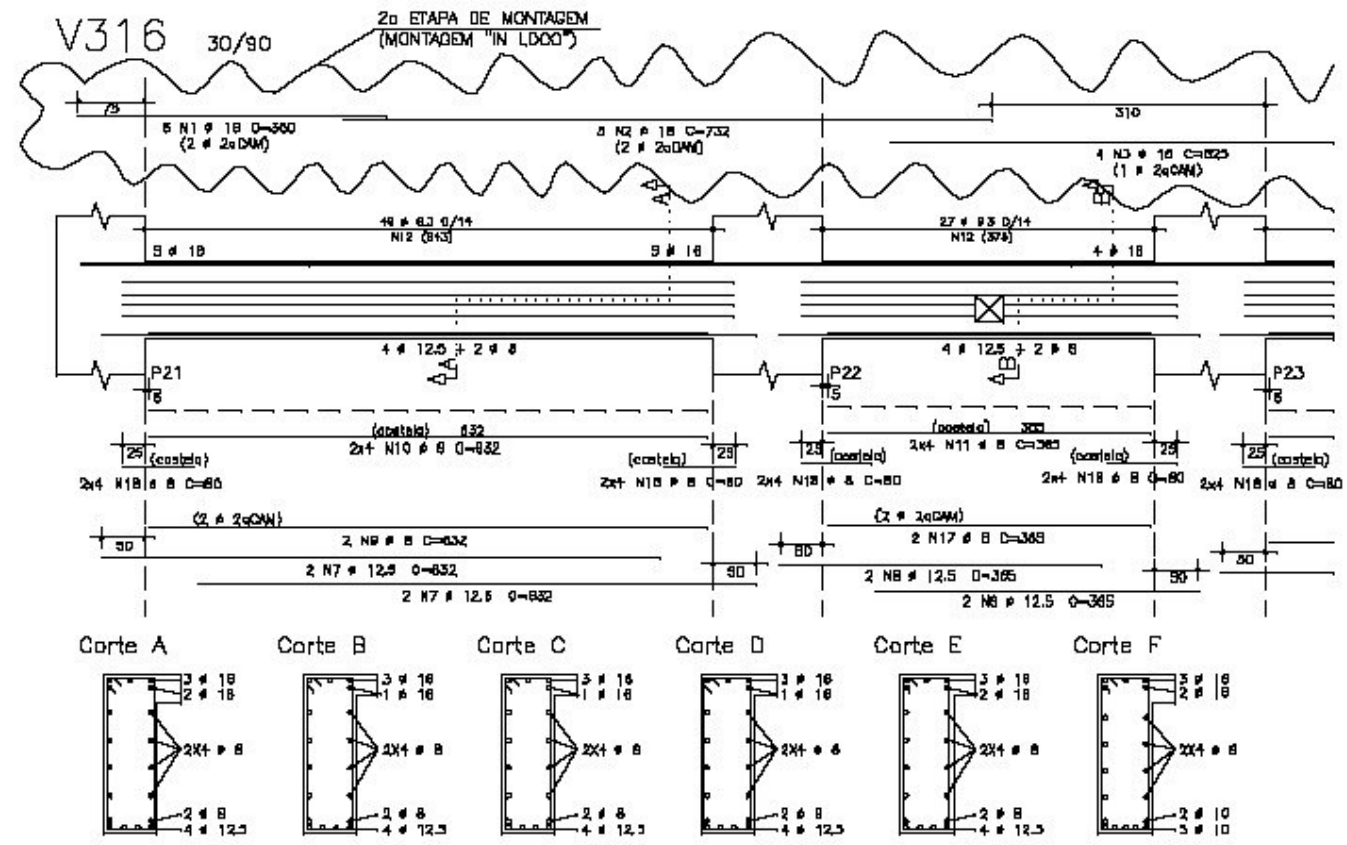

Figura 2.124 - Projeto de detalhamento com identificação das peças

O transporte das armaduras pré-montadas das vigas, pode ser mais ou menos trabalhoso que o transporte das armaduras dos pilares, em função das dimensões das gaiolas das vigas. Normalmente, em estruturas reticuladas de edifícios residenciais, têmse vigas de pequenas dimensões, que são montadas, geralmente, segmentadas, facilitando, nestes casos, o transporte das mesmas. Porém, há situações, como no caso de estruturas reticuladas com lajes que apresentam grandes vãos livres (geralmente edifícios comerciais) em que as vigas assumem grandes dimensões, podendo tornar a mobilidade das gaiolas bastante dificultosa. 
O fato de a fôrma da viga confinar a armadura e, portanto, dificultar a sua complementação, faz com que os armadores usem artifícios como o de manter a armadura suspensa acima do local onde será encaixada, através de escoras para que sejam efetivados os acertos e complementações necessárias (Figura 2.125 e Figura 2.126), antes de baixá-la para a sua posição final.

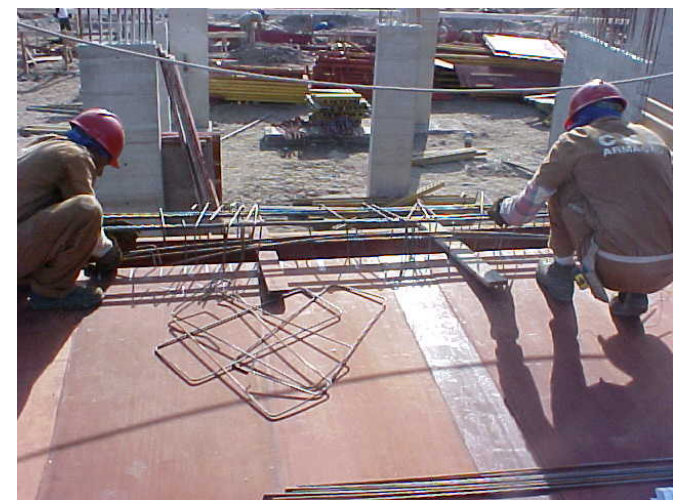

Figura 2.125 - Complementação na montagem da armadura da viga

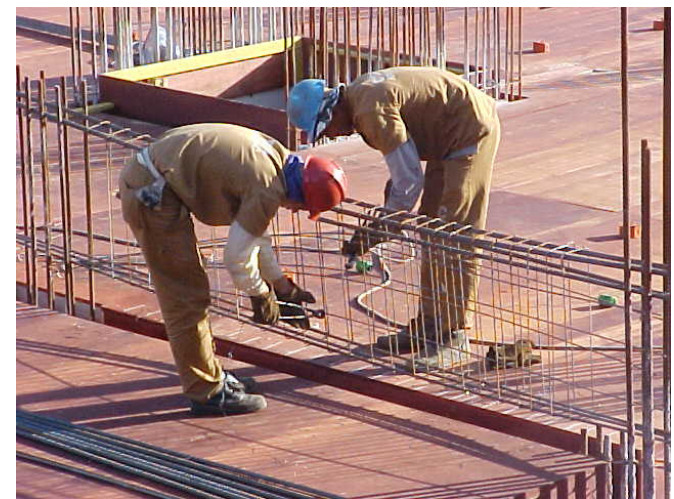

Figura 2.126 - Complementação na montagem da armadura da viga

Há situações, na montagem das vigas que são extremamente trabalhosas, como por exemplo, quando se tem "viga chegando em viga" (Figura 2.127 e Figura 2.128). Ainda nestas situações, quanto maior a densidade de aço, maior a dificuldade em executar a operação.

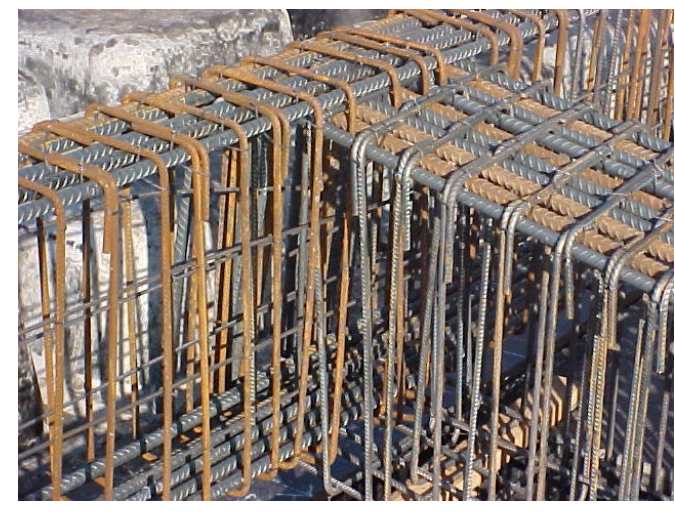

Figura 2.127 - Montagem de armadura vigas que se "encontram"

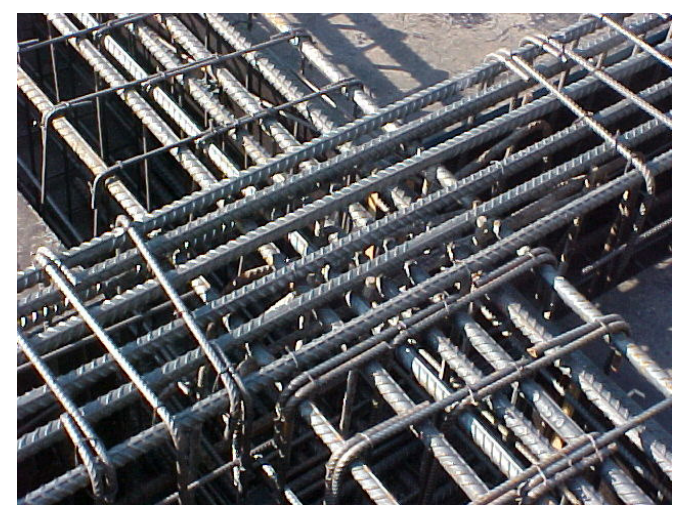

Figura 2.128 - Montagem de armadura vigas que se "encontram"

\subsection{A montagem das armaduras das lajes}

A montagem da armadura da laje pode ser separada em duas macro-etapas, quais sejam, a montagem da armadura positiva e a montagem da armadura negativa, sendo executadas, necessariamente, na mesma ordem em que foram citadas. 
A montagem da armadura positiva pode ser feita da maneira convencional, que se envolvendo a distribuição, sobre a fôrma da laje, de peças longitudinais em dois sentidos e que, depois de amarradas nas intersecções entre elas, constituirão a armadura, ou malha, positiva; ou pode ser feita com o uso de telas soldadas.

A montagem da armadura negativa se inicia após o término da montagem da armadura positiva e da passagem dos eletrodutos pela laje. Em algumas situações é possível que se faça a pré-montagem da armadura negativa, reduzindo o trabalho de montagem dessa armadura na laje (que passa a contemplar o posicionamento das malhas e não mais o de peças individuais).

A operação convencional de montagem da armadura da laje envolve, portanto, as seguintes etapas: i) o transporte das peças ou armaduras pré-montadas; ii) o posicionamento das peças da armadura positiva em um sentido (peças inferiores); iii) posicionamento das peças da armadura positiva transversalmente às primeiras (compondo uma camada superior à anterior); iv) o ponteamento na intersecção das peças; v) a colocação dos espaçadores nas peças inferiores; vi) a distribuição dos distanciadores da armadura negativas (caranguejos ou treliças metálicas, por exemplo); vii) o posicionamento das peças da armadura negativa.

\section{- transporte das peças ou armaduras pré-montadas}

As peças que irão compor a armadura da laje são acondicionadas em feixes, com a respectiva identificação das lajes a que são destinados, sendo, então, transportados ao pavimento em execução. A Figura 2.129 mostra os principais sistemas de transporte verticais adotados pelo canteiro de obras para o transporte das peças da armadura da laje (elevador de obra, grua e transporte manual mediante o uso de "corda", respectivamente). O transporte com o auxílio da grua torna o processo muito mais ágil e é sempre o mais aconselhado, embora requeira que uma série de cuidados sejam tomados, como por exemplo: i) constituição de feixes bem amarrados; ii) içamento com uso de fitas ou cabos apropriados; iii) correto posicionamento das fitas e cabos de içamento; iv) respeito à capacidade de carga do equipamento etc.
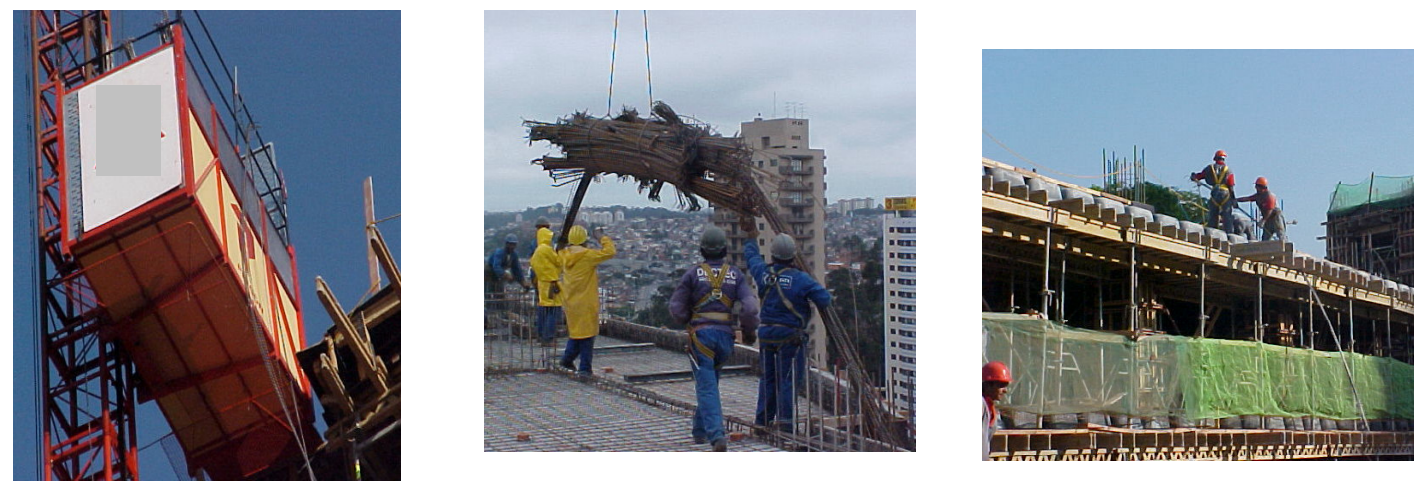

Figura 2.129 - Principais sistema de transporte vertical adotados pelas obras

- posicionamento das peças da armadura positiva 
O posicionamento das peças contempla a sua distribuição segundo os espaçamentos prescritos no projeto de detalhamento. Para tanto, é prática usual dos armadores marcarem previamente na fôrma da laje, com uso de um giz, os locais onde serão posicionadas cada uma das peças, facilitando a distribuição das mesmas, conforme ilustrado na Figura 2.130 e na Figura 2.131. O mesmo procedimento é adotado para a distribuição das peças superiores e transversais às inferiores.

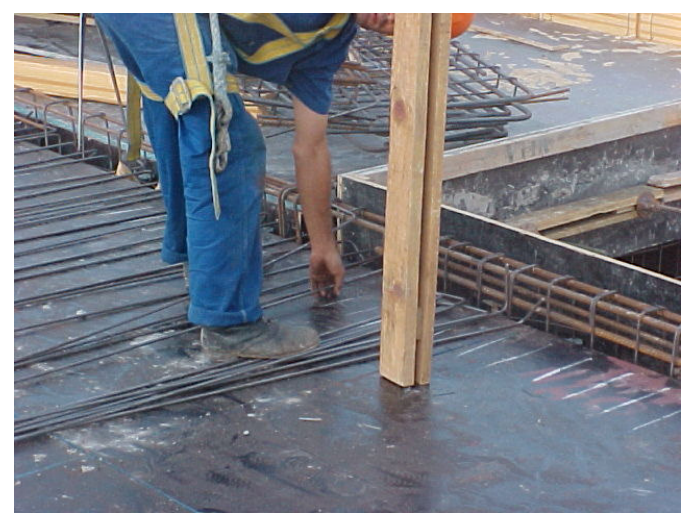

Figura 2.130 - Marcação na fôrma para facilitar a distribuição das peças

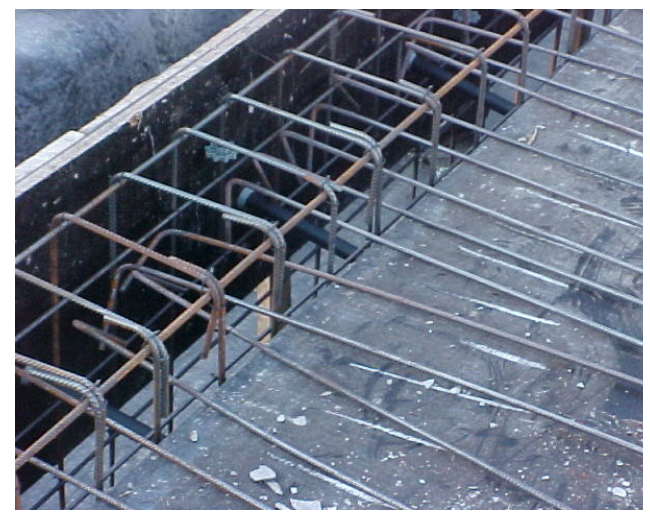

Figura 2.131 - Distribuição das peças positivas inferiores

\section{- ponteamento na intersecção das peças}

O ponteamento na intersecção entre as peças consolida a armadura positiva da laje (Figura 2.132), devendo assegurar que as barras permaneçam espaçadas, conforme previsto no projeto de detalhamento. Daí a necessidade de que os pontos sejam dados numa quantidade adequada. A quantidade de pontos não é prevista no projeto e nem mesmo descriminada em norma; acaba sendo definida pelos próprios armadores. 0 trânsito intenso sobre a laje armada pode tirar da posição as peças, indicando a necessidade de se aumentar a quantidade de pontos dados. Quando são previstas barras lisas (barras de aço CA 60 com diâmetro nominal de $5 \mathrm{~mm}$ ) para a armadura das lajes, faz-se necessário uma maior número de pontos (por $\mathrm{m}^{2}$ de laje armada), e/ou mesmo, pontos reforçados para evitar que as barras saiam do seu posicionamento ("escorreguem").

As pontas de arame recozido, oriundas do ponteamento devem ser recolhidas das fôrmas da laje antes da concretagem (a oxidação dos arames, quando não retirados, pode manchar os revestimentos em gesso); os armadores utilizam, para a realização desta tarefa, hastes com imãs na ponta, conforme ilustrado na Figura 2.133. 


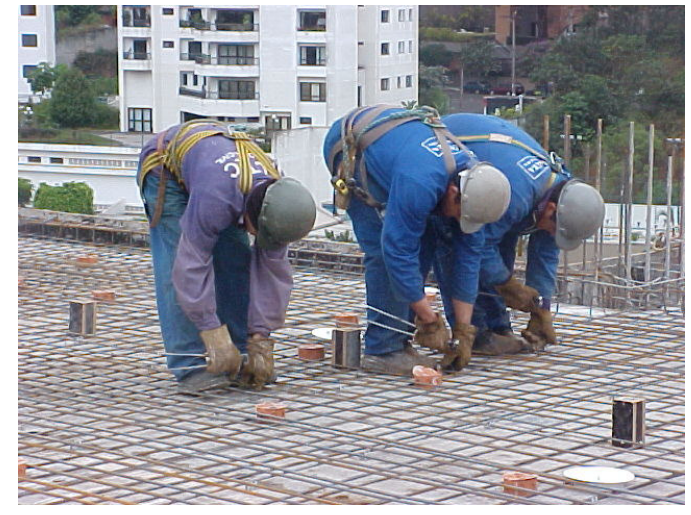

Figura 2.132 - Armadores dando pontos na armadura positiva

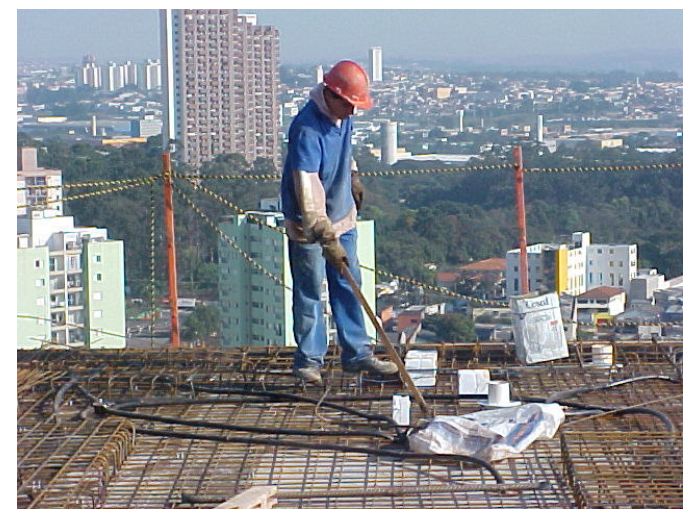

Figura 2.133 - Armador recolhendo sobras de arame recozido na laje

A Figura 2.134 e a Figura 2.135 mostram algumas sugestões para o ponteamento ${ }^{51}$ da armadura das lajes em função do espaçamento das peças.

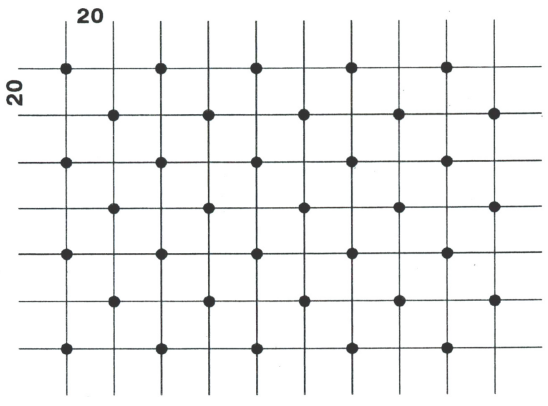

Figura 2.134 - Sugestão de ponteamento para espaçamento maior ou igual a $20 \mathrm{~cm}$

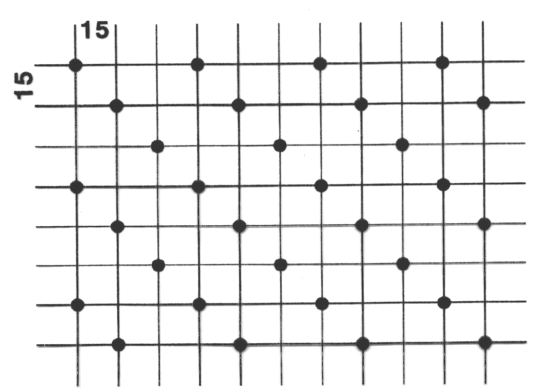

Figura 2.135 - Sugestão de ponteamento para espaçamento maior ou igual a $15 \mathrm{~cm}$

\section{- posicionamento dos espaçadores}

A garantia de que as espessuras de cobrimento das armaduras da laje, especificadas no projeto de detalhamento segundo prescrição da norma NBR 6118:2003, ocorram na prática depende do correto e adequado posicionamento dos espaçadores. Os espaçadores (Figura 2.136), no caso específico das lajes, irão manter a malha de armadura positiva coberta, e portanto, protegida, por uma camada de concreto. A distribuição dos espaçadores (quantidade por $\mathrm{m} 2$ de armadura de laje), não é prevista em projeto e normas; conforme já comentado, quando discutido o posicionamento dos espaçadores nas armaduras de pilares e vigas, a sua distribuição se dá de forma aleatória e é

51 Deve-se considerar, também, na determinação do número e na disposição dos pontos, os diâmetros das peças (na amarração de peças como diâmetros superiores a 6,3mm (densidades mais altas e presença de nervuras) pode-se reduzir o número de pontos (ou seja, ter-se pontos mais espaçados)). 
determinada pelos operários que executam o serviço. O momento para colocação dos espaçadores da armadura positiva da laje é aquele que precede o ponteamento das peças positivas. Vale dizer que quando a malha fica muito pesada (em razão da densidade de armadura e/ou diâmetro das barras utilizadas), os armadores utilizam barras como alavancas, suspendendo a armaduras para, em seguida, posicionarem os espaçadores.
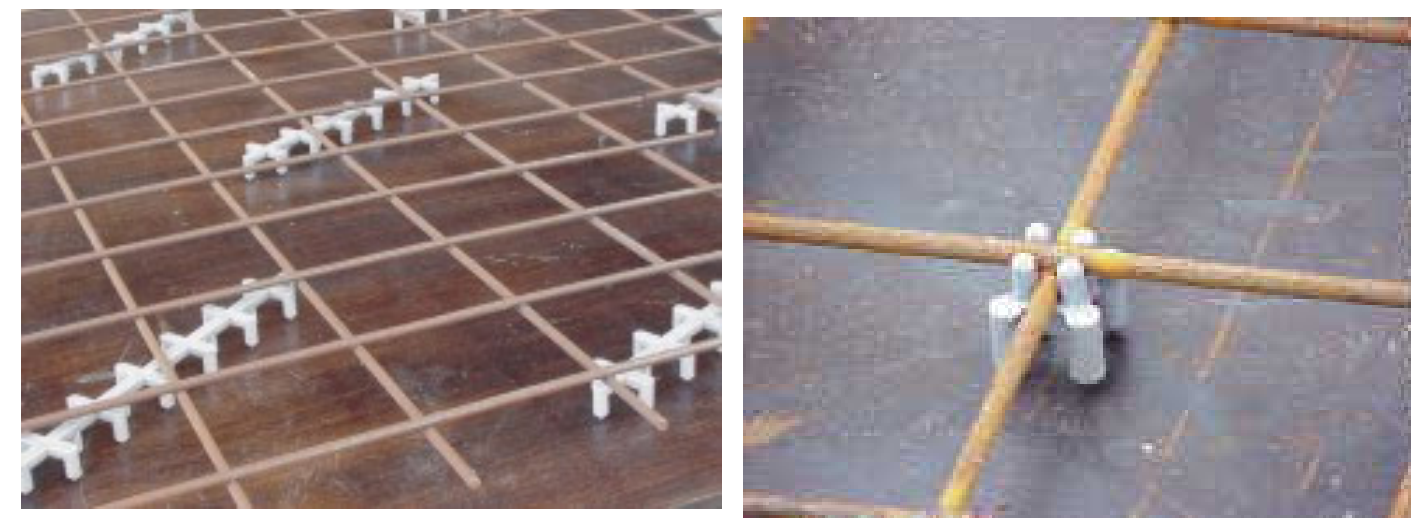

Figura 2.136 - Exemplos de espaçador para a armadura positiva da laje

\section{- posicionamento das peças da armadura negativa}

A armadura negativa da laje requer cuidados especiais a fim de que seja posicionada de acordo com as prescrições de projeto e assim permaneça durante e, principalmente, após a concretagem da laje. A não obediência aos distanciamentos impostos pelo projeto estrutural pode acarretar sérios prejuízos ao elemento estrutural devido a decréscimos na sua capacidade resistente. ZORZI (2001) alerta, através de um exemplo hipotético (Figura 2.137), que se a armadura negativa de uma laje, prevista para estar posicionada a $12 \mathrm{~cm}$ do fundo da laje, sofrer prejuízos e sair $4 \mathrm{~cm}$ da sua posição original, ficando a $8 \mathrm{~cm}$ do fundo da laje, a peça perderá $56 \%$ de sua capacidade resistente.

Para posicionar as peças que irão compor a armadura negativa a distâncias prédeterminadas do fundo da laje (Figura 2.138), são utilizados elementos de suporte, ou espaçadores. Os espaçadores mais comumente utilizados são peças denominadas "caranguejos", como ilustrado na Figura 2.139. Os caranguejos devem ser confeccionados com barras de aço de diâmetro igual ou superior a $8 \mathrm{~mm}$, a fim de que se garanta um suporte adequado e eficiente às peças posicionadas sobre eles. Para esta mesma causa, faz-se importante que se distribuam, corretamente, um número adequado de caranguejos. A quantidade, bem como o mapeamento com a distribuição destes elementos sob a armadura negativa são informações não disponibilizadas em projeto. Decisões a este respeito são tomadas empiricamente pelos armadores na obra. 


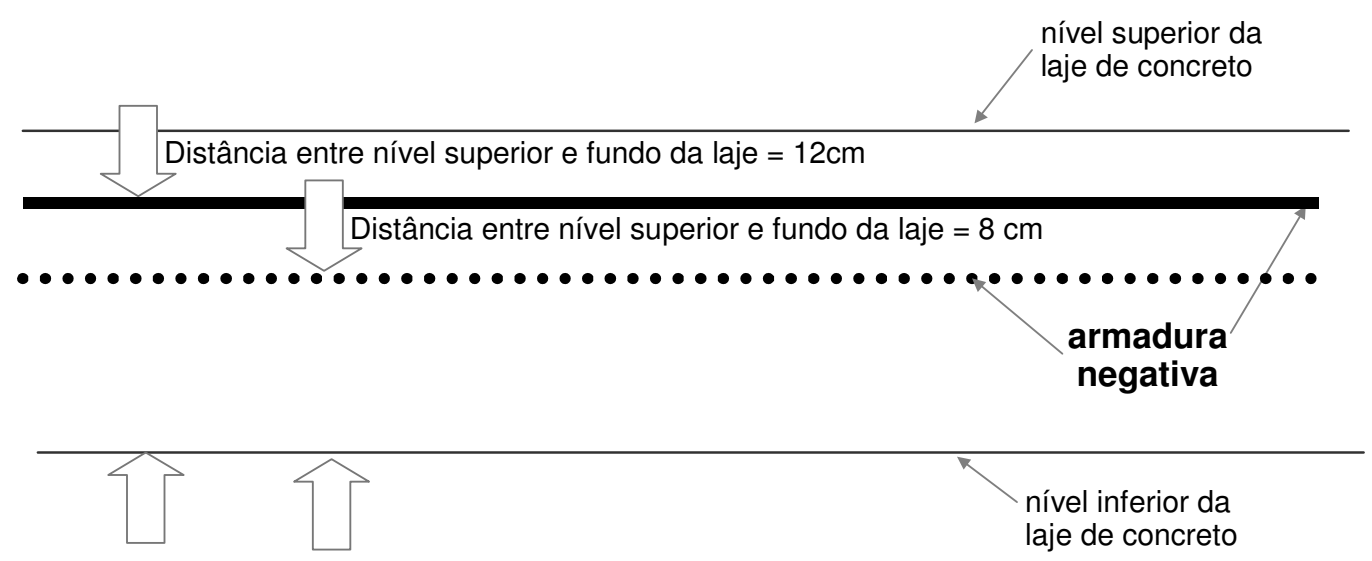

Figura 2.137 - Posicionamento da armadura negativa da laje. Fonte: ZORZI (2001)

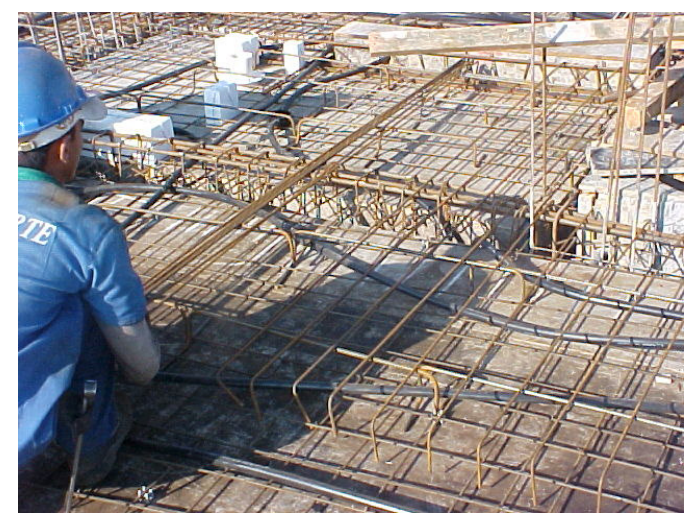

Figura 2.138 - Distribuição das peças da armadura negativa

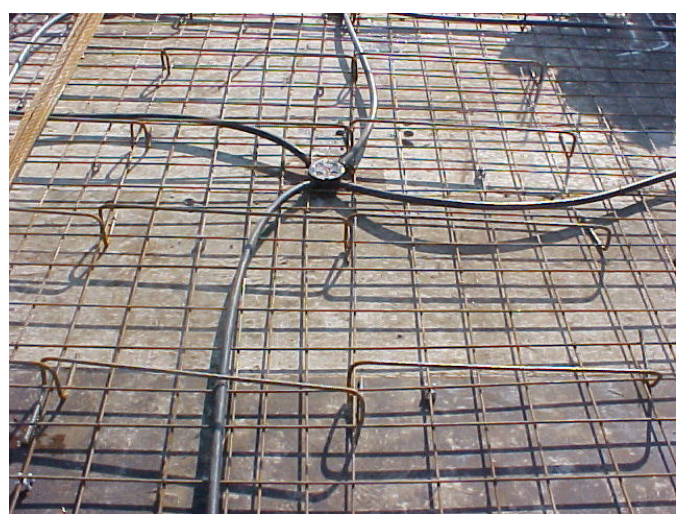

Figura 2.139 - Caranguejos distribuídos sobre a laje

Em substituição aos caranguejos, algumas construtoras paulistanas têm adotado o uso de treliças metálicas (Figura 2.140). As treliças, por serem elementos estruturados, são bem mais resistentes que os caranguejos na função de suportar a armadura negativa e as cargas incidentes sobre elas em razão do trânsito de pessoas e equipamentos durante, principalmente, a execução da concretagem da laje. A treliças, ao contrário dos caranguejos são elementos fabricados fora do canteiro de obras. Os fabricantes recomendam que o espaçamento entre linhas de treliça (Figura 2.140) esteja situado entre 80 e $120 \mathrm{~cm}$, variando em função do diâmetro das peças da armadura negativa; já os espaçamentos numa mesma linha, devem ser de $40 \mathrm{~cm}$, alternados entre linhas de treliça. Vale a pena citar que, atualmente, são comercializadas treliças com alturas variáveis (entre 6 e $25 \mathrm{~cm}$ ). 

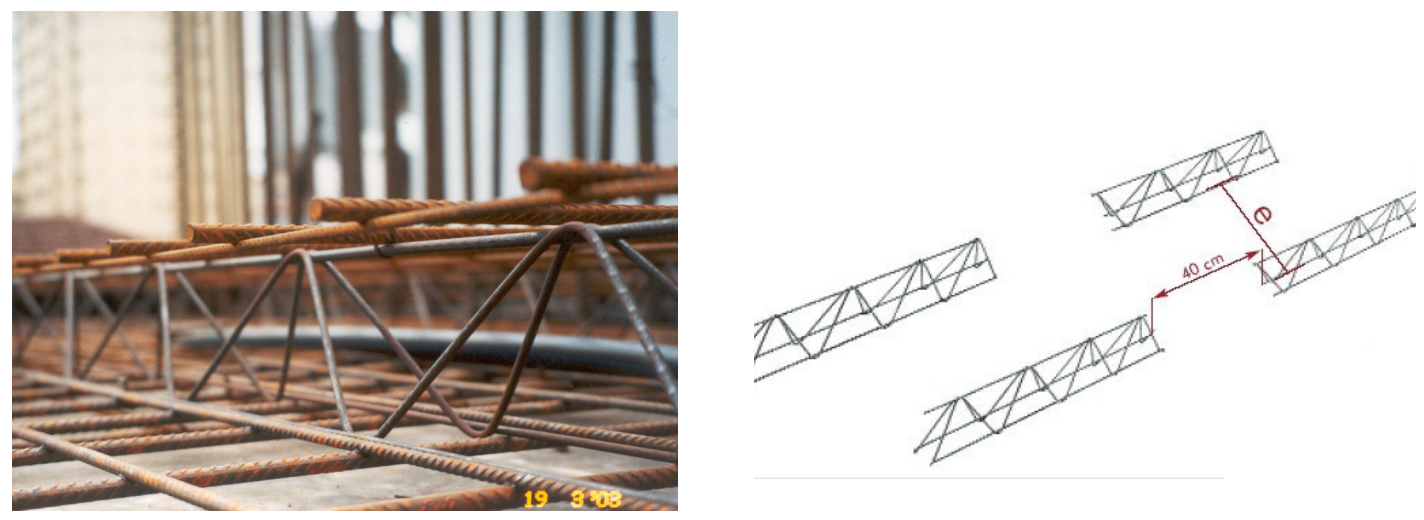

Figura 2.140 - Exemplos de treliças metálicas 


\section{A Organização do Trabalho no Âmbito da Gestão da Produção}

"Toda vez que os homens de negócio deram-lhe um uso correto, o caminhão a motor tem mostrado que é um excelente substituto para o cavalo. Mas o homem que usa o caminhão a motor simplesmente como um substituto do cavalo deixa de obter o máximo de suas potencialidades. $O$ cavalo não é uma máquina: seu dia de trabalho limita-se a 5 ou 6 horas, por um percurso de 25 a 40Km. Um caminhão a motor pode ser usado 24 horas por dia se necessário, e viaja com a mesma velocidade da primeira à ultima hora, do primeiro ao centésimo quilômetro.

Os executivos que estão usando com grande sucesso o caminhão a motor são aqueles que estudaram o problema atenciosamente. Em muitos casos foi necessário mudar as rotas - as esperas necessárias para o descanso dos cavalos foram eliminadas, e o projeto das rotas foi pensado para manter o caminhão ocupado o dia inteiro, com menos esperas possíveis..".

Propaganda de 1910 da International Commercial Truck. HAYES; JAIKUMAR, 1988

\subsection{Notas introdutórias do capítulo}

A organização do trabalho (como será tratada no decorrer do capítulo), está intimamente ligada à atividade (ou à arte) de gerenciar pessoas. Sua complexidade está justamente no fato de envolver-se com um recurso que possui vontade própria (assim como desejos e aspirações) e que precisa ser regido, com maestria, de maneira a proporcionar o melhor desempenho possível.

O presente capítulo se inicia com um rápido entendimento da "função produção" (pois é a partir da "produção" que se desenvolve o trabalho) dentro de uma empresa. O caráter central que assume essa função justifica preocupação especial com o gerenciamento, levando o capitulo a tratar a gestão da produção e sua importância estratégica para a empresa. O passo seguinte é a definição do escopo da gestão da produção e, por conseguinte, das suas atividades funcionais.

Entende-se que a organização do trabalho na produção trata-se de uma das atividades funcionais da gestão, assim como o planejamento da produção também o é, e que ambas mantêm fortes correlações entre si. Após uma rápida passada por alguns aspectos do planejamento, elege-se a organização do trabalho como o ponto central das discussões no capítulo.

Revisam-se algumas abordagens teóricas da organização do trabalho, cuja evolução está associada ao próprio desenvolvimento das teorias da administração ao longo dos séculos. Percebe-se que, à medida que as teorias evoluem, releva-se o papel do "recurso humano", que passa a ter o "status" e tratamento de principal "ativo", principalmente em funções operacionais no âmbito dos processos de produção conduzidos pela organização.

Embora se saiba que a organização do trabalho influencia e pode ser influenciada por outros recursos, que não apenas a mão-de-obra, no caso específico deste trabalho, ao se referir a ela, estar-se-á considerando apenas aspectos relacionados aos recursos humanos.

Passa-se, portanto, a enxergar a organização do trabalho como um processo que, ao ser conduzido, deverá, entre outros: i) definir a forma pela qual as pessoas deverão agir em relação ao seu trabalho; ii) alinhar as expectativas destas pessoas com o trabalho que 
Ihes é requerido; iii) influenciar a percepção das pessoas de como elas podem contribuir favoravelmente para a organização e para si próprias.

Entende-se que a organização do trabalho é (e deve ser cada vez mais) flexível. Tratase, ainda, de um processo evolutivo que precisa enxergar e considerar tanto mudanças comportamentais da sociedade, como mudanças nos processo de produção. Dessa forma, não existe uma receita de organização do trabalho, mas sim, pontos que devem ser considerados e que são imprescindíveis, seja para a melhoria da produtividade, seja para a melhoria das condições de vida e de trabalho dos participantes ${ }^{52}$. Encerra-se o capítulo com a eleição de alguns desses pontos que, no âmbito do processo de produção e dos objetivos pretendidos neste trabalho, serão de grande relevância.

\subsection{A Função Produção dentro de uma organização}

Diferentes organizações possuem estruturas organizacionais e funções bastante diferentes. Porém, qualquer que seja a organização, terá sempre a função produção porque produz algum tipo de bem e/ou serviço, razão da sua existência. Embora a função produção não seja única, pois existem outras tão importantes quanto ela (por exemplo a função marketing, a função contábil-financeira, a função desenvolvimento do produto entre outras), acaba assumindo caráter central na organização.

Essa importância é comentada por SLACK et al. (1999) que, em sua obra "Administração da Produção", ao colocar a função produção na estrutura de uma organização em posição de destaque, assim comentam:

[...] a função produção na organização representa a reunião de recursos destinados à produção de seus bens e serviços. Qualquer organização possui uma função produção porque produz algum tipo de bem e/ou serviço. Se a função produção for eficaz, deve usar eficientemente os seus recursos e produzir bens e serviços de maneira que satisfaça a seus consumidores". Ainda segundo o mesmo autor, "a função produção deve ser criativa, inovadora e vigorosa para introduzir formas novas e melhoradas de produzir bens e serviços. Se fizer isso ela proporcionará à organização os meios de sobrevivência em longo prazo porque dá a ela uma vantagem competitiva sobre seus rivais comerciais.

STARR (1988), de maneira objetiva, define a produção como sendo qualquer processo ou procedimento que tem por objetivo transformar um conjunto de entradas em um conjunto específico de saídas. E assim divide o sistema de produção em três partes: entradas, saídas e processo.

ROSSO (1980) define produção como sendo "a formação do produto conseguida através de transformações industriais que aumentam a utilidade dos bens e serviços empregados para consegui-lo, aos quais se denomina insumos".

52 Acredita-se que o passo mais importante para propor uma organização de trabalho, num determinado processo de produção, que contribua fortemente para a melhoria da produtividade da mão-de-obra, é entender que a relação entre as partes envolvidas nesta organização, quais sejam os "comandantes" e os "comandados", é "simbiótica", ou seja, deve render benefícios mútuos. 
A produção envolve um conjunto de recursos de entrada ("input") usado para transformar algo ou para ser transformado em saídas ("outputs"), sob a forma de bens e serviços.

Conforme apresentado na Figura 3.1, os inputs para a produção são classificados, segundo SLACK et al. (1999), em: i) recursos transformados, sendo aqueles que são tratados, transformados ou convertidos de alguma forma (materiais, informações e consumidores); ii) recursos de transformação, que são aqueles (instalações, funcionários) que agem sobre os recursos transformados.

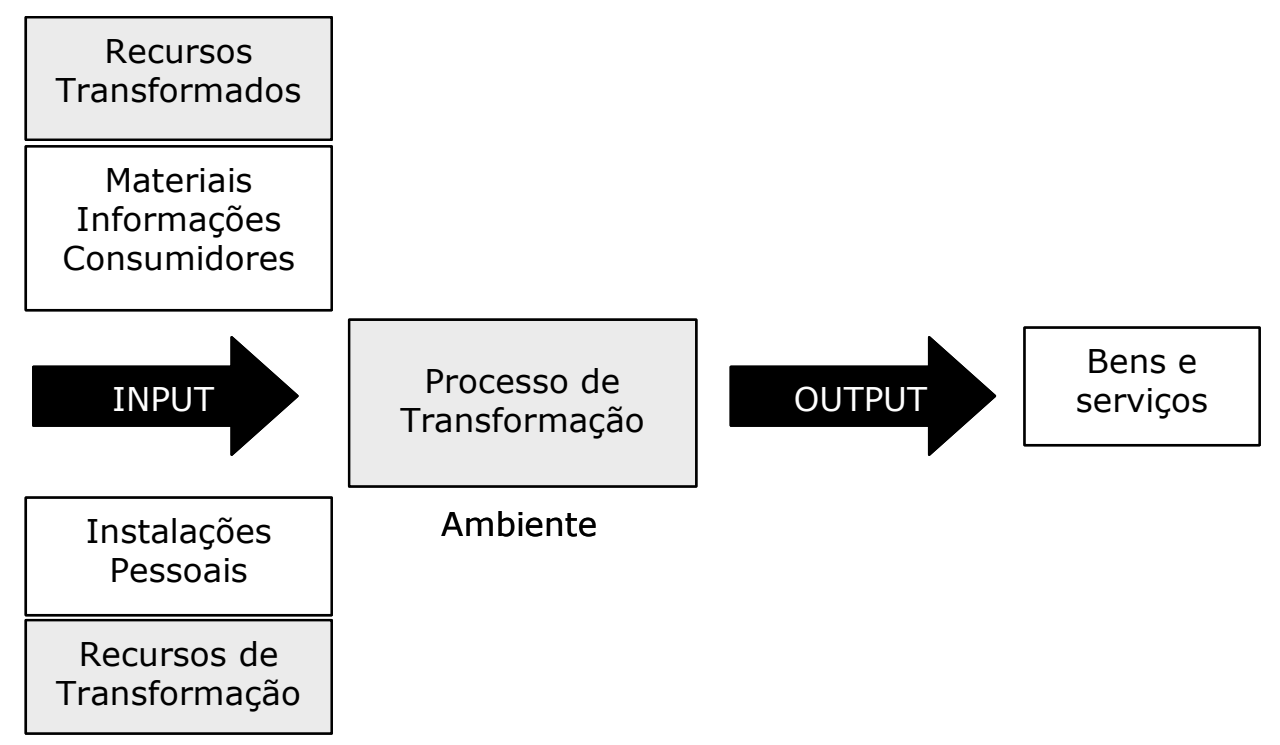

Figura 3.1 - Processo de produção segundo SLACK at al. (1999)

\subsubsection{A Hierarquia do sistema de produção}

Qualquer função produção pode ser considerada como envolvendo um conjunto de operações hierarquicamente arranjadas (Figura 3.2), tendo para SLACK et al. (1999), duas implicações importantes: a primeira diz respeito à ligação das micro-operações para formar os relacionamentos dos consumidores e clientes internos ${ }^{53}$; a outra se preocupa com a forma de enxergar todas as partes da organização como operações que requerem administração da produção.

CARDOSO (1997) entende o termo produção como sendo bastante abrangente e, para defini-lo, associa-o ora a um "processo", ora a um "sistema". Assim sendo, define o "processo de produção" como "um conjunto de etapas físicas, organizadas de forma coerente no tempo, que levam à construção e ao uso de uma edificação". O processo,

${ }^{53} \mathrm{Na}$ definição de SLACK et al. (1999), as expressões "consumidor interno" e "fornecedor interno" podem ser usadas para descrever aqueles que recebem outputs e fornecem inputs a qualquer micro-operação. 
segundo o autor, engloba as atividades de: i) projeto; ii) planejamento; iii) execução; iv) avaliação pós-ocupacional.

Quanto ao "sistema de produção", o autor o define como "os meios de articulações entre operações físicas de produção (que envolvem os métodos e procedimentos de execução, os recursos como equipamentos, ferramentas e mão-de-obra) e as operações de planificação, de direção, de controle, de avaliação dos resultados, assim como as estruturas organizacionais mobilizadas para tanto".

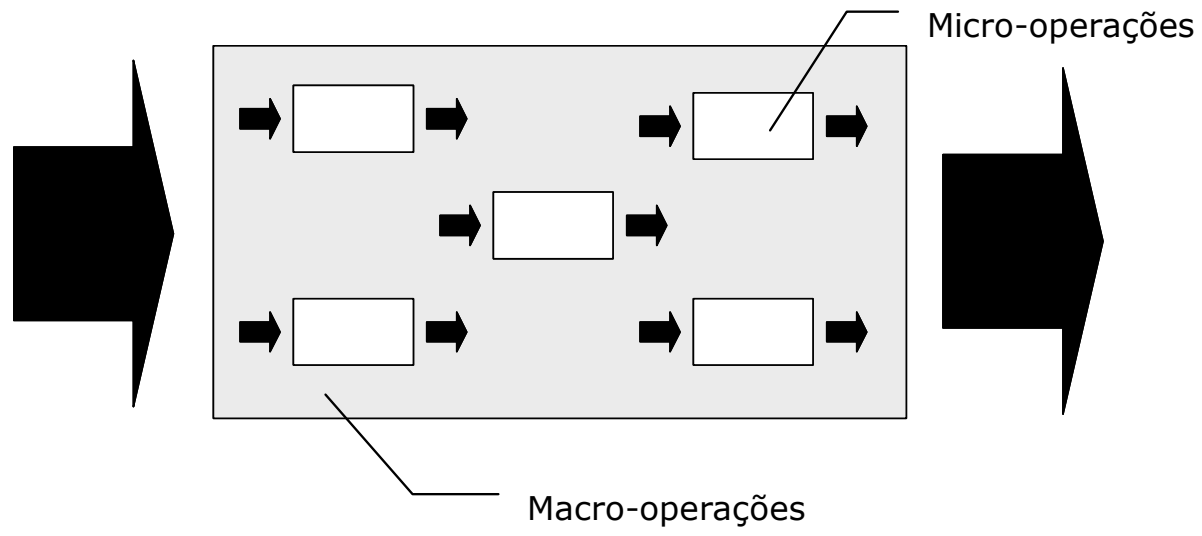

Figura 3.2 - Hierarquia das operações: as macro-operações são formadas de microoperações. Fonte: SLACK et al. (1999)

\subsubsection{O papel estratégico e os objetivos da função produção}

\subsubsection{A contribuição da função produção na competitividade da organização}

FLEURY (1997), ao fazer um resgate histórico das mudanças esperadas nas estratégias das empresas, aponta 1990 como o ano da transição para um contexto organizacional industrial marcado pelos parâmetros da competitividade. Esse mesmo autor, assim como outros que acompanharam o comportamento das empresas num cenário econômicofinanceiro inédito, constatou que "as novas condições ambientais alteraram algumas premissas básicas em que pautavam a condução das operações nas empresas".

O mesmo autor supracitado cita a descoberta da importância do mercado (o mercado não estava mais protegido e o desafio advindo de empresas estrangeiras era iminente) e de uma nova fórmula para a determinação dos "preços" (a fórmula que regia o comportamento das empresas e, até então, definia os preços (expressa por: preço=custo+lucro), funcionara muito bem nos tempos de proteção e subsídios, mas não mais no novo cenário macroeconômico).

$\mathrm{Na}$ nova fórmula (expressa por: preço (nível internacional)-custo=lucro), a gestão dos custos passou a ser "um determinante maior na lucratividade das empresas".

HOPP; LEITE (1990) assim anteviram o final da década de 90:

Um período de grandes ajustamentos na economia brasileira se avizinha, ditados pelo combate à inflação e aberturas de mercado. Esses fatores farão retomar na ordem do dia, o tema custos e a atenção dos administradores 
haverá de ser deslocada, do mercado financeiro para a fábrica, onde, afinal, nascem tanto os lucros quanto os prejuízos.

FLEURY (1997) analisou algumas reações de empresas brasileiras frente ao novo contexto competitivo que se firmara. Algumas pesquisas revelaram que melhorias na qualidade do produto estavam ocorrendo com aumento de custos e de preços.

Na prática das empresas, o custo é o principal indicador do uso eficiente e inteligente dos recursos disponíveis. A maior parte das empresas brasileiras tentou introduzir conceitos e técnicas de qualidade sem dispor de conceitos e sistemas sobre gestão de custos; ou seja, sem um posicionamento fundamentado quanto ao uso eficiente e inteligente de seus recursos.

Percebe-se que a função produção, no final do século passado, assumiu uma responsabilidade que, embora intrínseca, havia ficado em estado de dormência por alguns anos.

Para ARAÚjO (2000), "a eficiência nos processos produtivos surge como um objetivo a ser alcançado pelas empresas construtoras a fim de garantir lucratividade e, por conseguinte, assegurar sua permanência no mercado".

A função produção assume "papéis" que, segundo SLACK et al. (1999), vão além das "suas responsabilidades e tarefas óbvias na empresa". Segundo esse autor a função produção exerce três papéis importantes dentro de qualquer organização:

- como apoiadora da estratégia global da organização: através do desenvolvimento dos recursos de produção de maneira a torná-los mais apropriados, em qualquer que seja a estratégia escolhida;

- como implementadora das estratégias organizacionais: a operação deve assegurar que a estratégia da empresa funcione na prática;

- como líder da estratégia: a função produção deve fornecer à organização todos os aspectos de desempenho de que necessita para atingir seus objetivos (competitivos) no longo prazo.

SLACK et al. (1999), ao abordarem o papel da função produção nos planos estratégicos da produção, assumem a prerrogativa de que qualquer organização que deseje ser bem sucedida a longo prazo tem, na função produção, uma contribuição vital. "Ela dá à organização uma vantagem baseada em produção". Porém, o autor preocupa-se em como mensurar a contribuição da função produção para a competitividade da organização. Elege, para tanto, cinco objetivos de desempenho da função produção, que podem ser buscados caso a organização realmente deseje obter vantagem "baseada na produção", quais sejam:

- a qualidade dos bens e serviços oferecidos pela operação;

- a rapidez com que são entregues os bens e serviços;

- a confiabilidade na entrega;

- a flexibilidade da produção em mudar;

- o custo de produzir bens e serviços.

Todos os objetivos supracitados têm efeitos externos e internos (Figura 3.3). "Pode-se ter como efeito interno da alta qualidade, rapidez, confiabilidade e flexibilidade a redução dos custos da produção". (SLACK et al. 1999). 


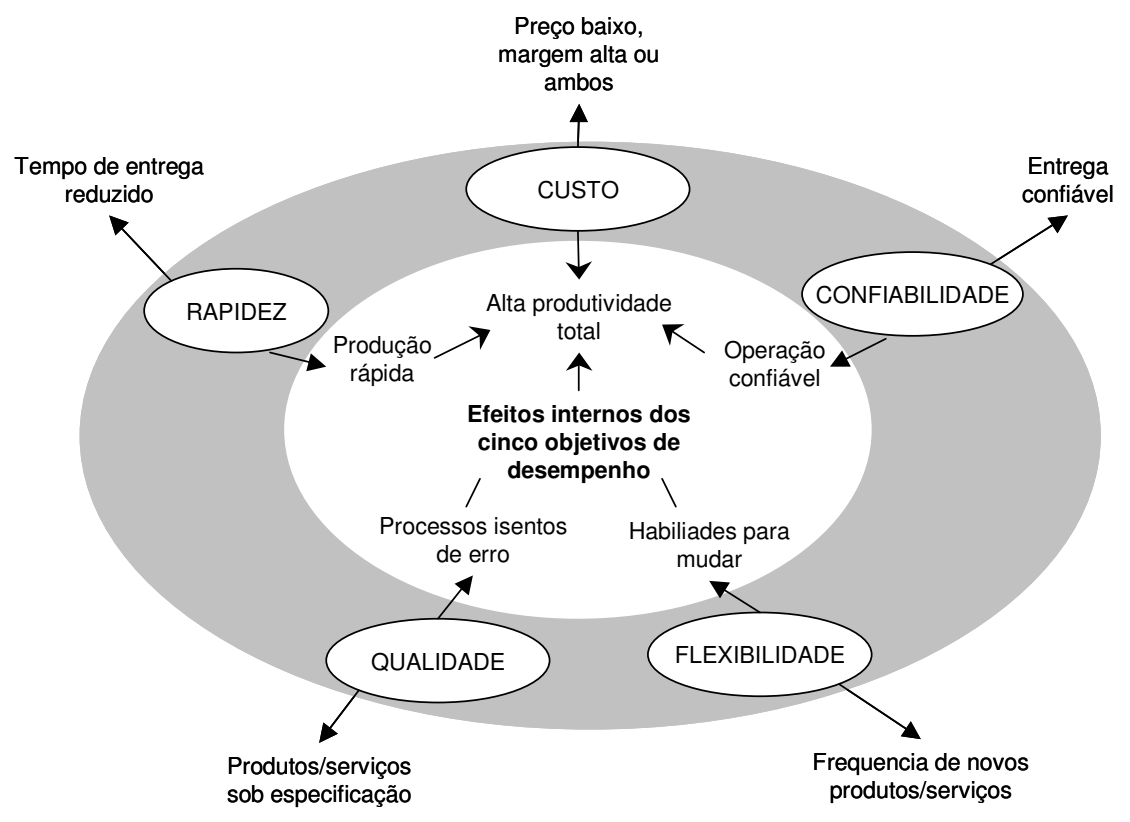

Figura 3.3 - Efeitos internos e externos dos objetivos de desempenho. Fonte: SLACK et al. (1999).

Dentre os objetivos apresentados o custo figura como o mais importante, principalmente dentre aquelas empresas que concorrem diretamente por preço. "Mesmo aquelas empresas que concorrem em outros aspectos que não preço estarão interessadas em manter seus custos baixos. Cada fração monetária retirada do custo de uma operação é acrescida a seus lucros. Não surpreende que o custo baixo é um objetivo universalmente atraente". (SLACK et al. 1999).

Para CARDOSO (1996a), o nível estratégico passou a representar um papel primordial na busca de melhoria das competências produtivas da empresa. Uma das conclusões a que chegou foi a de que

[...] o problema da ineficiência produtiva das empresas se associava ao de falta de eficácia competitiva. Para sobreviver, e se desenvolver no contexto do setor, a empresa de construção não se podia contentar em ser somente eficiente, nem de bem gerir as atividades que desenvolvia ao longo do sistema de produção, ou mesmo do processo de produção; ela deveria se tornar igualmente mais competitiva e tender à eficácia a partir desta perspectiva.

A essência da tese defendida por CARDOSO (1996a) foi a de que a "eficácia da empresa de construção, no contexto contemporâneo, está fortemente associada aos ganhos de eficiência obtidos ao longo das diferentes etapas do processo de produção em geral, e do sistema de produção em particular".

CARDOSO (1996a) é bastante objetivo ao dizer que a "eficácia da empresa, ou ainda, sua vantagem concorrencial, estabelece-se segundo uma lógica técnico-econômica: para sobreviver, a empresa deve ganhar a competição seja produzindo melhor, seja produzindo mais barato". 
A "solução" apontada por CARDOSO (1996a) para a questão da eficácia é obtida através da intervenção no seio da empresa de construção (ou seja, na produção), e/ou no nível dos atores da cadeia produtiva e suas relações.

\subsubsection{A estratégia de Produção}

SLACK et al. (1999) assumem a definição de que estratégia "é o padrão global de decisões e ações que posicionam a organização em seu ambiente e tem o objetivo de fazê-la atingir seus objetivos de longo prazo". Segundo os autores, todas as organizações precisam de alguma direção estratégica, ocorrendo a mesma necessidade para a função produção.

A bibliografia consultada (CARDOSO (1996a); SLACK et al. (1999) etc) trata a estratégia segundo três diferentes níveis, que constituem a hierarquia de estratégias:

- macro: neste nível a estratégia é denominada corporativa ("corporate strategy") e, em resumo, orienta e conduz a corporação em seu ambiente global, econômico, social e político corporativo;

- médio: neste nível fala-se em estratégia de "negócios" ou concorrencial ("business strategy"), da empresa com um setor preciso do mercado;

- micro: trata-se da estratégia de função ("operating" ou "functional strategy"), ou de um serviço da empresa em face do desempenho global esperado.

Neste trabalho considera-se essencialmente o último nível da hierarquia (micro), que trata da estratégia da função produção, ou simplesmente, estratégia de produção.

Uma vez que a função produção entendeu seu papel dentro do negócio como um todo, após determinar os objetivos de desempenho que definem sua contribuição para a estratégia, ela precisa formular um conjunto de princípios gerais que guiará o seu processo de tomada de decisões. Isto é a estratégia de produção da empresa. SLACK et al. (1999)

A produção, como já se comentou anteriormente, poder ser composta de diversas microoperações. Cada uma delas pode ter uma estratégia de produção que identifica como a micro-operação vai contribuir para a estratégia de produção da macro-operação.

No nível da microoperação, a estratégia de produção é definida por SLACK et al. (1999) como sendo o "padrão global de decisões e ações que define o papel, os objetivos e atividades de cada parte da produção de forma que apóiem e contribuam para a estratégia de produção do negócio".

O autor supracitado aponta que o conteúdo da estratégia de produção é o conjunto de políticas, planos e comportamentos que a produção escolhe para seguir. "Além de determinar quais são os objetivos de desempenho mais significativos (importância relativa dos objetivos de desempenho para a produção), uma outra característica de uma estratégia de produção é que ela estabelece a direção geral para cada uma das principais áreas de decisão da produção (faz isso formulando diversas estratégias que tratam com projeto, planejamento e controle e melhoria)".

CARDOSO (1997) aponta que, num nível abaixo da estratégia competitiva, encontram-se as estratégias ligadas às diferentes funções da empresa, dentre as quais a estratégia de produção. "Assim, uma vez escolhida a estratégia competitiva, a empresa deve optar por uma estratégia de produção que seja coerente com ela". A Tabela 3.1 reproduz a proposta de CARDOSO (1997) quanto à "tipologia para as estratégias de produção" passíveis de serem colocadas em prática pelas empresas construtoras. 
Tabela 3.1 - As diferentes estratégias de produção em função da estratégia competitiva escolhida. CARDOSO (1997)

\begin{tabular}{|c|c|c|}
\hline $\begin{array}{l}\text { Estratégia } \\
\text { Competitiva }\end{array}$ & $\begin{array}{l}\text { Estratégia de } \\
\text { Produção }\end{array}$ & $\begin{array}{c}\text { Lógicas técnico-econômicas } \\
\text { subentendidas }\end{array}$ \\
\hline \multirow{4}{*}{$\begin{array}{l}\text { Competição pela } \\
\text { liderança em } \\
\text { custos }\end{array}$} & $\begin{array}{l}\text { Engenharia } \\
\text { simultânea }\end{array}$ & $\begin{array}{l}\text { Centrada nas relações empresa } x \text { projetistas, visa } \\
\text { à integração precoce das necessidades da } \\
\text { produção desde a concepção. }\end{array}$ \\
\hline & Sócio-técnica & $\begin{array}{l}\text { Centrada no sistema de produção, permite ganhos } \\
\text { de custos devidos ao domínio das técnicas e dos } \\
\text { métodos construtivos e ao cuidado particular } \\
\text { dedicado à mão-de-obra de produção. }\end{array}$ \\
\hline & $\begin{array}{l}\text { Gestão pelos fluxos e } \\
\text { parcerias }\end{array}$ & $\begin{array}{l}\text { Supõe-se a externalização da produção, } \\
\text { permitindo realizar ganhos de custos graças à } \\
\text { capacidade de gestão bem desenvolvida dos fluxos } \\
\text { de operações e de informações que circulam na } \\
\text { obra. }\end{array}$ \\
\hline & Técnico-comercial & $\begin{array}{l}\text { Válida para os casos de autofinanciamentos, está } \\
\text { baseada em forma de organização que permita o } \\
\text { nivelamento das equipes de produção próprias e } \\
\text { daquelas dos subempreiteiros, atendendo à } \\
\text { necessidade de aumento dos prazos dos canteiros. }\end{array}$ \\
\hline $\begin{array}{l}\text { Competição pela } \\
\text { diferenciação }\end{array}$ & Qualidade total & $\begin{array}{l}\text { Visa fornecer aos clientes um produto que } \\
\text { apresente, ao mesmo tempo, qualidade enquanto } \\
\text { produto-edifício, assim como qualidades } \\
\text { intrínsecas ao objeto construído. }\end{array}$ \\
\hline \multirow[t]{2}{*}{$\begin{array}{l}\text { Competição pela } \\
\text { diferenciação }\end{array}$} & $\begin{array}{l}\text { Redução global dos } \\
\text { prazos }\end{array}$ & $\begin{array}{l}\text { Seu objetivo maior é atrair os clientes graças à } \\
\text { capacidade de organização e de condução dos } \\
\text { processos de produção que permitam ganhos de } \\
\text { tempo. Seu princípio é o de intervir, } \\
\text { simultaneamente, nas etapas associadas à } \\
\text { concepção e naquelas ligadas ao canteiro. }\end{array}$ \\
\hline & Oferta de serviços & $\begin{array}{l}\text { Seu objetivo maior é atrair os clientes graças à } \\
\text { oferta, por parte da empresa de construção, de } \\
\text { diferentes tipos de serviços, ao longo do processo } \\
\text { de produção. }\end{array}$ \\
\hline
\end{tabular}

Muito embora a análise estratégica não tenha constituído um fim em si da pesquisa feita por CARDOSO (1996b), ela serviu para tratar a questão da competência produtiva das empresas de construção. Permitiu ao autor, falar da estratégia de produção, à qual passou a se referir como racionalização da produção. Essa "troca terminológica" foi assim justificada pelo autor supracitado: "em vez de se empregar o termo "estratégia da produção", preferiu lançar mão do conceito de "racionalização da produção", à medida em que este último leva em consideração, ao mesmo tempo, a eficácia, os condicionantes ambientais e a eficiência técnico econômica dos processos de produção". 


\subsection{A Gestão ${ }^{54}$ da Produção}

O dicionário Aurélio traz, entre outras, as seguintes definições para a palavra gestão: 1 . atividade ou processo de administração de uma empresa, instituição, etc.; ato de gerir; 4. utilização racional de recursos em função de um determinado projeto ou de determinados objetivos.

MONKS (1987) define a administração da produção como sendo a "atividade pela qual os recursos, fluindo dentro de um sistema definido, são reunidos e transformados de uma forma controlada, a fim de agregar valor, de acordo com os objetivos empresariais".

Os administradores da produção concebem seu campo, segundo STARR (1988), como "consistindo de desenvolvimento e operação de um processo para conseguir que o trabalho seja feito. Em sua opinião, a organização confiou-lhes a responsabilidade de transformar as entradas em um conjunto desejado de saídas".

Para STARR (1988) a administração da produção é aplicável a todas as formas de trabalho organizado, isto é, "o trabalho não está limitado somente à manufatura; conseqüentemente, a administração da produção não está restrita aos processos manufatureiros".

SLACK et al. (1999), ao procurarem definir as atividades da administração da produção, preferem usar o termo "responsabilidade", que julgam contemplar uma área ainda mais ampla do que a própria administração da produção, não importando a amplitude definida pela organização para essa função. Assim, esse autor diz que os gerentes de produção possuem responsabilidades por algumas atividades, que ora podem ser responsabilidades diretas, ora responsabilidades indiretas.

CARDOSO (1997) defende que, ao pensar estabelecer "novas formas de gestão da produção", não se deve preocupar apenas com os aspectos ligados à gestão do "sistema de produção" (que considera apenas o conjunto de etapas físicas, ou seja, associadas à execução), mesmo que essa seja o foco principal, mas "se atentar igualmente aos aspectos relacionados com a gestão do "processo" como um todo". "Deve-se, portanto, procurar identificar em que medida as atividades desenvolvidas fora da etapa de execução (no canteiro) são importantes para a gestão da produção tratada globalmente".

Embora o trabalho em desenvolvimento esteja focado na gestão das operações físicas que acontecem dentro dos canteiros de obra, como bem lembrou CARDOSO (1997), será importante considerar as atividades que acontecem externamente ao canteiro e que influenciam o desenvolvimento das operações internas.

Quanto às responsabilidades indiretas, o mesmo autor diz que "muitas das atividades das organizações ocorrem fora das fronteiras tradicionais da função produção, embora tenham efeito sobre a maneira com que se produz bens e serviços". Resume tais responsabilidades indiretas da administração da produção em:

- "informar as outras funções sobre as oportunidades e as restrições fornecidas pela capacidade instalada";

- discutir com outras funções sobre como os planos de produção e os demais planos da empresa podem ser modificados para benefício mútuo;

\footnotetext{
${ }^{54}$ Entende-se que as palavras gestão e administração possuam definições bastante parecidas e que terão seu escopo explicitado pelo complemento nominal a elas associadas.
} 
- encorajar outras funções a dar sugestões para que a função produção possa prestar melhores "serviços" aos demais departamentos da empresa".

Em se tratando das responsabilidades diretas da administração da produção, SLACK et al. (1999) dizem que a sua natureza exata depende da forma escolhida pela organização para definir a função produção, cujas fronteiras e responsabilidades variam entre organizações, podendo adquirir uma maior (definição ampla) ou menor abrangência (definição estreita) como mostrado na Figura 3.4.

a)
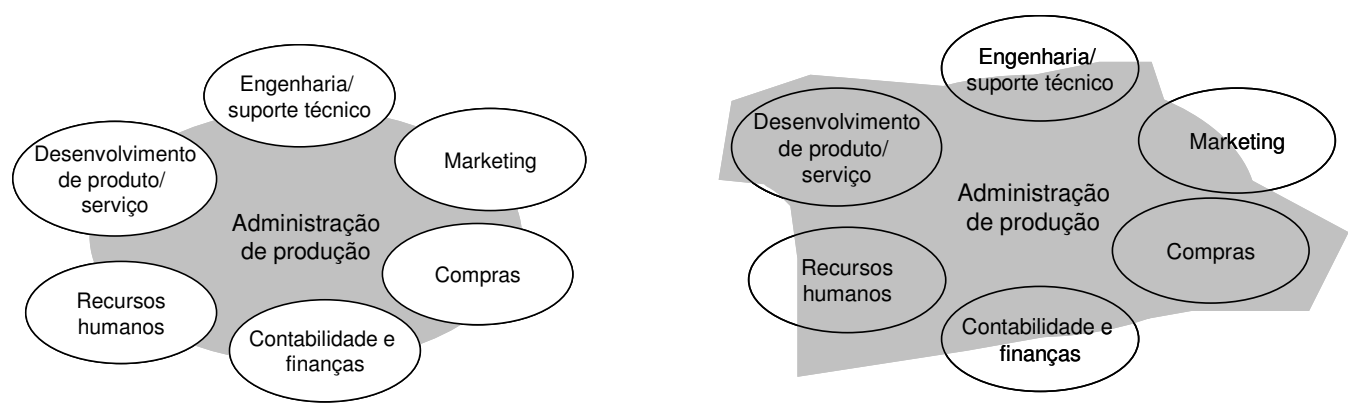

b)

Figura 3.4 - Fronteiras da função produção: a) definição estreita; b) definição ampla. Fonte: SLACK et al. 1999

Entretanto, o autor supracitado diz que "há algumas classes gerais de atividades que se aplicam a todos os tipos de produção, não importa como as fronteiras funcionais foram definidas". Tais atividades incluem:

- entender os objetivos estratégicos da produção;

- desenvolver uma estratégia de produção para a organização;

- desenhar produtos, serviços e processos de produção;

- planejar e controlar a produção;

- melhorar o desempenho da produção.

O Modelo (Figura 3.5), proposto por SLACK et al. 1999, apresenta dois "loops" de atividades inter-relacionadas. A base do modelo, que contempla as atividades de projeto, planejamento e controle e melhoria, caracteriza a administração da produção. As atividades do "loop" superior têm forte conotação "estratégica" e, portanto, configuram a estratégia de produção. O trabalho de SLACK et al. 1999 concentra-se no primeiro "loop", ou seja, na administração da produção. O autor julga importante considerar uma "perspectiva estratégica" sobre o assunto, ou seja, entender um pouco destas áreas de decisão na gestão da produção (isto é, o sentido estratégico do trabalho do gerente de produção) antes da discussão daquelas atividades mais funcionais. 


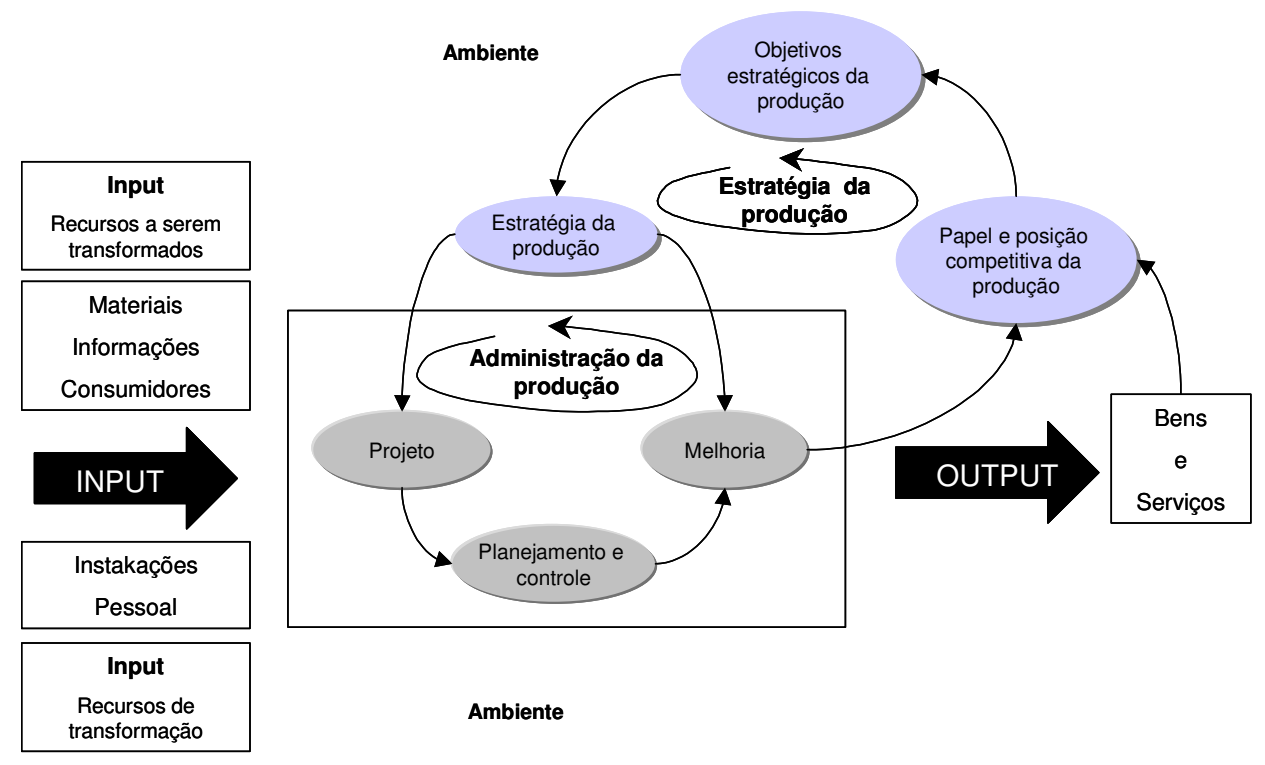

Figura 3.5 - Modelo geral de administração da produção e estratégia de produção. Fonte: SLACK et al. 1999

CARDOSO (1997) propõe que a gestão da produção possa assumir diferentes ênfases, em função da dimensão em que se deseja tratá-la. Tais ênfases, sob a óptica de uma empresa de construção, são: i) gestão estratégica; ii) gestão de tecnologia; iii) gestão de custos; iv) gestão de logística; v) gestão dos recursos humanos; vi) gestão das subcontratadas. Tal subdivisão é justificada pela facilidade de identificação da "verdadeira natureza do problema envolvido e a conseqüente definição de diretrizes para solucioná-lo".

Em seguida, o autor apresenta um conjunto de diretrizes (separando ainda aquelas que dizem respeito ao "processo" como um todo, das ligadas ao "sistema" de produção em particular), o qual julga relevante para o desenvolvimento das "novas formas de gestão da produção". A Tabela 3.2 reproduz algumas das diretrizes propostas por CARDOSO (1997) para as ênfases em gestão de logística, gestão dos recursos humanos e gestão das empresas subcontratadas. 
Tabela 3.2 - Diretrizes envolvidas na questão da gestão da produção. CARDOSO (1997)

\begin{tabular}{|c|c|c|c|}
\hline & \multicolumn{3}{|c|}{ Ênfase } \\
\hline & Gestão da Logística & Gestão dos R.H. & $\begin{array}{c}\text { Gestão das } \\
\text { Subcontratadas }\end{array}$ \\
\hline $\begin{array}{l}\text { Processo } \\
\text { de } \\
\text { Produção }\end{array}$ & $\begin{array}{l}\text { Planejamento físico da } \\
\text { execução dos serviços no } \\
\text { tempo. } \\
\text { Visão logística dos } \\
\text { suprimentos. }\end{array}$ & $\begin{array}{l}\text { Aumento da motivação } \\
\text { (conteúdo e condições do } \\
\text { trabalho). } \\
\text { Capacitação para a } \\
\text { tomada de decisões e } \\
\text { para reação às } \\
\text { disfunções. } \\
\text { Capacitação para o } \\
\text { trabalho em equipe e } \\
\text { desenvolvimento da } \\
\text { cooperação interna entre } \\
\text { trabalhadores. }\end{array}$ & $\begin{array}{l}\text { Qualificação de gestão } \\
\text { dos projetistas. } \\
\text { Preocupação com as } \\
\text { interfaces com e entre } \\
\text { projetistas. } \\
\text { Compatibilização de } \\
\text { projetos }\end{array}$ \\
\hline $\begin{array}{l}\text { Sistema de } \\
\text { Produção }\end{array}$ & $\begin{array}{l}\text { Elaboração do projeto do } \\
\text { canteiro. } \\
\text { Estudos de fluxos de } \\
\text { materiais e pessoas. } \\
\text { Estudo de interfaces } \\
\text { entre serviços de } \\
\text { execução. } \\
\text { Domínio dos } \\
\text { equipamentos de } \\
\text { transporte. } \\
\text { Garantia de um bom } \\
\text { funcionamento do } \\
\text { canteiro. }\end{array}$ & $\begin{array}{l}\text { Treinamento e } \\
\text { qualificação. } \\
\text { Emprego de novas } \\
\text { formas de organização do } \\
\text { trabalho. } \\
\text { Realização de } \\
\text { investimentos em higiene } \\
\text { e segurança do trabalho. }\end{array}$ & $\begin{array}{l}\text { Qualificação e gestão dos } \\
\text { subempreiteiros. } \\
\text { Preocupação com a } \\
\text { interface com e entre } \\
\text { subempreiteiros. } \\
\text { Desenvolvimento da } \\
\text { cooperação entre pessoal } \\
\text { interno e pessoal dos } \\
\text { subempreiteiros }\end{array}$ \\
\hline
\end{tabular}

\subsubsection{Ações preconizadas pela gestão da produção}

Passa-se, aqui, ao entendimento e caracterização das atividades pertencentes à gestão da produção propriamente dita, na visão de alguns autores, justificando-se, ao final, a escolha de uma das vertentes, dentre as preconizadas pelos modelos de gestão da produção, a ser seguido nesta tese.

FAYOL (1972) definiu administração como a realização das atividades administrativas, que envolvem:

- previsão: tentativa de avaliar o futuro por meio de um plano e fazer provisões para realizar este planejamento (essa função deu origem à função de planejamento);

- organização: mobilização de recursos humanos e materiais para transformar o plano em ação;

- comando: estabelecer orientações para os empregados e obter as coisas feitas;

- coordenação: obtenção da unificação e harmonia de todas as atividades e esforços;

- controle: verificação de que as coisas acontecem em conformidade com as regras estabelecidas e expressas pelo comando. 
SLACK et al. (1999), em seu modelo de administração da produção, identificaram três atividades principais: Projeto, Planejamento e Controle e Melhoria da Produção, comentados, brevemente, a seguir.

A primeira atividade é o Projeto, tratado no âmbito dos produtos, serviços e processos de produção. O autor aborda as atividades de projeto em gestão da produção de forma interessante. Começa por dizer que todos os gerentes da produção são projetistas "muitas das suas decisões do dia-a-dia formam o projeto dos processos que gerenciam e isso influencia os produtos e serviços que produzem". Cita, como exemplo, que a compra de máquinas e equipamentos é uma decisão de projeto, porque afeta a forma física e a natureza da produção.

A atividade de Projeto influencia todos os objetivos de desempenho da operação. É igualmente aplicável ao projeto de produto e serviços e ao projeto de processos, sendo essas duas atividades inter-relacionadas (uma não deveria ser feita independentemente da outra), como mostra a Figura 3.6.

Para SLACK et al. (1999) "seria tolice envolver uma organização no projeto detalhado de um produto ou serviço sem alguma consideração sobre o modo como deve ser produzido. Pequenas mudanças no projeto de produtos e serviços podem ter conseqüências profundas e dispendiosas para o modo como a produção deve fazê-los".

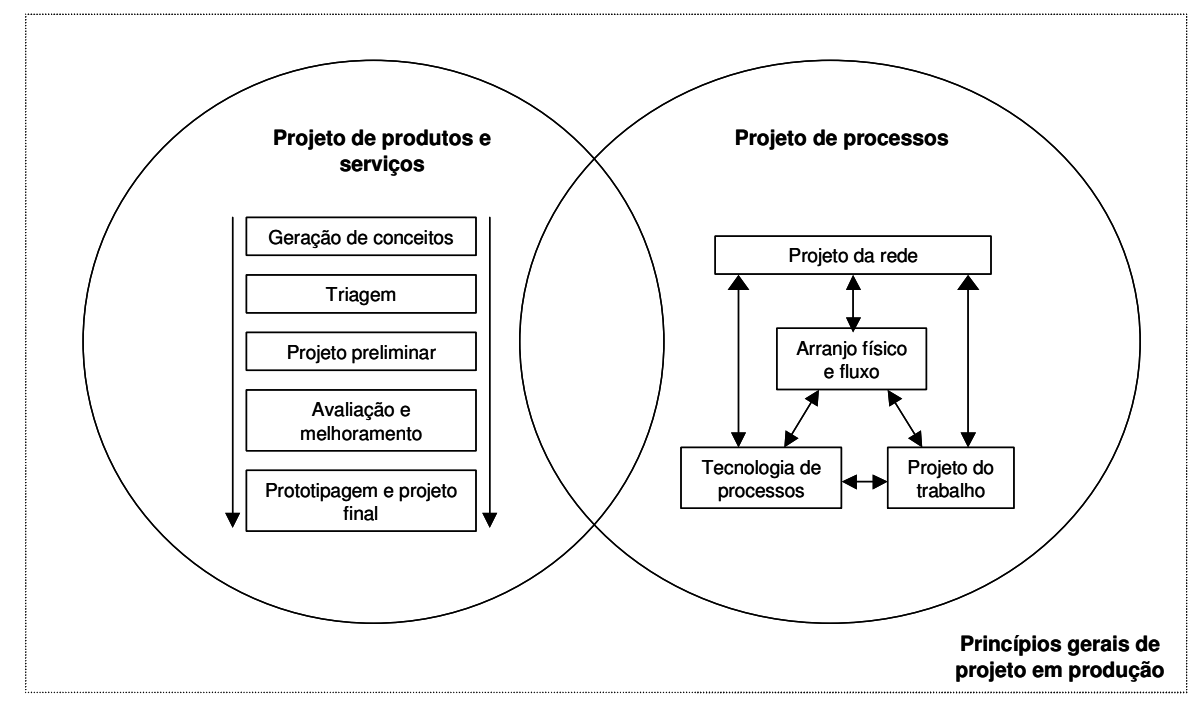

Figura 3.6 - Atividades de projeto em gestão de produção. Fonte: SLACK et al. 1999.

A atividade de Planejamento e Controle, na visão de SLACK et al. (1999), tem o propósito de garantir que a produção ocorra eficazmente e produza produtos e serviços como se deve, requerendo, para tanto, que os recursos produtivos estejam disponíveis: i) na quantidade adequada; ii) no momento adequado; iii) no nível de qualidade adequado.

Os atores supracitados comentam que embora planejamento e controle sejam atividades teoricamente separáveis, são usualmente tratadas juntos. Neste caso, o planejamento se configura como ato de estabelecer as expectativas de o que deveria acontecer e, 
controle, como processo de lidar com mudanças quando ocorrerem. Comentam, ainda, que todas as atividades de planejamento e controle estão, de alguma forma, dirigidas à conciliação das capacidades de fornecimento de uma operação com as demandas colocadas sobre ela.

No que tange à Melhoria da Produção, SLACK et al. (1999) são enfáticos ao afirmarem que mesmo quando uma operação produtiva é projetada e suas atividades são planejadas e controladas e, ainda que todas as operações sejam bem gerenciadas, é possível e factível o estabelecimento de melhorias.

No entanto, para que os gerentes da produção possam idealizar sua abordagem para o melhoramento das operações, é preciso referências para saber quão boa ela já é. Tais referências, que podem ser estabelecidas a partir de medidas de desempenho (podem ser estabelecidas a partir de cinco objetivos: qualidade, velocidade, confiabilidade, flexibilidade e custos), são, portanto, pré-requisitos para o melhoramento da produção.

A abordagem sobre melhoramento a ser definida por uma organização, segundo os autores supracitados, está localizada entre dois extremos, "melhoramento revolucionário" e "melhoramento contínuo". Enquanto o primeiro caso enfatiza grandes e dramáticas mudanças, que podem se dar de maneira abrupta e volátil, o segundo presume "uma série sem fim de pequenos, mas incrementais passos de melhoramento".

Para MOREIRA (1993) a administração da produção deve se preocupar com:

- o planejamento, que dá as bases para todas as atividades gerenciais futuras, ao estabelecer linhas de ação que devem ser seguidas para satisfazer os objetivos estabelecidos, bem como ao estipular o momento em que as ações devem ocorrer;

- a organização, que é o processo de combinar os recursos produtivos: pessoal (mãode-obra), matérias-primas, equipamentos e capital. Os recursos são essenciais às atividades planejadas, mas devem ser organizados coerentemente para um melhor aproveitamento;

- a direção, que é o processo de transformar planos, que estão no papel, em atividades concretas, designando tarefas e responsabilidades específicas aos empregados, motivando-os e coordenando seus esforços;

- o controle, que envolve a avaliação do desempenho dos empregados de setores específicos da empresa e dela própria como um bloco, e a conseqüente aplicação de medidas corretivas se necessário.

Percebe-se que a primeira "preocupação" da administração da produção defendida por MOREIRA (1993), o planejamento, condiz com as atividades do "loop" superior, apresentado por SLACK et. al. (1999) na Figura 3.5, salientando, também, uma conotação "estratégica".

STARR (1988) centraliza as responsabilidades da administração da produção em duas áreas: i) projeto do sistema de produção; ii) projeto dos sistemas de controle. Na Tabela 3.3 são apresentados os recursos e habilidades que, na visão de STARR (1988), são necessários aos dois projetos supracitados. Em ambas as áreas o projeto dá lugar ao reprojeto quando ocorrem perturbações externas tais como alterações competitivas, econômicas e tecnológicas. 
Tabela 3.3 - Responsabilidades da administração da produção segundo STARR (1988)

\begin{tabular}{|l|l|}
\hline \multicolumn{1}{|c|}{ Projeto do sistema de produção } & \multicolumn{1}{c|}{ Projeto do sistema de controle } \\
\hline Projeto do produto & Controle de estoques \\
\hline Projeto do processo de produção & Controle de qualidade \\
\hline Seleção do equipamento & Controle da programação da produção \\
\hline Habilidades necessárias à mão-de-obra & Controle de custo e produtividade \\
\hline Programas de treinamento & Estudos de controle de planejamento \\
\hline Seleção dos materiais recebidos & Modificação de projetos e políticas \\
\hline Localização da fábrica & Implantação e operação dos sistemas \\
\hline Arranjo físico da fábrica & \\
\hline Programação das etapas do plano & \\
\hline Implantação e controle do programa & \\
\hline Operação do sistema de produção & \\
\hline
\end{tabular}

As responsabilidades da administração da produção, na visão de MONKS (1987) "incluem a reunião dos insumos em um plano de produção aceitável que realmente utilize os materiais, a capacidade e o conhecimento disponíveis nas instalações de produção". Os gerentes de produção, segundo esse autor, são responsáveis pelo planejamento, organização, direção e controle das atividades de transformação.

Saindo da manufatura e buscando definições de gestão e do seu escopo na construção civil, CARDOSO (1997) entende que a gestão envolve uma pluralidade de ações afeitas a:

- planificação: organização das atividades no tempo, previsão, antecipação;

- organização: identificação das competências necessárias para a realização das atividades a serem desenvolvidas, na definição dos condicionantes que limitam tal desenvolvimento, na definição e obtenção dos meios a serem postos à disposição para tanto, na previsão das interfaces e na coordenação do conjunto dessas atividades;

- direção ou condução: fixação de objetivos, na transmissão das informações, na tomada de decisão, na transparência, no comprometimento das pessoas que participam do processo, na cooperação;

- controle: criação de sinalizadores que permitam garantir a obtenção dos resultados perseguidos e corrigir rapidamente desvios que venham a existir.

Para CARDOSO (1993) as ações assumem, também, distinção metodológica, podendo incorporar caráter "técnico-operacional" ou "social", marcados pelo aprimoramento das políticas de recursos-humanos, pela formação dos trabalhadores e aumento de sua motivação e pela melhoria da segurança. 


\subsubsection{Caminho adotado, nesta tese quanto à gestão da produção}

Assume-se ser a gestão da produção compreendida por pluralidade de ações que, alinhadas por um ou mais objetivos estratégicos e orientadas por padrões pré-definidos de desempenho, deverão conduzir, de maneira satisfatória, a função produção.

As indicações sobre as ações compreendidas pela gestão da produção são recorrentes, em sua maioria, em todas as citações dos autores supracitados. As distinções estão no entendimento, abrangências e delimitações dados a cada uma delas, menos pela individualidade de cada autor e mais pelo processo de produção a que elas se destinam.

Assim, adota-se que as ações preconizadas pela gestão de um processo de produção (Figura 3.7), com todas as particularidades prescritas no Capítulo 2, contemplem: i) a direção ii) o planejamento da produção; iii) a organização da produção; iv) o controle da produção.

As ações de direção são responsáveis por: i) apontar objetivos a serem alcançados por determinado processo de produção (consumo de recursos, produtividades etc); ii) transmitir tais objetivos à produção (por exemplo, estabelecimento de um programa de metas); iii) comprometer as pessoas que participam do processo de produção (programas de incentivos, entre outros). As ações de direção têm caráter informativo, ficando a cargo do planejamento e da organização da produção proporcionar condições para que o processo da produção atinja os objetivos pré-determinados.

As ações de planejamento contemplam a preparação de projetos em que as operações presentes no processo de produção são ordenadas técnica e temporalmente. Ao estabelecer as linhas de ação a serem seguidas e ao estipular o momento em que elas deverão ocorrer, estar-se-á colaborando para que se satisfaçam os objetivos estabelecidos.

As ações de organização da produção apontam como os recursos deverão ser ordenados/arranjados de maneira a que se chegue aos pontos determinados pelo planejamento com a máxima eficiência e eficácia na aplicação dos mesmos.

No que se refere às ações de controle, reconhece-se (LAUFER e HOWELL (1993)) duas funções básicas que devem ser cumpridas: i) a primeira, de caráter mais reativo, referese à medição e avaliação do desempenho, seguido da adoção de medidas corretivas; ii) a segunda tem caráter mais preventivo e baseado nas informações do desempenho, garantem que o trabalho planejado seja executado.

Dentre as ações preconizadas pela gestão do processo de produção, escolheu-se desenvolver a tese no âmbito da organização da produção. Acredita-se serem as ações inscritas neste contorno as responsáveis por dispor corretamente os recursos, contribuindo para que o processo de produção atinja os objetivos a que se destina (bons desempenhos marcados pela eficiência e eficácia na aplicação dos recursos). 


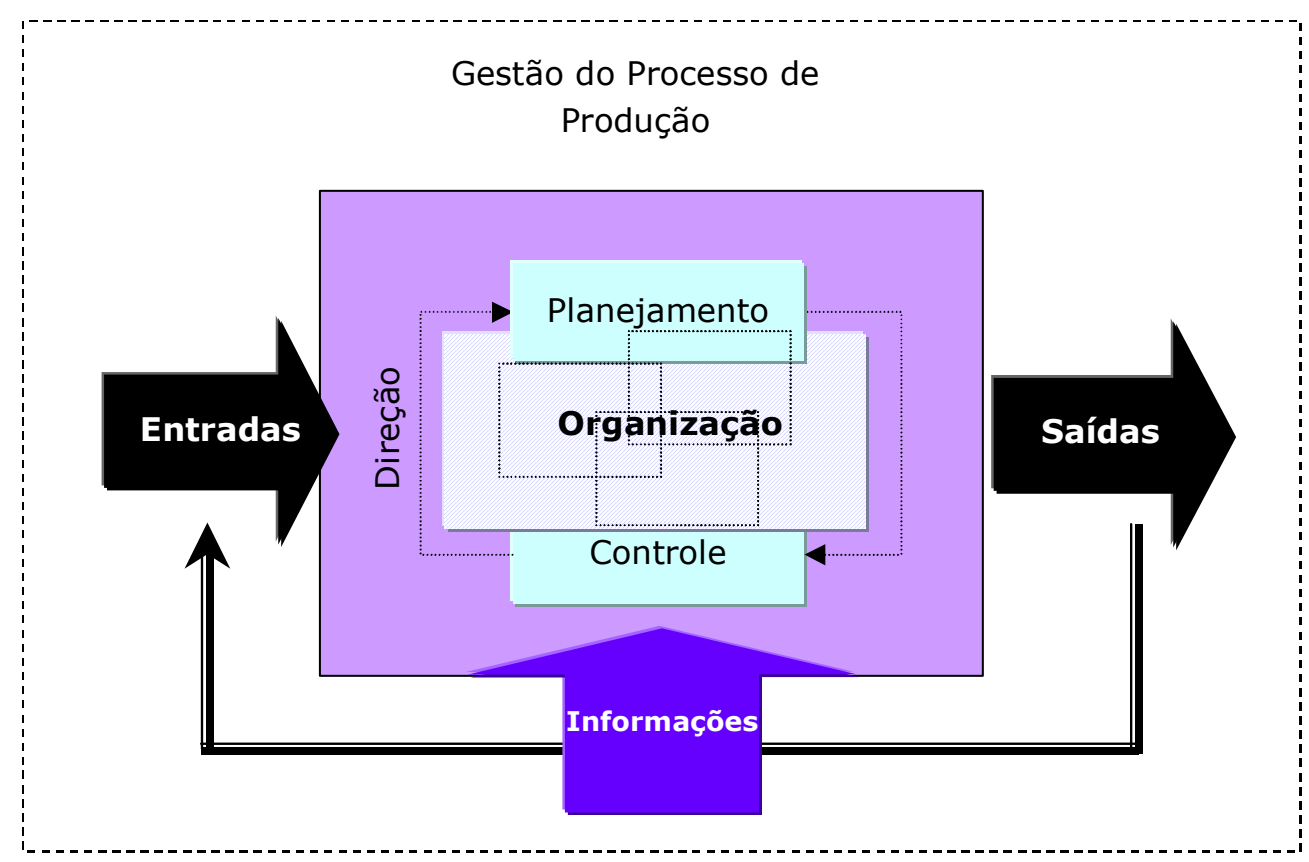

Figura 3.7 - Modelo de gestão do processo de produção.

O sucesso da organização da produção poderá e deverá ser percebido pelas ações de planejamento e controle, na medida em que a melhor eficiência do processo de produção (como a redução da variabilidade dessa eficiência, por exemplo) ajude a tornar cada vez menores os hiatos físico e financeiro entre as atividades planejadas e as atividades realizadas. Cabe citar que a recíproca é verdadeira, isto é, sistemas de planejamento e controle eficazes, ao possibilitarem o ordenamento temporal e físico das operações, tornam a organização da produção menos dificultosa.

Planejamento ${ }^{55}$ da produção e organização ${ }^{56}$ da produção, muito embora sejam ações intimamente ligadas, têm condução e objetivos bastante particulares. No planejamento elaboram-se roteiros, para que, partindo-se de um ponto chegue-se a outro, sem desvios de rotas e no tempo pré-determinado. Na organização da produção, os recursos são ordenados/arranjados de maneira a que os roteiros sejam cumpridos com a máxima eficiência e eficácia na aplicação dos recursos.

Este trabalho, ao preocupar-se em descobrir meios que promovam tal "arranjo" dos recursos (em especial, da mão-de-obra), carece de um maior entendimento sobre quais elementos são relevantes e devam, portanto, ser priorizados pela organização do

55 As definições encontradas no dicionário para "planejamento" (substantivo que define a ação de "planejar") são: 1. projeto que inclui uma série ordenada de operações e de meios destinado a atingir um fim; 2. programa; 3. intenção.

56 As definições encontradas no dicionário para o verbo "organizar" são: 1. criar, preparar, dispor convenientemente as peças de um organismo; 2 . instituir, constituir um organismo; 3. regularizar, dispor as coisas de forma a que elas concorram para determinado fim; 4. estabelecer as bases de; 5. ordenar; 6. arranjar, adaptar às condições; 7. apropriar. 
trabalho. Antes, porém, de se explorar a gestão da produção especificamente quanto à organização do trabalho, será feita uma concisa revisão dos sistemas de planejamento e controle, em razão, principalmente da proximidade dos elementos preconizados por esta ação em relação aos elementos preconizados pela organização do trabalho.

\subsubsection{O Planejamento e Controle da Produção}

O planejamento, visto como um processo gerencial, requer a participação e o envolvimento de diferentes níveis e agentes para que o plano seja cumprido com êxito. FORMOSO et al. (1999), ao apresentar algumas das suas deficiências mais comuns, citam o fato de que o planejamento e controle da produção "não é encarado como um processo gerencial, sendo confundido, com freqüência, com o trabalho isolado de um setor da empresa ou com a simples aplicação de técnicas para a geração de planos". Para esses autores o planejamento é eficaz somente quando realizado em conjunto com o controle.

Os conceitos de planejamento e controle da produção, originalmente formulados para a manufatura, podem ser revistos em inúmeros trabalhos cujas teorias começaram a ser desenvolvidas na primeira metade do século passado e se estendem até os dias atuais (SLACK et al. (1999); CORREA et al. (2001) etc).

SLACK et al. (1999) apresentam algumas limitações quanto à atividade de planejamento e controle que, segundo os autores, estão presentes na maioria das operações. São elas:

- limitações de custos: os produtos e custos devem ser produzidos dentro de custos determinados;

- limitações de capacidade: os produtos e serviços devem ser produzidos dentro de limites de capacidade projetados para a operação;

- limitações de tempo: os produtos e serviços devem ser produzidos dentro de um intervalo de tempo, que ainda apresente valor para o consumidor;

- limitações de qualidade: os produtos e serviços devem estar em conformidade com os limites de tolerância projetados para o produto ou serviço.

O planejamento é função essencial de um sistema de gestão da produção (SLACK et al. (1999); CORREA et al. (2001) etc) e deriva diretamente da inércia intrínseca dos processos decisórios. CORREA et al. (2001) explicam que essa inércia é entendida como o tempo que necessariamente tem de decorrer desde que se toma determinada decisão até que a decisão tome efeito. "Se fosse possível decidir alterações no processo produtivo e tê-las efetivadas de forma instantânea, num estalar de dedos, não seria necessário planejar; decidir no momento seria suficiente".

Para CORREA et al. (2001) um bom processo de planejamento depende, em primeiro lugar, de uma visão adequada de futuro e essa visão de futuro pode depender de sistemas de previsão que deverão ser eficazes; em segundo, da percepção de que é necessário o conhecimento fiel sobre a situação presente; e, por último, de que a "tradução" da situação presente, e a visão do futuro em decisões no presente, estejam disponíveis na forma de um modelo lógico para que o processo de planejamento realmente funcione bem.

Quanto ao sistema de controle, MOREIRA (1993) o define como sendo "a designação genérica que se dá ao conjunto de atividades que visa assegurar que programações sejam cumpridas, que padrões sejam obedecidos, que os recursos estejam sendo usados de forma eficaz e que a qualidade desejada seja obtida". 
CORREA et al. (2001) apresentam sucintamente a dinâmica de planejamento que, segundo eles, se dá em cinco passos, descritos na Tabela 3.4. Esses autores lembram que o processo de planejamento deve ser contínuo. "Em cada momento, deve-se ter a noção da situação presente, a visão de futuro, os objetivos pretendidos (que podem se alterar ao longo do tempo) e o entendimento de como esses elementos afetam as decisões que se devem tomar no presente".

Tabela 3.4 - Caracterização da dinâmica do processo de planejamento. Fonte: CORREA et al. (2001)

\begin{tabular}{|c|c|}
\hline Passos & Prática \\
\hline 1 & $\begin{array}{l}\text { Levantamento da situação presente. O sistema de planejamento deve "fotografar" a } \\
\text { situação em que se encontram as atividades e os recursos para que essa esteja } \\
\text { presente no processo de planejamento. }\end{array}$ \\
\hline 2 & $\begin{array}{l}\text { Desenvolvimento e reconhecimento da "visão" de futuro, com ou sem intervenção. O } \\
\text { sistema deve considerar a visão de futuro para que ela possa emprestar sua influência } \\
\text { ao processo decisório - de forma que inércias decisórias sejam respeitadas. }\end{array}$ \\
\hline 3 & $\begin{array}{l}\text { Tratamento conjunto da situação presente e da "visão" de futuro. Uso de alguma } \\
\text { lógica que transforme os dados coletados sobre presente e futuro em informações que } \\
\text { passam a ser disponibilizadas em forma útil para a tomada de decisão gerencial } \\
\text { logística. }\end{array}$ \\
\hline 4 & $\begin{array}{l}\text { Tomada de decisão gerencial. Com base nas informações disponibilizadas pelo } \\
\text { sistema, os tomadores de decisão efetivamente tomam decisões logísticas sobre o } \\
\text { que, quanto, quando produzir e comprar e com que recursos produzir. }\end{array}$ \\
\hline 5 & $\begin{array}{l}\text { Execução do plano. Decorre de um período em que efetivamente as diversas decisões } \\
\text { vão tomando efeito. Como o mundo não é perfeito, algumas coisas não acontecem da } \\
\text { forma como se planejou. O tempo vai decorrendo até que chega um determinado } \\
\text { momento em que é mais prudente tirar outra "fotografia" da situação presente e re- } \\
\text { disparar o processo. Este é o momento de voltar ciclicamente ao passo de número } \\
\text { um. }\end{array}$ \\
\hline
\end{tabular}

Para FORMOSO et al. (1999) planejamento é definido como um processo gerencial, que envolve o estabelecimento de objetivos e a determinação dos procedimentos necessários para atingi-los, sendo eficaz somente quando realizado em conjunto com o controle.

LAUFER; TUCKER (1987) definem planejamento como um processo de tomada de decisão que visa estabelecer um objetivo futuro desejado e os meios para atingi-lo. Propõem que o planejamento deva responder a quatro questões elementares: i) quais as atividades (o que) devem ser desempenhadas ii) como as atividades devem ser desempenhadas iii) quem deve desempenhar cada atividade e com quais recursos iv) quando as atividades devem ser desempenhadas.

Segundo ASSUMPÇÃO (1996), a maior parte das empresas do Setor de Construção Civil operam com sistemas de planejamento da produção de baixa eficiência, estruturados sem base conceitual consistente. O mesmo autor faz as seguintes constatações:

i) nestas mesmas empresas o planejamento não segue um padrão - os modelos são diferentes de obra para obra - tanto no que se refere ao uso de técnicas, sistemas, nível de detalhamento, como na formatação de relatórios e na definição do fluxo das informações geradas; ii) em muitas destas empresas o planejamento é informal e o modelo é o do engenheiro responsável pela obra, tendo cada um o seu. 
FARAH (1996) em seu estudo sobre o processo de trabalho na Construção Civil verificou que à estrutura de ofícios cabe o planejamento das atividades, o controle da qualidade da execução, da produtividade e do ritmo de trabalho. "Estabelece-se, assim, uma estrutura de comando, na qual desempenham funções centrais os próprios trabalhadores". Desta hierarquia de planejamento e controle participa também o engenheiro, porém, segundo FARAH (1996), essa atividade assume uma posição secundária com relação às funções administrativas, limitando-se a um controle empírico de resultados, com limitada interferência sobre o "como fazer".

Os cenários observados e comentados pelos dois atores supracitados chamam atenção para uma importante questão que é a falta de uma sistemática de planejamento para produção nas Empresas de Construção Civil brasileiras. Tal constatação, no entanto, parece não estar alinhada às mudanças estruturais e de comportamento observadas no setor nos últimos anos.

ASSUMPÇÃO (1996) aponta algumas causas para que essa situação ocorra, que continuam a valer e (também por isso) merecem ser mencionadas. São elas:

- "falta de tradição e cultura do setor no tratamento do planejamento que, ao longo de muitos anos, valorizou a figura do engenheiro "tocador de obras", cuja postura era a de resolver os problemas à medida em que fossem aparecendo, além da preocupação natural com os aspectos técnicos da obra, porém, dando pouca atenção aos problemas gerenciais;

- formação deficiente dos engenheiros civis no assunto, provenientes em sua maioria de escolas cuja estrutura curricular privilegia disciplinas de cálculo e tecnologias em detrimento das que abordam os temas de gestão e organização da produção;

- dificuldades que a Universidade e Centros de Pesquisa tiveram e ainda têm de desenvolver processos e sistemas de planejamento que, efetivamente, venham de encontro às necessidades das empresas, pelo distanciamento natural da realidade de canteiro;

- descrença em sistemas, gerada a partir de implementações mal conduzidas, a que se investiu em melhorias que não trouxeram resultado, mas excesso de informações e aumento da burocracia administrativa, fazendo a empresa retornar aos seus procedimentos anteriores".

As ações de planejamento da produção têm implicações com níveis hierárquicos superiores à produção/operações e, assim sendo, não podem e não devem ser tratadas individualmente para cada processo. Devem envolver, na sua condução, gestores da produção e executores, sendo o grau de sinergia entre as partes um dos fatores do sucesso do planejamento.

Alguns sistemas de planejamento, embora manipulados em nível operacional, servem basicamente a hierarquias superiores (ASSUMPÇÃO, 1996). Há sistemas que operando também no nível operacional buscam subsídios para intervir na produção, mas o fazem de maneira subjetiva e com critérios bastante discutíveis.

ASSUMPÇÃO (1996) apresenta um modelo para planejamento operacional de empreendimentos de construção civil "estruturado para atender à hierarquia das decisões estratégicas e táticas, gerando informações no âmbito do planejamento operacional, que permitam avaliar o impacto de estratégias de produção no resultado do empreendimento e na empresa como um todo". 
Segundo o autor citado, para o empreendimento as informações possibilitarão a escolha de estratégias que melhor se ajustem aos recursos disponíveis à sua execução - tanto financeiros quanto aos insumos para produção. No plano da empresa, as informações permitirão avaliar o seu volume de produção e as políticas a serem estabelecidas para ajustar esses volumes à sua capacidade de produção.

Nota-se que o planejamento é algo bastante abrangente podendo envolver diferentes níveis hierárquicos pertinentes a um empreendimento. ASSUMPÇÃO (1996) clarifica tais idéias ao subdividir o planejamento segundo as 3 funções que pode servir:

- estratégica: manipula dados e informações ao nível da empresa, considerando sua interface com o mercado e analisa alternativas de investimento para atingir seus objetivos de mais longo prazo;

- tática: subsidia decisões que levam à escolha dos empreendimentos a serem implantados;

- operacional: na sua hierarquia superior discute estratégias e metas de produção e na inferior, é responsável pelo planejamento das operações ou ordens de produção.

Segundo esse mesmo autor, em quaisquer dessas funções a essência do processo de planejamento consiste na construção de modelos que representam as relações entre as variáveis ou atividades que se desenvolvem no ambiente da empresa e de seus empreendimentos, aliado a sistemas que permitam operar com esses modelos e gerar informações, ora na forma de expectativas de comportamento do modelo (sistemas de programação), ora avaliando o comportamento das ações já empreendidas (sistemas de controle).

De forma resumida, conforme colocação do autor, o "modelo, embora desenvolvido no âmbito do planejamento operacional, subsidia principalmente decisões tomadas no ambiente da empresa e dos empreendimentos, através da geração de informações sobre o comportamento das principais varáveis de produção".

ASSUMPÇÃO (1996) identifica que

$\mathrm{Na}$ hierarquia inferior do planejamento operacional, os modelos para planejamento da produção são mais detalhados, pois devem representar o ato de produzir. As atividades ocorrem em períodos de curta duração, os programas devem contemplar o dimensionamento de insumos para a produção e os controles são estruturados para operar com o registro das informações no nível da sua ocorrência (consumo de materiais por serviço, produtividades por serviço, registro de notas fiscais, controle de empreiteiros, e outros, decorrentes de atividades de rotina da obra).

Um outro modelo de planejamento da produção adotado pela construção civil, e que merece ser destacado, trata-se daquele que adota a técnica "Last Planner" proposta por BALLARD (2000). Tal técnica envolve a elaboração de planos de longo prazo (segundo o conceito da produção protegida), de médio prazo (que envolve a aplicação de um conjunto de ferramentas, com a análise de restrições e o planejamento de pacotes de trabalho) e de curto prazo (com uso de um indicador denominado Porcentual do Planejamento Concluído (PPC), que é uma relação indicativa de desempenho entre o número de atividades efetivamente executadas e o número de atividades programadas para o período).

O autor supracitado entende a técnica "Last Planner" como um mecanismo para transformar "o que deveria ser feito no que pode ser feito". Sendo o "PPC" uma razão 
direta dos "pacotes executados na semana" pelo número total de pacotes de serviço planejados, deve-se sempre procurar por um "PPC" igual a 100, que significa que o programado foi realmente executado.

SAURIN (2002) em sua tese de doutorado fez ampla revisão bibliográfica quanto a adaptação dos conceitos e técnicas do $\mathrm{PCP}^{57}$ ao setor da construção civil. Apresentou tanto trabalhos brasileiros (SOARES et al., 2002; BERNARDES, 2001) quanto trabalhos de autores estrangeiros (ALARCON et al., 2002; FIALLO e REVELLO, 2002; BALLARD, 2000; LAUFER e TUCKER, 1987), sendo uma importante fonte de informações sobre o assunto aos leitores que desejem se aprofundar no tema.

\subsection{A Organização do Trabalho na Produção}

\subsubsection{Considerações iniciais sobre a organização do Trabalho}

Para SALERNO (2002), "pensar a organização é pensar a eficiência do sistema de trabalho, do sistema de criação de valor". Segundo esse mesmo autor, "há um consenso, entre estudiosos e pessoas com experiência prática, que a eficiência de uma empresa depende antes da qualidade da sua organização do que da última onda de equipamentos e computadores".

Segundo SALERNO (2002), antes de mecanizar, automatizar, informatizar, é preciso pensar o arranjo organizacional, a divisão do trabalho, a coordenação do trabalho, os procedimentos, a lógica das operações.

FLEURY (1998), ao defender que todos os engenheiros tenham conhecimentos básicos sobre organização do trabalho na produção, faz a seguinte constatação

Todo engenheiro, em sua atividade profissional, não só vai ter o seu próprio trabalho organizado em função das características da empresa em que atuar, como também vai influenciar a organização do trabalho, seja diretamente como gestor de processos de produção, seja indiretamente, em função das máquinas e equipamentos que projetar ou especificar.

O mesmo autor entende por organização do trabalho a "definição de atividades e responsabilidades de cada pessoa ou grupo de pessoas que participa de uma organização produtora de bens e serviços". Diz ainda que tal definição depende de um grande número de fatores, que vão desde o estilo gerencial adotado pela empresa até a tecnologia de processo (como os tipos de equipamentos utilizados na produção).

Na manufatura, visualiza-se a organização do trabalho na produção em função de três elementos básicos: pessoas, equipamentos e materiais em transformação. Segundo FLEURY (1998) são estabelecidas relações entre esses três elementos, sendo que a relação entre pessoas e materiais "tem sido vista como uma questão residual", ou seja, uma relação a ser minimizada: quanto menos pessoas interferirem no processo de transformação mais eficiente e produtivo ele será.

O autor supracitado diz vir dessa constatação "o sonho dos engenheiros" de ter fábricas totalmente automatizadas, o que tornaria a participação das pessoas completamente dispensável. "Este sonho tem-se mostrado não só inatingível, mas também

\footnotetext{
${ }^{57}$ Segundo CONTADOR (1994) PCP tanto pode significar programação e controle da produção como planejamento e controle da produção.
} 
contraproducente e dispendioso, não se justificando sob nenhum critério de avaliação de custo-benefício".

\subsubsection{A Evolução do Pensamento Administrativo com foco na organização do trabalho}

Vários autores brasileiros (FLEURY; FLEURY, 1995; MARX, 1996; SALERNO, 1992; ZILBOVICIUS, 1997) têm tratado de analisar as implicações e decorrências, os aspectos positivos e negativos, as relações que se estabelecem nos diferentes modelos (fordistas, tayloristas, ohnoístas, neo ou pós fordistas, japoneses etc), dentre diversos aspectos relevantes na organização do trabalho na produção.

Embora já exista uma bibliografia extensa e bastante analítica sobre o tema (em que se pese a revisão feita por SANTOS (1999)) cabe, nesta tese, uma passagem pelas abordagens teóricas da organização do trabalho, cuja evolução está associada ao próprio desenvolvimento das teorias da administração ao longo dos séculos, que apresenta enfoques diferenciados em função das épocas, das atividades e conseqüentes necessidades das organizações. O intuito aqui é o de evidenciar a principal mudança ocorrida no âmbito da organização do trabalho e que se faz cada vez mais forte e desejada nos tempos atuais, qual seja a ênfase no comprometimento, engajamento e na valorização das pessoas.

Faz-se isso, portanto, permeando algumas das facetas da evolução do pensamento administrativo, mostrando o longo caminho percorrido até o reconhecimento do valor da pessoa na organização e em todo e qualquer processo de melhoria. A partir daí fica muito mais contundente e verossímil a determinação dos elementos que comporão a atividade de organização do trabalho (que é o objetivo principal deste capítulo), tornando-a coresponsável no processo de melhoria da eficiência produtiva.

Ao negar contexto e processo e focalizar em ideologias integrais e holísticas, criamos a ilusão de que essas possuem uma racionalidade e um status científico, além das relações sociais que as produzem; negamos também a dinâmica que as produziu e que continua a produzi-las e modificá-las. Assim, congelamos o Taylorismo, ou o Fordismo, ou o Ohnísmo, ou o Volvismo na história, e não percebemos que sua contínua evolução e desenvolvimento são inevitáveis porque não há paradigmas fixos ou fórmulas científicas para emulação e adoção, mas um conjunto de idéias de contextos particulares, com sua própria trajetória evolucionária e conjunto de contradições. ZILBOVICIUS (1997)

SLACK at el. (1999) apontam que há diversas abordagens que podem ser dadas à organização do trabalho e que elas têm sido particularmente influentes em diferentes momentos (Figura 3.8). "Nenhuma dessas abordagens é mutuamente exclusiva em si, mas representam diferentes filosofias ou, pelo menos, enfatizam diferentes aspectos da organização do trabalho". E isso é devido principalmente ao fato de a organização ter tido avanços em diferentes pontos da história da administração da produção. 


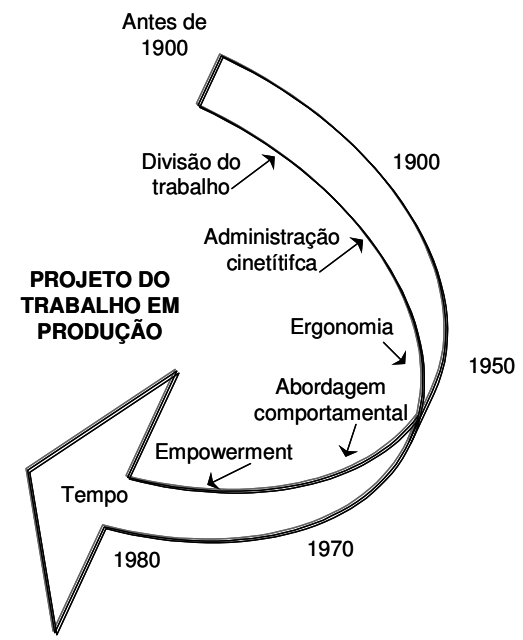

Figura 3.8 - Evolução cronológica do pensamento administrativo como foco na organização do trabalho. Fonte: SLACK et al. (1999)

Faz-se, a seguir, uma breve passagem pelas principais abordagens associadas à organização do trabalho ao longo do último século, no âmbito das teorias que fundamentaram as perspectivas clássica (1890-19920), humanística (1920-1940) e moderna/contemporânea (1940-1990) da administração da produção.

\subsubsection{Perspectiva Clássica da Administração ${ }^{58}$}

\subsection{A Administração Científica}

Na última década do século dezenove, e nas primeiras décadas do século vinte, alguns pensadores gerenciais (principalmente americanos) desenvolveram idéias de organização do trabalho que ficaram conhecidas como "administração cientifica" ${ }^{59 "}$ (tal denominação foi estabelecida em 1911 com a publicação do livro de mesmo nome por Frederick Taylor). Henry Ford, por sua vez, tornou a proposta de Taylor uma realidade, ao estruturar as tarefas de montagem de automóveis em torno de uma correia transportadora.

Outros contribuintes para o movimento da administração científica incluem Frank e Lílian Gilbreth, Henry Gantt, Bedaux, Carl Barth, Harrington Emerson e Morris Coke (para maiores detalhes do trabalho dessas pessoas, ver SILVA (2001)).

O Taylorismo trata-se do modelo de organização do trabalho mais difundido no mundo e está ligado à obra de Frederick W. Taylor, que foi um engenheiro mecânico, de origem norte-americana, e consolidado no livro intitulado "Princípios de Administração Científica". Taylor iniciou sua vida profissional como aprendiz de torneiro, rapidamente alcançou os postos de gerência. À medida em que publicava sua obra, por intermédio da ASME- American Society of Mechanical Engineers, ia se tornando um verdadeiro guru

\footnotetext{
${ }^{58}$ A revisão foi baseada nas obras de SALERNO (1999 e 2002); FLEURY (1998).

59 A abordagem da organização do trabalho, segundo o modelo da administração científica, é também chamado de taylorismo.
} 
sobre o tema. Taylor adquiriu grande parte de seus conhecimentos e idéias na observação do cotidiano.

Enquanto operário, Taylor notou que a questão da produtividade era "negociada" entre administradores e operários: como os gestores do processo de produção não sabiam como as atividades do processo de produção eram realizadas nem os tempos necessários para a sua execução, negociavam com os operários em termos de quantidades e prazos.

Para Taylor, a ineficiência, relacionada ao mau uso dos recursos humanos (que ele classificava segundo o tipo de "vadiagem" do trabalhador, ou seja: i) vadiagem natural; ii) vadiagem intencional; iii) o boicote), teria um custo mais significativo que os custos decorrentes do uso ineficiente dos recursos materiais.

A proposta desenvolvida por Taylor buscava resolver "cientificamente" o uso eficiente dos recursos humanos.

O cronômetro foi o instrumento básico da sua metodologia, que se consolidou no chamado Estudo de Tempos e Movimentos. A proposta era a de medir o tempo de cada um dos movimentos elementares de uma atividade produtiva e então, a partir de uma análise crítica dos movimentos necessários (separando movimentos dos operários e movimentos de máquinas) reorganizá-los para minimizar o tempo total da atividade.

Tal metodologia foi por ele denominada "administração científica". "Realmente Taylor procurou substituir o empirismo que reinava na organização dos processos de produção por procedimentos sistemáticos de análise, que utilizavam algumas informações relacionadas a experimentos científicos". (FLEURY, 1998).

A Tabela 3.5 sintetiza os três princípios que consolidaram a proposta de Taylor de organização do trabalho na produção.

Tabela 3.5 - Princípios da administração científica. Fonte: TAYLOR, 1970.

\begin{tabular}{|c|c|c|c|}
\hline Principio & \multicolumn{1}{|c|}{ Objetivo } & \multicolumn{1}{c|}{ Premissas } \\
\hline $\begin{array}{c}\text { Primeiro } \\
\text { princípio }\end{array}$ & $\begin{array}{l}\text { Planejar, organizar e } \\
\text { permitir o controle } \\
\text { do trabalho por parte } \\
\text { da gerência }\end{array}$ & $\begin{array}{l}\text { Dásicos. } \\
\text { Eliminar as atividades que não agregam valor. } \\
\text { Medir os tempos dos componentes restantes, } \\
\text { estabelecendo tempos padrão. } \\
\text { Tabular os dados obtidos de modo a formular regras e } \\
\text { procedimentos a serem seguidos pelo operário na }\end{array}$ \\
\hline $\begin{array}{l}\text { Segundo } \\
\text { princípio }\end{array}$ & $\begin{array}{l}\text { Seleção, treiname de sua tarefa. } \\
\text { e desenvolvimento } \\
\text { dos operários }\end{array}$ & $\begin{array}{l}\text { A gerência, tendo perfeito conhecimento da tarefa a ser } \\
\text { desempenhada, poderia selecionar pessoas com o nível de } \\
\text { habilidade, destreza e força requeridos em cada posto de } \\
\text { trabalho. Depois, teria que treinar e desenvolver cada } \\
\text { operário para que ele seguisse as regras e procedimentos } \\
\text { preestabelecidos. }\end{array}$ \\
\hline $\begin{array}{c}\text { Terceiro } \\
\text { princípio }\end{array}$ & $\begin{array}{l}\text { Estabelecer relações } \\
\text { entre a gerência e os } \\
\text { operários }\end{array}$ & $\begin{array}{l}\text { A gerência teria a responsabilidade pelo planejamento e } \\
\text { pelo controle do trabalho e aos operários caberia a } \\
\text { execução. }\end{array}$ \\
\hline
\end{tabular}

Com relação ao terceiro princípio, SALERNO (2002) o ilustra mostrando o exemplo típico de uma linha de montagem. 
É ela (a linha de montagem) que diz a cada um que é o momento de fazer a atividade e, como o trabalhador está num dado posto, não é preciso que alguém (ou que o chefe) Ihe diga o que fazer - está tudo lá, padronizadamente. Se faltar material, se quebrar a máquina, se a matériaprima está fora de especificação isso não será problema de quem está executando a operação; a chefia deverá ser chamada para resolver. O tempo é imposto ao trabalhador embutido na velocidade da própria linha: o trabalhador não tem opção a não ser executar a atividade naquele tempo. Caso não o faça, o trabalho dos demais ficará prejudicado, e ele estará sujeito a punições imediatas da chefia.

Como o método clássico (ou Taylorista) de organização do trabalho é baseado na análise das funções das partes do sistema que está sendo projetado, a "otimização das partes é feita a partir de um critério sintético de avaliação, geralmente o tempo ou outra variável dele derivada".

A tarefa, na noção Taylorista, é parte do processo organizacional e produtivo, e é otimizada através de método operacional que propicie o menor tempo de produção. $O$ tempo é que combina e dá consistência à relação produção/gestão, pois é ao mesmo tempo unidade física de desempenho da atividade de transformação e unidade física de valorização (tempo como unidade básica para apropriação de custos).

Para SALERNO (1999), "o pressuposto racionalista do projetista clássico seria, portanto, realizar antecipadamente planos explícitos detalhados de todos os passos futuros, vendo o trabalhador como alguém cujas capacidades podem ser reduzidas e descritas como procedimentos algoritmos".

As críticas à abordagem da administração científica começaram a surgir em 1915 e assim foram descritas por Hoxie (SLACK et al. 1999):

- sendo em "espírito e essência um sistema habilmente idealizado de fazer mais rápido e suar";

- intensificando as "tendências modernas no sentido da especialização do trabalho e das tarefas";

- condenando o trabalhador a uma rotina monótona;

- colocando nas mãos dos empregadores uma imensa massa de informações e métodos que podem ser usados inescrupulosamente em detrimento dos trabalhadores;

- tendendo a transferir para a administração todo o conhecimento tradicional, julgamento e habilidades dos trabalhadores;

- intensificando grandemente a administração desnecessariamente ditatorial e a disciplina;

- tendendo a enfatizar a quantidade do produto às custas da qualidade.

Segundo FLEURY (1983), muitas empresas não possuem serviços sofisticados de projetos e métodos e, mesmo assim, acabam trabalhando da mesma forma que no sistema Taylorista, ou seja, cobra-se a realização de cada atividade num dado tempo (a ser realizada) num dado posto de trabalho, e o trabalhador "que se vire para conseguir o ritmo pois, afinal, há muita gente na fila do lado de fora".

SALERNO (2002), entre tantos outros pesquisadores dos modelos de organização do trabalho, é enfático ao dizer que o Taylorismo recebeu severas críticas. Apresentam-se, na referida obra, as principais delas, listadas a seguir: 
- esquema de reconhecimento de desempenho baseado na premiação pela produtividade individual. A produtividade é mensurada pela quantidade de produtos produzida pelo trabalhador num dado intervalo de tempo, o que desconsidera a função precípua do trabalho e da produção, qual seja a de produzir produtos e serviços;

- reduz o critério de eficiência da produção ao tempo de operação (tempo-padrão das tarefas): quanto menor o tempo de uma operação, mais eficiente seria a produção, o que nem sempre é verdadeiro;

- objetiva o trabalho, tornando-o "independente" de quem o executa. Isso facilita a rotatividade, pois fica fácil a demissão, dado que o trabalho está modelado, os movimentos prescritos, o posto predefinido e a operação pode ser ensinada a qualquer pessoa que cumpra os requisitos mínimos para a execução da tarefa;

- o trabalhador é selecionado para uma determinada operação e não para uma empresa ou para uma entidade;

- o processo de soluções de problemas pode ser muito lento. Tudo o que sai da "norma", do padrão, deve ser hierarquicamente tratado;

- a organização clássica é bastante complexa: diversas funções, gerências, departamentos, seções. Há um contingente não produtivo bastante significativo, entre eles os analistas de métodos (ou de planejamento do trabalho), para especificar as tarefas a serem realizadas em cada posto. Cada operação na produção é simples, fruto da divisão extremada do trabalho, mas a contrapartida é uma organização bastante complexa;

- o Taylorismo significa determinada relação de poder nas empresas. O operariado perde o poder de definir como trabalhar, e o corpo técnico ganha esse poder. Nem o próprio chefe direto em uma linha de montagem tem poder para definir a divisão do trabalho na linha (isso já vem predefinido no projeto da linha). Tudo como se existisse uma racionalidade técnica universal e um grupo na empresa que zelaria por ela, definindo padrões de trabalho. "Sabe-se que isso é uma cortina de fumaça para esconder um sistema de dominação";

A contribuição de Henry Ford se coloca num plano diferente, a começar pelo fato de Ford ter sido um empreendedor, com visão privilegiada de negócios. Ele identificou as demandas de um enorme mercado inexplorado formado por consumidores potenciais: a classe média não tinha acesso aos carros produzidos na época. Ford solucionou essa situação com o desenvolvimento de um novo produto que atendeu aos anseios dessa classe: o Ford T, de 1908.

Ford atingiu com isso dois objetivos: o de ter um carro "projetado para a manufatura" e que qualquer pessoa poderia dirigi-lo, cuidar da sua manutenção, sem necessidade de ter um motorista e um mecânico.

Desenvolvido o produto, Ford desenvolveu um sistema de produção adequado à sua estratégia de produto e mercado. O conceito mais visível era a linha de montagem, onde eram montadas partes padronizadas e intercambiáveis por operários especializados. Tal processo de montagem era sustentado por grande esforço de engenharia, como o desenvolvimento de máquinas e ferramentas dedicadas à fabricação de peças padronizadas, com rígidas especificações e altos volumes de produção. 
A força de trabalho que Ford recrutou era formada especialmente por imigrantes da Europa Oriental e de migrantes do sul dos Estados Unidos, que haviam se deslocado devido à mecanização da agricultura. Para utilizar eficientemente estes recursos humanos (Ford era obcecado pelo uso racional de recursos, especialmente de recursos humanos), Ford desenvolveu um minucioso e precioso sistema de ferramentas e dispositivos, o que demandou grande capacitação em Engenharia de Processos. (FLEURY, 1999)

Ford criou o "trabalho intercambiável": tal como trocar peças num automóvel. A troca e reposição pelos trabalhadores eram minuciosamente planejadas, utilizando-se princípios de padronização completa do trabalho e do trabalhador. A contribuição do trabalhador era analisada de um ponto de vista mecânico, como uma peça. O uso da inteligência e da força eram totalmente desnecessários. "Não há contato pessoal em nossas fábricas; os operários cumprem o seu trabalho e logo voltam para seus lares. Uma fábrica não é um salão de conferências". (comentários de Ford)

Ford inovou em termos de remuneração. Partindo da premissa de que os operários da Ford deveriam ser consumidores potenciais dos carros que produziam e, baseado nos altos níveis de lucratividade, Ford instituiu o esquema de "five dollars a day", o que para a época era bastante significativo.

FLEURY (1999) relembra "que, se na Ford o trabalho operário exigia o mínimo de aptidões físicas, o trabalho do projeto, operação e manutenção desse sistema de produção requeria um enorme esforço de engenharia e de engenheiros".

ZILBOVICIUS (1999), ao analisar a evolução dos modelos de organização do trabalho, relata que, após o final da Segunda Guerra Mundial, a lógica clássica havia se difundido de maneira universal no Ocidente ("mesmo que não exatamente como prática, na medida em que nem todas as organizações apresentavam elementos dessa lógica, ao menos como representação orientadora dos tomadores de decisão").

Para FLEURY (1999) uma justificativa, ainda que parcial, para a difusão ampla, decorreu do fato de que o mercado era "comprador" (demanda maior que a oferta, onde o vendedor é que estabelece as regras), o que implicava em comprar tudo que fosse produzido. Assim, não era tão relevante o fato de uma empresa ter ou não ter seu trabalho de produção bem organizado, havendo muito espaço para empresas ineficientes.

"A importância crescente de organizar bem o trabalho na produção decorre da inversão lógica de mercado, pois hoje a oferta é maior que a demanda. Conseqüentemente, só as empresas bem organizadas conseguirão sobreviver com êxito". (FLEURY, 1999)

Apesar de o modelo clássico garantir que a aplicação dos seus elementos levaria a uma situação de otimização dos processos de produção, isto não ocorria; na prática, estes elementos permitiam atingir uma condição de desempenho dos processos de produção apenas suficiente. Porém, essa condição era, no quadro econômico dos países centrais, adequada às condições de concorrência e de valorização do capital. Por outro lado, ao ganhar a condição de legitimidade "científica", os pressupostos de divisão do trabalho e de separação planejamento-execução passam a ser inquestionáveis, e difundem-se como referência básica para todo e qualquer processo de concepção de arranjos e métodos de trabalho, independentemente da possibilidade teórica, não concretizada, de aumento de performance econômica. (ZILBOVICIUS, 1999) 
O mesmo autor ainda comenta que o ambiente onde essas formas de organização foram sendo implementadas se caracterizava (especialmente nos Estados Unidos e em menor medida na Europa) por mercados em franco crescimento, com baixo nível de competitividade, produtos estáveis, tecnologias consolidadas desde o início do século e pouco dinâmicas. Esse ambiente, basicamente estável e previsível, ao qual se consolida o que foi denominado por alguns autores como o "ciclo virtuoso do Fordismo", era propício a cristalização do paradigma do pensamento clássico.

As soluções organizacionais baseadas na racionalização e na simplificação eram adequadas e permitiam o atingir níveis de eficiência e rendimento aceitáveis: o processo de acumulação capitalista se desenvolvia saudavelmente e, mesmo nos países do Leste Europeu, onde supostamente os pressupostos econômicos eram outros, o paradigma, do ponto de vista da organização da produção e do trabalho, era exatamente o mesmo.

A Tabela 3.6, baseada em SILVA (2001), busca um posicionamento das idéias de Taylor frente às formas de administração contemporâneas.

Tabela 3.6 - Proposição das idéias e técnicas de Taylor na Administração Contemporânea

\begin{tabular}{|c|c|c|c|}
\hline Proposição & Válida? & $\begin{array}{l}\text { Aceita } \\
\text { atualmente? }\end{array}$ & Manifestada em \\
\hline $\begin{array}{l}\text { Tomada científica } \\
\text { da decisão }\end{array}$ & $\operatorname{sim}$ & $\operatorname{sim}$ & $\begin{array}{l}\text { Ciência da administração, pesquisa } \\
\text { operacional, contabilidade de custos etc. }\end{array}$ \\
\hline $\begin{array}{l}\text { Cooperação } \\
\text { gerência-mão-de- } \\
\text { obra }\end{array}$ & $\operatorname{sim}$ & Parcialmente & $\begin{array}{l}\text { Maior cooperação entre gerência e mão- } \\
\text { de-obra }\end{array}$ \\
\hline $\begin{array}{l}\text { Estudo do tempo e } \\
\text { movimento }\end{array}$ & $\operatorname{sim}$ & $\operatorname{sim}$ & Uso generalizado, tempos padronizados \\
\hline Padronização & $\operatorname{sim}$ & $\operatorname{sim}$ & $\begin{array}{l}\text { Procedimentos de padronização em } \\
\text { muitas esferas e engenharia humana }\end{array}$ \\
\hline Tarefa & $\operatorname{sim}$ & $\operatorname{sim}$ & $\begin{array}{l}\text { Definição de metas, administração por } \\
\text { objetivos (APO), feedback }\end{array}$ \\
\hline Bônus & $\operatorname{sim}$ & Cada vez mais & Proliferação de sistema de recompensas \\
\hline $\begin{array}{l}\text { Trabalho } \\
\text { individualizado }\end{array}$ & Parcialmente & Parcialmente & $\begin{array}{l}\text { Tarefas em grupos talvez sejam mais } \\
\text { eficientes }\end{array}$ \\
\hline $\begin{array}{l}\text { Treinamento } \\
\text { gerencial }\end{array}$ & $\operatorname{sim}$ & $\operatorname{sim}$ & $\begin{array}{l}\text { Responsabilidade gerencial pelo } \\
\text { treinamento do funcionário }\end{array}$ \\
\hline Seleção científica & $\operatorname{sim}$ & $\operatorname{sim}$ & $\begin{array}{l}\text { Desenvolvimento nas áreas de psicologia } \\
\text { industrial e administração de RH }\end{array}$ \\
\hline $\begin{array}{l}\text { Horário reduzido } \\
\text { de trabalho }\end{array}$ & $\operatorname{sim}$ & $\operatorname{sim}$ & Semana de trabalho de 40 horas \\
\hline $\begin{array}{l}\text { Pausa para } \\
\text { descanso }\end{array}$ & $\operatorname{sim}$ & $\operatorname{sim}$ & Uso comum de intervalos para descanso \\
\hline
\end{tabular}




\subsection{A Teoria Administrativa ${ }^{60}$}

A Teoria Administrativa é um segundo componente das teorias clássicas de organizações. Henry Fayol (1841-1925) foi o responsável por desenvolver a teoria administrativa, sendo considerado o maior influente teórico da perspectiva clássica. Até Fayol, o problema da administração se concentrava nas indústrias e usinas, com a preocupação pela produtividade. Fayol levou a administração do nível da oficina para a direção geral da empresa, mostrando como um processo administrativo complexo poderia ser separado em áreas interdependentes de responsabilidade ou de funções.

As diferenças entre o "fayolismo" e o taylorismo são pequenas: enquanto o sistema preconizado por Taylor voltava-se para as condições técnicas do trabalho, o sistema de Fayol se preocupava com a administração da empresa, sistematizando em seus estudos o resultado de suas observações experimentais e psicológicas.

Os princípios gerais da administração sugeridos por Fayol (escritos em 1916) são ainda considerados úteis na prática administrativa contemporânea. São apresentados na Tabela 3.7.

Tabela 3.7 (continua) - Princípios gerais da administração sugeridos por Fayol. SILVA (2001)

\begin{tabular}{|c|c|}
\hline Princípios & Explicação \\
\hline $\begin{array}{l}\text { Divisão do } \\
\text { trabalho }\end{array}$ & $\begin{array}{l}\text { Entre grupos e indivíduos, para garantir que esforço e atenção estejam } \\
\text { focados em porções especiais da tarefa (Fayol propôs a especialização do } \\
\text { trabalho como a melhor maneira de usar os recursos humanos da } \\
\text { organização). }\end{array}$ \\
\hline $\begin{array}{l}\text { Autoridade e } \\
\text { responsabilidade }\end{array}$ & $\begin{array}{l}\text { A autoridade, para Fayol, é definida como "o direito de dar ordens e o poder } \\
\text { para a exata obediência"; responsabilidade envolve ser confiável e, desse } \\
\text { modo, está naturalmente associada à autoridade. }\end{array}$ \\
\hline Disciplina & $\begin{array}{l}\text { Significa a necessidade de esforço comum dos trabalhadores, de maneira } \\
\text { ordenada; punições, entretanto, deveriam ser aplicadas criteriosamente } \\
\text { para encorajar o esforço comum. }\end{array}$ \\
\hline $\begin{array}{l}\text { Unidades de } \\
\text { comando }\end{array}$ & $\begin{array}{l}\text { Os trabalhadores nas organizações deveriam receber ordens de um gerente } \\
\text { somente para evitar conflitos e mal entendidos. }\end{array}$ \\
\hline $\begin{array}{l}\text { Unidade de } \\
\text { direção }\end{array}$ & $\begin{array}{l}\text { A organização toda deveria estar se movendo em direção a um objetivo } \\
\text { comum, numa direção comum. }\end{array}$ \\
\hline $\begin{array}{l}\text { Subordinação de } \\
\text { interesses }\end{array}$ & $\begin{array}{l}\text { Os interesses de uma pessoa não deveriam prevalecer sobre os interesses } \\
\text { da organização como um todo. }\end{array}$ \\
\hline $\begin{array}{l}\text { Remuneração do } \\
\text { pessoal }\end{array}$ & $\begin{array}{l}\text { O pagamento deveria ser justo, não explorativo, e deveria recompensar o } \\
\text { bom desempenho; deveriam ser usados vários modos de pagamento, tais } \\
\text { como tempo, trabalho, razão de produção etc.; recompensas não financeiras } \\
\text { também deveriam ser usadas. }\end{array}$ \\
\hline Centralização & $\begin{array}{l}\text { Segundo definição de Fayol, a centralização era como "a diminuição da } \\
\text { importância do papel do subordinado", enquanto a descentralização era a } \\
\text { elevação dessa importância. }\end{array}$ \\
\hline
\end{tabular}

${ }^{60}$ A revisão foi baseado na obra de SILVA (2001) 
Tabela 3.7 (conclusão) - Princípios gerais da administração sugeridos por Fayol. SILVA (2001)

\begin{tabular}{l|l|}
\multicolumn{1}{|c|}{ Princípios } & \multicolumn{1}{c}{ Explicação } \\
\hline Cadeia escalar & $\begin{array}{l}\text { Definida por Fayol como linha de autoridade, queria significar certa } \\
\text { quantidade de autoridade correspondente à posição hierárquica, mas } \\
\text { significava também que níveis mais baixos de administradores deveriam } \\
\text { sempre manter os níveis mais altos informados das suas atividades de } \\
\text { trabalho. }\end{array}$ \\
\hline Ordem & $\begin{array}{l}\text { Para o bem da eficiência e coordenação, todos os materiais e pessoas } \\
\text { relacionadas a um tipo específico de trabalho deveriam ser designados à } \\
\text { mesma localização geral na organização. }\end{array}$ \\
\hline $\begin{array}{l}\text { Equidade } \\
\text { Estabilidade do } \\
\text { pessoal no cargo }\end{array}$ & $\begin{array}{l}\text { A retenção dos trabalhadores mais produtivos deveria ser alta prioridade da } \\
\text { administração. }\end{array}$ \\
\hline $\begin{array}{l}\text { Espírito de } \\
\text { equipe }\end{array}$ & $\begin{array}{l}\text { Os administradores deveriam enfatizar a harmonia e a boa vontade geral } \\
\text { entre os empregados, como grandes forças da organização. }\end{array}$
\end{tabular}

\subsubsection{3}

\section{O modelo clássico posto em xeque}

ZILBOVICIUS (1999) lembra que durante os anos 70 ocorreram dois processos paralelos que abalaram as bases do modelo clássico. Se de um lado os mercados-chave da economia mundial se tornaram altamente competitivos e os mercados financeiros se instabilizaram, por outro, e contribuindo para o primeiro fenômeno, a indústria japonesa se superou. Ganhou uma capacidade competitiva inédita, atingindo o mercado mundial com rendimento, eficiência, qualidade etc. mais elevados do que o das empresas ocidentais, principalmente as americanas.

Ao fazer análise sob a ótica social, para um panorama macroeconômico, ZILBOVICIUS (1999) aponta que

de 1945 até a década de 70 as sociedades capitalistas avançadas experimentaram uma fase de expansão econômica sustentada. A noção de Fordismo aponta algumas razões para essa excepcional estabilidade, como meio de absorção de crescentes níveis de produtividade. A duração da estabilidade econômica do pós-guerra proporcionou estabilização paralela de instituições sociais na economia em geral e no mercado de trabalho em geral, consolidando estrutura integrada de organização e regulação. Recentemente, a economia do pós-guerra sucumbiu à crise, distúrbio ininterrupto de todas as condições sociais: um equivalente mais elegante para a noção de flexibilização.

Analisando as razões que levaram à construção de um novo modelo de organização, ZILBOVICIUS (1999) aponta que a questão não é apenas econômica.

Ainda que as condições do ambiente econômico tenham se modificado a partir dos anos 70 (aprofundando-se a necessidade de competitividade, de qualidade, de flexibilidade, de novo compromisso com a força de trabalho, de redução de custos), observa-se que as organizações têm grandes dificuldades para alterar seus pressupostos de modo a se adequarem a essas novas condições. É a permanência do modelo colocado em xeque.

Segundo ZILBOVICIUS (1999), qualquer que seja o ponto de vista de análise, passa a ser indiscutível que os resultados da economia e das empresas japonesas são melhores que os ocidentais. Inicia-se uma busca frenética por parte dos agentes industriais no 
sentido de compreender as razões desse sucesso, e descobrem-se diversas características japonesas às quais, em maior ou menor medida, conforme o analista, atribui-se o sucesso japonês. Aparecem no cenário ocidental o just in time, o total quality management, o total quality maintainence, os CCQ's, o Kaizen, o emprego vitalício, os traços culturais milenares do Japão, a Lean Production etc. Consolida-se, aos poucos, no ocidente, a idéia de que há um novo modelo, um novo paradigma que oferece melhor desempenho do que o anterior.

\subsubsection{Perspectiva Humanística}

A perspectiva humanística da administração teve início em 1930 (embora com raízes nos anos de 1920), principalmente pelas contribuições pioneiras de Mary Parker Follett, de Chester Barnard e de Elton Mayo. Os estudiosos caracterizam essa fase pelos movimentos que intitularam de "enfoque no elemento humano" (psicologia) e de "enfoque no comportamento coletivo" (sociologia). Esses movimentos, em que predominam as doutrinas psicológicas, com os respectivos estudos de interrelacionamentos, têm sido consideradas como a Escola Neoclássica da Administração.

A teoria desses movimentos se baseia no entendimento de que a escola clássica enfatiza os princípios e métodos formais da administração, numa concepção de que o ser humano era apenas um dos vários elementos necessários ao alcance da eficiência administrativa, encarada como produtividade ou rendimento, e a motivação maior era econômica e técnica. SILVA (2001)

A principal e mais conhecida escola surgida dentro dessa perspectiva humanística foi a Escola das Relações Humanas, de Elton Mayo. A ela se somam outras três escolas: i) as Teorias de Transição, de Follett e de Barnard; ii) a Escola Comportamentalista, de Maslow, Herzberg e Likert; iii) o Estruturalismo, de Etzioni e de Blau/Scott.

3.4.2.2.1

A Escola das Relações Humanas

A Escola das Relações Humanas foi construída com base na teoria clássica. As teorias administrativas desenvolvidas até então desencadearam uma alteração: a ênfase colocada na tarefa (Taylor), colocada na estrutura (Fayol) e colocada na autoridade (Weber), foi transferida para a ênfase nas pessoas que fazem parte da organização.

Os aspectos organizacionais mais importantes se concentram no homem e seu grupo social, ou seja, a preocupação passa dos aspectos técnicos e formais para os aspectos psicológicos e sociológicos.

O movimento das relações humanas foi um esforço combinado, dentre teóricos e práticos, para tornar os gerentes mais sensíveis às necessidades dos empregados. Isso veio como resultado de circunstâncias muito especiais que ocorreram durante a primeira metade do século $X X:$ i) enfraquecimento do sindicalismo; ii) filosofia do humanismo industrial; iii) estudos de hawthorne.

Elton Mayo (1880-1949), um psicólogo que trabalhou a maior parte da sua vida na Harvard Business School, foi o mais importante incentivador e protagonista da Escola das Relações Humanas. Mayo foi o responsável pela coordenação e realização da experiência de Hawthorne (MAYO, 1933), que desencadeou uma série de descobertas sobre o comportamento humano no trabalho (realizou quatro estudos importantes com relação ao comportamento e resultados da produtividade no trabalho). 
A Tabela 3.8 aponta algumas das críticas de estudiosos sobre a Teoria das Relações Humanas.

Tabela 3.8 - Algumas críticas à Teoria das Relações Humanas. Fonte: SILVA (2001)

\begin{tabular}{|c|c|}
\hline Crítica & Explicação \\
\hline Validade científica & $\begin{array}{l}\text { Muitas das conclusões não são sustentadas por adequada } \\
\text { evidência científica; são baseadas mais numa compreensão clínica } \\
\text { do que em experimentos controlados. }\end{array}$ \\
\hline Miopia dos enfoques & $\begin{array}{l}\text { Os seguintes pontos confirmam a visão curta das Relações } \\
\text { Humanas: i) falta de adequado foco no trabalho (muita ênfase nos } \\
\text { relacionamentos interpessoais e nos grupos informais); ii) } \\
\text { negligência da dimensão da satisfação do trabalho (excesso de } \\
\text { motivação econômica, para controlar o comportamento humano); } \\
\text { iii) pesquisas das relações humanas concernentes a operários. }\end{array}$ \\
\hline $\begin{array}{l}\text { Super-preocupação com a } \\
\text { felicidade }\end{array}$ & $\begin{array}{l}\text { Os estudos de Hawthorne sugeriam que "empregados felizes serão } \\
\text { empregados produtivos". Essa relação entre felicidade e satisfação } \\
\text { no trabalho é infeliz porque representa visão simplista da natureza } \\
\text { do homem. }\end{array}$ \\
\hline $\begin{array}{l}\text { Mal-entendimento do } \\
\text { sentido de participação }\end{array}$ & $\begin{array}{l}\text { Alguns dos estudiosos pós-Hawthorne viam a participação como } \\
\text { um lubrificante que reduziria a resistência à autoridade formal, e } \\
\text { levaria os trabalhadores ao alcance das metas organizacionais. }\end{array}$ \\
\hline $\begin{array}{l}\text { A visão de decisão de } \\
\text { grupo }\end{array}$ & $\begin{array}{l}\text { Mesmo com a evidência da pesquisa sobre a superioridade da } \\
\text { decisão do grupo ser conflitante e não conclusiva, a teoria } \\
\text { manteve esta superioridade sobre a decisão individual; o indivíduo } \\
\text { não quer perder sua identidade ou não quer ser identificado só } \\
\text { pelo grupo. }\end{array}$ \\
\hline Geração de conflitos & $\begin{array}{l}\text { A teoria falhou em reconhecer o conflito como uma força criativa } \\
\text { na sociedade; os estudiosos acreditavam que o conflito era ruim e } \\
\text { devia ser minimizado. O conflito existe e, se adequadamente } \\
\text { tratado, pode trazer ajustes e resultados mais eficazes. }\end{array}$ \\
\hline Antiindividualismo & $\begin{array}{l}\text { O Movimento das Relações Humanas é antiindividualista. A } \\
\text { disciplina do chefe é substituída pela disciplina do grupo, forçando } \\
\text { o indivíduo a sacrificar seus valores pessoais e atitudes, na } \\
\text { sufocante conformidade aos padrões grupais. }\end{array}$ \\
\hline
\end{tabular}

3.4.2.2.2

A Escola Comportamentalista

A abordagem comportamentalista, também denominada Novas Relações Humanas, teve origem com um desdobramento da Teoria das Relações Humanas e como tentativa de consolidar o enfoque das relações humanas nas teorias das organizações. Nomes como Herzberg, Maslow e Argyris, entre outros, pertenciam a esse grupo que surgiu partir da década de 30 nos Estado Unidos.

Essa corrente de pensamento gerencial centrou sua preocupação na tentativa de propor modelos para o equacionamento (ou minimização) dos conflitos ocorridos ao longo do processo de introdução e difusão dos princípios Tayloristas/Fordistas, entre os anos 20 e 50. A ênfase, portanto, concentrava-se no fato de que no Taylorismo/Fordismo pouca importância era dada ao fator humano no trabalho, uma vez que a preocupação gerencial era quase exclusivamente a de produzir o máximo possível, com estilos de liderança pouco propícios à motivação dos trabalhadores. (MARX, 1998) 
A maior parte dos autores dessa corrente parte do princípio de que é função da gerência tomar iniciativas que levem à motivação e equacionem o problema da produtividade das empresas.

Para MARX (1998), no que se refere às propostas de fato, tais autores se limitaram a recomendar mudanças que, no fundo, significaram somente alterações incrementais na lógica de organização da produção Taylorista/Fordista, nas responsabilidades assumidas pelos diversos agentes, no tratamento das informações e na autonomia para a tomada de decisão.

Do ponto de vista do corpo gerencial, tais recomendações, em muitos casos, pareceriam adequadas à prática. Dispunha-se agora de recomendações que objetivavam resolver os problemas oriundos da introdução do Taylorismo "a frio", ou seja, sem maiores preocupações com o lado humano da organização, com vantagem importante de que para tanto não era necessário alterar a lógica da produtividade e a estrutura de poder propostas por Taylor. MARX (1998)

As chamadas teorias clássicas, ainda que com todas as críticas que lhes cabem, exerceram grande influência nos campos da psicologia ou sociologia do trabalho e administração de empresas.

A abordagem comportamental para a organização do trabalho está fortemente respaldada em conceitos relativos a teorias motivacionais. Seus defensores alegam que os trabalhos organizados, segundo os princípios da administração científica, alienavam o indivíudo no trabalho, fazendo-se necessário uma abordagem de organização que levasse em conta a necessidade de obter algo positivo de seus trabalhos.

Para HACKMAN; LAWLER (1971), os trabalhos projetados, para preencher as necessidades de auto-estima e desenvolvimento pessoal, não seriam apenas mais compensadores, mas também mais motivadores. Incentivariam as pessoas a contribuir com mais talentos e habilidades e, com isso, atingir-se-iam importantes objetivos, desejados pela organização do trabalho, tais como: atividades com qualidade de vida no trabalho intrinsecamente maior (um fim eticamente desejável); trabalho com altos índices motivacionais conduziriam ao melhor desempenho das operações, tanto em termos de qualidade como de volume de saídas.

SLACK et al. (1999) observa que a abordagem comportamental introduziu uma variável interveniente de motivação pessoal para desempenhar o trabalho (Figura 3.9). 


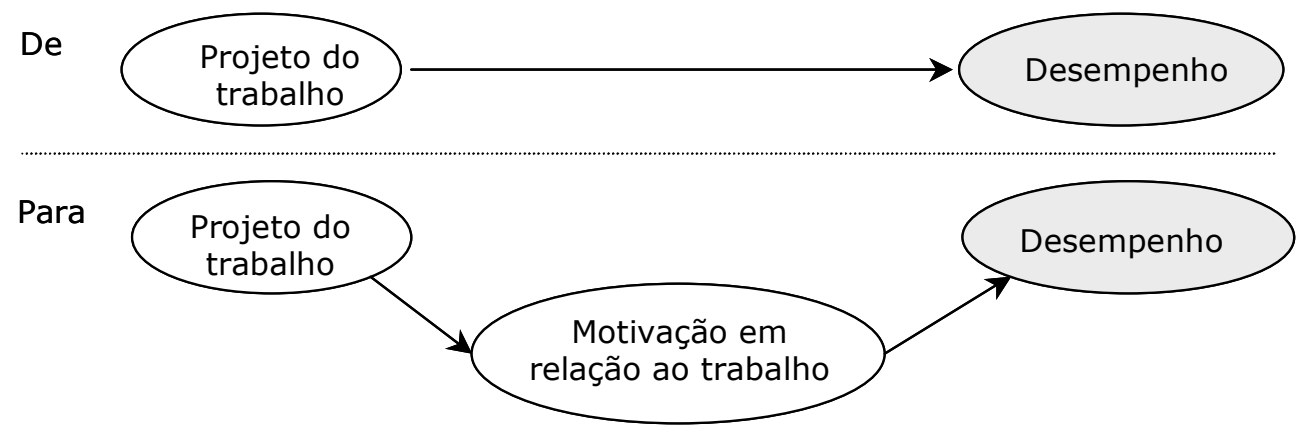

Figura 3.9 - Mudança da abordagem de organização do trabalho através da filosofia comportamental. Fonte: SLACK et al. 1999

THOMPSON (1976) avalia que a "variabilidade humana é enorme, cada pessoa é um fenômeno multidimensional, sujeito às influências de uma enormidade de variáveis. $O$ raio de diferenças em aptidões é grande e os padrões de comportamento apreendidos são diversos".

As diferenças individuais fazem com que cada um tenha suas próprias características de personalidade, suas aspirações, seus valores, suas atitudes, suas motivações, suas aptidões etc., aponta CHIAVENATO (2002). "Cada pessoa é um fenômeno multidimensional sujeito às influências de uma enormidade de variáveis".

Se as organizações são compostas de pessoas, o estudo das pessoas constitui a unidade básica para o estudo das organizações e, principalmente, para a administração dos recursos humanos.

Dentre os fatores internos que influenciam o comportamento humano (Figura 3.10), darse-á destaque à motivação.

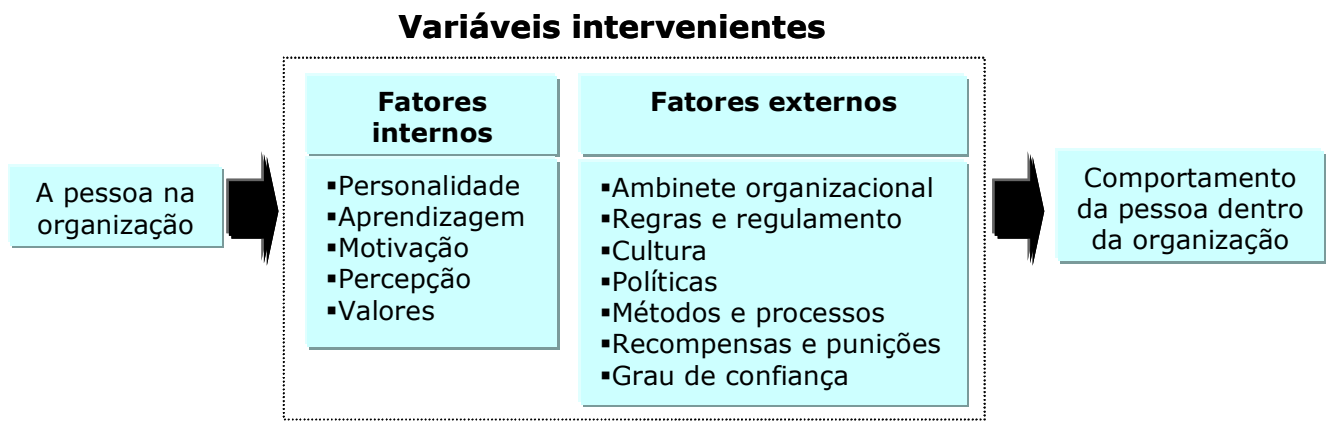

Figura 3.10 - Fatores internos e externas que influenciam o comportamento humano

O estudo da motivação se refere basicamente "às razões pelas quais as pessoas se comportam de certo modo". SILVA (2001). Para LEAVITT (1964) o comportamento não é 
espontâneo e nem isento de finalidade: sempre haverá algum objetivo implícito ou explícito para explicá-lo.

CHIAVENATO (2002), ao explicar o ciclo motivacional, afirma que surge a partir de uma necessidade. É uma força dinâmica e persistente que provoca comportamento.

Toda vez que surge uma necessidade, essa rompe o estado de equilíbrio do organismo, causando um estado de tensão, insatisfação e desequilíbrio. Esse estado leva o indivíduo a um comportamento, ou ação, capaz de descarregar a tensão ou livrá-lo do desconforto e desequilíbrio. Se o comportamento for eficaz, o indivíduo encontrará a satisfação da necessidade e, portanto, a descarga da tensão provocada por ela. Satisfeita a necessidade, o organismo volta ao estado de equilíbrio anterior à sua forma de ajustamento ao ambiente.

BERGAMINI (1991), após realizar uma extensa revisão bibliográfica, salienta que motivação não é condicionante, mas um fenômeno pessoal e não controlável desde fora. Com base numa pesquisa realizada, demonstra a relação existente entre o que chama estilo de comportamento motivacional e tipo de trabalho.

Cada um dos quatro tipos de estilos propostos - ação, manutenção, participação e conciliação - têm preferências que se manifestam em face do tipo de atividade e da configuração de trabalho proposta. Dessa forma, o papel gerencial para promover a motivação consta, segundo a autora, essencialmente em saber configurar corretamente a atividade em função do estilo individual de cada pessoa, criando condições para que o estímulo pelo trabalho aflore.

Para KONDO (1994), a motivação para o trabalho depende essencialmente de três fatores: criatividade (o prazer de pensar), atividade física (o prazer do trabalho físico) e sociabilidade (a satisfação em compartilhar alegrias e sofrimentos com colegas).

CAMPOS (1995) afirma, apoiado em sua experiência profissional, que a base da motivação é a confiança, conceito humanístico de difícil tratamento teórico e que transcende claramente dois níveis de fatores motivacionais classicamente estudados (fatores extrínsecos e intrínsecos).

Segundo SILVA (2001), qualquer teoria de motivação se preocupa em determinar as razões pelas quais as pessoas adotam determinados comportamentos, e o processo que os causa. As teorias, cujo foco está em "o que" motiva o comportamento, são chamadas "teorias de conteúdo" e aquelas, cujo foco está em "como" o comportamento é motivado, são chamadas "teorias de processo".

As teorias de conteúdo focalizam geralmente as necessidades humanas de algum tipo e são representadas pela: i) Teoria da Hierarquia das Necessidades, de Maslow; ii) Teoria ERC (existência, relacionamento e crescimento), de Alderfer; iii) Teoria dos dois fatores de Herzberg; iv) Teoria da Realização, de McClelland.

A força das necessidades e o modo específico como uma pessoa deseja satisfazê-las são usualmente diiscutidos pelas teorias de processo, que são: i) Teoria da Expectação, de Vroom; ii) Teoria da Eqüidade, de Stacy Adams.

A Tabela 3.9 apresenta uma comparação simplificada das várias teorias motivacionais. 
Tabela 3.9 - Comparação das principais teorias de motivação. Fonte: SILVA (2001)

\begin{tabular}{|c|c|c|}
\hline \multicolumn{2}{|c|}{ Teoria } & Implicações \\
\hline $\begin{array}{l}\text { Hierarquia } \\
\quad \text { das } \\
\text { Necessidades } \\
\text { de MASLOW }\end{array}$ & conteúdo & $\begin{array}{l}\text { As necessidades dos funcionários variam e os administradores } \\
\text { podem motivá-los a alcançar essas necessidades. }\end{array}$ \\
\hline $\begin{array}{l}\text { ERC, de } \\
\text { ALDERFER }\end{array}$ & conteúdo & $\begin{array}{c}\text { As necessidades de níveis mais baixos podem ser ativadas quando } \\
\text { as de níveis mais altos não podem ser satisfeitas; mais de uma } \\
\text { necessidade pode ser ativada ao mesmo tempo. }\end{array}$ \\
\hline $\begin{array}{l}\text { Dos dois } \\
\text { fatores, de } \\
\text { HERZBERG }\end{array}$ & conteúdo & $\begin{array}{l}\text { Compensações, condições razoáveis de trabalho e políticas não } \\
\text { necessariamente asseguram satisfação no trabalho, mas podem } \\
\text { evitar a insatisfação; outros fatores (responsabilidade, por } \\
\text { exemplo), podem ser necessários para motivar funcionários. }\end{array}$ \\
\hline $\begin{array}{l}\text { Necessidades } \\
\text { adquiridas, } \\
\text { de } \\
\text { McClelland }\end{array}$ & conteúdo & $\begin{array}{c}\text { As necessidades dos funcionários são adquiridas ao longo do tempo } \\
\text { em função da experiência de vida, o que exige que os } \\
\text { administradores aprendam a identificá-las e criem ambientes de } \\
\text { trabalho que sejam responsivos aos respectivos perfis de } \\
\text { necessidade. }\end{array}$ \\
\hline $\begin{array}{l}\text { Expectância, } \\
\text { de Vroom }\end{array}$ & processo & $\begin{array}{c}\text { Funcionários são motivados se as recompensas potenciais pelo alto } \\
\text { desempenho são desejáveis e alcançáveis. }\end{array}$ \\
\hline $\begin{array}{l}\text { Eqüidade, de } \\
\text { Stacy Adams }\end{array}$ & processo & $\begin{array}{l}\text { Funcionários são motivados se estão sendo compensados de acordo } \\
\text { com suas atribuições percebidas pela organização. }\end{array}$ \\
\hline
\end{tabular}

Cada uma das teorias de motivação é potencialmente útil e importante. Algumas têm enfoques mais fortes (por exemplo, as teorias da eqüidade e expectância) do que outras, mas todas apresentam contribuições. SILVA (2001) salienta que pensamentos correntes argumentam que uma abordagem combinada, com o desenvolvimento de modelos contingenciais, com aspectos das diversas teorias, funcionariam melhor.

Com o intuito de mostrar como se pode correlacionar aspectos psicológicos com a motivação, apresenta-se, a seguir, com maiores detalhes, uma dentre as teorias citadas na Tabela 3.9, a teoria da expectação, que apresenta abordagem compreensiva, válida e útil ao entendimento da motivação a qual se pretende ter nesta tese.

Em 1964, Victor Vroom apresentou a teoria da expectação, também chamada de teoria da expectância, como alternativas às teorias de conteúdo. Ela vê as pessoas como tendo suas próprias necessidades e expectativas do que desejam a partir do trabalho (e, obviamente, das recompensas). A Figura 3.11 apresenta o modelo básico da referida teoria.

LAUFER; JENKINS (1982), que foram seguidores da teoria proposta por Vroom, reforçam que as necessidades de um indivíduo só podem ser satisfeitas através do seu engajamento em comportamentos. Na maioria das situações, os indivíduos têm de optar entre os vários comportamentos potencialmente possíveis de satisfazerem as necessidades. A explicação mais aceita de como os indivíduos escolhem entre um conjunto de comportamentos alternativos é a chamada Teoria da Expectância. A Teoria da Expectância se baseia na proposição simples de que os indivíduos optam por aqueles comportamentos que acham que os levarão a resultados (recompensas, como pagamento ou reconhecimento pelo chefe) que lhes são atrativos (que atendem a suas necessidades específicas). A teoria, baseada nessa proposição, indica como analisar e 
predizer os cursos de ação que irão tomar quando tiverem oportunidade de realizar escolhas sobre seus comportamentos.

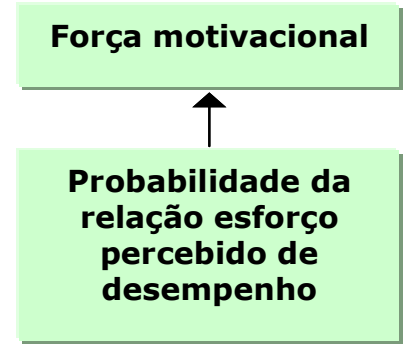

Quais as chances de obter o resultado se for colocado o esforço necessário?

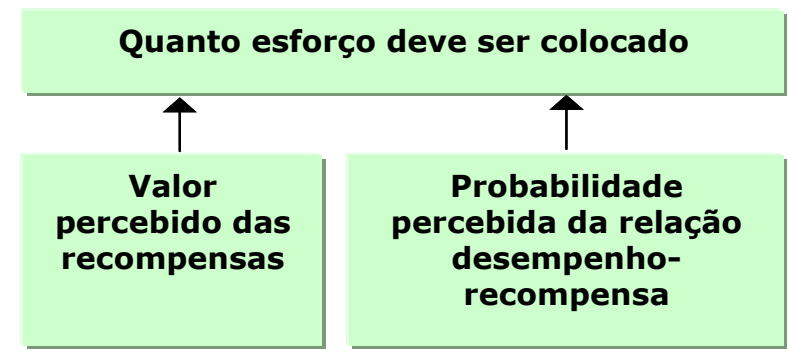

Quais as recompenses valorizadas?
Quais as chances de obter as recompensas valorizadas se o resultado for completamente satisfatório

Figura 3.11 - Modelo básico da teoria da expectação

A Figura 3.12 apresenta graficamente a teoria da expectativa. Mostra que os indivíduos, ao contemplarem a realização de uma ação, consideram vários fatores. Primeiro, a probabilidade de que se realizarem um determinado esforço serão capazes de atingir o nível de desempenho requerido (a expectativa esforço - desempenho, ou E $\rightarrow D$ ); segundo, a probabilidade de que, uma vez alcançado o desempenho requerido, ele leve à obtenção de resultados (a expectativa desempenho - resultado, ou $D \rightarrow R$ ); terceiro, a atratividade dos resultados.

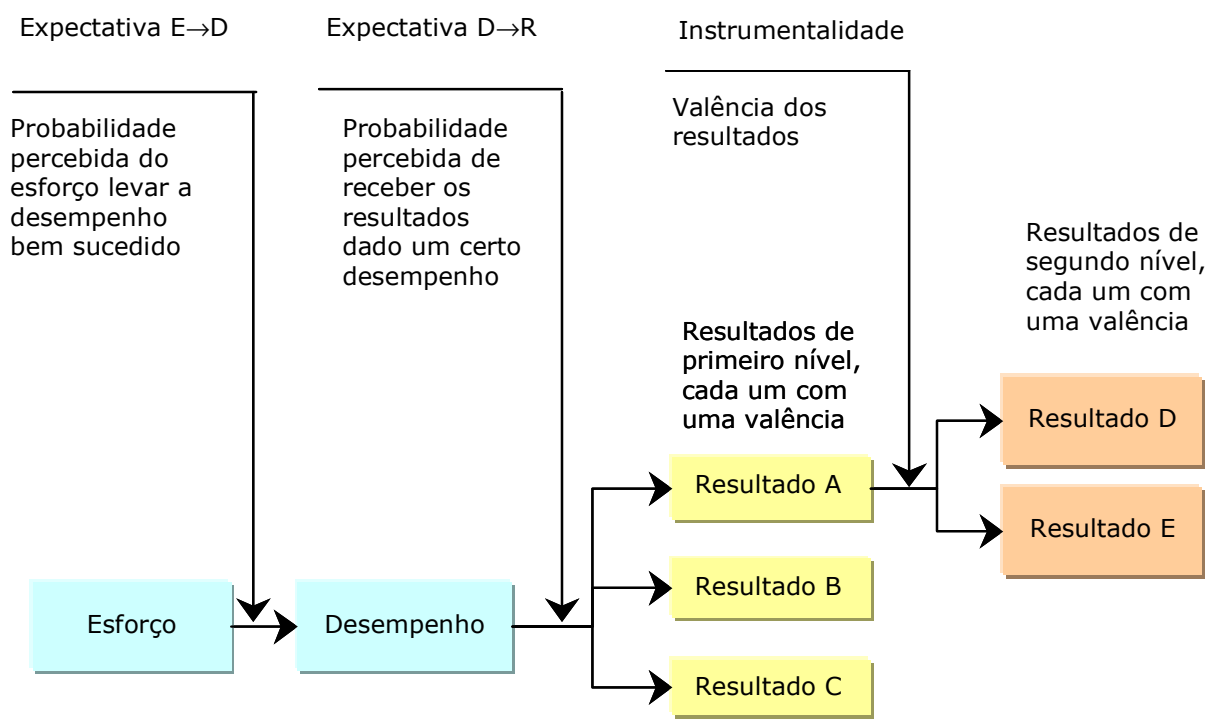

Figura 3.12 - Principais termos da teoria da Expectativa 
Dado esse modelo, a força motivacional, que puxa o comportamento em uma dada direção, é maior quando o indivíduo:

- acredita que o desempenho no nível desejado é possível (alta expectativa $E \rightarrow D$ );

- acredita que o comportamento levará aos resultados (alta expectativa $D \rightarrow R$ ) e esses resultados têm um valor positivo (alta atratividade).

Dado um conjunto de comportamentos alternativos $(10,15$ ou 20 unidades de produção por hora, ou trabalho versus faltar ao serviço, por exemplo), o modelo prediz que os indivíduos escolherão o comportamento com a maior força motivacional a ele associado. Em outras palavras, quando se tem que escolher um comportamento, o indivíduo colocará questões como: posso atingir aquele desempenho se tentar? O que acontecerá se atingi-lo? o que eu acharei do resultado? Decide-se pelo caminho que, aparentemente ,tem as melhores chances de produzir resultados positivos.

É importante notar que o modelo da expectativa não diz que as pessoas sempre se comportarão de determinada maneira para obter o que desejam. Assume que o indivíduo toma decisões racionais baseadas na percepção da situação, mas não pressupõe que elas têm informações completas e acuradas quando tomam as decisões.

A questão sobre o que determina a opinião que indivíduos sustentam quanto às relações entre esforço e desempenho e entre desempenho e realização tem sido examinada por LAUFER; JENKINS (1982). Eles concluem que o determinante individual mais importante de expectativa esforço-desempenho $(E \rightarrow D)$ do indivíduo é a situação objetiva. Acrescentando, os sentimentos de auto-estima, experiências em situações similares, e a comunicação com outros (colegas de trabalho, supervisores) são também maiores inputs para a percepção da situação. A percepção das pessoas da expectativa $D \rightarrow R$ é influenciada por muitas das mesmas coisas que a expectativa $E \rightarrow D$. Acrescentando, $a$ atração de realizações e a opinião sobre quem controla os resultados ( a própria pessoa ou outra) terão impacto sobre a percepção das pessoas quanto à expectativa $D \rightarrow R$.

É através da manipulação dessas expectativas, focado através de seus determinantes, que um gerente pode influenciar significativamente no nível de motivação do indivíduo. Por exemplo, para remover obstáculos para um desempenho efetivo (inadequados equipamentos, ferramentas e suprimento) um supervisor troca a situação objetiva e provavelmente incrementa a expectativa $E \rightarrow D$.

Similarmente, através da recompensa de desempenhos efetivos consistentemente, um supervisor pode mudar a credibilidade quanto à existência de recompensa para certos desempenhos.

\subsection{Outras abordagens comportamentais da organização do trabalho}

No final da década de 60 começam a ocorrer, nos Estados Unidos e na Europa, manifestações, por parte dos trabalhadores, contra a forma clássica de organização do trabalho, embasadas num pensamento de cunho sociológico/psicológico, no sentido de contrapor os efeitos da aplicação do modelo clássico.

O movimento que aparece, como contraponto ao modelo Taylorista/Fordista, que passou a ser conhecido como Escola de Relações Humanas, desenvolveu seus argumentos a partir das incongruências entre as necessidades associadas ao desenvolvimento das pessoas e as exigências dos cargos das organizações. 
ARGYRIS (1975) elaborou a Teoria da Maturidade e Imaturidade, buscando tornar explícito que o que as organizações estavam demandando das pessoas (como tarefas rotineiras, obediência cega às determinações e às regras etc) era relacionado às características de pessoas imaturas ou infantis, conflitante com as demandas das pessoas maduras. "Tornava-se imperioso, então, enriquecer os cargos para que as pessoas pudessem desenvolver suas características pessoais maduras no processo de trabalho".

FLEURY (1999) considera que essa linha de pensamento abriu espaço para as discussões sobre a questão da "participação no trabalho". A partir dos anos 60 começam a ser estudados modelos organizacionais participativos, desenvolvendo-se a idéia de que a participação dos operários em vários tipos de decisão nas empresas levava a um melhor desempenho competitivo.

Se o aumento do número de tarefas no trabalho é limitado pela tecnologia do processo, uma abordagem pode ser a de revezar os operários quanto ao trabalho que lhes cabe. Isso significa mover os indivíduos periodicamente entre diferentes conjuntos de tarefas para proporcionar variedade em suas atividades. "O revezamento do trabalho pode aumentar a flexibilidade de habilidades e contribuir para reduzir a monotonia". SLACK et al. (1999)

Em contraponto, aqueles que não apóiam essa prática, sejam eles administradores ou o próprio pessoal que desempenha o trabalho, apontam como desvantagens, respectivamente, a interrupção da normalidade do fluxo e possíveis interferências negativas no ritmo de trabalho.

SLACK et al. (1999) comentam que, na linha de montagem, por exemplo, "a linha original poderia ser mantida e poderia ser acordado um cronograma de revezamento de trabalho, que envolvesse cada pessoa movendo-se para um posição diferente da linha e, portanto, desempenhando um conjunto diferente de tarefas".

HACKMAN; OLDHAM (1975) comentam que o mais óbvio método de atingir pelo menos alguns dos objetivos do projeto comportamental do trabalho (Figura 3.13) é através da "alocação de um maior número de tarefas para os indivíduos" (ou tarefas combinadas). Se essas tarefas extras são do mesmo tipo das do trabalho original, a mudança é chamada "alargamento do trabalho".

SLACK et al. (1999) aponta que o alargamento do trabalho pode não envolver tarefas mais exigentes, mas pode proporcionar um trabalho mais completo e, portanto, mais compensatório. "A pessoa desempenhando um trabalho alargado, não repetirá atividades com tanta freqüência como faria, o que pode tornar o trabalho menos monótono; apesar de a variedade de tarefas aumentar, não deverá haver responsabilidade adicional ou mais autonomia dada a cada indivíduo". 


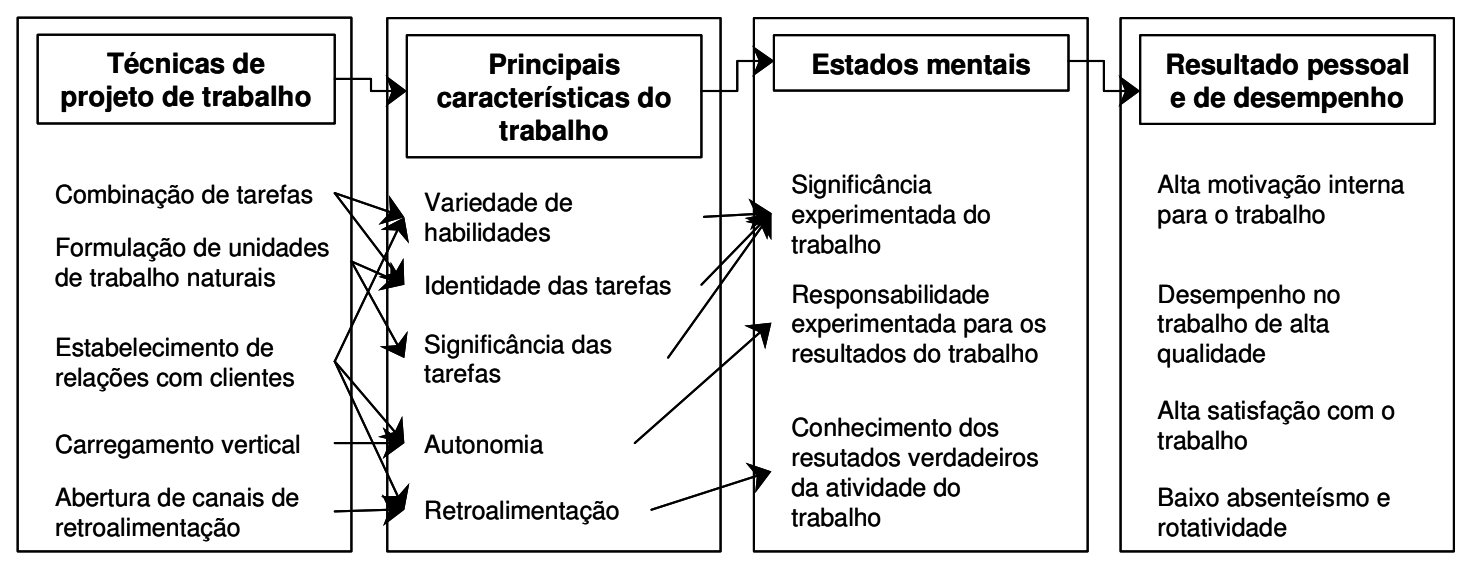

Figura 3.13 - Modelo de projeto do trabalho proposto por HACKMAN; OLDHAM (1975)

O enriquecimento do trabalho, assim como o seu alargamento, aumenta o número de tarefas que é alocada a cada trabalho. Porém significa a alocação de tarefas extras o que envolve mais tomada de decisões, maior autonomia e, portanto, maior controle sobre o trabalho. SLACK et al. (1999) cita, como exemplo de tarefas extras, a manutenção e o ajuste de qualquer tecnologia de processo usada, o planejamento e o controle de atividades internas ao trabalho ou o monitoramento dos níveis de qualidade. "O objetivo é tanto reduzir a repetição no trabalho como aumentar a autonomia e as oportunidades de desenvolvimento pessoal no trabalho".

A Figura 3.14 lustra a diferença entre enriquecimento e alargamento do trabalho. Mudanças no trabalho original que acontecem na horizontal são as que estendem à variedade das tarefas similares. As mudanças na vertical são aquelas que adicionam responsabilidade, tomadas de decisões e autonomia do trabalho. $O$ alargamento implica movimento apenas na escala horizontal, enquanto o enriquecimento certamente implica movimento na escala vertical, ou, talvez, em ambas as escalas. 


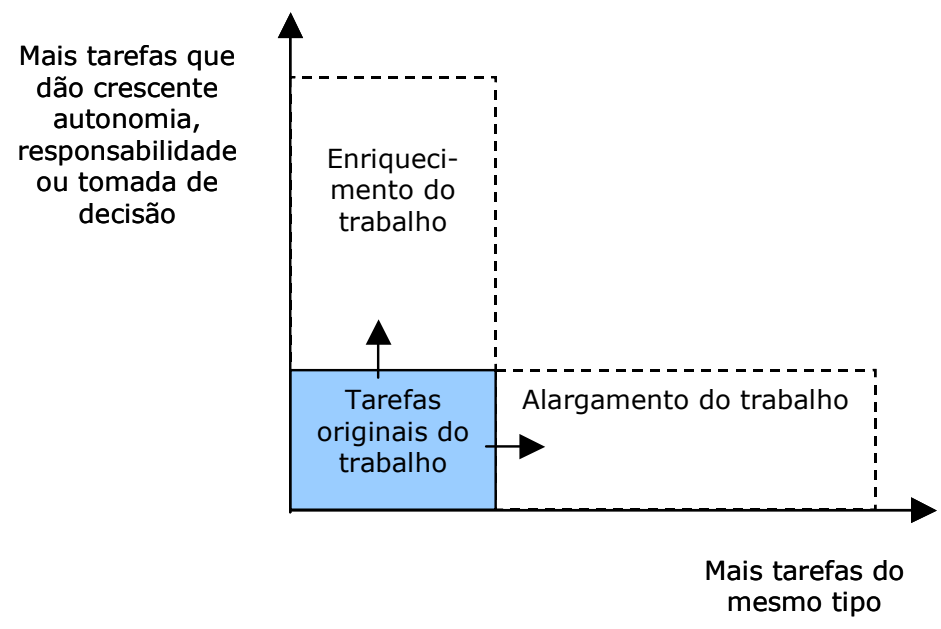

Figura 3.14 - Comparação entre alargamento e enriquecimento do trabalho

\subsubsection{Aspectos da Perspectiva Moderna e Contemporânea da Administração}

"O processo de reestruturação pelo qual passa um número significativo de empresas, contempla quase sempre um questionamento da forma como o trabalho direto é organizado" (MARX, 1998). Na indústria, o "modelo de posto de trabalho", em que a lógica do projeto e a operação da produção tem como base uma seqüência rígida de tarefas desempenhadas por trabalhadores praticamente fixos a tais postos, começa a ser substituída por outras abordagens. As iniciativas de mudança, segundo o autor supracitado, incluem diversos aspectos comuns, tais como redução de níveis hierárquicos, arranjos celulares de produção, programas de melhoria contínua, melhorias dos processos de comunicação, autonomia e polivalência dos trabalhadores entre as mais importantes.

Dessa forma, embora as exigências de flexibilidade sejam múltiplas e variem entre os setores produtivos e sistemas de produção, no âmbito industrial um número significativo de empresas tem adotado mudanças importantes na organização do trabalho. Como alternativa aos modelos clássicos de organização, merece destaque a abordagem da escola Sociotécnica, que anuncia uma organização de trabalho baseada no fato de que a autonomia crescente dos trabalhadores diretos pode responder com eficiência e eficácia às exigências de mercado. Na busca por novos modelos, vale também destacar as influências do "modelo japonês" de gestão, com destaque para os autores que o desenvolveram (em especial para Taichi Ohno, engenheiro japonês que implementou o conceito de "just in time"), já que se ressalta a questão do trabalho em grupo como ponto central das novas formas de organização anunciadas em contraposição aos modelos clássicos.

Embora estes novos modelos tenham sido desenvolvidos e orientados para a indústria seriada (que guarda significativas distinções em relação à indústria da construção), acredita-se que muitas das idéias que fundamentam este modelo venham a ter lógica 
também no setor da construção civil. Por exemplo, em alguns serviços de construção, têm-se percebido formas de organização do trabalho (grupos enriquecidos, ou mesmo semi-autônomos) que têm proporcionado aos trabalhadores níveis de autonomia significativos, como atestou SOUZA (1997). Para que se imagine alcançar os benefícios de formas de organização como a supracitada, sabe-se, no entanto, que há um trabalho de base a ser feito para adequar pontos básicos da organização do trabalho que ainda "engatinham" no setor da construção civil brasileira (citam-se, por exemplo, as práticas insipientes de contratação, seleção, treinamento e capacitação, entre outras, observados nas empresas do setor). Este trabalho pretende tratar a organização neste contexto.

\subsubsection{1}

\section{A Escola Sociotécnica ${ }^{61}$}

A abordagem sociotécnica tem sua proposta metodológica elaborada inicialmente por psicólogos industriais, mas numa perspectiva que supera as preocupações de caráter exclusivamente humanístico.

HERBST (1974), assim apresentou a crítica à abordagem mecanicistica do trabalho, que então prevalecia

[...] como conseqüência da subordinação do sistema social às condições do sistema técnico, e da inadequação desta forma à condição humana, o próprio desempenho das tarefas (e o alcance dos objetivos da organização) sofre disfunções. Estas disfunções em um sistema produtivo são geralmente traduzidas na forma de: redução de produtividade, queda dos níveis de qualidade, surgimento de distúrbios psicossomáticos, conflitos interpessoais e intergrupais, assim como elevação das taxas de absenteísmo e rotatividade. Podemos dizer que se o sistema tecnológico for otimizado às expensas do sistema social, o resultado alcançado será subótimo.

A sociotécnica representa uma corrente de pensamento que procura oferecer uma alternativa ao modelo clássico e à Escola de Relações Humanas. MARX (1998) reporta seu surgimento com base em estudos realizados por pesquisadores reunidos no Tavistock Institute of Londres, que puderam ser testados e reavaliados em certos casos de aplicação prática pioneiros, como o das minas de carvão de Durham na Inglaterra (em 1949), o de uma empresa têxtil em Ahmedabad na Índia (em 1952) e os de diversas empresas norueguesas (em torno de um projeto denominado Democracia Industrial, nas décadas de 60 e 70).

Das experiências práticas nas minas da Inglaterra, onde começaram a se consolidar os princípios da abordagem sociotécnica, duas conclusões foram tiradas. A primeira delas foi a eficácia do trabalho em grupo em determinadas circunstâncias. A segunda foi a da otimização conjunta: não adiantou otimizar o sistema técnico em detrimento do sistema social. A solução encontrada significou a otimização conjunta do sistema técnico e do sistema social.

Para FLEURY (1998), "a abordagem sociotécnica define como otimização conjunta dos aspectos sociais e técnicos aquela proposta que leva ao melhor alcance dos objetivos organizacionais, explorando a adaptabilidade e a criatividade das pessoas para o alcance das metas ao invés de determinar tecnicamente a maneira pela qual essas metas

${ }^{61}$ A revisão temática, apresentada a seguir, inspira-se diretamente nas obras de MARX (1998) e FLEURY (1998). 
deverão ser atingidas". O autor supracitado assim resume os critérios de planejamento de trabalho na perspectiva sociotécnica:

- o trabalho deve demandar outros esforços além do físico, tais como o esforço intelectual, a criatividade, bem como permitir alguma variedade;

- o trabalho deve possibilitar ao indivíduo um processo de aprendizagem contínuo, num ritmo coerente com suas capacidades individuais;

- o trabalho deve permitir que o indivíduo tome decisões a respeito das tarefas que realiza;

- o trabalho deve gerar reconhecimento perante os demais membros da empresa;

- o trabalhador deve relacionar o que faz à vida social, e seu trabalho deve posicioná-lo de forma digna em termos de valores compartilhados por seu grupo social;

- o bom desempenho do trabalho deve proporcionar acesso a um futuro desejável maiores salários, promoções, benefícios, ou participações em tomadas de decisões dentre outras.

CHIAVENATO (2002) entende que a abordagem sociotécnica focaliza a organização ou uma parte dela como uma combinação de tecnologia (exigências de tarefa, ambiente físico, equipamento disponível) e, ao mesmo tempo, um sistema social (um sistema de relações entre aqueles que realizam a tarefa). O fundamento dessa abordagem reside no fato de que qualquer sistema de produção requer tanto organização tecnológica (equipamentos e arranjos de processos), como organização de trabalho (envolvendo os que desempenham as tarefas necessárias).

Os princípios postulados pela escola sociotécnica formaram a base para os modelos de trabalho em grupo, que conquistaram atenção crescente a partir do início dos anos 90. Vale destacar dois tipos de grupos, os grupos semi-autônomos e os enriquecidos.

MARX (1998), ao versar sobre os grupos semi-autônomos, afirma que eles podem se considerados "alternativas organizacionais potencialmente capazes de possibilitar melhoria do desempenho operacional, sob uma perspectiva bastante diversa de iniciativas centradas na questão social (seja como decorrência de pressões sindicais ou do perfil do mercado de trabalho). Enfatizam a autonomia e a flexibilidade, possuem maior potencial de crescimento profissional dos componentes do grupo para a discussão e melhoria de resultados locais e globais da organização. Privilegiam a participação de todos os envolvidos (inclusive os trabalhadores) na formulação do projeto organizacional de mudança, o que inclui o desenho e a dinâmica de funcionamento dos grupos semiautônomos". O termo semi-autônomo procura enfatizar que nem todas as decisões passam a ser tomadas em grupo.

Já os grupos enriquecidos representam uma organização grupal com autonomia relativa, fortemente baseada no conceito de responsabilização e polivalência na gestão local. Seus graus de autonomia e alcance de suas atribuições são bastante restritos e predeterminados por um princípio de projeto organizacional que limita totalmente a participação dos trabalhadores em sua formulação. Os grupos teriam autonomia restrita, controlada pela supervisão; o alargamento crescente da autonomia não faria parte da prioridade dessa modalidade de grupos. Além disso, o projeto organizacional sob o qual se operaria, bem como mudanças nesse projeto, seriam decididos e implementados de maneira externalizada aos próprios grupos. MARX (1998) 
Na obra de MARX (1998) dá-se um destaque aos casos de implantação bem-sucedida de grupos semi-autônomos em empresas brasileiras. O autor credita boa parte da melhoria dos indicadores observados (montadoras de automóveis), nos últimos anos, ao processo de mudança organizacional, baseado em uma crescente autonomia decisória das equipes de trabalhadores que operam no chão de fábrica.

A escolha organizacional representada pelo trabalho em grupos semiautônomos procura apontar arranjos organizacionais avançados e que podem orientar trajetórias de empresas que apostem na autonomia e na busca de formas inovadoras de compromisso com seus funcionários.

CHIAVENATO (2002) apresenta uma série de recomendações que julga importantes no projeto de sistemas sóciotécnicos, como a capacidade de a organização do trabalho dar conta das "variáveis inerentes a um processo produtivo. Em vez de prescrever procedimentos para situações comuns, deve-se capacitar os trabalhadores a aprender sozinhos a dar conta das variações de toda ordem a que eles estão sujeitos no dia-adia".

MARX (1998) observa, a partir de meados da década de 80, um movimento de recuperação dos princípios sociotécnicos de projeto de organizações e sua implementação, seja na forma de introdução do conceito dos grupos semi-autônomos, seja na forma de conduzir mudanças organizacionais, sob a pressão da necessidade de se repensar mais profundamente as bases sobre as quais a produção e o trabalho se organizam. "O ambiente de crise mais profunda - que envolve a busca da sobrevivência em um novo ambiente competitivo em que flexibilidade, custos, qualidade e tempo são fatores competitivos de grande importância - parece estar contribuindo para que isto ocorra".

3.4.2.3.2

O Modelo Japonês

ZILBOVICIUS (1999) destaca em sua tese os principais aspectos do processo de reconversão do modelo clássico no Japão, buscando compreender o modo como os componentes desse modelo se integraram ao ambiente organizacional japonês, contribuindo para o desenvolvimento das práticas que mais tarde vieram a compor o modelo japonês.

O autor desenvolve sua argumentação e mostra que o modelo japonês pode ser compreendido como um produto do próprio método clássico ocidental, "que pressupõe a construção prévia de um modelo básico (uma determinada forma de articulação entre elementos e aspectos de um dado sistema segundo uma determinada racionalidade) que servirá como suporte para os projetos dos processos de produção e de trabalho".

WOOD (1992), ao comparar o modelo japonês e o Taylorismo, afirma que o modelo japonês "não foi desenvolvido isolado dos desenvolvimentos da teoria do "management" no Ocidente, ou abstraindo a pedra fundamental taylorista no pensamento mais remoto no Japão a respeito da administração da produção".

Os elementos do modelo clássico foram adaptados, no Japão, a condições específicas locais, tanto econômicas quanto sociais e culturais, permitindo a extrapolação de determinados limites que a formulação clássica havia cristalizado e permitindo que, a partir de uma nova formulação, fosse desenvolvido um novo modelo universalizável de eficiência. (ZILBOVICIUS, 1999)

No Japão, a lógica de organização do trabalho incorpora, "de maneira natural", aspectos que a sociotécnica propugnava como objetivos a serem alcançados. É o caso do trabalho 
em grupos. Sabe-se que as religiões orientais têm o "grupismo" como um dos seus pilares: o coletivo prevalece sobre o individual e a missão de cada indivíduo é preservar a harmonia do grupo com o qual se relaciona. (FLEURY, 1998).

Para Taiichi Ohno (OHNO, 1988), engenheiro japonês, que ajudou a implementar o modelo japonês de gestão, o trabalho em grupo é uma peça-chave para a redução dos desperdícios ("Teamwork é tudo"). O conceito de multiskilling utilizado pelo autor busca associar um trabalhador a vários postos de trabalho ("se um operador em um processo posterior estiver atrasado, outros deverão ajudá-lo"). "O objetivo final é a obtenção e, portanto, a fixação de metas, para um processo, para um grupo que nele trabalha. A organização em grupos presta não só aos objetivos de redução de custos (na medida em que se economiza com mão-de-obra), mas também permite que, via revezamentos e trocas de postos, obtenha-se melhor cobertura das porosidades e gargalos típicos de qualquer processo produtivo".

Rompe, portanto, com o modelo clássico ao enfatizar a preocupação com indicadores e controles de produtividade mais globalizantes do que propunham Taylor e Ford. Valorizam-se resultados de linhas ou plantas e não desempenhos individuais em postos específicos. A flexibilidade na alocação de postos de trabalho torna-se vital para que essa produtividade global possa ser atingida. MARX (1998).

Outro ponto que merece destaque, também observado por MARX (1998), é o fato de, no modelo aplicado por Ohno, ocorrer um alargamento dos níveis e abrangência das responsabilidades (e nem tanto da autonomia de decisão sobre a gestão) do trabalhador.

Se antes sua responsabilidade era executar a tarefa de maneira correta no tempo correto, agora ela passa a ser o desempenho de maior número de tarefas de operação, além do encargo em várias tarefas de apoio (do tipo inspeções da qualidade, primeira manutenção e limpeza) e do envolvimento de trabalhos de melhoria do processo produtivo. Diferentemente do enriquecimento de cargos (em que o revezamento dos postos é definido de maneira rígida pelos supervisores, o nível de responsabilização dos trabalhadores é reduzido e não existem grupos de trabalho), no ohnoísmo a formação, o reconhecimento e a importância dos grupos, dentro de uma estratégia global da empresa, são fatores formalmente reconhecidos e enfatizados.

\subsubsection{As Pessoas no Âmbito da Organização do Trabalho}

Na revisão apresentada até aqui, fez-se notar que em diferentes épocas, a teoria das organizações foi tomada por diferentes concepções a respeito da natureza humana, cada qual privilegiando aspectos de conduta das pessoas e marcando a maneira pela qual as organizações administram as pessoas. CHIAVENATO (2002) recorda que cada uma dessas concepções teve um contexto adequado para explicá-las e justificá-las.

A integração entre o indivíduo e a organização não é um problema recente. CHIAVENATO (2002) lembra que as primeiras preocupações surgiram com os antigos filósofos gregos.

MAYO (1933) analisou o impacto causado pela organização industrial e pelo sistema de autoridade unilateral sobre o indivíduo. Criticou a abordagem desumana imposta pelos teóricos da Administração Científica. Esta abordagem (centrada na tarefa e no método) cedeu lugar à abordagem humanística (centrada no homem e no grupo social). A ênfase dada à tecnologia cedeu lugar à ênfase dada às relações humanas. Desse momento 
(1930) em diante, CHIAVENATO (2002) coloca a existência do "conflito industrial", ou seja, a existência de interesses antagônicos entre o trabalhador e a organização e a necessidade de buscar uma harmonia baseada em uma mentalidade voltada para as relações humanas.

As organizações recrutam e selecionam seus recursos humanos para, com eles e por meio deles, alcançarem objetivos organizacionais (produção, rentabilidade, redução de custos, ampliação de mercado, satisfação das necessidades etc). Todavia, os indivíduos, uma vez recrutados e selecionados, têm objetivos pessoais que lutam para atingir e, muitas vezes, servem-se da organização para consegui-los. CHIAVENATO (2002)

Para ARGYRIS (1962), os objetivos organizacionais e os objetivos pessoais nem sempre se deram muito bem.

Para que a organização possa alcançar eficientemente seus objetivos, ela tende a criar nos indivíduos um profundo e íntimo sentimento de frustração, de malogro, de conflito e uma curta perspectiva temporal de permanência na organização. E isso acontece em virtude das exigências que as organizações impõem às pessoas, bitolando seu desempenho e confinando-as em tarefas isoladas, especializadas, repetitivas e destituídas de oportunidades para manifestação de sentimentos de independência, responsabilidade e autoconfiança.

BARNARD (1971) faz uma interessante distinção entre eficiência e eficácia quanto aos resultados da interação entre pessoas e organização. Para esse autor, todo indivíduo precisa ser eficiente para satisfazer suas necessidades individuais mediante sua participação na organização, mas também precisa ser eficaz para atingir os objetivos organizacionais por meio de sua participação. (Figura 3.15)

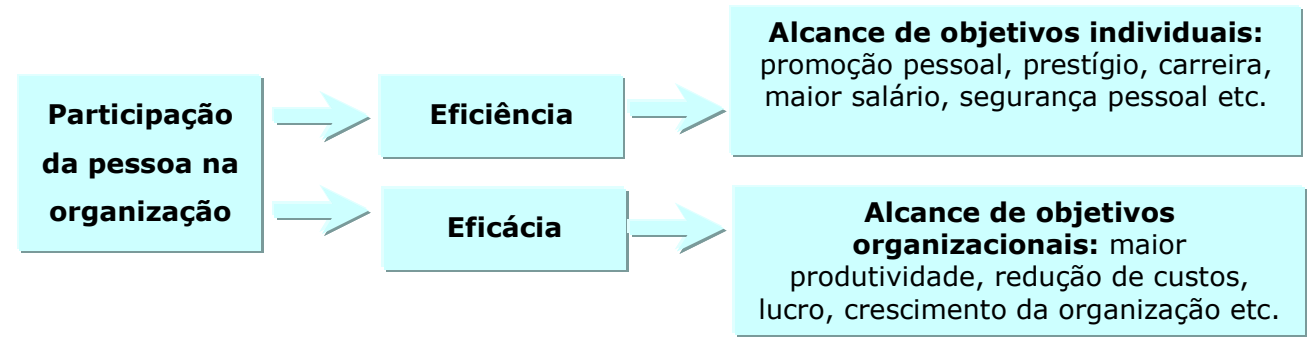

Figura 3.15 - Eficiência e eficácia segundo BARNARD (1971)

Para LEVINSON (1965), a interação psicológica entre empregado e organização é basicamente um "processo de reciprocidade", em que a organização realiza certas coisas para o participante e pelo participante; remunera-o, dá-lhe segurança etc. Reciprocamente, o participante responde trabalhando e desempenhando suas tarefas. "A organização espera que o empregado obedeça à sua autoridade, e, por seu turno, o empregado espera que a organização se comporte corretamente com ele e opere com justiça".

JAQUES (1988), ao tratar o mesmo tema, diz que ambas as partes da interação são orientadas por diretrizes que definem o que é correto e justo e o que não é. Alguns 
sociólogos, como GOULDNER (1960), referem-se a uma "norma de reciprocidade", enquanto alguns psicólogos, como SCHEIN (1972), chamam a isso "contrato psicológico".

SCHEIN (1972) aponta que todo contrato apresenta dois aspectos fundamentais: i) o contrato formal, que é um acordo assinado com relação ao cargo a ser ocupado, ao conteúdo do trabalho, ao horário, ao salário etc; ii) o contrato psicológico, que é uma expectativa que a organização e o indivíduo esperam realizar e ganhar com o novo relacionamento.

CHIAVENATO (2002) coloca que as pessoas formam organização, ou se engajam em algumas delas,

[...] porque esperam que sua participação satisfaça algumas necessidades pessoais (Figura 3.16). Para obter essas satisfações, as pessoas estão dispostas a incorrer em certos custos ou fazer certos investimentos e esforços na organização, pois esperam que a satisfação das suas necessidades pessoais sejam maiores do que os custos e avaliam suas satisfações esperadas e os custos por meio de seus sistema de valores.

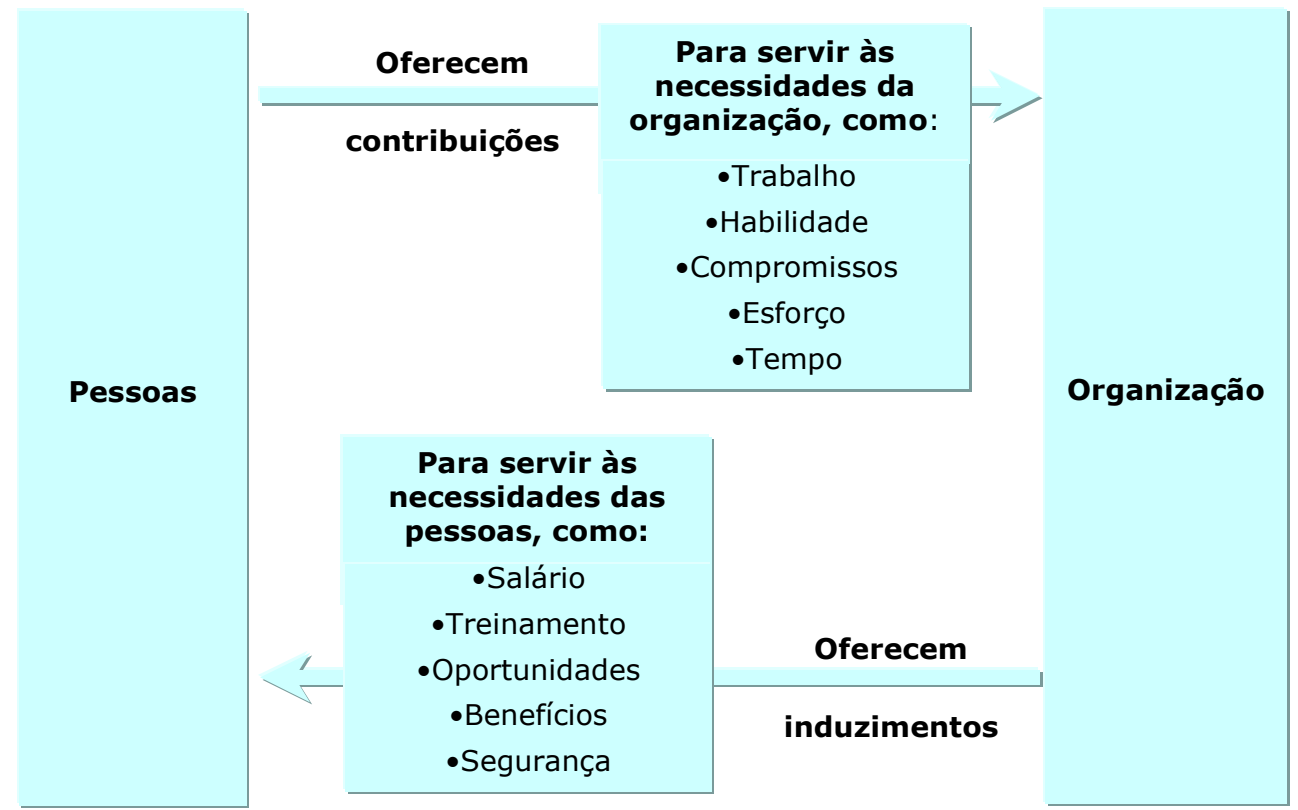

Figura 3.16 - Relações de intercâmbio entre pessoas e organizações. Fonte: CHIAVENATO (2002)

CHIAVENATO (2002) diz que a interação entre pessoas e organizações pode ser explicada pela troca de incentivos e contribuições. Como a organização é um sistema cooperativo racional, torna-se necessário conhecer os motivos que levam os indivíduos a cooperar. Daí, segundo o autor, decorrem os conceitos de incentivos e contribuições:

- incentivos: são "pagamentos" feitos pela organização a seus participantes (salários, prêmios, benefícios sociais, oportunidades de crescimento, segurança no emprego, supervisão aberta, elogios etc). Em troca de contribuições, cada incentivo possui um valor de utilidade que é subjetivo, pois varia de indivíduo 
para indivíduo. Os incentivos também são chamados alicientes, recompensas ou induzimentos;

- contribuições: são "pagamentos" que cada participante efetua à organização a que está ligado (trabalho, esforço, dedicação, pontualidade, assiduidade, esmero, elogios à organização etc). Em troca de incentivos, cada contribuição possui um valor de utilidade que varia conforme a organização.

Dos conceitos supracitados, CHIAVENATO (2002) aponta a decorrência do que chama de equilíbrio organizacional, que reflete o êxito da organização. "Remunerar" seus integrantes com incentivos adequados e motivá-los a continuar fazendo contribuições à organização, deve garantir a sobrevivência da organização e eficácia na sua atuação.

Segundo DUTRA (1993), a administração de pessoas tem sido encarada como um fardo incômodo na gestão das empresas, isso porque, diferentente de outros tipos de recursos, os recursos humanos têm vontade própria. Essa vontade própria nem sempre coincide com as expectativas e necessidades dos gestores e da empresa. Essa característica torna a administração muito particular.

DUTRA (2002) ressalta que, historicamente, as pessoas vêm sendo encaradas pela organização como um insumo, ou seja, como um recurso a ser administrado. "Apesar das grandes transformações na organização da produção, os conceitos sobre gestão de pessoas e sua transformação em práticas gerenciais têm ainda como principal fio condutor o controle sobre as pessoas".

Em contraponto à colocação anterior, DUTRA (2002) coloca que as empresas, a partir das pressões do contexto externo que vêm sofrendo, sentem-se forçadas a revisar as formas de gerir as pessoas. Modificações se dão também quanto às expectativas delas em relação às organizações e ao seu trabalho (como, por exemplo, pessoas estão mais atentas em relação a si mesmas em termos de integridade física, psíquica e social; cultivam a cidadania organizacional e exercem maior pressão por transparência na relação da empresa com elas e por processos de comunicação mais eficientes).

À empresa cabe o papel de estimular e dar suporte necessário para que as pessoas possam entregar o que têm de melhor, ao mesmo tempo em que recebem o que a organização tem de melhor a oferecer-lhes. A partir dessa colocação, DUTRA (2002) define a gestão de pessoas como sendo "um conjunto de políticas e práticas que permitem a conciliação de expectativas entre a organização e as pessoas para que ambas possam realizá-la ao longo do tempo".

CHIAVENATO (2002), ao discutir o papel das pessoas nas organizações, afirma, com convicção, que delas depende o sucesso e continuidade das organizações. O estudo das pessoas constitui a "unidade básica das organizações" e, principalmente, da Administração dos Recursos Humanos (ARH), que tem duas vertentes para considerar as pessoas, conforme ilustra a Figura 3.17.

A moderna ARH procura tratar as pessoas como pessoas e como importantes recursos organizacionais, mas rompe a maneira tradicional de tratá-las meramente como meios de produção (recursos ou insumos). Há muito pouco tempo, as pessoas eram tratadas como objetos e como recursos produtivos, como meros agentes passivos da administração. Percebeu-se que essa maneira bitolada e retrógrada de visualizar as pessoas provocou forte ressentimento e conflitos trabalhistas, além de um gradativo distanciamento e alheamento das pessoas em relação às suas tarefas na organização. Hoje a tendência é fazer com que todas as pessoas, em todos os níveis da 
organização, sejam os administradores (e não simplesmente os executores) de suas tarefas. Além de executar as tarefas, cada pessoa deve conscientizar-se de que ela deve ser o elemento de diagnóstico e de solução de problemas para obter uma melhoria contínua de seu trabalho dentro da organização. CHIAVENATO (2002)

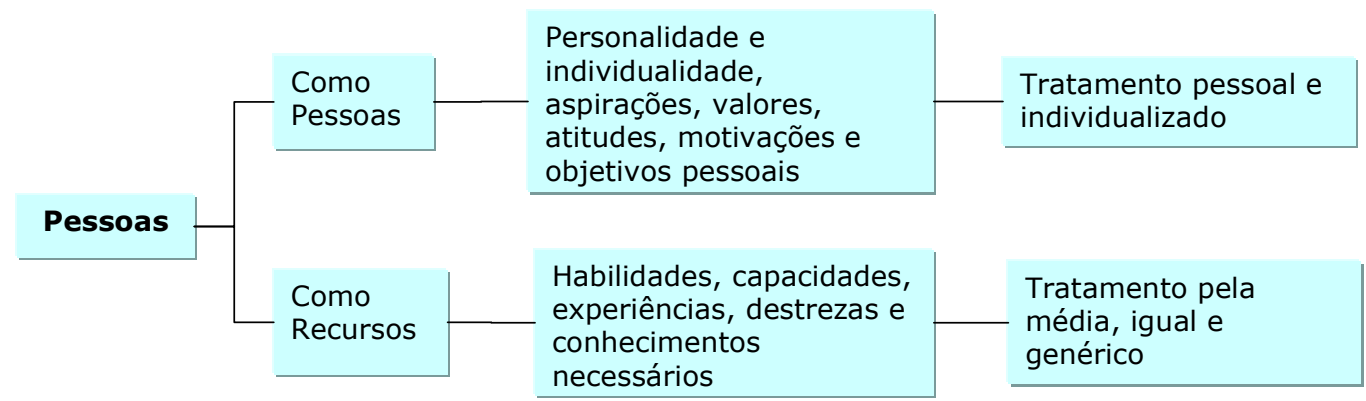

Figura 3.17 Consideração das pessoas pela ARH. Fonte: CHIAVENATO (2002)

\subsubsection{A gestão de pessoas}

A gestão de pessoas passou a ser tratada como uma função organizacional a partir de FAYOL e sua teoria administrativa. Nesses termos, a gestão de pessoas passou a ser entendida como um conjunto de atividades organizacionais. TOLEDO (1978) descreveu tais atividades como sendo "atração, manutenção, motivação e treinamento do pessoal de um grupo de trabalho".

Prover as organizações com uma força efetiva de trabalho era, segundo WERTHER (1983), um dos propósitos alcançados através da gestão de pessoas, que deveria revelar "como os empresários obtêm, desenvolvem, utilizam, avaliam, mantêm e retêm o número e tipo certo de trabalhadores".

FLIPPO (1980) ressalta que a gestão de pessoas "interessa-se pela procura, desenvolvimento, remuneração, integração e manutenção das pessoas de uma organização, com a finalidade de contribuir para que a mesma atinja suas principais metas ou objetivos".

Segundo CHIAVENATO (2002), "a maneira de lidar com as pessoas, de buscá-las no mercado, de integrá-las e orientá-las, de fazê-las trabalhar, de desenvolvê-las, de recompensá-las ou monitorá-las e controlá-las, ou seja, a qualidade da maneira como as pessoas são geridas na organização é um aspecto crucial na competitividade organizacional".

O autor aponta como sendo cinco os processos básicos na gestão de pessoas, apresentados na Tabela 3.10. 
Tabela 3.10 - Os cinco processos básicos na gestão de pessoas. Fonte: CHIAVENATO (2002)

\begin{tabular}{|c|c|c|}
\hline Processo & Objetivo & Atividades envolvidas \\
\hline Provisão & $\begin{array}{c}\text { Quem irá trabalhar na } \\
\text { organização }\end{array}$ & $\begin{array}{l}\text { Pesquisa de mercado de RH } \\
\text { Recrutamento de pessoas } \\
\text { Seleção de pessoas }\end{array}$ \\
\hline Aplicação & $\begin{array}{c}\text { O que as pessoas farão } \\
\text { na organização }\end{array}$ & $\begin{array}{l}\text { Integração de pessoas } \\
\text { Desenho de cargos } \\
\text { Descrição e análise de cargos } \\
\text { Avaliação de desempenho }\end{array}$ \\
\hline Manutenção & $\begin{array}{l}\text { Como manter as pessoas } \\
\text { trabalhando na } \\
\text { organização }\end{array}$ & $\begin{array}{l}\text { Remuneração e compensação } \\
\text { Benefícios e serviços sociais } \\
\text { Higiene e segurança do trabalho } \\
\text { Relação sindicais }\end{array}$ \\
\hline Desenvolvimento & $\begin{array}{c}\text { Como preparar e } \\
\text { desenvolver as pessoas }\end{array}$ & $\begin{array}{c}\text { Treinamento } \\
\text { Desenvolvimento organizacional }\end{array}$ \\
\hline Monitoração & $\begin{array}{l}\text { Como saber o que são e o } \\
\text { que fazem as pessoas }\end{array}$ & $\begin{array}{c}\text { Banco de dados/Sistema de informação } \\
\text { Controle/Freqüência/Produtividade/Balanço } \\
\text { social }\end{array}$ \\
\hline
\end{tabular}

DUTRA (2002) observa que são necessárias algumas condições ao processo de gestão das pessoas para ter assegurado sua efetividade. São elas:

- honestidade de intenções - o relacionamento transparente só se torna viável se as partes desenvolveram absoluta confiança nas intenções uma da outra. Essa confiança é construída a partir da honestidade com que as partes se conduzem no processo;

- sentimento de segurança - somente se as partes se sentirem seguras na relação é que poderão ser transparentes e absolutamente honestas. Sempre que se sentirem inseguras ou ameaçadas tentarão proteger-se;

- clareza das regras - para que as partes se sintam seguras é fundamental que as regras básicas das relações entre as mesmas estejam acordadas entre ambas;

- transparência - as pessoas devem ter total acesso às informações que Ihes digam respeito, assim como a empresa deve ser constantemente informada acerca das expectativas das pessoas e manter-se ciente das aspirações de seus empregados;

- flexibilidade - os critérios que norteiam a gestão de pessoas são validados a cada momento ao longo do tempo e permanecem, se tiverem a flexibilidade necessária para ajustarem-se aos diferentes contextos existentes e às pressões impostas pelas transformações desses contextos no tempo.

Com as condições citadas asseguradas, DUTRA (2002) apresenta o processo de gestão de pessoas. Quanto aos objetivos e parâmetros dos processos de gestão de pessoas, o autor os classifica, em função de sua natureza e dos objetivos básicos oferecidos, como apresentado na Tabela 3.11. Tais processos influenciam-se mutuamente, como se observa na Figura 3.18. 
Tabela 3.11 - Os três processos básicos na gestão de pessoas. Fonte: DUTRA (2002)

\begin{tabular}{|c|c|c|}
\hline Processo & Objetivo & Atividades envolvidas \\
\hline Movimentação & $\begin{array}{l}\text { Oferecer suporte a toda ação de } \\
\text { movimento da pessoa que estabelece } \\
\text { relação com a empresa }\end{array}$ & $\begin{array}{l}\text { Capacitação } \\
\text { Internalização } \\
\text { Transferências } \\
\text { Promoções } \\
\text { Expatriação } \\
\text { Recolocação }\end{array}$ \\
\hline Desenvolvimento & $\begin{array}{c}\text { Estimular e criar condições para o } \\
\text { desenvolvimento das pessoas e da } \\
\text { organização }\end{array}$ & $\begin{array}{l}\text { Capacitação } \\
\text { Carreira } \\
\text { Desempenho }\end{array}$ \\
\hline Valorização & $\begin{array}{l}\text { Estabelecer parâmetros e } \\
\text { procedimentos para distinção e } \\
\text { valorização das pessoas }\end{array}$ & $\begin{array}{c}\text { Remuneração } \\
\text { Premiação } \\
\text { Serviços e facilidades }\end{array}$ \\
\hline
\end{tabular}

DUTRA (2002) avalia que tais processos não são suficientes. Faz-se necessário um conjunto de políticas e práticas organizacionais - bases estruturais - que suportem e sirvam de base na sustentação dos processos. Agrupam-se, nesse conjunto, os compromissos vinculados ao contrato psicológico estabelecido entre as pessoas e a empresa, ao clima, às dinâmicas interpessoais e intergrupais e à integridade da pessoa. Fala-se de saúde, segurança e ergonomia, e dos compromissos da própria pessoa ou dessa com o ambiente onde se insere (qualidade de vida, por exemplo).

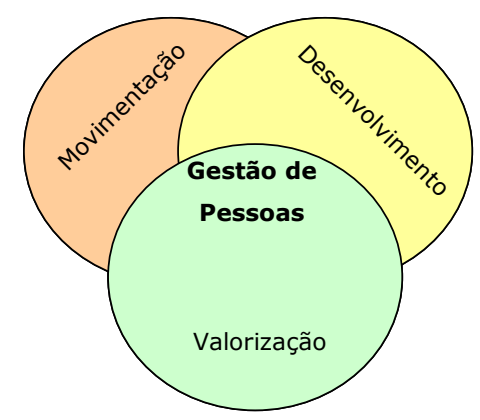

Figura 3.18 - Processo de Gestão de Pessoas segundo DUTRA (2002)

SLACK et al (1999) contestam a idéia de que no gerenciamento da produção o foco esteja na tecnologia, nos sistemas, nos procedimentos etc, ou seja, nas partes não humanas da gestão. "Ao contrário, a forma como os recursos humanos são gerenciados tem um impacto profundo sobre a eficácia de suas funções operacionais". Os autores, ao tratarem os elementos do gerenciamento de recursos humanos, consideram-nos como estando diretamente dentro da esfera da gestão da produção.

Os autores frisam a importância do que chamam "Projeto de Organização do Trabalho", que deve ser responsável por: i) definir a forma pela qual as pessoas agem em relação 
ao trabalho; ii) posicionar suas expectativas quanto àquilo que lhes é requerido; iii) influenciar as percepções de como contribuem para a organização; iv) posicionar as atividades delas em relação a seus colegas de trabalho; v) auxiliar a desenvolver a cultura da organização.

O "Projeto de Organização do Trabalho" é composto por elementos separados (Figura 3.19), embora relacionados, que quando tomados em conjunto, definem o trabalho das pessoas na produção. Tal projeto envolve decidir sobre quais tarefas alocar para cada pessoa na organização, e em qual seqüência desempenhá-las, onde alocar o trabalhador, quem mais estará envolvido com ele, como as pessoas devem interagir com seu local de trabalho, quanta autonomia será dada ao pessoal e quais habilidades deverão ser desenvolvidas. SLACK et al (1999)

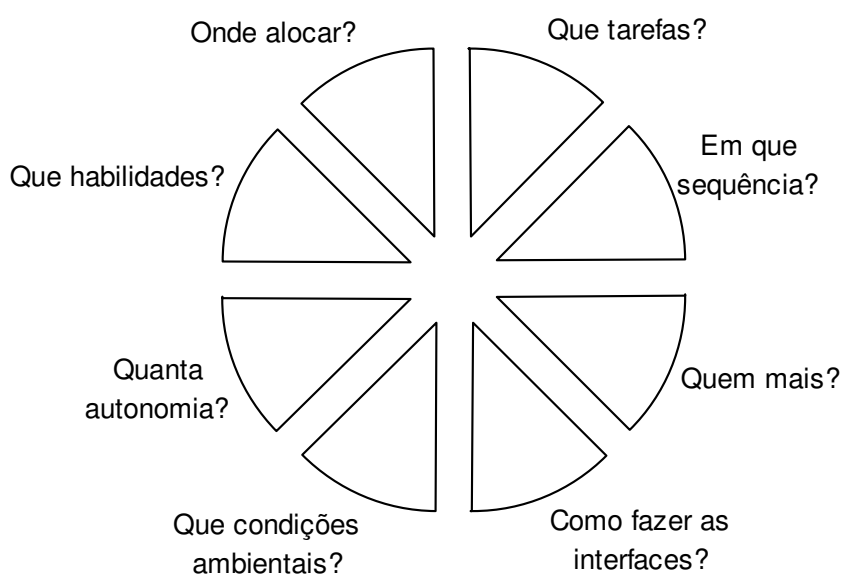

Figura 3.19 - Elementos do Projeto de Organização do Trabalho. Fonte: SLACK et al. (1999)

SLACK et al (1999) salientam que a compreensão de o que o projeto do trabalho deve atingir é particularmente importante. Apresentam, porém, os cinco objetivos de desempenho (qualidade, rapidez, confiabilidade, flexibilidade e custo) já comentados neste trabalho, aos quais somam mais dois (saúde e segurança e qualidade de vida), constituindo um guia de o que seria relevante considerar nas decisões de projeto de trabalho.

\subsubsection{Principais elementos considerados na organização do trabalho na produção}

O processo de produção contemplado neste trabalho caracteriza-se pelo uso intensivo de pessoas. Essas pessoas, por sua vez, interagem fortemente entre si, com a organização e com os demais recursos presentes no ambiente de produção. A revisão bibliográfica, conduzida neste capítulo, exaltou o papel desempenhado pelas pessoas que, ao deixarem de ser consideradas simples recursos e passarem a ser abordadas como seres dotados de conhecimentos, habilidades, personalidades, aspirações, percepções etc, poderão contribuir fortemente para o sucesso das organizações. O cuidado em gerir e organizá- 
las foi visto como sendo de vital importância, em qualquer que seja o ambiente organizacional considerado.

Viu-se, também, que a interação entre pessoas e organizações é um tema complexo e dinâmico e pode ser visualizado de diferentes maneiras. Concorda-se, aqui, com o enfoque de BARNARD (1971), ao analisar esta interação (Figura 3.15, item 3.2.3.2).

Segundo esse enfoque, de nada adianta ser somente eficiente, pois o indivíduo será avaliado negativamente pela organização por lutar apenas por seus próprios interesses pessoais. Ao contrário, o indivíduo somente eficaz produz resultados para a organização às custas de seus interesses pessoais, sacrificando seus compromissos sociais. É preciso, portanto, "ser eficaz para proporcionar resultados à organização e eficiente para progredir pessoalmente na vida". A organização do trabalho, segundo definição apresentada no item 3.3.2, já previa que os recursos fossem ordenados de maneira a se ter a máxima eficácia (maiores produtividades, por exemplo) e eficiência na aplicação dos mesmos.

Para que tal proposição se concretize, propõe-se que os elementos que venham a formatar o processo de organização do trabalho sejam definidos com base nos cinco processos de gestão de pessoas definidos por CHIAVENATO (2002) e já apresentados na Tabela 3.10, que "formam um sistema dinâmico através do qual as pessoas são provisionadas, aplicadas em suas tarefas, mantidas, desenvolvidas e monitoradas pela organização". A maneira de lidar com as pessoas, de buscá-las no mercado, de integrá-las e orientá-las, de fazê-las trabalhar, de desenvolvê-las, de recompensá-las ou monitorá-las e controlá-las, ou seja, a qualidade da maneira como as pessoas são geridas na organização é um aspecto crucial na competitividade organizacional, aqui tratada no âmbito de melhorias da produtividade da própria mão-de-obra.

Tratar a organização do trabalho no âmbito de um canteiro de obras, com foco em um processo de produção específico, requer cuidados especiais. Um dos principais refere-se à necessidade de delimitar o escopo da organização do trabalho. Um entendimento muito amplo remete a um processo de organização aberto e pretensiosamente abrangente, correndo-se o risco de se tornar extremamente burocrático, mascarando-se seus reais propósitos, além de elevar as dificuldades de entendimento dos agentes envolvidos com sua efetivação.

Dessa forma, a eleição dos pontos elementares ao processo de organização do trabalho (e que, de fato, é o que interessa aos desígnios desta tese, por serem o principal subsídio para a determinação de fatores potencialmente influenciadores da produtividade da mãode-obra) precisa ter como premissas a objetividade e a simplicidade. Ambas permitirão que a discussão, entre e com os agentes envolvidos com o processo de produção, seja facilitada. Tal facilidade é imprescindível para a efetiva participação desses agentes em discussões sobre o tema, bem como, para se conseguir uma maior confiabilidade nas informações por eles passadas.

Assim é que, à luz e para cada um dos cinco processos básicos na gestão de pessoas, preconizados por CHIAVENATO (2002), apontam-se, a seguir, elementos que, para os propósitos deste trabalho, devam ser considerados ao se invocar a organização do mesmo:

- provisão: políticas, procedimentos e práticas de contratação e dispensa dos trabalhadores; 
- aplicação: políticas, procedimentos e práticas de dimensionamento e alocação dos trabalhadores;

- manutenção: políticas, procedimentos e práticas quanto: i) à remuneração dos trabalhadores; ii) à motivação dos trabalhadores;

- desenvolvimento: políticas, procedimentos e práticas de alfabetização, treinamento e capacitação dos trabalhadores;

- monitoração: políticas, procedimentos e práticas de registros e controles para análise quantitativa e qualitativa dos recursos humanos disponíveis.

A maneira como a organização do trabalho é aqui tratada deverá servir para se disseminar a proposta de que a melhoria nos desempenhos de um processo de produção passa pela melhoria da produtividade que, por sua vez, pode ser diretamente influenciada por fatores relacionados, entre outros, à maneira como o trabalho é organizado. Nesse momento, uma visão simplificada e objetiva do que se entende por organização do trabalho, bem como o apontamento dos principais elementos que estariam por trás de um processo de organização, parece ser suficiente.

Ao chamar a atenção para a organização do trabalho e apontar a sua influência sobre a produtividade da mão-de-obra, abre-se um espaço importante para que novos trabalhos e pesquisas sejam conduzidos. 


\section{A Melhoria da Produtividade como Caminho para a Melhoria do Desempenho}

\subsection{Notas introdutórias ao quarto capítulo}

A melhoria da produtividade da mão-de-obra foi o caminho escolhido, neste trabalho, para auxiliar os agentes da cadeia produtiva da construção civil, mais especificamente aqueles envolvidos na produção de estruturas de concreto armado, na busca de melhores desempenhos (exemplificando, através dos extremos da cadeia produtiva: para o cliente, redução de custos; para o operário, melhores condições de trabalho, como aumento de salários, por exemplo).

Antes, porém, de se lançar a proposta de um método que se disponha a servir como ferramenta gerencial e, portanto, como catalisador de melhorias nos processos produtivos de obras de construção de edifícios, fazem-se necessários alguns esclarecimentos e comentários sobre "as bases" às quais tal método estará apoiado.

Para tanto, o primeiro aspecto contemplado por este capítulo remete o leitor à busca do entendimento de duas abordagens gerenciais orientadas para a melhoria do desempenho dos processos de produção no âmbito da construção civil. Adianta-se que uma delas apóia-se na utilização de princípios nascidos na engenharia de produção em outras indústrias, buscando neste ambiente ferramentas que auxiliem a gestão nos canteiros de obras. A outra, trata a construção civil com todas as suas particularidades, buscando o desenvolvimento de capacidades de gerenciamento que considerem, por exemplo, um contexto altamente mutante. Ambas as abordagens vêem na "variabilidade" presente nos processo de transformação um ponto a ser combatido. Enquanto uma abordagem vislumbra que melhores desempenhos podem ser conseguidos com redução da variabilidade das "entradas" e das "saídas" de um processo de transformação, a outra abordagem (e que será seguida neste trabalho) entende que reduzir a variabilidade da "eficiência na transformação de entradas em saídas" é o caminho a ser trilhado.

Depois de defendida e definida a abordagem que preconiza a redução da variabilidade da produtividade da mão-de-obra como balizadora para o desenvolvimento do método e, por conseguinte, dos objetivos buscados por esta tese, discorrer-se-á sobre os dois principais "fundamentos" da referida abordagem gerencial: a utilização de indicadores e fatores.

As discussões e os comentários quanto aos indicadores e fatores, da forma como serão conduzidos neste capítulo, têm o grande propósito de mostrar que o universo no qual indicadores e fatores estão inseridos é bem mais abrangente do que o considerado pelo método proposto por este pesquisador. Apesar da simplicidade (proposital) com que indicadores e fatores são tratados a partir do capítulo seguinte, há um conjunto de conceitos e possibilidades bastante grande que, se conhecido e bem trabalhado, poderá render benefícios muito maiores do que aqueles vislumbrados até aqui.

Sobre essa perspectiva, fica mais fácil entender o porquê de se raciocinar, mais à frente, sobre a importância do estabelecimento de indicadores de produtividade na Indústria da 
Construção Internacional (chama-se, neste caso, a atenção para o fato de que um sistema de mensuração forte e confiável é a base para a busca de melhoria de desempenhos, qualquer que seja o sistema de produção considerado!).

Se os indicadores são importantes, dentre outras coisas, por apontar eventuais variações ao que se propõem mensurar, os fatores são, também, tão importantes quanto, pois é através deles que se pode conhecer (e, portanto, intervir) nas razões de tais variações.

Assim é, que neste capítulo, após uma rápida passagem pelo Modelo dos Fatores, proposto inicialmente por THOMAS et al. (1990) (bastante difundido e aplicado por pesquisadores nacionais e internacionais, dentre os quais o próprio autor desta tese (ARAÚJO, 2000)), dar-se-á ênfase à discussão sobre os indicadores e os fatores influenciadores.

Em se tratando dos fatores, vale adiantar que serão divididos em três grupos, que compreendem, na visão deste pesquisador, pontos centrais de um processo de produção, quais sejam, o projeto do produto, o método de trabalho (ambos tratados no segundo capítulo) e a organização do trabalho (tratada no terceiro capítulo). A partir desta prerrogativa, procurar-se-á discutir, separadamente para cada um dos grupos de fatores supracitados, as suas influências sobre a produtividade da mão-de-obra.

Vale dizer que as discussões conduzidas no presente capítulo, ainda no âmbito dos fatores, remete a aspectos mais abrangentes, relacionados aos três grupos supracitados, destacando-se, entre outros, o conteúdo de cada um dos grupos, bem como sua influência quanto à produtividade. Cria-se, assim, um primeiro e importante entendimento sobre os fatores (bem como sobre o papel dos agentes da cadeia sobre tais fatores), que serão tratados de maneira mais direta e incisiva no capítulo seguinte deste trabalho.

\subsection{Gerenciamento de processos de produção com foco na melhoria do seu desempenho}

\subsubsection{Diferenças entre o canteiro de obras e a manufatura}

Muita energia tem sido gasta, ao longo dos últimos dez anos, segundo THOMAS (2002), na proposição de que os canteiros de obras deveriam ser vistos como uma planta fabril. Sob esta perspectiva, métodos desenvolvidos para a indústria manufatureira têm sido aplicados para analisar as operações da construção civil (KOSKELA (1992); BALLARD, HOWELL (1994)). Porém, o autor adverte que existem grandes diferenças entre as operações na manufatura e as atividades de construção. "Não considerá-las, qualquer que seja o âmbito tratado, pode induzir grandes equívocos". THOMAS (2002) evidencia tais diferenças, agrupando-as em sete áreas distintas, apresentadas a seguir:

\section{Orientação e ponto de vista}

Uma importante diferença filosófica é que a manufatura procura gerenciar os processos, e a construção enfatiza a produção de produtos. "Enquanto aparentemente ponto de menor importância, a orientação do processo na manufatura foca os métodos usados enquanto que, na construção, o foco está no produto final ou saída (output)".

Há diferenças significativas na maneira com que as operações são analisadas e como o desempenho é mensurado. Além disso, na manufatura, genericamente, tem-se centrais 
únicas de custo, enquanto que, no canteiro de obras, existem inúmeros centros de custos, um para cada serviço.

\section{Natureza da Integração das Atividades}

Na manufatura, o processo de produção e a programação são altamente seqüenciais, com o produto passando por inúmeras estações de trabalho. Em cada uma, algum valor é agregado ao produto. Cada estação de trabalho é dimensionada com o mesmo número de trabalhadores a cada dia, sendo esse número baseado na natureza do trabalho naquela estação. $O$ fato de o trabalho permanecer basicamente constante, sem mudanças, permite que muita atenção seja dada aos métodos de trabalho como caminho para melhorar o desempenho.

As atividades na construção são muito diferentes. O trabalho é altamente integrado e "concorrencial". E em atividades concorrentes, somente uma fração do trabalho potencialmente locado é realizado a cada dia. Diferentes equipes podem ocupar o local de trabalho a cada dia; o número de membros dessas equipes também pode variar. A natureza do trabalho muda diariamente, necessitando-se de diferentes habilidades, informações, materiais e serviços de apoio. Operações seqüenciais ocorrem na construção num nível macro, não sendo percebidas quando são feitas análises mais detalhadas, no nível da atividade.

\section{Mensuração de Desempenho}

Na manufatura, a fábrica produz um certo número de produtos diariamente. Em sendo o número de entradas (materiais e mão-de-obra) basicamente constante durante todo o tempo, o desempenho da fábrica pode ser igualado às saídas. Dentro dessa perspectiva, produzir 500 unidades de um determinado produto por dia é melhor que produzir qualquer quantidade inferior a esse número.

Tal contexto facilita a discussão do trabalho simplificado ou método de atividade simplificada. O foco do método é a identificação e eliminação de atividades desnecessárias, como movimentação de materiais e esperas. Outra ferramenta de incremento de desempenho é o gráfico de balanceamento de equipe. Esse método evidencia etapas desnecessárias e reduz o tempo dos ciclos. Outro objetivo do balanceamento de equipes é a redução do número de trabalhadores requeridos. Isso pode ser efetivamente feito porque as etapas do ciclo são sempre as mesmas e o tempo entre ciclos é insignificante.

Na construção o desempenho é mensurado na base de entradas (homens-hora) por unidade de saída (quantidades de serviço). Uma das razões para essa mensuração está no fato de que cada atividade de construção representa um centro de custo. O objetivo para melhorar o desempenho passa a ser o de usar o mínimo recurso possível para produzir uma quantidade fixa de serviço. Em sendo a mão-de-obra um recurso altamente variável, os homens-hora são parte da equação para mensurar o desempenho.

Ao contrário da manufatura, os métodos de construção, saídas, mudanças de tempo de ciclo, algumas vezes variam minuto a minuto.

\section{Ambiente de trabalho}

O ambiente no qual o trabalho é desenvolvido refere-se à seqüência, congestionamento, disponibilidade de recursos, clima e outros eventos que causam interrupção e que prejudicam o desempenho. Na manufatura, o trabalho é estável. Os recursos estão disponíveis, a seqüência de operações é fixa e as áreas de trabalho não são congestionadas. $O$ trabalho é feito em local coberto e protegido e o clima não prejudica o 
desempenho. Assim sendo, a manufatura foca seus esforços na melhoria dos métodos em invés do ambiente de trabalho.

Na construção o ambiente de trabalho muda completamente a cada dia. Recursos de vários tipos e quantidades são necessários para dar suporte às equipes. Melhorias nos métodos têm sempre vida-curta, pois os componentes e locação mudam freqüentemente. Pelo fato de o ambiente e a programação serem tão dinâmicos, muita atenção é dirigida à eliminação das interrupções. De fato, nos últimos dez anos, muito tem sido escrito sobre disponibilidades de recursos (materiais, ferramentas, equipamentos, informação), congestionamento, seqüências, aceleração de cronogramas, climas e outros fatores que provocam interrupções.

\section{Nível de Incerteza}

A manufatura é um ambiente bastante estável: os recursos estão prontamente disponíveis, as rotinas de trabalho estão estabelecidas e geralmente se conhece o cronograma de produção. Essa estabilidade significa que a operação é isenta de dificuldades aleatórias, sendo a mesma programação aplicada a cada dia. Com uma programação em curso, fluindo sem infortúnios, estoques de reserva podem ser reduzidos ao mínimo e operações "puxadas ${ }^{62 " ~ p o d e m ~ s e r ~ p r a t i c a d a s . ~}$

Na construção tudo é muito diferente, a começar pelo ambiente de trabalho, que é muito instável: há muitas interferências provocadas por situações climáticas adversas; perturbações na programação podem ser resultados de erros de projetos, quebra de equipamentos, falta de materiais, congestionamento em determinadas áreas etc; o canteiro de obras está em constante modificação; trabalha-se em regime de horas-extras etc. Todas essas incertezas significam que diferentes práticas de gestão devem ser aplicadas. Os estoques de reserva não podem ser reduzidos para perto de zero porque os estoques são uma segurança importante contra as incertezas.

\section{Diversidade do Produto}

A manufatura tem uma diversidade mínima de produtos numa mesma linha de produção. Esta condição resulta em trocas mínimas na programação e rotinas de trabalho.

Já a construção produz unidades bastante diversificadas e os recursos necessários podem variar significativamente para a produção de um mesmo "produto".

\section{Recursos Necessários}

Tanto a manufatura quanto a construção requerem recursos similares, mas as características que cercam o uso desses recursos variam largamente, como comentado a seguir:

\subsection{Materiais}

Os materiais de construção são entregues no canteiro de obras diariamente. A programação de entrega, o recebimento e a estocagem devem ser cuidadosamente planejados. A eliminação das perdas de materiais, incidentes no canteiro de obras, tratase de um item importante que deve considerado.

Na manufatura concentram-se grandes esforços no gerenciamento das relações com os vendedores. As entregas envolvem lotes com grande número de itens parecidos, e a programação de entrega pode ser muito apertada.

62 Produção puxada é aquela em que os recursos são solicitados ("puxados" para o processo) somente quando a produção realmente os demanda. 


\subsection{Equipamentos}

Na manufatura, a linha de equipamentos de montagem é usualmente estacionária, projetada para desempenhar uma função e operada por uma única equipe. Contrariamente, os equipamentos de construção são projetados para múltiplos propósitos e compartilhados por várias equipes. A maioria dos equipamentos não são estacionários e permanecem no canteiro por pequenos períodos de tempo. São operados, muitas vezes, sob condições insatisfatórias e costumam quebrar freqüentemente.

\subsection{Informação}

A informação é necessária para todas as operações, tanto na manufatura como na construção, embora a forma e a origem sejam distintas. Na manufatura, a principal fonte de informação é a solicitação do cliente, detalhando o que é para ser produzido. Sem essa ordem o produto não pode ser produzido. Na construção, as fontes de informação primária são as plantas e especificações. Mas o cronograma de serviços, os desenhos de fabricação, bem como outras correspondências são importantes e necessárias formas de comunicação, geradas pelo proprietário, projetistas, subcontratados, vendedores e outras fontes.

\subsection{Mão-de-obra}

A mão-de-obra na manufatura não é tida como um recurso que precisa ser gerenciado de forma apurada. Isto porque as estações de trabalho são operadas diariamente pelo mesmo número de operários e as tarefas designadas são geralmente as mesmas.

Nos canteiros de obras a força de trabalho se altera, o trabalho designado varia diariamente e o número de trabalhadores e as horas trabalhadas variam paralelamente à quantidade de trabalho a ser feito. Se houver mais trabalho, torna-se necessário estender a programação e/ou alocar mais operários. A Figura 4.1 ilustra a variação diária de armadores numa obra de edifícios na cidade de São Paulo ao longo de oito meses. Percebe-se uma forte tendência de crescimento no número de operários alocados (diariamente) nos primeiros quatros meses, seguido por um rápido decréscimo nos meses seguintes.

\subsection{Relacionamento das Equipes}

O trabalho na manufatura é altamente seqüencial. A relação de uma equipe com a outra também é seqüencial: uma equipe agrega valor a um produto e nunca mais volta a trabalhar nesse produto. Muitas operações na construção também são seqüenciais, mas algumas vezes as relações entre as equipes são cooperativas ou "simbióticas". 


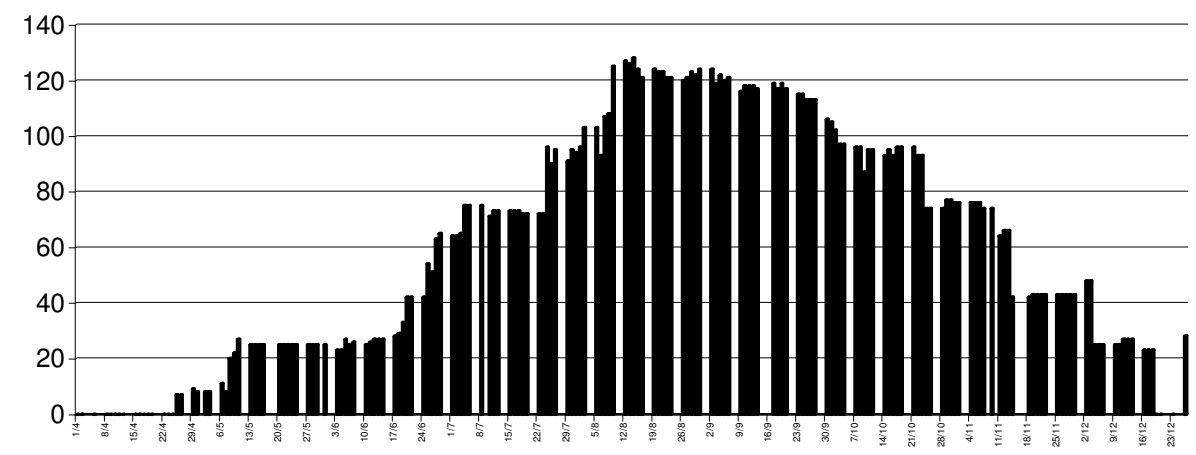

Figura 4.1 - Variação diárias do número de armadores numa obra de edifício. Fonte: levantamentos realizados pelo autor entre os meses de março e dezembro de 2001.

\subsubsection{A variabilidade no nível da atividade}

A variabilidade num processo de produção pode estar relacionada às entradas desse processo, às suas saídas ou, ainda, à eficiência conseguida na transformação de entradas em saídas (produtividade), tal como ilustrado na Figura 4.2.

No item anterior percebe-se que a construção difere da manufatura, dentre outros motivos, por apresentar uma alta variabilidade tanto nas entradas dos recursos no processo de produção, quanto nas saídas desses processos. Trata-se de uma característica intrínseca à construção civil, plenamente justificada, diante do contexto em que as operações são desenvolvidas (e que muito diferem do ambiente encontrado na manufatura).

Para THOMAS et al. (2002) a variabilidade é comum nas obras de construção e deve ser efetivamente gerenciada.

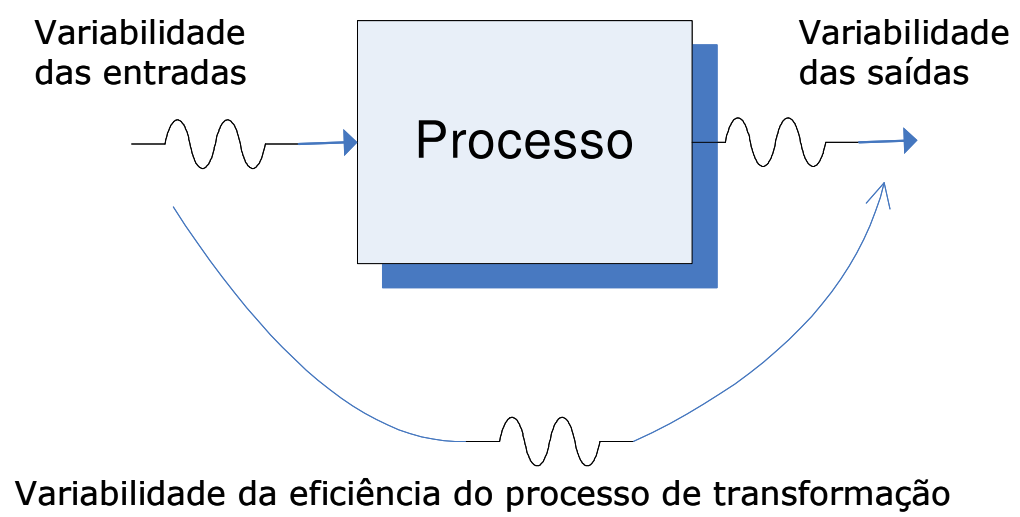

Figura 4.2 - Variabilidades num processo de produção 


\subsubsection{A Variabilidade na Manufatura}

Os princípios da Construção Enxuta se originaram na Indústria de Manufatura, onde o foco está na redução das variabilidades das saídas. Inúmeros aspectos dessa indústria fazem com que esse foco seja relevante: o sistema de produção é altamente linear (seqüencial), toda estação de trabalho tem os mesmos índices de produção diários, bem como os processos são os mesmos durante todo o tempo.

O desempenho das operações é definido pela relação entre as saídas do processo e as entradas (mão-de-obra). Em função das características supracitadas, a mão-de-obra é mantida constante, o que permite que se reescreva a equação de desempenho:

$$
\text { Desempenho } \cong \text { Saídas }
$$

\subsubsection{A Variabilidade na Construção Civil}

THOMAS et al. (2002) chamam a atenção para o fato de que os conceitos de variabilidade e desempenho na manufatura não se aplicam da mesma forma à construção civil. Novos modelos de gestão, como aqueles advindos da Construção Enxuta, têm sugerido que melhores desempenhos podem ser conseguidos através da redução da variabilidade das saídas do processo. "Esforços para utilizar os princípios do "Pensamento Enxuto" têm gerado evidências limitadas para sustentar esta reivindicação".

THOMAS et al. (2002) investigaram a relação entre as variabilidades (variações diárias) presentes nos processos de produção em obras de construção civil e o desempenho dessas obras para verificar se a redução da variabilidade poderia resultar em melhoria de desempenho.

Usando dados de produtividade da mão-de-obra (produtividades diárias) referentes ao serviço de fôrmas de um considerável número de obras (14 obras), várias medidas de variabilidade (entrada, saída e produtividade da mão-de-obra) foram testadas e comparadas ao desempenho ${ }^{63}$ do serviço em questão. Os resultados obtidos mostraram que: i) a variabilidade nas saídas dos processos é inevitável ${ }^{64}$, tanto nas obras que apresentaram bons como nas de maus desempenhos; ii) não se detectou correlação entre variabilidades na saída e desempenho do serviço ${ }^{65}$; iii) a variabilidade na produtividade da mão-de-obra está proximamente relacionada ao desempenho da obra. Concluiu-se que as iniciativas de melhoria "Enxuta" deveriam desenvolver capacidades de

$63 \mathrm{O}$ desempenho do serviço de fôrmas foi mensurado por um indicador (número adimensional) denominado "Project Waste Index" (PWI), fruto de uma relação que compara a produtividade cumulativa da mão-de-obra com a produtividade potencial da mão-de-obra (obtida e prevista para o serviço).

${ }^{64}$ As razões, segundo THOMAS et al. (2002), são várias, sendo as mais comuns: as adversidades climáticas, fluxos de materiais e equipamentos inconsistentes, variação nos tamanhos e complexidade dos componentes produzidos, mudanças no tamanhos das equipes, interação com outros subcontratados, variações nas tarefas etc.

65 THOMAS et al. (2002) vêem que seria necessário um esforço extraordinário para reduzir as variações nas saídas a níveis consistentes com aqueles previstos nos princípios da Construção Enxuta. "Talvez a melhor estratégia seja aceitar as variações nas saídas como inevitáveis e concentrar esforços gerenciais na melhoria da produtividade da mão-de-obra". 
gerenciamento de mão-de-obra flexível para reduzir a variabilidade na produtividade da mão-de-obra de forma a melhorar o desempenho da obra.

Os gráficos das Figura 4.3, Figura 4.4 e Figura 4.5 ilustram o que foi dito anteriormente. A Figura 4.3 mostra a variabilidade das saídas (quantidade de fôrmas feitas ao longo de vários dias para uma obra real) num processo de produção de fôrmas. A Figura 4.4 mostra a variação diária da produtividade da mão-de-obra para o mesmo processo. Percebe-se que, embora tenha existido uma grande variação nas saídas do processo, a variabilidade da produtividade foi baixa. A explicação está nos homens-hora (A Figura 4.5 mostra a sua variação), ou seja, o gestor da mão-de-obra variou os homens-hora diariamente de acordo com o conteúdo e o contexto de trabalho que se apresentava a cada dia de trabalho.

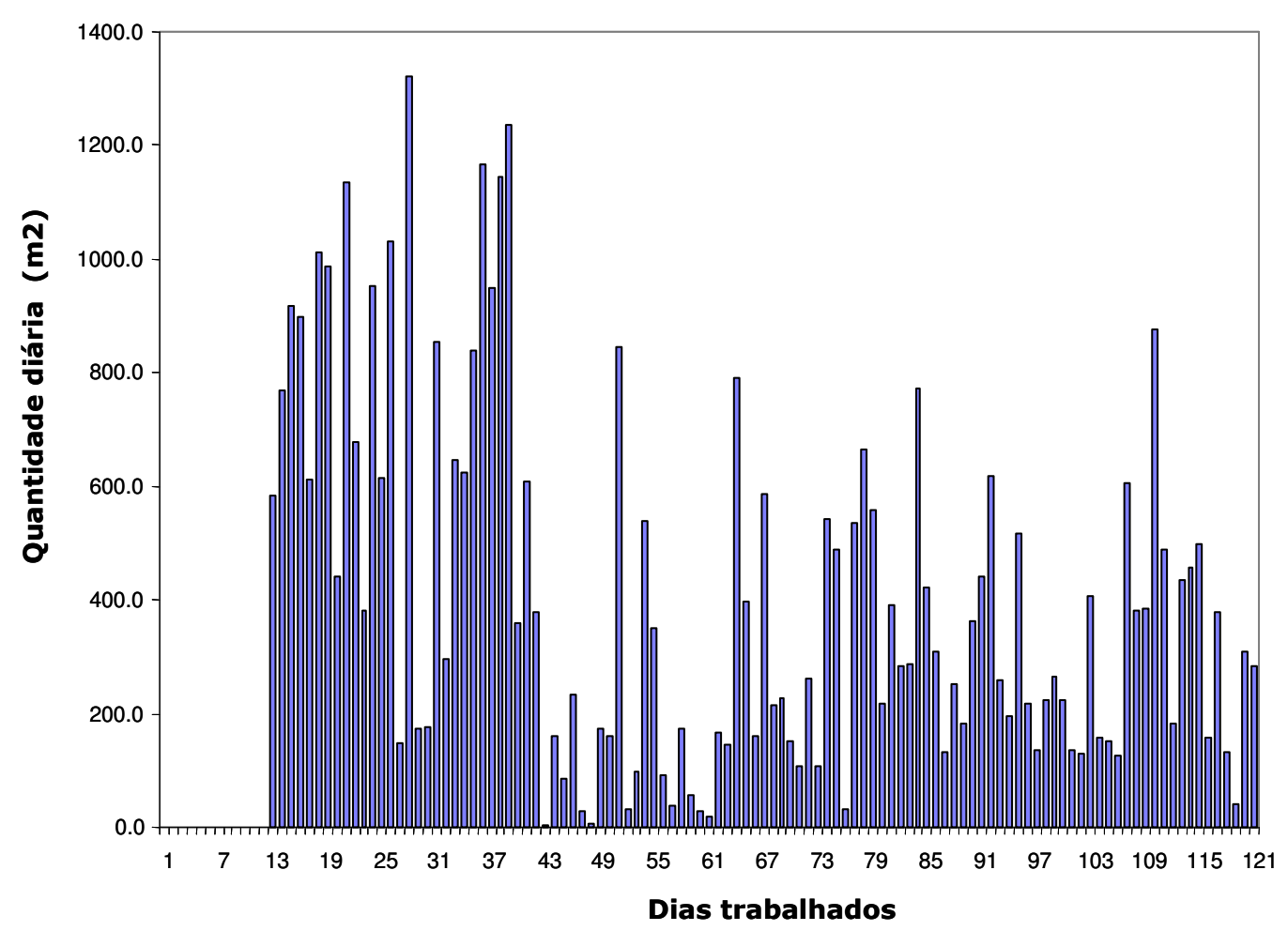

Figura 4.3 - Variação diária na quantidade de fôrmas produzida para uma obra real (obra 9601). Fonte: THOMAS et al. (2002) 


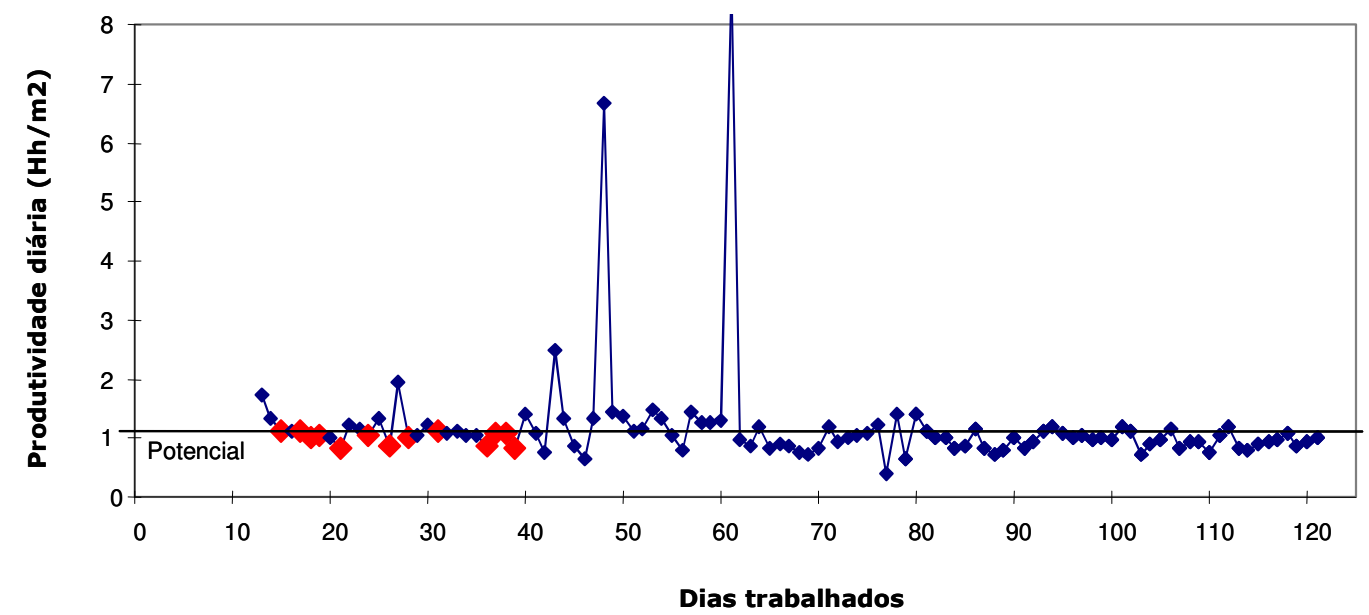

Figura 4.4 - Variação diária da produtividade da mão-de-obra para o serviço de fôrmas para uma obra real (obra 9601). Fonte: THOMAS et al. (2002)

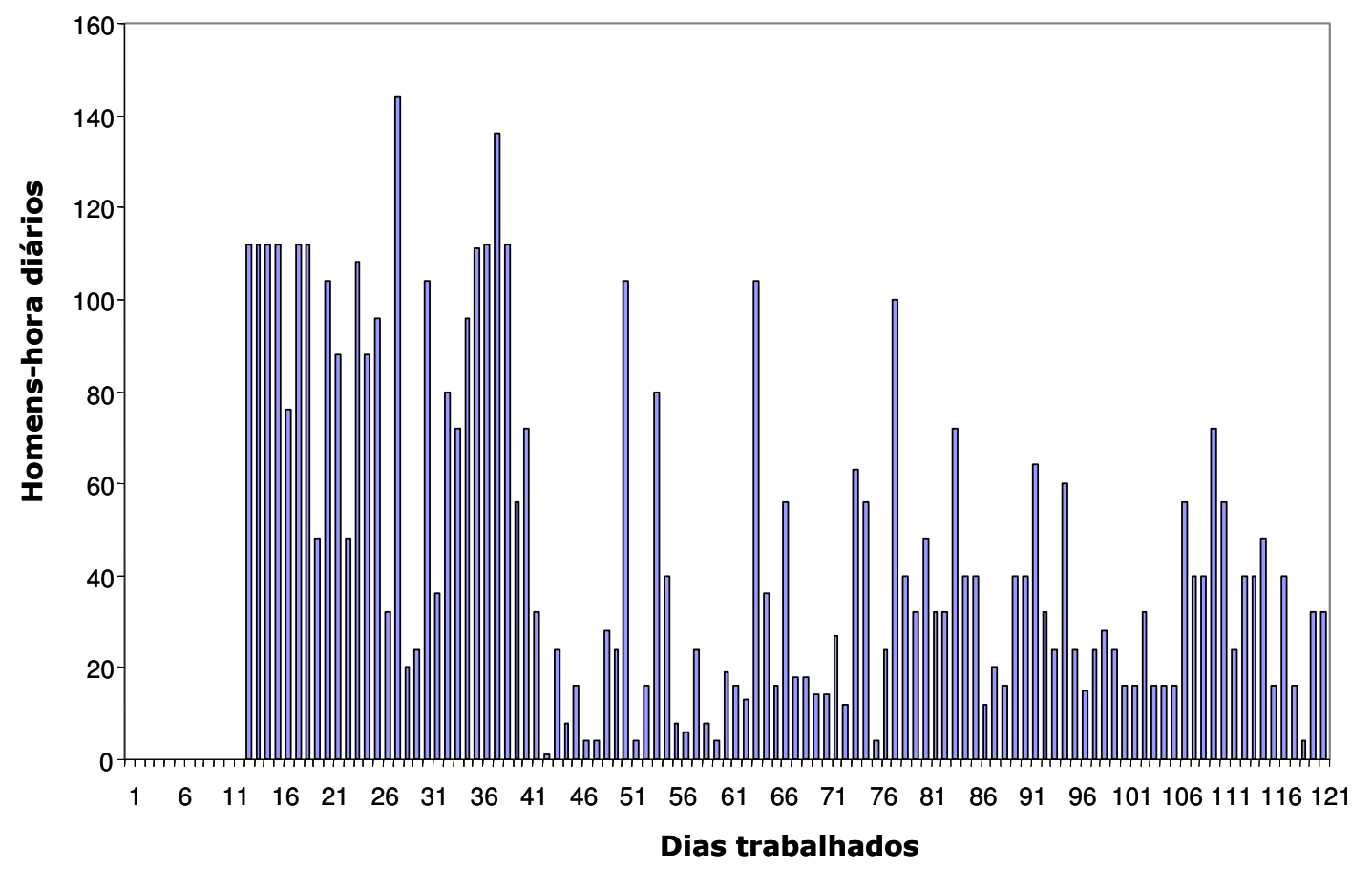

Figura 4.5 - Variação diária na quantidade de homens-hora para uma obra real (obra 9601). Fonte: THOMAS et al. (2002) 


\subsubsection{Modelos para redução da Variabilidade nos Processos de produção}

\subsubsection{O Modelo Lean}

\subsubsection{1}

Lean Production ou Produção Enxuta

MACHADO; HEINECK (2000), em visão compartilhada por outros autores (ZILBOVICIUS (1997)), vêem que os princípios que estão por trás da produção enxuta não são rigorosamente novos, sendo que muitos deles têm suas origens "rastreadas nos trabalhos de pioneiros como Taylor e seus princípios de administração científica, GILBRETH (1911) com os estudos de movimento nos postos de trabalho, SKINNER (1969) com seus estudos de estratégias de produção, DEMING (1986) em suas pesquisas sobre a qualidade, entre outros".

ZILBOVICIUS define a lean production como "um produto de analistas (ocidentais) que constroem um modelo abstrato a partir da observação técnicas; é um construto que aspira (e nesse caso é bem sucedido) à condição de modelo; seus inventores têm o objetivo estrito de conferir legitimidade a um conjunto de técnicas e proporcionar, assim, sua difusão em um mundo que depende de mais elementos, além de resultados, para incorporar determinados elementos à sua prática".

Dentre os principais analistas citados por ZILBOVICIUS está WOMACK que, em 1990, concluiu um trabalho (WOMACK et al. 1990) a respeito da indústria automobilística mundial, documentando as vantagens competitivas que empresas líderes, como o fabricante de automóveis TOYOTA, possuíam em relação às empresas ocidentais tipicamente organizadas no velho paradigma da produção em massa. O modelo de filosofia de produção enxuta (ou lean production ${ }^{66}$ ), foi assim definida por WOMACK et al (1990):

- é um sistema produtivo integrado, com enfoque no fluxo de produção, que se dá em pequenos lotes, segundo a filosofia "just in time", e com um nível reduzido de estoques;

- envolve ações de prevenção de defeitos em vez de correção;

- trabalha com produção puxada em vez de produção empurrada baseada em previsões de demanda;

- é flexível, preconizando a organização através de times de trabalho formados por mão-de-obra polivalente;

- pratica um desenvolvimento ativo na solução de causas de problemas com vistas à maximização da agregação de valor ao produto final;

- trabalha com um relacionamento de parceria intensivo desde o primeiro fornecedor até o cliente final.

KOSKELA (1992) definiu a lean production a partir do entendimento de que a produção é um fluxo de materiais e/ou informações, desde a matéria prima até o produto acabado.

66 O termo lean production, dado à "nova" filosofia de produção, foi "cunhado" por KRAFCIK (1988), ao comparar o sistema Toyota de Produção com o que denominou de fordismo maduro. KRAFCIK pertencia ao grupo de trabalho de WOMACK et al. (ZILBOVICIUS, 1997) 
Nesse fluxo o material pode estar sendo processado, inspecionado ou movimentado, ou ainda estar esperando (pelo processamento, inspeção ou movimentação). Tais atividades, às quais o material pode ser submetido, são inerentemente diferentes. $O$ processamento representa 0 aspecto de conversão do sistema de produção; a inspeção, a movimentação e a espera representam os aspectos de fluxo de produção.

A melhoria dos sistemas produtivos, segundo o autor supracitado, envolveria não somente a busca pela eficiência das atividades de conversão, mas também considerações sobre os fluxos. As atividades de conversão deveriam ser otimizadas e as de fluxos eliminadas, ou, ao menos, terem reduzido sua participação no processo produtivo. Em outras palavras (MACHADO; HEINECK (2000)), o que se constata a respeito da produção enxuta é que se trata de um balanceamento de esforços de melhoria entre ações voltadas para as conversões e para os fluxos que acontecem entre estas conversões.

Em 1996 Womack (WOMACK; JONES (1996)) evidenciaram as práticas que guiavam as empresas que tinham processos produtivos considerados enxutos. Na visão desses autores tais processos deveriam ser entendidos como aqueles sistemas que conviviam com um volume reduzido de perdas, relacionadas a atividades de projeto, gerenciamento de informações ou transformações físicas que não contribuíam para a geração de valor para o produto final do ponto de vista do cliente. Assim, tais autores sistematizaram cinco princípios necessários, apresentados a seguir, para orientar a configuração de um sistema de produção enxuto:

- definição detalhada do significado de valor de um produto a partir da perspectiva do cliente final, em termos de especificações que esse deveria ter, considerando aspectos relacionados às suas capacidades, ao seu preço e ao tempo de produção;

- identificação da cadeia de valor para cada produto ou família de produtos e a eliminação das perdas;

- geração de um fluxo de valor com base na cadeia de valor obtida;

- configuração do sistema produtivo de forma que o acionamento da cadeia de valor seja iniciado a partir do pedido do cliente ou, em outras palavras, a utilização de uma programação puxada;

- a busca incessante da melhoria da cadeia de valor através de um processo de redução de perdas.

MACHADO; HEINECK (2000) observam que a teoria de produção enxuta vem sendo moldada através da desagregação de princípios de algumas teorias já existentes e do aproveitamento somente daqueles associados aos fundamentos gerais assumidos como diretrizes para essa nova proposta de administração da produção.

Estes autores observam ainda "a necessidade de um melhor desenvolvimento de algumas etapas da lógica da produção enxuta (por exemplo, a produção enxuta ancorase na correta determinação do valor que um produto possui, porém as ferramentas destinadas a esta definição são ineficientes)". Por outro lado, quanto a programação puxada, o nível de evolução de filosofias como o Just in Time - JIT - e Total Quality Management - TQM, proporcionaram resultados satisfatórios em termos do que se esperava obter para estes aspectos.

Em seu trabalho MACHADO; HEINECK (2000) defendem a produção enxuta como um novo paradigma da administração da produção, porém são enfáticos ao ressaltar a 
necessidade do desenvolvimento do ferramental para tornar operacionais as diretrizes apresentadas por WOMACK; JONES (1996).

\subsection{Princípios da Construção Enxuta}

Os princípios gerais da Lean Construction ou Construção Enxuta foram desenvolvidos, inicialmente, por KOSKELA (1992). A elaboração e desenvolvimento da teoria vem sendo tratada por inúmeros autores (BALLARD; HOWELL (1994); BALLARD; HOWELL (1995); BALLARD; HOWELL (1998); TOMMELEIN, 1998 etc). Os princípios citados concentram-se em três áreas principais: i) melhoria das operações relacionadas às atividades ou tarefas; ii) otimização do processo global; iii) aprendizagem a partir de práticas externas (benchmarking).

THOMAS et al. (2002) propõem que os princípios da Construção Enxuta sejam avaliados sob a ótica da hierarquização da organização, ou seja, os princípios seriam relacionados a diferentes níveis, tal como apresentado na Figura 4.6. Exemplificam citando que, no nível do processo global, a construção pode ser vista como uma série de operações seqüenciais (para TOMMELEIN et al. (1999), uma "parade of trades"), enquanto nos níveis da atividade e subtarefa, o trabalho é composto principalmente por operações concorrentes. "No nível do processo global, as análises do trabalho tendem a estar na orientação do processo. No nível da atividade, as análises estão mais na orientação do produto". THOMAS et al. (2002)

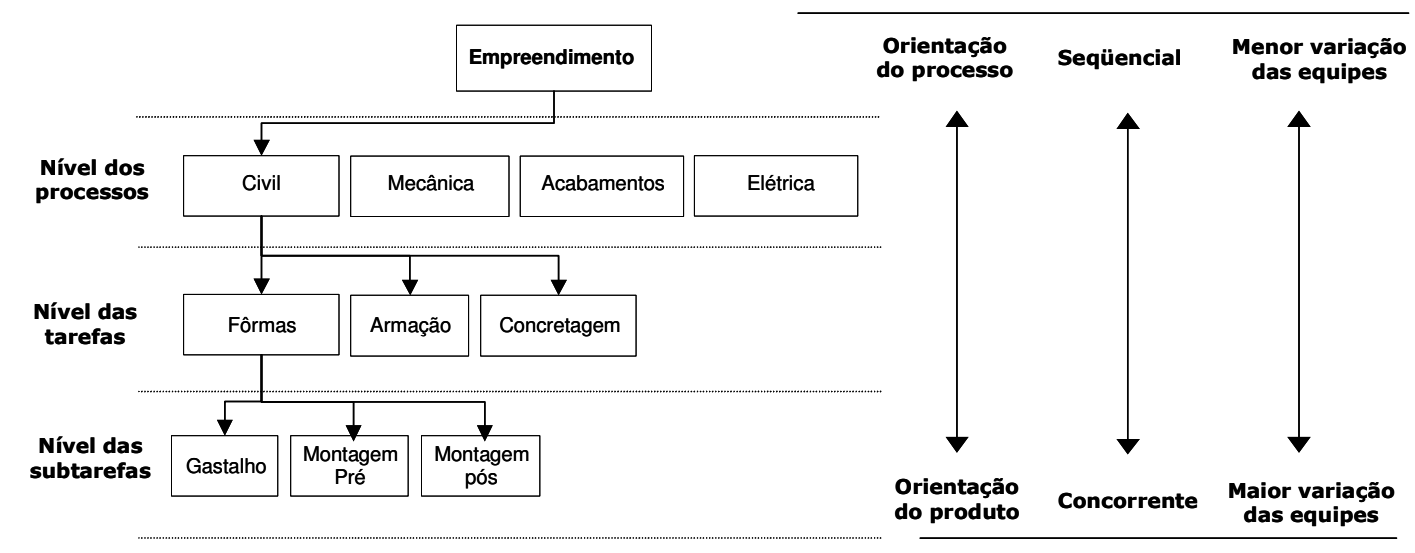

Figura 4.6 - Hierarquia na construção

Os princípios da Construção Enxuta, no nível da atividade ou tarefa, têm como principal objetivo a melhoria do desempenho da mão-de-obra através da redução do tempo dos ciclos das operações de construção. Para alcançar o objetivo proposto, apregoam a redução ou eliminação da "variabilidade das saídas", através, principalmente,: i) da melhoria na confiança dos fluxos; ii) da eliminação das perdas; iii) da simplificação das operações; iv) do uso de programações puxadas; v) da prática do "just in time" nas entregas de materiais.

A variabilidade no fluxo de trabalho, durante os processos de construção, é encarada como impedimento ao desempenho do sistema (BALLARD, HOWELL (1994). Proposições recentes da Construção Enxuta têm focado a variabilidade do fluxo de trabalho, para 
melhorar o desempenho da obra, como, por exemplo, na técnica de "Last Planner", que tem representado a principal aplicação do Pensamento Enxuto na construção civil. $\mathrm{Na}$ técnica de "Last Planner", a preocupação volta-se à habilidade do contratante em assegurar que as tarefas designadas sejam completadas. BALLARD, HOWELL (1994) argumentam que ordens de serviço mal definidas são a principal causa da variabilidade nos fluxos de trabalho da construção. A técnica do "Last Planner" é conduzida visando melhorar a formação e a transferência das tarefas para as equipes através da garantia de que todos os recursos estejam mobilizados e prontos para a execução da tarefa. Com essa técnica, a percentagem de tarefas planejadas completas (PPC) é medida para mostrar cumprimentos ou descumprimentos do planejamento estabelecido (PPC igual a $100 \%$ indica que todas as tarefas planejadas foram concluídas). No entanto, a extensão na qual o aumento do PPC melhora o desempenho da obra parece imprecisa. Há evidências limitadas, segundo BALLARD, HOWELL (1994), mostrando que o desempenho da produtividade para equipes com um PPC acima de $50 \%$ é $35 \%$ melhor do que para equipes com PPC abaixo de $50 \%$. Mais análises são necessárias para confirmar uma ligação causal entre reduções na variabilidade do fluxo de trabalho e melhorias no desempenho da obra (aumento de produtividade).

A redução da variabilidade do fluxo de trabalho, embora importante, pode não ser a melhor maneira para gestores de obra melhorarem as operações (THOMAS et al. 2002). A capacidade de flexibilidade estratégica (mão-de-obra e canteiro) permite aos contratantes responderem eficientemente à variabilidade. A capacidade de flexibilidade é uma importante parte do gerenciamento de variabilidades porque permite atuar-se, com responsabilidade e eficiência, quando as condições variam.

O gerenciamento da variabilidade é uma importante dimensão do Pensamento Enxuto. Os sistemas de Lean Production são marcados pela capacidade de produzir uma larga variedade de produtos de forma rápida e econômica (OHNO, 1998; WOMACK, 1996). Significativamente, a variedade de produtos é a principal origem da variabilidade na produção. Embora a Lean Production aceite variedade nos produtos, a variabilidade na produção é eficientemente dissipada em operações enxutas através de rápidas trocas de maquinários, just-in-time, cronogramas "puxados", práticas de capacidade flexíveis e outras técnicas. O foco da Lean Production está no fluxo de trabalho durante o processo e nas estratégias de capacidade flexíveis para gerenciar as dificuldades criadas pela variabilidade na produção.

A aplicação dos pensamentos enxutos na construção tem se concentrado nos fluxos de trabalho. De acordo com KOSKELA (1992), a variabilidade no fluxo de trabalho muitas vezes aumenta os tempos do ciclo. Dessa forma, melhorar a confiança no fluxo significa ter certeza de que recursos adequados estão disponíveis no tempo certo. Quando os recursos necessários não estão disponíveis no local, a construção é atrasada. Isso afeta as tarefas subseqüentes, ao variarem-se os pré-requisitos. Pesquisas na Pennsylvania State University têm mostrado que a disponibilização dos recursos é indicativo determinante de boa produtividade da mão-de-obra (HANDA; RIVERS, 1983; HORNER, TALHOUNI, 1993). Um dos problemas mais comuns na construção é a falta de habilidade do contratante para entregar materiais no tempo certo e no local certo (THOMAS \& SANVIDO, 2000). Outros trabalhos têm mostrado que, quando não há um adequado fornecimento de materiais, os trabalhadores diminuem o ritmo de trabalho (SWEIS 2000). 
O Fluxo de equipamentos também é importante. Um problema, em algumas operações na construção, é a manutenção precária dos equipamentos ou a utilização de equipamentos errados. O compartilhamento de equipamentos pode também diminuir o ritmo do trabalho.

THOMAS et al. (2002) apontam que os princípios da Construção Enxuta têm sido apresentados por seus autores e seguidores sem os benefícios advindos da análise científica de dados. Os autores propuseram organizar alguns desses princípios e "dissecálos" através de rigorosa análise, usando para tal dados coletados em mais de 20 obras de construção. O resultado dessa investigação, que atestou alguns dos princípios apontados pela Construção Enxuta como capazes de melhorar o desempenho e aumentar a confiabilidade dos fluxos, está resumido na Tabela 4.1.

Nenhum suporte foi encontrado, porém, entre os dados e informações levantados, que pudesse sugerir que a redução dos tempos dos ciclos (números de dias entre concretagens consecutivas para as fôrmas; e números de dias necessários para armar pilares, vigas e lajes de um pavimento, no caso das armações) levasse a um aumento de produtividade.

O aumento do desempenho através da redução da variabilidade das saídas foi mostrado como sendo um princípio equivocado. Da mesma forma, não foram encontrados subsídios para sustentar o princípio do "sizing criterion" que prevê a condução do trabalho segundo um ritmo constante e não excessivo.

O princípio baseado na melhoria da confiabilidade dos fluxos foi verificado como capaz de promover melhorias no desempenho. No entanto, o Pensamento Enxuto precisa ser ampliado consideravelmente. A gestão da mão-de-obra, que não é tratada na literatura "enxuta", mostrou-se como um fator altamente significativo. Os temas mais comumente tratados na referida literatura são o controle das empresas subcontratadas, a terceirização e a disponibilidade de materiais e componentes. Todos são importantes para a eficiência das operações de produção. Porém, THOMAS et al. (2002) verificaram que problemas relacionados aos materiais foram mínimos nos estudos de caso contemplados pela pesquisa. Ainda que o principio que propõe a melhoria do desempenho através da consistência dos fluxos tenha sido evidenciado, também foi constatada a necessidade de se manterem estoques de reserva. "O entendimento e a aplicação dos princípios de gestão dos fluxos vai muito além do simples controle de suprimentos e subcontratados e da gestão dos materiais ("just in time").

Ao se analisarem os dados referentes ao serviço de armação, na pesquisa conduzida pelos autores supracitados, permitiu-se que fossem examinados três princípios referentes aos materiais, que são sempre mencionados na bibliografia sobre a Construção Enxuta: a entrega de materiais "just in time" (que traduz o conceitos de "estoques zero"), as "programações puxadas" (que significam reduzir, ou mesmo, coibir, os estoques) e os "buffers" (estoques de serviço que deveriam ser minimizados). A análise dos dados levantados indicou que, para o serviço de armação, quanto mais "buffers" e mais estoques, melhores as produtividade potenciais do serviço.

Os estudos de caso analisados por THOMAS et al. (2002) mostraram, ainda, que a eliminação das perdas e a simplificação das operações levariam a melhores desempenhos. "No entanto, tem-se a impressão de que os benefícios sejam provavelmente menores quando comparados à promoção da adequação dos recursos e eliminação das interrupções". 
Tabela 4.1 - Análise dos princípios da Construção Enxuta. Fonte: THOMAS et al. (2002)

\begin{tabular}{|c|c|c|}
\hline Princípio & & Análise \\
\hline Redução dos tempos de ciclo & : : & Não suportado pelas análises \\
\hline Redução da variabilidade das saídas & : & Rejeitado como um princípio viável \\
\hline Melhoria da confiabilidade dos fluxos & ;) & Aceito (significativos impactos registrados) \\
\hline Mão-de-obra como um fluxo & ;) & $\begin{array}{l}\text { Deveria ser um novo foco (significativos } \\
\text { impactos registrados) }\end{array}$ \\
\hline $\begin{array}{l}\text { Equipamento e informação como um } \\
\text { fluxo }\end{array}$ & ;:) & $\begin{array}{l}\text { Deveria receber grande ênfase como um } \\
\text { "princípio enxuto" }\end{array}$ \\
\hline $\begin{array}{l}\text { Uso do "just in time" na entrega } \\
\text { de materiais }\end{array}$ & : : & Não suportado pelas análises \\
\hline Redução de "buffers" e estoques & : : & Não suportado pelas análises \\
\hline Aplicação da programação puxada & : & Não suportado pelas análises \\
\hline Simplificação das operações & $:-$ & $\begin{array}{l}\text { Algumas melhoria foram notadas; porém } \\
\text { pequenas quando comparadas à } \\
\text { confiabilidade do fluxo (eliminação de } \\
\text { interrupções) }\end{array}$ \\
\hline Aplicação "sizing criterion" & : & Não suportado pelas análises \\
\hline $\begin{array}{l}\text { Foco na produção (manutenção da } \\
\text { produção diária) - }\end{array}$ & : : & Não suportado pelas análises \\
\hline
\end{tabular}

\subsubsection{Modelo dos Fatores-Recursos}

O desenvolvimento do Modelo dos Fatores - originalmente proposto por THOMAS; YAKOUMIS (1987), graficamente ilustrado na Figura 4.7, assume a existência de uma condição padrão de trabalho; sob essa, a produtividade diária será a de referência (podese ou não assumir a existência de aprendizado). Variações no conteúdo ou no contexto do trabalho fazem a produtividade real variar em relação à de referência. $O$ modelo relaciona a produtividade real diária às características diárias do trabalho (SOUZA (1996)). 


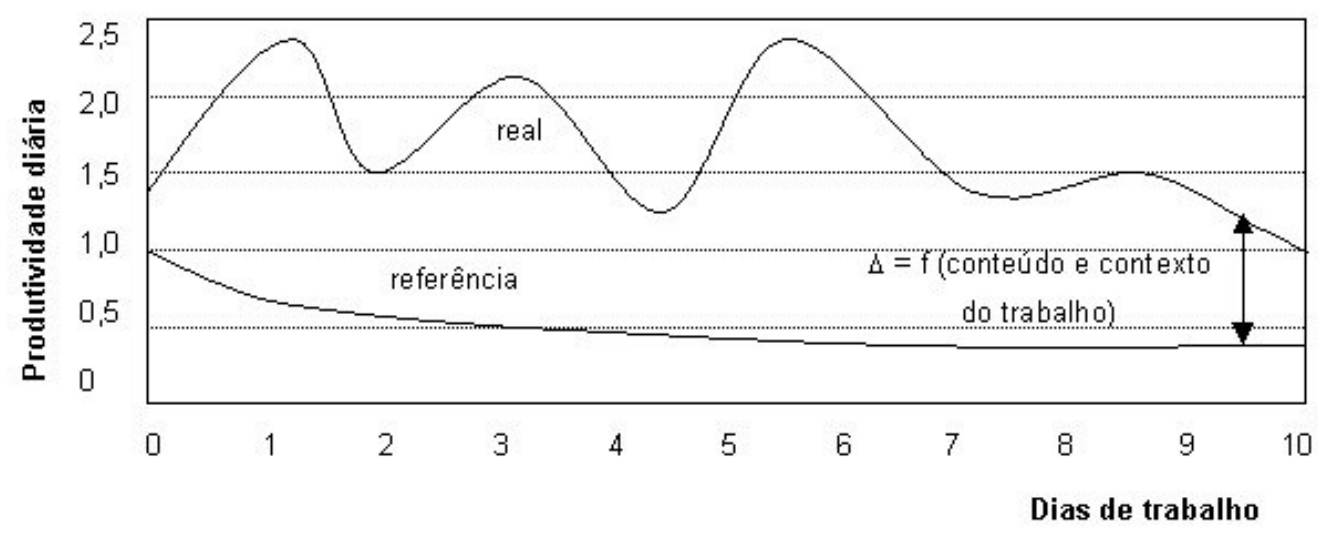

Figura 4.7 - Representação gráfica do Modelo dos Fatores. Fonte: (SOUZA, 1996)

O modelo proposto por THOMAS; YIAKOUMIS (1987) é voltado exclusivamente para a Indústria da Construção Civil. O seu nome advém do fato de o mesmo estar baseado no estudo dos fatores que afetam a produtividade da mão-de-obra.

THOMAS; SAKARCAN (1994) apresentaram o Modelo dos Fatores tal como mostrado na Figura 4.8. Percebe-se que os fatores ligados ao conteúdo e contexto do trabalho são análogos a catalisadores no processo de transformação de entradas (homens-hora), em saídas (quantidades de serviço).

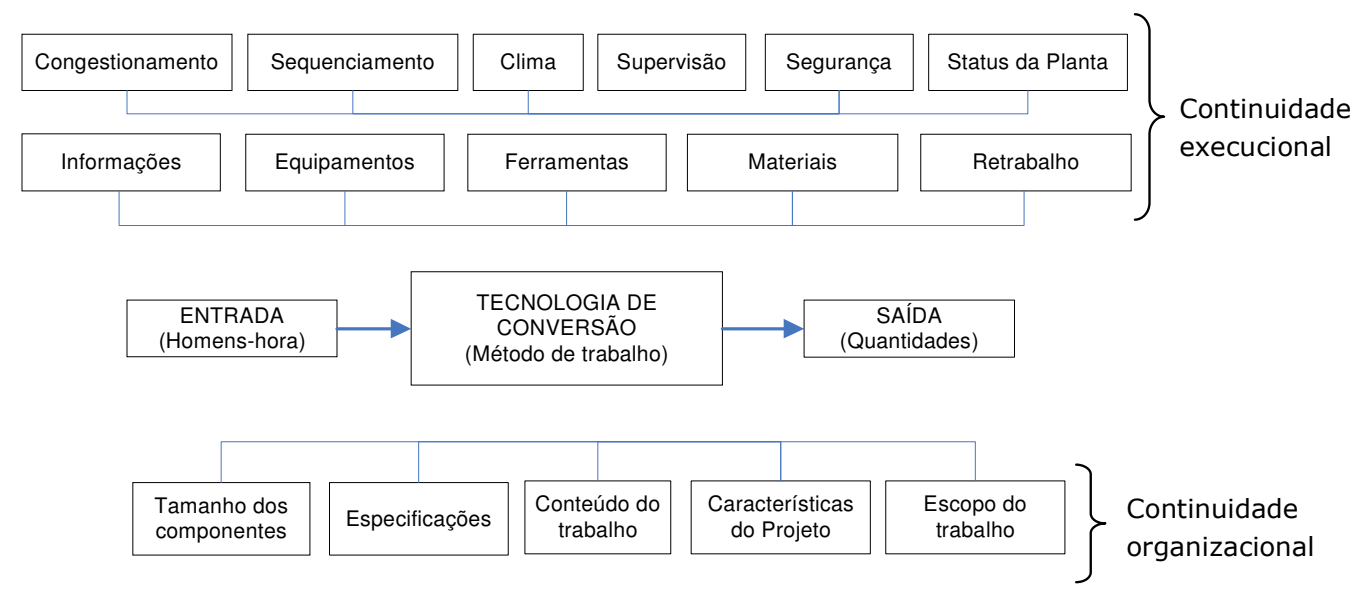

Figura 4.8 - Modelo dos Fatores. Fonte: THOMAS, SAKARCAN. (1994)

THOMAS et al. (2002) reformularam o Modelo dos Fatores. Tendo como base o modelo apresentada na Figura 4.8, apresentaram o Modelo dos Fatores-Recursos. Tal modelo preconiza que cada recurso deve ser provido no tempo e na proporção correta para que o processo de conversão seja eficiente. Interferências recorrentes (provocadas por congestionamentos, mau tempo, trabalho fora de seqüência e retrabalho, por exemplo) podem atrapalhar o processo de conversão. Segundo THOMAS et al. (2002), são quatro as categorias de fatores que influenciam a eficiência na transformação das entradas em 
saídas, afetando o desempenho dos processos de construção: i) recursos; ii) método de trabalho; iii) conteúdo de trabalho; iv) interferências (interrupções).

ARAUJO (2000) coloca que, em situações usuais, existem dois grandes grupos de fatores majoritários que afetam a produtividade da mão-de-obra. O primeiro deles diz respeito ao trabalho que precisa ser feito e abrange os componentes físicos do trabalho, especificações exigidas e detalhes de projeto entre outros. Segundo classificação de THOMAS; SMITH (1990), são os fatores relacionados ao conteúdo do trabalho. O outro grupo de fatores está relacionado ao ambiente de trabalho e como ele é organizado e gerenciado; aspectos gerenciais, incluindo também condições atmosféricas, disponibilidade de materiais e equipamentos, seqüência de trabalho etc caracterizam os chamados fatores de contexto do trabalho, segundo a classificação adotada pelos autores supracitados.

A filosofia do Modelo dos Fatores-Recursos considera que a simples apropriação de índices de produtividade não será tão importante, ou útil, caso não esteja associada ao entendimento dos mesmos. Desse modo, conhecer os fatores que fazem a produtividade de uma obra ser melhor ou pior que outra é tão ou mais relevante que simplesmente calcular índices de produtividade (CARRARO, 1998).

O Modelo dos Fatores-Recursos, proposto por THOMAS et al. (2002) e ilustrado na Figura 4.9 , mostra que, ao se prover um processo de produção com os recursos adequados e no tempo certo, permitir-se-á que a confiabilidade nos fluxos e o desempenho sejam melhorados. SANDERS, THOMAS (1991) mostraram que esses fatores são determinantes para o bom desempenho das equipes e, por conseguinte, para a obtenção de boas produtividades.

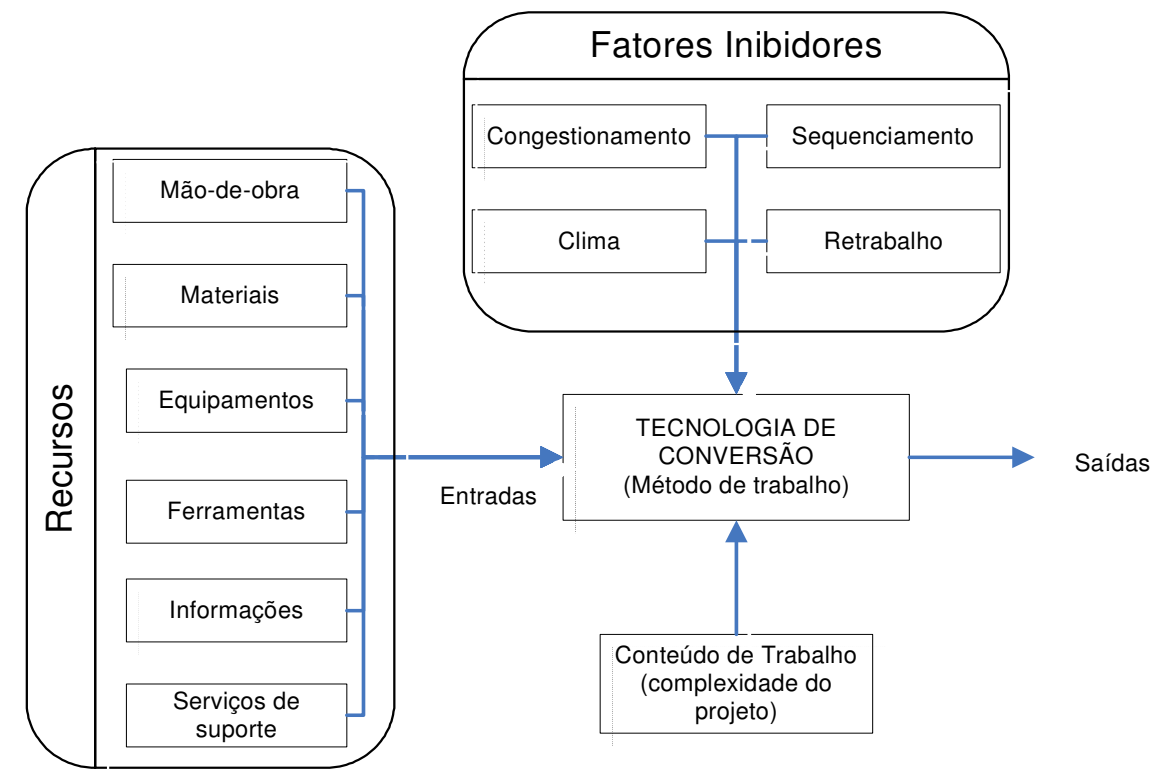

Figura 4.9 - Modelo dos Fatores-Recursos. Fonte: THOMAS et al. (2002) 
O gráfico mostrado na Figura 4.10 sumariza a ineficiência das horas trabalhadas em seis estudos de caso tratados por THOMAS et al. (2002). A principal causa da perda de eficiência está relacionada à gestão deficiente da mão-de-obra. Em segundo lugar, porém numa posição bastante distante da primeira, ficou o retrabalho, seguido de perto pelas condições climáticas e pelo método de trabalho. Chama a atenção o fato de que apenas o recurso mão-de-obra e o clima foram categorias de fatores que contribuíram para justificar a ineficiência em todos os estudos de caso considerados.

THOMAS et al. (2002) apontam que o fluxo de equipamentos é outro importante recurso e que, em certas operações de construção, a manutenção inadequada dos equipamentos pode causar problemas à produção, assim como um número insuficiente de ferramentas/equipamentos pode ter o mesmo efeito.

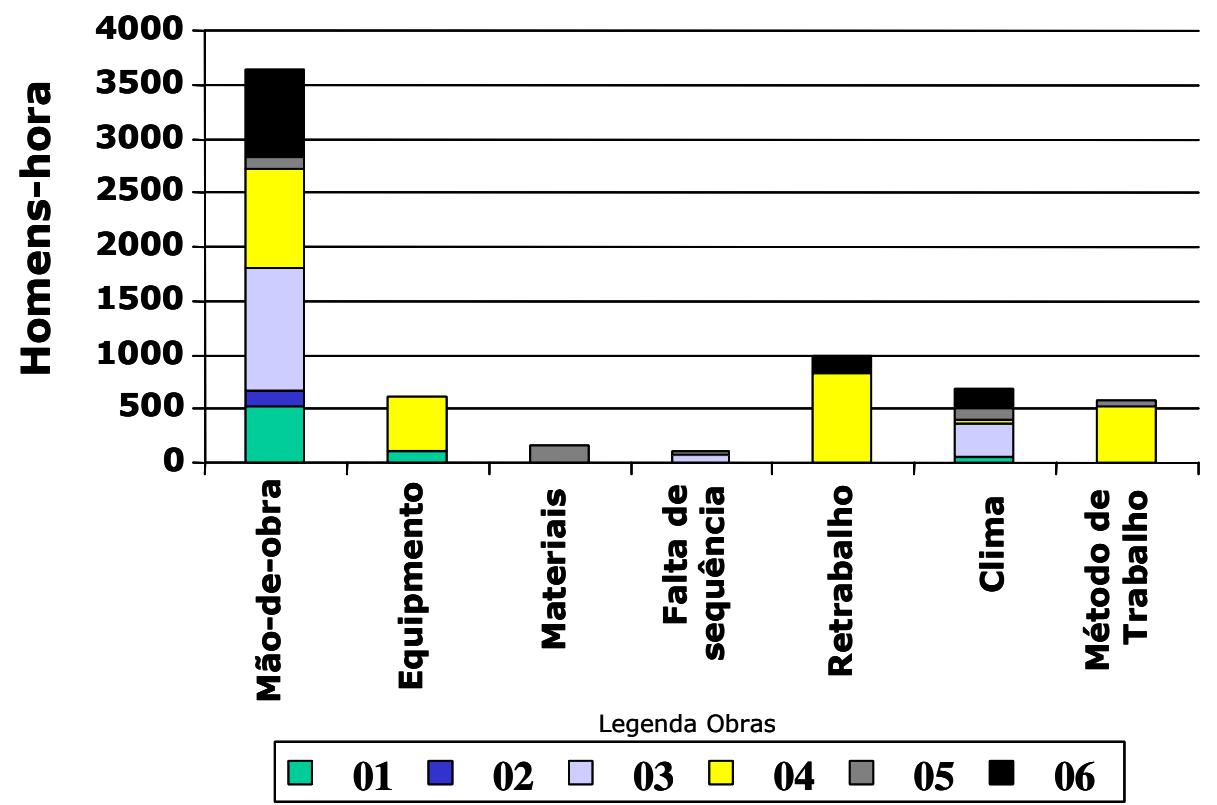

Figura 4.10 - Resumo da ineficiência dos homens-hora por causa. Fonte: THOMAS et al. (2002)

THOMAS et al. (2002) relacionam os fatores supracitados com os princípios da Construção Enxuta conforme apresentado na Tabela 4.2. Percebe-se que: i) exceto pelo "sizing criterion", os princípios da construção enxuta estão inclusos no Modelo dos Fatores-Recursos; ii) o conteúdo do trabalho não é tratado pela construção enxuta. 
Tabela 4.2 - Comparação entre Modelo dos Fatores-Recursos com os princípios da Construção Enxuta

\begin{tabular}{|l|l|}
\hline \multicolumn{1}{|c|}{ Modelo dos Fatores-Recursos } & \multicolumn{1}{|c|}{ Princípios da Construção Enxuta } \\
\hline Recursos & Melhoria na confiança dos fluxos \\
\hline Prática do "JIT" \\
\hline Interferências & Uso de programação puxada \\
\hline Conversão tecnológica & Melhoria na confiança dos fluxos \\
\hline Conteúdo de trabalho & Eliminação de desperdícios \\
\hline- & Simplificação das operações \\
\hline
\end{tabular}

4.2.3.2.1

Avaliação do Modelo dos Fatores

O Modelo dos Fatores foi desenvolvido especificamente para uso na Indústria da Construção Civil e validado internacionalmente através do expressivo número de aplicações práticas a que foi submetido. Tais aplicações trouxeram significativos benefícios (traduzidos em inúmeros relatórios conclusivos) ao setor da construção civil internacional. O Modelo dos Fatores/Recursos serviu, por exemplo, como base metodológica do projeto "International Construction Labor Productivity", promovido pelo "International Benchmarking Group" - CIB W65/55, que envolveu a participação de pesquisadores de dez países (Austrália, Brasil" ${ }^{67}$, Bulgária, Croácia, Escócia, Eslovênia, EUA, Quênia, Malásia e México).

O Modelo dos Fatores-Recursos expande importantes dimensões do modelo padrão de "entrada-processo-saídas" ao oferecer uma ferramenta que permite explorar a relação entre variabilidade e desempenho (THOMAS et al. (1990); SANDERS, THOMAS (1991)). Vem, dessa forma, permitindo que a Indústria da Construção Civil conheça os impactos de uma gama considerável de fatores sobre a produtividade da mão-de-obra envolvida em operações no nível das atividades. Tem-se, assim, provido o setor com informações valiosas sobre como melhorar a produtividade da mão-de-obra. GOODRUN, HASS (2004)

Neste trabalho, o Modelo de Fatores tem, novamente, importante papel, ao servir como base metodológica para a etapa de diagnóstico do método para proposição de diretrizes para melhoria da produtividade. As definições, instrumentação e operacionalização para a mensuração da produtividade da mão-de-obra já foram tratadas em trabalhos anteriores (ARAUJO (2000) e SOUZA (2001)) e serão seguidas ao longo deste trabalho. Já os fatores de conteúdo e contexto assumirão, a partir deste trabalho, uma nova subdivisão, qual seja: i) fatores relacionados ao projeto do produto; ii) fatores relacionados ao método de trabalho; iii) fatores relacionados à organização do trabalho.

\footnotetext{
67 No Brasil, o referido projeto é conduzido por grupo de pesquisa (no âmbito do Departamento de Engenharia de Construção Civil da EPUSP) no qual o autor desta Tese se insere.
} 
A subdivisão dos fatores, da forma supracitada, induz (intencionalmente) a que se enxergue o processo de produção, quando tratado no âmbito da produtividade da mãode-obra, como sendo formado por uma tríade, composta pelo projeto do produto, pelo método de trabalho e pela organização do trabalho. Acredita-se que a decomposição do processo em partes (analiticidade) facilite a própria operacionalização do método no que tange ao entendimento dos fatores, ao seu levantamento em campo e às posteriores análises, que balizarão a proposição das diretrizes pela construtora. Soma-se, a isso, o fato de que tais diretrizes terão procedência e destino conhecidos pelo pessoal de obra, facilitando o próprio encaminhamento de ações (que serão direcionadas aos responsáveis pelo projeto, ou pelo método e/ou pela organização do trabalho).

As anormalidades ou fatores inibidores têm grande relevância quando se está buscando entender as causas para valores detectados das RUP ${ }^{68}$ cumulativas (são estes fatores os grandes responsáveis pelo distanciamento dos valores de produtividade potencial em relação aos da produtividade cumulativa). No método proposto por este autor, as análises serão feitas tomando como base os valores de RUP potencial, que são influenciados por fatores pertencentes à tríade supracitada. Portanto, as anormalidades, apesar de serem sempre consideradas nos levantamentos, não serão enfatizadas neste trabalho.

\subsection{Indicadores de produtividade}

\subsubsection{O papel dos indicadores na melhoria no desempenho da Indústria da Construção Civil internacional}

O Ministério do Desenvolvimento e Ação Social do Governo Federal Brasileiro, através do documento intitulado "Informações Selecionadas para Monitoramento dos ResultadosConstrução Civil", datado de 18/03/2004, disponibiliza os seguintes indicadores (referentes ao ano de 2002) para a construção civil: i) participação no PIB: $8 \%$; ii) pessoal ocupado (2001): 3.923.700; iii) saldo da balança comercial (2003): US\$ 535 milhões;iv) produtividade em relação ao ano de 2001 : $-0,4 \%$; v) déficit habitacional (1999):5,2 milhões. MTE (2004)

O mesmo documento traz, de forma sintética, os principais aspectos a discutir no âmbito da construção civil: qualidade e produtividade insuficientes, falta de integração entre os elos da cadeia produtiva, baixo nível de qualificação da mão-de-obra, insuficiência da oferta de habitações para a população de baixa renda, necessidade de revisão dos sistemas e programas de financiamento, incremento do custo da construção e regularização fundiária urbana, recuperação e ampliação da infra-estrutura, redução dos custos e aprimoramento das relações do trabalho.

Após apresentar macrometas (como, por exemplo, a manutenção de 3,6 milhões de empregos diretos e a geração de 1,1 milhão de novos postos de trabalho por ano) e as metas instrumentais (por exemplo, aumentar a produtividade em $3 \%$ ao ano na construção civil) para o setor, o Ministério do Desenvolvimento e Ação Social do Governo Federal Brasileiro definiu as "principais políticas prioritárias" do governo para com a construção civil, destacando-se, aqui:

68 No capítulo cinco os indicadores de produtividade (RUP) são, de fato, apresentados e comentados. 
- a integração dos segmentos da cadeia produtiva e o aumento da produtividade da Indústria da Construção Civil, por meio do fortalecimento do Programa Brasileiro da Qualidade e Produtividade do Habitat (PBQP-H), do uso de inovações tecnológicas e da capacitação da mão-de-obra;

- o estímulo à privatização de obras e serviços com potencial técnico e econômico de atração do capital privado (Parcerias Público-Privadas - PPP);

- o incremento dos instrumentos de proteção e segurança no trabalho, a adoção de políticas de encargos sociais que promovam a desoneração dos custos de produção e a redução do número de empregos informais.

Nos resultados e situação do setor, divulgados pelo Ministério do Desenvolvimento e Ação Social do Governo Federal Brasileiro (referentes aos anos de 2000 a 2003 e a prospecção para o ano de 2004), dois pontos chamam atenção: i) a "sistematização de indicadores de produtividade", que aparece como prevista para 2002, mas não se mostra o estágio atual em que se encontra; ii) a gestão e capacitação de mão-de-obra e o desenvolvimento tecnológico da cadeia, por meio da industrialização da construção e do aproveitamento de resíduos sólidos (constam no cenário prospectado para o ano de 2004).

Tratou-se da primeira vez em que a palavra "indicadores" apareceu no documento do governo. Ainda que apenas um começo, este pesquisador acredita tratar-se de um ponto estratégico que deve ser fomentado pelo governo, o qual deverá envolver a comunidade acadêmica, entidades representativas de construtores, projetistas, fornecedores, fabricantes de materiais e componentes etc, no âmbito do Programa Brasileiro da Qualidade e Produtividade do Habitat (PBQP-H), e promover o desenvolvimento de um programa de indicadores setoriais, dentre os quais, os indicadores de produtividade, que irão possibilitar a mensuração e comparação do desempenho do setor.

No Reino Unido, o planejamento estratégico da Indústria da Construção Civil (responsável por uma política industrial séria e à altura da representatividade do setor no PIB do país) vêm sendo defendido e trabalhado há décadas ("Banwell's Report" em 1964; "Latham's Report" (CONSTRUCTING THE TEAM (1994)). O governo trabalha em parceria com a Indústria da Construção Civil (relação "estratégica de parceria" com seu principal "fornecedor"; dos 65 bilhões de libras anuais envolvidos no "Construbusiness" anglosaxão, 7,5 bilhões são gastos pelo governo) e vê no seu alto gasto com projetos de construção a necessidade de que melhorias no desempenho da construção se dêem, de fato. BOURN (2001)

Uma sucessão de estudos feitos no Reino Unido (mais recentemente, o "Latham's Report") tem frisado a ineficiência dos métodos tradicionais de contratação e gestão dos principais empreendimentos. A estimativa do custo dessas ineficiências é algo bastante impreciso, porém os estudos têm identificado que o potencial de redução de custos na construção, em se melhorando as práticas, seja algo em torno de 30\%. BOURN (2001)

Em 1998, a publicação do relatório intitulado "Rethinking Construction" (RETHINKING CONSTRUCTION (1998)), também conhecido como "Egan's Report" (em razão do nome do autor, John Egan), tornou-se uma "bandeira" sob a qual a indústria, os clientes e o governo passaram a trabalhar juntos para melhorar o desempenho da indústria da construção do Reino Unido. Muitas das recomendações propostas pelo "Latham's Report" começaram a ser implementadas a partir do "Egan's Report"., 
Os princípios defendidos pelo "Rethinking Construction" foram: i) liderança do cliente; ii) integração das equipes através da cadeia de suprimentos; e iii) o respeito pelas pessoas. Entre os principais objetivos estiveram a promoção de melhorias radicais nos projetos, a qualidade, a satisfação do cliente e sustentabilidade da construção no Reino Unido (incluindo a capacidade em recrutar e reter mão-de-obra em todos os níveis, através de melhorias nas práticas de contratação e nas condições de segurança e saúde).

A força tarefa propôs sete metas (anuais), para melhoria, que formaram a base do "Rethinking Construction": i) redução do custo do capital (10\%); ii) redução do tempo de construção (10\%); iii) melhor previsibilidade (10\%); iv) diminuição do número de defeitos (20\%); v) diminuição do número de acidentes (20\%); vi) melhoria da produtividade (10\%); vii) aumento dos rendimentos (10\%). O "Rethinking Construction" "desafiou" a Indústria da Construção Civil do Reino Unido a medir o desempenho de um conjunto de atividades e estipulou metas ambiciosas de melhorias. RAYNSFORD (2000)

Também em 1998, a comparação (benchmarking) da produtividade da mão-de-obra no Reino Unido foi discutida num relatório denominado "Benchmarking the Productivity of the UK Construction Industry". Constatou-se, neste trabalho, que não havia uma avaliação pública e sistemática de estimativa de produtividade na Indústria da Construção Civil do Reino Unido e que comparações ou normas de produtividade também não existiam. Desenvolveu-se, então, um questionário, que foi aplicado às empresas e instituições do setor para estabelecer quais seriam as áreas prioritárias no desenvolvimento de melhorias. Chegou-se à conclusão de que as mensurações de produtividade deveriam acontecer nos canteiros de obras.

Para responder aos desafios lançados, formaram-se, no Reino Unido, vários grupos de trabalho, destacando-se, aqui, o grupo responsável pelos "Key Performance Indicators" (KPIs).

Tal grupo de trabalho entende que o objetivo chave da produtividade é dar assistência e suporte necessários às empresas, organizações e indústria engajadas na mensuração e melhoria contínua dos seus processos (a mensuração e a comparação de desempenhos tratam-se do primeiro passo para se alcançar este propósito).

Para tanto, desenvolveram os KPIs que são mensuradores de desempenho de uma atividade que é crítica ao sucesso de uma organização. O KPI pode ser específico para uma empresa, mas, para se permitirem comparações entre empresas do setor, uma série de KPIs padrões para a construção têm sido desenvolvidos pelo grupo de trabalho desde 1999 (desde então, outros KPIs vêm sendo elaborados visando à avaliação de pessoas e das condições do ambiente de trabalho, assim como agentes específicos da indústria, como contratantes, projetistas etc).

O programa de produtividade, conduzido pelo grupo coordenador, trabalha com outros setores industriais para que se possa, a partir de comparações com a Indústria da Construção Civil, potencializar os benefícios a partir do entendimento de fatores que afetam o desempenho nas outras indústrias. O programa ainda tem desenvolvido relações de trabalho com outras empresas e centros de pesquisa de outros países para comparar desempenho e competitividade da Indústria da Construção Civil do Reino Unido. CONSTRUCTING EXCELLENCE ${ }^{69}$ (2004)

69 "Constructing Excellence" alcança sua missão ao influenciar o Governo na formulação de políticas, do trabalho com grupos de partes interessadas e como um catalisador na 
Para RAYNSFORD (2000) é extremamente necessário que as empresas usem os KPIs para examinar seu desempenho e para compará-lo com o desempenho de outras empresas, dentro do que chama "benchmarking clubs". "Somente através disso é que a indústria da construção poderá demonstrar que estará melhorando, com sucesso, seu desempenho".

Para PROVERBS et al. (1999), a consolidação do Mercado Comum Europeu, em janeiro de 1993, marcou o fim das barreiras comerciais, permitindo livre movimentação de empresas na União Européia. Na visão desses autores, tal acontecimento trouxe duas conseqüências significativas para os contratantes europeus: i) eles poderiam oferecer serviços de construção em qualquer lugar do continente e competir com as firmas locais ou, talvez, com firmas "estrangeiras", em base de igualdade; ii) os contratantes locais enfrentariam grande competição nos projetos locais diante da procura das empresas estrangeiras por trabalhos em todo o continente.

PROVERBS et al. (1999), ao analisar estatísticas européias (referentes ao ano de 1996), estimaram que os investimentos europeus no setor da construção civil seriam algo próximo a 690 bilhões de euros, o que representa aproximadamente $12 \%$ do PIB . Empregando mais de $7 \%$ dos trabalhadores europeus, o setor é o maior empregador do continente, representando um enorme potencial de oportunidades para aquelas firmas dispostas a "encarar" a competição "estrangeira". Esse cenário altamente competitivo foi o principal instigador da criação de indicadores de produtividade que permitiriam às empresas européias se compararem, com a intenção de se tornarem/manterem competitivas.

Ainda que o interesse na produtividade das operações de construção tenha sempre existido, SALIM, BERNOLD (1994) apontam que o crescimento da competição internacional reforçou sua importância para o futuro desejado para a Indústria da Construção Civil norte-americana. Os autores citam a publicação do Construction Industry Institute (CII), "Projects and Competition of the Future", ao relatarem que "para manterem a competitividade da sua indústria da construção, idéias criativas e inovadoras para melhorar a produtividade deverão ser exploradas".

Ainda no Reino Unido, organismos e associações como a "British Cement Association", "Concrete Structures Group", "Reinforced Concrete Council", entre outros, reuniram-se com o propósito de promover a "melhoria no desempenho na indústria do concreto armado."

Tais entidades participaram do "The European Concrete Building Project", programa que envolveu a construção de uma série de estruturas em concreto armado, em tamanho real, em Cardington, Reino Unido. Tais estruturas foram sujeitas a detalhados testes de desempenho durante seu processo de produção.

Com o apoio de entidades governamentais, como o "Department of the Environment Transport Regions", e do Conselho de Pesquisa de Engenharia e Ciências Físicas, o primeiro destes edifícios (estrutura com laje plana composta de 7 pavimentos) foi concluído em 1998. Os resultados das investigações foram sumarizados numa série intitulada "Guia das Melhores Práticas", que teve como objetivo "estimular a mudança

implementação de processos, estratégias de melhorias de negócios, sistemas avançados e tecnologias inovadoras. 
fundamental nos processos de produção de estruturas a fim de render melhorias significativas no custo, no tempo de entrega e na qualidade destas estruturas".

Dentre este guias, já publicados, destaca-se aqui aquele baseado no trabalho de KALIAN et al. (2000). Os autores, neste trabalho, apresentaram recomendações para um fornecimento de armaduras mais eficiente, através da melhoria na transferência de informações e da re-engenharia do fluxo do processo de informação do projetista para o armador.

Para ajudar a compreensão do fluxo de informação ao longo de toda a cadeia de fornecimento de armaduras, as práticas inglesas e os procedimentos usados na execução das armaduras foram estudados e modelados, desde o projeto, passando pela fabricação e produção, chegando ao fornecimento para a construção.

Os modelos desenvolvidos foram verificados comparando-os com os procedimentos observados nas empresas de fabricação, nos escritórios de projeto e nos canteiros e escritórios das construtoras. A análise de práticas atuais destacou áreas potenciais para melhorias.

\subsubsection{A importância dos indicadores de produtividade para a construção civil}

Questões relacionadas à produtividade da mão-de-obra estão recebendo atenção redobrada na Indústria da Construção Civil mundial (ALLMON et al. (2000); TEICHOLZ (2001)). A produtividade da mão-de-obra é considerada um dos melhores indicadores para se mensurar a eficiência dos processos de produção. (ROJAS et al. (2003)), tendo sido tratada por diversos autores, em inúmeros trabalhos publicados nos últimos anos. Embora esses autores apresentem métodos de levantamento e análise de dados bastante variáveis e discutíveis, são consensuais (MING LU; ANSON (2004); ROJAS et al. (2003); GOODRUM, HASS (2004); CONSTRUCTING EXCELLENCE (2004)) ao defenderem a idéia de que a comparação dos dados levantados, bem como sua associação a fatores influenciadores, tratam de passos importantes na busca da melhoria dos índices de produtividade.

STERN (1999) salienta que, embora a produtividade seja o "caminho-chave" para se caracterizar o desempenho econômico, são freqüentes as dificuldades encontradas na sua medição. Segundo GOODRUM; HASS (2004) não há indústria nos Estados Unidos que melhor comprove a afirmação de STERN (1999) do que a Indústria da Construção Civil. Devido às dificuldades de mensuração, a principal agência de estatísticas norteamericana ("Bureau of Labor Statistics") não mantém índices de produtividade para a Indústria da Construção Civil. Sem índices oficiais, as percepções de tendências da produtividade norte-americana variam bastante. Enquanto os indicadores de produtividade mão-de-obra, em níveis globais, mostram-se em declínio, a produtividade medida no nível das atividades (tarefas) revela melhorias. (ALLMON et al. 2000; TEICHOLZ, 2001)

Num passado recente, alguns trabalhos que tentaram caracterizar a Indústria da Construção Civil com indicadores globais de produtividade (nos Estados Unidos com ARDITI, 1985; TUCKER, 1986; CHRISTIAN, HACHEY, 1995 e no Brasil com McKINSEY GLOBAL INSTITUTE (1998)), o fizeram com base em dados coletados, principalmente, 
nos níveis hierárquicos superiores da cadeia produtiva, a partir de tratamentos e análises inadequados que os tornaram suscetíveis a duvidas ${ }^{70}$.

ARAUJO (2000) acredita ser a "padronização" um dos pontos a se destacar quando se deseja levantar e comparar indicadores, qualquer que seja sua natureza. KANITZ (2000), num artigo publicado em periódico nacional, faz algumas considerações apreciáveis sobre a importância de se terem sistemas de mensuração "fortes". Segundo esse autor, "não é a moeda do país que precisa ser forte. É a contabilidade que deve ser forte e precisa. Todo país requer um sistema de referência confiável, que permita aos indivíduos registrar e comparar preços". A utilização de padrões distintos impossibilita a comparação entre os indicadores, criando uma "torre de Babel"; como conseqüência, tem-se, por exemplo, que "nenhuma empresa nacional nem investidor têm a mínima noção do seu verdadeiro lucro."

"Defender um sistema de referência nacional forte pode parecer picuinha intelectual, um mero detalhe. Mas, tanto quanto a Constituição, nenhum país pode dispensar um forte sistema de mensuração para se guiar em relação ao futuro." (KANITZ, 2000)

Reportagem publicada na Folha de São Paulo ${ }^{71}$ alerta para o conflito dos indicadores de taxas de desemprego no Brasil. "Metodologias diferentes e um apagão estatístico no país distorcem os dados sobre desemprego no Brasil e transformam esses números em instrumentos de uso político. A seis meses das eleições municipais, a falta de sintonia desses indicadores leva o governo e oposição a utilizarem os resultados de cada uma das pesquisas $^{72}$ de acordo com seus interesses". Ainda segundo apurou a própria reportagem, a principal preocupação do governo federal é que as empresas freiem ainda mais seus investimentos devido à contradição dos indicadores.

Assim como os indicadores macroeconômicos, os indicadores microeconômicos (referentes ao nível das atividades) assumem uma importância estratégica para a Indústria da Construção Civil, em qualquer que seja o país considerado. Os indicadores de produtividade da mão-de-obra são considerados um dos melhores indicadores para se mensurar a eficiência dos processos de produção. (ROJAS et al (2003)).

As pesquisas que tratam a produtividade da mão-de-obra no nível das atividades de construção vêm sendo desenvolvidas com êxito pela comunidade científica internacional há mais de duas décadas (destaque para os trabalhos publicados na década de 70 (KOCH, MOAVENZADEH (1979)), de 80 (MALONEY (1983)), de 90 (onde merecem destaque os trabalhos publicados por R. THOMAS em conjunto com inúmeros pesquisadores internacionais (THOMAS; YIAKOUMIS (1987); THOMAS et al. (1990); THOMAS, SAKARCAN (1994)) e deste início de século (ROJAS et al. (2003); GOODRUM, HASS (2004); MING LU, ANSON (2004))), mostrando que o tema se mantém atual, instigador e fundamental para a Indústria da Construção Civil internacional.

${ }^{70}$ A constatação de ALLMON et al. (2000) e TEICHOLZ (2001) foi contestada por ROJAS et al. (2003), que aponta que os dados usados para calcular a produtividade da construção no nível macroeconômico, bem como as análises desses dados, apresentaram problemas, tornando as conclusões obtidas equivocadas.

71 Reportagem publicada no caderno "Dinheiro" da Folha de São Paulo, em 16/05/2004.

72 No Brasil, disponibilizam indicadores sobre taxas de desemprego: Caged (cadastro geral de empregos e desempregados), IBGE, Fundação Seade, do Dieese e FIESP. 
GOODRUM, HASS (2004) lembram que as pesquisas desenvolvidas nos últimos anos têm provido a indústria de construção civil (citam entre outros, THOMAS et al. (1990); THOMAS, SAKARCAN (1994)) com informações valiosas sobre como melhorar a produtividade nas obras de Construção Civil (basicamente ao identificarem os fatores que influenciam a produtividade no nível do empreendimento).

\subsubsection{A sistematização dos indicadores microeconômicos}

A tentativa de sistematização do uso de indicadores como mensuradores de desempenho, no subsetor de edificações na construção civil brasileira, data de meados da década de 1990, com a divulgação do "Sistema de Indicadores de Qualidade e Produtividade para a Construção Civil", desenvolvido pelo Núcleo Orientado para a Inovação da Edificação (NORIE) da Universidade Federal do Rio Grande do Sul (UFRGS).

O objetivo do trabalho supracitado era orientar as empresas de construção a "introduzir procedimentos de coleta de indicadores, assim como estabelecer valores de referência setorial que permitissem às empresas comparar seu desempenho com outras empresas do setor e estabelecer metas para a melhoria contínua". OLIVEIRA et al. (1995)

Os pesquisadores do NORIE selecionaram os indicadores que compuseram o sistema a partir de pesquisas sobre indicadores empregados em outros setores industriais, na indústria da construção de outros países e em função de problemas considerados críticos para o setor no Brasil, através da participação de grupos de empresas construtoras. O conjunto composto inicialmente por 28 indicadores, classificados em nove categorias (racionalidade; não conformidade; satisfação do cliente; desperdícios; produtividade; segurança do trabalho; relações do trabalho; qualificação; econômicos/financeiros), formaram o "Sistema de Indicadores", sendo que, para cada um deles, eram apresentados os objetivos, critérios e planilhas para coleta de dados. FORMOSO et al. 1993.

De acordo com OLIVEIRA et al. (1995), o Sistema de Indicadores constituía uma parceria em que o NORIE/UFRGS auxiliava as empresas na implantação das medidas de desempenho, através da produção de manuais e da realização de cursos e palestras. Os dados eram coletados pelas empresas e enviados para processamento e armazenamento em um banco de dados gerenciado pelo NORIE. Periodicamente eram produzidos relatórios em que se divulgavam médias setoriais e benchmarks.

Alguns dos indicadores propostos remetiam à produção, como os indicadores de produtividade do serviço, indicadores de tempos (produtivos, improdutivos e auxiliares), indicadores de consumos de materiais, indicadores relacionados aos recursos humanos (rotatividade, absenteísmo e treinamento), e sua interpretação, mediante comparações (benchmarks), poderia induzir melhorias na organização do trabalho, embora não fosse esse o principal objetivo do trabalho.

No Rio de Janeiro, AMORIM (1998), lembra-se do "Clube da Qualidade na Construção", que se trata de uma associação de empresas e instituições de pesquisa, sob coordenação do SENAI e SINDUSCON/RJ, e responsabilidade da Universidade Federal Fluminense, que desenvolveu um sistema de qualidade e produtividade para edificações.

Tal sistema, em semelhança com aquele proposto pelo NORIE e comentado anteriormente, abrange indicadores de produtividade do trabalho (através do acompanhamento da distribuição dos tempos produtivos, auxiliares e improdutivos), indicadores de perdas de materiais, indicadores de qualidade do produto (através do 
acompanhamento pós-entrega) e indicadores da qualidade dos serviços (através do levantamento do retrabalho).

Pode-se dizer que, a partir do Sistema de Indicadores proposto pelo NORIE, uma série de trabalhos sobre indicadores para a construção civil, no âmbito da produção de edificações, surgiram, permitindo que o setor se preocupasse com uma avaliação de caráter mais objetivo.

Trabalhos específicos sobre indicadores de perdas de materiais na construção de edifícios foram desenvolvidos ao longo dos últimos anos (PINTO (1989); FORMOSO et al. (1996); SOIBELMAN (1993); SOUZA (1997)).

Destaca-se o trabalho coordenado pelo Departamento de Construção Civil da Escola Politécnica da Universidade de São Paulo, intitulado "Alternativas para a redução do desperdício de materiais nos canteiros de obras - FINEP e construtoras" (AGOPYAN et al. (1998); SOUZA et al. (1999)), desenvolvido em âmbito nacional, envolvendo a participação de 20 universidades brasileiras (localizadas em 18 estados da União), com levantamento de dados em mais de uma centena de canteiros de obras.

Pesquisadores desta mesma Instituição conduziram outros projetos, em que trataram dos indicadores de produtividade da mão-de-obra para uma série de serviços. Os trabalhos sobre o tema, desenvolvidos entre 1998 e 2001 (CARRARO, 1998; ARAÚJO, 2000; LIBRAIS, 2001; SILVA, 2002; MAEDA, 2003; SOUZA, 2001), permitiram uma renovação, em 2003, do principal manual de orçamentação brasileiro, a Tabela para Composição de Preços para Orçamentos (TCPO), que passou a apresentar faixas de variações de produtividade para alguns dos principais serviços de obras de edifícios.

Os trabalhos com indicadores desenvolvidos pelo PCC-USP têm adotado uma linha particular de pesquisa, que muito difere dos trabalhos sobre sistemas de indicadores citados anteriormente (FORMOSO, 1993; OLIVEIRA, 1995; AMORIM, 1998). Mais que definir indicadores, sistematizar ${ }^{73}$ sua mensuração em obras e consolidar um importante banco de dados, o grupo procura desenvolver métodos, modelos e ferramentas de gestão da produção respaldados nas verdades expressas pelos indicadores levantados. A interpretação dos indicadores e o conjunto de proposições advindas dessas análises são o ponto principal das pesquisas conduzidas pelo grupo. Esse tema será retomado oportunamente, haja vista ser uma das linhas condutoras deste trabalho.

Ressalta-se, ainda, a interação com pesquisadores internacionais, no âmbito do grupo de trabalho W65 do CIB, denominado "International Benchimarking of Labor Productivity", do qual o pesquisador faz parte. Este grupo vem utilizando, há alguns anos, uma mesma metodologia ("Factor Model" proposto pelo professor Randolph Thomas da Pennsylvania State University"), que possibilita que as discussões, como, por exemplo, de alternativas quanto à gestão da produtividade, aconteçam e sejam bastante proveitosas, justamente pelo fatos de os pesquisadores falarem uma mesma "língua técnica".

73 Segundo SOUZA (2001), uma das grandes dificuldades em se trocar idéias quanto à produtividade da mão-de-obra diz respeito à falta de uma padronização dos indicadores de mensuração da produtividade. Porém, a transparência no desenvolvimento de pesquisas sobre o tema (SOUZA (2001)), tem permitido uniformizar os levantamentos de indicadores no âmbito nacional e internacional, induzindo a comparação dos dados, que é imprescindível para a busca das melhorias. 


\subsubsection{Patamares da produtividade da mão-de-obra que executa as estruturas de concreto armado}

A preocupação com os indicadores de produtividade, como visto anteriormente, fomentou o desenvolvimento de uma série de pesquisas sobre o tema, que trataram, num primeiro momento, de definir metodologias de levantamento padronizadas (THOMAS et al. 1990), imprescindíveis para a comparação dos dados. Isso feito, passou-se à divulgação, aprimoramento e implementação desta metodologia (ARAUJO, 2000; SOUZA, 2001; THOMAS et al. 2002) objetivando a consolidação e universalização da mesma e dos dados obtidos através dela.

Assim, a Tabela 4.3 apresenta um conjunto de indicadores reais de produtividade da mão-de-obra referente ao serviço de armação, obtidos em três países distintos (EUA, Brasil e Turquia). Tratam-se de dados levantados segundo uma mesma metodologia, coletados por diferentes pessoas, em vinte canteiros de obras.

Os dados apresentados na Tabela 4.3 ratificam a importância das questões discutidas até aqui (desenvolvimento de indicadores padronizados que permitam a comparação de dados); chamam também a atenção para uma das questões que induziram o desenvolvimento dessa tese, qual seja, a variabilidade da produtividade da mão-de-obra para a etapa de armação. Quando comparados os dados dos três países, a variação da produtividade chega a $700 \%$. Quando tomados apenas os dados brasileiros, a variação chega quase a $300 \%$.

Percebe-se, portanto, que a apropriação da produtividade com base em indicadores padronizados não basta para entender o problema. O desconhecimento do conteúdo e contexto de trabalho que estão por trás dos números apresentados na Tabela 4.3 impede que se faça qualquer tipo de comentário, ou até mesmo que se surpreenda com as variações constatadas. A análise só é factível quando se começa a caracterizar as obras e a "descobri-las" através de fatores que as caracterizam.

Tabela 4.3 (continua) - Valores de produtividade da mão-de-obra para o serviço de armação

\begin{tabular}{|c|c|c|}
\hline Projeto & País & $\begin{array}{c}\text { Produtividade } \\
\text { (Homens-hora/tonelada) }\end{array}$ \\
\hline 9901 & EUA & 10,2 \\
\hline 9903 & EUA & 12,2 \\
\hline 9904 & EUA & 14,3 \\
\hline 9905 & EUA & 11,1 \\
\hline SP 28 & Brasil & 36,7 \\
\hline SP 45 & Brasil & 30,9 \\
\hline SP 62 & Brasil & 63,3 \\
\hline SP 73 & Brasil & 41,8 \\
\hline SP 101 & Brasil & 40,6 \\
\hline
\end{tabular}


Tabela 4.3 (conclusão) - Valores de produtividade da mão-de-obra para o serviço de armação

\begin{tabular}{|c|c|c|}
\hline Projeto & País & $\begin{array}{c}\text { Produtividade } \\
\text { (Homens-hora/tonelada) }\end{array}$ \\
\hline SP 120 & Brasil & 71,9 \\
\hline SP 01 & Brasil & 55,0 \\
\hline SP 07 & Brasil & 46,0 \\
\hline SP 08 & Brasil & 57,0 \\
\hline SP 02 & Brasil & 25,0 \\
\hline SP 03 & Brasil & 46,0 \\
\hline SP 04 & Brasil & 30,0 \\
\hline SP 05 & Brasil & 50,0 \\
\hline SP 06 & Brasil & 60,0 \\
\hline TK 1 & Turquia & 12,8 \\
\hline TK 2 & Turquia & 21,5 \\
\hline
\end{tabular}

No conjunto de dados apresentados na Tabela 4.3, as obras identificadas com a sigla "SP" são bastante semelhantes (obras de edifícios construídas nos últimos cinco anos na cidade de São Paulo, com tipologia estrutural, sistemas construtivos, procedimentos executivos etc similares). Ainda assim, a variação entre os números de produtividade dessas obras foi de $300 \%$. Chama-se, novamente, a atenção para a necessidade de se conhecer as particularidades de cada obra (conteúdo e contexto de trabalho), pois é bem provável que existam obras que estejam conseguindo desempenhos muito melhores, apresentando práticas (de projeto, de gestão e organização) que mereçam ser tomadas como referências.

Vale ressaltar que nenhuma das obras com a identificação "SP" apresenta processo construtivo que não seja o denominado processo tradicional, com moldagem da estrutura no local.

\subsubsection{Caminhos que levam à melhoria da produtividade da mão- de-obra}

THOMAS (2002) afirma que muitas pesquisas têm sido conduzidas, desde a última década, na tentativa de melhorar a produtividade da mão-de-obra. O foco destes trabalhos está, muitas vezes, no desenvolvimento de equipamentos pesados, no uso de componentes pré-fabricados etc. A maioria das recomendações para melhoria da produtividade diz respeito a aplicações em países desenvolvidos, com alto nível de industrialização/mecanização, dando-se pouca importância aos países em desenvolvimento, em que se destaca o uso intensivo da mão-de-obra.

O desenvolvimento de capacidades de gerenciamento de uma mão-de-obra altamente variável (tal como se apresenta nas obras de construção civil e que representa uma dentre tantas outras particularidades intrínsecas aos processos de produção neste setor) é um dos caminhos a se percorrer para reduzir a variabilidade na produtividade da mãode-obra, contribuindo, dessa maneira, para se melhorar o desempenho das obras de construção. 
A preocupação do autor supracitado com a gestão da mão-de-obra em países que dela fazem uso intensivo, tem-no levado a conduzir uma série de trabalhos, com a coparticipação do Brasil, Croácia e Escócia, dentre outros países, com o objetivo de identificar princípios que relacionem a gestão da mão-de-obra com eventuais perdas de produtividade.

SCHIMITT et al. (1995), ao realizarem um estudo comparativo sobre a organização do trabalho no Brasil e na França, observaram o delineamento de três tendências principais de mudança do processo de trabalho na indústria da construção (mais forte na França e ainda em estágio inicial no Brasil), tendo como parâmetros a busca de produtividade, quais sejam: i) a incorporação de componentes industrializados; ii) o aprofundamento do processo de apropriação de atividades do canteiro de obras pelo setor produtivo de materiais; iii) a gestão do processo produtivo, como definição de estratégia de racionalização por parte das empresas.

Numa análise feita por FARAH (1992), a autora discute o impacto das mudanças tecnológicas sobre a o processo de trabalho. Identifica que, apesar da tecnologia poder trazer em si um tipo de impacto quanto à qualificação, emprego, maior controle etc, ela, sozinha, não poderá determinar todo o controle sobre o processo de trabalho.

FARAH (1992) aponta como elementos centrais, no "estágio manufatureiro da divisão capitalista do trabalho", a atividade manual como suporte do processo produtivo e uma divisão técnica do trabalho baseada no parcelamento desse e na especialização dos trabalhadores.

Outra característica, apontada pela autora, que assemelha a construção à manufatura, trata da absorção, pelo setor, de mão-de-obra não qualificada.

De fato, a qualificação da força de trabalho, expressa na estrutura de ofícios que caracterizava a atividade de construção, tem, como contrapartida, o emprego de um grande contingente de trabalhadores não qualificados, cujo trabalho no canteiro de obras é essencialmente braçal, não requerendo o domínio do saber fazer, controlado pelos trabalhadores de ofício.

\subsection{A representatividade dos fatores na produtividade da mão-de-obra}

A ineficiência no uso das horas disponibilizadas para o trabalho, num processo de produção da construção civil, é creditada, na maioria das vezes, ao mau uso da mão-deobra. O estudo de caso promovido por THOMAS et al. (2002) comprovou tal constatação. Quando se deseja melhorar o desempenho de processos que fazem uso intensivo da mão-de-obra, como é o caso do processo de produção de armaduras para estruturas de concreto armado, o caminho é o de melhorar a eficiência no uso dessa mão-de-obra.

A eficiência no uso mão-de-obra pode ser influenciada por uma diversidade de fatores presentes nos canteiros de obras, que vão desde as dificuldades de execução de projetos (que podem ser decorrentes da falta de detalhamentos, de dificuldades e/ou complexidades executivas etc), passam por contratempos que podem ser creditados à logística inadequada de canteiro, pela gestão propriamente dita da força de trabalho (dimensionamento de equipes, seqüenciamento de trabalho, formas de remuneração etc) e podem chegar a causas que estão fora dos controles habituais, como condições climáticas adversas, quebras repentinas de equipamentos etc. 
Espera-se que o estudo dos fatores capazes de alterar o desempenho dos processos de produção permita que, por meio deles, sejam formulados princípios e diretrizes que melhorem as práticas gerenciais da força de trabalho, que induzam aumento da construtibilidade, tornando os projetos mais exeqüíveis e racionais e que proporcionem alterações nos métodos de trabalho, criando-se um círculo virtuoso de produtividade.

Para garantir o embasamento necessário ao levantamento e análise de tais fatores será feita, a seguir, uma revisão sobre aspectos ligados ao projeto do produto, ao método de trabalho e à organização do trabalho, e como estes poderiam influenciar a produtividade da mão-de-obra no processo de produção de armaduras. A revisão não será totalmente focada no processo de produção de armaduras, podendo, em alguns momentos, suscitar discussões e depoimentos mais abertos, mas que, ainda assim, permitem uma reflexão extremamente necessária à etapa seguinte, relativa ao método para proposição de diretrizes.

\subsubsection{O projeto do produto e sua influÊncia na produtividade da mão-de-obra}

O aumento na construtibilidade ${ }^{74}$ tem se tornado um ponto-chave para clientes, projetistas e construtores que visam diminuir os custos e melhorar as operações da construção, beneficiando a todos os agentes envolvidos. Uma análise prévia quanto à construtibilidade pode ajudar a identificar limitações de projeto que reduzem a habilidade do construtor em planejar e desempenhar eficientemente as operações de construção.

Segundo STAUB (2003), as equipes de coordenação têm feito revisões de construtibilidade durante a fase de projeto para garantir que o conhecimento da construção esteja incorporado no projeto e os problemas durante a etapa de construção sejam minimizados. Tais revisões baseiam-se no conhecimento prévio dos profissionais envolvidos e regras são definidas para ajudar as equipes de projeto a identificar diferentes tipos de problemas. No entanto, tais procedimentos não fornecem uma base

74 SABBATINI (1989) faz uma importante revisão sobre a conceituação e apresenta diferentes enfoques e definições sobre a "construtibilidade" (baseia-se em O'CONNOR (1985); GRIFFITH (1986); O'CONNOR, TUCKER (1986); TATUM (1987)). Segundo este autor "as definições deixam explícito que o conceito de construtibilidade fundamenta-se no seguinte fato: para que seja otimizado todo o processo da construção, há a necessidade de se considerar, na etapa de projeto, os fatores relacionados com as operações construtivas".

SABBATINI (1989) apresenta, ainda, o termo "metodologia da construtibilidade", o qual define como sendo "uma maneira de conduzir o processo de construção que priorize, em todas as suas etapas (incorporação, planejamento, projeto e construção etc), o aperfeiçoamento da construtibilidade".

Entende-se, neste trabalho, que a melhoria da produtividade da mão-de-obra mantém uma relação direta com o aumento na construtibilidade, com destaque a ações promovidas na etapa de projeto. Assim sendo, concorda-se com o autor supracitado, que define a proposição principal da construtibilidade da seguinte forma: "integrar projeto e construção dentro de uma visão holística, adotar prioritariamente, em todas as etapas, os dados provenientes das operações construtivas e considerar que a solução ótima é a de maior construtibilidade". 
para comparar mais objetivamente alternativas de projetos, bem como fornecer respostas específicas aos problemas de construtibilidade que impactam as operações de construção. Soma-se a isso o fato de que as revisões de construtibilidade são freqüentemente realizadas com limitações de tempo (os processos manuais de conferência consomem tempo significativo), o que limita o número de alternativas de projetos consideradas e a quantidade de problemas relacionados à construtibilidade que poderiam ser identificados.

STAUB (2003) entende que, conseqüentemente, as equipes de projeto precisam ter um suporte automatizado para identificar os problemas de construtibilidade com maior rapidez, retornando aos projetistas o impacto que tais problemas trazem à construção.

Muitas pesquisas têm investigado diferentes aspectos da construtibilidade. Algumas têm focado a identificação de pontos mais significativos, desenvolvendo programas de melhorias na construtibilidade (IRELAND (1985); ASCE (1991); RUSSELL et al. (1994); FISCHER, TATUM (1997); HALON, SANVIDO (1995); O'CONNOR et al. (1988)), confirmando que o conhecimento sobre a integração da construção, durante o processo de projeto, aumenta as chances de se alcançar uma melhor qualidade do projeto, de terminá-lo de maneira segura, no prazo e no custo previamente determinados. Dentro deste espírito, o "Construction Industry Institute" propôs diretrizes para a implementação de programas de construtibilidade (CII (1986); CII (1987); CII (1993)). Outras pesquisas têm focado a identificação de aspectos relevantes nos projetos, favoráveis ou não à construtibilidade, para, então, automatizar as análises através de modelos em 3D (GRAY (1986); FISCHER (1991); KUPRENAS et al. (1995); SKIBNIEWSKI et al. (1997); NAVON et al. (2000)). Por exemplo, FISCHER (1991) desenvolveu uma ferramenta de suporte que fornecia decisões automáticas, provendo o projetista de respostas sobre a construtibilidade dos projetos estruturais em relação aos métodos construtivos empregados na construção. Pesquisas de opinião foram conduzidas nos Estados Unidos para entender melhor o fenômeno, identificar as barreiras que impediam a melhor construtibilidade e quantificar as vantagens obtidas com as revisões de construtibilidade (O'CONNOR, DAVIS (1988); CII (1993); GUGEL, RUSSELL (1994); RUSSELL et al. (1994a) UHLIK, LORES (1998); ANDERSON et al. (1999)). Algumas dessas pesquisas reportaram 0 ponto de vista dos contratantes; outras procuraram tratar a construtibilidade sob a perspectiva dos clientes.

STAUB (2003) critica alguns dos trabalhos supracitados por não relacionarem a construtibilidade aos custos específicos das soluções propostas. STAUB (2003) procura suprir essa lacuna, desenvolvendo um modelo para identificar problemas de construtibilidade, predizendo as implicações correspondentes com a construção e associando-as a custos.

Para ARDITI et al. (2002) os programas formais de construtibilidade tornaram-se indispensáveis para qualquer firma de projeto que se preocupa com a qualidade dos serviços prestados e com a sua sobrevivência num mercado altamente competitivo. Tais programas se baseiam na integração da engenharia, construção, conhecimento e experiência das operações para melhor alcançar os objetivos dos projetos. Porém, ARDITI et al. (2002) apontam que as contribuições da construtibilidade não têm sido atingidas de maneira satisfatória pela falta de conhecimento dos projetistas sobre a construção, por divergências de objetivos entre projetistas e construtores e pela resistência dos clientes em adotar a busca por alternativas de construtibilidade devido ao "encarecimento" do projeto. 
Através da pesquisa de opinião conduzida por ARDITI et al. (2002), direcionada a escritórios de projeto, onde se pretendia avaliar as práticas correntes de revisão de construtibilidade, os autores tiraram uma série de conclusões, sendo algumas delas citadas a seguir: i) mais da metade dos projetistas indicaram possuir documentos formais para conduzir as revisões de construtibilidade nas suas empresas; ii) ficou evidente que os projetistas estão abandonando os métodos tradicionais (modelos físicos em pequenas escalas) em favor de modelos em "3D" gerados por programas computacionais. Apenas um terço dos projetistas usam os modelos físicos; iii) revisões por projeto e sistemas de "feedback" são as ferramentas mais comumente usadas para alcançar altos níveis de construtibilidade; iv) muitos projetistas conduzem a revisão da construtibilidade tanto nos estágios de projeto pré-executivo quanto no de executivo; v) os projetistas acreditam que a complexidade do projeto é um fator essencial que afeta a maneira com que a revisão de construtibilidade é conduzida; vi) os projetistas consideram o desenvolvimento de boas relações entre contratantes e clientes o melhor caminho para aumentar a construtibilidade dos projetos.

WYLLIE JR; LAPLANTE (2003) reconhecem que os projetistas estruturais têm muitas responsabilidades quando projetam uma estrutura. Precisam projetar componentes estruturais para resistir às cargas requeridas e atender aos códigos de construção, dimensionar as armaduras que resistam aos esforços solicitantes, detalhar as armaduras que possam ser posicionadas eficientemente etc. "Em outras palavras, os projetistas precisam projetar componentes e armaduras de maneira que a estrutura possa ser construída tal qual foi projetada".

Tradicionalmente os projetistas estruturais são "educados" nas escolas de engenharia e cobrados pelos clientes para minimizar as taxas de aço e o volume de concreto das estruturas nos projetos, seguindo a falsa premissa de que o menor consumo de materiais leva a estruturas mais econômicas. WYLLIE JR; LAPLANTE (2003) chamam atenção para o fato de que, nos Estados Unidos, a mão-de-obra é o item mais oneroso quando comparado aos demais recursos envolvidos na produção de estruturas de concreto armado. "Quando se gasta um pouco mais de concreto, projetando-se peças estruturais "mais largas", permitindo que as armaduras sejam posicionadas mais facilmente e o concreto consolidado a ela mais eficiente, estar-se-á, de fato, diminuindo os custos dessa estrutura".

Se for verdade que a inexperiência dos profissionais de projeto que fazem o detalhamento das armaduras é ainda um dos principais responsáveis por projetos que desfavorecem a racionalização construtiva, é também verdade que essa ineficiência existe porque os projetos gerados são aceitos, sem ressalvas. "Aceitam-se freqüentemente os detalhes mostrados nos desenhos dos projetos estruturais, sendo que nenhuma consideração é dada ao grau de dificuldade de se fabricar e de se armar de acordo com os detalhes mostrados. As configurações mostradas nos originais do projeto são aceitas e as mesmas configurações, equivocadas, são repetidas, infelizmente, em desenhos futuros." CRSI (CRSI, 1990)

Os construtores e os executores são os maiores beneficiados com as economias conseguidas com o aumento da eficiência no detalhamento das armaduras. Justifica-se, aí, uma maior participação desses agentes no processo de projeto estrutural. A descoberta de erros ou falhas de projeto, no ato da sua execução no campo, é extremamente prejudicial e poderia ser minimizada se os problemas fossem devidamente registrados (registros dos problemas, das causas e das correções efetuadas), discutidos e 
formalmente repassados ao projetista (interação pró-ativa entre projetista e obra). A prática tem mostrado que a interação da obra com o projetista é reativa (envio de fax ao projetista e/ou telefonema cobrando a solução no momento da detecção do problema) e essa prática não irá impedir que os mesmos problemas apareçam em projetos futuros.

BATLOUNI NETO (2003) defende a parceria "projetista de estrutura-contratante" e afirma que ela se torna mais sedimentada à medida que se repete em diversos trabalhos. "Assim, cada novo projeto incorporará novas soluções criadas para resolver as dificuldades construtivas verificadas nos projetos anteriores. Para tanto, é importante a visita do projetista ao canteiro de obras, verificando no local as ocorrências."

SCHEVANO FILHO (2003) aponta que as construtoras trabalham com diversos empreiteiros que, por sua vez, trabalham cada qual à sua maneira. Fazer um projeto que agrade especificamente a cada empreiteiro é muito difícil.

Os problemas relacionados à construtibilidade dos detalhamento das armaduras são comuns nos projetos estruturais. Em muitos casos os problemas são descobertos pouco tempo antes da montagem da armadura. Como conseqüência, o ciclo de execução da estrutura pode atrasar, os custos podem aumentar (com o retrabalho a produtividade da mão-de-obra é penalizada) e a qualidade do produto final pode ficar comprometida. NAVON et al. 2000

NAVON et al. (2000) afirmam que uma das razões pela qual os problemas de construtibilidade das armaduras são descobertos no momento iminente da montagem é que o projeto é feito em duas dimensões, dificultando a visualização das limitações espaciais das soluções prescritas no projeto. As conseqüências da dificuldade em visualizar espacialmente o detalhamento das armaduras afeta vários membros do processo de construção, como: i) o projetista estrutural, que é quem, assim que o problema é detectado, é acionado, tendo de investir tempo adicional de trabalho para fornecer uma solução alternativa imediata; ii) o contratante (e também a sua mão-deobra), que arcará com os ônus decorrentes de atraso no ciclo de execução da estrutura; iii) o dono do empreendimento, com eventuais atrasos e prejuízos financeiros.

NAVON et al. (2000) entendem que um "sistema para análise de construtibilidade das armaduras" automatizado, que melhore o processo de montagem das armaduras no canteiro de obras, é claramente necessário. Como um sistema, deveria cumprir duas importantes funções de análise de construtibilidade, isto é, detectar problemas potenciais de construtibilidade nas fases preliminares do ciclo de vida do projeto e, depois, achar soluções para elas. YU, SKIBNIEWSKI (1999)

Inúmeros sistemas computadorizados para melhorar a construtibilidade têm sido desenvolvidos; porém, segundo NAVON et al. (2000), nenhum deles trata das armaduras. Diante desta constatação, os autores supracitados vêm trabalhando no desenvolvimento de um modelo de construtibilidade das armaduras, formatado em dois módulos. O primeiro trata-se do Módulo de Diagnóstico, que analisa um projeto e alerta o projetista quando descobre um problema. O segundo módulo trata-se do Módulo de Correção, que propõe soluções para os problemas detectados pelo primeiro módulo e, se aprovadas, promove a alteração do projeto.

Para o desenvolvimento do Módulo de Diagnóstico, NAVON et al. (2000) realizaram uma pesquisa de campo para identificar os problemas de construtibilidade das armaduras. Os autores entrevistaram, individualmente, setenta pessoas, incluindo projetistas, gerentes de projeto, engenheiros de produção e mestres-de-obras. Entre as principais causas dos 
problemas de construtibilidade encontrados, constataram: a necessidade de mais experiência de construção entre muitos dos projetistas estruturais, a necessidade de coordenação entre os diferentes projetos (estrutural, de instalações etc) e o baixo envolvimento dos contratantes no estágio de desenvolvimento do projeto estrutural. A pesquisa de campo mostrou que os problemas de construtibilidade são numerosos e diversificados. Citam-se, a seguir, alguns desses problemas:

- a distância livre entre barras adjacentes é, freqüentemente, muito pequena para permitir o fluxo do concreto entre elas. Isso resulta em bolsas de segregação onde as barras não são completamente cobertas com concreto, não permitindo que as barras funcionem propriamente como elementos de reforço. A presença de muitas barras numa única camada pode causar problemas de congestionamento, como nas regiões onde há sobreposição de barras de pilares e vigas, por exemplo;

- outro problema de congestionamento é ilustrado na Figura 4.11, que mostra a vista do topo de uma viga suportada por um pilar. A distância livre entre as barras na viga poderia ter sido suficiente (b) se ela não tivesse sido restringida pela barras verticais da coluna (a);

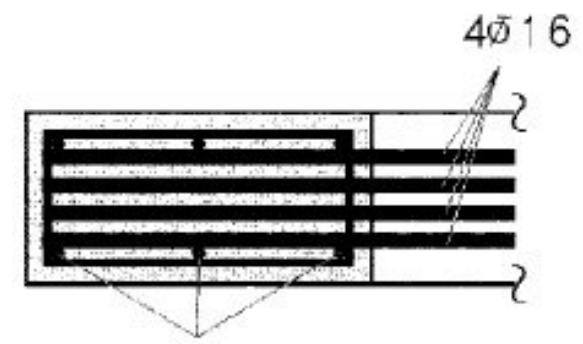

$3+3 \bar{\emptyset} 14$

(a)

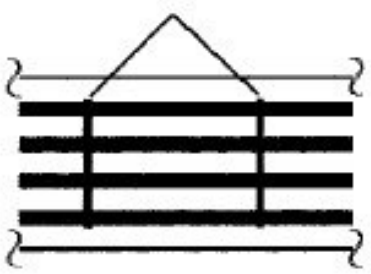

(b)

Figura 4.11 - Problemas de congestionamento das armaduras causados pela integração de armaduras verticais e horizontais: a) barras restringidas pela armadura do pilar; b) disposição das barras na mesma viga se não houvesse a restrição do pilar.

- para ajustar a armadura às posições das vigas conhecidas como "cavaletes" é muito mais difícil. Esta solução causa problemas de construtibilidade, sendo mais difícil de ser fabricada e montada quando comparada à solução que prevê barras retas associadas a estribos para as vigas;

- outro exemplo que mostra que a montagem foi ignorada pelo projeto é o do caso da laje suportada por vigas, em que a armadura da laje é uma tela e a viga inclui estribos fechados (Figura 4.12). Depois de dispor a tela (que, devido à ancoragem, "entra" na viga) é impossível montar os estribos sem cortar as barras longitudinais da tela (indicadas na Figura 4.12), ou dobrar cada estribo para posicionar a tela e depois fechá-lo. A ordem inversa, isto é, montar primeiro a viga, é igualmente complicada; 


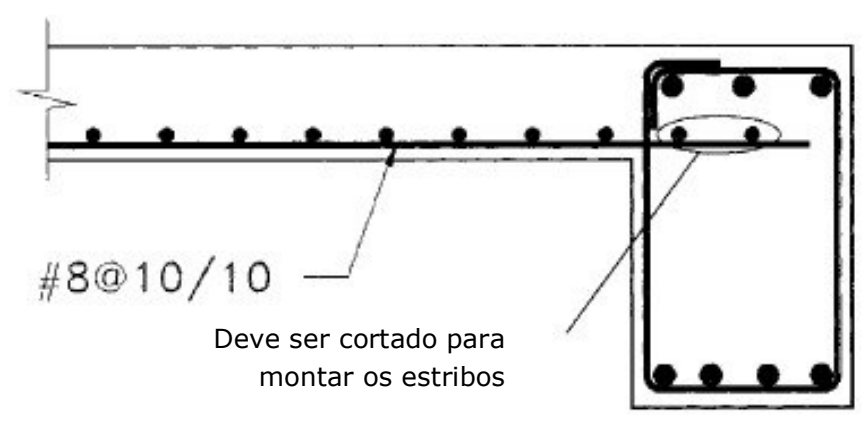

Figura 4.12 - Integração de tela e estribos causa problemas de construtibilidade.

- a integração dos elementos das estruturas de concreto armado também pode causar problemas de construtibilidade; barras longitudinais de vigas perpendiculares podem colidir se sua integração não tiver sido prevista no projeto (fato este que acontece freqüentemente, pois as vigas são projetadas separadamente). Para resolver esse problema no canteiro, as barras de uma das vigas são, muitas vezes, dispostas diferentemente das posições originais previstas no projeto. Se as barras tiverem sido dobradas, é provável que elas não mais se acomodem nas vigas, sendo necessário o corte e a dobra de novas barras;

- se não houver a coordenação do projeto estrutural com os projetos de instalação, pode acontecer, por exemplo, a colisão de armaduras com tubulação de drenagem. A "solução" comum de canteiro, ou seja, o corte das barras, é inaceitável.

- a colocação de barras de ancoragem nas fôrmas verticais requer o adequado espaçamento entre as barras da armadura, dependendo do tipo e do tamanho das barras de ancoragem. Se o espaço não tiver sido considerado no projeto de detalhamento, pode ser que a disposição de barras muito próximas umas das outras impossibilitem a inserção das barras de ancoragem.

NAVON et al. (2000) lembram que o protótipo do Módulo de Diagnóstico limitou-se a detectar os seguintes problemas de construtibilidade: congestionamento das barras, colisão entre armaduras, problemas causados pela integração dos outros sistemas (por exemplo, drenagem e fôrmas) com os elementos estruturais e checagem de taxas de armaduras (mínimas e máximas).

Dois importantes projetistas estruturais brasileiros, Ricardo Leopoldo e Silva França ${ }^{75}$ e Gino Schevano Filho ${ }^{76}$ e um construtor (BATLOUNI NETO (2003)) reforçam a lista de problemas de construtibilidade levantados por NAVON et al. (2000).

Um ponto bastante problemático, e para o qual Ricardo França chama a atenção, trata-se das interferências entre posições nos encontros viga-pilar (Figura 4.13) e pilar-laje, no momento da montagem das armaduras. "O como solucionar este tipo de problema depende do software, do lançamento e da mudança de alguns paradigmas". Segundo o

\footnotetext{
75 Relatos a partir de entrevista concedida pelo projetista estrutural Ricardo Leopoldo e Silva França a este pesquisador em 26/05/2003.

${ }^{76}$ Relatos a partir de entrevista concedida pelo projetista estrutural Gino Schevano Filho a este pesquisador em 25/08/2003.
} 
autor, nenhum software verifica tais interferências por se tratarem de um problema de "terceira dimensão".

Gino Schevano reconhece que a checagem de interferências (vigas que chegam em vigas, por exemplo) não é feita com muita ênfase nos escritórios de projeto. As idas dos projetistas às obras servem também para terem uma melhor noção sobre esses aspectos. "Ainda depende muito do engenheiro da obra perceber eventuais dificuldades e chamar o projetista à obra".

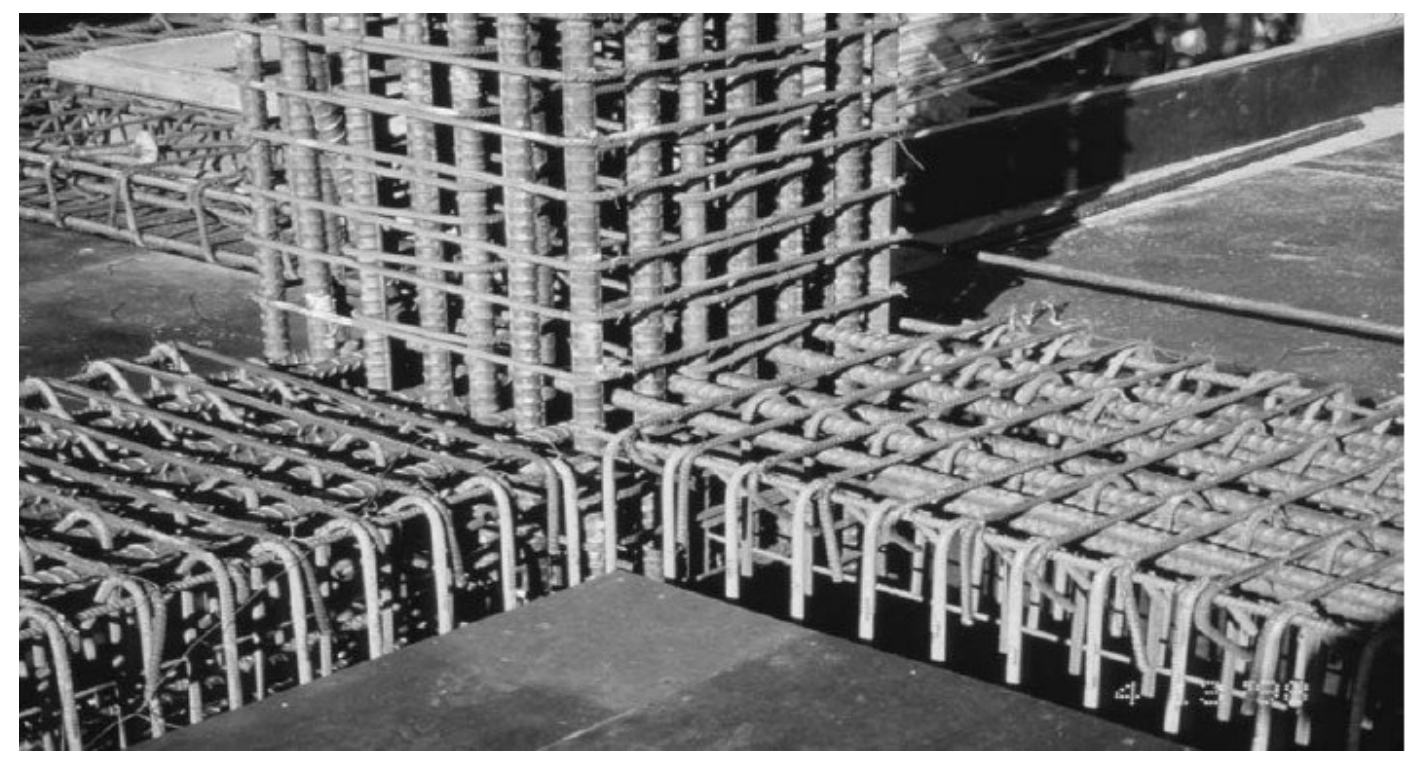

Figura 4.13 - Exemplo de interferência pilar-viga.

Ricardo França conta que existe uma série de regras de alojamento das vigas, por exemplo, que vêm sendo determinadas através de estudos envolvendo projetistas e executores. Existem pré-soluções, para alguns casos, que diminuem essas interferências. Porém, a minimização, de fato, das interferências na montagem das armaduras depende muito do lançamento das fôrmas. "Por exemplo, o melhor lançamento de fôrmas prevê pilar e viga com a mesma largura. Tal situação, para a armação, é ruim, pois as barras longitudinais da lateral da viga irão coincidir com as barras longitudinais do pilar. Privilegia-se, nesse caso, a montagem da fôrma, prejudicando-se a montagem da armadura".

Para Gino Schevano um bom projeto de fôrmas, teoricamente, deveria gerar um bom projeto de armação. Novos entrantes, como o projetista de alvenaria, têm induzido melhorias no projeto estrutural (como, por exemplo, a indução da padronização de alturas de vigas).

Ricardo França cita que em obras especiais (de grande envergadura e com elementos estruturais fora dos padrões habituais, como aqueles presentes em obras de edifícios) há uma preocupação em detalhar pontos de interferência dos elementos estruturais com um maior nível de detalhes. Exemplifica citando a estrutura de um edifício comercial, onde se fez um detalhe de $3 \times 3 \mathrm{~m}$, em planta, para mostrar o encontro do apoio de uma laje cogumelo em um pilar muito congestionado. "Fez-se o desenho detalhando-se camada 
por camada, com sucessivos cortes, mostrando toda a seqüência de montagem". Nesse tipo de obra, o projetista ainda dava assessoria à obra para orientar a produção, mostrando detalhes da execução que, porventura, não tivessem ficado claros no desenho.

Dentre as necessidades de quebras de paradigmas citadas por Ricardo França, está a necessidade de rever as formas como os próprios projetos são contratados. O aumento das dimensões de alguns elementos estruturais de maneira a acomodarem melhor as armaduras (e evitar congestionamento indesejado, como mostrado na Figura 4.14) pode aumentar relações como a espessura média das estruturas, criando impasse junto ao contratante. As taxas médias de aço normalmente exigidas pelo contratante nem sempre proporcionam as estruturas mais econômicas. Ricardo França aponta que, em se tratando de pilares, é econômico, muitas vezes, chegar a taxas de armação altíssimas $(200 \mathrm{~kg} / \mathrm{m} 3$, em média, ao longo do edifício), o que eleva a taxa média de aço da estrutura global. Por outro lado, em situações em que o custo do aço esteja elevado, ao se fazer análise individual do custo do pilar (contemplando as fôrmas, o concreto e as armaduras), percebe-se que manter o pilar com a seção constante andar a andar (não se fazendo uso da possível redução de seção devido à redução das cargas incidentes nos pilares de pavimentos mais elevados, e, portanto, aumentando o consumo de concreto), o que implica em diminuir a taxa de aço, pode torná-lo, ainda assim, mais econômico.

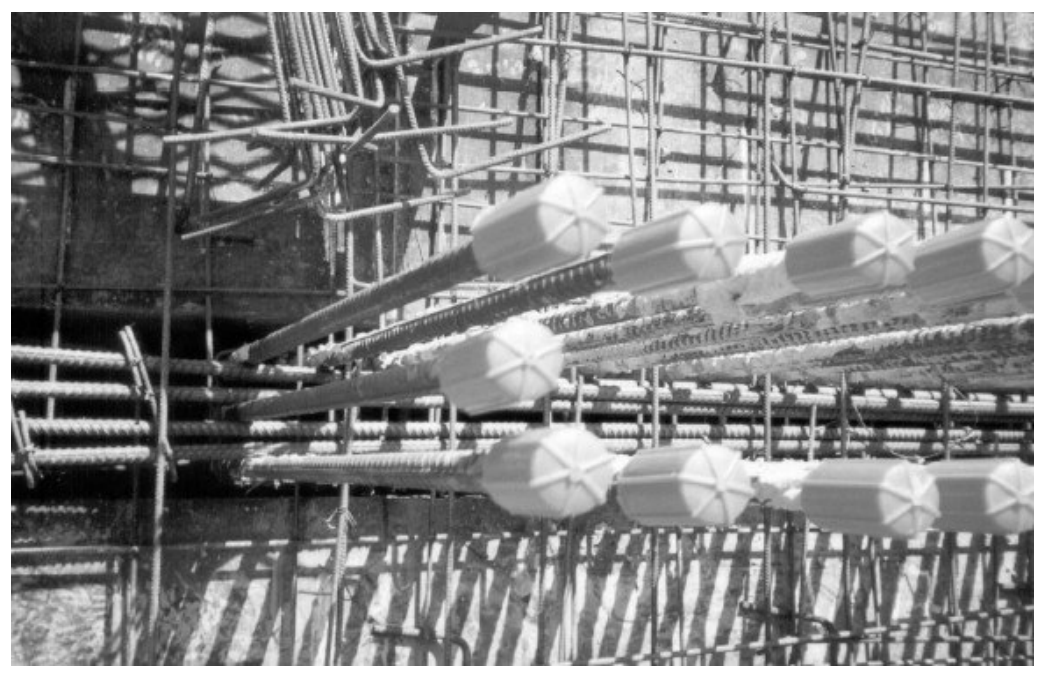

Figura 4.14 - Congestionamento da armadura da viga e pilar

Ricardo França comenta ainda que a adoção de pilares com taxas de aço elevadas e com detalhamento das armaduras gerado automaticamente por softwares (aceitos sem "edição" (revisão) do projetista) pode aumentar as interferências na montagem.

Gino Schevano lembra que os softwares usados para o cálculo estrutural não misturam bitolas ("se é calculada uma necessidade por uma área de ferro de $2,90 \mathrm{~cm}^{2}$, o programa coloca 3 ferros de 12,5mm, quando se poderiam colocar 2 ferros de 12,5 e um de $10 \mathrm{~mm})$, sendo esse trabalho feito manualmente. "Os escritórios devem ter procedimentos para checar esse e outros pontos". 
Para BATLOUNI NETO (2003) os problemas e deficiências encontrados nos projetos de detalhamento das armaduras muitas vezes não configuram erros, mas sim, soluções de difícil execução. O autor cita o exemplo das dificuldades de alojar as armaduras de engastamento das vigas em pilares (as larguras das vigas e dos pilares, impostas pelo projeto arquitetônico, não são suficientes para acomodar adequadamente a armadura necessária), conforme exemplo já mostrado na Figura 4.13.

Ricardo França chama atenção para o fato de que o estribo do pilar na zona da viga é importantíssimo e vital para a segurança da peça. Quando você arma a gaiola da viga para entrar no pilar, cortam-se os estribos e é onde justamente mais se precisa dos mesmos.

A Tabela 4.4 lista os principais problemas e deficiências detectados em projetos de detalhamento das armaduras por BATLOUNI NETO (2003).

Tabela 4.4 (continua) - Principais problemas detectados em projetos de detalhamento das armaduras. BATLOUNI NETO (2003).

\begin{tabular}{|c|c|}
\hline Projeto & Problemas detectados \\
\hline Pilares & $\begin{array}{l}\text { - Arranques curtos para emendas por traspasse, fora das normas } \\
\text { - } \text { Aécnicas. } \\
\text { - } \quad \text { Previsão de luvas de aços em locais onde não é possível executá-las, por } \\
\text { não permitir acesso do equipamento. } \\
\text { - Dificuldade ou até impossibilidade de colocar estribos dos pilares na } \\
\text { região de engaste da viga. } \\
\text { - Barras longitudinais muito afastadas umas das outras, desrespeitando } \\
\text { normas técnicas. } \\
\text { Barras longitudinais com comprimento muito grande em pilares de } \\
\text { grande altura, gerando dificuldade na montagem. } \\
\text { Regiões com excesso de armadura, como os pés dos pilares na região } \\
\text { dos poços do elevador, dificultando a concretagem. }\end{array}$ \\
\hline Vigas & $\begin{array}{l}\text { - Armadura negativa mal distribuída, impedindo entrada do vibrador. } \\
\text { - } \text { ser. } \\
\text { - Vigas armadas com largura ou altura diferente da fôrma. } \\
\text { - Falta de representação dos apoios. } \\
\text { - Falta de clareza no desenho longitudinal da viga, não se definindo qual } \\
\text { barra deverá estar na região positiva e qual na negativa no caso de } \\
\text { várias camadas. } \\
\text { - Nas vigas apoiadas sobre outras vigas, falta de armadura de suspensão. } \\
\text { Dificuldade excessiva de introduzir as armaduras de engastamento das } \\
\text { vigas dentro das armaduras dos pilares. }\end{array}$ \\
\hline
\end{tabular}


Tabela 4.4 (conclusão) - Principais problemas detectados em projetos de detalhamento das armaduras. BATLOUNI NETO (2003).

\begin{tabular}{|c|c|}
\hline Projeto & Problemas detectados \\
\hline Lajes & $\begin{array}{l}\text { - Armadura negativa com diâmetro muito pequeno, facilmente amassável } \\
\text { durante a concretagem, sendo mais grave na armadura de balanços. } \\
\text { - Armadura negativa mal detalhada na região de interface entre uma laje } \\
\text { e outra justaposta rebaixada. }\end{array}$ \\
\hline Geral & $\begin{array}{l}\text { - Regiões com excesso de concentração de aço, impossibilitando uma } \\
\text { adequada concretagem } \\
\text { - Falta de cobrimento coerente com as normas técnicas, principalmente } \\
\text { em peças de fundação e em estruturas de subsolos } \\
\text { - Dificuldade no atendimento do detalhe da armadura } \\
\text { - Falta de reforços em furos } \\
\text { - Falta de padronização das armaduras }\end{array}$ \\
\hline
\end{tabular}

Os caminhos adotados pelos projetistas estruturais, na busca de projetos mais exeqüíveis, passam, necessariamente, pelo conceito de padronização das armaduras e pela consideração, em projetos, de proposições que requeiram o mínimo esforço das pessoas envolvidas na sua execução.

O detalhamento das armaduras é uma questão amplamente debatida em artigos internacionais, como se pode observar nos relatórios do CRSI dos Estados Unidos (Engineering Data Report números 30, 35, 39). Ricardo França chamou a atenção para a necessidade mundial de se padronizarem as posições que compõem as armaduras.

Para Francisco Ozzi ${ }^{77}$ falta de detalhamento não impede que se gerem projetos corretos do ponto de vista estrutural (estaticamente perfeitos, com a devida consideração dos efeitos de ventos, por exemplo); porém, esses acabam, em muitos casos, não sendo nada racionais sob a ótica da construtibilidade (número de posições exagerado, podendo chegar a 3, 4, 5 mil posições de aço diferentes por projeto; variações de comprimentos das barras na casa dos centímetros $(3,40 ; 3,23 ; 3,28 \mathrm{~m})$.

Na visão do CRSI (CRSI, 1990), ao se executarem projetos arquitetônicos inovadores ou fora dos padrões habituais, não se deve pressupor que economias na construção da estrutura devam ser ignoradas, mesmo porque muitos edifícios são construídos com orçamentos bastantes enxutos.

No trabalho supracitado comenta-se que, quase sempre, nas mais simples ou elaboradas estruturas, há limitações práticas à forma e aos comprimentos das armaduras, que devem "caber" dentro das fôrmas. O CRSI (CRSI, 1990) indica que, a fim de se conseguir uma estrutura de concreto mais econômica, seria desejável a familiarização dos arquitetos e engenheiros com as configurações das barras que são dispendiosas tanto para quem as irá fabricar (cortar e dobrar) quanto para o armador, no campo, que irá montá-la. Infelizmente, por fruto da inexperiência de muitos detalhadores de armaduras,

\footnotetext{
77 Relatos a partir de entrevista concedida pelo engenheiro Francisco Ozzi a este pesquisador em
} $25 / 08 / 2003$. 
se aceitam freqüentemente os detalhes mostrados nos desenhos dos projetos estruturais e nenhuma consideração é dada ao grau de dificuldade de fabricar e de armar de acordo com os detalhes mostrados. As configurações designadas nos originais do projeto são aceitas e as mesmas configurações são repetidas, infelizmente, nos desenhos de montagem.

Em vista das preocupações supracitadas, o CRSI tem buscado informar os projetistas com exemplos específicos, de que as configurações mostradas em detalhes típicos poderiam ser melhoradas a fim de proporcionar um método mais econômico de fornecer, fabricar e montar as armaduras nas estruturas de concreto armado.

Segundo o CRSI (CRSI, 1990), uma boa regra para que a equipe de projeto siga é manter as formas e as configurações das barras tão simples quanto possível. Além disso, há de se considerar limitações práticas quanto ao comprimento das barras e à largura das gaiolas a serem fabricadas, inerentes às etapas de fabricação, beneficiamento e transporte ao canteiro de obras.

A Tabela 4.5 mostra alguns exemplos específicos ${ }^{78}$, propostos pelo CRSI (CRSI, 1990), onde detalhes típicos poderiam ser melhorados a fim de fornecer um método mais econômico de se fabricar e de se montar a armadura requerida.

Tabela 4.5 (continua) - Exemplos específicos de detalhamento propostos pelo CRSI. Fonte: CRSI (1990)

\begin{tabular}{|c|c|c|}
\hline Peça & Detalhe inicial & Sugestão de detalhes alternativos \\
\hline $\begin{array}{l}\text { Pilar quadrado } \\
\qquad(30 \mathrm{~cm})\end{array}$ & & y \\
\hline $\begin{array}{l}\text { Pilar quadrado } \\
\qquad(20 \mathrm{~cm})\end{array}$ & & 8 \\
\hline $\begin{array}{c}\text { Pilares } \\
\text { circulares com } \\
\text { pequeno } \\
\text { diâmetro }\end{array}$ & & \\
\hline $\begin{array}{l}\text { Posição com } \\
\text { múltiplos raios }\end{array}$ & & \\
\hline
\end{tabular}

${ }^{78}$ Ressalta-se que se tratam de soluções de detalhamento, propostas pela CRSI, sujeitas a críticas. 
Tabela 4.6 (conclusão) - Exemplos específicos de detalhamento propostos pelo CRSI. Fonte: CRSI (1990)

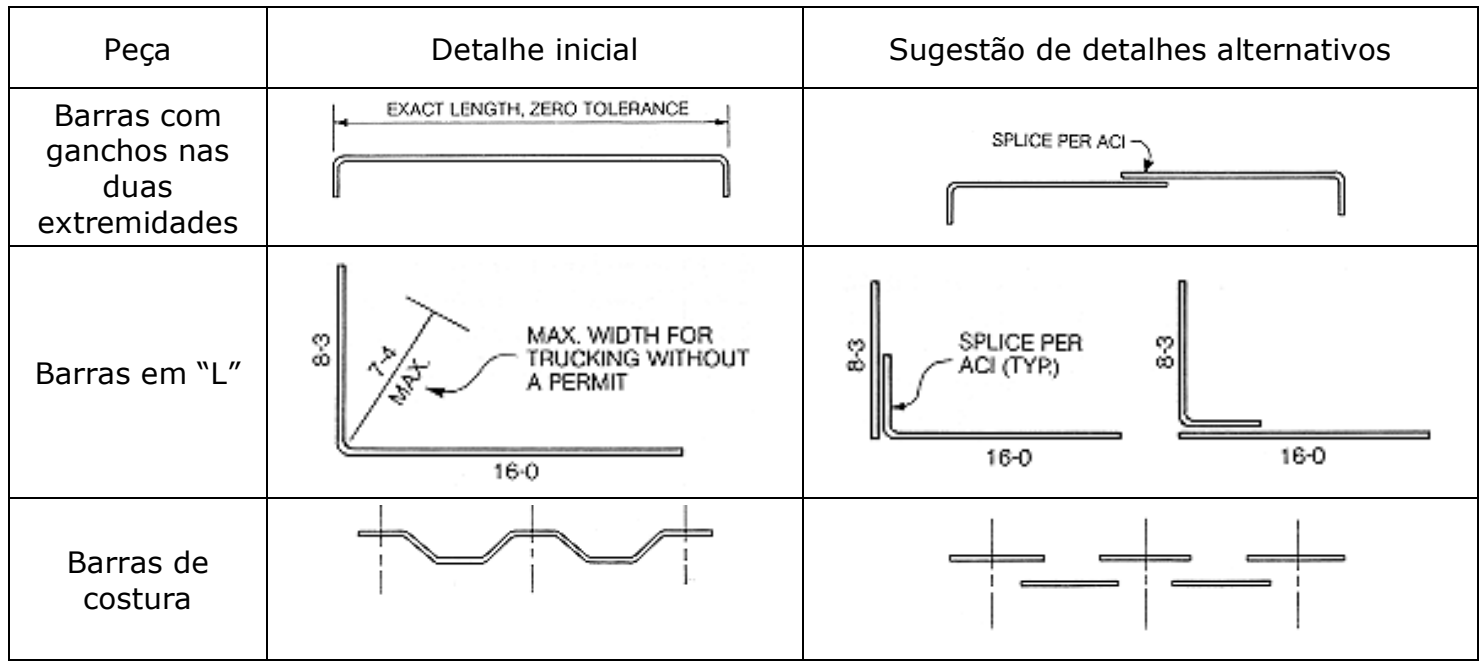

WYLLIE JR; LAPLANTE (2003), no trabalho "The Designer's Responsibility: for Rebar Design", oferecem algumas sugestões aos engenheiros estruturais para que os projetos e os detalhes dos projetos estruturais, que servem os construtores e os subempreiteiros (responsáveis pela montagem das armaduras), sejam tão econômicos e exeqüíveis quanto possíveis. Muitas dessas sugestões são comumente percebidas e simplesmente requeridas ao pensar como o projeto será executado. A experiência tem mostrado aos autores que um melhor detalhamento dos desenhos, em que a construtibilidade tenha sido considerada, resulta em estruturas mais econômicas. Uma vez estabelecida a reputação nesse caminho, os contratantes irão elogiar os desenhos; parte da economia conseguida com projetos mais exeqüíveis poderão ser repassadas aos projetistas.

Ricardo França aponta que, em termos da exeqüibilidade das armaduras, há uma série de detalhes (mesmo para obras comuns) que precisam ser revistos e que podem se refletir em mudanças nos detalhes padrões feitos pelos programas. "Nestas obras padrões é importante se ter "um denominador comum" (como formatos padronizados de posições) que permita melhorar a construtibilidade e, conseqüentemente, a produtividade das etapas de corte e dobra, da montagem etc. "Conseguir-se-ia, desta maneira, com algumas mudanças, um efeito de escala bastante significativo".

O mesmo autor recorda que alguns estudos antigos já tratavam dos problemas decorrentes da existência de diferentes tipos de detalhamento das armaduras e das dificuldades de se armar determinadas posições. Cita "A Arte de Armar", de LEONHARDT, em que se pensava bastante em como detalhar e armar para melhorar o funcionamento da peça sob o ponto de vista da segurança da estrutura, para que "funcionasse direito" (esse autor também defendia a discussão sobre o que "era mais fácil de construir", pois o que fosse mais fácil de construir teria menos erros e, portanto, seria mais confiável do ponto de vista de segurança). Ricardo França recorda que, na década de 60, começou-se a retirar o "cavalete" dos projetos estruturais, os quais, além de ineficientes do ponto de vista estrutural, apresentavam uma montagem muito mais difícil quando comparados aos estribos. 


\subsubsection{A melhoria do processo de projeto de detalhamento como indutora da melhoria da eficiência}

FABRÍCIO, MELHADO (1998b) apontam que a melhoria da qualidade e da produtividade das construções passa pelo aprimoramento e coordenação dos serviços de projetos e pela adequação desses às necessidades de cada sistema de produção. Estes autores defendem a "exeqüibilidade" dos projetos que, para ser conseguida, precisa de profissionais que conheçam o processo produtivo.

Para ZORZI (2002), uma estrutura de concreto armado econômica nasce no projeto, com projetistas que tenham conhecimento das dificuldades existentes na execução, principalmente quanto aos aspectos do sistema de fôrmas, armação e concretagem.

No Brasil, a busca pela construtibilidade dos projetos estruturais mostra-se bastante avançada no que se refere aos projetos de fôrmas. Quanto ao projeto de detalhamento das armaduras, a mesma evolução não é sentida, como denota a Figura 4.15. Entre as justificativas para a aparente falta de atenção com as armaduras, destacam-se os fatos:

- não existe projeto de produção;

- as armações ainda não recebem, na obra, a mesma atenção dispensada às fôrmas. Eventuais problemas decorrentes da execução das fôrmas, por exemplo, podem ficar evidenciados no produto executado; o mesmo não acontece com as armaduras;

- os projetos de detalhamento das armaduras são os últimos a serem realizados no processo de projeto estrutural. Não é incomum chegarem à obra às vésperas da execução, sem tempo hábil para que sejam analisados criticamente. Eventuais erros ou dúvidas são apenas levantados no momento da execução (no pior momento);

- a construção civil não tem o costume de analisar projetos de detalhamento de armaduras em obras convencionais, talvez até por falta de embasamento técnico dos seus gestores em revisar criticamente tais projetos sob a ótica da construtibilidade;

- com a subcontratação do serviço de estrutura/armação (prática predominante no mercado de São Paulo, segundo FREIRE (2001)), a produção e todos os problemas decorrentes não são sentidos pela construtora, ou não chegam a ela com o nível de profundidade necessário à tomada de ações corretivas;

- as empresas de corte e dobra, que se isentam da análise do projeto por questões de responsabilidade legal, acabam executando projetos elaborados (desfavoráveis à sua produtividade também), acumulando erros que, novamente, serão percebidos na obra, nas etapas de pré-montagem e, principalmente, na montagem.

As razões supracitadas contribuem para que os projetos de detalhamento cheguem ao campo com soluções que não as melhores sob o ponto de vista da construtibilidade. Daí decorrerem problemas, tais como: dificuldades na execução comprometendo a qualidade do serviço, levando a consumos de recursos (tempo, material, mão-de-obra, equipamentos) maiores que os teoricamente necessários.

Trabalhos recentes têm elevado o nível de discussão quanto a diretrizes a serem seguidas pelos projetistas estruturais na elaboração dos projetos de fôrmas. O trabalho de ZORZI (2002), por exemplo, propõe diretrizes para a racionalização de sistemas de 
fôrmas (a começar pela prescrição relativa a fazer-se um projeto de fôrmas) que utilizam o molde em madeira e que são empregados na execução de estruturas de concreto armado de edifícios multipavimentos. Como resultados obtidos, tem-se uma melhor qualidade da estrutura executada, maior produtividade da mão de obra e conseqüente redução de custos. ZORZI (2002)

A sistemática de elaboração dos projetos estruturais adotada por alguns escritórios de projeto permite que as fôrmas possam ser analisadas e discutidas em tempo hábil de se promoverem alterações em favor da exeqüibilidade do projeto na obra (é esse um dos principais objetivos das "pré-fôrmas"). Para tanto, é importante que o projeto seja interpretado por profissionais capacitados, que tenham uma visão sistêmica e bastante conhecimento de obra e dos procedimentos executivos adotados pela empresa, das tecnologias que serão adotadas e da mão-de-obra que estará envolvida no processo. É importante, nesta etapa, a participação de profissionais de campo, como o mestre de obras, técnicos e encarregados da execução da estrutura.

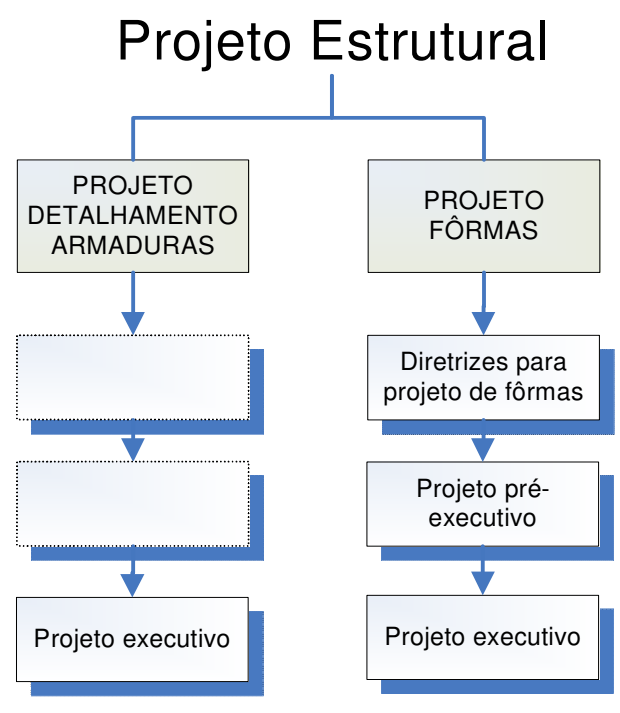

Figura 4.15 - Diferença entre o desenvolvimento do projeto de fôrmas e o de armaduras.

Os projetos executivos de fôrmas que chegam ao construtor, ao considerarem no seu desenvolvimento, as diretrizes de projeto favoráveis à construtibilidade e as análises, pela equipe envolvida na execução, feitas a partir de projeto pré-executivo (em tempo hábil pra que eventuais modificações sejam implementadas), terão muito mais chance de garantir melhores desempenhos durante a sua execução.

Em se tratando do projeto de detalhamento das armaduras, ainda não existe uma proposição válida de diretrizes que orientem os escritórios de projetos a desenvolverem projetos de detalhamento compatíveis com a sua execução no campo, ou seja, voltados à construtibilidade. 
Os projetos pré-executivos de armaduras $^{79}$ não são prática comum no desenvolvimento dos projetos de estrutura. O projeto de detalhamento das armaduras trata-se, portanto, de um único ${ }^{80}$ documento para servir a diferentes agentes (orçamentistas, planejadores, fornecedores, executores, gerentes de produção), que tem diferentes necessidades e diferentes graus de instrução, servindo a vários propósitos em vários momentos do processo, tais como: i) na determinação de quantitativos pela obra (ou pelo ornamentista); ii) nas solicitações de pedidos de aço pela obra ao fornecedor; iii) no planilhamento do aço para emissão de ordens às máquinas de corte e dobra (fornecedores); iv) nas instruções de corte das posições; v) nas instruções de dobra das posições; vi) nas instruções para a pré-montagem das peças; vii) nas instruções para a montagem; viii) nas instruções para a conferência etc.

Ricardo França lembra que, quando se fala em projeto de detalhamento de armaduras e construtibilidade, há duas formas distintas de se olhar a questão. A primeira delas é sob o ponto de vista da atividade de corte e dobra e das questões que tratam de como tornar o corte e dobra mais produtivo a partir do projeto gerado. A segunda diz respeito à montagem da armação. Haveria, ainda, uma terceira que diz respeito à supervisão.

Algumas das questões supracitadas aventam a necessidade de melhorias no processo de projeto de detalhamento das armaduras. Os caminhos que tornem os projetos de detalhamento das armaduras mais exeqüíveis passam, necessariamente, pelo levantamento dos principais problemas de construtibilidade. Dentro do cenário mostrado, associar, portanto, características do projeto estrutural (projeto de fôrmas e de detalhamento das armaduras) a desempenhos alcançados durante a sua execução (desempenhos mensurados, quantitativamente e qualitativamente) é um dos caminhos propostos, por este pesquisador, para a determinação de diretrizes que agreguem construtibilidade aos projetos de detalhamento de armaduras.

Cabe ressaltar, para que sirva de exemplo, a ocorrência de significativas melhorias no processo do projeto de fôrmas e, por conseguinte, na produção das fôrmas (fabricação e montagem) nos canteiros, destacando-se o "surgimento" do projeto de produção de

79 O projetista estrutural Ricardo França apresentou a idéia da "pré-armação". França defende que, assim como no caso das fôrmas, no detalhamento de armação também deveria existir um projeto preliminar que serviria de informação inicial para uma conversa a ser feita com o pessoal de obra (que iria executar o projeto), a fim de checar detalhes e a exeqüibilidade do projeto. Para algumas obras, e dentro do espírito da "préarmação", França diz que seria interessante repassar aos executores os detalhes gerados pelo programa e, só após a análise do pessoal da obra, trabalhar no "pente fino". Gino Schevano Filho, porém, relata ser muito complicado trabalhar com pré-executivo de armação. "Demoraria muito para o projeto ser feito e custaria mais. O ideal é que a construtora passe suas diretrizes ao projetista - por exemplo, pode ser o caso de a construtora liberar o projetista a eventualmente gastar um pouco mais de aço no caso de considerar que isto traga ganhos de produtividade".

${ }^{80}$ Apesar de o projeto de detalhamento das armaduras de uma estrutura de concreto armado ser composto por um conjunto de pranchas, tratam-se do mesmo tipo de documento. 
fôrmas, desenvolvido fora da obra ${ }^{81}$, por especialistas. ZORZI (2002) defende fortemente o emprego do projeto de produção da fôrma, justificando sua necessidade para que se obtenha qualidade, produtividade e baixo custo. Imagina-se que resultado semelhante pudesse ser obtido para o caso das armaduras.

\subsection{2 $O$ método de trabalho e a influência na produtividade da mão-de-obra}

Conforme já comentado no segundo capítulo deste trabalho, entende-se método de trabalho como sendo o conjunto de operações relacionadas ao processo de produção de armaduras, presentes nos canteiros de obras, dentre as quais encontram-se o recebimento, estocagem, transportes, beneficiamento, pré-montagem e montagem final. A proposição de um método de trabalho potencialmente mais produtivo passa por tratar, separadamente, cada uma dessas operações. Acredita-se que, melhorando a produtividade das partes (operações), chegar-se-á a um todo (método) mais eficiente.

As limitações das operações, que reduzem a eficiência do método de trabalho, podem ser intrínsecas ou decorrentes de equívocos cometidos no momento de definição do método. Diz-se intrínsecas devido às formas rudimentares com que a maioria das operações são conduzidas no canteiro de obras. As operações são caracterizadas pelo uso intensivo da mão-de-obra, em condições de trabalho desfavoráveis sob a ótica da ergonomia e segurança. As ferramentas ainda são, em muitos casos, as mesmas utilizadas há décadas. Dessa forma, a agilidade que conferem à operação está mais na destreza do operário em manuseá-las do que no seu aperfeiçoamento. A modernização dos equipamentos de corte e dobra do aço, e que serviu para disseminar fábricas que prestam esse tipo de serviço, não ajudou a melhorar as operações supracitadas quando realizadas nos canteiros de obras (um bom número de empresas brasileiras ainda beneficia o aço nos canteiros de obras e usam equipamentos arcaicos e inadequados).

Os equívocos, por sua vez, são originados a partir de uma série de razões, dentre as quais se destacam: i) o despreparo técnico das pessoas responsáveis por planejar e definir o método de trabalho; ii) as limitações impostas pela contratante (como, por exemplo, aquelas decorrentes de indefinições quanto à logística de canteiros ou de falta de recursos); iii) as limitações apresentadas pela empresa contratada (como, por exemplo, a utilização de equipamentos e/ou técnicas inadequadas aos volumes de produção desejados).

Seja a partir de limitações intrínsecas às operações e/ou por equívocos cometidos na definição do método de trabalho, sabe-se (levantamentos sobre a produtividade da mãode-obra realizados por este autor comprovam isto) que a eficiência no processo de produção das armaduras nos canteiros de obras é fortemente influenciada pela diversidade e pela forma como tais operações são conduzidas. Em alguns casos, simples alterações na logística de canteiros (como a previsão de áreas de recebimento próximas a áreas de estocagem) podem surtir efeitos positivos sobre a produtividade. Em outras situações, esta melhora pode demandar aportes financeiros mais significativos, como no caso da adoção de gruas para o transporte do aço.

${ }^{81}$ Segundo ZORZI (2002), uma prática ainda consagrada em canteiros de obras consiste em entregar o projeto estrutural ao mestre de obras e este ser o responsável por "projetar" o molde da fôrma. 
O conhecimento das diferentes possibilidades existentes para a execução de uma mesma operação deve estar associado ao conhecimento das implicações que a operação assim definida terá sobre desempenho do processo de produção. A dificuldade e complexidade do serviço são, em parte, determinadas pelo método de trabalho adotado. Configurar um método de trabalho que melhor se adapte às condições técnicas e financeiras da obra é condição básica para reduzir a complexidade do serviço e, dessa forma, contribuir para a redução dos recursos demandados na sua execução. Relegar essa configuração a um segundo plano pode significar perdas de eficiência produtiva.

Apresentam-se, a seguir, algumas operações, referentes à etapa de armação do processo de produção das armaduras, definidas e conduzidas em alguns canteiros de obras visitados pelo autor ao longo do desenvolvimento deste trabalho. Nota-se que as operações, tal como executadas, limitam significativamente a produtividade da mão-deobra envolvida no serviço.

O descarregamento, seja do aço em barras ou de peças já beneficiadas, é, em muitas situações de obra, ainda feito manualmente (Figura 4.16), ou com uso de equipamentos inadequados, contribuindo significativamente para a ineficiência do método de trabalho e, por conseguinte, piora da produtividade.
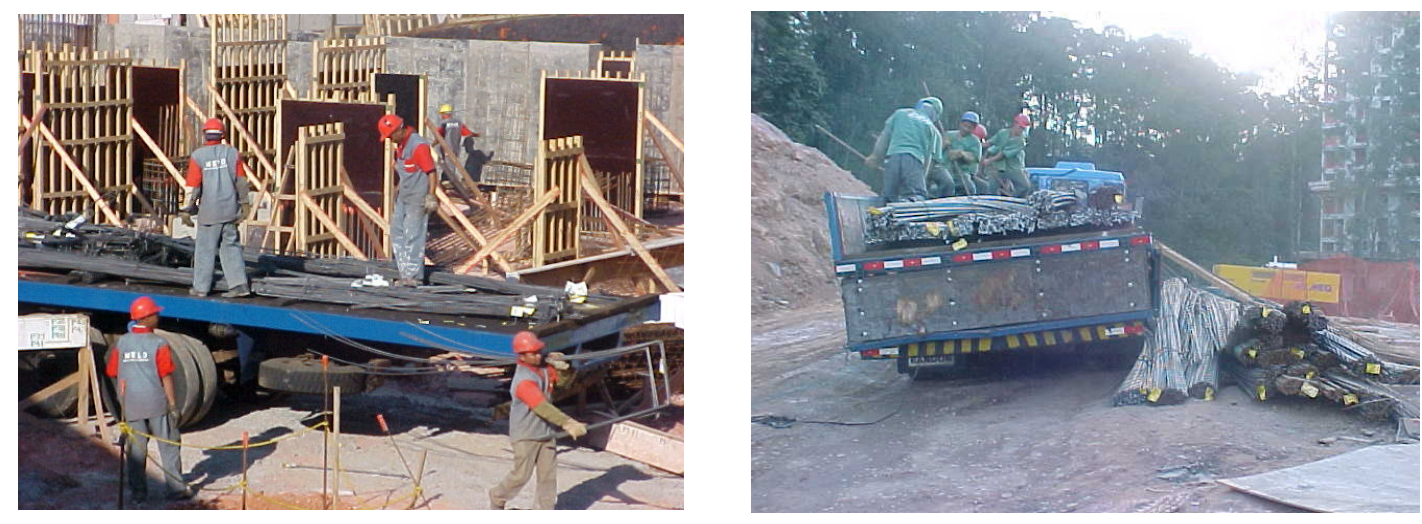

Figura 4.16 - Exemplos de descarregamento manual do aço

Outros exemplos de operações realizadas de maneira rudimentar podem ser observados nas Figura 4.17 e Figura 4.18. Na Figura 4.17, chama-se atenção para a má produtividade potencial da mão-de-obra no transporte vertical do aço, que é feito manualmente a partir do pavimento térreo e conta com o auxílio de cordas. Na Figura 4.18 , o transporte vertical é feito através do elevador cremalheira da torre vizinha ao edifício onde o aço será usado, numa operação perigosa e contrária às normas de segurança para canteiros de obras (NBR-18). Em ambas as situações, os operários estão, ainda, sujeitos a maiores riscos quanto ao comprometimento de sua integridade física. 


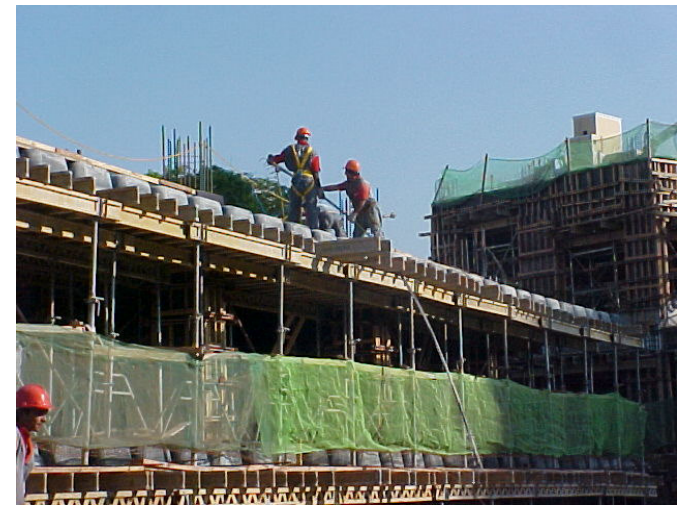

Figura 4.17 - Transporte vertical do aço com o auxílio de cordas

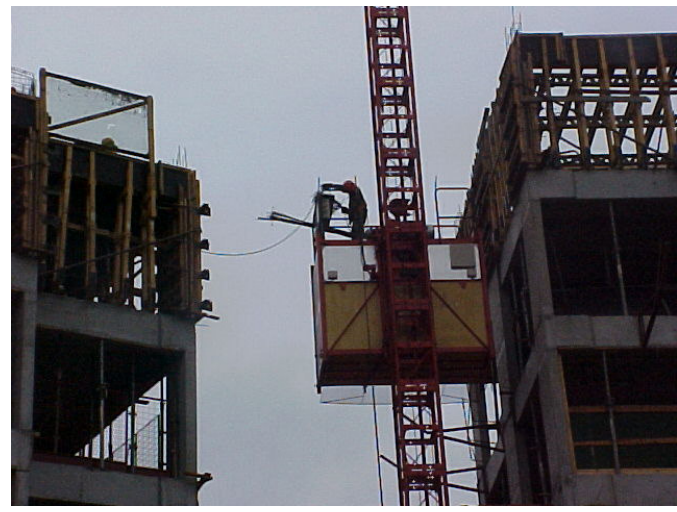

Figura 4.18 - Transporte vertical do aço com o elevador cremalheira

A estocagem do aço no canteiro de obras, quando este é recebido cortado e dobrado, pode comprometer a potencialidade oferecida por esse sistema de fornecimento. As áreas destinadas aos estoques do aço cortado dobrado, ao contrário do que se pode imaginar, são necessariamente maiores (Figura 4.19), devido ao fato, principalmente, de as peças, se sobrepostas, elevarem as dificuldades de encontrar e retirar os feixes do estoque. A sobreposição de feixes de peças requer cuidados redobrados na organização dos estoques. A maioria dos canteiros de obras visitados por este autor amontoava os feixes (Figura 4.20) criando, dessa forma, "estoques caóticos", prejudiciais à produtividade das operações subseqüentes bem como à organização do canteiro de obras e aos benefícios advindos desta organização.

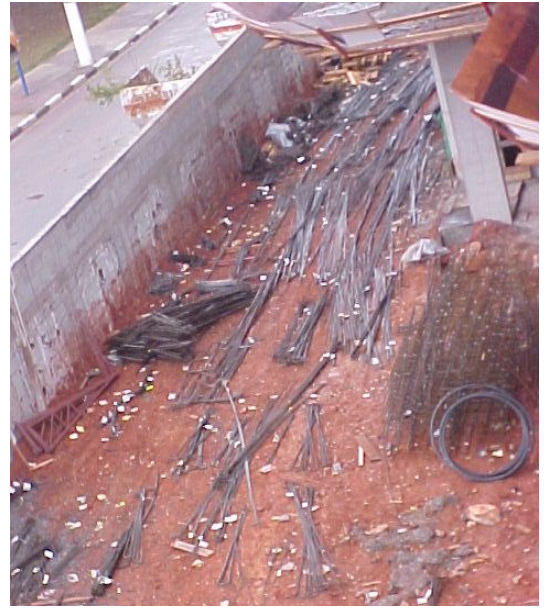

Figura 4.19 - Área para estoque de aço cortado e dobrado

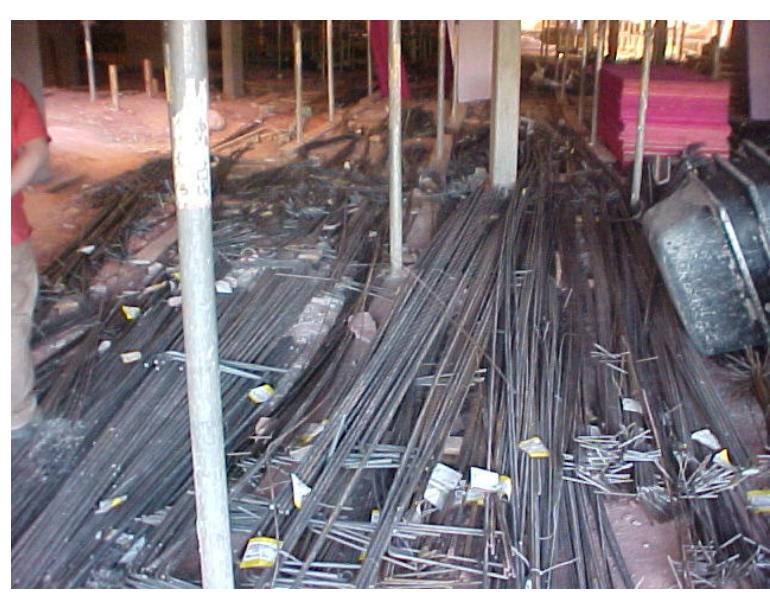

Figura 4.20 - Estoque com sobreposição de feixes

As variações permitidas às operações de corte e dobra de aço no canteiro de obras são muitas, contribuindo, para isso, tipos e quantidades de equipamentos e ferramentas utilizados até a seqüência de execução determinada pelas ordens de produção, ou mesmo, as particularidades com que cada operário conduz o serviço. Chama-se atenção 
para a operação de dobramento das barras, realizada através de máquinas eletrohidráulicas; o tempo gasto pelo operador da máquina no apontamento das posições-guia na bancada de dobra, conforme ilustrado na Figura 4.21 (no caso de estribos, são quatro marcações por peça), consome $75 \%$ do tempo total da operação de dobramento. Quando a ordem de produção prevê que as peças sejam dobradas elemento a elemento (dobramse, por exemplo, todas as peças de um pilar, para, em seguida, dobrarem-se as peças do pilar seguinte e assim sucessivamente), tem-se que uma mesma peça, que se repete dez vezes num projeto (situação hipotética), implicará na necessidade de que as marcações das posições guia sejam feitas repetidas vezes, consumindo mais tempo e onerando, por conseguinte, a produtividade da mão-de-obra envolvida na operação.
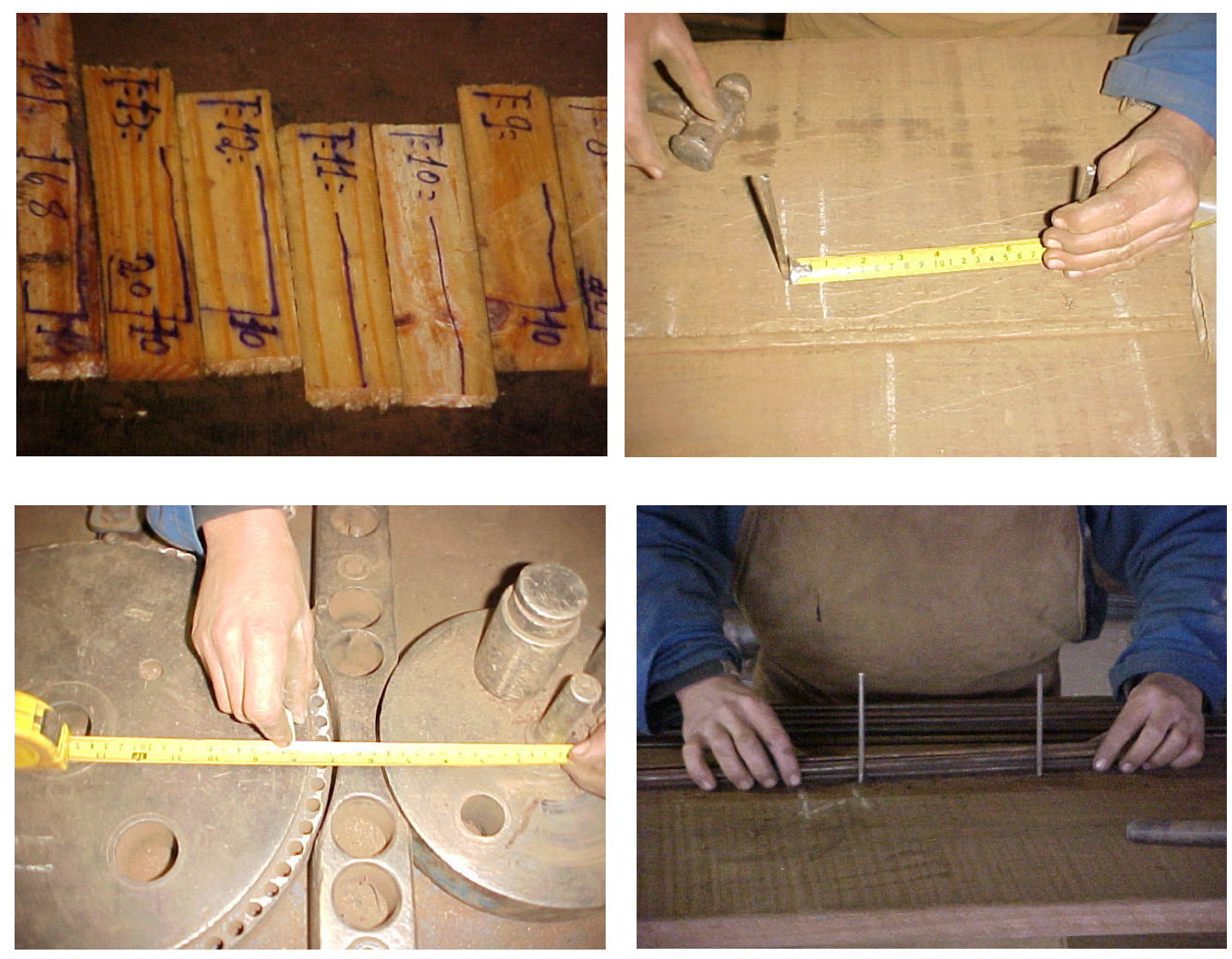

Figura 4.21 - Exemplo de marcações de "posições-guias" para o dobramento de peças em máquinas eletro-hidráulicas

DUNSTON, BERNOLD (2000) indicam que as propriedades mecânicas do aço norteamericano são bastante variáveis, devendo, portanto, haver uma atenção redobrada nas operações de dobramento para evitar problemas nas peças geradas (como fissuras nas regiões de dobramento). No entanto, segundo os autores supracitados, nos Estados Unidos apenas uma pequena quantidade dos dois milhões de toneladas de aço processados anualmente são dobrados usando-se máquinas automáticas; a grande maioria do aço é dobrada manualmente em bancadas de dobra. "A maioria das máquinas automáticas de dobra é encontrada na Europa, em plantas de corte e dobra, não sendo 
usadas largamente nos Estados Unidos devido aos altos investimentos financeiros necessários." Assim sendo, a realidade norte-americana se assemelha à brasileira, onde as operações de dobramento requerem, em muitos casos, o trabalho intensivo e injurioso da mão-de-obra.

Em se tratando das operações de montagem das armaduras, têm-se que a prémontagem deve sempre ser realizada quando as condições de canteiro permitirem (em muitas situações a pré-montagem das armaduras não é possível devido ao peso das gaiolas e malhas, não comportado pelos equipamentos de transporte disponibilizados no canteiro de obras). A principal justificativa deve-se ao aumento de produtividade proporcionado pela ocupação da equipe de armadores quando esses estão impedidos de trabalharem na laje. Um outro ponto favorável à pré-montagem trata-se de permitir que o armador trabalhe em ambientes mais salubres (protegidos de intempéries e de riscos de acidentes), desfrutando de melhores condições ergonômicas etc.

Mesmo assim, tanto ao trabalharem com a pré-montagem ou com a montagem definitiva das armaduras, os armadores estão, freqüentemente, sujeitos a condições de trabalho desfavoráveis, permanecendo durante boa parte do tempo, em que estão desenvolvendo tais atividades, em posições que contrariam os manuais de ergonomia e saúde do trabalhador. Mensurar o impacto dessas condições desfavoráveis de trabalho sobre a produtividade da mão-de-obra é totalmente relevante. E adotar métodos de trabalho para que situações como aquelas ilustradas na Figura 4.22 sejam minimizadas deve ser objetivo de todo bom gestor.
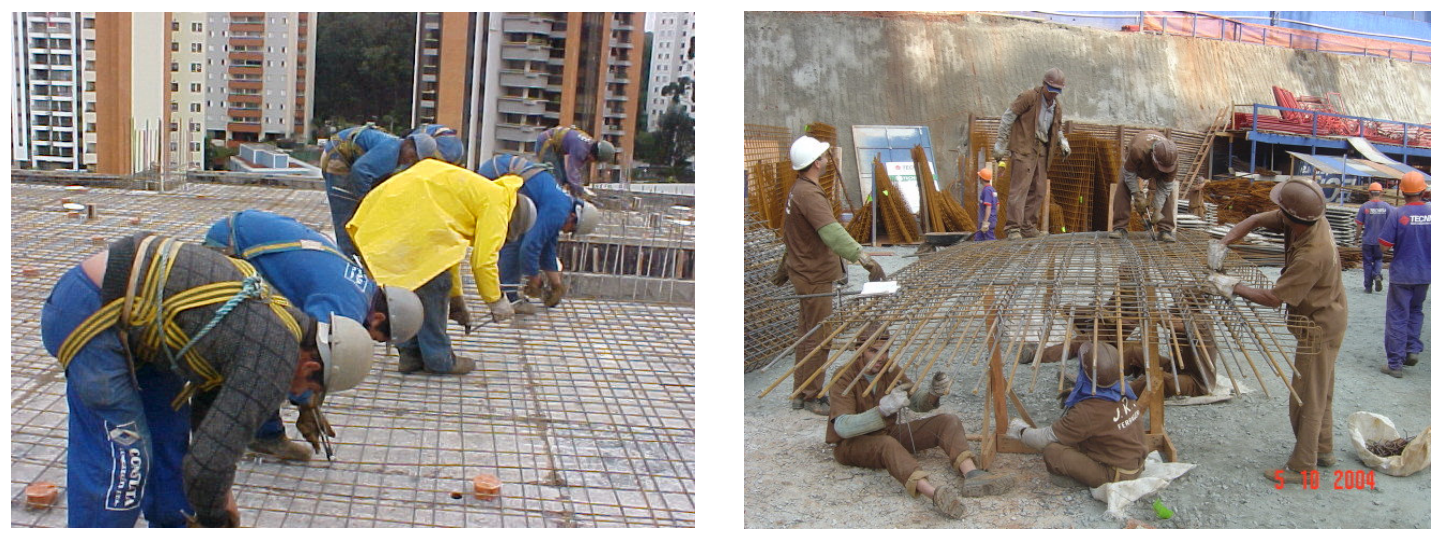

Figura 4.22 - Operações de montagem e pré-montagem de armaduras com operários em condições ergonômicas desfavoráveis

\subsubsection{A sistematização dos processos como contribuição para a melhoria da eficiência}

Em um levantamento feito por ARAÚjO, SOUZA (2003), constatou-se que o esforço da mão-de-obra, destinada à etapa de armação no processo de produção de armaduras 
para estrutura de edifícios ${ }^{82}$, assume valores distintos para cada uma das operações que compõem o método de trabalho, tal como apresentado no gráfico da Figura 4.23.

Os principais avanços percebidos nos últimos anos, no sentido de racionalizar as operações da etapa de armação, surgiram a partir da deteç̧ão de uma nova oportunidade de negócio, caracterizada pela agregação de valor ao produto "aço" a partir da prestação do serviço de corte e dobra em plantas fabris especializadas. Com o advento do aço cortado e dobrado, parte do esforço da mão-de-obra foi retirado do canteiro de obras, imaginando-se retirar toda a ineficiência e problemas intrínsecos a essas operações (operações com elevado potencial de acidentes de trabalho, falta de qualidade das peças beneficiadas no canteiro, desperdício de material etc).

Porém, não se pode dizer, ainda, que o método de trabalho e, por conseguinte, a produtividade da mão-de-obra envolvida na produção de armaduras tenham melhorado substancialmente com a adoção dessa prática. O potencial de racionalização do sistema de "aço pronto" (como é chamado comercialmente) ainda não foi completamente explorado pelas empresas construtoras que adotaram tal prática.

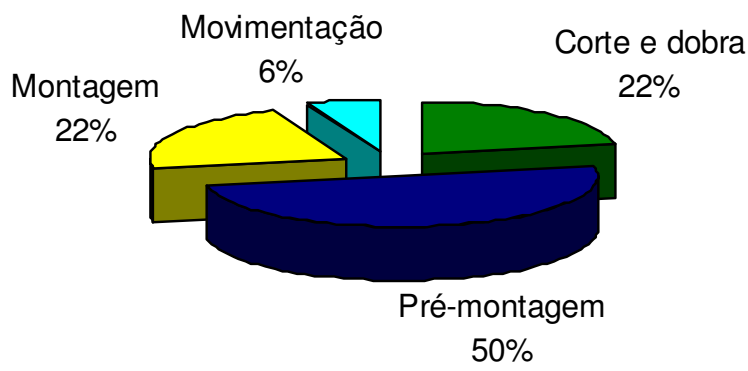

Figura 4.23 - Distribuição percentual do esforço da mão-de-obra (em termos do tempo dedicado) nas operações que compõem o método de trabalho do processo de produção de armaduras

ARAÚJO (2000), ao comparar valores de produtividade de mão-de-obra de armação entre obras que trabalhavam com o aço pronto e obras que cortavam e dobravam o aço no canteiro, chegou a valores de produtividade melhores para as obras que adotaram o beneficiamento do aço no canteiro. Justificou, naquele momento, tal percepção, principalmente por problemas relacionados à ociosidade da mão-de-obra nas obras que trabalharam com o aço pronto. Em levantamentos recentes o autor tem percebido que o percentual de esforço que deveria ser subtraído do canteiro de dobras, referente à adoção do aço pronto, não vem acontecendo. O manejo do aço pronto (recebimento, transporte, organização de estoques etc) nos canteiros de obras requer um esforço de mão-de-obra que não é desprezível, podendo ser superior, em alguns casos, ao esforço destinado às operações de corte e dobra de aço.

82 O estudo foi feito para pavimentos tipo de estruturas reticuladas de concreto armado, com corte e dobra do aço no canteiro de obras. 
Parte desse esforço poderia ser minimizado, tornando o aço cortado e dobrado muito mais atrativo, se algumas ações fossem tomadas, como, por exemplo, no momento da expedição das cargas pelo fornecedor do aço. Para BERNOLD, SALIM (1993), a eficiência das operações do processo de produção das armaduras, que acontecem no canteiro de obras, depende muito da forma como o aço é organizado para a expedição (entrega no canteiro). "Infelizmente, o planejamento e a coordenação da expedição e as operações de "shake-out" recebem muito pouca atenção". Nos processos tradicionais de fabricação e expedição das armaduras privilegia-se a otimização no tempo das máquinas de corte e dobra. Como resultado, o aço é cortado, dobrado e separado em feixes de acordo com os formatos e tamanhos, não se considerando a seqüência de montagem das barras.

Os mesmos autores supracitados propuseram um caminho alternativo para projetar e entregar as armaduras. Para tanto, desenvolveram o "Computerized Rebar Placement Planner" (CRPP), que se trata de um sistema de planejamento inteligente visando aumentar a produtividade das atividades do PCPA no canteiro de obras. "Para alcançar as melhores produtividades possíveis em atividades como a de montagem das armaduras, é desejável que se tenham entregas de armaduras na mesma seqüência em que elas serão montadas". Os autores referem-se a organizar a expedição prevendo-se o seqüenciamento das atividades no canteiro, peça a peça, posição a posição. Para tanto, esse seqüenciamento deve ser desenvolvido na etapa de projeto, com a ajuda do sistema computacional supracitado. "O conceito de "entrega orientando o processo" requer que o planejamento do processo de detalhamento exista tanto num nível macro como nível micro. Assim sendo, um sistema que promova a interface entre o detalhamento do projeto, a entrega e o controle de montagem reduz perdas de tempo no processo e em eventuais redundâncias nos esforços de planejamento, contribuindo para a redução dos custos do referido processo".

Estudos de campo comparativos, realizados por SALIM, BERNOLD (1994), mostraram que, através do conceito de "entrega orientando a produção", tal como comentado anteriormente (a Figura 4.24 ilustra esse conceito), podem-se obter reduções nos tempos gastos no processo, melhorando-se a produtividade da mão-de-obra em 30\% quando comparada ao método tradicional. "Ganhos de produtividade na montagem da armadura da laje se deram em função da escolha de um fornecedor que colaborou com o subempreiteiro, entregando as barras em feixes organizados de acordo com a seqüência de utilização na laje". 


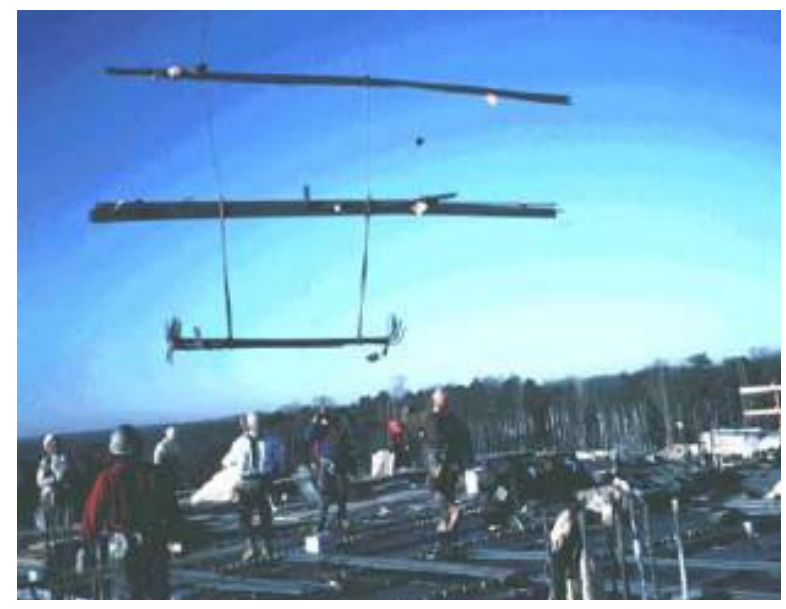

Figura 4.24 - Entrega do aço de acordo com a seqüência de montagem

O aço fornecido à obra cortado e dobrado, no âmbito das discussões sobre a melhoria do método de trabalho, remete a considerações, também, no ambiente fabril. Autores como DUNSTON, BERNOLD (2000); BERNOLD, SALIM (1993); SALIM, BERNOLD (1994) vêm discutindo há mais de uma década alternativas para incrementar a eficiência do processo de fabricação do aço cortado e dobrado nas fábricas, através da automatização das máquinas (transferência de informação de máquinas para máquinas), do aumento da flexibilidade de produção, do aumento da construtibilidade dos projetos etc.

No Brasil, softwares vêm sendo desenvolvidos para ajudar na transferência de informação do projeto de detalhamento de armaduras às máquinas de processamento de corte e dobra. A empresa paulistana "TQS-PLANEAR" desenvolveu um programa, conhecido como "G-Bar IGV", que permite a racionalização das atividades dos departamentos técnicos das centrais de corte e dobra, através da importação digital de dados de projetos gerados pelo sistema TQS e de uma série de facilidades para verificação da consistência dos projetos e gerenciamento das entregas. Segundo Marcos Monteiro ${ }^{83}$, "está-se dando um grande passo para auxiliar a integração da cadeia produtiva das armaduras, que envolve as construtoras, os projetistas e os fornecedores do serviço. O "G-Bar IGV" consegue agilizar sensivelmente a comunicação e, principalmente, reduzir muito as possibilidades de erros, o que é interesse de todos. Esse é o caminho: utilizar as ferramentas computacionais para melhorar a produtividade e a qualidade de vida dos envolvidos".

Em se tratando das operações de pré-montagem das armaduras, essas devem ser sempre previstas no método de trabalho adotado. Situações de detalhamento de projeto podem ser revistas no sentido de permitir a pré-montagem. FRANÇA (2003) cita o exemplo das armaduras de pilares parede do edifício "E-Tower", em construção (20022005) na cidade de São Paulo. O detalhamento inicial induziu a montagem das armaduras no local (Figura 4.25), o que onerou o ciclo de execução da estrutura em

83 O projetista estrutural Marcos Monteiro é sócio-diretor da empresa TQS-Planear. Seus depoimentos foram obtidos em entrevista concedida ao autor em outubro de 2004. 
razão da complexidade e dificuldade do serviço. A partir de solicitação da obra e de discussões entre os agentes participantes da execução da estrutura (engenheiros residentes, projetistas, consultores e subempreiteiro), o projetista alterou o detalhamento das armaduras, segmentando aquela que era uma única armadura em uma série de gaiolas (Figura 4.26). Essas gaiolas, de tamanho reduzido, passaram a ser pré-montadas na central de armação localizada no pavimento térreo e, posteriormente, a serem montadas e unidas no local definitivo. Tal solução conferiu agilidade e maior rapidez à operação, reduzindo em dois dias a duração do ciclo de execução dos pavimentos do edifício em questão.

As armaduras pré-montadas, em muitas situações, precisam ser enrijecidas para poderem ser transportadas verticalmente. Ainda assim, durante o transporte é comum a ocorrência de desarranjos nas armaduras (peças que saem das posições previstas no projeto), levando à necessidade de retrabalhos.
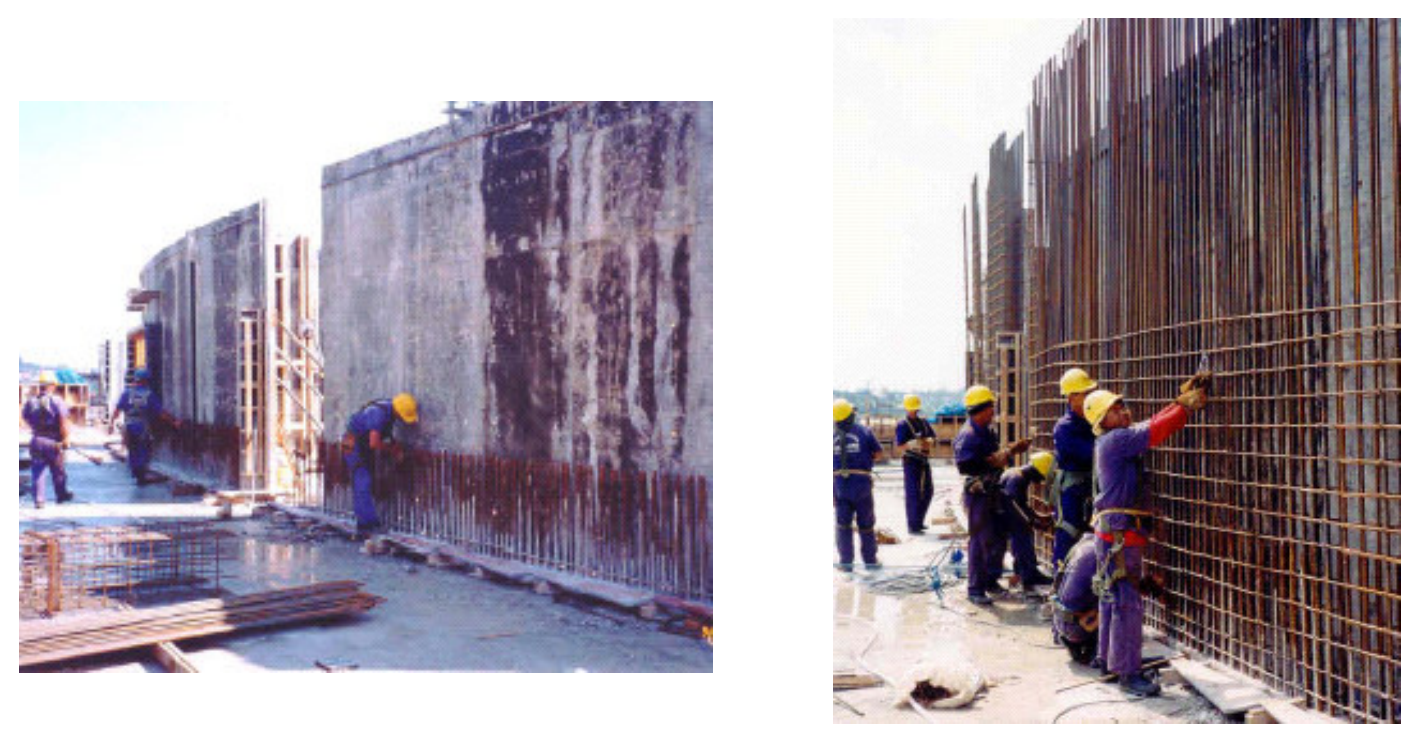

Figura 4.25 - Detalhes da armadura de pilar parede montada no local
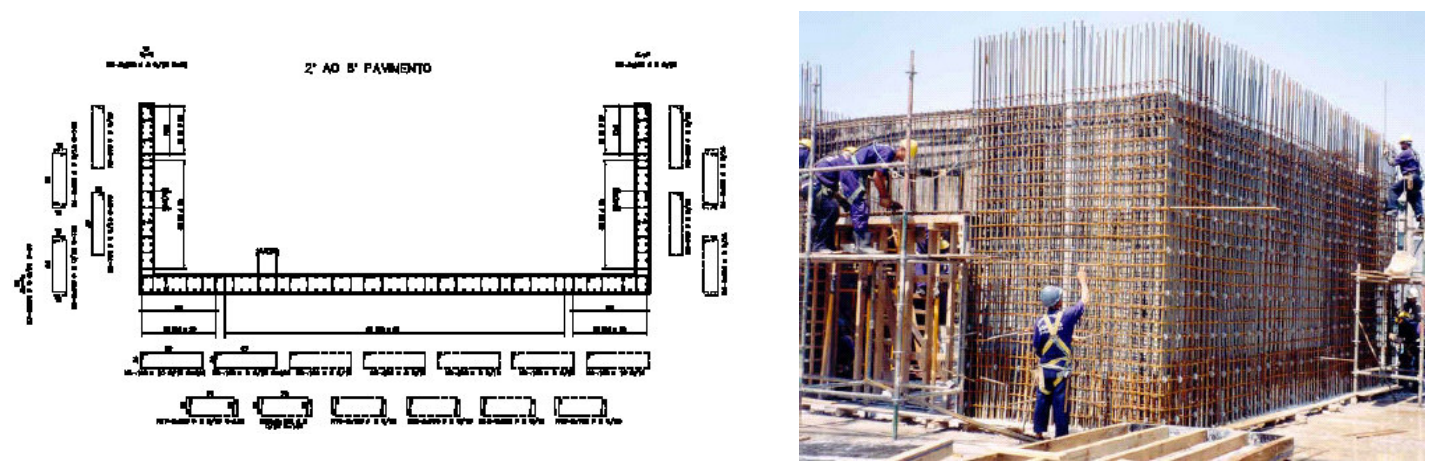

Figura 4.26 - Detalhamento da armadura de pilar parede segmentada para possibilitar a pré-montagem e posterior união das gaiolas no local 
A pré-montagem, embora mais comumente utilizada para as armaduras de pilares e vigas, pode ser adotada em armaduras de lajes. Nesse caso, a pré-montagem pode ser feita no próprio canteiro de obras, sempre que o detalhamento do projeto permitir (tornando atraente essa possibilidade para a obra). Neste, como em todos os outros casos em que se optar pela pré-montagem, subentende-se que haja, na obra, equipamento de transporte vertical que permita levar as armaduras para os andares em execução. Em algumas situações, o deslocamento horizontal das armaduras até o ponto de içamento pode dificultar ou, até mesmo, impedir a pré-montagem de alguns elementos. A Figura 4.27 mostra a solução encontrada pelos armadores de uma obra para viabilizar o transporte horizontal das armaduras pré-montadas.
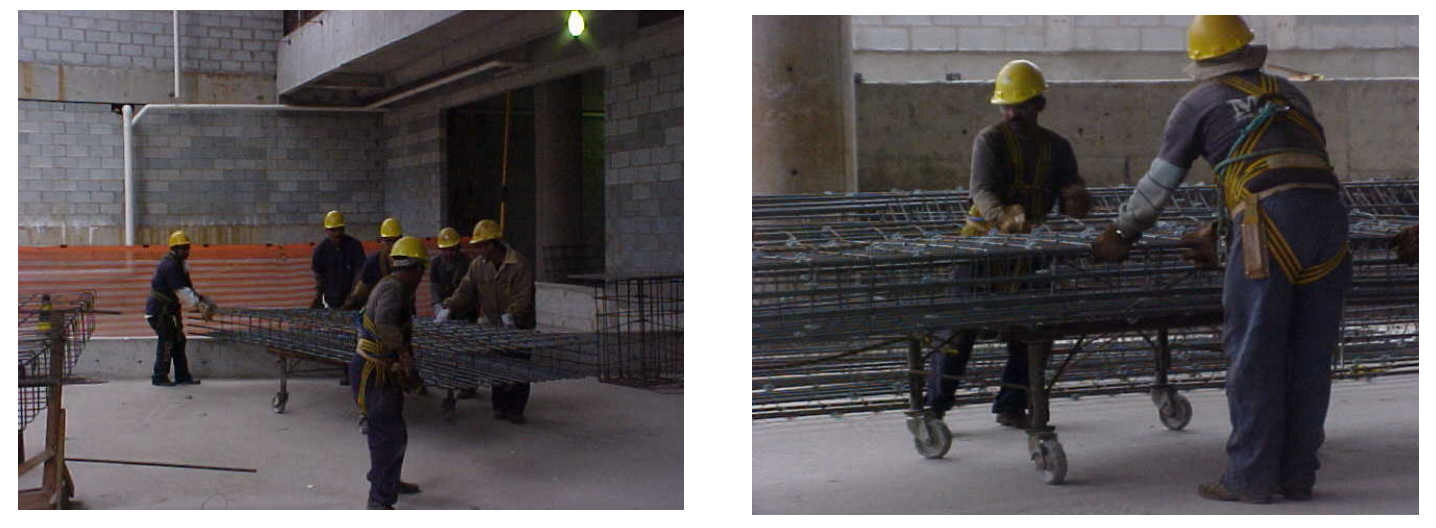

Figura 4.27 - Carrinho para o transporte das armaduras pré-montadas

O uso de telas soldadas pode ser tratado como um caso de pré-montagem das armaduras, realizada fora do canteiro de obras em regime industrial. As telas podem racionalizar as operações em campo, principalmente quanto à montagem das armaduras positivas e negativas das lajes. Apesar de estar disponível para utilização nas obras brasileiras desde meados do século passado, o uso das telas nas estruturas de edifícios brasileiros ainda não é prática comum.

Dentre as razões paro o uso incipiente de telas soldadas pelo mercado nacional de edificações, destacam-se, aqui, o estigma de que as telas apresentem custos mais altos que as armaduras convencionais, a problemática quanto a se projetar com tela (os projetos não são concebidos originalmente em telas soldadas) e a morosidade do processo, que começa com a decisão (tardia, em muitos casos) do construtor em considerar a opção, passando pelo re-projeto em telas até que se cheguem às negociações comerciais. Soma-se, ainda, o fato de que um projeto em telas soldadas dificilmente é concebido utilizando-se apenas telas padrão (mais econômicas, por serem produzidas em escala).

Dessa forma, a necessidade do uso de telas especiais (produzidas sob encomenda) contribui para o encarecimento da solução e, por conseguinte, para o distanciamento do seu uso. Por outro lado, os benefícios advindos do uso das telas, que podem ser significativos (desde que usadas em situações propícias e por mão-de-obra especializada), são de difícil mensuração e quase nunca ponderados no momento da decisão. 
A montagem das armaduras é a operação da etapa de armação onde os operários enfrentam as condições de trabalho mais desfavoráveis. Por outro lado, sob o ponto de vista da produtividade da mão-de-obra, trata-se da operação que apresenta o melhor desempenho. Ainda assim, acredita-se que haja a possibilidade de que melhorias possam ser efetivadas, com o intuito principal de resguardar, principalmente, a integridade física do operário. Questões discutidas anteriormente, como os conceitos de entrega orientando o processo e a indução da pré-montagem, podem contribuir, significativamente, para que a operação de montagem das armaduras demande esforços ainda menores da mão-de-obra.

Alguns equipamentos comercializados nos Estados Unidos prometem melhorar a ergonomia do trabalho do armador, bem como melhorar a produtividade das operações que envolvem, principalmente, amarrações entre peças que irão compor as armaduras. A Figura 4.28 ilustra uma máquina que faz amarrações automáticas conhecida como "UTier". Essa máquina exige menor esforço e movimentos repetidos do armador, além de minimizar os riscos de danos musculares aos armadores, ocasionados pelos movimentos repetidos necessários à amarração convencional das armaduras.
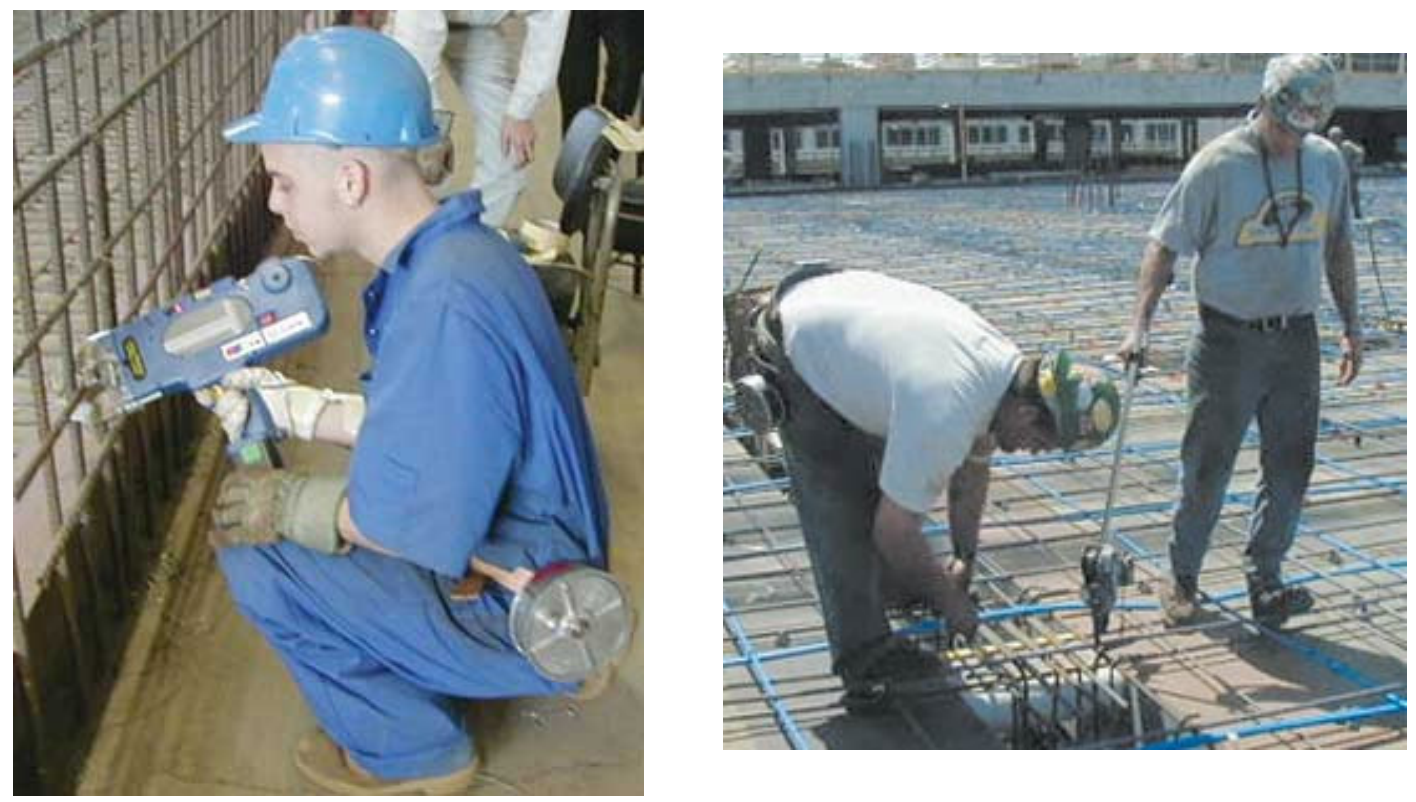

Figura 4.28 - Exemplo de máquina para amarrar peças das armaduras

\subsubsection{A organização do trabalho e sua influência na produtividade da mão-de-obra}

A organização do trabalho, segundo os pontos discutidos no terceiro capítulo, pode ser um importante instrumento para melhorar a eficiência da mão-de-obra. A evolução das teorias organizacionais colocou, a partir da segunda metade do século passado, a mãode-obra, ou a pessoa, em posição de destaque, evidenciando-se que melhorias nos desempenhos dos processos de produção deveriam passar, necessariamente, a tratar com atenção devida essa mão-de-obra. 
As práticas organizacionais na construção civil têm sido orientadas de maneira a atender, principalmente, os anseios e necessidades dos níveis hierárquicos superiores (vide, por exemplo, as políticas de contratação dos subempreiteiros, em que se prioriza preço). Porém, a adoção de posturas organizacionais diferenciadas (que re-avaliem e modifiquem as habituais políticas de contratação e remuneração de subempreiteiros e operários, que considerem a importância de práticas motivacionais e programas de capacitação da mão-de-obra, por exemplo) pode levar a reflexos positivos quanto à produtividade da mão-de-obra. ARAUJO (2000) constatou que empresas subempreiteiras que adotavam o pagamento de "extras" aos seus funcionários no cumprimento de uma tarefa obtiveram melhores produtividades para o serviço em questão. PROVERBS et al. (1999) lembrou alguns trabalhos (KAMING et al. (1997a); THOMAS (1992); KAMING et al. (1997b)) que apontaram ornadas de trabalho superiores a 40 horas semanais pioravam a produtividade e inflacionavam os custos da mão-de-obra da construção.

Exemplos como os supracitados têm ratificado a proposição de que a forma como o trabalho é organizado tem implicações diretas no desempenho da sua mão-de-obra. Porém, promover a organização do trabalho de forma a favorecer o incremento da produtividade (rendendo benefícios para o empregador (melhores desempenhos) e para o empregado (melhores condições de trabalho e de vida)), envolve uma pluralidade de ações que não dizem respeito apenas ao responsável direto pela mão-de-obra (por exemplo, o empreiteiro, no caso da mão-de-obra subempreitada), mas, também, aos outros agentes participantes da cadeia produtiva (do construtor ao próprio operário), envolvendo inclusive agentes externos ao processo de produção em questão (como o próprio Estado).

Apresenta-se, portanto, a seguir, o papel desses agentes na promoção dos principais elementos preconizados pelo processo de organização do trabalho. Antes, porém, discute-se um ponto de extrema importância, qual seja, o das barreiras que alguns países têm enfrentado para atrair mão-de-obra para o trabalho na construção civil. Embora possa parecer um problema distante da realidade brasileira atual, numa situação de crescimento econômico a falta de mão-de-obra pode ser um entrave ao setor da construção civil brasileira. Para UWAKWEH (2003), entendendo as experiências vividas pelos países desenvolvidos, os países em desenvolvimento podem ser beneficiar, ao não repetir os mesmo erros dos países desenvolvidos.

Para isso, é importante que se conheçam e se discutam, mais a fundo, as razões que denigrem a imagem da construção civil e dificultam a entrada da força de trabalho no setor. Conhecer as ações que outros países (como os Estados Unidos da América, Alemanha e Inglaterra) vêm tomando para solucionar este entrave, no âmbito da organização do trabalho, contribuirá, significativamente, para os propósitos desta tese.

\subsubsection{Visão da força de trabalho na construção civil - uma perspectiva globalizada}

Previsões do governo e de outras agências norte-americanas interessadas em análises de fluxos de trabalho têm apontado que haverá uma escassez de trabalhadores na construção civil nos Estados Unidos, em razão, principalmente, da imagem negativa dessa indústria. Há mais trabalhadores saindo (em razão de aposentadorias, recolocações etc) do que entrando para compor a força de trabalho neste setor da economia. 
Embora mais alarmante nos Estados Unidos, situação parecida é vivenciada por países europeus, como a Alemanha e a Inglaterra. Segundo PROVERBS et al. (1999), na Alemanha, a situação da mão-de-obra é preocupante em termos da idade atual dos trabalhadores, conforme já citado.

Embora no Brasil a construção civil tenha uma imagem negativa na sociedade como um todo (justificada por números e estatísticas muitas vezes divulgadas), o setor ainda não enfrenta problemas quanto à escassez de mão-de-obra. Questões sociais, amplamente conhecidas, têm colaborado para manter os portões dos canteiros de obras sempre cheios de mão-de-obra à espera de uma oportunidade de trabalho.

Para muitos norte-americanos, a construção tem se tornado a última opção de carreira, principalmente em razão do estigma de "trabalho sujo", "pesado", perigoso e da instabilidade do emprego. De acordo com um ranking elaborado em 1999, sobre preferências por carreiras, o trabalho na construção civil ficou com a $247^{\circ}$ posição dentre 250 possibilidades de escolha. UWAKWEH (2003)

Algumas das razões para essa percepção negativa podem ser relacionadas à natureza do trabalho, à falta de segurança, às falências de empresas e à falta de profissionalismo entre os trabalhadores. Contribui para isso, segundo UWAKWEH (2003), a mídia americana, que está mais propensa a reportar os acidentes e problemas associados às construções. Muitos relatos são sensacionalistas e contribuem para a persistência da imagem negativa da indústria da construção.

O problema de escassez de mão-de-obra para a construção civil, segundo UWAKWEH (2003), não se justifica apenas pela dificuldade de novos entrantes para compor a força de trabalho, mas também pela saída daqueles que compõem a atual força de trabalho. A maioria dos trabalhadores que entraram no mercado de trabalho entre 1950 e 1960 estão se aproximando de suas aposentadorias. Não bastasse isso, há um crescente número de trabalhadores capacitados, de meia idade, que estão indo para outras indústrias à procura de melhores colocações e estabilidade de emprego. A perda dessa mão-de-obra, em especial, é extremamente prejudicial para a construção civil, por acarretar a perda de experiência no setor.

LISKA; PIPPER (1999) conduziram um trabalho, sob responsabilidade do CII, o qual thes permitiu apontar as seguintes razões para a carência de trabalhadores qualificados na indústria da construção (que atestam as afirmações de UWAKWEH (2003)): i) pequeno número de novos entrantes para compor a força de trabalho, devido, entre outros fatores, às baixas taxas de natalidade; ii) trabalhadores da construção que migram para outras indústrias; iii) leis correntes de imigração.

O Departamento de Trabalho norte americano estima que a indústria da construção necessite, anualmente, de mais de 240 mil trabalhadores para repor as perdas supracitadas. Não há outra saída que não seja o "recrutamento" de jovens para suprir essa demanda, o que trata de uma tarefa bastante dificultosa, haja vista a percepção que esses jovens têm dessa indústria. Uma pesquisa feita com jovens americanos (Seattle Daily Journal of Commerce) sobre oportunidades de carreira mostrou que apenas $16 \%$ indicaram seguir carreira na construção.

LISKA (2002) diz que a criança começa a vislumbrar uma carreira profissional na $5^{\text {a }}$ série e que, nesse momento, muitos fatores contribuem para suas decisões. Além dos conselhos dos pais e professores, contribui aquilo que a criança escuta, lê ou vê, o que, em se tratando da indústria da construção, não é nada estimulante (casos de acidentes; 
má organização e falta de segurança nos canteiros de obras; falta de profissionalismo entre os trabalhadores; dificuldades dos trabalhos a serem desempenhados e más condições dos locais de trabalho; baixos salários e poucos benefícios; falta de prestígio da carreira etc).

Segundo a Organização Internacional do Trabalho (OIT), há evidências, de várias partes do mundo, que indicam que os trabalhadores da construção não vêem seus empregos favoravelmente. VAID (1999) aponta que, na Malásia, a juventude local prefere ficar desempregada a trabalhar na Indústria da Construção Civil, posição justificada pelas práticas arcaicas de emprego, pelo trabalho em ambientes desprotegidos contra as condições climáticas desfavoráveis e pelo uso do trabalho temporário. Em conseqüência disso, a mão-de-obra absorvida pela construção na Malásia provém da Indonésia e, segundo relatórios da OIT de 2002, tal grupo representava $80 \%$ da força de trabalho naquele país.

A mesma situação prevalece nos Estados Unidos, onde é muito comum encontrar trabalhadores hispânicos nos canteiros de obras. A porcentagem desses trabalhadores é maior em estados como a Califórnia e o Texas, que fazem divisa com o México. Alguns contratantes, que trabalham com essa mão-de-obra, acabam tirando vantagem do fato de a maioria desses trabalhadores não terem os documentos autorizando-os a trabalhar legalmente no país.

BOWEN (1996) lembrou que a Espanha tem dificuldades em recrutar mão-de-obra qualificada e jovem para a construção, mesmo frente a taxas de desemprego no país de $12 \%$. Na Inglaterra a situação é parecida e a dificuldade em encontrar jovens dispostos a trabalhar na construção tem levado à entrada de mulheres e "minorias sociais" nesse mercado.

A maioria das famílias, em qualquer parte do mundo, deseja outras opções de carreira para seus filhos. Numa pesquisa conduzida por VAID (1999), foram entrevistados 2600 trabalhadores da construção na Índia, dos quais 90\% disseram aceitar trabalhar na construção civil por não terem outra chance. Na China a opção pelo trabalho na construção está atrás de outras 69 ocupações, situação essa que não é melhor em países como o Quênia e a Nigéria.

Na Inglaterra, MURRAY et al. (2002) aponta que os trabalhadores da construção civil são caracterizados por imagens de sujeira, práticas de trabalho sem segurança, comportamento machista e padrões humanitários insatisfatórios. Essas percepções são reconhecidas como prejudiciais à imagem da indústria da construção e consideradas contribuintes para que grandes setores da construção civil fossem estigmatizados. Isso levou muitos jovens a desconsiderarem a construção civil como carreira profissional.

No entanto, há países, como a Dinamarca e a Suécia, onde, segundo a OIT, o trabalho na construção é bem remunerado, protegido e recompensado. O trabalhador exerce sua atividade mais satisfeito devido à autonomia que the é atribuída, por trabalhar em equipes, ter maior controle sobre o ambiente de trabalho e ter mínima supervisão.

(2003) afirma que o grande desafio a ser encarado pela Indústria da Construção Civil mundial, até a próxima década, será atrair e reter trabalhadores qualificados. Para isso é preciso melhorar sua imagem, o que começa com a mudança de atitudes de cada e qualquer pessoa na profissão. O autor supracitado diz que os trabalhadores da construção, em qualquer nível, podem ajudar a melhorar a imagem do setor, adotando 
posturas como a de ser digno de confiança, manter alto nível de integridade e ser centrado em sua profissão e em sua vida pessoal.

O autor supracitado coloca, ainda, que no estágio seguinte para a melhoria da imagem, os trabalhadores se uniriam para melhorar as empresas onde trabalham, o que incluiria: i) o alinhamento das metas e valores da empresa com as metas e valores dos trabalhadores; ii) o conhecimento das expectativas dos trabalhadores; iii) o desenvolvimento efetivo de programas formais para atrair trabalhadores qualificados; iv) o desenvolvimento efetivo de programas formais para reter equipes com boas produtividades.

O último passo para melhorar a imagem da construção, apresentado por LISKA (2002), seria o de ter-se empresas trabalhando juntas, através de entidades de classe, associações profissionais e outras organizações, para promover a indústria como uma das que oferece significativa e desafiadora carreira para os trabalhadores.

Indivíduos, empresas e organizações estão trabalhando para melhorar a imagem da Indústria da Construção Civil nos Estados Unidos e em outros países. Um dos maiores esforços, nesse sentido, está sendo empreendido pelo Centro Nacional para Pesquisa e Educação na Construção, em Gainesville, Flórida. Uma coalizão de 20 associações nacionalmente reconhecidas tem desenvolvido um amplo esforço para a melhoria da imagem da construção, incluindo programa anual para os ensinos fundamental e médio e o desenvolvimento de um plano de carreira envolvendo plano de treinamento e ações educacionais.

O trabalho de LISKA; PIPPER (1999) resultou na identificação de cinco atributos ${ }^{84}$ fundamentais, necessários para atrair e reter equipes de trabalhadores na construção, que, em ordem de importância, são:

- pagamentos de salários e benefícios competitivos com outras indústrias relacionadas;

- proporcionar trabalhos seguros;

- proporcionar ambiente de trabalho seguro;

- tratar os trabalhadores com justiça e com respeito;

- proporcionar boas condições de trabalho.

$\mathrm{Na}$ Inglaterra, o Departamento de Comércio e Indústria está desenvolvendo um programa, conhecido como "Respect for People" (MURRAY et al. 2002), que visa encorajar a Indústria da Construção Civil inglesa a melhorar a saúde, a segurança e o bem-estar dos operários nos seus novos projetos e, assim, eliminar algumas das imagens negativas associadas ao trabalho e ao trabalhador da construção civil.

\subsubsection{O Papel dos Principais Agentes do Setor de Edificações na Organização do Trabalho}

Ao final do capítulo três chegou-se a um entendimento sobre os principais elementos que deveriam ser preconizados pela organização do trabalho. Como já comentado, esses elementos são de grande importância ao ajudarem na condução segura da organização do trabalho quando o foco são as pessoas envolvidas na produção.

84 Segundo os autores, a idade do trabalhador, os anos de experiência, o tipo e tamanho da empresa, a localização geográfica não fazem diferença na composição dos atributos listados. 
A condução de processo de organização do trabalho, que tenha como objetivo a melhoria da produtividade da mão-de-obra e, por conseguinte, os benefícios dela advindos (e que atendem indivíduos e organização), ainda que orientada a um grupo de trabalhadores de um setor específico, não é tarefa fácil e não deve ser entendida como "obra" bancada por um único agente.

A organização do trabalho, tal como entendida nesta tese, envolve uma pluralidade de ações e a participação de agentes diversos, a começar pelo Governo Federal, na pasta do Ministério do Desenvolvimento e Ação Social, que tem papel importantíssimo na indução da capacitação da força de trabalho, do reconhecimento formal das profissões e do apoio ao trabalhador, entre outros.

Os agentes específicos do setor de construção civil, neste caso representados pelo contratante, projetista, fornecedor, subempreiteiro e operário têm, da mesma forma, e cada um, a sua parcela de contribuição ao conduzir e a efetivar a organização do trabalho.

Dessa forma, por exemplo, o contratante estará colaborando à medida que proporcionar, ao processo de produção, condições físicas (canteiro de obras planejado e orientado à produção), técnico-financeiras (contratações técnicas e não meramente pelo menor preço), sociais (planos de alfabetização do operário, programas de treinamento e capacitação da mão-de-obra etc), gerenciais (implementação de programas de gestão de subempreiteiros) dentre outras, adequadas aos preceitos da organização do trabalho; o projetista, ao elaborar projetos que atentem para a questão da segurança do trabalhador que o executa, por exemplo; o fornecedor, ao se preocupar em dispor as cargas de maneira a facilitar o recebimento de materiais nos canteiros; o subempreiteiro, ao monitorar e provisionar corretamente a mão-de-obra; os operários, ao serem íntegros e dignos de confiança, por exemplo.

Procurar-se-á, a seguir, discutir ${ }^{85}$, à luz de situações reais referentes ao processo de concepção e produção de armaduras, algumas das principais atribuições dos agentes supracitados na condução do processo de organização do trabalho, com base nos principais elementos apontados no capítulo três (visando à melhoria da produtividade da mão-de-obra).

\subsubsection{1}

\section{O Papel da União na Organização do Trabalho}

"o primeiro armador a se manifestar mostrou o desejo de mudar de profissão, de trabalhar para si próprio, mas num outro setor que não o da construção. O descontentamento é creditado ao esforço físico que se faz na obra, que leva o trabalhador à exaustão. Esse pensamento é seguido por quase metade (5 em 13) dos armadores, que dizem estar na construção pela falta de oportunidades fora dela (um dos armadores já foi auxiliar de cozinha e revelou que gostaria de voltar a trabalhar em restaurante). Por outro lado, existem armadores que dizem estar satisfeitos com o trabalho e

${ }^{85}$ Não se tem a intenção de, nesta tese e, especificamente, neste capítulo, esgotar o assunto, ou seja, percorrer, em detalhes, as atribuições de todos agentes no âmbito da organização do trabalho. Mesmo porque se trata de um assunto amplo, controverso em alguns pontos e que, em muitas situações, pode estar amarrado e/ou ser dependente de esforços que estão além do domínio dos agentes e do contexto considerados neste trabalho. Espera-se que os pontos aqui tratados, ainda que não englobem todos os elementos preconizados pela organização do trabalho e apresentados ao leitor no capítulo três, possam servir de argumentos preliminares para fomentar novas e ricas discussões, que deverão ser continuadas em trabalhos futuros, deste e de outros autores. 
posição: "eu criei os meus 5 filhos trabalhando em obra; como é que posso reclamar, falar mal do meu trabalho e da minha vida".

Depoimentos de armadores ao autor em 2003

O desenvolvimento de sistema de classificação ocupacional trata de um passo importante para toda e qualquer nação que deseje melhorar as relações de trabalho, o nível do trabalho e de emprego, bem como tirar da informalidade algumas carreiras que, nessa condição, desmerecem e desmotivam os trabalhadores que compõem sua força de trabalho ou aqueles potenciais candidatos a ingressarem na mesma.

A Classificação Internacional Uniforme de Ocupações (CIUO) constitui uma ferramenta indispensável para a comparação internacional de dados ocupacionais, permitindo sua descrição e apresentação. Foi pensada, também, para que pudesse servir como modelo e inspiração para o estabelecimento de classificações ocupacionais em diversas nações.

A necessidade de estabelecer uma classificação internacional uniforme de ocupações surgiu em 1921, sendo que o primeiro passo concreto para sua realização foi a adoção de uma classificação provisória, sugerida durante a $7^{\text {a }}$ Conferência Internacional de Estatísticos do Trabalho, realizada em 1949, que incluiu 9 grandes grupos ocupacionais. Poucos anos mais tarde, em 1952, a OIT publicou a Classificação Internacional Uniforme de Ocupações para as Migrações e Colocação, em que descrevia detalhadamente 1727 ocupações, a partir de oito classificações nacionais de países industrializados.

A primeira edição da Classificação Internacional Uniforme de Ocupações (CIUO) foi publicada em 1958 e revisada dez anos mais tarde, em 1968. A CIUO 88 (última versão) é uma revisão da versão publicada em 1968. Tal revisão levou em consideração as recomendações das $13^{a}$ e $14^{a}$ Conferências Internacionais de Estatísticos do Trabalho, realizadas em Genebra, em 1982 e 1987 respectivamente, sob a responsabilidade da Organização Internacional do Trabalho (OIT). Muitos países têm desenvolvido suas classificações ocupacionais de acordo com os princípios da CIUO88.

No Brasil, tem-se a Classificação Brasileira de Ocupações (MTE, 2004), que é o documento normalizador do reconhecimento (reconhecimento para fins classificatórios, sem função de regulamentação profissional), da nomeação e da codificação dos títulos e conteúdos das ocupações do mercado de trabalho brasileiro. É, ao mesmo tempo, uma classificação enumerativa e descritiva, entendendo-se que:

- enquanto classificação enumerativa: codifica empregos e outras situações de trabalho para fins estatísticos de registros administrativos, censos populacionais e outras pesquisas domiciliares. Inclui códigos e títulos ocupacionais e a descrição sumária. Também é conhecida pelos nomes de nomenclatura ocupacional e estrutura ocupacional.

- Enquanto classificação descritiva: inventaria detalhadamente as atividades realizadas no trabalho, os requisitos de formação e experiência profissionais e as condições de trabalho.

A função enumerativa da CBO é utilizada em registros administrativos como a Relação Anual de Informações Sociais (RAIS), Cadastro Geral de Empregados e Desempregados (CAGED), Seguro Desemprego, Declaração do Imposto de Renda de Pessoa Física (DIRPF), dentre outros. Em pesquisas domiciliares é utilizada para codificar a ocupação como, por exemplo, no Censo Demográfico, na Pesquisa Nacional por Amostra de Domicílios (PNAD) e outras pesquisas de institutos de estatísticas, como o IBGE e congêneres, nas esferas dos estados e dos municípios. 
A função descritiva da CBO é utilizada nos serviços de recolocação de trabalhadores, como o realizado no Sistema Nacional de Empregos (SINE), na elaboração de currículos e a avaliação de formação profissional, nas atividades educativas das empresas e dos sindicatos, nas escolas, nos serviços de imigração, enfim, em atividades cujas informações do conteúdo do trabalho sejam requeridas.

A nomenclatura ou estrutura da $\mathrm{CBO}$ é o conjunto de códigos e títulos que é utilizado na sua função enumerativa. Trata-se de uma estrutura hierárquico-piramidal composta de: i) 10 grandes grupos (GG);ii) 47 sete subgrupos principais (SGP); iii) 192 subgrupos (SG); iv) 596 grupos de base ou famílias ocupacionais (SG), onde se agrupam 2.422 ocupações e cerca de 7.258 títulos sinônimos.

A estrutura básica da CBO foi elaborada em 1977, resultado do convênio firmado entre o Brasil e a Organização das Nações Unidas (ONU), por intermédio da Organização Internacional do Trabalho (OIT), no Projeto de Planejamento de Recursos Humanos (Projeto BRA/70/550), tendo como base a Classificação Internacional Uniforme de Ocupações (CIUO) de 1968.

Coube a responsabilidade de elaboração e atualização da CBO ao Ministério do Trabalho e Emprego (MTE, 2004), com base legal nas Portarias no 3.654, de 24.11.1977, e no 1.334, de 21.12.1994. É referência obrigatória dos registros administrativos informações sobre os diversos programas da política de trabalho do País. É ferramenta fundamental para as estatísticas de emprego-desemprego, para o estudo das taxas de natalidade e mortalidade das ocupações, para o planejamento das reconversões e re-qualificações ocupacionais, na elaboração de currículos, no planejamento da educação profissional, no rastreamento de vagas dos serviços de intermediação de mão-de-obra.

Desde a sua publicação, a CBO sofreu atualizações pontuais, sem modificações estruturais e metodológicas. A grande novidade do processo descritivo, em relação à CBO anterior, é a descrição de cada família ocupacional por um grupo de 8 a 12 trabalhadores da área, em oficina de trabalho (ou painel) com duração de três dias, sendo dois dias destinados à descrição e um dia de revisão, por outro comitê, também formado por trabalhadores. Ao todo, foram 1.800 reuniões-dia, em vários pontos do Brasil, com a participação de aproximadamente 7 mil trabalhadores.

A outra novidade foi a mudança de filosofia de trabalho na $\mathrm{CBO}$, a partir do desenvolvimento de sua nova base - de uma publicação ocupacional, atualizada pontualmente, em um corte no tempo, publicada em papel. Passou-se à montagem de uma rede de informações organizada em banco de dados, apoiada por um conjunto de instituições conveniadas que atualiza a base, de forma contínua, e incrementa novos desenvolvimentos, sob a coordenação do Ministério do Trabalho e do Emprego (MTE).

As fichas de descrição da CBO2002 estão organizadas por grupo de base ou família ocupacional e trazem informações do tipo das apresentadas na Tabela 4.7, que considera, como exemplo, a família ocupacional 7153 - Montadores de estruturas de concreto armado. 
Tabela 4.7 (continua) - Ficha de descrição da CBO2002, família ocupacional 7153 (Montadores de estruturas de concreto armado). Fonte: MTE, 2004.

\begin{tabular}{|c|c|c|}
\hline Aspectos & & Descrição \\
\hline Títulos & $\begin{array}{l}7153-15 \text { - } \\
\text { ferragens na } \\
\text { construção civ }\end{array}$ & $\begin{array}{l}\text { Idor de estrutura de concreto armado - Armador de } \\
\text { strução civil, Armador de ferros, Ferreiro armador na }\end{array}$ \\
\hline Descrição & $\begin{array}{l}\text { Preparam a c } \\
\text { de prova. Cc } \\
\text { armações de } f\end{array}$ & $\begin{array}{l}\text { cção de armações e estruturas de concreto e de corpos } \\
\text { n e dobram ferragens de lajes. Montam e aplicam } \\
\text { ações, pilares e vigas. Moldam corpos de prova }\end{array}$ \\
\hline $\begin{array}{l}\text { Condições gerais } \\
\text { do serviço }\end{array}$ & $\begin{array}{l}\text { Atuam nas i } \\
\text { assinada. Os } \\
\text { trabalham en } \\
\text { concreto tra } \\
\text { ocasional. O } \\
\text { armadores de } \\
\text { atividades en } \\
\text { grandes altura } \\
\text { prova em usin }\end{array}$ & $\begin{array}{l}\text { strias de construção como assalariados com carteira } \\
\text { ladores de estrutura de concreto e de concreto armado } \\
\text { uipe e o Moldador de corpos de prova em usinas de } \\
\text { a individualmente. Todos atuam com supervisão } \\
\text { balho é realizado a céu aberto, durante o dia. Os } \\
\text { rutura de concreto e de concreto armado realizam suas } \\
\text { osições desconfortáveis durante longos períodos, em } \\
\text { estão expostos a ruído intenso. O Moldador de corpos de } \\
\text { le concreto está sujeito à exposição de materiais tóxicos }\end{array}$ \\
\hline $\begin{array}{l}\text { Formação e } \\
\text { experiência }\end{array}$ & $\begin{array}{l}\text { Para o exercí } \\
\text { sétima séries } \\
\text { profissional cc } \\
\text { pleno das a } \\
\text { profissional }\end{array}$ & $\begin{array}{l}\text { dessas ocupações requer-se escolaridade entre quarta e } \\
\text { ensino fundamental e curso básico de qualificação } \\
\text { carga horária superior a quatrocentas horas. O exercício } \\
\text { ades ocorre após um a dois anos de experiência }\end{array}$ \\
\hline \multirow{13}{*}{ Áreas de } & \multirow{7}{*}{$\begin{array}{l}\text { A. Preparar a } \\
\text { confecção de } \\
\text { armações de } \\
\text { estruturas de } \\
\text { concreto }\end{array}$} & Interpretar projetos de arquitetura e estrutural \\
\hline & & Definir o local de trabalho \\
\hline & & Montar bancadas \\
\hline & & Montar máquinas de corte \\
\hline & & Relacionar materiais para armação de ferragens \\
\hline & & Selecionar vergalhões \\
\hline & & Medir ferragens e armações \\
\hline & \multirow{6}{*}{$\begin{array}{l}\text { B. Cortar } \\
\text { ferragens }\end{array}$} & Analisar medidas das peças para corte \\
\hline & & Esboçar o processo de corte \\
\hline & & $\begin{array}{l}\text { Definir o corte nas barras conforme o comprimento das } \\
\text { peças }\end{array}$ \\
\hline & & Montar gabaritos para corte \\
\hline & & Serrar peças conforme o projeto \\
\hline & & Cortar peças conforme o projeto \\
\hline
\end{tabular}


Tabela 4.6 (conclusão) - Ficha de descrição da CBO2002, família ocupacional 7153 (Montadores de estruturas de concreto armado). Fonte: MTE, 2004.

\begin{tabular}{|c|c|}
\hline Aspectos & Descrição \\
\hline \multirow{17}{*}{$\begin{array}{l}\text { Áreas de } \\
\text { atividades }\end{array}$} & $\begin{array}{l}\text { Analisar as características de armações (ângulos e } \\
\text { medidas) }\end{array}$ \\
\hline & Fixar pinos em bancadas \\
\hline & Montar gabarito para dobragem \\
\hline & Avaliar o diâmetro da ferragem \\
\hline & Posicionar a chave de dobragem (cano ou cantoneira) \\
\hline & Girar a chave de dobragem conforme o ângulo pedido \\
\hline & Identificar as barras de distribuição de armações \\
\hline & Montar barras de distribuição \\
\hline & Emendar barras de distribuição \\
\hline & Marcar espaçamentos de estribos \\
\hline & Fixar os estribos \\
\hline & Posicionar armações conforme gabaritos \\
\hline & Identificar as posições de montagem das vigas \\
\hline & Fixar espaçadores externos às armações \\
\hline & Unir armações de fundações e pilares \\
\hline & Unir armações de vigas e pilares \\
\hline & Amarrar ferragens de lajes em vigas \\
\hline \multirow{6}{*}{$\begin{array}{l}\text { Competências } \\
\text { pessoais }\end{array}$} & 01. Trabalhar em equipe \\
\hline & 02. Demonstrar responsabilidade \\
\hline & 03. Demonstrar iniciativa \\
\hline & 04. Trabalhar em grandes alturas \\
\hline & 05. Reconhecer limitações pessoais \\
\hline & 06. Trabalhar sob pressão \\
\hline $\begin{array}{l}\text { Recursos } \\
\text { trabalho }\end{array}$ & $\begin{array}{l}\text { Policorte; Arco de serra; Trena; Metro; Gesso; Giz para marcação; } \\
\text { Calculadora manual; Equipamentos de proteção individual; Vergalhão; } \\
\text { Arame de aço recozido; Tesourão; Bancadas para montagem das } \\
\text { armações; Guilhotina manual; Guilhotina elétrica; Chave torquesa; Chave } \\
\text { de dobrar ferro; Tubo de aço. }\end{array}$ \\
\hline
\end{tabular}


Nos Estados Unidos, o Departamento de Trabalho, sob responsabilidade do Bureau of Labor Statistics ${ }^{86}$ (BLS), está desenvolvendo o "Sistema de Classificação Ocupacional Padrão" (SOC) em resposta à crescente necessidade de um sistema universal de classificação. O sistema é usado por todas as Agências Federais de Estatísticas na classificação dos trabalhadores dentro das categorias ocupacionais, com o propósito de coletar, calcular e disseminar dados. O sistema é capaz de atender às agências governamentais e à iniciativa privada, servindo a: i) programas governamentais de gestão; ii) jovens no momento da escolha de suas carreiras; iii) pessoas que procuram empregos; iv) treinamento vocacional nas escolas; v) empregadores que desejam ajustar faixas salariais; vi) agências do governo que desejem cruzar informações entre si.

Todos os trabalhadores foram classificados em uma dentre as 820 ocupações definidas. Para facilitar a classificação, as ocupações foram divididas em 23 grupos principais, que reúnem 96 grupos secundários, nos quais estão consideradas 449 macro ocupações, que podem ser, ainda, detalhadas.

Cada item na hierarquia é designado por um código de seis dígitos. Os primeiros dois dígitos do código do SOC representam o grupo principal; o terceiro dígito representa o grupo secundário; os quarto e quinto dígitos representam as macro ocupações, sendo o detalhe dessa ocupação representado pelo sexto dígito. Os códigos dos grupos principais terminam em 0000 (por exemplo, 47-0000, refere-se às ocupações de construção e escavação); os dos grupos secundários terminam em 000 (por exemplo, 47-2000, referem-se aos trabalhadores da construção); e os das macro-operações, em 0 (por exemplo, 47-2170, refere-se aos armadores).

Todos os códigos estão catalogados em um documento denominado "Manual de Previsão Ocupacional", que é uma fonte nacionalmente reconhecida de informação sobre carreiras. Revisado a cada dois anos, o Manual permite ao leitor conhecer alguns aspectos relacionados à ocupação, tais como: i) o tipo de trabalho que é desempenhado; ii) os treinamentos e a educação requeridos para desempenhar o trabalho; iii) possibilidades de melhoria na carreira; iv) faixas salariais; v) o futuro do trabalho numa perspectiva de dez anos; vi) as ocupações relacionadas. Cada indicação da ocupação, ou descrição, segue, no Manual, um formato padrão, facilitando a comparação entre ocupações.

A Tabela 4.8 traz uma caracterização genérica dos aspectos supracitados, bem como um exemplo prático apresentado no "Manual de Previsão Ocupacional" americano para a carreira de armadores (código SOC 47-2171) ${ }^{87}$.

${ }^{86}$ O "Bureau of Labor Statistics" é a principal agência de análise de Mercado do governo Federal na área de economia e estatísticas do trabalho.

87 Nos Estados Unidos, os armadores tanto podem ser os "Ironworkers", responsáveis pela montagem das estruturas metálicas pré-fabricadas, como os "Reinforcing iron and rebar workers", que são responsáveis pela confecção e montagem das armaduras das estruturas de concreto armado. 
Tabela 4.8 (continua) - Descrição dos aspectos contemplados no "Manual de Previsão Ocupacional" quanto aos armadores. Fonte: BLS (2004)

\begin{tabular}{|c|c|}
\hline $\begin{array}{l}\text { As } \\
\text { cons }\end{array}$ & Exemplo para os Armadores \\
\hline $\begin{array}{l}\text { PONTOS } \\
\text { SIGNIFICATIVOS }\end{array}$ & $\begin{array}{l}\text { Muitos empregadores recomendam entre } 3 \text { a } 4 \text { anos de experiência. } \\
\text { Durante períodos de crise econômica, os trabalhadores podem enfrentar } \\
\text { altos índices de desemprego. } \\
\text { O risco de acidentes durante o trabalho é alto; todos aqueles que trabalham } \\
\text { em grandes alturas, expostos a intempéries, não trabalham com chuvas } \\
\text { torrenciais e demais condições climáticas extremas. }\end{array}$ \\
\hline $\begin{array}{l}\text { Tipo de trabalho } \\
\text { que é } \\
\text { desempenhado }\end{array}$ & $\begin{array}{l}\text { Os armadores montam as armaduras nas fôrmas que irão receber concreto, } \\
\text { seguindo desenhos de detalhamento que mostram a localização, o tamanho } \\
\text { e o número de barras. Eles unem as barras através de amarrações (nós ou } \\
\text { pontos) usando para isso arames, pontos de solda etc. Eles também } \\
\text { colocam espaçadores nas barras que estarão em contato com as fôrmas, } \\
\text { garantindo o distanciamento entre ambos. Quase sempre o material chega } \\
\text { pronto para o uso, sendo que, ocasionalmente, os armadores precisam } \\
\text { cortar as barras usando serras ou maçaricos, ou dobrá-las, usando, para } \\
\text { isso, ferramentas manuais ou máquinas especiais. Alguns elementos } \\
\text { prevêem o uso de armaduras pré-fabricadas; nesses casos os armadores } \\
\text { apenas cortam e posicionam as armaduras. A pós-tensão trata-se de uma } \\
\text { outra técnica usada no concreto armado. Nessa técnica, os armadores } \\
\text { substituem as barras por cabos; após a concretagem e cura do concreto, os } \\
\text { cabos são tensionados, com equipamentos especialmente projetados para } \\
\text { este propósito. Essa técnica permite que sejam projetadas lajes com } \\
\text { grandes vãos, sendo usualmente empregadas em lajes de garagens e em } \\
\text { lajes de edifícios comerciais. }\end{array}$ \\
\hline
\end{tabular}

Os armadores trabalham, usualmente, expostos a todos os tipos de condições climáticas. Em razão disso, em condições adversas precisam interromper o seu trabalho. Por causa dos riscos de acidentes (como

\section{AMBIENTE DE TRABALHO}

Treinamento e a educação requeridos para desempenhar 0 trabalho quedas de grandes alturas), os armadores usam cintos de segurança (do tipo pára-quedista) e outros equipamentos para minimizar os riscos.

Alguns armadores trabalham em locais protegidos, como fábricas de beneficiamento de aço. Esses armadores são denominados montadores e recebem uma outra classificação.

Muitos dos empregadores recomendam de três a quatro anos de aprendizagem, através de treinamento em campo, complementadas por aulas teóricas (instruções). Programas de treinamento e capacitação são, geralmente, administrados por comitês formados por representantes das uniões locais da Associação Internacional de Armadores ou por divisões locais das associações de contratantes.

Os armadores devem ter idade mínima de 18 anos. O diploma do ensino médio é recomendado pelos empregadores e pelos comitês locais de treinamento e capacitação. Cursos profissionalizantes, com ênfase em matemática, desenho mecânico e detalhamento são importantes. Pelo fato de os materiais manuseados serem pesados, os armadores precisam ter boas condições físicas. Eles também precisam ter boa agilidade, visão e percepção de profundidade para trabalharem em grandes alturas e em regiões periféricas (bordas) das edificações. Os armadores não devem ter medo de altura. 
Tabela 4.7 (continua) - Descrição dos aspectos contemplados no "Manual de Previsão Ocupacional" quanto aos armadores. Fonte: BLS (2004)

\begin{tabular}{|c|c|}
\hline $\begin{array}{c}\text { Aspectos } \\
\text { considerados }\end{array}$ & Exemplo para os Armadores \\
\hline $\begin{array}{l}\text { Treinamento e a } \\
\text { educação } \\
\text { requeridos para } \\
\text { desempenhar o } \\
\text { trabalho }\end{array}$ & $\begin{array}{l}\text { Nas aulas, os aprendizes estudam leitura de projeto, matemática, conceitos } \\
\text { estruturais básicos (como a função dos elementos estruturais), técnicas das } \\
\text { operações etc. Eles também aprendem a utilizar, com segurança, os } \\
\text { equipamentos. No canteiro, os aprendizes trabalham em todas as } \\
\text { operações, desde o recebimento e estocagem dos materiais, passando pela } \\
\text { movimentação com o uso da grua e chegando à montagem das armaduras. } \\
\text { Alguns armadores aprendem a profissão informalmente, no canteiro. Esses } \\
\text { armadores, normalmente, não recebem treinamentos em classe, com } \\
\text { exceção dos que trabalham para grandes contratantes que possuem } \\
\text { extensivos programas de treinamento. No treinamento em campo, } \\
\text { começam assistindo os armadores em tarefas simples, como o transporte } \\
\text { de materiais. À medida que vão adquirindo experiência, vão sendo } \\
\text { delegadas tarefas mais complexas, como medir e cortar peças de diferentes } \\
\text { tamanhos. Por outro lado, o aprendizado através da experiência adquirida } \\
\text { em campo, de forma independente, talvez não proporcione o treinamento } \\
\text { completo ofertado por um programa, levando muito mais tempo a capacitar } \\
\text { um armador para o exercício do seu ofício. } \\
\text { Alguns armadores mais experientes são promovidos a supervisores. Outros } \\
\text { podem ir na direção de abrirem suas próprias empresas. }\end{array}$ \\
\hline Salários & $\begin{array}{l}\text { Em } 2002 \text { a média salarial horária para os armadores foi de } \$ 17.66 \text { (a média } \\
\text { dos demais profissionais que atuam no demais serviços ligados à execução } \\
\text { das estruturas foi de } \$ 19.55 \text { ). Os valores médios se situaram numa faixa que } \\
\text { vai de } \$ 12.72 \text { a } 25.74 \text {. A média dos valores mais baixos ( } 10 \% \text { inferiores) foi } \\
\text { de } \$ 10.07 ; \text {; a média dos valores mais altos ( } 10 \% \text { superiores) foi de } \$ 31.40 \text {. } \\
\text { Muitos desses trabalhadores são membros da "International Association of } \\
\text { Bridge, Structural, Ornamental, and Reinforcing Iron Workers". De acordo } \\
\text { com a união, a média horária, incluindo benefícios, dos trabalhadores que } \\
\text { pertencem à Associação e trabalham em tempo integral foi } 34 \% \text { superior à } \\
\text { média dos trabalhadores que não fazem parte da Associação. Armadores } \\
\text { que trabalham em Nova Iorque, Boston, São Francisco, Chicago, Los } \\
\text { Angeles, Filadélfia e outras grandes cidades têm médias salariais mais altas. } \\
\text { Aprendizes, geralmente, começam ganhando } 50 \text { a } 60 \% \text { dos valores pagos } \\
\text { aos trabalhadores mais experientes. Ao longo do curso de aprendizagem, } \\
\text { assim que vão adquirindo habilidades para o serviço, recebem aumentos nos } \\
\text { salários, que vão se aproximando dos valores pagos aos mais experientes. } \\
\text { Os ganhos dos armadores podem ser reduzidos em certas ocasiões, em } \\
\text { razão do trabalho estar limitado por condições climáticas, trabalhos de } \\
\text { curto-prazo e períodos desfavoráveis da economia. }\end{array}$ \\
\hline Empregabilidade & $\begin{array}{l}\text { Os armadores assumiram aproximadamente } 107.000 \text { postos de trabalho em } \\
\text { 2002. Quatro em cada cinco trabalhadores da construção trabalham em } \\
\text { atividades ligadas às estruturas. Os armadores são empregados em todas as } \\
\text { partes do país, porém a maioria dos empregos é disponibilizada nas regiões } \\
\text { metropolitanas, onde as edificações comerciais e industriais são mais } \\
\text { comuns. }\end{array}$ \\
\hline
\end{tabular}


Tabela 4.7 (conclusão) - Descrição dos aspectos contemplados no "Manual de Previsão Ocupacional" quanto aos armadores. Fonte: BLS (2004)

\begin{tabular}{|c|c|}
\hline $\begin{array}{l}\text { Aspectos } \\
\text { considerados }\end{array}$ & Exemplo para os Armadores \\
\hline \multirow{4}{*}{$\begin{array}{l}\text { Futuro } \\
\text { trabalho }\end{array}$} & $\begin{array}{l}\text { É esperado um crescimento no número de emprego de armadores, numa } \\
\text { mesma velocidade de crescimento da média das demais ocupações até o ano } \\
\text { de } 2012 \text {. Este crescimento está baseado na continuidade do crescimento da } \\
\text { construção comercial e industrial. }\end{array}$ \\
\hline & $\begin{array}{l}\text { Os trabalhos de recuperação, manutenção e reformas de um grande número } \\
\text { de edifícios, fábricas, pontes, rodovias etc é esperado e deverá contribuir } \\
\text { para o aumento das oportunidades de emprego. }\end{array}$ \\
\hline & $\begin{array}{l}\text { Em adição aos novos empregos, outras vagas deverão surgir em razão da } \\
\text { necessidade de repor os armadores mais experientes que se transferem para } \\
\text { outras ocupações ou deixam a força de trabalho. }\end{array}$ \\
\hline & $\begin{array}{l}\text { O número de empregos abertos varia ano a ano em função das condições } \\
\text { econômicas e do nível das atividades de construção. Durante os períodos de } \\
\text { recessão econômica, os armadores podem experimentar altas taxas de } \\
\text { desemprego. Similarmente, oportunidade de trabalho para armadores pode } \\
\text { variar em razão das localidades geográficas. A oferta de emprego para os } \\
\text { armadores é mais abundante durante os meses de primavera e verão, } \\
\text { quando o nível das atividades de construção aumenta. }\end{array}$ \\
\hline $\begin{array}{l}\text { Ocupações } \\
\text { relacionadas }\end{array}$ & $\begin{array}{l}\text { Armadores e demais trabalhadores (montadores e fabricantes, engenheiros, } \\
\text { acabadores de concreto, carpinteiros etc) que desenvolvem atividades } \\
\text { ligadas às estruturas são essenciais para o setor de construção. }\end{array}$ \\
\hline \multirow{6}{*}{$\begin{array}{l}\text { Informações } \\
\text { adicionais }\end{array}$} & $\begin{array}{l}\text { Para maiores informações sobre programas de capacitação e oportunidade } \\
\text { de trabalho contacte a sede local da "International Association of Bridge, } \\
\text { Structural, Ornamental, and Reinforcing Iron Workers Union", da } \\
\text { "Ironworkers' joint union-management apprenticeship committee", do } \\
\text { "State chapter of the Associated Builders and Contractors or the Associated } \\
\text { General Contractors" ou, ainda, do escritório mas próximo da agência de } \\
\text { empregos do seu estado. }\end{array}$ \\
\hline & Para informações sobre cursos, contacte: \\
\hline & $\begin{array}{l}\text { International Association of Bridge, Structural, Ornamental, and Reinforcing } \\
\text { Iron Workers, Apprenticeship Department, } 1750 \text { New York Ave. NW., Suite } \\
\text { 400, Washington, DC } 20006 \text {. }\end{array}$ \\
\hline & $\begin{array}{l}\text { Para informações gerais sobre armadores contacte as seguintes } \\
\text { associações: }\end{array}$ \\
\hline & $\begin{array}{l}\text { Associated Builders and Contractors, Workforce Development Department, } \\
4250 \text { North Fairfax Dr., 9th Floor, Arlington, VA } 22203 .\end{array}$ \\
\hline & $\begin{array}{l}\text { Associated General Contractors of America, } 333 \text { John Carlyle St., Suite 200, } \\
\text { Alexandria, VA 22314. Internet: http://www.agc.org }\end{array}$ \\
\hline
\end{tabular}

O sistema norte-americano de classificação das ocupações começou a ser desenvolvido em 1999 e, dentro de um programa de implantação evolutivo, deverá estar concluído em 2006.

Dentre as várias virtudes desse sistema, aquela que mais chama atenção é o reconhecimento do trabalhador através do reconhecimento formal da sua profissão. Como se evidenciou na Tabela 4.8, mais que clarificar, para qualquer pessoa, o conteúdo e o contexto de trabalho de ocupações como, por exemplo, a dos armadores da construção civil, o sistema norte-americano apresenta variações nos níveis de emprego 
ao longo dos anos, traça perspectivas de trabalho, apresenta faixas salariais detalhadas por regiões (estados norte-americanos) etc. São, ainda, inúmeros os dados estatísticos disponibilizados que retratam desde características demográficas da força de trabalho a projeções de emprego por ocupação.

É claro o empenho do Governo Norte-Americano na melhoria das condições do emprego e empregabilidade, sendo ele, o Estado, o agente precursor e, por vezes, facilitador da gestão e organização do trabalho. Questões como a remuneração, jornadas de trabalho, habilidades e treinamento requeridos etc, são tratados em âmbito nacional, a partir de bases conhecidas e amplamente divulgadas. A existência de sindicatos dos trabalhadores por carreira, como é o caso do Sindicato dos Armadores, corrobora também para que o trabalhador, nesse exemplo, o armador norte-americano, não fique à mercê de imposições patronais, tendo respaldo governamental e sindical para conhecer e conquistar seus direitos.

Para BATLOUNI NETO (2003), o pior inimigo do posto de trabalho no Brasil é a rotatividade da mão-de-obra, "pois ela tira da empresa o estímulo de investir em treinamento e qualificação dos trabalhadores, fazendo com que caia a qualidade deste posto de trabalho". Para o autor, antes de priorizar a geração de emprego, é necessário e fundamental melhorar a qualidade do posto de trabalho através da diminuição da rotatividade da mão-de-obra.

Nesse sentido, reformas trabalhistas tratadas no âmbito do governo federal são tidas como essenciais para a correção de uma série de distorções que vêm incidindo sobre o contratante (empregador) e, por conseqüência, sobre o contratado (empregado).

BATLOUNI NETO (2003) enxerga que a reforma trabalhista deva contemplar os seguintes pontos:

- necessidade de contratos de trabalho mais flexíveis, que dêem espaço de manobra para as empresas e sindicatos em momentos de baixo faturamento e, também, que levem em consideração as características da construção (diminuição de direitos e deveres; flexibilização da jornada de trabalho; sistema "lay off", em que a empresa mantém o vínculo com o funcionário demitido para recontratá-lo);

- diminuição dos encargos relativos à decisão de demitir ou admitir (fazendo referência à suposta experiência norte-americana);

- desoneração dos encargos relativos às ocupações com nível superior (engenheiros e arquitetos);

- término da equiparação salarial (funcionários mais produtivos deveriam receber mais).

\subsection{O Papel do Contratante na Organização do Trabalho}

Ao contratar o projeto estrutural, o contratante pode passar ao projetista diretrizes de projeto que o orientem na concepção estrutural, de maneira que aspectos referentes à exeqüibilidade do projeto (segurança durante a execução e construtibilidade, dentre outros) sejam considerados, induzindo arranjos organizacionais (como, por exemplo, ao permitir que uma dada solução executiva seja executada com um menor contingente de mão-de-obra) mais favoráveis à produtividade.

Para FABRÍCIO, MELHADO (1998), o ideal é que haja uma parceria entre o contratante e o projetista estrutural que, por sua vez, deve estar embasada numa ligação de 
competência técnica e intercâmbio de informações na busca da melhoria contínua do processos de produção e qualidade do produto.

BATLOUNI NETO (2003) afirma que a parceria entre o projetista estrutural e o contratante torna-se mais sedimentada à medida que se repete por diversos trabalhos. "Como conseqüência, obtém-se um processo de melhoria contínua na busca de um detalhamento cada vez mais adequado, com crescente potencial produtivo".

O contratante é, geralmente, quem toma todas as decisões sobre os recursos físicos e sua disponibilização no canteiro de obras. No caso específico do sistema de armação, os recursos, tal como visto no capítulo 2, podem assumir diferentes configurações no canteiro de obras, o que implica em formas de organização do trabalho distintas. Ao se decidir trabalhar, por exemplo, com aço beneficiado (cortado e dobrado) em relação ao aço fornecido em barras, o contratante deve saber que a organização do trabalho deverá contemplar uma série de fatores intrínsecos à opção escolhida, para que se consiga absorver todo o potencial de racionalização oferecido pelo aço cortado e dobrado.

O exemplo supracitado chama a atenção para o fato de que as decisões tomadas pelo contratante, que configuram seus sistemas de armação, têm implicações diretas na organização do referido trabalho. Ao tomar decisões, que muitas vezes são baseadas no custo direto da opção escolhida, o contratante precisa antever as implicações (como as produtividades esperadas) que tais decisões terão sobre o processo de produção. Fazendo isso terá mais chances de dimensionar corretamente o sistema e obter o melhor desempenho possível do processo de produção.

O subitem seguinte trata de ponto bastante importante, qual seja, a questão da gestão da mão-de-obra subempreitada pelo contratante.

\subsection{A Gestão do subempreiteiro}

FREIRE (2001) apontou que $80 \%$ da mão-de-obra envolvida no trabalho de armação de estruturas de concreto pertencia a empresas subempreitadas. ARAÚJO, SOUZA (2003) constataram, em um conjunto de levantamentos feitos em canteiros de obras na cidade de São Paulo, que $100 \%$ das construtoras utilizavam mão-de-obra subempreitada para executarem as estruturas de concreto armado e, por conseguinte, o serviço de armação.

Seja a subcontratação entendida como uma estratégia competitiva adotada pelas empresas de construção ((ECCLES, 1981); (BEARDSWORTH，1988); (HILLEBRANDT, 1990); (FURUSAKA, 1991); (FARAH, 1993); (VILLACRESES, 1994); (CARDOSO, 1996a); (REIS, 1998); (BRANDLI, 1998); (SERRA, 2001); (MDIC, 2002); OHNUMA, 2003), seja um caminho "natural", haja vista as particularidades do setor de construção de edificações que favorecem a sua adoção ((ECCLES, 1981); (HILLEBRANDT, 1990); (FARAH, 1993); (VILLACRESES, 1994); (CARDOSO, 1996a); (BRANDLI, 1998); (KALE; ARDITI, 2001) E (MILLER; PACKHAM; THOMAS, 2002); OHNUMA, 2003), tem-se percebido que a força de trabalho responsável pela execução das estruturas de concreto armado pertence, na maioria dos casos, a empresas subcontratadas (PROVERBS et al. 1999; TOMAS, 2001; ARAUJO, 2003).

O panorama do atual mercado do subsetor de edificações da Região Metropolitana de São Paulo, segundo OHNUMA (2003), favorece tal estratégia de atuação, haja vista a acentuada ênfase na busca, pelas médias e grandes empresas, em coordenar e gerenciar a produção e na especialização dos serviços pelas pequenas empresas ou subempreiteiras. 
OHNUMA (2003) enfatiza que, "diante da escolha pela utilização da mão-de-obra subempreitada, ou até anteriormente à opção pela estratégia da subcontratação, a empresa construtora precisa ter consciência de quais são as atividades administrativas, gerenciais e operacionais que devem estar envolvidas neste trabalho conjunto. Essa gestão normalmente envolve vários subempreiteiros que, na maioria das vezes, atuam simultaneamente em mais de uma obra".

O mesmo autor aponta, ao citar HINZE; TRACEY (1994); SHASH (1998) e KUMARASWAMY; MATTHEWS (2000), que o grande problema é que o estudo dos processos de gestão de subempreiteiros, no que se refere especificamente à identificação das atividades a serem desenvolvidas pelas empresas construtoras, tem sido pouco explorado por pesquisadores da área do gerenciamento da construção.

Ao fazer uma revisão dos trabalhos que tratam das atividades que devem ser desempenhadas pelas construtoras na gestão dos subempreiteiros, OHNUMA (2003) destaca, no Brasil, o trabalho de SERRA (2001) que enfoca, principalmente, os processos de seleção, avaliação, formalização da contratação e organização desses agentes no canteiro de obras (organização essa, situada na interface subempreiteiro/construtora), e VILLACRESES (1994); BRANDLI (1998) que descrevem algumas recomendações para a gestão dos subempreiteiros, enfatizando os aspectos a serem observados em torno da seleção para contratação, da pré-qualificação, da gestão de cadastro e da avaliação de desempenho.

OHNUMA (2003) cita, no panorama internacional, os trabalhos de MAHER (1982), ABDEL-RAZEK; MCAFFER (1987), COOMBS; PALMER (1989), FURUSAKA (1991), GIAMMUSSO (1991), ASHFORD (1992), HINZE; TRACEY (1994), CALVERT et al. (1995), OLSSON (1998), SHASH (1998), ISATTO (1996), KUMARASWAMY; MATTHEWS (2000), que destacam as seguintes atividades de gestão dos subempreiteiros a serem desempenhadas pelos contratantes: a) planejamento e orçamento da obra; b) seleção para contratação de fornecedores; c) avaliação inicial ou pré-qualificação de fornecedores; d) gestão do cadastro de fornecedores; e) controle da qualidade do serviço; f) avaliação e qualificação de fornecedores; g) medição do serviço; $h$ ) pagamento do serviço; i) gestão do contrato; j) treinamento da mão-de-obra; k) contratação; I) planejamento e programação.

OHNUMA (2003) propõe um modelo de gestão dos subempreiteiros por processos (MPGSEs), em que há três grandes ações ou macroprocessos que devem ser executados por uma empresa construtora para uma gestão eficiente da mão-de-obra subempreitada: i) processo de planejamento; ii) processo de contratação; iii) processo de gerenciamento. Atrelados a esses macroprocessos de gestão, OHNUMA (2003) identificou 14 (quatorze) processos tidos como fundamentais pelo MPGSEs, conforme ilustrado na Figura 4.29. Salienta ainda que, especificamente o processo de Planejamento e Programação tem um papel fundamental na gestão dos subempreiteiros, pois estabelece as rotinas de controle da produção. "Trata-se de um processo central que troca informações com quase todos os outros para: planejar ou definir metas para produção; ajustar a produção e o fluxo financeiro ao prazo da obra; balancear as equipes de produção e acompanhar o andamento da obra (ou as ações dos subempreiteiros) através de um ciclo de programação e monitoramento da produção". 


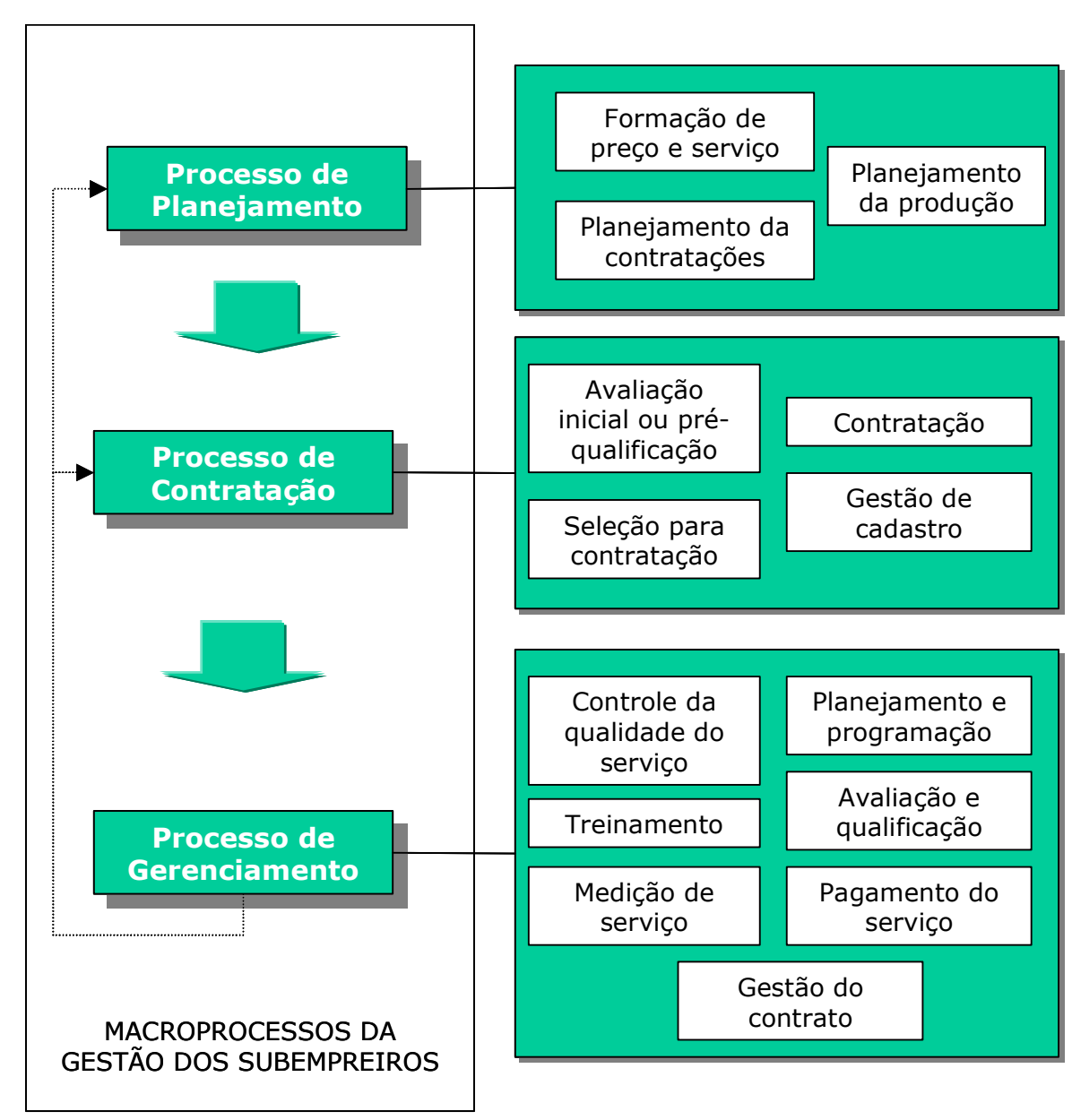

Figura 4.29 - Esquema do modelo de gestão dos subempreiteiros. Fonte: OHNUMA (2003).

Os processos contemplados pelo modelo de gestão dos subempreiteiros proposto por OHNUMA (2003) estão fortemente relacionados às áreas administrativas e se situam na interface entre os agentes. A gestão do processo de planejamento e programação, da forma como foi proposta, é a que mais se aproxima e interage com a produção propriamente dita, ainda que citando mais as atividades do que descrevendo uma operacionalização.

O autor propõe a elaboração de um "plano de qualidade do subempreiteiro", em que se deveriam contemplar informações e/ou diretrizes para uma "gestão eficiente do subempreiteiro escolhido", dentre as quais: a) auxílio ao subempreiteiro no balanceamento ou equalização das equipes de produção; b) definição de responsabilidades entre as partes; c) definição da freqüência e local das reuniões de planejamento e programação, assim como do formato e meio de circulação das informações (formulários, fax, e-mail etc.); d) fixação de objetivos e datas previstas de treinamento; e) estabelecimento de procedimentos executivos, normas técnicas e/ou especificações/projetos que devem ser atendidos pelo subempreiteiro; f) elaboração de cronograma de execução do serviço etc. 
As se analisarem as empresas subempreiteiras e a força de trabalho que elas absorvem, perceber-se-á que, em sua grande maioria, tratam-se de pequenas empresas caracterizadas (FARAH，1993; VILLACRESES, 1994; CARDOSO, 1996a; REIS, 1998; BRANDLI, 1998; SERRA, 2001), basicamente, por apresentarem: i) baixo nível educacional em todos os níveis; ii) baixa capacidade gerencial; iii) baixa capitalização.

A necessidade de redução de custos da construção, imposta pelo mercado, tem reflexos penosos sobre esses subempreiteiros. BATLOUNI NETO (2003) tem percebido que o subempreiteiro, "por ser o elo mais fraco da cadeia", está arcando com grande parte do ônus de reduzir o custo de construção através da redução do seu preço. O seu despreparo administrativo/financeiro durante a formação de preço, somado às pressões do contratante, têm levado o subempreiteiro a determinar preços para serviços que estão abaixo dos valores mínimos necessários para que consiga honrar o pagamento de sua folha e ainda ter algum lucro.

Do lado do contratante, as práticas de contratação dos subempreiteiros enfatizam o lado comercial, visando, preferencialmente, o menor custo em detrimento à consideração de aspectos técnicos (por exemplo, a ponderação, no momento da contratação de subempreiteiros, quanto à existência de um corpo técnico mais capacitado).

Diante desse cenário, BATLOUNI NETO (2003) identifica, como fundamental, que as construtoras monitorem seus subempreiteiros, orientando-os na formação de preços e em programas e ações que busquem o incremento da produtividade.

A formação equivocada de preços pelos subempreiteiros pode levá-los, numa situação extrema, à falência e acarretar prejuízos significativos para a empresa contratante. Um dos maiores problemas sofridos por empresas na cidade de São Paulo tem sido o abandono da obra pelo subempreiteiro, tendo a construtora que se responsabilizar legal e financeiramente pelos trabalhadores da mesma.

Uma formação de preços mais próxima da situação real de obra deve contemplar, de maneira resumida, um número suficiente de trabalhadores para desempenharem serviço, com características especificas, em prazo pré-determinado.

As deficiências no processo de formação de preços pelos subempreiteiros não podem ser justificadas apenas pela baixa capacitação gerencial e administrativa dos mesmos. Um subempreiteiro tecnicamente capaz que resolvesse usar um manual de orçamentação, como as Tabelas de Composições de Preço para Orçamento (TCPO), para compor seus custos, poderia, ainda assim, enfrentar sérios problemas.

Para SOUZA (2001), ao se dispor de uma única fonte para formar o preço (compor um orçamento), "corre-se o risco de eventuais defeitos da mesma passarem desapercebidos". O autor justifica sua colocação citando que "quando se comparam os manuais americanos, depara-se com diferenças nada desprezíveis, algumas vezes geradas por diferenças tecnológicas próprias de diferentes regiões, por diferenças de concepção na abordagem dos indicadores, ou mesmo devido a inadequações dos valores. A percepção de tais diferenças induz um cuidado maior, de parte do usuário da informação, bem como, provavelmente, incentiva uma reavaliação dos números propostos por parte dos geradores dos manuais".

O autor supracitado foi o responsável por uma readequação do principal manual de orçamentação brasileiro, o TCPO, que, em 2003, na sua $10^{a}$ edição, passou a contemplar réguas de produtividade como ferramenta para auxiliar o usuário na composição de preços de serviços. Os valores apontados nas réguas foram frutos de extensas pesquisas 
de campo (ARAUJO, 2000; LIBRAIS, 2001; SILVA, 2002; MAEDA, 2002), que levantaram dados reais de produtividade da mão-de-obra para os principais serviços presentes nas obras de edifícios.

A melhoria dos manuais de orçamentação, com dados mais próximos da realidade do setor, não é condição suficiente para que o processo de formação de preços pelo subempreiteiro melhore.

A forma empírica de formação de preços, respaldada no conhecimento do subempreiteiro, é prática comum e bastante utilizada no setor.

A mesma sistemática adotada nos levantamentos supracitados, que permitiu "revigorar" - TCPO, pode e tem sido usada por construtoras como instrumento de gestão da produção. Essas empresas perceberam que incremento da produtividade nas obras de construção é, sem dúvida, um dos principais artifícios para a redução de custo. Mais que isso, as contratantes têm percebido que devem fomentar e induzir programas de melhoria da produtividade dos subempreiteiros, criando um círculo virtuoso que as beneficie e Ihes permita compartilhar os benefícios com os seus subempreiteiros e, esses, com os operários.

Constatações já comentadas, quanto ao despreparo do subempreiteiro e à baixa qualificação da sua mão-de-obra, têm sido usadas para justificar supostas baixas qualidades dos serviços prestados e altos consumos de recursos físicos (expressos por má produtividade da mão-de-obra, elevadas taxas de desperdício etc) no setor da construção civil.

Porém, os mais recentes trabalhos (ARAUJO, 2000; SOUZA, 2001; THOMAS et al. 2002) sobre mensuração e análises quanto à eficiência no uso de recursos na construção civil (Brasil, Croácia, Turquia) não têm correlacionado "fatores" ligados à qualificação da mãode-obra (níveis de escolaridade, cargas e qualidade de treinamento etc) à variabilidade dos indicadores de produtividade encontrados.

Tem-se levantado níveis de eficiência no uso de recursos, em obras de construção de edifícios em países em desenvolvimento, tão bons, ou melhores, que números divulgados por países desenvolvidos que, em teoria, possuem melhor qualificação da sua força de trabalho.

No entanto, acredita-se que a constatada variabilidade dos indicadores de produtividade de obras de construção de edifícios (SOUZA, 2001), prejudicial ao desempenho de subempreiteiros e contratantes, possa ser minimizada ao se aumentar a sinergia e a cooperação entre esses agentes no âmbito da organização do trabalho.

A desprovida capacidade, nos campos gerencial e organizacional, dos subempreiteiros no canteiro de obras, impossibilita-os, muitas vezes, de atuarem para minimizar problemas relacionados tanto a aspectos ligados ao conteúdo do trabalho (por exemplo, a baixa construtibilidade apresentada em alguns projetos de produto), quanto ao contexto do mesmo (por exemplo, a ociosidade e falta de motivação dos operários), esses sim, responsáveis pela variabilidade comentada que acomete e prejudica o setor e, sobre os quais, o contratante é, na maioria das vezes, no mínimo, co-responsável.

Assim sendo, o apoio sistematizado e formalizado dos contratantes aos subempreiteiros é essencial. Nesse espírito, algumas experiências nacionais, em que as empresas construtoras entenderam a importância de olhar "para dentro" da produção, enxergando o subempreiteiro como um parceiro que "carece de ajuda para poder ajudar", têm sido plenamente satisfatórias e serão devidamente comentadas neste trabalho. 


\subsection{O Papel dos Projetistas na Organização do Trabalho}

SAMPAIO (2002) entende que a deficiência de projetos ocasiona riscos na execução da obra. Parte destes riscos pode incidir sobre aspectos relacionados à organização do trabalho como, por exemplo, a segurança do trabalhador e as avaliações de desempenho entre outros.

GRILO (2002) vê que o estabelecimento de uma parceria ${ }^{88}$ "pode implementar a cooperação no empreendimento, proporcionando aumento da produtividade, redução das disputas e a introdução de inovações tecnológicas". As modalidades de parceria podem enfatizar a criação de sinergia entre os participantes, o processo de gerenciamento, a formação de equipes com objetivos comuns. O autor supracitado cita as vantagens potenciais das parcerias: maior segurança nos canteiros, redução dos prazos e custos de execução, consonância com orçamento e cronograma, diminuição das reivindicações e melhoria na imagem pública.

Para BRADBURN (1995), as parcerias podem facultar aos arquitetos o retorno ao canteiro de obras. Um autor cita o exemplo de um empreendimento viabilizado por meio do estabelecimento de uma parceria entre arquiteto, construtor e empreendedor. Reivindicações constantes e alterações de projeto comprometiam os resultados. "O processo foi difícil. Requisitou um comprometimento intenso por todas as partes e reforçou a necessidade de os arquitetos assumirem um papel importante na solução dos problemas relacionados com a construção".

Em virtude de um conjunto de fatores, tal como a formação profissional, os arquitetos brasileiros enfocam, preponderantemente, a qualidade do produto, colocando o controle físico e financeiro, requisitos fundamentais para o cliente, em um segundo plano. Os engenheiros, por sua vez, focalizam a economia, a segurança e a eficiência produtiva. As visões não devem ser excludentes, porém complementares. Os profissionais consultados reforçaram que o enfoque na qualidade do desenho arquitetônico deve incorporar a ótica econômica, com o propósito de atender, simultaneamente, às expectativas dos clientes, projetistas, construtores e usuários.

A segurança construtiva deve ser tratada, portanto, na proposta arquitetônica, validada pelos pareceres dos demais profissionais envolvidos nesta fase do empreendimento. Após esta fase, o projetista estrutural, embora limitado pela arquitetura quanto às soluções estruturais que poderá adotar, deverá continuar atento para questões relativas à segurança da estrutura a ser executada. A geometria das peças e o seu posicionamento devem estar condizentes com as técnicas executivas apontadas e discutidas pelo cliente (que pode e deve contar, neste momento, com a assessoria técnica de profissionais especializados bem como dos próprios executores) como factíveis do ponto de vista técnico e econômico.

Ainda sob o ponto de vista da organização do trabalho, os projetos devem possuir um nível de detalhamento e uma padronização nas formas de representação do detalhamento de tal forma que a mão-de-obra responsável por executá-los consiga compreendê-los sem que, para isso, sejam necessárias demasiadas intervenções da engenharia. Projetos com níveis de detalhamento insuficientes podem demandar equipes

88 As parcerias designam um "conjunto de práticas destinadas à promoção de uma maior cooperação entre os agentes envolvidos no empreendimento" (BARLOW et al., 1997). 
com um número maior de profissionais mais capacitados e, portanto, mais caros, para compreendê-los e executá-los.

\subsubsection{4 \\ O Papel dos Fornecedores na Organização do Trabalho}

O papel desempenhado pelos fornecedores de aço, neste caso especificamente do aço cortado e dobrado, tem afetado significativamente a organização do trabalho nos canteiros de obra. Conforme já discutido no item que versou sobre a influência do método de trabalho na produtividade da mão-de-obra, as operações de recebimento (que envolve a conferência, descarregamento e estocagem do aço no canteiro) do aço pronto fazem uso intensivo da mão-de-obra, mesmo quando há equipamentos auxiliando tal operação.

Os carregamentos de aço nos pátios das fábricas, quando feitos com total isenção de responsabilidades sobre o descarregamento a ser realizado nos canteiros de obras, provocam: i) sobreconsumo da mão-de-obra, que é obrigada a deixar os postos de trabalho, onerando a produtividade do serviço (atritos e desentendimentos podem acontecer quando armadores em regime de tarefa são deslocados para ajudarem no descarregamento do material); ii) uso excessivo da grua, quando presente no canteiro, devido à carga não ter sido preparada prevendo a sua utilização (feixes para ascensão do material precisam ser feitos no local, por exemplo); iii) maiores riscos aos operários envolvidos na operação (pontas que se prendem entre feixes, soltando-se perigosamente, representam uma dentre várias outras situações que colocam em risco a integridade física dos operários).

O conceito de "carregamento orientando a produção", discutido anteriormente, pode influenciar positivamente a organização do trabalho, na medida em que possibilita alocações mais racionais da mão-de-obra para a realização das operações, do recebimento à montagem das armaduras. O próprio dimensionamento da mão-de-obra pode ser revisto em função das facilidades potenciais de um carregamento feito segundo o conceito supracitado.

Quanto à estocagem do material, o fornecedor pode agir, também, de maneira proativa, ao orientar a obra quanto à melhor maneira de acondicionar o seu produto nas situações específicas de cada canteiro. O aço pronto, comercializado como um "sistema", deveria apresentar soluções mais completas, tais como se espera de um sistema. As vantagens apresentadas em catálogos de fornecedores sugerem que a utilização do aço pronto proporcione a racionalização dos canteiros de obras. No entanto, sabe-se dos problemas enfrentados com a estocagem deste material, e das conseqüências negativas observadas em algumas obras, que não foram orientadas ou não se prepararam para receber o aço pronto.

Acredita-se que o sistema de fornecimento de aço pronto possa evoluir ainda mais à medida que os fornecedores tomem conhecimento da problemática enfrentada pela obras. Poderão, dessa forma, agregar mais valor ao sistema ofertado, contribuindo para melhorias da produtividade do serviço e, com isso, consolidando-se, definitivamente, no mercado.

MARDER; FORMOSO (2004) ao realizarem uma pesquisa na qual buscaram identificar oportunidades de melhoria na cadeia de suprimentos de aço cortado e dobrado, identificaram o descarregamento do aço no canteiro como um dos principais problemas do processo de produção de armaduras. 
Devido às características do produto (volume e peso) o descarregamento sem a utilização de um equipamento adequado pode ser difícil, já que um pequeno número de canteiros dispõe de grua. As empresas fornecedoras não dispõem de equipamento para a realização do descarregamento, que é geralmente feito de forma manual. As conseqüências citadas com relação às dificuldades com o descarregamento estão relacionadas em sua maioria, à segurança dos funcionários, perda de identificação das peças e dupla movimentação.

As considerações feitas para o aço pronto valem, também, para o fornecimento de telas soldadas que sofrem, no momento de seu recebimento no canteiro de obras, problemas e conseqüências de mesma ordem e natureza.

A Figura 4.30 ilustra o momento de descarregamento de aço pronto e de telas soldadas nos canteiros de obras. Em ambas as situações, a descarga era feita com grua. Ainda assim, a menor equipe disponibilizada para auxiliar a operação contou com seis operários (que permaneceram durante quatro horas e meia para descarregarem, aproximadamente, seis toneladas das telas de aço).
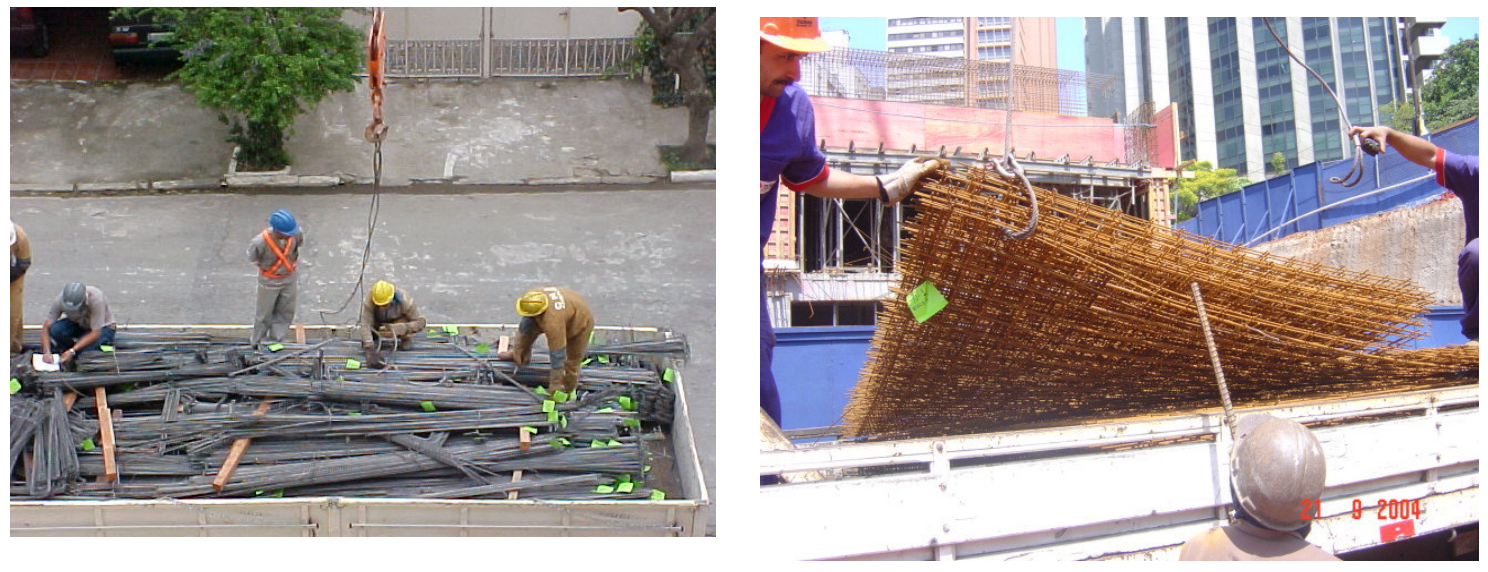

Figura 4.30 - Dificuldade no içamento de aço pronto e telas, pela grua, no momento do descarregamento (recebimento)

\subsubsection{5}

O Papel dos Subempreiteiros na Organização do Trabalho

FARAH (1992), em seu trabalho realizado há doze anos, constatara que a subempreitada vinha sendo utilizada para disfarçar práticas ilegais de absorção de mão-de-obra. Havia, então, no mercado de construção, subempreiteiras de mão-de-obra, vulgarmente denominadas de "gatas", que arregimentavam mão-de-obra sem muita qualificação e ofereciam às construtoras quando estas necessitavam de pessoal.

A autora, em constatação semelhante à feita por VILLACRESES (1994), identificou que tais subempreiteiras eram pequenas, sem organização e, freqüentemente, trabalhavam à margem da legislação (gastos eram reduzidos com a ausência de vínculo empregatício e eliminação de gastos com segurança e benefícios do trabalhador).

Mais de dez anos se passaram do momento em que foram feitos os trabalhos supracitados e subempreiteiras, como as descritas, ainda existem e encontram espaço para atuarem no setor da construção civil brasileira. LORDSLEEM (2002) diz que a 
situação do mercado de construção atual (no qual a concorrência por preço é prioritária) é o ambiente favorável à existência do padrão irracional de absorção da força de trabalho ${ }^{89}$.

Porém, a realidade "proporcionada" por um bom número de construtoras atuantes na cidade de São Paulo (como aquelas contempladas nos levantamentos de campo deste trabalho) tem barrado o acesso das subempreiteiras que não atendem às exigências prescritas pelas leis trabalhistas vigentes no país. Critérios padronizados e sistematizados de contratação de fornecedores, induzidos pelos sistemas de qualidade, têm levado várias construtoras a manterem em seus quadros apenas subempreiteiras com saúde fiscal.

No entanto, a manutenção desta "saúde fiscal" tem tido um custo substancial para as subempreiteiras, custo esse que nem sempre é possível de ser repassado às construtoras. Uma das grandes reivindicações dos subempreiteiros é, justamente, o de que as construtoras considerem, nos seus quadros de concorrências, apenas a presença de subempreiteiras que respeitem e arquem integralmente com os custos de atendimento às leis trabalhistas, limitando o risco de concorrência desleal por parte de subempreiteiras que não levem a sério esta questão. As diferenças de preços, fruto de algumas situações distorcidas na consideração dos custos tributários (encargos trabalhistas) incidentes, podem não ser corretamente analisadas e usadas na negociação.

Alguns autores (SERRA, 2001; OHNUMA, 2002; BAUTLOUNI NETO, 2003) têm comentado as exigências que os subempreiteiros precisam atender para melhorarem sua prestação de serviço. Dentre elas, podem-se citar:

- cumprimento de Normas Regulamentadoras (NR-18, incluindo o PCMAT; NR-5), quanto à implementação de medidas de controle e sistemas preventivos de segurança;

- fornecimento do PPRA (NR-9: programa de prevenção de riscos ambientais);

- fornecimento do PCMSO (NR-7: programa de controle médico de saúde ocupacional);

- fornecimento de equipamentos de proteção individual (EPIs) com qualidade exigida pela NR-6 e atestada por certificados de registro do fabricante ou do importador;

- cumprimento de leis trabalhistas quanto ao registro dos funcionários (apresentação de documentação, como guias do ISS, FGTS, INSS, folhas de pagamento etc);

- comprometimento com a qualidade dos serviços prestados na obra, através do emprego de mão-de-obra qualificada e treinada, controle de qualidade do serviço, terminabilidade do mesmo e cumprimento dos prazos (disponibilizar os funcionários para treinamento na execução dos serviços e segurança);

- bom atendimento à equipe do cliente, na obra e no escritório, inclusive na prestação de serviço de assistência técnica após a entrega do serviço.

Para LORDSLEEM (2002), embora as empresas subempreiteiras estejam "se vendo obrigadas a atender às exigências das construtoras, é preciso que enxerguem as vantagens desse momento, buscando compreender o esforço despendido na melhoria como um investimento, que vai futuramente gerar resultados".

89 Segundo LORDSLEEM (2002), "a redução de custos acontece através da burla à legislação trabalhista e da preservação de condições inadequadas de trabalho, principalmente nas cidades onde a fiscalização do trabalho não exerce a sua atividade ostensivamente". 
$\mathrm{Na}$ sua tese de doutorado, LORDSLEEM (2002) desenvolve uma metodologia que visa capacitar gerencialmente as empresas subempreiteiras, "contribuindo para orientar a condução de ações organizacionais da empresa para uma prestação de serviço condizente com as exigências do mercado de construção de edifícios".

Dentre as ações preconizadas pela metodologia proposta pelo autor supracitado, destacam-se: a melhoria da capacitação técnica, a formação e re-qualificação dos profissionais, o desenvolvimento de medidas preventivas no âmbito da segurança e o cumprimento da legislação pertinente à atividade e ao funcionamento da empresa. Salienta, ainda, que são responsáveis por estimular e implementar tais ações não apenas o governo e os órgãos públicos, os sindicatos e as entidades de classe, através de ações setoriais, mas também as empresas construtoras e as próprias empreiteiras.

No que se refere à formação de preços, entende-se que a adoção de uma nova forma de contratação dos serviços de execução da estrutura, levando também em conta a produtividade que o projeto da estrutura irá propiciar, além de mais justa e realista, induzirá a elaboração de projetos cada vez mais eficientes, na busca de uma melhoria crescente da produtividade no canteiro e da conseqüente redução de custos. BATLOUNI NETO (2003)

\subsection{O papel da força de trabalho na organização do trabalho}

Para se alcançarem bons níveis quanto ao desempenho construtivo, a força de trabalho e seus gestores devem possuir um relacionamento forte e positivo. Com o aumento da complexibilidade e modernidade dos projetos de construção, há uma necessidade ainda maior por gestores realmente competentes, capazes não apenas tecnologicamente, mas com habilidades para tratar os recursos humanos. Os gestores são responsáveis por selecionar, contratar, distribuir, organizar e deixar "prontos para o uso" todos aqueles recursos que são necessários para o alcance dos objetivos da organização. Incluem-se aí os operários (subcontratados ou não).

PROVERBS et al. (1999), ao fazerem um estudo comparativo quanto à gestão do trabalho na construção em três países europeus, elegeram quatro pontos principais a tratar: i) níveis administrativos no canteiro; ii) carga horária dos operários; iii) duração semanal do trabalho; iv) formas de contratação (mão-de-obra própria ou subcontratada); v) e a organização das equipes (relação entre oficiais e ajudantes). 0 trabalho de PROVERBS et al. (1999) objetivou indicar as práticas internacionais quanto à utilização da força de trabalho por construtoras da Inglaterra, França e Alemanha, na execução de estruturas reticuladas de concreto armado moldadas no local.

Os autores, a partir de um questionário estruturado, fizeram uma pesquisa de opinião com empresas construtoras alemãs, francesas e inglesas, onde, a partir de uma tipologia estrutural pré-definida e única, levantaram: i) quem e quantas pessoas constituíam o staff administrativo presente no canteiro (do gerente de projeto ao mestre de obras); ii) os horários de início e término e de almoço dos operários no canteiro; iii) o número de dias trabalhados semanalmente; iv) a composição da equipe (número de ajudantes, meio oficiais e oficiais); v) a forma de contratação da mão-de-obra (direta e/ou indireta).

PROVERBS et al (1999) fizeram então as seguintes constatações:

$\checkmark$ quanto à administração/supervisão no canteiro de obras: as construtoras inglesas mantêm nas suas obras uma estrutura administrativa $40 \%$ e $20 \%$ superior àquelas encontradas na França e Alemanha respectivamente. Em números 
absolutos, as construtoras inglesas mantinham uma média de cinco funcionários na administração/supervisão, com número máximo de oito pessoas. Situação esta que poderia trazer implicações (em relação aos custos) negativas devido a interferências desnecessárias no trabalho, haja vista o número elevado de superiores (vozes de comando). Os autores lembram THOMAS et al (1990), que constataram que equipes administrativas super dimensionadas poderiam acarretar piora da produtividade da mão-de-obra. Salienta-se que as construtoras inglesas compõem sua equipes com um número maior de meio-oficiais, em comparação às equipes das empresas francesas e alemãs (que empregam mais oficiais) e, talvez, isso acarrete a necessidade de um maior número de supervisores. Além disso, a prática da subcontratação é mais evidente na Inglaterra ( $74 \%$ da mão-de-obra usada é subcontratada), o que também pode ser uma razão para o maior número de supervisores.

$\checkmark$ quanto ao regime de trabalho: os trabalhadores ingleses e alemães têm uma maior carga horária quando comparados aos franceses (trabalham uma média de 45,5 horas semanais; os franceses, 40 horas semanais). Na França, os regulamentos impostos pelos sindicatos prevêem jornadas de trabalho menores, que são respeitadas pelas empresas. Porém, enquanto na Inglaterra trabalha-se aos sábados, na Alemanha a jornada de trabalho diária passa das 10 horas, indo, no entanto, até sexta-feira apenas. Trabalhos têm apontado que jornadas de trabalho que excedam 40 horas semanais reduzem a produtividade e inflacionam os custos da mão-de-obra da construção.

$\checkmark$ quanto às características da força de trabalho: na Inglaterra predomina a subcontratação e o uso de meio-oficiais na composição da equipes. Na França e Alemanha as empresas preferem usar mão-de-obra própria e compor suas equipes basicamente com oficiais. As construtoras francesas são as que mantêm equipes mais enxutas, enquanto as alemãs possuem as maiores equipes, porém com apenas 5\% de ajudantes na sua formação. RAINBIRD (1991) apontou as causas da vasta carência de oficiais na Indústria da Construção Civil inglesa e BRISCOE (1990) reportou como a falta de habilidade na obtenção de trabalhadores contribuiu para que se contraíssem atrasos. RAINBIRD (1991) cita que a institucionalização do "self employment" e a subseqüente fragmentação da força de trabalho deram início à época de carência de operários na Inglaterra. A externalização da força de trabalho resultou em firmas que renunciaram às responsabilidades pelo treinamento dos operários. Os operários na Inglaterra esperam uma supervisão forte (conforme refletido nos números de supervisores reportados anteriormente), e são provavelmente semi-capacitados. A cultura da subcontratação na França é similar à da Inglaterra, mas, devido às exigências legais da França (por exemplo, os subcontratados podem entrar com uma ação diretamente contra o provedor do empreendimento caso a construtora não honre seus pagamentos), ela não é largamente utilizada. Em contraste, as empresas francesas estão buscando novas estratégias de trabalho, baseadas na internalização e engajadas no desenvolvimento de uma força de trabalho polivalente e autônoma. Os benefícios, a partir desta troca de estratégia de trabalho, são evidenciados pela facilidade na utilização de uma menor, mas mais talentosa, força de trabalho, que demanda menos supervisão. Na Alemanha, a situação da mão-de-obra é alarmante. Supunha-se que, no ano 2000, 30\% da 
força de trabalho teria mais de 50 anos. A associação dos maiores empregadores tem introduzido novas políticas de treinamento vocacional e de recrutamento de aprendizes, bem como programas de treinamento para melhorar a eficiência na utilização de equipamentos.

PROVERBS et al. (1999) concluem o trabalho afirmando que a utilização eficiente dos recursos tem um impacto positivo no desempenho e produtividade. Os levantamentos feitos evidenciaram as distinções entre França, Alemanha e Inglaterra quanto às práticas nas seguintes áreas de utilização da mão-de-obra: equipe administrativa no canteiro; jornada de trabalho diária; tempos de paradas; jornada semanal de trabalho; horas totais trabalhadas; níveis de capacitação dos trabalhadores; tamanhos das equipes; formas de contratação (mão-de-obra direta ou subcontratada). Para o autor, um modelo similar ao sistema francês poderia ser a base para as recomendações das "melhores práticas européias".

"A definição sobre como executar o trabalho, a constituição de equipes, a programação e a alocação de tempos, o estabelecimento do ritmo de trabalho e o próprio controle da produção se dão no interior da força de trabalho, sob a liderança do mestre e do encarregado do ofício". FARAH (1992)

Para FARAH (1992), algumas iniciativas do setor que visam reinstaurar a "competência" incluem medidas voltadas ao resgate da competência operária. "A consolidação desta tendência e o próprio significado deste movimento constituem, ainda, um processo em aberto. Podem, de um lado, caracterizar um processo de agressão do trabalho pelo capital, numa conjuntura de crise. Porém, por outro lado, vir a se aprofundar como conquista de condições dignas de trabalho, por parte dos trabalhadores, e de afirmação de sua autonomia e de sua participação no controle sobre o fazer".

A habilidade do trabalhador ainda é adquirida no próprio canteiro de obras, o que equivale a dizer que sua formação se dá no interior da própria força de trabalho. VARGAS (1993) salienta que, embora tenham havido iniciativas no sentido de formalizar o processo de aquisição do saber requerido pela atividade de construção, predomina, ainda, na formação do trabalhador, o aprendizado estabelecido na relação direta entre oficial e ajudante.

FARAH (1992) vê que este processo, ao qual chamou formação "on the job", caracteriza a construção, visa não apenas à "transmissão de modos operatórios complexos e diversificados, mas também à capacitação do trabalhador para o exercício da iniciativa e da criatividade, frente ao desafio colocado pela variabilidade característica da atividade de construção". Segundo a autora, uma outra dimensão está envolvida nesse tipo de formação, qual seja, a disciplinar. A autonomia na condução da atividade produtiva tem, como contrapartida, a existência de uma estrutura hierárquica bastante rígida no canteiro de obras, à qual o trabalhador aprende a se submeter.

A mesma autora, ao apontar as principais tendências identificadas na construção civil, no final do século passado, assinalou a estratégia da subcontratação como um delas (fato comprovado pelo mercado até este momento). Porém, identificou que tal estratégia aprofunda uma outra tendência, qual seja, a da "desqualificação dos trabalhadores de ofício e de solapamento da estrutura tradicional do saber no setor, processo que configura uma crise de competência operária na atividade de construção".

SCHIMITT et al. (1995) apontam que a preparação profissional do operário da construção, realizada através do sistema informal, ou seja, no próprio canteiro de obras, 
depende de uma série de fatores, como o interesse do empregador e do profissional em ensinar, do tempo de permanência na empresa, dos prazos de execução das obras.

Os autores supracitados citam que, no Brasil, o sistema formal de preparo profissional para o setor da construção só existe para as ocupações de técnico de nível médio e superior, engenheiros e arquitetos. O órgão responsável pela preparação profissional da mão-de-obra operária do setor, o Serviço Nacional de Aprendizagem Industrial (SENAI), não tem um programa estruturado e sistematizado. Atua, tradicionalmente, através de um programa denominado Formação de Monitores, o qual se baseia no princípio de que a preparação dos operários pode ser feita através dos próprios mestres de obras, em seus locais de trabalho.

Segundo BATLOUNI NETO (2003), os custos retidos na folha de pagamento dos operários e repassados pelas construtoras a entidades como SENAI, SESI, entre outras, são altamente significativos, sendo que os benefícios no campo da capacitação e qualificação da força de trabalho são irrisórios. Ou seja, não há programas de formação/renovação da força de trabalho nas ocupações aglutinadas pela construção civil.

A discussão de responsabilidades sobre quais seriam os responsáveis por promover e fomentar programas de formação profissional para os operários da construção civil não será tratada neste trabalho.

Registra-se, porém, o posicionamento deste autor que acredita tratar-se esta, de uma questão a ser debatida em nível institucional, com a participação de agentes do governo e representantes da cadeia produtiva (os construtores, através dos sindicatos patronais, e, no caso específico dos armadores, das grandes empresas siderúrgicas, que estão no topo financeiro (receita bruta) da cadeia produtiva). As empresas siderúrgicas ${ }^{90}$, com o apoio das partes já citadas, poderiam, através de seus programas de responsabilidade social (com ou sem política de benefícios fiscais), promover um programa nacional de formação/capacitação/qualificação da força de trabalho, que beneficia anualmente toneladas de aço destinado à construção civil, e que, no entanto, tem pequenas perspectivas profissionais.

Ainda sobre a formação do trabalhador, vale a pena comentar os programas de alfabetização e de treinamento oferecidos por empresas da construção civil. Embora não capacitem o trabalhador no sentido de formá-los oficialmente profissionais, contribuem para: i) o resgate da dignidade do trabalhador ao lhe alfabetizarem; ii) favorecer a segurança do trabalhador na obra, com treinamentos de segurança no canteiro; iii) melhorar o entendimento do serviço a ser executado, a partir de treinamento baseado em procedimentos executivos, entre outros.

\footnotetext{
90 Uma das principais siderúrgicas brasileiras possui um programa denominado "Clube Amigos do Campo", que se trata de um canal de comunicação e negócios entre a empresa e o homem do campo (ligado ao agronegócio). O "Clube", através de diversos projetos, publicações e palestras com consultores especializados, procura levar ao produtor rural atualização e orientação para melhor gerenciamento de seu negócio, estimulando, desta forma, o desenvolvimento do setor Agropecuário.

Dentre as inúmeras ações desenvolvidas pelo Clube destaca-se o "Projeto Aramador". Em conjunto com os sindicatos rurais, distribuidores regionais e outros orgãos, o Clube oferece um curso teórico e prático, com duração de um dia, em que o aramador recebe e fornece informações visando sempre o desenvolvimento e a aplicação de técnicas de dimensionamento e montagem de cercas com maior rapidez, segurança e economia.
} 
Um esforço considerável, por parte das construtoras brasileiras, tem sido despendido no que se refere a programas de alfabetização da mão-de-obra operária. Tais programas absorvem, em sua grande maioria, a mão-de-obra pertencente aos subempreiteiros que atuam nas obras. Sejam esses programas entendidos como contribuição social dessas empresas e/ou como uma expressão da visão estratégica das mesmas, o fato é que grande número de operários deixa, a cada ano, de engrossar as estatísticas brasileiras do analfabetismo graças ao empenho das empresas construtoras, que mantêm salas de aulas em seus canteiros de obras.

Porém, há ainda um grande número de operários que não se beneficiam desses programas de alfabetização, mesmo tendo, teoricamente, acesso a eles. Refere-se, aqui, aos casos em que, mesmo sendo mantidas salas de aulas nas obras e havendo o interesse em participar, o operário fica impedido de freqüentar a sala de aula. As razões para tal impedimento estão, na maioria das vezes, relacionadas a: i) jornadas de trabalho "flexíveis", que se alongam devido à necessidade de cumprimento de tarefas, previamente combinadas ou não; ii) esgotamento físico no final do dia de trabalho, que desmotiva/desanima o trabalhador; iii) deslocamento entre o serviço e a residência do operário bastante oneroso (grandes distâncias a serem vencidas, consumindo horas e disposição no trajeto), fazendo com que o trabalhador necessite sair do trabalho o quanto antes para chegar à sua casa num horário não tão avançado.

Pontos como os supracitados, que dificultam a entrada do operário na sala de aula, podem e devem ser tratados no âmbito da organização do trabalho. Acredita-se que "reorganizações" do trabalho, como alterações na jornada diária em função de adequações nas estipulações de tarefas, por exemplo, podem permitir que mais operários tenham acesso as bancos escolares.

FARAH (1992) entende que a valorização do trabalhador e o resgate da competência operária constituem, ainda, uma tendência restrita a uma parcela reduzida de empresas, atingindo, por outro lado, um segmento da força de trabalho, qual seja, o mais qualificado.

Nos Estados Unidos, os armadores são representados por associações, entidades e sindicatos que mantêm uma gama diversificada de programas de treinamento e qualificação para seus associados. Destaca-se a União Internacional dos Armadores (Iron Workers International Union). 


\section{Método para Proposição de Diretrizes para a Melhoria na Produtividade da Mão-de-obra}

\subsection{Notas introdutórias ao capítulo}

O processo de concepção e produção de armaduras, instituído com base em diretrizes que visem melhorar a construtibilidade do projeto do produto e a eficácia do método e da organização do trabalho, é condição essencial para influenciar positivamente a produtividade da mão-de-obra envolvida. A partir da hipótese supracitada, apresenta-se o objetivo do presente capítulo, qual seja o desenvolvimento de uma ferramenta de gestão que permita às empresas construtoras chegarem à proposição de tais diretrizes a partir de constatações obtidas, por elas mesmas, de dentro dos seus canteiros de obras.

O conhecimento das curvas de produtividade de um processo de produção e das razões que explicam sua eventual "sinuosidade" é a base do método proposto por este pesquisador, voltado às empresas construtoras de pequeno e médio porte que desejam buscar meios para se tornarem mais eficientes e eficazes no uso de seus recursos e que enxergam na melhoria sustentada da produtividade da mão-de-obra um caminho interessante a ser seguido.

Especificamente para este trabalho, e frente às justificativas apresentadas no capítulo inicial, o desenvolvimento do método voltou-se a um processo de produção específico, qual seja o processo de produção de armaduras. No entanto, procurou-se, durante tal desenvolvimento, fazer uso de conceitos genéricos, possibilitando que, com algumas adaptações, o método possa ser aplicado a outros processos de produção.

Denominado "Método para Proposição de Diretrizes para a Melhoria na Produtividade da Mão-de-obra Envolvida na Produção de Armaduras" (representado, a partir deste momento, pela sigla "MPDPro"), o método está dividido em quatro etapas. A primeira etapa possibilita que as empresas construtoras definam os indicadores que lhes permitam mensurar a eficiência do seu processo de produção (neste caso, através da mensuração da produtividade da mão-de-obra) e identifiquem fatores, associáveis à produtividade, capazes de explicar possíveis variações. Na etapa seguinte as empresas são orientadas a realizarem levantamento de dados. Nesta etapa a empresa começa a fundamentar suas bases de dados e informações, que serão utilizadas na terceira etapa prevista no método, qual seja, a de processar o conjunto d e dados obtidos, chegandose, a partir de análises objetivas e subjetivas, a um grupo de fatores influenciadores. $\mathrm{Na}$ quarta e última etapa são determinadas diretrizes, a partir dos fatores considerados os mais relevantes, contando, para tal, com o engajamento dos demais agentes que participam do processo de produção em questão. Tais diretrizes, ao serem implementadas, deverão contribuir para os desejados ganhos de eficiência produtiva. 


\subsection{Conceitos iniciais necessários ao desenvolvimento do método}

\subsubsection{A visão analítica do processo de produção das armaduras}

A analiticidade no tratamento dado ao processo de produção das estruturas é fundamental para o alcance dos anseios preconizados pelo método. Ao se olharem as armaduras, no âmbito dos elementos que compõem as estruturas, consegue-se chegar a um nível de detalhamento tal que as ações estabelecidas, a partir da implementação do método, possam estar direcionadas aos pontos que careçam, realmente, de intervenção.

Posto isso, tem-se que as estruturas de edifícios em concreto armado serão desmembradas em porções; os elementos estruturais que compõem cada porção, quais sejam os pilares, vigas e lajes, serão tratados individualmente em cada uma das etapas constituintes do método. O processo de produção das armaduras será analisado, portanto, no nível das tarefas que o compõem (a execução de cada elemento estrutural corresponde a uma tarefa). Tais tarefas poderão ser subdivididas em subtarefas, quando o nível de análise desejado requerer tal grau de analiticidade. As subtarefas, no tocante ao serviço de armação, são representadas por operações básicas (por exemplo, corte, dobra etc) ou pela associação de duas ou mais operações (corte+dobra, transporte+montagem final), pertencentes à etapa de armação (do processo anteriormente definido como englobando as etapas de projeto, de fabricação e de armação). A Figura 5.1 ilustra a abordagem analítica do processo de produção de estruturas de concreto armado.

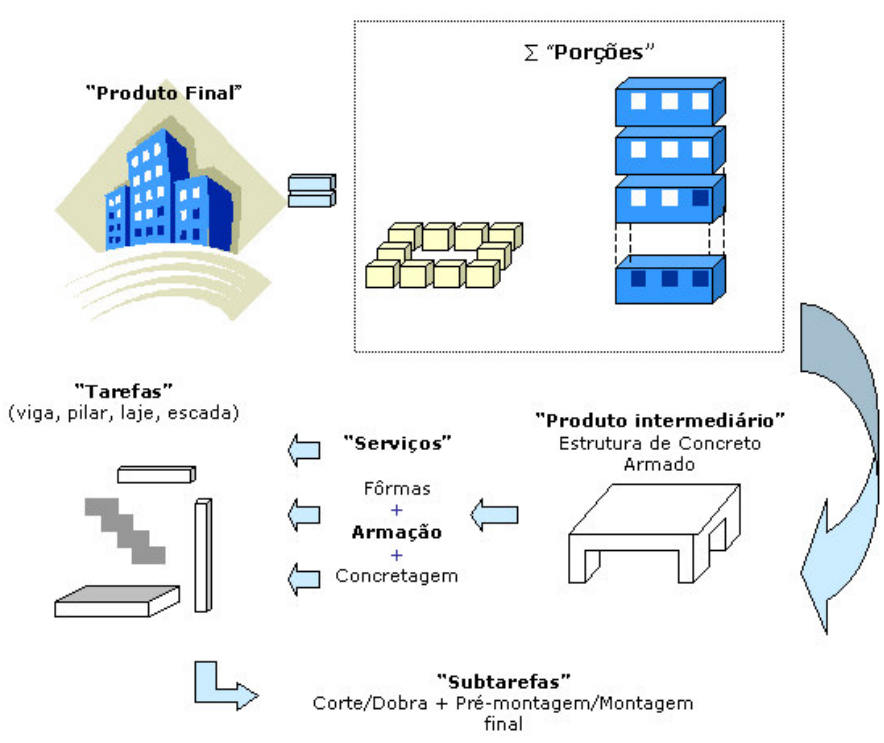

Figura 5.1 - Abordagem analítica do processo de produção

Note-se que em qualquer nível hierárquico da estrutura analítica apresentada pode-se considerar a existência de um produto e de um processo de produção visando à obtenção 
de tal produto. Assim é que se pode falar na armadura da estrutura de concreto armado do edifício e no serviço de armação da estrutura do edifício (igualmente podem-se considerar, por exemplo, os gastalhos como sendo o produto resultante da operação de "engastalhamento" do serviço de montagem de fôrmas).

\subsubsection{Abordagem relativa ao entendimento dos fatores influenciadores da produtividade}

SOUZA (2001) recorda que, "de acordo com o Modelo dos Fatores, se o conteúdo de um serviço e o contexto em que é realizado não se alterassem ao longo do tempo, a produtividade seria constante". A produtividade da mão-de-obra pode variar, diariamente, na medida em que ocorram alterações dos fatores associados ao conteúdo ou ao contexto do serviço, conforme mostrado na Figura 5.2.

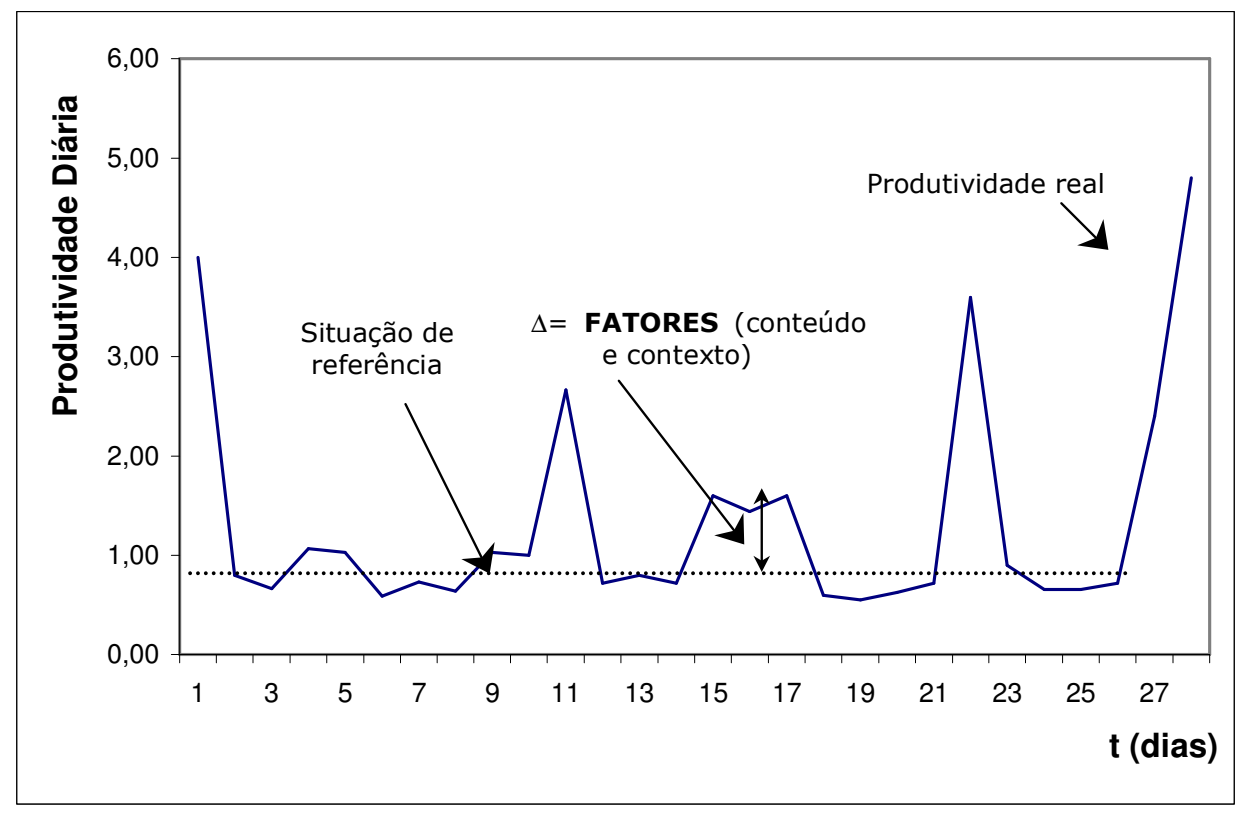

Figura 5.2 - Variação da produtividade ao longo do serviço. Fonte: SOUZA (2001)

$\mathrm{Na}$ curva da produtividade real mostrada no gráfico da Figura 5.2, supondo ser a armação dos elementos de um pavimento tipo o serviço em questão, as variações diárias percebidas podem ser intrínsecas ao próprio processo, como também podem estar relacionadas a acontecimentos não previstos.

O processo de produção de armaduras é composto por tarefas e subtarefas distintas (com diferentes graus de dificuldade/complexidade) que variam a cada dia ao longo de um ciclo. Logo, a produtividade da equipe para o dia em que os armadores só fazem a pré-montagem das armaduras de pilares de um pavimento (representada pelo primeiro dia no gráfico da Figura 5.3), por exemplo, é, previsivelmente, díspar daquela relativa ao dia em que os mesmos armadores estiverem fazendo a montagem das armaduras das vigas deste mesmo pavimento (representada pelo quarto dia no gráfico da Figura 5.3). 
Por essa razão, não seria de causar nenhuma estranheza a percepção de variações diárias no gráfico da produtividade. Portanto, antes de se julgar um valor mais alto de RUP diária, há que se analisar a dificuldade do trabalho associado a tal dia. Em se tratando das variações que aparecem nos primeiros seis dias do gráfico da Figura 5.3, pode-se dizer, com base nos comentários supracitados, que elas são previsíveis. Para essa situação, a produtividade cumulativa ao final do período/ciclo será igual à produtividade potencial (gráfico da Figura 5.4).

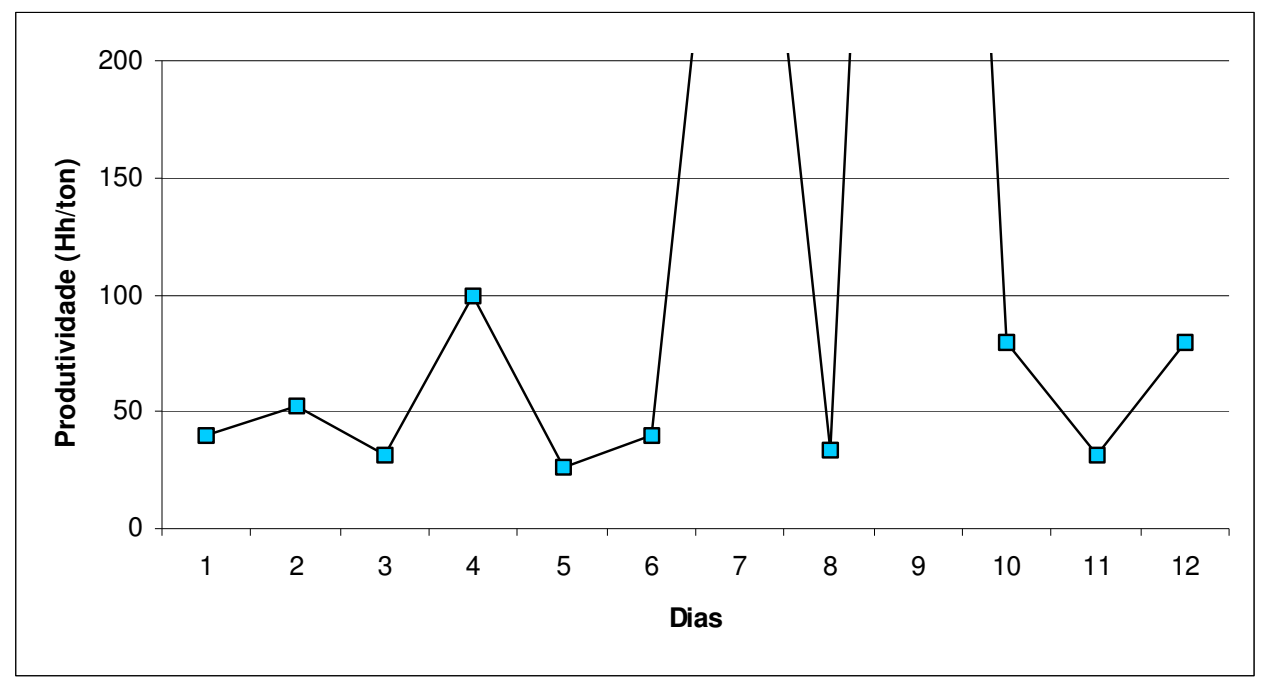

Figura 5.3 - Gráfico com produtividades diárias de um ciclo hipotético

Porém, as variações podem se dar por outras razões que não apenas a disparidade das dificuldades associadas às tarefas/subtarefas executadas ao longo do ciclo. Neste caso, acontecimentos externos ao processo (observem-se os dias 7 e 9 do gráfico da Figura 5.3), podem afetar a produtividade da mão-de-obra, sendo os responsáveis diretos por elevar os índices de produtividade ao final do dia, bem como podem fazer distanciar a produtividade cumulativa (observada ao final do ciclo) da produtividade potencialmente prevista (gráfico da Figura 5.4). 


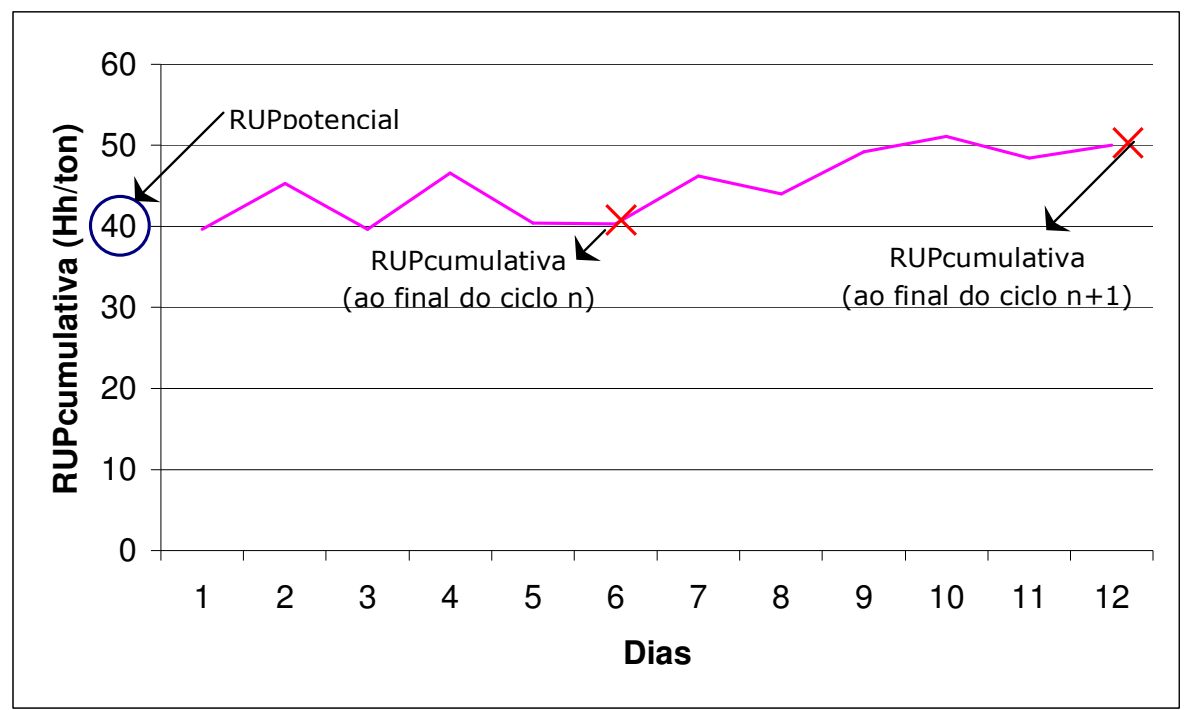

Figura 5.4 - Gráfico de produtividades cumulativas

A produtividade da mão-de-obra, em se tratando de processos de produção de mesma natureza (produção de armaduras, por exemplo), não está limitada a um único valor (como até bem pouco tempo preconizava o principal manual de orçamentação brasileiro (Tabelas de Composições de Preço para Orçamento - TCPO)). As características de conteúdo (como o grau de construtibilidade apresentado por um determinado projeto e mensurado através de indicadores específicos) e do contexto (como o sistema de transporte para a movimentação dos materiais no canteiro de obras) de trabalho, dificilmente se mantêm constantes, seja de uma obra para outra, seja dentro da mesma obra, quando consideradas as diferentes porções que compõem a estrutura da edificação. Dessa maneira, não se pode esperar que partes distintas, com projetos e arranjos organizacionais particulares, por exemplo, apresentem índices de produtividade potencial da mão-de-obra semelhantes.

Prevendo tais diferenças, a última edição da TCPO (2003) apresentou faixas de variações de produtividade da mão-de-obra em razão de alguns fatores relacionados ao conteúdo e contexto do trabalho para alguns dos principais serviços de construção de edifícios.

A Figura 5.5 apresenta uma "régua de produtividade" (nome como foram chamadas as faixas de variações) para o conjunto de operações da etapa de armação do processo de concepção e produção de armaduras. Na régua são apresentados valores mínimos, medianos e máximos de produtividade, bem como dois conjuntos de fatores associados a situações distintas (como, por exemplo, lajes planas versus lajes com vigas), indutores dos melhores ou piores índices de produtividade. 

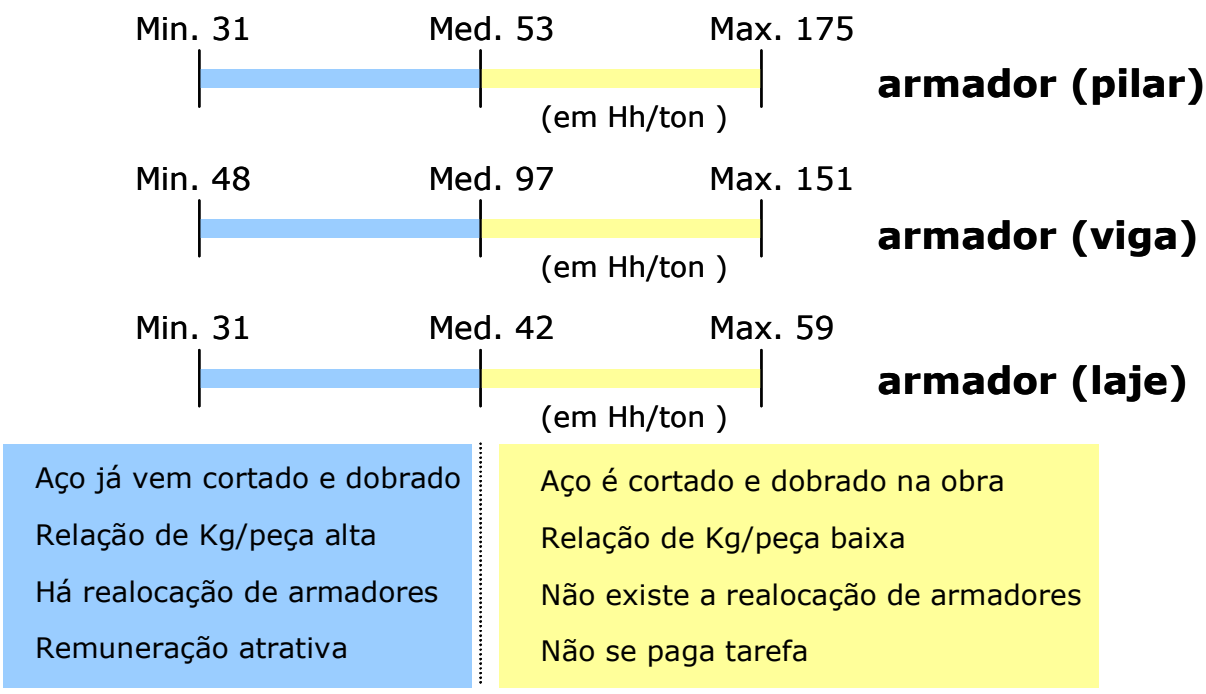

Figura 5.5 - Faixas de variação da produtividade da mão-de-obra para a produção de armaduras. Fonte: PINI, 2003

A partir das constatações supracitadas, fica evidente que é preciso mais cuidado ao afirmar que a melhoria da produtividade associa-se diretamente à redução da variabilidade dessa produtividade. As variações diárias, como se viu, podem ser inerentes ao processo e minimizá-las pode não ser, nesse caso, o caminho para melhorar a eficiência global do processo.

Já as demais variações discutidas estão associadas, normalmente, a:

i) diferenças constatadas no âmbito do projeto do produto, no método e na organização do trabalho entre diferentes porções analisadas. Essas diferenças podem ser expressas através de fatores. Dessa forma, o entendimento desses fatores surge como um caminho imprescindível para a melhoria da produtividade: fatores que se mostrarem influenciadores de bons desempenhos, passam a servir como parâmetros para a "configuração" de processos futuros. Dessa forma é possível que se intervenha, sabiamente, na fase de concepção de projetos e de configuração do processo de produção para que a produtividade potencial seja a melhor possível.

ii) acontecimentos, de ordem diversa, ora previsíveis e portanto evitáveis (como a falta de material), ora imprevisíveis (como alterações climáticas que impedem a continuidade do serviço), que provoquem ineficiência na produção. Esses acontecimentos são os responsáveis pelo descolamento entre a produtividade real (que pode ser expressa pela RUP cumulativa ao final de um período) e a produtividade potencial.

\subsection{Estruturação do método}

A estruturação do método foi pensada de maneira a atender às necessidades daqueles que serão seus principais usuários: os construtores. Considera-se que um método a ser utilizado pelos mesmos deva ser marcado por: i) objetividade conferida a cada etapa da aplicação; ii) simplicidade na aplicação; iii) potencialidade na obtenção de resultados. 
Assim sendo, o MPDPro é dividido em quatro etapas principais, evidenciadas na Figura 5.6, seqüenciais e complementares sob o ponto de vista da sua aplicação, embora possuam escopos e objetivos bem delimitados de maneira a garantir uma condução segura e eficaz de cada uma das partes.

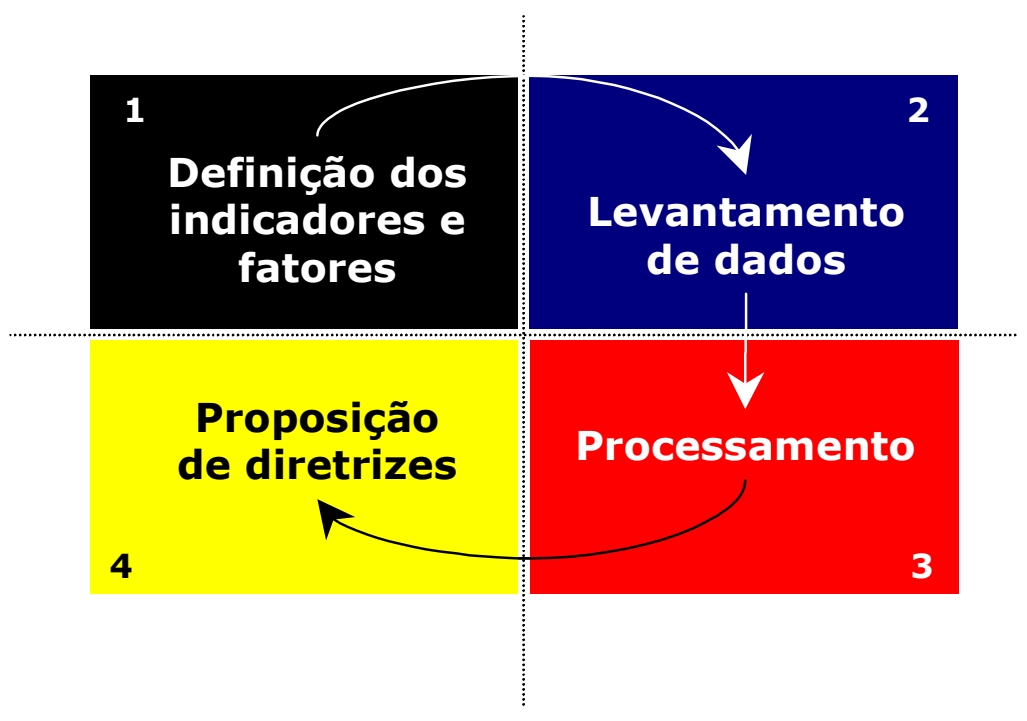

Figura 5.6 - Estruturação do MPDPro

Apresentam-se, a seguir, as quatro etapas principais que consolidam o MPDPro, quais sejam: i) a definição de indicadores e fatores; ii) o levantamento de dados; iii) o processamento dos dados; iv) a proposição de diretrizes.

\subsubsection{Definição dos Indicadores e Fatores}

A primeira etapa do método apresenta e define os principais indicadores, bem como um conjunto de fatores que poderão ser usados pelas construtoras, na etapa seguinte, qual seja, a de levantamento de dados.

Os fatores, como já comentado anteriormente, explicitam aspectos relacionados ao projeto do produto, ao método e à organização do trabalho. Permitem uma abordagem detalhista e analítica dos aspectos mencionados, ao mesmo tempo em que possibilitam uma leitura "simplista", em razão de estarem, na maioria das vezes, traduzidos objetivamente (no caso de fatores quantitativos, através de números reais e percentuais; quanto aos fatores qualitativos, através da constatação de sua presença ou não).

Nessa primeira fase do método, cabe à construtora escolher, dentre os fatores propostos, aqueles que julgar mais relevantes e/ou prioritários para os seus propósitos num dado momento. Vale dizer que os fatores podem, ainda, ser redefinidos, ou mesmo, novos fatores podem ser propostos, na medida em que a construtora sentir a necessidade de considerar aspectos não contemplados por aqueles pré-determinados pelo método.

Já os indicadores, entendidos aqui como índices que refletem, sinteticamente, as variações da produtividade da mão-de-obra num dado período, para um determinado serviço, referentes a uma porção específica da obra, são apresentados de maneira direta 
e sucinta, haja vista a extensa bibliografia ${ }^{91}$ sobre o assunto. Recomenda-se que os trabalhos citados sejam leitura básica e preliminar àqueles que desejarem implementar o método em questão.

Faz-se, a seguir, a apresentação dos indicadores de produtividade e dos grupos de fatores preconizados pelo MPDPro.

\subsubsection{Apresentação dos Indicadores}

Adota-se o indicador denominado razão unitária de produção (RUP) como mensurador da produtividade, relacionando o esforço humano, contabilizado em Homens-hora (Hh), com as quantidades de serviço ${ }^{92}$ realizado (no caso desta tese, a quantidade de serviço será computada em toneladas (ton)):

$$
R U P=H h / \text { Quantidade de serviço }
$$

As RUP, em função de diferentes períodos de tempo associados às mensurações de entradas e saídas, são classificadas (SOUZA, 2001) como: i) RUP diária (neste caso o período de tempo é o dia de trabalho e a mensuração, de entradas e saídas, também diária); ii) RUP cumulativa (aqui se considera um período acumulado, sendo as quantidades de entradas e saídas aquelas acumuladas desde o primeiro dia do estudo até a data de sua avaliação); iii) RUP cíclica (o período de tempo diz respeito a um ciclo do serviço, adotado quando o serviço possui ciclos bem definidos, como é o caso da armação para andares repetitivos de prédios de múltiplos pavimentos, quando o ciclo representaria todo o período de tempo envolvido na produção das armaduras de um pavimento); iv) RUP potencial (trata-se de um valor de RUP cíclica ${ }^{93}$ associado à sensação de bom desempenho e que, ao mesmo tempo, mostra-se factível em função dos valores das RUP cíclicas detectados. Matematicamente a RUP potencial é calculada como o valor da mediana das RUP cíclicas inferiores ao valor da RUPcum ao final do período de estudo).

SOUZA (2001) apresenta algumas particularidades dos indicadores de produtividade relacionadas ao serviço de armação quando tratado analiticamente como no caso deste trabalho. São elas:

- o serviço de armação é composto por 4 tarefas: armação de pilar; armação de viga; armação de laje; e armação de escada;

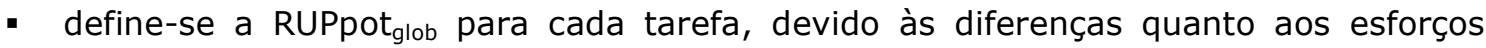

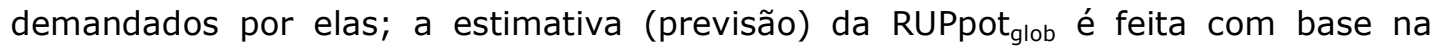
presença de fatores associados ao conteúdo e contexto do trabalho;

\footnotetext{
${ }^{91}$ Recomenda-se consultar os trabalhos de SOUZA (1996), ARAÚJO (2000) e SOUZA (2001).

92 Fala-se em quantidade de "serviço" (quando está se falando, na verdade, do produto resultante do serviço) por se tratar da linguagem mais comum dentre os construtores.

93 RUP potencial, segundo SOUZA (2001), é definida como um valor de RUP diária associado à sensação de bom desempenho. No caso da definição adotada neste trabalho, a determinação de RUP potencial é feita com base nos desempenhos das RUP cíclicas.
} 


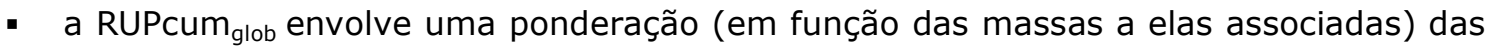
RUPpot $_{\text {glob }}$ para cada tarefa, bem como uma correção do valor potencial em função da maior ou menor probabilidade de ocorrência de anormalidades.

No caso específico deste trabalho, buscar-se-á a melhoria do processo de produção de armaduras a partir do entendimento das RUPpot ${ }_{\text {glob, }}$ passando-se, portanto, por tratar os fatores capazes de influenciá-la, ou seja, fatores relacionados ao conteúdo e contexto do trabalho.

\subsubsection{Apresentação dos Fatores}

Ao se discutir, no capítulo quatro, a representatividade dos fatores na produtividade da mão-de-obra, acabou-se por implementar uma reestruturação na forma de se enxergar o processo de produção. Motivado por: i) definir responsabilidades e identificar responsáveis pelos grupos de fatores associáveis à produtividade; ii) facilitar a condução dos levantamentos e posterior análise dos dados; iii) dar mais objetividade às discussões sobre os fatores e suas influências na produtividade; iv) assegurar a devida notoriedade a grupos de fatores específicos; $v$ ) propor e defender a postura de que as melhorias desejadas na produtividade da mão-de-obra são fruto de intervenções pontuais em fatores específicos; vi) permitir que o método seja implementado (se necessário) em partes, ou seja, focado em grupo de fatores específicos a cada etapa de implementação, este pesquisador propôs o reagrupamento dos fatores de conteúdo e contexto (THOMAS, 1999) em três grupos distintos (Figura 5.7), quais sejam: i) projeto do produto (com ênfase no projeto de detalhamento de armaduras); ii) método de trabalho; iii) organização do trabalho.

Percebeu-se, ao longo do desenvolvimento do trabalho, que tal divisão de fatores se firmou como uma nova e interessante proposta de se enxergar e, por conseguinte, tratar os processos de produção (específicos ao setor da construção civil) quando se deseja

buscar melhorias de eficiência produtiva. Acredita-se que, no ambiente de produção, a ineficiência esteja associada a deficiências intrínsecas ao projeto e/ou ao método de trabalho e/ou a aspectos relacionados à organização do trabalho.

Assume-se, a partir desta perspectiva, a necessidade de levantar, separadamente, fatores relacionados a cada um dos três grupos supracitados, conferindo, neste momento do trabalho ${ }^{94}$, o mesmo grau de importância/relevância quando se imagina a influência que terão sobre a produtividade da mão-de-obra.

\footnotetext{
${ }^{94}$ Imagina-se que, a partir de trabalhos futuros que tragam mais dados/informações, seja possível identificar qual, dentre os grupos de fatores (e, possivelmente, quais fatores dentro desses grupos) citados, tenha a maior capacidade de influenciar a produtividade da mão-de-obra. A partir daí, os esforços poderão ser melhor dirigidos.
} 


\section{Projeto do produto}

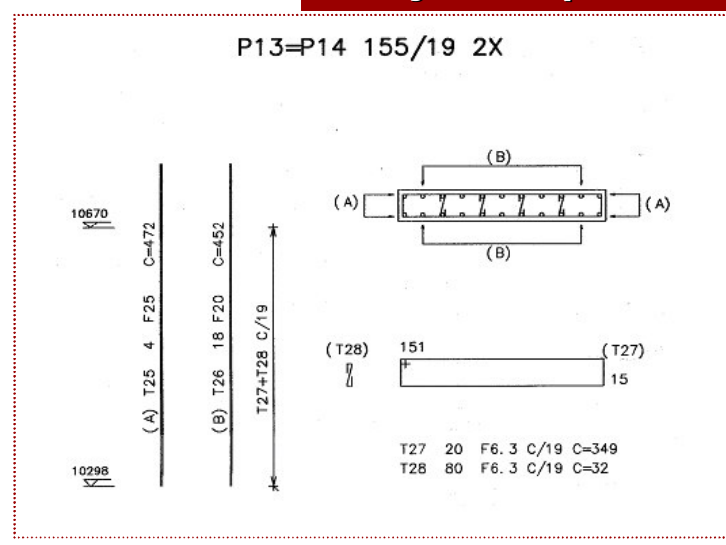

\section{Organização do trabalho}

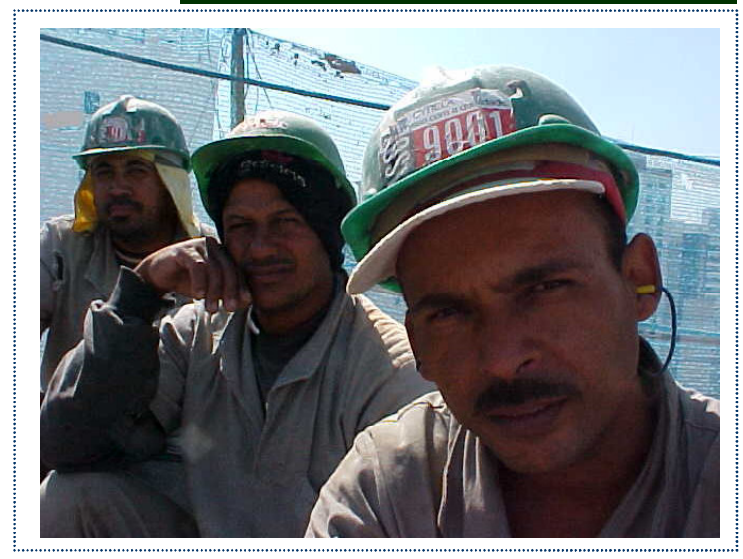

Método de trabalho
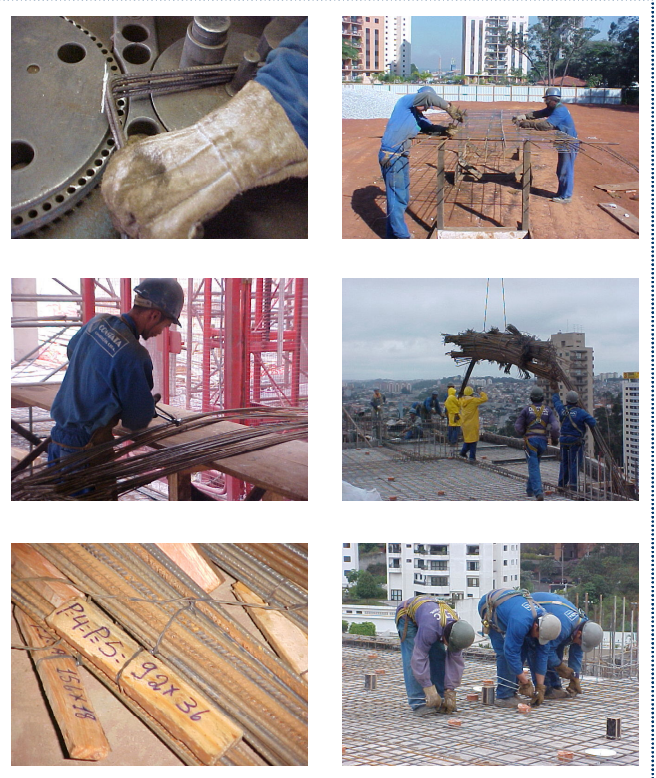

Figura 5.7 - Divisão dos fatores segundo três grupos principais

Discutem-se e apresentam-se, a seguir, fatores relacionados ao projeto do produto, ao método e à organização do trabalho. Reforça-se que esta primeira etapa do método tem o grande propósito de provocar uma discussão sobre os fatores. Pontos duvidosos, desentendimentos etc. deverão ser sanados neste momento. Vale lembrar que as listas de fatores apresentadas são "sugestivas" e não "impositivas", cabendo à construtora optar por aquele(s) grupo(s) de fatores que julgar mais relevantes ou, mesmo, propor novos fatores melhor identificados com sua realidade/necessidade.

\subsubsection{1}

Fatores relacionados ao projeto do produto

Os fatores associados ao projeto do produto que têm impacto na produtividade da mãode-obra envolvida na produção de armaduras são obtidos a partir do "projeto de fôrmas" e "projeto de detalhamento das armaduras"; esses dois projetos, juntos, compõem, como já apresentado no segundo capítulo, o projeto estrutural do edifício.

Em verdade, os fatores associados ao projeto de fôrmas são muitas vezes pré-definidos já no lançamento arquitetônico do edifício (como é o caso de fatores que exprimem características geométricas de elementos como pilares, vigas e lajes; cita-se, por exemplo, a "seção mediana de pilares"). 
O projeto arquitetônico pode, portanto, restringir substancialmente as possibilidades de lançamento estrutural pelo projetista estrutural e, como efeito direto, definir uma parcela do valor estimado para produtividade potencial da mão-de-obra. É bem verdade que, quanto mais cedo o projetista estrutural for envolvido no processo de concepção do edifício, maiores oportunidades terá para sugerir alterações na concepção arquitetônica ${ }^{95}$ que o levem a soluções estruturais mais favoráveis no âmbito da construtibilidade e, por conseguinte, da produtividade.

Porém, há de se considerar que aspectos relacionados à construtibilidade e à produtividade não são e não poderiam ser os únicos motivos de preocupação do projetista ao buscar o melhor lançamento estrutural. Os custos com materiais (concreto e aço, com destaque atualmente para os custos do aço) são altamente representativos e, certamente, deverão pesar nos cálculos para o dimensionamento da estrutura.

Os comentários supracitados, ainda que incipientes frente à importância da questão, têm aqui o propósito de mostrar que o autor, embora se enverede por discutir a influência física dos fatores associados ao projeto estrutural sobre a produtividade da mão-de-obra, têm a noção da importância do desenvolvimento de trabalhos futuros ${ }^{96}$, complementares a este, que versem sobre os impactos financeiros desses fatores sobre os custos globais das estruturas.

Os fatores de conteúdo, relacionados ao processo de produção de armaduras e, considerados neste trabalho, estarão focados no projeto de detalhamento das armaduras. Optou-se por relevar, neste estudo, os fatores obtidos a partir do "projeto de formas". As variações destes fatores (como aqueles expressos por variações de geometria dos elementos estruturais ${ }^{97}$ ), ainda que possam influenciar significativamente a produtividade física, fazem variar consideravelmente os consumos de materiais ${ }^{98}$ (concreto e aço), sendo, nesses casos, imprescindíveis análises complexas que fugiriam do "plano físico".

Os projetos de detalhamento das armaduras apresentam significativas distinções ${ }^{99}$ no seu conteúdo (a começar pelas diferentes porções ${ }^{100}$ da obra a que se referem, chegando

\footnotetext{
95 Vale lembrar que, em algumas situações específicas, para que se viabilize o lançamento de determinados empreendimentos, o projeto exija tal grau de sofisticação arquitetônica que preocupações com construtibilidade e produtividade do projeto estrutural, e ganhos recorrentes, sejam irrelevantes e, certamente, descartados.

96 Trabalhos que ao discutirem, por exemplo, conjuntos de soluções estruturais alternativas, forneçam parâmetros que permitam compará-las a partir dos custos diretos e indiretos resultantes (em que se pese, na composição dos custos destas estruturas, não somente os custos dos materiais (que poderão variar significativamente em função dos lançamentos estruturais) mas também os custos da mão-de-obra, em função das variações da construtibilidade/produtividade das soluções).

97 As seções dos elementos estruturais (pilares e vigas), por exemplo, aparecem com um fator capaz de influenciar substancialmente a produtividade da mão-de-obra; permite supor, por exemplo, que vigas mais estreitas têm armaduras mais confinadas, que dificultam a sua montagem, influenciando negativamente a produtividade.

98 Geram variações de ordem financeira no valor dos projetos, que estão fora do escopo do trabalho.

99 Observa-se que a distinção, tal como aqui colocada, diz respeito não apenas a projetos provenientes de diferentes escritórios, por exemplo, mas também a projetos desenvolvidos por um
} 
à distinção dos elementos estruturais dessas porções, que levam à necessidade de arranjos de armaduras bastante particulares e, por conseguinte, a peças bem diferentes (seja nos formatos, diâmetros, comprimentos, quantidades e disposições construtivas), conforme mostra a Figura 5.8), sendo tais distinções responsáveis por conferir diferentes níveis de construtibilidade ao projeto e, por conseguinte, variações na produtividade potencial da mão-de-obra que o irá executar.

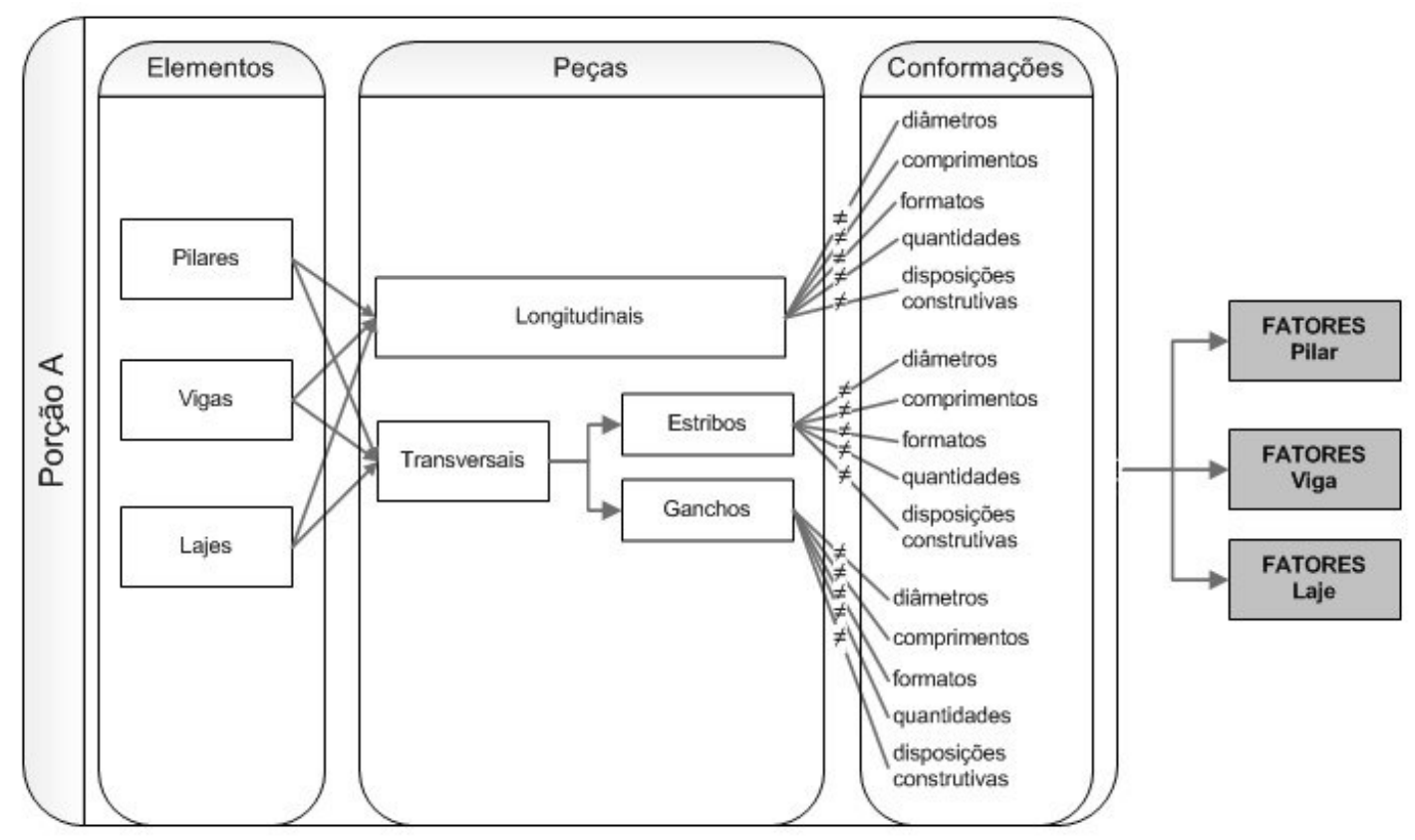

Figura 5.8 - Determinação dos fatores de conteúdo - PDA

Para a determinação dos fatores relacionados ao projeto do produto (que se acredita, possam ter influência na produtividade da mão-de-obra), tomou-se como base o trabalho de ARAUJO (2000). Alguns dos fatores listados pelo autor supracitado foram considerados; a esses se somaram outros fatores, determinados a partir da experiência do autor, que foi conquistada a partir de conversas mantidas com especialistas (projetistas, consultores, engenheiros, mestres de obras e encarregados), de observações dos processos de produção em diversas obras, de discussões envolvendo os integrantes do grupo de pesquisa do qual o autor participa, bem como através do extenso trabalho de revisão bibliográfica apresentado no capítulo dois deste trabalho.

mesmo projetista, referentes a um único empreendimento, onde uma simples mudança de pavimento pode provocar alterações sensíveis de alguns fatores.

100 Vale ressaltar que as análises contemplarão, sempre, porções semelhantes (pavimentos tipo, por exemplo) das obras estudadas, evitando-se, dessa forma, que outros fatores (como ritmos de obra distintos entre ciclos típicos e atípicos) mascarem ou ressaltem, incorretamente, possíveis fatores influenciadores. 
Ressalta-se que os fatores relacionados ao projeto do produto permitem, por si só, uma "leitura" mais detalhista e objetiva das singularidades e dos hiatos entre projetos distintos.

As Tabela 5.1, Tabela 5.2 e Tabela 5.3 apresentam os principais fatores de conteúdo, determinados a partir do projeto de detalhamento das armaduras de pilares, vigas e lajes, respectivamente. Nestas tabelas procura-se explicar, de maneira resumida, as relações e possíveis influências de cada fator sobre a produtividade da mão-de-obra envolvida na produção de armaduras de pilares, vigas e lajes. As influências tal como apresentadas neste momento, são frutos de suposições deste autor, determinadas a partir de seu senso crítico (desenvolvido, com certeza, tendo por suporte todo o estudo que envolveu o desenvolvimento deste e de outros trabalhos na área). As análises dos dados servirão, justamente, para apontar quais desses fatores seriam capazes de influenciar a produtividade da mão-de-obra.

Tabela 5.1 (continua) - Fatores de conteúdo - pilares

ID

\section{Taxa de armadura}

1 Quanto maior o valor da taxa de armadura, maior a quantidade (em massa) de aço num mesmo m3 de concreto. Para uma mesma quantidade de homens-hora, quanto maior a quantidade de aço, melhor a produtividade.

Porcentagem de armaduras servindo dois pavimentos

2 Quanto maior a quantidade de pilares com armaduras montadas de uma vez e que sirvam dois pavimentos, maior a quantidade de serviço executado a cada ciclo (operação repetida a cada dois pavimentos, levando ao um menor consumo da mão-de-obra)

\section{Porcentagem de peças transversais}

\%petrans

Acredita-se que quanto menor a porcentagem de peças transversais (em massa) em relação à massa total das armaduras dos pilares, melhor seja a produtividade da mão-de-obra relativa à tarefa. Isso porque, quanto mais peças transversais, maiores serão os esforços nas operações de corte, dobra e pré-montagem desses elementos.

Massa mediana das armaduras dos pilares

Mmedarm

5

Acredita-se que quanto menor a massa das armaduras de cada pilar, menores os esforços, principalmente na operação de montagem.

Massa mediana das peças longitudinais

Mmedlong

6

Quanto maior a massa mediana das peças longitudinais, ter-se-á, com o mesmo esforço, maior quantidade (em massa) de armadura produzida, melhorando-se, assim, a produtividade da mão-de-obra relativa à tarefa. 
Tabela 5.1 (conclusão) - Fatores de conteúdo - pilares

O trabalho para se executarem estribos de tamanhos distintos e com diâmetros próximos acaba sendo o mesmo (mesmo número de cortes e dobras). Portanto, acredita-se que maiores massas médias de estribos induzam melhores produtividades. Além de o fato das barras com diâmetros superiores a $5 \mathrm{~mm}$ apresentarem nervuras, o que facilita a prémontagem computarem um quilo. Quanto mais peças, num mesmo quilo, pior a produtividade.

Diâmetro equivalente das peças das armaduras

Quanto maior o diâmetro equivalente das barras de aço de uma tarefa, serão necessários mais $\mathrm{Kg}$ de aço para cada metro linear processado. Supondo-se o trabalho demandado associado ao comprimento processado de armaduras, diâmetros equivalentes maiores levariam a menores RUP.

Raciocínio análogo ao fator anteriro

Número de posições distintas por ton

Quanto menor a quantidade de posições distintas numa mesma quantidade (em massa) de aço, maior o número de operações (corte e dobra) que poderão ser repetidas, bem como mais facilitado/organizado será o processo de produção

Número de ganchos por $\mathrm{ml}$ de pilar

Quanto menor a quantidade de ganchos por metro linear de pilares, mais facilitada será a operação de pré-montagem

Comprimento total das peças por $\mathrm{ml}$ de pilar

Relcomp

Quanto menor a quantidade de peças (em metros lineares) por metro linear de pilar, menor será o esforço demandado nas operações de corte, dobra e pré-montagem

Quanto menor a quantidade de pilares com estribos acorrentados, menor será o esforço demandado nas operações de corte, dobra e pré-montagem demandado nas operações de corte, dobra e pré-montagem 
Tabela 5.2 - Fatores de conteúdo - vigas

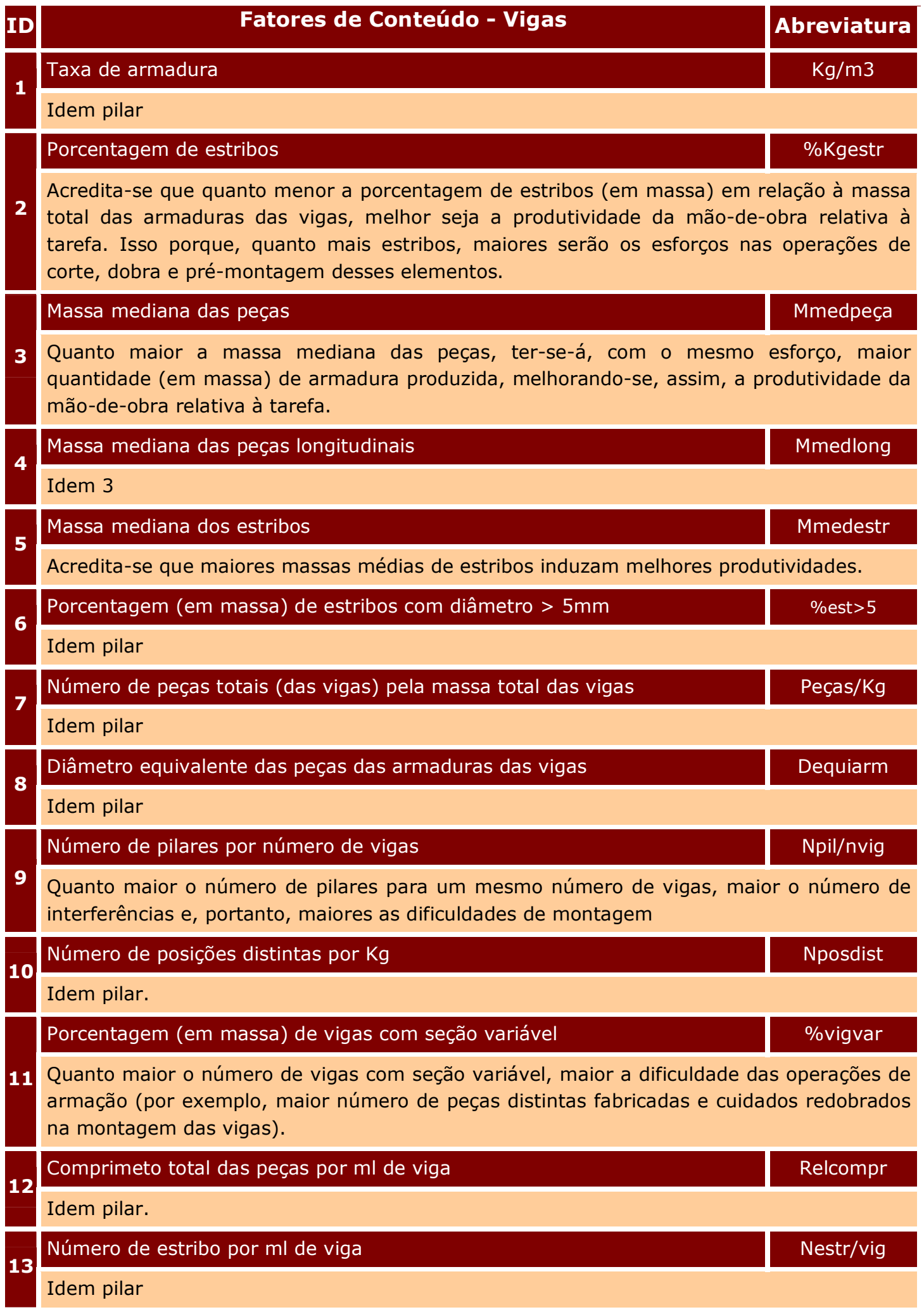


Tabela 5.3 (continua) - Fatores de conteúdo - lajes

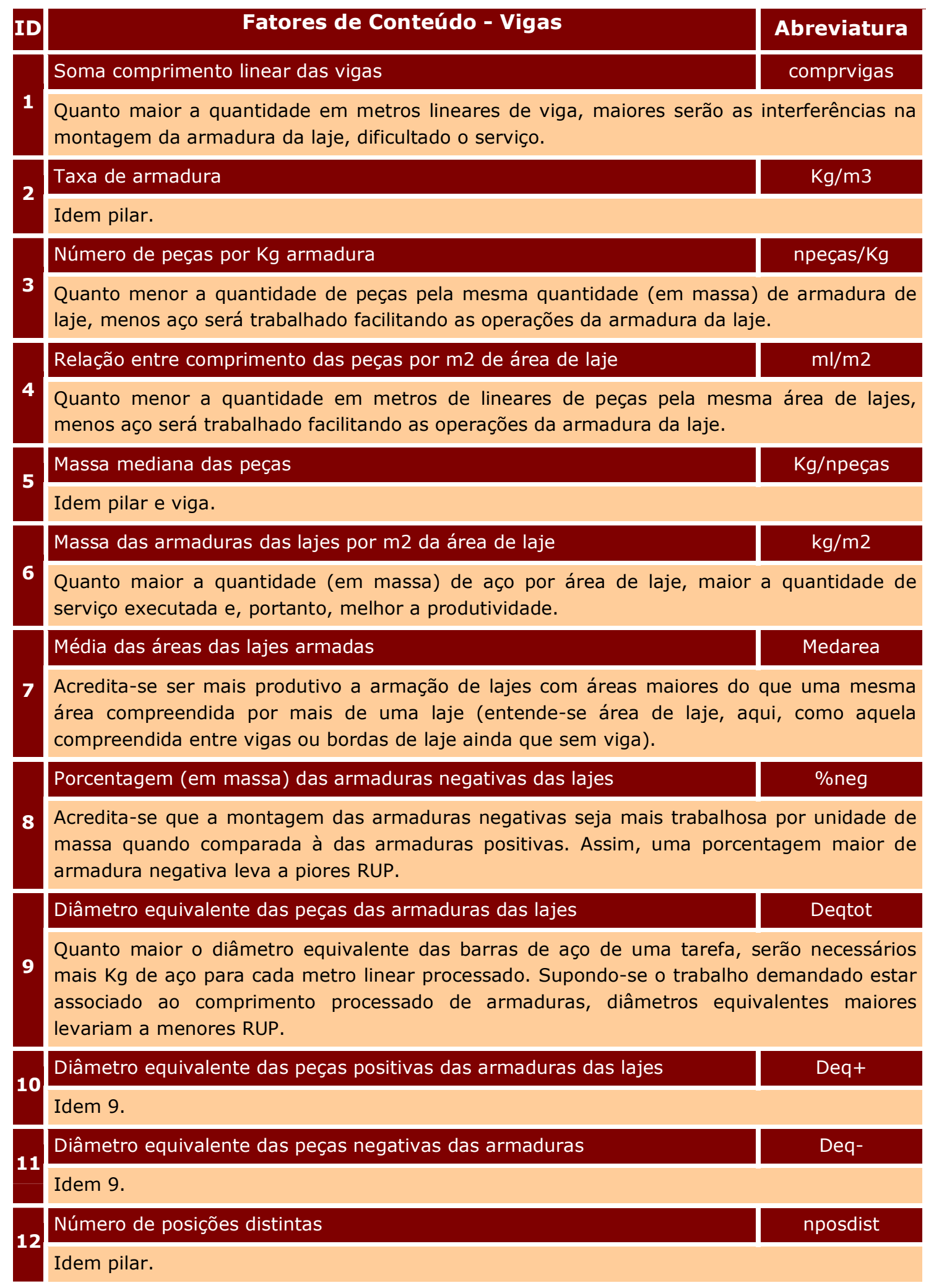


Tabela 5.3 (conclusão) - Fatores de conteúdo - lajes

\begin{tabular}{l|l|c|}
\hline \multicolumn{1}{|c|}{ ID } & \multicolumn{1}{|c|}{ Fatores de Conteúdo - Vigas } & Abreviatura \\
\hline 13 & $\begin{array}{l}\text { Porcentagem (em massa) das posições variáveis } \\
\text { Quanto maior a quantidade de posições com comprimentos variáveis, mais trabalhosa é a } \\
\text { montagem da armadura. Em muitas situações estas peças são confeccionadas na própria } \\
\text { laje. }\end{array}$ \\
\hline $\mathbf{1 4}$ & \begin{tabular}{l} 
Porcentagem (em massa) das posições negativa variáveis \\
\hline
\end{tabular} & \% \\
\hline
\end{tabular}

5.3.1.2.2

Fatores relacionados ao método de trabalho

O método de trabalho costuma variar, a cada obra, em função, principalmente, de aspectos técnicos e financeiros considerados na sua definição. Os gestores do serviço, ao configurarem o método de trabalho, estão, neste momento, contribuindo para o estabelecimento da produtividade potencial da mão-de-obra para o processo de produção em questão bem como, colaborando para que o padrão de qualidade previamente estabelecido para o serviço seja, ou não, alcançado. Assim sendo, a tomada de decisão quanto ao método de trabalho, com base em critérios técnicos (e não apenas em critérios financeiros), é extremamente importante.

O entendimento do método do trabalho pode ser facilitado quando tratado no nível de cada uma das operações que o compõem. Tal analiticidade favorece a identificação de uma série de particularidades, intrínsecas a cada operação, de difícil observação quando o processo é tratado globalmente (como uma "caixa preta"). Afirmar que o processo de produção de armaduras vai bem ou mal (sob a ótica da produtividade, por exemplo) significa atestar que as operações que o compõem (ou o conjunto das operações mais representativas (em relação ao nível de recursos empenhados num determinado processo), vão respectivamente, bem ou mal. Assim, processos de produção que apresentem, por exemplo, consumo de recursos acima de patamares médios aceitáveis, podem estar apresentando problemas em operações isoladas. A visão analítica do processo pode, nestes casos, ajudar os gestores a identificar com mais precisão e rapidez eventuais ineficiências.

As particularidades de cada operação do método de trabalho podem influenciar a produtividade da mão-de-obra envolvida em um determinado processo. No caso do PCPA, as particularidades relacionadas a cada uma das operações que, no entendimento deste pesquisador ${ }^{101}$, poderiam induzir tal influência, foram transformadas em fatores ("fatores de contexto relacionados ao método de trabalho"). Tais fatores se caracterizam por serem, em sua grande maioria, qualitativos, sendo verificados quanto à sua presença ou não, ou, eventualmente, quanto ao grau com que se apresentam.

Muitos desses fatores são bastante evidentes quanto ao tipo de influência (positiva ou negativa) que poderiam exercer sobre a produtividade da mão-de-obra. Por exemplo,

101 O entendimento foi proporcionado por trocas de informações, observações diretas e discussões com especialistas e pessoal de produção (engenheiros, mestres, encarregados e operários) pertencentes às inúmeras obras contempladas ao longo do desenvolvimento deste trabalho. 
não deixa margens a dúvidas o fator, referente à operação de recebimento do aço no canteiro, que diz respeito à "configuração da carga de aço"; as cargas que foram montadas seguindo critérios que priorizaram facilitar o descarregamento (como, por exemplo, o uso de pontaletes separando os feixes) favorecerão positivamente a produtividade.

O caminho para atestar a influência, ou mesmo, verificar uma tendência de que o fator, de fato influencia a produtividade da mão-de-obra, passaria por correlacionar "fator" e "indicador de produtividade" para um conjunto de obras, verificando, a partir daí, o estabelecimento, ou não, das influências. Embora a questão referente à análise de dados seja oportunamente tratada neste trabalho, adianta-se que, principalmente para uma amostra de dados de pequena envergadura (para fins de análises estatísticas), como deverão se caracterizar as amostras de cada construtora (principalmente nas primeiras aplicações do método), seriam pouco confiáveis as respostas obtidas ao se correlacionar cada um dos fatores aos indicadores de produtividade. Soma-se a isso um outro agravante relacionado à representatividade de cada fator. Por exemplo, numa listagem de fatores, ter-se-á, provavelmente, fatores como mais "força" de provocar influência do que outros. Mensurar esse grau de influência, para fatores pontuais relacionados ao método de trabalho, no atual estágio de desenvolvimento dos trabalhos na área, ainda não seria possível.

No entanto, não se pode abrir mão, por motivos já comentados, de tratar cada operação, e, por conseguinte, os fatores a ela relacionados, de maneira individualizada. Propõe-se que ao método de trabalho - de cada obra - seja atribuída uma nota, obtida mediante o somatório dos fatores. Para isso, deve-se, a priori, identificar o tipo de influência ${ }^{102}$ causada por fator ${ }^{103}$.

Somatórios parciais devem ser gerados para cada uma das operações que constituem o método de trabalho. A soma total será obtida ponderando-se as somas parciais em função dos esforços ${ }^{104}$ atribuídos a cada operação.

A Tabela 5.4 apresenta os fatores de contexto relacionados às principais operações preconizadas pelo método de trabalho julgados relevantes quanto à influência que podem exercer sobre a produtividade da mão-de-obra no PCPA. Percebe-se que para cada um dos fatores são três as possibilidades de serem encontrados nas obras. Como já discutido, na maioria dos casos há, quase sempre, uma possibilidade que representa uma boa prática, caracterizando um fator que tenderia a influenciar positivamente a produtividade. Além da possibilidade situada no outro extremo há, ainda, um posicionamento central.

\footnotetext{
102 Sugere-se que, aos fatores capazes de influenciar positivamente a produtividade, atribua-se o valor "1" quando detectada a sua presença; aos fatores capazes de influenciar negativamente a produtividade, o valor atribuído seria " 0 ".

103 Neste caso, para os fatores que deixam margens a dúvidas, as construtoras, durante a aplicação do MPDPro, na fase de levantamento de dados, devem realizar um questionamento dirigido ao pessoal envolvido na produção (mestres, encarregados e operários), para atestar o tipo de influência que aquele fator pode gerar.

104 Durante a etapa de levantamento de dados, ao se levantar o número de homens-hora, por ciclo, para cada operação, ter-se-á, percentualmente, o esforço, ou seja, a quantidade de homenshora consumidos em cada uma delas.
} 
Vale lembrar que, na etapa de levantamento de dados, depois de selecionados os fatores que serão adotados na aplicação do MPDPro, dever-se-á proceder a verificação quanto ao tipo de influência que cada um deles possa causar.

Tabela 5.4 (continua) - Fatores de contexto (sugeridos) relacionados ao método de trabalho

\begin{tabular}{|c|c|c|c|c|}
\hline \multirow{2}{*}{$\begin{array}{l}\text { Opera- } \\
\text { ção }\end{array}$} & \multirow{2}{*}{ Fator } & \multicolumn{3}{|c|}{ Possibilidades } \\
\hline & & $\mathbf{A}$ & B & C \\
\hline \multirow{6}{*}{ 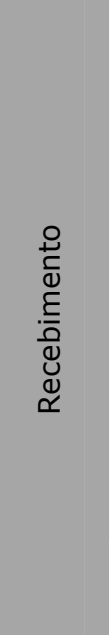 } & Tipo de aço recebido & $\begin{array}{l}\text { predominância de } \\
\text { cortado e dobrado }\end{array}$ & $>21$ e $<80 \%$ do total & $\begin{array}{l}\text { predominância de } \\
\text { barras }\end{array}$ \\
\hline & $\begin{array}{l}\text { Carregamento preparado para } \\
\text { descarregamento }\end{array}$ & sem preparo & relativa preparação & preparado \\
\hline & $\begin{array}{l}\text { Sistema de etiquetas para } \\
\text { identificação dos feixes }\end{array}$ & sem etiquetas & $\begin{array}{l}\text { etiquetas soltas e sem } \\
\text { identificação visual }\end{array}$ & $\begin{array}{l}\text { etiquetas presas e } \\
\text { com sistema de cores }\end{array}$ \\
\hline & $\begin{array}{l}\text { Acessibilidade do caminhão ao } \\
\text { canteiro }\end{array}$ & ruim & razoável & boa \\
\hline & Conferência dos feixes & $\begin{array}{l}\text { no caminhão, com } \\
\text { instrumentos métricos }\end{array}$ & $\begin{array}{l}\text { no caminhão, através } \\
\text { das etiquetas }\end{array}$ & $\begin{array}{c}\text { após } \\
\text { descarregamento, } \\
\text { através das etiquetas }\end{array}$ \\
\hline & Descarregamento & manual & $\begin{array}{l}\text { com eventual auxílio } \\
\text { de equipamento }\end{array}$ & $\begin{array}{l}\text { com freqüente uso de } \\
\text { equipamento }\end{array}$ \\
\hline \multirow{7}{*}{ 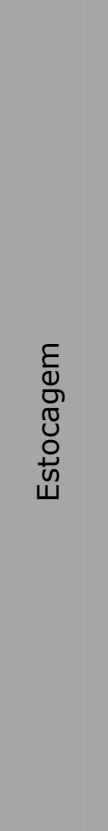 } & $\begin{array}{l}\text { Distância entre áreas de } \\
\text { descarregamento e estocagem }\end{array}$ & $>20 \mathrm{~m}$ & $<20 \mathrm{~m}$ & desprezível \\
\hline & $\begin{array}{l}\text { Estoques intermediários até } \\
\text { estocagem definitiva }\end{array}$ & $\begin{array}{l}\text { mais que dois } \\
\text { estoques } \\
\text { intermediários }\end{array}$ & um estoque & $\begin{array}{l}\text { sem estoques } \\
\text { intermediários }\end{array}$ \\
\hline & Classes de estocagem & $\begin{array}{l}\text { estoques de feixes } \\
\text { sobrepostos }\end{array}$ & $\begin{array}{l}\text { estoque de feixes } \\
\text { espalhados }\end{array}$ & estoques em barras \\
\hline & $\begin{array}{l}\text { Acessibilidade à área de } \\
\text { estocagem }\end{array}$ & ruim & razoável & boa \\
\hline & $\begin{array}{l}\text { Localização e identificação das } \\
\text { Estocagens intermediárias } \\
\text { (peças/armaduras) }\end{array}$ & $\begin{array}{l}\text { dispersas, sem } \\
\text { identificação }\end{array}$ & $\begin{array}{l}\text { dispersas, com } \\
\text { identificação }\end{array}$ & $\begin{array}{c}\text { próximas, com } \\
\text { identificação, } \\
\text { pensadas para } \\
\text { facilitar a operação } \\
\text { seguinte }\end{array}$ \\
\hline & $\begin{array}{l}\text { Configuração/disposição das } \\
\text { áreas de estocagem }\end{array}$ & $\begin{array}{c}\text { dispersas, } \\
\text { desorganizadas }\end{array}$ & $\begin{array}{l}\text { centralizadas, porém } \\
\text { sem organização }\end{array}$ & $\begin{array}{l}\text { centralizadas e } \\
\text { organizadas }\end{array}$ \\
\hline & $\begin{array}{l}\text { Porções de obras servidas a } \\
\text { partir de um mesmo estoque }\end{array}$ & mais que duas & duas & apenas uma \\
\hline
\end{tabular}


Tabela 5.4 (continua) - Fatores de contexto (sugeridos) relacionados ao método de trabalho

\begin{tabular}{|c|c|c|c|c|}
\hline \multirow{2}{*}{$\begin{array}{l}\text { Opera- } \\
\text { ção }\end{array}$} & \multirow{2}{*}{ Fator } & \multicolumn{3}{|c|}{ Possibilidades } \\
\hline & & $\mathbf{A}$ & B & C \\
\hline \multirow{2}{*}{ 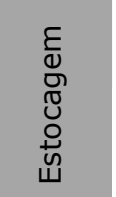 } & $\begin{array}{l}\text { Restrição de áreas no canteiro } \\
\text { para estocagem }\end{array}$ & $\begin{array}{c}\text { com restrições de } \\
\text { espaço }\end{array}$ & $\begin{array}{l}\text { com restrições } \\
\text { relativas }\end{array}$ & sem restrições \\
\hline & $\begin{array}{l}\text { Nível geral de organização dos } \\
\text { estoques de peças e armaduras }\end{array}$ & ruim & razoável & bom \\
\hline \multirow{6}{*}{ 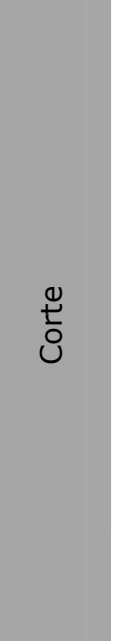 } & $\begin{array}{l}\text { Distância entre área de } \\
\text { estoques e bancadas de corte }\end{array}$ & $>10 \mathrm{~m}$ & $<10 \mathrm{~m}$ & desprezível \\
\hline & $\begin{array}{l}\text { Configuração/disposição da(s) } \\
\text { bancada(s) de corte }\end{array}$ & $\begin{array}{l}\text { fora dos padrões, } \\
\text { desprotegidas }\end{array}$ & $\begin{array}{c}\text { dentro dos padrões, } \\
\text { desprotegidas }\end{array}$ & $\begin{array}{c}\text { dentro dos padrões, } \\
\text { protegidas }\end{array}$ \\
\hline & $\begin{array}{l}\text { Equipamentos de corte das } \\
\text { barras }\end{array}$ & $\begin{array}{l}\text { uso de equipamentos } \\
\text { manuais }\end{array}$ & $\begin{array}{l}\text { uso de policorte, } \\
\text { predominantemente }\end{array}$ & $\begin{array}{l}\text { uso de máquinas } \\
\text { hidráulicas, } \\
\text { predominantemente }\end{array}$ \\
\hline & $\begin{array}{l}\text { Planejamento prévio das peças } \\
\text { a serem cortadas }\end{array}$ & sem planejamento & $\begin{array}{l}\text { planejamento da } \\
\text { produção para a } \\
\text { produção }\end{array}$ & $\begin{array}{c}\text { planejamento da } \\
\text { engenharia para a } \\
\text { produção }\end{array}$ \\
\hline & Ordem de corte & sem ordem de corte & "rascunhos" & "planos de corte" \\
\hline & $\begin{array}{l}\text { Separação/identificação das } \\
\text { peças cortadas }\end{array}$ & $\begin{array}{l}\text { sem identificação/ } \\
\text { separação }\end{array}$ & - & $\begin{array}{c}\text { identificação/ } \\
\text { separação em feixes }\end{array}$ \\
\hline \multirow{6}{*}{$\frac{\text { ㅁํ }}{\text { อ̊ }}$} & $\begin{array}{l}\text { Distância entre áreas de } \\
\text { estoques e bancadas de dobra }\end{array}$ & $>10 \mathrm{~m}$ & $<10 \mathrm{~m}$ & desprezível \\
\hline & $\begin{array}{l}\text { Configuração/disposição da(s) } \\
\text { bancada(s) de dobra }\end{array}$ & $\begin{array}{l}\text { fora dos padrões, } \\
\text { desprotegidas }\end{array}$ & $\begin{array}{c}\text { dentro dos padrões, } \\
\text { desprotegidas }\end{array}$ & $\begin{array}{c}\text { dentro dos padrões, } \\
\text { protegidas }\end{array}$ \\
\hline & $\begin{array}{l}\text { Uso de equipamentos com } \\
\text { sistema de dobramento }\end{array}$ & $\begin{array}{l}\text { uso de mesas de } \\
\text { pinos com } \\
\text { dobramento manual }\end{array}$ & $\begin{array}{c}\text { uso de mesas de } \\
\text { pinos } \\
\text { (industrializadas) } \\
\text { com dobramento } \\
\text { manual }\end{array}$ & $\begin{array}{l}\text { uso de máquinas } \\
\text { hidráulicas, } \\
\text { predominantemente }\end{array}$ \\
\hline & $\begin{array}{l}\text { Planejamento prévio das peças } \\
\text { a serem dobradas }\end{array}$ & sem planejamento & $\begin{array}{l}\text { planejamento da } \\
\text { produção para a } \\
\text { produção }\end{array}$ & $\begin{array}{c}\text { planejamento da } \\
\text { engenharia para a } \\
\text { produção }\end{array}$ \\
\hline & Ordem de dobra & sem ordem de dobra & "rascunhos" & "planos de dobra" \\
\hline & $\begin{array}{l}\text { Separação/identificação das } \\
\text { peças dobradas }\end{array}$ & $\begin{array}{l}\text { sem identificação/ } \\
\text { separação }\end{array}$ & - & $\begin{array}{c}\text { identificação/ } \\
\text { separação em feixes }\end{array}$ \\
\hline \multirow{3}{*}{ 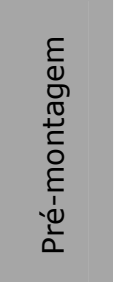 } & $\begin{array}{l}\text { Armaduras de pilares pré- } \\
\text { montadas ( } \% \text { do total) }\end{array}$ & $<50 \%$ & $>51$ e $<80 \%$ & $100 \%$ \\
\hline & $\begin{array}{l}\text { Armaduras de vigas pré- } \\
\text { montadas (\%do total) }\end{array}$ & $<50 \%$ & $>51$ e $<80 \%$ & $100 \%$ \\
\hline & $\begin{array}{l}\text { Armaduras de lajes pré- } \\
\text { montadas (\% do total) }\end{array}$ & $<50 \%$ & $>51$ e $<80 \%$ & $100 \%$ \\
\hline
\end{tabular}


Tabela 5.4 (conclusão) - Fatores de contexto (sugeridos) relacionados ao método de trabalho

\begin{tabular}{|c|c|c|c|c|}
\hline \multirow{2}{*}{$\begin{array}{l}\text { Opera- } \\
\text { ção }\end{array}$} & \multirow{2}{*}{ Fator } & \multicolumn{3}{|c|}{ Possibilidades } \\
\hline & & A & B & C \\
\hline \multirow{4}{*}{ 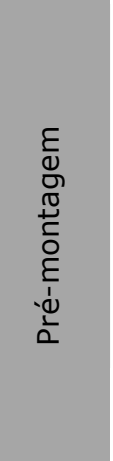 } & $\begin{array}{l}\text { Configuração/disposição da(s) } \\
\text { área(s) destinada à pré- } \\
\text { montagem }\end{array}$ & $\begin{array}{l}\text { dispersas, sem } \\
\text { proteção }\end{array}$ & $\begin{array}{c}\text { centralizadas, sem } \\
\text { proteção e ambientes } \\
\text { com trânsito intenso } \\
\text { de pessoas }\end{array}$ & $\begin{array}{l}\text { centralizadas, em } \\
\text { ambientes protegidos e } \\
\text { relativamente } \\
\text { tranqüilos }\end{array}$ \\
\hline & $\begin{array}{l}\text { Condições de trabalho dos } \\
\text { armadores }\end{array}$ & desfavoráveis & razoáveis & boas \\
\hline & Sistema de Transporte vertical & Manual (cordas) & $\begin{array}{c}\text { elevador cremalheira, } \\
\text { mini-grua }\end{array}$ & grua \\
\hline & Posicionamento das armaduras & $\begin{array}{c}\text { predominantemente } \\
\text { manual }\end{array}$ & $\begin{array}{l}\text { eventualmente } \\
\text { manual/ com grua }\end{array}$ & $\begin{array}{l}\text { predominantemente } \\
\text { com auxílio da grua }\end{array}$ \\
\hline \multirow{5}{*}{ 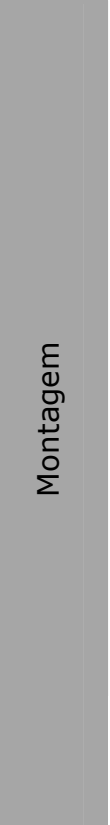 } & $\begin{array}{l}\text { Posicionamento da armadura de } \\
\text { pilares com fôrma (três faces) } \\
\text { montada }\end{array}$ & freqüentemente & eventualmente & dificilmente \\
\hline & $\begin{array}{l}\text { Complementação da armadura } \\
\text { de pilares após posicionamento } \\
\text { da gaiola (\% do total da } \\
\text { armadura) }\end{array}$ & $>51 \%$ & $>11$ e $<50 \%$ & $<10 \%$ \\
\hline & $\begin{array}{l}\text { Complementação da armadura } \\
\text { de vigas após posicionamento } \\
\text { da gaiola. Complementação da } \\
\text { armadura de pilares após } \\
\text { posicionamento da gaiola (\% do } \\
\text { total da armadura) }\end{array}$ & $>51 \%$ & $>11$ e $<50 \%$ & $<10 \%$ \\
\hline & $\begin{array}{l}\text { Configuração/disposição dos } \\
\text { espaçadores para armadura } \\
\text { negativa }\end{array}$ & - & caranguejos & treliças metálicas \\
\hline & $\begin{array}{l}\text { Montagem das vigas no } \\
\text { momento seguinte à } \\
\text { concretagem de pilares }\end{array}$ & freqüentemente & eventualmente & dificilmente \\
\hline
\end{tabular}

5.3.1.2.3

Fatores relacionados à organização do trabalho

A definição da organização do trabalho, assim como visto para o método de trabalho, também é variável, não se mantendo constante a cada obra, ou mesmo em porções distintas dentro de uma mesma obra. As variações dão-se, neste caso, não apenas por questões técnicas e financeiras, mas também, principalmente, pela cultura gerencial/organizacional da empresa detentora da mão-de-obra e da responsável direta pala sua contração (que se trata de uma construtora, na maioria das vezes).

A idéia de enxergar a organização do trabalho presente num determinado processo de produção de maneira analítica pode, também nesse caso, facilitar o seu entendimento, tornando essa tarefa mais objetiva e, logo, mais produtiva. As justificativas para a decomposição e posterior análise da organização do trabalho nas principais partes que a 
compõem são semelhantes àquelas apresentadas para o tratamento analítico adotado para o método de trabalho.

Dessa forma, ratifica-se aqui a importância do capítulo três deste trabalho, ao se chegar a um entendimento analítico da organização do trabalho. As particularidades relacionadas aos principais elementos preconizados pela organização do trabalho podem influenciar a produtividade da mão-de-obra envolvida em um determinado processo. No caso do PCPA, as particularidades relacionadas a cada um destes elementos, assim como se procedeu em se tratando do método de trabalho, foram transformadas em fatores ("fatores de contexto relacionados à organização do trabalho"). Tais fatores se caracterizam por serem, em sua grande maioria, qualitativos, em relação aos quais pode-se fazer uma simples constatação quanto à sua presença ou não.

O tipo de influência que se espera que estes fatores tenham sobre a produtividade da mão-de-obra não é tão supostamente evidente quanto àquela percebida nos fatores relacionados ao método de trabalho. Justifica-se a colocação anterior ao lembrar-se de que grande parte dos fatores de contexto relacionada à organização do trabalho tratam de necessidades específicas de indivíduos complexos e distintos (como o caso dos fatores relacionados ao elemento que trata da "manutenção" dos trabalhadores no âmbito da organização do trabalho).

Para os fatores que deixam margens a dúvidas, as construtoras, durante a aplicação do MPDPro, na fase de levantamento de dados, devem realizar (a exemplo do que foi proposto para os fatores relacionados ao método de trabalho) um questionamento dirigido ao pessoal envolvido na produção (mestres, encarregados e operários), para conhecer (ou simplesmente verificar) o tipo de influência que aquele fator pode proporcionar.

O caminho para atestar as influências dos potenciais fatores é análogo à proposta discutida para os fatores relacionadas ao método, assim como são similares os problemas verificados (níveis de representatividade e amostra de pequena envergadura).

Entende-se que tratar a organização do trabalho da maneira analítica a que se propõe é condição essencial para elevar o nível de discussão sobre a melhoria dos processos de produção. Dessa maneira o MPDPro coloca o trabalhador e os elementos relativos à sua organização, presentes em cada canteiro de obras, não mais às margens, mas sim, em posição de destaque nos debates que tratem de melhorias de processos na construção civil.

Assim como se procedeu para o método de trabalho, propõe-se que à organização do trabalho, de cada obra, seja atribuída uma nota, obtida mediante o somatório dos fatores. Para isso, deve-se, a priori, identificar o tipo de influência ${ }^{105}$ causada por cada fator.

105 Sugere-se, aqui também, que aos fatores capazes de influenciar positivamente a produtividade, atribua-se o valor " 1 " quando detectada a sua presença; aos fatores capazes de influenciar negativamente a produtividade, o valor atribuído seria " 0 ". 
Somatórios parciais podem ser gerados para cada um dos elementos que caracterizam a organização do trabalho. Neste caso a soma total seria obtida ponderando-se as somas parciais em função de pesos ${ }^{106}$ atribuídos a cada elemento.

A Tabela 5.5 sugere alguns fatores de contexto, relacionados aos principais elementos preconizadas pela organização do trabalho, julgados relevantes quanto à influência que podem exercer sobre a produtividade da mão-de-obra no PCPA. Percebe-se que, para cada fator, são duas as possibilidades de serem encontrados nas obras. Como já discutido, uma possibilidade deverá representar uma boa prática, caracterizando um fator que tenderia a influenciar positivamente a produtividade.

Tabela 5.5 (continua) - Fatores de contexto (sugeridos) relacionados à organização do trabalho

\begin{tabular}{|c|c|c|c|}
\hline \multirow[b]{2}{*}{$\begin{array}{l}\text { Aspec- } \\
\text { to }\end{array}$} & \multirow{2}{*}{ Fator } & \multicolumn{2}{|c|}{ Possibilidades } \\
\hline & & $\mathbf{A}$ & B \\
\hline \multirow{3}{*}{ 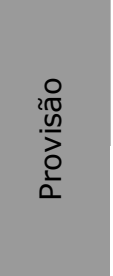 } & Regime de contratação & Tempo determinado & Tempo indeterminado \\
\hline & Experiência profissional & $\begin{array}{l}\text { Tempo de experiência comprovada } \\
\qquad 66 \text { meses }\end{array}$ & $\begin{array}{l}\text { Tempo de experiência comprovada } \\
>6 \text { meses }\end{array}$ \\
\hline & Política de contratação & $\begin{array}{l}\text { Operários novos, com experiência } \\
\text { comprovada em carteira }\end{array}$ & $\begin{array}{c}\text { Preferência por operários indicados } \\
\text { e/ou que já trabalharam para a } \\
\text { empresa }\end{array}$ \\
\hline \multirow{6}{*}{ 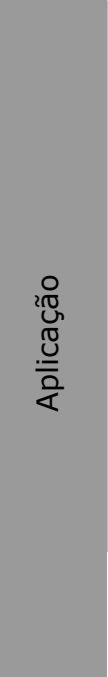 } & $\begin{array}{l}\text { Dimensionamento das } \\
\text { equipes }\end{array}$ & Base empírica & Base metodológica \\
\hline & $\begin{array}{l}\text { Alocação das equipes } 1 \\
\text { (mesmo serviço) }\end{array}$ & Realocações intra-obra pouco usuais & $\begin{array}{c}\text { Realocações freqüentes dos } \\
\text { operários em porções distintas na } \\
\text { mesma obra }\end{array}$ \\
\hline & $\begin{array}{l}\text { Alocação das equipes } 2 \\
\text { (mesmo serviço) }\end{array}$ & $\begin{array}{c}\text { Realocações inter-obras pouco } \\
\text { usuais }\end{array}$ & $\begin{array}{c}\text { Realocações freqüentes dos } \\
\text { operários em porções de obras } \\
\text { distintas }\end{array}$ \\
\hline & $\begin{array}{l}\text { Jornada de trabalho } \\
\text { diária } 1\end{array}$ & $\begin{array}{c}>9 \text { horas disponíveis para o } \\
\text { trabalho }\end{array}$ & $\begin{array}{c}<=9 \text { horas disponíveis para o } \\
\text { trabalho }\end{array}$ \\
\hline & $\begin{array}{l}\text { Jornada de trabalho } \\
\text { semanal } 2\end{array}$ & $>44$ & $<=44$ \\
\hline & $\begin{array}{l}\text { Realocação nos } \\
\text { momentos de ociosidade } \\
\text { do ciclo (outro serviço) }\end{array}$ & $\begin{array}{c}\text { Apenas nas tarefas habituais } \\
\text { relacionadas ao ofício registrado em } \\
\text { carteira profissional }\end{array}$ & $\begin{array}{c}\text { Eventualmente em tarefas que não } \\
\text { as relacionadas ao ofício registrado } \\
\text { em carteira profissional }\end{array}$ \\
\hline
\end{tabular}

106 Os pesos podem ser determinados a partir de consultas (questionamentos e/ou enquetes) a especialistas em gestão da produção, adicionalmente ou não às opiniões de subempreiteiros e demais responsáveis por grupos de trabalhadores. 
Tabela 5.5 (conclusão) - Fatores de contexto (sugeridos) relacionados à organização do trabalho

\begin{tabular}{|c|c|c|c|}
\hline \multirow[b]{2}{*}{$\begin{array}{l}\text { Aspec- } \\
\text { tn }\end{array}$} & \multirow{2}{*}{ Fator } & \multicolumn{2}{|c|}{ Possibilidades } \\
\hline & & $\mathbf{A}$ & $\mathbf{B}$ \\
\hline \multirow{5}{*}{ 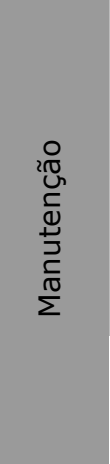 } & Aditivos salariais & Esporádicos (horas-extras) & Permanentes (tarefas) \\
\hline & Nível salarial & $\begin{array}{c}\text { Média salarial mensal }(\mathrm{R} \$)<1,1 \times \\
\text { piso categoria }\end{array}$ & $\begin{array}{c}\text { Média salarial mensal }(\mathrm{R} \$)>1,1 \times \\
\text { piso categoria }\end{array}$ \\
\hline & Horas ociosas no ciclo & $\begin{array}{l}\text { Operários dispensados ("acabou- } \\
\text { lavou") }\end{array}$ & $\begin{array}{c}\text { Operários remanejados para outras } \\
\text { atividades }\end{array}$ \\
\hline & Benefícios & $\begin{array}{c}\text { Não disponibilizados ou } \\
\text { disponibilizados com atraso }\end{array}$ & Disponibilizados sem atraso \\
\hline & Motivação & $\begin{array}{l}\text { Práticas não identificadas ou } \\
\text { identificadas mas não valoradas } \\
\text { pelos operários }\end{array}$ & $\begin{array}{l}\text { Práticas identificadas e valoradas } \\
\text { pelos operários }\end{array}$ \\
\hline \multirow{3}{*}{ 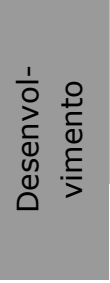 } & $\begin{array}{l}\text { Leitura e interpretação } \\
\text { de projetos }\end{array}$ & $\begin{array}{c}<30 \% \text { dos operários com tais } \\
\text { habilidades }\end{array}$ & $\begin{array}{c}>30 \% \text { dos operários com tais } \\
\text { habilidades }\end{array}$ \\
\hline & $\begin{array}{l}\text { Programas de reciclagem } \\
\text { profissional }\end{array}$ & Não disponíveis aos operários & Disponíveis aos operários \\
\hline & Profissionalização & $\begin{array}{c}\text { Capacitação mediante observações } \\
\text { de profissionais experientes }\end{array}$ & $\begin{array}{l}\text { Através de programas oficiais de } \\
\text { formação/capacitação }\end{array}$ \\
\hline 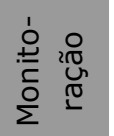 & $\begin{array}{l}\text { Apontamento dos } \\
\text { operários }\end{array}$ & $\begin{array}{c}\text { Para pagamentos/controles de } \\
\text { custos }\end{array}$ & Para subsidiar gestão \\
\hline
\end{tabular}

\subsubsection{Levantamento de dados}

A etapa de levantamento de dados está fundamentada em dois tipos de levantamento de dados: i) levantamentos objetivos, que permitem a determinação dos indicadores de produtividade da mão-de-obra e dos fatores (de conteúdo e contexto) potenciais influenciadores desta produtividade; ii) levantamentos subjetivos, que possibilitem a determinação das opiniões pessoais ${ }^{107}$ de mestres e encarregados de armação e armadores (quanto a aspectos relacionados ao projeto do produto, ao método e à organização do trabalho que seriam favoráveis, ou não, à exeqüibilidade do serviço). Ambos os levantamentos são realizados a partir de quatro fontes de evidência principais, apresentadas e comentadas na Tabela 5.6.

107 A lista de opiniões, ainda que tragam informações com elevado grau de subjetividade, serem levantadas tomando como base os fatores de conteúdo e contexto propostos (levantamento objetivo). Antecipa-se que a etapa de proposição de diretrizes preconiza dois tipos de análises (objetivas e subjetivas). As análises subjetivas serão baseadas nas expectativas da produção, que por sua vez, são determinadas a partir das listas de opiniões. 
Tabela 5.6 - Caracterização das fontes de evidência utilizadas nos levantamentos de dados

\begin{tabular}{|c|c|}
\hline Levanta- & Fontes de Evidência \\
\hline \multirow{3}{*}{ Objetivo } & $\begin{array}{l}\text { 1. Leitura crítica dos projetos do produto: a partir do projeto de } \\
\text { detalhamento de armadura e do projeto de fôrmas, faz-se um levantamento } \\
\text { pormenorizado sobre o produto a executar, extraindo-se um conjunto de } \\
\text { indicadores de caracterização do projeto do produto (ICPP), a partir dos } \\
\text { quais determinam-se os quantitativos do projeto (ou seja, quantidade de } \\
\text { aço, em toneladas, por tarefa e por porção da obra) e os fatores de } \\
\text { conteúdo; }\end{array}$ \\
\hline & $\begin{array}{l}\text { 2. Observações diretas: o posicionamento junto à produção permite que se } \\
\text { faça uma acolhida de informações, possibilitando uma descrição tanto do } \\
\text { método quanto da organização do trabalho referente ao processo de } \\
\text { produção em questão. Os principais aspectos a serem observados devem } \\
\text { estar previamente definidos (o conjunto de fatores de contexto, previamente } \\
\text { determinado, deve servir como roteiro para o levantamento de dados); }\end{array}$ \\
\hline & $\begin{array}{l}\text { 3. Levantamentos periódicos: durante um período e para porções pré- } \\
\text { determinadas, fazem-se coletas de dados nas obras (referentes às entradas } \\
\text { (homens-hora) e saídas (quantidade de serviço executada)) a partir das } \\
\text { quais determinar-se-ão os indicadores de produtividade da mão-de-obra. }\end{array}$ \\
\hline Subjetivo & $\begin{array}{l}\text { 4. Entrevistas semi-estruturadas: novamente, os fatores de conteúdo e } \\
\text { contexto, pré-determinados na primeira etapa do método, servirão como } \\
\text { referência para a elaboração de um questionário, que será a base para a } \\
\text { realização de reuniões com as pessoas das obras participantes do MPDPro } \\
\text { (deverão participar o engenheiro de produção responsável pela obra, o } \\
\text { subempreiteiro de estrutura, o mestre de obras e oncarregado (ou mestre) } \\
\text { de armação). Nestas reuniões dever-se-á obter um conjunto de opiniões dos } \\
\text { participantes (registrada num documento denominado "lista de opiniões") } \\
\text { quanto aos pontos favoráveis e desfavoráveis, dentre os aspectos } \\
\text { apresentados (relativos ao projeto do produto, método e organização do } \\
\text { trabalho), referentes à exeqüibilidade das operações presentes na etapa de } \\
\text { armação do PCPA. }\end{array}$ \\
\hline
\end{tabular}

Vale dizer que, com exceção dos indicadores de caracterização do projeto do produto, os demais dados são obtidos a partir de levantamentos realizados em campo (Figura 5.9). Os produtos, obtidos após o processamento dos dados levantados, são três: i) indicadores de produtividade da mão-de-obra; ii) fatores potenciais influenciadores; iii) expectativas da produção. 


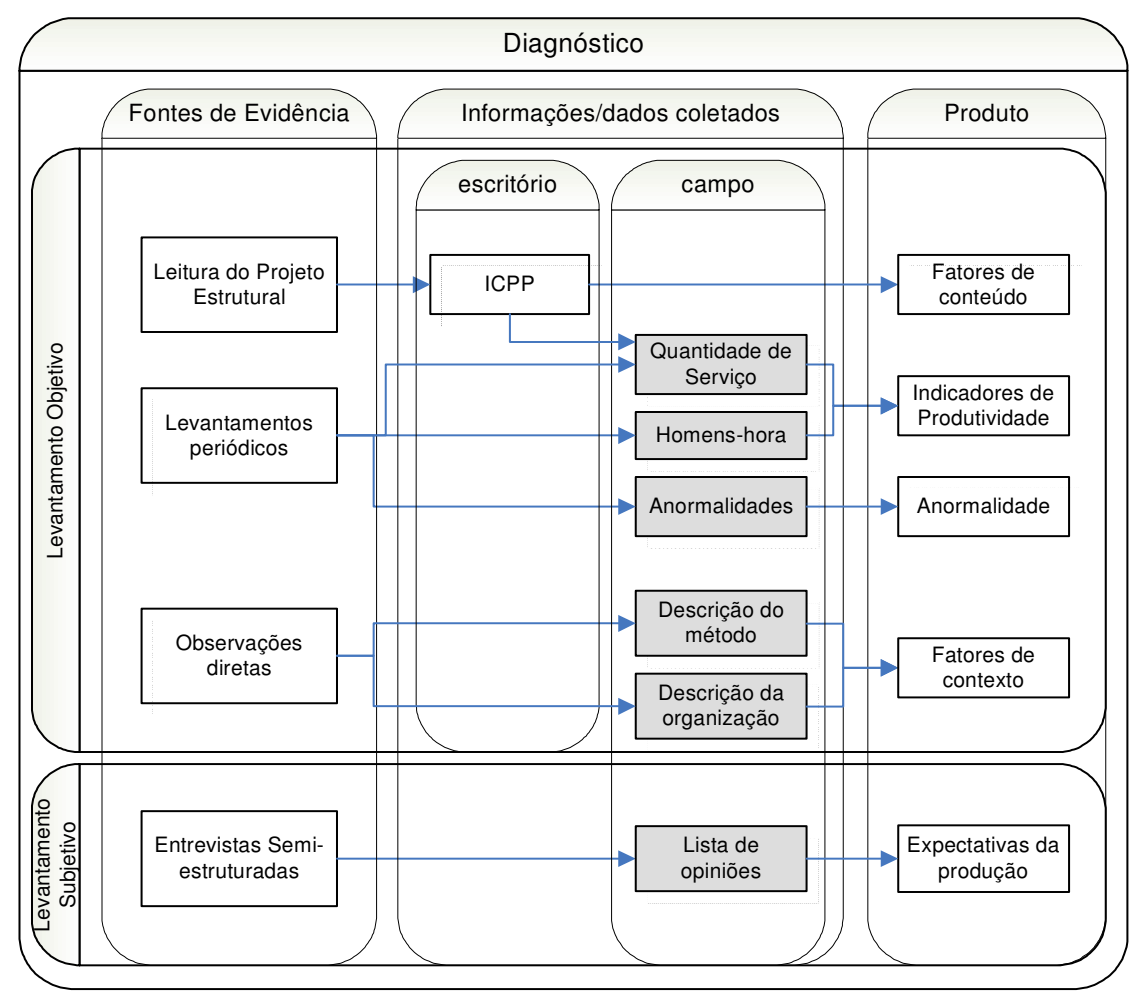

Figura 5.9 - Fluxograma da etapa de levantamento de dados do método

Apresenta-se, a seguir, a proposta de operacionalização da etapa de levantamento de dados do MPDPro.

\subsubsection{Operacionalização do Levantamento de dados}

\subsubsection{1}

Definição da amostra

O levantamento de dados visando à determinação de indicadores de produtividade da mão-de-obra e de fatores influenciadores deve ser sempre feito para ciclos completos de porções da estruturas. Uma vez levantados os dados referentes a uma porção específica, esses devem ser ordenados e armazenados num banco de dados da empresa para que possam ser comparados com outras porções da mesma ou de outras obras. Recomendase que o levantamento de dados seja feito, sempre que possível, para mais de um ciclo, em se tratando de porções semelhantes e que assim o permitam (por exemplo, para os pavimentos tipo).

Para os objetivos preconizados pelo MPDPro, a etapa de levantamento de dados, tal qual comentada anteriormente, não precisa se estender ao longo de todo o período de execução da estrutura. No entanto, após a implementação do método, a construtora, que estará familiarizada com a etapa de levantamento de dados, poderá mantê-lo. Dessa forma, ao promover um monitoramento contínuo do processo de produção, poderá constatar, através dos indicadores continuamente levantados, por exemplo, se ações postas em prática estarão se convertendo em melhorias da produtividade da mão-deobra. 
Já a fase de levantamento de dados visando à determinação das expectativas da produção, independentemente do número de porções/ciclos da obra cujos indicadores de produtividade e fatores serão determinados, está baseada, a princípio, em uma única reunião (por obra participante), envolvendo, preferencialmente, todo o efetivo administrativo da obra relacionado ao processo de produção das armaduras (mestres, encarregados, subempreiteiros e engenheiros de produção).

Apresentam-se, a seguir, orientações para a determinação do conjunto de dados previsto na etapa de levantamento de dados.

\subsubsection{Determinação dos indicadores de produtividade}

Para a determinação dos indicadores de produtividade (RUP) é preciso que sejam mensurados os homens-hora (entradas) e a quantidade de serviço (saídas, expressas em toneladas de armaduras produzidas), relativas à execução de porções específicas e prédeterminadas da estrutura. Nesse caso a fonte de evidência diz respeito aos levantamentos periódicos de dados realizados no canteiro de obras (em se tratando da quantidade de serviço, é preciso que se levante, no campo, as porções cujo serviço foi executado, pois as quantidades de aço, referentes a tais porções, foram levantadas, preliminarmente, no escritório (a partir da determinação dos ICPP)).

O período de tempo adotado para mensuração das entradas e saídas será o relativo à duração dos $\operatorname{ciclos}^{108}$ contemplados no levantamento de dados. Para que os indicadores de produtividade da mão-de-obra sejam confiáveis e passíveis de análises, as mensurações devem ser feitas seguindo critérios pré-estabelecidos, listados nas Tabela 5.7 e Tabela 5.8 .

Tabela 5.7 (continua) - Critérios para a mensuração das entradas (homens-hora).

\begin{tabular}{|c|c|}
\hline Aspectos & Homens-hora \\
\hline Considerações & $\begin{array}{l}\checkmark \text { no que diz respeito ao tempo de dedicação, consideram-se apenas } \\
\text { as horas disponíveis para o trabalho, apropriando-se o tempo total } \\
\text { que o operário está presente no canteiro e pronto para trabalhar; } \\
\checkmark \quad \text { não devem ser descontadas horas de paralisação; } \\
\checkmark \quad \text { não se deve adotar a postura de computar apenas os tempos } \\
\text { produtivos; não se consideram as horas prêmio recebidas sem que o } \\
\text { operário as tenha realmente trabalhado. }\end{array}$ \\
\hline Analiticidade & $\begin{array}{l}\checkmark \text { devem-se apropriar os homens-hora, separadamente, de acordo } \\
\text { com as tarefas (pilar, viga, laje e escada) em que eles estejam } \\
\text { envolvidos. No caso de se trabalhar com o corte e dobra das barras } \\
\text { no canteiro de obras, os homens-hora envolvidos nessas operações } \\
\text { devem ser mensurados em separado dos demais. }\end{array}$ \\
\hline
\end{tabular}

108 Em se tratando de estruturas de edifícios multipavimentos, os ciclos são entendidos como o período de tempo gasto entre o início (normalmente a primeira atividade pertencente à produção dessa estrutura trata-se da marcação dos eixos para locação dos pilares (gastalhos)) e a conclusão (marcada, geralmente, pela concretagem da laje) da execução da estrutura de uma determinada porção. 
Tabela 5.7 (conclusão) - Critérios para a mensuração das entradas (homens-hora).

\begin{tabular}{|c|c|}
\hline Aspectos & Homens-hora \\
\hline Periodicidade & $\begin{array}{l}\text { recomenda-se que as mensurações dos homens-hora sejam feitas } \\
\text { diariamente pela pessoa responsável por essa coleta, evitando-se, } \\
\text { com isso, possíveis dúvidas, fruto basicamente, de "esquecimentos" } \\
\text { e minimizando-se, assim, as chances de apontamentos de } \\
\text { informações incorretas. }\end{array}$ \\
\hline $\begin{array}{l}\text { Metodologia de } \\
\text { mensuração }\end{array}$ & $\begin{array}{l}\text { as mensurações podem ser feitas a partir de observações diretas da } \\
\text { equipe no posto do trabalho. Essa prática, porém, não é } \\
\text { recomendável, haja vista a quantidade de tempo demandada; } \\
\text { recomenda-se que as mensurações sejam feitas diretamente pelo } \\
\text { encarregado da equipe (ele próprio, desde que treinado/orientado, } \\
\text { pode ser incumbido de fazer o apontamento). Em não sendo } \\
\text { possível a prática supracitada (por exemplo, havendo dificuldades } \\
\text { do encarregado no registro das informações) passa-se a } \\
\text { incumbência a uma outra pessoa (normalmente um estagiário ou } \\
\text { apontador da obra), que fará a mensuração a partir das informações } \\
\text { passadas pelo responsável direto pelo serviço (encarregado, líder de } \\
\text { equipe ou mestre de obras) }\end{array}$ \\
\hline $\begin{array}{l}\text { Instrumentos para } \\
\text { mensuração }\end{array}$ & $\begin{array}{l}\text { Planilha para levantamento dos homens-hora, em campo, } \\
\text { semelhantes àquelas apresentadas por ARAÚJO (2000) }\end{array}$ \\
\hline Responsabilidades & $\begin{array}{l}\text { recomenda-se que a responsabilidade pela coerência e, portanto, } \\
\text { confiabilidade das mensurações deva ser assumida por um } \\
\text { profissional da construtora, designado para conduzir a } \\
\text { implementação do método (recomenda-se que seja o engenheiro } \\
\text { responsável pela obra, ou, eventualmente, outra pessoa definida } \\
\text { pelos responsáveis superiores da empresa, desde que assumidas e } \\
\text { mantidas as mesmas responsabilidades), seja numa obra ou num } \\
\text { conjunto de obras. Essa pessoa deverá se cercar de instrumentos } \\
\text { (tais como treinamento, sistemática de conferências etc) para que } \\
\text { as informações passadas sejam procedentes. }\end{array}$ \\
\hline
\end{tabular}

Tabela 5.8 (continua) - Critérios para a mensuração da quantidade de serviço

Aspectos

Unidade de mensuração

Considerações

\section{Quantidade de serviço}

$\checkmark$ tonelada

a mensuração da quantidade de serviço, em se tratando da produção de armaduras, é determinada somando-se a massa das armaduras dos elementos que compõem a porção da estrutura considerada. Como a mensuração está associada a ciclos de produção, a quantificação das saídas não requer que sejam feitos levantamentos de campo, posto que a quantidade de serviço executada a cada ciclo consta, portanto, nos projetos estruturais (mais especificamente, no projeto de detalhamento de armaduras). 
Tabela 5.8 (conclusão) - Critérios para a mensuração da quantidade de serviço

\begin{tabular}{|c|c|}
\hline Aspectos & Quantidade de serviço \\
\hline Analiticidade & $\begin{array}{l}\checkmark \text { a mensuração das saídas, embora seja feita com o simples } \\
\text { apontamento de encerramento de ciclo, deve subentender que } \\
\text { foram produzidas quantidades (em massa) distintas de armaduras } \\
\text { de pilares, vigas, lajes e escadas. São essas quantidades, separadas } \\
\text { por elementos, que devem constar, efetivamente, como saídas. }\end{array}$ \\
\hline Periodicidade & $\begin{array}{l}\checkmark \text { a mensuração das saídas, ao contrário da recomendação feita para o } \\
\text { levantamento dos homens-hora, é realizada ao final do ciclo. }\end{array}$ \\
\hline $\begin{array}{l}\text { Metodologia de } \\
\text { mensuração }\end{array}$ & $\begin{array}{l}\checkmark \text { a mensuração das saídas é determinada de forma direta e objetiva, } \\
\text { bastando para tal apenas o apontamento de encerramento do ciclo. } \\
\checkmark \text { nas obras que trabalham com o beneficiamento do aço no canteiro, } \\
\text { é prática comum que as operações de corte e dobra das barras se } \\
\text { adiantem em relação às operações de montagem das armaduras. } \\
\text { Assim, ao final de um ciclo, o aço cortado e dobrado no período } \\
\text { pode não ter sido destinado apenas ao ciclo em questão. Para esse } \\
\text { caso, cabe uma mensuração isolada e discriminada das peças que } \\
\text { foram beneficiadas não condizentes com o ciclo do pavimento cujas } \\
\text { armaduras foram montadas. }\end{array}$ \\
\hline $\begin{array}{l}\text { Unidade de } \\
\text { mensuração }\end{array}$ & $\checkmark$ tonelada \\
\hline Responsabilidades & $\begin{array}{l}\checkmark \text { a responsabilidade, neste caso, está associada à quantificação das } \\
\text { armaduras (em massa), que deve ser feita através dos projetos de } \\
\text { detalhamento das armaduras. } \\
\checkmark \text { os projetos das porções, cujas produtividades da mão-de-obra } \\
\text { pretende-se levantar, devem ser quantificados previamente, } \\
\text { estando as quantificações disponíveis no momento em que o ciclo se } \\
\text { encerrar. }\end{array}$ \\
\hline $\begin{array}{l}\text { Instrumentos para } \\
\text { mensuração }\end{array}$ & $\begin{array}{l}\checkmark \text { baseados na proposta apresentada por ARAÚJO (2000), as planilhas } \\
\text { para mensuração das saídas, devem prever e assegurar o correto } \\
\text { levantamento de subtarefas, como o corte e a dobra das barras, que } \\
\text { são normalmente antecipadas (ou seja, estão descoladas) em } \\
\text { relação ao ciclo do pavimento cujas armaduras estão sendo } \\
\text { montadas. }\end{array}$ \\
\hline
\end{tabular}

A partir da mensuração das entradas e saídas determinam-se as RUP ${ }^{109}$ cíclicas. As RUP potencial e cumulativa são calculadas a partir das RUP cíclicas, como mostra a Figura 5.10. Para a determinação das RUP cumulativas, os homens-hora e a quantidade de serviço devem ser acumulados ao longo das porções semelhantes contempladas no levantamento de dados.

${ }^{109}$ Vale ressaltar que as RUP são determinadas no nível das tarefas; no caso de se trabalhar com o corte e dobra das barras no canteiro de obras, as RUP devem ser determinadas no nível das subtarefas que, neste caso são duas: corte+dobra e pré-montagem+montagem. 
A partir das RUP cíclica e RUP cumulativa determina-se a RUP potencial que, para cada porção de obra estudada, é um valor de RUP cíclica associado à sensação de bom desempenho e que, ao mesmo tempo, mostre-se factível em função dos valores de RUP cíclicas detectados. Matematicamente, como já comentado, a RUP potencial é calculada como o valor da mediana das RUP cíclicas inferiores ao valor da RUP cumulativa ao final do período de estudo. Ressalta-se que a RUP utilizada nas análises será a RUPpot. A RUPpot da forma como é determinada não "carrega" as influências provocadas por anormalidades.

Em se tratando dos pilares é importante mencionar que, quando há variações na quantidade de aço das armaduras nos andares, deve-se tomar cuidados especiais ao se determinar RUP cumulativas e RUP potenciais de maneira a evitar que essas variações comprometam a interpretação dos dados.

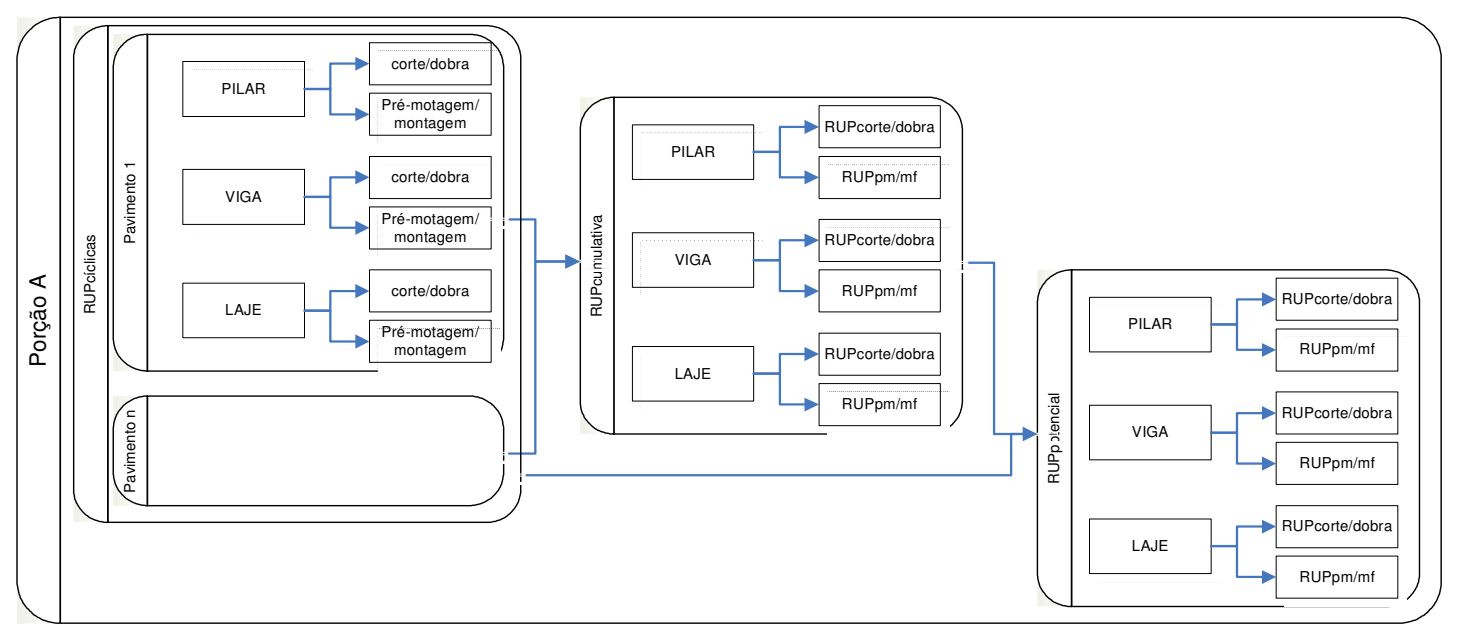

Figura 5.10 - Fluxograma explicativo para a determinação das RUP

A Tabela 5.9 ilustra um exemplo de tabela desenvolvida para a organização das RUP cíclicas (RUP cic) e determinação das RUP potenciais (RUP pot) e RUP cumulativas (RUP cum) para uma obra hipotética (SP A) que não realiza as operações de corte e dobra no canteiro de obras. 
Tabela 5.9 - Exemplo de tabela para organização das RUP de uma obra

\begin{tabular}{|c|c|c|c|c|c|c|c|c|c|c|}
\hline \multirow{2}{*}{ OBRA } & \multirow{2}{*}{ Porção } & \multirow{2}{*}{$\begin{array}{l}\text { Tipo de } \\
\text { RUP }\end{array}$} & \multicolumn{2}{|c|}{$\begin{array}{c}\text { RUP PILAR } \\
\text { (Hh/ton) }\end{array}$} & \multicolumn{2}{|c|}{$\begin{array}{c}\text { RUP VIGA } \\
\text { (Hh/ton) }\end{array}$} & \multicolumn{2}{|c|}{$\begin{array}{l}\text { RUP LAJE } \\
\text { (Hh/ton) }\end{array}$} & \multicolumn{2}{|c|}{$\begin{array}{c}\text { SERVIÇO } \\
\text { (Hh/ton) }\end{array}$} \\
\hline & & & $C / D$ & $P M / M F$ & $C / D$ & $P M / M F$ & $C / D$ & $P M / M F$ & sem $C / D$ & com $C / D$ \\
\hline \multirow{10}{*}{ SP A } & 1\%/Tipo & $\mathrm{cic}$ & - & 35 & - & 39 & - & 14 & 21 & 36 \\
\hline & $2^{\circ} /$ Tipo & $\mathrm{cic}$ & - & 28 & - & 59 & - & 26 & 27 & 42 \\
\hline & 3\%/Tipo & $\mathrm{cic}$ & - & 25 & - & 50 & - & 26 & 24 & 37 \\
\hline & $4^{\circ} /$ Tipo & cic & - & 31 & - & 70 & - & 18 & 27 & 40 \\
\hline & 5\%/Tipo & cic & - & 73 & - & 48 & - & 21 & 34 & 48 \\
\hline & 6\%/Tipo & cic & - & 63 & - & 40 & - & 19 & 33 & 43 \\
\hline & \multirow{2}{*}{$\begin{array}{l}1^{\circ} \text { ao } 3^{\circ} \\
\text { pilares }\end{array}$} & RUP cum & - & 30 & - & 51 & - & 21 & 25 & 39 \\
\hline & & RUP pot & - & 29 & - & 46 & - & 20 & 23 & 37 \\
\hline & \multirow{2}{*}{$\begin{array}{l}4^{\circ} \text { ao } 6^{\circ} \\
\text { (pilares) }\end{array}$} & RUP cum & - & 68 & - & - & - & - & 34 & 45 \\
\hline & & RUP pot & - & 63 & - & - & - & - & 33 & 43 \\
\hline
\end{tabular}

onde: $C / D=$ corte e dobra; $P M / M F=$ pré-montagem e montagem final

5.3.2.1.3

A determinação dos fatores de conteúdo, referentes ao projeto do produto, é feita através do projeto de detalhamento de armadura (que se trata, portanto, da "fonte de evidência" a ser considerada para este levantamento) referente à porção da estrutura que se deseja analisar. Em função do significativo número de pranchas que compõem o projeto estrutural de uma obra, ou mesmo de uma pequena porção da estrutura, tornouse necessário o desenvolvimento de ferramentas que otimizem o cálculo destes fatores.

Um conjunto de planilhas eletrônicas, denominadas "instrumentos para caracterização analítica do projeto do produto" (ICAPP), foram desenvolvidas. Dessa maneira, a partir do planilhamento do projeto de detalhamento das armaduras (em que, no modelo proposto de planilha, entram os seguintes dados: i) identificação do elemento estrutural; ii) características das peças (posições) pertencentes a cada elemento estrutural (nome, tipo da posição (se peça longitudinal ou transversal), diâmetro, comprimento e quantidade)), chegam-se aos indicadores de caracterização do projeto ${ }^{110}$ e, a partir desses indicadores, aos valores dos fatores ${ }^{111}$ de conteúdo. Tantos os indicadores de caracterização do projeto do produto, quanto os fatores, são calculados

110 Os indicadores de caracterização do projeto permitem uma primeira análise do projeto, ao permitirem sua leitura através de valores, como a média ponderada dos diâmetros de todos os componentes, por exemplo.

111 Enquanto os indicadores de projeto "traduzem" em números as informações do projeto do produto (por exemplo, massa de aço (em tonelada) das peças longitudinais dos pilares), os fatores (de conteúdo) procuram exprimir uma característica do projeto passível de ser relacionada à produtividade da mão-de-obra. Geralmente, a relação estabelecida entre dois indicadores origina um fator (massa de peças longitudinais de pilares em relação à massa total de pilares). 
automaticamente. A Figura 5.11 ilustra um exemplo da planilha supracitada (ICPP, à esquerda, e fatores de conteúdo (determinados automaticamente), à direita).

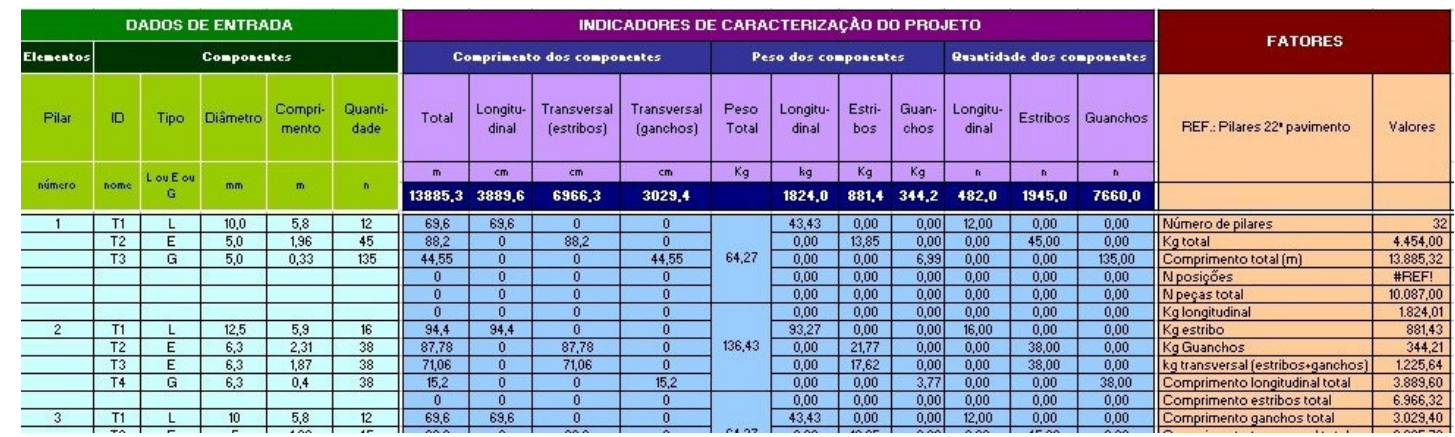

Figura 5.11 - Exemplo de planilha eletrônica proposta

Os fatores de contexto, relacionados ao método e à organização do trabalho, são determinados através das observações diretas da produção (que se trata, portanto, da "fonte de evidência" a ser considerada para tal levantamento), sendo as constatações agrupadas em tabelas específicas para este fim.

Para assegurar que todas os dados necessários à determinação dos fatores sejam coletadas, é importante que o responsável por esta fase de levantamento de dados elabore um roteiro baseado, a princípio, na listagem com os próprios fatores previamente estabelecidos. As Tabela 5.4 e Tabela 5.5, apresentadas anteriormente, podem servir como tal roteiro para as observações, na medida em que explicitam os fatores e suas possibilidades de ocorrência. É importante ressaltar que, enquanto as questões referentes ao método de trabalho podem ser determinadas a partir de simples observações em campo, as questões relativas à organização do trabalho requerem conversas (entrevistas não necessariamente formais) com os responsáveis pelas equipes de produção (mestres ou encarregados do serviço).

Vale lembrar que, para os fatores relacionados ao método e à organização do trabalho, faz-se necessário levantar, também, o tipo de influência (positiva ou negativa) que cada um deles possa causar na produtividade da mão-de-obra. Aconselha-se que essa verificação, junto ao pessoal de obra, seja realizada no momento em que são feitos os levantamentos subjetivos (item seguinte).

Percebe-se que a partir do momento em que os fatores tenham sido levantados e, com eles, o tipo de influência causada (positiva ou negativa), começam "a nascer", no âmbito do método e organização do trabalho, um conjunto de "boas práticas" que conduzirão, naturalmente, à proposição de diretrizes. As eventuais correlações com os indicadores de produtividade da mão-de-obra levantados permitirão respaldar a importância (ou melhor, a significância) dos grupos de fatores (projeto do produto, método e organização), ou seja, das boas ou más práticas que caracterizam cada obra, no tocante à influência que podem causar sobre a produtividade.

\section{3 .2 .1 .4}

Determinação das listas de opiniões 
As listas com opiniões do pessoal de obra são obtidas a partir da condução de entrevistas semi-estruturadas (que se trata da fonte de evidência utilizada nesta fase da etapa de levantamento de dados). Entre as pessoas envolvidas nas entrevistas, é importante que estejam presentes o engenheiro de produção residente no canteiro de obras, o mestre de obras (e/ou mestre de armação, caso ele exista), o responsável pela subempreiteira (se a mão-de-obra for subempreitada), o encarregado (ou encarregados, se mais de um), na obra, pela etapa de armação.

A estruturação prévia dos questionamentos permite que as entrevistas sejam conduzidas de maneira ordenada, impedindo o desprendimento demasiado da lógica estabelecida para tal fim. O questionário semi-entruturado (elaborado pelo condutor das entrevistas) deve estar baseado na lista de fatores de conteúdo e contexto previamente determinados (primeira etapa do método), contemplando, necessariamente, e, preferencialmente, nesta ordem, aspectos relacionados a: i) o projeto de detalhamento das armaduras (pilares, vigas e lajes); o método de trabalho; iii) a organização do trabalho. Apresentam-se, a seguir, algumas dicas importantes sobre como conduzir esta fase de levantamento de dados de maneira a obter uma lista com um maior número de opiniões convincentes e confiáveis:

- as entrevistas devem ser conduzidas de tal forma a deixar os participantes à vontade para expressarem sua opiniões;

- todos os aspectos abordados devem ser previamente esclarecidos, elucidando-se, assim, as dúvidas dos participantes e permitindo-se ter uma maior confiança no que está sendo falado pelo respondente;

- respostas muito contrárias ao senso comum devem ser rebatidas com novos questionamentos;

- deve-se usar muita imagem gráfica nas entrevistas (projetos de detalhamento distintos e croquis), ilustrando, dessa forma, grande parte dos aspectos considerados e consolidando o entendimento necessário a esse tipo de abordagem;

- pode-se, durante as entrevistas, relacionar os aspectos listados ao grau de facilidade, ou dificuldade da mão-de-obra na realização das operações de produção, sempre que existirem dificuldades, por parte dos entrevistados, quanto ao correto entendimento de conceitos relativos à produtividade da mão-de-obra.

\subsubsection{Processamento}

$\mathrm{Na}$ terceira etapa do método, os indicadores de produtividade da mão-de-obra, os fatores potenciais influenciadores e as listas de opiniões, obtidos a partir dos dados levantados na etapa de levantamento são processados, isto é, organizados e, em seguida, analisados, culminando com a determinação dos fatores influenciadores, que serão a base para a condução da quarta e última etapa do método (Figura 5.12).

No que diz respeito à organização, prevê-se a constituição de duas bases de dados (objetivas, representadas pelas planilhas com RUP e fatores; e subjetivas, representadas pelas "listas de opiniões"), especialmente formatadas para: i) reunirem os dados de todas as obras contempladas na aplicação do MPDPro; ii) serem facilmente acessadas e atualizadas pela construtora; iii) servirem às análises.

As análises, por sua vez, deverão ser conduzidas, num primeiro momento, de maneira independente, em razão da distinção quanto ao tipo das informações geradas (objetivas e subjetivas), conforme ilustrado na Figura 5.12. As análises das informações subjetivas 
são mais simples e diretas e se dão a partir das interpretações da lista de opiniões do pessoal de obra, quanto a aspectos que podem favorecer ou não a produtividade da mão-de-obra, resultando nas "expectativas da produção". As análises das informações objetivas necessitam de um procedimento específico, que permita correlacionar os fatores (potenciais influenciadores) a índices de produtividade da mão-de-obra, resultando nas "tendências da produção".

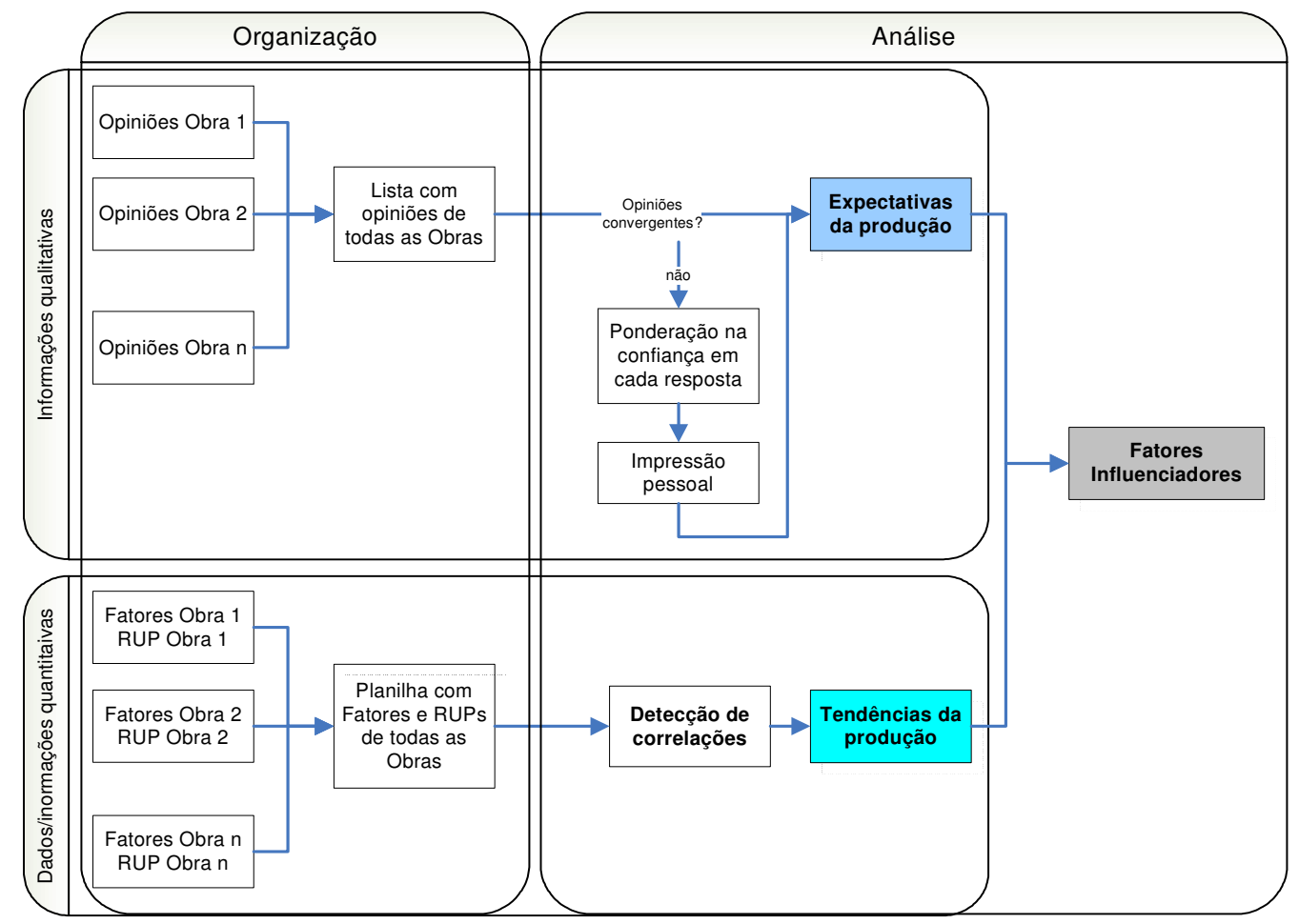

Figura 5.12 - Fluxograma da terceira etapa do MPDPro

Os produtos das análises das informações objetivas e subjetivas, quais sejam, respectivamente, as "expectativas da produção" e as "tendências da produção", são então confrontados, tecendo-se uma análise conjunta, que prima pelo caráter de complementaridade, entre expectativas e tendências (subjetivismo e objetivismo), balizando e sustentando a eleição dos fatores que influenciaram a produtividade da mãode-obra para o conjunto de obras estudadas.

\subsubsection{Processamento Subjetivo}

O produto esperado das análises qualitativas, qual seja, um conjunto de expectativas da produção, deve refletir o posicionamento das pessoas diretamente envolvidas na produção de armaduras quanto aos fatores que influenciam a produtividade da mão-deobra.

As opiniões colhidas nas diferentes obras poderão se revelar convergentes, evidenciando pontos comuns e que serão transcritos na forma de expectativas da produção. No entanto, divergências quanto às opiniões podem aparecer. Nesses casos, deve-se 
ponderar o grau de confiança que se tem em cada resposta/respondente. Após tal ponderação, e mediante as impressões pessoais da pessoa que está conduzindo a entrevista, as opiniões que se mostraram mais embasadas poderão ser adicionadas ao conjunto de expectativas da produção.

Foram desenvolvidas tabelas específicas para o agrupamento das expectativas da produção, de maneira a favorecer a análise das informações.

Nessas tabelas, as expectativas são separadas por tarefas e pela natureza dos fatores a elas relacionados (projeto do produto (fôrmas e detalhamento das armaduras), método e organização do trabalho). Para cada categoria de fator, faz-se, ainda, uma subdivisão quanto a aspectos específicos, que devem ser determinados a partir dos fatores considerados na primeira etapa do método.

As tabelas de expectativas trazem algumas indicações que objetivam tornar as análises mais focadas; indica-se, por exemplo, se as expectativas são frutos de opiniões consensuais (as setas " $\rightarrow$ " deverão evidenciar que as opiniões foram consensuais) ou não (as setas " $\leftrightarrow$ " deverão indicar expectativas fruto de opiniões que apresentaram divergências, mas que mantiveram uma certa lógica). A tabelas prevêem, também, um campo, onde as expectativas são relacionadas às operações da etapa de armação às quais se associam.

A Figura 5.13 ilustra um pequeno trecho de uma tabela (hipotética) de expectativas referentes ao processo de produção de armaduras de pilares. Evidenciam-se, como exemplo, duas expectativas, relacionadas a aspectos específicos de fatores distintos (fator de conteúdo (detalhamento) e fator de contexto (método)). Ambas as expectativas, pelas indicações constantes da tabela $(" \rightarrow$ "), foram fruto de opiniões convergentes. Uma delas tem maiores implicações na operação de montagem, daí o fato de o campo112 " $\mathrm{M}$ " (que representa esta operação) estar hachurado; a outra traz implicações nas operações de recebimento e estocagem, estando hachurados, portanto, os campos condizentes a estas operações ("R" e "E").

112 Os campos "R", "E", "C", "D", "P", "T" e "M", referem-se, respectivamente às operações de recebimento, estocagem, corte, dobra, pré-montagem, transporte e montagem. 


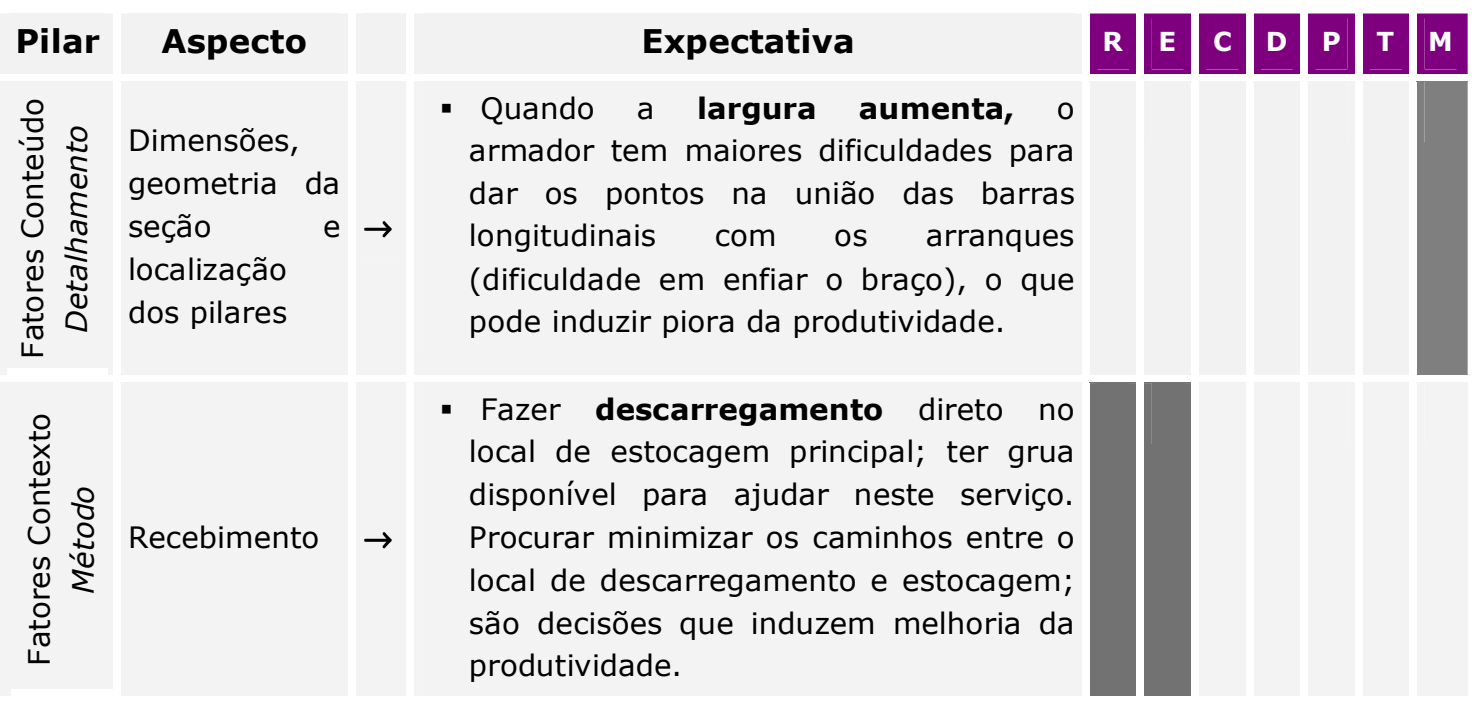

Figura 5.13 - Exemplo de tabela para análise das expectativas da produção

\subsubsection{Processamento Objetivo}

O produto esperado das análises objetivas, qual seja, um conjunto de tendências da produção, deve evidenciar eventuais correlações entre os fatores influenciadores (produto, método e organização) e os indicadores de produtividade da mão-de-obra (RUP potencial) levantados em campo.

Para tornar simplificada ${ }^{113}$ esta tarefa, os grupo de fatores de conteúdo e de contexto serão "convertidos" em índices de avaliação, sendo que esses índices é que serão correlacionados, num primeiro momento, com os indicadores de produtividade da mãode-obra.

O fato de os fatores de conteúdo e contexto, quando coletados, já apresentarem um posicionamento ${ }^{114}$ quanto ao tipo de influência que, espera-se, sejam capazes de provocar, permite que nas três situações que se apresentam (projeto, método e organização), seja possível estabelecer índices de avaliação, quais sejam, índices de avaliação do PDA (IAP), índices de avaliação do método de trabalho (IAM) e índices de avaliação da organização do trabalho (IAO).

\footnotetext{
113 A necessidade de simplificar a aplicação do MPDPro, em todas as suas instâncias, é um dos objetivos pretendidos por este autor. Nessa etapa de processamento, a simplificação consiste em permitir que o construtor inicie as análises fazendo uma leitura dos fatores que levantou, através de "índices de avaliação". Esses índices, de caráter agregador, têm o propósito inicial de "sinalizar" ao construtor o "comportamento" (ou posicionamento) do PDA, do método e da organização do trabalho de cada uma das suas obras quando comparados a uma situação de referência.

114 O posicionamento a que o ator se refere diz respeito ao tipo de influência que cada fator é capaz de causar à produtividade da mão-de-obra. Tanto os fatores de conteúdo quanto os de contexto, quando apresentados neste capítulo (Tabela 5.1, Tabela 5.2, Tabela 5.3, Tabela 5.4 e Tabela 5.5apontam (na visão e entendimento do autor, que se baseou para isso em levantamentos bibliográficos, conversas com especialistas, vivência prática etc) o tipo de influência que seriam capazes de causar.
} 


\subsubsection{1}

\section{Determinação dos Índices de Avaliação}

Guardadas algumas particularidades (comentadas a cada caso), a determinação dos índices de avaliação se dá a partir da constatação da presença de fatores capazes de influenciar positivamente a produtividade.

Os IAP foram determinados separadamente para as tarefas de pilares, vigas e lajes. Tabela 5.10 ilustra o exemplo de uma tabela utilizada para a determinação do IAP" de pilares ("IAPp"). Os fatores de conteúdo são dispostos em colunas, evidenciando-se eventuais variações dos valores apresentados entre o conjunto de obras considerado. Os extremos desta "régua de variação" são associados ao tipo de influência (positiva e negativa) que o fator pode causar. Os fatores são, portanto, "ranqueados" quanto o tipo de influência causada ${ }^{115}$. Tomando-se como exemplo um conjunto hipotético de cinco obras, os fatores mais próximos ao extremo relacionado à influência positiva, receberam a nota " 1 "; os fatores com valores situados no extremo oposto receberam a nota " 5 ". Conseqüentemente, os valores intermediários receberam notas que variaram de 2 a 4 . Foram contemplados nesse exemplo 10 fatores. Assim, uma obra que detivesse nota igual a "5", obteria um IAPp igual a 100 (máxima avaliação positiva); a pior avaliação, nesse caso, seria uma nota "30", com um IAPp igual a zero.

Tabela 5.10 - Exemplo de tabela para determinação do índice de avaliação do PDA IAPp

\begin{tabular}{|c|c|c|c|c|c|c|c|c|c|c|c|c|c|c|}
\hline & & & \multicolumn{2}{|c|}{ 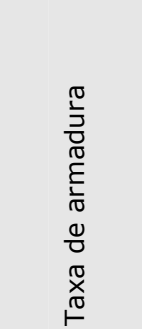 } & \multicolumn{2}{|c|}{ 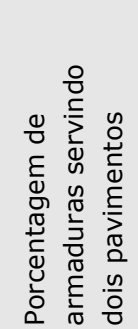 } & \multicolumn{2}{|c|}{ 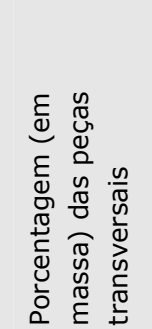 } & \multicolumn{2}{|c|}{ 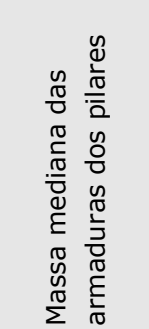 } & \multicolumn{2}{|c|}{ 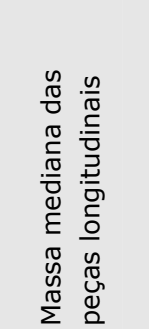 } & \multicolumn{2}{|c|}{ 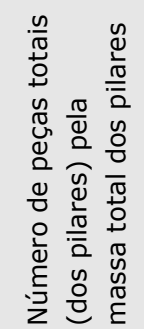 } \\
\hline & & & \multicolumn{2}{|c|}{$\mathrm{Kg} / \mathrm{m} 3$} & \multicolumn{2}{|c|}{$\% \operatorname{arm} 2 x$} & \multicolumn{2}{|c|}{ \%petrans } & \multicolumn{2}{|c|}{ Mmedarm } & \multicolumn{2}{|c|}{ Mmedlong } & \multicolumn{2}{|c|}{ Peças/Kg } \\
\hline \multicolumn{2}{|c|}{ OBRA } & IAPp & \multicolumn{2}{|c|}{$<\otimes$} & \multicolumn{2}{|c|}{$<\theta$} & \multicolumn{2}{|c|}{$<+$} & \multicolumn{2}{|c|}{$<+$} & \multicolumn{2}{|c|}{$<$ (8) } & \multicolumn{2}{|c|}{$<\otimes$} \\
\hline A & $5^{\circ}$ de 20 & 64 & 90 & 2 & 100 & 1 & 30 & 3 & 65 & 2 & 2,5 & 4 & 2,5 & 2 \\
\hline B & $6^{\circ}$ de 23 & 52 & 56 & 5 & 0 & 4 & 18 & 1 & 45 & 1 & 2,3 & 5 & 3,0 & 1 \\
\hline C & $10^{\circ}$ de 25 & 72 & 94 & 1 & 100 & 1 & 27 & 2 & 88 & 4 & 6,0 & 1 & 2,1 & 3 \\
\hline B & $10^{\circ}$ de 20 & 28 & 70 & 4 & 0 & 4 & 32 & 4 & 80 & 3 & 3,5 & 3 & 1,5 & 5 \\
\hline$E$ & $20^{\circ}$ de 25 & 40 & 85 & 3 & 100 & 1 & 35 & 5 & 150 & 5 & 5,5 & 2 & 2,0 & 4 \\
\hline
\end{tabular}

Em se tratando da determinação dos índices de avaliação do PDA de vigas e lajes (IAPv e IAPI, respectivamente), deve-se seguir o mesmo raciocínio utilizado e apresentado para a determinação do IAPp.

115 A simbologia "< : ${ }^{\prime}$ " sinaliza que no grupo de fatores assim identificados, o menor valor seria desfavorável a produtividade; conseqüentemente, a simbologia "< ;)" identifica que os grupos de fatores com tal identificação teria o menor valor associado a melhor produtividade). 
A determinação dos "IAM" e "IAO" apresentam algumas particularidades quando comparadas ao roteiro apresentado para a determinação do "IAP".

Os "IAM" e o "IAO" revelam "tendências de comportamento" (boas ou más práticas relacionadas ao método e à organização do trabalho) e são determinadas pelo somatório dos valores atribuídos aos fatores de contexto. Tais valores deverão expressar o "posicionamento" de cada fator quanto ao tipo de influência capaz de proporcionar à produtividade da mão-de-obra (para fatores capazes de influenciar positivamente a produtividade, atribui-se o valor "1" quando detectada a sua presença; aos fatores capazes de influenciar negativamente a produtividade, o valor atribuído seria " 0 "; eventualmente, pode-se atribuir valores intermediários para fatores que assim se posicionem).

A Tabela 5.11 ilustra um trecho de uma tabela utilizada para "posicionar ${ }^{116 " ~ o s ~ f a t o r e s ~}$ (no caso deste exemplo, relacionados a uma das operações contidas no método de trabalho) quanto ao tipo de influência que poderiam causar à produtividade.

Tabela 5.11 - Exemplo de tabela para posicionamento das influências dos fatores relacionados ao método de trabalho

\begin{tabular}{|c|c|c|c|c|}
\hline \multirow{2}{*}{$\begin{array}{l}\text { Opera- } \\
\text { ção }\end{array}$} & \multirow{2}{*}{ Fator } & \multicolumn{3}{|c|}{ Possibilidades } \\
\hline & & $\mathbf{0}$ & 0,5 & 1 \\
\hline \multirow{6}{*}{ 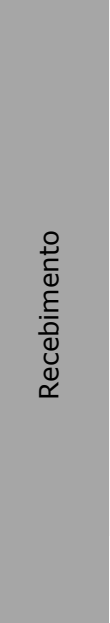 } & Tipo de aço recebido & $\begin{array}{l}\text { predominância de } \\
\text { cortado e dobrado }\end{array}$ & $>21$ e $<80 \%$ do total & $\begin{array}{l}\text { predominância de } \\
\text { barras }\end{array}$ \\
\hline & $\begin{array}{l}\text { Carregamento preparado para } \\
\text { descarregamento }\end{array}$ & sem preparo & relativa preparação & preparado \\
\hline & $\begin{array}{l}\text { Sistema de etiquetas para } \\
\text { identificação dos feixes }\end{array}$ & sem etiquetas & $\begin{array}{l}\text { etiquetas soltas e sem } \\
\text { identificação visual }\end{array}$ & $\begin{array}{l}\text { etiquetas presas e } \\
\text { com sistema de cores }\end{array}$ \\
\hline & $\begin{array}{l}\text { Acessibilidade do caminhão ao } \\
\text { canteiro }\end{array}$ & ruim & razoável & boa \\
\hline & Conferência dos feixes & $\begin{array}{l}\text { no caminhão, com } \\
\text { instrumentos métricos }\end{array}$ & $\begin{array}{c}\text { no caminhão, através } \\
\text { das etiquetas }\end{array}$ & $\begin{array}{c}\text { após } \\
\text { descarregamento, } \\
\text { através das etiquetas }\end{array}$ \\
\hline & Descarregamento & manual & $\begin{array}{l}\text { com eventual auxílio } \\
\text { de equipamento }\end{array}$ & $\begin{array}{l}\text { com freqüente uso de } \\
\text { equipamento }\end{array}$ \\
\hline
\end{tabular}

O somatório do número dos valores atribuídos às operações ou elementos é, então, relacionado a uma situação de referência ${ }^{117}$, obtendo-se, assim, os índices de avaliação

116 Entende-se que o a leitura que cada obra faz sobre o tipo de influência causada por um determinado fator possa variar; daí a necessidade de a obra, eventualmente, reposicionar as possibilidades aventadas para cada fator em razão do tipo de influência (positiva ou negativa) e valor correspondente.

117 A situação de referência é aquela em que todos os fatores sejam capazes de influenciar positivamente a produtividade. A situação de referência é aquela determinada pela máxima "pontuação" que a obra poderia conferir a cada uma das operações/elementos e, por conseguinte, ao método e à organização do trabalho. Em outras palavras, expressa uma situação hipotética (e 
parciais, para o método e para a organização do trabalho (IAM parciais e IAO parciais). Tabela 5.12 um trecho de uma tabela para determinação dos IAM parciais de três obras hipotéticas, nesse caso, para a operação de "recebimento".

Tabela 5.12 - Exemplo de tabela para determinação dos IAM parciais
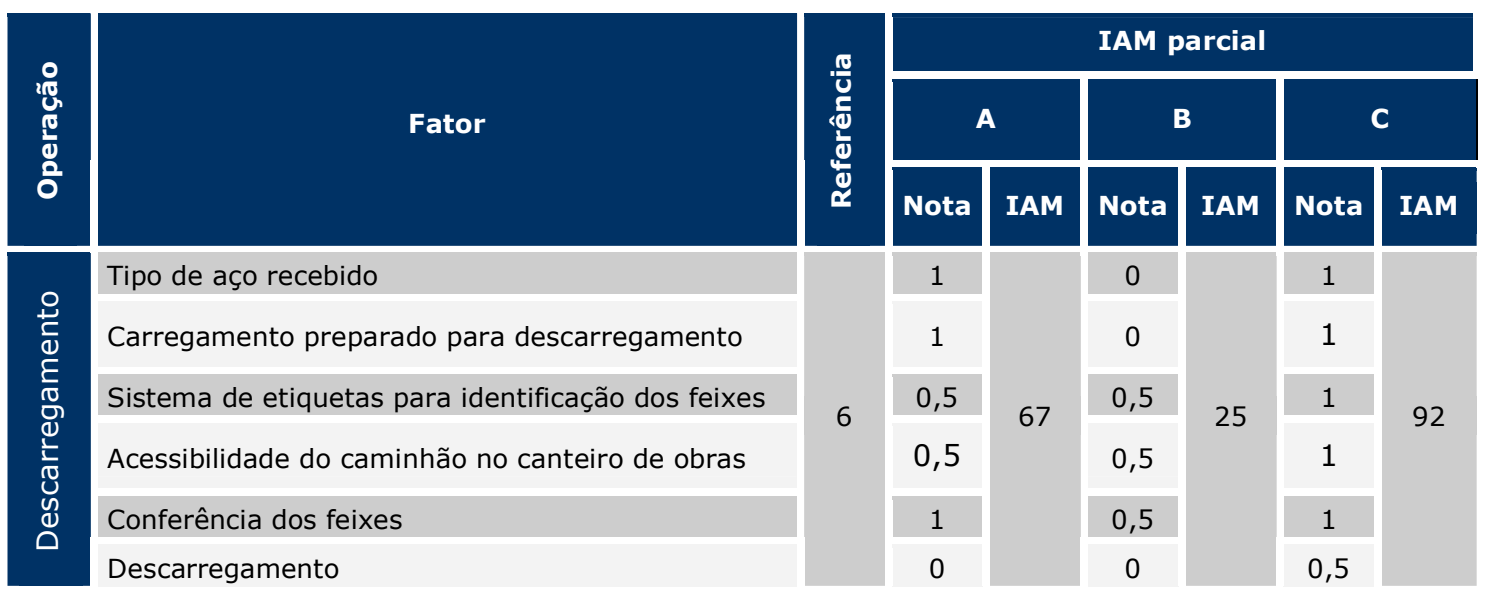

Após a determinação dos IAM e IAO parciais, pode-se determinar os valores do IAM e IAO relativos ao método e à organização do trabalho.

Os IAM e IAO são determinadas a partir da soma ponderada dos valores dos IAM e IAO parciais de cada uma das operações/elementos. A ponderação se dá a partir dos "pesos" que são atribuídos às operações/elementos.

Para o método de trabalho o peso é determinado pelo esforço demandado em cada uma das operações que o compõem. A partir de uma média da quantidade de homens-hora consumidos, nos ciclos contemplados em uma aplicação do MPDPro (aqueles ao qual se apresentaram as produtividades potenciais), são determinados os pesos de cada operação, como mostra a Figura 5.16, para uma situação hipotética.

desejada), em que todos os fatores a serem levantados sejam capazes de proporcionar influência positiva sobre a produtividade. É definida no momento em que a construtora, ao caracterizar o método e organização do trabalho através de fatores, identifica, para cada uma deles, situações que caracterizariam as boas práticas (atribuindo a esta situação o valor "1"), práticas intermediárias (atribuindo a esta situação o valor "0,5") e más práticas (atribuindo a esta situação o valor " 0 "). 


\begin{tabular}{|l|c|c|}
\hline \multicolumn{1}{|c|}{ Operações } & Hh (média) & Peso \\
\hline Descarregamento & 30 & 6 \\
\hline Estocagem & 28 & 6 \\
\hline Corte & 59 & 12 \\
\hline Dobra & 50 & 10 \\
\hline Pré-montagem & 170 & 34 \\
\hline Montagem & 167 & 33 \\
\hline
\end{tabular}

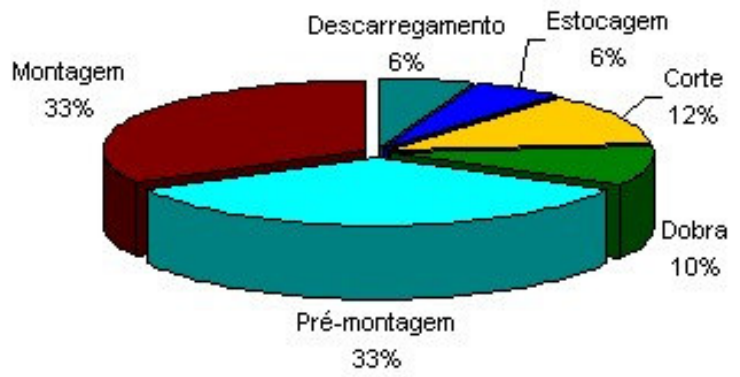

Figura 5.16 - "Peso" atribuídos às operações do método de trabalho

Em se tratando da organização do trabalho, os pesos atribuídos aos seus elementos podem ser determinados a partir de consultas (questionamentos e/ou enquetes) a especialistas em gestão da produção, somados ou não às opiniões de subempreiteiros e demais responsáveis por grupos de trabalhadores.

A Tabela 5.13 traz o exemplo de uma tabela utilizada para a determinação dos IAM de três obras hipotéticas. Para a determinação dos IAO, adotam-se tabelas semelhantes.

Tabela 5.13 - Exemplo de tabela para determinação dos IAM

\begin{tabular}{|c|c|c|c|c|c|c|c|c|c|c|c|c|c|}
\hline \multirow{3}{*}{ Obra } & \multicolumn{13}{|c|}{ IAM - Método } \\
\hline & \multicolumn{2}{|c|}{$\begin{array}{c}\text { Descarrega- } \\
\text { mento }\end{array}$} & \multicolumn{2}{|c|}{ Estocagem } & \multicolumn{2}{|c|}{ Corte } & \multicolumn{2}{|c|}{ Dobra } & \multicolumn{2}{|c|}{$\begin{array}{c}\text { Pré- } \\
\text { montagem }\end{array}$} & \multicolumn{2}{|c|}{ Montagem } & MÉTODO \\
\hline & Peso & IAM & Peso & IAM & Peso & IAM & Peso & IAM & Peso & IAM & Peso & IAM & IAM \\
\hline A & \multirow{3}{*}{0,5} & 67 & \multirow{3}{*}{0,5} & 75 & \multirow{3}{*}{1,5} & 75 & \multirow{3}{*}{1,5} & 75 & \multirow{3}{*}{3} & 79 & \multirow{3}{*}{3} & 80 & 77 \\
\hline B & & 25 & & 6 & & 100 & & 100 & & 36 & & 50 & 57 \\
\hline $\mathrm{C}$ & & 92 & & 100 & & 75 & & 67 & & 43 & & 70 & 65 \\
\hline
\end{tabular}

\subsubsection{2}

Determinação das Tendências da Produção

As tendências da produção refletem o posicionamento dos fatores, para um conjunto de dados pré-determinado, favorável à produtividade da mão-de-obra. São determinados a partir das análises de informações numericamente levantadas (RUP e fatores matematicamente quantificáveis), que devem evidenciar correlação dos fatores com os indicadores de produtividade (valores de fatores capazes de influenciar positivamente à produtividade associados às melhores RUPpot). 
Os fatores "quantificáveis"119", permitem nível de detalhamento nas análises mais aprofundado, necessárias à determinação das tendências da produção. Assim é que, para os fatores associados ao método e à organização do trabalho, a determinação das tendências da produção não são factíveis (os fatores que compõem os IAM e IAO são de difícil quantificação (por exemplo, avaliar quão bem foi desenvolvido um programa de capacitação da mão-de-obra é diferente de ter ou não ter um programa de capacitação implementado)). Neste caso, ao invés da determinação de tendências da produção para o método e para a organização do trabalho, propõem a verificação, nas obras cujo MPDPro seja aplicado, dos níveis de desempenho dos IAM e IAO.

A determinação dos níveis de desempenho, que será expresso percentualmente, se dá pela relação direta entre a soma dos valores do IAM atribuídos ao conjunto de obras analisado e a máxima avaliação positiva dos IAM (que é igual ao número de obras multiplicado por "100"). A determinação do desempenho para cada operação (IAM parcial) e fatores, segue raciocínio análogo. O mesmo desenvolvimento é utilizado para a determinação do desempenho da organização do trabalho nas obras.

A Tabela 5.14 ilustra um trecho de tabela utilizada para a determinação do método de trabalho para um conjunto de três obras hipotéticas. Os desempenhos menores e iguais a uma valor pré-determinado (no caso da Tabela 5.14 esse valor foi igual a $50 \%$ ) devem ser destacados, facilitando a identificação, na referida Tabela, dos IAM parciais e fatores a eles associados que assim se apresentaram.

Tabela 5.14 - Exemplo de tabela para determinação do desempenho do método de trabalho
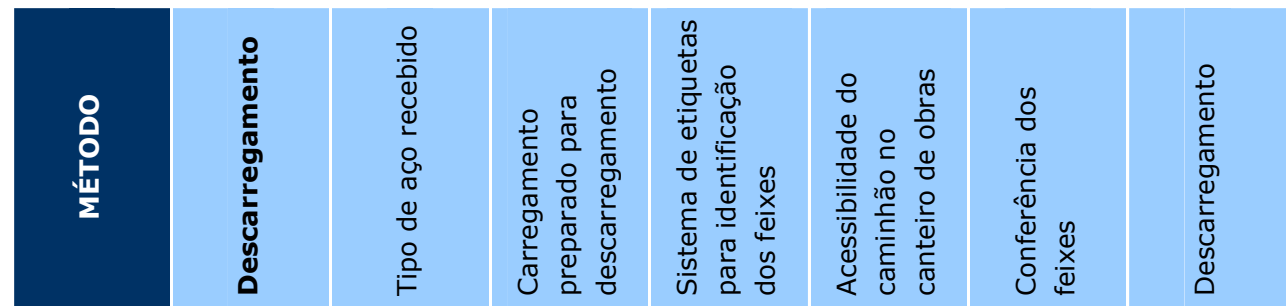

\begin{tabular}{|c|c|c|c|c|c|c|c|c|}
\hline Obra & IAM & IAM & & & & & & \\
\hline A & 77 & 75 & 1 & 1 & 0,5 & 1 & 1 & 0 \\
\hline B & 49 & 25 & 0 & 0 & 0,5 & 0,5 & 0,5 & 0 \\
\hline C & 66 & 83 & 1 & 1 & 0,5 & 1 & 1 & 0,5 \\
\hline Desempenho & 64 & 61 & 67 & 67 & 50 & 83 & 83 & 17 \\
\hline
\end{tabular}

Considerando-se que os IAO e IAM, quando bem avaliados, representam boas práticas de caráter pouco discutível (por exemplo, usar um procedimento racional de dimensionamento da equipe é melhor do que não ter procedimento para tal decisão), pode-se tirar, das verificações em obra, registradas e avaliadas através dos valores de

119 Por exemplo, o diâmetro equivalente, medido em "mm", em se tratando dos IAP e a "motivação", no caso dos IAO, em que pode-se determinar se está presente ou não mas ter-se-á dificuldades em mensurar quão boa é essa prática. 
IAO e IAM, dos seus desempenhos e dos desempenhos dos fatores e ele relacionados, lições para as melhorias das próprias obras ou de seus gestores.

Por razões já comentadas, a análise dos "IAP" é a única a possibilitar a determinação das tendências da produção. Somada ao fato de se ter fatores quantificáveis, atribui-se a importância da determinação das tendências da produção, neste caso, aos seguintes fatos:

$\checkmark$ para os índices de avaliação do projeto de detalhamento das armaduras (os IAP) são esperadas variações significativas, mesmo em se tratando de porções de obras semelhantes (tais variações já foram comentadas por ARAÚjO (2000)), justificando análises mais detalhadas;

$\checkmark$ seja pela alta variabilidade, seja pela objetividade dos fatores associáveis ao PDA, espera-se o estabelecimento de correlações entre os IAP e as RUPpot, principalmente nas obras que apresentem bons valores de IAM e IAO;

$\checkmark$ o "posicionamento dos fatores" (determinados numericamente e com precisão dimensional) é definido pelo projetista estrutural, que não é aquele cuja atuação é influenciada, caracterizando um motivo a mais para se investir nas análises detalhadas do PDA;

Assim é que, para se avaliar a influência de diversas posturas do PDA, propõem que se faça uma análise mais aprofundada quanto aos resultados obtidos das obras consideradas na aplicação do MPDPro. A operacionalização dessa análise dar-se-á da seguinte maneira:

1. Organização dos dados (RUPpot (de pilares, vigas e lajes), IAP (de pilares, vigas e lajes), IAM e IAO para o conjunto de obras contempladas), numa tabela denominada "tabela para detecção de tendências" - nível de detalhamento "1" (TDT I). A Tabela 5.15 mostra uma "TDT I" para um conjunto de três obras hipotéticas. A última linha dessa tabela deve apresentar as variações dos dados.

Tabela 5.15 - Exemplo de TDT I

\begin{tabular}{|c|c|c|c|c|c|c|c|c|}
\hline \multirow{2}{*}{ Obra } & \multicolumn{3}{|c|}{ RUP pot } & \multicolumn{3}{c|}{ PDA } & Método & Organização \\
\hline & pilar & viga & laje & IAPp & IAPv & IAPI & IAM & IAO \\
\hline A & 30 & 60 & 80 & 64 & 30 & 15 & 77 & 30 \\
\hline B & 90 & 60 & 30 & 52 & 60 & 56 & 57 & 50 \\
\hline C & 70 & 30 & 20 & 72 & 70 & 90 & 65 & 60 \\
\hline Variação & 200 & 100 & 300 & 38 & 133 & 500 & 35 & 50 \\
\hline
\end{tabular}

2. Análise dos dados contidos na "TDT I" com atenção especial para as variações apresentadas. Aconselha-se que as análises por tarefa comecem por aquela que apresentou a maior variação do IAP.

3. Reorganização da "TDT I" que originarão três outras tabelas ("TDT I - pilares", "TDT I - vigas" e "TDT I - lajes"), com as seguintes particularidades: i) ordenamento das obras em função das RUPpot das tarefas, que devem ser dispostas em ordem decrescente; ii) ranqueamento das RUPpot e dos IAP, IAM e IAO, com distinção dos 
melhores e piores valores, para cada conjunto de dados com sistema de cores; iii) acréscimo de informações como o menor, o maior e o valor mediano dos dados apresentados, identificados com cores e símbolos (*) para o pior valor, $:)$ para o melhor e $\odot$ para o valor mediano). A Tabela 5.16 traz um exemplo de uma tabela para detecção de tendências da produção para laje. Como são seis as obras consideradas nesse exemplo, os três melhores valores (posições " 1 ", "2" e "3" do ranking) são identificados com a cor "azul"; os três piores (posições " 4 ", " 5 " e "6" do ranking), identificados com a cor "vermelha".

Tabela 5.16 - TDT com nível de detalhamento "1" para laje

\begin{tabular}{|c|c|c|c|c|c|c|c|c|}
\hline \multirow{3}{*}{$\begin{array}{c}\text { Obra } \\
\text { C }\end{array}$} & \multirow{2}{*}{\multicolumn{2}{|c|}{$\begin{array}{c}\text { RUP pot }(\mathrm{Hh} / \mathrm{t}) \\
\text { laje }\end{array}$}} & \multirow{2}{*}{\multicolumn{2}{|c|}{$\begin{array}{l}\text { PDA } \\
\text { IAPI }\end{array}$}} & \multirow{2}{*}{\multicolumn{2}{|c|}{$\begin{array}{c}\text { Método } \\
\text { IAM }\end{array}$}} & \multirow{2}{*}{\multicolumn{2}{|c|}{$\begin{array}{c}\text { Organização } \\
\text { IAO }\end{array}$}} \\
\hline & & & & & & & & \\
\hline & 17 & 1 & 72 & 1 & 65 & 5 & 41 & 4 \\
\hline A & 19 & 2 & 64 & 2 & 77 & 4 & 30 & 5 \\
\hline B & 25 & 3 & 52 & 3 & 57 & 6 & 25 & 6 \\
\hline E & 28 & 4 & 15 & 6 & 80 & 2 & 48 & 3 \\
\hline D & 40 & 5 & 40 & 4 & 79 & 3 & 61 & 1 \\
\hline $\mathrm{F}$ & 50 & 6 & 30 & 5 & 88 & 1 & 55 & 2 \\
\hline Menor & 16 & ()) & 17 & (:) & 36 & (:) & 30 & (8) \\
\hline Maior & 52 & () & 88 & () & 77 & (;) & 61 & (;) \\
\hline Mediano & 28 & $\oplus$ & 49 & $\oplus$ & 66 & () & 46 & (-) \\
\hline
\end{tabular}

4. Análise das TDT I das tarefas, identificando possíveis correlações entre as RUP e os índices de avaliação. Ressalta-se que os IAM e IAO são contemplados nas análises dos IAP com o intuito de poder-se ponderar eventuais efeitos dos mesmos sobre condições mais ou menos favoráveis dos fatores que compõem o IAP. Acredita-se que a influência dos fatores relacionados aos IAM e IAP, em algumas situações, possa mascarar influências dos fatores que compõem os IAP.

5. "Abertura" das TDT I por tarefas em tabelas para detecção de tendências com maior nível de detalhamento (TDT II). A Tabela 5.17 apresenta um exemplo de TDT II. Nela as seis obras hipotéticas são apresentadas dispostas, também, em função do ordenamento crescente das RUPpot de laje. Os fatores "ranqueados" que originaram o IAPI das lajes são apresentados novamente. Propõe-se que tais fatores sejam analisados isoladamente, objetivando-se detectar o seu posicionamento e eventual influência sobre a produtividade. A idéia (com limitações do ponto de vista estatístico) é a de buscarem-se prováveis correlações através da análise da variação de cada fator individualmente e da correspondente variação da RUP. Onde tal observação for positiva $^{120}$, assume-se a existência de uma "tendência" a influenciar a RUPpot,

\footnotetext{
${ }^{120}$ Nessa situação, espera-se que cada fator varie coerentemente com a variação das RUP, o que, do ponto de vista do sistema de cores adotado (azul para os três primeiros valores e vermelho
} 


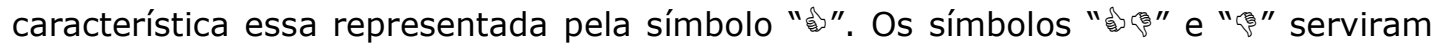
para evidenciar, respectivamente, tendências pouco representativas ${ }^{121}$ e ausência ${ }^{122}$ de tendências, para os dados considerados na análise.

Tabela 5.17 - Exemplo de TDT II relacionados ao PDA de laje

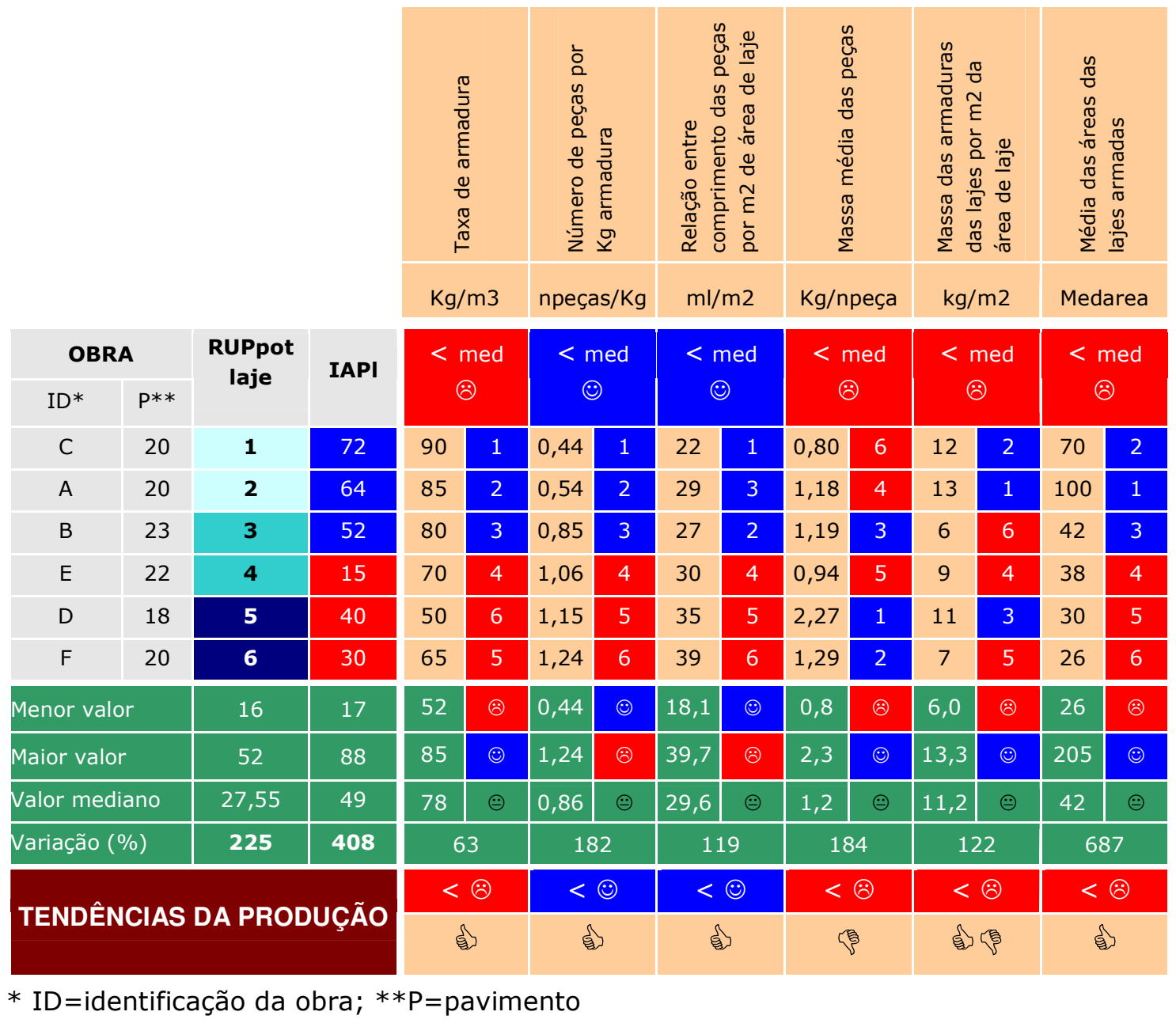

6. Análise das TDT II, objetivando: i) detectar a presença de tendências da produção, a partir das correlações estabelecidas entre os índices de avaliação e fatores a eles relacionados e os indicadores de produtividade; ii) reforçar as verdades assumidas

para os três últimos) levaria a ter-se 2 subconjuntos separados de cor (azul em cima e vermelho embaixo).

121 2/3 dos melhores valores de um determinado fator (valores acima do valor mediano) pertencente ao conjunto de obras com valores de RUPpot iguais ou melhores que o valor mediano.

122 Ausência até $1 / 3$ dos melhores valores de um determinado fator (valores acima do valor mediano) pertencente ao conjunto de obras com valores de RUPpot iguais ou melhores que o valor mediano. 
quanto ao tipo de influência causada pelos fatores, ou mesmo, sinalizar para tendências opostas àquelas inicialmente pensadas.

A organização dos dados contidos nas "TDT" deve seguir algumas recomendações, tais como as prescritas a seguir (presentes na Tabela $\mathrm{x}$ ), a fim de que se facilite o trabalho de interpretação e análise:

- as tabelas devem prever a disposição das obras em linhas (segundo a ordem crescente das suas RUP, tal como ilustrado na Tabela 5.17) e os índices de avaliação, a elas relacionados, em colunas;

- as tabelas devem ser geradas em softwares de planilhamento eletrônico, como o Microsoft Excel, a fim de que se permita dispor, facilmente, de algumas informações, de cunho estatístico, que tornarão as análises mais ágeis e focadas, tais como os valores mínimos, máximos e medianos dos conjuntos, bem como as variações dos valores apresentados.

Vale ressaltar que o procedimento para detecção de eventuais correlações entre os índices de produtividade e fatores potenciais influenciadores, previsto no MPDPro, é, propositalmente, dotado de significativo grau de subjetividade. Apresentam-se, a seguir, as principais justificativas, para se adotar tal postura:

- os dados levantados pela construtora, nas primeiras aplicações do método, não constituem amostras relevantes para serem tratadas objetivamente, com rigor estatístico a partir de ferramentas especialmente desenhadas para esse fim;

- mesmo que a amostragem tivesse validade estatística, as pessoas habilitadas a operarem o método, pela construtora, dificilmente possuiriam conhecimento $e$ habilidades para darem aos dados o tratamento estatístico devido, ou mesmo, teriam, à disposição, ferramentas específicas para auxiliá-las nesta tarefa.

A partir dessas constatações, salienta-se que as correlações podem, ainda assim, serem estabelecidas. Não devem, no entanto, ser entendidas como verdades absolutas, mas sim tendências (principalmente para a construtora que fez a aplicação do método), que somadas às expectativas da produção, poderão indicar, com significativo grau de confiabilidade (ou, no mínimo, consciência), fatores, de fato, capazes de influenciar a produtividade da mão-de-obra.

\subsubsection{Determinação dos Fatores Influenciadores}

As expectativas e tendências da produção deverão ser analisadas conjuntamente para a determinação dos fatores influenciadores da produtividade. A operacionalização dessa análise final dar-se-á da seguinte maneira:

1. os fatores evidenciados pelo pessoal da produção como uma expectativa favorável a melhoria da produtividade devem ser identificados como o símbolo "§".

2. os fatores relacionados ao PDA deverão ser dispostos num tabela (segunda coluna) denominada "tabela para deteç̧ão dos fatores influenciadores". A terceira coluna dessa tabela apresentará a expectativa da produção relacionado a cada fator ("®" para a presença da expectativa; "-" quando a expectativa não tiver sido evidenciada pela produção). A terceira coluna apresentará a tendência da produção associada a cada fator (símbolos "缩", " e " serviram para evidenciar, respectivamente, tendências representativas, tendências pouco representativas e ausência de tendências). 
3. Na primeira coluna, serão identificados os fatores influenciadores da produtividade. Propõe-se que o fator seja tido com o influenciador da produtividade quando tanto

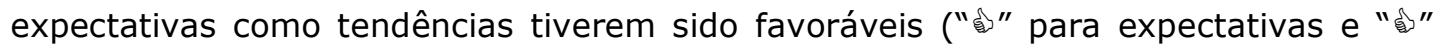

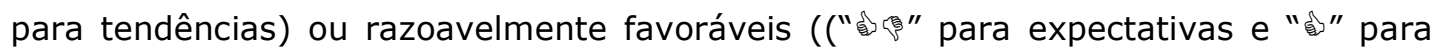
tendências, ou vice-versa).

A Tabela 5.18 ilustra uma tabela para detecção dos fatores influenciadores.

Tabela 5.18 - Fatores influenciadores da produtividade da mão-de-obra no âmbito do PDA de pilares

\begin{tabular}{|c|c|c|c|c|}
\hline Influência & \multicolumn{2}{|l|}{ Fatores } & Expectativas & Tendências \\
\hline & Taxa de armadura & $\mathrm{Kg} / \mathrm{m} 3$ & $\Leftrightarrow$ & 得 \\
\hline $\mathbf{x}$ & Diâmetro equivalente das peças (total) & Dequi & $\Leftrightarrow$ & $\Leftrightarrow$ \\
\hline & $\begin{array}{l}\text { Diâmetro equivalente das peças } \\
\text { longitudinais }\end{array}$ & Dequilong & is & $\Rightarrow$ \\
\hline $\mathbf{x}$ & Número de posições distintas por tonelada & Nposdist & $\Leftrightarrow$ & 综 \\
\hline$x$ & $\begin{array}{l}\text { Número de ganchos por comprimento }(\mathrm{ml}) \\
\text { de pilar }\end{array}$ & Ngan & $\Leftrightarrow$ & ही \\
\hline
\end{tabular}

\subsubsection{Proposição das diretrizes}

A quarta e última etapa, cujo objetivo está implícito na própria denominação do método, trata, finalmente, da proposição das diretrizes que possam contribuir (ao serem efetivadas) para a melhoria da produtividade da mão-de-obra envolvida no processo de produção das armaduras.

As lições aprendidas ao se olhar o processo de produção sob a ótica da produtividade da mão-de-obra e de todas as implicações presentes neste processo que fazem esta produtividade ser melhor ou pior, devem ser praticadas pela empresa construtora. As diretrizes a que se refere a quarta etapa do MPDPro têm o propósito de ajudar a construtora nesta tarefa. Posto que um dado fator tem capacidade de influenciar positivamente a produtividade da mão-de-obra surge, de imediato, a necessidade de que tal fator se faça presente em situações futuras. Porém, a transformação desse fator em "realidade" pode não ser tão simples assim. Ou, mesmo, pode ser inviável (financeira ou tecnicamente) em determinados processos de produção.

Dessa forma, é desejável que a construtora proponha diretrizes (que possibilitem a efetivação, nos seus processos de produção, de fatores, comprovados por ela, como sendo capazes de influenciar positivamente a produtividade), factíveis de serem implementadas.

Para isso, a construtora deve envolver, nesta etapa, outros agentes que participam do processo de produção. Ao fazê-lo, ela terá maiores chances de propor diretrizes com possibilidades reais de serem efetivadas. Mesmo porque, muitas das diretrizes, apesar de definidas pela construtora, serão repassadas aos agentes, sendo esses, os grandes 
responsáveis por aplicá-las e efetivá-las. Por exemplo, diretrizes de projeto deverão ser encaminhadas aos projetistas estruturais para que possam "participar" das concepções e detalhamento de projetos futuros. Se anteriormente discutidas (ao invés de simplesmente impostas), contando com envolvimento e participação de projetistas, construtoras e executores, tal como propõe o MPDPo, maiores serão as contribuições e ganhos proporcionados e, por conseqüência, maior será a potencialidade da diretriz proposta.

Tem-se, assim, que o produto gerado (a diretriz), estará mais próximo da realidade de cada proponente que, ao participar ativamente da sua definição, deverá fazê-lo sem desprezar as chances reais de sua futura efetivação (poderá, por exemplo, considerar e justificar, eventualmente, os critérios técnicos e as implicações nos custos quando da aplicação das diretrizes sugeridas).

Por essa razão, passa a ser fundamental, nesta etapa do método, o engajamento dos agentes que co-participam do processo de concepção e produção de armaduras e com os quais a construtora mantém boas relações de trabalho. Deve-se frisar aqui, como fator motivador para a efetiva participação de todos, a riqueza das informações e a forma com que elas serão compartilhadas. Trata-se de um momento de real amadurecimento das relações entre construtora e seus parceiros, em razão, principalmente, de se estar abdicando de medidas paliativas e reativas, que só causam desgastes entre as partes e comprometem os resultados. Ao contrário, passa-se a discutir melhorias com base em fatos criteriosamente determinados e oportunamente compartilhados. Sinergia e próação, enfim, poderão se tornar realidade nos canteiros de obras.

\subsubsection{Operacionalização da proposição das diretrizes}

No âmbito do projeto de detalhamento das armaduras (PDA) a construtora, de posse dos fatores eleitos na etapa anterior, deverá submetê-los para a apreciação de projetistas estruturais para que esses manifestem suas opiniões sobre as influências detectadas (capacidade de influenciar positivamente a produtividade da mão-de-obra) e apontem diretrizes para a implementação desses fatores em projetos e processos futuros.

No que se refere ao método e à organização do trabalho, as diretrizes a eles relacionadas deverão orientar a implementação e/ou consolidação das boas práticas já listadas e apontadas anteriormente. Para que sejam propostas diretrizes capazes de serem realmente efetivadas, a construtora deve, também aqui, envolver os agentes participantes do processo (empreiteiros, mão-de-obra e fornecedores), apresentandoIhes os pontos críticos diagnosticados durante aplicação do MPDPro (evidenciados pelos desempenhos detectados para o conjunto de obras), discutindo conjuntamente os caminhos necessários para reverter as más práticas detectadas.

Para ambas os casos (referentes ao PDA e ao método e à organização do trabalho) a construtora deverá estruturar um ciclo interativo de discussões (Figura 5.17), a partir de reuniões de trabalho individuais com os agentes escolhidos (recomenda-se que sejam envolvidos, na medida do possível, no mínimo, dois projetistas estruturais, dois subempreiteiros e um fornecedor de materiais (ou de serviço, no caso do aço fornecido cortado e dobrado)). Apresenta-se, a seguir (Tabela 5.19), uma proposta de dinâmica, envolvendo a construtora e os agentes participantes, visando à determinação das diretrizes. 


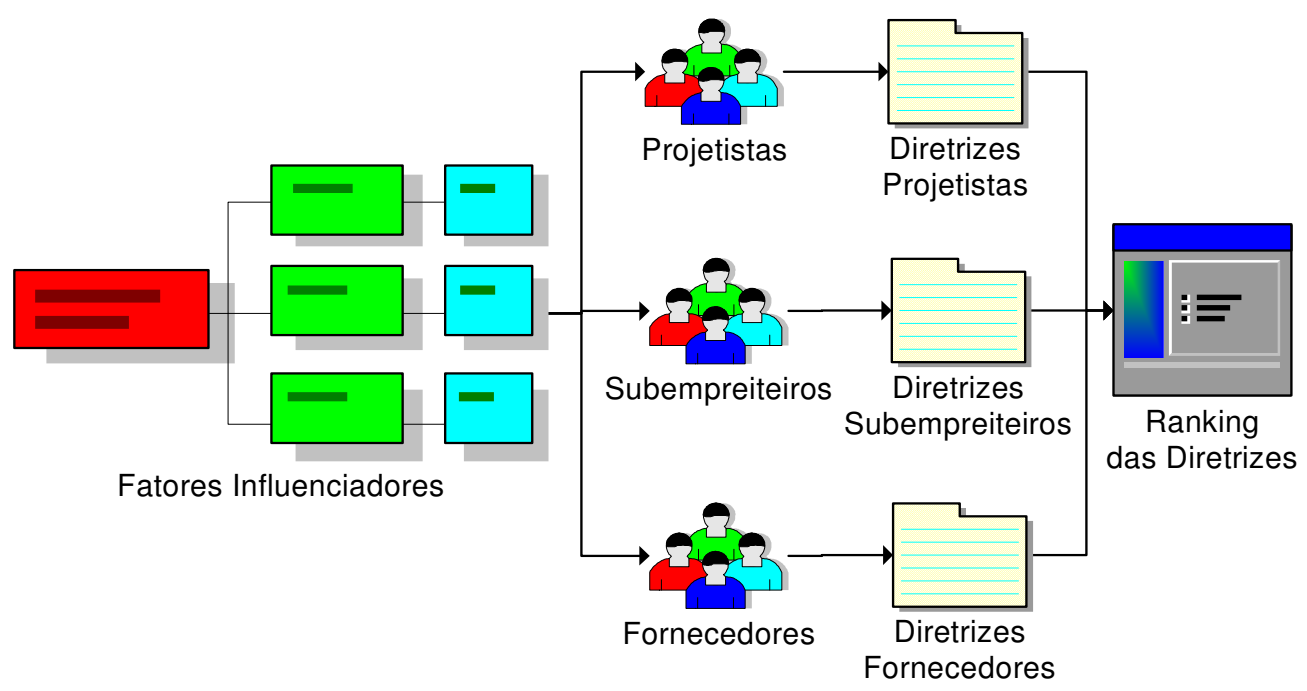

Figura 5.17 - Fluxograma para proposição de diretrizes

Tabela 5.19 (continua) - Dinâmica proposta para a determinação das diretrizes

\begin{tabular}{|c|c|c|}
\hline Agente & $\begin{array}{l}\text { Documentos } \\
\text { apresentados }\end{array}$ & Dinâmica \\
\hline $\begin{array}{l}\text { Projetista } \\
\text { Estrutural }\end{array}$ & 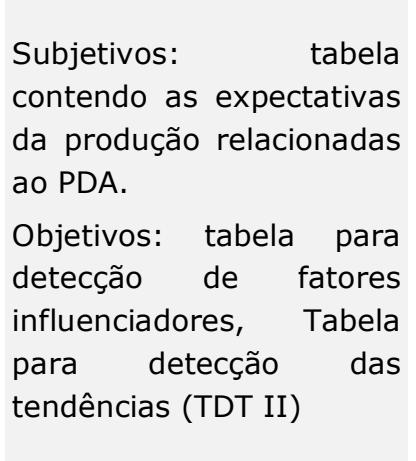 & $\begin{array}{l}\text { 1. Apresentar as expectativas e as tendências da } \\
\text { produção ao projetista estrutural (chamar atenção para } \\
\text { os fatores que se mostraram capazes de influenciar } \\
\text { positivamente a produtividade). } \\
\text { 2. Solicitar um parecer sobre o posicionamento } \\
\text { assumido no MPDPro quanto ao tipo de influência } \\
\text { causada pelos fatores de conteúdo contemplados. } \\
\text { 3. Convidar o projetista a apresentar caminhos } \\
\text { (diretrizes) para que os PDA futuros contemplem as } \\
\text { prerrogativas expressas pelos fatores influenciadores. }\end{array}$ \\
\hline $\begin{array}{c}\text { Empreiteiro } \\
\text { de mão-de- } \\
\text { obra }\end{array}$ & $\begin{array}{l}\text { Subjetivos: tabela } \\
\text { contendo as expectativas } \\
\text { da produção relacionadas } \\
\text { ao método e à } \\
\text { organização do trabalho. } \\
\text { Objetivos: tabelas para } \\
\text { determinação do } \\
\text { desempenho do método e } \\
\text { da organização do } \\
\text { trabalho. }\end{array}$ & $\begin{array}{l}\text { 1. Apresentar as expectativas (chamar a atenção para } \\
\text { os fatores de contexto que se mostraram capazes de } \\
\text { influenciar positivamente a produtividade), juntamente } \\
\text { com as tabelas nas quais os fatores relacionados ao } \\
\text { método e à organização do trabalho foram associados a } \\
\text { boas ou a más práticas (tabelas de desempenho). } \\
\text { 2. Solicitar que ele ordene, em ordem decrescente, a } \\
\text { importância de cada operação/elemento e, em seguida, } \\
\text { de cada fator relacionado ao método e à organização } \\
\text { do trabalho. } \\
\text { 3. Convidar o empreiteiro a apresentar caminhos } \\
\text { (diretrizes) para que os cinco primeiros fatores (em } \\
\text { ordem de importância) sejam efetivados numa próxima } \\
\text { obra que venha a executar }\end{array}$ \\
\hline
\end{tabular}


Tabela 5.19 (conclusão) - Dinâmica proposta para a determinação das diretrizes

\begin{tabular}{|c|c|c|}
\hline Agente & $\begin{array}{l}\text { Documentos } \\
\text { apresentados }\end{array}$ & Dinâmica \\
\hline $\begin{array}{l}\text { Fornecedor } \\
\text { de } \\
\text { materiais }\end{array}$ & $\begin{array}{l}\text { Subjetivos: } \\
\text { contendo as expectativas } \\
\text { da produção relacionadas } \\
\text { ao método e à } \\
\text { organização do trabalho. } \\
\text { Objetivos: tabelas para } \\
\text { determinação do } \\
\text { desempenho do método } \\
\text { de trabalho. }\end{array}$ & $\begin{array}{l}\text { 1. Apresentar as expectativas (chamar a atenção para } \\
\text { os fatores de contexto que se mostraram capazes de } \\
\text { influenciar positivamente a produtividade e que estão } \\
\text { diretamente associados a ele), juntamente com as } \\
\text { tabelas nas quais os fatores relacionados ao método fr } \\
\text { trabalho foram associados a boa ou a má práticas } \\
\text { (tabelas de desempenho). } \\
\text { 2. Solicitar que o fornecedor apresente caminhos } \\
\text { (diretrizes) para que fatores, associados a sua conduta, } \\
\text { sejam efetivados numa próxima obra de que venha } \\
\text { participar. }\end{array}$ \\
\hline
\end{tabular}

Propõe-se que a construtora faça um "ranking" das diretrizes apontadas pelos diferentes agentes consultados, separando-as por grupo (relacionados ao projeto do produto, ao método e à organização do trabalho) e identificando o número de vezes que foram citadas (se repetidas vezes) por agente participante.

As diretrizes mais citadas, ou defendidas pela construtora como capazes de proporcionar maiores benefícios ao processo de produção (melhorias na produtividade da mão-deobra) deverão ser divulgadas pela empresa, a todos os agentes participantes, bem como demais partes interessadas (como departamentos da construtora que tenham ficado distantes da aplicação do MPDPro). Feito isso, a construtora deverá tomar as medidas cabíveis para que tais diretrizes possam ser devidamente implementadas.

Pode-se, por exemplo, estabelecer um programa evolutivo de implementação das diretrizes. Por exemplo, as diretrizes voltadas ao método do trabalho podem ser incorporadas aos procedimentos executivos e de inspeção do serviço da construtora; as diretrizes relacionadas à organização do trabalho podem constar das cartas-convite elaboradas pela construtora ou serem pontos de discussão em reuniões de planejamento entre a contratante e o contratado. 


\section{Aplicação do Método para Proposição de Diretrizes para a Melhoria na Produtividade da Mão-de-obra}

\subsection{Notas introdutórias ao capítulo}

Vê-se aqui a aplicação do MPDPro proposto no quinto capítulo do trabalho. Objetivou-se analisar, através de um caso prático, a sua aplicabilidade, que deveria estar refletida no cumprimento de um conjunto de desafios apresentados a seguir:

- praticidade: um dos grandes desafios foi o de conferir à aplicação do método um caráter prático (extremamente desejável e já pensado na concepção do método), sem perder de vista o rigor de pesquisa científica necessário à sua validação. Para tanto, aspectos como o tempo demandado na condução das etapas preconizadas nas etapas do MPDPro deveria ser tal que não comprometesse o trabalho dos colaboradores ${ }^{123}$ em suas atividades e atribuições rotineiras no canteiro de obras;

- qualidade: outro desafio disse respeito à qualidade dos dados levantados e informações geradas a partir da aplicação do método, avaliado a partir do caráter consensual e da precisão das respostas obtidas, bem como pela análise crítica do responsável pela condução do MPDPro na empresa sobre os levantamentos que the eram passados;

- comprometimento: o engajamento dos envolvidos (colaboradores) tratou de um dos maiores e mais importantes desafios colocados por este autor ao longo da aplicação do MPDPro. A aceitação e o posterior comprometimento das pessoas que estariam envolvidas em conduzir o trabalho na empresa seria imprescindível para o alcance dos demais desafios já comentados, bem como para o sucesso na utilização do método proposto pelo autor. Apenas com um nível satisfatório de comprometimento seria possível ter-se uma condução segura das etapas preconizadas, consistência dos dados levantados, das informações geradas dos resultados finais alcançados, representados pelo conjunto de diretrizes a serem apresentadas visando melhorias na produtividade da mão-de-obra envolvida no processo de produção de armaduras;

Vale aqui ressaltar que os desafios supracitados mostraram-se pertinentes e factíveis de serem atingidos já no transcorrer dos estudos preliminares conduzidos pelo autor (em duas aplicações preliminares da etapa de levantamento de dados do método, comentadas a seguir) quando, com o método ainda não formalmente estabelecido, procurou-se entender quais seriam os aspectos-chave para uso real numa empresa.

Para vencer os desafios aqui colocados, destaca-se a excelente oportunidade aberta a este autor por uma empresa de Construção Civil atuante na cidade de São Paulo em que, através de um trabalho em parceria com o Departamento de Engenharia de Construção

123 Os colaboradores são profissionais da construtora e/ou dos subempreiteiros escolhidos e alocados pela própria construtora para participarem da aplicação do método na obra em que já desempenham algum tipo de serviço. 
Civil da Escola Politécnica da Universidade de São Paulo, viabilizou-se a aplicação do método proposto, tal como se imaginava, percorrendo, com êxito, todas as suas etapas.

\subsection{Ações que antecederam a aplicação do método}

Com o fim de certificar-se de que as fontes de evidência (Tabela 6.1) previstas na etapa de levantamento de dados do MPDPro trariam as informações desejadas, fez-se a aplicação de uma versão preliminar do método (etapa de levantamento de dados) em duas obras de edifícios de duas construtoras, que foram denominadas "aplicações-piloto". Essa prática permitiu aferir e calibrar os instrumentos utilizados para a coleta de dados, dominar as técnicas de abordagem, bem como conhecer a qualidade das informações levantadas junto a algumas das fontes de evidência consideradas pelo método.

Tabela 6.1 - Fontes de evidência contempladas no MPDPro

\begin{tabular}{|c|c|c|}
\hline Fontes de evidência & Dados/Informações & Produto \\
\hline $\begin{array}{l}\text { Leitura crítica dos projetos } \\
\text { do produto }\end{array}$ & quantificações & fatores de conteúdo \\
\hline $\begin{array}{l}\text { Observações do método de } \\
\text { trabalho }\end{array}$ & $\begin{array}{l}\text { descrição das etapas que compõem o } \\
\text { método de trabalho }\end{array}$ & fatores de contexto \\
\hline $\begin{array}{l}\text { Observações da } \\
\text { organização do trabalho }\end{array}$ & descrição da organização do trabalho & fatores de contexto \\
\hline $\begin{array}{l}\text { Entrevistas semi- } \\
\text { estruturadas }\end{array}$ & $\begin{array}{l}\text { lista de opiniões com a percepção sob o } \\
\text { ponto de vista dos executores }\end{array}$ & $\begin{array}{l}\text { expectativas da } \\
\text { produção }\end{array}$ \\
\hline Levantamentos periódicos & $\begin{array}{l}\text { número de homens-hora e as } \\
\text { quantidades de serviço executado por } \\
\text { eles durante intervalos de tempo pré- } \\
\text { determinados }\end{array}$ & $\begin{array}{l}\text { indicadores de } \\
\text { produtividade }\end{array}$ \\
\hline
\end{tabular}

Os estudos de caso piloto, mais que um preciso instrumento de calibração do método para sua aplicação real em campo, proporcionaram contato positivo deste pesquisador com o processo de produção de estruturas de concreto armado em dois canteiros de obras pertencentes a duas construtoras da cidade de São Paulo.

O contato do pesquisador com o canteiro de obras na primeira aplicação piloto (SP 201), estendeu-se por, aproximadamente, doze meses, permitindo que se acompanhasse, com freqüência diária, a execução das estruturas reticuladas de concreto armado de seis edifícios residenciais multipavimentos (construídas simultaneamente, totalizando aproximadamente $60.000 \mathrm{~m}^{2}$ construídos). A Figura 6.1 ilustra uma vista de parte da obra em questão. A obra referente à segunda aplicação piloto (SP 202), de menor duração (contemplou aproximadamente seis visitas do pesquisador ao canteiro de obras), teve o propósito de validar os questionários semi-estruturados que objetivavam descrever a organização do trabalho dos armadores. A Figura 6.2 ilustra parte da estrutura do edifício pertencente à obra SP 202. 


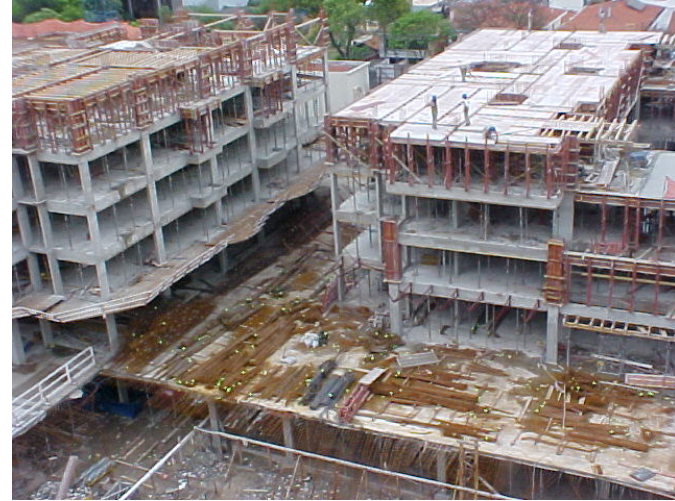

Figura 6.1 - Estrutura dos edifícios pertencentes ao estudo de caso SP 201

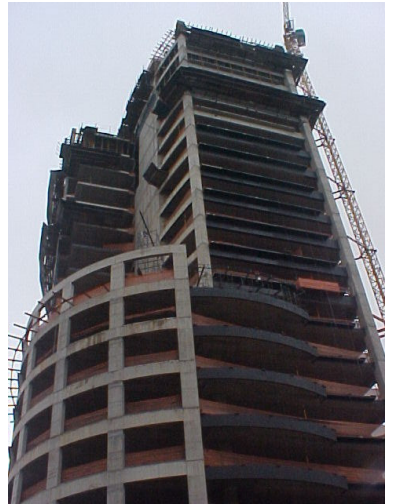

Figura 6.2 - Estrutura do edifício pertencente ao estudo de caso SP 202

Ambos os estudos permitiram coleta de dados e a geração de informações importantes, possibilitando ao autor, um avanço no conhecimento prático do processo de produção de estruturas (com ênfase no processo de produção de armaduras), no âmbito, principalmente, da organização e dos métodos do trabalho.

\subsection{Aplicação do método}

O MPDPro exige a presença de um profissional que assuma as responsabilidades na condução da sua aplicação na construtora. Sugere-se que este "condutor" seja um especialista externo, como um pesquisador com conhecimento no assunto. Porém, dada a praticidade que the foi conferida ao longo do seu desenvolvimento, imagina-se que aplicações futuras possam ser conduzidas por pessoas internas à construtora, com o perfil, por exemplo, de um gerente técnico.

No caso da aplicação do MPDPro (realizada numa construtora atuante na cidade de São Paulo, no período compreendido entre os meses de março de 2003 a janeiro de 2004) e apresentada neste trabalho, o responsável pela aplicação foi o próprio autor.

É importante ressaltar quão imprescindível para o propósito do trabalho foi o engajamento da construtora ao dedicar tempo e recursos (principalmente recursos humanos) para a viabilização da aplicação completa do MPDPro.

Desenvolveu-se preliminarmente na construtora um trabalho inicial de sensibilização com todos os envolvidos na condução do método. Para tanto, foram conduzidas reuniões coletivas em que participaram engenheiros, estagiários, mestres de obras, encarregados e subempreiteiros das obras envolvidas, bem como reuniões individuais em cada umas das obras. Buscou-se, assim, levar ao conhecimento de todos os envolvidos os objetivos pretendidos com a pesquisa, assim como noções básicas sobre questões relacionadas à produtividade da mão-de-obra e sobre as ferramentas utilizadas, principalmente na fase de levantamento de dados, quanto a participação do pessoal de obra seria de extrema importância.

A construtora garantiu acesso amplo e irrestrito às informações necessárias ao cumprimento dos objetivos pretendidos pelas etapas preconizadas pelo método. Algumas 
condições, como as comentadas a seguir, cruciais para aplicação satisfatória do método, foram prontamente atendidas: i) disponibilidade de obras na fase de execução de estruturas (reticuladas em concreto armado); ii) disponibilidade de informações (principalmente projetos estruturais) e colaboradores para o engajamento na pesquisa (principalmente na etapa de levantamento de dados); iii) comprometimento/convencimento próprio e dos agentes participantes (destaque para os empreiteiros), quanto à importância da pesquisa a ser conduzida em seus canteiros de obras; iv) garantia de acesso irrestrito aos canteiros de obras e aos funcionários residentes nos mesmos (fossem eles engenheiros de obras, mestres, encarregados ou operários).

\subsubsection{Caracterização da empresa construtora onde o método foi aplicado}

Trata-se de uma construtora e incorporadora, fundada há 50 anos, que, de acordo com o ranking da Empresa Brasileira de Estudos do Patrimônio (Embraesp), mantinha, no ano de 2004, a liderança do mercado imobiliário brasileiro (indicador considerou a área total construída nos últimos dez anos (2,61 milhões de $\mathrm{m}^{2}$ )). No biênio 2003/2004, segundo depoimento feito pelo presidente da empresa em 2004, construíam, simultaneamente, 0 maior volume de obras da história da empresa (75 empreendimentos em execução no

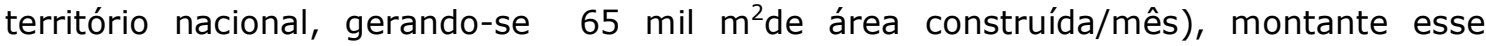
composto, quase em sua totalidade, por unidades de alto padrão em edificações de múltiplos pavimentos habitacionais (imóveis acima de $\mathrm{R} \$ 500 \mathrm{mil}$ ) e comerciais, que correspondem justamente ao segmento de mercado da empresa.

A empresa, classificada como de grande porte, empregava, no primeiro semestre de 2004, aproximadamente mil funcionários. Neste mesmo período, e após alguns rearranjos organizacionais, caracterizava-se como empresa de capital aberto, com 70\% de suas ações administradas por grandes fundos. Os antigos sócios permanecem com $20 \%$, os executivos com $6 \%$ e os funcionários com $4 \%$. Entre as modernas ferramentas de administração implantadas pela empresa, destaca-se a de remuneração variável com base no rendimento individual e da equipe. FORBES BRASIL (2004)

\subsubsection{Caracterização das obras contempladas}

Foram contemplados, na aplicação do método, sete canteiros de obras onde estiveram presentes seis empreiteiras de mão-de-obra para estruturas e cinco projetistas estruturais distintos, conforme ilustrado na Figura 6.3. O universo, assim caracterizado $^{124}$ (que levou a uma maior diversidade dos fatores e indicadores de produtividade em função da distinção quanto a dois aspectos principais, quais sejam, o projeto do produto e o fornecedor de mão-de-obra), gerou "ganhos" de conhecimento adicionais ao possibilitar: i) que fatores de conteúdo refletissem diferentes concepções de edifícios, enriquecendo, sobretudo, as análises; ii) que fatores de contexto não se limitassem às diferenciações impostas apenas pelas características da obra (duração dos ciclos, logística de canteiro etc), mas sim, que revelassem distinções de métodos e organização do trabalho.

${ }^{124}$ A diversidade das obras contempladas, no âmbito do projeto do produto e dos fornecedores de mão-de-obra, embora tenha sido observada nesta aplicação do MPDPro, não é considerada obrigatória, nesta intensidade, pelo autor. 


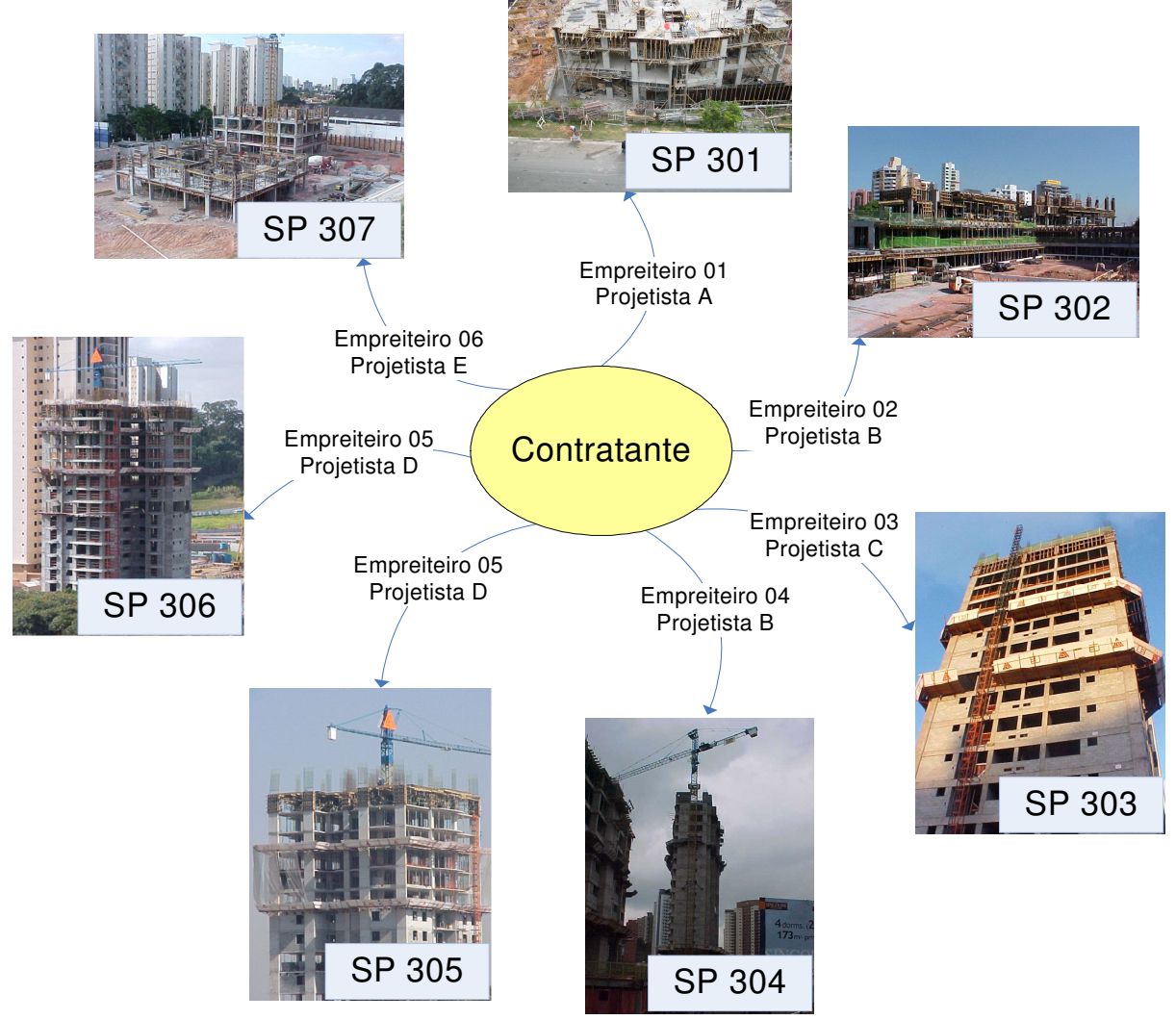

Figura 6.3 - Definição da amostragem dos estudos de casos

A Tabela 6.2 caracteriza, resumidamente, através de alguns indicadores, o universo compreendido pelas obras pertencentes à construtora escolhida para a aplicação do MPDPro, conduzido por este autor, e apresentado na seqüência do desenvolvimento deste capítulo.

Tabela 6.2 (continua) - Caracterização do estudo de caso

\begin{tabular}{l|c|}
\multicolumn{1}{c|}{ Características } & Valores \\
\hline Número de empreendimentos contemplados & 07 \\
\hline Número de empreiteiros envolvidos & 06 \\
\hline Número de projetistas estruturais envolvidos & 05 \\
\hline $\begin{array}{l}\text { Área, em projeção, das porções estruturais consideradas nos } \\
\text { levantamentos }\end{array}$ & $\cong 20.000 \mathrm{~m}^{2}$ \\
\hline $\begin{array}{l}\text { Metros cúbicos de concreto das porções estruturais consideradas nos } \\
\text { levantamentos }\end{array}$ & $\cong 5.000$ \\
\hline
\end{tabular}


Tabela 6.2 (conclusão) - Caracterização do estudo de caso

\begin{tabular}{l|l|l|}
\multicolumn{1}{c|}{ Características } & Valores \\
\hline $\begin{array}{l}\text { Toneladas de aço empregadas nas porções estruturais consideradas nos } \\
\text { levantamentos }\end{array}$ & $\cong 500$ ton \\
\hline Número de homens-hora analisados & $\cong 30.000$ \\
\hline $\begin{array}{l}\text { Números de funcionários (engenheiros, mestres de obras e } \\
\text { encarregados) entrevistados }\end{array}$ & $\cong 40$ \\
\hline $\begin{array}{l}\text { Número de pessoas envolvidas nas coletas de dados } \\
\text { Número de meses consumidos para a realização dos estudos de caso }\end{array}$ & $\cong 20$ \\
\hline
\end{tabular}

\subsubsection{Considerações iniciais sobre a condução das etapas do método}

A primeira etapa do MPDPro trata da definição dos indicadores e fatores a serem considerados ao longo de sua aplicação. Tal definição cabe ao "condutor", que deverá partir da lista proposta no método e, eventualmente, acrescentar ou propor novos fatores em função de suas opiniões ou das dos demais envolvidos (antes, durante ou após o contato com as obras). As discussões, envolvendo a escolha dos fatores precedem o levantamento, aumentam a percepção e o entendimento sobre cada um dos fatores, facilitam o levantamento, bem como tornam mais dinâmicas e produtivas as análises realizadas nas etapas seguintes.

A segunda etapa é a de levantamento de dados, conduzida simultaneamente, nos sete canteiros de obras ${ }^{125}$ contemplados na aplicação do método. A primeira fase dessa etapa ficou marcada pelos levantamentos realizados no escritório a partir da leitura crítica dos projetos do produto, no âmbito de dois aspectos principais: as formas de representação dos projetos e o entendimento analítico das armaduras para cada uma das porções definidas inicialmente. O uso de indicadores de caracterização analítica do projeto do produto ("ICAPP") possibilitou a quantificação dos projetos de detalhamento das armaduras, bem como a determinação dos fatores de conteúdo, nas porções de obra onde seriam feitos os levantamentos peródicos de dados para se calcular a produtividade. A fase de quantificação e determinação dos fatores de conteúdo demandou aproximadamente um mês de trabalho.

$\mathrm{Na}$ fase seguinte tiveram início os levantamentos de dados em campo ${ }^{126}$, que se estenderam por, aproximadamente, cinco meses e contemplaram as observações dos

\footnotetext{
125 Para cada uma dos canteiros foram definidas, previamente, as porções das obras que seriam contempladas na etapa de levantamento de dados.

126 Estes levantamentos tiveram seu inicio marcado pelas reuniões iniciais mantidas com a contratante e os empreiteiros responsáveis pela condução do serviço de armação em cada uma das sete obras escolhidas. Foram inicialmente reuniões de sensibilização para frisar a importância do tema que estaria sendo tratado na empresa a partir daquele momento, qual seja a produtividade da mão-de-obra e a percepção dos fatores potencialmente influenciadores. Durante essas reuniões definiram-se, também, as pessoas que se envolveriam diretamente com a pesquisa e com a coleta de dados em cada uma das obras.
} 
métodos e organização do trabalho, as entrevistas semi-estruturadas e os levantamentos periódicos.

As observações dos métodos e da organização do trabalho foram feitas pelo pesquisador, durante visitas às obras contempladas. As observações diretas em campo, os questionamentos aos operários sobre cada uma das operações do processo de produção de armaduras, as reuniões com encarregados do serviço e mestre de obra para tratar aspectos relativos à organização do trabalho foram alguns dos artifícios utilizados pelo pesquisador para conhecer, em detalhes, cada obra, as particularidades dos métodos de trabalho e da sua organização.

As entrevistas semi-estruturadas envolveram, em média, quatro pessoas por obra, estando sempre presente entre elas o engenheiro, o mestre de obras, o empreiteiro e o encarregado do serviço de armação. Essas pessoas eram reunidas em espaços reservados no próprio canteiro de obras onde, através da mediação do pesquisador (que usou o artifício de "espalhar" projetos de detalhamento de armadura nas paredes da sala onde foram feitas as reuniões), foram instigados a emitir seus pareceres e impressões sobre aspectos relacionados aos projetos que lhes foram apresentados (exemplos de outros projetos lembrados também foram trazidos à discussão), aos métodos e às formas de organização do trabalho referentes ao processo de produção de armaduras em seus canteiros e suas influências sobre a produtividade da mão-de-obra. Os depoimentos obtidos em cada uma das sete obras foram tabulados numa única planilha para serem analisados num momento seguinte.

A condução simultânea dos estudos de caso, na etapa de levantamento periódico de dados em campo, envolveu a colaboração de estagiários (sob a supervisão dos engenheiros de produção), encarregados e apontadores (das empreiteiras de estrutura), designados pela construtora para promoverem, especificamente, a coleta dos homenshora e da quantidade de serviço durante os ciclos de execução das estruturas. Essas pessoas foram orientadas, mediante treinamentos e levantamentos piloto (realizados na própria obra), conduzidos pelo pesquisador, que também se responsabilizou por fornecer toda a instrumentação necessária para a coleta e armazenamento dos dados. Permitiuse, assim, que as coletas de dados supracitadas fossem feitas diariamente, não com o intuito de se determinarem, posteriormente, indicadores com base diária de produtividade, mas sim, de se minimizarem equívocos ou erros nas coletas, que teriam maior chance de ocorrer se essas fossem feitas, por exemplo, ao final de um ciclo de execução da estrutura (após cinco ou seis dias).

A segunda etapa da fase de levantamento de dados foi concluída com a realização de discussões individuais (em cada obra) sobre os dados coletados e informações geradas, que contaram sempre com a participação dos envolvidos na coleta de dados, dos engenheiros da obra, mestre, encarregado do serviço de armação e empreiteiro. Essas discussões visavam o esclarecimento de dúvidas e a solução de problemas detectados pelo pesquisador nos levantamentos realizados.

$\mathrm{Na}$ terceira etapa do método (que começou no momento em que se encerraram os levantamentos de dados nos sete canteiros de obras, estendendo-se por dois meses), a construtora definiu uma lista com os fatores influenciadores, a partir da análise das "tendências" e "expectativas" da produção, ambas determinadas também nesta etapa a partir da organização e processamento do conjunto de dados (obtidos na etapa de levantamento de dados). 
Os fatores "eleitos" pela construtora foram submetidos à apreciação dos projetistas, submepreiteiros e fornecedores, mediante a realização de reuniões individuais promovidas pela construtora. A partir das constatações observadas nessas reuniões, os agentes participantes foram estimulados a propor diretrizes; foi essa a tônica da quarta etapa do método. Os agentes, ao considerarem as idéias preconizadas pelos fatores associados a boas práticas na proposição das diretrizes, criaram referências concretas para que processos futuros pudessem ser melhorados criteriosa e substancialmente.

Apresenta-se, a seguir, um caso real de aplicação do MPDPro em que todas as quatro etapas supracitadas foram desenvolvidas, com destaque, para o registro dos levantamentos, análises e proposições realizados.

\subsubsection{Etapa de definição dos indicadores e fatores}

O caráter e o rigor científico da primeira aplicação do método levou à necessidade de que todos os fatores inicialmente propostos no capítulo cinco fossem levantados. Não houve, portanto, como previsto na primeira etapa, a escolha de quais fatores, dentre uma listagem inicialmente proposta, a construtora optaria por levantar. Imagina-se que, em aplicações futuras, as construtoras optem por um conjunto mais restrito de fatores, ou, mesmo, proponham outros fatores que julguem de maior interesse. Essa abertura na definição dos fatores é proposital e bastante saudável à medida que, ao criar o primeiro fórum de discussões, já se começa a trabalhar a integração e a efetiva participação de todos os envolvidos.

Dessa forma, as discussões iniciais entre construtora, demais empresas (empreiteiras de mão-de-obra) escolhidas pela construtora e o pesquisador tiveram como pauta predominante a apresentação e explicação ${ }^{127}$ dos indicadores de produtividade (Tabela 6.3), fatores de conteúdo (Tabela 6.4), fatores de contexto relacionados ao método de trabalho (Tabela 6.5) e à organização do trabalho (Tabela 6.6) a todos os participantes envolvidos.

Tabela 6.3 - Indicadores de produtividade levantados

\begin{tabular}{|l|c|c|c|c|}
\hline & Pilar & Viga & Laje & Global \\
\hline RUP cíclica & $\mathrm{X}$ & $\mathrm{X}$ & $\mathrm{X}$ & $\mathrm{X}$ \\
\hline RUP cumulativa & $\mathrm{X}$ & $\mathrm{X}$ & $\mathrm{X}$ & $\mathrm{X}$ \\
\hline RUP potencial & $\mathrm{X}$ & $\mathrm{X}$ & $\mathrm{X}$ & $\mathrm{X}$ \\
\hline
\end{tabular}

${ }^{127}$ Realizaram-se algumas reuniões coletivas (participação de todas as obras), onde os indicadores de produtividade, as RUP potencial das tarefas e os fatores relacionados ao contexto e conteúdo do trabalho, foram devidamente comentados. 
Tabela 6.4 (continua) - Fatores escolhidos - conteúdo

\section{Fatores de conteúdo a serem levantados na etapa de levantamento de dados}

\begin{tabular}{|c|c|c|}
\hline \multirow{14}{*}{ 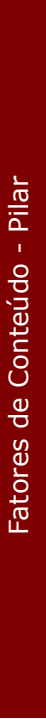 } & 1 & Taxa de armadura \\
\hline & 2 & Porcentagem de armaduras servindo dois pavimentos \\
\hline & 3 & Porcentagem (em massa) das peças transversais (em relação ao total) \\
\hline & 4 & Massa mediana das armaduras dos pilares \\
\hline & 5 & Massa mediana das peças longitudinais \\
\hline & 6 & Porcentagem (em massa) de estribos com diâmetro $>5 \mathrm{~mm}$ \\
\hline & 7 & Número de peças totais (dos pilares) pela massa total dos pilares \\
\hline & 8 & Diâmetro equivalente das peças (total) \\
\hline & 9 & Diâmetro equivalente das peças longitudinais \\
\hline & 10 & Número de posições distintas por tonelada \\
\hline & 11 & Número de ganchos por comprimento $(\mathrm{ml})$ de pilar \\
\hline & 12 & Comprimento total das peças por comprimento $(\mathrm{ml})$ de pilar \\
\hline & 13 & Porcentagem de pilares com estribos "acorrentados" \\
\hline & 14 & Número de estribos por comprimento $(\mathrm{ml})$ de pilar \\
\hline \multirow{13}{*}{ 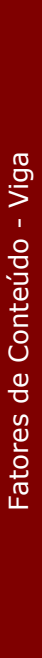 } & 1 & Taxa de armadura \\
\hline & 2 & Porcentagem (em massa) dos estribos (em relação ao total) \\
\hline & 3 & Massa mediana das peças \\
\hline & 4 & Massa mediana das peças longitudinais \\
\hline & 5 & Massa mediana de estribo \\
\hline & 6 & Porcentagem (em massa) de estribos com diâmetro $>5 \mathrm{~mm}$ \\
\hline & 7 & Número de peças totais (das vigas) pela massa total das vigas \\
\hline & 8 & Diâmetro equivalente das peças das armaduras das vigas \\
\hline & 9 & Número de pilares por número de vigas \\
\hline & 10 & Número de posições distintas por $\mathrm{Kg}$ \\
\hline & 11 & Porcentagem (em massa) de vigas com seção variável \\
\hline & 12 & Comprimento total das peças por comprimento $(\mathrm{ml})$ de viga \\
\hline & 13 & Número de estribo por comprimento $(\mathrm{ml})$ de viga \\
\hline
\end{tabular}


Tabela 6.4 (conclusão) - Fatores escolhidos - conteúdo

\section{Fatores de conteúdo a serem levantados na etapa de levantamento de dados}

\begin{tabular}{|c|c|c|}
\hline \multirow{14}{*}{ 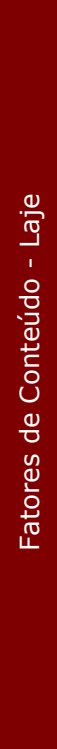 } & 1 & Soma comprimento linear das vigas \\
\hline & 2 & Taxa de armadura \\
\hline & 3 & Número de peças por $\mathrm{Kg}$ armadura \\
\hline & 4 & Relação entre comprimento das peças por $\mathrm{m} 2$ de área de laje \\
\hline & 5 & Massa média das peças \\
\hline & 6 & Massa das armaduras das lajes por m2 da área de laje \\
\hline & 7 & Média das áreas das lajes armadas \\
\hline & 8 & Porcentagem (em massa) das armaduras negativas das lajes \\
\hline & 9 & Diâmetro equivalente das peças das armaduras das lajes \\
\hline & 10 & Diâmetro equivalente das peças positivas das armaduras das lajes \\
\hline & 11 & Diâmetro equivalente das peças negativas das armaduras das lajes \\
\hline & 12 & Número de posições distintas \\
\hline & 13 & Porcentagem (em massa) das posições variáveis \\
\hline & 14 & Porcentagem (em massa) das posições negativa variáveis \\
\hline
\end{tabular}

Em se tratando dos fatores de contexto (método e organização do trabalho, apresentados na Tabela 6.5 e na Tabela 6.6), encontram-se associados a eles complementos que indicavam o posicionamento do fator quanto ao tipo de influência (positiva ou negativa) que, provavelmente, causariam à produtividade. Tal posicionamento (expresso qualitativo e quantitativamente ${ }^{128}$ ) foi determinado pela construtora na presente etapa de definição de indicadores e de fatores. Na etapa seguinte, de levantamento de dados, o posicionamento foi checado e, possivelmente, corrigido em situações em que as percepções do pessoal de obra sobre a influência do fator apresentaram divergências em relação à situação pré-estabelecida.

128 Para os fatores relacionados ao método de trabalho, os complementos foram posicionados em três categorias: uma primeira, relacionada a práticas indesejadas (influência negativa), à qual se atribuiria o valor " 0 "; uma segunda, intermediária entre à má e a boa prática, à qual atribuiu-se o valor "0,5"; e a última, associável à boa prática (influência positiva), cujo valor a ser atribuído seria "1". Para os fatores relacionados à organização do trabalho, suprimiu-se a categoria intermediária, devido ao grau maior de subjetivismo na percepção do tipo de influência. 
Tabela 6.5 (continua) - Fatores escolhidos - contexto: método de trabalho

\section{Fatores de contexto a serem levantados na etapa de levantamento de dados}

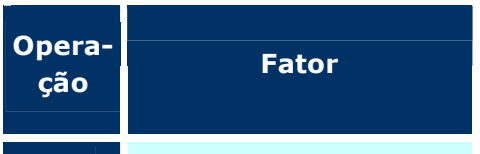

Tipo de aço recebido

Carregamento

preparado para descarregamento

Sistema de etiquetas para identificação dos feixes

Acessibilidade do caminhão no canteiro

Conferência dos feixes

Descarregamento

Distância entre áreas de descarregamento e estocagem

Estoques intermediários até estocagem definitiva

Classes de estocagem

Acessibilidade à área de estocagem

Estocagem

intermediárias

(peças/armaduras)

Configuração/disposição das áreas de estocagem

Porções de obras

realizadas

simultaneamente

Restrição de áreas no

canteiro para estocagem

Nível geral de

organização dos

estoques de peças e

armaduras

\begin{tabular}{|c|c|c|}
\hline \multicolumn{3}{|c|}{ Complemento } \\
\hline $\mathbf{0}$ & 0,5 & 1 \\
\hline $\begin{array}{l}\text { predominância de } \\
\text { cortado e dobrado }\end{array}$ & $>21$ e $<80 \%$ & predominância de barras \\
\hline sem preparo & relativa preparação & preparado \\
\hline sem etiquetas & $\begin{array}{l}\text { etiquetas soltas e sem } \\
\text { identificação visual }\end{array}$ & $\begin{array}{l}\text { etiquetas presas e com } \\
\text { sistema de cores }\end{array}$ \\
\hline Ruim & razoável & boa \\
\hline $\begin{array}{l}\text { no caminhão, com } \\
\text { instrumentos métricos }\end{array}$ & $\begin{array}{c}\text { no caminhão, através } \\
\text { das etiquetas }\end{array}$ & $\begin{array}{c}\text { após descarregamento, } \\
\text { através das etiquetas }\end{array}$ \\
\hline Manual & $\begin{array}{l}\text { com eventual auxílio } \\
\text { de equipamento }\end{array}$ & $\begin{array}{l}\text { com freqüente uso de } \\
\text { equipamento }\end{array}$ \\
\hline$>20 \mathrm{~m}$ & $<20 \mathrm{~m}$ & desprezível \\
\hline $\begin{array}{l}\text { mais que dois } \\
\text { estoques } \\
\text { intermediários }\end{array}$ & um estoque & $\begin{array}{l}\text { sem estoques } \\
\text { intermediários }\end{array}$ \\
\hline $\begin{array}{l}\text { estoques de feixes } \\
\text { sobrepostos }\end{array}$ & $\begin{array}{l}\text { estoque de feixes } \\
\text { espalhados }\end{array}$ & estoques em barras \\
\hline ruim & razoável & boa \\
\hline $\begin{array}{l}\text { dispersos, sem } \\
\text { identificação }\end{array}$ & $\begin{array}{l}\text { dispersos, com } \\
\text { identificação }\end{array}$ & $\begin{array}{c}\text { próximos, com } \\
\text { identificação, pensadas } \\
\text { a facilitar a operação } \\
\text { seguinte }\end{array}$ \\
\hline $\begin{array}{c}\text { dispersas, } \\
\text { desorganizadas }\end{array}$ & $\begin{array}{l}\text { centralizadas, porém } \\
\text { sem organização }\end{array}$ & $\begin{array}{c}\text { centralizadas e } \\
\text { organizadas }\end{array}$ \\
\hline mais que duas & duas & apenas uma \\
\hline $\begin{array}{c}\text { com restrições de } \\
\text { espaço }\end{array}$ & $\begin{array}{l}\text { com restrições } \\
\text { relativas }\end{array}$ & sem restrições \\
\hline ruim & razoável & bom \\
\hline
\end{tabular}


Tabela 6.5 (continua) - Fatores escolhidos - contexto: método de trabalho

\section{Fatores de contexto a serem levantados na etapa de levantamento de dados}

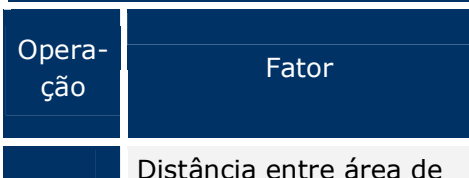

estoques e bancadas de corte

Configuração/disposição $\mathrm{da}(\mathrm{s})$ bancada(s) de corte

Equipamentos de corte das barras

Planejamento prévio das peças a serem cortadas

Ordem de corte

Separação/identificação das peças cortadas

Distância entre área de estoques e bancadas de dobra

Configuração/disposição $\mathrm{da}(\mathrm{s})$ bancada(s) de dobra

Equipamento de dobra das peças

Planejamento prévio das peças a serem dobradas

Ordem de dobra

Separação/identificação das peças dobradas

Armaduras de pilares pré-montadas

Armaduras de vigas prémontadas

Armaduras de lajes prémontadas

Configuração/disposição $\mathrm{da}(\mathrm{s})$ área(s) destinada à pré-montagem

Condições gerais de trabalho dos armadores

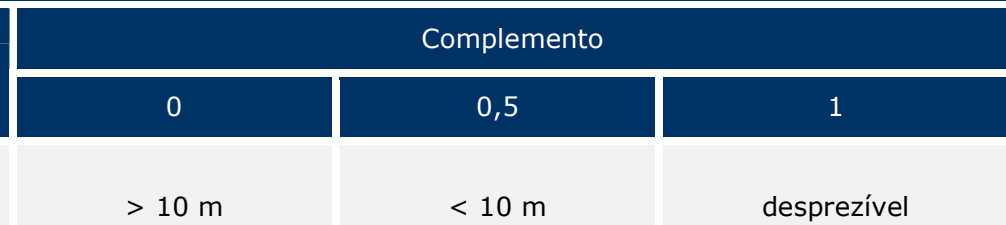

fora dos padrões, desprotegidas

uso de equipamentos manuais

sem planejamento

sem ordem de corte

sem identificação/ separação

$>10 \mathrm{~m}$

fora dos padrões, desprotegidas

uso de mesas de pinos com dobramento manual

sem planejamento

sem ordem de dobra sem identificação/ separação

$<50 \%$

$<50 \%$

$<50 \%$

dispersas, sem proteção

desfavoráveis dentro dos padrões, desprotegidas

uso de policorte, predominantemente

planejamento da produção para a produção

"rascunhos"

dentro dos padrões, desprotegidas

uso de mesas de pinos

(industrializadas) com dobramento manual

\section{planejamento da} produção para a produção

"rascunhos"

centralizadas, sem proteção e ambientes com trânsito intenso de pessoas

razoáveis dentro dos padrões, protegidas

uso de máquinas hidráulicas, predominantemente

planejamento da engenharia para a produção

"planos de corte" identificação/ separação em feixes

desprezível

dentro dos padrões, protegidas

uso de máquinas hidráulicas, predominantemente

planejamento da engenharia para a produção

"planos de dobra" identificação/ separação em feixes

$100 \%$

$100 \%$

$100 \%$

centralizadas, em ambientes protegidos e relativamente tranqüilos

boas 
Tabela 6.5 (conclusão) - Fatores escolhidos - contexto: método de trabalho

\section{Fatores de contexto a serem levantados na etapa de levantamento de dados}

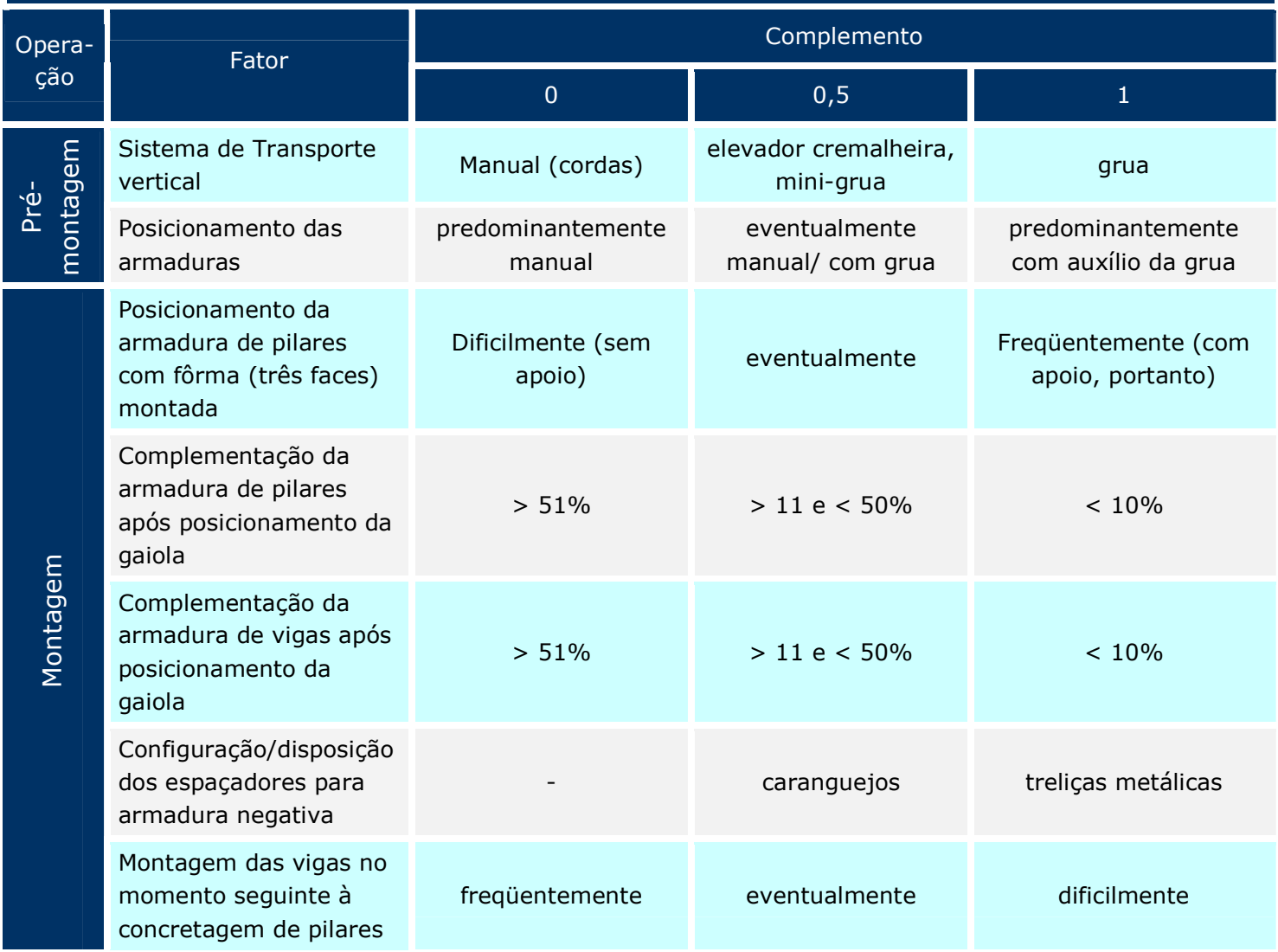

Tabela 6.6 (continua) - Fatores escolhidos - contexto: organização

\section{Fatores de contexto a serem levantados na etapa de levantamento de dados}

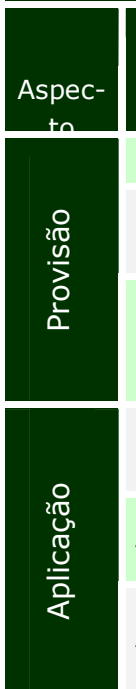

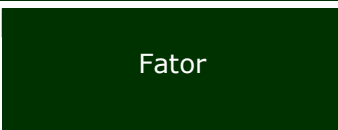

Regime de contratação

Experiência profissional (> 50\% armadores)

Política de contratação

Dimensionamento das equipes

Alocação das equipes 1

Alocação das equipes 2

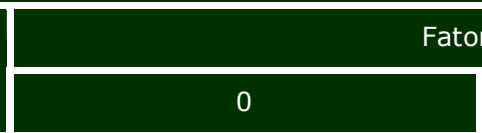

Sem registro

Tempo de experiência comprovada $<6$ meses

Operários novos, com experiência comprovada em carteira

Base empírica

Realocações intra-obra pouco usuais

Realocações inter-obras pouco usuais
Fator objetivo

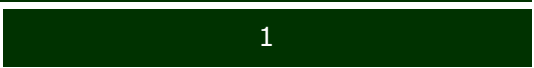

Registro em carteira

Tempo de experiência comprovada > 6 meses

Preferência por operários indicados e/ou que já trabalharam para a empresa

Base metodológica

Realocações freqüentes dos operários em porções distintas na mesma obra

Realocações freqüentes dos operários em porções de obras distintas 
Tabela 6.6 (conclusão) - Fatores escolhidos - contexto: organização

\section{Fatores de contexto a serem levantados na etapa de levantamento de dados}

\begin{tabular}{|c|c|c|c|}
\hline \multirow{2}{*}{ Aspec- } & \multirow{2}{*}{ Fator } & \multicolumn{2}{|c|}{ Fator objetivo } \\
\hline & & 0 & 1 \\
\hline \multirow{3}{*}{ 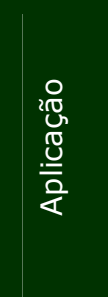 } & $\begin{array}{l}\text { Jornada de trabalho } \\
\text { diária } 1\end{array}$ & $\begin{array}{c}>9 \text { horas disponíveis para o } \\
\text { trabalho (média diária) }\end{array}$ & $\begin{array}{c}=9 \text { horas disponíveis para o trabalho } \\
\text { (média diária) }\end{array}$ \\
\hline & $\begin{array}{l}\text { Jornada de trabalho } \\
\text { semanal } 2\end{array}$ & > 5 dias (média semanal) & 5 dias (média semanal) \\
\hline & Alocação dos operários & $\begin{array}{l}\text { Apenas nas tarefas habituais } \\
\text { relacionadas ao ofício registrado } \\
\text { em carteira profissional }\end{array}$ & $\begin{array}{c}\text { Eventualmente em tarefas que não às } \\
\text { relacionadas ao ofício registrado em } \\
\text { carteira profissional }\end{array}$ \\
\hline \multirow{3}{*}{ 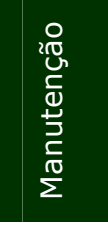 } & Aditivos salariais & Esporádicos (horas-extras) & Permanentes (tarefas) \\
\hline & Nível salarial & $\begin{array}{c}\text { Média }(\mathrm{R} \$ \text { ) salarial mensal }<1,2 \\
\mathrm{x} \text { piso categoria }\end{array}$ & $\begin{array}{l}\text { Média }(\mathrm{R} \$ \text { ) salarial mensal }>1,2 \times \\
\text { piso categoria }\end{array}$ \\
\hline & Horas ociosas no ciclo & $\begin{array}{l}\text { Operários dispensados ("acabou- } \\
\text { lavou") }\end{array}$ & $\begin{array}{c}\text { Operários remanejados para outras } \\
\text { atividades }\end{array}$ \\
\hline \multirow{2}{*}{ 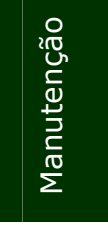 } & Benefícios & $\begin{array}{l}\text { Não disponibilizados ou } \\
\text { disponibilizados com atraso }\end{array}$ & Disponibilizados sem atraso \\
\hline & Motivação & $\begin{array}{l}\text { Práticas não identificadas ou } \\
\text { identificadas mas não valoradas } \\
\text { pelos operários }\end{array}$ & $\begin{array}{l}\text { Práticas identificadas e valoradas } \\
\text { pelos operários }\end{array}$ \\
\hline \multirow{3}{*}{ 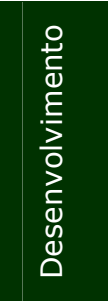 } & $\begin{array}{l}\text { Leitura e interpretação } \\
\text { de projetos }\end{array}$ & $\begin{array}{c}<30 \% \text { dos operários com tais } \\
\text { habilidades }\end{array}$ & $\begin{array}{c}>30 \% \text { dos operários com tais } \\
\text { habilidades }\end{array}$ \\
\hline & $\begin{array}{l}\text { Programas de } \\
\text { reciclagem profissional }\end{array}$ & Indisponíveis aos operários & Disponíveis aos operários \\
\hline & Profissionalização & $\begin{array}{c}\text { Capacitação mediante } \\
\text { observações de profissionais } \\
\text { experientes }\end{array}$ & $\begin{array}{l}\text { Através de programas oficiais de } \\
\text { formação/capacitação }\end{array}$ \\
\hline 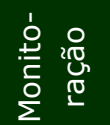 & $\begin{array}{l}\text { Monitoramento dos } \\
\text { operários como } \\
\text { ferramenta gerencial }\end{array}$ & $\begin{array}{c}\text { Monitoramento apenas para } \\
\text { pagamentos/controles de custos }\end{array}$ & $\begin{array}{c}\text { Monitoramento consistente e } \\
\text { constante dos operários pelo } \\
\text { empreiteiro }\end{array}$ \\
\hline
\end{tabular}

\subsubsection{Etapa de levantamento de dados}

Esta etapa do método compreendeu um amplo levantamento de dados no âmbito do processo de produção das armaduras, conforme prescrições contidas no quinto capítulo deste trabalho.

Procurando-se proporcionar aos futuros usuários do MPDPro um exemplo prático da etapa de levantamento de dados, apresenta-se, a seguir, o resultado obtido mediante a sua aplicação em um estudo de caso conduzido em uma construtora de edifícios, já caracterizado anteriormente. É importante salientar que a apresentação dos dados e informações foi estruturada de maneira a conferir dinamismo e objetividade ao texto, sem que, para isso, deixe de contemplar todos os aspectos julgados relevantes no nessa etapa. 
O levantamento de dados será dividido em dois grupos principais: um primeiro, que tratará dos levantamentos objetivos, e outro, que contemplará os levantamentos subjetivos.

Em se tratando dos levantamentos objetivos, a apresentação será subdividida em duas partes, de acordo com o nível de detalhamento das informações e dados apresentados. A primeira parte contemplará apenas uma, dentre as sete obras (SP 301). Objetiva-se, dessa forma, evidenciar o grau de detalhamento das informações obtidas (a partir das fontes de evidência propostas), orientando as construtoras na realização de levantamento de dadoss futuros.

Na segunda parte da apresentação, os levantamentos objetivos obtidos nas outras seis obras serão condensados e apresentados de forma resumida. Objetiva-se, com isso, aumentar a densidade do conteúdo dos levantamentos, tornando o texto mais direto e menos repetitivo.

Ambas as apresentações (ainda que com dois níveis de detalhamento) terão a mesma estruturação, mostrando, para cada obra: i) a caracterização do empreendimento; ii) os indicadores de caracterização do projeto (ICP); iii) a descrição do método de trabalho; iv) a descrição da organização do trabalho.

A apresentação dos levantamentos subjetivos remete diretamente aos produtos desta intervenção, que trata da lista com opiniões do pessoal de obra sobre aspectos relacionados ao projeto do produto, método e organização do trabalho e suas influências sobre a produtividade da mão-de-obra.

O produto dos levantamentos objetivos e subjetivos, respectivamente a lista de opiniões, os indicadores de produtividade da mão-de-obra e os fatores de conteúdo e de contexto, serão apresentados na etapa seguinte, a de processamento. Optou-se por não mostrá-los ao fim da etapa de levantamento, como seria coerente, justamente para evitar que conteúdo do capítulo se tornasse repetitivo.

Vale observar que essa etapa, tal como realizada nesta aplicação do MPDpro, permitiu um levantamento extenso e detalhado de dados relacionados ao processo de produção de armaduras. O caráter minucioso e detalhista conferido a esse levantamento, ainda que sirva a propósitos científicos em se tratando da primeira aplicação de um modelo proposto, revelou-se factível de ser repetido em aplicações futuras (do método).

\subsubsection{Levantamentos Objetivos}

\subsection{Caracterização da obra SP 301 no âmbito do processo de concepção e produção de armaduras}

A obra escolhida para ser caracterizada em detalhes neste trabalho trata da obra SP 301, sendo sua apresentação estruturada em quatro tópicos principais: i) caracterização do empreendimento; ii) indicadores de caracterização do projeto do produto; iii) descrição do método de trabalho; iv) descrição da organização do trabalho.

\section{i) Caracterização do Empreendimento}

A Tabela 6.7 traz algumas características do empreendimento. 
Tabela 6.7 - Caracterização do empreendimento

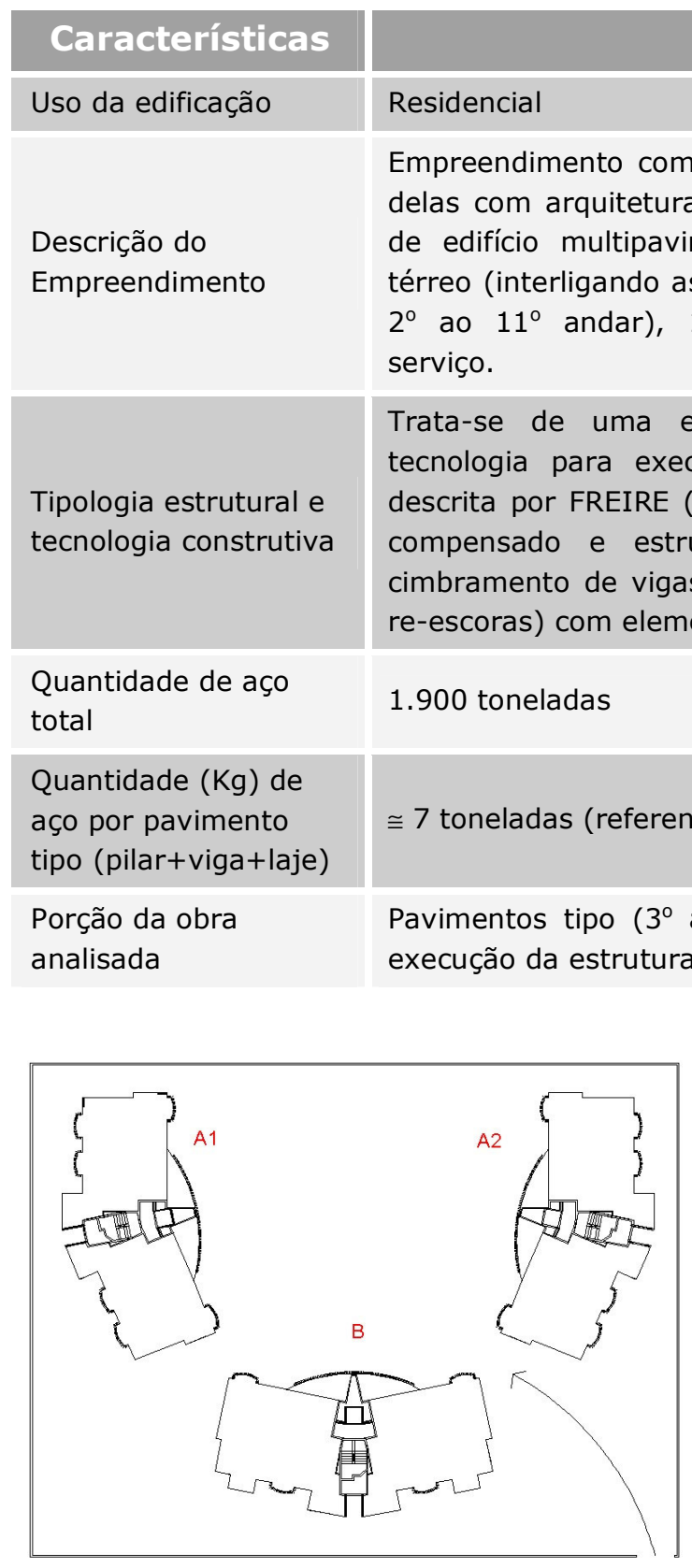

Figura 6.4 - Vista da implantação das torres no terreno

\section{Descrição}

Residencia

Empreendimento composto por três torres (Figura 6.4), sendo duas terreo (interligando as três torres), $1^{\circ}$ andar, 10 pavimentos tipo (do ao $11^{\circ}$ andar), $11^{\circ}$ pavimento (cobertura) + pavimentos de Trata-se de uma estrutura reticulada de concreto armado. A tecnologia para execução destas estruturas é aquela tradicional, (2000), com fôrmas com moldes em chapas de estruturação dos painéis em madeira serrada; cimbramento de vigas com garfos de madeira e de lajes (escoras e re-escoras) com elementos metálicos locados.

\subsection{0 toneladas}

\section{$\cong 7$ toneladas (referente ao $3^{\circ}$ pavimento)}

Pavimentos tipo $\left(3^{\circ}\right.$ ao $\left.7^{\circ}\right)$ da Torre "A1". A (Figura 6.5) ilustra a execução da estrutura da obra analisada.

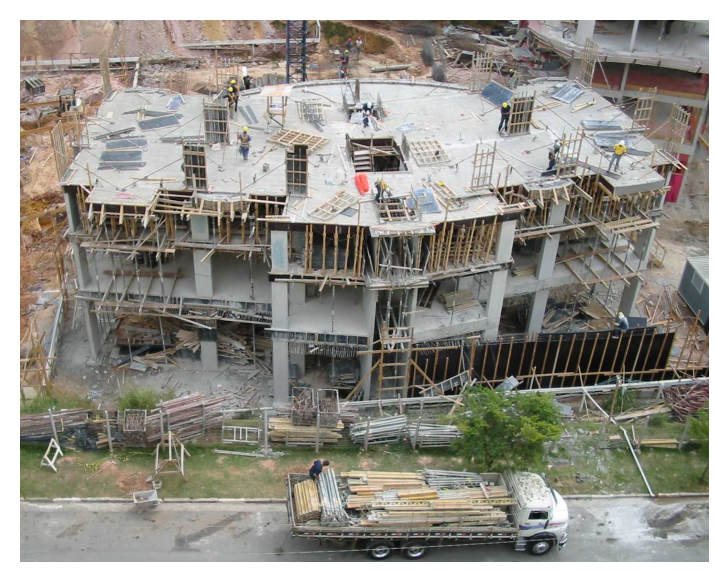

Figura 6.5 - Estrutura em execução da torre "B"

\section{ii) Caracterização do Projeto do Produto}

O projeto do produto é entendido aqui como composto do projeto de formas e do projeto de detalhamento das armaduras (PDA). Será feito, portanto, uma breve caracterização do projeto de formas (referente à principal porção da obra considerada nos levantamentos), passando-se, em seguida, à caracterização do PDA. Em ambos os casos, 
serão usados indicadores de caracterização (ICAPP). Por fim, faz-se uma discussão quanto às formas de representação gráfica dos PDA de pilares, vigas e lajes, ilustrandose e comentando detalhes desses projetos.

A Tabela 6.8 traz alguns indicadores, referentes ao projeto estrutural de formas referente ao pavimento tipo da torre "A1", ilustrado na Figura 6.6. Esses indicadores, além de proporcionarem ao leitor uma idéia das dimensões estruturais do edifício, são também usados na determinação de fatores (como, por exemplo, o fator que relaciona a massa total de aço do pavimento com a área de fôrmas do respectivo pavimento).

Tabela 6.8 - Visão analítica da estrutura da torre "A1"

\begin{tabular}{|l|c|}
\hline \multicolumn{1}{|c|}{ Características } & Valores \\
\hline Área de projeção do pavimento tipo (Figura 6.6) $\left(\mathrm{m}^{2}\right)$ & 285,48 \\
\hline Área total de fôrmas $\left(\mathrm{m}^{2}\right)$ & 583 \\
\hline \% da área de fôrmas dos pilares em relação à área de fôrmas total & 30 \\
\hline \% da área de fôrmas das vigas em relação à área de fôrmas total & 25 \\
\hline \% da área de fôrmas das lajes em relação à área de fôrmas total & 45 \\
\hline Altura do pé-direito $(\mathrm{m})$ & 2,7 \\
\hline
\end{tabular}

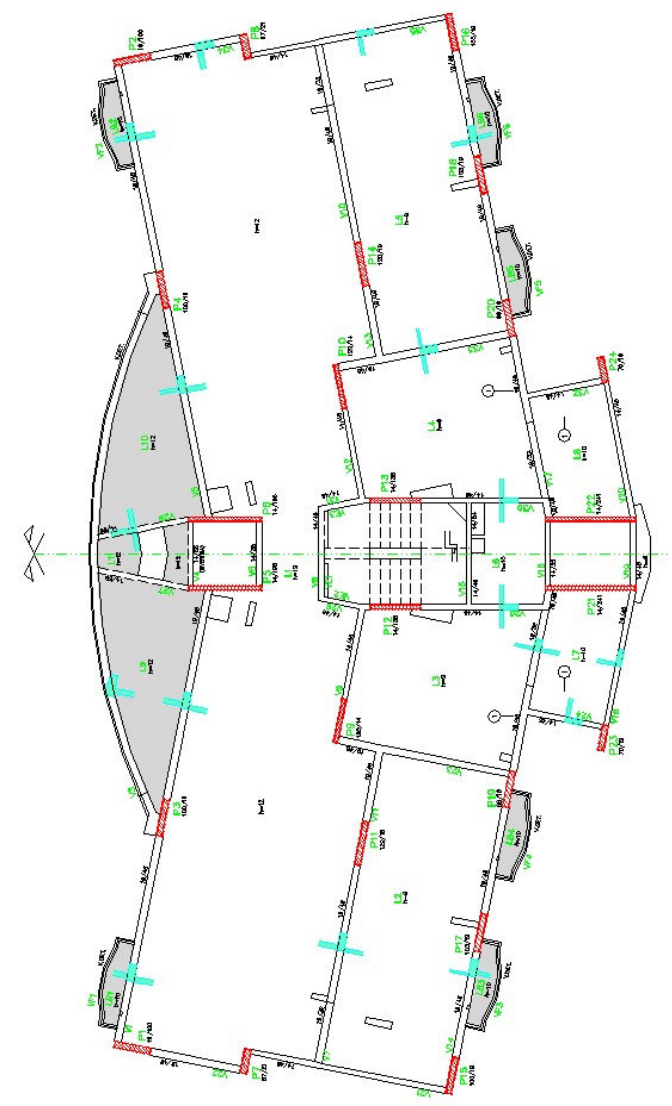

Figura 6.6 - Projeto executivo da fôrma do pavimento tipo da obra SP 301 
Os projetos de detalhamento das armaduras foram traduzidos em indicadores, permitindo uma interpretação analítica dos mesmos (principalmente quando reunidos com os indicadores obtidos junto aos PDA das demais obras). A Tabela 6.9 apresenta alguns dos ICAPP referentes ao detalhamento da armaduras dos pilares, vigas e lajes da obra SP 301.

Tabela 6.9 - Visão analítica do PDA - obra SP 301

\begin{tabular}{|c|c|c|c|c|c|}
\hline \multicolumn{6}{|c|}{ Indicadores de Caracterização do PDA ${ }^{129}$} \\
\hline \multicolumn{2}{|l|}{ Pilares } & \multicolumn{2}{|l|}{ Vigas } & \multicolumn{2}{|l|}{ Lajes } \\
\hline Número de pilares & 24 & Número de vigas & 39 & $\begin{array}{l}\text { Massa total de aço das } \\
\text { lajes }(\mathrm{Kg})\end{array}$ & 3843 \\
\hline $\begin{array}{l}\text { Massa total de aço dos } \\
\text { pilares }(\mathrm{Kg})\end{array}$ & 1800 & $\begin{array}{l}\text { Número de gaiolas } \\
\text { reais }\end{array}$ & 42 & Número total de peças & 1209 \\
\hline $\begin{array}{l}\text { Comprimento total das } \\
\text { peças }(\mathrm{m})\end{array}$ & 3518 & $\begin{array}{l}\text { Massa total de aço } \\
\text { das vigas }(\mathrm{Kg})\end{array}$ & 1317 & $\begin{array}{l}\text { Massa total de aço das } \\
\text { lajes positivas }(\mathrm{Kg})\end{array}$ & 3010 \\
\hline $\begin{array}{l}\text { Número total de peças } \\
\text { distintas }\end{array}$ & 24 & $\begin{array}{l}\text { Comprimento total } \\
\text { das peças }(m)\end{array}$ & 2702 & $\begin{array}{l}\text { Massa total de aço das } \\
\text { lajes negativas }(\mathrm{Kg})\end{array}$ & 773 \\
\hline $\begin{array}{l}\text { Número total de peças } \\
\text { total }\end{array}$ & 3188 & $\begin{array}{l}\text { Número total de peças } \\
\text { distintas }\end{array}$ & 94 & $\begin{array}{l}\text { Comprimento total das } \\
\text { peças }(\mathrm{m})\end{array}$ & 9298 \\
\hline $\begin{array}{l}\text { Massa total das peças } \\
\text { longitudinais }(\mathrm{Kg})\end{array}$ & 1454 & $\begin{array}{l}\text { Número de peças } \\
\text { total }\end{array}$ & 1331 & $\begin{array}{l}\text { Comprimento total das } \\
\text { peças positivas }(m)\end{array}$ & 7202 \\
\hline $\begin{array}{l}\text { Massa total das peças } \\
\text { transversais (estribos) } \\
(\mathrm{Kg})\end{array}$ & 274 & $\begin{array}{l}\text { Massa total das peças } \\
\text { longitudinais }(\mathrm{Kg})\end{array}$ & 952 & $\begin{array}{l}\text { Comprimento total das } \\
\text { peças negativas }(\mathrm{m})\end{array}$ & 2095 \\
\hline $\begin{array}{l}\text { Massa total das peças } \\
\text { transversais (ganchos) } \\
(\mathrm{Kg})\end{array}$ & 72 & $\begin{array}{l}\text { Massa total das peças } \\
\text { transversais (estribos) } \\
(\mathrm{Kg})\end{array}$ & 315 & $\begin{array}{l}\text { Diâmetro equivalente total } \\
(\mathrm{mm})\end{array}$ & 8,2 \\
\hline $\begin{array}{l}\text { Comprimento total das } \\
\text { peças longitudinais ( } m \text { ) }\end{array}$ & 1314 & $\begin{array}{l}\text { Diâmetro equivalente } \\
\text { total }(\mathrm{mm})\end{array}$ & 9 & $\begin{array}{l}\text { Diâmetro equivalente da } \\
\text { armadura positiva ( } \mathrm{mm} \text { ) }\end{array}$ & 8,3 \\
\hline $\begin{array}{l}\text { Comprimento total das } \\
\text { peças transversais }(m)\end{array}$ & 2204 & & & $\begin{array}{l}\text { Diâmetro equivalente da } \\
\text { armadura negativa (mm) }\end{array}$ & 7,7 \\
\hline $\begin{array}{l}\text { Diâmetro equivalente total } \\
(\mathrm{mm})\end{array}$ & 9,0 & & & $\begin{array}{l}\text { Número peças positivas } \\
\text { distintas }\end{array}$ & 56 \\
\hline
\end{tabular}

A Tabela 6.10 traz uma breve caracterização dos projetos de detalhamento das armaduras do pavimento tipo quanto à forma de representação dos desenhos apresentada pelo projetista estrutural. Ressalta-se que a forma de representação adotada está condizente com as prescrições da norma NBR 7140:1986. Vale mencionar que, quando comparadas, são observadas significativas diferenças entre as formas de representação dos PDA das sete obras contempladas no estudo (ARAÚJO, SOUZA (2004)).

${ }^{129}$ A listagem completa dos ICAPP da obra SP 301 será apresentada conjuntamente com as demais na seqüência do capítulo. 
Tabela 6.10 - Caracterização da representação dos PDA

\begin{tabular}{|l|c|c|c|}
\hline \multicolumn{1}{|c|}{ Características } & Pilares & Vigas & Lajes \\
\hline Número de elementos por pavimento tipo & 24 & 41 & - \\
\hline Número de pranchas utilizadas & 5 & 2 & 2 \\
\hline Organização da tabela resumo de aço & por pilar & por viga & por posições \\
\hline Distribuição dos elementos na prancha & para andar & por andar & por andar \\
\hline
\end{tabular}

A Figura 6.7 ilustra uma prancha com o detalhamento da armadura dos pilares. $\mathrm{Na}$ mesma prancha são detalhados cinco pilares (que, devido à simetria do projeto, equivalem a dez dos 24 pilares do pavimento tipo), ao longo dos sete pavimentos tipo (as peças que compõem a armadura de cada pilar, principalmente as barras longitudinais, podem variar (quantidade e diâmetro das barras) de um pavimento para o outro). A Figura 6.8 exemplifica como é feito o detalhamento das peças dos pilares a cada pavimento. A tabela resumo de aço dos pilares (Figura 6.9) separa as peças por pilares; porém, para cada pilar, constam as peças distribuídas ao longo dos sete pavimentos.

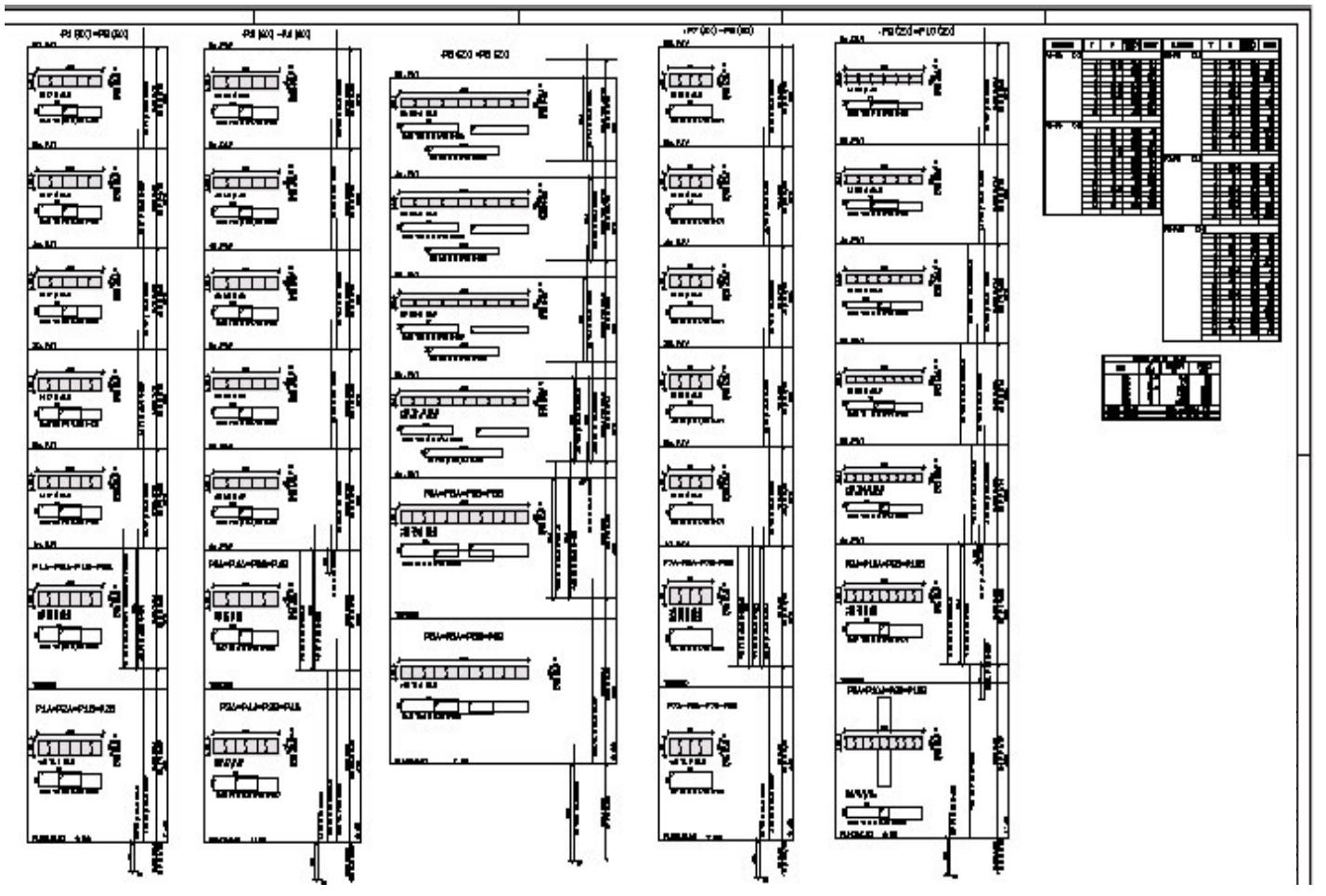

Figura 6.7 - Exemplo de prancha para detalhamento das armaduras de pilares 


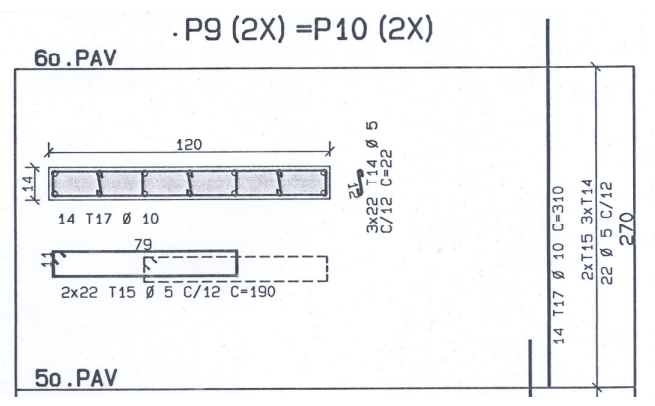

Figura 6.8 - Detalhe da representação da armadura de pilar para um pavimento

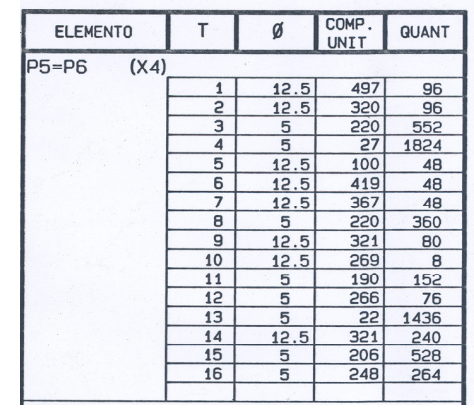

Figura 6.9 - Detalhe da tabela resumo de aço para os pilares.

A Figura 6.10 ilustra uma das duas pranchas que trazem o detalhamento das vigas do pavimento tipo. A Figura 6.11 mostra que as peças que compõem a armadura são detalhadas externamente (abaixo) ao desenho da viga; vistas em corte de seções das vigas ajudam a entender o posicionamento das peças distribuídas longitudinalmente. A Tabela resumo do aço (Figura 6.12) traz as peças separadas por vigas, com quantidades condizentes a apenas um pavimento.

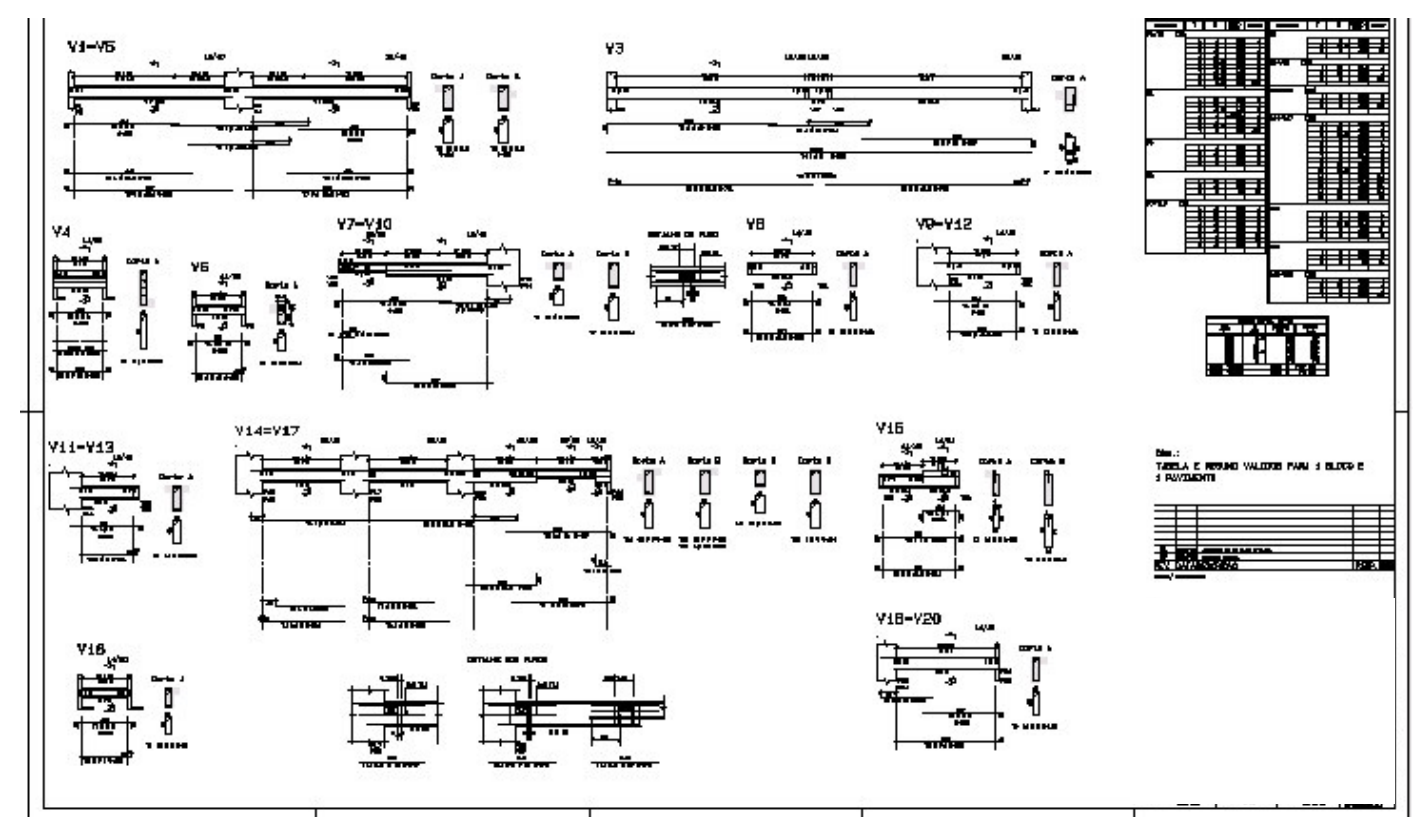

Figura 6.10 - Exemplo de prancha para detalhamento das armaduras de vigas 


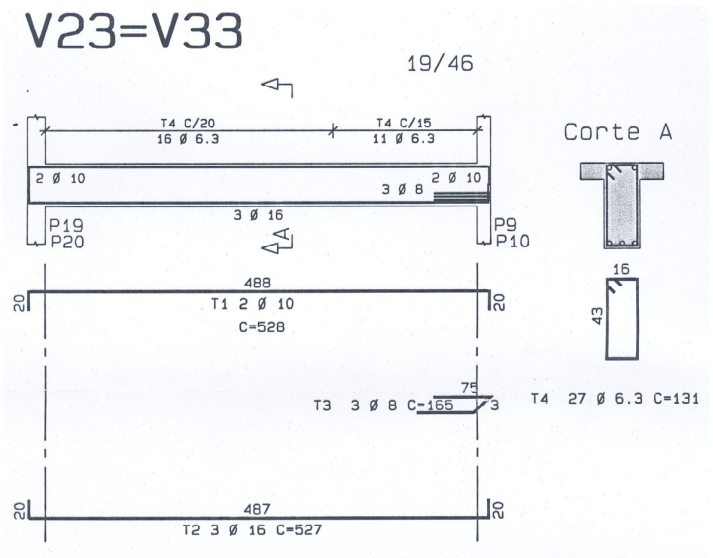

Figura 6.11 - Detalhe da representação da armadura de viga

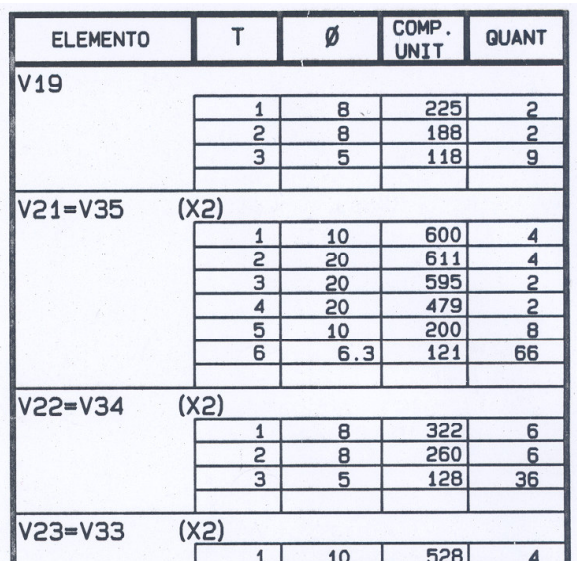

Figura 6.12 - Detalhe da tabela resumo de aço para as vigas

A Figura 6.13 traz o detalhamento da armadura positiva da laje (nas duas direções). $\mathrm{Na}$ Figura 6.14 amplia-se uma trecho da armadura positiva da laje, evidenciando a representação das peças no que se refere a sua identificação (diâmetro, quantidade e espaçamentos) e distribuição das mesmas na laje. A Figura 6.15 mostra a tabela resumo de aço para a armadura positiva. Nota-se a identificação "VAR" para as peças com comprimento variável no campo "comprimento" da referida tabela. As peças que constam da tabela, embora sejam as mesmas nos sete pavimentos tipo, representam a armadura (em quantidade de peças) de apenas um pavimento.

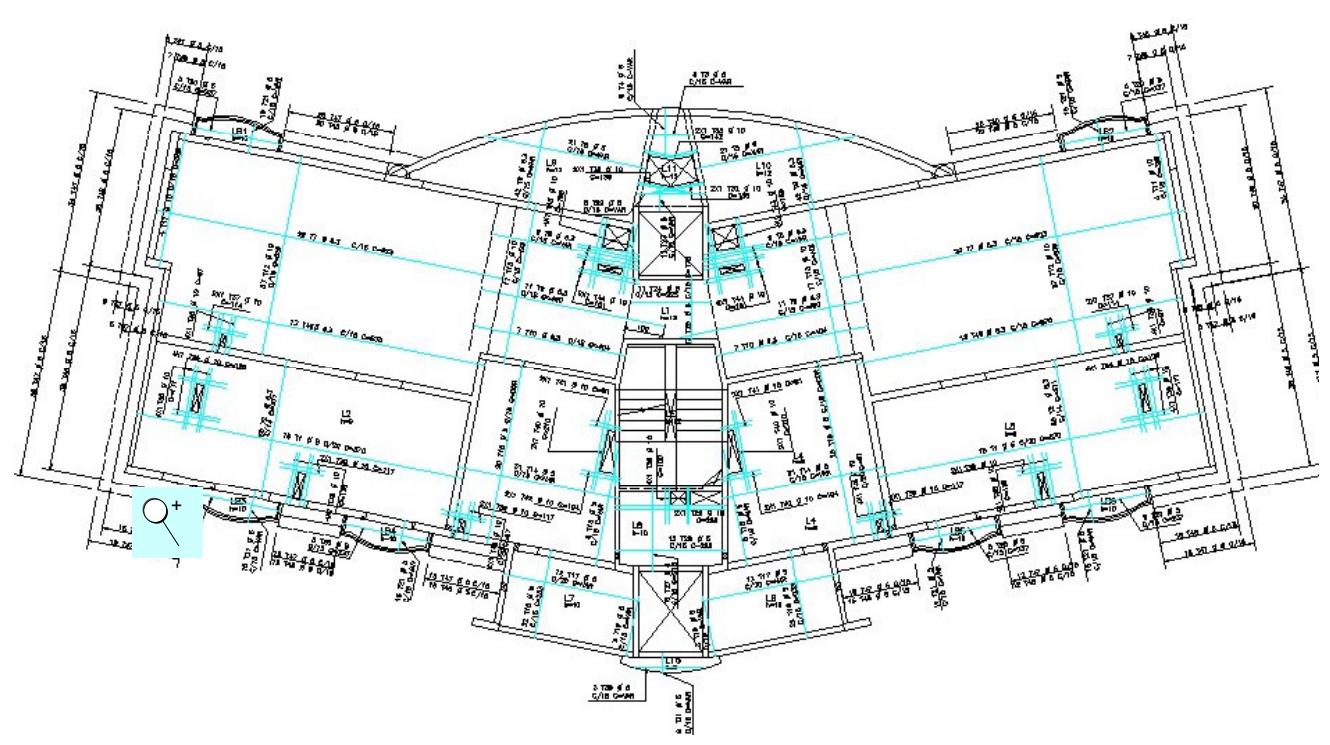

Figura 6.13 - Exemplo de prancha para detalhamento da armadura da laje (+) 


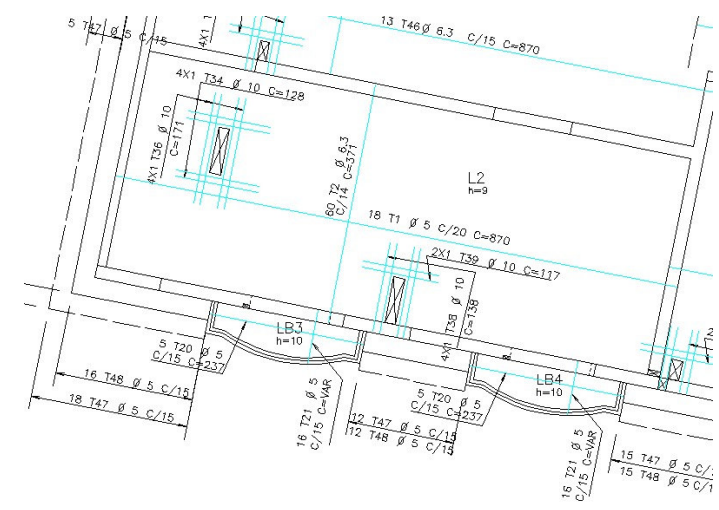

Figura 6.14 - Detalhe da representação da armadura positiva da laje

\begin{tabular}{|c|c|c|c|c|}
\hline ELEMENTO & $T$ & $\emptyset$ & $\begin{array}{l}\text { COMP. } \\
\text { UNIT }\end{array}$ & GUANT \\
\hline \multirow[t]{17}{*}{ LAJES PAV. } & \multicolumn{4}{|c|}{ PO E DUPLEX INFERIOR } \\
\hline & 1 & 5 & 870 & 36 \\
\hline & 2 & 6.3 & 371 & 120 \\
\hline & 3 & 5 & - -VAR- & 8 \\
\hline & 4 & 5 & - -VAR- & 8 \\
\hline & 5 & 5 & - -VAR- & 42 \\
\hline & 6 & 6.3 & --VAR- & 84 \\
\hline & 7 & 6.3 & 923 & 44 \\
\hline & 8 & 6.3 & - -VAR- & 18 \\
\hline & 9 & 6.3 & 490 & 22 \\
\hline & 10 & 6.3 & 404 & 14 \\
\hline & 11 & 10 & 358 & 8 \\
\hline & 12 & 10 & 526 & 114 \\
\hline & 13 & 10 & 423 & 34 \\
\hline & 14 & 5 & - VAR- & 62 \\
\hline & 15 & 5 & -CORR- & 40 \\
\hline & & $=$ & - -1/A口_ & 15 \\
\hline
\end{tabular}

Figura 6.15 - Detalhe da tabela resumo de aço para armadura positiva de laje

A Figura 6.16 mostra o detalhamento da armadura negativa da laje do pavimento, representada no desenho nas duas direções. Na Figura 6.17 amplia-se um trecho da armadura negativa da laje, evidenciando a representação das peças no que se refere a sua identificação (diâmetro, quantidade, formato e espaçamentos). Quanto ao formato, chama-se atenção para as peças da armadura negativa que chegam na laje em balanço (marquises). A Figura 6.18 mostra a tabela resumo de aço para a armadura negativa. As peças que constam da tabela, embora sejam as mesma nos sete pavimentos tipo, representam a armadura (em quantidade de peças) de apenas um pavimento.

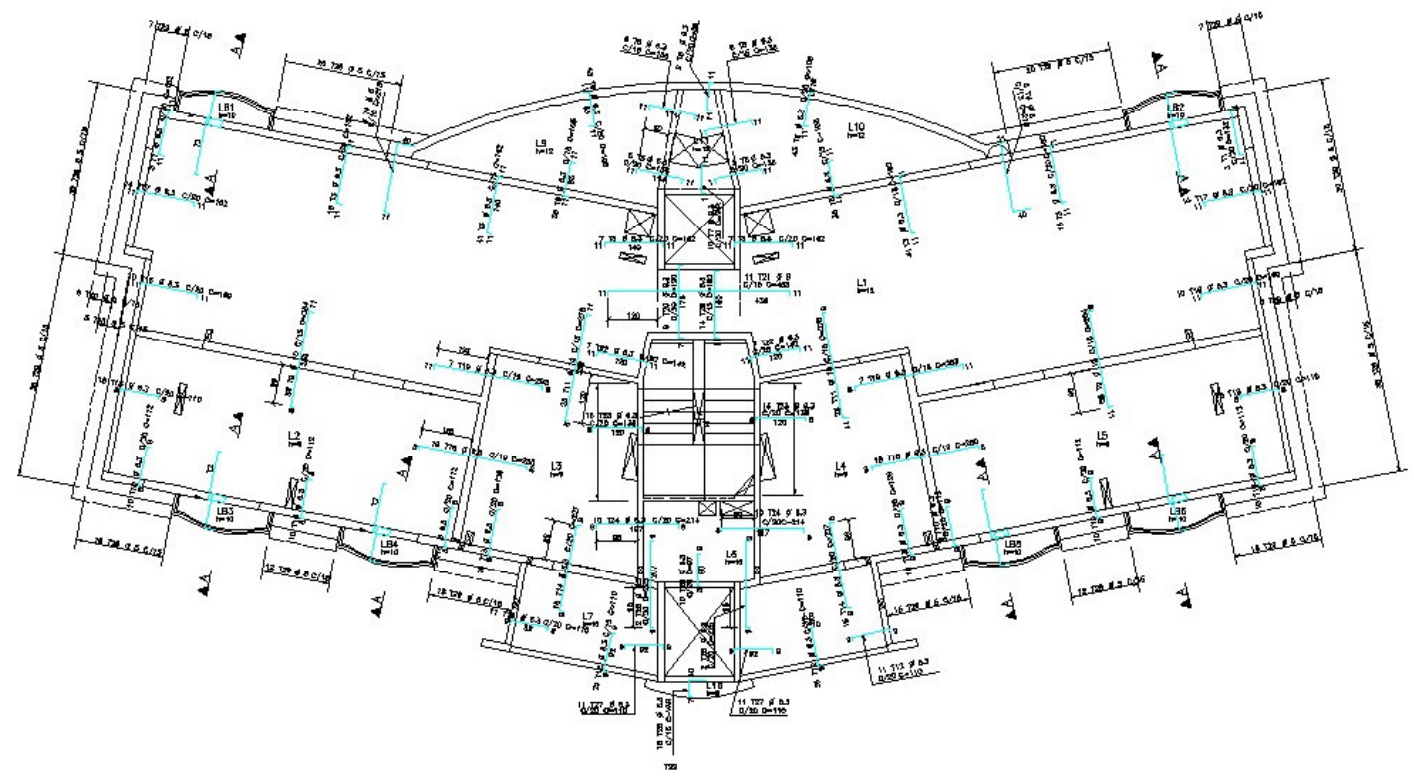

Figura 6.16 - Exemplo de prancha para detalhamento da armadura da laje (-) 


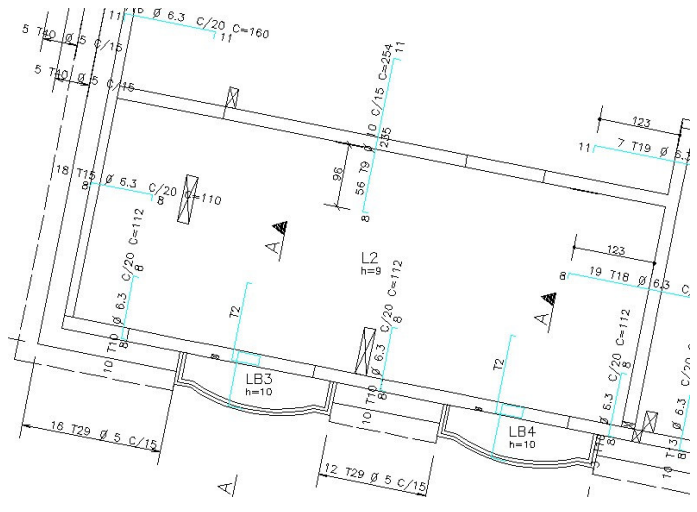

Figura 6.17 - Detalhe da representação da armadura negativa da laje

\begin{tabular}{|c|c|c|c|c|}
\hline ELEMENTO & $\mathrm{T}$ & $\varnothing$ & $\begin{array}{l}\text { COMP. } \\
\text { UNIT }\end{array}$ & QUANT \\
\hline \multicolumn{5}{|c|}{ LAJES PAV. TIPO $\ominus$ DUPLEX INFERIOR } \\
\hline & 1 & 6.3 & 132 & 6 \\
\hline & 2 & 5 & - -VAR- & 96 \\
\hline & $\frac{2}{3}$ & 6.3 & 162 & 128 \\
\hline & 4 & 8 & 218 & 10 \\
\hline & 5 & 6.3 & 136 & 26 \\
\hline & $\frac{6}{5}$ & 6.3 & 105 & 162 \\
\hline & 7 & 5.3 & $--V A R-$ & 10 \\
\hline & 8 & 6.3 & 89 & 9 \\
\hline & 9 & 10 & 254 & 112 \\
\hline & 10 & 6.3 & 112 & 46 \\
\hline & 11 & 10 & 278 & 46 \\
\hline & 12 & 6.3 & 110 & 72 \\
\hline & 13 & 5.3 & 129 & 20 \\
\hline & 14 & 6.3 & 227 & 30 \\
\hline & 15 & 6.3 & 110 & 36 \\
\hline & 16 & 6.3 & 160 & 20 \\
\hline & 17 & 6.3 & 162 & 28 \\
\hline & 18 & 6.3 & 280 & 38 \\
\hline
\end{tabular}

Figura 6.18 - Detalhe da tabela resumo de aço para armadura negativa da laje

\section{iii) Descrição do Método de Trabalho}

O aço era fornecido em barras de $11 \mathrm{~m}$ à obra SP 301, que utilizava o empreiteiro de armação para beneficiá-lo dentro do canteiro de obras. A solicitação do aço era feita pela obra, com antecedência necessária para que os estoques se mantivessem sempre repostos. $\mathrm{O}$ aviso, quanto à necessidade de novas solicitações, era feito pelo encarregado de armação ao mestre da obra, que se reportava à engenharia da obra para efetivação do pedido junto ao fornecedor. Entre a solicitação do aço e seu recebimento na obra, levavam-se, em média, vinte dias.

O recebimento do aço era operacionalizado por funcionários do empreiteiro, que contavam com dois aspectos facilitadores: i) auxilio freqüente da grua; ii) local de estacionamento do veículo de transporte do aço próximo ao local de estocagem (Figura 6.19). O caminhão e/ou carreta que o transportava teve acesso ao interior do canteiro de obras durante o período em que o autor acompanhou a obra (Figura 6.20).

A estocagem das barras, conforme já ilustrado através da Figura 6.19, era feita no nível do subsolo, próximo ao local onde as barras seriam beneficiadas. A base da baia, em que as barras eram estocadas, recebiam tábuas, dispostas transversalmente ao comprimento das barras, com objetivo de impedir o contato dessas com o solo. Pontaletes e pedaços de barras de aço eram usados para fazer a separação das barras por diâmetro, que eram identificados por plaquetas dispostas junto a cada conjunto de barras (Figura 6.21).

As peças, assim como as armaduras pré-montadas, eram estocadas, preferencialmente, nas proximidade da central de armação ou em locais mais afastados, desde que dentro do raio de alcance da grua (Figura 6.22). 


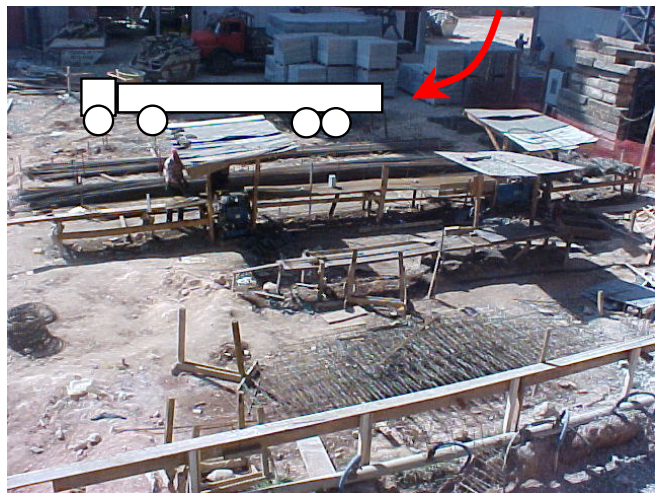

Figura 6.19 - Local de posicionamento do veículo no interior do canteiro de obras

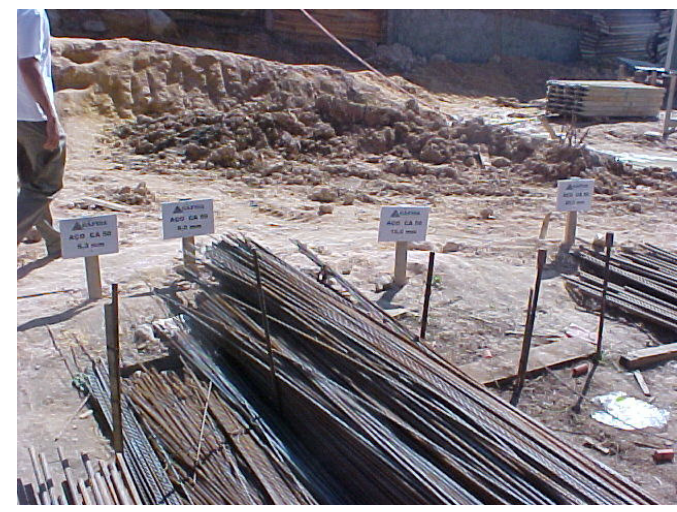

Figura 6.21 - Baia de estocagem das barras de aço

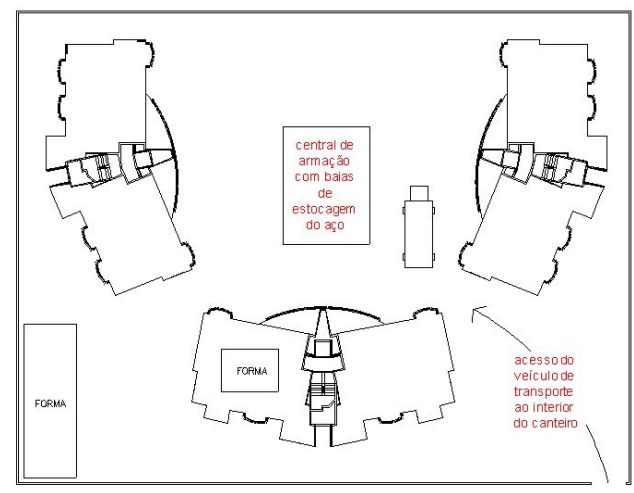

Figura 6.20 - Vista do acesso à central de armação no interior do canteiro de obras

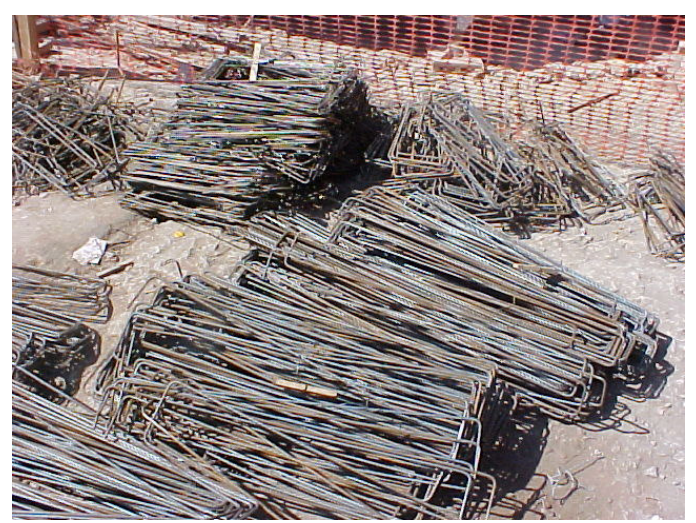

Figura 6.22 - Estoque das peças antes da pré-montagem

O beneficiamento das barras, ou seja, as operações de corte e dobra, como já comentado, eram desenvolvidas no canteiro de obras por uma mesma dupla de armadores, ou seja, a mesma dupla que cortava era a que dobrava. Tal dupla era composta por um armador e um ajudante 130 ("o ajudante com oito meses está apto para operar as máquinas"). Esses operários eram alocados pelo empreiteiro exclusivamente para essas funções. Tinham, à sua disposição, máquinas hidráulicas para o corte e a dobra das barras (Figura 6.23 e Figura 6.24), dispostas, seqüencialmente, na bancada, conforme ilustrado na Figura 6.25.

A obra contava ainda com um segunda bancada de dobra (para a execução de serviços menores ou como apoio em momentos de pico do serviço), onde a operação era realizada convencionalmente (pinos fixos à bancada e chave de dobra), conforme ilustrado na Figura 6.26. Segundo depoimento do empreiteiro, os dois armadores, ao utilizarem as máquinas hidráulicas, eram capazes de atender a demanda de duas torres,

130 O ajudante, segundo depoimentos dos próprios armadores era fundamental para garantir o esquadro das posições (em vigas principalmente). 
embora, no momento em que a obra era acompanhada pelo autor, o beneficiamento do aço destinava-se, predominantemente, à torre "A1". "Quando o serviço está muito "corrido" coloca-se uma dupla para o corte e uma dupla para a dobra".

As listagens das peças a serem cortadas e dobradas eram passadas pelo encarregado do serviço, na forma de "rascunhos" (Figura 6.27). Após cortadas e dobradas, as peças eram identificadas com plaquetas de madeira, conforme ilustrado na Figura 6.28.

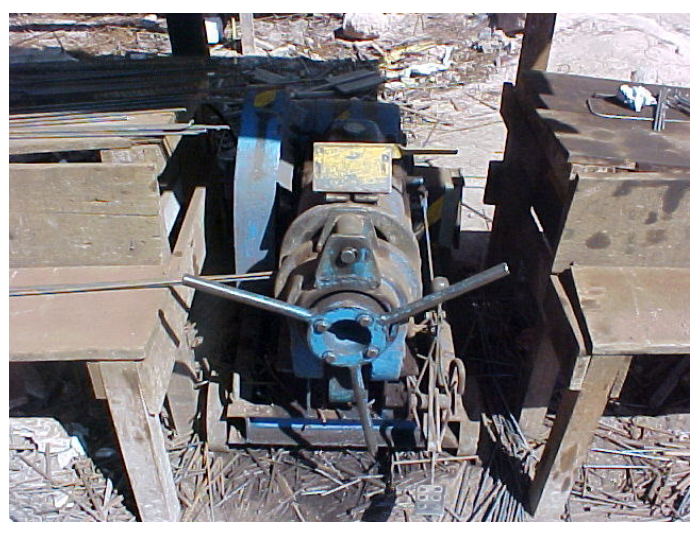

Figura 6.23 - Detalhe da máquina de corte hidráulica

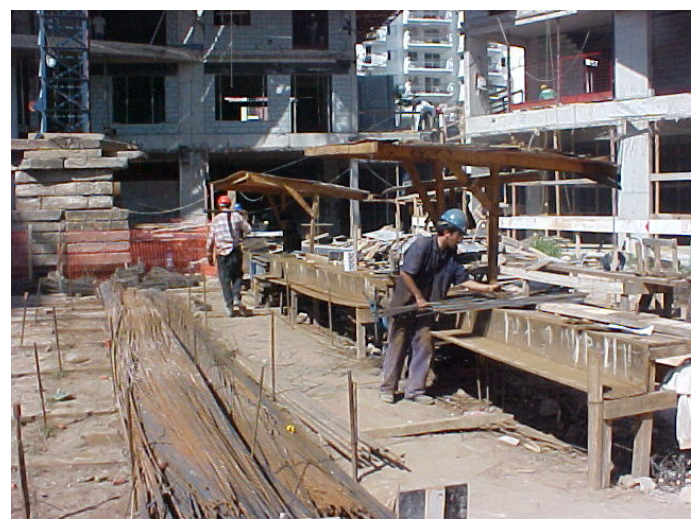

Figura 6.25 - Detalhe da disposição das bancadas de corte e dobra das barras

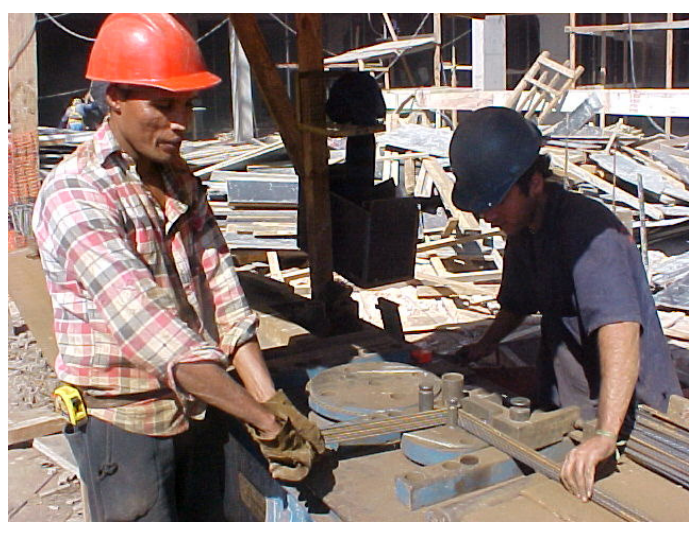

Figura 6.24 - Detalhe da operação de dobra das barras

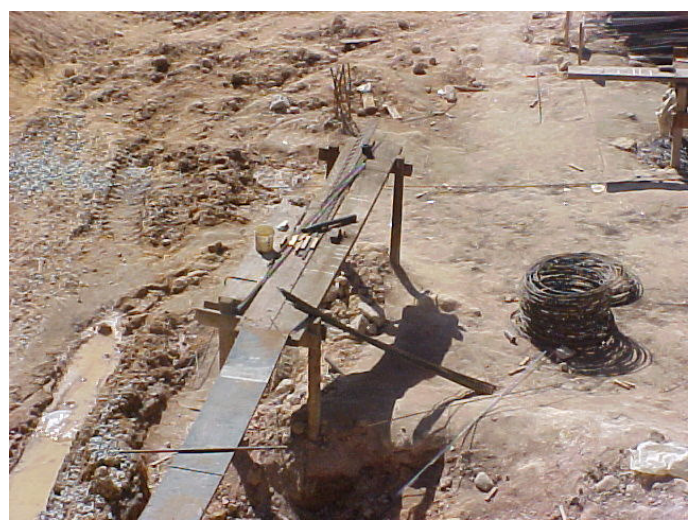

Figura 6.26 - Bancada de dobra auxiliar 


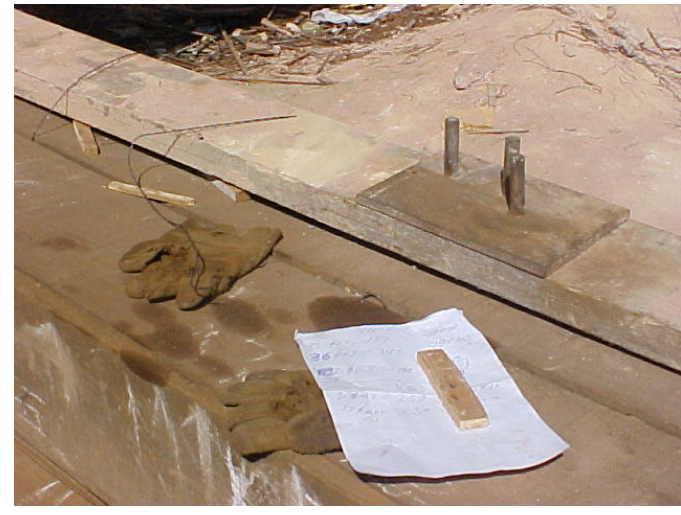

Figura 6.27 - Rascunho para corte e sobra sobre a bancada de dobra

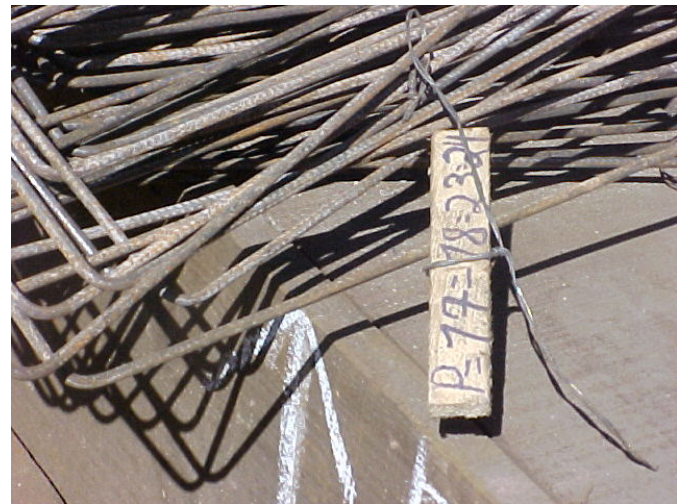

Figura 6.28 - Identificação das peças (de pilares) com plaquetas de madeira

A pré-montagem das armaduras tratou-se de uma prática constante na referida obra. A utilização da grua para o transporte das gaiolas, ao andar, permitiu que todos os pilares (incluindo os pilares de maiores dimensões, como os da caixa de escada e do elevador), fossem pré-montados.

O mesmo aconteceu com as armaduras das vigas, que também foram pré-montadas. Algumas delas, porém, foram complementadas no andar (após posicionadas nas fôrmas); a existência de pilares intermediários às vigas não permitia que todas as suas peças fossem previamente montadas.

A armadura negativa das lajes também foi pré-montada, constituindo "malhas" (Figura 6.29) que eram içadas pela grua e colocadas, definitivamente, em suas posições. Quando a "malha" da armadura negativa de um determinado trecho excedia as dimensões necessárias à segurança da operação de transporte, ela era pré-montada e, portanto, transportada em partes.

A operação de pré-montagem era realizada em espaços do canteiro próximos à central de armação. Esses locais não eram fixos e costumavam ser determinados em função da disponibilidade dos espaços a cada momento. Os armadores utilizavam "cavaletes" de madeira (Figura 6.30) para servir de apoio às armaduras.

A operação de montagem das armaduras dos pilares começou com o transporte das gaiolas para o pavimento de trabalho, com auxílio da grua e o seu posicionamento final. As gaiolas dos pilares menores eram dispostas na laje, sendo posteriormente transportadas e posicionadas, manualmente, nas fôrmas dos pilares correspondentes, (as fôrmas apresentavam três de suas faces já montadas, servido, portanto, de apoio e referência para o posicionamento das gaiolas). As gaiolas maiores (mais pesadas), dos pilares dos poços dos elevadores eram posicionadas nas fôrmas, geralmente, com o auxilio da grua. Os armadores, após o posicionamento das gaiolas, amarravam as barras longitudinais nos respectivos arranques, redistribuindo e amarrando os estribos na região inferior do pilar. 


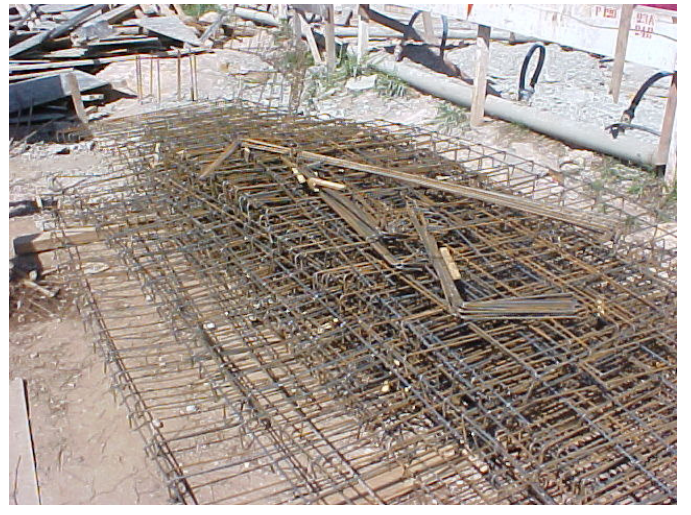

Figura 6.29 - Armadura negativa de laje pré-montadas

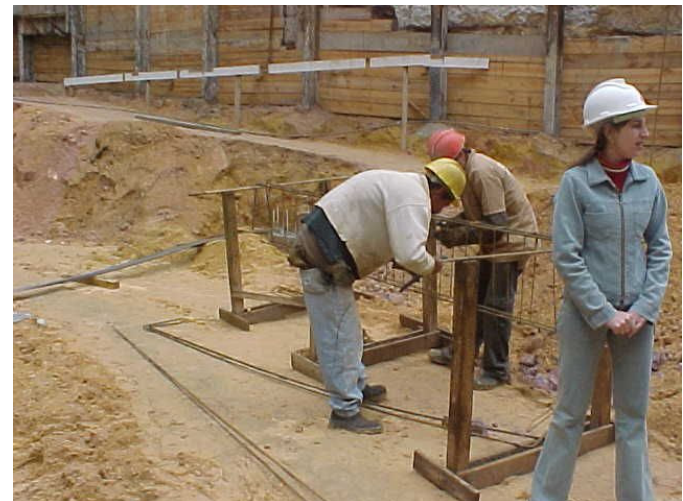

Figura 6.30 - Operação de pré-montagem

A montagem da armadura das vigas, em algumas situações, foi facilitada pela ausência de interferências intermediárias de outras vigas e/ou pilares. Nesses casos a operação de montagem consistiu apenas no transporte das gaiolas ao pavimento de trabalho e seu posicionamento nas fôrmas. As vigas secundárias da marquise foram pré-montadas, compondo uma gaiola única, como mostrado na Figura 6.31. Já a viga principal da marquise (que recebia a viga secundária) precisou ser montada totalmente no local definitivo devido a interferência de algumas peças da armadura negativa da laje. No entanto, algumas vigas que tiveram suas gaiolas segmentadas na pré-montagem (Figura 6.32) precisaram ser complementadas após posicionadas nas fôrmas. As peças faltantes foram distribuídas após a armadura estar posicionada e, então, amarradas a elas.

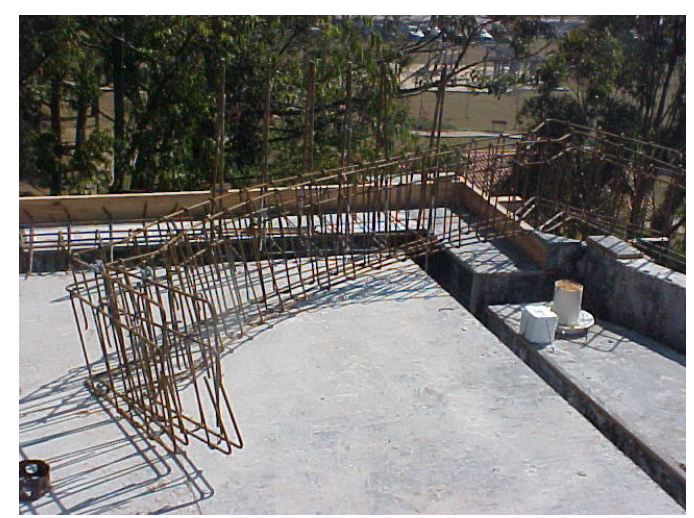

Figura 6.31 - Detalhe da armadura da viga da marquise pré-montada

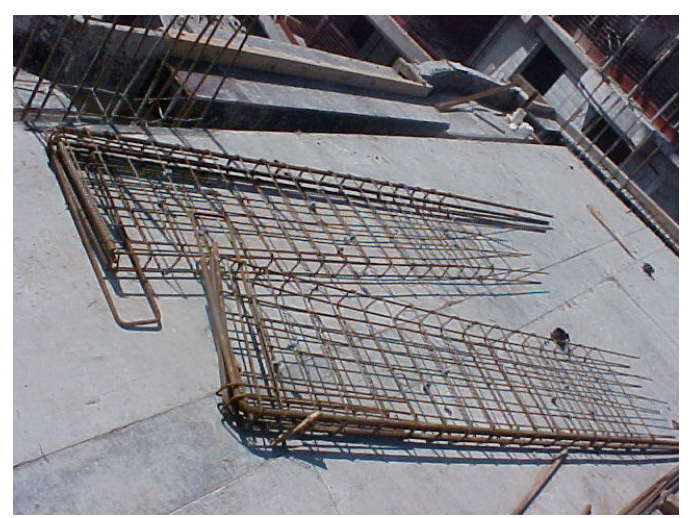

Figura 6.32 - Armaduras de uma viga pré-montada em dois segmentos

A montagem das armaduras das lajes foi feita de forma tradicional, em se tratando da armadura positiva (marcação de espaçamentos, distribuição, posicionamento das peças de uma direção seguidos das mesmas etapas na outra direção). Em se tratando das peças que exigiriam variações no comprimento (armadura positiva das marquises), o empreiteiro optou por cortá-las, na central de armação, com um único tamanho e 
adequá-las (cortar as barras de acordo com as variações exigidas e dobrar as pontas para a ancoragem) no próprio local.

A montagem da armadura negativa, iniciada após a colocação dos eletrodutos pela laje (a colcação dos eletrodutos era liberada após a amarração das peças positivas, como mostra a Figura 6.), era simplificada devido ao fato das armaduras terem sido prémontadas. A maior dificuldade desta operação estava em posicionar as peças negativas, ilustradas na Figura 6.33, que promoviam significativa interferência nas vigas das marquises. A manutenção da armadura negativa, na posição solicitada em projeto, era garantida por peças conhecidas como "caranguejos".

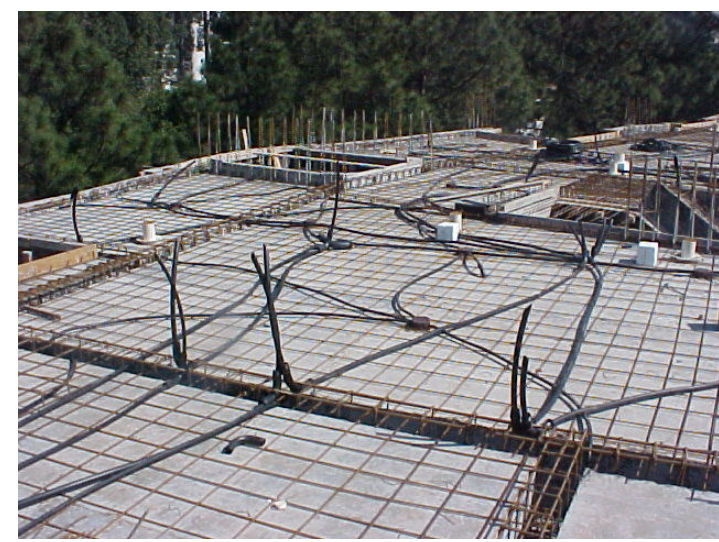

Figura 6.- Posicionamento dos eletrodutos após armadura positiva

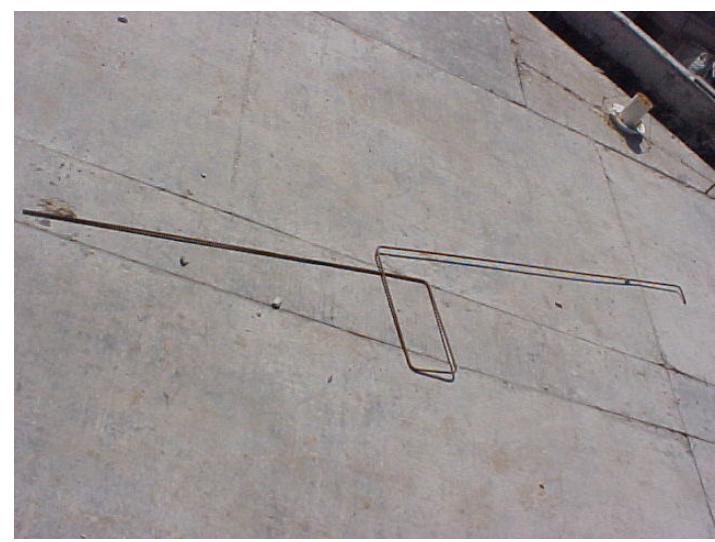

Figura 6.33 - Peças da armadura negativa de difícil montagem

\section{iv) Descrição da Organização do Trabalho}

A contratação do pessoal é feita no canteiro de obras pelo "administrativo" mantido pela empreiteira na obra. Porém, o mestre de obras costuma olhar a carteira de trabalho dos operários e entrevistar o candidato em seguida, procurando saber: i) as razões que o levaram a trabalhar e a se desligar dos trabalhos anteriores; ii) qual o seu conhecimento de obra na área que pretende trabalhar.

Quando um armador "não está servindo mais" aos propósitos do mestre de armação, ele comunica ao engenheiro da empreiteira, que entra em contato com o departamento pessoal, para, então, autorizar a demissão do operário.

Os armadores são contratados de acordo com o andamento do serviço e a experiência do mestre de armação que é quem dimensiona o número necessário para se fazer determinado serviço num dado período. "A gente tem uma boa noção...tem que ter um bom golpe de vista sobre isso aí. Porque o carpinteiro a gente dimensiona por $\mathrm{m}^{2}$ e ao armador não tem como a gente ver isso em $\mathrm{Kg}$. A gente sabe que o armador tem que produzir por dia (deixa montado pronto para a concretagem), no mínimo $350 \mathrm{Kg}$ de aço. E tem dias que ele produz muito mais que isso; é o caso de pilares, que são pesados e relativamente fáceis (o armador rende bem). O que não rende muito é laje, tanto a armação dos negativos como dos positivos. Os ferros são "finos" e o serviço é trabalhoso. 
Quando o encarregado precisa contratar mais armadores para realizar determinado serviço (casos em que há equipe formada, mas que se constata a necessidade de mais gente) ele se reporta ao engenheiro da empreiteira, pedindo autorização para a contratação, mediante justificativa. Quando os engenheiros da construtora solicitam à empreiteira a colocação de mais armadores, o mestre de armação analisa se há realmente necessidade. "Quem vai dizer se precisa mais armadores ou não, sou eu que estou fazendo o serviço quem vai dize. Eu já trabalhei em algumas obras em que os engenheiros fazem pressão, querem ver número. E o número de pessoas (quantidade) não faz o serviço. O que faz o serviço é o número exato de armadores e a boa distribuição/organização do pessoal. Para os render a gente tem que fazer uma peça pensando na outra que vem na seqüência. Eu não gosto que encarregado meu no canteiro de obras trabalhe. Encarregado que pega ferramenta não é encarregado. Enquanto o encarregado esta trabalhando com a ferramenta, o armador esta batendo papo com o outro ou fazendo o servi" (mestre de armação da empreiteira).

O mestre de armação é o responsável pela conferência do serviço. O encarregado é quem passa o trabalho aos armadores, é quem risca as peças indicando o correto espaçamento e distribuição, garantindo que as barras sejam amarradas no lugar correto.

O mestre de armação costuma colocar toda sua equipe para fazer a mesma tarefa ("se é para pré-montar pilar, coloco todos os armadores pré-montando; encerrada a montagem de pilares, coloco todo mundo fazendo a montagem das vigas; na seqüência, todos fazendo a armação positiva, depois negativa").

O mestre de armação estima (empiricamente) que se o aço fosse cortado e dobrado na obra, seriam necessárias duas máquina de dobra, uma de corte e um contingente de 10 armadores na bancada para "servir" de aço os demais armadores.

O mestre de armação tarefa os armadores por atividade realizada (montagem de pilares, vigas, laje positiva e laje negativa), isto é, as tarefas são "segmentadas", ao contrário, por exemplo, da tarefa dos carpinteiros, que é global (no mês precisam entregar um determinado número de lajes concretadas).

$\checkmark$ atratividade (\$) da Tarefa: calcula-se uma tarefa diária de 12 horas, em que será descontado as nove horas normais, restando 3 horas. Os armadores acabam recebendo, em média, 70 horas relativas às tarefas, no final do mês. Aos sábados, os armadores recebem uma tarefa de 8 horas;

$\checkmark$ formulação da Tarefa: o mestre de armação adota a prática de dar aos armadores uma quantidade de horas, além das horas normais, para que entreguem uma determinada parcela do serviço concluída no dia. Geralmente os armadores recebem três horas-extras. Não há nada pré-acordado, podendo o mestre retirar ou acrescentar as horas à medida que julgar necessário (quando sabe que o serviço "apertou", seja no prazo ou no volume, dá algumas horas para que os armadores cumpram o serviço no tempo desejado). O mestre de armação trabalha, na verdade com um limite mensal de horas-prêmio para dar aos armadores. Ele sabe que não pode ultrapassar as três horas-extras diárias. Se necessário, precisa justificar aos donos da empreiteira. Os armadores irão forçar pra que seja dado o máximo e os donos da empreiteira para que seja repassado o mínimo. Quando o serviço está adiantado, o mestre de armação pára a jornada de trabalho às cinco horas. Segundo o mestre de armação, os armadores não recebem "tarefa" neste dia. 
"Se o patrão me dá 100 horas para trabalhar (foras as horas normais (220 horas mensais)), eu não posso usar essas 100 horas de uma só vez. Eu tenho que trabalhar com 50 horas, ou seja, oferecer 50 horas e ir negociando as demais (se o serviço "apertar" eu tenho que ter da onde tirar algumas horas).

$\checkmark$ particularidades do serviço: a empreiteira precisa saber quanto cada armador precisa produzir para que ele se pague (o mínimo é algo em torno de $350 \mathrm{Kg}$ de aço por dia) e gere lucro à empresa. Para isso precisa apontar, com precisão quanto cada armador está produzindo.

"O mestre de armação na obra é o mestre que mais trabalha, sendo a armação o serviço mais difícil da obra ("o coração da obra é a armação"). O mestre de obras (fôrmas), via fazer um assoalho, coloca uma chapa e ela já cobre um bom espaço; já o mestre de armação tem que se preocupar com um monte de estribos, ganchinhos, que, conferir aquilo tudo, de perto; precisa estar sempre encima, orientando. E tem que ter muito mais conhecimento."

$\checkmark$ envolvimento do operário: não existe "clima ruim" entre os armadores. O Mestre de armação está constantemente observando a sua equipe e quando percebe que há alguém criando um "anticlima", adverte-o e, persistindo o problema demite o operário.

Todos os armadores (assim como os demais funcionários da empreiteira) possuem contas bancárias, que são abertas no dia em que eles fazem exame médico. Todo dia vinte do mês os armadores recebem as horas relativas à tarefa e parte do valetransporte (ambos depositado na conta bancária); no quinto dia do mês recebem o pagamento (horas normais) e restante do vale-transporte, também mediante depósito bancário. Recebem uma cesta básica mensal e não lhes é oferecida refeição na obra (trazem o almoço de casa).

É comum aos armadores, quando descontentes, queixarem-se de que, na execução da estrutura, apenas os carpinteiros é que "têm valor". Isso acontece, principalmente, nas obras em que a tarefa do armador é diferente da realizada pelo carpinteiro. Porém, na visão do mestre de obras, os carpinteiros trabalham muito mais que os armadores (participam ativamente da concretagem, o que não acontece com os armadores).

Não há problemas com atrasos de pagamentos aos operários pela empreiteira. Recentemente a empreiteira mudou de nome. Fechou uma firma e abriu outra. Segundo o mestre de armação, ela fez a rescisão de contrato de mais de 500 operários, pagando a todos (em parcelas), sem exceção.

Os conhecimentos básicos exigidos na profissão, segundo encarregado da empreiteira da obra SP 301 são: i) saber dar ponto muito bem; ii) saber dobrar aço na bancada, mesmo quando a obra trabalha com aço pré-cortada e dobrado. Não é necessário que o armador saiba ler projeto. "Se souber ler projeto o armador pode ajudar o encarregado do serviço e até mesmo melhorar um pouquinho sua produção, mas o armador não tem por obrigação saber ler projeto. Por outro lado, se cada armador souber ler projeto, isso pode atrapalhar a produção, isto é, se cada vez ele for consultar o projeto, ele vai acabar não produzindo tão bem assim (de minuto em minuto ele vai ter que olhar o projeto e se todo mundo fizer isso vai virar uma bagunça)."

O treinamento dado aos armadores que ingressam na obra (contratados pela empreiteira) é feito pelo mestre de armação de maneira informal (passa-lhes a maneira como o trabalho é conduzido na obra, a sistemática de trabalho do mestre de armação, o 
jeito que se deseja o serviço). Antes, porém, eles recebem um treinamento de segurança, ministrado por um técnico de segurança, que é reforçado no treinamento dado pelo mestre de armação.

"Armadores que chegam para trabalhar com torquês muito grande não bom sinal. Vai ter muito serviço que ele não vai conseguir fazer, como dar ponto dentro de viga. Armador que fica fazendo"malabarismo"com a torquês também não é bom sinal. Se ele esta "treinado" é porque fica a toa. Está mais para artista de circo do que para armador."

O mestre de armação começou a trabalhar com armação, em uma obra quando faltou um encarregado de armação. Então pediu ao mestre da obra para que o deixasse desempenhar a função (trabalhava como ajudante). Começou a ler projeto e se firmou na função. A partir daí passou a acompanhar o mestre em outras obras, como encarregado de armação. O mestre, ao perceber que ele lia projeto muito bem, passou a treiná-lo como encarregado de pedreiro também, "porque a armação, se é o primeiro serviço que entra na obra, é também o primeiro que sai". Assim, segurava-o na obra por mais tempo.

No caso da obra SP 301 a empreiteira foi contratada para fazer a estrutura. Possui na obra, um mestre de armação e dois encarregados. O mestre de armação é o responsável pela conferência do serviço.

É comum o empréstimo de armadores entre as obras em que a empreiteira trabalha. " $A$ empresa é uma só e se está precisando numa obra não é justo não emprestar, desde que o serviço esteja adiantado e os armadores estejam meio ociosos. Porém, é necessário que se faça uma programação antecipada (de uma a dois dias) entre as obras, para que sejam agendados os horários e meio de transporte, minimizando o tempo em que a mãode-obra ficará sem produzir, em razão de tempos de espera, locomoção etc".

"O melhor aço é aquele que você faz. Quando você faz, não falta. Eu fico irritado quando estou produzindo uma peça e chega na hora faltou uma posição ou uma posição veio errada. Porém, é preciso uma perfeita organização de que estiver coordenando o serviço, para que o aço cortado e dobrado na obra também não falte."

A programação do que será feito num determinado período é passada pela engenharia ao mestre de armação. Apresentam-se as datas em que serão concretados um conjunto de peças. A partir daí o mestre passa a trabalhar nessas peças para permitir que sejam concretadas no dia programado. Antes que se conclua esse serviço o mestre de armação procura a engenharia para saber o que será feito na seqüência (isso em caso de regiões periféricas). As programações passadas pela engenharia são sempre cumpridas no prazo pelos armadores. "Nesta obra, desde que comecei eu nunca falei para os engenheiros que não daria para executar um serviço num prazo estipulado por eles."

O dia mais crítico para os armadores, durante a execução de um pavimento tipo, é o dia de armação da laje ("tem que aprontar porque o concreto está com o dia marcado").

\subsection{Caracterização das demais obras no âmbito do processo de concepção e produção de armaduras}

A caracterização das demais obras (SP 302, SP 303, SP 304, SP 305, SP 306 e SP 307), apresentada a seguir, abordará os mesmo tópicos considerados pela obra SP 301: i) caracterização do empreendimento; ii) indicadores de caracterização do projeto do produto; iii) descrição do método de trabalho; iv) descrição da organização do trabalho, porém de maneira resumida. 


\subsection{Caracterização do projeto do produto}

A Tabela 6.11 traz os indicadores de caracterização dos projetos estruturais (ICP) de formas das obras contempladas na aplicação do método. As Tabela 6.12, Tabela 6.13 e Tabela 6.14 trazem os indicadores de caracterização dos projetos estruturais de detalhamento das armaduras, respectivamente, para pilares, vigas e lajes. Vale ressaltar que os indicadores de caracterização permitem que se tenha uma visão analítica do projeto, que poderá fundamentar e dar maior sustentação a análises comparativas entre projetos. Lembra que, a partir desses indicadores, foram determinados os fatores de conteúdo. 
Tabela 6.11 - ICP de formas

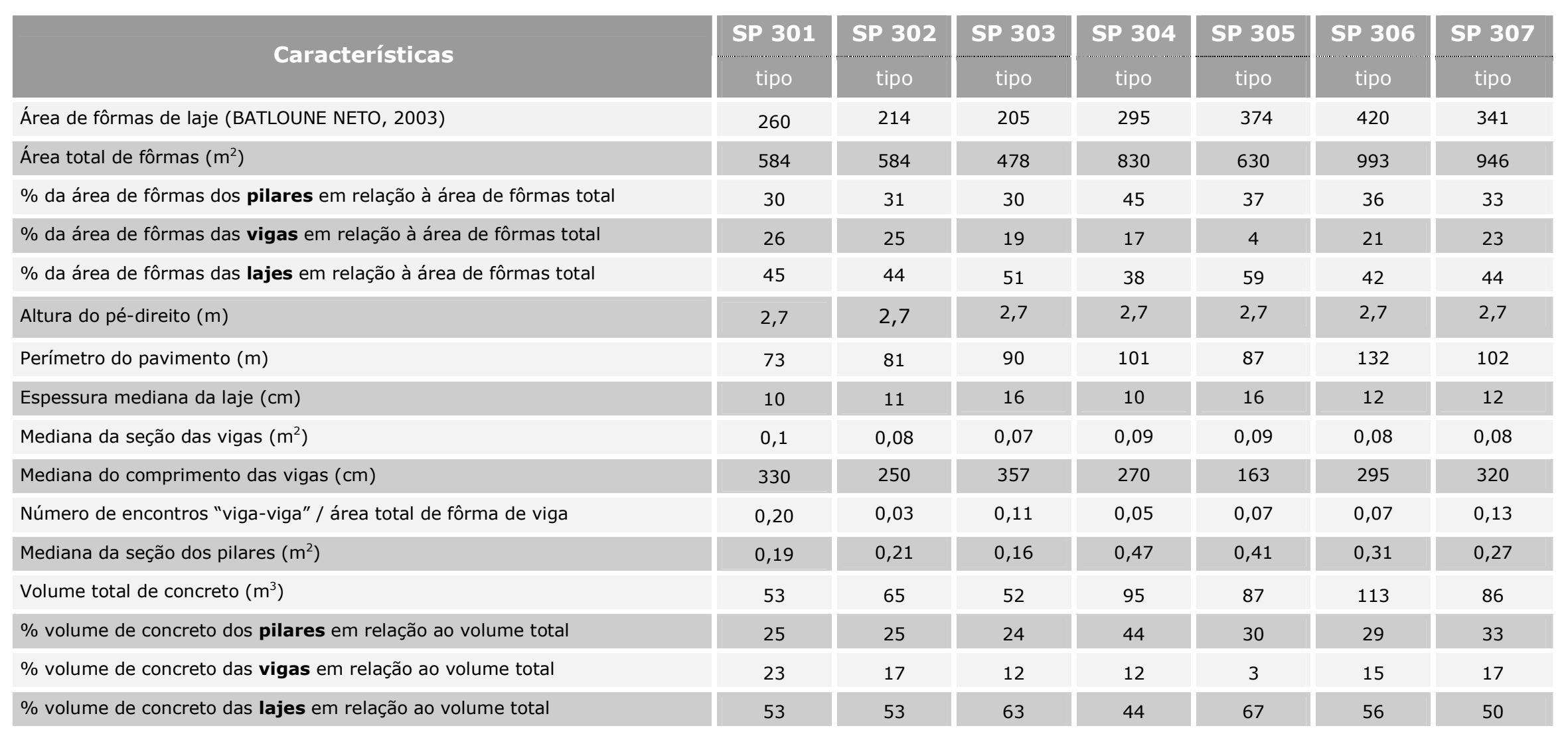


Tabela 6.12 - ICP de detalhamento de armaduras - pilares

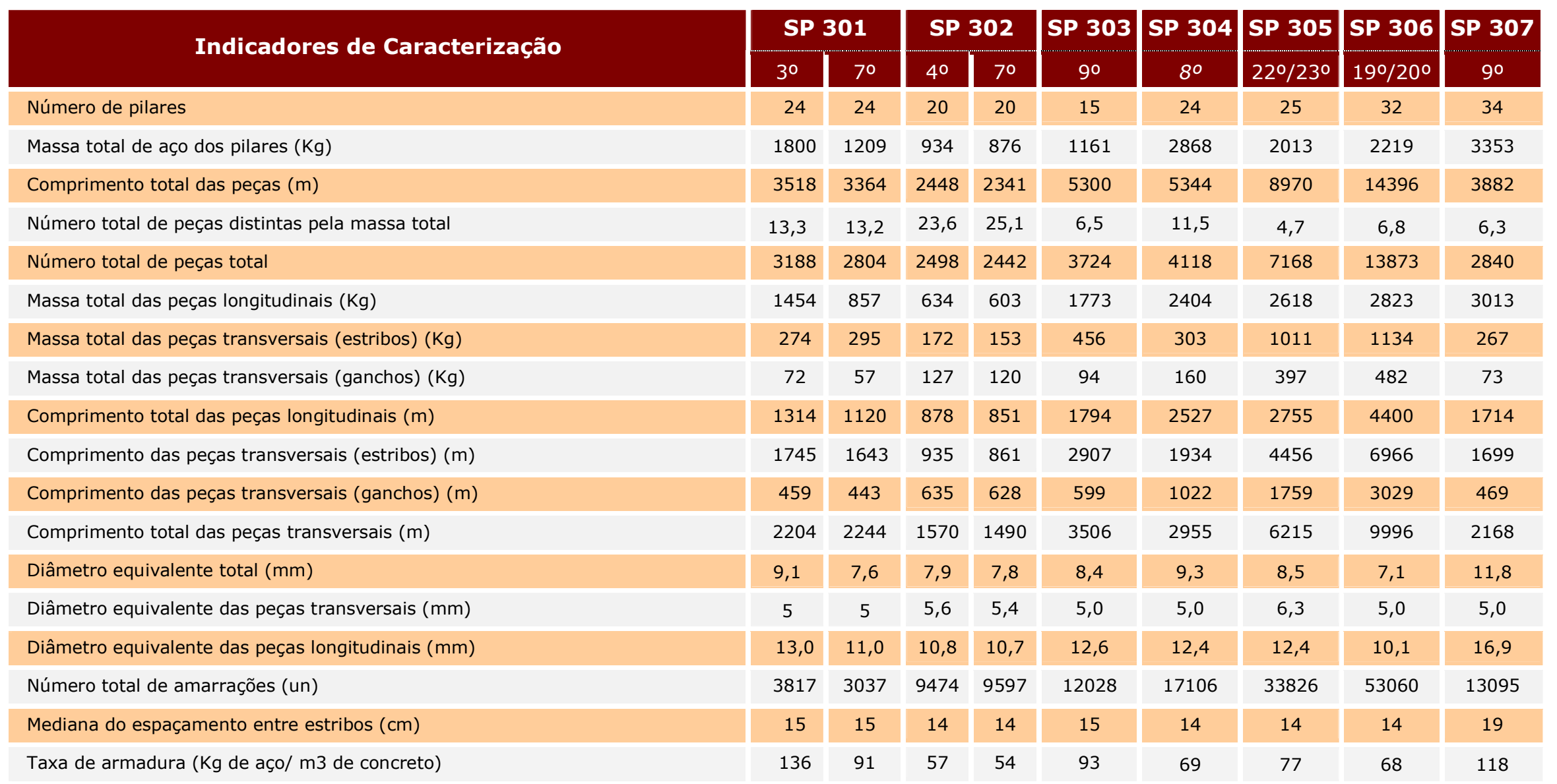


Tabela 6.13 - ICP de detalhamento de armaduras - vigas

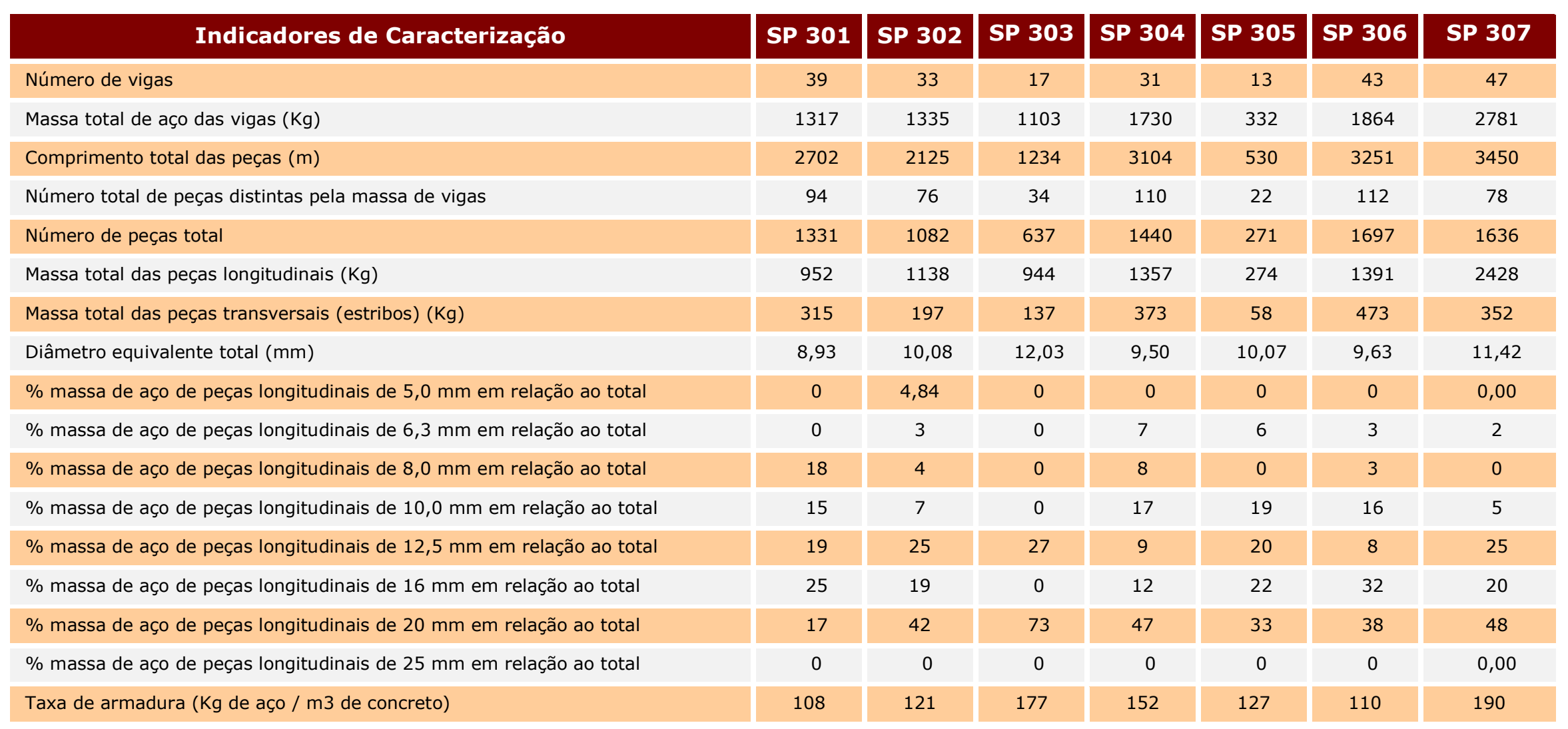


Tabela 6.14 - ICP de detalhamento de armaduras - lajes

\begin{tabular}{|c|c|c|c|c|c|c|c|}
\hline Indicadores de Caracterização & SP 301 & SP 302 & SP 303 & SP 304 & SP 305 & SP 306 & SP 307 \\
\hline Massa total de aço das lajes $(\mathrm{Kg})$ & 3843 & 2330 & 1773 & 3592 & 2255 & 4845 & 2044 \\
\hline Número total de peças & 1209 & 1971 & 1201 & 2783 & 757 * & 5127 & 1714 \\
\hline Massa total de aço das lajes negativas $(\mathrm{Kg})$ & 773 & 1024 & 1460 & 1559 & 1492 & 2302 & 1413 \\
\hline Comprimento total das peças $(\mathrm{m})$ & 9298 & 6728 & 2993 & 9641 & $1836 *$ & 16664 & 6189 \\
\hline Diâmetro equivalente total $(\mathrm{mm})$ & 8,2 & 7,5 & 9,8 & 7,8 & $11,5 *$ & 6,86 & 7,31 \\
\hline Diâmetro equivalente da armadura positiva (mm) & 8,3 & 6,7 & 7,1 & 7,1 & - & 6,51 & 8,76 \\
\hline Diâmetro equivalente da armadura negativa ( $\mathrm{mm}$ ) & 7,7 & 9,1 & 10,9 & 8,9 & 11,5 & 7,32 & 6,86 \\
\hline Número peças positivas distintas & 56 & 45 & 11 & 64 & - & - & 7 \\
\hline Número peças negativas distintas & 35 & 43 & 27 & 46 & 46 & & 38 \\
\hline \% massa de aço de peças longitudinais de $10,0 \mathrm{~mm}$ em relação ao total & 68,7 & 11 & 0 & 17 & $19 *$ & 13 & 18 \\
\hline \% massa de aço de peças longitudinais de $12,5 \mathrm{~mm}$ em relação ao total & - & 17 & 51 & 19 & $74 *$ & 3 & 0 \\
\hline Taxa de armadura ( $\mathrm{Kg}$ de aço / $\mathrm{m} 3$ de concreto) & 137 & 68 & 54 & 86 & $39 * *$ & 77 & 48 \\
\hline
\end{tabular}




\subsection{Caracterização dos empreendimentos, descrição do método e da organização do trabalho}

Apresenta-se, a seguir, para cada uma das obras contempladas no trabalho (com exceção da SP 301), algumas características relativas, basicamente, ao método de trabalho e a aspectos relacionados à organização do trabalho, ambos, no âmbito do processo de produção de armaduras.

A Tabela 6.15 traz uma descrição resumida da obra SP 302, apresentando alguns aspectos do método e da organização do trabalho adotados. Vale ressaltar que foi a única obra da empresa em que se trabalhou com o aço pré-cortado/dobrado ${ }^{131}$.

Tabela 6.15 (continua) - Caracterização da obra SP 302 e do seu PCPA

\begin{tabular}{|c|c|}
\hline Características & Descrição \\
\hline Uso da edificação & Residencial \\
\hline $\begin{array}{l}\text { Descrição do } \\
\text { Empreendimento }\end{array}$ & $\begin{array}{l}\text { Empreendimento composto por } 5 \text { torres construídas simultaneamente. } \\
\text { Tratavam de edifícios multipavimentos composto por } 2 \text { subsolos, pavimento } \\
\text { térreo (interligando as cinco torres), } 1^{\circ} \text { andar, } 10 \text { pavimentos tipo (do } 2^{\circ} \text { ao } \\
11^{\circ} \text { andar), } 11^{\circ} \text { pavimento (cobertura) + pavimentos de serviço. }\end{array}$ \\
\hline $\begin{array}{l}\text { Tipologia estrutural e } \\
\text { tecnologia construtiva }\end{array}$ & $\begin{array}{l}\text { Trata-se de uma estrutura reticulada de concreto armado. A tecnologia para } \\
\text { execução destas estruturas é aquela tradicional, descrita por FREIRE (2000), } \\
\text { com fôrmas com moldes em chapas de compensado e estruturação dos } \\
\text { painéis em madeira serrada; cimbramento de vigas com garfos de madeira e } \\
\text { de lajes (escoras e torres) com elementos metálicos. }\end{array}$ \\
\hline Quantidade aço/pav tipo & $\cong 5$ toneladas (referente ao $3^{\circ}$ pavimento) \\
\hline Porção da obra analisada & Pavimentos tipo $\left(2^{\circ}\right.$ ao $\left.9^{\circ}\right)$ da Torre " $2^{\prime \prime}$. \\
\hline Fornecimento do aço & $\begin{array}{l}\text { Aço fornecido cortado e dobrado; telas soldadas usadas até a laje do } \\
\text { pavimento térreo (nos demais, armação convencional). }\end{array}$ \\
\hline Empresa de corte e dobra & Armafer \\
\hline $\begin{array}{l}\text { Sistema de } \\
\text { descarregamento do aço }\end{array}$ & $\begin{array}{l}\text { Descarregamento manual do caminhão (12 ton), posicionado dentro } \\
\text { do canteiro de obras (Figura } 6.34 \text { e Figura } 6.35 \text { ) }\end{array}$ \\
\hline Armazenamento do aço & $\begin{array}{l}\text { No } 20 \text { subsolo (projeção das torres) e nos recuos do terreno (Figura } \\
6.36 \text { ) }\end{array}$ \\
\hline
\end{tabular}

131 O engenheiro da obra alegou que buscou agilidade ao optar pelo aço cortado e dobrado. "Como teria uma equipe que ficaria rodando a obra, se tivesse apenas uma equipe para ficar cortando e dobrando seria difícil atender a demanda, sendo necessário colocar muitos armadores nesta operação. Então eu negocie com empreiteiro, propondo que trabalharia com o aço cortado e dobrado em troca de uma otimização de mão-de-obra (cujo reflexo deveria aparecer através de redução dos valores pelo qual o serviço seria contratado, bem como por conta da "perda zero"). Porém, hoje eu percebi que a perda não é zero, se perde mais aço do que se fosse cortado e dobrado na obra. Tem sobrado aço na obra após a concretagem das lajes, principalmente em função das dificuldades de gerenciar os estoques de aço ( muitos prédios, há vários locais de estocagem e as áreas de armazenamento são muito grandes. Em função disso, hoje eu prefiro o aço cortado e dobrado na obra". 
Tabela 6.17 (conclusão) - Caracterização da obra SP 302 e do seu PCPA

\section{Características}

Sistema de transporte vertical do aço

Pré-montagem
(limitada pelo sistema
de transporte)

Montagem

Aspectos organizacionais
As armaduras foram transportadas manualmente, com o auxílio de cordas (Figura 6.37) e através de "caronas" no elevador de cremalheira da torre vizinha (Figura 6.38)

Feita no pavimento térreo da torre "vizinha" e/ou no subsolo e 10 pavimento do bloco estudado (bloco 2) após retirada de escoramento (Figura 6.39). Algumas peças mais pesadas (pilares e vigas) eram pré-montadas na própria laje, após cura do concreto (subia-se as posições ao invés de subir com armaduras prontas: limitação imposta pelo sistema de transporte (corda)).

Para a montagem da armadura da laje (positivo e negativo) consumia-se um dia e meio, com os 10 armadores envolvidos na operação (Figura 6.40 e Figura 6.41). Entre subir as armaduras das vigas e terminar de armar a laje (o aço subia na corda ou com a ajuda do elevador do prédio vizinho), gastava-se, em média, 2,5 dias. "Se uma grua fosse disponibilizada, seriam necessários 1,5 dias. Se gasta um dia para armar os pilares (pré-montar e posicionar). Um dia para se pré-montar as vigas. As vigas são mais complicadas para transportar por conta das maiores dimensões".

Serviço subcontratado pela construtora. Encarregado, da empresa subcontratada, exclusivo para o serviço (coordena o serviço de armação em duas torres (blocos 2 e 3 ).

Equipe composta por 10 armadores (que trabalham na armação das torres 2 e 3). Todos os dias os armadores trabalham até às $18 \mathrm{~h}$ (estando ou não na tarefa). Remuneração: foram dadas 10 horas por laje, somadas às horas extras que forem feitas. As horas-extras são combinadas antes. No inicio do dia o encarregado combina um determinado serviço valendo até um horário. Os armadores "colocam no bolso" um valor que varia de 600,00 a 750,00 reais mensais.

"Normalmente é o encarregado quem tem que decidir o que deve ser feito com a equipe. Mas o encarregado trabalha para o empreiteiro, que não aceita o que 0 encarregado faz, então, praticamente, a gente não tem força nenhuma para resolver isso."

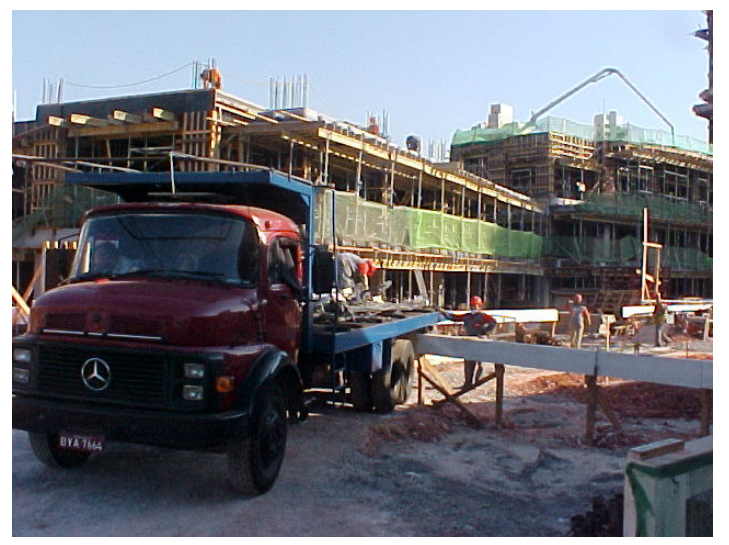

Figura 6.34 - Caminhão posicionado no canteiro para descarregamento do aço

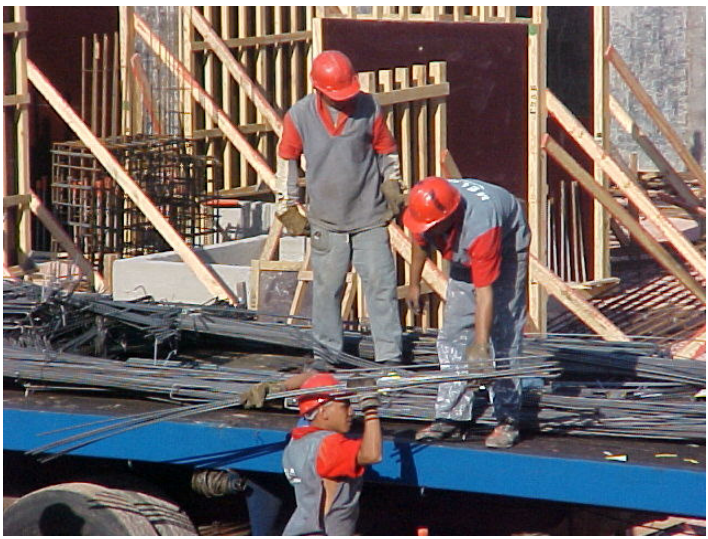

Figura 6.35 - Descarregamento manual do aço beneficiado 

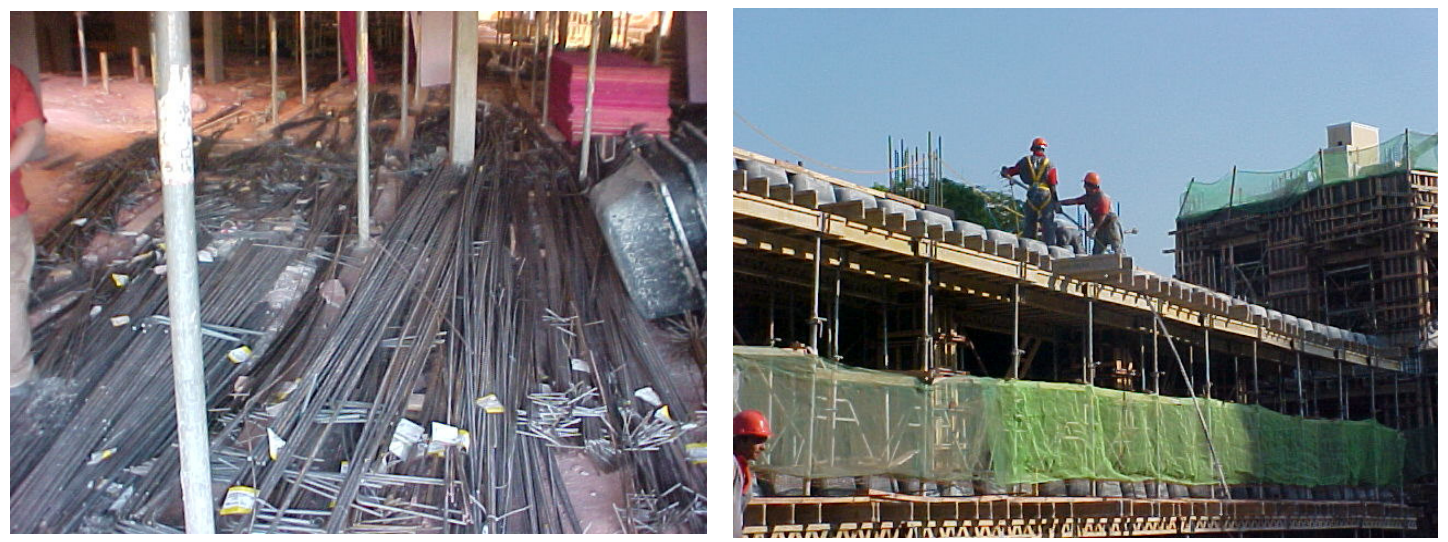

Figura 6.36 - Um dos locais de estoque do aço na obra: $2^{\circ}$ subsolo

Figura 6.37 - Transporte vertical das barras (manual com corda)
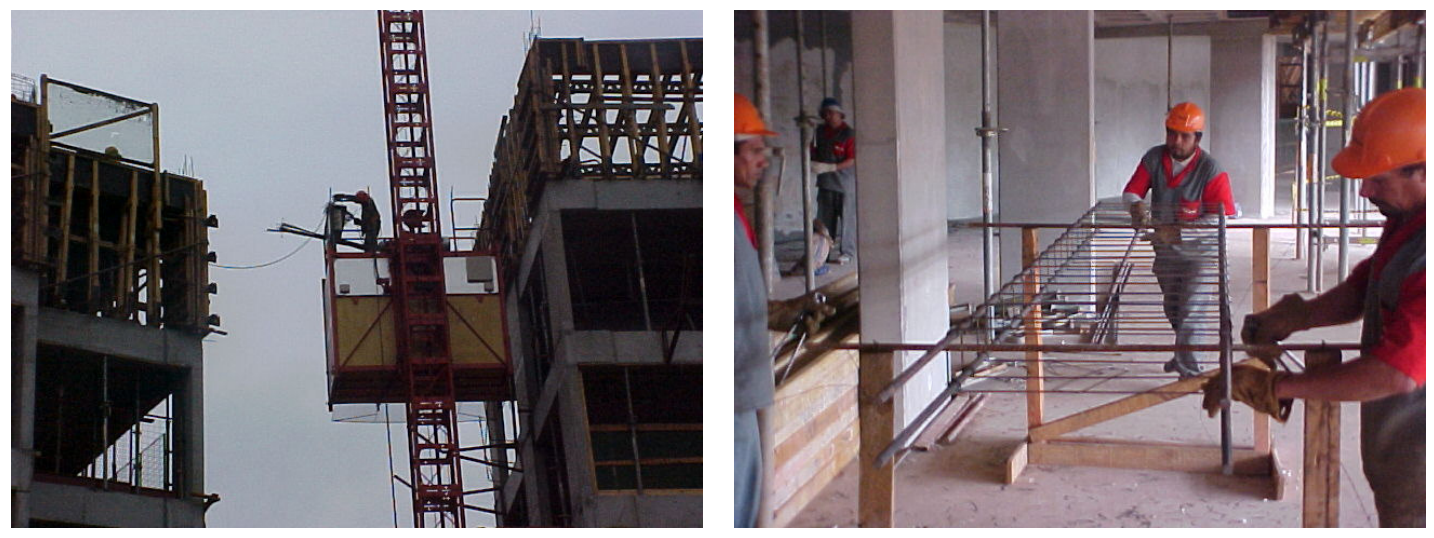

Figura 6.38 - Transporte vertical do aço com elevador da torre vizinha

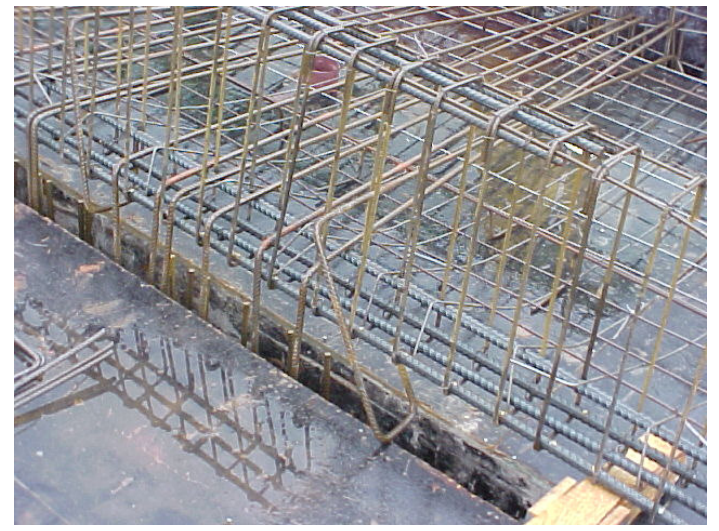

Figura 6.39 - Pré-montagem de pilares no pavimento térreo

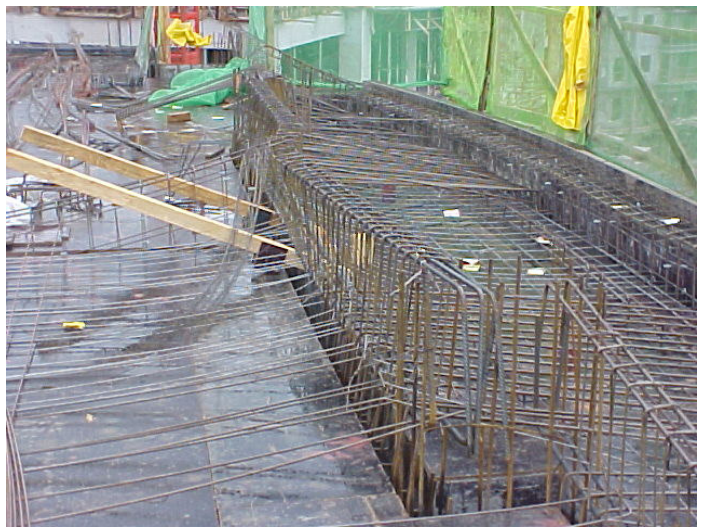

Figura 6.40 - Detalhe da montagem de da armadura da marquise

Figura 6.41 - Detalhe da montagem de viga entre laje da sala e varanda

A Figura 6.42 ilustra a planta de formas referente ao pavimento tipo da obra SP 302. 


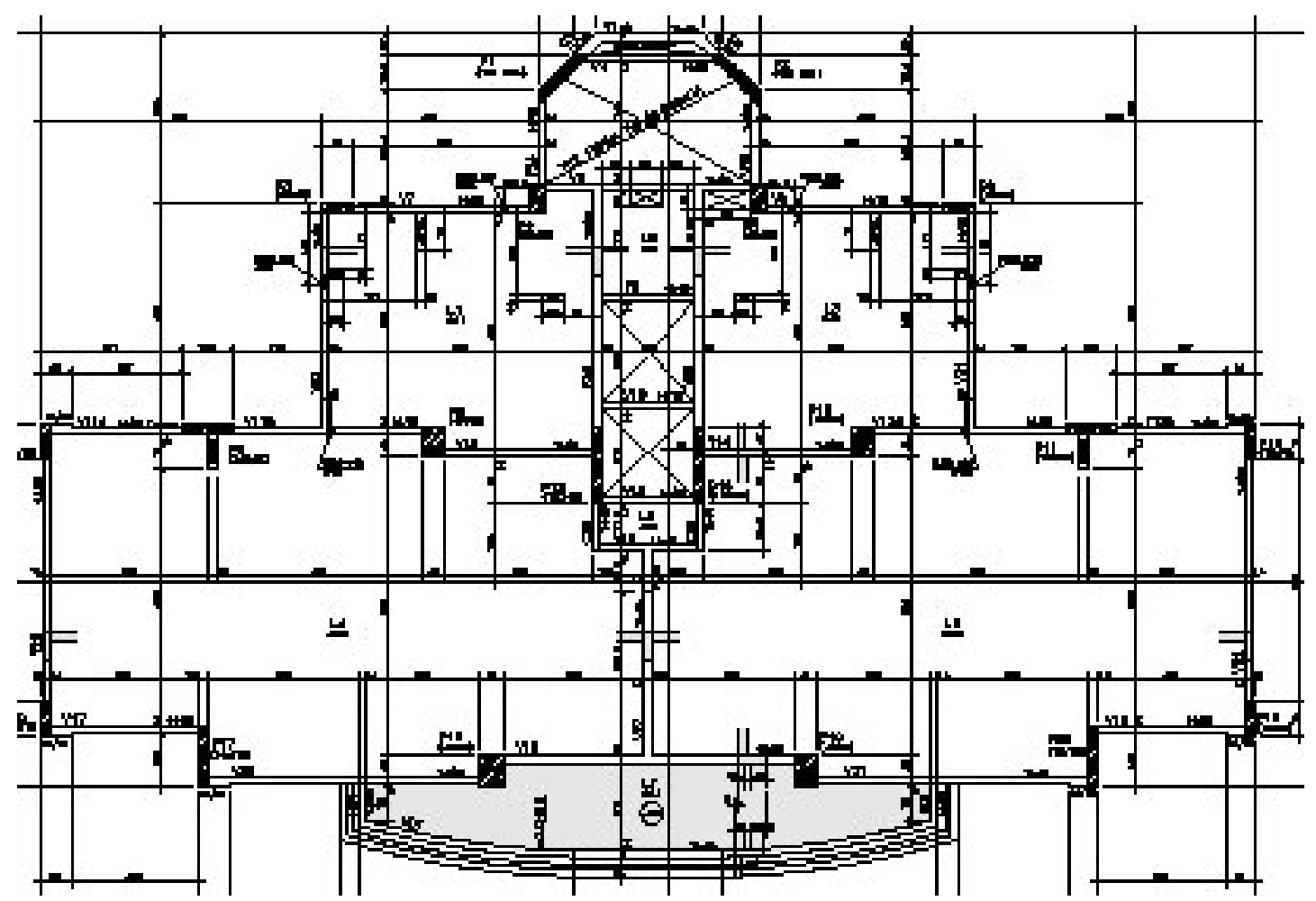

Figura 6.42 - Planta de forma referente ao pavimento tipo da OBRA SP 302

A Tabela 6.16 traz uma descrição resumida da obra SP 303, apresentando alguns aspectos do método e da organização do trabalho adotados no âmbito do processo de produção das armaduras.

Tabela 6.16 (continua) - Caracterização da Obra SP 303 e do seu PCPA

\begin{tabular}{l|l|l|}
\multicolumn{1}{|c|}{ Características } & \multicolumn{1}{c|}{ Descrição } \\
\hline Uso da edificação & Residencial \\
\hline $\begin{array}{l}\text { Descrição } \\
\text { Empreendimento }\end{array}$ & $\begin{array}{l}\text { do } \\
\text { Empreendimento de } 1 \text { torre composta por } 2 \text { subsolos, pavimento térreo, } 25 \\
\text { pavimentos tipo (do } 10 \text { ao } 250 \text { andar) + pavimentos de serviço. }\end{array}$ \\
\hline $\begin{array}{l}\text { Tipologia estrutural } \\
\text { tecnologia construtiva }\end{array}$ & $\begin{array}{l}\text { Trata-se de uma estrutura reticulada de concreto armado. A tecnologia para } \\
\text { execução destas estruturas é a tradicional, descrita por FREIRE (2000), com } \\
\text { fôrmas com moldes em chapas de compensado e estruturação dos painéis em } \\
\text { madeira serrada; cimbramento de vigas com garfos de madeira e de lajes } \\
\text { (escoras) com elementos metálicos. }\end{array}$ \\
\hline $\begin{array}{l}\text { Quantidade aço/pav tipo } \\
\text { Porção da obra analisada }\end{array}$ & $\cong 4.900 \mathrm{Kg}$ (referente ao 170 pavimento) \\
\hline Fornecimento do aço & Pavimentos tipo (100 ao $19^{\circ}$ ). \\
\hline
\end{tabular}


Tabela 6.14 (conclusão) - Caracterização da Obra SP 303 e do seu PCPA

\begin{tabular}{|c|c|}
\hline Características & Descrição \\
\hline $\begin{array}{l}\text { Sistema de } \\
\text { descarregamento do aço }\end{array}$ & $\begin{array}{l}\text { Descarregamento manual do caminhão, posicionado dentro do canteiro de } \\
\text { obras. }\end{array}$ \\
\hline Armazenamento do aço & $\begin{array}{l}\text { O armazenamento do aço era feito em baias (Figura } 6.43 \text { ), no nível do } 1^{\circ} \\
\text { subsolo, porém numa região onde a carreta de transporte tinha acesso. }\end{array}$ \\
\hline $\begin{array}{l}\text { Sistema de transporte } \\
\text { vertical do aço }\end{array}$ & $\begin{array}{l}\text { As armaduras foram transportadas pelo elevador de cremalheira (as } \\
\text { armaduras de pilares e vigas eram presas externamente à cabine do } \\
\text { elevador; peças da armadura das lajes com menos de } 1,5 \mathrm{~m} \text { eram levadas no } \\
\text { interior da cabine). }\end{array}$ \\
\hline Corte e dobra & $\begin{array}{l}\text { Corte das barras com serra policorte e dobra, manual, em bancadas de pinos } \\
\text { (Figura } 6.44 \text { e Figura 6.45). Segundo o engenheiro residente "as máquinas } \\
\text { de corte hidráulicas, apesar de serem mais produtivas, não foram } \\
\text { viabilizadas em função da quantidade (Kg)de aço trabalhado na obra em } \\
\text { questão. Seria necessário do dobro da quantidade de aço cortada para } \\
\text { viabilizá-la". }\end{array}$ \\
\hline Pré-montagem & $\begin{array}{l}\text { Houve pré-montagem das peças, que ficavam estocadas no subsolo (Figura } \\
6.46 \text { ) até o momento de subirem para a laje onde seriam montadas. }\end{array}$ \\
\hline Aspectos organizacionais & $\begin{array}{l}\text { Serviço subcontratado pela construtora. Presença de encarregado da } \\
\text { construtora, que não era exclusivo para o serviço (coordena o serviço de } \\
\text { armação e fôrmas). } \\
\text { Presença de encarregado exclusivo da empreiteira. } \\
\text { Equipe composta por } 6 \text { armadores (sendo que } 1 \text { era o encarregado). } \\
\text { Remuneração: a forma de remuneração é por kg; a empreiteira de estrutura } \\
\text { paga o valor de } \mathrm{R} \$ 0,25 / \mathrm{kg} \text { para a subcontratada de armação mais o vale } \\
\text { refeição e vale transporte dos operários da subcontratada. Os armadores } \\
\text { eram tarefados ( } \$ 50,00 \text { por laje por armador). No mês eram feitas, em } \\
\text { média quatro (o que levava os armadores a receberem } \mathrm{R} \$ 200,00 \text { por mês } \\
\text { de tarefa). Somada as horas normais, garantia ao armador um salário de } \\
\text { aproximadamente } \mathrm{R} \$ 800,00 \text { reais mensais. } \\
\text { A quantidade de armadores }{ }^{132} \text { era determinada de forma empírica, } \\
\text { considerando-se alguns fatores como, por exemplo, o número de posições da } \\
\text { laje (o que poderia levar a uma menor ou maior quantidade de armadores } \\
\text { para cortarem ou dobrarem as posições). }\end{array}$ \\
\hline
\end{tabular}

132 Depoimento do encarregado de armação da obra SP 303 sobre seu ofício: "Os armadores tem orgulho de serem armadores. Aqui nesta obra todo serviço difícil fica fácil. Porque o engenheiro sobe na obra e explica. Eu gosto de trabalhar onde as pessoas entendem e explicam. Agora tem um engenheiros aí que são "cancela vermelha". Desejo do encarregado em continuar na obra (contentamento com o trabalho), pedindo ao dono da empreiteira que comece logo os demais prédios. "É importante a valorização e o respeito de cada armador, de cada operário, porque cada um está defendendo o ser pão de cada dia. Não interessa se é o engenheiro ou o ajudante, somos todos uma só equipe, uma família. Nós não estamos aqui por vicio, estamos aqui por que precisamos. Alem de precisar, é preciso gostar do que faz. Eu sou encarregado de armação há mais de 20 anos. Se eu não gostasse da minha profissão, o que estaria fazendo aqui? Eu talvez estivesse tomando o lugar de uma pessoa que está com vontade de trabalhar e podia estar desempregado. Eu sempre converso com os meninos no sentido de trabalharmos direitinho e não sermos chamado a atenção; vamos respeitar para ser respeitados. Aqui todo mundo trabalha num clima de amizade total. Eu uma vez falei para o Doutor: eu não vim aqui para arrumar problema, eu vim para fazer o serviço." 


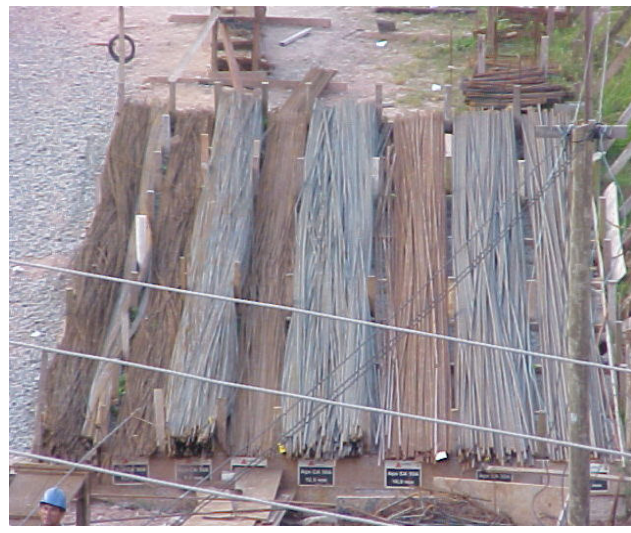

Figura 6.43 - Local de estocagem do aço

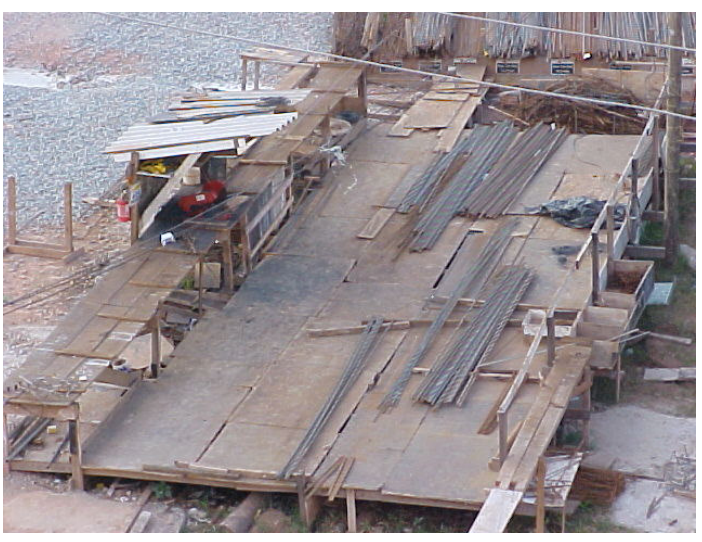

Figura 6.45 - Local da estocagem

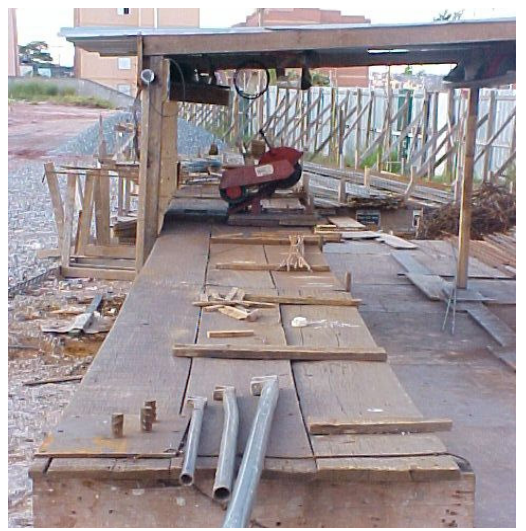

Figura 6.44 - Bancada de corte (fundo) e dobra (frente).

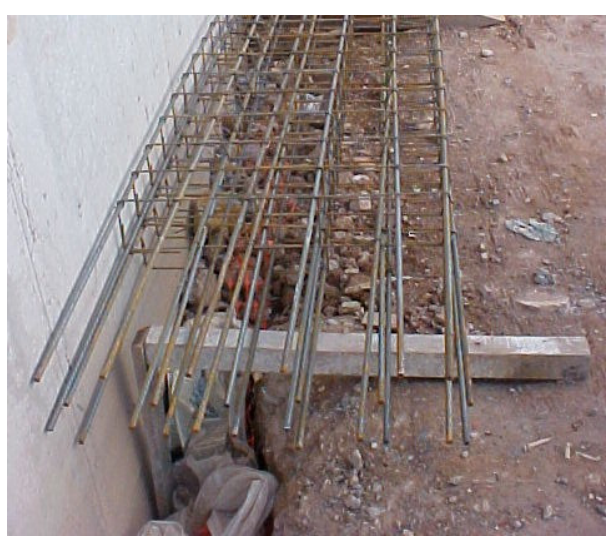

Figura 6.46 - Armaduras pré-montadas de pilares

A Figura 6.47 ilustra a planta de formas referente ao pavimento tipo da obra SP 303. 


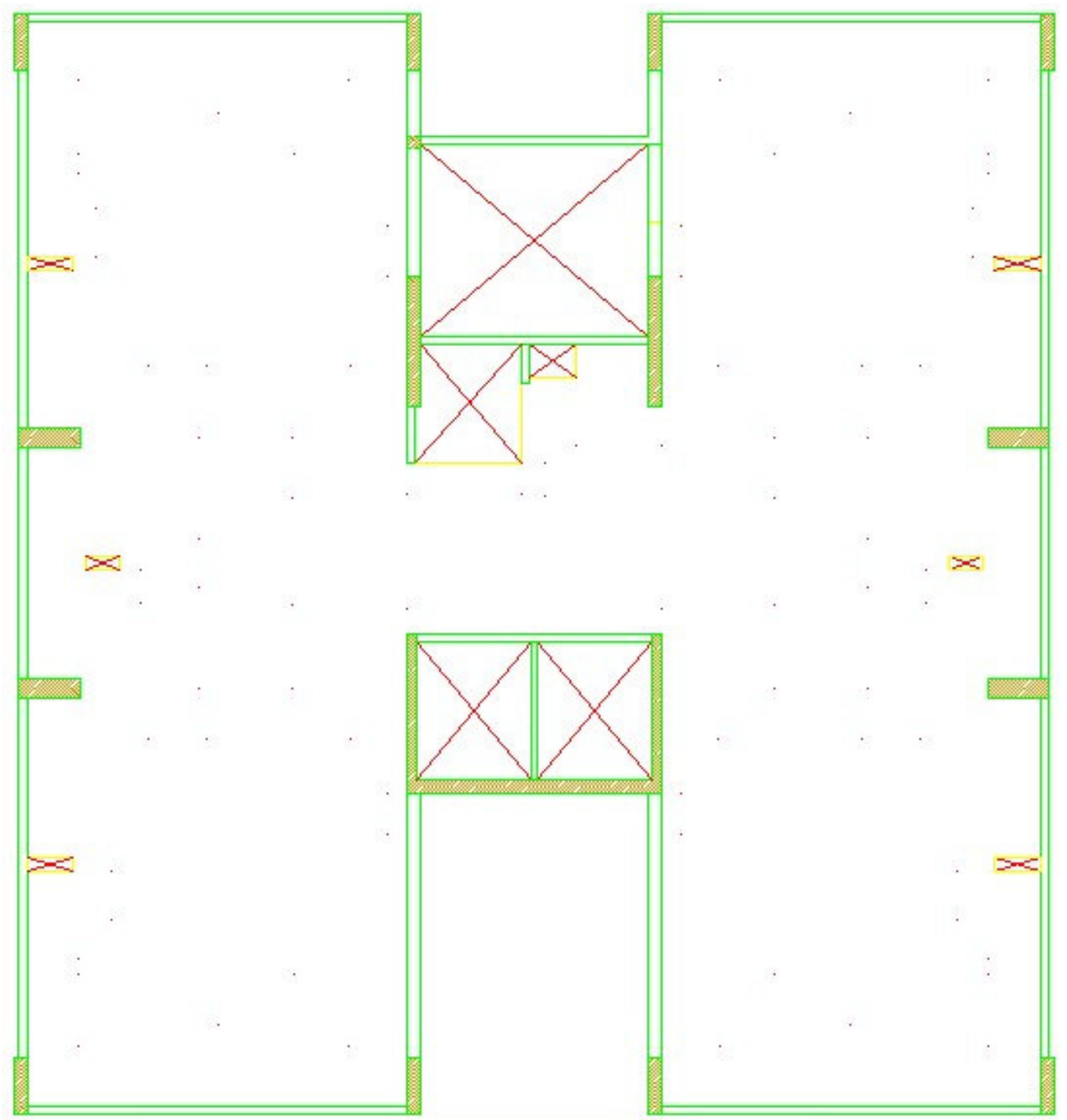

Figura 6.47 - Planta de forma referente ao pavimento tipo da obra SP 303

A Tabela 6.17 traz uma descrição resumida da obra SP 304, apresentando alguns aspectos do método e da organização do trabalho adotados no âmbito do processo de produção das armaduras. 
Tabela 6.17 (continua) - Caracterização da obra SP 304 e do seu PCPA

\begin{tabular}{l} 
Características \\
Uso da edificação \\
Descrição do Empreendimento \\
Tipologia estrutural e \\
tecnologia construtiva \\
\hline Quantidade aço/pav tipo \\
Fornecimento do aço \\
Corte e dobra \\
\hline Sistema de descarregamento \\
do aço
\end{tabular}

Armazenamento do aço

Pré-montagem

Sistema de transporte vertical do aço

Montagem

Descrição

Empreendimento composto por 2 torres com 2 subsolos, pavimento térreo, $1^{\circ}$ pavimento, 26 pavimentos tipo (do $2^{\circ}$ ao $27^{\circ}$ andar) + cobertura + pavimentos de serviço.

Trata-se de uma estrutura reticulada de concreto armado. A tecnologia para execução destas estruturas é a tradicional, descrita por FREIRE (2000), com fôrmas com moldes em chapas de compensado e estruturação dos painéis em madeira serrada; cimbramento de vigas com garfos de madeira e de lajes (escoras e torres) com elementos metálicos.

$\cong 7.300 \mathrm{Kg}$ (referente ao $20^{\circ}$ pavimento)

Aço fornecido em barras de $12 \mathrm{~m}$

Realizado pela subempreiteira no canteiro de obras (equipamentos locados pela subempreiteira: 01 máquina hidráulica de corte +01 policorte; 01 máquina hidráulica de dobra (Figura 6.48))

Descarregamento manual das carretas (25 ton) e/ou com o auxílio da grua quando ela não estava ocupada.

O aço era previamente estocado num local próximo onde a carreta se posicionava. Em seguida era transportado manualmente para a baia de estocagem (distante aproximadamente $80 \mathrm{~m}$ da região de estoque provisório).

Feita na região do subsolo (Figura 6.50), na projeção de ambas as torres (todas as vigas e pilares eram pré-montados), a partir de feixes com peças confeccionadas (cortadas e dobradas) e identificadas (Figura 6.49).

O aço (armaduras) era transportado pela grua (Figura 6.51) até o andar em que seria utilizado. O encarregado disse não aconselhar o uso da "mini-grua" para o transporte do aço ("o pessoal se esforça muito e não faz quase nada; além do guincho ser lento, quando chega no final são necessários, no mínimo, quatro armadores para puxar o aço para o interior da torre; é muito perigoso para o armador". Esses quatro armadores ficam o dia inteiro só transportando o aço").

"Quanto ao elevador cremalheira para o transporte de aço, apresenta dificuldades semelhantes àquelas relacionada à mini-grua. Há situações em que os elevadores cremalheiras não chegam até a laje em execução; param no andar inferior embaixo, tendo que se transportar o aço para cima manualmente (é trabalhoso, com a passagem feita com o uso de corda)".

Para a montagem das armaduras das lajes (Figura 6.52), costumava-se alocar de 12 a 14 armadores (eventualmente, quando a pré-montagem de pilares já havia sido adiantada, o encarregado disponibilizava 18 armadores na laje; nesse dia, o serviço se iniciava às $8 \mathrm{~h}$ e às $15 \mathrm{~h}$ a montagem da armadura da laje já estava concluída).

Quanto às vigas, essas eram quase todas de borda, sendo que algumas precisavam ser complementadas no local (são pré-montadas embaixo), como mostra a Figura 6.53. 
Tabela 6.19 (conclusão) - Caracterização da obra SP 304 e do seu PCPA

Características

Aspectos organizacionais

\section{Descrição}

Serviço subcontratado pela construtora. Encarregado, da empresa subcontratada, exclusivo para o serviço (coordena o serviço de armação em duas torres (blocos A e B)).

Equipe composta por 22 armadores que armam as duas torres mais a periferia (sendo que desses 22, dois armadores estão no corte (máquina de corte) e dois armadores estão na dobra (máquina de dobra); eventualmente dois outros armadores são deslocados para a policorte (existe uma na obra), principalmente para cortar o aço destinado à periferia).

Os armadores estão tarefados em 90 horas por laje (fazem, em média, cinco lajes por mês por torre). Para cada armador, multiplica-se o número total de lajes por 90 horas e descontam-se os dias trabalhados ( 8 horas). Tal prática levou os armadores a faturarem, no mês, aproximadamente 500 horas (trabalhavam nas duas torres), levando-os a receber mais de $\mathrm{R} \$ 1000,00$ mensais. A empreiteira fornece almoço, vale-transporte e não costuma atrasar o pagamento. O salário é depositado em cartão-salário no banco. Se o operário tiver poupança, a empreiteira deposita na poupança.

No começo da obra o encarregado pede uma quantidade "a mais" de armadores para o patrão. Vai, então, verificando quanto tempo está se gastando para armar uma laje. Com esse referencial o encarregado pode tirar ou acrescentar armadores no serviço. Por exemplo, se tiver com 25 armadores e fizer o serviço em $1 / 2$ dia, suprime da equipe três armadores para fazer o serviço ao longo de todo o dia. O dono da subempreiteira confia esse "dimensionamento" ao encarregado ("você vê quantos armadores precisa, depois vê quantos armadores pode tirar"). Caso perceba que irá precisar de mais armadores, o encarregado liga para o patrão e solicita " $x$ " armadores na obra para o dia seguinte. Quando precisa de armadores em outra obra, o patrão pergunta ao encarregado se ele pode "emprestá-los" (este irá atender a solicitação se estiver "aliviado" com o serviço no dia seguinte). A prática de uma obra "socorrer" a outra é comum na empreiteira ("não dá para ficar pegando gente e depois mandando embora; a firma tem um controle, mantendo um certo número de armadores e remanejando-os entre obras à medida que se faça necessário"). 

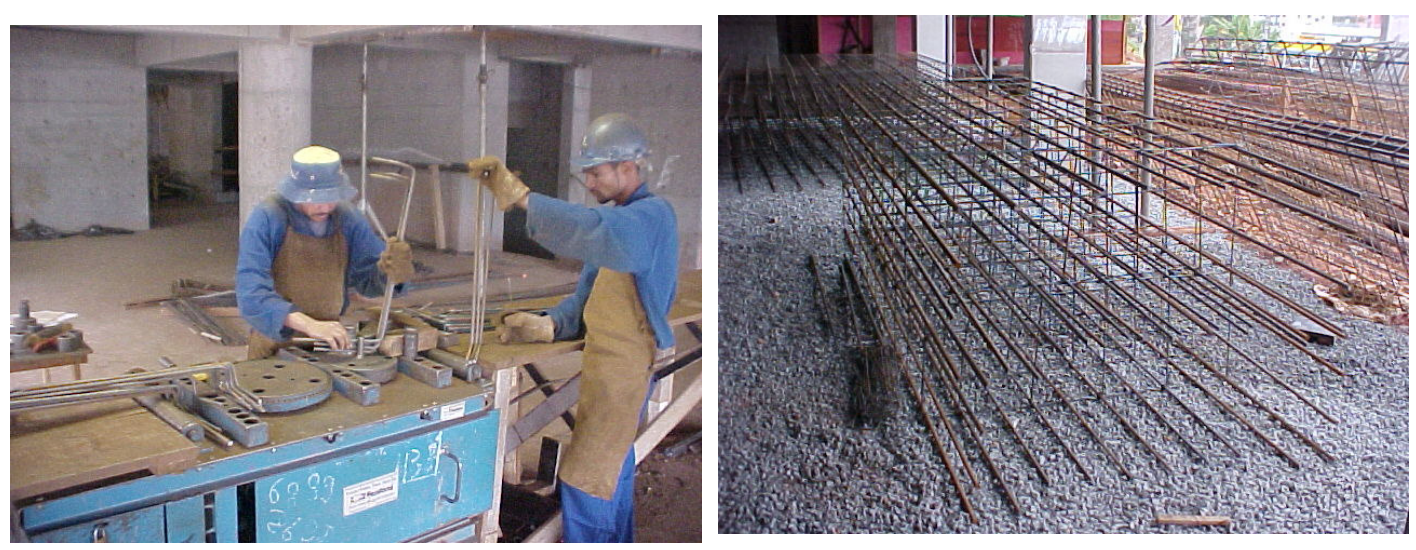

Figura 6.48 - Máquina hidráulica de dobra

Figura 6.49 - Armaduras de pilares
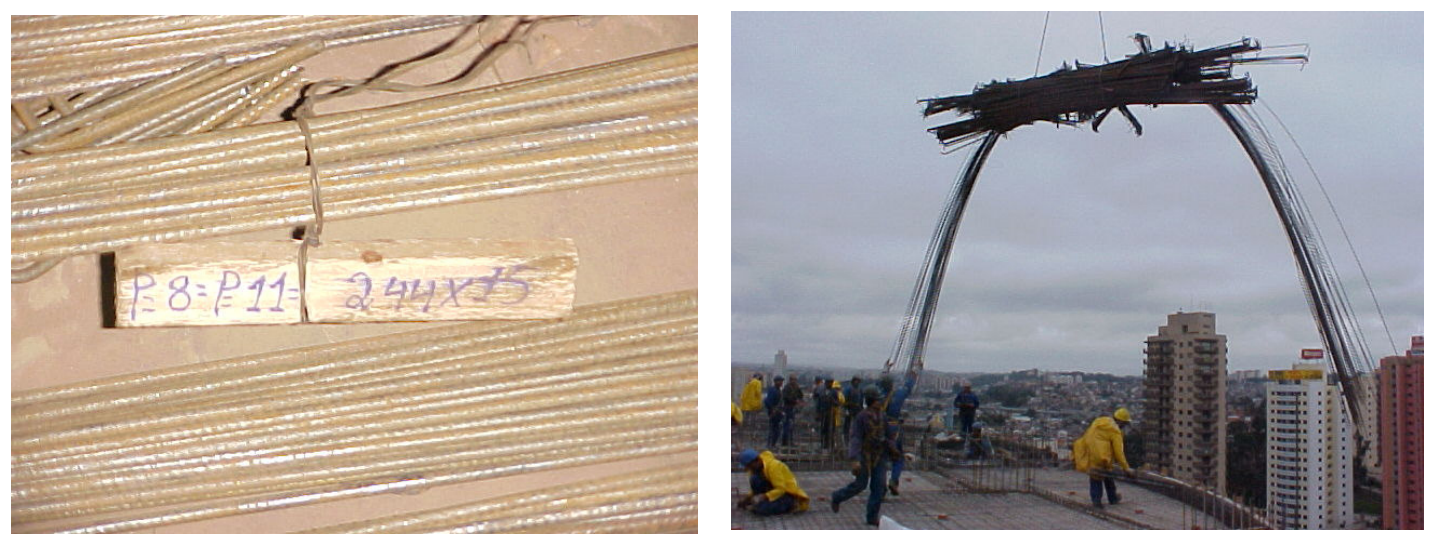

Figura 6.50 - Feixe de aço com posições dos pilares

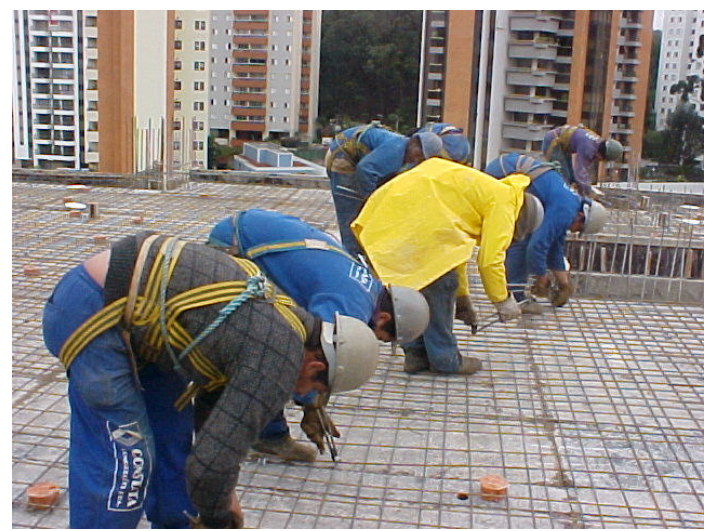

Figura 6.51 - Içamento pela grua da armação da laje

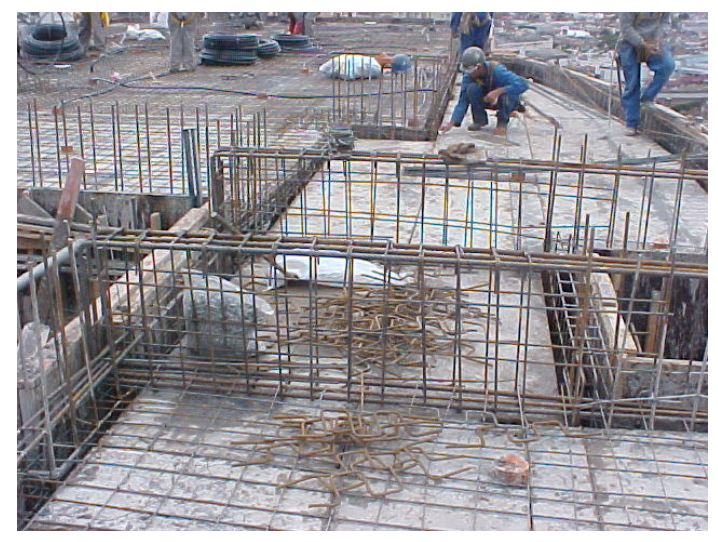

Figura 6.52 - Montagem da armadura da laje positiva

Figura 6.53 - Montagem da armadura das vigas

A Figura 6.54 ilustra a planta de formas referente ao pavimento tipo da obra SP 304. 


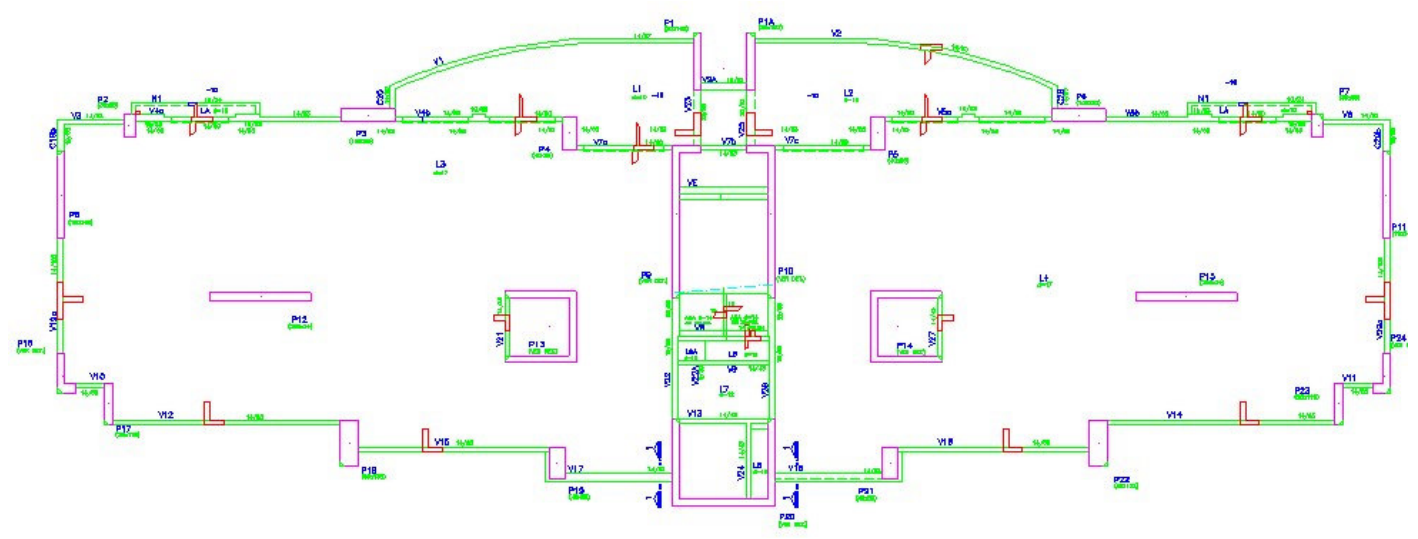

Figura 6.54 - Planta de forma referente ao pavimento tipo da obra SP 304

A Tabela 6.18 traz uma descrição resumida da obra SP 305, apresentando alguns aspectos do método e da organização do trabalho adotados no âmbito do processo de produção das armaduras.

Tabela 6.18 (continua) - Caracterização da obra SP 305 e do seu PCPA

\begin{tabular}{|c|c|}
\hline Características & Descrição \\
\hline Uso da edificação & Residencial \\
\hline Descrição do Empreendimento & $\begin{array}{l}\text { Empreendimento de } 1 \text { torre composta por } 2 \text { subsolos, pavimento térreo, } 25 \\
\text { pavimentos tipo (do } 1^{\circ} \text { ao } 25^{\circ} \text { andar) + cobertura+ pavimentos de serviço. }\end{array}$ \\
\hline $\begin{array}{l}\text { Tipologia estrutural e } \\
\text { tecnologia construtiva }\end{array}$ & $\begin{array}{l}\text { Trata-se de uma estrutura de concreto armado com laje plana protendida, } \\
\text { onde as poucas vigas existentes se fizeram presentes apenas nas bordas } \\
\text { das escadas e caixas de elevadores. }\end{array}$ \\
\hline Quantidade aço/pav tipo & $\cong 6.500 \mathrm{Kg}$ (referente ao $22^{\circ}$ pavimento) \\
\hline Porção da obra analisada & Pavimentos tipo $\left(19^{\circ}\right.$ ao $\left.25^{\circ}\right)$ \\
\hline Fornecimento do aço & Aço fornecido em barras de $12 \mathrm{~m}$ \\
\hline Corte e dobra & $\begin{array}{l}\text { Realizado pela subempreiteira no canteiro de obras (uso de uma serra } \\
\text { policorte e de duas bancadas de pinos para dobramento para a confecção } \\
\text { das peças) em local adequando conforme ilustram as Figura } 6.55 \text { e Figura } \\
6.56 \text {. }\end{array}$ \\
\hline $\begin{array}{l}\text { Sistema de descarregamento } \\
\text { do aço }\end{array}$ & $\begin{array}{l}\text { Descarregamento manual das carretas ( } 25 \text { ton) e/ou com o auxílio da grua } \\
\text { quando ela não estava ocupada. }\end{array}$ \\
\hline Armazenamento do aço & $\begin{array}{l}\text { A baia de estocagem do aço (Figura } 6.57 \text { ) ficava na parte frontal do } \\
\text { terreno, bem próxima à rua onde a carreta parava. }\end{array}$ \\
\hline $\begin{array}{l}\text { Sistema de transporte vertical } \\
\text { do aço }\end{array}$ & $\begin{array}{l}\text { O aço (armaduras) era transportado pela grua até o andar em que seria } \\
\text { utilizado. }\end{array}$ \\
\hline
\end{tabular}


Tabela 6.20 (conclusão) - Caracterização da obra SP 305 e do seu PCPA

\begin{tabular}{|c|c|}
\hline Características & Descrição \\
\hline Pré-montagem & $\begin{array}{l}\text { A pré-montagem das armaduras era realizada na central de armação } \\
\text { (Figura 6.58); em se tratando dos pilares, as armaduras eram pré- } \\
\text { montadas para dois pavimentos consecutivos (armaduras duplas }{ }^{133} \text {, como } \\
\text { mostrado na Figura 6.59). Nesta mesma central, localizada lateralmente à } \\
\text { torre, no térreo (não havia subsolos neste empreendimento), era feita a } \\
\text { preparação dos cabos para protensão. }\end{array}$ \\
\hline Montagem & $\begin{array}{l}\text { Tratou-se da única obra, entre as sete contempladas, em que se trabalhou } \\
\text { com a protensão das lajes. O reflexo no processo executivo se deu, } \\
\text { principalmente, pela entrada de uma operação a mais, desempenhada } \\
\text { também pelos armadores, qual seja o posicionamento dos cabos de } \\
\text { protensão (Figura 6.60) no momento precedente à montagem da } \\
\text { armadura positiva da laje. }\end{array}$ \\
\hline Aspectos organizacionais & $\begin{array}{l}\text { Serviço subcontratado pela construtora. Encarregado, da empresa } \\
\text { subcontratada, exclusivo para o serviço. } \\
\text { Equipe composta por } 10 \text { armadores: dois armadores constantes nos cabos } \\
\text { de protensão (cortando, fazendo limpeza, rebocando); um armador } \\
\text { constante na policorte e outro na bancada de dobra. O restante se dividia } \\
\text { na demais tarefas (eventualmente um armador era deslocado para ajudar } \\
\text { na operação de dobra, por exemplo), como a pré-montagem de vigas, } \\
\text { pilares. No dia de montagem da armadura da laje, todos os armadores } \\
\text { eram alocados para essa tarefa, inclusive aqueles que trabalhavam nas } \\
\text { bancadas. No dia de montagem das armaduras dos pilares os armadores } \\
\text { de bancada permaneciam em suas posições. }\end{array}$ \\
\hline
\end{tabular}

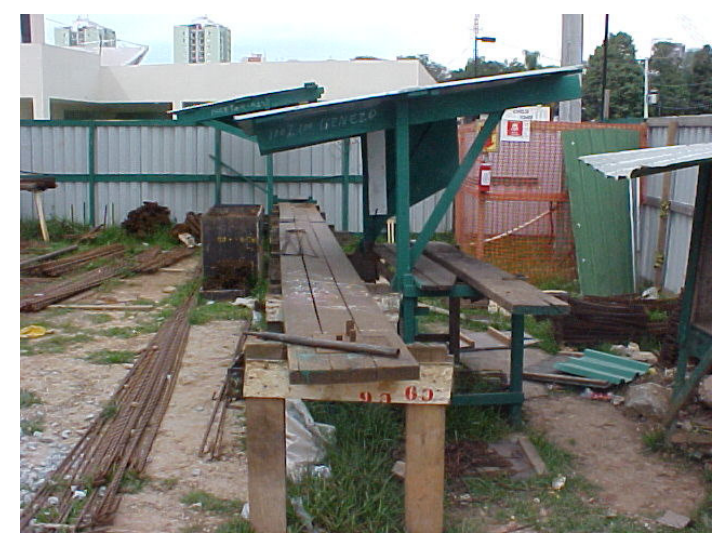

Figura 6.55 - Vista da bancada de corte e dobra

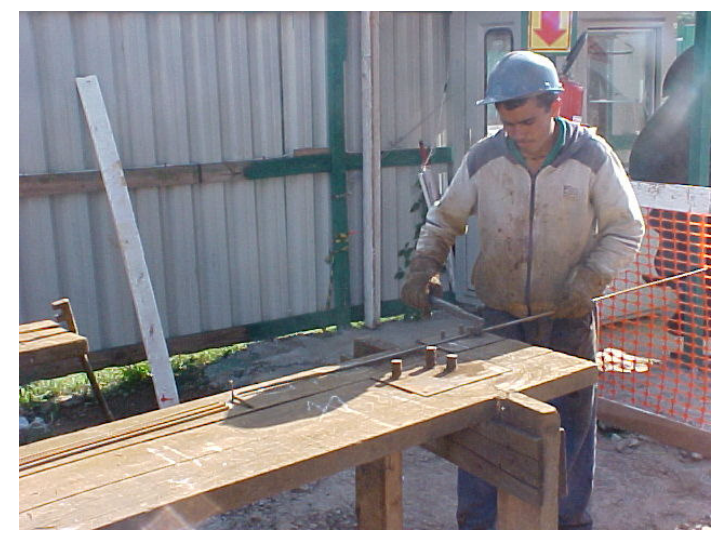

Figura 6.56 - Bancada de dobramento das barras

133 As armaduras dos pilares foram projetadas para serem armadas de forma a vencerem dois pésdireito. Trata-se de uma solução adotada pelo projetista, a partir de solicitação da construtora, visando basicamente à economia de aço (reduz-se o número de transpasse pela metade). 


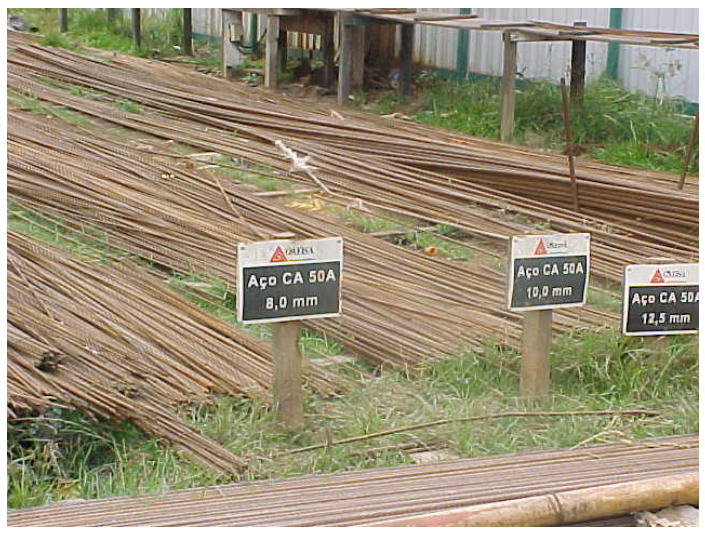

Figura 6.57 - Baias de estocagem do aço em barras

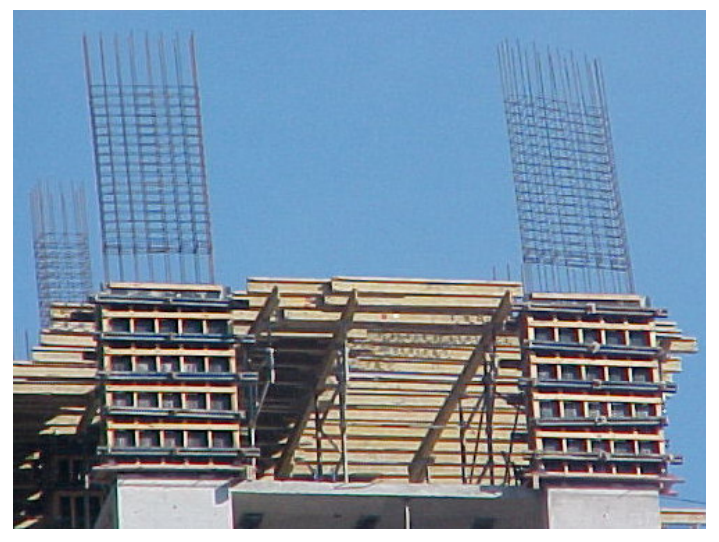

Figura 6.59 - Armaduras duplas para pilares

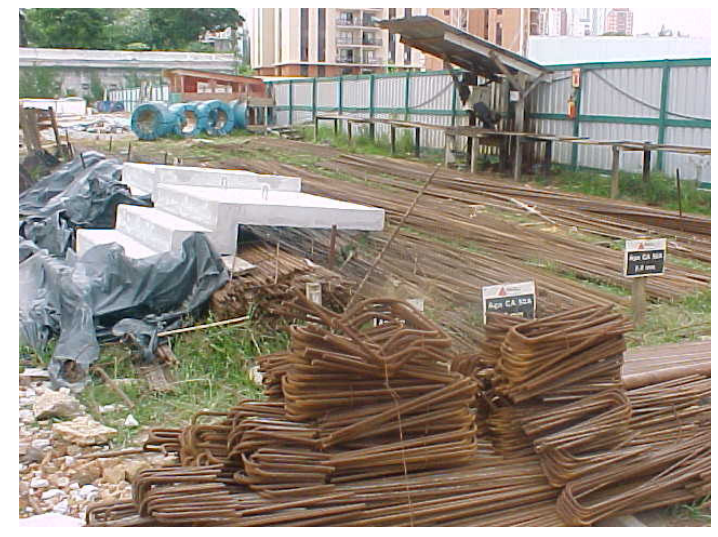

Figura 6.58 - Central de armação

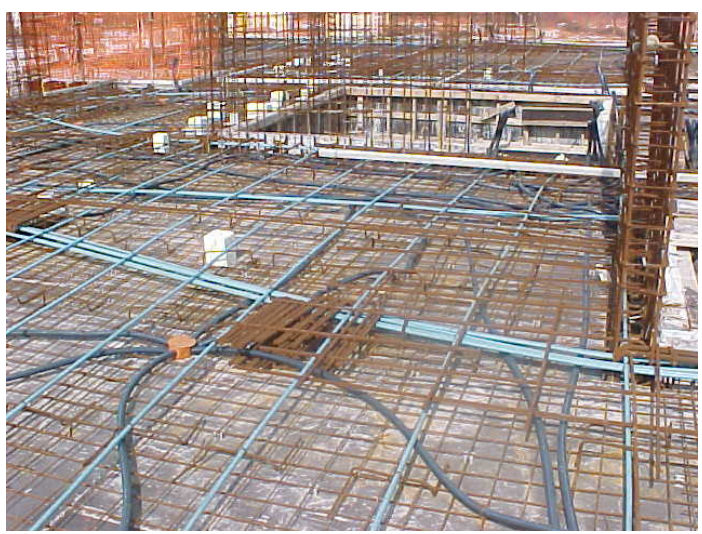

Figura 6.60 - Distribuição dos cabos de protensão - armadura da laje

A Figura 6.61 ilustra a planta de formas referente ao pavimento tipo da obra SP 305. 


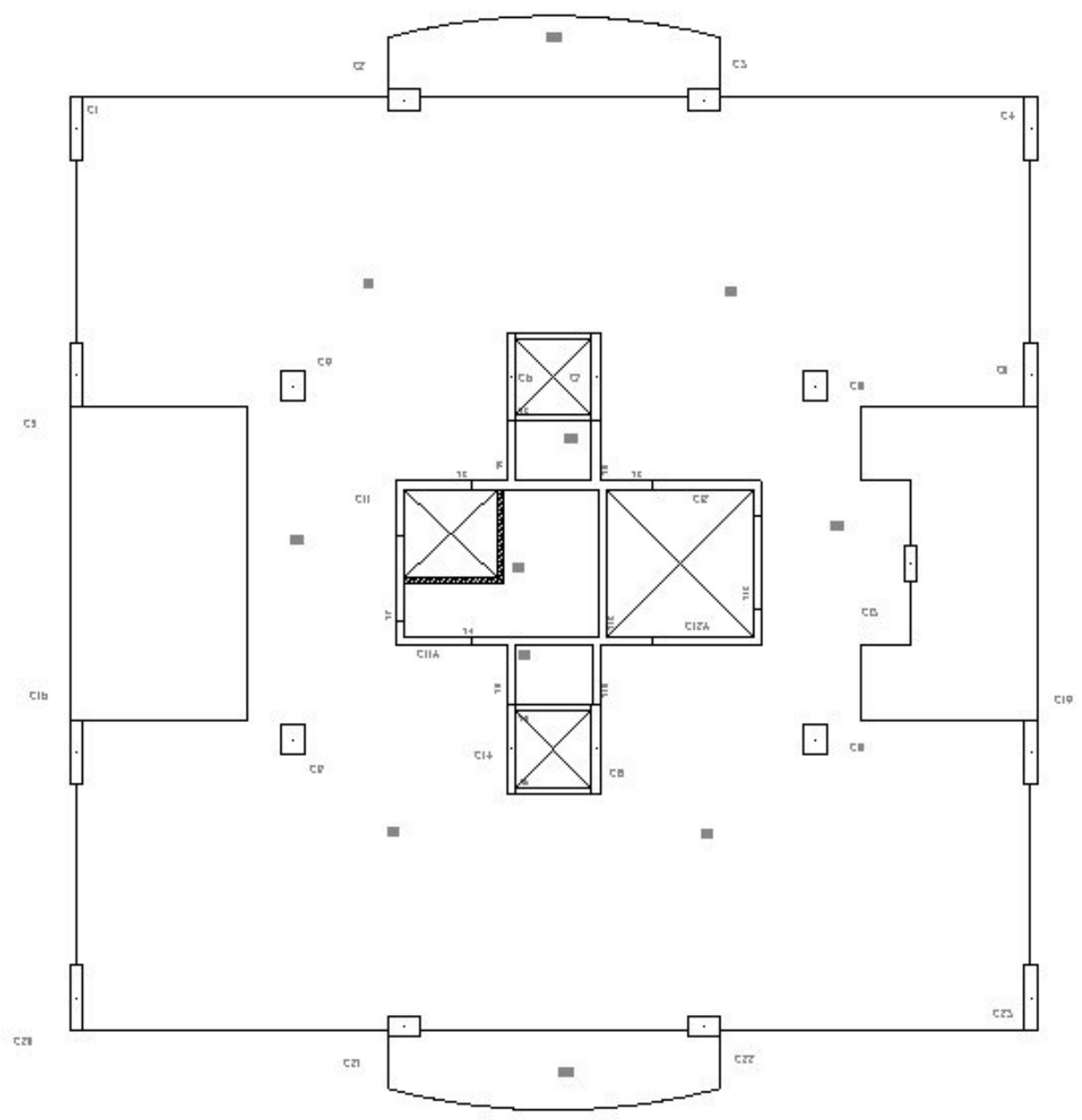

Figura 6.61 - Planta de forma referente ao pavimento tipo da obra SP 305

A Tabela 6.19 traz uma descrição da obra SP 306, apresentando alguns aspectos do método e da organização do trabalho adotados no âmbito do processo de produção das armaduras.

Tabela 6.19 (continua) - Caracterização da obra SP 306 e do seu PCPA

\begin{tabular}{l|l}
\hline Características & \multicolumn{1}{c}{ Descrição } \\
\hline Uso da edificação & Residencial \\
\hline $\begin{array}{l}\text { Descrição do } \\
\text { Empreendimento }\end{array}$ & $\begin{array}{l}\text { Empreendimento de uma torre composta por } 2 \text { subsolos, pavimento térreo, } 25 \\
\text { pavimentos tipo (do } 1^{\circ} \text { ao } 25^{\circ} \text { andar) + cobertura+ pavimentos de serviço. }\end{array}$
\end{tabular}


Tabela 6.17 (continuação) - Caracterização da obra SP 306 e do seu PCPA

\begin{tabular}{l|ll}
\hline Características & \multicolumn{1}{c}{ Descrição } \\
\hline $\begin{array}{l}\text { Tipologia estrutural e } \\
\text { tecnologia construtiva }\end{array}$ & $\begin{array}{l}\text { Trata-se de uma estrutura reticulada de concreto armado. A tecnologia para } \\
\text { execuão destas estruturas é aquela tradicional, descrita por FREIRE (2000), com } \\
\text { madeira serrada; cimbramento de vigas com garfos de madeira e torres metálicas } \\
\text { (para as vigas de borda) e de lajes com elementos (escoras) metálicos. }\end{array}$
\end{tabular}

Quantidade aço/pav tipo

$\cong 4.700 \mathrm{Kg}$ (referente ao $22^{\circ}$ pavimento)

Porção da obra analisada

Pavimentos tipo $\left(19^{\circ}\right.$ ao $\left.25^{\circ}\right)$.

Fornecimento do aço

Aço fornecido em barras de $12 \mathrm{~m}$

Recebimento do aço

O recebimento do aço era operacionalizado por funcionários do empreiteiro de armação. O aço era descarregado na posição "R1" (Figura 6.62 e Figura 6.63), que se distanciava, aproximadamente, vinte metros do local de estoque. O posicionamento das bancadas de dobra do aço impedia que o veiculo de transporte se aproximasse ainda mais das baias de estocagem. O caminhão e/ou carreta que transportava o aço teve acesso ao interior do canteiro de obras, e à posição indicada na Figura 6.63, onde os feixes de barras eram "derrubados", durante todo o período em que se executou a estrutura do edifício. O descarregamento era feito manualmente, sem o auxílio da grua presente na obra (alegaram que era perigoso a grua puxar feixes de barras com $12 \mathrm{~m}$ ).

A estocagem definitiva das barras, conforme ilustrado através da Figura 6.64 e Figura 6.65 , era feita próximo ao local onde as barras seriam beneficiadas. A base da baia, onde as barras eram estocadas, recebia uma camada de pedrisco e tábuas, dispostas transversalmente ao comprimento das barras, com o objetivo de impedir o contato dessas com o solo. Pontaletes e pedaços de barras de aço eram usados para fazer a separação das barras por diâmetro, que eram identificados por plaquetas dispostas junto a cada conjunto de barras.

As peças, assim como as armaduras pré-montadas, eram estocadas, preferencialmente, nas proximidades da central de armação ou em locais mais afastados, desde que dentro do raio de alcance da grua.

O aço era todo cortado na obra mediante o uso de duas serras policortes (Figura 6.66 e Figura 6.67), sendo três armadores autorizados a operá-las. Em uma das policortes cortavam-se, preferencialmente, barras de menores diâmetros (para armação de negativos e positivos de lajes e estribos de pilares e vigas). A outra era destinada ao corte das barras de diâmetros maiores (barras longitudinais de pilares e vigas). A policorte que cortava os diâmetros maiores tinha um motor melhor, mais potente.

Corte e dobra

A operação de dobra era realizada convencionalmente (com o auxílio de pinos fixos a bancadas e chaves de dobra), conforme ilustrado na Figura 6.68, em três bancadas separadas. Numa delas, um armador dobrava, na maior parte do tempo, peças conhecidas como "caranguejo", como mostrado na Figura 6.69. Uma outra bancada era usada para o dobramento das peças destinada à armadura da escada. $\mathrm{Na}$ terceira bancada, que tinha aproximadamente dez metros de comprimento, costumavam trabalhar três armadores: um armador, num dos extremos, dobrava apenas "ganchos" e estribos (Figura 6.70). No outro extremo, dobravam-se peças longitudinais de vigas e lajes (Figura 6.71).

Sistema de
transporte vertical do
aço $\mathrm{O}$ aço (armaduras) era transportado pela grua até o andar em que seria utilizado. 
Tabela 6.17 (continuação) - Caracterização da obra SP 306 e do seu PCPA

\begin{tabular}{|c|c|}
\hline Características & Descrição \\
\hline Pré-montagem & $\begin{array}{l}\text { A pré-montagem das armaduras tratou de uma prática constante na referida obra. } \\
\text { Devido a grande área disponibilizada no canteiro para a central de armação, a pré- } \\
\text { montagem acontecia em pontos espalhados, como mostra a Figura } 6.72 \text {. Estes } \\
\text { locais não eram fixos e costumavam ser determinados em função da disponibilidade } \\
\text { dos espaços a cada momento. Os armadores utilizavam "cavaletes" de madeira } \\
\text { para servir de apoio às armaduras. A utilização da grua para o transporte das } \\
\text { gaiolas, ao andar, permitiu que todos os pilares da obra (incluindo os pilares de } \\
\text { maiores dimensões, como os da caixa de escada e do elevador), fossem pré- } \\
\text { montados Figura 6.73). } \\
\text { o mesmo aconteceu com as armaduras das vigas, que também foram pré- } \\
\text { montadas. Algumas delas, porém, foram complementadas no andar (após serem } \\
\text { posicionadas nas fôrmas); a existência de pilares intermediários às vigas não } \\
\text { permitia que todas as suas peças fossem previamente montadas. }\end{array}$ \\
\hline
\end{tabular}

A operação de montagem das armaduras dos pilares começou com o transporte das gaiolas para o pavimento de trabalho, com o auxílio da grua, que podia ajudar no seu posicionamento final. As gaiolas dos pilares menores eram dispostas na laje, sendo posteriormente transportadas e posicionadas, manualmente, nas fôrmas dos pilares correspondentes, (as fôrmas apresentavam três de suas faces já montadas, servido, portanto, de apoio e referência para o posicionamento das gaiolas). As gaiolas maiores (mais pesadas) dos pilares dos poços dos elevadores eram posicionadas nas fôrmas, geralmente, com o auxílio da grua. Os armadores, após o posicionamento das gaiolas, amarravam as barras longitudinais nos respectivos arranques, redistribuindo e amarrando os estribos na região inferior do pilar.

Montagem A montagem da armadura das vigas, em algumas situações, foi facilitada pela ausência de interferência intermediária de outras vigas e/ou pilares. No entanto, algumas vigas que tiveram suas gaiolas segmentadas na pré-montagem precisaram ser complementadas após posicionadas nas fôrmas. As peças faltantes foram distribuídas após a armadura estar posicionada e, então, amarradas a elas.

A montagem da armadura negativa (Figura 6.74 e Figura 6.75), iniciada após a passagem dos eletrodutos pela laje era dificultada devido a quantidade de posições de peças negativas distintas (172) previstas no projeto.

Foram utilizados 470 caranguejos para o posicionamento das barras negativas da laje. No entanto, o projeto (que traz apenas um detalhe genérico da referida peça) não indicava o posicionamento e, por conseguinte, a quantidade de caranguejos necessários, ficando a critério da obra e do encarregado de armação tais definições.

Aspectos organizacionais

Serviço subcontratado pela construtora. Encarregado, da empresa subcontratada, exclusivo para o serviço.

Durante a maior parte deste período, a equipe de armadores foi constituída por 13 armadores e um encarregado.

As bancadas de dobra, que eram três e estavam fisicamente separadas, eram ocupadas, na maioria das vezes, por três armadores, que tinham um escopo diferenciado e bem definido: i) um armador dobrando as barras longitudinais de lajes e os caranguejos que dariam sustentação à armadura negativa; ii) um armador dobrando estribos e ganchinhos dos pilares e estribos das vigas; iii) um terceiro armador que dobrava as barras longitudinais das vigas e estribos de vigas. 
Tabela 6.17 (conclusão) - Caracterização da obra SP 306 e do seu PCPA

\begin{tabular}{|c|c|}
\hline Características & Descrição \\
\hline $\begin{array}{l}\text { Aspectos } \\
\text { organizacionais }\end{array}$ & 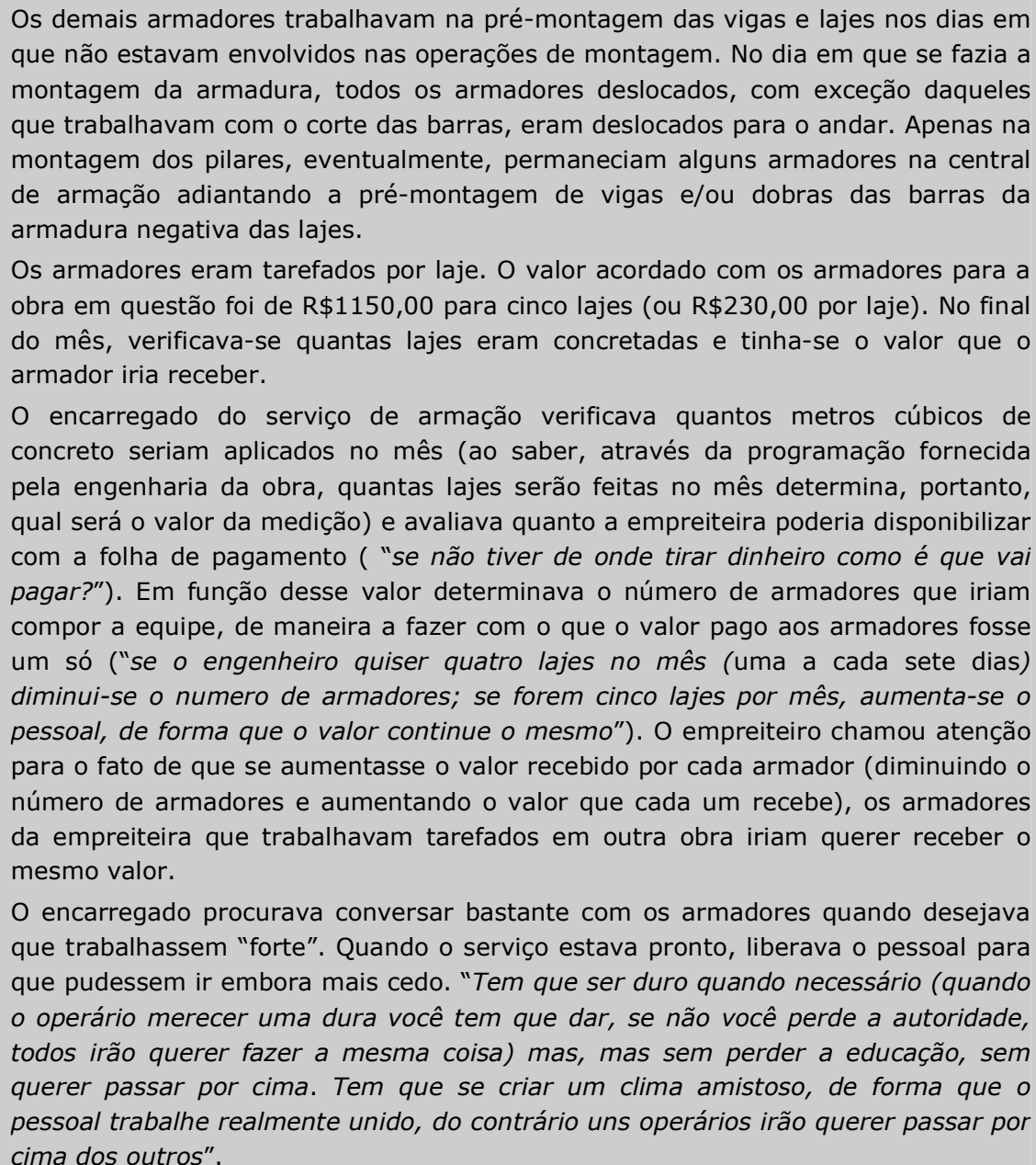 \\
\hline
\end{tabular}




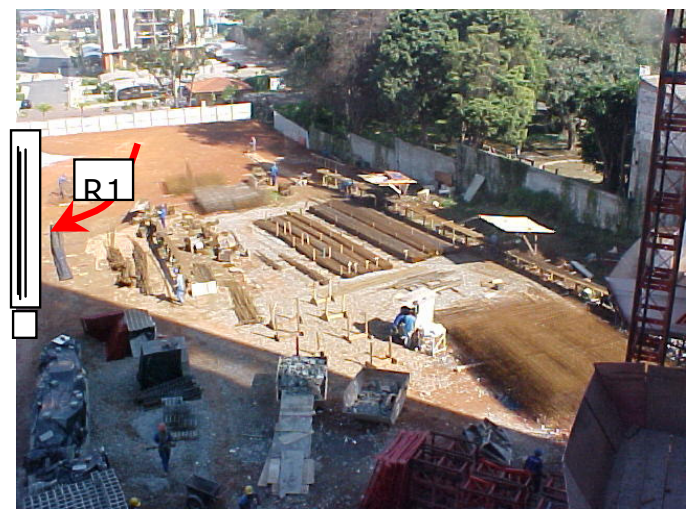

Figura 6.62- Local de posicionamento do veículo no interior do canteiro de obras

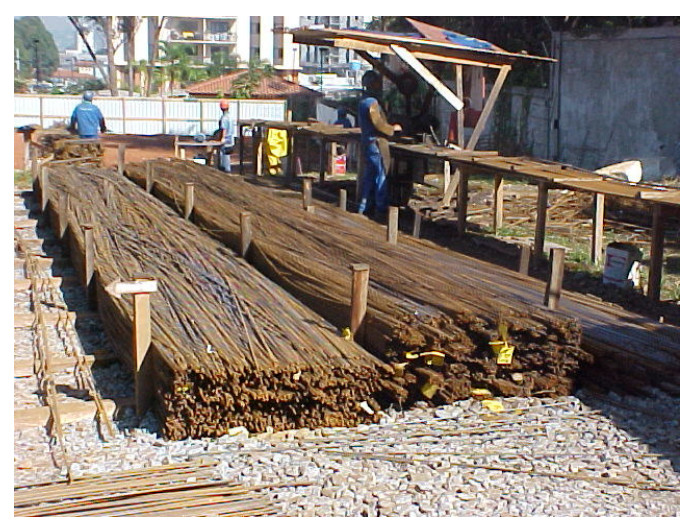

Figura 6.64 - Baia de estocagem das barras de aço próxima às bancadas

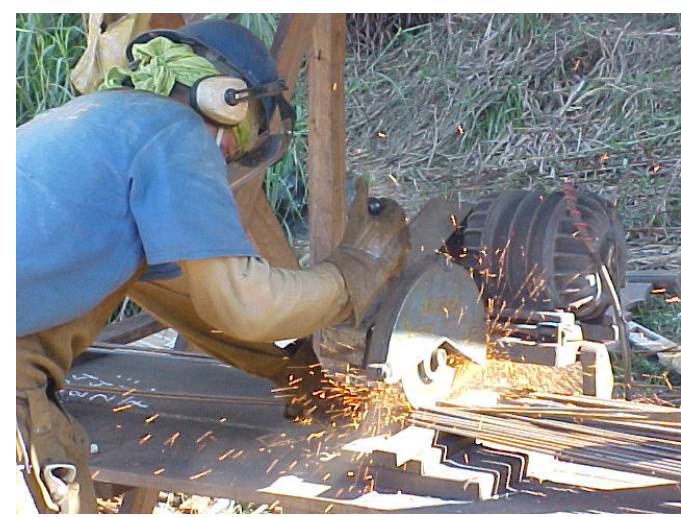

Figura 6.66 - Detalhe do corte das barras com uso de máquina policorte

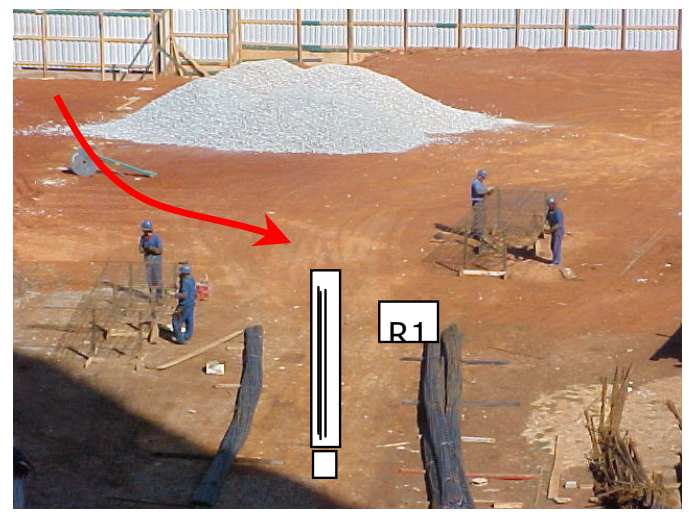

Figura 6.63 - Área de acesso e de posicionamento do veículo

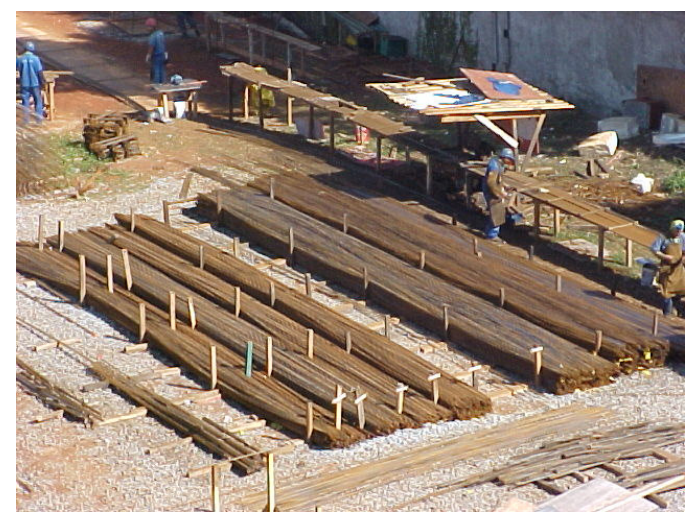

Figura 6.65 - Vista da baia de estocagem das barras de aço

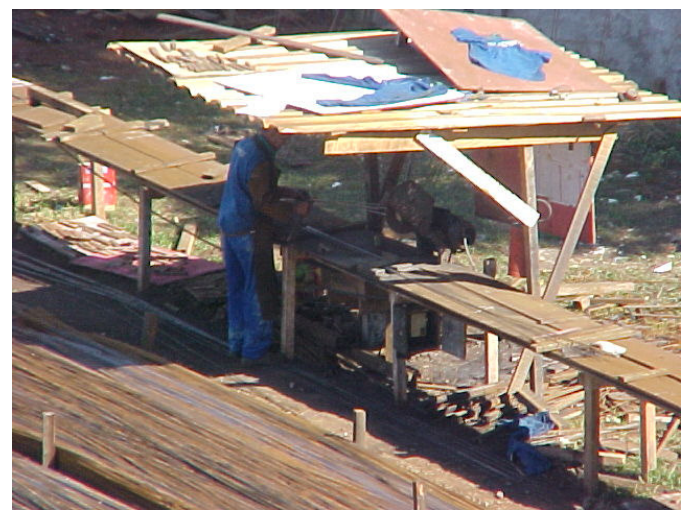

Figura 6.67 - Vista da bancada de corte de aço 


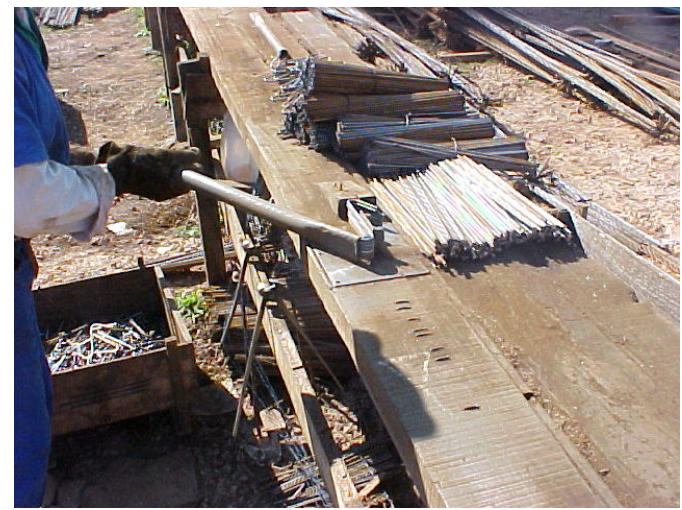

Figura 6.68 - Operação convencional de dobramento das barras

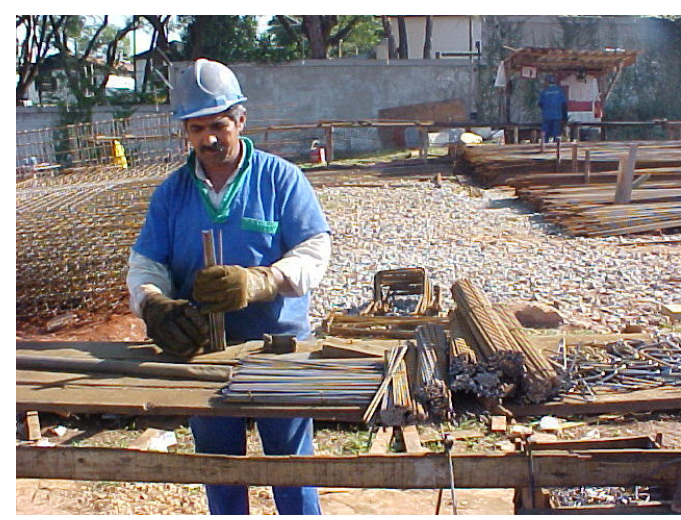

Figura 6.70 - Bancada com armador dobrando ganchos numa extremidade

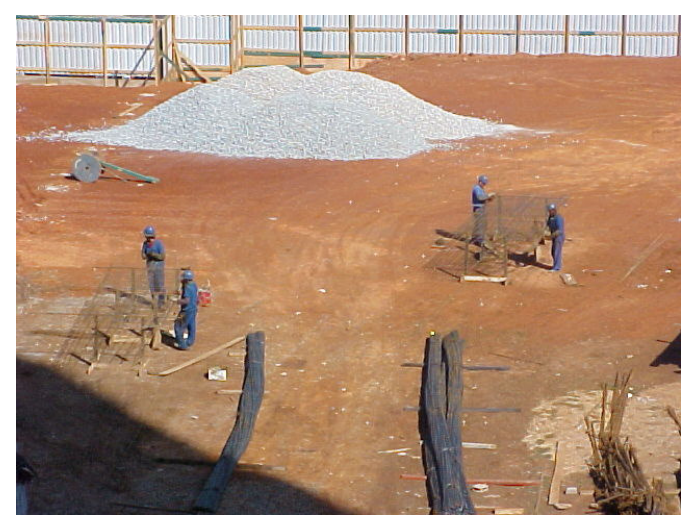

Figura 6.72 - Vista do canteiro com armadores na pré-montagem

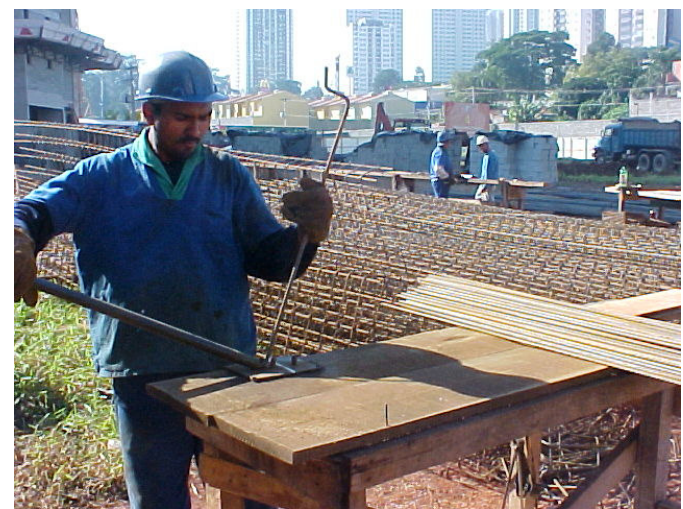

Figura 6.69 - Bancada de dobra de "caranguejos"

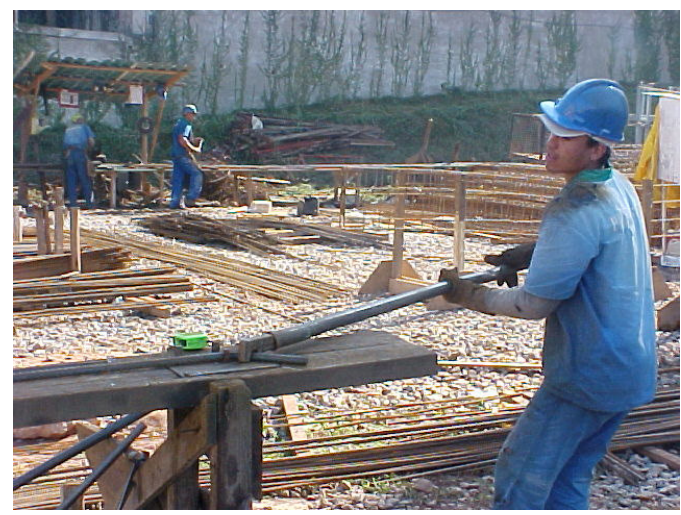

Figura 6.71 - Bancada com armador dobrando peças longitudinais de vigas

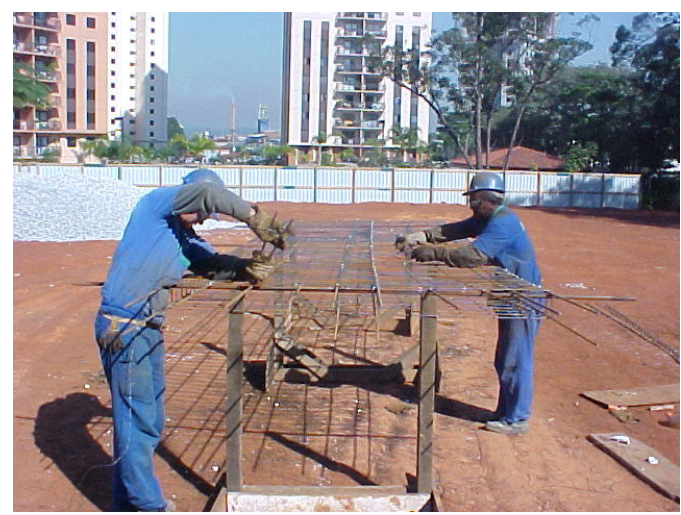

Figura 6.73 - Operação de pré-montagem de armadura de pilares 


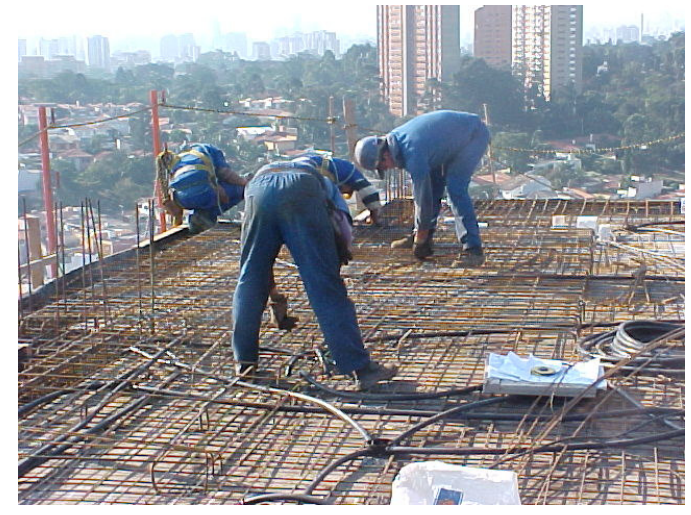

Figura 6.74 - Detalhe da montagem da armadura da laje

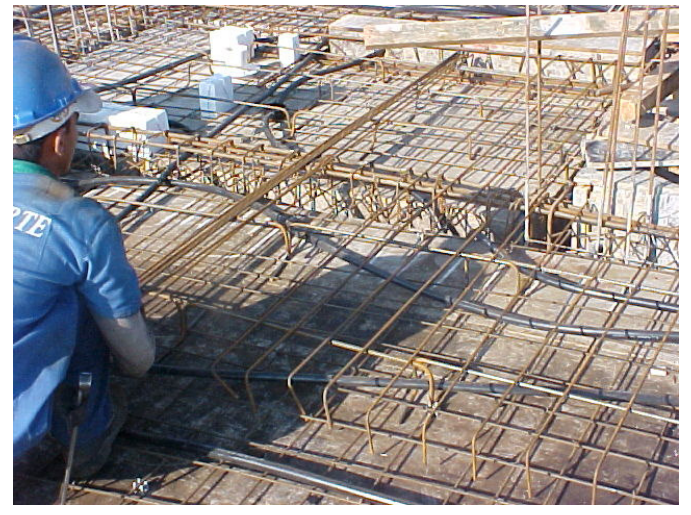

Figura 6.75 - Distribuição das peças da armadura negativa da laje

A Figura 6.76 ilustra a planta de formas referente ao pavimento tipo da obra SP 306.

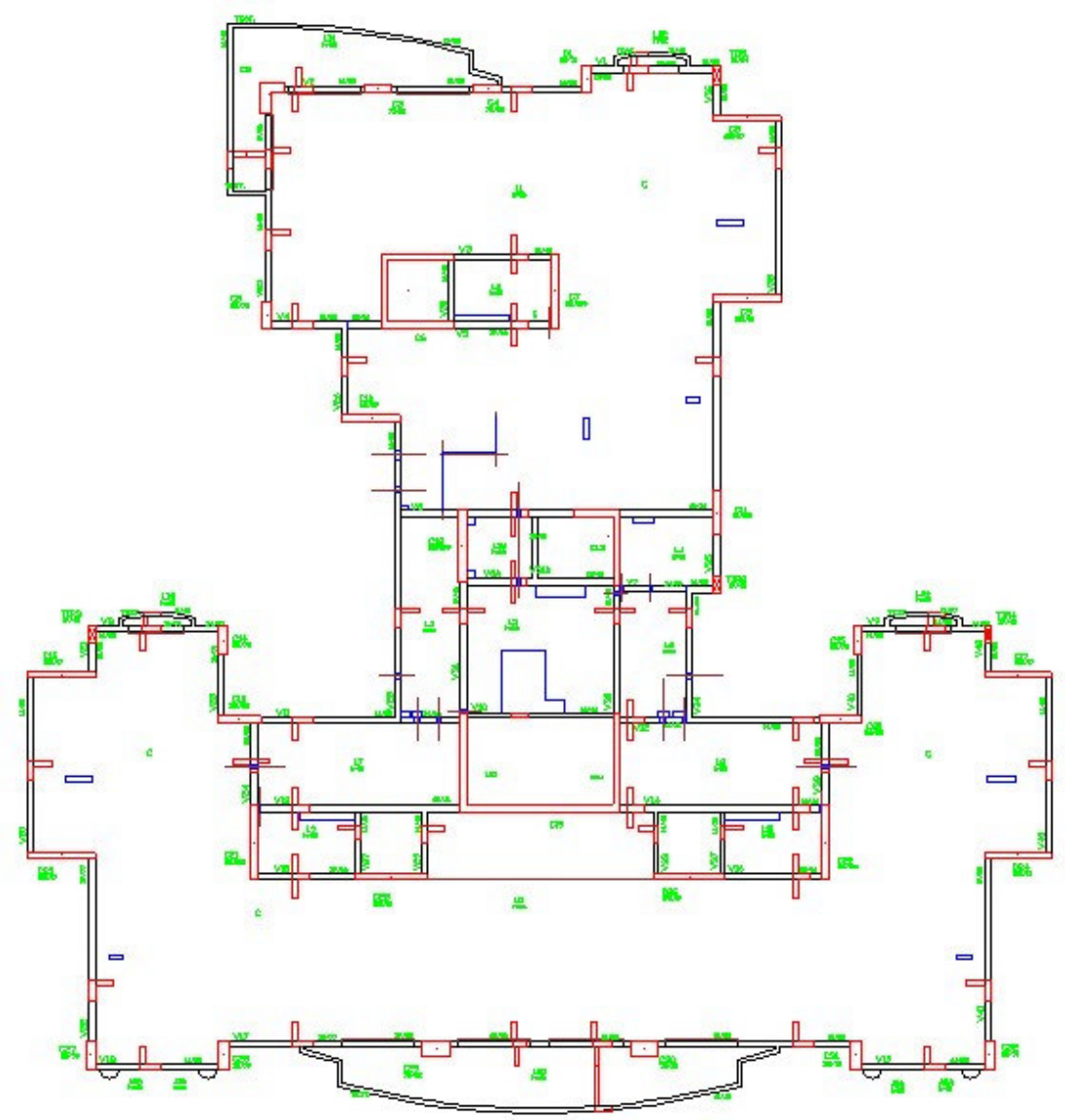

Figura 6.76 - Planta de forma referente ao pavimento tipo da obra SP 306 
A Tabela 6.20 traz uma descrição da obra SP 307, apresentando alguns aspectos do método e da organização do trabalho adotados no âmbito do processo de produção das armaduras.

Tabela 6.20 (continua) - Caracterização da obra SP 307 e do seu PCPA

\begin{tabular}{|c|c|}
\hline Características & Descrição \\
\hline Uso da edificação & Residencial \\
\hline $\begin{array}{l}\text { Descrição do } \\
\text { Empreendimento }\end{array}$ & $\begin{array}{l}\text { Empreendimento de três torres compostas por dois subsolos, pavimento térreo, } 25 \\
\text { pavimentos tipo (do } 1^{\circ} \text { ao } 25^{\circ} \text { andar) + cobertura+ pavimentos de serviço. }\end{array}$ \\
\hline $\begin{array}{l}\text { Tipologia estrutural } \\
\text { e tecnologia } \\
\text { construtiva }\end{array}$ & $\begin{array}{l}\text { Trata-se de uma estrutura reticulada de concreto armado. Esta obra difere daquelas } \\
\text { anteriormente descritas por fazer uso de vigas pré-moldadas, confeccionadas no } \\
\text { canteiro pela mesma equipe de carpinteiros responsáveis por moldar, no local, os } \\
\text { demais elementos estruturais do edifício. }\end{array}$ \\
\hline $\begin{array}{l}\text { Quantidade aço/pav } \\
\text { tipo }\end{array}$ & $\cong 8.100 \mathrm{Kg}$ (referente ao $9^{\circ}$ pavimento $)$ \\
\hline $\begin{array}{l}\text { Porção da obra } \\
\text { analisada }\end{array}$ & Pavimentos tipo $\left(9^{\circ}\right.$ ao $\left.15^{\circ}\right)$ da torre "A". \\
\hline $\begin{array}{l}\text { Fornecimento do } \\
\text { aço }\end{array}$ & Aço cortado e dobrado na obra. \\
\hline $\begin{array}{l}\text { Recebimento do } \\
\text { aço }\end{array}$ & $\begin{array}{l}\text { Descarregamento manual do caminhão, que era posicionado dentro do canteiro de } \\
\text { obras. O armazenamento era feito no térreo, próximo às bancadas de corte e dobra } \\
\text { do aço (Figura } 6.77 \text { e Figura } 6.78 \text { ). }\end{array}$ \\
\hline Corte e dobra & $\begin{array}{l}\text { Realizado pela subempreiteira no canteiro de obras (equipamentos locados pela } \\
\text { subempreiteira: } 01 \text { máquina hidráulica de corte }+01 \text { policorte; } 01 \text { máquina hidráulica } \\
\text { de dobra), em bancadas específicas para o corte e dobra do aço (Figura } 6.79 \text {, Figura } \\
6.80 \text { e Figura } 6.81 \text { ). Comentários do encarregado de armação quanto ao uso de } \\
\text { máquinas hidráulicas: "Não tem comparação uma máquina hidráulica com uma } \\
\text { máquina elétrica. As máquinas hidráulicas causam muito menos acidentes, por entre } \\
\text { outras razões, terem proteções específicas de segurança". } \\
\text { O fato das três torres serem idênticas e, portanto, terem projetos estruturais } \\
\text { idênticos, possibilitou a seguinte organização das operações de corte e dobra do aço: } \\
\text { os armadores da bancada, quando iam produzir as posições de um pavimento, já } \\
\text { cortavam ou dobravam a mesma posição duas ou três vezes mais, de maneira a } \\
\text { atender as demais torres (por exemplo, ao identificar que teriam que cortar } 10 \\
\text { posições de determinada bitola e comprimento, cortavam } 20 \text { ou } 30 \text { posições). }\end{array}$ \\
\hline $\begin{array}{l}\text { Sistema de } \\
\text { transporte vertical } \\
\text { do aço }\end{array}$ & As armaduras eram transportadas aos pavimentos em execução através da grua. \\
\hline
\end{tabular}


Tabela 6.21 (conclusão) - Caracterização da obra SP 307 e do seu PCPA

\begin{tabular}{|c|c|}
\hline $\begin{array}{c}\text { Caracte- } \\
\text { rísticas }\end{array}$ & Descrição \\
\hline $\begin{array}{l}\text { Pré- } \\
\text { montagem }\end{array}$ & $\begin{array}{l}\text { Todos os pilares eram pré-montados, não havendo limite de tamanho ou peso, em razão de } \\
\text { serem transportados com a grua. Na pré-montagem dos pilares (Figura } 6.82 \text { e Figura } 6.83 \text { ), } \\
\text { os armadores se organizavam em grupos de dois ou três operários, responsabilizado-se por } \\
\text { conjuntos específicos de pilares (um grupo faz apenas os pilares com barras de } 16 \mathrm{~mm} \text {, } \\
\text { outro só os pilares menores, outro só os pilares maiores). Dessa forma, em casos de erros } \\
\text { na armação conseguia-se identificar os armadores responsáveis, podendo reorientá-los } \\
\text { diretamente. } \\
\text { A armação negativa das lajes era pré-montada (Figura 6.84) previamente, no pátio de } \\
\text { armação. "Monto o negativo embaixo e, na laje, resta colocar o caranguejo e posicionar os } \\
\text { negativos, em cima das vigas e amarrar." O fato da obra contar com uma grua favorece } \\
\text { esse processo. "A pré-montagem dos negativos é feito sempre quando sobra um tempinho } \\
\text { (e normalmente sobra tempo); evita com que os armadores fiquem muito tempo abaixados } \\
\text { na laje. E suja menos a laje, com os araminhos que sobram das amarrações." }\end{array}$ \\
\hline $\begin{array}{l}\text { Aspectos } \\
\text { organizacio- } \\
\text { nais }\end{array}$ & 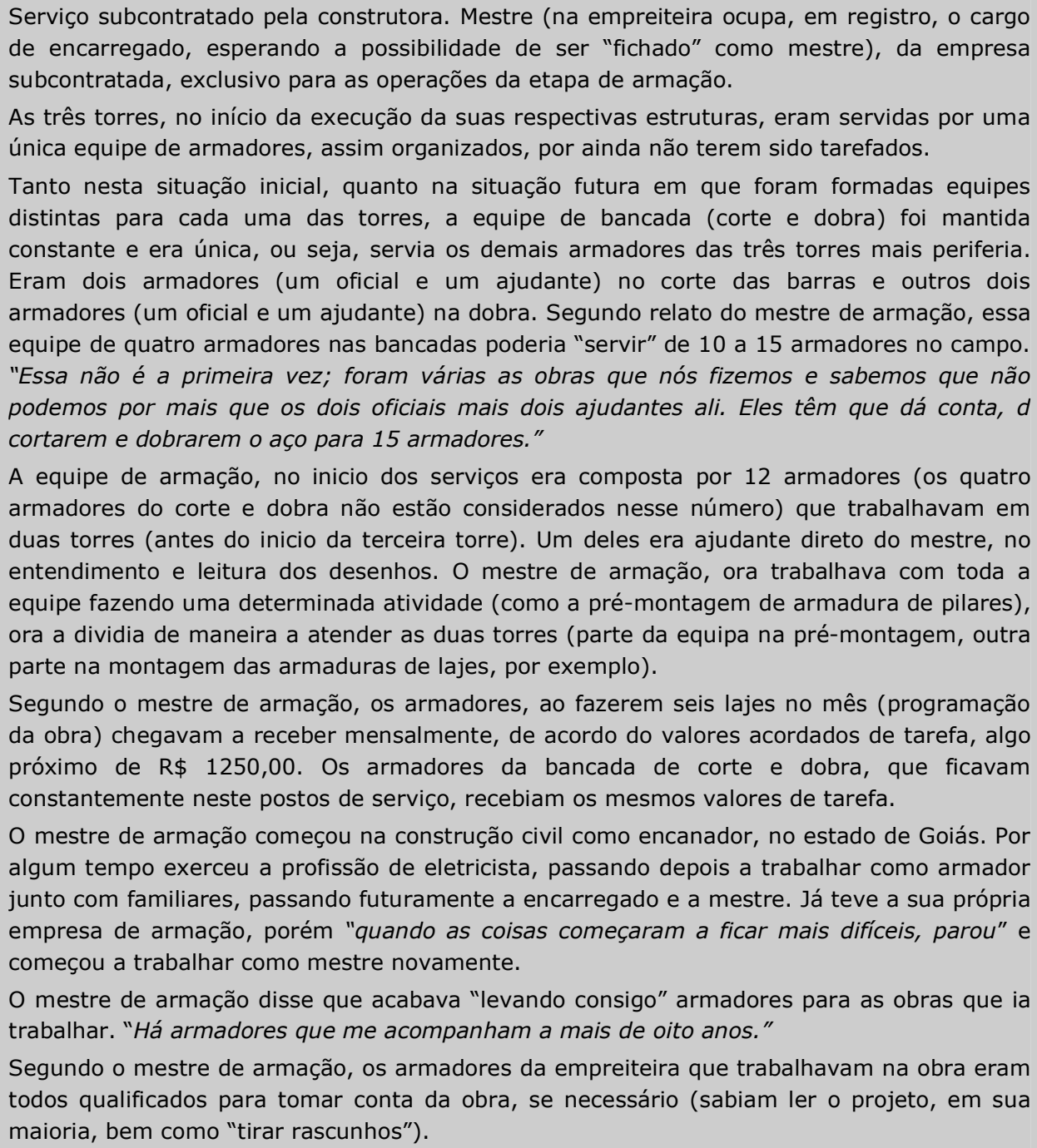 \\
\hline
\end{tabular}




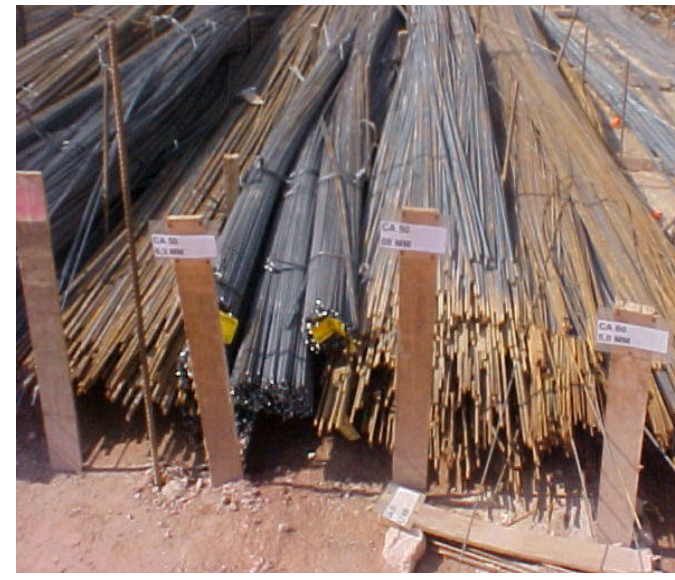

Figura 6.77 - Baia de estocagem das barras de aço

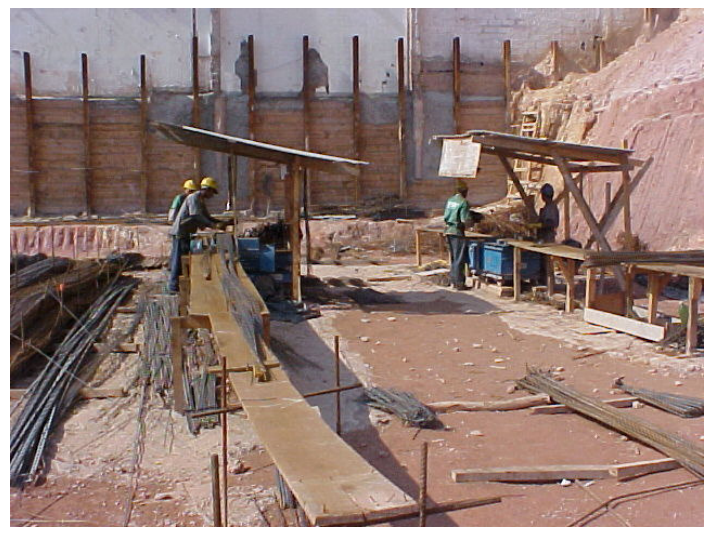

Figura 6.79 - Detalhe das bancadas de corte e dobra

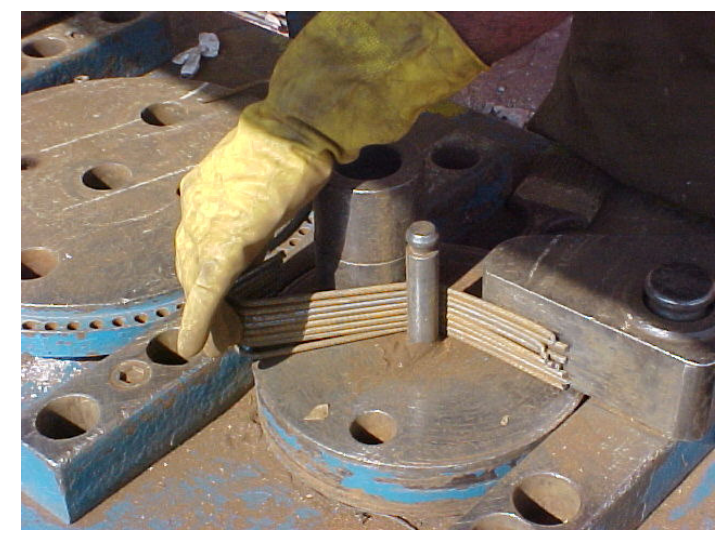

Figura 6.81 - Detalhe da operação de dobra

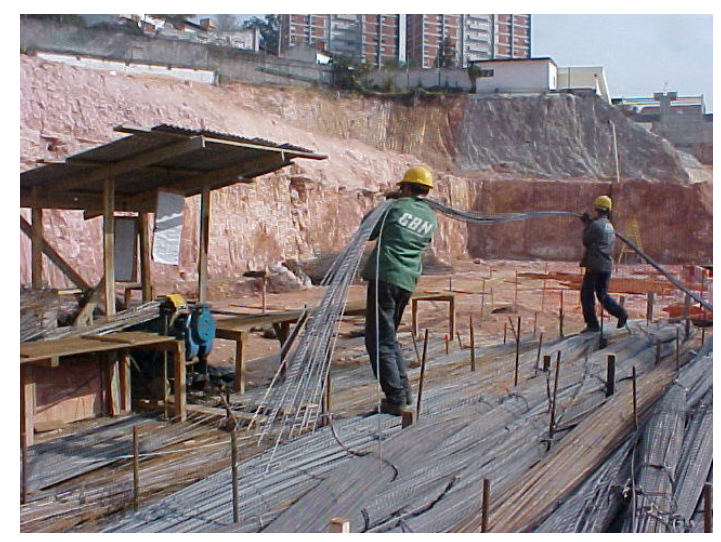

Figura 6.78 - Detalhe da proximidade do estoque da bancada de corte

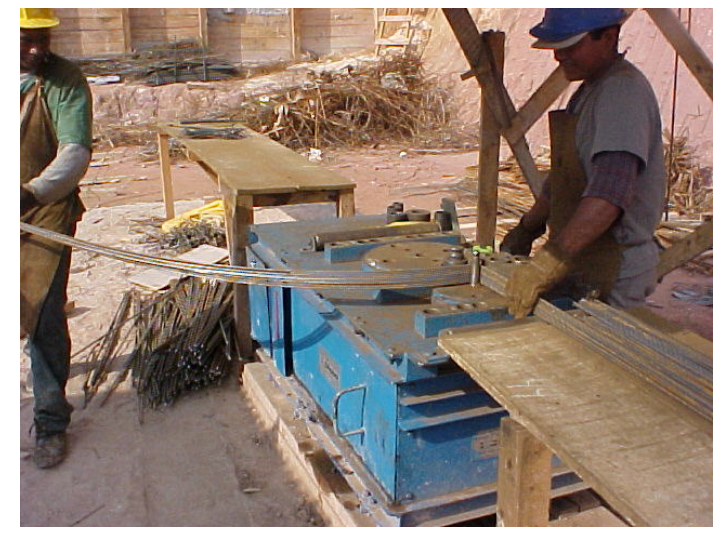

Figura 6.80 - Bancada de dobramento das barras

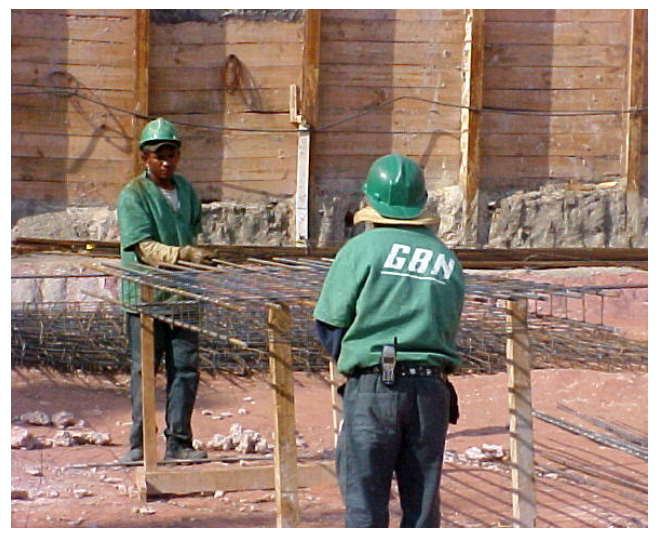

Figura 6.82 - Pré-montagem de armaduras de pilares 


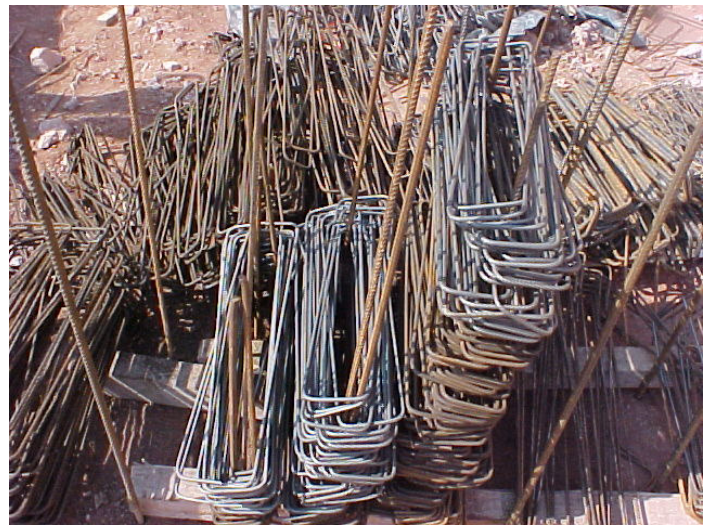

Figura 6.83 - Detalhe do armazenamento de estribos

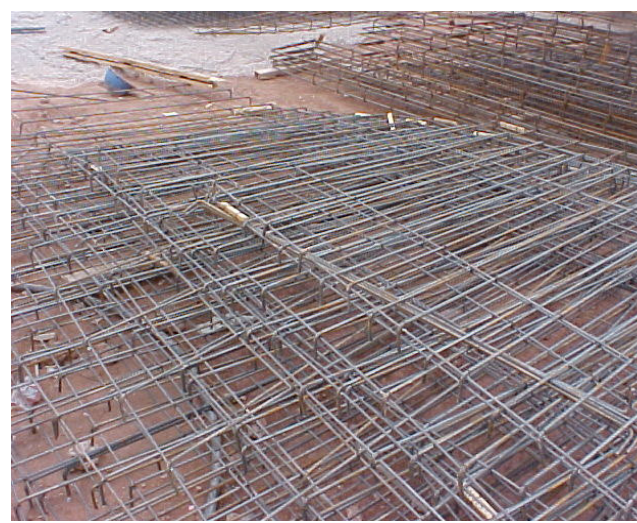

Figura 6.84 - Detalhe das armaduras negativas da laje pré-montadas

A Figura 6.85 ilustra a planta de formas referente ao pavimento tipo da obra SP 307.

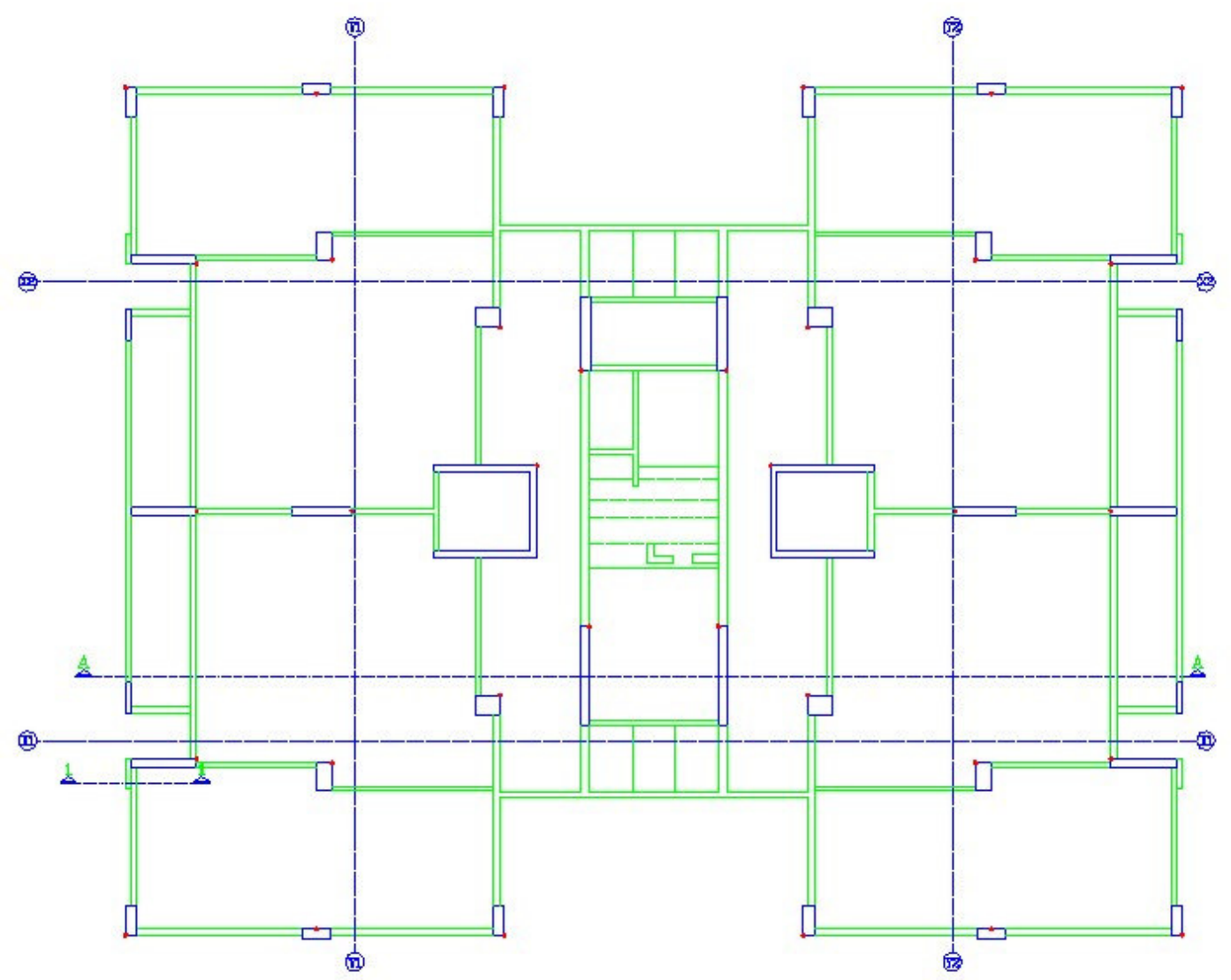

Figura 6.85 - Planta de forma referente ao pavimento tipo da obra SP 307 


\subsubsection{Levantamentos Subjetivos}

Os levantamentos subjetivos remetem diretamente ao produto desta intervenção, que se trata da lista com opiniões do pessoal de obra sobre aspectos relacionados ao projeto do produto, ao método e à organização do trabalho e suas influências sobre a produtividade da mão-de-obra.

\subsubsection{1}

\section{Lista de opiniões de todas as obras}

As opiniões do pessoal de obra (engenheiros, mestres, encarregados, subempreiteiros e operários) quanto aos aspectos relacionados ao projeto do produto e método do trabalho e as respectivas influências (declaradas) sobre a produtividade da mão-de-obra envolvida no processo de produção das armaduras foram colhidas nos sete canteiros de obras. Foram conduzidas entrevistas coletivas, das quais participaram, em cada obra, o engenheiro residente, o responsável pela subempreiteira de estrutura e/ou armação, o mestre de obras e o encarregado de armação. Elaborou-se, previamente, um roteiro para uniformizar e orientar os que versavam sobre os aspectos baseados nas listas de fatores de conteúdo e contexto determinados na primeira etapa do método.

A lista completa com opinião do pessoal de todos os setes canteiros obras sobre aspectos referentes ao projeto do produto e ao método de trabalho é apresentada no Apêndice A desta tese.

O leitor perceberá que a lista de opiniões sobre os aspectos relacionados à organização do trabalho não é contemplada no Apêndice $A$, em razão de que muitos dos questionamentos feitos ao pessoal de obra, no âmbito da organização do trabalho, não alcançaram os propósitos desta intervenção, qual seja, o de expressarem eventuais influências sobre a produtividade da mão-de-obra. Ainda assim foram coletadas dados de grande importância sobre assuntos relacionados à organização. Algumas, com caráter mais objetivo (como, por exemplo, médias salariais), serviram para a determinação de fatores de contexto, sendo apresentadas, portanto, no item que tratou de levantamentos objetivos e que apresentou a descrição da organização do trabalho das obras contempladas.

\subsubsection{Etapa de processamento}

Os produtos dos levantamentos, os indicadores de produtividade e fatores de conteúdo e contexto e a lista com opiniões foram, nesta terceira etapa da aplicação do MPDPro, organizados e processados pela construtora, dando origem, respectivamente, às "tendências" (fruto do processamento e análise dos levantamentos objetivos) e "expectativas" (fruto do processamento e análise dos levantamentos subjetivos) da produção no âmbito do processo de produção de armaduras. Ambas, tendências e expectativas, balizaram o apontamento dos fatores influenciadores da produtividade da mão-de-obra considerados mais relevantes no referido processo.

A determinação das expectativas da produção baseou-se no estabelecimento de "convergências" entre as opiniões (nascidas de avaliações subjetivas) colhidas nas diferentes obras contempladas na aplicação do método. Já a determinação das tendências da produção se deu de maneira mais objetiva, a partir do estabelecimento de correlações entre os indicadores de produtividade da mão-de-obra e fatores a eles associados. Apresentam-se, a seguir, as expectativas e tendências da produção. 


\subsubsection{Apresentação das expectativas da produção}

As expectativas da produção foram determinadas a partir da proposta de "processamento subjetivo" preconizada pelo MPDPro, a partir da lista com opiniões do pessoal de obra apresentada no Apêndice A. A apresentação das expectativas está dividida em três grupos, relacionados, respectivamente, a aspectos ligados ao projeto do produto, ao método e à organização do trabalho. No grupo que se remete ao projeto do produto há, ainda, uma subdivisão; dessa forma, são apresentadas, em separado, as expectativas referentes ao projeto de detalhamento das armaduras de pilares (Tabela 6.22), vigas (Tabela 6.23) e lajes (Tabela 6.24). Uma última tabela, referente a este subgrupo (Tabela 6.25), traz expectativas relacionadas às representações gráficas dos projetos de detalhamento. As Tabela 6.26 e Tabela 6.27 trazem as expectativas relacionas ao método e à organização do trabalho. 
Tabela 6.22 (continua) - Expectativas da produção quanto ao PDA - Pilares

\begin{tabular}{|c|c|c|c|c|c|c|c|}
\hline Aspecto & & Expectativa & $\mathbf{R} \mid \mathbf{E}$ & C & $\mathbf{D} \mid \mathbf{P}$ & $\mathbf{T}$ & M \\
\hline \multirow{4}{*}{$\begin{array}{l}\text { Dimensões, } \\
\text { geometria da } \\
\text { seção e } \\
\text { localização dos } \\
\text { pilares }\end{array}$} & $\rightarrow$ & $\begin{array}{l}\text { - Quando a largura aumenta, o armador tem maiores dificuldades para dar os } \\
\text { pontos na união das barras longitudinais com os arranques (dificuldade em enfiar o } \\
\text { braço). }\end{array}$ & & & & & \\
\hline & & $\begin{array}{l}\text { - Quando o comprimento aumenta, a armadura pré-montada fica mais pesada, o } \\
\text { que dificulta o transporte e posicionamento. Citaram pilares de } 3 \text { metros de largura } \\
\text { como bastante complicados (na pré-montagem, demandam que o armador suba } \\
\text { sobre a gaiola ou entre por baixo; para a movimentação e posicionamento há } \\
\text { dificuldades também). A referência para considerar um pilar com comprimento } \\
\text { "indesejado" é o comprimento do braço do armador (para permitir dar ponto ficando } \\
\text { de um lado só da peça sendo armada). }\end{array}$ & & & & & \\
\hline & & $\begin{array}{l}\text { - Associam seções maiores a maior peso, o que teria o efeito de dificultar a } \\
\text { movimentação e posicionamento da gaiola pré-montada. Citaram preferir } 2 \text { pilares } \\
\text { de } 1 \text { metro que } 1 \text { de } 2 \text { metros (não chamou atenção o fato de ter-se mais peso } \\
\text { "ganho" ao montar o pilar maior); pilar muito grande é muito pesado, obrigando uso } \\
\text { da grua para posicionamento caso haja pré-montagem. }\end{array}$ & & & & & \\
\hline & & $\begin{array}{l}\text { - Pilares com seções retangulares são mais fáceis de pré-montar que pilares com } \\
\text { seção quadrada de mesma área: é mais fácil acessar os locais para dar os pontos de } \\
\text { amarração. }\end{array}$ & & & & & \\
\hline
\end{tabular}

Tabela 6.23 (continuação) - Expectativas da produção quanto ao PDA - Pilares 


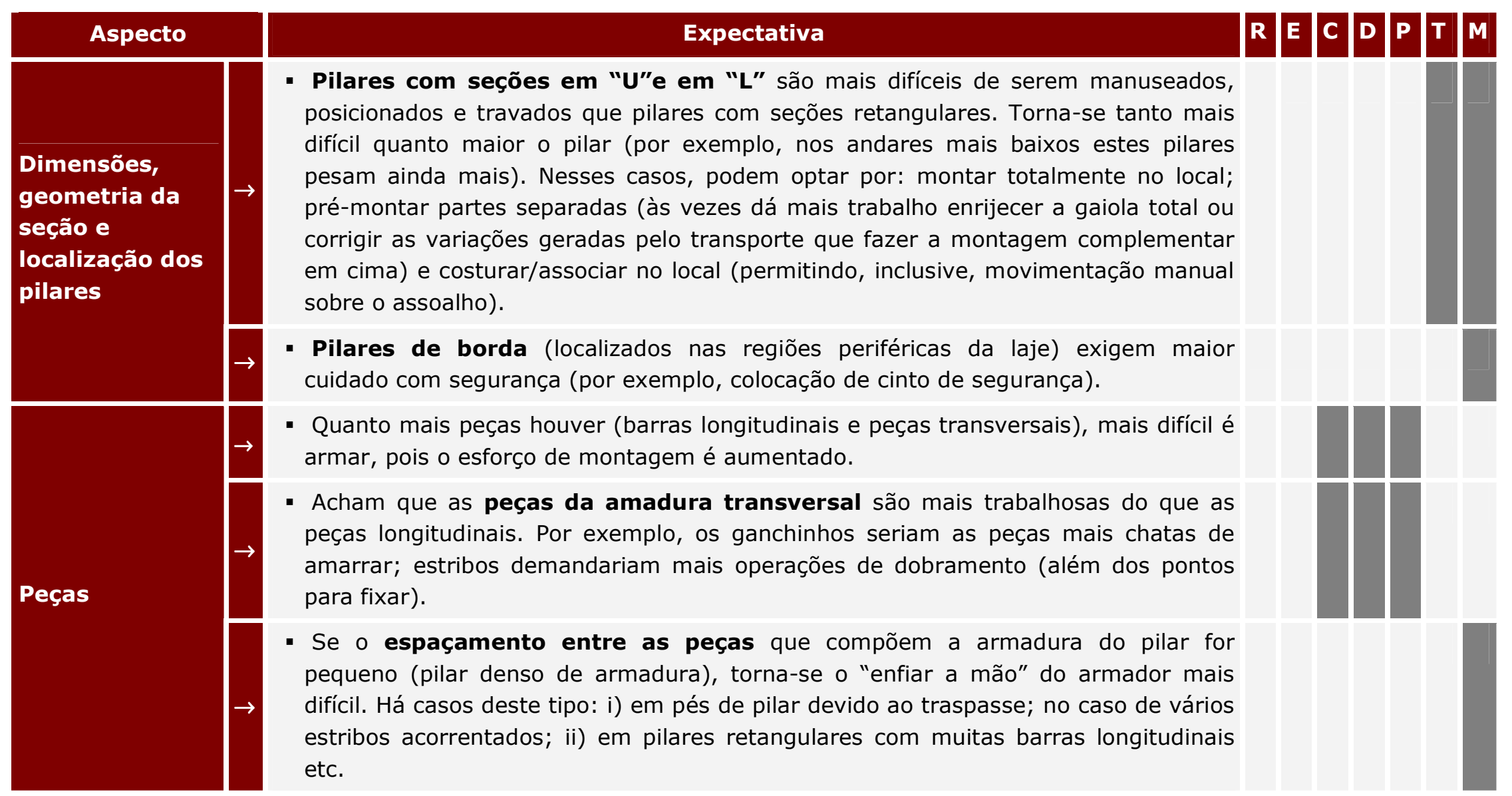


Tabela 6.23 (continuação) - Expectativas da produção quanto ao PDA - Pilares

\begin{tabular}{l|l|l}
\multicolumn{1}{c|}{ Aspecto } & \begin{tabular}{l}
\multicolumn{1}{c}{ Expectativa } \\
- Quanto ao peso da gaiola do pilar, diâmetros maiores tendem a associarem-se a \\
pilares mais pesados e, portanto, mais difíceis de manusear (impedindo, às vezes, \\
pré-montar, devido ao alto peso).
\end{tabular} \\
Diâmetro das \\
peças \\
longitudinais
\end{tabular}$\quad \rightarrow \begin{aligned} & \text { Diâmetros maiores demandam pouco esforço a mais por peça para cortar/dobrar } \\
& \text { (por exemplo, um 16mm demandaria muito pouco esforço a mais por metro que um } \\
& \text { de } 10 \mathrm{~mm} \text { ). }\end{aligned}$
pilares mais pesados e, portanto, mais difíceis de manusear (impedindo, às vezes,

ro das

peças

Diâmetros maiores demandam pouco esforço a mais por peça para cortar/dobrar (por exemplo, um $16 \mathrm{~mm}$ demandaria muito pouco esforço a mais por metro que um $10 \mathrm{~mm}$ )

Diâmetros superiores a $16 \mathrm{~mm}$ trariam a dificuldade de acentuar a falta de espaço Unanimidade em escolher peças com diâmetro de 6,3mm em lugar de $5 \mathrm{~mm}$, por facilitarem algumas operações: as nervuras das barras de 6,3 "ajudam" na dê pontos mais simples e fáceis, impedindo, dessa forma, que o estribo "escorregue"; a chave não encosta no pino ao executar a operação de dobramento; as peças não amassam com tanta ilidade.

O dobramento de estribos de $20 \mathrm{~cm}$ ou de $50 \mathrm{~cm}$ dá o mesmo trabalho (o que

acorrentados. A "galga" da armadura com estribos associados formando uma corrente é muito trabalhosa (tanto na vertical quanto na horizontal de cada camada
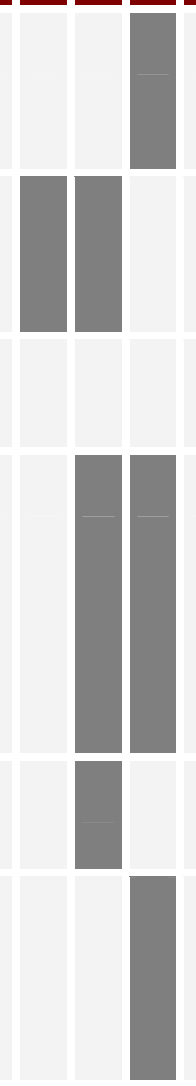
Tabela 6.23 (continuação) - Expectativas da produção quanto ao PDA - Pilares

\begin{tabular}{|c|c|c|c|c|c|c|c|}
\hline Aspecto & & Expectativa & \begin{tabular}{|l|l|}
$\mathbf{R}$ & $\mathbf{E}$
\end{tabular} & $\mathbf{C}$ & D & $\mathbf{P}$ & $\mathbf{T}$ \\
\hline $\begin{array}{l}\text { Tamanho, } \\
\text { diâmetro e } \\
\text { associação das } \\
\text { peças } \\
\text { transversais }\end{array}$ & & $\begin{array}{l}\text { - Ainda que não queiram substituir por estribos acorrentados, a quantidade de } \\
\text { ganchinhos ajuda a definir se um pilar é mais ou menos difícil de ser pré-montado. } \\
\text { É prática comum nos canteiros de obras que as barras aço para a confecção dos } \\
\text { ganchinhos seja buscado, nas pontas que sobraram no corte de outras peças, o que } \\
\text { dificulta o trabalho. Ganchinhos inclinados em pilares quadrados são mais difíceis. }\end{array}$ & & & & & \\
\hline Armadura dupla & & $\begin{array}{l}\text { - É mais difícil trabalhar com a armadura dupla do que com a armadura simples: } \\
\text { mais pesada; dificuldade de estaiá-la; necessidade de prendê-la na hora de alinhar } \\
\text { a viga; maiores cuidados para o tramo superior não sair do lugar durante a } \\
\text { concretagem (neste momento é difícil recolocá-la no lugar). Em pilares com barras } \\
\text { longitudinais de } 12,5 \mathrm{~mm} \text { tudo bem. Quando se trabalha com barras longitudinais } \\
\text { iguais ou superiores a } 20 \mathrm{~mm} \text { os problemas se tornam maiores: gaiola torna-se } \\
\text { muito pesada; os riscos de tombar (segurança) aumentam. Mas o balanço de } \\
\text { esforço ( } 1 \text { dupla } X 2 \text { simples) costuma se mostrar favorável para a dupla. }\end{array}$ & & & & & \\
\hline $\begin{array}{l}\text { Engarrafamento } \\
\text { da armadura } \\
\text { longitudinal }\end{array}$ & $\Rightarrow$ & $\begin{array}{l}\text { - Traz dificuldades; gostariam de evitar. Caso necessário, é melhor fazer o } \\
\text { engarrafamento no local e não na gaiola pré-moldada (difícil dobrar e manter os } \\
\text { ferros no lugar certo. }\end{array}$ & & & & & \\
\hline
\end{tabular}


Tabela 6.23 (continua) - Expectativas da produção quanto ao PDA - Vigas

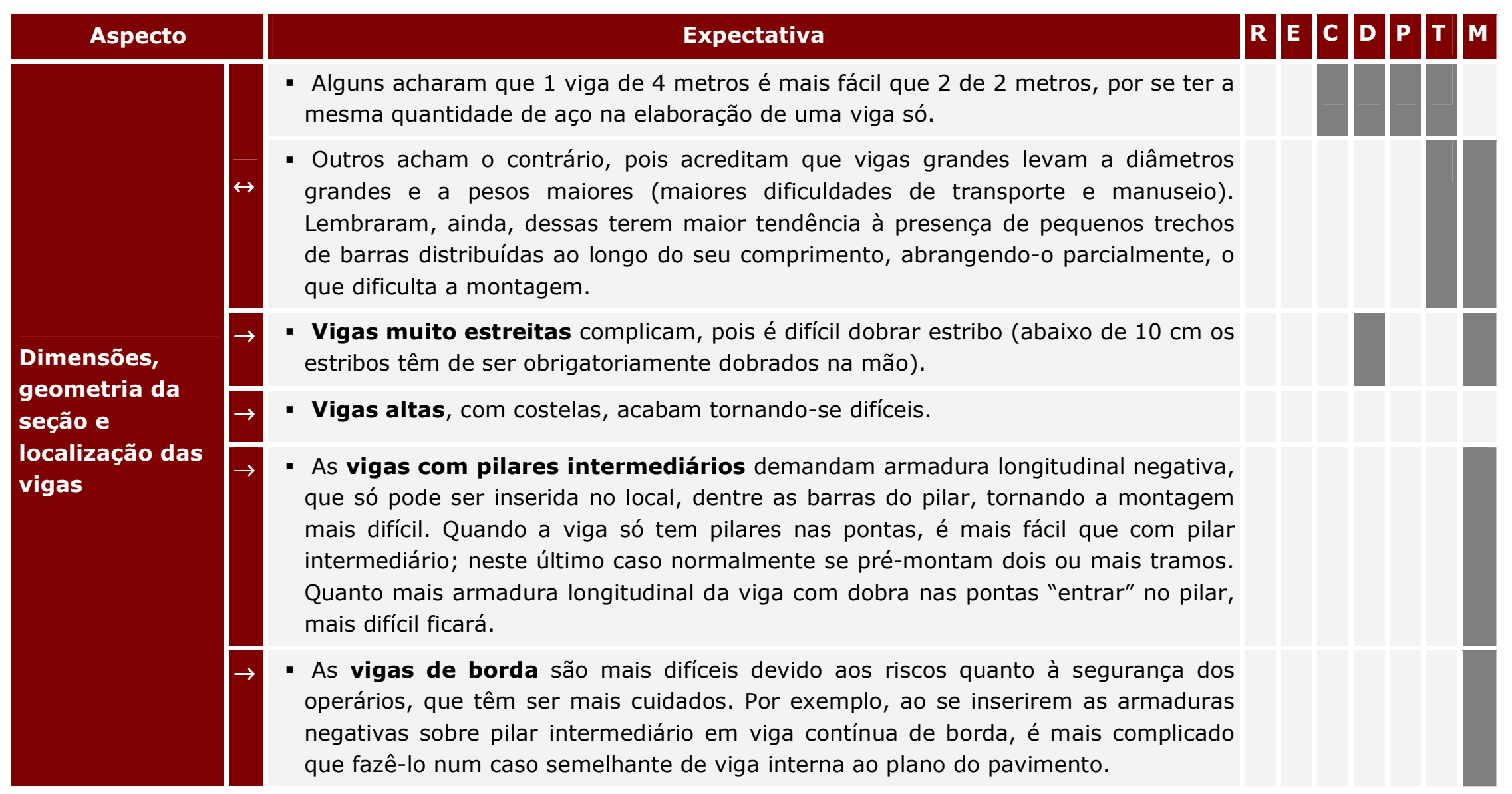


Tabela 6.24 (continuação) - Expectativas da produção quanto ao PDA - Vigas

\begin{tabular}{|c|c|c|c|c|c|c|c|c|}
\hline \multicolumn{2}{|l|}{ Aspecto } & Expectativa & \begin{tabular}{|l|l|l|l}
$\mathbf{R}$ & $\mathbf{E}$
\end{tabular} & C & D & $\mathbf{P}$ & $\mathbf{T}$ & M \\
\hline \multirow{3}{*}{$\begin{array}{l}\text { Dimensões, } \\
\text { geometria da } \\
\text { seção e } \\
\text { localização das } \\
\text { vigas }\end{array}$} & $\rightarrow$ & $\begin{array}{l}\text { - As vigas em balanço são mais difíceis pois, normalmente, aparecem mais barras } \\
\text { longitudinais superiores e costelas. Se houver encontro no topo da viga em balanço } \\
\text { com outra viga em balanço, há necessidade de armadura de reforço, o que traz uma } \\
\text { dificuldade a mais. }\end{array}$ & & & & & & \\
\hline & $\rightarrow$ & $\begin{array}{l}\text { - As vigas curvas são difíceis, pois é preciso "raiar" as peças na central e depois ir } \\
\text { acertando na montagem final. }\end{array}$ & & & & & & \\
\hline & $\rightarrow$ & $\begin{array}{l}\text { - No encontro entre vigas, a presença de "costelas" dificulta o encaixe de outras } \\
\text { vigas. Quando as vigas possuem a mesma altura o encaixe entre elas também fica } \\
\text { mais difícil (é preciso "laçá-las"). }\end{array}$ & & & & & & \\
\hline \multirow{3}{*}{$\begin{array}{l}\text { Disposição das } \\
\text { peças }\end{array}$} & & $\begin{array}{l}\text { - Variação das peças da armadura ao longo de uma viga é algo que dificulta o } \\
\text { serviço; o "ideal" seria ter um só diâmetro de barra longitudinal em cima (vencendo } \\
\text { todo o comprimento), outro embaixo e estribos iguais e igualmente espaçados. }\end{array}$ & & & & & & \\
\hline & & - Quanto maior for o número de peças diferentes por viga, pior será. & & & & & & \\
\hline & $\rightarrow$ & $\begin{array}{l}\text { - Mais de uma camada de barras longitudinais na parte superior da armadura } \\
\text { atrapalha. Dentre outras coisas, acaba dificultando entrada dos ferros da laje. }\end{array}$ & & & & & & \\
\hline
\end{tabular}


Tabela 6.24 (conclusão) - Expectativas da produção quanto PDA - Vigas

\begin{tabular}{|c|c|c|c|c|c|c|c|c|}
\hline Aspecto & & Expectativa & $\mathbf{R}$ & $\mathbf{E}$ & C & $\mathbf{D}$ & $\mathbf{P} \mid \mathbf{T}$ & M \\
\hline & $\leftrightarrow$ & $\begin{array}{l}\text { - Diâmetro das peças maior ou igual a } 6,3 \mathrm{~mm} \text { é melhor: não amassa; não } \\
\text { escorrega. Porém, quando o dobramento é manual, talvez a barra de } 5 \mathrm{~mm} \text { seja } \\
\text { conveniente, por demandar menos esforço do operário. }\end{array}$ & & & & & & \\
\hline $\begin{array}{l}\text { diâmetro e } \\
\text { associação das }\end{array}$ & $\rightarrow$ & $\begin{array}{l}\text { - Diâmetros variáveis numa mesma viga dificulta (pois podem confundir o } \\
\text { armador). }\end{array}$ & & & & & & \\
\hline peças & $\rightarrow$ & - Espaçamento variável dificulta (confunde, exigindo mais atenção). & & & & & & \\
\hline & $\rightarrow$ & $\begin{array}{l}\text { - Estribos acorrentados dificultam bastante a pré-montagem. No caso de } \\
\text { pequenos "L" previstos para serem compostos por dois estribos pequenos, é } \\
\text { preferível pedir ao projetista para prever uma peça só. }\end{array}$ & & & & & & \\
\hline $\begin{array}{l}\text { Formato das } \\
\text { peças } \\
\text { longitudinais }\end{array}$ & $\rightarrow$ & $\begin{array}{l}\text { - Ganchos nas extremidades das barras longitudinais dificultam o encaixe, tanto } \\
\text { em eventuais encontros com pilares quanto com vigas. É preciso levantar a viga } \\
\text { para encaixar por cima; ou deslocar estribos de pilares; ou mesmo cortar estribos; } \\
\text { ou desmontar parcialmente (ou deixar algumas vigas para montar no local). }\end{array}$ & & & & & & \\
\hline & $\rightarrow$ & - Quanto mais furos reforçados mais difícil a armadura. & & & & & & \\
\hline Reforços & $\leftrightarrow$ & $\begin{array}{l}\text { - Dilema quanto ao reforço: colocá-lo na pré-montagem demanda mais cuidado, } \\
\text { tanto no posicionamento na gaiola quanto na montagem final (para não sair do } \\
\text { lugar); colocá-lo após a montagem da viga na fôrma dificulta, pois o espaço para o } \\
\text { acesso fica muito pequeno. Alternativa às vezes usada: montar viga sobre cavalete } \\
\text { sobre a fôrma e aí inserir o reforço antes de baixar a viga para o local final. }\end{array}$ & & & & & & \\
\hline & $\rightarrow$ & $\begin{array}{l}\text { - Parece haver preferência por reforços com segmentos de barras verticais e } \\
\text { horizontais em lugar de diagonais. }\end{array}$ & & & & & & \\
\hline
\end{tabular}


Tabela 6.24 - Expectativas da produção quanto ao PDA - Lajes (+)

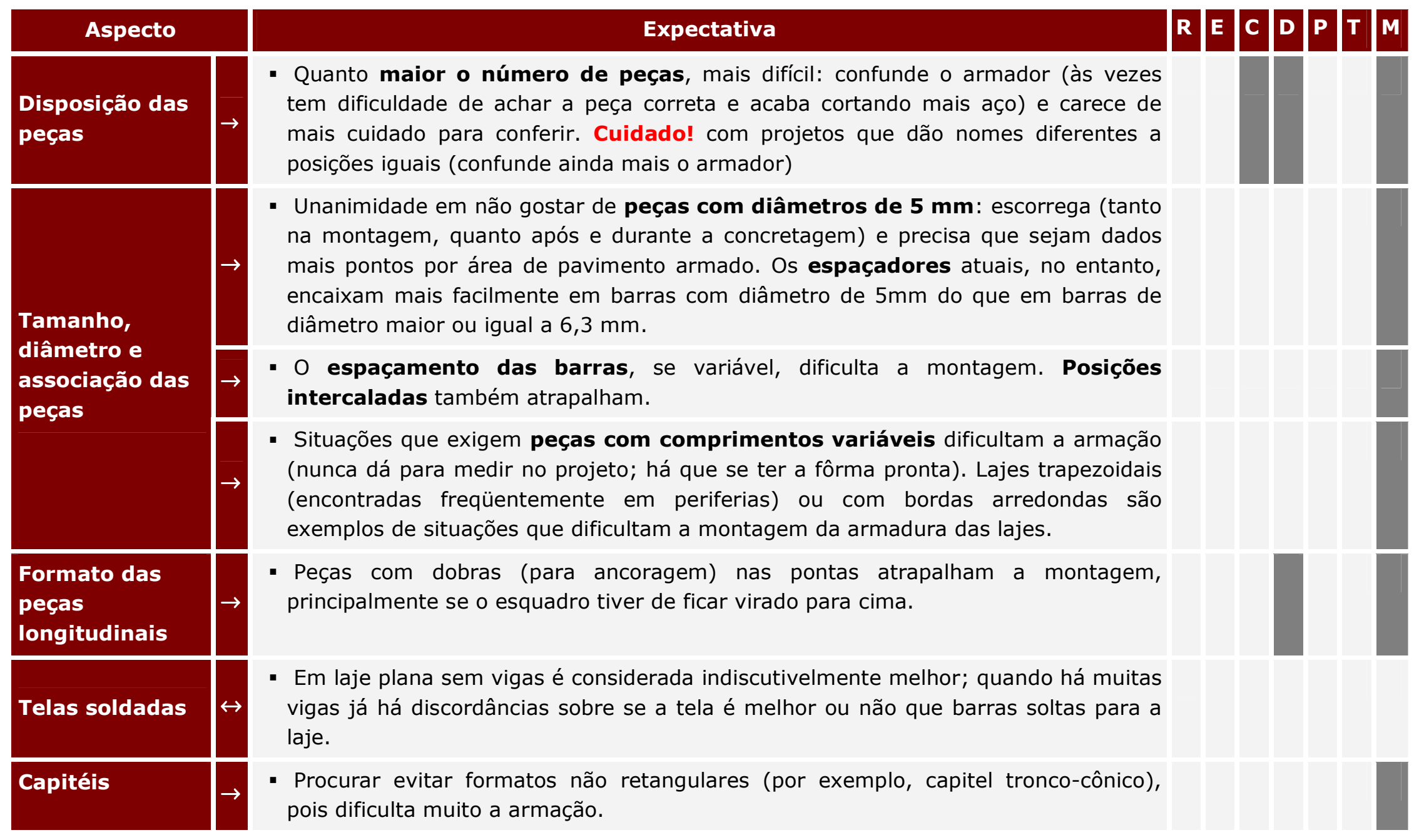


Tabela 6.25 - Expectativas da produção quanto ao PDA - Lajes (-)

\begin{tabular}{|c|c|c|c|c|c|c|c|c|}
\hline Aspecto & & Expectativa & $\mathbf{R}$ & E & D & $\mathbf{P}$ & $\mathbf{T}$ & M \\
\hline $\begin{array}{l}\text { Disposição das } \\
\text { peças }\end{array}$ & $\rightarrow$ & - Quanto maior o número de peças (principalmente peças distintas), pior será. & & & & & & \\
\hline $\begin{array}{l}\text { Tamanho, } \\
\text { diâmetro e }\end{array}$ & $\rightarrow$ & $\begin{array}{l}\text { - Diâmetro ideal para a armadura negativa: } 8 \text { ou } 10 \mathrm{~mm} \text {. Abaixo disso, entorta } \\
\text { facilmente; acima, fica pesado para colocar e puxar para acertar posição na } \\
\text { montagem. }\end{array}$ & & & & & & \\
\hline peças & $\rightarrow$ & $\begin{array}{l}\text { - Situações que exigem peças com comprimento variáveis dificultam a armação. } \\
\text { Variação curvilínea é ainda mais complicada que retilínea. }\end{array}$ & & & & & & \\
\hline & $\rightarrow$ & $\begin{array}{l}\text { - Seu uso é preferido em relação à idéia de fazer dobras no negativo para apoio } \\
\text { sobre o assoalho. }\end{array}$ & & & & & & \\
\hline & $\rightarrow$ & $\begin{array}{l}\text { - Reclamam que é necessária uma quantidade muito grande (principalmente quando } \\
\text { a fiscalização é exigente) e não se valoriza tal esforço. }\end{array}$ & & & & & & \\
\hline cair aingugus & $\rightarrow$ & - Gostam de diâmetro de $10 \mathrm{~mm}$ (não amassa e não é tão difícil de dobrar). & & & & & & \\
\hline & $\leftrightarrow$ & $\begin{array}{l}\text { - Não houve concordância quanto à preferência pelo uso de treliças pré-fabricadas ou } \\
\text { caranguejo: alguns não conhecem; outros preferem o caranguejo, pois pode soltar } \\
\text { os negativos e depois insere o caranguejo por baixo. }\end{array}$ & & & & & & \\
\hline $\begin{array}{l}\text { Comparação } \\
\text { com armadura } \\
\text { positiva }\end{array}$ & $\rightarrow$ & - A armadura negativa é sempre mais difícil & & & & & & \\
\hline Interação com & $\rightarrow$ & - A interação com vigas de varanda é sempre um ponto complexo. & & & & & & \\
\hline viga & $\rightarrow$ & - Peça com formato de "nó de cachorro" é bem complicada. & & & & & & \\
\hline
\end{tabular}



Tabela 6.25 - Expectativas da produção - representações de projeto

\begin{tabular}{|c|c|c|}
\hline Projetc & & Expectativa \\
\hline \multirow{3}{*}{ Laje } & $\rightarrow$ & $\begin{array}{l}\text { - É bom ter } 2 \text { plantas (pois representam duas montagens distintas): } \\
1 \text { para positivos; outra para os negativos das duas direções (separar } \\
\text { os negativos em } 2 \text { plantas - uma para cada direção - complica). }\end{array}$ \\
\hline & & $\begin{array}{l}\text { - É bom ter todas as medidas e quantidades em lugar de indicações } \\
\text { do tipo "a cada 15" (demandam ver a medida da laje) }\end{array}$ \\
\hline & & $\begin{array}{l}\text { - Deve-se representar melhor os caranguejos (não somente com a } \\
\text { indicação de um detalhe geral) }\end{array}$ \\
\hline \multirow{8}{*}{ Viga } & $\rightarrow$ & - Cuidar para ficar claro onde é a esquerda e a direita da viga. \\
\hline & $\rightarrow$ & - Lista de quantitativos por viga é desejável. \\
\hline & $\rightarrow$ & $\begin{array}{l}\text { - Indicar todas as medidas é interessante (por exemplo, para a } \\
\text { posição dos estribos acorrentados na seção transversal em que se } \\
\text { inserem) }\end{array}$ \\
\hline & & $\begin{array}{l}\text { - Trazer a identificação do número total de estribos e não somente } \\
\text { "a cada } 15 \text { ". }\end{array}$ \\
\hline & & $\begin{array}{l}\text { - Indicar claramente onde se inicia a colocação de estribos variáveis } \\
\text { (por tipo ou afastamento). }\end{array}$ \\
\hline & & $\begin{array}{l}\text { - Cuidar melhor das informações sobre barras de comprimento } \\
\text { variáveis, tanto na planta quanto no quantitativo. }\end{array}$ \\
\hline & $\rightarrow$ & $\begin{array}{l}\text { - Seria interessante concentrar as vigas numa planta só para não } \\
\text { confundir; ou cuidar da seqüência e indicação de quais vigas estão } \\
\text { em cada planta, para não dificultar o trabalho do encarregado e } \\
\text { armadores. }\end{array}$ \\
\hline & $\rightarrow$ & - Detalhar melhor (em escalas maiores) o encontro de vigas. \\
\hline Pilar & $\rightarrow$ & - Lista de ferros por pilar é desejável. \\
\hline \multirow{3}{*}{$\begin{array}{l}\text { Projetos } \\
\text { em geral }\end{array}$} & $\rightarrow$ & $\begin{array}{l}\text { - Possuem representações/legendas/etc diferentes, o que obriga os } \\
\text { armadores a conhecerem todo tipo de representação (e, } \\
\text { certamente, provoca confusão). }\end{array}$ \\
\hline & $\rightarrow$ & $\begin{array}{l}\text { - Há muitos erros (nomenclatura de posições, quantitativos etc). } \\
\text { - Procurar usar nomenclatura das peças mais fisicamente ilustrativa } \\
\text { (por exemplo, V201 seria a viga } 01 \text { da torre } 2 \text { ). }\end{array}$ \\
\hline & & $\begin{array}{l}\text { - Procurar avaliar os projetistas pela facilidade de montagem de seu } \\
\text { projeto e não somente pela taxa de armadura. }\end{array}$ \\
\hline
\end{tabular}


Tabela 6.26 (continua) - Expectativas da produção - método de trabalho

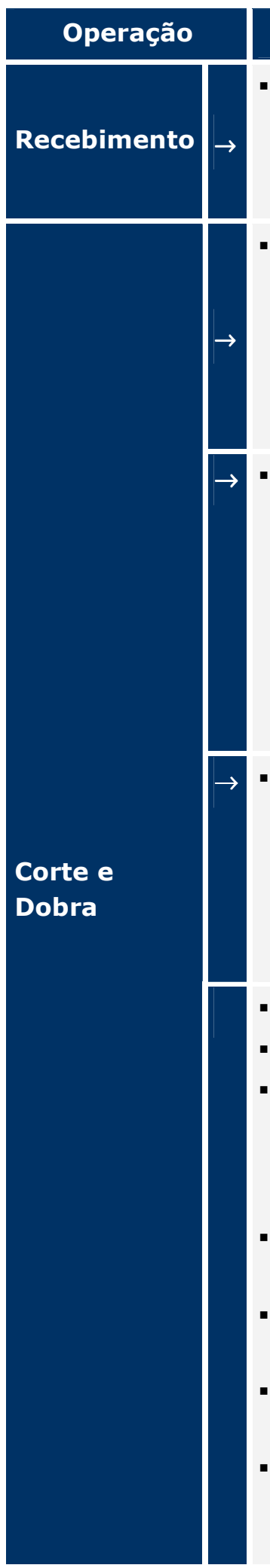

\section{Expectativa}

- Fazer descarregamento direto no local de estocagem principal; ter grua disponível para ajudar neste serviço. Procurar minimizar os caminhos entre o local de descarregamento e estocagem

- Quanto maior o número de diâmetros e posições distintas, mais difícil: no caso de operações manuais, os operários têm de buscar várias vezes no estoque e organizar as operações posição por posição (para não confundir o armador); no caso de máquinas, há que se refazer medidas ou trocar pinos mais vezes.

Quanto ao corte: policorte só serve para diâmetros pequenos e quantidades não muito grandes (é fraca; quebra muito; há risco de segurança); a máquina hidráulica é obrigatória para diâmetros maiores, tendo alguma dificuldade de cortar diâmetros pequenos ("masca"). Às vezes tem-se policorte como garantia para o caso da quebra de máquina hidráulica; ou para ir fazendo periferia quando o tipo é o caminho crítico (para o qual a máquina hidráulica estaria dedicada exclusivamente).

- Quanto ao dobramento: chave é usada para diâmetros e quantidades menores; máquina automática é boa para diâmetros e quantidades maiores, demandando, no entanto, operário treinado (armador que a opera tem de possuir a "manha" para não errar muito nas dobras de estribos, por exemplo).

- Quanto ao uso de aço pronto:

- Houve reclamação geral quanto ao aço pré-cortado/dobrado.

- Na entrega costuma vir faltando algumas posições. Normalmente o tempo disponibilizado para a conferência não é suficiente, o que leva a terem de cortar/dobrar peças faltantes depois.

- Se descobrir erro na hora da montagem, isso torna-se transtorno maior ainda.

- Deslocar um armador da equipe para cortar/dobrar atrapalha a organização do trabalho.

- O recebimento tem de ser feito por armador mais qualificado, pois não é tão fácil assim.

- Demanda muito espaço para estoque e muita organização (para não se confundir ou perder plaquetas de identificação); senão, tem de andar com trena para identificar posições. 
Tabela 6.27 (continuação) - Expectativas da produção quanto ao método de trabalho

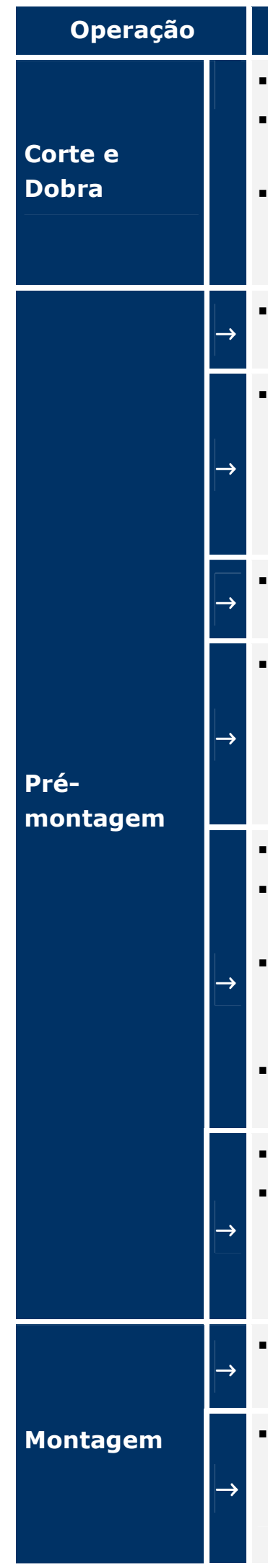

\section{Expectativa}

- Quanto ao uso de aço pronto:

- Se houver erro de projeto, a peça vem conforme o projeto e não conforme a solução real que vai ser dada na obra.

- Fornecedor não tem os macetes de mudar um pouco as dimensões do projeto para tornar as peças cortadas/dobradas mais viáveis de serem montadas.

- Pilares: unanimidade em ser interessante usá-la sempre que possível.

- Vigas: também desejável (deixando-se os reforços sobre pilares para montagem in loco). Dificuldades: quando as vigas são muito pesadas; quando há muitas vigas contínuas com fortes interações com pilares; quando há variação de estribos (quanto ao espaçamento ou ao tipo) ao longo da viga etc.

- Laje+: telas são interessantes para lajes com poucas vigas e sem panos irregulares.

- Laje-: a pré-montagem é desejável, sendo interessante quando tem-se grua e quando o projeto de armação favorece (sem sobreposições de negativos; sem negativos largos demais; etc). Extensões não muito pequenas de negativos iguais favorecem.

- Equipamento de transporte:

- Grua é desejável por facilitar transporte de gaiolas e movimentação de barras do caminhão para o estoque.

- Não gostam de cremalheira nem de mini-grua; acham que os riscos quanto à segurança e o esforço demandado não variam muito adotando-se uma ou outra opção.

- Cremalheira muitas vezes não chega para os primeiros andares, o que obriga o uso da corda, que é terrível.

- Equipamento de transporte:

- Uso de torquês correta, seja em termos de tamanho do cabo e da boca, quanto em termos de procedências de bom fornecedor (variam bastante a resistência do aço adotado, a capacidade de corte e a durabilidade).

- Viga: observar a posição correta da viga (tanto quanto às suas extremidades, com em relação à parte de cima e de baixo).

- Laje: quanto menor o diâmetro das barras, maior a demanda por pontos. Barras lisas ( $5 \mathrm{~mm}$ ) demandam maior quantidade e cuidado nos pontos. 
Tabela 6.27 (conclusão) - Expectativas da produção quanto ao método de trabalho

\begin{tabular}{|c|c|c|}
\hline \multicolumn{2}{|l|}{ Operação } & Expectativa \\
\hline & & $\begin{array}{l}\text { - Seqüência adequada de operação na montagem no } \\
\text { pavimento: primeiro as vigas que se apóiam somente em } \\
\text { pilares; depois as vigas que se apóiam em vigas (muitas vezes } \\
\text { há que se encaixar por cima); fazer conferência de viga antes } \\
\text { de montar laje (pois se detectar erro na viga após montar laje, } \\
\text { a correção fica muito mais difícil) etc. }\end{array}$ \\
\hline Montagem & & $\begin{array}{l}\text { - Interação com fôrmas: } \\
\text { - Pilares: preferem montar (tanto quando usam gaiola, mas } \\
\text { principalmente para o caso de montagem total "in loco") tendo } \\
\text { pelo menos o fundo da fôrma já montado, pois esse serve de } \\
\text { apoio para a armadura. } \\
\text { Viga: preferem que a caixa da viga já esteja pronta, para } \\
\text { evitar retrabalho posterior de armação. }\end{array}$ \\
\hline
\end{tabular}

Tabela 6.27 (continua) - Expectativas da produção - organização do trabalho

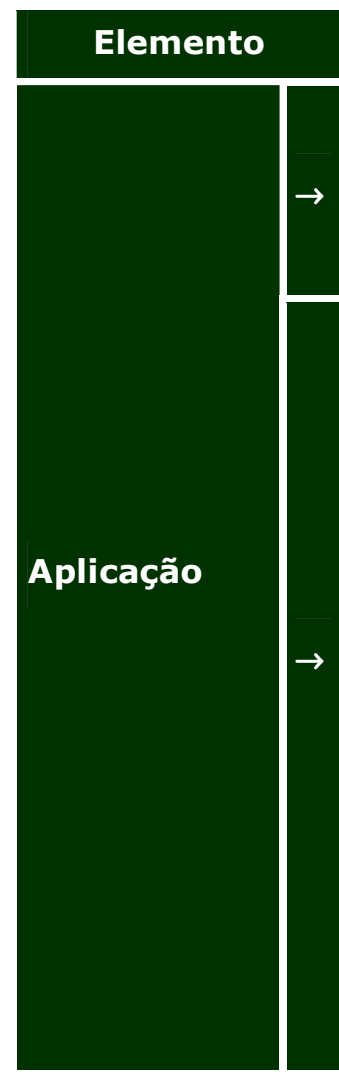

\section{Expectativa}

\section{Dimensionamento da equipe:}

- Há encarregados que começam com um número de armadores um pouco acima do que imaginam ser necessário e vão cortando até enxugar a equipe.

\section{$\checkmark$ Alocação da equipe:}

- É comum uma obra emprestar armadores de (e para) outras obras. Neste caso, uma certa antecedência na programação da troca é interessante para conseguir programar o transporte e a alocação do operário, para não desperdiçar mão-de-obra.

- É usual separem pessoal de corte/dobra do pessoal de prémontagem e montagem final.

- Costumam-se alocar pares (1 ou mais, em função da demanda de corte e dobra) armador-ajudante; se for um par único, este fará o corte e a dobra; quando existem 2 pares, pode-se pôr um no corte e outro na dobra.

- É bom ter na pré-montagem pelo menos um armador experiente, que daria dicas de como não dificultar o trabalho posterior de montagem final das gaiolas sendo compostas. 
Tabela 6.42 (continuação) - Expectativas da produção quanto à organização do trabalho

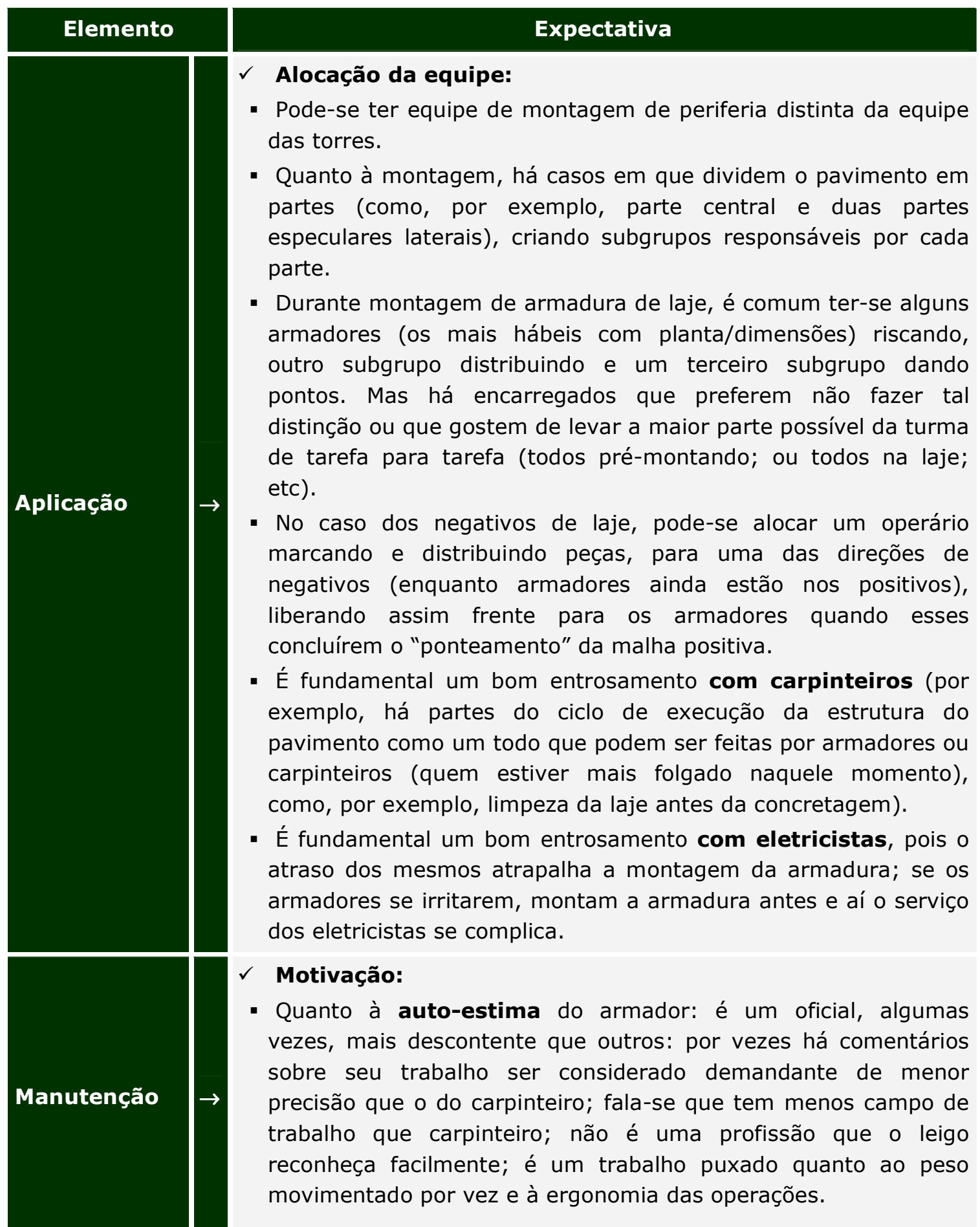


Tabela 6.42 (conclusão) - Expectativas da produção quanto à organização do trabalho

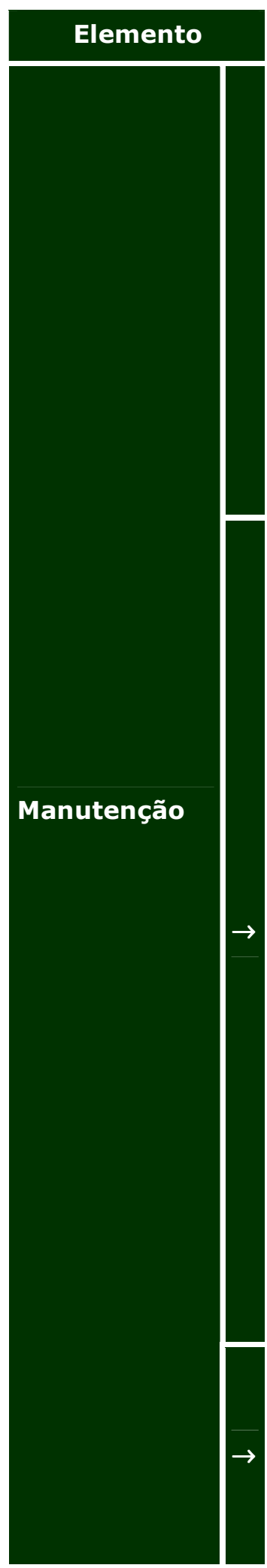

Expectativa

$\checkmark$ Motivação:

- Os incentivos dados aos armadores são diferentes nas porções repetitivas da obra em relação às porções não repetitivas. É comum que as tarefas sejam combinadas após a primeira repetição.

- As tarefas podem ser de diferentes formatos: dar um valor por laje; ou não fixar valor por laje. No que se refere a um valor por laje: pode ser um valor fixo em reais (normalmente considera-se um valor fixo mensal relativo a um certo número de pavimentos; pode-se transformar $o$ valor mensal em um valor por pavimento); pode dar um número de horas por laje, que serão descontadas das horas reais demandadas

\section{$\checkmark$ Aditivos salariais:}

- Outras posturas (alguns encarregados não gostam de dar tarefa por andar tipo em obras onde a equipe vá se envolver com partes não-tipo, para poder mais facilmente deslocá-los de um lugar para outro ou mesmo conseguir ocupar produtivamente horas que sobram em alguns dias durante aa produção de andares-tipo) podem ser: pagar horas extras; pagar horas prêmio para certas porções acabarem num certo prazo; etc.

- Procuram não ter ganhos mensais, fruto de tarefas globais, muito diferentes entre obras, para não ter armadores querendo mudar de obra da própria empresa.

- Na periferia, o uso de prêmios definidos caso a caso parece ser mais predominante. O acabou-lavou acaba sendo usado para permitir que o operário possa ir mais cedo para casa às custas de uma produtividade desejada.

- O acabou-lavou pode ser interessante (complementarmente a outras posturas de incentivo; ou mesmo por si só) em dias críticos para o cumprimento do ciclo do andar (por exemplo, armar vigas e laje + após concretagem de pilares).

- Para caso dos pavimentos do edifício acima dos pavimentos tipo, procuram criar mecanismos para que o operário continue com uma remuneração não muito inferior à que tinha no tipo.

\section{$\checkmark$ Benefícios:}

- Ter política de "ajudar o armador quando ele precisa" normalmente leva à recíproca como verdadeira.

- Tentar minimizar o tempo gasto no transporte casa-trabalhocasa parece ser um ponto importante de se investir. 


\subsubsection{Apresentação das tendências da produção}

As tendências da produção foram obtidas a partir da proposta de "processamento objetivo" preconizado pelo MPDPro. Para isso, são determinados os "índices de avaliação" do projeto, do método e da organização do trabalho. Tais índices serão, posteriormente, correlacionados aos indicadores de produtividade da mão-de-obra (RUP potencial), buscando-se evidenciar as influências do projeto, método e organização sobre a produtividade, caracterizando as tendências da produção.

\subsubsection{1}

Determinação dos Índices de Avaliação do PDA - IAP

Os IAP foram determinados separadamente para pilares, vigas e lajes. Como já comentado no capítulo cinco, os fatores foram "ranqueados" quanto o tipo de influência causada. Para o conjunto de sete obras contempladas no estudo de caso, os fatores mais próximos ao extremo relacionado à influência positiva receberam a nota "1"; os fatores com valores situados no extremo oposto receberam a nota "7". Conseqüentemente, os valores intermediários receberam notas que variaram de 2 a 6 . Para pilares, vigas e lajes foram contemplados 14, 13 e 14 fatores respectivamente. Assim, uma obra que detivesse nota igual a "14" para pilares, por exemplo, teria um IAPp igual a 100 (máxima avaliação positiva); a pior avaliação, nesse caso, seria uma nota "98", com um IAPp igual a zero.

As Tabela 6.28, Tabela 6.29 e Tabela 6.30 apresentam os IAP para pilares, vigas e lajes, respectivamente. Nestas tabelas, são mostrados os valores de cada fator, por obra, bem como a nota atribuída em relação ao seu posicionamento frente aos dados do conjunto de obras, que permitiu a determinação dos IAP. 

Tabela 6.28 - Determinação do IAP - pilares

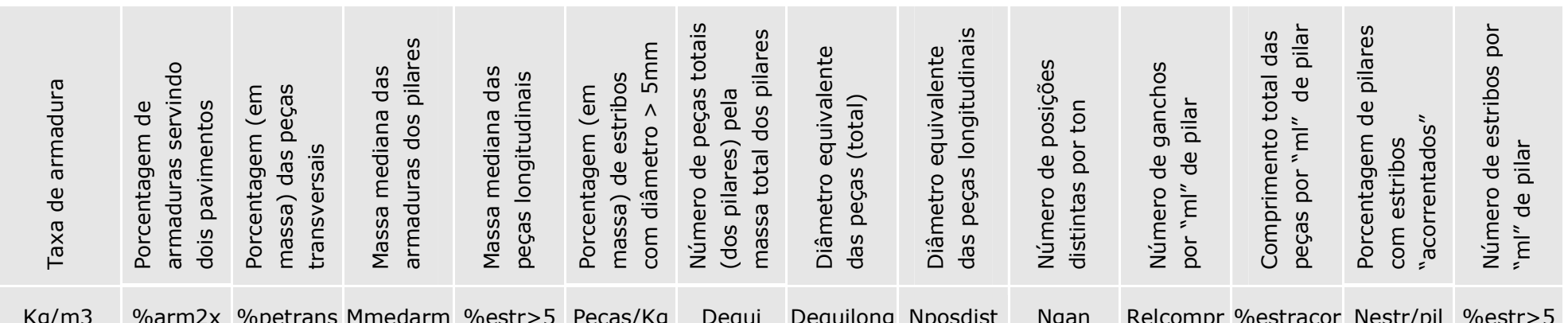

\begin{tabular}{|c|c|c|c|c|c|c|c|c|c|c|c|c|c|c|c|c|c|c|c|c|c|c|c|c|c|c|c|c|c|c|}
\hline \multicolumn{2}{|c|}{ OBRA } & \multirow{2}{*}{$\begin{array}{c}\text { IAPp } \\
39\end{array}$} & \multicolumn{2}{|c|}{$<+(;)$} & \multicolumn{2}{|c|}{$<$ (*) } & \multicolumn{2}{|c|}{$<+()$} & \multicolumn{2}{|c|}{$<+(-)$} & \multicolumn{2}{|c|}{$<$ < } & \multicolumn{2}{|c|}{$<$ (*) } & \multicolumn{2}{|c|}{$<\theta$} & \multicolumn{2}{|c|}{$<+()$} & \multicolumn{2}{|c|}{$<$ (8) } & \multicolumn{2}{|c|}{$<$ (:) } & \multicolumn{2}{|c|}{$<$ (2) } & \multicolumn{2}{|c|}{$<$ (e) } & \multicolumn{2}{|c|}{$<+(-)$} & \multicolumn{2}{|c|}{$<+()$} \\
\hline SP 301 & $8^{\circ}$ de 11 & & 1,2 & 5 & 0 & 1 & 9,1 & 4 & 65 & , & 2,3 & 6 & 0 & 4 & 2,32 & 3 & 7,6 & 6 & 11,1 & $\Gamma$ & 13,2 & 6 & 20,0 & 2 & 51,9 & & 87 & 6 & 14,2 & 5 \\
\hline SP 302 & $7^{\circ}$ de 1 & 56 & 3,9 & 1 & 0 & 1 & 1,2 & 5 & 43 & 1 & 2,3 & 6 & 32 & 2 & 2,79 & $\epsilon$ & 7,8 & 5 & 10,7 & 6 & 25,1 & 7 & 33,4 & 4 & 37,0 & & 0 & 1 & 5,1 & 1 \\
\hline 303 & 1 & 39 & & 6 & 100 & 5 & $y^{\prime}$ & 3 & 91 & 4 & 5,9 & 2 & 0 & 4 & 1,60 & 3 & 8,4 & 4 & 12,7 & J & 6,4 & 3 & 46,0 & 6 & 57,4 & 5 & 100 & 7 & 19,2 & 7 \\
\hline 304 & e & 60 & 3,6 & 3 & 0 & 1 & 6,1 & 3 & 82 & 3 & 3,2 & 5 & 0 & 4 & 1,44 & 3 & 9,3 & 3 & 12,4 & 4 & 11,5 & 5 & 44,3 & 5 & 44,3 & 3 & 15 & 3 & 7,6 & 3 \\
\hline 305 & $20^{\circ} \mathrm{de}$ & $4 !$ & 7,1 & 4 & 100 & 5 & $; 0$ & 6 & 62 & 7 & 5 & 3 & 100 & 1 & 1,78 & 4 & 8,9 & 3 & 13,1 & 2 & 4,7 & 1 & 26,9 & 3 & 63,5 & 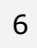 & 72 & 5 & 13,9 & 4 \\
\hline SP 306 & $22^{\circ}$ de 25 & 19 & 67,7 & 2 & 100 & 5 & 36,4 & 7 & 116 & 6 & 3,7 & 4 & 10 & 3 & 3,13 & 7 & 7,1 & 7 & 10,2 & 7 & 6,7 & 4 & 56,3 & 7 & 83,3 & 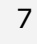 & 45 & 4 & 15,4 & 6 \\
\hline 307 & de 2 & , & 18,2 & 7 & 0 & 1 & 10,1 & 1 & 1 & 5 & 0 & 1 & 0 & 4 & 0,85 & 1 & 11,8 & 1 & 16,9 & 1 & 6,2 & 2 & 19,2 & 1 & 42,3 & 2 & 0 & 1 & 6,2 & 2 \\
\hline
\end{tabular}


Tabela 6.29 - Determinação do IAP - vigas

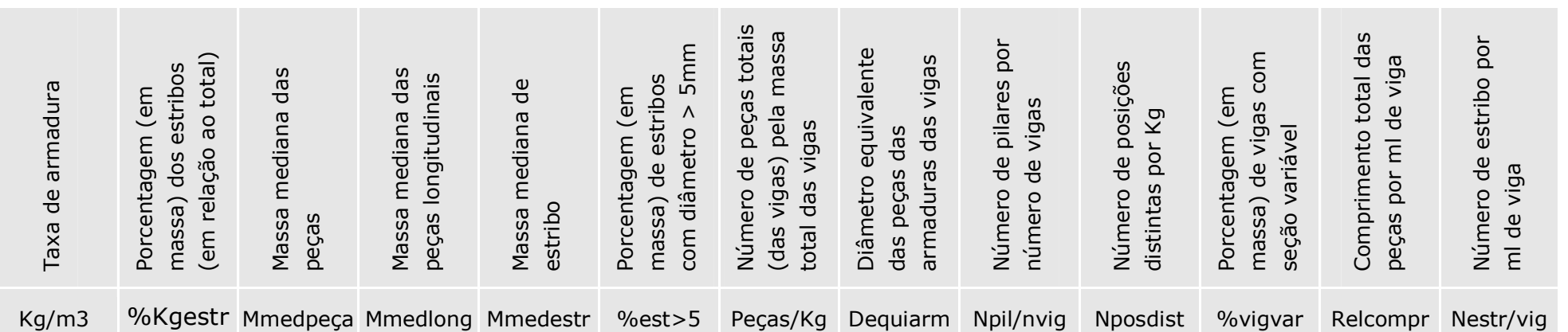

\begin{tabular}{|c|c|c|c|c|c|c|c|c|c|c|c|c|c|c|c|c|c|c|c|c|c|c|c|c|c|c|c|c|}
\hline \multicolumn{2}{|c|}{ OBRA } & \multirow{2}{*}{$\begin{array}{c}\text { IAPv } \\
36\end{array}$} & \multicolumn{2}{|c|}{$<$ (2) } & \multicolumn{2}{|c|}{$<$ (-) } & \multicolumn{2}{|c|}{$<$ (:) } & \multicolumn{2}{|c|}{$<$ (8) } & \multicolumn{2}{|c|}{$<$ (*) } & \multicolumn{2}{|c|}{$<$ (:) } & \multicolumn{2}{|c|}{$<\theta$} & \multicolumn{2}{|c|}{$<+$} & \multicolumn{2}{|c|}{$<$ (:) } & \multicolumn{2}{|c|}{$<$ (:) } & \multicolumn{2}{|c|}{$<+$} & \multicolumn{2}{|c|}{$<+(;)$} & \multicolumn{2}{|c|}{$<$ (;) } \\
\hline SP 301 & 2 & & 106,2 & 1 & 24,3 & 5 & 1,23 & 3 & 1,87 & 4 & 0,20 & 5 & 59,4 & 6 & 1,03 & 6 & 8,93 & 6 & 1,62 & 7 & 0,07 & 6 & 16,7 & 5 & 16,6 & 4 & 6,65 & 5 \\
\hline SP 302 & 2 & 56 & 121,0 & 3 & 14,8 & 3 & 1,05 & 5 & 1,43 & 6 & 0,21 & 4 & 69,5 & 3 & 0,81 & 3 & 10,1 & 3 & 0,61 & 1 & 0,06 & 3 & 18,0 & 6 & 19,1 & 6 & 6,07 & 2 \\
\hline SP 303 & 3 & 73 & 176,8 & 5 & 12,5 & 1 & 3,12 & 1 & 5,44 & 1 & 0,21 & 6 & 61,0 & 5 & 0,58 & 1 & 12,0 & 1 & 0,94 & 5 & 0,03 & 2 & 5,9 & 3 & 14,6 & 1 & 6,09 & 3 \\
\hline SP 304 & 4 & 47 & 151,8 & 4 & 21,6 & 4 & 1,01 & 6 & 1,61 & 5 & 0,27 & 3 & 63,8 & 4 & 0,83 & 4 & 9,5 & 5 & 0,77 & 3 & 0,06 & 5 & 12,5 & 4 & 14,7 & 2 & 8,54 & 6 \\
\hline SP 306 & 6 & 61 & 110,0 & 2 & 25,4 & 6 & 1,09 & 4 & 2,50 & 3 & 0,32 & 2 & 77,8 & 2 & 0,91 & 5 & 9,63 & 4 & 0,84 & 4 & 0,06 & 4 & 4,6 & 2 & 15,4 & 3 & 6,09 & 3 \\
\hline SP 307 & 7 & 83 & 190,2 & 1 & 12,7 & 2 & 2,40 & 2 & 4,85 & 3 & 0,33 & 1 & 78,7 & 1 & 0,59 & 2 & 11,4 & 2 & 0,72 & 2 & 0,03 & 1 & 4,3 & 1 & 16,8 & 5 & 5,59 & 1 \\
\hline
\end{tabular}


Tabela 6.30 - Determinação IAP - lajes






\subsection{Determinação dos Índices de Avaliação do Método de \\ Trabalho - IAM}

Determinou-se, para cada uma das sete obras, um Índice de Avaliação do Método de Trabalho (IAM). Como previsto pelo MPDPro, foram determinados, preliminarmente, IAM parciais para as obras, referentes a cada uma das operações contempladas no método de trabalho: descarregamento, estocagem, corte, dobra, pré-montagem e montagem.

A Tabela 5.12 traz os IAM parciais para as sete obras contempladas nos estudos de caso. As notas atribuídas a cada uma dos fatores (" 1 " para boas práticas (influência positiva); "0,5" para práticas intermediárias; " 0 " para más práticas (influência negativa)), foram somadas e relacionadas a uma situação de referência ${ }^{134}$, o que permitiu a determinação dos IAM parciais. Para a operação de recebimento, por exemplo, como foram seis os fatores contemplados, a melhor nota que poderia ser atribuída à obra seria "6"; essa nota, quando relacionada à situação de referência, levaria a um IAM parcial igual a 100 (máxima avaliação positiva).

Para a obtenção do IAM "global", os IAM parciais foram somados, ponderando-se os pesos $^{135}$ atribuídos a cada operação. A Tabela 5.13 traz um resumo dos IAM parciais e o IAM para cada uma das sete obras.

\footnotetext{
${ }^{134} \mathrm{Na}$ situação de referência todos os fatores relacionados às operações foram considerados capazes de influenciar positivamente a produtividade da mão-de-obra (às operações foram atribuídas, portanto, as notas máximas).

135 O peso foi determinado em função do nível de esforço despendido pela mão-de-obra a cada operação. As operações de pré-montagem e montagem têm os maiores pesos porque para as obras analisadas, a maior parte do esforço estava ali concentrado.
} 
Tabela 6.31 (continua) - Determinação dos IAM parciais

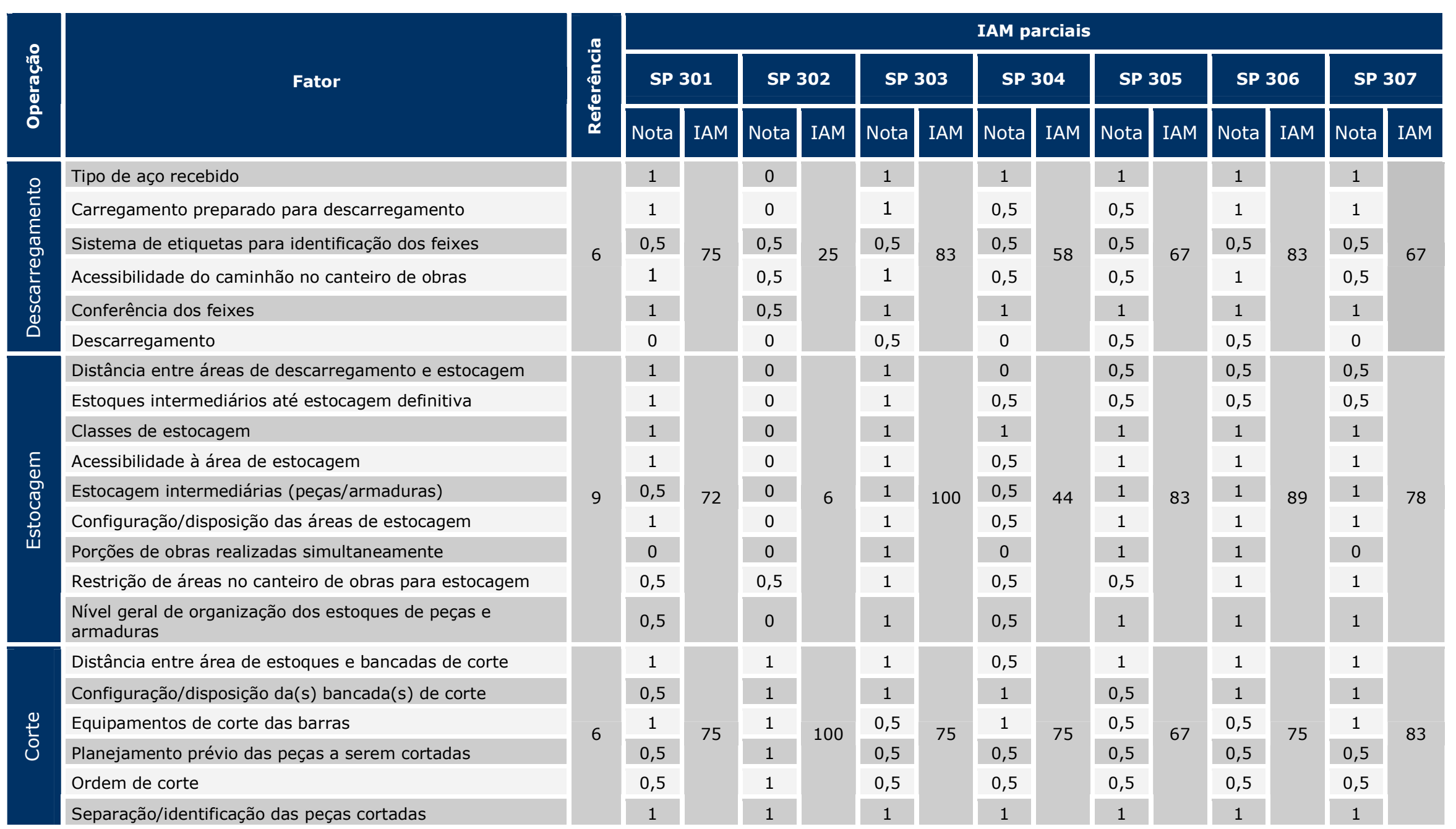


Tabela 6.32 (conclusão) - Determinação dos IAM parciais

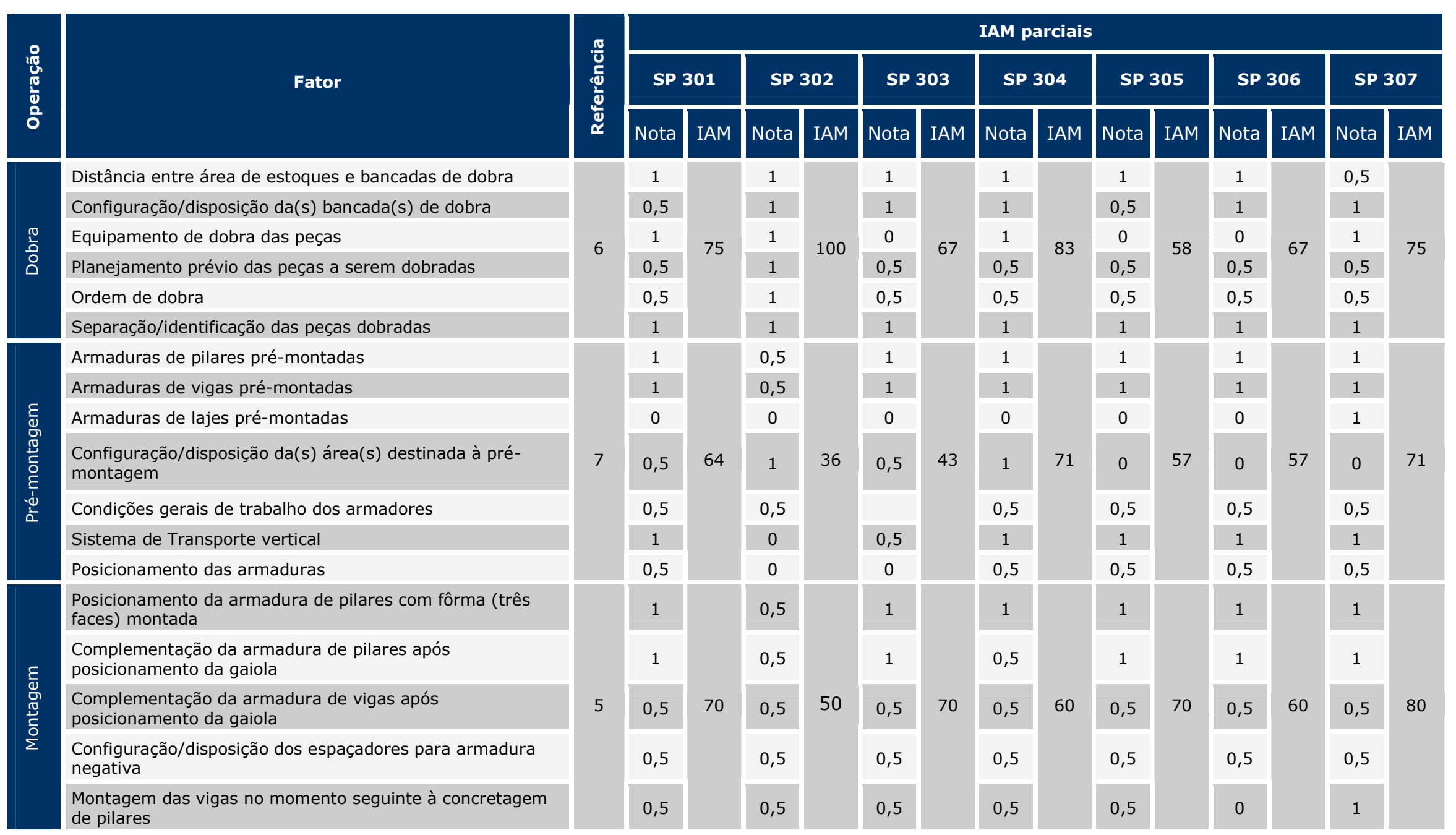


Tabela 6.32 - Determinação do IAM

\begin{tabular}{|c|c|c|c|c|c|c|c|c|c|c|c|c|c|}
\hline \multirow{3}{*}{ Obra } & \multicolumn{13}{|c|}{ IAM - Método } \\
\hline & \multicolumn{2}{|c|}{$\begin{array}{c}\text { Descarrega- } \\
\text { mento }\end{array}$} & \multicolumn{2}{|c|}{ Estocagem } & \multicolumn{2}{|c|}{ Corte } & \multicolumn{2}{|c|}{ Dobra } & \multicolumn{2}{|c|}{$\begin{array}{c}\text { Pré- } \\
\text { montagem }\end{array}$} & \multicolumn{2}{|c|}{ Montagem } & \multirow{2}{*}{$\begin{array}{l}\text { MÉTODO } \\
\text { IAM }\end{array}$} \\
\hline & Peso & IAM & Peso & IAM & Peso & IAM & Peso & IAM & Peso & IAM & Peso & IAM & \\
\hline SP 301 & \multirow{7}{*}{1} & 75 & \multirow{7}{*}{1} & 72 & \multirow{7}{*}{1} & 75 & \multirow{7}{*}{1} & 75 & \multirow{7}{*}{3} & 79 & \multirow{7}{*}{3} & 80 & 77 \\
\hline SP 302 & & 25 & & 6 & & 100 & & 100 & & 36 & & 50 & 49 \\
\hline SP 303 & & 83 & & 100 & & 75 & & 67 & & 43 & & 70 & 66 \\
\hline SP 304 & & 58 & & 44 & & 75 & & 83 & & 71 & & 60 & 66 \\
\hline SP 305 & & 67 & & 83 & & 67 & & 58 & & 57 & & 70 & 66 \\
\hline SP 306 & & 83 & & 89 & & 75 & & 67 & & 57 & & 60 & 67 \\
\hline SP 307 & & 67 & & 78 & & 83 & & 75 & & 71 & & 80 & 76 \\
\hline
\end{tabular}

\subsection{Determinação dos Índices de Avaliação da Organização do Trabalho - IAO}

Os Índices de Avaliação da Organização do Trabalho (IAO) foram determinados de maneira análoga aos IAM. Assim, foram obtidos, preliminarmente, IAO parciais para cada um dos elementos preconizados pela organização do trabalho.

A Tabela 6.33 traz os IAO parciais para as sete obras contempladas nos estudos de caso. As notas atribuídas a cada uma dos fatores ("1" para boas práticas (influência positiva); "0" para más práticas (influência negativa)), foram somadas e relacionadas a uma situação de referência ${ }^{136}$, o que permitiu a determinação dos IAO parciais. Para o elemento "aplicação", por exemplo, como foram seis os fatores contemplados, a melhor nota que poderia ser atribuída à obra seria "6"; essa nota, quando relacionada à situação de referência levaria a um IAO parcial igual a 100 (máxima avaliação positiva).

Para a obtenção do IAO "global", os IAO parciais foram somados, ponderando-se os pesos $^{137}$ atribuído a cada elemento. A Tabela 6.34 traz um resumo dos IAO parciais e o IAO para cada uma das sete obras.

\footnotetext{
${ }^{136} \mathrm{Na}$ situação de referência todos os fatores relacionados aos elementos foram considerados capazes de influenciar positivamente a produtividade da mão-de-obra.

137 O peso foi determinado em função da representatividade (grau de importância) de cada elemento, declarada pelo pessoal de obra durante os levantamentos qualitativos.
} 

Tabela 6.33 - Determinação dos IAO parciais

\begin{tabular}{|c|c|c|c|c|c|c|c|c|c|c|c|c|c|c|c|c|}
\hline \multirow{3}{*}{ 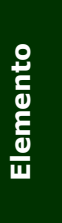 } & \multirow{3}{*}{ Fator } & \multirow{3}{*}{$\begin{array}{l}\frac{\pi}{0} \\
\frac{50}{0} \\
\frac{d}{0} \\
\frac{0}{0}\end{array}$} & \multicolumn{14}{|c|}{ IAO parciais } \\
\hline & & & \multicolumn{2}{|c|}{ SP 301} & \multicolumn{2}{|c|}{ SP 302} & \multicolumn{2}{|c|}{ SP 303} & \multicolumn{2}{|c|}{ SP 304} & \multicolumn{2}{|c|}{ SP 305} & \multicolumn{2}{|c|}{ SP 306} & \multicolumn{2}{|c|}{ SP 307} \\
\hline & & & Nota & IAO & Nota & IAO & Nota & IAO & Nota & IAO & Nota & IAO & Nota & IAO & Nota & IAO \\
\hline \multirow{3}{*}{ 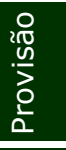 } & Regime de contratação & \multirow{3}{*}{3} & 1 & \multirow{3}{*}{100} & 1 & \multirow{3}{*}{100} & 1 & \multirow{3}{*}{100} & 1 & \multirow{3}{*}{100} & 1 & \multirow{3}{*}{100} & 1 & \multirow{3}{*}{100} & 1 & \multirow{3}{*}{100} \\
\hline & Experiência profissional & & 1 & & 1 & & 1 & & 1 & & 1 & & 1 & & 1 & \\
\hline & Política de contratação & & 1 & & 1 & & 1 & & 1 & & 1 & & 1 & & 1 & \\
\hline \multirow{4}{*}{ 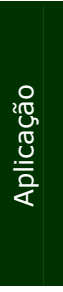 } & Alocação das equipes 2 & \multirow{4}{*}{6} & 0 & \multirow{4}{*}{33} & 0 & \multirow{4}{*}{33} & 0 & \multirow{4}{*}{33} & 1 & \multirow{4}{*}{50} & 0 & \multirow{4}{*}{33} & 0 & \multirow{4}{*}{17} & 0 & \multirow{4}{*}{33} \\
\hline & Jornada de trabalho diária 1 & & 0 & & 0 & & 1 & & 0 & & 1 & & 0 & & 0 & \\
\hline & Jornada de trabalho semanal 2 & & 1 & & 1 & & 1 & & 1 & & 1 & & 1 & & 1 & \\
\hline & Alocação dos operários & & 0 & & 0 & & 0 & & 0 & & 0 & & 0 & & 0 & \\
\hline 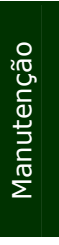 & Aditivos salariais & & 0 & & 0 & & 1 & & 1 & & 1 & & 1 & & 0 & \\
\hline$\frac{1}{0}$ & Leitura e interpretação de projetos & & 0 & & 1 & & 0 & & 1 & & 0 & & 1 & & 0 & \\
\hline în & Programas de reciclagem profissional & 3 & 0 & 0 & 0 & 33 & 0 & 0 & 0 & 33 & 0 & 0 & 0 & 33 & 0 & 0 \\
\hline ă & Profissionalização & & 0 & & 0 & & 0 & & 0 & & 0 & & 0 & & 0 & \\
\hline 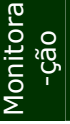 & Apontamento dos operários & 1 & 0 & 0 & 0 & 0 & 0 & 0 & 0 & 0 & 0 & 0 & 0 & 0 & 0 & 0 \\
\hline
\end{tabular}


Tabela 6.34 - Determinação do IAO

\begin{tabular}{|c|c|c|c|c|c|c|c|c|c|c|c|}
\hline \multirow{3}{*}{ Obra } & \multicolumn{11}{|c|}{ IAO } \\
\hline & \multicolumn{2}{|c|}{ Provisão } & \multicolumn{2}{|c|}{ Aplicação } & \multicolumn{2}{|c|}{$\begin{array}{c}\text { Manuten- } \\
\text { ção }\end{array}$} & \multicolumn{2}{|c|}{$\begin{array}{c}\text { Desenvolvi- } \\
\text { mento }\end{array}$} & \multicolumn{2}{|c|}{$\begin{array}{c}\text { Monitora- } \\
\text { ção }\end{array}$} & \multirow{2}{*}{$\begin{array}{c}\text { Organização } \\
\text { IAO }\end{array}$} \\
\hline & Peso & IAO & Peso & IAO & Peso & IAO & Peso & IAO & Peso & IAO & \\
\hline SP 301 & \multirow{7}{*}{3} & 100 & \multirow{7}{*}{4} & 33 & \multirow{7}{*}{5} & 20 & \multirow{7}{*}{3} & 0 & \multirow{7}{*}{3} & 0 & 30 \\
\hline SP 302 & & 100 & & 33 & & 60 & & 33 & & 0 & 46 \\
\hline SP 303 & & 100 & & 33 & & 80 & & 0 & & 0 & 46 \\
\hline SP 304 & & 100 & & 50 & & 100 & & 33 & & 0 & 61 \\
\hline SP 305 & & 100 & & 33 & & 60 & & 0 & & 0 & 41 \\
\hline SP 306 & & 100 & & 17 & & 80 & & 33 & & 0 & 48 \\
\hline SP 307 & & 100 & & 33 & & 60 & & 0 & & 0 & 41 \\
\hline
\end{tabular}

6.3.6.2.4

Determinação das tendências da produção

Para a determinação das tendências da produção (relacionados ao PDA) e dos desempenhos do método e da organização do trabalho para o conjunto de obras considerado, foram seguidas as orientações preconizadas pelo MPDPro, apresentadas no capítulo anterior.

A Tabela 5.15 trata-se de uma tabela para detecção de tendências (TDT), num primeiro nível (informações sintetizadas). Apresenta os valores das RUPpot das tarefas, bem como os IAP por tarefa, os IAM e os IAO das sete obras contempladas na aplicação piloto do MPDpro. A última linha da Tabela supracitada apresenta as variações percentuais dos indicadores de produtividade e índices de avaliação para o conjunto de obras. A análise dessas variações tratou-se do primeiro "exercício" realizado para a busca das tendências da produção. Chegou-se, através dela, às seguintes constatações:

$\checkmark$ percebe-se significativa variabilidade dos indicadores de produtividade da mão-deobra $^{138}$ (225\%, 214\% e 193\%, respectivamente, para as RUPpot de pilares, vigas e lajes), evidenciando a problemática que suscitou o desenvolvimento desse trabalho;

$\checkmark$ as variações detectadas nos índices de avaliação do PDA foram altas (314\%, 118\% e $408 \%$, respectivamente para pilares, vigas e lajes), mostrando-se bastante superiores às variações do IAM (53\%) e IAO (106), que ainda assim mostraram-se também significativas.

Como já vislumbrado na apresentação do MPDPro no capítulo anterior, ao se analisar o PDA para o conjunto de obras contempladas nessa aplicação piloto, verificou-se que:

$\checkmark \quad$ os índices de avaliação do projeto PDA (os IAP) apresentaram as maiores variações;

$\checkmark$ os IAP, seja pela alta variação detectada, seja pelas correlações estabelecidas com os indicadores de produtividade (RUP), mostraram-se como os potencialmente mais

138 O Apêndice B traz uma tabela com todas as RUP (cíclicas, potencias e cumulativas) determinadas durante a etapa de levantamento de dados para o conjunto de obras contempladas na aplicação do MPDPro. 
influentes (quando comparados aos índices de avaliação do método e da organização do trabalho (IAM e IAO), respectivamente).

Tabela 6.35 - TDT com nível de detalhamento "1".

\begin{tabular}{|l|c|c|c|c|c|c|c|c|}
\hline \multirow{2}{*}{ Obra } & \multicolumn{3}{|c|}{ RUP pot } & \multicolumn{3}{c|}{ PDA } & Método & Organização \\
\hline & pilar & viga & laje & IAPp & IAPV & IAPI & IAM & IAO \\
\hline SP 301 & 64 & 61 & 52 & 39 & 36 & 31 & 77 & 30 \\
\hline SP 302 & 103 & 66 & 27 & 56 & 56 & 56 & 49 & 46 \\
\hline SP 303 & 67 & 32 & 17 & 39 & 73 & 88 & 66 & 46 \\
\hline SP 304 & 43 & 55 & 16 & 60 & 47 & 68 & 66 & 61 \\
\hline SP 305 & 42 & 47 & 52 & 49 & - & - & 66 & 41 \\
\hline SP 306 & 44 & 34 & 28 & 19 & 61 & 17 & 67 & 48 \\
\hline SP 307 & 35 & 21 & 8 & 77 & 78 & 41 & 76 & 41 \\
\hline Variação & 193 & 214 & 225 & 314 & 118 & 408 & 48 & 106 \\
\hline
\end{tabular}

Assim é que, para se avaliar a influência de diversas posturas do PDA, fez-se uma análise mais aprofundada quanto aos resultados obtidos das obras. Vale lembrar que os IAM e IAO serão contemplados nas análises dos IAP com o intuito de poder-se ponderar eventuais efeitos dos mesmos sobre condições mais ou menos favoráveis dos fatores que compõem o IAP. Acredita-se que a influência dos fatores relacionados aos IAM e IAP, em algumas situações, possa mascarar influências dos fatores que compõem os IAP.

Antes, porém, de se passar às discussões no âmbito do PDA, fez-se a análise dos desempenhos obtidos pelo método e pela organização do trabalho para o conjunto de obras consideradas.

Foram analisados, portanto, os desempenhos dos IAM e IAO e de seus respectivos fatores, evidenciando-se níveis de desempenho distintos entre eles nas obras consideradas (no momento da proposição de diretrizes, as operações/elementos com desempenhos inferiores ao valor médio deverão, conseqüentemente, ser priorizados).

A Tabela 6.36 traz os valores de IAM obtidos pelas obras, bem como o desempenho obtido pela construtora em cada uma das operações e fatores associados ao método de trabalho. O bom desempenho do IAM chamou atenção, evidenciando relativa eficiência do método de trabalho no conjunto de obras analisadas. Com exceção da obra SP 302, todas as demais apresentaram IAM superiores a $66 \%$. A variação do IAM foi a menor dentre os índices de avaliação determinados (48\%).

A observação individual dos fatores permitiu, através dos desempenhos atribuídos a eles, identificar, por exemplo, que a operação de descarregamento, apesar de ter um bom desempenho, apresentou deficiência nos sistemas de identificação dos feixes de aço recebidos pela obra, bem como na maneira como o carregamento foi feito pelas obras (manualmente, na maioria das obras).

De maneira geral, pode-se dizer que o método de trabalho do processo de produção e concepção das armaduras (PCPA) no conjunto de obras estudado encontrou-se bem 
definido, com a maioria das operações compreendidas dentro daquilo que se definiu como "boas práticas". Porém, o baixo desempenho obtido pela obra SP 302, que foi a única a trabalhar com aço fornecido à obra cortado e dobrado, deu evidências de que as operações preconizadas pelo método de trabalho, em obras que optam por trabalhar com - "aço pronto", precisam se adequar às diferenças intrínsecas a esse tipo de fornecimento, principalmente aquelas relacionadas às operações de descarregamento e estocagem do aço no canteiro de obras.

A Tabela 6.37 traz os valores de IAO obtidos pelas obras, bem como o desempenho obtido pela construtora em cada um dos elementos e fatores associados à organização do trabalho. O mau desempenho do IAO chamou atenção, evidenciando relativa ineficiência na organização do trabalho no conjunto de obras analisadas (desempenho médio de $45 \%$ ). Com exceção da obra SP 304 , todas as demais obras apresentaram IAO inferiores a $50 \%$.

A observação individual dos fatores permitiu, através dos desempenhos atribuídos a eles, identificar, por exemplo, que os elementos "aplicação", "desenvolvimento" e "monitoração" mostram-se abaixo de um valor médio, evidenciando deficiências organizacionais no conjunto de obras analisadas. A observação individual dos fatores permitiu, através dos desempenhos atribuídos a eles, identificar, por exemplo, que o elemento "manutenção", apesar de ter um bom desempenho, apresentou deficiência no que diz respeito às práticas motivacionais encontradas nas obras.

A deteç̧ão de valores baixos para o IAO mostra à construtora que cuidados relativos à organização do trabalho deveriam ser priorizados, a começar pelo trabalho com os gestores (da mão-de-obra própria ou da mão-de-obra subempreitada), que deveriam ser treinados na percepção e no aumento de sua capacidade para implementar boas práticas de gestão. 
Tabela 6.36 (continua) - Desempenho do método de trabalho

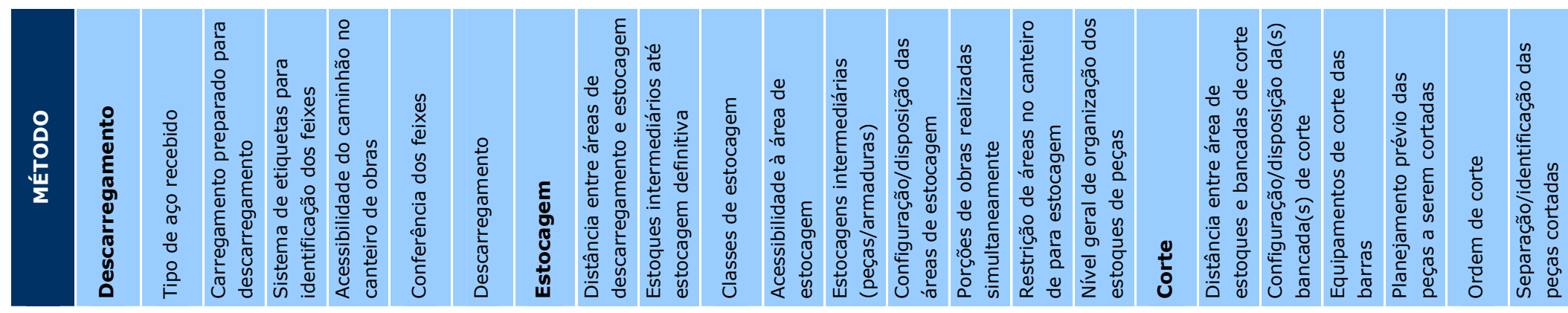

\begin{tabular}{|c|c|c|c|c|c|c|c|c|c|c|c|c|c|c|c|c|c|c|c|c|c|c|c|c|c|}
\hline Obra & IAM & IAM & & & & & & & IAM & & & & & & & & & & IAM & & & & & & \\
\hline SP 302 & 49 & 25 & 0 & 0 & 0,5 & 0,5 & 0,5 & 0 & 6 & 0 & 0 & 0 & 0 & 0 & 0 & 0 & 0,5 & 0 & 100 & 1 & 1 & 1 & 1 & 1 & 1 \\
\hline SP 304 & 66 & 58 & 1 & 0,5 & 0,5 & 0,5 & 1 & 0 & 44 & 0 & 0,5 & 1 & 0,5 & 0,5 & 0,5 & 0 & 0,5 & 0,5 & 75 & 0,5 & 1 & 1 & 0,5 & 0,5 & 1 \\
\hline SP 305 & 66 & 67 & 1 & 0,5 & 0,5 & 0,5 & 1 & 0,5 & 83 & 0,5 & 0,5 & 1 & 1 & 1 & 1 & 1 & 0,5 & 1 & 67 & 1 & 0,5 & 0,5 & 0,5 & 0,5 & 1 \\
\hline SP 306 & 67 & 83 & 1 & 1 & 0,5 & 1 & 1 & 0,5 & 89 & 0,5 & 0,5 & 1 & 1 & 1 & 1 & 1 & 1 & 1 & 75 & 1 & 1 & 0,5 & 0,5 & 0,5 & 1 \\
\hline Desempenho & 67 & 65 & 86 & 71 & 50 & 71 & 93 & 21 & 67 & 50 & 57 & 86 & 79 & 71 & 79 & 43 & 71 & 71 & 79 & 93 & 86 & 79 & 57 & 57 & 93 \\
\hline
\end{tabular}




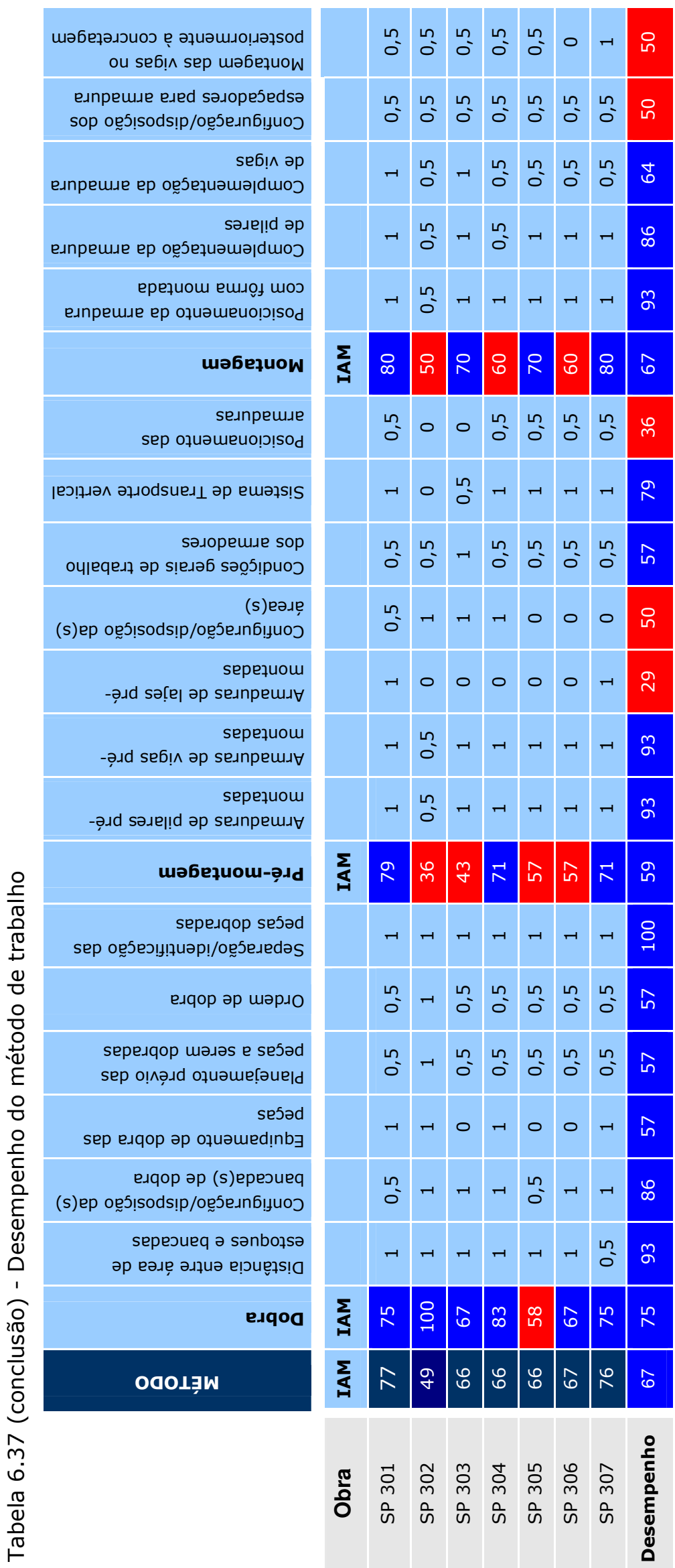


Tabela 6.37 - Desempenho da organização do trabalho

\begin{tabular}{|c|c|c|c|c|c|c|c|c|c|c|c|c|c|c|c|c|c|c|c|c|c|c|c|c|}
\hline & 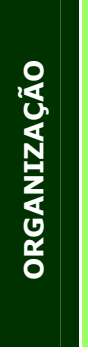 & $\begin{array}{l}0 \\
2 \pi \\
\frac{20}{3} \\
0 \\
0\end{array}$ & 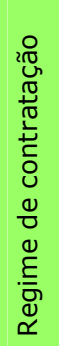 & 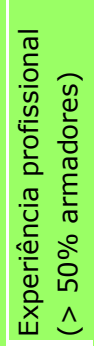 & 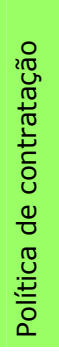 & 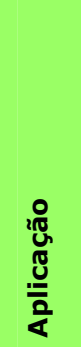 & 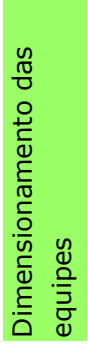 & 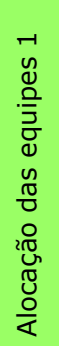 & 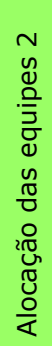 & 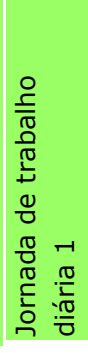 & 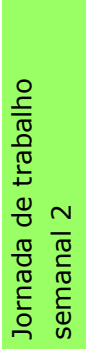 & 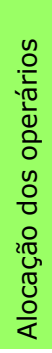 & 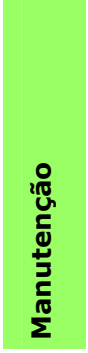 & 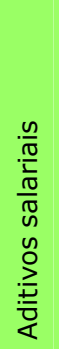 & 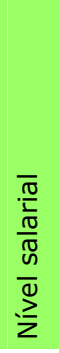 & 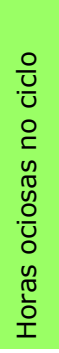 & 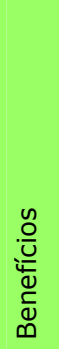 & 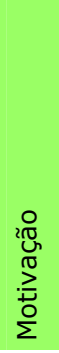 & 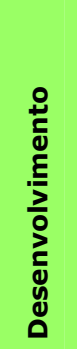 & 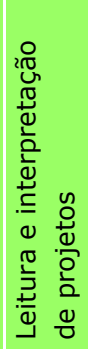 & 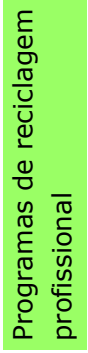 & 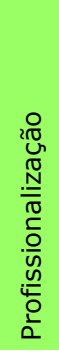 & 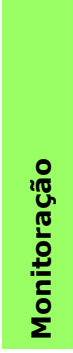 & 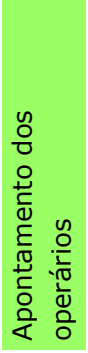 \\
\hline Obra & IAO & IAO & & & & IAO & & & & & & & IAO & & & & & & IAO & & & & IAO & \\
\hline SP 301 & 30 & 100 & 1 & 1 & 1 & 33 & 0 & 1 & 0 & 1 & 1 & 0 & 20 & 0 & 1 & 1 & 0 & 0 & 0 & 0 & 0 & 0 & 0 & 0 \\
\hline SP 305 & 41 & 100 & 1 & 1 & 1 & 33 & 0 & 0 & 0 & 1 & 1 & 0 & 60 & 1 & 0 & 1 & 1 & 0 & 0 & 0 & 0 & 0 & 0 & 0 \\
\hline SP 307 & 41 & 100 & 1 & 1 & 1 & 33 & 0 & 1 & 0 & 0 & 1 & 0 & 60 & 0 & 1 & 0 & 1 & 1 & 0 & 0 & 0 & 0 & 0 & 0 \\
\hline SP 302 & 46 & 100 & 1 & 1 & 1 & 33 & 0 & 1 & 0 & 0 & 1 & 0 & 60 & 0 & 1 & 1 & 1 & 0 & 33 & 1 & 0 & 0 & 0 & 0 \\
\hline SP 303 & 46 & 100 & 1 & 1 & 1 & 33 & 0 & 0 & 0 & 1 & 1 & 0 & 80 & 1 & 1 & 0 & 1 & 1 & 0 & 0 & 0 & 0 & 0 & 0 \\
\hline SP 306 & 48 & 100 & 1 & 1 & 1 & 17 & 0 & 0 & 0 & 0 & 1 & 0 & 80 & 1 & 1 & 0 & 1 & 1 & 33 & 1 & 0 & 0 & 0 & 0 \\
\hline SP 304 & 61 & 100 & 1 & 1 & 1 & 50 & 0 & 1 & 0 & 0 & 1 & 0 & 100 & 1 & 1 & 1 & 1 & 0 & 33 & 1 & 0 & 0 & 0 & 0 \\
\hline Desempenho & 45 & 100 & 100 & 100 & 100 & 33 & 0 & 57 & 0 & 43 & 100 & 0 & 66 & 57 & 86 & 57 & 86 & 43 & 14 & 43 & 0 & 0 & 0 & 0 \\
\hline
\end{tabular}



A partir deste momento, as análises focaram, por razões apresentadas anteriormente, o PDA, sendo conduzidas de maneira analítica e, portanto, em separado para as tarefas de pilares, vigas e lajes. Como as RUPpot e os IAP referentes à laje evidenciaram a maior variação, priorizou-se que as análises fossem iniciadas pela já citada tarefa.

A Tabela 5.15 foi reorganizada originando a Tabela 5.16, que apresentou as seguintes particularidades: i) ordenamento das obras em função das RUPpot da laje, que foram dispostas em ordem decrescente; ii) ranqueamento das RUPpot e dos IAPlaje, IAM e IAO; iii) acréscimo de informações como o menor, o maior e o valor mediano dos dados apresentados, identificados com cores e símbolos. Observe-se que a obra SP 305 foi suprimida da Tabela 5.16 e, por conseguinte, das análises, devido a sua laje diferir "tecnologiamente ${ }^{139 "}$ das lajes das demais obras.

Tabela 6.38 - TDT com nível de detalhamento "1" para laje

\begin{tabular}{|c|c|c|c|c|c|c|c|c|}
\hline \multirow{3}{*}{$\begin{array}{l}\text { Obra } \\
\text { SP } 304\end{array}$} & \multirow{2}{*}{\multicolumn{2}{|c|}{$\begin{array}{c}\text { RUP pot }(\mathbf{H h} / \mathbf{t}) \\
\text { laje }\end{array}$}} & \multicolumn{2}{|c|}{ PDA } & \multicolumn{2}{|c|}{ Método } & \multicolumn{2}{|c|}{ Organização } \\
\hline & & & \multicolumn{2}{|c|}{ IAPI } & \multicolumn{2}{|c|}{ IAM } & \multicolumn{2}{|c|}{ IAO } \\
\hline & 16 & 1 & 68 & 2 & 66 & 4 & 61 & 1 \\
\hline SP 303 & 17 & 2 & 88 & 1 & 66 & 4 & 46 & 3 \\
\hline SP 302 & 27 & 3 & 56 & 3 & 36 & 6 & 46 & 3 \\
\hline SP 306 & 28 & 4 & 17 & 6 & 67 & 3 & 48 & 2 \\
\hline SP 307 & 38 & 5 & 41 & 4 & 76 & 2 & 41 & 5 \\
\hline SP 301 & 52 & 6 & 31 & 5 & 77 & 1 & 30 & 6 \\
\hline Menor & 16 & (-) & 17 & (8) & 36 & (2) & 30 & (8) \\
\hline Maior & 52 & (2) & 88 & () & 77 & () & 61 & () \\
\hline Mediano & 28 & $\odot$ & 49 & $\Theta$ & 66 & () & 46 & (-) \\
\hline
\end{tabular}

A análise dos dados dispostos na Tabela 5.16 chama a atenção para os seguintes pontos: i) as obras com as melhores RUPpot apresentaram, também, os melhores IAPI, evidenciando correlação; ii) na medida em que se considera que bons valores de IAM e IAO são desejáveis para melhorar a produtividade, cabe sua observação conjunta com os fatores que determinam o IAP para melhor elucidação da provável força de cada um deles

A Tabela 5.17 trata-se de uma TDT como um nível de detalhamento mais alto (nível dois). Nela as seis obras foram dispostas, também, em função do ordenamento crescente das RUPpot de laje. Os fatores "ranqueados" que originaram o IAPI das lajes são apresentados novamente, sendo que sua análise isolada permite detectar o seu posicionamento e eventual influência sobre a produtividade. A idéia (com limitações do ponto de vista estatístico) é a de buscarem-se prováveis correlações através da análise da variação de cada fator individualmente e da correspondente variação da RUP. Onde tal observação for positiva, assume-se a existência de uma "tendência" a influenciar a

${ }^{139}$ A laje da obra SP 305 era protendida. 


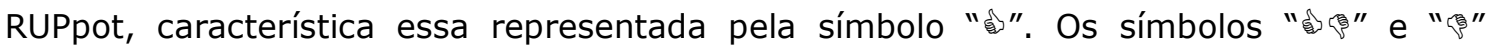
serviram para evidenciar, respectivamente, tendências pouco representativas e ausência de tendências, para os dados considerados na análise.

Analisando-se $\mathrm{e}^{140}$ os dados contidos na Tabela 5.17, destacam-se as seguintes observações:

$\checkmark$ esperava-se que cada fator variasse coerentemente com a variação das RUP, o que, do ponto de vista do sistema de cores adotado (azul para os três primeiros valores e vermelho para os três últimos) levaria a ter-se 2 subconjuntos separados de cor (azul em cima e vermelho embaixo)

$\checkmark$ a busca visual por tal padrão leva à consideração da existência de correlação da produtividade com os fatores: comprimento de viga, taxa de armadura, média das áreas das lajes armadas, diâmetro equivalente das peças das armaduras das lajes, porcentagem (em massa) das posições variáveis e porcentagem (em massa) das posições negativas variáveis;

$\checkmark$ alguns destes fatores podem nascer de uma composição de outros fatores; por exemplo, nota-se que o aço das obras com maiores taxas de armaduras apresentaram, também, maiores diâmetros equivalentes das peças e um menor número de peças por massa total de aço. Ou seja, a boa produtividade dessas obras pode ser explicada, em parte, pelo fato de se ter trabalhado com peças mais pesadas que, a principio, demandam o mesmo esforço que peças mais leves por peça trabalhada;

$\checkmark$ a obra SP 303, que obteve a segunda melhor RUPpot, expressa bem, através de dois outros fatores ("relação entre comprimento das peças por $\mathrm{m}^{2}$ de área de laje" $\mathrm{e}$ "massa das armaduras das lajes por $\mathrm{m}^{2}$ da área de laje") a situação desejável comentada anteriormente: a sua laje possui mais massa de aço por $\mathrm{m}^{2}$ de laje e, ao mesmo tempo, menor quantidade de peças (metros lineares) pelo mesmo $\mathrm{m}^{2}$;

$\checkmark$ com base em raciocínios semelhantes aos citados o autor analisou os diversos fatores e concluiu que cinco dentre os quatorze fatores considerados correlacionaram-se com as RUPpot, apresentando-se como os com maior tendência a influenciar a produtividade. Outros seis fatores revelaram tendência menos expressiva de influenciar as RUP. Os demais não evidenciaram tendências;

$\checkmark$ não se pode afirmar que os fatores cujas tendências não foram evidenciadas, pelo conjunto de dados analisados, não são capazes de influenciar a produtividade. A pequena amostra de dados, bem como a influência de fatores mais marcantes, para o conjunto analisado, pode mascarar (bem como enaltecer) tendências. Apenas com um conjunto de dados maior e mais expressivo poder-se-á ter posicionamento mais acertado.

140 Observe-se que, à medida que se acredita não ser conveniente, com a dimensão esperada de banco de dados de uma empresa e os conhecimentos matemáticos dos usuários de tal banco partir-se para uma análise de cunho fortemente estatísticos, buscar-se-ão explicações para a variação da produtividade com base em raciocínos mais simples que, desta maneira, deverão basear-se em percepções físicas dos analistas quanto ao fenômeno sendo avaliado 
Tabela 6.39 - TDT relacionados ao PDA de laje com nível de detalhamento "2"

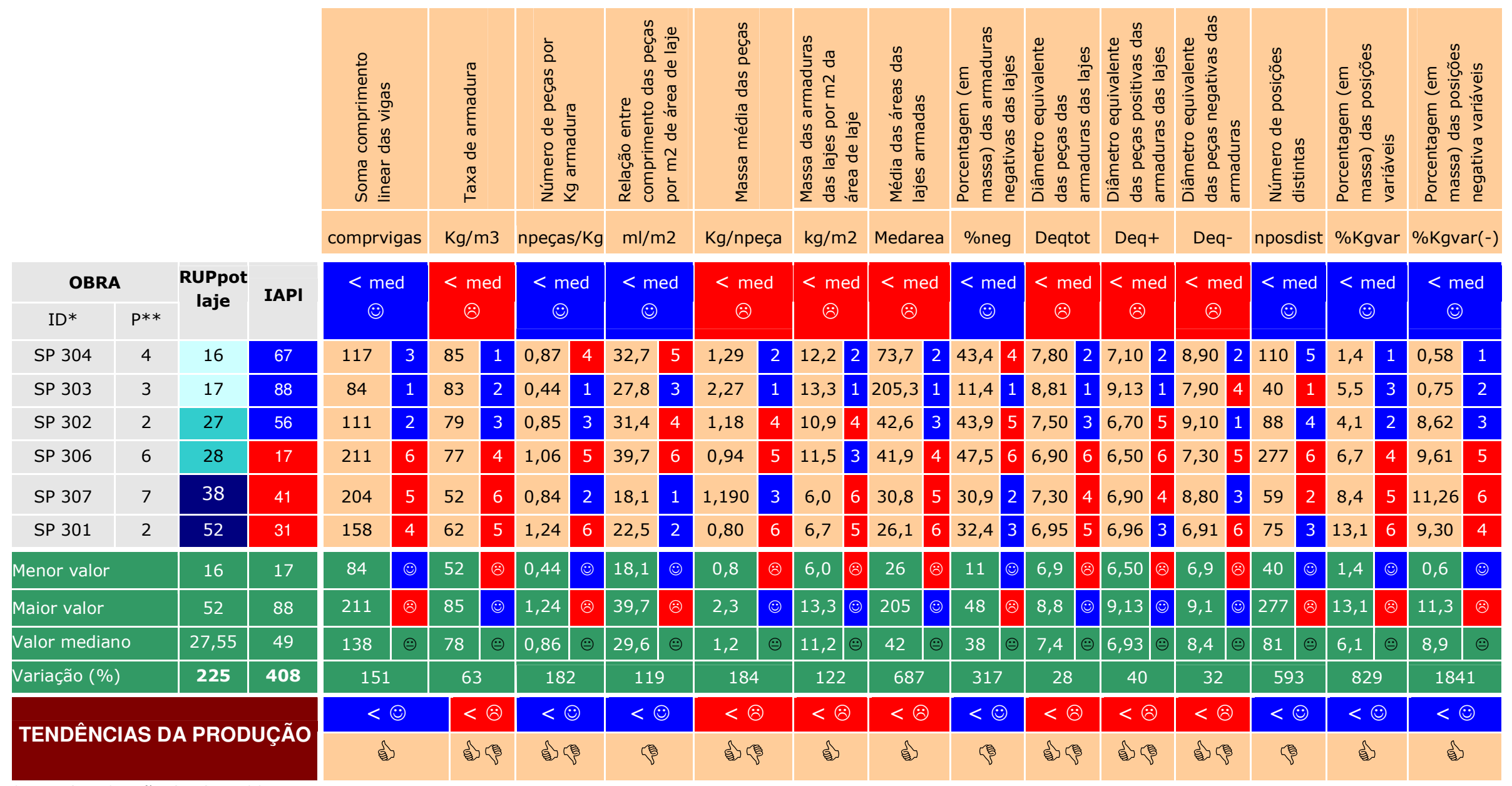

* ID=identificação da obra; **P=pavimento. 

Para a detecção das tendências da produção relativas às vigas, a Tabela 5.15 foi novamente reorganizada originando a Tabela 6.40, que apresentou as seguintes particularidades: i) ordenamento das obras em função das RUPpot da viga, que foram dispostas em ordem decrescente; ii) ranqueamento das RUPpot e dos IAPviga, IAM e IAO; iii) acréscimo de informações como o menor, o maior e o valor mediano dos dados apresentados, identificados com cores e símbolos. Atenta-se para o fato de que a obra SP 305 foi suprimida da Tabela 6.40 e, por conseguinte, das análises, pelos motivos já comentados.

Tabela 6.40 - TDT com nível de detalhamento " 1 " para viga

\begin{tabular}{|c|c|c|c|c|c|c|c|c|}
\hline \multirow{3}{*}{$\begin{array}{l}\text { Obra } \\
\text { SP } 307\end{array}$} & \multirow{2}{*}{\multicolumn{2}{|c|}{$\begin{array}{c}\text { RUP pot }(\mathbf{H h} / \mathbf{t}) \\
\text { viga }\end{array}$}} & \multirow{2}{*}{\multicolumn{2}{|c|}{$\begin{array}{l}\text { PDA } \\
\text { IAPV }\end{array}$}} & \multirow{2}{*}{\multicolumn{2}{|c|}{$\begin{array}{c}\text { Método } \\
\text { IAM }\end{array}$}} & \multirow{2}{*}{\multicolumn{2}{|c|}{$\begin{array}{c}\text { Organização } \\
\text { IAO }\end{array}$}} \\
\hline & & & & & & & & \\
\hline & 21 & 1 & 78 & 1 & 76 & 2 & 41 & 5 \\
\hline SP 303 & 32 & 2 & 73 & 2 & 66 & 5 & 46 & 3 \\
\hline SP 306 & 34 & 3 & 61 & 3 & 67 & 4 & 48 & 2 \\
\hline SP 304 & 55 & 4 & 47 & 5 & 66 & 3 & 61 & 1 \\
\hline SP 301 & 61 & 5 & 36 & 6 & 77 & 1 & 30 & 6 \\
\hline SP 302 & 66 & 6 & 56 & 4 & 36 & 6 & 46 & 3 \\
\hline Menor & 21 & (-) & 36 & (:) & 36 & (:) & 30 & (:) \\
\hline Maior & 66 & ;: & 78 & (ब) & 77 & (;) & 61 & (:) \\
\hline Mediano & 45 & $\oplus$ & 59 & $\oplus$ & 66 & $\oplus$ & 46 & $\oplus$ \\
\hline Variação & 214 & $! ! !$ & 118 & $! ! ! !$ & 53 & $!$ & 106 & $!$ \\
\hline
\end{tabular}

A análise dos dados dispostos na Tabela 6.40 chama a atenção para os seguintes pontos: i) aqui também as obras com as melhores RUPpot apresentaram, também, os melhores IAPV, evidenciando, também aqui, uma correlação; ii) idem lajes

A Tabela 6.41 trata-se de uma TDT como um nível de detalhamento mais alto (nível dois). Nela as seis obras foram dispostas, também, em função do ordenamento crescente da RUPpot viga. As análises seguiram caminho similar ao adotado para o caso das lajes. Analisando-se os dados contidos na Tabela 6.41, destacam-se as seguintes observações:

$\checkmark$ os projetos com menor quantidade de viga com seção variável e com os maiores valores de massa mediana das peças longitudinais foram os que obtiveram os melhores valores de RUPpot vigas. Os dois fatores que exprimem essas relações podem ser caracterizados como influentes;

$\checkmark$ apesar das pequenas variações entre os valores dos diâmetros equivalentes (já esperadas em se tratando de armaduras de vigas), nota-se que as duas obras que obtiveram as melhores RUPpot apresentaram os maiores diâmetros equivalentes;

$\checkmark$ como resultado das análises feita pelo autor deste trabalho, apenas três dentre os treze fatores considerados correlacionaram-se com as RUPpot viga, apresentando-se 
com os mais tendenciosos a influenciar a produtividade. Outros oito fatores revelaram relativa tendência. Os demais não evidenciaram tendências;

$\checkmark$ não se pode afirmar que os fatores cujas tendências não foram evidenciadas pelo conjunto de dados analisados, não são capazes de influenciar a produtividade. A pequena amostra de dados bem como a influência de fatores mais marcantes, para o conjunto analisado, pode mascarar (bem como enaltecer) tendências. Apenas com um conjunto de dados maior e mais expressivo poder-se-á ter posicionamento mais acertado;

$\checkmark \quad$ o fato de ser terem analisado dados de pavimentos tipo, de edifícios com diferentes alturas (o edifício mais baixo tinha onze pavimentos e, o mais alto, 26), podem-se ter mascarado as correlações e, por conseguinte, as análises. Na medida em que forem acrescentados mais dados ao banco, será interessante refazer as análises separando as obras por altura dos edifícios e pelos pavimentos considerados. 
Tabela 6.41 - TDT relacionados ao PDA de viga com nível de detalhamento "2"

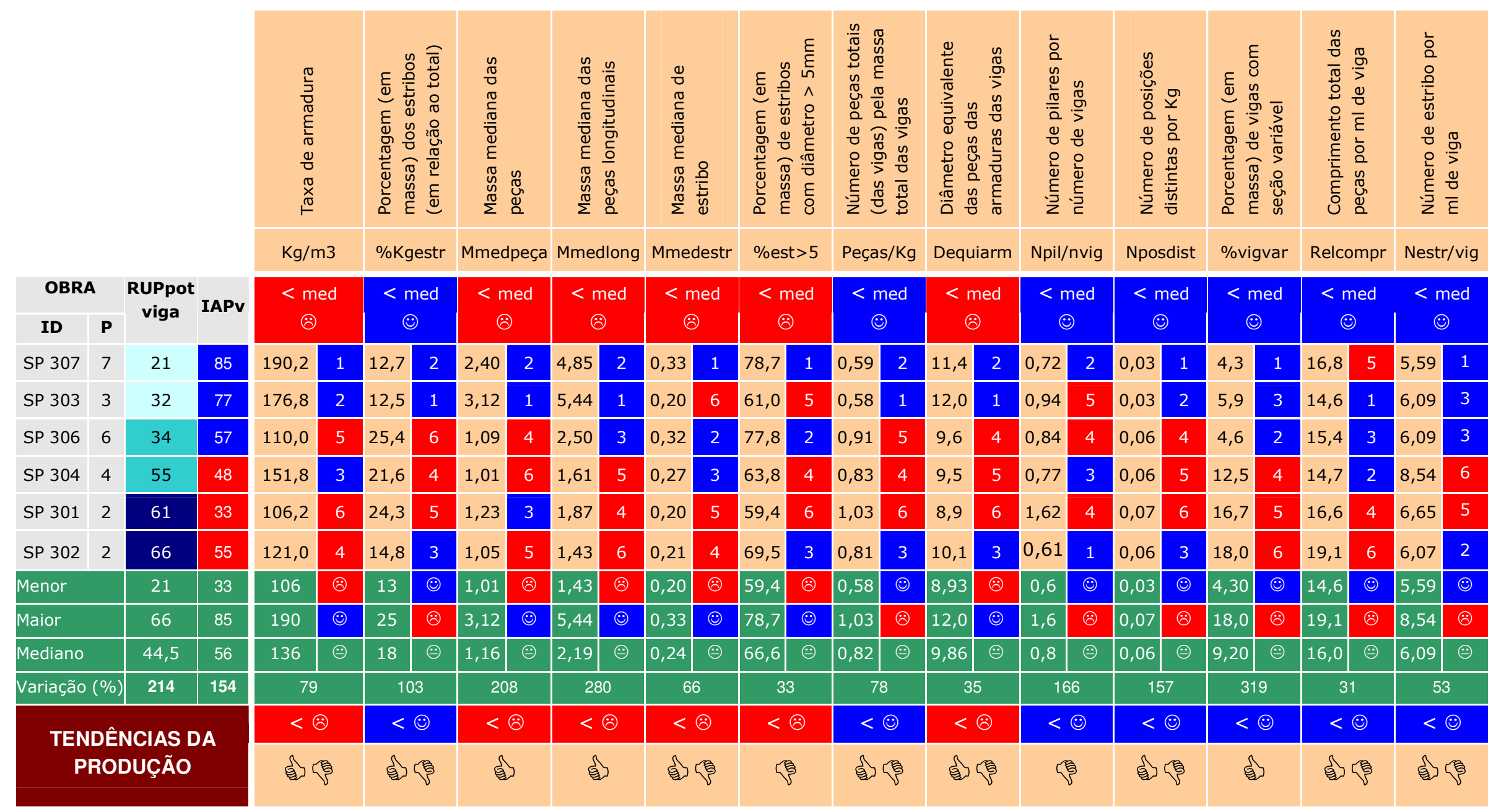



Para a detecção das tendências da produção relativas aos pilares, a Tabela 5.15 foi reorganizada originando a Tabela 6.42, que apresentou as seguintes particularidades: i) ordenamento das obras em função das RUPpot dos pilares, que foram dispostas em ordem decrescente; ii) ranqueamento das RUPpot e dos IAPpilar, IAM e IAO; iii) acréscimo de informações como o menor, o maior e o valor mediano dos dados apresentados, identificados com cores e símbolos.

Tabela 6.42 - TDT com nível de detalhamento "1" para pilar

\begin{tabular}{|c|c|c|c|c|c|c|c|c|c|}
\hline \multirow{3}{*}{$\begin{array}{l}\text { Obra } \\
\text { SP } 307\end{array}$} & \multirow{3}{*}{\begin{tabular}{|c|} 
Andar \\
$9^{\circ}$ de 25
\end{tabular}} & \multirow{2}{*}{\multicolumn{2}{|c|}{$\begin{array}{c}\text { RUP pot }(\mathbf{H h} / \mathbf{t}) \\
\text { pilar }\end{array}$}} & \multicolumn{2}{|c|}{ PDA } & \multicolumn{2}{|c|}{ Método } & \multicolumn{2}{|c|}{ Organização } \\
\hline & & & & \multicolumn{2}{|c|}{ IAPp } & \multicolumn{2}{|c|}{ IAM } & \multicolumn{2}{|c|}{ IAO } \\
\hline & & 35 & 1 & 69 & 1 & 76 & 2 & 41 & 5 \\
\hline SP 305 & $20^{\circ}$ de 25 & 42 & 2 & 47 & 4 & 66 & 4 & 41 & 5 \\
\hline SP 304 & $8^{\circ}$ de 26 & 43 & 3 & 59 & 2 & 66 & 3 & 61 & 1 \\
\hline SP 306 & $22^{\circ}$ de 25 & 44 & 4 & 13 & 7 & 67 & 5 & 48 & 2 \\
\hline SP 301 & $8^{\circ}$ de 11 & 64 & 5 & 29 & 6 & 77 & 1 & 30 & 7 \\
\hline SP 303 & $10^{\circ}$ de 25 & 67 & 6 & 32 & 5 & 66 & 6 & 46 & 3 \\
\hline SP 302 & $7^{\circ}$ de 11 & 103 & 7 & 52 & 3 & 36 & 7 & 46 & 3 \\
\hline \multicolumn{2}{|c|}{ Menor } & 35 & (e) & 13 & (2) & 36 & (2) & 30 & (2) \\
\hline \multicolumn{2}{|c|}{ Maior } & 103 & (2) & 72 & (e) & 77 & (e) & 61 & (ङ) \\
\hline \multicolumn{2}{|c|}{ Mediano } & 44 & $\oplus$ & 39 & $\oplus$ & 66 & $\oplus$ & 46 & $\oplus$ \\
\hline \multicolumn{2}{|c|}{ Variação } & 193 & $! ! !$ & 440 & !!!! & 53 & $!$ & 106 & $! !$ \\
\hline
\end{tabular}

A análise dos dados dispostos na Tabela 6.42 chama a atenção para os seguintes pontos: i) a correlação entre as RUPpot de pilar e os IAPp não foi tão evidente quanto às correlações detectadas para as lajes e vigas, apresentadas anteriormente; ainda assim as obras que obtiveram a primeira e terceira melhores RUP, apresentaram os melhores valores de IAPp; ii) idem lajes

Em se tratando dos pilares, as correlações com os IAPp são mais suscetíveis às variações entre os pavimentos (e alturas dos edifícios) existentes entre as obras analisadas. Seria necessário, nesse caso, o tratamento de pavimentos semelhantes (altura do edifício e pavimento considerados semelhantes). Tal segmentação não foi feita nessa aplicação piloto (seria necessário um conjunto de dados maior), limitando-se, portanto, as análises referentes ao PDA de pilares. Assim, as tendências de produção para pilares, determinadas a partir a Tabela 6.43, precisam ser tratadas com ressalvas ainda maiores que as já indicadas para as laje e vigas. As tendências consideradas pelo autor estão indicadas nas linhas inferiores da Tabela 6.43. 
Tabela 6.43 - TDT relacionados ao PDA de pilar com nível de detalhamento "2"

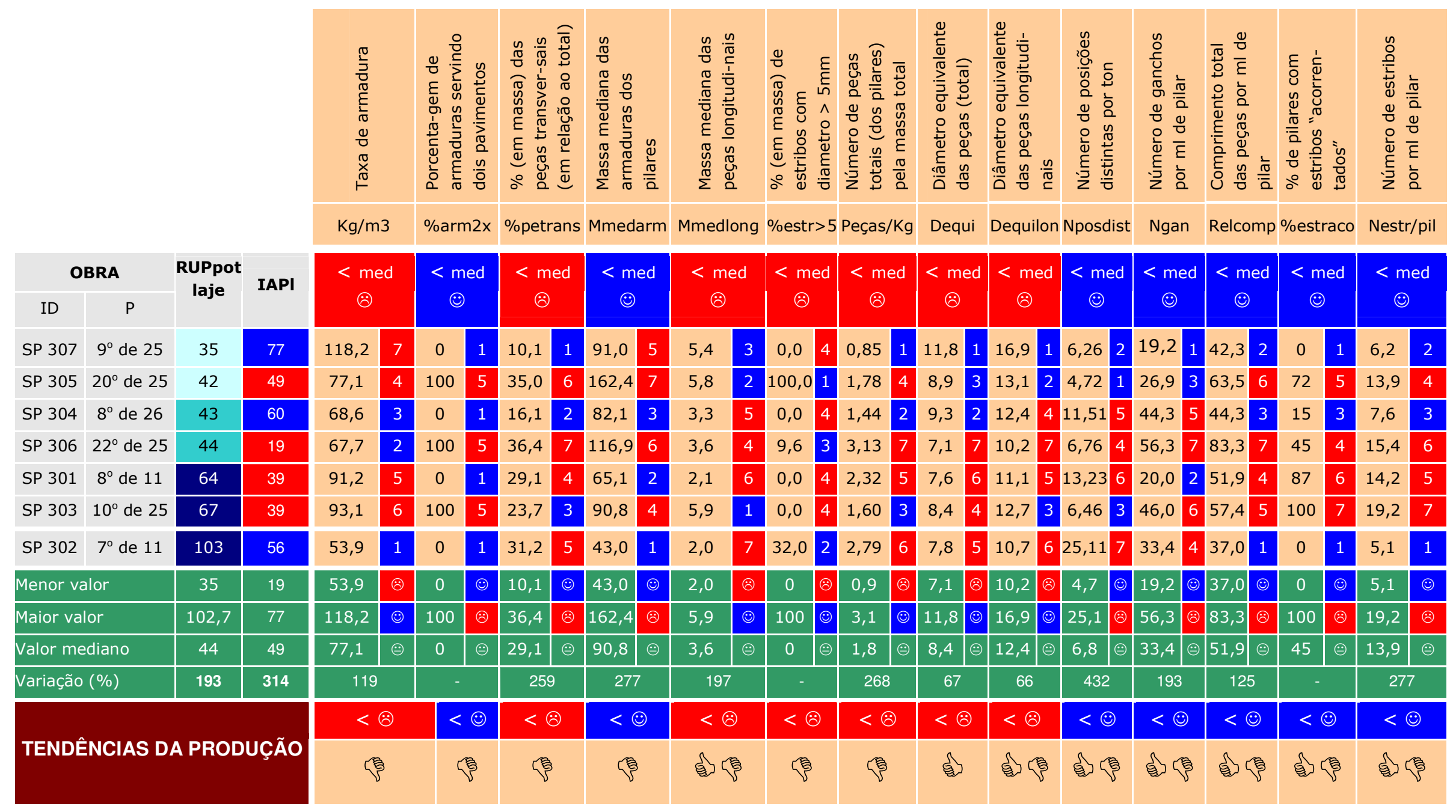




\subsubsection{Determinação dos fatores influenciadores}

A definição dos fatores influenciadores da produtividade da mão-de-obra, tal como preconizado pelo MPDPro, deu-se a partir da análise conjunta das expectativas e tendências da produção.

No âmbito do PDA, os fatores foram considerados influenciadores da produtividade quando as expectativas e as tendências a eles relacionados foram evidenciadas por ambas as análises. Ressalta-se que a influência do método e da organização do trabalho pode, em certos momentos, mascarar certas tendências. Ponderada essa questão, há de se comentar, também, que as tendências, assim como apresentadas nessa aplicação piloto, "carregam" o posicionamento pessoal do responsável pela condução da aplicação do MPDPro que, nesse caso, foi o próprio autor. Assim, as mesmas informações apresentadas podem dar margens a entendimentos distintos, em função da pessoa que os analise.

Assim é que os fatores cujas tendências não foram detectadas, principalmente aqueles em que houve uma expectativa favorável da produção quanto a sua influência, deverão ser continuamente monitorados (à medida que o banco de dados da construtora for aumentado, novas evidências poderão ser percebidas). As Tabela 5.18, Tabela $6.45 \mathrm{e}$ Tabela 6.46 destacam os fatores cuja influência foi observada (identificados na primeira coluna da referida tabela por um " $x$ "), pelo autor, nesta aplicação piloto do MPDPro.

Tabela 6.44 (continua) - Fatores influenciadores - PDA de pilares

\begin{tabular}{|c|c|c|c|c|}
\hline \multirow[t]{2}{*}{ Influência } & \multicolumn{2}{|l|}{ Fatores } & Expectativas & Tendências \\
\hline & Taxa de armadura & $\mathrm{Kg} / \mathrm{m} 3$ & है하 & $\xi$ \\
\hline & $\begin{array}{l}\text { Porcentagem de armaduras servindo dois } \\
\text { pavimentos }\end{array}$ & $\% \operatorname{arm} 2 x$ & है일 & $\xi$ \\
\hline & $\begin{array}{l}\text { \% (em massa) das peças transversais } \\
\text { (em relação ao total) }\end{array}$ & \%peçatrans & है & $\xi$ \\
\hline & Massa mediana das armaduras dos pilares & Mmedarm & $\Leftrightarrow$ & 乌 \\
\hline & Massa mediana das peças longitudinais & Mmedlong & 约 & 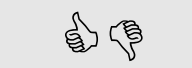 \\
\hline & $\begin{array}{l}\% \text { (em massa) de estribos com diâmetro } \\
>5 \mathrm{~mm}\end{array}$ & \%estr $>5$ & 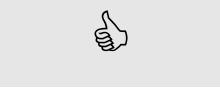 & 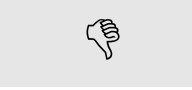 \\
\hline & $\begin{array}{l}\text { Número de peças totais (dos pilares) pela } \\
\text { massa total dos pilares }\end{array}$ & Peças/Kg & हैํㅐ & $\xi$ \\
\hline & Diâmetro equivalente das peças (total) & Dequi & 约 & हो) \\
\hline & $\begin{array}{l}\text { Diâmetro equivalente das peças } \\
\text { longitudinais }\end{array}$ & Dequilong & $\xi$ & छ़े \\
\hline $\mathbf{X}$ & Número de posições distintas por tonelada & Nposdist & ह્छे & 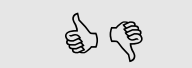 \\
\hline
\end{tabular}


Tabela 6.45 (conclusão) - Fatores influenciadores - PDA de pilares

\begin{tabular}{|c|c|c|c|c|}
\hline Influência & \multicolumn{2}{|l|}{ Fatores } & Expectativas & Tendências \\
\hline$x$ & $\begin{array}{l}\text { Número de ganchos por comprimento } \\
(\mathrm{ml}) \text { de pilar }\end{array}$ & Ngan & $\Leftrightarrow$ & $\Rightarrow$ \\
\hline$x$ & $\begin{array}{l}\text { Comprimento total das peças por } \\
\text { comprimento }(\mathrm{ml}) \text { de pilar }\end{array}$ & Relcompr & हो & $\Rightarrow$ \\
\hline 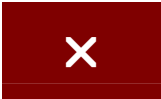 & $\begin{array}{l}\text { \% de pilares com estribos } \\
\text { "acorrentados" }\end{array}$ & \%estracor & हो & $\Leftrightarrow$ \\
\hline $\mathrm{x}$ & $\begin{array}{l}\text { Número de estribos por comprimento (ml) } \\
\text { de pilar }\end{array}$ & Nestr/pil & हो & $\Rightarrow$ \\
\hline
\end{tabular}

Tabela 6.45 - Fatores influenciadores - PDA de vigas

\begin{tabular}{|c|c|c|}
\hline \multirow[t]{2}{*}{ Influência } & \multicolumn{2}{|l|}{ Fatores } \\
\hline & Taxa de armadura & $\mathrm{Kg} / \mathrm{m} 3$ \\
\hline & $\begin{array}{l}\text { Porcentagem (em massa) dos estribos } \\
\text { (em relação ao total) }\end{array}$ & $\%$ Kgestribo \\
\hline $\mathbf{x}$ & Massa mediana das peças & Mmedpeça \\
\hline $\mathbf{x}$ & Massa mediana das peças longitudinais & Mmedlong \\
\hline & Massa mediana de estribo & Mmedestr \\
\hline & $\begin{array}{l}\text { Porcentagem (em massa) de estribos com } \\
\text { diâmetro }>5 \mathrm{~mm}\end{array}$ & \%est >5 \\
\hline & $\begin{array}{l}\text { Número de peças totais (das vigas) pela } \\
\text { massa total das vigas }\end{array}$ & Peças/Kg \\
\hline & $\begin{array}{l}\text { Diâmetro equivalente das peças das } \\
\text { armaduras das vigas }\end{array}$ & Dequiarm \\
\hline & Número de pilares por número de vigas & Npil/nvig \\
\hline $\mathbf{x}$ & Número de posições distintas por Kg & Nposdist \\
\hline$x$ & $\begin{array}{l}\text { Porcentagem (em massa) de vigas com } \\
\text { seção variável }\end{array}$ & \%vigvar \\
\hline & $\begin{array}{l}\text { Comprimento total das peças por } \\
\text { comprimento }(\mathrm{ml}) \text { de viga }\end{array}$ & Relcompr \\
\hline & $\begin{array}{l}\text { Número de estribo por comprimento (ml) } \\
\text { de viga }\end{array}$ & Nestr/vig \\
\hline
\end{tabular}

\section{Expectativas Tendências}

德

हो

$\Leftrightarrow$

क्षे

हो

$\Leftrightarrow$

$-$

क्रे है

ही

$\Rightarrow$ की

हो क्षे

항

हो

हो

क्षे 
Tabela 6.46 - Fatores influenciadores - PDA de lajes

\begin{tabular}{|c|c|c|c|c|}
\hline Influência & Fatores & & Expectativas & Tendências \\
\hline $\mathbf{X}$ & Soma comprimento linear das vigas & comprvigas & छ્छ & छ્छ \\
\hline & Taxa de armadura & $\mathrm{Kg} / \mathrm{m} 3$ & - & ही \\
\hline X & Número de peças por $\mathrm{Kg}$ armadura & npeças/Kg & क्षे & ही \\
\hline & $\begin{array}{l}\text { Relação entre comprimento das peças por } \\
\text { m2 de área de laje }\end{array}$ & $\mathrm{ml} / \mathrm{m} 2$ & - & $\sqrt{3}$ \\
\hline & Massa média das peças & $\mathrm{Kg} / \mathrm{npeças}$ & - & 행 \\
\hline $\mathbf{X}$ & $\begin{array}{l}\text { Massa das armaduras das lajes por m2 da } \\
\text { área de laje }\end{array}$ & $\mathrm{kg} / \mathrm{m} 2$ & - & $\Leftrightarrow$ \\
\hline $\mathbf{X}$ & Média das áreas das lajes armadas & Medarea & - & ही \\
\hline & $\begin{array}{l}\text { Porcentagem (em massa) das armaduras } \\
\text { negativas das lajes }\end{array}$ & $\%$ neg & $\Leftrightarrow$ & 得 \\
\hline $\mathbf{X}$ & $\begin{array}{l}\text { Diâmetro equivalente das peças das } \\
\text { armaduras das lajes }\end{array}$ & Deqtot & है하 & है하 \\
\hline $\mathbf{X}$ & $\begin{array}{l}\text { Diâmetro equivalente das peças positivas } \\
\text { das armaduras das lajes }\end{array}$ & Deq+ & है을 & है일 \\
\hline $\mathbf{X}$ & $\begin{array}{l}\text { Diâmetro equivalente das peças negativas } \\
\text { das armaduras das lajes }\end{array}$ & Deq- & 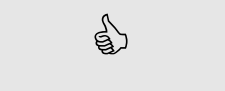 & 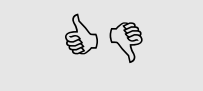 \\
\hline & Número de posições distintas & nposdist & क्षेत्र & 绝 \\
\hline 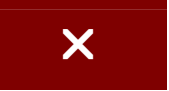 & $\begin{array}{l}\text { Porcentagem (em massa) das posições } \\
\text { variáveis }\end{array}$ & \%Kgvar & हुदध & है하 \\
\hline$<$ & $\begin{array}{l}\text { Porcentagem (em massa) das posições } \\
\text { negativa variáveis }\end{array}$ & \%Kgvar(-) & है의 & है이 \\
\hline
\end{tabular}

As boas práticas atribuídas aos fatores relacionados ao método e à organização do trabalho foram consideradas, nesta aplicação, fundamentais ao bom desempenho do PCPA e, por conseguinte, da produtividade da mão-de-obra. Ainda que não se tenha analisado a influência direta destes fatores na produtividade da mão-de-obra por razões já destacadas, acredita-se na sua relação e na sua importância para a melhoria da produtividade. Recomenda-se que a implementação das boas práticas contempladas nos fatores determinantes do IAO e IAM pela construtora, com a anuência (ou ciência) dos empreiteiros e da mão-de-obra, que visem à consolidação/implementação das boas práticas, enfatize as operações (método) e elementos (organização) que apresentaram os piores desempenhos. 


\subsubsection{Etapa de Proposição de Diretrizes}

O trabalho de análise das informações, realizado anteriormente, teve o propósito de evidenciar a influência dos fatores sobre a produtividade da mão-de-obra a partir de constatações obtidas através das expectativas e tendências da produção. Os fatores declarados, desde o princípio do desenvolvimento deste trabalho, como "potenciais" influenciadores de boa produtividade evidenciaram à construtora que alguns deles seriam capazes de causar a influência inicialmente presumida.

Vale dizer que muitas correlações que, acredita-se, sejam pertinentes, não foram detectadas junto ao conjunto de dados analisados. Isso se justifica, entre outras razões, pela pequena amostragem considerada pelo trabalho, bem como pela ação (mesmo trabalhando com indicadores de produtividade potencial) de fatores de outras naturezas (relacionados ao método e/ou à organização do trabalho). Tais correlações, ainda que apenas presumidas, não serão descartadas nessa etapa de proposição das diretrizes.

Diante do universo limitado em que tais análises foram feitas salienta-se, mais uma vez, que as correlações obtidas não devem ser tratadas, em hipótese alguma, como verdades absolutas, mas sim como evidências restritas a um universo bastante particular.

Apesar das limitações e dos cuidados que devem ser tomados, as "evidências" detectadas possuem significativo grau de coerência. São, portanto, bem mais "sensatas" que "suposições" ou "achismos", configurando-se como o elemento balizador para a melhoria do processo de produção das armaduras preconizado pelo MPDPro.

A significativa variabilidade dos indicadores de produtividade da mão-de-obra referentes à etapa de armação $(225 \%, 214 \%$ e $193 \%$, respectivamente para as RUPpot de de pilares, vigas e lajes) diagnosticada no conjunto de obras contempladas nesta aplicação do MPDPro (mostradas na Tabela 5.15) evidencia a problemática que suscitou o desenvolvimento desse trabalho, servindo como principal argumento para a construtora lançar-se à aplicação da última etapa do método, qual seja a proposição de diretrizes para melhoria da produtividade da mão-de-obra.

A construtora deve, assim como fez quando analisou os dados, estabelecer prioridades, focando num primeiro momento os pontos mais críticos, aqueles que apresentaram as maiores variações dos índices de avaliação. Com base nessa colocação, elegeram-se as diretrizes relacionadas ao PDA como as que deveriam ser inicialmente buscadas pela construtora. Soma-se a essa justificativa o fato da maior complexidade apresentada pelas discussões no âmbito do projeto.

\subsubsection{Diretrizes de projeto}

Nesta etapa foram consultados alguns dos escritórios de projetos estruturais responsáveis (autoria) pelos PDA contemplados neste trabalho. Ressalta-se que esses escritórios estão entre os mais respeitados e importantes do país, seja pela extrema competência do seu corpo técnico, ou pelo volume considerável de projetos de edifícios (muitos emblemáticos) concebidos e executados no país.

Após a exposição dos objetivos preconizados pelo trabalho, forma apresentados a tais projetistas: i) os fatores influenciadores referentes ao PDA (identificados nas Tabela 5.18, Tabela 6.45 e Tabela 6.46); ii) as tabelas de detecção de tendências (Tabela 5.17, Tabela 6.41 e Tabela 6.43) relacionadas ao PDA de lajes, vigas e pilares. 
Solicitou-se aos projetistas que analisassem as informações disponibilizadas e, a partir delas, apontassem caminhos para que projetos futuros de detalhamento das armaduras "respondessem" às constatações obtidas pela construtora.

O primeiro posicionamento consensual entre os projetistas consultados chamou a atenção para as implicações nos custos do material e na qualidade das soluções ao promoverem alterações no PDA favoráveis à melhoria da produtividade da mão-de-obra. O projetista " $A$ " disse que seria importante que o projetista conhecesse as economias geradas com o menor consumo da mão-de-obra proporcionado pelas alterações sugeridas ao projeto. Os eventuais acréscimos da taxa de armadura proporcionados por algumas das alterações no PDA precisariam, a seu ver, serem compensadas por ganhos reais com a mão-de-obra, para se tornarem interessantes ao cliente.

O projetista "B" comentou que "o aumento do preço do aço, nos últimos anos, levou projetistas a trabalharem com maiores consumos de concreto nos elementos estruturais em detrimento ao consumo de aço". Porém, lembra que as construtoras contratam, equivocadamente, o serviço de execução das estruturas, pagando os empreiteiros por $\mathrm{m}^{3}$ de concreto. "Não posso gastar muito concreto porque o cliente remunera o empreiteiro por $\mathrm{m}^{3}$. Dessa forma, e sob essa perspectiva, menos concreto na estrutura é mais conveniente para o cliente. Por outro lado, economizar em concreto leva a estrutura a consumir mais aço, o que é ruim diante da supervalorização recente desse material. Taxas maiores de aço podem ainda levar a piores produtividades da mão-deobra, pois haverá mais movimentação deste material no canteiro, por exemplo".

O projetista " $B$ " também lembra as implicações na qualidade da estrutura provocadas por alterações no detalhamento das armaduras, que precisam ser consideradas nas análises que visem promover melhorias de produtividade. Cita o exemplo das armaduras positivas das lajes. "Armaduras positivas de lajes com maiores diâmetros das barras tendem a ter maiores espaçamentos. Menor quantidade de peças com maiores diâmetros constituem dois aspectos que podem ser extremamente benéficos à produtividade da mão-de-obra durante a montagem dessas armaduras. Porém, o elemento estrutural, neste exemplo, a laje, pode ter o seu desempenho prejudicado, pois estará sujeito ao aparecimento de um maior número de fissuras (quando a malha fica mais aberta, isto é, as barras que a constituem ficam mais espaçadas, há uma maior tendência de a laje fissurar). A produtividade boa de hoje pode se voltar contra a obra diante da necessidade de reparos de fissuras, que terá um custo não desprezível". Os comentários supracitados objetivam chamar a atenção para a complexidade das discussões preconizadas pelo MPDPro na sua última etapa de aplicação. As diretrizes dificilmente serão apontadas de forma direta e objetiva como inicialmente ter-se-ia suposto.

Apesar de os projetistas queixarem-se com freqüência da falta de retorno dos construtores quanto aos projetos por ele desenvolvidos, bem como da importância e necessidade desse retorno para o aprimoramento de projetos futuros, acredita-se (e a experiência do autor com a aplicação piloto reforçou isso) que seja necessário um tempo de adequação dos agentes para aprender a tratar e assimilar as informações disponibilizadas pela construtora no âmbito do MPDPro.

Nas primeiras discussões promovidas pela construtora com seus parceiros talvez haja receios e desconfianças que impeçam uma leitura clara e objetiva do conjunto de informações disponibilizadas, inédita até aqui, justamente pela forma criteriosa e pelo embasamento metodológico com que foram determinados. 
Neste início as conclusões obtidas talvez não se mostrem "explícitas" como se espera. É preciso, no entanto que as discussões não fiquem restritas ao primeiro plano de argumentações, relacionadas, por exemplo, a custos adicionais de projeto, responsabilidades extras dos projetistas etc. Tais pautas, sempre que colocadas à mesa, deverão ser devidamente tratadas. Porém, as discussões precisam amadurecer e prosperar, atingindo àquilo a que realmente se propõem. Deverão ficar evidentes que os objetivos pretendidos têm propósitos maiores que deverão se estender a todos os agentes/parceiros da construtora.

Após os comentários anteriores, apresenta-se, a seguir (Tabela 6.47, Tabela 6.48, Tabela 6.49 e Tabela 6.50), o conjunto de diretrizes, relacionado ao PDA, a que a construtora chegou, após percorrer as quatro etapas do MPDPro.

Algumas delas, da forma em que estão colocadas, podem e deverão ser implementadas pela construtora, de maneira simples e direta, visando contribuir imediatamente para a melhoria do processo de produção de armaduras no âmbito da produtividade da mãode-obra em empreendimentos futuros.

Outras carecem de investigações e análises mais complexas, bem como ponderações que contemplem ganhos econômicos entre alternativas apresentadas, ou mesmo que considerem aspectos ligados à qualidade e desempenho de algumas soluções cogitadas. Tais ponderações são, no entendimento deste autor, imprescindíveis. Porém, fogem do propósito deste trabalho, lançando-se como desafio imediato para trabalhos posteriores, à medida que se apresentam como conseqüência direta das discussões fomentadas até aqui. 
Tabela 6.47 - Diretrizes para o PDA - Pilares

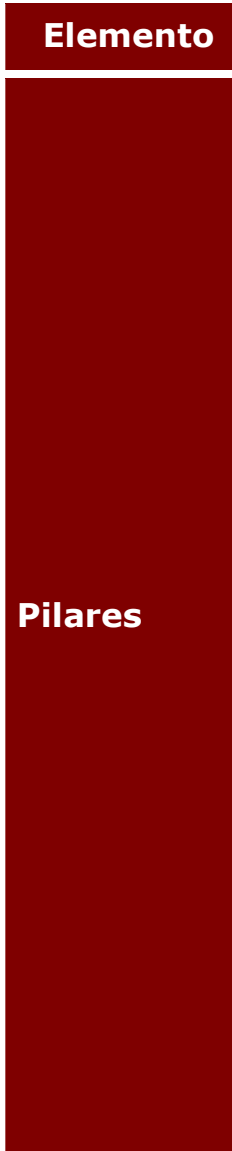

- Evitar o detalhamento prevendo o "engarrafamento" das peças longitudinais

Implementação

- Atentar-se para a largura das armaduras dos pilares. Em casos de pilares com larguras superiores a $1,5 \mathrm{~m}$, estudar a segmentação da armadura em gaiolas consecutivas, que poderiam ser assim prémontadas e transportadas, sendo complementadas (unidas por peças de ligação) quando posicionadas nas fôrmas.

- Priorizar armaduras de pilares servindo dois pavimentos em situações em que a economia de aço (com a redução dos transpasses) seja significativa do aço para pilar consumido a cada pavimento. 0 projetista deverá consultar a construtora quanto à adoção desta prática no projeto. A construtora deverá possuir grua na obra, bem como um sistema de fôrmas que preveja reforço no travamento das fôrmas de pilares, além de uma maior qualificação e cuidados dos armadores e carpinteiros (que trabalharão de maneira muito mais integrada).

- Dar preferência a peças longitudinais como maiores diâmetros, analisando, a cada pilar, o congestionamento de armaduras na região de traspasse. Em situações de congestionamento, prever algumas peças longitudinais passando direto para o pavimento seguinte.

- Utilizar barras de $5 \mathrm{~mm}$ para estribos apenas em situações que requeiram armadura mínima. Priorizar o uso de estribos de 6,3 $\mathrm{mm}$ nas armaduras de pilares

- Não utilizar o detalhamento de estribos prevendo "correntes" (mais de um estribo num mesmo plano). Priorizar a utilização de estribos únicos, delineando a seção completa dos pilares

Imediata

Imediata

- Não detalhar estribos de pilares compostos por duas peças, abertos na sua maior dimensão. Prever esse tipo de peça apenas nas regiões onde o estribo fica confinado no interior das vigas 
Tabela 6.48 - Diretrizes para o PDA - Vigas

\begin{tabular}{|l|l|l|}
\hline Elemento & Diretriz & Im \\
\hline & - Utilizar barras de $5 \mathrm{~mm}$ para estribos apenas em situações que requeiram armadura mínima. Priorizar \\
& o uso de estribos de $6,3 \mathrm{~mm}$ nas armaduras de vigas \\
& - Evitar a utilização de variações de espaçamento e de diâmetros dos estribos numa mesma viga \\
& - Não utilizar o detalhamento de estribos prevendo "correntes" (mais de um estribo num mesmo \\
& plano). Priorizar a utilização de estribos únicos, delineado a seção completa das vigas \\
\hline Vigas & - Considerar segmentação das armaduras das vigas em havendo pilares intermediários. O \\
& conhecimento prévio de que as armaduras serão desmembradas em gaiolas (nas operações de pré- \\
& montagem e transporte) pode-se levar à previsão de peças suplementares no detalhamento, que \\
& facilitarão a montagem das vigas. \\
\hline - Detalhar a armadura de reforços dos furos eventuais com peças dispostas paralelamente às \\
dimensões das vigas. \\
- Prever estribos abertos na face superior da viga quando estes elementos forem protendidos.
\end{tabular}

Tabela 6.49 (continua) - Diretrizes para o PDA - Lajes

Elemento

Lajes

\section{Diretriz}

- Não utilizar barras de $5 \mathrm{~mm}$ de diâmetro nas malhas positivas da armadura das lajes, mesmo quando este elemento solicite armadura mínima. Exceção para as situações em que o uso das barras de $5 \mathrm{~mm}$, na situação supracitada, acarrete economia relevante de material por pavimento.

- Limitar o número de posições distintas (positivas + negativas) em relação à área de fôrma de laje.
Implementação

Imediata

Imediata 
Tabela 6.51 (conclusão) - Diretrizes para o PDA - Lajes

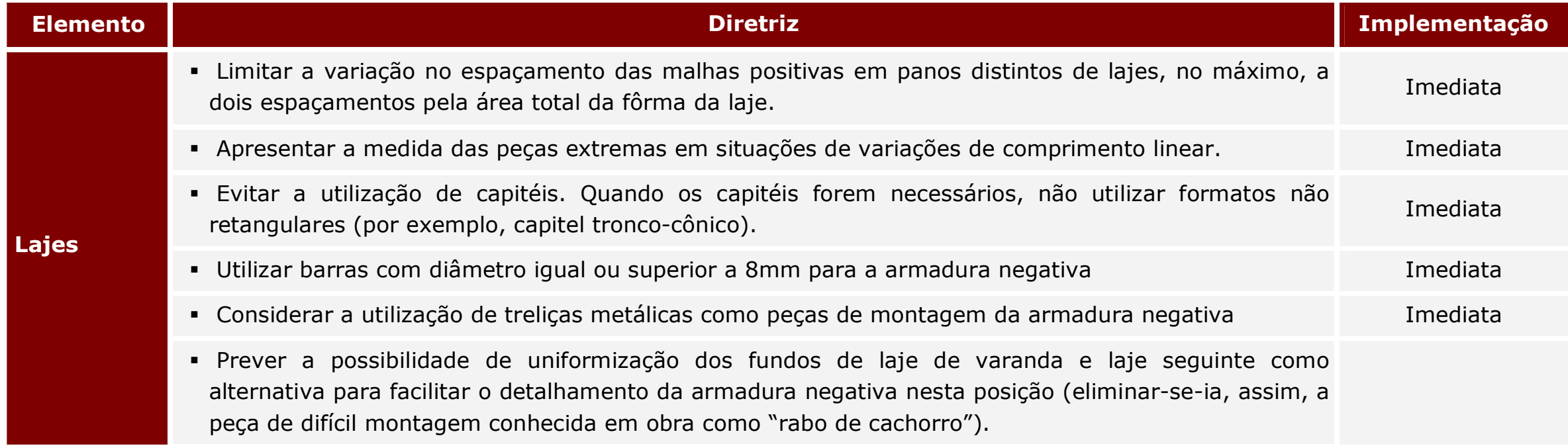


As diretrizes para representação do PDA, apresentadas na Tabela 6.50, avançam ao que inicialmente se propôs fazer neste trabalho, na medida em que sugerem que o projeto traga informações adicionais àquelas comumente disponibilizadas. Imagina-se que tais informações sejam a base do conjunto de necessidades a serem contempladas em um "projeto para a produção" das armaduras em canteiros de obras. Possível de ser elaborado pelo escritório de projeto estrutural, a partir de solicitação e apoio (técnico e financeiro) da construtora, o projeto para a produção das armaduras poderá configurarse como uma ferramenta complementar aos propósitos do MPDPro, ao assistir o pessoal de campo com informações orientativas e esclarecedoras à condução das principais etapas do processo.

Tabela 6.50 (continua) - Diretrizes para o PDA - representações

\begin{tabular}{|l|l|}
\hline PDA & \multicolumn{1}{|c|}{ Diretriz } \\
\hline - Trazer o detalhamento das armaduras de lajes representado em duas \\
plantas: uma planta para peças positivas; outra para as peças da \\
armadura negativa. \\
- Delimitar as regiões em que as peças serão dispostas com hachuras \\
e/ou traços pontilhados (prever hachuras distintas para malhas com \\
espaçamento e bitolas distintas da estabelecida como padrão). \\
- Indicar em planta o posicionamento das armaduras suplementares \\
(de montagem), prevendo, entre outros, a disposição dos \\
espaçadores para malhas positivas e armaduras negativas. \\
- Trazer detalhes na planta em que foram "chamados". \\
- Indicar no detalhamento de cada viga os nomes dos apoios \\
associados à suas extremidades (pilares e/ou vigas). \\
- Trazer a lista resumo de aço com as posições agrupadas por vigas (e \\
não seqüencialmente). \\
- Diferenciar (com nomes distintos) as vigas com armaduras idênticas, \\
porém "espelhadas". \\
- Trazer a identificação do número total de estribos num determinado \\
trecho da viga e não somente o seu espaçamento. \\
- Indicar claramente as regiões da viga onde haja a presença de \\
estribos com espaçamento e/ou diâmetro variáveis. \\
- Posicionar os detalhes das peças longitudinais positivas abaixo do \\
desenho da viga e as negativas acima do mesmo desenho. Quando as \\
barras longitudinais estiverem dispostas em várias camadas, além da \\
separação prevista anteriormente, mostrar a distribuição através de \\
cortes, com cotas a partir de uma referência.
\end{tabular}


Tabela 6.52 (conclusão) - Diretrizes para o projeto de detalhamento das armaduras representações

\begin{tabular}{|c|c|}
\hline PDA & Diretriz \\
\hline Viga & $\begin{array}{l}\text { - Detalhar a armadura de suspensão para vigas apoiadas sobre vigas. } \\
\text { - Dispor seqüencialmente os desenhos das vigas nas plantas para } \\
\text { facilitar a sua localização. } \\
\text { - Detalhar em escalas maiores os encontros de vigas que apresentem } \\
\text { congestionamento de armadura nesta região. }\end{array}$ \\
\hline & $\begin{array}{l}\text { - Trazer a lista resumo de aço com as posições agrupadas por pilares } \\
\text { (e não seqüencialmente). }\end{array}$ \\
\hline Pilar & - Separar o detalhamento das armaduras por pavimentos. \\
\hline & $\begin{array}{l}\text { - Dispor seqüencialmente os desenhos dos pilares nas plantas para } \\
\text { facilitar a sua localização. }\end{array}$ \\
\hline
\end{tabular}

\subsubsection{Diretrizes relacionadas ao método e à organização do trabalho}

As discussões, conduzidas pela construtora nesta etapa com os seus principais empreiteiros e fornecedores, basearam-se nos desempenhos referentes ao método e à organização do trabalho detectados para o conjunto de obras participantes da aplicação do MPDPro.

Tais discussões objetivaram a proposição de diretrizes que orientassem a implementação e/ou consolidação, nos canteiros de obras da construtora, das boas práticas referentes ao método e organização do trabalho.

As diretrizes apresentadas nas Tabela 6.51 e Tabela 6.52 foram determinadas pela construtora ao final das discussões mantidas com os agentes. Algumas delas envolvem ações mais complexas da construtora para a sua implementação (como, por exemplo, a diretriz que prevê um programa de capacitação da mão-de-obra mantido e fomentado pela construtora). Outras diretrizes, de aplicação mais imediata, seriam contempladas em procedimentos de execução do serviço (PES-Armação) da construtora, bem como na carta-convite para a contratação de serviços e nos próprios contratos, como cláusulas a serem atendidas. 
Tabela 6.51 (continua) - Diretrizes para o método de trabalho

\begin{tabular}{|c|c|c|}
\hline OPERAÇÕES DO MÉTODO & BOA PRÁTICA & DIRETRIZ \\
\hline \multicolumn{3}{|l|}{ Descarregamento } \\
\hline $\begin{array}{l}\text { Carregamento preparado } \\
\text { para descarregamento }\end{array}$ & preparado & $\begin{array}{l}\text { Solicitar ao fornecedor de aço que oriente o } \\
\text { carregamento, arrumando a carga no caminhão de } \\
\text { maneira a tornar o descarregamento menos } \\
\text { dispendioso. Elaborar proposta para ser submetida ao } \\
\text { fornecedor. }\end{array}$ \\
\hline $\begin{array}{l}\text { Sistema de etiquetas para } \\
\text { identificação dos feixes }\end{array}$ & $\begin{array}{l}\text { etiquetas presas e com } \\
\text { sistema de cores }\end{array}$ & $\begin{array}{l}\text { Solicitar ao fornecedor de aço que utilize sistemas de } \\
\text { etiquetas coloridas para distinguir peças (de porções } \\
\text { e de elementos distintos) }\end{array}$ \\
\hline $\begin{array}{l}\text { Acessibilidade do caminhão } \\
\text { no canteiro }\end{array}$ & boa & $\begin{array}{l}\text { Contemplar no projeto de canteiro de obras o acesso } \\
\text { inteligente dos caminhões com cargas de aço em } \\
\text { todas as fases da obra. }\end{array}$ \\
\hline Descarregamento & $\begin{array}{l}\text { com freqüente uso de } \\
\text { equipamento }\end{array}$ & $\begin{array}{l}\text { Propor, já na fase de orçamento, a utilização de } \\
\text { gruas em todas as obras em que esteja previsto } \\
\text { recebimento de aço superior a cinco toneladas } \\
\text { semanais. Considerar a grua nas negociações com o } \\
\text { empreiteiro de armação. }\end{array}$ \\
\hline \multicolumn{3}{|l|}{ Estocagem } \\
\hline $\begin{array}{l}\text { Distância entre áreas de } \\
\text { descarregamento e } \\
\text { estocagem }\end{array}$ & desprezível & $\begin{array}{l}\text { Racionalizar, na fase de projeto do canteiro de obras, } \\
\text { o posicionamento das áreas de estocagem de aço, } \\
\text { que devem estar próximas ao local de } \\
\text { descarregamento (referência: ambas as áreas (local } \\
\text { de parada do caminhão e estoque do aço) atendidas } \\
\text { pela grua). }\end{array}$ \\
\hline $\begin{array}{l}\text { Estoques intermediários até } \\
\text { estocagem definitiva }\end{array}$ & $\begin{array}{l}\text { sem estoques } \\
\text { intermediários }\end{array}$ & $\begin{array}{l}\text { Eliminar estoques intermediários. Quando necessário, } \\
\text { mantê-lo centralizado com as peças separadas e } \\
\text { corretamente identificadas. }\end{array}$ \\
\hline $\begin{array}{l}\text { Nível geral de organização } \\
\text { dos estoques de peças }\end{array}$ & bom & $\begin{array}{l}\text { Desenvolver, junto ao fornecedor, páletes para o } \\
\text { recebimento e estocagem de aço pré- } \\
\text { cortado/dobrado }\end{array}$ \\
\hline \multicolumn{3}{|l|}{ Corte/Dobra } \\
\hline $\begin{array}{l}\text { Distância entre área de } \\
\text { estoques e bancadas de } \\
\text { corte }\end{array}$ & desprezível & $\begin{array}{l}\text { Priorizar que as bancadas de corte/dobra estejam } \\
\text { localizadas em regiões protegidas (preferencialmente, } \\
\text { debaixo de lajes) e próximas às áreas de estoque. }\end{array}$ \\
\hline $\begin{array}{l}\text { Equipamentos de corte das } \\
\text { barras }\end{array}$ & $\begin{array}{l}\text { uso de máquinas } \\
\text { hidráulicas, } \\
\text { predominantemente }\end{array}$ & $\begin{array}{l}\text { Estimular o uso de máquinas hidráulicas pelos } \\
\text { empreiteiros. }\end{array}$ \\
\hline $\begin{array}{l}\text { Planejamento prévio das } \\
\text { peças a serem cortadas }\end{array}$ & $\begin{array}{l}\text { planejamento da } \\
\text { engenharia para a } \\
\text { produção }\end{array}$ & $\begin{array}{l}\text { Elaborar planos de corte para o empreiteiro, visando } \\
\text { reduzir as perdas de aço e otimizar a operação. }\end{array}$ \\
\hline \multicolumn{3}{|l|}{ Pré-montagem } \\
\hline $\begin{array}{l}\text { Armaduras de pilares, vigas } \\
\text { e lajes pré-montadas }\end{array}$ & $100 \%$ & $\begin{array}{l}\text { Orientar o projetista estrutural para que os } \\
\text { detalhamentos das armaduras permitam e facilitem a } \\
\text { pré-montagem da maioria delas. }\end{array}$ \\
\hline $\begin{array}{l}\text { Configuração/disposição } \\
\text { da(s) área(s) }\end{array}$ & $\begin{array}{l}\text { centralizadas, em } \\
\text { ambientes protegidos e } \\
\text { relativamente tranqüilos }\end{array}$ & $\begin{array}{l}\text { Priorizar que as regiões destinadas à pré-montagem } \\
\text { estejam localizadas em regiões protegidas } \\
\text { (preferencialmente, debaixo de lajes) e centralizadas. }\end{array}$ \\
\hline $\begin{array}{l}\text { Posicionamento das } \\
\text { armaduras }\end{array}$ & $\begin{array}{l}\text { predominantemente com } \\
\text { auxílio da grua }\end{array}$ & $\begin{array}{l}\text { prever no mapa de utilização da grua a sua utilização } \\
\text { para o transporte e posicionamento de armaduras } \\
\text { pré-montadas nas fôrmas. }\end{array}$ \\
\hline
\end{tabular}


Tabela 6.53 (conclusão) - Diretrizes para o método de trabalho

\begin{tabular}{|c|c|c|}
\hline OPERAÇÕES DO MÉTODO & BOA PRÁTICA & DIRETRIZ \\
\hline \multicolumn{3}{|l|}{ Montagem } \\
\hline $\begin{array}{l}\text { Configuração/disposição dos } \\
\text { espaçadores para armadura }\end{array}$ & treliças metálicas & $\begin{array}{l}\text { Adotar treliças metálicas como armadura de } \\
\text { montagem (espaçamento da armadura negativa). }\end{array}$ \\
\hline $\begin{array}{l}\text { Montagem das vigas } \\
\text { posteriormente à } \\
\text { concretagem dos pilares }\end{array}$ & não adotada & $\begin{array}{l}\text { Dimensionar ciclos para a execução da estrutura em } \\
\text { que se evite a montagem das armaduras das vigas } \\
\text { no mesmo período em que os pilares tenham sido } \\
\text { concretados. }\end{array}$ \\
\hline
\end{tabular}

Tabela 6.52 (continua) - Diretrizes para a organização do trabalho

\begin{tabular}{|c|c|c|}
\hline $\begin{array}{l}\text { ELEMENTOS DA } \\
\text { ORGANIZAÇÃO }\end{array}$ & BOA PRÁTICA & DIRETRIZ \\
\hline \multicolumn{3}{|l|}{ Aplicação } \\
\hline $\begin{array}{l}\text { Dimensionamento das } \\
\text { equipes }\end{array}$ & Base metodológica & $\begin{array}{l}\text { Dimensionar, em conjunto com o empreiteiro, o } \\
\text { tamanho da equipe de trabalhadores. O tamanho da } \\
\text { equipe deve ser tratado como algo que se calcula } \\
\text { (determina criteriosamente) e não algo com relação à } \\
\text { que se trabalha com a opinião da própria mão-de- } \\
\text { obra. }\end{array}$ \\
\hline Alocação das equipes 1 & $\begin{array}{l}\text { Realocações freqüentes } \\
\text { dos operários em } \\
\text { porções distintas na } \\
\text { mesma obra }\end{array}$ & $\begin{array}{l}\text { Prever, no planejamento, a existência de porções de } \\
\text { estruturas que possam ser executadas pela mão-de- } \\
\text { obra alocada em porções pertencentes ao caminho } \\
\text { crítico, em seus momentos de ociosidade (criar } \\
\text { situações em que a mão-de-obra possa melhorar } \\
\text { seus rendimentos com trabalho ao invés de aceitarem } \\
\text { como "prêmio" o "acabou-lavou"). }\end{array}$ \\
\hline Alocação das equipes 2 & $\begin{array}{l}\text { Realocações freqüentes } \\
\text { dos operários em } \\
\text { porções de obras } \\
\text { distintas }\end{array}$ & $\begin{array}{l}\text { Dar prioridades para trabalhar com o mesmo } \\
\text { empreiteiro em obras próximas, facilitando } \\
\text { realocações de operários entre as obras (suprindo } \\
\text { demandas localizadas das obras em momentos de } \\
\text { "pico"). }\end{array}$ \\
\hline $\begin{array}{l}\text { Jornada de trabalho diária } \\
1\end{array}$ & $\begin{array}{l}\text { = } 9 \text { horas disponíveis } \\
\text { para o trabalho (média } \\
\text { diária) }\end{array}$ & $\begin{array}{l}\text { Dar condições para que a mão-de-obra consiga } \\
\text { cumprir os cronogramas estipulados, respeitando a } \\
\text { jornada de trabalho diária prevista em lei. }\end{array}$ \\
\hline Alocação dos operários & $\begin{array}{l}\text { Eventualmente em } \\
\text { tarefas que não às } \\
\text { relacionadas ao ofício } \\
\text { registrado em carteira } \\
\text { profissional }\end{array}$ & $\begin{array}{l}\text { Estimular a polivalência dos operários através da } \\
\text { proposição de programas de capacitação de } \\
\text { trabalhadores. Priorizar que o operário tenha } \\
\text { habilidades para exercer atividades seqüenciais } \\
\text { àquela para a qual é qualificado. }\end{array}$ \\
\hline \multicolumn{3}{|l|}{ Manutenção } \\
\hline Horas ociosas $n$ & $\begin{array}{l}\text { Operários remanejados } \\
\text { para outras atividades }\end{array}$ & $\begin{array}{l}\text { Manter o operário ocupado no canteiro de obras } \\
\text { durante toda a jornada de trabalho, substituindo a } \\
\text { prática da "dispensa" pela sua alocação em outras } \\
\text { atividades e remunerá-lo por isso. }\end{array}$ \\
\hline
\end{tabular}


Tabela 6.54 (conclusão) - Diretrizes para a organização do trabalho

\begin{tabular}{|c|c|c|}
\hline $\begin{array}{l}\text { ELEMENTOS DA } \\
\text { ORGANIZAÇÃOO }\end{array}$ & BOA PRÁTICA & DIRETRIZ \\
\hline \multicolumn{3}{|l|}{ Manutenção } \\
\hline Motivação & $\begin{array}{l}\text { Práticas identificadas e } \\
\text { valoradas pelos } \\
\text { operários }\end{array}$ & $\begin{array}{l}\text { Desenvolver um programa motivacional que tome por } \\
\text { base o entendimento das expectativas dos } \\
\text { trabalhadores, imaginando-se que considerações } \\
\text { únicas para todos são menos eficazes em criar } \\
\text { entendimentos que facilitem a gestão do trabalho. }\end{array}$ \\
\hline \multicolumn{3}{|l|}{ Desenvolvimento } \\
\hline $\begin{array}{l}\text { Leitura e interpretação de } \\
\text { projetos }\end{array}$ & $\begin{array}{l}>30 \% \text { dos operários } \\
\text { com tais habilidades }\end{array}$ & $\begin{array}{l}\text { Utilizar programas de treinamento já disponíveis ou } \\
\text { criar novos caminhos para tanto }\end{array}$ \\
\hline $\begin{array}{l}\text { Programas de reciclagem } \\
\text { profissional }\end{array}$ & $\begin{array}{l}\text { Disponíveis aos } \\
\text { operários }\end{array}$ & $\begin{array}{l}\text { Desenvolver, em parcerias com demais agentes, } \\
\text { programas de reciclagem profissional com apelo ao } \\
\text { desenvolvimento de novas habilidades (e, portanto, } \\
\text { oportunidades) ao trabalhador. }\end{array}$ \\
\hline Profissionalização & $\begin{array}{l}\text { Presença de programas } \\
\text { oficiais de } \\
\text { formação/capacitação }\end{array}$ & $\begin{array}{l}\text { Fomentar a criação de um programa de capacitação } \\
\text { dos profissionais menos habilitados, de maneira a } \\
\text { formar uma mão-de-obra diferenciada e com melhor } \\
\text { qualificada. }\end{array}$ \\
\hline \multicolumn{3}{|l|}{ Monitoração } \\
\hline $\begin{array}{l}\text { Monitoramento consciente } \\
\text { e constante dos operários } \\
\text { como ferramenta gerencial }\end{array}$ & $\begin{array}{l}\text { Monitoramento } \\
\text { consciente e constante } \\
\text { dos operários pelo } \\
\text { empreiteiro }\end{array}$ & $\begin{array}{l}\text { Envolver os empreiteiros de maneira mais forte nas } \\
\text { próximas aplicações do MPDPro, de maneira a } \\
\text { desenvolvê-los no âmbito da organização do trabalho. }\end{array}$ \\
\hline
\end{tabular}




\section{Considerações Finais}

\subsection{Considerações Preliminares}

Acredita-se que o trabalho cumpriu um papel significativo ao enfatizar a importância de se estudar o serviço de armação, muitas vezes motivo de menos atenção por parte tanto dos pesquisadores quanto do meio produtivo em comparação com outros serviços relativos à obra bruta. Somente seu impacto financeiro considerável (haja vista a representatividade dos custos do material (o aumento do aço no ano de 2004 foi da ordem de 50\%) e da mão-de-obra envolvida), por si só o faz merecedor de investimentos em projetos de pesquisa que pleiteiam ganhos em eficiência produtiva e possibilitem o compartilhamento desses ganhos entre todos os agentes envolvidos.

O ineditismo desta tese está na proposição de um método de gestão da produção que tem no esforço coordenado dos vários agentes participantes do processo (leia-se, sinergia) a sua maior garantia de sucesso. Não são apresentadas soluções prontas, indiscutíveis no sentido de levar ao desejado aumento da eficiência dos processos (e nem se poderia acreditar em tais soluções únicas, a julgar pela imensa variabilidade de contextos e conteúdos que acometem a construção civil em seus inúmeros processos produtivos); apresenta-se, sim, um caminho claro, organizado e sistematizado, este sim, que, se percorrido, contribuirá, efetivamente, para a melhoria no desempenho dos processos de produção.

\subsection{Atualidade do Tema}

O mercado imobiliário, para alguns segmentos, como, por exemplo, o de edifícios multipavimentos, vem impondo gradativas reduções nos custos das construções, que afligem os construtores, bem como todos os demais agentes da cadeia (principalmente os menores e mais fracos (entenda-se, empresas subcontratadas, por exemplo)). Desconsiderando-se toda a problemática mercadológica da questão supracitada (que não faz parte do escopo deste trabalho), tem-se que a redução (em relação ao custo total do empreendimento) acaba incidindo sobre centros de custos como aqueles que englobam a mão-de-obra. É muito mais fácil conseguir as reduções impostas arrochando, por exemplo, um subempreiteiro do que tentando barganhar na compra de materiais (os mais representativos não apresentam margens para negociação).

A pressão que a construtora exerce sobre seus contratados é, em muitos casos, justificável. $O$ que não se aceita é a política que tem sido adotada por algumas empresas do mercado, que se posicionam como isentas de qualquer responsabilidade ao fecharem contratos, sabidamente infundados sob o ponto de vista da viabilidade financeira e, por assim ser, com mínimas chances de serem honrados.

Reverter tal situação passa, a priori, pelo aumento de renda da população brasileira que, por sua vez, está atrelado ao crescimento econômico (aumento sustentado do PIB, por exemplo), ao crescimento social (políticas fortes de distribuição de rendas, por exemplo), à condução de políticas eficientes de reestruturação nas esferas tributárias e fiscais (readequação das cargas tributárias com incentivo às pequenas e médias empresas a 
operarem dentro da formalidade, a partir de uma arrecadação mais justa de impostos e taxas) do país, entre outros.

Por outro lado, as pressões exercidas sobre construtores, e por esses sobre seus subcontratados podem ser minimizadas, e as ações para tal propósito, neste caso, não dependem apenas de políticas macroeconômicas, mas sim de mudanças nas políticas internas das próprias empresas no que tange à forma de condução da gestão dos seus processos.

Este trabalho de doutoramento, apesar de não ter falado explicitamente em "parceria", está totalmente fundamentado nesse conceito. Deve ficar entendido, com tudo o que foi colocado até aqui, que "o grande poder transformador" está, necessariamente, atrelado à articulação dos agentes em prol de causas comuns, ou melhor, de interesses comuns. A articulação e a sinergia passam a ser palavras de ordem para a promoção de melhorias, a começar pelo relacionamento entre as partes, até que se atinjam as melhorias de desempenho que façam frente à elevada competição, hoje intrínseca ao setor de construção civil brasileiro.

A parceria entre construtor e subempreiteiro, por exemplo, não pode se limitar apenas à garantia de obras futuras (em que perdas possam ser compensadas). É preciso ir além, o que significa começar ajudando o sucontratado a fazer a sua "lição de casa" (por exemplo, avaliar se o preço acordado para a realização de um serviço é realmente factível com o minimamente necessário para se honrarem todos os compromissos assumidos). Feito isso, deve-se promover um acompanhamento mais incisivo, principalmente nas situações mais críticas. Ajudá-lo com a proposição de organização do trabalho que o leve a ser mais eficiente na utilização do seu principal recurso, a mão-deobra, outro ponto a ser considerado. Criar condições mais favoráveis no ambiente de trabalho, a partir de observações e de investigações junto à produção, trata de um meio de ampliar ainda mais o conceito de parceria entre esses dois agentes, e garantir ganhos para ambos.

Outro exemplo de parceria envolve a construtora, o projetista e o pessoal da produção. A análise crítica dos projetos contribui para a melhoria de desempenho no processo de produção à medida que evidencia pontos que possam desfavorecer a construtibilidade e, por conseguinte, a produtividade da mão-de-obra.

Os dois exemplos supracitados ressaltam que, sozinho, qualquer que seja o agente considerado, fica limitado, rendendo pouco, seja no aspecto considerado neste trabalho, qual seja a melhoria da eficiência produtiva, ou em outros aspectos nas mais distintas esferas do empreendimento.

Dessa forma, a proposição de diretrizes, objetivo do método proposto e defendido neste trabalho, estará consolidada a partir, justamente, da interlocução entre os agentes (projetistas, fornecedores, subempreiteiros e mão-de-obra). São eles os grandes responsáveis pela proposição de tais diretrizes que, ao serem implementadas, poderão de fato contribuir para melhorar a eficiência nos processos de produção no âmbito da mão-de-obra da qual participa.

\subsection{Cumprimento dos Objetivos}

Os objetivos propostos inicialmente foram plenamente atendidos, comprovando a tese defendida neste trabalho de que o "o processo de concepção e produção de armaduras, 
com base em diretrizes que visem à construtibilidade do projeto do produto e à eficácia do método e da organização do trabalho, é condição essencial para influenciar positivamente a produtividade da mão-de-obra envolvida."

O método para a proposição de diretrizes, denominado "MPDPro", mostrou-se aplicável tal como inicialmente previsto. A comprovação deu-se através do sucesso no cumprimento de todas as etapas previstas durante a implementação real, envolvendo uma construtora importante do mercado de construção de edifícios, através de sete canteiros de obras. Destacam-se, a seguir, os principais pontos que justificam a eficiência do método e, dessa forma, o cumprimento do objetivo:

- Mobilização: o método mostrou-se capaz de mobilizar os agentes envolvidos em prol do objetivo proposto, em função do apelo do tema tratado, qual seja a melhoria da produtividade da mão-de-obra e as possibilidades reais de compartilhamento dos resultados obtidos. Através da forma clara e objetiva como foram conduzidas as etapas preconizadas pelo método, procurou-se não deixar dúvidas sobre a potencialidade do instrumento (que se tornavam evidentes à medida que se avançava na sua aplicação) e sobre os ganhos obtidos com a sua aplicação em todos os níveis do processo de produção em questão. Os tons da crítica utilizados, fossem para readequar um levantamento de dados que precisou de ajustes, ou para discutir números de produtividade, foram sempre construtivos, o que muito contribuiu para manter os envolvidos motivados e participativos.

- Padronização: a padronização da implementação, previamente garantida pelo método e imposta nas obras, proporcionou os ganhos já esperados quanto à uniformidade dos dados e informações levantadas. Contribuiu ainda para criar na empresa uma uniformização da comunicação no âmbito das discussões sobre a produtividade da mão-de-obra e dos fatores escolhidos para explicá-la, como também, sobre o processo de produção das armaduras, em virtude da analiticidade com a qual foi tratado. A sistematização do levantamento de dados possibilitou que as ferramentas utilizadas se firmassem na construtora e pudessem ser continuamente empregadas, permitindo que a empresa fizesse um acompanhamento permanente das produtividades obtidas em seus canteiros de obras.

- Conscientização: o discurso dispersivo e incipiente sobre a produtividade da mãode-obra entre os níveis gerenciais e administrativos, presentes nos canteiros de obras, cedeu lugar a uma discussão fundamentada e embasada em dados e informações confiáveis, seja pala forma transparente com que foram levantadas, seja por terem sido obtidas por pessoal interno ao próprio canteiro. As informações, mostraram-se isentas de dúvidas e receios quanto a sua veracidade, contribuindo para aumentar a confiança sobre o levantamento de dados e chamar a atenção para o que as informações geradas estariam dizendo.

- Autenticidade: o método se revelou autêntico ao expressar, através de índices e fatores realísticos, o processo de produção de armaduras, minimizando as margens para "senões", dúvidas ou incertezas.

- Integração: o método, tal como proposto, permitiu a valorização e a indução da integração dos agentes que participaram, fomentando diálogos saudáveis e gerando propostas consensuais e concretas (através das diretrizes apresentadas) para a promoção de melhorias na produtividade da mão-de-obra. 
- Informação: o método ("caminho para que se atinja um objetivo") sistematiza valiosas informações para a construtora. Essa passa a gerenciar sua produção com base em informações, geradas e gerenciadas por ela própria. Mais que os benefícios advindos com o alcance dos objetivos inicialmente propostos, a construtora pode e deve se beneficiar com todas as possibilidades aventadas e percebidas através do caminho percorrido para a determinação dos objetivos ("mais que o fim, os meios que levam ao fim"). As iterações e interações, intrínsecas ao caminho, fazem dele um exercício gerencial extremamente valioso.

Comprovada a eficiência, seria também desejável que o método fosse eficaz ao que se propõe, isto é, no aumento da produtividade da mão-de-obra envolvida no processo de produção de armadura para as estruturas de concreto armado. Para que fossem mensurados os efeitos das diretrizes propostas, seria necessário que o método previsse a implementação das diretrizes e a realização de um novo diagnóstico, ao final daquilo que seria uma nova etapa. No entanto, os tempos demandados para o cumprimento das etapas supracitadas seriam incompatíveis com os tempos disponíveis para o desenvolvimento desta tese.

Ainda assim, acredita-se que alguns aspectos observados ao longo da implementação do método (transformados em diretrizes, ou não), ainda que não tenham seus efeitos mensurados neste trabalho (o que seria a prova "concreta" da eficácia do método) são, por si só, pontos que deveriam, na visão deste autor, ser considerados em novos projetos estruturais, na definição de métodos e na organização do trabalho de todas as empresas que desejem aperfeiçoar, desenvolver e aumentar a eficiência do processo de produção de armaduras.

- Os objetivos complementares, inicialmente propostos, foram atingidos. Desta forma, este trabalho disponibilizou ao meio acadêmico e profissional uma proposta de uma sistematização de abordagem do PCPA (caracterização minuciosa, através de uma visão analítica do processo), que facilitará o entendimento do referido processo, colaborando, assim, para trabalhos futuros que versem sobre o assunto.

- Outro objetivo cumprido e, também, sumariamente importante ao próprio desenvolvimento deste trabalho, bem como de trabalhos futuros no âmbito da gestão dos processos de produção, foi a proposta defendida quanto ao que se entende por organização do trabalho. Permite-se, assim, que a organização seja estabelecida com base em uma série de aspectos intimamente ligados ao sucesso do processo de produção.

Por fim, tem-se que os dados levantados na etapa de diagnóstico, ainda que obtidos a partir de uma única empresa, contribuirão para continuar a consolidação de um banco de informações quanto à produtividade e fatores influenciadores em obras reais (iniciada, pelo grupo de pesquisadores do qual este autor faz parte, em 1998, e que tem servido a importantes propósitos (como, por exemplo, a reformulação do TCPO 2002 e trabalhos internacionais como aqueles desenvolvidos pelo grupo de trabalho em produtividade do CIB W55)).

\subsection{Fechamento dos Capítulos}

As propostas estabelecidas inicialmente para o desenvolvimentos dos capítulos mostraram-se pertinentes e fundamentais ao desenvolvimento da tese. Os objetivos de 
cada capítulo, comentados nas notas que o introduziram, foram alcançados, como mostrado resumidamente na Figura 7.1. Apresentam-se "amarrados", como haveria de se esperar, e comprometidos íntima e solidariamente como a tese de que "seja possível subsidiar o processo de concepção e produção de armaduras, com base em diretrizes para a elaboração do projeto do produto e a concepção do método e da organização do trabalho, de forma a aumentar a produtividade da mão-de-obra".

\begin{tabular}{|c|c|c|}
\hline \multirow[b]{2}{*}{$\begin{array}{l}\text { Capítulo } \\
1\end{array}$} & $\begin{array}{l}\text { Síntese dos } \\
\text { capítulos }\end{array}$ & $\begin{array}{c}\text { Principais objetivos } \\
\text { alcançados }\end{array}$ \\
\hline & Apresentação do tema & $\begin{array}{l}\text { apresentação da tese, dos objetivos e metodologia } \\
\text { adotada para o seu desenvolvimento }\end{array}$ \\
\hline $\begin{array}{c}\text { Capítulo } \\
2\end{array}$ & $\begin{array}{l}\text { Caracterização do processo de } \\
\text { produção que serviu de base ao } \\
\text { desenvolvimento do método } \\
\text { proposto. }\end{array}$ & $\begin{array}{l}\text { i) entendimento analítico do processo de } \\
\text { concepção e produção das armaduras (PCPA); ii) } \\
\text { caracterização do "Projeto de Detalhamento das } \\
\text { Armaduras" (PDA) iii) definição do "Método de } \\
\text { Trabalho" }\end{array}$ \\
\hline \multirow{2}{*}{$\begin{array}{c}\text { Capítulo } \\
3\end{array}$} & $\begin{array}{l}\text { A organização do trabalho no âmbito } \\
\text { da gestão da produção e da proposta }\end{array}$ & \multirow[t]{2}{*}{$\begin{array}{l}\text { definição dos elementos preconizados pela } \\
\text { "Organização do trabalho" }\end{array}$} \\
\hline & $\begin{array}{l}\text { de melhoria do processo de } \\
\text { produção a partir da melhoria da } \\
\text { produtividade mão-de-obra. }\end{array}$ & \\
\hline \multirow{2}{*}{$\begin{array}{c}\text { Capítulo } \\
4\end{array}$} & $\begin{array}{l}\text { A escolha e o embasamento teórico } \\
\text { do caminho para a melhoria da } \\
\text { produtividade. }\end{array}$ & \multirow{2}{*}{$\begin{array}{l}\text { i) identificação e justificativa da necessidade de } \\
\text { redução da variabilidade da produtividade; ii) } \\
\text { identificação dos fatores responsáveis pelas } \\
\text { variações; iii) agrupamento dos fatores em três } \\
\text { grupos distintos; iv) definição de uma nova } \\
\text { maneira de se enxergar o processo de produção } \\
\text { (projeto, método e organização do trabalho) }\end{array}$} \\
\hline & & \\
\hline $\begin{array}{l}\text { Capítulo } \\
5\end{array}$ & $\begin{array}{l}\text { Apresentação de um método } \\
\text { orientado a promover melhorias no } \\
\text { processo de concepção e produção } \\
\text { visando à melhoria da produtividade } \\
\text { da mão-de-obra. }\end{array}$ & $\begin{array}{l}\text { apresentação do Método para a Proposição de } \\
\text { Diretrizes para a Melhoria da Produtividade } \\
\text { (MPDPro), no âmbito do PDA, Método e } \\
\text { Organização do Trabalho }\end{array}$ \\
\hline $\begin{array}{c}\text { Capítulo } \\
6\end{array}$ & Aplicação do MPDPro & $\begin{array}{l}\text { Constatação da aplicabilidade de potencialidade do } \\
\text { método }\end{array}$ \\
\hline
\end{tabular}

Figura 7.1 - Síntese dos capítulos e principais objetivos alcançados

Se analisados separadamente, os capítulos, tais como apresentados, têm "vida própria" e podem servir a diferentes objetivos. O capítulo dois, por exemplo, avança na definição de nomenclaturas e na visão detalhada que se lança sobre o "serviço de armação", até este momento pouco presente em trabalhos acadêmicos. Novos trabalhos poderão se orientar por ele, seja adotando (e melhorando) a nomenclatura estabelecida, ou mesmo, partindo dela para buscarem o desenvolvimento dos projetos de detalhamento e das tecnologias empregadas nas operações preconizadas pelo método de trabalho, entre outros. Servir como material didático para disciplinas de tecnologia de cursos de graduação em 
engenharia civil, ou como base para o desenvolvimento de programas de capacitação profissional, também são possibilidades factíveis e permitidas pelo capítulo em questão.

O capítulo três, que a princípio faz uma revisão das teorias organizacionais para chegar ao seu principal objetivo, que foi o de definir os "elementos organizacionais", correlacionados à mão-de-obra (a mão-de-obra está presente de forma intensiva no processo de produção escolhido) e, portanto, imprescindíveis num trabalho que versa sobre a melhoria da produtividade dessa mesma mão-de-obra apresenta, também, contribuições valiosas, se tratado isoladamente. Menos importante do que o conhecimento da evolução das teorias e práticas organizacionais ao longo dos últimos cem anos (o autor sabe que há muito bons trabalhos sobre o tema, que tratam o assunto de maneira muito mais didática e brilhante), está a correlação, sempre atual, ainda que pouco valorizada, do tema "organização do trabalho" à força de trabalho presente nos canteiros de obras brasileiros.

O capítulo supracitado ganha força e objetividade ao enfatizar a importância e o valor do recurso-humano menos valorizado dentro dos canteiros de obras, o operário da construção. Muitas vezes, chamado e tratado equivocadamente por e como "peão" (termo pejorativo, que dentre tantas análises possíveis para explicar a sua adoção, parece ser melhor explicado quando se entende a representatividade do peão num jogo de xadrez). Esquece-se, no seu tratamento diário,de que o operário é um ser humano, com vontade própria, com anseios, aspirações, (vícios e fraquezas também) e desejos. Precisa ser devidamente tratado, inserido, em resumo, melhor "organizado" no seu ambiente de trabalho. Chama atenção para o fato de que a relação entre empregado e empregador, seja do tipo "ganha-ganha" (tanto nas cobranças e obrigações, como no compartilhamento de resultados e conquistas) é um dos objetivos "secundários" que se espera ter sido atingido no referido capítulo.

Ao quarto capítulo, também passível de ser olhado separadamente, sem perda de "sentido", traz lições que extrapolam o processo de produção contemplado nessa tese, servindo a todos os outros processos que utilizem intensivamente a mão-de-obra. Ao propor que os processos sejam tratados de forma dissociada, sob a ótica dos três pontos principais que o compõem (projeto, método e organização), amplifica a percepção e facilita a identificação das razões que podem provocar falhas (como a produtividade ruim, mas não só isso).

Quando chama a atenção para a importância dos indicadores na gestão em seus diferentes níveis, o quarto capítulo reforça a teoria de que é inadmissível a proposição de programas ou projeto de melhorias que não tenham como um dos seus pilares de sustentação referências próprias e externas, que apontem o posicionamento, o distanciamento da meta a que se pretenda atingir. É sempre prudente (e racional) que se saiba onde está para se decidir aonde ir.

Ainda no quarto capítulo, aponta-se para um ponto vital a ser "considerado" pelas empresas que decidam investir em melhorias nos seus processos: a sinergia ("ato ou esforço coordenado de vários órgãos na realização de uma função") entre os agentes participantes do processo que se desejava melhorar. Sinaliza-se, ainda que discretamente, que as relações (degradadas) entre os agentes que participam do setor da Construção Civil precisam evoluir, e essa evolução só acontecerá, de modo satisfatório, quando as responsabilidades, obrigações, ganhos etc forem compartilhados. 
O capítulo cinco, ainda que tenha sua aplicação "potencializada" por empresas que consigam "transitar com relativa desenvoltura" entre as linhas do conhecimento discutidas nos capítulos anteriores, traz ensinamentos que podem ser utilizados de distintas maneiras, sem que o seu operador seja um especialista em gestão, em processos ou em tecnologia. Da forma como o método foi apresentado, pode-se utilizálo, por exemplo, como uma ferramenta de gestão de projetos, servindo para munir coordenadores de projetos em suas análises. Aventa-se a possibilidade de servir, também, como base para um sistema de informações que permita integrar áreas distintas da empresa, como orçamentos, desenvolvimento, projeto, produção etc.

Vale dizer que aplicação do método apresentado no capítulo cinco pode ser "personalizada" pela empresa, que pode optar por restringi-la ao focar um serviço ou aspecto específico desse serviço (como o projeto), ou mesmo, por aumentar o escopo dessa aplicação, que passaria a ser dirigida não apenas a um serviço, mas a um conjunto de serviços pertencentes a um subsistema. Seria interessante, nesse último caso, que a empresa já detivesse certo domínio na condução e aplicação do método e/ou contasse com a participação de especialistas para assessorá-la nessa tarefa.

O sexto capítulo, mais que apresentar a aplicação do método através de um caso particular ("aplicação piloto"), constatando o alcance dos objetivos a que se propõe, disponibiliza um conjunto de dados (e informações geradas através deles) extenso e significativo, passíveis de uma série de outras análises e desenvolvimentos. Amplia, assim, a bases de dados sobre a produtividade da mão-de-obra envolvida na produção de estruturas e contribui, entre outros agentes, com as empresas voltadas à produção de estruturas, principalmente aquelas que contratam ou são contratadas tanto por $\mathrm{m}^{3}$ de estrutura como também (e principalmente) por quantidade de aço (em massa) das armaduras produzidas.

Por fim, olhando apenas as variações detectadas nos indicadores de produtividade e nos índices de avaliação, principalmente no âmbito do projeto de detalhamento das armaduras, trazidos à tona no capítulo seis, evidenciam-se discrepâncias significativas num universo bastante restrito (sete obras semelhantes de uma mesma empresa), dando sinais claros de que o atual sistema de contratação dos serviços de execução das estruturas ( $R \$ / m 3$ de estrutura produzida), ao ignorar tais variações, pode ser desfavorável tanto ao contratado como ao contratante.

\subsection{Avanços com o Desenvolvimento desta Tese}

O desenvolvimento da tese permitiu, a este pesquisador, avançar numa área do conhecimento que começou a ser trilhada na sua dissertação de mestrado (pode-se dizer que este trabalho não seria factível sem o desenvolvimento do trabalho antecessor). Enquanto o trabalho de mestrado tratou de consolidar uma ferramenta de diagnóstico, o presente trabalho tomou o diagnóstico, tal como proposto, e fez dele um potente instrumento para o balizamento de decisões com o intuito de promover, de fato, melhorias.

Em outras palavras, enquanto a dissertação de mestrado possibilitou mensurar a eficiência e posicionar o índice encontrado numa escala de valores (através da proposição de um método para tal fim), o trabalho de doutoramento deu condições de se estabelecer um diagnóstico pormenorizado do processo de produção, bem como avançar, com base no diagnóstico obtido, ao viabilizar a proposição de diretrizes que, se 
implementadas, poderão contribuir para o aumento da eficiência desse processo (através de um método também específico para este fim).

O método proposto, embora tenha tomado como base para o seu desenvolvimento o processo de concepção e produção de armaduras (PCPA), foi estruturado de tal forma que possa ser facilmente adaptado e aplicado em outros processos de produção.

A idéia de se desmembrar o processo de produção segundo uma tríade formada pelo projeto do produto, método e organização de trabalho provou-se interessante, permitindo melhor compreensão, tanto na etapa de levantamento de dados, quanto nas etapas de análise e proposição das diretrizes. Nesta última, os agentes participantes puderam ser mais contundentes nas suas opiniões, justamente pelo fato de o "problema" estar segmentado.

Entende-se que a divisão supracitada trouxe ganhos adicionais ao principal objetivo deste trabalho, justamente ao permitir um diagnóstico mais especifico da produtividade, o qual poderá, por si só, subsidiar outras decisões no processo de produção em questão.

O diagnóstico a que se refere o parágrafo anterior atentou para uma significativa variabilidade dos índices de produtividade (faixas largas de produtividade, com variação superior a 200\%), o que mostra que os ganhos com a implementação do método proposto possam ser bastante consideráveis. As distinções percebidas entre os processos estudados, nos sete canteiros de obras contemplados, acredita o autor, podem ser minimizadas, uniformizado-se, assim, os processos vigentes e contribuindo para o estreitamento das faixas de produtividade.

Em face às variações detectadas para os indicadores de produtividade, este pesquisador acredita haver espaço para os especialistas na concepção do projeto estrutural, do método e da organização do trabalho definirem posturas que levem a melhores RUP; ou não sendo possível adotar tais posturas, conhecer o "ônus" que outras posturas possam trazer. Assumir que variações são frutos de "algo inexplicável" ("típicas do setor", "acontecem ao sabor do vento"...) poderiam ser até aceitáveis vindas de um leigo em engenharia, mas não podem servir como argumento para um técnico em construção.

Ao longo do desenvolvimento do trabalho procurou-se discutir os problemas levantados com base na "transparência": assim como se gostaria de induzir que o contratante não abusasse do operário, não se gostaria de perpetuar a idéia de que manter baixas produtividades da mão-de-obra geraria mais empregos. O novo paradigma, que se espera estabelecer, envolve idéias mais ousadas, tais como reformular as práticas de contratação que, por exemplo, no caso da estrutura de concreto armado, envolvem contratações por " $\mathrm{m3}$ " de estrutura medida em projeto, o que tem significado preferir-se o uso de estruturas convencionais em lugar de estruturas com menos vigas.Assim permitiriam fazer o mesmo metro quadrado de construção com menor consumo de material e de mão-de-obra para alguns dos serviços que tomam parte na execução da estrutura, mas que são descartadas em função de aumentarem o consumo de concreto.

Certamente, implementar essas novas idéias não será uma tarefa fácil, mas o autor acredita que, com base em dados confiáveis, abertos e transparentes, quanto à produtividade, tais discussões passem a ser feitas com mais clareza e chances de sucesso. Acredita-se, também, que os agentes, num ambiente menos claro, procurem se defender, até mesmo por "medo do desconhecido". O caráter mais impessoal proporcionado pelos dados e informações geradas com a aplicação do MPDPro permitirá uma franqueza maior na discussão dos problemas. 
A verdade revelada pelos valores de produtividade e dos fatores a ela associados irá aumentar a percepção dos agentes da cadeia quanto à importância do processo, quanto aos pontos que precisam ser melhor tratados para que se alcancem melhores níveis de eficiência. Os agentes poderão cobrar e serem cobrados de maneira salutar, embasados em verdades expressas por números (terão suas sugestões técnicas ouvidas, testadas e sua eficiência mensurada).

Os projetistas estruturais, por exemplo, poderiam ter seus projetos avaliados quanto aos níveis de construtibilidade que oferecessem (efeito das boas posturas de projeto sobre a produtividade e o consumo de materiais). Tal condição poderia contribuir, por exemplo, para tornar mais atraente e justa a forma com que os projetos são remunerados.

Os ganhos advindos da melhoria da produtividade podem proporcionar relações mais justas com os operários que, conforme já comentado, caracterizam o último elo da cadeia, sendo, portanto, os mais "espremidos".

Da forma como foi desenvolvido e apresentado este trabalho, deixou-se claro que melhorar o desempenho na produção das estruturas passa, também (detecta-se, na bibliografia, um número de trabalhos bastante mais expressivo quanto a outros serviços, quais sejam fôrmas e concretagem), por assistir com pesquisa e desenvolvimento o processo de concepção e produção das armaduras. Espera-se que este trabalho seja o primeiro de uma série, constatação esta ainda mais evidente quando se considera a atual representatividade dos recursos envolvidos neste processo de produção.

\subsection{Ganhos com a Aplicação do Método pela Construtora}

A aplicação do método em uma construtora mostrou uma série de avanços que podem ser facilmente obtidos no que se refere à condução da gestão da produção num canteiro de obras. O primeiro ponto a se observar é o abandono do empirismo e dos "achismos" que acometem os diversos níveis gerenciais e operacionais presentes na obra.

A empresa de construção, no que tange à gestão dos seus processos, passa a contar com uma sistemática de acompanhamento e controle da sua produção (diagnóstico) e tem, no aprendizado consolidado através da interpretação solidária dos levantamentos realizados (análise e proposição de diretrizes), reais e concretas possibilidades de atingir patamares superiores de eficiência em seus processos produtivos.

Os canteiros de obras e, respectivamente, a empresa, fazendo uma analogia à aviação, "passam a ser guiados por instrumentos" , e todo o registro do percurso fica armazenado numa "caixa preta". A diferença é que a caixa preta dos aviões só é investigada quando o avião interrompe abruptamente sua trajetória. Já, em se tratando de uma empresa de construção, a caixa preta deve ser avaliada constantemente, justamente para impedir contratempos como a própria derrocada do empreendimento, ou mesmo, da empresa.

Como já comentando, a aplicação do método proporciona à empresa de construção uma aproximação "saudável" dos seus parceiros. As cobranças e queixas dão lugar à discussão pautada em levantamentos consistentes, que exprimem a realidade de determinado processo. A melhoria buscada deixa de ser individual e passa a ser coletiva, motivada pelo espírito (apregoado pelo método) de participação, de todos os agentes incluídos no processo, nos resultados que venham a ser conquistados. 
As empresas construtoras, habilitadas para a aplicação do método, são, certamente, empresas que entenderam a necessidade de se unirem a seus parceiros e ajudá-los com a gestão dos serviços prestados. Não há, portanto, mais espaço para políticas como a do "subempreiteiro que se vire", em que a construtora o "arroxa" e, em seguida, dá as costas, como se, daquele momento em diante, não precisasse fazer mais nada. $O$ método em questão ajuda com essa percepção, do mesmo modo que ela é condição imprescindível para a aplicação do método.

Não apenas as diretrizes apresentadas pela construtora, mas todo o desenvolvimento até que se chegasse a elas, devem proporcionar mudanças nas relações entre a construtora e os agentes participantes. Ao envolver, com sabedoria, esses agentes, assumindo a importância dessa participação, já se estarão quebrando paradigmas seculares e que, até hoje, colocam-se como impeditivos para que relações de parceria sejam efetivamente praticadas.

À medida que se aproxima, por exemplo, do projetista estrutural, e se passa a lhe dar retorno dos sucessos e insucessos dos seus projetos, com base em diagnósticos realizados com coerência e com base em critérios conhecidos (que podem ser previamente calibrados com a participação do próprio projetista), provoca-se: i) mudança nos níveis de cobrança dos próprios projetistas, que se sentirão mais motivados e instigados a darem retorno; ii) melhoria gradual e evolutiva dos projetos ("os projetos podem e devem ser sempre melhorados"), a partir da implementação do ajuste "fino" do projeto. Por outro lado, os projetistas que se dispuserem a sofisticar as análises, trabalhando as informações que Ihes são passadas, devem ser mais valorizados em todos os sentidos.

\subsection{Autocríticas}

Ao analisar criticamente o trabalho, pretende-se chamar atenção para alguns pontos em que o mesmo, na visão do seu autor, tratou com superficialidade (ou mesmo não considerou) e que pareciam carecer de maior atenção. Tais pontos e justificativas são apresentados a seguir.

\section{$\checkmark$ Custo}

O trabalho está fortemente focado na questão física da produtividade da mão-de-obra, sendo intenção proposital do autor a de não se enveredar em discussão de questões relativas a custos. Pretende-se, sim, criar bases para aprimorar a discussão entre os agentes da cadeia de produção de armaduras para estruturas de concreto, focada na transparência advinda do uso de informações confiáveis a partir da implementação de um método que, entre outros objetivos, consolide um processo de fomento à interação entre os agentes.

Cabe acrescentar que a discussão entre os agentes da cadeia vem, ao longo dos anos (na opinião do autor), sendo prejudicada pela falta de dados objetivos como subsídio. Por exemplo, tem-se brigado, devido a uma intensa pressão de mercado, pela redução dos preços das construções, esquecendo-se muitas vezes das componentes do custo que entram na formulação do preço. Embora olhar o lado financeiro da questão seja algo bastante relevante, menosprezar as componentes do custo pode ser muito perigoso. Diversos especialistas (sejam eles acadêmicos ou diretamente ligados à atividade profissional) demonstram a clara percepção de que a estratégia de baixar preços com 
base na pressão da negociação, e não em ganhos reais de produtividade, está levando o mercado da construção a uma situação bastante ruim. Estabeleceu-se uma onda de "pressões quanto à negociação de preços baixos" que nasce no incorporador, que atua sobre o construtor; este pressiona o subempreiteiro, que repassa o "aperto" ao trabalhador. Este último tem trabalhado com "tarefas" (usualmente à margem da legislação trabalhista), que nascem, não da observação da dificuldade do trabalho ou da eficiência em fazê-lo e, sim, do fato de que, caso não aceite as condições propostas, perderia o seu trabalho. Chama-se a atenção para o fato de que, à medida que se está ruindo a base, todos os outros agentes irão ter problemas. Nota-se a existência de condições propícias para se implementar uma discussão mais justa (até porque os construtores/incorporadores estão sentindo a própria pressão dos custos das ações trabalhistas). Portanto, mais do que melhorar a produtividade, busca-se ter uma linguagem isenta, clara, transparente para sua discussão e para discussão dos ônus e benefícios advindos de possíveis ações que visem a sua melhoria.

$\checkmark$ Foco restrito ao estudo de edifícios altos

O foco do método proposto é a edificação de múltiplos pavimentos (acima de um pavimento), envolvendo tanto edifícios habitacionais quanto comerciais. A atuação no foco definido tem uma série de vantagens: i) é onde se tem uma grande presença de projetistas competentes (e que, portanto, poderiam contribuir mais para a definição de diretrizes que pudessem ser usadas tanto no mercado dos edifícios de múltiplos pavimentos quanto nos outros); ii) é onde se encontram as principais inovações tecnológicas; é o local onde está a maioria dos operários legalmente contratados; dentre outros.

Em outros mercados representativos, como os de unidades unifamiliares, embora se reconheça sua importância, deparar-se-ia com dificuldades do tipo: i) ser a estrutura de concreto armado menos importante (do ponto de vista técnico e econômico); ii) terem-se dificuldades em detectar gestores com formação técnica etc. Este outro foco, portanto, não é, na opinião do autor, apropriado para o trabalho proposto (que demanda a existência de informações para ajudar na interação dos vários agentes). Provavelmente coubesse, neste outro mercado, um trabalho ainda na área de diagnóstico da produtividade vigente e dos fatores determinantes.

\section{$\checkmark$ Base conceitual}

Embora se tenha procurado tratar os conceitos com cuidado nos capítulos 2, 3 e 4, o trabalho tem um forte apoio empírico, no sentido de valorizar e se apoiar nas evidências advindas do levantamento das experiências reais das empresas e agentes envolvidos direta ou indiretamente com a produção das armaduras. Deve-se aqui relembrar um desafio do trabalho, qual seja o de criar um método implementável pelas empresas de construção e, portanto, que deveria ter como orientação, no seu desenvolvimento, a necessidade de balancear a precisão acadêmica com a praticidade da atividade de produção.

\subsection{Sugestão para Trabalhos Futuros}

Como encaminhamento para trabalhos futuros, apresentam-se, a seguir, os objetivos já delimitados e que constam numa proposta de projeto de pesquisa (nível de pósdoutoramento), que seguiria a trajetória de desenvolvimento, iniciada em 1998 por este 
pesquisador, e que, desde aquele momento, tem se inspirado e se motivado no cumprimento de um objetivo maior, qual seja, o de contribuir, efetivamente, para alavancar o desempenho da construção civil através da melhoria "sustentada" da produtividade dos processos de produção.

Buscar-se-ia, assim, com uma pesquisa a ser desenvolvida, o cumprimento dos seguintes objetivos:

Objetivo Principal: implementar ações, junto a agentes da cadeia produtora de armaduras, segundo orientações prescritas por um programa de melhorias previamente estruturado, de maneira a: i) melhorar a produtividade da mão-de-obra envolvida na produção de armaduras para estruturas de concreto armado de edifícios multipavimentos (edifícios altos) em 10\%, num período de dois anos; ii) reduzir as perdas de aço na produção de armaduras para estruturas de concreto armado de edifícios multipavimentos em $5 \%$, num período de dois anos.

Objetivos Específicos:

- Melhorar a interlocução entre os agentes da cadeia (interação pró-ativa entre projetistas estruturais e obra, por exemplo).

- Trazer novamente para discussão a proposta de reformulação da NBR 7191 (NB-16), partindo-se do projeto de reformulação aprovado (mas não sancionado) em dezembro de 1980.

- Reduzir a quantidade de resíduos gerados e, por conseguinte, minimizar a demanda por recursos energéticos e matérias-primas envolvidas na produção do aço.

- Melhorar as condições de trabalho dos operários que, espera-se, poderão compartilhar dos benefícios adquiridos com a melhoria da produtividade no uso dos recursos físicos.

- Contribuir para a formação e capacitação profissional de novos ingressantes: almejase a valorização profissional de novos entrantes a partir da ministração de cursos estruturados (através de cartilhas) que, além de oferecer uma formação qualificada de armador, resgatem a dignidade do trabalhador na Construção Civil.

- Favorecer o aprimoramento das empresas beneficiadoras de aço: conceito de agregação de valor ao serviço prestado por estas empresas.

- Contribuir para a capacitação das empresas subempreiteiras que produzem armaduras: conceito de cooperação dos agentes da cadeia na busca de "facilidades" para a produção; reorganização das subempreiteiras para absorverem o potencial de racionalização destas "facilidades" no canteiro de obras. 
APÊNDICE A - Levantamentos subjetivos: lista com as opiniões do pessoal de obra 
A lista com as opiniões do pessoal de obra (engenheiros, mestres, encarregados, subempreiteiros e operários) quanto aos aspectos relacionados ao projeto do produto e método do trabalho (aspectos estes, baseados nas listas de fatores de conteúdo e contexto determinadas na primeira etapa do método) e as respectivas influências (declaradas) sobre a produtividade da mão-de-obra envolvida no processo de produção das armaduras são apresentadas a seguir. As Tabela A 1, Tabela A 2, Tabela A 3 e Tabela A 4 trazem, respectivamente das opiniões referentes os projeto do produto para detalhamento de armaduras de pilares, vigas e lajes positivas e lajes negativas.

A Tabela A 5 exprime as opiniões do pessoal de obra sobre aspectos relacionados ao método de trabalho. 
Tabela A 1 - Lista de Opiniões referentes ao projeto do produto - PDA de pilares

\begin{tabular}{|c|c|c|c|c|c|c|c|c|c|}
\hline \multicolumn{2}{|r|}{ ASPECTOS } & \multicolumn{8}{|c|}{ OPINIÕES OBRAS } \\
\hline \multirow{6}{*}{ 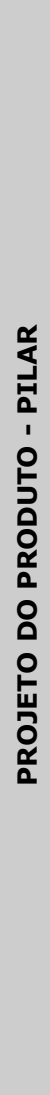 } & \multirow[b]{2}{*}{$\begin{array}{c}\text { Dificuldade } \\
\text { comparada da } \\
\text { armação de } \\
\text { pilares }\end{array}$} & SP 301 & SP 302 & \multicolumn{2}{|c|}{ SP 303} & SP 304 & \multicolumn{2}{|r|}{ SP 306} & SP 307 \\
\hline & & $\begin{array}{l}\text { Dificuldade do serviço: pilares é } \\
\text { mais fácil. A laje é o mais rápido } \\
\text { de amarrar (é a que mostra mais } \\
\text { serviço). A laje dá trabalho para } \\
\text { cortar e transportar o aço. As } \\
\text { vigas são mais complicadas de } \\
\text { armar. Porém hoje são mais } \\
\text { fáceis do que antigamente } \\
\text { (cavaletes). As vigas requerem } \\
\text { mais atenção devido ao grande } \\
\text { número de posições. }\end{array}$ & $\begin{array}{l}\text { Quando } \\
\text { questionado quanto } \\
\text { a dificuldade para } \\
\text { se fazer pilar, vigas } \\
\text { e lajes, o } \\
\text { encarregado alegou } \\
\text { que as vigas são as } \\
\text { peças mais difíceis } \\
\text { de serem armadas e } \\
\text { os pilares as mais } \\
\text { fáceis. }\end{array}$ & \multicolumn{2}{|c|}{\begin{tabular}{|l} 
O encarregado \\
apontoura \\
seguinte ordem \\
crescente de \\
dificuldade: \\
lajes, pilares e, \\
por último, as \\
vigas.
\end{tabular}} & $\begin{array}{l}\text { Pilar é muito mais fácil de armar do } \\
\text { que as vigas. Os pilares são levados } \\
\text { montado e só são encaixados no } \\
\text { local. Em se tratando de vigas, } \\
\text { algumas precisam ser armadas no } \\
\text { local (travadas uma nas outras), o } \\
\text { que tornam sua armação mais } \\
\text { complicada. A laje da obra em } \\
\text { questão é tranqüila de ser feita, não } \\
\text { apresenta dificuldades. }\end{array}$ & \multicolumn{2}{|c|}{$\begin{array}{l}\text { Com muito } \\
\text { estribo; } \\
\text { estribos } \\
\text { acorrentados } \\
\text {; armadura } \\
\text { para andar } \\
\text { duplo. }\end{array}$} & $\begin{array}{l}\text { A armação dos } \\
\text { pilares é mais fácil } \\
\text { quando comparada } \\
\text { a vigas e a lajes (a } \\
\text { quantidade de } \\
\text { dobras é muito } \\
\text { menor, } \\
\text { restringindo-se aos } \\
\text { estribos). As vigas } \\
\text { são a parte mais } \\
\text { difícil do serviço. }\end{array}$ \\
\hline & \multirow[b]{2}{*}{$\begin{array}{l}\text { Tamanho da } \\
\text { seção } \\
\text { retangular }\end{array}$} & \multicolumn{3}{|l|}{ SP 303} & \multicolumn{3}{|c|}{ SP 305} & \multicolumn{2}{|r|}{ SP 306} \\
\hline & & \multicolumn{3}{|c|}{$\begin{array}{l}\text { Geometria da seção dos pilares: os pilares retangulares } \\
\text { (estreitos numa direção) são mais fáceis de serem pré- } \\
\text { montados que os pilares quadrados. "Toda forma que permita } \\
\text { o armador esticar o braço e alcançar o ferro para dar o ponto } \\
\text { é mais fácil". Nos pilares retangulares, com largura tal que o } \\
\text { armador não consegue alcançar as barras e ganchinhos } \\
\text { centrais para "pontear", eles se posicionam embaixo da } \\
\text { armadura (que está sobre um cavalete) e ponteiam tantos as } \\
\text { barras inferiores quanto superiores. }\end{array}$} & \multicolumn{3}{|c|}{$\begin{array}{l}\text { Encarregado não pareceu perceber o fato de cada } \\
\text { pilar grande ter } \mathrm{kg} \text { de armadura maior (o que os } \\
\text { tornaria mais fáceis por } \mathrm{kg} \text { ). Comentou, isto sim, } \\
\text { que quando o pilar fica muito grande, sua gaiola } \\
\text { fica muito pesada (acho que já embutiu a idéia de } \\
\text { pré-montagem), o que demanda mais de } 1 \\
\text { operário para manuseá-la. Falou que acha os } \\
\text { pilares com largura de } 3 \text { a } 4 \text { metros difíceis. }\end{array}$} & \multicolumn{2}{|c|}{$\begin{array}{l}\text { Preferem } 2 \text { pilares menores } \\
\text { que } 1 \text { com o dobro do } \\
\text { comprimento; este último seria } \\
\text { de difícil pré-montagem } \\
\text { (armador precisa subir ou se } \\
\text { posicionar embaixo da gaiola } \\
\text { para dispor e amarrar as } \\
\text { barras) }\end{array}$} \\
\hline & \multirow[b]{2}{*}{$\begin{array}{c}\% \text { das } \\
\text { diferentes } \\
\text { peças do pilar }\end{array}$} & \multicolumn{3}{|c|}{ SP 303} & \multicolumn{5}{|c|}{ SP 305} \\
\hline & & \multicolumn{3}{|c|}{$\begin{array}{l}\text { A etapa mais trabalhosa na montagem dos pilares é a } \\
\text { colocação dos ganchinhos, devido a necessidade de dar } \\
\text { pontos em todos eles, o que é bastante trabalhoso. }\end{array}$} & \multicolumn{5}{|c|}{$\begin{array}{l}\text { Estribo é mais chato que barra longitudinal. Acha que a dificuldade de um pilar é } \\
\text { dada pelo número de dobras e de pontos a amarrar. }\end{array}$} \\
\hline
\end{tabular}


Tabela A 1 - (continuação) - Lista de Opiniões referentes ao projeto do produto - PDA de pilares

\begin{tabular}{|c|c|c|c|c|c|c|c|c|c|c|}
\hline \multicolumn{2}{|c|}{ ASPECTOS } & \multicolumn{9}{|c|}{ OPINIÕES OBRAS } \\
\hline \multirow{4}{*}{$\begin{array}{l}\frac{\alpha}{5} \\
\frac{1}{a} \\
1 \\
0 \\
\frac{1}{5} \\
0 \\
0 \\
\frac{\alpha}{a} \\
0 \\
0 \\
0 \\
\frac{1}{4} \\
0 \\
\frac{\alpha}{a}\end{array}$} & \multirow[b]{2}{*}{$\begin{array}{c}\text { Seções não } \\
\text { retangulares } \\
(U, L) \text { e } \\
\text { escada }\end{array}$} & SP 301 & SP 302 & \multicolumn{2}{|c|}{ SP 304} & SP 305 & \multicolumn{2}{|c|}{ SP 306} & \multicolumn{2}{|r|}{ SP 307} \\
\hline & & \begin{tabular}{|l} 
Os pilares \\
em $\quad$ U \\
(caixa de \\
escada), \\
no inicio da \\
obra, são \\
muito \\
pesados e \\
devem ser \\
levados em \\
partes e \\
complemen \\
tados \\
encima.
\end{tabular} & $\begin{array}{l}\text { Pilares retangulares são } \\
\text { mais fáceis que pilares } \\
\text { "compostos" (H, U, L). O } \\
\text { encarregado optaria por } \\
\text { armar os pilares em "L" } \\
\text { no local devido à } \\
\text { dificuldade de poscioná- } \\
\text { lo. Na obra em questão } \\
\text { todos os pilares são pré- } \\
\text { montados. Nos } \\
\text { primeiros pavimentos } \\
\text { (pilares mais pesados), } \\
\text { alguns pilares eram } \\
\text { montados diretamente } \\
\text { no local. }\end{array}$ & \multicolumn{2}{|c|}{$\begin{array}{l}\text { Pilares em } L \text { são mais difíceis do que } \\
\text { pilares retangulares. Pilares "chatos" } \\
\text { são mais fáceis do que pilares } \\
\text { quadrados (é mais fácil e dar os pontos } \\
\text { nos pilares retangulares "chatos"). } \\
\text { Melhor dois pilares de } 1 \mathrm{~m} \text { do que } 1 \text { de } \\
2 \mathrm{~m} \text { de largura (dificuldade dar os } \\
\text { pontos no meio do pilar; o braço não } \\
\text { alcança, sendo necessário entra por } \\
\text { baixo ou por cima, ou colocar o pilar } \\
\text { encostado), desde que a quantidade de } \\
\text { ferro seja a mesma. A quantidade de } \\
\text { ferro (barras longitudinais, estribos e } \\
\text { ganchinhos) torna um pilar mais difícil } \\
\text { ou mais fácil de ser montado (não deve } \\
\text { se olhar apenas o tamanho). }\end{array}$} & \begin{tabular}{|l|} 
Escada é \\
o que \\
acha \\
difícil; \\
pilares \\
em U e L \\
não \\
assusta \\
m tanto \\
(forma \\
não \\
atrapalh \\
a).
\end{tabular} & \multicolumn{2}{|c|}{\begin{tabular}{|lr} 
O pilar & $\mathrm{U}$ \\
se & muito \\
grande, & é \\
difícil & de \\
manusear, \\
travar; \\
entorta. \\
obra: pré- \\
montam \\
um ramo \\
do U por \\
vez r e \\
costuram \\
depois.
\end{tabular}} & \multicolumn{2}{|c|}{$\begin{array}{l}\text { As armaduras compostas (pilares } U \text {, por } \\
\text { exemplo), nesta obra são pré-montados } \\
\text { separados, subindo para o andar também } \\
\text { separados. São montados em cada um } \\
\text { dos lados separadamente, colocando-se } \\
\text { as barras longitudinais complementares } \\
\text { no local. Isso é devido ao peso da } \\
\text { armadura, ao trabalho a mais para } \\
\text { enrijecer a armadura para subi-la } \\
\text { montada e as grandes chances de haver } \\
\text { retrabalho para colocar estribos e barras } \\
\text { nas posições (durante o transporte e } \\
\text { posicionamento as barras pode fugir da } \\
\text { posição). Sendo montado em partes, a } \\
\text { grua coloca as armaduras em cima da laje } \\
\text { e os armadores podem posicioná-los sem } \\
\text { o auxílio da grua. }\end{array}$} \\
\hline & & \multicolumn{3}{|c|}{ SP 301} & \multicolumn{3}{|c|}{ SP 302} & \multicolumn{2}{|c|}{ SP 306} & SP 307 \\
\hline & Ganchinhos & \multicolumn{3}{|c|}{$\begin{array}{l}\text { Os ganchinhos são os pontos críticos na armação dos pilares. } \\
\text { Se pudesse modificar o projeto iria diminuir o número de } \\
\text { ganchinhos. A dificuldade de montar o pilar está nos } \\
\text { ganchinhos. O tempo que se leva para colocar os ganchinhos } \\
\text { daria para dobrar outro jogo de estribos de pilar. Para dobrar } \\
\text { tem que ir pegar os pedaços de ferros que sobraram, não } \\
\text { pode pegar das barras. Já os estribos não, pega as barras. }\end{array}$} & \multicolumn{3}{|c|}{$\begin{array}{l}\text { A quantidade de ganchinhos } \\
\text { por pilar também é indicador } \\
\text { de pilar mais fácil ou mais } \\
\text { difícil para montar. Pilares } \\
\text { come estribos de } 6,3 \mathrm{~mm} \text { são } \\
\text { melhores porque facilita o } \\
\text { ponto de amarração (ponto } \\
\text { simples). }\end{array}$} & \multicolumn{2}{|c|}{$\begin{array}{l}\text { Quanto menos é } \\
\text { mais fácil (mas } \\
\text { não gostam de } \\
\text { substituir por } \\
\text { estribos } \\
\text { acorrentados). }\end{array}$} & $\begin{array}{l}\text { Pilar quadrado com ganchinhos } \\
\text { na diagonal: a colocação } \\
\text { desses ganchinhos é bastante } \\
\text { trabalhosa. Na pré-montagem } \\
\text { dos pilares, gasta-se mais } \\
\text { tempo na colocação dos } \\
\text { ganchinhos. }\end{array}$ \\
\hline
\end{tabular}


Tabela A 1 - (continuação)- Lista de Opiniões referentes ao projeto do produto - PDA de pilares

\begin{tabular}{|c|c|c|c|c|c|c|}
\hline \multicolumn{2}{|c|}{ ASPECTOS } & \multicolumn{5}{|c|}{ OPINIÕES OBRAS } \\
\hline & & SP 301 & SP 303 & SP 304 & SP 306 & SP 307 \\
\hline 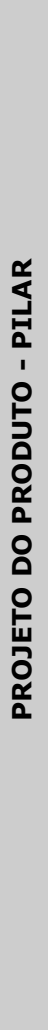 & $\begin{array}{c}\text { Posição/ } \\
\text { dimensão do } \\
\text { pilar }\end{array}$ & $\begin{array}{l}\text { A grua joga os } \\
\text { pilares na laje; o } \\
\text { posicionamento é } \\
\text { manual }\end{array}$ & $\begin{array}{l}\text { Posicionamento de pilares } \\
\text { com uma face de fundo de } \\
\text { fôrmas ou sem face de } \\
\text { fundo: é preferível que a } \\
\text { face de fundo das fôrmas } \\
\text { esteja colocada, para servir } \\
\text { de apoio à armadura. Nos } \\
\text { caso do pilar que é montado } \\
\text { no local, é preciso que, após } \\
\text { colocadas as barras } \\
\text { longitudinais, os carpinteiros } \\
\text { entre com o fundo, para os } \\
\text { armadores, em seguida, } \\
\text { estribarem os pilares (a face } \\
\text { de fundo serve de apoio para } \\
\text { que o pilar não tombe). "Fica } \\
\text { difícil para mim, porque o } \\
\text { meu ferro não tem apoio em } \\
\text { nada." A necessidade de face } \\
\text { de fundo é mais evidente } \\
\text { para o pilares armados no } \\
\text { local. Quanto ao } \\
\text { posicionamento dos pilares } \\
\text { (internos ou externos), não } \\
\text { diferença desde que a face } \\
\text { de fundo de fôrmas esteja } \\
\text { colocada. }\end{array}$ & $\begin{array}{l}\text { Pilares de canto, na beirada do } \\
\text { prédio, sempre exige mais cautela } \\
\text { e cuidado do armador (prender } \\
\text { cinto de segurança) do que a } \\
\text { armação dos pilares que estão em } \\
\text { regiões não periféricas da laje. } \\
\text { Para o armador é melhor que se } \\
\text { tenha as } 3 \text { laterais de fôrmas } \\
\text { colocadas para que seja } \\
\text { posicionada a armadura (serve } \\
\text { como apoio para a armadura; } \\
\text { apóia-se a armadura na fôrma). Se } \\
\text { não tiver a fôrma é preciso de dois } \\
\text { armadores de cada lado para } \\
\text { apoiar a armadura. Em caso de } \\
\text { pilares com larguras superiores ao } \\
\text { comprimento do braço do armador } \\
\text { e/ou muito denso de armaduras } \\
\text { (ferros em 2, } 3 \text { camadas) é preciso } \\
\text { que sua montagem seja feita (em } \\
\text { alguma situações toda a } \\
\text { montagem é feita no local) sem } \\
\text { que nenhuma das faces de fôrmas } \\
\text { tenha sido colocada, permitindo ao } \\
\text { acesso e amarração (nos } \\
\text { arranques) de todas as barras } \\
\text { (acesso a todas a laterais). }\end{array}$ & $\begin{array}{l}\text { Mesmo que não seja } \\
\text { pequena, em geral não é } \\
\text { um problema enfiar a mão } \\
\text { para dar o ponto do outro } \\
\text { lado (até o comprimento do } \\
\text { braço seria possível). A } \\
\text { dificuldade de entrar o braço } \\
\text { pode vir de ter-se } \\
\text { espaçamentos muito } \\
\text { pequenos entre as barras na } \\
\text { superfície do pilar (o } \\
\text { comentário vale para a viga } \\
\text { também). No caso de } \\
\text { pilares quadrados grandes e } \\
\text { com armadura densa, às } \\
\text { vezes opta-se por uma } \\
\text { montagem e amarração } \\
\text { com pontos de dentro para } \\
\text { fora, isto é, lida-se com as } \\
\text { barras do meio e, depois } \\
\text { colocam-se as mais } \\
\text { periféricas. a a }\end{array}$ & $\begin{array}{l}\text { Pilares de borda são mais } \\
\text { difíceis de serem montados } \\
\text { por envolverem mais riscos. } \\
\text { Pilares mais quadrados e mais } \\
\text { abertos são amarrados com } \\
\text { mais facilidade. Os pilares } \\
\text { com comprimentos maiores } \\
\text { dificultam a amarração (os } \\
\text { armadores não alcançam as } \\
\text { barras centrais para dar } \\
\text { ponto). Pilares com alta } \\
\text { densidade de ferros na região } \\
\text { do transpasse dificultam o } \\
\text { armador enfiar a mão para } \\
\text { amarrar as barras. }\end{array}$ \\
\hline
\end{tabular}


Tabela A 1 - (continuação)- Lista de Opiniões referentes ao projeto do produto - PDA de pilares

\begin{tabular}{|c|c|c|c|c|c|c|c|c|}
\hline \multicolumn{2}{|c|}{ ASPECTOS } & \multicolumn{7}{|c|}{ OPINIÕES OBRAS } \\
\hline \multirow{6}{*}{ 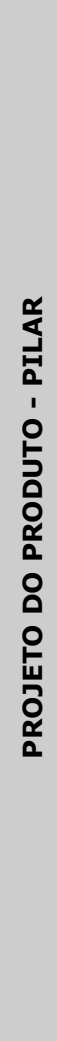 } & \multirow[b]{2}{*}{ Diâmetros } & SP 302 & SP 303 & & SP 304 & SP 305 & & SP 307 \\
\hline & & $\begin{array}{l}\text { O melhor diâmetro para } \\
\text { dobrar estribos é o } \\
6,3 \mathrm{~mm} \text { ("é o mais } \\
\text { cobiçado da armação). } \\
\text { Estribos muito estreitos } \\
\text { são mais difíceis (junta- } \\
\text { se a chave com o pino, } \\
\text { é difícil fazê-lo na } \\
\text { dimensão correta). A } \\
\text { barra de } 5,0 \mathrm{~mm} \text { é } \\
\text { muito ruim. }\end{array}$ & $\begin{array}{l}\text { Preferências de barras de } 5 \\
\text { ou 6,3mm nos estribos: } \\
\text { melhor as barras de } 6,3 \\
\text { porque evita que as barras } \\
\text { "escorreguem" (a barra de } \\
5 \mathrm{~m} \text { é lisa), sendo o tipo do } \\
\text { nó de ponto mais simples. } \\
\text { "Eu não sei por que ainda } \\
\text { está existindo o ferro de } \\
5 \mathrm{~mm} . . \text { já era para ter } \\
\text { acabado. Você vê, para o } \\
\text { armador dar um nó do tipo } \\
\text { "rabo de macaco" } \\
\text { (necessário quando se } \\
\text { trabalha com barras de } \\
5 \mathrm{~mm} \text { ) ele gasta mais arame } \\
\text { e mais tempo." }\end{array}$ & $\begin{array}{l}\text { Maioria do pilare } \\
5 \mathrm{~mm} \text {, o que d } \\
\text { estribos fog } \\
\text { (escorregam), } \\
\text { momento em } \\
\text { sobre os outros } \\
\text { cima. Requer } \\
\text { pontos no local } \\
\text { estribos de } 6,3 r \\
\text { O armador pre } \\
\text { tenham ferros d } \\
\text { são mais leves, } \\
\text { leves, mais } \\
\text { transportadas. } \\
32 \mathrm{~mm} \text { é muitc } \\
\text { arranques. }\end{array}$ & $\begin{array}{l}\text { s da obra com estribos de } \\
\text { ificulta a montagem. Os } \\
\text { em das posições } \\
\text { principalmente no } \\
\text { que você posiciona uns } \\
\text { para do transportá-lo para } \\
\text { que seja dados novos } \\
\text { (mais trabalho). Se fosse } \\
\text { nm isso não aconteceria. } \\
\text { fere armar pilares que } \\
\text { menores diâmetros, pois } \\
\text { as armaduras ficam mais } \\
\text { fáceis de serem } \\
\text { Jm pilar com barras de } \\
\text { difícil posicioná-los no }\end{array}$ & 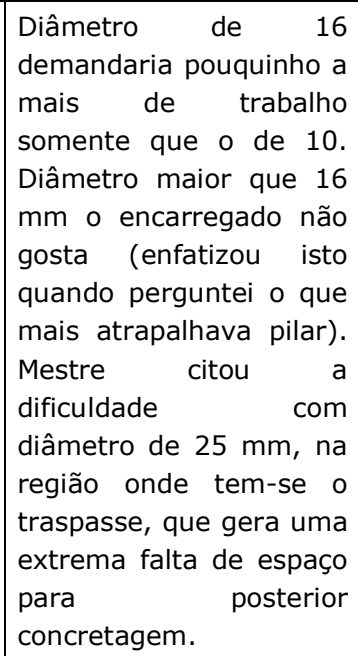 & $\begin{array}{l}\text { Pilare } \\
\text { mais } \\
\text { fáceis } \\
\text { de } \\
\text { pilare } \\
\text { ferros } \\
\text { são } \\
\text { tem } \\
\text { no loc } \\
\text { melho } \\
\text { para } \\
\text { o de } \\
5 \text { mm } \\
\text { amas } \\
\text { segur }\end{array}$ & $\begin{array}{l}\text { es com ferros } \\
\text { finos são mais } \\
\text { s. Dificuldade } \\
\text { levantar os } \\
\text { es. Quando os } \\
\text { s dos pilares } \\
\text { muito grossos } \\
\text { que se armar } \\
\text { cal. Estribos: o } \\
\text { or diâmetro } \\
\text { se trabalhar é } \\
6 \text { mm. O de } \\
\text { é fino demais, } \\
\text { ssa muito, não } \\
\text { ra o ponto. }\end{array}$ \\
\hline & \multirow{3}{*}{$\begin{array}{c}\text { Tamanho dos } \\
\text { estribos }\end{array}$} & \multicolumn{3}{|c|}{ SP 305} & \multicolumn{4}{|c|}{ SP 306} \\
\hline & & \multicolumn{3}{|c|}{$\begin{array}{l}\text { Dobrar estribo com comprimentos de } 20 \mathrm{~cm} \text { ou } 50 \mathrm{~cm} \text { daria o mesmo } \\
\text { trabalho (o que indica que pilares maiores seriam mais fáceis por } \mathrm{kg} \text { ). }\end{array}$} & \multicolumn{4}{|c|}{$\begin{array}{l}\text { Quanto ao tamanho do estribo estar limitado pelo espaço para a dobra } \\
\text { do mesmo, isso não é limitante na maioria das situações. }\end{array}$} \\
\hline & & \multicolumn{6}{|c|}{ SP 304} & SP 306 \\
\hline & $\begin{array}{l}\text { Engarrafar } \\
\text { armadura } \\
\text { longitudinal }\end{array}$ & \multicolumn{6}{|c|}{$\begin{array}{l}\text { É difícil trabalhar com pilares engarrafados. O melhor é que os ferros que não vão seguir "morram". Coloca-se, então, os ferros de } \\
\text { transpasse para a ancoragem das barras que iram nascer no novo posicionamento. O engarrafamento é feito no local. É difícil fazê-lo } \\
\text { durante a pré-montagem, pois mantê-lo na posição requer muita atenção e trabalho. A dobra (engarrafar) também é difícil de fazer. }\end{array}$} & $\begin{array}{l}\text { Acham algo } \\
\text { complicado } \\
\text { de fazer. }\end{array}$ \\
\hline
\end{tabular}


Tabela A 1 - (continuação)- Lista de Opiniões referentes ao projeto do produto - PDA de pilares

\begin{tabular}{|c|c|c|c|c|c|c|c|c|}
\hline \multicolumn{2}{|c|}{ ASPECTOS } & \multicolumn{7}{|c|}{ OPINIÕES OBRAS } \\
\hline & & SP 301 & SP 302 & SP 303 & SP 304 & SP 305 & SP 306 & SP 307 \\
\hline 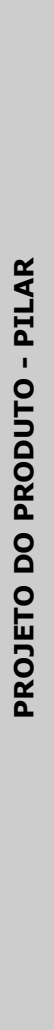 & $\begin{array}{c}\text { Armadura } \\
\text { dupla }\end{array}$ & $\begin{array}{l}\text { Pé-direito } \\
\text { duplo: } \\
\text { duplo é } \\
\text { melhor } \\
\text { para a } \\
\text { ferragem, } \\
\text { porque ao } \\
\text { montar } \\
\text { um jogo } \\
\text { vc tem } \\
\text { dois. É } \\
\text { melhor } \\
\text { também } \\
\text { para a } \\
\text { conferenci } \\
\text { a, por esta } \\
\text { mesma } \\
\text { razão. } \\
\text { Perde-se } \\
\text { menos } \\
\text { ferro. }\end{array}$ & 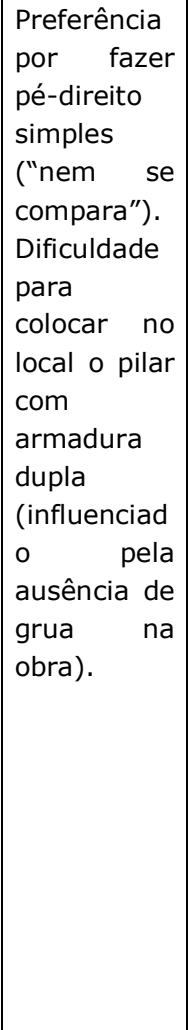 & $\begin{array}{l}\text { Para posições longitudinais até um } \\
\text { determinado diâmetro (limitante é o } \\
\text { equipamento de transporte), como } 12,5 \mathrm{~mm} \text {, } \\
\text { é melhor se trabalhar com armaduras duplas. } \\
\text { Tem-se mais trabalho numa montagem, mas } \\
\text { na seguinte o trabalho inexiste. Quando se } \\
\text { trabalha com barras longitudinais de maiores } \\
\text { diâmetros (20, } 25 \mathrm{~mm} \text { ) torna-se mais difícil o } \\
\text { trabalho com armaduras duplas (a armadura } \\
\text { fica muito pesada, o que torna o trabalho de } \\
\text { posicionamento mais difícil e perigoso (a } \\
\text { armadura de } 6 \mathrm{~m} \text { com barras de } 20,25 \mathrm{~mm} \text {, é } \\
\text { muito pesada e muito mais suscetível a } \\
\text { tombar)). Na obra, solicitou-se que alguns } \\
\text { pilares, com posições longitudinais com } \\
\text { diâmetro de } 20 \text { e } 25 \mathrm{~mm} \text {, e que previam } \\
\text { armaduras duplas, fossem feitos do modo } \\
\text { convencional (um pé-direito). Alem de facilitar } \\
\text { o trabalho dos armadores pelos motivos } \\
\text { supracitados, proporcionou, neste caso uma } \\
\text { economia do aço (o transpasse exigido nos } \\
\text { arranques, a cada dois pavimentos era algo, } \\
\text { era algo em torno de } 40 \text { vezes o diâmetro da } \\
\text { barras; assim, para soma dois pé-direito e } \\
\text { comprimento de transpasse, seria necessário } \\
\text { uma barra (12m), porém se descartaria um } \\
\text { pedaço significativo da barra. }\end{array}$ & $\begin{array}{l}\text { Um dos } \\
\text { complicadores de se } \\
\text { trabalhar com } \\
\text { armadura dupla são } \\
\text { as barras } \\
\text { longitudinais } \\
\text { "fugirem" durante a } \\
\text { concretagem do } \\
\text { tramo da armadura } \\
\text { inferior. Tentar } \\
\text { trazê-lo para o } \\
\text { lugar é muito difícil, } \\
\text { pelo fato de estar } \\
\text { estribado e ter } \\
\text { passado direto } \\
\text { (mais de 3m de } \\
\text { comprimento). É } \\
\text { preferível trabalhar } \\
\text { com pé-direito } \\
\text { simples. É mais } \\
\text { difícil transportá-lo } \\
\text { e posicioná-lo. Pé- } \\
\text { direito duplo é bom } \\
\text { para a fundação. }\end{array}$ & 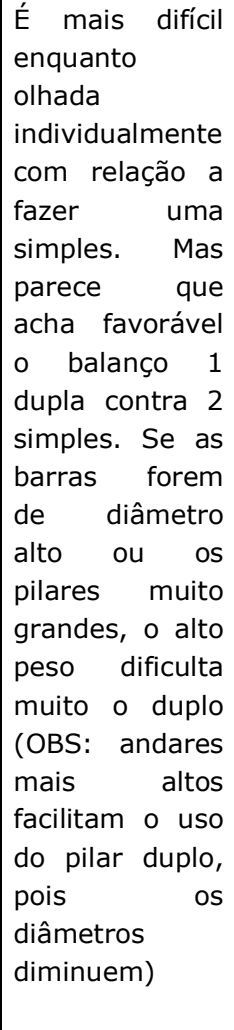 & $\begin{array}{l}\text { Não são muito } \\
\text { admiradores da idéia: } \\
\text { é ruim de lidar com a } \\
\text { gaiola dupla (tanto no } \\
\text { que se refere ao } \\
\text { armador quanto ao } \\
\text { carpinteiro de } \\
\text { fôrmas). Fica bamba e } \\
\text { precisa prender com } \\
\text { corda para alinhar a } \\
\text { viga. Convém checar } \\
\text { o projeto estrutural } \\
\text { pois o projetista às } \\
\text { vezes não faz a conta } \\
\text { de perdas correta } \\
\text { (exemplo: se o corte } \\
\text { para pilar simples é } \\
\text { de } 3,3 \text { e de duplo de } \\
6,3, \text { há que se fazer } 1 \\
\text { duplo seguido de } 1 \\
\text { simples para ter } \\
\text { melhor } \\
\text { aproveitamento, } \\
\text { senão dos } 5,7 \text { que } \\
\text { sobram no duplo não } \\
\text { serve para nada). }\end{array}$ & $\begin{array}{l}\text { Armadur } \\
\text { as } \\
\text { duplas } \\
\text { de } \\
\text { pilares: } \\
\text { é mais } \\
\text { difícil de } \\
\text { se } \\
\text { trabalhar } \\
\text {. } \quad \text { O } \\
\text { encarreg } \\
\text { ado não } \\
\text { gosta de } \\
\text { trabalhar } \\
\text { com } \\
\text { armadur } \\
\text { as } \\
\text { duplas } \\
\text { (necessi } \\
\text { dade de } \\
\text { estaiar a } \\
\text { armadur } \\
\text { a entre } \\
\text { outros). } \\
\text { "É ruim } \\
\text { demais". }\end{array}$ \\
\hline
\end{tabular}


Tabela A 1 - (continuação)- Lista de Opiniões referentes ao projeto do produto - PDA de pilares

\begin{tabular}{|c|c|c|c|c|c|c|c|c|}
\hline \multicolumn{2}{|c|}{ ASPECTOS } & \multicolumn{7}{|c|}{ OPINIÕES OBRAS } \\
\hline & & SP 301 & SP 302 & SP 303 & SP 304 & SP 305 & SP 306 & SP 307 \\
\hline 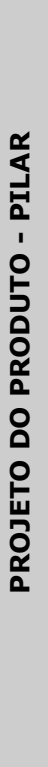 & $\begin{array}{c}\text { Estribos } \\
\text { acorrentados }\end{array}$ & $\begin{array}{l}\text { Estribos } \\
\text { acorrentados: } \\
\text { um estribo só é } \\
\text { melhor, mesmo } \\
\text { aumentado } r \\
\text { número de } \\
\text { ganchinhos; é } \\
\text { mais rápido } \\
\text { para armar. Um } \\
\text { estribo só tem } \\
\text { menos dobras e } \\
\text { cortes. } \quad \text { Na } \\
\text { montagem, é } \\
\text { bem mais fácil } \\
\text { dividir os ferros } \\
\text { do que dividir } \\
\text { todas ras } \\
\text { galgas. }\end{array}$ & $\begin{array}{l}\text { Preferência por } \\
\text { trabalhar com estribos } \\
\text { únicos e mais ganchos } \\
\text { (tem que fazer a } \\
\text { emenda das correntes } \\
\text { para chegar na } \\
\text { dimensão correta. } \\
\text { Com o estribo } \\
\text { "acabado" não precisa } \\
\text { ser preocupar com } \\
\text { isso). Trabalhar com } \\
\text { estribos acorrentados } \\
\text { exige que se tenha } \\
\text { mais orientação do } \\
\text { encarregado. }\end{array}$ & $\begin{array}{l}\text { É preferível se trabalhar com } \\
\text { menos estribos, mesmo que } \\
\text { isso gere a necessidade de } \\
\text { se ter mais ganchinhos. } \\
\text { Quando se têm estribos } \\
\text { acorrentados, há mais } \\
\text { trabalho para garantir o seu } \\
\text { correto posicionamento (ele } \\
\text { precisam ser "galgados"), ao } \\
\text { passo que quando se tem } \\
\text { um estribo apenas, não se } \\
\text { tem essa preocupação (é só } \\
\text { distribuir a ferragem). }\end{array}$ & $\begin{array}{l}\text { São muito mais } \\
\text { trabalhosos que os } \\
\text { pilares com estribo } \\
\text { único. No tempo } \\
\text { que se faz um } \\
\text { pilar com linha de } \\
3 \text { estribos } \\
\text { acorrentados, se } \\
\text { monta } 3 \text { pilares } \\
\text { sem corrente. Para } \\
\text { se trabalhar com } \\
\text { estribos res } \\
\text { acorrentados, faz- } \\
\text { se uma "galga", } \\
\text { ou seja, um } \\
\text { estribo único que } \\
\text { sirva rara como } \\
\text { referência, para } \\
\text { facilitar parte do } \\
\text { serviço. }\end{array}$ & 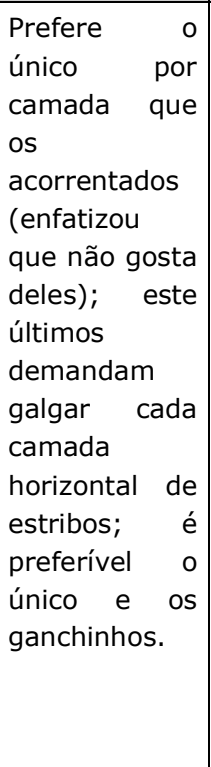 & $\begin{array}{l}\text { É chato para pré- } \\
\text { montagem e para } \\
\text { montar no local fica } \\
\text { terrível: demanda } \\
\text { mais cuidado para } \\
\text { galgar tanto na } \\
\text { vertical quanto na } \\
\text { horizontal. }\end{array}$ & $\begin{array}{lr}\text { Pilares } & \text { com } \\
\text { estribos } \\
\text { acorrentados } \\
\text { são mais difíceis } \\
\text { (pode-se } \\
\text { recorrer } \\
\text { calculista ao } \\
\text { solicitar que, } \\
\text { pelo menos, } \\
\text { face um "laço" } \\
\text { maior). }\end{array}$ \\
\hline
\end{tabular}


Tabela A 2 - Lista de Opiniões referentes ao projeto do produto - PDA de vigas

\begin{tabular}{|c|c|c|c|c|c|c|}
\hline \multicolumn{2}{|r|}{ ASPECTOS } & \multicolumn{5}{|c|}{ OPINIÕES OBRAS } \\
\hline & & SP 302 & SP 303 & SP 304 & SP 306 & SP 307 \\
\hline 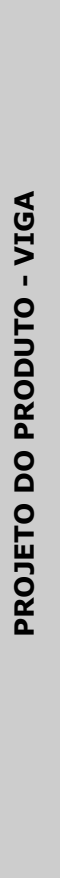 & $\begin{array}{c}\text { Dificuldade das } \\
\text { vigas }\end{array}$ & 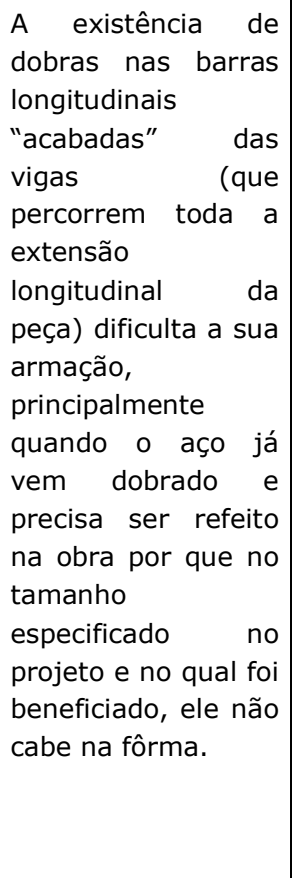 & $\begin{array}{l}\text { As vigas exigem um maior esforço no momento em } \\
\text { que são posicionadas ("na hora de encavalá-las") } \\
\text { nas fôrmas (interferências com pilares, outras } \\
\text { vigas). O número de posições para compor uma } \\
\text { viga é outro dificultador, tanto na hora de cortar e, } \\
\text { eventualmente dobrar, quanto na hora de montá-la } \\
\text { (o número médio de posições por peça, nas vigas, } \\
\text { é muito superior ao número médio de posições por } \\
\text { peças nos pilares). As vigas exigem que muitas das } \\
\text { suas posições ("ferros de reforço" ou } \\
\text { complementos) sejam colocadas com a viga na } \\
\text { posição final (ora quando a viga possui pilares } \\
\text { intermediários e, portanto, posições longitudinais } \\
\text { negativas, que atravessam a armação destes } \\
\text { pilares, ou, numa outra situação, em que as vigas } \\
\text { são compridas (sem pilares intermediários) e as } \\
\text { posições positivas têm diâmetros considerados, } \\
\text { tornando a armadura pesada (neste caso o } \\
\text { equipamento de transporte é limitante); são, } \\
\text { então, posicionadas na pré-montagem, uma } \\
\text { quantidade de posições tal que a armadura possa } \\
\text { ser transportada, sendo complementada com as } \\
\text { demais barras na posição final). }\end{array}$ & $\begin{array}{l}\text { Um fator que torna as vigas } \\
\text { difíceis de serem armadas é } \\
\text { quando se tem vigas com } \\
\text { estribos acorrentadas } \\
\text { (trabalham com } 4 \text { a } 5 \\
\text { estribos) com bastante ferro } \\
\text { no fundo. São vigas de } 2,5 \\
\text { m de largura, } 0,80 \mathrm{~m} \text { de } \\
\text { altura. Vigas de grande } \\
\text { tamanho são muito mais } \\
\text { difíceis de serem armadas } \\
\text { (diâmetros maiores } \\
\text { também). Exemplo de viga } \\
\text { complicada, de uma outra } \\
\text { obra que no fundo tinha } 22 \\
\text { ferros de 25mm de } \\
\text { diâmetro, com estribos de } \\
\text { acorrentados de } 10 \text { mm } \\
\text { (eram necessário seis } \\
\text { armadores armando a viga } \\
\text { no local, durante um dia } \\
\text { inteiro de trabalho). }\end{array}$ & $\begin{array}{l}\text { Exemplo de situações } \\
\text { que dificultam a } \\
\text { armação da viga: } \\
\text { variações das peças ao } \\
\text { longo da viga; muitas } \\
\text { posições; costelas na } \\
\text { lateral; altura variável } \\
\text { ao longo do } \\
\text { comprimento (não dá } \\
\text { para pré-montar, pois } \\
\text { tem de acertar no } \\
\text { local); estribos abertos. } \\
\text { Viga em balanço em } \\
\text { geral é difícil: tem } \\
\text { costela; tem reforço de } \\
\text { ponta quando junta-se } \\
\text { duas vigas em balanço. } \\
\text { Viga com aba é difícil. } \\
\text { Existência de furo } \\
\text { demandando reforço } \\
\text { dificulta. }\end{array}$ & \begin{tabular}{|lr} 
O & grande \\
número & de \\
posições de & determinadas \\
deter & \\
vigas tornam o \\
serviço mais \\
dispendioso \\
(aumenta-se o \\
número de \\
ferros, e, \\
conseqüenteme \\
nte, o número \\
de cortes e \\
dobras).
\end{tabular} \\
\hline
\end{tabular}


Tabela A 2 - (continuação)- Lista de Opiniões referentes ao projeto do produto - PDA de vigas

\begin{tabular}{|c|c|c|c|c|c|c|}
\hline \multicolumn{2}{|c|}{ ASPECTOS } & \multicolumn{5}{|c|}{ OPINIÕES OBRAS } \\
\hline \multirow{8}{*}{ 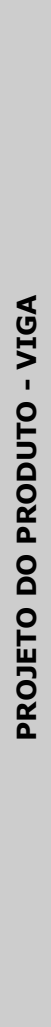 } & \multirow{3}{*}{$\begin{array}{l}\text { Comprimento } \\
\text { das vigas }\end{array}$} & SP 301 & \multicolumn{2}{|l|}{ SP 302} & SP 305 & SP 306 \\
\hline & & $\begin{array}{l}\text { As vigas mais compridas são } \\
\text { mais fáceis de se armar, isto é, } \\
\text { rendem mais (uma viga de } 3 \\
\text { metros é mais vantajosa de ser } \\
\text { feita do que } 3 \text { vigas de um } \\
\text { metro; a viga de } 3 \mathrm{~m} \text { dá o } \\
\text { mesmo trabalho que as de } 1 \text { e } \\
\text { leva mais ferro). }\end{array}$ & \multicolumn{2}{|c|}{$\begin{array}{l}\text { Montar } 3 \text { vigas de } 2 \text { metros é mais fácil que armar } \\
\text { uma viga de } 6 \mathrm{~m} \text {. Levou-se em conta, nesta análise o } \\
\text { sistema de transporte da obra, que dificulta o } \\
\text { transporte de peças mais pesadas. A viga grande } \\
\text { tem também muita "puxada" (barras que cobrem um } \\
\text { pequeno trecho da viga). Vigas que têm pilares } \\
\text { intermediários, tem posições negativas que precisam } \\
\text { ser posicionadas no local. }\end{array}$} & $\begin{array}{l}\text { Não atentou para o fato de viga maior } \\
\text { representar ganhar mais } \mathrm{kg} \text { prontos. } \\
\text { Falou que o tamanho da viga não é um } \\
\text { fator e sim, o é, o peso total da mesma, } \\
\text { no sentido de gerar a necessidade, } \\
\text { quando fica muito pesado, de ter mais de } \\
\text { um armador para tirar a gaiola do } \\
\text { cavalete. }\end{array}$ & $\begin{array}{l}\text { Uma viga de } \\
4 \mathrm{~m} \text { é melhor } \\
\text { que } 2 \text { vigas de } \\
2 \mathrm{~m} \text {. }\end{array}$ \\
\hline & & SP 303 & \multicolumn{2}{|l|}{ SP 306} & \multicolumn{2}{|l|}{ SP 307} \\
\hline & $\begin{array}{l}\text { Largura da } \\
\text { viga }\end{array}$ & $\begin{array}{l}\text { Quanto a geometria da seção } \\
\text { das vigas: as vigas com seções } \\
\text { maiores são mais fáceis de se } \\
\text { trabalhar. Vigas com seções } \\
\text { reduzidas são mais difíceis. Tal } \\
\text { dificuldade é sentida até } \\
\text { mesmo ao se dobrar os } \\
\text { estribos. }\end{array}$ & \multicolumn{2}{|c|}{$\begin{array}{l}\text { Viga estreita dificulta o trabalho; por exemplo, } \\
\text { estribo de } 7 \mathrm{~cm} \text { é difícil de dobrar e de conseguir } \\
\text { fazê-lo geometricamente correto. }\end{array}$} & \multicolumn{2}{|c|}{$\begin{array}{l}\text { Estribos muito pequenos ( } 10 \mathrm{~cm} \text { de largura) são difíceis de } \\
\text { serem dobrados. Não é possível fazê-los na máquina; são } \\
\text { dobrados manualmente. Estribos pequenos compostos (dois } \\
\text { estribos formando um "L") são mais difíceis de serem } \\
\text { dobrados e montados. O engenheiro comentou que prefere } \\
\text { que seja uma peça única e que quando percebe o contrário, } \\
\text { pede para o projetista alterar. }\end{array}$} \\
\hline & \multirow{3}{*}{$\begin{array}{c}\text { Variação da } \\
\text { armadura ao } \\
\text { longo da viga }\end{array}$} & \multicolumn{5}{|c|}{ SP 306} \\
\hline & & \multicolumn{5}{|l|}{ Isto atrapalha bastante. } \\
\hline & & \multicolumn{2}{|r|}{ SP 301} & \multicolumn{3}{|c|}{ SP 305} \\
\hline & Altura variável & \multicolumn{2}{|c|}{$\begin{array}{l}\text { Diferença de altura: as vigas baixas são mais fáceis; as vigas altas, que } \\
\text { tem costelas, são mais demoradas. }\end{array}$} & \multicolumn{3}{|c|}{ Dificulta a armadura das vigas. } \\
\hline
\end{tabular}


Tabela A 2 - (continuação)- Lista de Opiniões referentes ao projeto do produto - PDA de vigas

\begin{tabular}{|c|c|c|c|c|c|c|c|}
\hline \multicolumn{2}{|c|}{ ASPECTOS } & \multicolumn{6}{|c|}{ OPINIÕES OBRAS } \\
\hline \multirow{8}{*}{ 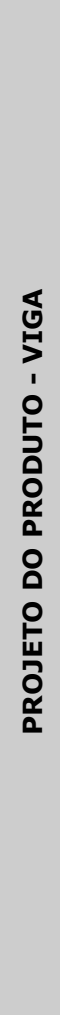 } & \multirow[b]{2}{*}{$\begin{array}{l}\text { Mais de uma } \\
\text { camada de } \\
\text { barras } \\
\text { longitudinais } \\
\text { na parte } \\
\text { superior }\end{array}$} & \multicolumn{3}{|c|}{ SP 302} & \multicolumn{3}{|c|}{ SP 305} \\
\hline & & \multicolumn{3}{|c|}{$\begin{array}{l}\text { Quando tem ferros na segunda camada, geralmente o esquadro, que } \\
\text { acaba tendo o mesmo tamanho que o do ferro da primeira camada, } \\
\text { pode encostar-se à fôrma, comprometendo o cobrimento e não } \\
\text { permanecendo na posição correta. Na obra em questão existe esta } \\
\text { situação e toda vez que se arma a viga, precisa-se cortar o ferro }\end{array}$} & \multicolumn{3}{|c|}{ Dificulta a entrada da armadura da laje } \\
\hline & \multirow{3}{*}{$\begin{array}{c}\text { Diâmetro dos } \\
\text { estribos }\end{array}$} & \multicolumn{3}{|c|}{ SP 301} & \multicolumn{3}{|c|}{ SP 306} \\
\hline & & $\begin{array}{l}\text { Na máquina é melhor estribo }> \\
\text { melhor o de } 5 \mathrm{~mm} \text {. }\end{array}$ & 6,3. Para dobrar mar & nualmente é & \multicolumn{3}{|c|}{$\begin{array}{l}\text { Barras de } 5 \mathrm{~mm} \text { (liso) são muito ruins: escorrega o ponto; é frágil; amassa. } \\
6,3 \mathrm{~mm} \text { é muito melhor. }\end{array}$} \\
\hline & & SP 302 & SP 303 & & SP 304 & & SP 305 \\
\hline & \multirow[t]{2}{*}{$\begin{array}{c}\text { Espaçamento } \\
\text { de estribos } \\
\text { variável }\end{array}$} & $\begin{array}{l}\text { Variações no espaçamento de } \\
\text { estribos não tornam o serviço } \\
\text { mais difícil (porém se o } \\
\text { espaçamento for uniforme é } \\
\text { melhor). }\end{array}$ & \begin{tabular}{|l} 
É ruim tanto para o \\
armador em posicioná- \\
los $\quad$ corretamente \\
quanto para a \\
conferência do serviço \\
pela construtora.
\end{tabular} & \multicolumn{2}{|c|}{$\begin{array}{l}\text { Requerem mais atenção para não } \\
\text { confundir as r bitolas } \\
\text { (principalmente) } \\
\text { espaçamentos. Ficaria mais fácil } \\
\text { se não houvesse variação. }\end{array}$} & \multicolumn{2}{|c|}{ Quando é variável atrapalha a execução } \\
\hline & & \multicolumn{2}{|l|}{ SP 302} & \multicolumn{3}{|c|}{ SP 304} & SP 307 \\
\hline & $\begin{array}{c}\text { Estribos } \\
\text { acorrentados }\end{array}$ & $\begin{array}{l}\text { Vigas com estribos acorrenta } \\
\text { (porém uma técnica para facilita } \\
\text { estribo grande, que garanta } \\
\text { trabalhar com os estribos acorrent }\end{array}$ & $\begin{array}{l}\text { dos são mais difíceis } \\
\text { Ir o serviço é fazer um } \\
\text { a dimensão, e depois } \\
\text { tados no meio). }\end{array}$ & $\begin{array}{l}\text { "Se eu fo } \\
\text { comparação } \\
\text { quantidade } \\
\text { acorrentado, } \\
\text { três corren } \\
\text { dimensão) s }\end{array}$ & $\begin{array}{l}\text { fazer uma viga } \\
\text { com uma viga, } \\
\text { de ferro mas que n } \\
\text {, no tempo que eu fac } \\
\text { ntes, eu faço três } \\
\text { sem corrente." }\end{array}$ & $\begin{array}{l}\text { acorrentada em } \\
\text { com a mesma } \\
\text { ão exija estribo } \\
\text { ço uma viga com } \\
\text { vigas (mesma }\end{array}$ & $\begin{array}{l}\text { Vigas com estribos acorrentados } \\
\text { são difíceis (dificuldade em galgar } \\
\text { os estribos). Monta-se o primeiro } \\
\text { estribo na galga certa, que irá } \\
\text { servir com referência para o } \\
\text { posicionamento dos demais }\end{array}$ \\
\hline
\end{tabular}


Tabela A 2 - (continuação)- Lista de Opiniões referentes ao projeto do produto - PDA de vigas

\begin{tabular}{|c|c|c|c|c|c|}
\hline \multicolumn{2}{|r|}{ ASPECTOS } & \multicolumn{4}{|c|}{ OPINIÕES OBRAS } \\
\hline \multirow{6}{*}{ 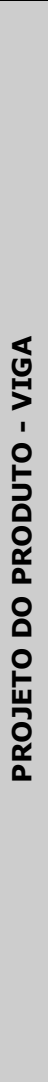 } & \multirow[b]{2}{*}{$\begin{array}{c}\text { Posiciona- } \\
\text { mento da Viga }\end{array}$} & SP 301 & SP 302 & SP 303 & SP 304 \\
\hline & & $\begin{array}{l}\text { Na hora de posicionar a } \\
\text { viga deve-se prestar } \\
\text { atenção para não } \\
\text { inverter os lados (os } \\
\text { ferros do fundo podem } \\
\text { mudar). Conferencia do } \\
\text { serviço deve vir logo em } \\
\text { seguida para facilitar } \\
\text { correção (dá muito } \\
\text { trabalho ter que tirar a } \\
\text { viga para inverte-la } \\
\text { após armada a laje). } \\
\text { Obras com muitos } \\
\text { pilares subentende-se } \\
\text { que terão muitas vigas e } \\
\text { que vai levar mais } \\
\text { tempo para colocar as } \\
\text { vigas na posição. }\end{array}$ & $\begin{array}{l}\text { Vigas com } \\
\text { barras de } \\
\text { diâmetros } \\
\text { maiores ficam } \\
\text { mais pesadas } \\
\text { e dificultam o } \\
\text { seu } \\
\text { posicionament } \\
\text { o. }\end{array}$ & $\begin{array}{l}\text { O peso da armadura é determinado pela "sentimento" dos } \\
\text { armadores e encarregado, que sabem a densidade de cada } \\
\text { diâmetro e, em função da quantidade, comprimento e } \\
\text { diâmetro, sabem quantas posições podem colocar na pré- } \\
\text { montagem ("viga de } 7 \mathrm{~m} \text {, com três ferros de 12,5: ok!; se } \\
\text { fosse ferro de } 20 \text { não daria; colocaria } 2 \text { ferros e deixava um } \\
\text { para colocar em cima"). Pré-monta-se com a quantidade de } \\
\text { ferro factível de se transportar com o equipamento } \\
\text { disponível (neste caso um elevador cremalheira). Os ferros } \\
\text { faltantes são posicionados no local (sobem-se as barras). } \\
\text { Posicionamento das armaduras: melhor quando a fôrma já } \\
\text { está fechada. Evita-se que os carpinteiros danifiquem as } \\
\text { peças já montadas ("quando a armadura é posicionada para } \\
\text { depois os carpinteiros fecharem a viga a ferragem vira uma } \\
\text { bagunça; fechou, coloco as armaduras e não preciso voltar } \\
\text { mais (reparar possíveis danos)"). }\end{array}$ & $\begin{array}{l}\text { Quando as vigas são de bordas e requerem } \\
\text { que complementos (negativos) sejam } \\
\text { posicionados no local, fica mais difícil. } \\
\text { Nestes casos os estribos do meio da viga } \\
\text { precisam ser espaçados para se criar um } \\
\text { espaço por onde irá entra a posição (fazê- } \\
\text { la entrar pela extremidade da viga, requer } \\
\text { cuidados maiores por motivos de } \\
\text { segurança (trabalhar na borda do prédio); } \\
\text { depois é preciso voltar com os estribos nas } \\
\text { posições corretas. "se a viga está no meio } \\
\text { do prédio é melhor do que no final dele, } \\
\text { porque aí você vai ter que se arriscar, se } \\
\text { esforçar mais.") }\end{array}$ \\
\hline & \multirow[b]{2}{*}{$\begin{array}{l}\text { Viga em } \\
\text { balanço }\end{array}$} & \multicolumn{4}{|c|}{ SP 306} \\
\hline & & \multicolumn{4}{|c|}{$\begin{array}{l}\text { Em geral são difíceis devido a terem costelas. No caso de encontro de duas vigas na ponta em balanço, há que se reforçar tal região (por exemplo } \\
\text { com pecinha a cada } 2,8 \mathrm{~cm} ! ! \text { ) tendo de se abrir os estribos na hora da concretagem e fechar depois para que o concreto tenha acesso a todo c } \\
\text { componente. }\end{array}$} \\
\hline & \multirow{2}{*}{ Viga curva } & \multicolumn{4}{|c|}{ SP 306} \\
\hline & & \multicolumn{4}{|c|}{ É muito ruim, pois tem de "rair"o ferro na chave embaixo e ir depois acertando em cima na montagem final. } \\
\hline
\end{tabular}


Tabela A 2 - (continuação)- Lista de Opiniões referentes ao projeto do produto - PDA de vigas

\begin{tabular}{|c|c|c|c|c|c|c|}
\hline \multicolumn{2}{|r|}{ ASPECTOS } & \multicolumn{5}{|c|}{ OPINIÕES OBRAS } \\
\hline \multirow{6}{*}{ 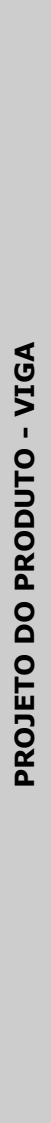 } & \multirow{4}{*}{$\begin{array}{l}\text { Vigas com } \\
\text { barras } \\
\text { longitudinais } \\
\text { com esquadros } \\
\text { (ganchos) na } \\
\text { extremidade } \\
\\
\text { Encontro viga- } \\
\text { viga }\end{array}$} & SP 301 & \multicolumn{2}{|l|}{ SP 303} & \multicolumn{2}{|r|}{ SP 304} \\
\hline & & $\begin{array}{ll}\text { Os } & \text { esquadros } \\
\text { dificultam } & \text { o encaixe } \\
\text { da viga no pilar } \\
\text { (precisa cortar os } \\
\text { estribos do pilar). }\end{array}$ & $\begin{array}{l}\text { No caso do projeto de } \\
\text { de armaduras de vigas } \\
\text { barras longitudinais } \\
\text { negativas têm um ganch } \\
\text { que dificulta o po } \\
\text { (engastamento) da ar } \\
\text { encontros entre vigas. U } \\
\text { acaba tendo que ser } \\
\text { lugar. }\end{array}$ & $\begin{array}{l}\text { detalhamento } \\
\text { da obra, as } \\
\text { positivas e } \\
\text { o na ponta, o } \\
\text { sicionamento } \\
\text { madura nos } \\
\text { ma das vigas } \\
\text { montada no }\end{array}$ & \multicolumn{2}{|c|}{$\begin{array}{l}\text { Vigas com "ganchos" (esquadros) na ponta tornam a montagem mais difícil (é preciso } \\
\text { levantar as vigas para conseguir encaixar, o que consome mais tempo; ou levantar os } \\
\text { estribos, nos casos em que as vigas chegam nos pilares). Quando o esquadro tem o } \\
\text { tamanho do estribo, mais difícil fica. Quando a viga que irá receber a outra tem } \\
\text { costela também dificulta a montagem (é preciso retirar a costela). O tempo que o } \\
\text { armador leva para posicionar uma viga que tem gancho na aponta é suficiente para } \\
\text { ele posicionar } 3 \text { vigas sem ganchos. Em muitos desses encontros, é preciso } \\
\text { desmanchar a viga para poder montá-la ("tem que ir encaixando ferro por ferro para } \\
\text { poder dar certo, tomando, dessa forma, mais tempo"). }\end{array}$} \\
\hline & & SP 301 & \multicolumn{2}{|l|}{ SP 302} & SP 303 & SP 304 \\
\hline & & $\begin{array}{l}\text { Viga-viga: seqüência } \\
\text { correta do } \\
\text { posicionamento: } \\
\text { entram as vigas que } \\
\text { descansam nas } \\
\text { colunas e depois a } \\
\text { viga que chega na } \\
\text { viga (que entra por } \\
\text { cima). }\end{array}$ & \multicolumn{2}{|c|}{$\begin{array}{l}\text { A montagem das armaduras em } \\
\text { encontro de vigas fica mais difícil } \\
\text { quando as vigas têm a mesma } \\
\text { dimensão (é preciso que uma "lace" a } \\
\text { outra), e quando a viga que entra } \\
\text { possui barras acabadas com } \\
\text { esquadros (não é possível tirar a } \\
\text { barra e, depois, colocar de novo). }\end{array}$} & $\begin{array}{l}\text { O fato da viga ser externa ou } \\
\text { interna não interfere na } \\
\text { montagem. O complicador } \\
\text { está no posicionamento das } \\
\text { vigas nos encontros viga- } \\
\text { viga, }\end{array}$ & $\begin{array}{l}\text { Dá mais trabalho que encontro de viga com pilar (a } \\
\text { viga tem esquadro, costelas o que torna o } \\
\text { posicionamento muito mais difícil). É preciso saber } \\
\text { qual viga irá ficar embaixo para receber a outra. } \\
\text { Primeiro são colocadas as vigas que "descansam" nos } \\
\text { pilares, depois as vigas que chegam em vigas. }\end{array}$ \\
\hline & & \multicolumn{2}{|c|}{ SP 304} & \multicolumn{2}{|r|}{ SP 305} & SP 307 \\
\hline & $\begin{array}{c}\text { Encontro viga- } \\
\text { pilar }\end{array}$ & \multicolumn{2}{|c|}{$\begin{array}{l}\text { As vigas sem pilar intermediários são mais } \\
\text { fáceis pois sobem completas, isto é, não é } \\
\text { necessário que sejam complementadas no } \\
\text { local. As vigas são pré-montados em tramos } \\
\text { (entre pilares). }\end{array}$} & \multicolumn{2}{|c|}{$\begin{array}{l}\text { Toda vez que os ferros da viga entram } \\
\text { muito no pilar isto traz dificuldade, pois é } \\
\text { difícil encaixá-los (muitas vezes precisam } \\
\text { desmanchar um pouco a gaiola da viga } \\
\text { para encaixar) }\end{array}$} & $\begin{array}{l}\text { Há situações em que a viga pode ser toda pré- } \\
\text { montada, fazendo uso da grua para posicioná-la, não } \\
\text { havendo a necessidade da viga subir em "tramos" } \\
\text { separados. }\end{array}$ \\
\hline
\end{tabular}


Tabela A 2 - (continuação)- Lista de Opiniões referentes ao projeto do produto - PDA de vigas

\begin{tabular}{|c|c|c|c|c|c|c|c|}
\hline \multicolumn{2}{|r|}{ ASPECTOS } & \multicolumn{6}{|c|}{ OPINIÕES OBRAS } \\
\hline & & SP 301 & SP 302 & SP 303 & SP 304 & SP 305 & SP 307 \\
\hline 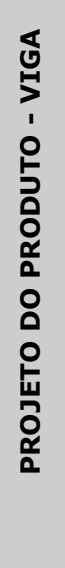 & $\begin{array}{c}\text { Reforço nos } \\
\text { furos e inserts }\end{array}$ & $\begin{array}{l}\text { Os reforços } \\
\text { de furos } \\
\text { são } \\
\text { levados } \\
\text { prontos. } \\
\text { Não vê } \\
\text { problemas } \\
\text { nos } \\
\text { reforços } \\
\text { saírem do } \\
\text { lugar no } \\
\text { momento } \\
\text { de } \\
\text { posicionar } \\
\text { as vigas. }\end{array}$ & $\begin{array}{l}\text { As armaduras } \\
\text { de reforços de } \\
\text { furos nas vigas } \\
\text { são colocadas, } \\
\text { ou } \\
\text { complementada } \\
\text { s no local, para } \\
\text { garantir que a } \\
\text { armadura de } \\
\text { reforço fique na } \\
\text { posição correta. }\end{array}$ & $\begin{array}{l}\text { O número de furos nas vigas também é um indicador } \\
\text { que expressa a dificuldade na montagem das vigas. } \\
\text { Posicionar os reforços para os furos durante a pré- } \\
\text { montagem exige uma preocupação maior com a sua } \\
\text { locação e, mesmo locando corretamente, fica difícil } \\
\text { manter a posição quando a armadura é posicionada na } \\
\text { fôrma (ela acaba sempre "fugindo" para um dos lados). } \\
\text { Colocar os reforços com a armadura já posicionada na } \\
\text { fôrma é muito difícil para o armador ("o armador } \\
\text { precisa ter uns quatros pares de mão; cada semana vai } \\
\text { uma"), pois não há espaço físico para o armador enfiar } \\
\text { a mão. Uma alternativa é manter a viga posicionada } \\
\text { porém suspensa (apoiada em pontaletes) para a } \\
\text { colocação dos reforços nos furos }\end{array}$ & 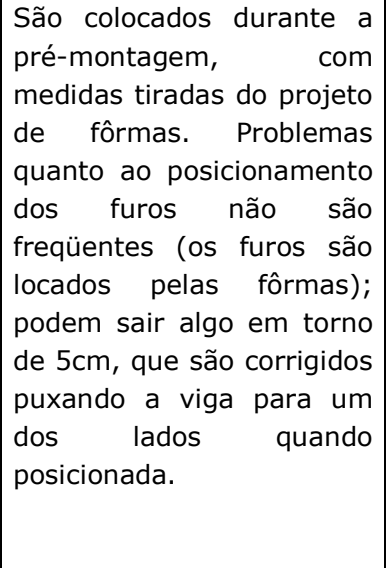 & $\begin{array}{lr}\text { Prefere } & \text { os } \\
\text { reforços } & \text { na } \\
\text { vertical } & \text { e } \\
\text { horizontal; } & \\
\text { não gosta } \\
\text { dos diagonais } \\
\text { (sempre r } \\
\text { acontece de } \\
\text { pré- } \\
\text { montarem e } \\
\text { terem de } \\
\text { desmontar } \\
\text { no local e } \\
\text { refazerem). }\end{array}$ & $\begin{array}{l}\text { Os reforços de } \\
\text { furos nas vigas } \\
\text { (em vigas } \\
\text { tradicionais) } \\
\text { são colocados } \\
\text { durante a pré- } \\
\text { montagem, } \\
\text { embaixo, e } \\
\text { conferidos } \\
\text { quando a } \\
\text { armadura é } \\
\text { posicionada na } \\
\text { fôrma. }\end{array}$ \\
\hline
\end{tabular}


Tabela A 3 - Lista de Opiniões referentes ao projeto do produto - PDA de lajes positivas

\begin{tabular}{|c|c|c|c|c|c|c|c|c|c|c|}
\hline \multicolumn{2}{|c|}{ ASPECTOS } & \multicolumn{9}{|c|}{ OPINIÕES OBRAS } \\
\hline \multirow{6}{*}{ 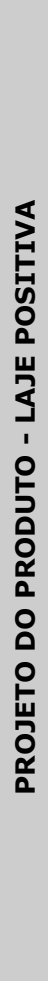 } & \multirow[b]{2}{*}{ Diâmetro } & SP 302 & \multicolumn{2}{|c|}{ SP 304} & \multicolumn{4}{|c|}{ SP 305} & \multicolumn{2}{|r|}{ SP 306} \\
\hline & & $\begin{array}{l}\text { Na laje é preferível que se aumente a } \\
\text { bitola do aço e o espaçamento, para se } \\
\text { evitar de trabalhar com barras de } 5 \mathrm{~mm} \text {. } \\
\text { As barras de aço fino não ficam no lugar } \\
\text { (durante a concretagem o mangote tira } \\
\text { a armação do lugar). Ferro fino só serve } \\
\text { para estribo. }\end{array}$ & \multicolumn{2}{|c|}{$\begin{array}{l}\text { Ferro de } 5 \mathrm{~mm} \text { é muito } \\
\text { ruim, os ferros correm } \\
\text { todos. Tem que ter } \\
\text { um armador só para } \\
\text { ficar colocando os } \\
\text { ferros nas posições. }\end{array}$} & \multicolumn{4}{|c|}{$\begin{array}{l}\text { As barras de aço de } 5 \mathrm{~mm} \text { (é lisa) são ruins; } 6,3 \text { (é } \\
\text { corrugada) é melhor. Na barra lisa o ponto escorrega } \\
\text { muito; na corrugada ele segura mais. Mais que isto, no } 5 \\
\mathrm{~mm} \text { precisa amarrar a cada } 2 \text { ou } 3 \text { encontros; no } 6,3 \text {, a } \\
\text { cada } 3 \text { ou } 4 \text { encontros (gasta menos mão-de-obra). Mas } \\
5 \mathrm{~mm} \text { é mais fácil de por o espaçador (encaixa mais fácil) } \\
\text { que } 6,3 \text { e } 8 \mathrm{~mm} \text {. }\end{array}$} & \multicolumn{2}{|c|}{$\begin{array}{l}\text { Preferem diâmetro } \\
\text { maior pois aumenta o } \\
\text { espaçamento e tem- } \\
\text { se menos necessidade } \\
\text { de pontos de } \\
\text { amarração. }\end{array}$} \\
\hline & \multirow[b]{2}{*}{$\begin{array}{l}\text { Número de } \\
\text { posições }\end{array}$} & \multicolumn{2}{|l|}{ SP 302} & \multicolumn{2}{|l|}{ SP 303} & SP 304 & SP 305 & \multicolumn{2}{|c|}{ SP 306} & SP 307 \\
\hline & & \multicolumn{2}{|c|}{$\begin{array}{l}\text { Maior número de posições também é pior. Na obra } \\
\text { em questão existem ferros iguais com nomes } \\
\text { diferentes (vai com um numero até o pilar e depois } \\
\text { do pilar muda o número). O que acontece é que } \\
\text { quando há muita posição o armador não encontra } \\
\text { e manda cortar, o que leva a perda do material. } \\
\text { Dificuldades de conferência quando se têm muitas } \\
\text { posições. }\end{array}$} & $\begin{array}{l}\text { O número } \\
\text { posições } \\
\text { aumenta } \\
\text { trabalho } \\
\text { corte } \\
\text { barras. }\end{array}$ & $\begin{array}{r}\text { de } \\
0 \\
\text { de } \\
\text { das }\end{array}$ & $\begin{array}{|lr|}\text { Quanto mais } & \text { posições mais } \\
\text { difícil é armar a laje (aumenta } \\
\text { também o } \quad \text { número de } \\
\text { transpasses). Aumenta } \quad \text { o } \\
\text { número de dobras, o trabalho } \\
\text { de posicioná-los (riscar a laje). }\end{array}$ & $\begin{array}{l}\text { Quanto } \\
\text { maior o } \\
\text { número } \\
\text { de } \\
\text { posições, } \\
\text { mais } \\
\text { difícil, }\end{array}$ & $\begin{array}{l}\text { Quando } \\
\text { grande } \\
\text { pois há } \\
\text { plaquetas } \\
\text { organizar } \\
\text { peças } \\
\text { cortadas/ } \\
\text { s; é difíci } \\
\text { e é difícil }\end{array}$ & $\begin{array}{r}\text { é muito } \\
\text { dificulta, } \\
\text { muitas } \\
\text { para } \\
\text { as } \\
\text { dobrada } \\
\text { I montar } \\
\text { conferir. }\end{array}$ & $\begin{array}{ll}\text { No caso } & \text { cas obra, } \\
\text { desta } & \text { são poucas } \\
\text { as posições, } & \\
\text { tanto de } & \text { armadura } \\
\text { positivas } & \\
\text { quanto de } \\
\text { negativas. }\end{array}$ \\
\hline & \multirow[b]{2}{*}{$\begin{array}{c}\text { Espaçamento } \\
\text { das barras }\end{array}$} & \multicolumn{2}{|l|}{ SP 302} & \multicolumn{3}{|r|}{ SP 304} & \multicolumn{4}{|c|}{ SP 306} \\
\hline & & \multicolumn{2}{|c|}{$\begin{array}{l}\text { Melhor espaçamento é a cada } 20 \mathrm{~cm} \text {. Espaçamento } \\
\text { variável também é mais difícil. }\end{array}$} & \multicolumn{3}{|c|}{$\begin{array}{l}\text { Posições intercaladas são mais chatas de serem } \\
\text { feitas (precisa puxar medidas) que quando se } \\
\text { tem uma medida só. }\end{array}$} & \multicolumn{4}{|c|}{$\begin{array}{l}\text { Se variável atrapalha. Ideal seria } 20 \mathrm{~cm} \text { de } \\
\text { espaçamento na inferior e } 30 \mathrm{~cm} \mathrm{na} \\
\text { eventual dupla superior. }\end{array}$} \\
\hline
\end{tabular}


Tabela A 3 - (continuação)- Lista de Opiniões referentes ao projeto do produto - PDA de lajes positivas

\begin{tabular}{|c|c|c|c|c|c|c|c|c|c|}
\hline \multicolumn{2}{|c|}{ ASPECTOS } & \multicolumn{8}{|c|}{ OPINIÕES OBRAS } \\
\hline \multirow{4}{*}{ 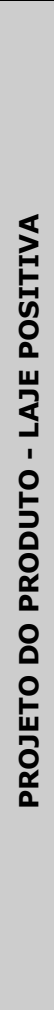 } & \multirow[b]{2}{*}{$\begin{array}{c}\text { Comprimento } \\
\text { variável }\end{array}$} & \multicolumn{2}{|c|}{ SP 301} & \multicolumn{2}{|r|}{ SP 303} & \multicolumn{3}{|c|}{ SP 304} & SP 305 \\
\hline & & \multicolumn{2}{|c|}{$\begin{array}{l}\text { Ferro variável é } \\
\text { mais difícil. A obra } \\
\text { tinha uma marquise } \\
\text { com ferro variável, } \\
\text { que era pequena e } \\
\text { permitia que os } \\
\text { ferros viessem com } \\
\text { um só comprimento } \\
\text { e fossem cortados } \\
\text { com tesoura em } \\
\text { cima da laje, } \\
\text { facilitando assim o } \\
\text { serviço. }\end{array}$} & $\begin{array}{l}\text { Projetos com ferros } \\
\text { variáveis são sempre } \\
\text { mais difíceis. Barras } \\
\text { com esquadros (que } \\
\text { devem ficar na } \\
\text { posição vertical) são } \\
\text { difíceis de serem } \\
\text { mantidas na posição; } \\
\text { é preciso colocar uma } \\
\text { barrinha e dar pontos } \\
\text { em todos os ferros } \\
\text { com esquadro da laje. } \\
\text { O ideal seria os ferros } \\
\text { retos. }\end{array}$ & $\begin{array}{l}\text { Um forte indicador que } \\
\text { expressa a dificuldade de } \\
\text { montar uma laje é o numero } \\
\text { de posições variáveis. Quanto } \\
\text { mais posições variáveis mais } \\
\text { trabalhosa é a armação. Isso } \\
\text { pode ser sentida na própria } \\
\text { geometria da laje: lajes } \\
\text { retangulares são mais fáceis; } \\
\text { quando a forma começa a fugir } \\
\text { disso (arcos, trapézios etc) } \\
\text { mais difícil fica (aumenta-se o } \\
\text { número de posições, de barras } \\
\text { variáveis). }\end{array}$ & \multicolumn{3}{|c|}{$\begin{array}{l}\text { Dificultam ainda mais quando chegam numa } \\
\text { "cambota" (uma viga curva, por exemplo). "Pega } \\
\text { um com cambota, é ruim, ruim mesmo de } \\
\text { fazer". Exige muito mais trabalho e cuidado na } \\
\text { hora de rascunhar (tem que dividir a cambota } \\
\text { em duas, três.. partes (uma posição só dividida } \\
\text { em várias)). Quando os ferros variam } \\
\text { uniformemente (variação linear) é mais fácil } \\
\text { trabalhar com posições variáveis. Exemplo de } \\
\text { rascunho de posição variável: } 30 \text { d } 6,37,40- \\
6,00 \text { (variação de } 1,4 m \text { em } 30 \text { ferros). Lajes } \\
\text { quadradas (retangulares) são muito mais fáceis } \\
\text { (não têm variáveis). }\end{array}$} & $\begin{array}{lr}\text { Atrapalha. } & \text { Nunca } \\
\text { consegue definir } \\
\text { dimensões em } \\
\text { projeto; ra } \\
\text { primeira laje em } \\
\text { que ocorre, as } \\
\text { peças rão } \\
\text { cortadas no local; } \\
\text { mede-se, então, } \\
\text { os vários } \\
\text { comprimentos } \\
\text { para criar a lista } \\
\text { de pré-corte para } \\
\text { a próxima laje. }\end{array}$ \\
\hline & & SP 301 & SP 302 & SP 303 & SP 304 & & SP 306 & & SP 307 \\
\hline & Tela soldadas & $\begin{array}{l}\text { É mais } \\
\text { rápido; } \\
\text { já vem } \\
\text { toda } \\
\text { medida; } \\
\text { é melhor }\end{array}$ & $\begin{array}{l}\text { A tela } \\
\text { soldada é } \\
\text { muito } \\
\text { melhor do } \\
\text { que a } \\
\text { armação } \\
\text { convencion } \\
\text { al }\end{array}$ & \begin{tabular}{l|lrr} 
aelas & \multicolumn{2}{r}{ soldadas: } \\
devem & ser & usadas \\
em & lajes & que \\
exigem & & poucos \\
recortes & na & mesma \\
(como & em & lajes \\
planas & & \\
retangulares).
\end{tabular} & $\begin{array}{l}\text { A tela soldada é melhor quando } \\
\text { lajes retangulares, sem vigas } \\
\text { demandam poucos recortes } \\
\text { encarregado trabalho numa ob } \\
\text { que se estava usando a tela, } m \\
\text { foi retirada, pois se percebe } \\
\text { estava atrasando a laje (sem } \\
\text { tela é rapidamente colocada). }\end{array}$ & $\begin{array}{l}\text { se têm } \\
\text { s (que } \\
\text { s). } \quad 0 \\
\text { bra em } \\
\text { nas que } \\
\text { eu que } \\
\text { viga, a }\end{array}$ & $\begin{array}{l}\text { Melhor que usar barras. Em } \\
\text { termos de exeqüibilidade para } \\
\text { diferentes lajes, o mestre acha } \\
\text { que dá para em quaisquer tipos } \\
\text { de laje; daria para ir cortando as } \\
\text { telas para adaptá-las a recortes } \\
\text { da laje enquanto se vai } \\
\text { montando outros tipos de ferros. }\end{array}$ & $\begin{array}{l}\text { O m } \\
\text { tela é } \\
\text { vigas, } \\
\text { tesou } \\
\text { trabal } \\
\text { plana } \\
\text { telas } \\
\text { que } \\
\text { conve }\end{array}$ & $\begin{array}{l}\text { aior problema da } \\
\text { no encaixe com as } \\
\text { tem que cortar na } \\
\text { ra, dá mais } \\
\text { lho. Em lajes } \\
\text { s, trabalhar com } \\
\text { é muito melhor } \\
\text { a armação } \\
\text { ncional. }\end{array}$ \\
\hline
\end{tabular}


Tabela A 3 - (continuação) - Lista de Opiniões referentes ao projeto do produto - PDA de lajes positivas

\begin{tabular}{|c|c|c|c|c|c|c|}
\hline \multicolumn{2}{|c|}{ ASPECTOS } & \multicolumn{5}{|c|}{ OPINIÕES OBRAS } \\
\hline \multirow{4}{*}{ 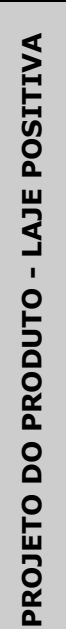 } & \multirow[b]{2}{*}{$\begin{array}{l}\text { Dobra } \\
\text { (esquadro) na } \\
\text { ponta da barra }\end{array}$} & \multicolumn{3}{|r|}{ SP 304} & SP 305 & \multirow[b]{2}{*}{\begin{tabular}{|l} 
SP $\mathbf{3 0 7}$ \\
Barras positivas com esquadros \\
nas pontas são mais difíceis de \\
serem montadas: aumenta \\
trabalho de dobra e dificulta a \\
montagem, por ter que se \\
garantir que o esquadro fique \\
"virado" para cima; é difícil \\
encaixá-los nas vigas.
\end{tabular}} \\
\hline & & $\begin{array}{l}\text { Esquadros nas } \\
\text { pontas: demora } \\
\text { mais para } \\
\text { cortar, dobrar e } \\
\text { posicionar } \quad \text { o } \\
\text { esquadro na } \\
\text { posição. }\end{array}$ & $\begin{array}{l}\text { Posição de barras negativas } \\
\text { com dobra nas extremidades } \\
\text { (uma ou duas) ou sem } \\
\text { dobra: facilita a distribuição } \\
\text { os ferros que não tem } \\
\text { dobras (em pelo uma das } \\
\text { extremidades (no meio da } \\
\text { laje)). }\end{array}$ & $\begin{array}{l}\text { Preferência por barras positivas sem } \\
\text { esquadros nas pontas (ganha tempo na dobra } \\
\text { e no posicionamento (colocar dentro da viga), } \\
\text { deixar na posição certa (esquadro para cima)). } \\
\text { Quando a barra não tem o esquadro o } \\
\text { trabalho se limita a passar o ferro dentro da } \\
\text { viga ( } 15 \text { a } 20 \mathrm{~cm} \text { ) e amarrá-lo posteriormente. }\end{array}$ & $\begin{array}{l}\text { Atrapalha muito } \\
\text { na montagem; se } \\
\text { não há dobras, } \\
\text { vai-se, } \\
\text { simplesmente, } \\
\text { jogando as barras } \\
\text { e as espaçando. }\end{array}$ & \\
\hline & & \multicolumn{5}{|c|}{ SP 306} \\
\hline & $\begin{array}{l}\text { Capitel de laje } \\
\text { plana } \\
\text { (encontro com } \\
\text { o pilar) }\end{array}$ & \multicolumn{5}{|c|}{$\begin{array}{l}\text { Lembrou-se de uma obra que tinha um capitel tronco cônico, levando-se a duas grandes dificuldades: a) quanto às armadura do tronco de cone; b) } \\
\text { quanto aos comprimentos variáveis da armadura da laje (as horizontais entrando dentro do tronco de cone) nesta região. Tentaram pré-montar mas } \\
\text { não conseguiram posicioná-la na fôrma; precisaram montar fôrma e medir in loco para então fazer a armadura. O arquiteto depois disse que } \\
\text { aceitaria terem criado o efeito do tronco de cone em gesso e não necessariamente na própria estrutura. }\end{array}$} \\
\hline
\end{tabular}


Tabela A 4 - Lista de Opiniões referentes ao projeto do produto - PDA de lajes negativas

\begin{tabular}{|c|c|c|c|c|c|c|c|c|}
\hline \multicolumn{2}{|c|}{ ASPECTOS } & \multicolumn{7}{|c|}{ OPINIÕES OBRAS } \\
\hline \multirow{6}{*}{ 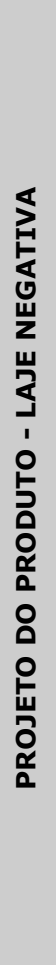 } & \multirow{4}{*}{$\begin{array}{c}\begin{array}{c}\text { Número de } \\
\text { pontos }\end{array} \\
\\
\text { Comparação } \\
\text { com positiva }\end{array}$} & \multicolumn{2}{|c|}{ SP 301} & \multicolumn{5}{|c|}{ SP 303} \\
\hline & & \multicolumn{2}{|c|}{$\begin{array}{l}\text { Espaçamento e número de pontos: depende } \\
\text { do diâmetro dos ferros: quanto menor maior o } \\
\text { numero de pontos ferros de } 10 \mathrm{~mm} \text { pode } \\
\text { pontear a cada } 3 \text { ferros. }\end{array}$} & \multicolumn{5}{|c|}{$\begin{array}{l}\text { Número de pontos: quanto mais pontos mais difícil. O número de pontos a ser dado na malha da } \\
\text { laje que se está armando dependo muito do engenheiro da obra. "Tem engenheiro que chega } \\
\text { chutando os ferros na laje só para ver se o ferro sacudiu. Se sim, chama o armador para dar o } \\
\text { ponto naquele local." "Nas lajes com ferros a cada } 20 \mathrm{~cm} \text {, os pontos são dados a cada duas barras } \\
\text { ("ponto em um, pula-se dois"); nas lajes com ferros a cada } 10 \mathrm{~cm} \text {, os pontos são dados a cada } 4 \\
\text { barras (em um sentido)." }\end{array}$} \\
\hline & & \multicolumn{2}{|c|}{ SP 301} & SP 302 & SP 303 & SP 304 & SP 305 & SP 306 \\
\hline & & \multicolumn{2}{|c|}{$\begin{array}{l}\text { A armação negativa é mais complicada que a } \\
\text { positiva. A armação negativa sofre ainda a } \\
\text { interferência da elétrica e hidráulica. Os ferros } \\
\text { positivos vão de viga a viga; já os negativos } \\
\text { têm que "fazer a puxada" na viga para } \\
\text { posicioná-lo corretamente. Melhor armar lajes } \\
\text { quadradas. Lajes com marquises são mais } \\
\text { difíceis. As marquises seguram o serviço. } \\
\text { Reforço nas caixinhas segura também o } \\
\text { serviço na laje; "esquecer o reforço é trabalho } \\
\text { dobrado". }\end{array}$} & $\begin{array}{lr}\text { A } r \text { laje } \\
\text { nervurada } \\
\text { ér mais } \\
\text { difícil } & \text { de } \\
\text { armar } & \text { que } \\
\text { a laje } & \text { sem } \\
\text { nervuras. }\end{array}$ & 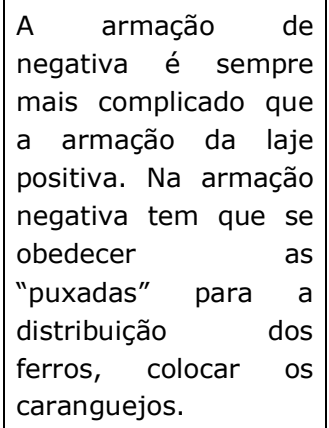 & $\begin{array}{l}\text { Entre positivo e negativo, } \\
\text { o positivo é, na maioria } \\
\text { dos casos, mais fácil de se } \\
\text { armar (entre outros } \\
\text { porque as barras podem, } \\
\text { não ter dobras, não } \\
\text { requerendo maiores } \\
\text { cuidados no seu } \\
\text { posicionamento). }\end{array}$ & $\begin{array}{l}1 \mathrm{~kg} \text { de } \\
\text { negativo } \\
\text { é mais } \\
\text { difícil } \\
\text { que } 1 \mathrm{~kg} \\
\text { de } \\
\text { positivo. }\end{array}$ & $\begin{array}{l}\text { Negativo é } \\
\text { normalmente mais } \\
\text { difícil que positivo: só } \\
\text { o esquadro na barra } \\
\text { do negativo já dá } \\
\text { muito trabalho; } \\
\text { número de posições é } \\
\text { maior, levando a } \\
\text { muitas plaquetas e } \\
\text { pacotinhos de peças }\end{array}$ \\
\hline & \multirow[b]{2}{*}{$\begin{array}{c}\text { Comprimento } \\
\text { variável }\end{array}$} & SP 305 & \multicolumn{2}{|l|}{ SP 306} & \multicolumn{4}{|c|}{ SP 307} \\
\hline & & É mais chato. & \multicolumn{2}{|c|}{$\begin{array}{l}\text { É muito chato; no caso de } \\
\text { bordas arredondadas muitas } \\
\text { vezes têm de medir no local. }\end{array}$} & \multicolumn{4}{|c|}{$\begin{array}{l}\text { Ferros variáveis: quando a variação é linear é bem mais fácil do que a variação em } \\
\text { trechos curvilíneos. É preferível trabalhar com ferro variável a se trabalhar com barras } \\
\text { com esquadros nas pontas. }\end{array}$} \\
\hline
\end{tabular}


Tabela A 4 - (continuação) - Lista de Opiniões referentes ao projeto do produto - PDA de lajes negativas

\begin{tabular}{|c|c|c|c|c|c|c|c|c|c|c|}
\hline \multicolumn{2}{|c|}{ ASPECTOS } & \multicolumn{9}{|c|}{ OPINIÕES OBRAS } \\
\hline \multirow[b]{6}{*}{$\begin{array}{l}\frac{1}{\mathbf{L}} \\
\frac{\mathbf{\alpha}}{\alpha} \\
\frac{\alpha}{\alpha}\end{array}$} & \multirow{4}{*}{$\begin{array}{c}\text { Diâmetro } \\
\text { Espaça-mento } \\
\text { do fundo }\end{array}$} & \multicolumn{3}{|c|}{ SP 304} & SP 305 & \multicolumn{3}{|c|}{ SP 306} & \multicolumn{2}{|c|}{ SP 307} \\
\hline & & \multicolumn{3}{|c|}{$\begin{array}{l}\text { Melhor bitola para armar positivos da laje é de } \\
8 \text { e } 10 \mathrm{~mm} \text { (fica no peso certo, não muito } \\
\text { pesada). As barras são lançadas, vindo um } \\
\text { armador (ajudante) colocando os } \\
\text { espaçadores, para, em seguida, vir os outros } \\
\text { armadores dando os pontos. }\end{array}$} & $\begin{array}{l}\text { Encarregado não gosta de } \\
\text { trabalhar com diâmetro inferior } \\
\text { a } 8 \mathrm{~mm} \text {, pois entortam muito } \\
\text { facilmente, } \\
\text { retrabalho. }\end{array}$ & \multicolumn{3}{|c|}{$\begin{array}{l}\text { Bom é diâmetro de } 8 \mathrm{~mm} \text { (ponto fica } \\
\text { firme); } 5 \mathrm{~mm} \text { fica entortado. } \\
\text { Diâmetro maior que } 10 \mathrm{~mm} \text { ficaria } \\
\text { ruim também, pois ficaria muito } \\
\text { pesado, dificultando puxar armadura } \\
\text { para acertar seu posicionamento. }\end{array}$} & \multicolumn{2}{|c|}{$\begin{array}{l}\text { Melhor bitola para se } \\
\text { trabalhar em laje é de } \\
8 \mathrm{~mm} \text {. A laje fica bonita, } \\
\text { fica reta, é mais fácil para } \\
\text { amarrar. }\end{array}$} \\
\hline & & \multicolumn{5}{|c|}{ SP 302} & \multicolumn{4}{|c|}{ SP 306} \\
\hline & & \multicolumn{5}{|c|}{$\begin{array}{l}\text { Toda concretagem tem que ter o armador acompanhando só para posicionar o } \\
\text { esquadro. }\end{array}$} & \multicolumn{4}{|c|}{$\begin{array}{l}\text { Não gostam de fazer dobra na ponta para apoiar no fundo; } \\
\text { preferem caranguejo }\end{array}$} \\
\hline & & SP 301 & SP 302 & \multicolumn{4}{|c|}{ SP 303} & \multicolumn{2}{|r|}{ SP 306} & SP 307 \\
\hline & Caranguejo & $\begin{array}{l}\text { Caranguejo: } \\
\text { são feito com } \\
\text { sobras }(10 \mathrm{~mm} \\
\text { e } 12 \mathrm{~mm}) \text {. Não } \\
\text { conhecem as } \\
\text { treliças. }\end{array}$ & $\begin{array}{l}\text { Caranguejo } \\
\text { de ferro de } \\
10 \mathrm{~mm} \text { já } \\
\text { vem } \\
\text { dobrado. }\end{array}$ & \multicolumn{4}{|c|}{$\begin{array}{l}\text { Os caranguejos não são contemplados no projeto (lista resumo). São } \\
\text { representativos na quantidade }(\mathrm{Kg}) \text { de aço na obra, são trabalhosos de serem } \\
\text { feitos (cortados e dobrados (ferros curtos de diâmetros considerados - } 10 \mathrm{~mm}- \\
\text { que consomem tempo e discos de serra)), a distribuição na laje é feita seguindo } \\
\text { os critérios da obra, que pode exigi-los em maior ou em menor número. A queixa } \\
\text { do subempreiteiro de armação é que ele não recebe pelo trabalho nos } \\
\text { caranguejos. A distribuição prevista em detalhe genérico no projeto, consumiria } \\
\text { aproximadamente três toneladas de aço. A obra, neste caso, considerou o } \\
\text { número elevado e diminuiu a quantidade (aumento o distanciamento entre eles, } \\
\text { cuja distribuição estava prevista em } 3 \text { a } 4 \text { linhas). "Lembro-me de uma obra em } \\
\text { que o engenheiro subia em cima dos caranguejos, na laje que estava sendo } \\
\text { armada, e balançava; se o ferro "sacudisse", ele exigia a colocação de mais } \\
\text { caranguejo." }\end{array}$} & \multicolumn{2}{|c|}{$\begin{array}{l}\text { O ideal é usar fio } \\
\text { com diâmetro maior } \\
\text { ou igual a } 10 \mathrm{~mm} \text {, } \\
\text { com } 80 \text { a } 100 \mathrm{~cm} \text { e } \\
\text { com } 3 \text { dobras. Não } \\
\text { conhecem as } \\
\text { treliças metálicas } \\
\text { pré-fabricadas. } \\
\text { Ideal é diâmetro de } \\
10: 8 \text { fica frágil e } \\
12,5 \text { é difícil de } \\
\text { dobrar. }\end{array}$} & \begin{tabular}{|l} 
Acha \\
melhor \\
caranguejo \\
que \\
treliça, pois \\
sobe \\
negativo \\
pronto \\
joga \\
caranguejo \\
por baixo. \\
\end{tabular} \\
\hline
\end{tabular}


Tabela A 4 - (continuação) - Lista de Opiniões referentes ao projeto do produto - PDA de lajes negativas

\begin{tabular}{|c|c|c|c|c|c|c|c|}
\hline \multicolumn{8}{|c|}{ OPINIÕES OBRAS } \\
\hline & & SP 301 & SP 302 & SP 304 & SP 305 & SP 306 & SP 307 \\
\hline 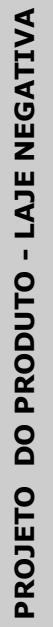 & $\begin{array}{c}\text { Interação } \\
\text { com } \\
\text { armadura da } \\
\text { viga }\end{array}$ & $\begin{array}{l}\text { Nó de cachorro: quando o ferro é } \\
\text { fino o armador dobra o ferro no } \\
\text { local, na mão (faz o esquadro a } \\
\text { chave e desce o ferro). Quando o } \\
\text { ferro é de } 10 \text { ou } 12 \text { não dá para } \\
\text { fazer assim. Posiciona-se a viga } \\
\text { depois entra com o ferro } \\
\text { negativo da marquise. Na obra } \\
\text { este ferro era de } 5 \mathrm{~mm} \text { e a virada } \\
\text { era feita no local (o comprimento } \\
\text { é variável, e vai ficando o ferro } \\
\text { que entra na viga maior a } \\
\text { medida que varia, ou quando não } \\
\text { cabe o ferro é cortado). }\end{array}$ & $\begin{array}{l}\text { Negativos da marquise são muito } \\
\text { complicados (esquadro de } 15 \mathrm{~cm} \\
\text { dificulta a colocação). Ou faria a } \\
\text { dobra com um tamanho superior ao } \\
\text { estribo da viga, ou tiraria o esquadro } \\
\text { de 15. As costelas da viga só são } \\
\text { colocadas depois da armação } \\
\text { negativa da marquise. A viga fica } \\
\text { suspensa para a armação, quando ela } \\
\text { desce, se um ganchinho fugir do } \\
\text { local, tem que levantar a viga de } \\
\text { novo para acertar o seu } \\
\text { posicionamento. Dois estribos na aba } \\
\text { da marquise ao invés de um estribo } \\
\text { só, que facilitaria a montagem }\end{array}$ & $\begin{array}{l}\text { Detalhe da posição } \\
\text { negativa da marquise. } \\
\text { Situação mais difícil é } \\
\text { quando são duas } \\
\text { posições (uma para } \\
\text { cada lada) e uma, ou } \\
\text { ambas, tem um gancho } \\
\text { na ponta ("u", uma } \\
\text { perninha a mais). } \\
\text { Situação intermediária é } \\
\text { a posição única (um } \\
\text { ferro só), para a } \\
\text { montagem; já na dobra } \\
\text { esta é a situação mais } \\
\text { difícil. }\end{array}$ & $\begin{array}{l}\text { Quando laça a } \\
\text { armadura da viga } \\
\text { é mais difícil. Por } \\
\text { exemplo, } \\
\text { detestam } \\
\text { negativo para os } \\
\text { dois lados em } \\
\text { peça única do } \\
\text { tipo "nó de } \\
\text { cachorro" (ainda } \\
\text { mais se, de um } \\
\text { lado - por } \\
\text { exemplo um } \\
\text { varanda curva - } \\
\text { ele é variável) }\end{array}$ & $\begin{array}{l}\text { O nó de } \\
\text { cachorro é o } \\
\text { pior tipo de } \\
\text { negativo que } \\
\text { existe: difícil } \\
\text { montar pois } \\
\text { entra junto } \\
\text { com r a } \\
\text { distribuição } \\
\text { darriga; } \\
\text { atrapalha a } \\
\text { própria viga, } \\
\text { que só pode } \\
\text { armar no } \\
\text { local }\end{array}$ & $\begin{array}{l}\text { A montagem } \\
\text { da armação } \\
\text { negativa da } \\
\text { varanda } \\
\text { (posições com } \\
\text { "nó de } \\
\text { cachorro") é } \\
\text { sempre a } \\
\text { parte mais } \\
\text { trabalhosa } \\
\text { (precisa ser } \\
\text { armador } \\
\text { junto com a } \\
\text { viga). }\end{array}$ \\
\hline
\end{tabular}


Tabela A 5 - Lista de Opiniões referentes ao método de trabalho

\begin{tabular}{|c|c|c|c|c|c|}
\hline \multicolumn{2}{|c|}{ ASPECTOS } & \multicolumn{4}{|c|}{ OPINIÕES OBRAS } \\
\hline \multirow{4}{*}{ 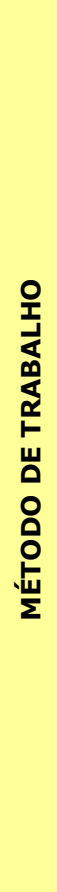 } & \multirow{4}{*}{$\begin{array}{l}\text { Corte } \\
\text { Dobra }\end{array}$} & SP 301 & \multicolumn{3}{|c|}{ SP 304} \\
\hline & & $\begin{array}{l}\text { O corte e a dobra das barras são feitos na obra. Aloca-se } \\
\text { um armador fixo na bancada com um ajudante (o ajudante, } \\
\text { a partir de oito meses, está apto para operar as } \\
\text { máquinas). O ajudante é fundamental para garantir o } \\
\text { esquadro das posições (em vigas principalmente). A mesma } \\
\text { dupla que corta é a que dobra. Quando o serviço está } \\
\text { muito "corrido" coloca-se uma dupla para corte e uma dupla } \\
\text { para dobra. }\end{array}$ & \multicolumn{3}{|c|}{$\begin{array}{l}\text { Quanto menor o número de posições e menor a variação das bitolas das barras, mais } \\
\text { produtivo é o corte (reduz-se o trabalho de precisar ir várias vezes ao estoque buscar o } \\
\text { aço de bitolas distintas (o armador não traz duas três bitolas de uma vez, para não } \\
\text { misturar)). Cortam todas as posições de uma viga, para só então passar para a viga } \\
\text { seguinte (não cortam todas as posições de uma determinada bitola para diferentes vigas, } \\
\text { porque o armador pode se confundir). A medida que vão cortando a posição, vão } \\
\text { amarrando-as em feixes com plaquetas de identificação (nome da viga e da posição). }\end{array}$} \\
\hline & & \multicolumn{2}{|l|}{ SP 303} & SP 304 & SP 306 \\
\hline & & \multicolumn{2}{|c|}{$\begin{array}{l}\text { Quando se dobram os estribos é preciso que se dê um desconto na dimensão } \\
\text { apontada no projeto, para que ele fique menor, garantindo-se, assim, o } \\
\text { cobrimento mínimo da armadura (esse cobrimento pode ficar prejudicado } \\
\text { quando, soma-se ao estribo o negativo da laje). Esse "desconto" (algo como } \\
5 \mathrm{~cm} \text { por estribo) acaba não sendo contabilizado na compra do aço, podendo } \\
\text { ocasionar uma perda do material. "Na hora que vou "rascunhar" o projeto, eu } \\
\text { já dou o "desconto" no comprimento de todos os estribos. O estribo de } 51 \mathrm{~cm} \text {, } \\
\text { por exemplo, eu já mando o armador fazer com } 50 \mathrm{~cm} \text { para ter o } \\
\text { recobrimento." "No caso dos pilares é a mesma coisa, se seguir as } \\
\text { prescrições do projeto, não se garante o cobrimento de } 25 \mathrm{~mm} \text { exigido (a } \\
\text { distância da curvatura do estribo ao abraçar a posição longitudinal torna-se, } \\
\text { de fato, maior que aquela apontada no projeto)". }\end{array}$} & $\begin{array}{l}\text { Se a viga tem estribos com várias medidas (bitolas e } \\
\text { dimensões) isto dificulta o corte (vai estar sempre } \\
\text { mudando as medidas na máquina, porque ele não } \\
\text { pode, para uma mesma dimensão de estribo, dobrar } \\
\text { um ferro de } 5 \text { e outro de } 6,3 \mathrm{~mm} \text {, sem mudar as } \\
\text { medidas e pinos na máquina). O tempo que o } \\
\text { armador leva para acertar as medidas (referencias } \\
\text { com pinos) na bancada de dobra é maior do que o } \\
\text { tempo que ele gasta para dobrar as posições para } \\
\text { qual ele acertou as medidas ("para dobrar é } \\
\text { rapidinho, o que mais dificulta é acertar as } \\
\text { medidas"). }\end{array}$ & $\begin{array}{l}\text { Dobrar barras } \\
\text { de diâmetro de } \\
12,5 \text { e } 16 \text { é } \\
\text { quase } \\
\text { impossível na } \\
\text { mão; precisa de } \\
\text { máquina. }\end{array}$ \\
\hline
\end{tabular}


Tabela A 5 - (continuação) - Lista de Opiniões referentes ao método de trabalho

\begin{tabular}{|c|c|c|c|c|c|c|c|c|c|}
\hline \multicolumn{2}{|c|}{ ASPECTOS } & \multicolumn{8}{|c|}{ OPINIÕES OBRAS } \\
\hline \multirow{4}{*}{ 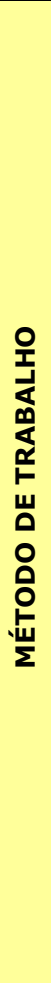 } & \multirow[b]{2}{*}{$\begin{array}{c}\text { Pré- } \\
\text { montagem }\end{array}$} & SP 301 & S302 & \multicolumn{2}{|l|}{ SP 303} & SP 304 & SP 306 & \multicolumn{2}{|r|}{ SP 307} \\
\hline & & \begin{tabular}{lr}
\multicolumn{3}{l}{ Todos os pilares são pré- } \\
montados. As vigas \\
também são pré-montadas \\
(as "puxadas" & são \\
colocadas no lugar \\
quando há pilares \\
intermediários). r Os \\
negativos são pré- \\
montados. Quando a "tela" \\
de negativo fica muito \\
grande ela é pré-montada \\
em duas partes. A \\
armadura da laje positiva \\
foi feita da maneira \\
convencional.
\end{tabular} & 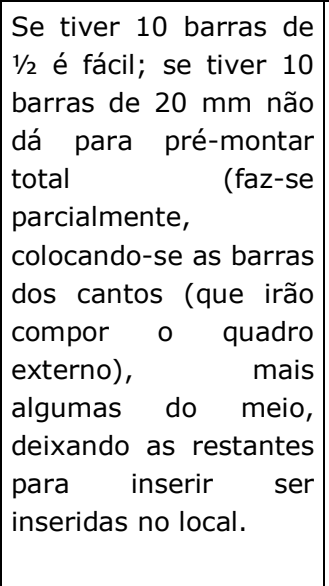 & \multicolumn{2}{|c|}{$\begin{array}{l}\text { Quando se trabalha com o aço } \\
\text { cortado e dobrado os } \\
\text { armadores, para evitarem } \\
\text { problemas com o cobrimento } \\
\text { acabam abrindo e fechando os } \\
\text { estribos novamente, } \\
\text { acertando-se, assim, as suas } \\
\text { dimensões. Isso acaba } \\
\text { acontecendo principalmente } \\
\text { nas primeiras lajes (depois de } \\
\text { constatado o problema, a obra } \\
\text { solicita alteração à empresa de } \\
\text { corte e dobra). }\end{array}$} & $\begin{array}{|lr|}\text { Vigas } & \text { com } \\
\text { seção } & \text { variável } \\
\text { (largura } & \text { e/ou } \\
\text { altura) } & \text { que } \\
\text { trabalham } & \text { com } \\
\text { duas dimensões } \\
\text { de estribos } & \text { são } \\
\text { mais difíceis } & \text { de } \\
\text { serem } & \\
\text { montadas. }\end{array}$ & \begin{tabular}{|lr} 
Detalhes & que \\
facilitam a & pré- \\
montagem r da \\
armadura \\
negativa da laje: \\
ferros \\
semelhantes \\
comprimento ou \\
diâmetro); ferros \\
longos; trechos \\
grandes.
\end{tabular} & $\begin{array}{l}\text { A a } \\
\text { e } \mathrm{g} \\
\text { com } \\
\text { ao } \\
\text { arm } \\
\text { por } \\
\text { (fic } \\
\text { que } \\
\text { cav } \\
\text { ferr } \\
\text { pod } \\
\text { arm } \\
\text { pon }\end{array}$ & $\begin{array}{l}\text { marração dos estribos } \\
\text { janchinhos em pilares } \\
\text { larguras superiores } \\
\text { alcance do braço do } \\
\text { ador: o armador entra } \\
\text { baixo da armadura } \\
\text { sentado no chão), } \\
\text { está suspensa pelos } \\
\text { aletes. Em pilares com } \\
\text { o grosso o armador } \\
\text { e subir encima da } \\
\text { ladura para dar os } \\
\text { tos. }\end{array}$ \\
\hline & & \multicolumn{3}{|c|}{ SP 301} & \multicolumn{4}{|c|}{ SP 304} & SP 306 \\
\hline & Montagem & \multicolumn{3}{|c|}{$\begin{array}{l}\text { Quando os carpinteiros liberam a laje após a concretagem dos pilares, } \\
\text { o encarregado dá um "Acabou lavou" para os armadores, que entram } \\
\text { todos na laje, posicionando as armaduras das vigas e deixando a } \\
\text { armadura positiva da laje distribuída e amarrada; só, então, vão } \\
\text { embora. No dia seguinte, após a colocação dos eletrodutos, os } \\
\text { armadores "soltam" os negativos, gastando neste serviço de uma hora } \\
\text { a uma hora e meia. }\end{array}$} & \multicolumn{4}{|c|}{$\begin{array}{l}\text { Vigas: As barras complementares são posicionadas } \\
\text { no local; as puxadas, para o correto posicionamento, } \\
\text { são tiradas do projeto de fôrmas (os pilares são } \\
\text { referencias). Sempre colocar as barras na primeira } \\
\text { camada é mais fácil que nas camadas subseqüentes } \\
\text { (quando existem); tem que cortar e colocar uns } \\
\text { "tarugos" para as barras ficarem na posição certa. }\end{array}$} & $\begin{array}{l}\text { É bom ter a face do } \\
\text { fundo da fôrma } \\
\text { montada para servir } \\
\text { de "apoio" para a } \\
\text { armadura. }\end{array}$ \\
\hline
\end{tabular}


Tabela A 5 - (continuação) - Lista de Opiniões referentes ao método de trabalho

\begin{tabular}{|c|c|c|c|c|c|}
\hline \multicolumn{2}{|r|}{ ASPECTOS } & \multicolumn{4}{|c|}{ OPINIÕES OBRAS } \\
\hline & & SP 301 & SP 302 & SP 303 & SP 305 \\
\hline 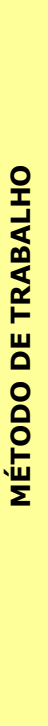 & $\begin{array}{c}\text { Uso de aço } \\
\text { pré- } \\
\text { cortado/dobra } \\
\text { do }\end{array}$ & $\begin{array}{l}\text { Prefere trabalhar } \\
\text { com o aço } \\
\text { cortado } \\
\text { dobrado na obra. } \\
\text { O aço beneficiado } \\
\text { vem com muitos } \\
\text { problemas, } \\
\text { faltando posições. } \\
\text { Ferros variáveis } \\
\text { vêm com um } \\
\text { tamanho só. É } \\
\text { demorado para } \\
\text { receber o aço. }\end{array}$ & $\begin{array}{l}\text { O engenheiro alegou que buscou agilidade para optar } \\
\text { pelo aço cortado e dobrado. "Como terei uma equipe } \\
\text { que ficaria rodando a obra, se tivesse apenas uma } \\
\text { equipe para ficar cortando e dobrando não atenderia } \\
\text { a demanda, teria que colocar muita mais gente. } \\
\text { Então eu negocie com empreiteiro, de dar o aço } \\
\text { cortado e dobrado (por este aspecto de otimização } \\
\text { de mão-de-obra e também por conta da "perda } \\
\text { zero"). Porém hoje eu percebi que a perda não é } \\
\text { zero, se perde mais aço do que se fosse cortado e } \\
\text { dobrado na obra." Tem sobrado aço na obra após a } \\
\text { concretagem das lajes ("a empresa de corte e dobra } \\
\text { não manda um Kg a mais mas a obra não controla } \\
\text { onde armazena e coloca o aço"). São muitos prédios, } \\
\text { o que leva a uma grande quantidade de aço, exigindo } \\
\text { grandes áreas de estocagem. "Em função disso, hoje } \\
\text { eu prefiro o aço cortado e dobrado na obra". Para se } \\
\text { propor a cortar e dobra aço na obra é preciso que se } \\
\text { tenha uma organização do trabalho para isso. }\end{array}$ & $\begin{array}{l}\text { Preferência por cortar e } \\
\text { dobrar o aço na obra. o } \\
\text { encarregado condena o aço } \\
\text { pronto. Quando se trabalha } \\
\text { com aço pronto, ele vem } \\
\text { sempre faltado, e nesse caso } \\
\text { precisa ser feito na obra } \\
\text { (precisa tirar um armador da } \\
\text { equipe para fazer aquela } \\
\text { posição). No momento do } \\
\text { descarregamento, } \\
\text { geralmente perde-se a placa } \\
\text { de identificação dos feixes. É } \\
\text { preciso ficar com uma trena, } \\
\text { achando as posições. O } \\
\text { tempo que se perde seria } \\
\text { suficiente para cortar e } \\
\text { dobrar o aço. }\end{array}$ & $\begin{array}{l}\text { Mestre não gosta: vem errado (fornecedor } \\
\text { só dá } 48 \text { horas para reclamação, e às vezes } \\
\text { não acha tempo para tal conferência neste } \\
\text { prazo). Descobrir o erro na hora da } \\
\text { montagem pode prejudicar muito o serviço } \\
\text { (é difícil cobrar do armador a correção pois } \\
\text { o erro não foi cometido por ele e sim pelo } \\
\text { fornecedor do aço). Costuma-se atrasar as } \\
\text { entregas do aço. "Se o projeto tem erro, a } \\
\text { peça chega conforme o projeto e também dá } \\
\text { problemas na hora da montagem (por } \\
\text { exemplo, os armadores que vão também } \\
\text { montar, sabem que, no caso de uma } \\
\text { armadura com barra grossa têm de fazer o } \\
\text { corte e a dobra deixando uma folga maior } \\
\text { que para uma barra fina para não terem } \\
\text { problemas na hora de encaixar uma gaiola } \\
\text { na fôrma). O fornecedor, normalmente, não } \\
\text { atenta para tais "macetes" de obra. }\end{array}$ \\
\hline
\end{tabular}


Tabela A 5 - (continuação) - Lista de Opiniões referentes ao método de trabalho

\begin{tabular}{|c|c|c|c|c|c|}
\hline \multicolumn{2}{|c|}{ ASPECTOS } & \multicolumn{4}{|c|}{ OPINIÕES OBRAS } \\
\hline \multirow{6}{*}{ 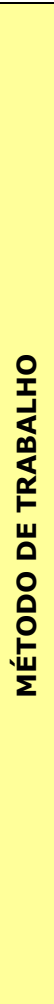 } & \multirow[b]{2}{*}{$\begin{array}{c}\text { Uso de aço } \\
\text { pré-cortado/ } \\
\text { dobrado }\end{array}$} & \multicolumn{4}{|c|}{ SP 306} \\
\hline & & $\begin{array}{l}\text { A decisão por se trabalhar com o aço beneficiado ou não costu } \\
\text { dificuldade do projeto. O preço passado pelo empreiteiro para } \\
\text { barras (onde terá que cortá-lo e dobrá-lo)". Justifica-se pelo fa } \\
\text { posições. "Parece que é mais fácil mas a mão-de-obra que tra } \\
\text { perda do aço. A decisão é tomada em cima destes aspectos. } \\
\text { relação à perda de aço gerado pelo sei projeto, nos casos em } \\
\text { estar projetando pensando que o aço chegará a obra cortado } \\
\text { encontrou muitos problemas com as posições (posições errada } \\
\text { das dificuldades encontradas. "Se você perguntar para qualqu } \\
\text { aço convencional." Porém a qualidade do aço pronto é bem su } \\
\text { que permite corrigir algumas posições que estejam com proble } \\
\text { beneficiado, pois a empresa, já pode ter cortado e dobrado aqu }\end{array}$ & $\begin{array}{l}\text { Ima partir da própria o } \\
\text { trabalhar com o aço be } \\
\text { ato do empreiteiro ter } \\
\text { balha com o aço corta } \\
\text { Não é definido no orça } \\
\text { que o aço é cortado } \\
\text { e dobrado. O enge } \\
\text { s, a mais, a menos). } \\
\text { er pessoa que trabalh } \\
\text { ıperior; por outro lado } \\
\text { emas". "Pode-se não t } \\
\text { lela posição para a obr }\end{array}$ & $\begin{array}{l}\text { bra. Faz-se um estudo preli } \\
\text { eneficiado é, "por incrível qu } \\
\text { que manter pessoas mais e } \\
\text { ado e dobrado é mais". Qua } \\
\text { amento. O projetista é avali } \\
\text { na obra). Talvez não se pre } \\
\text { nheiro recorda que já traba } \\
\text { prefere trabalhar com o aço } \\
\text { ou em obra com aço prontc } \\
\text { o, usando-se o aço pronto " } \\
\text { er tempo de fazer modificaç } \\
\text { ra inteira". }\end{array}$ & $\begin{array}{l}\text { liminar onde se contempla o custo e da } \\
\text { ue se pareça, maior que para o aço em } \\
\text { especialistas em conhecer e analisar as } \\
\text { anto ao material faz-se uma análise da } \\
\text { liado pela taxa de armação (e nem em } \\
\text { eocupe, da maneira como deveria, por } \\
\text { alhou com o aço beneficiado mas que } \\
\text { cortado e dobrado na obra, em função } \\
\text { o ela dirá que prefere trabalhar com o } \\
\text { "perde-se um pouco a análise da obra, } \\
\text { ções em posições quando o aço já vem }\end{array}$ \\
\hline & \multirow{3}{*}{$\begin{array}{l}\text { Transporte- } \\
\text { grua }\end{array}$} & \multicolumn{2}{|l|}{ SP 303} & \multicolumn{2}{|r|}{ SP 305} \\
\hline & & \multicolumn{2}{|c|}{$\begin{array}{l}\text { O uso da grua para o transporte das barras e armaduras e posicionamento trata-se } \\
\text { da melhor solução, quanto à praticidade e rapidez proporcionada. }\end{array}$} & \multicolumn{2}{|c|}{$\begin{array}{l}\text { Pilar: é importante quando se têm pilares pesados a movimentar. } \\
\text { Ë muito útil para pilares U. }\end{array}$} \\
\hline & & \multicolumn{3}{|c|}{ SP 304} & SP 306 \\
\hline & $\begin{array}{c}\text { Transporte - } \\
\text { elevador }\end{array}$ & $\begin{array}{l}\text { O aço é transportado com uso do elevador cremalheira (as } \\
\text { armaduras de pilares e vigas são presas externamente a } \\
\text { cabine do elevador; ferros de lajes com menos de } 1,5 \mathrm{~m} \text { são } \\
\text { levados no interior da cabine). Tempos de transporte: pilares } \\
\text { aproximadamente } 3 \text { horas; vigas, } 2 \text { horas e barras da laje, } 2 \\
\text { horas. }\end{array}$ & $\begin{array}{l}\text { Quanto à cremalheira } \\
\text { têm-se as mesmas } \\
\text { Têm-se, ainda, crem } \\
\text { na laje em execuçã } \\
\text { preciso puxar o aço } \\
\text { manualmente, com a }\end{array}$ & $\begin{array}{l}\text { a para o transporte de aço, } \\
\text { dificuldades da mini-grua. } \\
\text { nalheiras que não chegam } \\
\text { o. Param embaixo, sendo } \\
\text { para o andar de cima, } \\
\text { ajuda de cordas. }\end{array}$ & $\begin{array}{l}\text { Acham a velocidade muito baixa ao } \\
\text { descerem engrenados. A dimensão da } \\
\text { cabine dos elevadores de cremalheira } \\
\text { é de } 1,9 \text { a } 2 \mathrm{~m} \text {; portanto a gaiola só } \\
\text { pode ter até } 1,8 \mathrm{~m} \text { de largura para que } \\
\text { caiba dentro da cabine. }\end{array}$ \\
\hline
\end{tabular}


Tabela A 5 - (continuação) - Lista de Opiniões referentes ao método de trabalho

\begin{tabular}{|c|c|c|c|c|c|c|}
\hline \multicolumn{2}{|c|}{ ASPECTOS } & \multicolumn{5}{|c|}{ OPINIÕES OBRAS } \\
\hline & \multirow{4}{*}{$\begin{array}{c}\text { Transporte - } \\
\text { mini-grua } \\
\\
\\
\text { Equipa- } \\
\text { mentos de } \\
\text { corte e dobra }\end{array}$} & \multicolumn{5}{|c|}{ SP 304} \\
\hline & & \multicolumn{5}{|c|}{$\begin{array}{l}\text { O encarregado não aconselha o uso da "mini-grua" para o transporte do aço ("o pessoal se mata e não faz quase nada. Além do guincho ser lento, } \\
\text { quando chega no final tem que ter no mínimo quatro armadores para puxar o ferro para dentro; é ainda perigoso para o armador"). "Esses quatro } \\
\text { armadores ficam o dia inteiro só "puxando" ferro". }\end{array}$} \\
\hline & & SP 301 & SP 302 & SP 303 & SP 304 & SP 306 \\
\hline & & $\begin{array}{ll}\text { A máquina } \\
\text { de dobra faz } \\
\text { o trabalho de } \\
\text { cinco } \\
\text { homens. } \\
\text { Costuma ter } \\
\text { problemas } \\
\text { quando há } \\
\text { queda de } \\
\text { força. } & \text { A } \\
\text { Policorte } & \\
\text { prejudica } & \text { a } \\
\text { saúde } & \\
\text { (fuligem) }\end{array}$ & $\begin{array}{l}\text { O policorte não é } \\
\text { maquina apropriado } \\
\text { para cortar ferro. } \\
\text { Serve apenas para } \\
\text { cortar ferro fino. Para } \\
\text { ferro grosso, quando } \\
\text { o disco chega à } \\
\text { metade, o ferro } \\
\text { começa a esquentar, } \\
\text { prendendo o disco, } \\
\text { que pode estourar e } \\
\text { causar um acidente. } \\
\text { "Policorte é máquina } \\
\text { para se trabalhar em } \\
\text { serralharia, cortando } \\
\text { cantoneiras e chapas } \\
\text { de alumínio". }\end{array}$ & $\begin{array}{lr}\text { Uso na obra de } \\
\text { policorte. } \\
\text { máquina de corte } \\
\text { hidráulica, apesar } \\
\text { de r mais } \\
\text { produtiva, não foi } \\
\text { viabilizada ra em } \\
\text { função do porte } \\
\text { da obra. Seria } \\
\text { necessário do } \\
\text { dobro de aço } \\
\text { para viabilizá-la. }\end{array}$ & $\begin{array}{l}\text { Há diferenças entre torquês. Torquês } \\
\text { do cabo grande não serve para dar } \\
\text { pontos em vigas pequenas. Umas } \\
\text { cortam mais que as outras. Quanto } \\
\text { aos "puxadores" (amoladores) de } \\
\text { torquês, são poucos os que são bons } \\
\text { ("alguns amolam hoje e quando é no } \\
\text { final se semana a torquês não corta } \\
\text { mais nada"). "Lá no Mogi quando os } \\
\text { armadores vão puxar a torquês, eles } \\
\text { dão garantia de um ano". } \\
\text { A policorte não agüenta muito o ritmo } \\
\text { de obra. Queima com facilidade. Dá } \\
\text { para se trabalhar com a policorte } \\
\text { quando é pouco serviço, os ferros são } \\
\text { finos. Já a máquina hidráulica é difícil } \\
\text { de quebrar; "pega" uma quantidade } \\
\text { certa de ferro para cada diâmetro. }\end{array}$ & $\begin{array}{l}\text { Uso de máquinas hidráulicas não foi viável para } \\
\text { esta obra. Nesta obra o aço é fino, o que os levou } \\
\text { a adotar policorte para o corte e dobrar na chave } \\
\text { Para o uso de máquinas de dobra automáticas é } \\
\text { preciso ter a "manha" (precisa ser treinado para } \\
\text { operar a máquina) quanto ao seu uso para dobrar } \\
\text { estribos. Por exemplo, peças que "fecham", isto é } \\
\text { as extremidades do segmento de barra que está } \\
\text { sendo dobrado chegam próximas na peça final, } \\
\text { demandando experiência para ir dobrando } \\
\text { checando o aumento do comprimento em cada } \\
\text { dobra (para não se errar nas dimensões internas } \\
\text { ou externas da peça final). A policorte só é usada } \\
\text { para diâmetro maior ou igual a } 12,5 \text { mm; para aço } \\
\text { mais fino que isto ela "masca" em lugar de cortar } \\
\text { vai danificando algumas partes da própria } \\
\text { máquina. }\end{array}$ \\
\hline
\end{tabular}


APÊNDICE B - Tabela com as RUP de todas as obras 
A Tabela A 6 apresenta os valores das RUP cíclicas (RUPcic), cumulativas (RUPcum) e potencias (RUPpot) levantadas nas sete obras contempladas no estudo.

Tabela A 6 - (continua) - Indicadores de produtividade (expressos em Hh/tonelada)

\begin{tabular}{|c|c|c|c|c|c|c|c|c|c|c|}
\hline \multirow{2}{*}{ OBRA } & \multirow{2}{*}{ Porção } & \multirow{2}{*}{$\begin{array}{l}\text { Tipo de } \\
\text { RUP }\end{array}$} & \multicolumn{2}{|c|}{ RUP PILAR } & \multicolumn{2}{|c|}{ RUP VIGA } & \multicolumn{2}{|c|}{ RUP LAJE } & \multicolumn{2}{|c|}{ GLOBAL } \\
\hline & & & $C / D^{141}$ & $P M / M F$ & $C / D$ & $P M / M F$ & $C / D$ & $P M / M F$ & sem $C / D$ & com $C / D$ \\
\hline SP 301 & 3\%/Tipo & cic & - & 35,56 & - & 39,49 & - & 14,05 & 21,44 & 36,38 \\
\hline SP 301 & $4^{\circ} /$ Tipo & cic & - & 28,02 & - & 59,99 & - & 26,28 & 27,94 & 42,61 \\
\hline SP 301 & $5 \% /$ Tipo & cic & - & 25,33 & - & 50,12 & - & 26,02 & 24,90 & 37,63 \\
\hline SP 301 & 6\%/Tipo & cic & - & 31,79 & - & 70,63 & - & 18,47 & 27,53 & 40,39 \\
\hline SP 301 & 7\%/Tipo & $\mathrm{cic}$ & - & 73,82 & - & 48,60 & - & 21,86 & 34,84 & 48,05 \\
\hline SP 301 & $8^{\circ} /$ Tipo & cic & - & 63,72 & - & 40,25 & - & 19,77 & 33,33 & 43,39 \\
\hline SP 301 & 3 ao 6 & RUP cum & - & 30,17 & - & 51,51 & - & 21,08 & 25,45 & 39,25 \\
\hline SP 301 & pilares & RUP pot & - & 29,37 & - & 46,32 & - & 20,56 & 23,17 & 37,01 \\
\hline SP 301 & 7 e 8 & RUP cum & - & 68,77 & - & - & - & - & 34,09 & 45,72 \\
\hline SP 301 & (pilares) & RUP pot & - & 63,72 & - & - & - & - & 33,33 & 45,72 \\
\hline SP 301 & 9 & $\mathrm{cic}$ & - & 53,67 & - & 40,73 & - & 36,61 & 38,14 & 53,76 \\
\hline SP 302 & $1^{\circ} \mathrm{Pav}$ & cic & - & 41,6 & - & 240,1 & - & 67,8 & 92,5 & - \\
\hline SP 302 & $2^{\circ} \mathrm{Pav}$ & $\mathrm{cic}$ & - & 58,5 & - & 43,9 & - & 35,2 & 43,1 & - \\
\hline SP 302 & $3^{\circ} /$ Tipo & cic & - & 83,0 & - & 61,5 & - & 24,4 & 46,0 & - \\
\hline SP 302 & $4^{\circ} /$ Tipo & cic & - & 76,1 & - & 65,9 & - & 30,5 & 47,8 & - \\
\hline SP 302 & $5^{\circ} /$ Tipo & $\mathrm{cic}$ & - & 85,7 & - & 65,9 & - & 27,1 & 47,6 & - \\
\hline SP 302 & $6 \% /$ Tipo & cic & - & 91,1 & - & 73,2 & - & 20,3 & 46,7 & - \\
\hline SP 302 & 7\%/Tipo & $\mathrm{cic}$ & - & 102,7 & - & 70,3 & - & 54,2 & 66,6 & - \\
\hline SP 302 & $8^{\circ} /$ Tipo & cic & - & 102,7 & - & 73,2 & - & 37,3 & 57,8 & - \\
\hline SP 302 & $9^{\circ} /$ Tipo & $\mathrm{cic}$ & - & 102,7 & - & 65,9 & - & 27,1 & 50,1 & - \\
\hline SP 302 & 4 ao 6 & RUP cum & - & 84,3 & - & 68,0 & - & 31,6 & 51,7 & - \\
\hline SP 302 & (pilares) & RUP pot & - & 80,9 & - & 65,9 & - & 27,1 & 47,2 & - \\
\hline SP 302 & 7 ao 9 & RUP cum & - & 102,7 & - & - & - & - & - & - \\
\hline SP 302 & (pilares) & RUP pot & - & 102,7 & - & - & - & - & - & - \\
\hline SP 303 & 10\%/Tipo & cic & - & 68,00 & - & 34,45 & - & 20,09 & 37,98 & 45,72 \\
\hline SP 303 & 11 \%Тіро & cic & - & - & - & 36,26 & - & 17,98 & 29,85 & 42,89 \\
\hline SP 303 & $12 \%$ Tipo & cic & - & 67,57 & - & 34,45 & - & 16,92 & 34,86 & 43,55 \\
\hline SP 303 & $13 \%$ Tipo & cic & - & - & - & 25,38 & - & 17,98 & 27,68 & 40,34 \\
\hline SP 303 & $14 \%$ Tipo & cic & - & 67,14 & - & 34,45 & - & 18,33 & 34,10 & 45,35 \\
\hline
\end{tabular}

${ }^{141}$ C/D: subtarefas de corte e dobra; PM/MF: subterfas de pré-monatem e montagem final 
Tabela A 6 - (continuação) - Indicadores de produtividade (expressos em $\mathrm{Hh} /$ tonelada)

\begin{tabular}{|c|c|c|c|c|c|c|c|c|c|c|}
\hline \multirow{2}{*}{ OBRA } & \multirow{2}{*}{ Porção } & \multirow{2}{*}{$\begin{array}{l}\text { Tipo de } \\
\text { RUP }\end{array}$} & \multicolumn{2}{|c|}{ RUP PILAR } & \multicolumn{2}{|c|}{ RUP VIGA } & \multicolumn{2}{|c|}{ RUP LAJE } & \multicolumn{2}{|c|}{ GLOBAL } \\
\hline & & & $C / D^{142}$ & $P M / M F$ & $C / D$ & $P M / M F$ & $C / D$ & $P M / M F$ & sem $C / D$ & $\operatorname{com} C / D$ \\
\hline SP 303 & $15 \% /$ Tipo & Cic & - & - & - & 38,07 & - & 16,57 & 30,89 & 41,19 \\
\hline SP 303 & $16 \%$ Tipo & $\mathrm{cic}$ & - & 75,84 & - & 35,35 & - & 17,98 & 35,31 & 47,69 \\
\hline SP 303 & $17^{\circ} /$ Tipo & $\mathrm{cic}$ & - & & - & 31,73 & - & 17,27 & 29,46 & 41,65 \\
\hline SP 303 & $18 \%$ Tipo & $\mathrm{cic}$ & - & 31,72 & - & 32,63 & - & 17,98 & 23,97 & 36,62 \\
\hline \multirow{2}{*}{ OBRA } & \multirow{2}{*}{ Porção } & \multirow{2}{*}{$\begin{array}{l}\text { Tipo de } \\
\text { RUP }\end{array}$} & \multicolumn{2}{|c|}{ RUP PILAR } & \multicolumn{2}{|c|}{ RUP VIGA } & \multicolumn{2}{|c|}{ RUP LAJE } & \multicolumn{2}{|c|}{ SERVIÇO } \\
\hline & & & $C / D$ & $P M / M F$ & $C / D$ & $P M / M F$ & $C / D$ & $P M / M F$ & sem $C / D$ & $\operatorname{com} C / D$ \\
\hline SP 303 & \multirow{2}{*}{$\begin{array}{c}10 \text { ao } 15 \\
\text { (pilares) e }\end{array}$} & RUP cum & - & 67,57 & - & 33,64 & - & 17,90 & 31,56 & 42,76 \\
\hline SP 303 & & RUP pot & - & 67,36 & - & 31,73 & - & 16,92 & 29,46 & 40,77 \\
\hline SP 303 & \multirow{2}{*}{$\begin{array}{l}16 \text { ao } 17 \\
\text { (pilares) }\end{array}$} & RUP cum & - & 37,92 & - & - & - & - & - & - \\
\hline SP 303 & & RUP pot & - & 37,92 & - & - & - & - & - & - \\
\hline SP 304 A & 6\%/Tipo & $\mathrm{cic}$ & - & 61,6 & - & 60,7 & - & 19,1 & - & 52,3 \\
\hline SP 304 A & 7\%/Tipo & cic & - & 43,1 & - & 61,8 & - & 17,4 & - & 46,1 \\
\hline SP 304 A & $8^{\circ} /$ Tipo & $\mathrm{cic}$ & - & 44,3 & - & 53,2 & - & 16,3 & - & 43,3 \\
\hline SP 304 A & $9 \% /$ Tipo & $\mathrm{cic}$ & - & 44,3 & - & 57,2 & - & 19,9 & 35,3 & - \\
\hline SP 304 A & $10^{\circ} /$ Tipo & cic & - & 55,3 & - & 50,9 & - & 18,5 & 34,8 & - \\
\hline SP 304 A & $11 \% /$ Tipo & $\mathrm{cic}$ & - & 50,0 & - & 59,5 & - & 16,1 & 35,2 & - \\
\hline SP 304 A & $12 \% /$ Tipo & $\mathrm{cic}$ & - & 52,6 & - & 60,1 & - & 19,1 & 37,5 & - \\
\hline SP 304 A & $13 \% /$ Tipo & cic & - & 59,5 & - & 68,8 & - & 15,3 & 39,4 & - \\
\hline SP 304 A & $14 \%$ Tipo & cic & - & 69,1 & - & 59,0 & - & 16,3 & 40,1 & - \\
\hline SP 304 A & $15 \% /$ Tipo & cic & - & 53,2 & - & 60,1 & - & 16,3 & 36,2 & - \\
\hline SP 304 A & \multirow{2}{*}{$\begin{array}{c}7 \text { ao } 8 \\
\text { (pilares) }\end{array}$} & RUP cum & - & 43,7 & - & 59,1 & - & 17,4 & 37,0 & 47,2 \\
\hline SP 304 A & & RUP pot & - & 43,1 & - & 55,2 & - & 16,3 & 35,3 & 44,7 \\
\hline SP 304 A & & RUP pot s & - & 37,0 & - & 50,6 & - & 16,3 & 35,3 & 46,2 \\
\hline SP 304 A & \multirow{2}{*}{$\begin{array}{l}10 \text { ao } 15 \\
\text { (pilares) }\end{array}$} & RUP cum & - & 56,6 & - & - & - & - & - & - \\
\hline SP $304 \mathrm{~A}$ & & RUP pot & - & 52,6 & - & - & - & - & - & - \\
\hline SP 304 A & & RUP pot s & - & 49,1 & - & - & - & - & - & - \\
\hline SP 304 B & $12 \%$ Tipo & $\mathrm{cic}$ & - & 50,5 & - & 73,4 & - & 23,4 & 42,3 & - \\
\hline SP 304 B & $13 \%$ Tipo & $\mathrm{cic}$ & & 59,0 & & 86,1 & & 15,3 & 43,4 & - \\
\hline SP 304 B & $14 \%$ Tipo & $\mathrm{cic}$ & - & 51,0 & - & 73,4 & - & 19,6 & 40,5 & - \\
\hline SP 304 B & $15 \% /$ Tipo & $\mathrm{cic}$ & & 51,0 & & 72,8 & & 17,7 & 39,4 & - \\
\hline SP 304 B & $16 \% /$ Tipo & $\mathrm{cic}$ & - & 47,3 & - & 82,7 & - & 19,3 & 41,6 & - \\
\hline
\end{tabular}

${ }^{142}$ C/D: subtarefas de corte e dobra; PM/MF: subterfas de pré-monatem e montagem final 
Tabela A 6 - (continuação) - Indicadores de produtividade (expressos em $\mathrm{Hh} /$ tonelada)

\begin{tabular}{|c|c|c|c|c|c|c|c|c|c|c|}
\hline \multirow{2}{*}{ OBRA } & \multirow{2}{*}{ Porção } & \multirow{2}{*}{$\begin{array}{l}\text { Tipo de } \\
\text { RUP }\end{array}$} & \multicolumn{2}{|c|}{ RUP PILAR } & \multicolumn{2}{|c|}{ RUP VIGA } & \multicolumn{2}{|c|}{ RUP LAJE } & \multicolumn{2}{|c|}{ GLOBAL } \\
\hline & & & $C / D^{143}$ & $P M / M F$ & $C / D$ & $P M / M F$ & $C / D$ & $P M / M F$ & sem $C / D$ & com $C / D$ \\
\hline SP 304 B & $17^{\circ} /$ Tipo & $\mathrm{cic}$ & & 54,8 & & 87,3 & & 22,3 & 46,1 & - \\
\hline SP 304 B & $18 \%$ Tipo & $\mathrm{cic}$ & - & 55,8 & - & 67,1 & - & 17,7 & 39,3 & - \\
\hline SP 304 B & $19 \% /$ Tipo & $\mathrm{cic}$ & & 52,6 & & 64,7 & & 16,6 & 37,3 & - \\
\hline SP 304 B & $20 \% /$ Tipo & $\mathrm{cic}$ & - & 79,2 & - & 77,5 & - & 23,1 & 48,0 & - \\
\hline SP 304 B & $21 \% /$ Tipo & cic & & 76,2 & & 63,6 & & 15,0 & 39,4 & - \\
\hline SP 304 B & \multirow{2}{*}{$\begin{array}{l}12 \text { ao } 19 \\
\text { (pilares) }\end{array}$} & RUP cum & - & 52,8 & - & 74,9 & - & 19,0 & 41,7 & - \\
\hline SP 304 B & & RUP pot & - & 51,6 & - & 69,9 & - & 16,6 & 39,4 & - \\
\hline SP 304 B & & RUP pot s & - & 50,0 & - & 63,0 & - & 16,6 & 39,4 & - \\
\hline SP 304 B & 20 ao 21 & RUP cum & - & 77,7 & - & - & - & - & - & - \\
\hline SP 304 B & (pilares) & RUP pot & - & 76,2 & - & - & - & - & - & - \\
\hline SP 304 B & & RUP pot s & - & 74,6 & - & - & - & - & - & - \\
\hline \multirow{2}{*}{ OBRA } & \multirow{2}{*}{ Porção } & \multirow{2}{*}{$\begin{array}{l}\text { Tipo de } \\
\text { RUP }\end{array}$} & \multicolumn{2}{|c|}{ RUP PILAR } & \multicolumn{2}{|c|}{ RUP VIGA } & \multicolumn{2}{|c|}{ RUP LAJE } & \multicolumn{2}{|c|}{ SERVIÇO } \\
\hline & & & $C / D$ & $P M / M F$ & $C / D$ & $P M / M F$ & $C / D$ & $P M / M F$ & sem $C / D$ & $\operatorname{com} C / D$ \\
\hline SP 305 & $19 \% /$ Tipo & $\mathrm{Cic}$ & - & - & - & 86,2 & - & 33,3 & 52,6 & 62,0 \\
\hline SP 305 & $20 \% /$ Tipo & $\mathrm{cic}$ & - & \multirow{2}{*}{56,0} & - & 95,1 & - & 32,4 & 47,0 & 59,4 \\
\hline SP 305 & $21 \% /$ Tipo & cic & - & & - & 71,3 & - & 20,9 & 35,1 & 55,1 \\
\hline SP 305 & $22 \% /$ Tipo & cic & - & \multirow{2}{*}{27,8} & - & 68,3 & - & 24,4 & 28,9 & 38,5 \\
\hline SP 305 & $23 \% /$ Tipo & $\mathrm{cic}$ & - & & - & 47,5 & - & 35,0 & 31,9 & 47,7 \\
\hline SP 305 & $24 \%$ Tipo & cic & - & \multirow{2}{*}{45,2} & - & 38,6 & - & 43,9 & 41,8 & 57,5 \\
\hline SP 305 & $25 \% /$ Tipo & $\mathrm{cic}$ & - & & - & 35,7 & - & 44,8 & 47,9 & 66,2 \\
\hline SP 305 & \multirow{2}{*}{ Todos } & RUP cum & - & - & - & 63,2 & - & 33,5 & 37,7 & 51,6 \\
\hline SP 305 & & RUP pot & - & - & - & 47,5 & - & 28,4 & 33,5 & 53,5 \\
\hline SP 305 & & RUP pot $s$ & - & - & - & 43,1 & - & 28,4 & 33,5 & 43,1 \\
\hline SP 306 & $24 \%$ Tipo & cic & - & 43,6 & - & 34,6 & - & 22,2 & 35,8 & 43,8 \\
\hline SP 307 & 9\%/Tipo & cic & - & 43,84 & - & 48,55 & - & 44,52 & 45,61 & 62,97 \\
\hline SP 307 & 10\%/Tipo & cic & - & 70,09 & - & 25,17 & - & 39,62 & 47,20 & 68,23 \\
\hline SP 307 & $11 \% /$ Tipo & cic & - & 26,25 & - & 33,80 & - & 44,52 & 33,38 & 47,81 \\
\hline SP 307 & $12 \% /$ Tipo & $\mathrm{cic}$ & - & 28,04 & - & 19,06 & - & 28,86 & 24,78 & 39,90 \\
\hline SP 307 & $13 \% /$ Tipo & cic & - & 25,89 & - & 32,01 & - & 37,67 & 31,64 & 49,84 \\
\hline SP 307 & $14 \%$ Tipo & $\mathrm{cic}$ & - & 28,48 & - & 15,10 & - & 46,47 & 28,42 & 46,06 \\
\hline SP 307 & $15 \% /$ Tipo & $\mathrm{cic}$ & - & 64,29 & - & 24,09 & - & 38,16 & 41,16 & 61,32 \\
\hline
\end{tabular}

${ }^{143}$ C/D: subtarefas de corte e dobra; PM/MF: subterfas de pré-monatem e montagem final 
Tabela A 6 - (conclusão) - Indicadores de produtividade (expressos em Hh/tonelada)

\begin{tabular}{|c|c|c|c|c|c|c|c|c|c|c|}
\hline \multirow{2}{*}{ OBRA } & \multirow{2}{*}{ Porção } & \multirow{2}{*}{$\begin{array}{l}\text { Tipo de } \\
\text { RUP }\end{array}$} & \multicolumn{2}{|c|}{ RUP PILAR } & \multicolumn{2}{|c|}{ RUP VIGA } & \multicolumn{2}{|c|}{ RUP LAJE } & \multicolumn{2}{|c|}{ GLOBAL } \\
\hline & & & $C / D^{144}$ & $P M / M F$ & $C / D$ & $P M / M F$ & $C / D$ & $P M / M F$ & sem $C / D$ & $\operatorname{com} C / D$ \\
\hline SP 307 & $9^{\circ}$ ao $11^{\circ}$ & RUP cum & - & 46,72 & - & 28,26 & - & 39,97 & 36,38 & 54,08 \\
\hline SP 307 & (pilares) & RUP pot & - & 35,04 & - & 21,58 & - & 37,91 & 30,03 & 46,27 \\
\hline SP 308 & $12^{\circ}$ ao & RUP cum & - & 36,67 & - & - & - & - & - & - \\
\hline 309 & (pilares) & RUP pot & - & 28,04 & - & - & - & - & - & - \\
\hline
\end{tabular}

${ }^{144}$ C/D: subtarefas de corte e dobra; PM/MF: subterfas de pré-monatem e montagem final 


\section{Referências Bibliográficas}

AMERICAN CONCRETE INSTITUTE. Details of Concrete Reinforcement - ACI 31592. ACI detailing manual-1994 / ACI Committee 315, Details of Concrete Reinforcement. 1994. 244 p.

.ACI 318-92. ACI. Building code requirements for reinforced concrete. American Concrete Institute, c1994. 347 p.

.Áreas de vivência em canteiros de obras - NB-1367. Rio de Janeiro, 1991.

.Barras e fios de aço destinados a armaduras de concreto armado Especificações - NBR 7480. Rio de Janeiro, 1996.

.Determinação do coeficiente de conformação superficial de barras e fios de aço destinados a armaduras de concreto armado - Método de ensaio - NBR 7477. Rio de Janeiro, 1982.

.Execução de estrutura de concreto - Procedimento - NBR 14931:2003. Rio de Janeiro, 2004.

.Projeto de estrutura de concreto - Procedimento - NBR 6118:2003. Rio de Janeiro, 2003.

.Tela de aço soldada - Armadura de concreto - Especificações - NBR 7481. Rio de Janeiro, 1990.

ABDEL-RAZEK, R.; MCAFFER, R. A Change in the UK Construction Industry Structure: implications for estimating. Construction management and economics. v. 5, p.227242, 1987.

AGOPYAN, V. et al. Alternativas para a redução do desperdício de materiais nos canteiros de obras: introdução. São Paulo, PCC/EPUSP, 1998 (Relatório Final: v.1. Departamento de Engenharia de Construção Civil - PCC-EPUSP).

AHLSTRÖM, P.; KARLSSON, C. Change processes towards lean production. International Journal of Operations and Production Management. v. 16, n.11, p. 42-56, 1996.

ALARCON. L.A.; DIETHELMAND, S.; ROJO, O. Collaborative implementation of lean planning systems in Chilean construction companies. In: ANNUAL CONFERENCE ON LEAN CONSTRUCTION, 10, Gramado. 2002. Proceedings. Porto Alegre: UFRGS, 2002. CDROM.

ALLMON, E. et al. Construction labor productivity trends, 1970-1998. Journal of Construction Engineering and Management. v. 126, n. 2, p. 97-104, 2000

AMARAL, N. A. Construções de concreto. São Paulo: EPUSP, 1964.

AMERICAN CONCRETE INSTITUTE. Details of Concrete Reinforcement - ACI 31592. ACI detailing manual-1994 / ACI Committee 315, Details of Concrete Reinforcement. 1994. 244 p.

AMORIM, S. R. L. O sistema de indicadores de qualidade e produtividade do clube da construção do Rio de Janeiro: novas ferramentas para a gerência do canteiro. In: ENCONTRO NACIONAL DE TECNOLOGIA DO AMBIENTE CONSTRUÍDO: QUALIDADE NO PROCESSO CONSTRUÍDO, Florianópolis, 1998. Anais. Santa Catarina: NPC/ECV/CTC/UFSC, 1998. p.723-29. 
ANDERSON, S. D., FISHER, D. J.; RAHMAN, S. P. Constructability issues for highway projects. Journal of Management Engineering. v. 15, p. 60-68, 1999.

ANDRADE, A.C. Método para quantificação das perdas de materiais em obras de construção de edifícios: superestrutura e alvenaria. 1999. 235p. Dissertação (Mestrado) - Escola Politécnica, Universidade de São Paulo. São Paulo, 1999.

ARAÚJO, L.O.C. Método para a previsão e controle da produtividade da mão-deobra na execução de fôrmas, armação, concretagem e alvenaria. 2000. 385p. Dissertação (Mestrado) - Escola Politécnica, Universidade de São Paulo. São Paulo, 2000. ARAÚJO, L.O.C.; RIBEIRO, M.H.; SOUZA, U.E.L. A padronização do projeto de detalhamento das armaduras como facilitadora da produção. In: CONFERÊNCIA LATINO AMERICANA DE CONSTRUÇÃO SUSTENTÁVEL, I, São Paulo, 2004. Anais. São Paulo: EPUSP, 2004. CD-ROM.

ARAUJO, L.O.C.; SOUZA, U.E.L. Gestão do serviço de armação: a organização do trabalho para a produção. In: SIMPÓSIO BRASILIERO DE GESTÃO E ECONOMIA DA CONSTRUÇÃO, III, São Carlos, 2003. Anais. São Carlos: UFSCar, 2003. CD-ROM

ARDITI et al. Constructability Analysis in the Design Firm. Journal of Construction Engineering and Management. v. 128, n. 2, p. 117-126, 2002

ARDITI, D. Construction productivity improvement. Journal of Construction Engineering and Management. v. 111, n. 1, p. 1-14, 1985

ARGYRIS, C. A. Integração indivíduo-organização. São Paulo: Atlas, 1975.

ARGYRIS, C. Interpersonal competence and organizational effectiveness. Homewood: Dorsey, Richard D. Irwin, 1962.

AMERICAN SOCIETY OF CIVIL ENGINEERS - ASCE. Construction Management Committee of the Construction Division. Constructability and constructability programs: white paper. Journal of Construction Engineering and Management. v. 117, n. 1, p. 67-89, 1991.

ASHFORD, J. L. The Management of quality in construction. London: E \& FN SPON, 1992.

ASSAHI, P. N. Qualidade e produtividade na construção civil: fôrma para estrutura de concreto armado. São Paulo: EPUSP/ITQC. 2002

ASSAHI, P. N. Sistema de produção de fôrmas. São Paulo, 2004. (Notas de aula. MBATGP/USP, 2004)

ASSOCIAÇÃO BRASILEIRA DE CIMENTO PORTLAND - ABCP. Manual de estruturas de concreto armado. São Paulo: ABCP. Versão preliminar. 2002

ASSOCIAÇÃO BRASILEIRA DE NORMAS TÉCNICAS. Execução de desenhos para obras de concreto simples ou armado - Procedimento - NBR-7191 (NB16). Rio de Janeiro, 1992.

ASSUMPÇÃO, J.F.P. Gerenciamento de empreendimentos na construção civil: modelo para planejamento estratégico da produção de edifícios. 1996. 206p. Tese (Doutorado) - Escola Politécnica, Universidade de São Paulo. São Paulo, 1996.

BALLARD, G. The last planner system of production control. PhD thesis. School of Civil Engineering, University of Birmingham, UK, 2000.

BALLARD, G.; HOWELL, G. Implementing lean construction: stabilizing work flow. In: ANNUAL CONFERENCE OF THE INTERNATIONAL GROUP FOR LEAN CONSTRUCTION, II, Santiago, 1994. Proceedings. Chile: Pontificia Universidad Catolica de Chile, 1994. 
BALLARD, G.; HOWELL, G. Shielding production: an essential step in production control. Journal of Construction Engineering and Management. V. 124, n. 1. p. 11-17, 1998.

BALLARD, G.; HOWELL, G. Towards construction JIT. In: ANNUAL ARCOM CONFERENCE, 11, Reading, 1995. Proceedings. United Kingdom: University of York, 1995. p. 338-346

BARKER, R.C. The design of lean manufacturing systems using time-based analysis. International Journal of Operations and Production Management. v. 14, n. 11, p. 86-96, 1994.

BARLOW, $\mathrm{H}$. The placing and management of contracts for building and civil engineering work. London: HMSO, 1964.

BARNARD, C. I. Funções do executivo. São Paulo: Atlas, 1971. p. 286.

BARROS, M.M.S.B. Metodologia para implantação de tecnologias construtivas racionalizadas na produção de edifícios. 1996. 422p. Tese (Doutorado) - Escola Politécnica, Universidade de São Paulo. São Paulo, 1996.

BATLOUNI NETO, J. Projeto de estruturas de concreto armado: diretrizes para otimização do desempenho e do custo do edifício. 2000. 166p. Dissertação (Mestrado) Instituto de Pesquisas Tecnológicas do Estado de São Paulo, 2003.

BEARDSWORTH, A. D. et al. Management, Transience and Subcontracting: the case of the construction site. Journal of Management Studies, ASCE, New York, v.25, n.6, p.603-625, 1988.

BELGO ARCELOR (a). Belgo 50 e Belgo 60. Artigo Técnico. Disponível em: <http://belgo.com.br>. Acesso em: 30 out. 2003.

BELGO ARCELOR (b). Alterações da norma brasileira NBR 7480. Artigo Técnico. Disponível em: <http://belgo.com.br>. Acesso em: 30 out. 2003.

BELGO ARCELOR (c). Dobramento de aço para a construção civil. Artigo Técnico. Disponível em: <http://belgo.com.br>. Acesso em: 30 out. 2003.

Bergamini, C. W. Motivação. São Paulo: Atlas, 1991.

BERNARDES, M.M.S. Desenvolvimento de um modelo de planejamento e controle da produção para micro e pequenas empresas de construção. 2001. Tese (Doutorado). Universidade Federal do Rio Grande do Sul. Porto Alegre, 2001.

BERNOLD, L. E.; ABRAHAM, D. M.; LIVINGSTON, E. E. Emulation for control system analysis in automated construction. Journal of Computing in Civil Engineering. ASCE, v. 3, n. 4, p. 320-332, 1989.

BERNOLD, L. E.; SALIM, M. Placement-oriented design and delivery of concrete reinforcement. Journal of Construction Engineering and Management. ASCE, $v$. 119, n.2, p. 323-335, 1993.

BOWEN, P. Skills for construction: the current situation in Britain. Worshop on skills and the construction labor process in Europe, University of Westminster, London. 1996.

BRADBURN, J. Can architects return to the construction site partnering? Partnering in Design and Construction. New York: McGraw-Hill, 1995.

BRANCO, F. C. Remédio amargo: estudo demonstra que juro alto retrai PIB. Folha de São Paulo. São Paulo, maio de 2004.

BRANDLI, L. L. A estratégia de subcontratação e as relações organizacionais na construção civil de Florianópolis. 1998. 147p. Dissertação (Mestrado) - 
Departamento de Engenharia Civil, Universidade Federal de Santa Catarina. Florianópolis, 1998.

BRISCOE, G. Skill shortages in the construction sector. International Journal of Manpower. v. 11, n. 2/3, p. 23-28, 1990.

BUREAU OF LABOR STATISTICS - BLS. Standard Occupational Classification. Disponível em: <http://www.bls.gov/soc/soc_s2ro.htm> Acesso em: 20 Mar. 2004.

CALVERT, R. E.; COLES, D. C. H.; BAILEY, G. J. Introduction to building management. 6 ed. London: Butterworth-Heinemann, 1995.

CAMPOS, V.F. O valor dos recursos humanos na era do conhecimento. Belo Horizonte: Fundação Christiano Ottoni, 1995

CARDOSO, F. F. Competitividade na construção civil: o papel dos subempreiteiros. São Paulo: EPUSP, 1998. (Projeto de Pesquisa CNPQ)

CARDOSO, F. F. Desenvolvimento de Novas Formas de Gestão da Produção. In: SEMINÁRIO INTERNACIONAL DE GESTÃO E TECNOLOGIA NA PRODUÇÃO DE EDIFÍCIOS. São Paulo, 1997. Anais. São Paulo, EPUSP, 1997b.

CARDOSO, F. F. Estratégias empresariais e novas formas de racionalização da produção no setor de edificações no Brasil e na França. Estudos Econômicos da Construção, São Paulo, v. 1, n.2, p.97-156, 1996a

CARDOSO, F. F. Estratégias empresariais e novas formas de racionalização da produção no setor de edificações no Brasil e na França. Estudos Econômicos da Construção, São Paulo, v.2, n.3, pt. 2, p.119-160, 1997a.

CARDOSO, F. F. Importância dos Estudos de Preparação e da Logística na Organização dos Sistemas de Produção de Edifícios: alguns aprendizados a partir da experiência francesa. In: SEMINÁRIO INTERNACIONAL LEAN CONSTRUCTION, 1, São Paulo, 1996. Anais. São Paulo: Instituto de Engenharia, 1996b.

CARDOSO, F.F. Gestão da produção na construção civil. In: SIMPOSIO DE PESQUISA DA ESCOLA POLITECNICA DA USP, São Paulo, 1997. São Paulo : EPUSP, 1997. p.499-501.

CARDOSO, F.F. Novos enfoques sobre a gestão da produção: como melhorar o desempenho das empresas de construção civil. In: ENCONTRO NACIONAL DE TECNOLOGIA DO AMBIENTE CONSTRUÍDO. São Paulo, 1993. Anais. São Paulo: EPUSP/ANTAC, 1993. v.2, p. 557 - 569.

CARRARO, F. Produtividade da mão-de-obra no serviço de alvenaria. São Paulo, 1998. 226p. Dissertação (Mestrado) - Escola Politécnica, Universidade de São Paulo. São Paulo, 1998.

CHIAVEnATO, I. Recursos Humanos. São Paulo: 2002.

CHIN, C.S. Integrated IT enabled workflow improvement in rebar fabrication and fixing. California, 2003. Tese em desenvolvimento (Doutorado). University of California at Berkeley, 2003

CHRISTIAN, J.; HACHEY, D. Effects of delay times on production rates in construction. Journal of Construction Engineering and Management. V. 121, n. 20, p. 20-26, $1995^{\prime}$.

CONCRETE REINFORCING STEEL INSTITUTE - CRSI. Efficient and economical rebar details - part 1. Engineering Data Report, n. 35, 1990. 
CONCRETE REINFORCING STEEL INSTITUTE - CRSI. Manual of standard practice for detailing reinforced concrete structures (ACI 315-74): adopted as a standard of the American Concrete Institute. 1974. 167 p.

CONCRETE REINFORCING STEEL INSTITUTE - CRSI. Manual of standard practice. Concrete Reinforcing Steel Institute, Schaumburg, III. 25th Ed, 1990.

CONCRETE REINFORCING STEEL INSTITUTE - CRSI. Rebar detailing placing drawings and approvals. Engineering data report, n. 38, 1993.

CONCRETE REINFORCING STEEL INSTITUTE - CRSI. Steel Reinforcing Bars: recycled. Special Reporter. Schaumburg, III. 2002

CONCRETE REINFORCING STEEL INSTITUTE - CRSI. The 1992 CRSI shop production statistics survey. Annual Reporter. Schaumburg, III. 1992

CONFEDERAÇÃO NACIONAL DA INDÚSTRIA - CNI. Coleção básica Senai. São Paulo: Senai. 1 ed. 1980.

CONSIDERA, C.M . Perdas e danos dos cartéis. Jornal Folha de São Paulo, 31 maio 2002.

CONSTRUCTING EXCELLENCE. Disponível em <http//: www.constructing excellence.com> Acesso em: 1 Apr. 2004.

CONSTRUCTION INDUSTRY INSTITUTE - CII. Constructability: a primer. Publication 3-1, Austin, Texas, 1986.

CONSTRUCTION INDUSTRY INSTITUTE - CII. Guidelines for implementing a constructability program. Publication 3-2, Austin, Texas, 1987.

CONSTRUCTION INDUSTRY INSTITUTE - CII. Preview of constructability implementation. Publication 34-2, Austin, Texas, 1993.

CONTADOR, J. C (a). Produtividade fabril II: método para rápido aumento da produtividade fabril. Gestão \& Produção, v.2, n.1, p.25-37, 1995.

CONTADOR, J. C. Produtividade fabril I: método para rápido aumento da produtividade fabril. Gestão \& Produção, v.1, n.3, p.217-38, 1994.

CONTADOR, J. C. (b) Produtividade fabril III: método para rápido aumento da produtividade fabril. Gestão \& Produção, v.2, n.2, p. 134-151, 1995.

COOMBS, W. E.; PALMER, W. J. Construction accounting and financial management. 4 ed., New York: McGraw-Hill, 1989.

CORREA, H. L. Flexibilidade nos sistemas de produção. Revista de Administração de Empresas, v. 33, n. 3, maio/jun. 1993.

CORREA, H.; GIANESI, I.G.N.; CAON, M. Planejamento, programação e controle da produção. 4 ed. São Paulo: Atlas, 2001.

COUTINHO. L. Agenda de política industrial para a cadeia produtiva da construção. In: SEMINÁRIO DA INDÚSTRIA BRASILEIRA DA CONSTRUÇÃO, 5, São Paulo, 2003. Anais. São Paulo: LCA Consultores, 2003.

CUSUMANO, Michael A. The Limits of "Lean". Sloan Management Review, p. 27- 32, 1994.

DEMING, W. E. Out of crisis. Cambridge, MA: MIT Center, 1986.

DEMING, W. E. Quality, Productivity and Competitive Position. Cambridge, MA: MIT Center, 1982. 
DUNSTON, P. S. Control structures for the automated bending of steel reinforcing bars. 1994. Dissertação (Mestrado) - North Carolina State University, Raleigh, N.C, 1994.

DUNSTON, P. S.; BERNOLD, L. E. Intelligent control for robotic rebar bending. In: WATSON, X. G.; TUCKER, R. L. WALTERS, J. K. (Ed.) Automation and robotics in construction. New York: Elsevier, 1993. 101- 108.

DUNSTON, P. S.; BERNOLD, L. E. Adaptive control for robotic rebar bending. Microcomputers in Civil Engineering. Oxford, England, 9, 53-60. 1994a.

DUNSTON, P. S.; BERNOLD, L. E. Real-time control for a robotic rebar bender. In: DEMSETZ, L. A; KLARER, P. R. (Ed.). Robotics for challenging environments. New York: ASCE, 1994b. p. 392-400.

DUNSTON, P. S.; RANJITHAN, S.; BERNOLD, L. E. Neural network model for automated control of springback in rebars. Intelligent System and their Applications. V. $11, \mathrm{n}$. 4, p. 45-49, 1996.

DUNSTON, P.S.; BERNOLD, L.E. Adaptive control for safe and quality rebar fabrication. Journal of Construction Engineering and Management. v. 126, n. 2, p. 122-129, 2000.

DUTRA, J. S. Administração de carreiras: uma proposta para repensar a gestao de pessoas. 1993. Tese (Doutorado) - Faculdade de Administração, Universidade de São Paulo. São Paulo, 1993.

DUTRA, J. S. Gestão de pessoas: modelos, processos, tendências e perspectivas. São Paulo. Atlas, 2002

ECCLES, Robert G. The quasi-firm in the construction industry. Journal of Economic Behavior and Organization. EUA, North-Holland, p. 335-357, 1981.

EGAN, SIR J. Construction task force. Rethinking construction. London: Department of the Environment, Transport and Regions. 1998. (report).

FABRÍCIO, M.M.; MELHADO, S.B. A importância do estabelecimento de parcerias construtora/projetistas para a qualidade na construção de edifícios. In: ENCONTRO NACIONAL DE TECNOLOGIA DO AMBIENTE CONSTRUÍDO, 7. Florianópolis, 1998. Anais. Florianópolis: ANTAC/UFSC, 1998. v.2, p. 453-459.

FABRÍCIO, M.M.; MELHADO, S.B. O papel do projeto para produção na construção de edifícios. In: ARQUITETURA E URBANISMO: TECNOLOGIAS PARA O SÉCULO XXI. São Paulo, 1998. Anais. São Paulo: NUTAU-FAU/USP, 1998(b).

FARAH, M. F. S. Processo de trabalho na construção habitacional: tradição e mudança. São Paulo, Annablume, 1996.

FARAH, M. F. S. Tecnologia, processo de trabalho e construção habitacional. 1992. 296p. Tese (Doutorado) - Faculdade de Filosofia, Letras e Ciências Humanas, Universidade de São Paulo. São Paulo, 1992.

FARAH, M.F.S. Estratégias empresariais e mudanças no processo de trabalho na construção habitacional no Brasil. In: ENCONTRO NACIONAL TECNOLOGIA DO AMBIENTE CONSTRUÍDO. São Paulo, 1993. Anais. São Paulo: EPUSP/ANTAC, 1993. p. 581-590.

FAYOL, H. Administração industrial e geral. São Paulo: Atlas: 1972. 
FIALLO, M.; REVELO, V. Applying the last planner control system to a construction project: a case study in Quito, Ecuador. In: ANNUAL CONFERENCE ON LEAN CONSTRUCTION, 10, Gramado, 2002. Proceedings. Porto Alegre: UFRGS, 2002.

FISCHER, M. Constructability Input to Preliminary Design of Reinforced Concrete Structures. Technical Report, n. 64, Center for Integrated Facility Engineering, Stanford, 1991.

FISCHER, M.; TATUM, C. B. Characteristics of design-relevant constructability knowledge. Journal of Construction Engineering and Management. v. 123, n. 3, p. 253- 260, 1997.

FLEURY, A. C. C. Qualidade e produtividade na estratégia competitiva das empresas indústrias brasileiras. In: WORKSHOP: GESTÃO PARTICIPATIVA PARA QUALIDADE \& PRODUTIVIDADE. São Paulo, 1993. Anais. São Paulo: EPUSP, 1993.

FLEURY, A. C. C. Administrando na economia baseada em conhecimento: a contribuição das empresas japonesas às indústrias brasileira e mexicana. Texas: BALAS/University of Texas, 1998. v. 2, p. 561-568.

FLEURY, A. C. C. Aprendizagem e inovação organizacional as experiências: de Japão, Coréia e Brasil. São Paulo: Atlas, 1995. 237p.

FLEURY, A. C. C. Gerenciamento do desenvolvimento de produtos na economia globalizada. Belo Horizonte: UFMG, 1999.

FLEURY, A. C. C; FLEURY, M. T. L. Aprendizagem e inovação organizacional. São Paulo: Atlas, 1995.

FLEURY, A.C. Organização do trabalho: uma abordagem interdisciplinar: sete estudos sobre a realidade brasileira. Coordenação de Afonso Carlos Corrêa Fleury e Nilton Vargas. São Paulo: Atlas, 1983.

FLEURY, M.T. O ambiente para a aprendizagem organizacional. In: CASALI, A. et al. (Orgs). Empregabilidade e organização. São Paulo: Educ Rodhia, 1997.

FLIPPO, E.B. Princípios de administração de pessoal. São Paulo: Atlas, 1980.

FORMOSO et al. Termo de referencia para o processo de planejamento e controle da produção em empresas construtoras. São Paulo: SINDUSCON/SP, 1999.

FORMOSO, C. T. et al. Desenvolvimento de um modelo para a gestão da qualidade e produtividade em empresas de construção civil de pequeno porte. In: SEMINÁRIO DE QUALIDADE NA CONSTRUÇÃO CIVIL, 2, Porto Alegre, 1993. Anais. Porto Alegre: UFRGS, 1993. p. 55-95.

FORMOSO, C.T et al. As perdas na construção civil: conceitos, classificação e seu papel na melhoria do setor. Texto apresentado na mesa redonda sobre perdas na construção civil. São Paulo: Sinduscon-SP, 1996.

FRANÇA, R.L.S. A influência do projeto arquitetônico e da possibilidade de investimentos de horas de projeto no custo das estruturas. In: SEMINÁRIO DE TECNOLOGIA DE ESTRUTURAS: PROJETO E PRODUÇÃO COM FOCO NA RACIONALIZAÇÃO E QUALIDADE, 6. Material distribuído. São Paulo: Sinduscon-SP, 2004.

FRANÇA, R.L.S. Projeto de estruturas: influência na construtibilidade, no desempenho e nos custos. In: SEMINÁRIO DE TECNOLOGIA DE ESTRUTURAS: PROJETO E PRODUÇÃO COM FOCO NA RACIONALIZAÇÃO E QUALIDADE, 4, São paulo, 2002. Material distribuído. São Paulo: Sinduscon-SP, 2002. 
FRANCO, C. Padronização das armaduras: um salto para a produtividade. In: SEMINÁRIO DE TECNOLOGIA DE ESTRUTURAS: PROJETO E PRODUÇÃO COM FOCO NA RACIONALIZAÇÃO E QUALIDADE, 2. Material distribuído. São Paulo: Sinduscon-SP, 2000.

FREIRE, T.M. Produção de estruturas de concreto armado, moldadas in loco, para edificações: caracterização das principais tecnologias e formas de gestão adotadas em São Paulo. 2001. 325p. Dissertação (Mestrado) - Escola Politécnica, Universidade de São Paulo. São Paulo, 2001.

FURUSAKA, S. Construction contracting/subcontracting systems in Japan. In: EUROPEAN SYMPOSIUM ON MANAGEMENT, QUALITY AND ECONOMICS IN HOUSING AND OTHER BUILDING SECTORS. Lisbon, 1991. Management, quality and economics in building: transactions. London, Spon, 1991. p. 443-52.

FUSCO, P. B. Estrutura de concreto. São Paulo: Grêmio Politécnico, 1975.

FUSCO, P. B. Técnica de armar as estruturas de concreto. São Paulo: Pini, 1995. $382 \mathrm{p}$.

GIAMMUSSO, S. E. Orçamento e Custos na Construção Civil. 2 ed. São Paulo: Pini, 1991.

GILBRETH, F. B. Motion study: a method for increasing the efficiency of the workman. New York: D. Van Nostrand Company, 1911.

GOODRUM, P. M; HAAS, C.T. Long-Term Impact of Equipment Technology Productivity in the U.S. Journal of Construction Engineering and Management. v. 130, n. 1, p.124-133, 2004.

GOULDNER, A. W. The norm of reciprocity. American Sociological review. N. 25, p. 161$178,1960$.

GRAY, C. Intelligent construction time and cost analysis. Construction management and economics. v. 4, n. 2, p. 135-150, 1986.

GRAZIANO, F. P. Parâmetros para interface entre estruturas e os demais subsistemas. In: SEMINÁRIO DE TECNOLOGIA DE ESTRUTURAS: PROJETO E PRODUÇÃO COM FOCO NA RACIONALIZAÇÃO E QUALIDADE, 4. Material distribuído. São Paulo: Sinduscon-SP, 2002.

GRAZIANO, F. P. Sistemas construtivos: decisões, escolhas e relações com o desempenho técnico e econômico. In: SEMINÁRIO DE TECNOLOGIA DE ESTRUTURAS: PROJETO E PRODUÇÃO COM FOCO NA RACIONALIZAÇÃO E QUALIDADE, 5, São Paulo, 2003. Material distribuído. São Paulo: Sinduscon-SP, 2003.

GRIFFITH, A. Buildability: the effect of design and management on construction. In: Advancing Building Technology, 10. Anais. Gaithersburg (EEUU), CIB/NBS, 1986,. v.8, p. 3504-3512.

GRILO, L. M. Gestão do processo de projeto no segmento de construção de edifícios por encomenda. 2002. 375p. Dissertação (Mestrado) - Escola Politécnica, Universidade de São Paulo. São Paulo, 2002.

GUGEL, J. G.; RUSSELL, J. S. Model for constructability approach selection. Journal of Construction Engineering and Management. v. 120, n. 3, 509-521, 1994.

HACKMAN, R.; LAWLER, E. E. Behavior in organizations. London: McGraw-Hill, 1975

HANDA, V. K.; RIVERS, D. Downgrading Construction Incidences. Journal of Construction Engineering and Management. v. 109, n. 2, p. 190-205, 1983. 
HANLON, E. J.; SANVIDO, V. E. Constructability information classification scheme. Journal of Construction Engineering and Management. v. 121, n. 4, p. 337-345, 1995.

HARRISON, A. Manufacturing strategy and the concept of world class manufacturing. International Journal of Operations and Production Management. v. 18, n. 4, p. 397-408, 1998.

HAUSSLER, W.; NIEDER, N. Reinforcement Tehnology. Report n. 1, 2004. Disponível em: <http://www.bamtec.com> Acesso em: 12 Mar. 2004.

HAYES, R.; JAIKUMAR. Manufacturing Crisis: New Technologies, Old Organizations. Harvard Business Review, Sep/Oct, 1988.

HELENE, P e BATLOUNI, J. Récord en concreto de alto desempeño. Revista Noticreto. n. 65, p. 22-29, oct./dec., 2002.

HERBST, P. G. Autonomus groups functioning: exploration in behavior and theory measurement. Londo: Tavistock Publications, 1974

HERZBERG, F. Work and nature of man. Cleveland: World, 1966.

HILLEBRANDT, P. Management of the Building firm. In: INTERNATIONAL SYNPOSIUM ON BUILDING ECONOMICS AND CONSTRUCTION MANAGEMENT. Sydney, 1990. Anais. Sydney: CIB, 1990. p.1-10.

HINZE, J.; TRACEY, A. The Contractor-Subcontractor Relationship: the subcontractor's view. Journal of Construction Engineering and Management. v. 120, n. 2, 1994.

HOPP, J.C.; LEITE, H. P. Onde nascem os prejuízos. Revista de Administração de Empresas. São Paulo, v.30, n. 4, 1990.

HORMAN, M. J. Process dynamics: buffer management in building project operations. PhD Thesis, The University of Melbourne, Australia, 2000.

HORMAN, M. J.; KENLEY, R. Process dynamics: identifying a strategy for the deployment of buffers in building projects. International Journal of Logistics: Research and Applications. v. 1, n. 3, p. 221-237, 1998.

HORNER, R. M. W.; TALHOUNI, B. T. Effects of Accelerated Working, Delays and Disruption on Labour Productivity. London: The Chartered Institute of Building, 1993. 40p.

HOWELL, G.; BALLARD, G. Implementing lean construction: reducing inflow variation. In: ANNUAL CONFERENCE OF THE INTERNATIONAL GROUP FOR LEAN CONSTRUCTION, 2. Santiago, 1994. Proceedings. Chile: Pontificia Universidad Catolica de Chile, 1994.

HOWELL, G.; LAUFER, A.; BALLARD, G. Interaction between subcycles: one key to improved methods. Journal of Construction Engineering and Management. v. 119, n. 4, p. 714-728, 1993.

INSTITUTO BRASILEIRO DE SIDERURGIA - IBS. Perfil da siderurgia brasileira. São Paulo: IBS, 2002.

INSTITUTO BRASILEIRO DE SIDERURGIA - IBS. Siderurgia brasileira: princípios e políticas. São Paulo: IBS, 2001.

INSTITUTO BRASILEIRO DE TELAS SOLDADAS - IBTS. Disponível em: <http://www.ibts.com> Acesso em: 14 abr. 2004. 
IRELAND, $\mathrm{V}$. The role of managerial actions in the cost, time and quality performance of high-rise commercial building projects. Construction management and economics. v. 3, n. 1, p. 59-87, 1985.

ISATTO, E. L. As Relações entre empresas construtoras de edificações e seus fornecedores de materiais. 1996. Dissertação (Mestrado) - Escola de Engenharia, Universidade Federal do Rio Grande do Sul. Porto Alegre, 1996.

JAQUES, E. Requisite organization. Arlington: Cason Hall, 1988.

KALE, S; ARDITI, D. General contractor's relationships with subcontractors: a strategic asset. Construction management and economics. v. 19, p. 541-549, 2001.

KALIAN, A.; THORPE, A.; AUSTIN, S. A. Best practice guides for in-situ concrete frame buildings: improving rebar and information supply. United Kingdom, British Cement Association, 2000(b). ISBN 0721015557.

KALIAN, A.; THORPE, A.; AUSTIN, S.A. Improving rebar and information supply. United Kingdom: Building Research Establishment, 2000. (Technical Report).

KAMING, P. et al. Factors influencing time and cost overruns on high-rise projects in Indonesia. Construction Management and Economics, 1997(a). (in press).

KAMING, P. et al. Severity diagnosis of productivity problem's reliability analysis. International Journal of Project Management, 1997(b). (in press).

KANITZ, S. O sexto aniversário do real. VEJA. São Paulo, maio de 2000.

KARLSSON, C. Radically new production systems. International Journal of Operations and Production Management. v. 16, n. 11, p. 8-19, 1996.

$\mathrm{KOCH}, \mathrm{J}$.; MOAVENZADEH, F. Productivity and technology in construction. Construction Division, ASCE. v. 105, n. 4, 351-366, 1979.

KOSKELA, L. Application of the New Production Philosophy to Construction. Stanford, CA, 1992. (Technical Report n. 72).

KRAFCIK, J F. Triumph of the lean production system. Sloan Management Review. $v$. 30, n. 1, p. 41-52, 1988.

KUMARASWAMY, M. M.; MATTHEWS, J. D. Improved Subcontractor Selection Employing Partnering Principles. Journal of Management in Enginnering. V. 16, n. 3. May/June, 2000.

KUPRENAS, J. A.; UM, J. T.; BOOTH, C. E. Use of CAD three-dimensional modeling as a constructability review tool. Proc., 2nd Congr. Computing in Civil Engineering. v. 1, p. 195-202, 1995.

LATHAM, S. M. Constructing the team. London: Department of the Environment, HMSO, 1994. (report).

LAUFER, A.; HOWELL, G. Constructing planning: revising the paradigm. Project Management Journal, n. 3, 1993.

LAUFER, A.; JENKINS, D. Motivating construction workers. Journal of Construction Engineering and Management. v.108, n. C04, p.531-45, 1982.

LAUFER, A.; TUCKER, R. L. Is constructing planning really doing its job? A critical examination of focus, role and process. Constructing Management and Economics. $v$. 5, n. 5, 1987.

LEAVITT, H. J. Managerial psychology. Chicago: University of Chigago Press, 1964.

LEONHARDT, F. Construções de concreto. Rio de Janeiro: Interciência, 1983 
LEONHARDT, F; MONNIG, E. Construções de concreto. Rio de Janeiro: Interciência, 1978.

LEVINSON, H. Reciprocation: the relationship between man and organization. Administrative Science Quartely. V. 9, n. 4, p. 373, mar. 1965.

LEVINSON, H. Saúde mental na empresa moderna. São Paulo: Ibrasa, 1970.

LIBRAIS, C.F. Método prático para estudo da produtividade da mão-de-obra no serviço de revestimento interno de paredes e pisos com placas cerâmicas. 2001. 117p. Dissertação (Mestrado)- Escola Politécnica, Universidade de São Paulo. São Paulo, 2001.

LISKA, R. W. Attracting and retaining a skilled construction workforce. In: Construction Innovation and global competitiveness: Proceedings of 10 International Symposium, v.2, p. 1270-1282. 2002. CRC press, Cincinnati

LISKA, R. W. PIPER, C. Attracting and maintaining a skilled construction worforce. Austin, TX: Construction Industry Institute, 1999.

LORDSLEEM JÚNIOR, A.C. Metodologia para capacitação gerencial de empresas subempreiteiras. 2002. 288p. Tese (Doutorado). Escola Politécnica, Universidade de São Paulo. São Paulo, 2002.

MACHADO, R. L.; HEINECK, L. F. M. . Um Modelo Enxuto de Administração da Produção. In: Simpósio de Administração da Produção, Logística e Operações Industriais, 3, 2000, São Paulo. Anais. São Paulo - SP, FGV-SP, POI, 25 a 28 de setembro de 2000, 2000.

MAEDA, F.M. Produtividade da mão-de-obra nos serviços de revestimento interno de paredes e tetos em argamassa e em gesso. 2002. 177p. Dissertação (Mestrado). Escola Politécnica, Universidade de São Paulo. São Paulo, 2002.

MAHER, R. P. Introduction to construction operation. USA: John Wiley \& Sons, 1982. MAIA, A. C. Método para conceber o arranjo físico dos elementos do canteiro de obras de edifícios. 2003. 236p. Dissertação (Mestrado). Escola Politécnica, Universidade de São Paulo. São Paulo, 2003.

MALONEY, W. Productivity improvement: The influence of labor. Journal of Construction Engineering and Management. v. 109, n. 3, p. 321-334, 1983.

MARDER, T.; FORMOSO, C.T. O papel do comprometimento na integração das cadeias de produtos feitos sob encomenda na indústria da construção. In: CONFERÊNCIA LATINOAMERICANA DE CONSTRUÇÃO SUSTENTÁVEL, 1. São Paulo, 2004. Anais. São Paulo: EPUSP/ANTAC, 2004(b). CD-ROM.

MARDER, T.; FORMOSO, C.T. Oportunidades de melhorias na cadeia de suprimentos do aço cortado e dobrado para a construção civil. In: CONFERÊNCIA LATINO-AMERICANA DE CONSTRUÇÃo SUSTENTÁVEL, 1. São Paulo, 2004. Anais. São Paulo: EPUSP/ANTAC, 2004(a). CD-ROM.

MARX, R. Análise dos projetos de implantação de trabalho em grupo na industria: a questão da autonomia no chão de fabrica. 1996. 244p. Tese (Doutorado) Escola Politécnica, Universidade de São Paulo. São Paulo, 1996.

MARX, R. Trabalho em grupos e autonomia como instrumentos da competição. São Paulo: Atlas, 1998.

MAYO, E. The human problems of an industrial civilization. New York: MacMillan, 1933. 
McKINSEY GLOBAL INSTITUTE. Produtividade: a chave do desenvolvimento acelerado no Brasil. São Paulo: McKinsey Brasil, 1998. (Relatório)

MILLER, C. J.; PACKHAM, G. A; THOMAS, B. C. Harmonization between main contractors and subcontractors: a prerequisite for lean construction. Journal of Construction Research. v. 3, n. 1. p. 67-82, 2002.

MILTENBERGER, M. A.; BERNOLD, L. E. CAD-integrated rebar bending. In: COMPUTING IN CIVIL ENGINEERING AND SYMPOSIUM ON DATA BASES, 7. Proceedings. New York: ASCE, 1991. p. 819-828. 1991.

MING LU, M; ANSON, Michael. Establish Concrete Placing Rates Using Quality Control Records from Hong Kong Building Construction Projects. Journal of Construction Engineering and Management. v. 130, n. 2, 2004.

MINISTÉRIO DO DESENVOLVIMENTO, INDÚSTRIA E COMÉRCIO EXTERIOR - MDIC. Plano Estratégico para Ciência, Tecnologia e Inovação na Área de Tecnologia do Ambiente Construído, com ênfase na construção habitacional. Disponível em: <http://www.desenvolvimento.gov.br/tecnologia/prospectiva/pti.html> Acesso em: 1 mar. 2002.

MINISTÉRIO DO DESENVOLVIMENTO, INDÚSTRIA E COMÉRCIO EXTERIOR. Fórum de competitividade: construção civil. Disponível em: <http//:www.desenvolvimento.gov.br> Acesso em: 10 mar. 2004

MINISTÉRIO DO DESENVOLVIMENTO, INDÚSTRIA E COMÉRCIO EXTERIOR. Desenvolvimento da Produção. Ações setoriais para o aumento da competitividade da indústria brasileira: indústria da construção. Disponível em: <http//:www.desenvolvimento.gov.br> Acesso em: 10 mar. 2004.

MINISTÉRIO DO TRABALHO E DO EMPREGO - MTE. Classificação brasileira de ocupações. Disponível em: <http://www.mtecbo.gov.br/index.htm> Acesso em: 3 abr. 2004.

MINISTÉRIO DO TRABALHO E DO EMPREGO - MTE. Disponível em: <http://www.mte.gov.br> Acesso em: 10 maio 2004.

MINISTÉRIO DO TRABALHO. NR-18: Condições e meio ambiente do trabalho na indústria da construção. Brasília, 1995. 43p.

MONKS, J. G. Administração da produção. Trad. de Lauro Santos Blandy. São Paulo: McGraw-Hill, 1987.

MOORE, S. M. J.; GIBBONS, A. Is Lean Manufacture Universally Relevant? An Investigative Methodology. International journal of operations \& production management. v. 17, n. 9, p. 899-911, 1997.

MURRAY et al. Dirty construction workers: who you looking at buddy? In: Construction Innovation and global competitiveness: Proceedings of 10 International Symposium, v.2, p. 1309-1321. 2002. CRC press, Cincinnati

MUTHER, R. Planejamento do layout: sistema SLP. São Paulo: Edgard Blücher, 1986. $192 \mathrm{p}$.

NAVON, R.; SHAPIRA, A.; SHECHRI, Y. Automated rebar constructability diagnosis. Journal of Construction Engineering and Management. v. 126, n. 5, p. 389-397, 2000.

O'CONNOR, J. T. Impacts of constructability improvement. Journal of Construction Engineering and Management. v. 111, n. 4, p. 404-410, 1985. 
O'CONNOR, J. T.; DAVIS, V. S. Constructability improvement during field operations. Journal of Construction Engineering and Management. v. 114, n. 4, p. 548-564, 1988.

O'CONNOR, J. T. TUCKER, R. L. Industrial project constructability improvement. Journal of Construction Engineering and Management. v. 112, n. 1, p. 69-82, 1986.

OHNO, T. Toyota production system: beyond large-scale production. Portland,OR: Productivity Press. 1988.

OHNUMA, D. K. Modelo de processos para a gestão de subempreiteiros: estudo de casos em empresas construtoras de edifícios. 2003. 211p. Dissertação (Mestrado) Escola Politécnica, Universidade de São Paulo. São Paulo, 2003.

OLIVEIRA, M.; LANTELME, E.; FORMOSO, C.T. Sistema de indicadores de qualidade e produtividade para a construção civil: manual de utilização. 2.ed. Porto Alegre: Sebrae/RS, 1995. v. 1.

OLSSON, R. Subcontract Coordination in Construction. International Journal of Production Economics. v. 56-57, p. 503-509, 1998.

PALIARI, J.C. Metodologia para a coleta e análise de informações sobre consumos e perdas de materiais e componentes nos canteiros de obras de edifícios. 1999. 473p. Dissertação (Mestrado) - Escola Politécnica, Universidade de São Paulo. São Paulo, 1999.

PELIZZARI, R. Cresce mercado de estruturas metálicas. O Estado de São Paulo, 2001. Caderno Construção.

PINTO, T. P. Perdas de materiais em processos construtivos tradicionais. São Carlos: UFSCar/Depto de Engenharia Civil, 1989.

PROVERBS, D. G.; HOLT, G. D.; OLOMOLAIYE. The management of labour on high rise construction projects: an international investigation. International Journal of Project Management. v. 17, n. 3, p. 195-204, 1999.

RAINBIRD, $\mathrm{H}$. Labour force fragmentation and skills supply in the British construction industry. In: ReSTRUCTRING A TRADITIONAL INDUSTRY. Proceedings, Oxford, 201222, 1991.

RAYSNFORD, N. KPI Report for The Minister for Construction. London: Department of the Environment, Transport and the Regions. The KPI Working Group dated January 2000 (report)

REIS, P. F. Análise dos impactos da implementação de sistemas de gestão da qualidade nos processos de produção de pequenas e médias empresas de construção de edifícios. 1998. Dissertação (Mestrado) - Escola Politécnica, Universidade de São Paulo. São Paulo, 1998.

REVISTA COSTRUÇÃO MERCADO. Índices e custos. São Paulo: Pini Editora. n. 35, junho de 2004.

ROJAS et al. Is Construction Labor Productivity Really Declining? Journal of Construction Engineering and Management. v. 129, n. 1, Feb. 2003.

ROMMINGER, R. Um método racional para o aproveitamento das sobras do corte de barras de aço para estruturas de concreto armado. 2003. 151p. Dissertação (Mestrado). Escola de Engenharia de São Carlos, Universidade de São Paulo. São Carlos, 2003.

ROSSO, T. Racionalização da construção. São Paulo : FAU/USP, 1980. 
RUSSELL, J. S.; GUGEL, J. G.; RADTKE, M. W. Comparative analysis of three constructability approaches. Journal of Construction Engineering and Management. v. 120 , n. 1, p. 180-195, 1994a.

RUSSELL, J. S.; SWIGGUM, K. E.; SHAPIRO, J. M.; ALAYDRUS, A. F. Constructability related to TQM, value engineering, and cost/benefits. Journal of Performance of Constructed Facilities. v. 8, n. 1, p. 31-45, 1994.

SABBATINI, F. H. Desenvolvimento de métodos, processos e sistemas construtivos : formulação e aplicação de uma metodológica. 1989. 336p. Tese (Doutorado) - Escola Politécnica, Universidade de São Paulo. São Paulo, 1989.

SALERNO, M. Organização da produção e do trabalho da organização capitalista tradicional às possibilidades inovadoras de gestão democrática das cooperativas de produção. São Paulo: CUT, 2002.

SALERNO, M. Projeto de organizações integradas e flexíveis: processos, grupos e gestão democrática via espaços de comunicação-negociação. São Paulo: Atlas, c1999.

SALERNO, M. Reestruturação industrial e novos padrões de produção. São Paulo em Perspectiva. v.6, n.3, p.100-8, set. 1992.

SALERNO, M. S. S. Flexibilidade, organização e trabalho operatório: elementos para análise da produção na indústria. 1991. 232p. Tese (Doutorado) - Escola Politécnica, Universidade de São Paulo. São Paulo, 1991.

SALERNO, M.S.S. Eventos e Comunicação na Produção: uma alternativa frente a abordagem clássica de organização (taylorismo). São Paulo: mimeo, 1998.

SALIM, M. D.; BERNOLD, L. E. Effects of design-integrated process planning on productivity in rebar placement. Journal of Construction Engineering and Management. v. 120, n. 4, p. 720-738, 1994.

SALIM, M. D.; BERNOLD, L. E. AI supported process planning for automated rebar fabrication. IN: CONFEREENCE ON COMPUTATIONAL IN CIVIL ENGINEERING, 8. New York, 1992. Proceedings. New York: ASCE, 1992. p. 872-879.

SALIM, M. D.; BERNOLD, L. E. Effects of design-integrated process planning on productivity in rebar placement. Journal of Construction Engineering and Management. v. 120, n. 4, p. 720-738, 1994.

SAMPAIO, J. C. A. A influência das decisões de projeto na segurança do trabalho. In: SEMINÁRIO DE TECNOLOGIA DE ESTRUTURAS: PROJETO E PRODUÇÃO COM FOCO NA RACIONALIZAÇÃO E QUALIDADE, 4. Material distribuído. São Paulo: Sinduscon-SP, 2002.

SANDERS, S. R.; THOMAS, H. R. Factors Affecting Masonry-Labor Productivity. Journal of Construction Engineering and Management. v. 117, n. 4, p. 626-644, 1991.

SANTOS, A. Application of flow principles in the production management of construction sites. 1999. Tese (Doutorado). School of Construction and Property Management. The University of Salford. Salford, UK. 1999.

SAURIN, T.A. Segurança e produção: um modelo para o planejamento e controle integrado. 2002. Tese (Doutorado). Universidade Federal do Rio Grande do Sul. Porto Alegre, 2002.

SCHEIN, E.H. Consultoria de procedimentos: seu papel no desenvolvimento organizacional. São Paulo: Edgard Blucher, 1972. 
SERRA, S. M. B. Diretrizes para gestão dos subempreiteiros. 2001. 360p. Tese (Doutorado) - Escola Politécnica, Universidade de São Paulo. São Paulo, 2001.

SHASH, A. A. Bidding Practices of Subcontracting in Colorado. Journal of Construction Engineering and Management. v. 124, n. 3, 1998.

SILVA, L.L.R. Luciano. Método de intervenção para a melhoria da eficiência na execução de revestimentos de argamassa de fachada. 2002. 199p. Dissertação (Mestrado). Escola Politécnica, Universidade de São Paulo. São Paulo, 2002.

SILVA, R. Teorias da administração. São Paulo: Pioneira, 2001.

SINDICATO DA INDÚSTRIA DA CONSTRUÇÃO CIVIL - SINDUSCON-SP. São Paulo. Disponível em: <http//: www.sindusconsp.com.br> Acesso em: 10 mar. 2004.

SKIBNIEWSKI, M.; ARCISZEWSKI, T.; LUEPRASERT, K. Constructability analysis: Machine learning approach. Journal of Computing in Civil Engineering. v. 11, n. 1, p. 8-16, 1997.

SKINNER, B. F. Science and human behavior. New York: Free Press, 1953.

SKINNER, W. Manufacturing: missing link in the corporate strategy. Harvard Business Review. P. 136-145. 1969.

SLACK, N et al. Administração da Produção. São Paulo. Atlas, 1999.

SOARES, A.; BERNARDES, M. FORMOSO, C.T. Improving the production planning and control system in a building company: contributions after stabilization, In: ANNUAL CONFERENCE ON LEAN CONSTRUCTION, 10, Gramado. Proceedings. Porto Alegre: UFRGS, 2002.

SOIBELMAN, L. As perdas de materiais na construção de edificações: sai incidência e controle. 1993. Dissertação (Mestrado). Universidade Federal do Rio Grande do Sul. Porto Alegre, 1993.

SOUZA, R. Metodologia para o desenvolvimento e implantação de sistemas de gestão da qualidade em empresas construtoras de pequeno e médio porte. 1997. Tese (Doutorado). Escola Politécnica, Universidade de São Paulo. São Paulo., 1997.

SOUZA, U. E. L. et al. In: SIMPÓSIO NACIONAL DESPERDÍCIO DE MATERIAIS NOS CANTEIROS DE OBRAS: A QUEBRA DO MITO. São Paulo, 1999. Anais. São Paulo: PCCUSP/FINEP/SENAI/ITQC, 1999. 48p.

SOUZA, U. E. L. Método para a previsão da produtividade da mão-de-obra e do consumo unitário de materiais para os serviços de fôrmas, armação, concretagem, alvenaria, revestimentos com argamassa, contrapiso, revestimentos com gesso e revestimentos cerâmicos. 2001. 357p. Tese (Livre Docência). Escola Politécnica, Universidade de São Paulo. São Paulo, 2001.

SOUZA, U. E. L. Metodologia para o estudo da produtividade da mão-de-obra no serviço de fôrmas para estruturas de concreto armado. 1996. 280p. Tese (Doutorado) - Escola Politécnica, Universidade de São Paulo. São Paulo, 1996.

SOUZA, U. E. L. Redução do desperdício de argamassa através do controle do consumo em obra. In: SIMPÓSIO BRASILEIRO DE TECNOLOGIA DAS ARGAMASSAS, 2, Salvador, 1997. Anais. Salvador: ANTAC. 1997. p 459-468.

SOUZA, U. E. L. São Paulo: EPUSP/ITQC, 1993. 30p.

SOUZA, U.E.L et al. Recomendações gerais quanto à localização e tamanho dos elementos do canteiro de obras. 1997. 26p. (Boletim Técnico, do Departamento de Engenharia de Construção Civil, Universidade de São Paulo- BT/PCC/178). 
SOUZA, U.E.L; FRANCO, L.S. Definição de layout do canteiro de obras. 1997. 23p. (Boletim Técnico, do Departamento de Engenharia de Construção Civil, Universidade de São Paulo- BT/PCC/177).

STARR, M.K. Administração da produção: sistemas e sínteses. São Paulo: Edgard Blucher, 1988.

STAUB, S. Providing Cost and Constructability Feedback to Designers. Construction Research Congress, 2003.

STERN, G. A robust economy: A view from the FED. Keynotespeech by the president of the Federal Reserve Bank of Minneapolis, Alfred P. Sloan Industry Conference, Minneapolis, Minn., 8 April 1999.

SUSSEKIND, J.C. Curso de concreto. 3. ed. Porto Alegre: Globo, 1983.

SWEIS, G. J. Impact of Conversion Technology on Productivity in Masonry Construction. 2000. 187p. Dissertation (Ph.D. degree). Northwestern University, Department of Civil Engineering. Evanston, 2000.

TABELAS DE COMPOSIÇÕES DE PREÇO PARA ORÇAMENTO - TCPO. 13.ed. São Paulo: PINI, 2003.

TATUM, C. B. Process of innovation in construction firm. Journal of Construction Engineering and Management. v. 112, n. 2. p. 178-191, 1986.

TAYLOR, F.W. Princípios da administração científica. São Paulo: Atlas, 1970.

TEICHOLZ, P. Discussion of U.S. construction labor productivity trends, 1970-1998. Journal of Construction Engineering and Management. v. 127, n. 5, p. 427-428, 2001.

THOMAS, H. R. Labor Productivity and Work Sampling: The Bottom Line. Journal of Construction Engineering and Management. v. 117, n. 3. p. 423-444, 1991.

THOMAS, H. R. Peurifoy Lecture: Construction practices in developing countries. Journal of Construction Engineering and Management. V. 128, n. 1, p. 1-7, 2002.

THOMAS, H. R. Efects of scheduled overtime on labour productivity. Journal of Construction Engineering and Management. v. 118, n. 1, p. 60-76, 1992.

THOMAS, H. R. et al. Modeling Construction Labor Productivity. Journal of Construction Engineering and Management. v. 116, n. 4, p. 705-726, 1990.

THOMAS, H. R. et al. Reducing Variability to improve performance as a lean construction principle. Journal of Construction Engineering and Management. v. 128, n. 2, 2002.

THOMAS, H. R. Principles of Construction Labor Productivity Measurement and Processing. Pennsylvania: Penn State Transport Institute, University Park, 2000. (Report N. 2K14).

THOMAS, H. R.; SANVIDO, V. E.; SANDERS, S. R. Impact of Material Management on Productivity-A Case Study. Journal of Construction Engineering and Management. v. 115, n. 3, p. 370-384, 1989.

THOMAS, H. R; SANVIDO, V. E. Role of the Fabricator in Labor Productivity. Journal of Construction Engineering and Management. v. 126, n. 5, p. 358-365, 2000.

THOMAS, H. R; SMITH, G. R. Loss of Construction Labor Productivity Due to Inefficiencies and Disruptions: The Weight of Expert Opinion. Pennsylvania: Penn State Transport Institute, University Park, 1990. (Report N. 9019). 


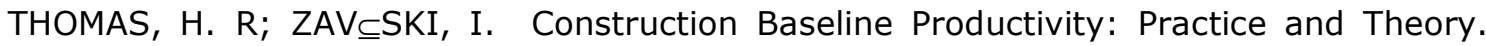
Journal of Construction Engineering and Management. v. 125, n. 5, p. 295-303, 1999.

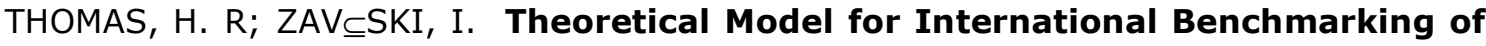
Labor Productivity. Pennsylvania: Penn State Transport Institute, University Park, 1998. (Report N. 9913).

THOMAS, H.; SAKARCAN, A. Forecasting labor productivity using factor model. Journal of Construction Engineering and Management. v. 120, n. 1, p. 228-239, 1994.

THOMAS, H.; YIAKOUMIS, I. Factor model of construction productivity. Journal of Construction Engineering and Management. v. 113, n. 4, p. 623-639, 1987.

THOMAS. H. R.; RILEY, D. R.; SANVIDO, V. E. Loss of Labor Productivity due to Delivery Methods and Weather. Journal of Construction Engineering and Management. $v$. 126, n. 5, p. 39-46, 1999.

THOMAZ, E. Requisitos técnicos e operacionais visando à qualidade na construção de edifícios. 1999. 2v. Tese (Doutorado). Escola Politécnica, Universidade de São Paulo. São Paulo, 1999.

THOMAZ, E. Tecnologia, Gerenciamento e Qualidade na Construção. São Paulo: Pini, 2001. 449p.

THOMPSON, J. D. Dinâmica organizacional: fundamentos sociológicos da teoria da administração. São Paulo: McGraw-Hill do Brasil, 1976.

TOMMELEIN, I. D. Pull-driven scheduling for pipe-spool installation: simulation of lean construction technique. Journal of Construction Engineering and Management. v. 124, n. 4, p. 279-288, 1998.

TOMMELEIN, I. D., Riley, D. R.; Howell, G. A. Parade Game: Impact of Work Flow Variability on Trade Performance. Journal of Construction Engineering and Management. v. 125, n. 5, p. 304-310, 1999.

TUCKER, R. L. Management of construction productivity. Journal of Management in Engineering. v. 2, n. 3, p. 148-156, 1986.

UHLIK, F. T.; LORES, G. V. Assessment of constructability practices among general contractors. Journal of Architectural Engineering. v. 4, n. 3, p. 113-123, 1998.

UWAKWEH, B. O. Motivating craft workers: a case study with Syrian workers. In: JOINT INTERNATIONAL SYMPOSYIUM OF CIB WORKING COMMISSIONS. Singapore. 2003. Proceedings. Singapore: /Department of Building, National University of Singapore/CIB, 2003.

VAID, K. N. Contract labor in the Construction Industry in India. In: NAIDU O. P. A. (Ed), Contract Labor is South Asia. I. L. O., Bureau of Workers, Archives. 1999.

VARGAS, N. Tendências de mudança na indústria da construção. Obra - Planejamento e Construção, v.4, n. 44, p.25-9, fev. 1993.

VASDCONCELOS, A. C. Concreto no Brasil: pré-fabricação, monumentos, fundações. São Paulo: Studio Nobel, 2002. 352 p. ISBN 85-7553-008

VASCONCELOS, A. C. O concreto no Brasil: recordes, realizações, história. São Paulo: Copiare, 1985. 254p.

VILLACRESES, X. E. V. Análise estratégica da subcontratação em empresas de construção de pequeno porte. 1994. Dissertação (Mestrado) - Universidade Federal do Rio Grande do Sul. Porto Alegre, 1994. 
WERTHER JR. Administração de pessoal: desenvolvimento de recursos humanos. São Paulo: MacGraw-Hill, 1983.

WOMACK, J. P.; JONES, D.T.: ROOS, D. The machine that changed the world. New York: Rawson Associates, c1990.

WOMACK, J.P.; JONES, D.T. Lean Thinking: banish waste and create wealth in your corporation. New York: Simon and Shuster, 1996.

WONG, H. L. Contractual arrangements for the kepala system. Unpublished Undergraduate's Dissertation. School of Building and Real Estate, National University of Singapore, 1990.

WONG, S. M.; MAKHLOUF, G.; KAMEGAWA, H. Construction productivity \& operations analysis. Pennsylvania: State College. 1986. (Report).

WOOD, S. Administração estratégica e administração de recursos humanos. Revista de administração da USP, v.27, n. 4, 1992.

WYLLIE JR. L.A.; LAPLANTE, R.W. The designer's responsibility: for rebar design CRSI. The Structural Bulletin Series. No 1(2003)

YU, W.D.; SKIBNIEWSKI, M.J. . Quantitative constructability analysis with a neuro-fuzzy knowledge-based multi-criterion decision support system. Automation in Construction. v. 8, n. 5, p. 553-565, 1999.

ZAKERI, M. et al. Factors Affecting the motivation of Iranian construction operatives. Building and Environment. v. 32, n. 2, p. 161-6, 1997.

ZILBOVICIUS, M. Modelos para a produção, produção de modelos: contribuição a analise da gênese, lógica e difusão do modelo japonês. 1997. Tese (Doutorado). Escola Politécnica, Universidade de São Paulo. São Paulo, 1997

ZILBOVICIUS, M. Modelos para a Produção, Produção de Modelos: gênese, Lógica e difusão do modelo japonês. São Paulo: Fapesp/Anna Blume, 1999.

ZORZI, A. C. Fôrma com molde em madeira para estruturas de concreto armado: recomendações para melhoria da qualidade e da produtividade com redução de custos. 2002. 210p. Dissertação (Mestrado) - Instituto de Pesquisas Tecnológicas do Estado de São Paulo-IPT. São Paulo, 2002.

ZORZI, A. C. Produção de estrutura de concreto armado. São Paulo, 2001. (Notas de aula. MBA-TGP/USP, 2001) 